UNIVERSIDADE DE SÃO PAULO

FACULDADE DE ECONOMIA, ADMINISTRAÇÃO E CONTABILIDADE DEPARTAMENTO DE ADMINISTRAÇÃO

PROGRAMA DE PÓS-GRADUAÇÃO EM ADMINISTRAÇÃO

RELAÇÕES ENTRE VALORES, GESTÃO DE PRÁTICAS, COMPROMETIMENTO E RESULTADOS ORGANIZACIONAIS EM INSTITUIÇÕES TRANSCULTURAIS

Conceição Rejane Miranda da Cruz

Orientadora: Prof. ${ }^{a}$ Dr. $^{a}$ Tania Casado

São Paulo

2018 


\section{Prof. Dr. Vahan Agopyan \\ Reitor da Universidade}

Prof. Dr. Adalberto Américo Fischmann

Diretor da Faculdade de Economia, Administração e Contabilidade

Prof. Dr. Moacir de Miranda Oliveira Jr.

Chefe do Departamento de Administração

Prof. Dr. Moacir de Miranda Oliveira Jr.

Coordenador do Programa de Pós-Graduação em Administração

CONCEIÇÃO REJANE MIRANDA DA CRUZ 


\title{
RELAÇÕES ENTRE VALORES, GESTÃO DE PRÁTICAS, COMPROMETIMENTO E RESULTADOS ORGANIZACIONAIS EM INSTITUIÇÕES TRANSCULTURAIS
}

\author{
Tese apresentada ao Programa de Pós-Graduação em \\ Administração, do Departamento de Administração, da \\ Faculdade de Economia, Administração e Contabilidade da \\ Universidade de São Paulo, como requisito parcial para a \\ obtenção do título de Doutor(a) em Ciências
}

\section{Orientadora: Prof. ${ }^{a}$ Dr. ${ }^{a}$ Tania Casado}

Versão original

\section{SÃO PAULO}

2018 
FICHA CATALOGRÁFICA

Elaborada por Rafael Mielli Rodrigues - CRB-8/7286 Seção de Processamento Técnico do SBD/FEA/USP

Cruz, Conceição Rejane Miranda da

Relações entre valores, gestão de práticas, comprometimento e resultados organizacionais em instituições transculturais / Conceição Rejane Miranda da Cruz. - São Paulo, 2018.

$513 \mathrm{p}$.

Tese (Doutorado) - Universidade de São Paulo, 2018.

Orientador: Tania Casado.

1. Comprometimento organizacional 2. Organização (Administração) 3. Valor (Administração) I. Universidade de São Paulo. Faculdade de Economia, Administração e Contabilidade. II. Título.

CDD - 658.4094 
Ao alicerce, Bento P. Cruz e $\mathrm{M}^{a}$ Luíza M. Cruz (in memoriam)

À paz e apoio irrestrito, Robson Mourthé e meus queridos irmãos, Ricardo e Lucineide Cruz

Ao futuro, João Victor Miranda M. Silva, meu amado filho; sobrinhos, Érika e Jônatas Chagas Cruz; e enteado, Fábio Mourthé. 



\section{AGRADECIMENTOS}

\section{AGRADECIMENTOS}

A elaboração de uma tese de doutorado não requer tão somente o esforço da autora. Antes disso, trata-se de um trabalho conjunto de diversos colaboradores que, direta ou indiretamente, cooperaram para que este trabalho fosse realizado. A cada um de vocês deixo meus sinceros agradecimentos.

Ao meu amigo Evandro Tsufa Lepletier, por ter me apresentado o Departamento de Promoção Comercial (DPR) e ao Conselheiro Carlos Moscardo, à época, Coordenador Geral do DPR do Ministério das Relações Exteriores, pela confiança e suporte para o desenvolvimento do trabalho de campo, e que, juntamente com sua equipe técnica, esteve presente em todas as fases da pesquisa realizada com os colaboradores do DPR e dos SECOMs. Muito obrigada! Ao Programa de Pós-Graduação em Administração da Universidade de São Paulo, por ter me recebido e possibilitado a construção deste trabalho. Aos professores, pelos conhecimentos compartilhados.

À minha orientadora, profa. Tania Casado, pelo afeto, dedicação e competência. Soube repassar, com perfeição e simplicidade, muito mais que conhecimento, transmitiu amor e seriedade à docência. Sua paciência e alto astral foram essenciais para a realização deste trabalho.

Aos membros da minha banca de qualificação, professores Ana Carolina de Aguiar Rodrigues e José Afonso Mazzon, pelas ricas contribuições a este trabalho. Em especial, deixo meus sinceros agradecimentos ao professor Mazzon, pelo auxílio no desenvolvimento da metodologia e das análises multivariadas, uma vez que sem a sua cooperação, essa parte da tese teria sido difícil de realizar-se. Deixo aqui meu reconhecimento e admiração pela sua pessoa e profissionalismo.

Aos amigos que ganhei durante o tempo de estudos na FEA/USP, em especial, à Franciele e ao Rafael, pelos nossos almoços e prosas; à minha querida Cristiane Nogueira, companheira de viagem, estudos e de longas conversas; à Juliana Rodrigues, por nossas intermináveis horas de estudos; à Paula Brant, Tainá Brito, Jefferson e Tiepo, pela agradável convivência durante o curso.

Às amigas de sempre, Simone Cerveira, Analia Soria e Fátima Stacciarini, mulheres guerreiras que conquistaram seus lugares e são merecedoras de reconhecimento.

À profa. Tereza Cavalcanti, pela revisão do texto. Aprendi um pouquinho mais da nossa língua! 
Ao meu amado filho João Victor, pela compreensão das minhas ausências e auxílio às traduções do inglês. Além de o agradecer, gostaria que esse trabalho the servisse como exemplo de que sonhos não têm idade.

Ao meu irmão, Ricardo Henrique Paulino da Cruz, pelo suporte às viagens a São Paulo. Foi muito bom ter tido a sua companhia. Fez lembrar nossa "velha infância".

À minha irmã, Lucineide Alessandra Miranda da Cruz, pelos incentivos que sempre proporciona nas horas difíceis da vida.

Ao Robson Mourthé, pelo apoio, preocupação, cumplicidade e respeito. Você soube conduzir com maestria essa fase. Meu companheiro de vida, saiba que você é fonte de inspiração para que eu sempre tente mostrar ao mundo o melhor de mim. Essa conquista é nossa!

A Deus, por ter me dado a força e a serenidade necessárias para elaborar este trabalho.

Rejane Miranda 
A cultura enforma tudo e todos nos contextos organizacionais Bilhim 



\section{RESUMO}

Cruz, Conceição Rejane Miranda da. (2018). Relações entre valores, gestão de práticas, comprometimento e resultados organizacionais em instituições transculturais (Tese de Doutorado). Faculdade de Economia, Administração e Contabilidade, Universidade de São Paulo.

Este estudo tratou das relações entre valores, gestão de práticas, comprometimento e resultados organizacionais em instituições transculturais. Foram utilizados os seguintes referenciais teóricos: a cultura organizacional, definida por Hofstede como composta por dois principais elementos: valores e práticas organizacionais; os valores organizacionais, tendo como pressuposto o isomorfismo entre a estrutura dos valores humanos definido por Schwartz e dos valores organizacionais estabelecidos por Tamayo; as práticas organizacionais definidas sob a teoria de lócus de valor humano de Jackson, que identifica a forma como as pessoas são valorizadas a partir dos aspectos culturais característicos de cada sociedade, que refletem no estilo de práticas de gestão, distinguindo entre a visão instrumental ou humanista; e o comprometimento organizacional, entendido como o envolvimento do empregado com a organização, e como este envolvimento é afetado pela natureza do vínculo: afetiva, instrumental ou normativa. O objetivo deste trabalho é identificar e descrever a influência das manifestações da cultura da Instituição, expressas por meio dos valores e dos tipos de práticas organizacionais, sobre o comprometimento, bem como a influência dessas manifestações e do comprometimento sobre os resultados organizacionais. Utilizaram-se como instrumentos de pesquisa a escala de Inventário de Perfis de Valores Organizacionais (IPVO), a escala de comprometimento EBACO e a escala de lócus de valor humano. Os instrumentos foram aplicados a uma amostra de colaboradores do Departamento de Promoção Comercial e Investimentos (DPR) do Ministério das Relações Exteriores e seus respectivos Setores de Promoção Comercial (SECOMs) localizados nas embaixadas e consulados brasileiros, abrangendo todos os continentes e fixados em 83 países. Os resultados demonstraram que, na organização pesquisada, há similaridades dos valores e dos tipos de práticas entre o DPR e os SECOMs. Os tipos de práticas e o comprometimento impactam diretamente nos resultados alcançados pelos SECOMs, mas valor não apresentou impacto de forma direta nos resultados. Entretanto, comprometimento se mostrou mediadora da relação entre valores e resultados organizacionais. Como consequência deste trabalho, espera-se estimular novas pesquisas, com vistas a aprofundar os conhecimentos acerca da estratégia de gestão de pessoas.

Palavras-chave: 1. Comprometimento organizacional 2. Organização (Administração) 3. Valor (Administração) 


\begin{abstract}
Cruz, Conceição Rejane Miranda da. (2018). Relationship between values, management of practices, commitment and organizational results in transcultural institutions (Doctoral thesis). Faculty of Economics, Administration and Accounting, University of São Paulo.
\end{abstract}

This study dealt with the relation among values, practice management, commitment and organizational results in cross-cultural institutions. The organizational culture, defined by Hofstede as composed of two main elements: organizational values and practices, was used as the theoretical reference. The organizational values have as presupposition the isomorphism between the structure of human values defined by Schwartz and the organizational values established by Tamayo. The Organizational practices were defined under Jackson's human-value locus theory that identifies how people are valued from typical cultural aspects of each society, which are reflected in the style of management practices, distinguishing instrumental and humanist ideas. The organizational commitment, understood as the engagement of the worker with the organization, and how such involvement is affected by the nature of the bond: affective, instrumental or normative, according to Meyer et al. The purpose of this work is to identify and describe the influence of the Institution's culture manifestation, expressed through the values and types of organizational practices, on the commitment, as well as the influence of these manifestations and the commitment on the organizational results. The scale of Organizational Values Profiles Inventory (IPVO), the EBACO commitment scale, and the human value locus scale were used as research instruments. These instruments were applied to a group of employees from the Trade Promotion Department (DPR) of the Ministry of Foreign Affairs and their respective Trade Promotion Sections (SECOMs), located in Brazilian Embassies and Consulates, covering all continents and established in 83 countries. The results showed that in the researched organization there are similarities of values and types of practices between DPR and SECOMs. The types of practices and the commitment directly impacted the results achieved by the SECOMs, but the value did not have a direct impact on the results. However, the commitment was mediating the relationship between values and organizational results. With the results obtained of this work, it is expected to stimulate new researches, in order to deepen the knowledge about the strategy of people management.

Key-words: 1. Organizational commitment 2. Organization (Administration) 3. Value (Administration) 
01 Estrutura da tese

\section{Lista de Figuras}

02 Pressupostos de dimensão

03 Níveis da cultura e sua interação

04 Níveis de manifestação da cultura

05 Dimensões culturais

056

06 O mapa cultural do mundo em 2000

057

07 O mapa cultural do mundo em 2015

080

08 Estrutura Circular dos Valores segundo Schwartz

081

09 Círculo motivacional de acordo com a teoria de valores básicos refinada

094

10 Classificação dos Valores Organizacionais

098

1 Modelo conceitual de lócus de valor humano

102

2 Síntese dos modelos e suas abordagens conceituais

114

3 Modelo integrador geral

117

Modelo integrador específico e hipóteses

138

Modelo de moderação para a organização local

Modelo de moderação para a organização local 149

16 Diagrama do trajeto metodológico

152

$\begin{array}{ll}\text { Etapas para o desenvolvimento da pesquisa } & 153\end{array}$

18 Modelo complexo e modelo hierárquico 186

19 Tipos de relações entre o HOC e os respectivos LOCs 188

20 Tipos de relações entre o HOC e os respectivos LOCs com repetição 189

21 Modelo geral de mediação 196

22 Relações de mediação 197

23 Modelo de medição múltipla $\quad 198$

24 Classificação dos Valores Organizacionais DPR e SECOMs 240

25 Comparação de médias: Tradição e Conformidade DPR e SECOMs por continente

26 Comparação de médias - Bem-estar e Autonomia DPR e SECOMs por continente

27 Comparação de médias - Prestígio e Realização DPR e SECOMs por continente

28 Comparação de médias - Domínio e Coletividade DPR e SECOMs por continente

Comparação de médias DPR e SECOMs por continente - Instrumental e Humanista

0 Comparação de médias SECOMs por continente - Obrigação pelo desempenho

Comparação de médias SECOMs por continente - Bases Afiliativa e Afetiva

32 SECOMs por continente - Bases Falta de Recompensas e L. Const. de Atividade

33 SECOMs por continente - Bases Escassez de alternativas e Ob.em Permanecer

Resultados da Escala EBACO para os SECOMs da Europa

38 Resultados da Escala EBACO para os SECOMs da Oceania 292

39 Resultados da Escala EBACO para os SECOMs da América do Sul 294

40 Resultados da Escala EBACO para os SECOMs da América Central e Caribe 296

41 Valores e práticas da Instituição nacional e valores e práticas da organização local 299

42 Modelo conceitual teórico para a organização local - relações entre os construtos 326

43 Análise multivariada conjunta para a organização local 338

44 Modelo de medição reflexivo-formativo para o HOC Valores 352

45 Efeito total que cada LOC sobre o HOC valores 354

46 Medição reflexivo-reflexivo para o HOC Práticas 355 
47 Efeito total que cada LOC sobre o HOC - práticas 357

48 Medição reflexivo-reflexivo para o HOC Comprometimento 358

49 Efeito total que cada LOC sobre o HOC - Comprometimento 360

50 Etapas para a análise do modelo estrutural 361

51 Modelo conceitual teórico para a organização local testado 367

52 Mediação entre os construtos para a organização local 368

53 Mediação múltipla metas motivacionais para resultados 372

54 Mediação múltipla metas motivacionais para tipos de práticas 373

55 Mediação múltipla metas motivacionais para resultados via valores e 375 comprometimento

56 Mediação múltipla metas motivacionais para resultados via valores, práticas e 376 comprometimento

57 Mediação múltipla metas motivacionais bases de comprometimento via valores e 377 comprometimento

58 Modelo conceitual teórico

59 Modelo conceitual integrador 


\section{Lista de Quadros}

01 Tipologia de Alvesson e Berg para o estudo da cultura 050

02 Dimensões de problemas humanos básicos 065

03 Dimensões culturais de Hall 066

04 Dimensões culturais de Trompenaars $\quad 067$

05 Padrões culturais de Parsons 068

06 Síndromes culturais de Triands 069

07 Dimensões da teoria cultural de Douglas 070

08 Dimensões culturais de Schwartz 071

09 Dimensões culturais de Hofstede 072

10 Dimensões do Projeto GLOBE $\quad 077$

11 Dimensões de Inglehart $\quad 079$

12 Dimensões de Minkov 082

13 Temas comuns entre os modelos relativos a cultura nacional 083

14 Conjunto de dimensões culturais 085

15 Tipos motivacionais de valores do modelo de Schwartz 092

16 Os 19 Valores da Teoria Refinada, definidos em termos de Metas Motivacionais 097

17 Resumo das dimensões e tipologias de valores organizacionais 104

18 Correspondência entre os tipos motivacionais de valores pessoais e organizacionais 107

19 Comparativo entre as dimensões culturais de Schwartz e Hofstede com o IPVO 108

20 Diferentes bases de comprometimento e autores seminais 128

21 Bases de comprometimento e fundamentação teórica da EBACO 130

22 Avaliação quantitativa dos resultados conforme critérios estabelecidos pelo DPR 132

23 Variáveis antecedentes e mediadora e Hipóteses da pesquisa 150

24 Variáveis Sociodemográficas e Hipótese da pesquisa 151

25 Dimensões e itens da escala do Inventário de Perfis dos Valores Organizacionais 161

26 Dimensões e itens da escala de percepções de práticas de práticas de gestão de 163 pessoas

27 Bases e definições dos itens da escala de bases de comprometimento 165 organizacional

28 Avaliação quantitativa dos resultados conforme os critérios estabelecidos pelo DPR 167

29 Síntese da operacionalização das variáveis 170

30 Matriz de Amarração Metodológica 171

31 Avaliação dos Modelos de Medição 179

32 Intepretação dos resultados da escala EBACO para os SECOMs 280

33 Resultado dos testes de amostras independentes para as dimensões do DPR e 313 dos SECOMs

34 Resultado dos testes de amostras independentes para as dimensões do DPR e 313 dos SECOMs

35 Avaliação dos Modelos de Medição - Outer Model 339

36 Mediação e efeitos indiretos 369

37 Resultados das análises mediadoras para comprometimento e tipos de práticas 371

38 Resultados das análises de mediação múltipla entre metas motivacionais e resultados 372

39 Resultados das análises de mediação múltipla entre valores e tipos de práticas 374

40 Resultados das análises de mediação múltipla entre valores e comprometimento 375

41 Resultados das análises de mediação múltipla entre valores e base de 377 comprometimento afetiva 
42 Resultados das análises de mediação múltipla entre valores e base de 378 comprometimento afiliativa

43 Resultados das análises de mediação múltipla entre valores e base de 379 comprometimento obrigação pelo desempenho

44 Resultados das análises de mediação múltipla entre valores e base de 379 comprometimento obrigação em permanecer

45 Resultados das análises de mediação múltipla entre valores e base de 380 comprometimento linha consistente de atividade

46 Resultados das análises de mediação múltipla entre valores e base de 380 comprometimento escassez de alternativas

47 Resultados das análises de mediação múltipla entre valores e base de 381 comprometimento falta de recompensas e oportunidades

48 Resultados das análises bivariadas para $\mathrm{H}_{1} \quad 383$

49 Resultados das análises bivariadas para $\mathrm{H}_{2}$

50 Resultados das análises para $\mathrm{H}_{3} \quad 386$

51 Resultados das análises para $\mathrm{H}_{4} \quad 387$

52 Resultados das análises para $\mathrm{H}_{5}$

53 Resultados das análises para $\mathrm{H}_{6} \quad 388$

54 Resultados das análises para $\mathrm{H}_{7} \quad 388$

55 Resultados das análises para $\mathrm{H}_{8} \quad 389$

56 Resultados das análises para $\mathrm{H}_{11} \quad 395$

57 Sumário dos testes das hipóteses da pesquisa 397 


\section{Lista de Tabelas}

01 Estatísticas descritivas das atividades SECOMs 168

02 Resultados SECOMs e respectivas escalas 169

03 Possíveis resultados para o teste-t de amostras independentes 176

04 Características socioprofissionais dos colaboradores do DPR/MRE e SECOMs 205

05 Nacionalidade dos respondentes por SECOM 206

06 Percentual de respondentes dos SECOMs nos países por área continental - África 207

07 Características socioprofissionais dos colaboradores dos SECOMs por 208 continente e área continental - África

08 Percentual de respondentes dos SECOMs nos países por área continental - 209 América Central e Caribe

09 Características socioprofissionais dos colaboradores dos SECOMs por 209 continente e área continental - América Central e Caribe

10 Percentual de respondentes dos SECOMs nos países por área continental - 210 América do Norte

11 Características socioprofissionais dos colaboradores dos SECOMs por 211 continente e área continental - América do Norte

12 Percentual de respondentes dos SECOMs nos países por área continental América do Sul

13 Características socioprofissionais dos colaboradores dos SECOMs por continente e área continental - América do Sul

14 Percentual de respondentes dos SECOMs nos países por área continental - Ásia

15 Características socioprofissionais dos colaboradores dos SECOMs por continente e área continental - Ásia

16 Percentual de respondentes dos SECOMs nos países por área continental - Europa

17 Características socioprofissionais dos colaboradores dos SECOMs por continente e área continental - Europa

18 Percentual de respondentes dos SECOMs nos países por área continental - Oceania

19 Características socioprofissionais dos colaboradores dos SECOMs por 217 continente e área continental - Oceania

20 Medidas descritivas - Valores Organizacionais

21 Medidas descritivas - Tipos de Práticas Organizacionais 231

22 Medidas descritivas - Comprometimento 235

23 ANOVA com teste de Tukey e de Friedman para não aditividade - Valores 239

24 Resultado da Análise Fatorial - Tipos de práticas organizacionais 265

25 ANOVA com teste de Tukey e Friedman para não aditividade - Tipos de Práticas 266 Organizacionais

26 Resultado da Análise Fatorial - Escala EBACO 273

27 ANOVA com teste de Tukey e de Friedman para não aditividade - 274 Comprometimento

28 Interpretação dos resultados - escala EBACO

Possíveis resultados para o teste-t de amostras independentes 300

30 Teste de amostras independentes para a dimensão autonomia no DPR e SECOMs

300

31 Teste de amostras independentes para a dimensão coletividade no DPR e SECOMs

32 Teste de amostras independentes para a dimensão realização no DPR e SECOMs

33 Teste de amostras independentes para a dimensão bem-estar no DPR e SECOMs 
35 Teste de amostras independentes para a dimensão prestígio no DPR e SECOMs

36 Teste de amostras independentes para a dimensão conformidade no DPR e 303 SECOMs

37 Teste de amostras independentes para a dimensão domínio no DPR e SECOMs

38 Teste de amostras independentes para os valores do DPR e colaboradores brasileiros nos SECOMs

39 Teste de amostras independentes para os valores do DPR e colaboradores não brasileiros nos SECOMs

40 Teste de amostras independentes para os valores do DPR e dos SECOMs por continente - Autonomia

41 Teste de amostras independentes para os valores do DPR e dos SECOMs por continente - Coletividade

42 Teste de amostras independentes para os valores do DPR e dos SECOMs por continente - Realização

43 Teste de amostras independentes para os valores do DPR e dos SECOMs por continente - Bem-estar

44 Teste de amostras independentes para os valores do DPR e dos SECOMs por continente - Prestígio

45 Teste de amostras independentes para os valores do DPR e dos SECOMs por continente - Conformidade

46 Teste de amostras independentes para os valores do DPR e dos SECOMs por 311 continente - Tradição

47 Teste de amostras independentes para os valores do DPR e dos SECOMs por 312 continente - Domínio

48 Teste de amostras independentes para os tipos de práticas instrumentais no 313 DPR e SECOMs

49 Teste de amostras independentes para os tipos de práticas humanistas no DPR e SECOMs

50 Teste de amostras independentes para os tipos de práticas instrumentais no DPR e SECOMs localizados nos continentes

51 Teste de amostras independentes para os tipos de práticas humanistas no DPR 315 e SECOMs localizados nos continentes

52 Teste de amostras independentes - Valores e tempo de serviço até 1 ano e até 316 5 anos de casa

53 Teste de amostras independentes - Valores e tempo de serviço até 5 anos e 317 acima de 5 anos de casa

54 Teste de amostras independentes - Valores e nacionalidade dos colaboradores 318 nos SECOMs

55 Teste de amostras independentes - valores dos colaboradores nos SECOMs 319 analisados quanto ao sexo

56 Teste de amostras independentes - Comprometimento e tempo de serviço 321

57 Teste de amostras independentes - comprometimento e nacionalidade 322

58 Teste de amostras independentes - Comprometimento e sexo 323

59 Correlações - valores organizacionais e resultados proativos e produtivos $\quad 327$

60 Correlações - práticas organizacionais e resultados proativos e produtivos 327

61 Correlações - Comprometimento e Resultados Organizacionais 328

62 Correlações entre Valores e tipos de Práticas Organizacionais- SECOMs 329

63 Correlações entre Comprometimento e tipos de Práticas Organizacionais 329 
64 Correlações entre Valores Organizacionais e Comprometimento - SECOMs

65 Correlações entre valores organizacionais dos SECOMs e comprometimento em função do tempo de serviço

66 Correlações entre valores organizacionais dos SECOMs e comprometimento em função da nacionalidade

67 Correlações - Valores Organizacionais dos SECOMs e Comprometimento em função do sexo

68 Análise de confiabilidade e de validade convergente - Valores Organizacionais - SECOMs

69 Critério Cross-loadings para avaliar a Validade Discriminante - Valores

70 Critério Fornell-Larcker para avaliar a validade discriminante - Valores

71 Análise de confiabilidade e de validade convergente - Tipos de Práticas Organizacionais - SECOMs

72 Critério Cross-loadings para avaliar a validade discriminante - Tipos de Práticas

73 Critério Fornell-Larcker para avaliar a validade discriminante - Tipos de Práticas

74 Análise de confiabilidade e de validade convergente - Comprometimento SECOMs

75 Critério Cross-loadings para avaliar a validade discriminante - Comprometimento

76 Critério Fornell-Larcker para avaliar a validade discriminante - Comprometimento

77 Análise de confiabilidade e de validade convergente - Resultados - SECOMs

80 VIF - LOCs do HOC Valores

81 Análise das variáveis latentes 361

82 Valores VIF no modelo estrutural 362

83 Relações entre as variáveis latentes 363

84 Coeficiente de determinação R2 do modelo proposto 364

85 Relações entre as variáveis e seus efeitos 365

86 Relevância Preditiva das variáveis 365

87 Efeitos diretos práticas, valores e comprometimento 370

88 Efeitos indiretos valores, práticas, comprometimento e resultados 370

89 Resultado da Análise de significância para efeitos indiretos total - Mediação 370 múltipla 
01 Índice das dimensões de Hofstede para o Brasil 073

02 Percentual de colaboradores e percentual de respondentes 204

03 Comparação do percentual de brasileiros e de respostas das dimensões tradição 248 e conformidade

04 Comparação do percentual de brasileiros e de respostas nas dimensões 252 Autonomia e Bem-estar

05 Comparação do percentual de brasileiros e de respostas nas dimensões 258 Realização e Prestígio

06 Comparação do percentual de brasileiros e de respostas nas dimensões Domínio 261 e Coletividade 


\section{Lista de Abreviaturas}

$\begin{array}{ll}\text { ALSCAL } & \text { Algorithmic Scalling } \\ \text { AVE } & \text { Variância média extraída } \\ \text { CB-SEM } & \text { Modelagem de Equações Estruturais Baseada em Covariância } \\ \text { CER } & \text { Closer Economic Relations } \\ \text { DPR } & \text { Departamento de Promoção Comercial e Investimentos } \\ \text { EACT } & \text { Escala de Avaliação de Contexto de Trabalho } \\ \text { EBACO } & \text { Escala de Bases de Comprometimento Organizacional } \\ \text { ECOA } & \text { Escala de Comprometimento Organizacional Afetivo } \\ \text { ECOC } & \text { Escala de Comprometimento Organizacional Calculativo } \\ \text { ECON } & \text { Escala de Comprometimento Organizacional Normativo } \\ \text { EICCO } & \text { Escala de Intensões Comportamentais de Comprometimento } \\ & \text { Organizacional } \\ \text { EPPGP } & \text { Escala de Políticas e Práticas de Gestão de Pessoas } \\ \text { EPPRH } & \text { Escala de Políticas e Práticas de Recursos Humanos } \\ \text { EUA } & \text { Estados Unidos da América } \\ \text { HCM } & \text { Modelos de componentes hierárquicos } \\ \text { HOC } & \text { Higher-order component } \\ \text { HTMT } & \text { Heterotraço-Monotraço (Validade discriminante) } \\ \text { IDV } & \text { Índice de Individualidade } \\ \text { IMAS } & \text { Índice de masculinidade } \\ \text { IPVO } & \text { Inventário de Perfis de Valores Organizacionais } \\ \text { GRH } & \text { Gestão de Recursos Humanos } \\ \text { LOC } & \text { Lower-order component } \\ \text { MEE } & \text { Modelagem de Equações Estruturais } \\ \text { MRE } & \text { Ministério das Relações Exteriores } \\ \text { OCQ } & \text { Organizational Commitment Questionnaire } \\ \text { PLS-SEM } & \text { Partial Least Squares method to Structural Equation Modeling } \\ \text { SECOMs } & \text { Setores Comerciais } \\ \text { SPSS } & \text { Statistical Package for the Social Sciences } \\ \text { SSA } & \text { Smallest Space Analysis } \\ \text { SVS } & \text { Schwartz Values Survey } \\ \text { TOL } & \text { valor de tolerância } \\ \text { VIF } & \text { Variance Inflation Factor } \\ & \end{array}$





\section{Sumário}

RESUMO

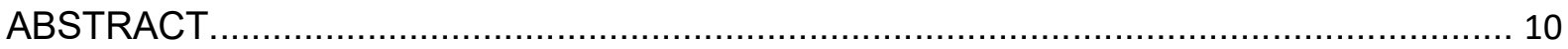

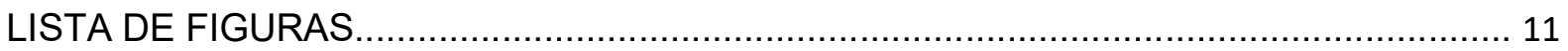

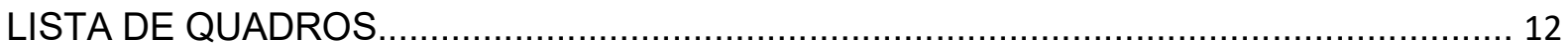

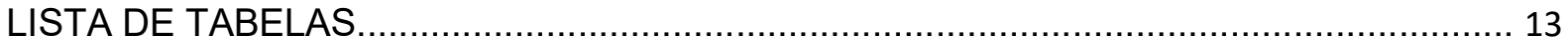

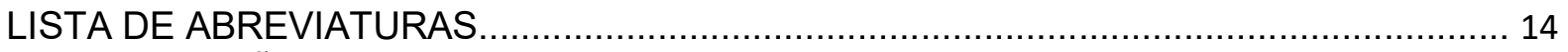

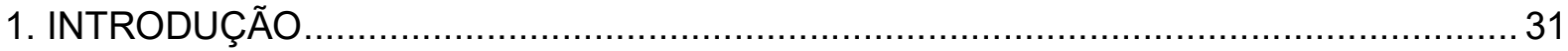

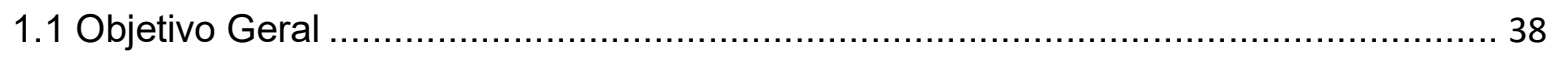

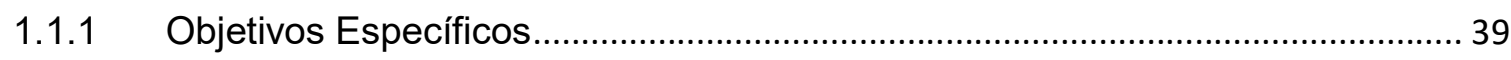

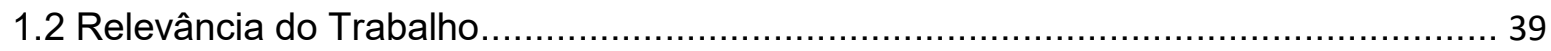

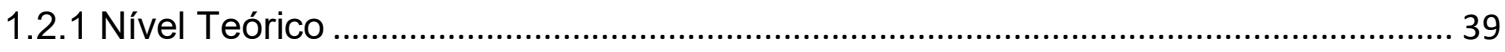

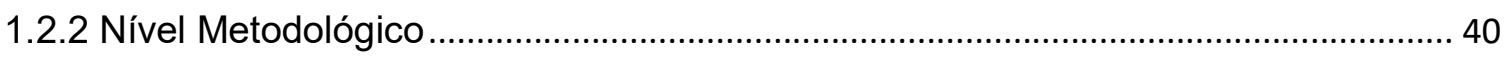

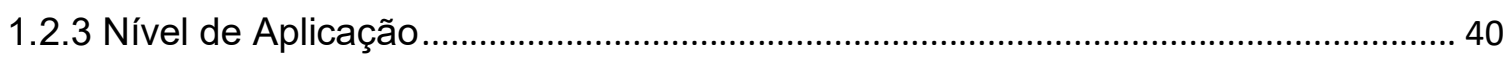

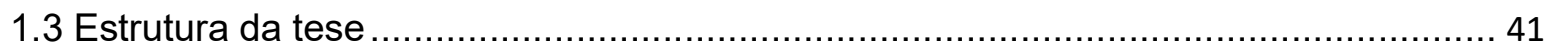

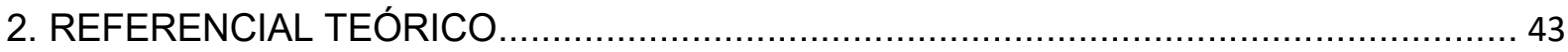

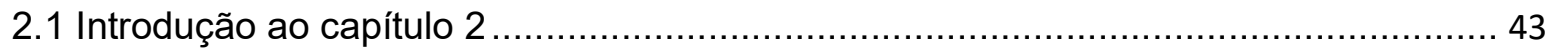

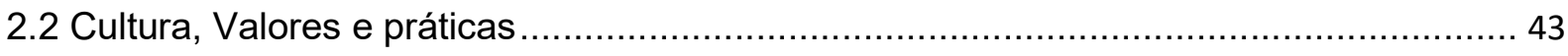

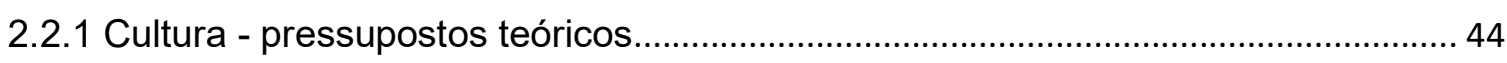

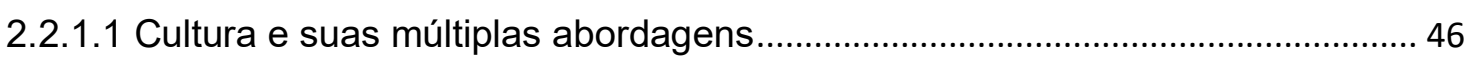

2.2.1.1.1 Abordagem da cultura nesta pesquisa ............................................... 53

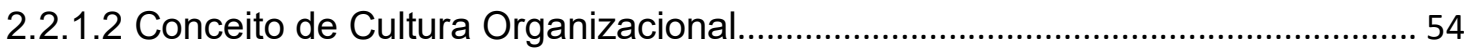

2.2.1.2.1 Abordagem conceitual de cultura organizacional referenciada neste

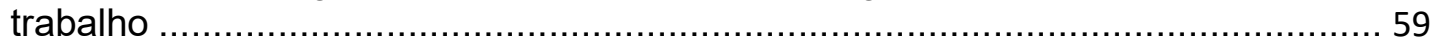

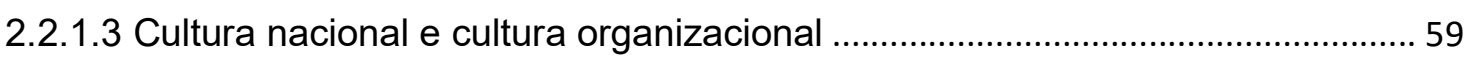

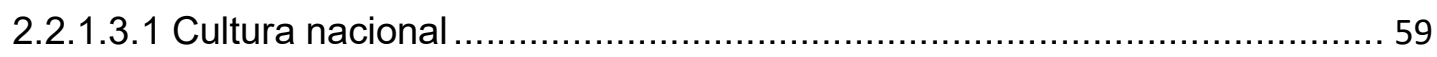

2.2.1.3.2 A atuação da cultura nacional na cultura organizacional .......................63 63

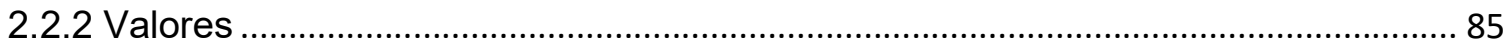

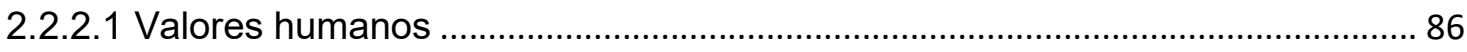

2.2.2.1.1 Modelo teórico dos valores humanos de Schwartz ............................. 90

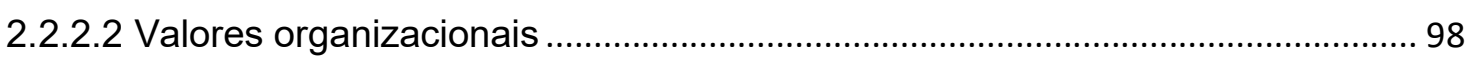

2.2.2.2.1 Dimensões e tipologias para a identificação dos valores organizacionais

2.2.2.2.2 A Escala de Valores Organizacionais - EVO ....................................105

2.2.2.2.3 Inventário de Valores Organizacionais - IVO.......................................105

2.2.2.2.3 Inventário de Perfis de Valores Organizacionais - IPVO ........................106

2.2.2.2.4 Abordagem conceitual de valores organizacionais referenciadas neste

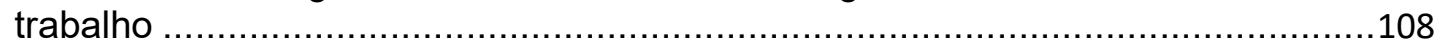

2.2.2.2.5 Estudos empíricos sobre a predição dos valores ................................108

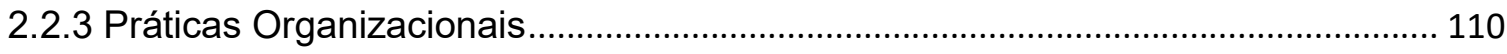


2.2.3.1 Práticas Organizacionais: uma retrospectiva................................................. 110

2.2.3.2 conceituando práticas organizacionais ............................................................. 111

2.3 Comprometimento organizacional ............................................................116

2.3.1 Comprometimento Organizacional: pressupostos conceituais................................ 116

2.3.2 Comprometimento Organizacional - conceitos ......................................................... 120

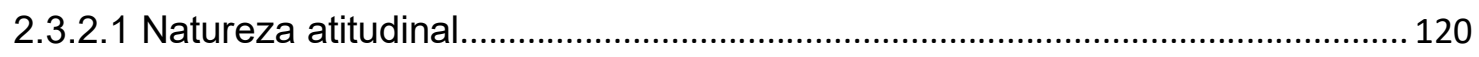

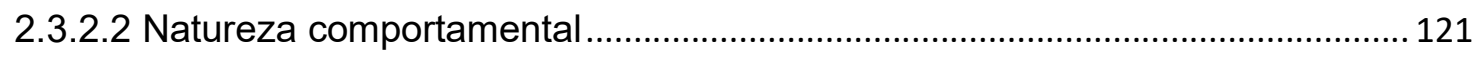

2.3.2.3 Articulação da Natureza atitudinal e comportamental ....................................... 122

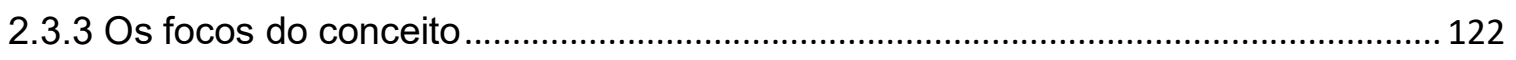

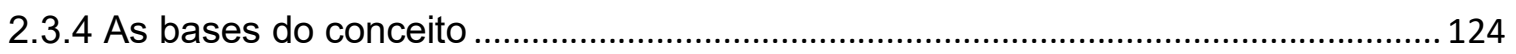

2.3.5 Antecedentes, correlatos e consequentes do comprometimento no trabalho ....... 125

2.3.5 Dimensões e tipologias para a identificação do comprometimento.......................... 126

2.3.6 A Escala de Bases do Comprometimento Organizacional - EBACO ...................... 129

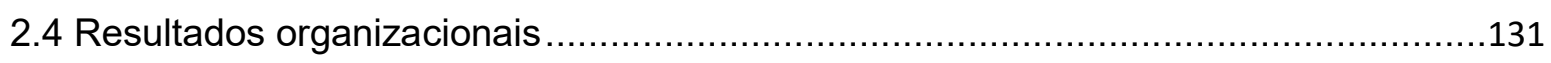

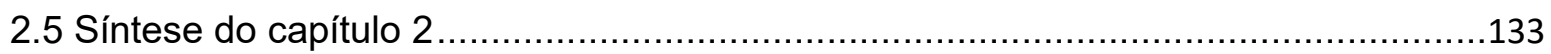

3. OBJETIVOS DA PESQUISA E PROPOSIÇÃO DO MODELO INTEGRADOR ................134

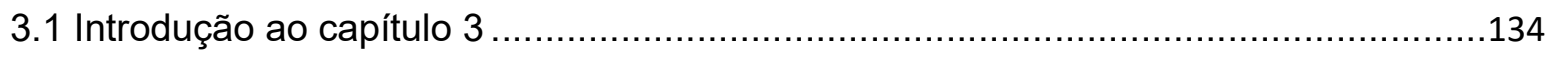

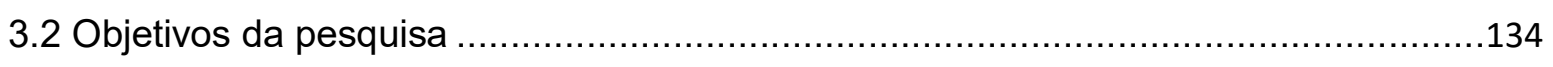

3.3 Pressupostos do modelo conceitual integrador ..............................................136

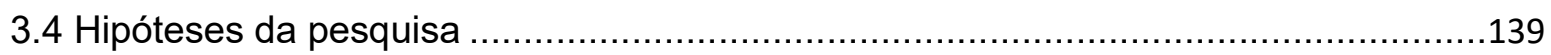

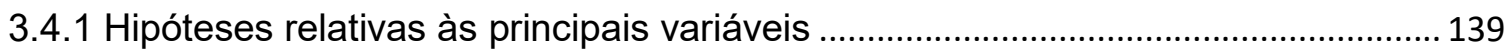

3.4.1.2 Efeito dos valores da organização local (SECOMs) sobre seus tipos de práticas

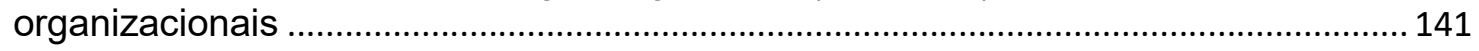

3.4.1.3 Efeito da cultura organizacional local sobre o comprometimento .................... 142

3.4.1.4 Efeito da cultura organizacional local sobre os resultados locais..................... 144

3.4.1.5 Efeito do comprometimento da organização local sobre seus resultados ..... 146

3.4.1.6 Efeito mediador do comprometimento na relação entre valores organizacionais e tipos de práticas e os resultados organizacionais ....................................................... 147

3.4.2 Hipóteses relativas às variáveis sociodemográficas ................................................ 148

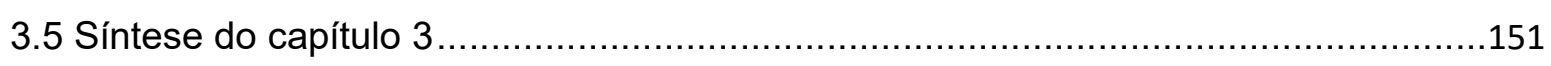

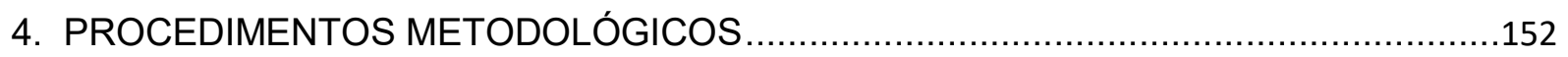

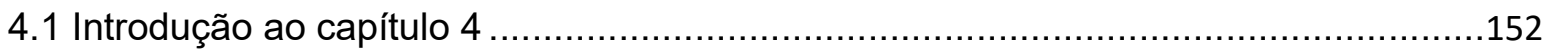

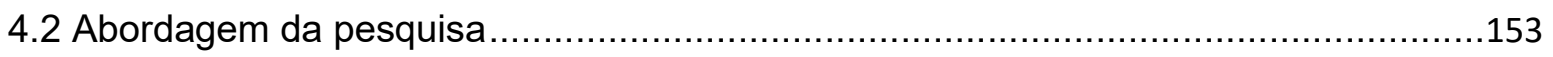

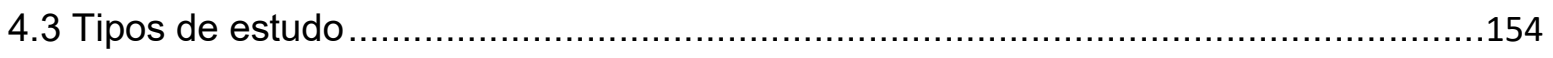

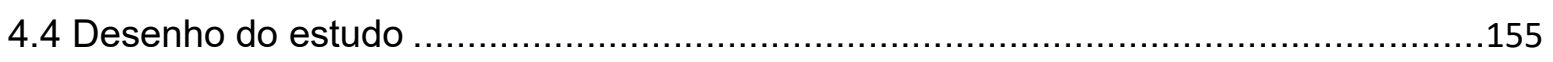

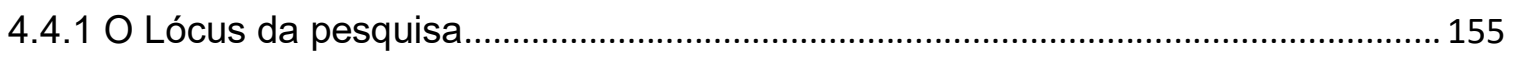

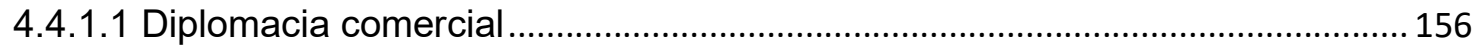

4.4.1.2 DPR - Departamento de Promoção Comercial e Investimentos....................... 157 


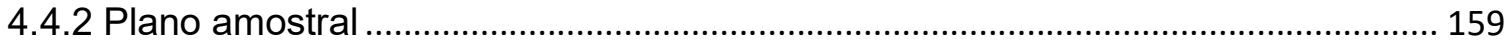

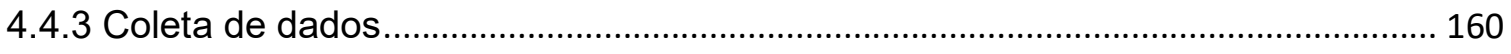

4.4.3.1 Considerações sobre os instrumentos de coleta de dados .............................. 160

4.4.3.1.1 Escala do Inventário de Perfis dos Valores Organizacionais...................160

4.4.3.1.2 Escala de percepções de práticas de gestão de pessoas ......................162

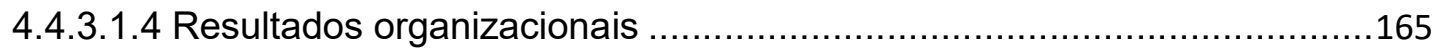

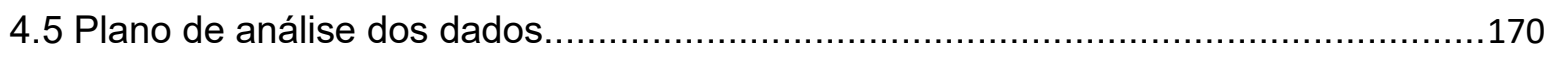

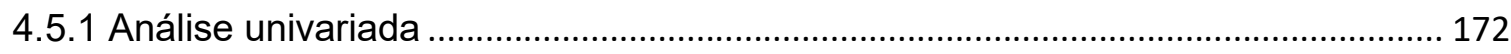

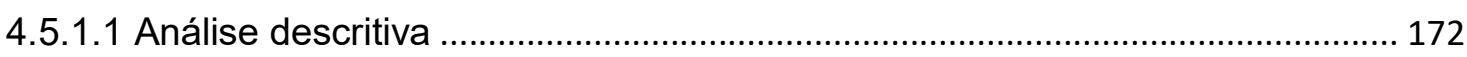

4.5.1.2 Homogeneidade, confiabilidade dos itens e comparação de médias.............. 172

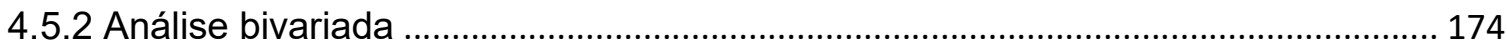

4.5.2.1 Teste t entre amostras independentes ............................................................. 174

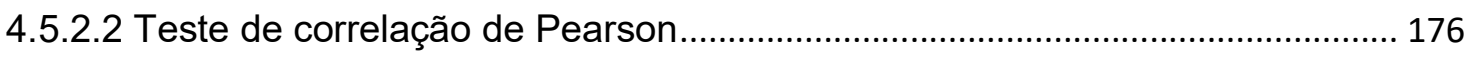

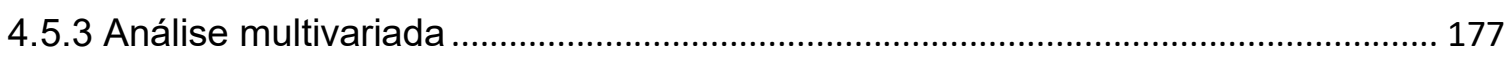

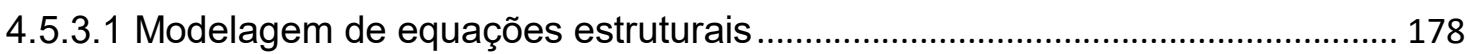

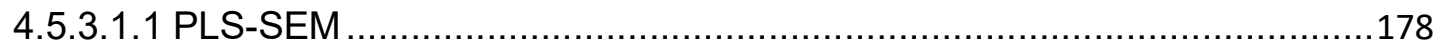

4.5.3.2 Princípios básicos da avaliação do modelo de mensuração - Outer Model 180

4.5.3.2.1 Confiabilidade - consistência interna..................................................180

4.5.3.2.2 Validade convergente ............................................................. 181

4.5.3.2.3 Variância Média Extraída - AVE ..........................................................182

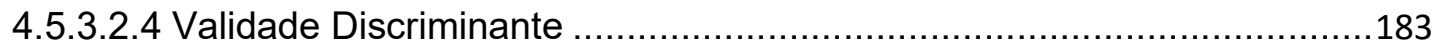

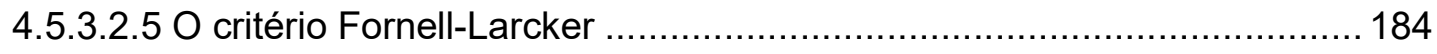

4.5.3.3 Modelos de componentes hierárquicos - HCM ................................................ 184

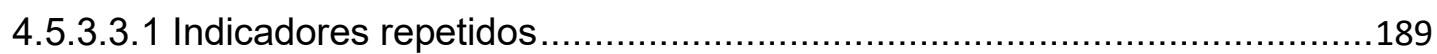

4.5.3.4 Princípios básicos da avaliação do modelo estrutural - Inner Model .............. 191

4.5.3.4.1 Avaliando o modelo estrutural quanto a problemas de colinearidade - VIF 191

4.5.3.4.2 Avaliando a importância e a significância do modelo estrutural (path

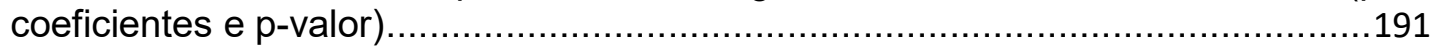

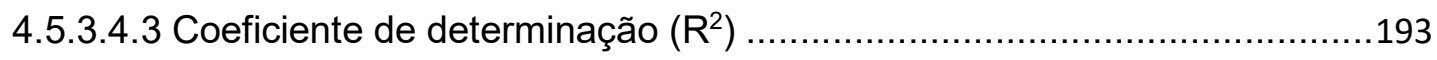

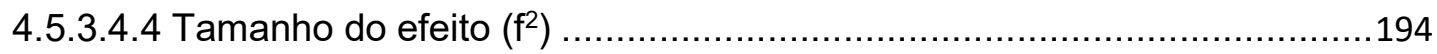

4.5.3.4.5 Teste da relevância preditiva do Modelo Estrutural $\left(\mathrm{Q}^{2}\right) \ldots \ldots \ldots \ldots \ldots \ldots \ldots \ldots . . . . . . . . .195$

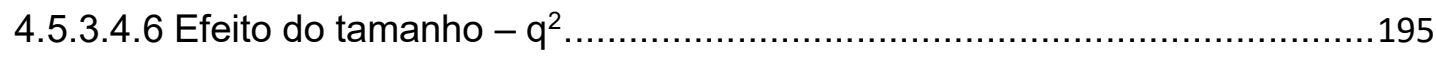

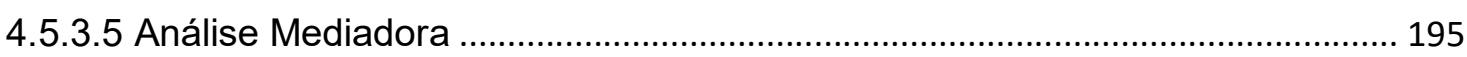

4.5.3.5.1 Mediação múltipla ................................................................... 198

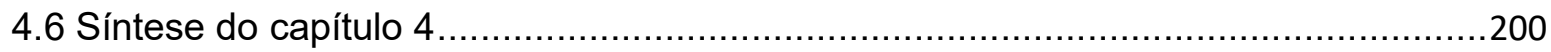

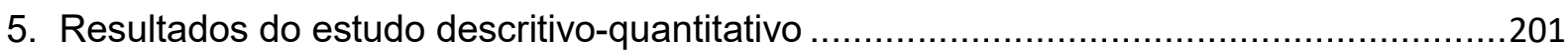

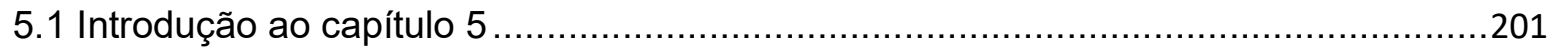




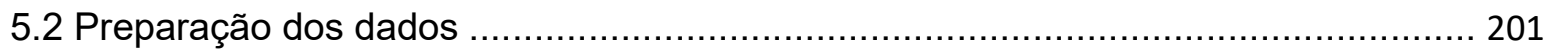

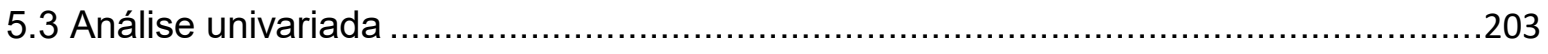

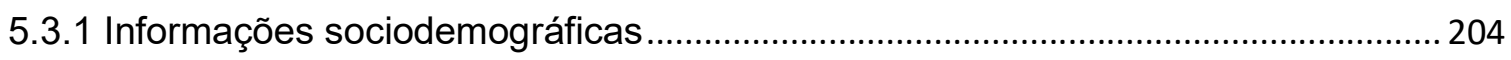

5.3.1.1 Características sociodemográficas dos colaboradores do DPR/MRE ............. 205

5.3.1.1.1 Informações sociodemográficas por continente e área continental ........207

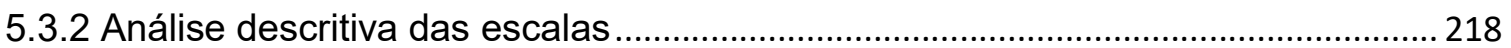

5.3.2.2 Análise descritiva das escalas - Tipos de Práticas Organizacionais.............. 228

5.3.2.3 Análise descritiva das escalas -Comprometimento Organizacional ................ 232

5.3.3 A confiabilidade dos itens e comparação de médias ................................................. 236

5.3.3.1 A confiabilidade dos itens e comparação de médias - Valores........................... 237

5.3.3.1.1 Classificação dos Valores Organizacionais .........................................239

5.3.3.1.2 Comparação de médias entre continentes e DPR- Valores.....................241

5.3.3.2 A confiabilidade dos itens e comparação de médias - Tipos de Práticas

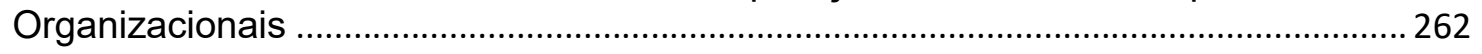

5.3.3.2.1 Análise Fatorial - Escala de percepções de práticas de gestão de pessoas .262

5.3.3.2.2 ANOVA com teste de Tukey para não aditividade - Tipos de Práticas...265

5.3.3.2.3 Comparação de médias entre continentes e DPR - Tipos de Práticas

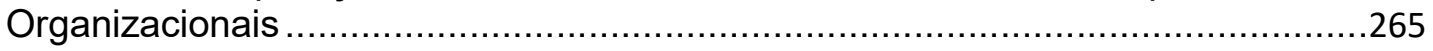

5.3.3.3 Comprometimento organizacional - análise das dimensões ........................... 270

5.3.3.3.1 Análise Fatorial - Escala EBACO ..............................................271

5.3.3.3.2 A confiabilidade dos itens e comparação de médias - Comprometimento .273

5.3.3.3.3 Comparação de médias entre continentes e DPR- Comprometimento...274

5.3.3.3.4 Interpretação das bases de comprometimento segundo a escala EBACO .278

5.3.3.3.5 Interpretação dos resultados da escala EBACO por continente e áreas

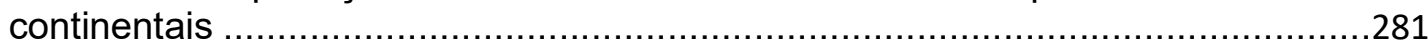

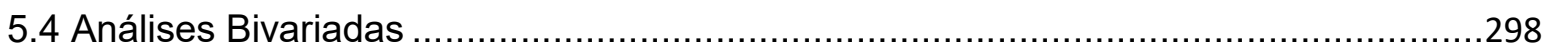

5.4.1 Análises bivariadas entre o DPR e os SECOMs ..................................................... 298

5.4.1.1 Diferenças entre os valores organizacionais identificados no DPR e nos

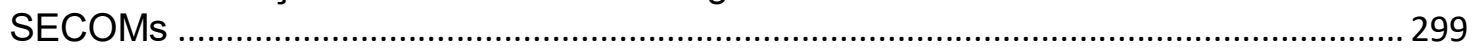

5.4.1.1.1 Diferenças entre a percepção dos valores organizacionais do DPR e dos valores organizacionais dos colaboradores brasileiros nos SECOMs ....................304

5.4.1.1.2 Diferenças entre os valores organizacionais identificadas no DPR e nos colaboradores não brasileiros nos SECOMs ..................................................305

5.4.1.1.3 Diferenças entre a percepção dos valores organizacionais do DPR e dos valores organizacionais dos colaboradores nos SECOMs por continente ..............306

5.4.1.2 Diferenças entre os tipos de práticas organizacionais identificadas no DPR e nos SECOMs.

5.4.1.2.1 Diferenças entre os tipos de práticas organizacionais identificadas no DPR e nos continentes onde os SECOMs estão localizados ......................................313 
5.4.2 Análises bivariadas entre variáveis sociodemográficas dos SECOMs e Valores Teste t.

5.4.2.1 Diferenças na percepção dos valores na organização local (SECOMs) em função do tempo de serviço.

5.4.2.2 Diferenças na percepção dos valores na organização local (SECOMs) em função da nacionalidade.

5.4.2.3 Diferenças na percepção dos valores na organização local (SECOMs) em função do sexo.

318

5.4.3 Análises bivariadas entre variáveis sociodemográficas dos SECOMs e Comprometimento - Teste $\mathrm{t}$ 319

5.4.3.1 Diferenças na percepção do comprometimento em função do tempo de serviço 319

5.4.3.2 Diferenças na percepção do comprometimento na organização local em função da nacionalidade.

5.4.3.3 Diferenças na percepção comprometimento na organização local em função do sexo

5.4.4 Análises bivariadas entre Valores, Práticas e Comprometimento e os resultados nos SECOMs - Teste de Correlação de Pearson. 325

5.4.4.1 Relações entre valores organizacionais e resultados organizacionais nos SECOMs

5.4.4.2 Relações entre tipos práticas organizacionais e resultados organizacionais 326

5.4.4.3 Relações entre comprometimento da organização local e resultados organizacionais 327

5.4.4.4 Relações entre valores e tipos de práticas organizacionais ........................... 327

5.4.4.5 Relações entre tipos de práticas organizacionais e comprometimento 328

5.4.4.6 Relações entre os valores organizacionais e comprometimento organizacional 328

5.4.4.6.1 Relações entre valores e comprometimento em função do tempo de serviço 330

5.4.4.6.2 Relações entre valores e comprometimento em função da nacionalidade 331

5.4.4.6.3 Relações entre valores e comprometimento em função do sexo .333

5.5 Análises Multivariadas .337

5.5.1 Avaliação do Modelo - SECOMs 337

5.5.1.1 Avaliação do Outer Model - Modelo de Medição 338

5.5.1.1.1 Resultados do modelo de medição reflexivo (Outer Model) para as variáveis latentes - Valores

5.5.1.1.2 Resultados do modelo de medição reflexivo (Outer Model) para as variáveis latentes do construto Práticas Organizacionais 343

5.5.1.1.3 Resultados do modelo de medição reflexivo (Outer Model) para as variáveis latentes do construto Comprometimento 346

5.5.1.1.4 Resultados do modelo de medição reflexivo (Outer Model) para as variáveis latentes do construto Resultados Organizacionais. 
5.5.1.1.5 Modelo de medição reflexivo-formativo para o HOC Valores (Outer Model) 351

5.5.1.1.6 Modelo de medição reflexivo-reflexivo para o HOC Práticas (Outer Model) 354

5.5.1.1.7 Modelo de medição reflexivo-reflexivo para o HOC Comprometimento

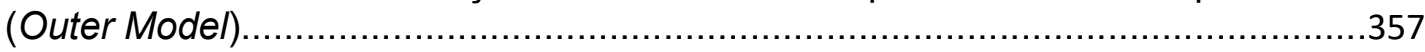

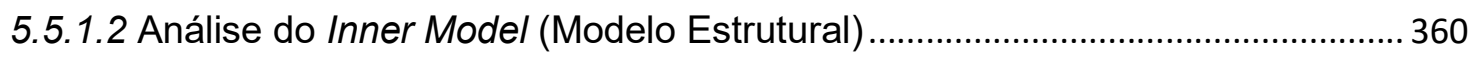

5.5.1.2.1 Avaliando o modelo estrutural quanto a problemas de colinearidade - VIF ..361

5.5.1.2.2 Avaliando a importância e a significância do modelo estrutural (path

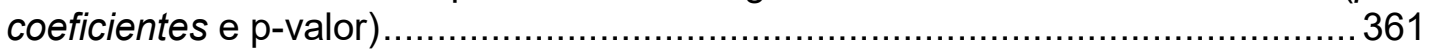

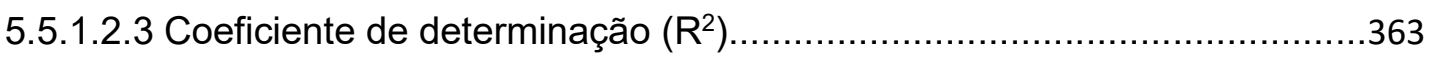

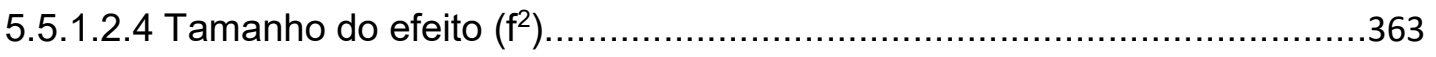

5.5.1.2.5 Teste da relevância preditiva do Modelo Estrutural $\left(Q^{2}\right) \ldots \ldots \ldots \ldots \ldots \ldots \ldots . . . . . . . . .364$

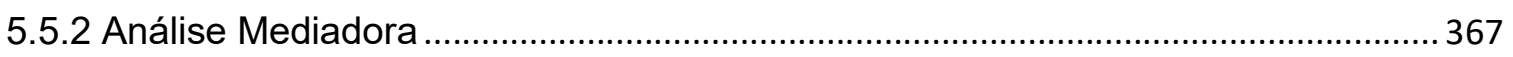

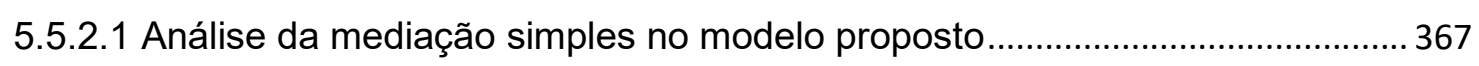

Figura 52 - Mediação entre os construtos para a organização local ............................. 367

5.5.2.2 Análise da mediação múltipla no modelo proposto............................................. 371

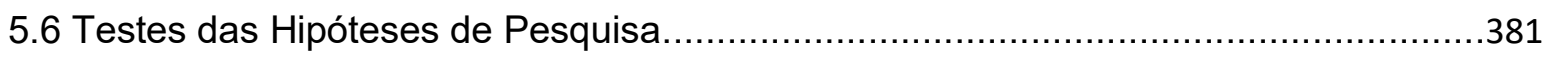

5.6.1 - Teste das hipóteses de similaridade cultural do DPR e dos SECOMs................. 381

5.6 .2 - Teste das hipóteses das relações do modelo proposto para os SECOMs ......... 384

5.6.3 Teste das hipóteses das relações indiretas (efeitos mediadores) ............................ 388

5.6.3.1 Teste das hipóteses de mediação simples de práticas organizacionais entre os

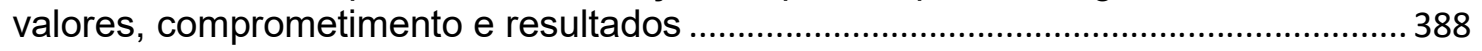

5.6.3.2 Teste das hipóteses de mediação simples de comprometimento organizacional

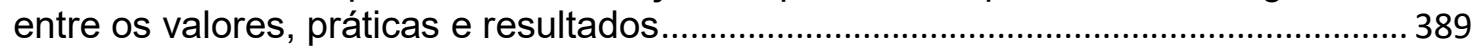

5.6.3.3 Teste das hipóteses de mediação múltipla de práticas organizacionais entre as metas motivacionais, comprometimento e resultados ...................................................... 390

5.6.4 Teste das hipóteses das relações entre as variáveis individuais e os construtos

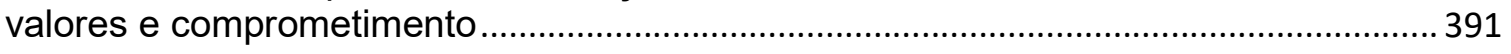

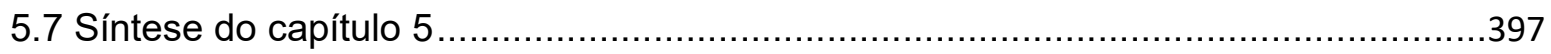

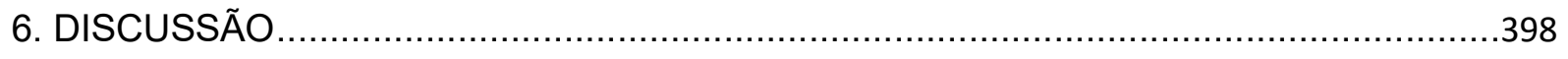

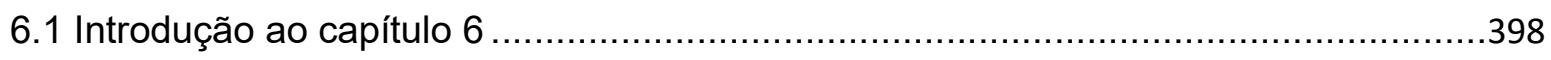

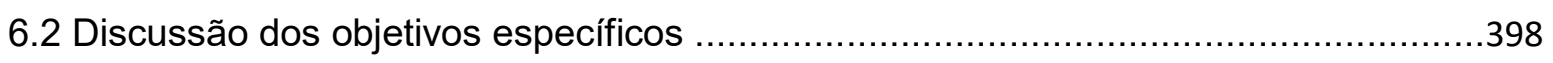

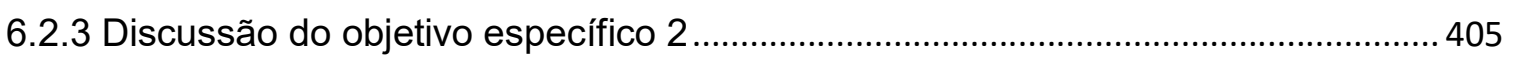

6.2.4 Discussão do objetivo específico 3 ……….............................................................. 411

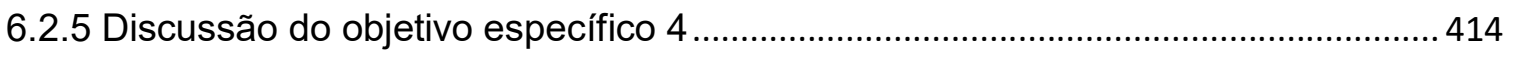

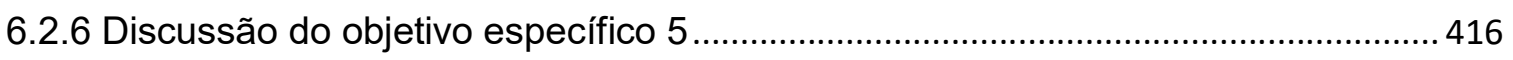

6.3 Modelo conceitual teórico e modelo conceitual integrador............................................ 417

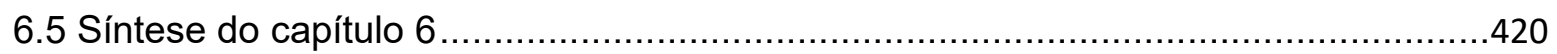

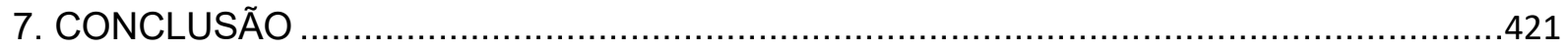




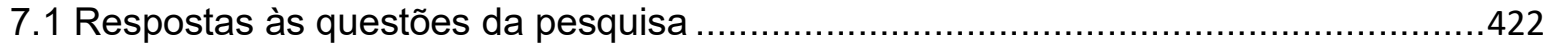

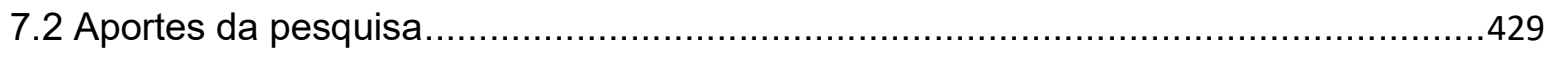

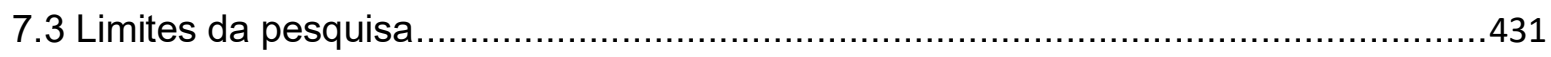

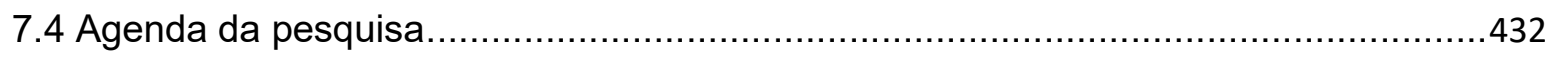

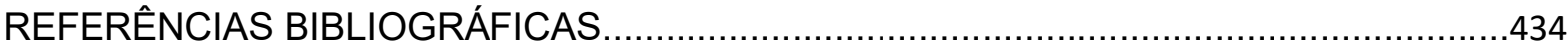

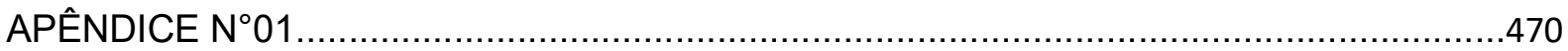

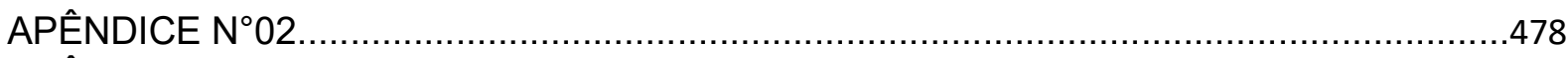

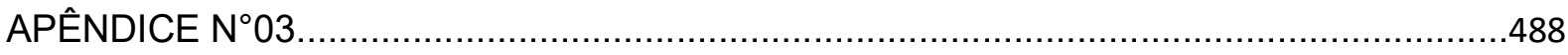

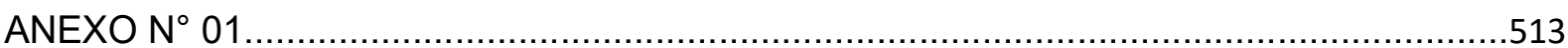





\section{INTRODUÇÃO}

No contexto atual, as sociedades estão passando por processos de transformações sociais, econômicas, políticas e culturais rápidas e profundas. Estas mudanças tiveram suas origens na revolução técnico-científica-informacional iniciada em meados do século XX em decorrência de inovações no campo da informática e suas aplicações, gerando novas tendências no fluxo de comunicações, na estrutura da matriz tecnológica e na expansão da globalização (Lévy, 1993; Negroponte, 1995; Silva, 2003).

As novas tecnologias vêm contribuindo para o encurtamento das distâncias geográficas e para o aumento da interdependência entre as nações, pois, ao permitir maior interação entre os países, foi possível o aumento das trocas de mercadorias entre eles (aumento da movimentação de bens), assim como o aumento da movimentação das pessoas e, consequentemente, das ideias (Baldwin, 2016).

As mudanças nas relações econômicas mundiais têm colocado o comércio internacional como fator decisivo para a economia dos países, tendo em vista que parte da produção é destinada aos mercados externos. A relação do estágio de desenvolvimento econômico de um país com o comércio internacional é direta, pois um país pode oferecer maiores oportunidades de emprego e melhores condições de renda, conforme for o seu posicionamento na política comercial (Morini et al., 2010).

Desde o final dos anos de 1990, as políticas públicas brasileiras vêm estimulando e sensibilizando o empresariado para a prática da exportação. E o que se viu foi um crescimento exponencial das exportações brasileiras, principalmente no período de 2003 a 2008, quando o comércio mundial passou por uma das fases mais prósperas, e o Brasil soube aproveitar essa fase, alcançando uma expansão de $21,9 \%$ ao ano no período, gerando empregos e tornando um fator importante no crescimento da economia brasileira (Ribeiro, 2009; Morini et al., 2010). Entretanto, o País passou por um período de retração, pois entre os anos de 2012 a 2016 a média das exportações brasileiras foi de $-6,1 \%$, entretanto o ano de 2017 apresentou resultado positivo de 17,4\% em relação ao ano anterior (MDIC - Balança Comercial Brasileira, 2018).

Vários são os órgãos que atuam em comércio exterior no Brasil: Conselho Monetário Nacional (CMN); Câmara de Comércio Exterior (CAMEX); Ministério do 
Desenvolvimento, Indústria e Comércio Exterior (MDIC); Ministério da Fazenda (MF); Ministério das Comunicações (MC); Ministério da Agricultura, Pecuária e Abastecimento (MAPA); Ministério da Ciência, Tecnologia e Inovação (MCTI); Agência Brasileira de Promoção de Exportações e Investimentos (Apex-Brasil); Serviço Brasileiro de Apoio às Micro e Pequenas Empresas (Sebrae); Seguradora Brasileira de Crédito à Exportação S.A. (SBCE); Confederação Nacional da Indústria (CNI); Associação de Comércio Exterior do Brasil (AEB); Fundação Centro de Estudos do Comércio Exterior (FUNCEX); Federações Estaduais; e Câmaras de Comércio. E empresas de sociedades de economia mista, tais como Banco do Brasil , Petrobras, Embraer e Eletrobrás têm operações no exterior. Aliás, a Eletrobrás e a Embraer estão entre as 20 maiores empresas exportadoras no Brasil, (Revista Exame, 2017). Entre todos esses órgãos e empresas públicas, o único que trata da diplomacia comercial é o MRE - Ministério das Relações Exteriores.

A diplomacia comercial está relacionada à promoção dos interesses da iniciativa privada do Estado no plano internacional. Sendo a promoção comercial e a atração de investimentos estrangeiros diretos para o país, suas principais funções. Entretanto, em decorrência disso, surgem outras atividades como a inteligência comercial e a prospecção de mercados, que trata de fornecer informações e obter respostas às demandas feitas pelas empresas, a promoção de pesquisa e desenvolvimento (ações de cooperação técnica), e a promoção da imagem do país no exterior (com efeitos positivos para o turismo).

Para tratar do interesse da iniciativa privada do Brasil no plano internacional, as empresas brasileiras possuem o apoio do Departamento de Promoção Comercial e Investimentos (DPR) do Ministério das Relações Exteriores (MRE), que efetua pesquisas de mercado no exterior, prepara informações sobre produtos brasileiros com potencial de exportação, identifica oportunidades de exportação e orienta exportadores sobre como exportar para mercados específicos.

No exterior, o DPR presta apoio aos exportadores brasileiros por meio da sua rede de Setores de Promoção Comercial (SECOMs), localizados em embaixadas e consulados do Brasil. No ano de 2015, o DPR ampliou para 104 o número de SECOMs fixados em 83 países que estabelecem relações comerciais com o País. Reforçando a promoção comercial brasileira em mercados tradicionais e intensificando a aproximação com os mercados emergentes. Os SECOMs captam e divulgam informações sobre 
demandas por produtos brasileiros e sobre oportunidades de investimento. Também oferecem suporte às empresas brasileiras em busca de novos mercados e negócios, bem como apoio ostensivo às missões de empresários e aos órgãos do Governo brasileiro nos países em que atuam. Produzem, ainda, estudos de inteligência comercial, como pesquisas de mercado e análises de competitividade e de concorrência (Exportação passo a passo, 2011).

A gestão dos SECOMs exige uma adaptação eficiente das estratégias do DPR às condições locais. Adquirir pessoal adequado, desenvolver as pessoas na capacidade gerencial local e reconhecer os fatores locais que possam limitar ou alterar ações gerenciais, são elementos importantes da gestão estratégica de pessoas para o DPR.

A gestão estratégica de pessoas é um tema que tem recebido atenção nos últimos anos. O número de publicações tem-se multiplicado, nacional e internacionalmente. Deadrick e Gibson (2009) ao realizarem uma análise longitudinal dos últimos 30 anos, verificaram um decréscimo do interesse em temas tradicionais que tratam das atividades funcionais de Recursos Humanos e o aumento do interesse em temas contemporâneos, como a estratégia de gestão de pessoas.

A questão de como criar valor às organizações e de como fazer para que a empresa cresça sempre permeou as discussões organizacionais. No contexto atual, a gestão de pessoas tem ganhado mais espaço na tentativa de responder a esses desafios, assumindo um papel mais estratégico e orientado para os resultados (Ulrich, 2000; Al Ariss, 2014). Para Lacombe e Albuquerque (2008), avaliar os resultados por meio da gestão de pessoas tornou-se um tema relevante porque as organizações, para adequarem-se ao novo contexto social, tiveram de investir na capacitação do seu pessoal dado o retorno que esta traz às organizações, como, por exemplo, o aumento da produtividade.

Pesquisas têm mostrado a importância de analisar a gestão de pessoas e o seu alinhamento com os resultados organizacionais como uma etapa importante do ciclo de gestão da estratégia (Coutinho \& Kallás, 2005; Lengnick-Hall et al., 2005; Farndale \& Sparrow, 2010; Meyers \& Van Woerkom, 2014). Apesar de haver vários estudos que comprovem correlações positivas entre as práticas de gestão de pessoas e investimentos na área e os resultados financeiros das organizações, poucas são as explicações sobre o motivo da existência dessas relações e sobre a forma como elas 
acontecem (Ulrich, 2000), ou seja, a investigação das etapas intermediárias deste processo, descrevendo o caminho percorrido entre a gestão de pessoas e os resultados organizacionais.

As etapas intermediárias, podem ser entendidas como os fatores que podem ser preditores ou mediadores no resultado organizacional, como, por exemplo, os valores, os tipos de práticas realizadas na organização e o comprometimento das pessoas na organização.

Práticas organizacionais podem ser entendidas como atividades e práticas sociais que fazem com que a estratégia declarada pela organização aconteça. Estas práticas se reportam às atividades formais e informais por meio das quais as ações são levadas a cabo, sendo, portanto, ações regulares e recorrentes realizadas por atores sociais, em organizações delimitadas no espaço e no tempo, que continuamente constroem e reconstroem esse sistema social (Whittington, 1996; Jarzabkowski 2004).

As práticas organizacionais passam por um processo de institucionalização, em um ambiente imerso em crenças, valores dos indivíduos e grupos que o compõem, dado que as práticas não estão dissociadas das atividades sociais. Hofstede (2003) sugere que a cultura organizacional seja estudada por meio das práticas, já que estas podem ser analisadas por observadores externos. Para o autor, a cultura organizacional é composta por dois elementos: valores e práticas organizacionais. As práticas organizacionais representam a camada mais externa e visível da cultura. E, na camada mais subjetiva e interna, configurando o núcleo da cultura, estão os valores. Nesta linha, Jackson (2002) definiu como locus of human value (lócus de valor humano) o conceito para descrever como as pessoas são valorizadas a partir dos aspectos culturais característicos de cada perfil de sociedade, e consequentemente no estilo de práticas de gestão nas diferentes culturas, distinguindo entre a visão instrumental ou humanista em relação às pessoas nas organizações.

A perspectiva instrumental tem sua origem mais fortemente atribuída aos Estados Unidos, resultado de aspectos culturais de maior separação entre vida profissional (trabalho) e pessoal (casa e comunidade), percepção individualista e foco no alcance de resultados. Já a visão humanista está mais associada a países orientais, como Japão, em que se observa maior integração entre vida profissional (trabalho) e 
pessoal (casa e comunidade) e cultura baseada no dever e no coletivismo (Jackson, 2002).

Já os valores culturais podem ser compreendidos como um conjunto compartilhado de ideias abstratas, que definem o que é bom e desejado para uma determinada sociedade, grupos e organizações (Schwartz, 2005), pois todo grupo social, toda organização produz valores. Os valores têm como função, além da manutenção da identidade organizacional, propiciar condições favoráveis para a emergência e o desenvolvimento do bem-estar da organização e do trabalhador (Tamayo, 2005). Então, o estudo dos valores organizacionais tem a possibilidade de funcionar como conector entre numerosos aspectos da ciência social, como já foi visto em pesquisas de valores associados com motivação, ética na tomada de decisão, corrupção, comportamento do consumidor, entre outros (Casado, T. et al., 2005).

O comprometimento organizacional, em termos gerais, pode ser entendido como o envolvimento com a organização que estimula a realizar um esforço considerável em prol da empresa, sendo este afetado pela natureza do vínculo: afetiva, instrumental ou normativa (Meyer, Allen E Smith, 1997). O comprometimento normativo exprime sentimentos de obrigação de que o trabalhador tem de permanecer na organização; o comprometimento instrumental relaciona-se ao interesse do trabalhador em continuar na instituição com vistas a não perder seus investimentos pessoais na organização; e o comprometimento afetivo é percebido a partir da identificação e do envolvimento do empregado com a sua organização.

Os valores pessoais e os organizacionais têm-se mostrado importantes preditores do comprometimento organizacional. Assim, é possível verificar pesquisas que tratam desses construtos em relação às dimensões de eficácia/eficiência, interação no trabalho, gestão, inovação, respeito ao servidor (Tamayo, 1998), relações humanas (Kalliath, Bluedorn e Strube, 1999), suporte, alcance de metas (Vandenberghe e Peiró, 1999), humanidade e visão (Abbott, White \& Charles, 2005; Finegan, 2000), justiça no trabalho (Jiang, 2015).

Em que pese o fato de já haver, na literatura nacional e estrangeira, várias investigações com foco nas relações entre os valores pessoais e organizacionais e o comprometimento, não foram identificadas, até a elaboração desta tese, investigações que tratem o comprometimento como mediador dos valores organizacionais sobre os 
resultados alcançados pela organização. Tampouco foi investigado o comprometimento como mediador tanto dos valores quanto do valor atribuído às pessoas por meio das práticas organizacionais sobre os resultados.

Em função do contexto de globalização, há uma tendência mercadológica de expansão de empresas para além de suas fronteiras nacionais, por meio do estabelecimento de filiais em outros países. Entretanto, ao se estruturarem essas empresas locais, há uma forte tendência da matriz em replicar suas práticas de gestão sobre as filiais, estabelecendo o seu lócus de valor humano (Brewster, Wood \& Brookes, 2008; Jackson, 2002). Porém, essa replicação direta pode ser dificultada por conta da cultura nacional local, podendo gerar impactos negativos na motivação e na produtividade (Jackson, 2002), percebendo que o local não é necessariamente um simples reflexo ou um "apêndice" da matriz. O que se percebe é que a distância cultural aumenta as dificuldades nas relações entre empresas. E quanto maior esta distância, maiores são as diferenças nas práticas organizacionais, administrativas e nas tentativas de interpretar e responder a questões estratégicas (Ariño et al., 1998).

Diante disso, a relevância em se estudarem as relações de construtos da cultura organizacional (valores e gestão de práticas organizacionais) e comprometimento como antecedentes do resultado organizacional pode ser uma boa medida para compreender fatores impeditivos e colaborativos de que organizações locais cumpram com os objetivos estabelecidos pela instituição nacional.

Temas atuais sobre gestão de pessoas têm abordado fatores macro-organizacionais como antecedentes do resultado organizacional. A exemplo disto, tem-se: Tamayo (2005) e Finegan (2000), que investigaram a influência dos valores organizacionais sobre o comprometimento afetivo; Gomes (2013), que estudou os determinantes do desempenho e o efeito moderador da cultura; Dias (2010), que analisou a relação entre liderança, confiança e desempenho organizacional; Nascimento (2014), que analisou o desempenho profissional por meio das relações entre valores, práticas organizacionais e identidade. Alguns estudos sobre cultura organizacional veem relação entre tipo de cultura e desempenho organizacional ou efetividade, em que a cultura organizacional é o que sustenta a vantagem competitiva das organizações (Deal \& Kennedy, 1982; Denison, 1997). Para Barney (1986), uma forte relação entre a estratégia organizacional e cultura organizacional é crucial para a implementação de estratégias bem-sucedidas. Outra relação importante, vista por O’Reilly (1989), é 
que a cultura organizacional contribui para o desenvolvimento de altos desempenhos e aumento do comprometimento dos empregados.

Pesquisadores brasileiros no campo de estudos do trabalho e das organizações têm concentrado suas análises sob a ótica transcultural. Talvez um dos fatores que explique esse fato seja a necessidade de acompanhar a tendência mercadológica de expansão de empresas para além de suas fronteiras nacionais. Neste contexto, Carvalho e Borges (2012), por meio de um levantamento do que foi publicado nos anos de 2006 a 2012, apontaram o crescimento da participação de brasileiros nas pesquisas transculturais relativas aos estudos de valores humanos e culturais (Borges; Vikan; Pilati, 2011; Carvalho et al., 2011; Ferreira et al., 2006; Fischer et al., 2007; França, 2009; Gouveia et al., 2010; Omar et al., 2007; Silva; Gomes; Correia, 2009; Smith et al., 2011; Teixeira; Domenico, 2008; Torres; Allen, 2009; Torres; PérezNebra, 2007). Entretanto, não foram encontrados até a elaboração desta pesquisa, estudos que tratem da atuação brasileira em nível governamental em outros países e, especificamente, que tenham como foco a efetividade de instituições governamentais na captação de recursos a serem investidos no País, assim como na efetividade de instituições governamentais que fomentam a internacionalização de empresas brasileiras, por meio de organizações brasileiras localizadas em outros países e que se utilizam, além de nacionais, da força de trabalho local para cumprir os objetivos estratégicos determinados pelo órgão federal brasileiro.

O conhecimento a respeito do valor atribuído às pessoas em diferentes localidades, a partir do ponto de vista de uma organização pública nacional, pode contribuir para construir uma visão mais próxima à realidade dos aspectos da cultura brasileira de gestão de pessoas em operações internacionais. É neste contexto que se insere este trabalho.

A pesquisa que fundamenta esta tese foi desenvolvida no Departamento de Promoção Comercial e Investimentos do Ministério das Relações Exteriores (DPR) e nos Setores de Promoção Comercial (SECOMs). Dada a diversidade de países em que os SECOMs estão localizados, passou-se a indagar se há similaridades na cultura organizacional do DPR e dos seus SECOMs, pois, a partir da similaridade dos valores e das práticas, a gestão de estruturas organizacionais tão distantes poderia ser facilitada pela sintonia da cultura entre o DPR e os SECOMs

Nesta linha, surgem as seguintes questões: os valores e os tipos de práticas 
identificados na instituição nacional (DPR) são próximos aos valores e as práticas identificados na organização local (SECOMs)? E, para as organizações locais (SECOMs), questiona-se se os valores organizacionais influenciam os tipos de práticas organizacionais e o comprometimento? Ou somente os tipos de práticas organizacionais influenciam o comprometimento? Será que os valores, os tipos de práticas (humanista ou instrumental) e o comprometimento organizacional são variáveis antecedentes e explicativas do resultado organizacional? Caso sejam, que dimensões emergem dos valores, dos tipos de práticas e do comprometimento para explicar o resultado organizacional? Há diferenças na percepção dos valores e do comprometimento para os brasileiros e os não brasileiros que trabalham nos SECOMs? E estas diferenças seriam percebidas entre os que têm mais tempo de serviço em relação aos mais novos? Há diferenças entre homens e mulheres? Os tipos de práticas organizacionais atuam como mediadoras da relação entre valores e os resultados? E da relação entre valores e comprometimento? O comprometimento atua como mediador da relação entre os tipos de práticas e os resultados? E da relação entre valores e resultados?

Com base nesses questionamentos, este trabalho propõe-se a estudar, no âmbito de organizações transculturais, a cultura organizacional, por meio dos valores e das práticas, e o comprometimento e como suas relações podem ser estabelecidas com os resultados organizacionais.

\subsection{Objetivo Geral}

Os questionamentos apresentados estão no contexto da estratégia de recursos humanos em organizações transnacionais. Este trabalho tem como objetivos geral e específicos:

Identificar e descrever a influência das manifestações da cultura da Instituição, ${ }^{1}$ por meio dos valores e dos tipos de práticas organizacionais, sobre o comprometimento, bem como a influência dessas manifestações e do comprometimento sobre os resultados organizacionais.

\footnotetext{
${ }^{1}$ Por Instituição se entende a instituição nacional (DPR) e as organizações locais (SECOMs)
} 


\subsubsection{Objetivos Específicos}

Para o alcance do objetivo geral, os seguintes objetivos específicos foram propostos:

OE1: Estudar a influência da cultura organizacional, mensurada por meio dos valores e dos tipos de práticas organizacionais, da instituição nacional (DPR) sobre as organizações locais (SECOMs).

OE2: Estudar o comprometimento das organizações locais (SECOMs), identificando a natureza do comprometimento que mais se destaca: normativa, afetiva ou instrumental.

OEз: Analisar a influência da cultura organizacional das organizações locais (SECOMs), mensurada por meio dos valores e dos tipos de práticas organizacionais, sobre os demais construtos do estudo (comprometimento e resultados).

OE4: Estudar as possíveis relações entre as variáveis sociodemográficas das organizações locais (SECOMs) sobre os valores e o comprometimento organizacional.

Oe5: Verificar se comprometimento é mediador das relações entre os tipos de práticas e os valores da organização local e seus resultados. E verificar se práticas organizacionais são mediadoras das relações entre valores da organização local e seus resultados, bem como o comprometimento.

\subsection{Relevância do Trabalho}

\subsubsection{Nível Teórico}

A relevância desta pesquisa está na contribuição aos trabalhos empíricos em Estratégias de Gestão de Pessoas, sobretudo na descrição dos resultados da organização por meio da cultura organizacional. O que se espera é que esta pesquisa auxilie no avanço dos estudos, ao descrever e modelar a influência dos valores, dos tipos de práticas organizacionais e do comprometimento sobre os resultados organizacionais.

Contribuição importante é o fato de a pesquisa ser realizada em organização pública 
no contexto de diplomacia comercial, a qual tem por objetivo, em conjunto com outros órgãos da Administração Pública Federal, auxiliar o Brasil no comércio internacional. Nesta área, há escassez de pesquisas sobre a identificação de similaridades da cultura e do comprometimento entre os colaboradores que, apesar de cumprirem o mesmo objetivo institucional, estão localizados em países muitas vezes diversos aos costumes e práticas das organizações brasileiras.

\subsubsection{Nível Metodológico}

A contribuição desta pesquisa neste nível está na utilização de uma abordagem quantitativa e da utilização de recursos estatísticos modernos como a modelagem de equações estruturais (MEE), com aplicação do método de estimação dos mínimos quadrados parciais (PLS-PM), assim como na validação da escala de comprometimento EBACO elaborada por Medeiros (2003) e na utilização da escala de lócus de valor humano de Jackson (2002), inédita em pesquisas no Brasil. A contribuição também se manifesta na proposta de um modelo integrativo que visa mostrar a significância dos valores, dos tipos de práticas e do comprometimento sobre os resultados em organização pública que opera em outros países.

\subsubsection{Nível de Aplicação}

Sobre a contribuição gerencial, a descrição dos valores e das práticas similares entre a instituição nacional e as organizações locais, bem como a identificação de quais bases comprometimentos são mais preponderantes, poderão contribuir para a formulação de políticas de Recursos Humanos do DPR para os seus Setores de Promoção Comercial, de forma que os SECOMs se sintam mais identificados com o DPR.

O estudo das variáveis sociodemográficas poderá permitir ações pontuais dos gestores para com os seus colaboradores, a partir de informações segmentadas pelo tempo de serviço, nacionalidade e sexo que possam explicar diferenças nas similaridades ou dissimilaridades das percepções dos seus colaboradores que possam influenciar no comprometimento e, consequentemente, no desempenho da organização. 


\subsection{Estrutura da tese}

Dado que o objetivo principal desta tese é examinar a influência das manifestações da cultura da Instituição (DPR e SECOMs) por meio dos valores e dos tipos de práticas organizacionais e do comprometimento sobre os resultados organizacionais, diversas etapas foram seguidas para o alcance desse objetivo.

O capítulo dois apresenta o referencial teórico que, por meio de uma abordagem histórica, conceitual e multidisciplinar trata da cultura e suas múltiplas abordagens e a forma como cultura será abordada nesta pesquisa. Apresentam-se os valores pessoais e os valores organizacionais, as práticas organizacionais e o comprometimento e de como suas abordagens conceituais serão desenvolvidas neste trabalho.

O terceiro capítulo versa sobre os objetivos da pesquisa e a proposição do modelo conceitual integrador. Neste capítulo também serão apresentadas as hipóteses da pesquisa para as variáveis principais (valores, práticas e comprometimento) e para as variáveis sociodemográficas (tempo de serviço, nacionalidade e sexo).

O capítulo quatro discorre sobre os procedimentos metodológicos: a abordagem da pesquisa; o desenho do estudo quanto ao lócus da pesquisa, o plano amostral, a coleta de dados e os instrumentos de pesquisa (escalas valores, de percepções de práticas e de comprometimento); e apresentação dos resultados organizacionais dos SECOMs. Outro item deste capítulo é o que trata da forma como os dados serão analisados: por meio da análise univariada, em que os itens das escalas serão avaliados quanto a homogeneidade e confiabilidade; a análise bivariada em que se apresenta o teste t entre amostras independentes e o teste de correlação de Pearson; e a análise multivariada, em que são apresentados os princípios básicos da modelagem de equações estruturais, a análise mediadora e a análise de mediação múltipla.

O quinto capítulo apresenta a forma como os dados foram preparados e a amostra obtida, as características sociodemográficas dos colaboradores do DPR. Já na análise univariada das escalas é feita uma descrição dos principais resultados encontrados por meio de suas médias e coeficientes de variação; e no teste de comparação de médias, é realizada uma análise das médias obtidas em cada uma das escalas 
(valores, práticas e comprometimento) e para as escalas de valores e de práticas fazse a comparação das médias do DPR e dos SECOMs por continente; e para a escala de valores faz-se a comparação entre os SECOMs por continente. A análise bivariada trata de avaliar as diferenças entre os valores organizacionais e os tipos de práticas do DPR e dos SECOMS, diferenças na percepção do comprometimento em função do tempo de serviço, da nacionalidade e do sexo. $\mathrm{Na}$ análise de correlação de Pearson, estudam-se as relações entre os valores, os tipos de práticas e o comprometimento com os resultados obtidos pelos SECOMs, além das relações entre valores e tipos de práticas, tipos de práticas e comprometimento e entre valores e comprometimento organizacional. Na análise multivariada, testa-se a relação conjunta dos valores, das práticas e do comprometimento e seus impactos nos resultados organizacionais dos SECOMs. E, por fim, apresentam-se todas as análises sobre as hipóteses que foram estabelecidas no terceiro capítulo.

No capítulo seis, discutem-se, interpretam-se e colocam-se em evidências os resultados da pesquisa. A discussão dos resultados é feita sob a perspectiva dos objetivos específicos que foram elaborados para subsidiar o objetivo geral.

Finalmente, na conclusão da tese, retomam-se o objetivo geral e as questões da pesquisa, as contribuições teóricas, metodológicas e as implicações gerenciais do estudo. Finaliza-se com a apresentação das limitações da pesquisa e com uma agenda para futuras investigações. A estrutura da pesquisa é mostrada na figura 01.

Figura 01 - Estrutura da tese

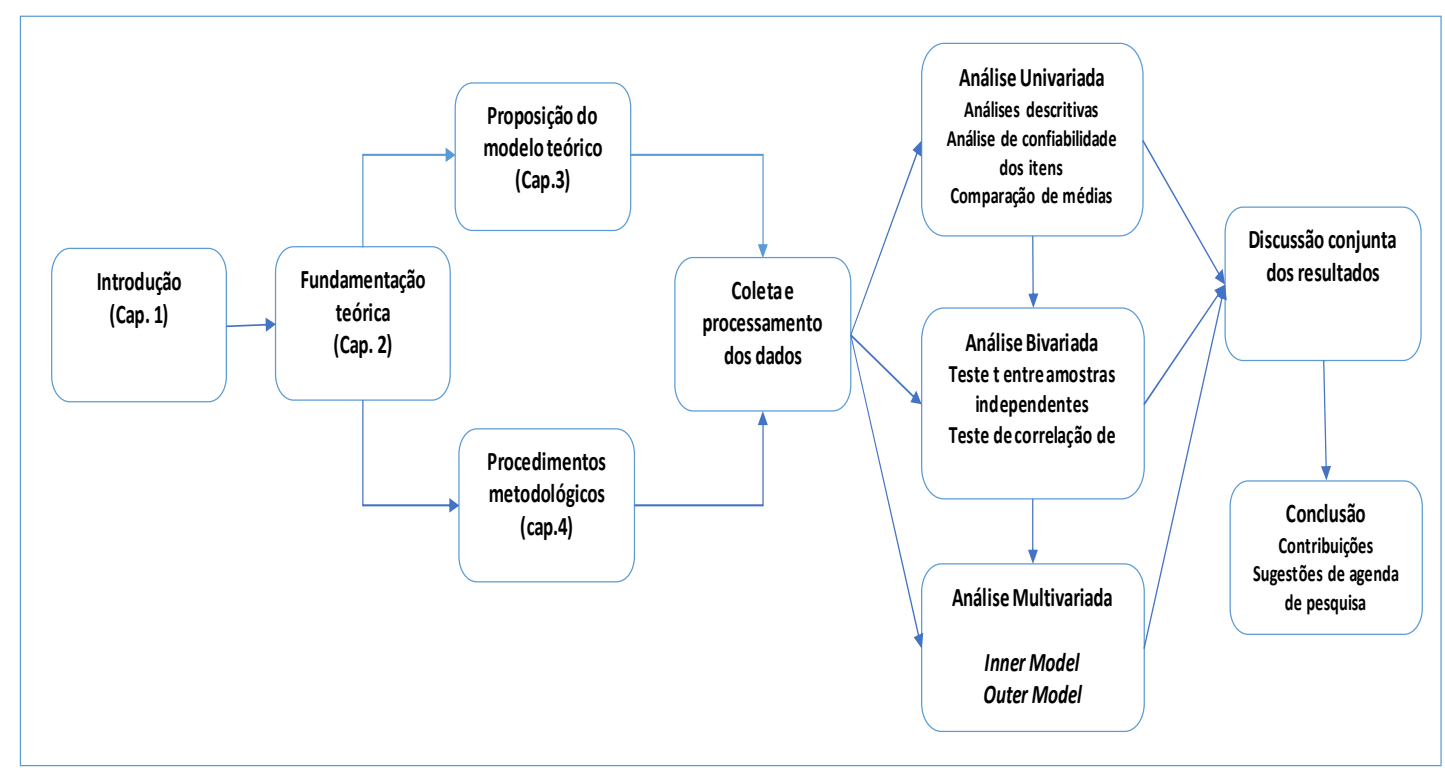

Fonte: elaborado pela autora 


\section{REFERENCIAL TEÓRICO}

\section{A ciência nada mais é que o senso comum refinado e disciplinado}

Gunnar Myrdal

\subsection{Introdução ao capítulo 2}

O referencial teórico visa estabelecer a base teórica que irá dar sustentação ao desenvolvimento do tema aqui apresentado. Segundo Severino (2007 p. 131) "Trata de esclarecer as várias categorias que serão utilizadas para dar conta dos fenômenos a serem abordados e explicados (...) outras vezes, trata de definir bem as categorias explicativas de que se precisa para analisar os fenômenos que são objeto de pesquisa". Neste trabalho, as bases teóricas que irão subsidiar a utilização das escalas de medidas e análise das conclusões obtidas sobre o campo de pesquisa serão os estudos referente à cultura, em específico à cultura organizacional, os valores pessoais e organizacionais, as práticas organizacionais e a forma como esta pode ser percebida por seus gestores, o comprometimento e os resultados organizacionais.

\subsection{Cultura, Valores e práticas}

A seguir apresenta-se uma revisão do complexo e polissêmico tema cultura, e, de forma específica, a cultura organizacional. A primeira parte aborda as origens e bases teóricas, depois segue para a conceitualização da cultura organizacional e de como esta será entendida neste trabalho. Como o tema aborda uma perspectiva transcultural, será apresentado como a cultura nacional pode influenciar a cultura organizacional, apresentando autores tradicionais sobre o tema e um breve estudo comparativo destes autores quanto às suas metodologias. No estudo de valores, inicia-se por uma abordagem dos valores humanos (individuais) e converge-se para os valores organizacionais e, em seguida, apresenta-se uma descrição do modelo teórico como referência para o instrumento de pesquisa que foi utilizado nesta pesquisa. Em seguida, será tratado o tema sobre práticas organizacionais, como elemento manifesto da cultura organizacional e de como as práticas organizacionais 
e o valor atribuído às pessoas são percebidos pelos seus gestores, de forma mais instrumental ou mais humanista. Dando continuidade, aborda-se o tema comprometimento organizacional, que será tratado sobre suas diferentes perspectivas e bases conceituais. E, por último, apresentam-se conceitos sobre o que se entende por resultados organizacionais e de como este será abordado neste trabalho.

\subsubsection{Cultura - pressupostos teóricos}

Apesar de os estudos sobre cultura terem sido abordados pela Antropologia e Sociologia desde o século XIX e pela Psicologia a partir do início do século XX, foi a partir de 1970 (Schein, 1988) que este tema se tornou centro de estudos nas organizações. Estudos precursores sobre cultura organizacional podem ser vistos, por exemplo, na pesquisa realizada em Hawthorne (1920 a 1930) por Elton Mayo, cuja preocupação estava em relacionar produtividade e comportamento das pessoas; ou Jaques (1951/2003), que, a partir da sua pesquisa longitudinal em uma metalúrgica inglesa e fundamentado em princípios sociológicos, descreveu alguns elementos da cultura que retratavam o contexto fabril, como hábitos, costumes, normas e valores relacionando esses elementos à estrutura organizacional e as suas práticas.

De acordo com Schein (1988), na década de 1940, investigadores que desenvolveram pesquisas em ambientes organizacionais, especificamente quanto ao treinamento gerencial, valiam-se do termo "ilha cultural" para explicar diferenças comportamentais em momentos de treinamento no ambiente organizacional. Nesta época, havia pouca ênfase na cultura, visto que as normas grupais eram até então suficientes para abordar este fenômeno. Nos anos de 1950 e 1960, o foco estava sobre as equipes de trabalho e, dessa forma, a cultura organizacional foi preterida para estudos relacionados às normas de atitudes e comportamentos percebidos no microambiente do trabalho e ao clima organizacional.

Schein (1988) alega que, a partir da década de 1970, investigadores, utilizando-se de pensamentos da área da sociologia e da antropologia, passaram a investigar a cultura das organizações como um construto que possibilitou analisar os grupos de trabalho, os padrões de comportamento e a dinâmica da organização como um todo. Os estudos do pesquisador Pettigrew (1979) foram decisivos para a evolução do conceito de cultura organizacional. O sistema social de Katz e Kahn (1996) destacou a 
relevância dos valores, normas e papéis para a organização, mas nessa abordagem clima e cultura são tratadas como similares. E, somente com a evolução dos estudos, mostrou-se distinção entre esses dois conceitos, uma vez que cultura trata de ser um construto mais complexo do que clima organizacional (Schneider, 1985), pois este é relativo às percepções e interpretações das políticas, atividades e ambiente da organização (Tamayo, 1999; Brown \& Leigh, 1996) e aquele está mais relacionado à compreensão e ao compartilhamento das normas e dos valores precursores das atividades e das políticas institucionais e pela forma como essas atividades e políticas são comunicadas e transmitidas à organização (Schneider, 1985).

Entretanto, foi a partir da década de 1980 que estudos sobre cultura passaram a ser mais frequentes. A razão desse interesse pode ter ocorrido por dois fenômenos: a queda da produtividade norte-americana e o ganho de competitividade dos japoneses (Deal, T. \& Kennedy, 1982; Hofstede, 1986; Fleury, 1987; Sparrow, 2001).

Para Alvesson (2002) a explicação para este entusiasmo não seria unicamente o milagre japonês, mas outros fatores também teriam sido significativos: (1) o avanço da tecnologia gerou quebra de unidade nos padrões organizacionais, surgindo novos formatos organizacionais que refletiram na estrutura da organização, diminuindo seus níveis hierárquicos e proporcionando formas diferentes de organização do trabalho; (2) ocorreram mudanças nos valores e no estilo de vida da sociedade, tornando o controle corporativo mais complicado, fazendo perceber a importância de envolver os trabalhadores nas empresas e estabelecendo estilos menos autoritários de gestão; (3) métodos tradicionais de realizar pesquisas organizacionais, por vezes objetivistas e abstratas, revelaram-se não satisfatórios para interpretarem a nova realidade das organizações, diferentemente da cultura, a qual teria a vantagem de realizar uma ponte conceitual entre micro e macro níveis de análises e entre o comportamento organizacional e a gestão estratégica, pois consegue conectar a organização como um todo por meio das experiências diárias proporcionadas pelas ações individuais e coletivas das pessoas; (4) a dúvida, um penetrante recurso da razão crítica moderna, passa a permear a vida cotidiana, formando uma dimensão existencial geral do mundo social contemporâneo, com isso a obediência tradicional às autoridades desapareceu. Os gestores, assim como outras autoridades convencionais, foram cada vez mais confrontados com uma falta de vontade dos subordinados para aceitarem cegamente suas ordens. Em vez disso, os gerentes precisavam convencer seus subordinados, 
clientes e parceiros sobre as crenças, valores e ideais que deveriam lutar e aceitar como diretrizes. Assim, houve uma nítida mudança na prática de gestão de pessoas: de monitoramento do comportamento e mensuração dos resultados para monitoramento de atitudes e estabelecimento de meios de como melhorar o comprometimento das pessoas na organização (Alvesson, 2002).

Estas tendências geraram desintegrações nos modelos tradicionais de gestão. A diversidade de pensamentos das pessoas propiciou dificuldades no processo de interação social e isso fez com que o conteúdo das ideologias organizacionais fosse revisado. Assim, a cultura organizacional surge como uma fascinante oportunidade de compreender este processo de diversidade e desintegração bem como instrumento integrador, evidenciando ideias comuns, valores, formas de pensar e de trabalhar, por meio da formação de uma ordem interna particular, mediante consenso, cooperação e reciprocidade entre os membros da organização.

\subsubsection{Cultura e suas múltiplas abordagens}

Semelhantemente às escolas que definem as teorias organizacionais, a cultura organizacional também apresenta diferentes formas de tratar e categorizar seus estudos, cujas bases conceituais são advindas de várias áreas do conhecimento das ciências sociais, como a Antropologia, a Sociologia, a Economia ou as Ciências Empresariais, e essa multiplicidade de bases teóricas tem gerando incertezas quanto a sua epistemologia. Aliada a essa fragilidade epistemológica, há uma diversidade de pesquisas que vêm produzindo tipologias de culturas, mas com pouco consenso entre os acadêmicos, tornando-as inconsistentes. Mesmo diante disso, observa-se que a maioria dos estudos referentes ao processo de construção da cultura tem sido desenvolvida a partir de dois polos. Para Linda Smircich (1983), os estudos referentes sobre esse construto podem ser idealizados sobre duas óticas:

(1) Como metáfora -> considera cultura como algo que a organização é. A cultura é compreendida como uma metáfora da própria organização, ou seja, um fenômeno social e histórico, investigando o modo pelo qual a organização atingiu o seu status atual e o que isto significa para a organização. 
(2) Como variável -> considera a cultura como algo que a organização tem. Fundamentada no paradigma funcionalista, ora se torna variável independente cujo comportamento provoca, dentro de uma relação causal, efeitos sobre os resultados organizacionais, ora como variável dependente, em que a cultura é resultante das interações dos vários elementos que compõem a organização: pessoas, ambiente e estruturas.

De acordo com Schultz (1995), a cultura como variável seria elaborada tanto pela concepção racionalista, exemplificada por Peters e Waterman (1982) e Deal e Kennedy (1982), em que a cultura é ferramenta para o alcance dos resultados organizacionais, quanto pela concepção funcionalista, concebida por Parsons (1960) e Schein (1985), em que a cultura é um conjunto de valores compartilhados e de pressupostos básicos e tem como função proporcionar a adaptação e a integração da organização ao seu ambiente (a organização só sobrevive por meio do desempenho de suas funções essenciais). E a cultura como metáfora na perspectiva simbólica, desenvolvida por antropólogos como, por exemplo, Geertz (1993), em que a cultura é vista como um padrão de símbolos e de significados.

Smircich (1983) convergiu formulações antropológicas referentes à cultura com os estudos sobre organização, transversalizando as duas formas (metáfora e variável) de distinguir cultura, e identificou os cinco principais paradigmas que embasam os estudos sobre cultura nas organizações:

Administração corporativa (cross-cultural) -> centra-se no contexto cultural de forma mais ampla e na sua influência sobre os membros da organização.

Cultura corporativa $->$ as organizações são percebidas como instrumentos sociais que produzem bens e serviços e como subprodutos. Como são produtoras de artefatos culturais, a cultura é vista como uma variável interna. Este modelo é o mais utilizado em pesquisas relativas à mudança e ao desenvolvimento organizacional (Freitas, 1999).

Cognição organizacional -> tenta identificar como os membros de uma determinada cultura percebem internamente a organização, bem como sua autoimagem.

Simbolismo organizacional -> representa o que se faz necessário para compreender e interpretar a organização. 
Processos inconscientes e organização (psicoestruturalismo) -> concentra-se nas expressões dos processos psicológicos inconscientes.

Burrel e Morgan (1979) apresentam um modelo bidimensional a partir da tese de que "todas as teorias das organizações são baseadas em uma filosofia da ciência e em uma teoria da sociedade". Burrel e Morgan (1979, p. 1) perceberam que essas questões poderiam ser sustentadas por quatro amplas visões mutuamente exclusivas de mundo: (1) a dimensão subjetiva-objetiva ${ }^{2}$, que integra postulados interconectados e não dissociados referentes às ciências sociais, sendo de natureza ontológica (realismo/nominalismo), epistemológica (positivismo/antipositivismo), humana (determinismo/voluntarismo) e metodológica (nomotética/ideográfica); e (2) a dimensão mudança radical/regulação, que configura suposições relativas à natureza da sociedade que pode ser tanto reguladora ${ }^{3}$ quanto de natureza ágil, em processo radical de mudança 4 (ordem/mudança) (Morgan, 2007).

A partir desses pressupostos, foram estabelecidos quatro paradigmas que são especificados por Burrell e Morgan (1987) da seguinte forma: sob a dimensão subjetiva, tem-se o paradigma Humanismo Radical e o paradigma Interpretativo; sob a dimensão objetiva, tem-se o paradigma Estruturalismo Radical e o paradigma Funcionalismo. Os paradigmas interpretativista e funcionalista compartilham de um entendimento regulador da sociedade e os paradigmas humanismo radical e estruturalismo radical partilham do pressuposto de mudanças radicais da sociedade, como pode ser visto na figura 02 , abaixo.

\footnotetext{
${ }^{2}$ Natureza da ciência social subjetiva: quanto a proposição ontológica, a realidade é interpretada por meio do indivíduo; é construída socialmente (nominalismo). Quanto a proposição epistemológica, o conhecimento é relativo; os investigadores devem focalizar no significado e examinar a totalidade de uma situação (anti-positivismo). Nessa modalidade os seres humanos possuem a vontade livre e têm autonomia (voluntarismo). E nas proposições metodológicas o mundo é melhor compreendido pela análise subjetiva em acordo a uma situação ou aos fenômenos - ideográfico - (Santos \& Farias, 2010).
}

Natureza da ciência social objetiva: quanto a proposição ontológica, a realidade é externa ao indivíduo, é "dada" (realismo). Quanto a proposição epistemológica, os investigadores devem enfatizar nas evidências empíricas e no teste de hipóteses, procurando leis fundamentais e no estabelecimento de causa e efeito (positivismo). Nessa modalidade os seres humanos são produtos de seus ambientes (determinismo. E nas proposições metodológicas foca-se na operacionalização e na construção de medidas, associadas a técnicas de análises quantitativas e testes de hipóteses, cuja finalidade é a descoberta de leis universais que explicam e governam a realidade - Nomotético - (Santos \& Farias, 2010).

${ }^{3}$ A sociedade tende para a unidade e a coesão. As forças da sociedade mantêm o estado atual.

${ }^{4} \mathrm{~A}$ sociedade tem uma estrutura profunda e conflitante e tende a oprimir e a constranger seus membros 
Figura 02 - Pressupostos de dimensão

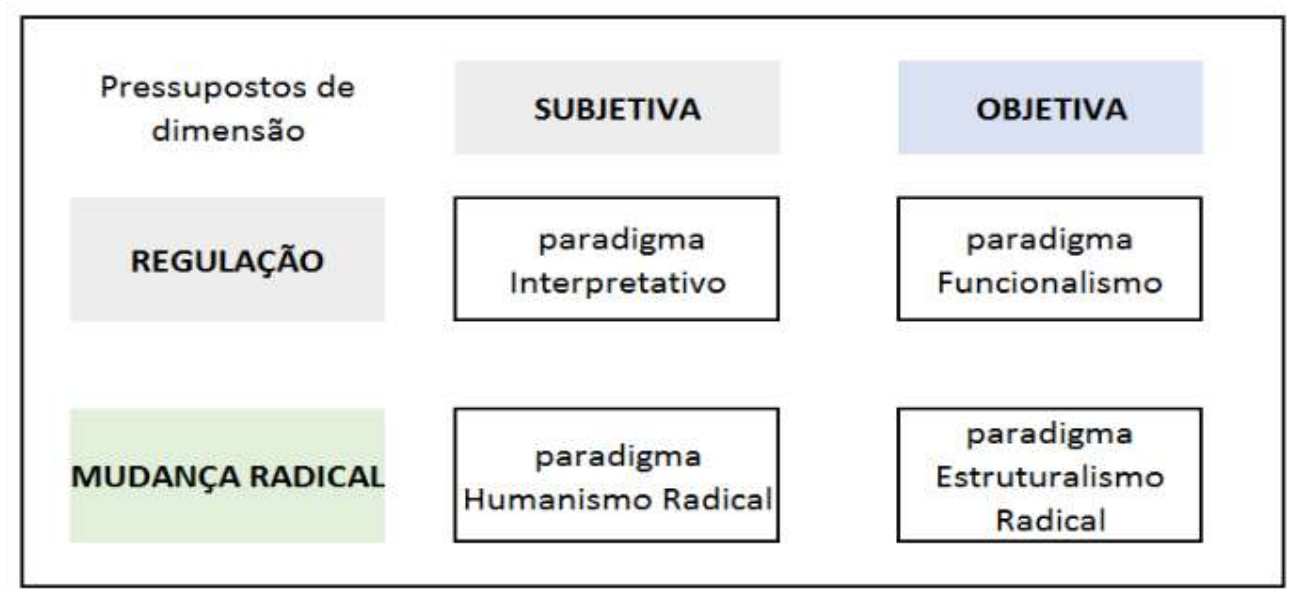

Fonte: Burrel e Morgan (1987), com adaptações

Cada um desses paradigmas, segundo Morgan (2007, p.15), "representa uma rede de escolas de pensamento inter-relacionadas, diferenciadas em abordagem e perspectiva, mas que compartilham pressupostos fundamentais sobre a natureza da realidade que tratam", ou seja, essas perspectivas são de total oposição um ao outro, se a teoria foi inserida em um paradigma, então não haverá possibilidade de estar vinculada aos outros três paradigmas.

Paradigma funcionalista -> presume a objetividade, investiga o que pode ser observável no mundo e estabelece generalizações a fim de prever e controlar as situações.

Paradigma interpretativo -> presume a subjetividade, parte do pressuposto de que a realidade social é um processo simbólico criado por ações contínuas da experiência subjetiva e intersubjetiva das pessoas,

Paradigma humanismo radical -> presume a subjetividade, a realidade e a ordem social são construídas e sustentadas como fruto de coerção e não de consentimento.

Paradigma estruturalismo radical -> presume a objetividade, a realidade é algo que existe por si mesma, caracterizada por tensões e contradições entre elementos antagônicos e que convergirá em mudanças radicais no sistema como um todo.

No anexo 1 apresenta-se um quadro com as principais características dos quatro paradigmas de Burrel e Morgan. 
Alvesson e Berg (1992) agrupou os estudos referentes à cultura em convenções e perspectivas, ou seja, para cada conceito associado à cultura, tem-se um conjunto de perspectivas que lhe dão suporte, que representam uma visão comum de um grupo de pesquisadores na caracterização e na construção de um objeto de pesquisa. "Todas as perspectivas abordam aspectos como: normas, atitudes, valores, emoções, cognição, significados, suposições, fantasias e símbolos. A diferença está no grau dessa abordagem, ou seja, alguns elementos são mais profundamente e fortemente estudados, enquanto outros são deixados de lado" (Carrieri, 2001 P.7), como pode ser visto no quadro 01, abaixo:

Quadro 01 - Tipologia de Alvesson e Berg para o estudo da cultura

\begin{tabular}{|c|c|c|}
\hline Convenções & Perspectivas & Autores \\
\hline Cultura & $\begin{array}{l}\text { Cultura corporativa } \\
\text { Cultura como sistema de valores } \\
\text { Cognitivismo cultural } \\
\text { Cultura como sistema de símbolos }\end{array}$ & $\begin{array}{l}\text { Kalmann, Davis, Deal, Kennedy, Saffold } \\
\text { Schein, Dyer, Patterson } \\
\text { Brown, Ouchi } \\
\text { Guagliardi, Louis, Pettigrew }\end{array}$ \\
\hline $\begin{array}{l}\text { Construçãa de } \\
\text { significados }\end{array}$ & $\begin{array}{l}\text { Significados compartilhados } \\
\text { Construção e desconstrução de significados }\end{array}$ & $\begin{array}{l}\text { Smircich, Morgan, Frost } \\
\text { Martin, Meyeraon, Gray, Gzarnawska-Joerges }\end{array}$ \\
\hline Ideologia & $\begin{array}{l}\text { Ideologia corporativa } \\
\text { Ideologia política }\end{array}$ & $\begin{array}{l}\text { Beyer, Harrison, Meyer } \\
\text { Deetz, Wilmont, Mumby }\end{array}$ \\
\hline Psicodinâmica & $\begin{array}{l}\text { Fantasias compartilhadas } \\
\text { Cultura como arquétipos }\end{array}$ & $\begin{array}{l}\text { Kets de Vries, Miller, Bion } \\
\text { Bird }\end{array}$ \\
\hline Simbolismo & $\begin{array}{l}\text { Particularismo simbólico } \\
\text { Universalismo simbólico }\end{array}$ & $\begin{array}{l}\text { Feldman, March } \\
\text { Berg, Cassirer, Langer }\end{array}$ \\
\hline
\end{tabular}

Fonte: Adaptado de Alvesson e Berg (1992)

Importante ressaltar que as perspectivas são dinâmicas, podendo se sobrepor ou se mesclar. Carrieri (2001) traz uma descrição dessas convenções:

Cultura -> as organizações dessa perspectiva têm uma única cultura com uma orientação instrumental, sendo assim, predominantemente, funcionalistas. A perspectiva da cultura como sistema de símbolos está mais associada ao paradigma interpretativo, já que sua abordagem é mais subjetiva, pois se ocupa com a ordem e a regulação do mundo social. 
Construção de significados -> busca assimilar a realidade social e organizacional fundamentada em aspectos históricos. Aproxima-se da abordagem que investiga a cultura como metáfora das organizações, sendo fortemente influenciada pelo paradigma interpretativo, já que comporta duas perspectivas conexas à visão subjetiva da realidade (a organização como significados coletivamente compartilhados; e a organização como construção e desconstrução de significados).

Ideologia -> a ideologia se destaca dos demais elementos constitutivos da cultura (ritos, mitos, cerimônias) e passa a ser componente principal dos estudos do construto cultura.

Psicodinâmica -> a cultura é descrita como produto do inconsciente das pessoas, as perspectivas dessa convenção objetivam identificar ansiedades e impulsos agressivos dos indivíduos que podem interferir na sua produção.

Simbolismo -> suas perspectivas são influenciadas pelo paradigma interpretativo. Tem como conjectura a desordem e a ambiguidade na realidade do contexto organizacional, e tem como pressuposto que essa realidade pode ser constituída por uma infinidade de parâmetros, tornando-se base para a construção dos seus significados.

Neves (2000) alega que o conceito pluralista e sociocultural de cultura organizacional, que caracterizou o pensamento antropológico por décadas, foi partilhado em duas grandes linhas de pensamento: (1) a que percebe a cultura como um composto de padrões culturais - (a) os indivíduos produzem a cultura por meio da interação e (b) o foco está na estrutura de padrões ao invés de estar nas suas dimensões; e (2) a que considera a cultura como estrutura social - (a) cultura como sistema de relações sociais e (b) cada sistema estrutural é uma unidade funcional em que todas as partes contribuem coordenadamente para sua permanência. Observam-se dois grandes polos: (1) o que objetiva compreender a natureza ontológica da cultura e saber se esta é um evento exógeno à organização (variável independente e externa) ou endógeno da organização (variável dependente e interna). O segundo polo dispõe a forma como a cultura se revela e se expressa na organização, buscando compreender o 
significado das suas manifestações em contexto organizacional, ou seja, o grau de partilha.

Alvesson (1993) sumarizou as perspectivas até então apresentadas por meio da principal diferença conceitual: as abordagens objetivo-funcionalista versus subjetivointerpretativa, assemelhando-se à tipologia de Schultz (1994). Essas abordagens, respectivamente, podem estar relacionadas aos conceitos de cultura organizacional e de cultura na organização (Carrieri, 2000; Bedani, 2008). E é sob a ótica de cultura nas organizações que Martin (1992) apresenta três modalidades de partilha: integradora, diferenciadora e fragmentadora.

Os pressupostos metodológicos para a diferenciação dessas três modalidades são: (1) a essência (homogeneidade e harmonia, diferença e conflito); (2) forma como as manifestações da cultura se relacionam (consistência e inconsistência); (3) grau de consenso (organizacional, grupal, individual); (4) orientação na presença de ambiguidade (exclusão, controle); e (5) matriz cultural (uma e singular, múltipla e plural) (Torres, 2005).

Sob a ótica integradora, a cultura é tida como um todo unitário (formal e informal), consistente e universalmente aceito por todos, pois há clareza e consensualidade nos valores e nas crenças que são partilhadas pelos membros da organização, consequentemente desconsidera-se o conflito, a ambiguidade e a diferenciação. Dominante nos estudos realizados sobre cultura organizacional, essa perspectiva pressupõe correlações positivas entre desempenho e cultura organizacional. A unidade de análise é a organização (Torres, 2005; Bedani, 2008).

Diferentemente da modalidade anterior, na perspectiva diferenciadora a unidade cultural é dissimulada, sendo sua essência o antagonismo e a divergência. Segundo Martin (1992), os conflitos de interesses e interpretações diferentes para um mesmo problema são latentes nas dinâmicas dos atores organizacionais, mas não são fatores impeditivos da convergência de pontos de vista. A departamentalização predispõe a coexistência de subculturas, favorecendo o consenso e a harmonia dentro dessas subculturas e a ambiguidade e a inconsistência entre subculturas. A unidade de análise é o grupo.

Contrapondo as modalidades anteriores, na fragmentadora a unidade de análise é o indivíduo, tendo na ambiguidade o âmago dessa perspectiva em que o consenso e a dissensão convivem, uma vez que qualquer ação pode ser interpretada de diferentes formas. Parte-se do pressuposto de que as opiniões das pessoas são modificadas 
conforme a informação acessada ou a relevância da tarefa a ser realizada. Assim, as pessoas se agrupam de forma temporária (grupos de pertenças), não havendo possibilidade para a coexistência de subculturas estáveis (Martin, 1992).

As diferenças entre as três modalidades são complementares. Estas perspectivas, segundo Martin (1992), devem ser compreendidas como "tipos ideais" e não apenas como descrições objetivas da realidade organizacional.

\subsection{Abordagem da cultura nesta pesquisa}

Burrell e Morgan (1987) explicam a relevância em conhecer os requisitos básicos que compõem cada paradigma ao realizar pesquisas, haja vista que cada modelo tem como pressuposto teorias que são embasadas por outras teorias. Então, para não haver divergências epistemológicas, seria viável que as teorias escolhidas para desenvolver as pesquisas fossem niveladas sob os mesmos pressupostos e sob um mesmo paradigma, caso contrário poderá não se obter a sustentabilidade necessária para conseguir credibilidade.

Neste trabalho, a instrumentalização da cultura tem como alicerce o paradigma funcionalista. A partir desta opção, entende-se cultura como variável interna (Smircich, 1983), sendo um construto quantitativamente mensurável e capaz de influenciar outras variáveis organizacionais a fim de manter estabilidade e coesão do sistema social, sendo percebida como um conjunto de valores compartilhados e de pressupostos básicos cujo objetivo é integrar e adaptar a organização ao seu ambiente (Schultz, 1995) e provedora dos padrões básicos sobre o que seja certo ou errado e da forma adequada de executar as atividades e de conduzir os negócios. Empregam-se suposições orientadoras das concepções da Administração Corporativa (cross-cultural) e da Cultura Corporativa, bem como da concepção objetivo-funcionalista (Alvesson, 1993). Quanto `à perspectiva de cultura na organização, utiliza-se a modalidade da diferenciação, em que há o reconhecimento de subculturas que podem viver em conformidade ou não com a cultura dominante da organização (Martin, 1992).

Sendo a cultura vista como variável que pode ser medida quantitativamente, poderá ser submetida a métodos de entrevistas semiestruturadas, análise documental, questionários autoaplicáveis que poderão ser realizados sobre amostras 
representativas da população pesquisada (Hofstedee, 1980, 2001; D'iribarne, 2003; Bedani, 2008, Nascimento, 2014).

\subsubsection{Conceito de Cultura Organizacional}

A cultura organizacional tem sua base estrutural apoiada na multidisciplinaridade, gerando, assim, uma multiplicidade de definições, bem como sua correlação com as estruturas sociais, os mecanismos históricos, as experiências subjetivas das pessoas no ambiente organizacional, além de considerar os níveis de análise, a metodologia de investigação e a abrangência pretendida. Todos estes fatores conduzem à compreensão adequada das definições referentes à cultura organizacional (Gelfand et al., 2007; Ferreira \& Assmar, 2008; Ashkanasy, Wilderom \& Peterson, 2011; Schneider et al., 2013; Nascimento, 2014).

A partir da forma de abordagem operacionalizada neste trabalho, buscou-se identificar conceitos sobre cultura que tivessem os pressupostos básicos delineados neste contexto. Dessa forma, Schwartz \& Davis (1981) definem cultura como padrões de crenças e expectativas compartilhadas pelos membros da organização, a partir das quais são produzidas as normas que moldam o comportamento dos indivíduos e dos grupos na organização. Nessa mesma linha, Denison (1997) retrata cultura tanto como valores latentes, crenças e princípios que auxiliam o sistema de gerenciamento da organização, quanto o conjunto de práticas e comportamentos que exemplificam e reforçam os princípios básicos.

A cultura abrange a maneira como as coisas são feitas na organização, podendo ser observada em cada aspecto da atividade organizacional, já que se manifesta a partir de conhecimentos, valores, preferências, hábitos e costumes, práticas estabelecidas e artefatos (Child \& Faulkner, 1998). Conforme Tanure (2005), a dimensão mais visível da cultura está nos mitos, nos símbolos e nos rituais, que são fundamentais para a compreensão do contexto organizacional. Para Tamayo (1996), a cultura consiste de elementos compartilhados que constituem os padrões para perceber, pensar, agir e comunicar.

A definição elaborada por Schein (2004) é uma das mais evidentes tanto em pesquisas quanto na literatura sobre o assunto. Para ele, cultura organizacional representa um conjunto de pressupostos básicos que foram desenvolvidos pelo grupo 
quando da necessidade de aprenderem a lidar com questões de adaptação externa e integração interna e quando esses pressupostos são bem-sucedidos, então devem ser compartilhados para os novos membros como sendo a forma correta de identificar, pensar e sentir em relação a essas questões.

Caracteriza cultura em três níveis distintos: artefatos ou práticas, valores manifestos e pressupostos básicos, que se organizam em um continuum do muito visível ao muito tácito e invisível (Schein, 1999 p. 32). No nível mais perceptível, a cultura deixa claro o modo de agir do grupo, impactando-o emocionalmente. Aqui se encontram todas as manifestações produzidas pelo grupo que podem ser observadas, tais como: forma de vestuário, linguagem, rituais, comemorações, linguagem e jargões; neste nível também se encontram as práticas, os processos organizacionais e os comportamentos para a execução desses processos. Neste nível os artefatos e as práticas, deliberadamente ou não, mostram significativas informações sobre os níveis mais baixos: os valores e os pressupostos básicos (Schein, 1985). A figura 03 mostra a cultura em três níveis.

Figura 03 - Níveis da cultura e sua interação

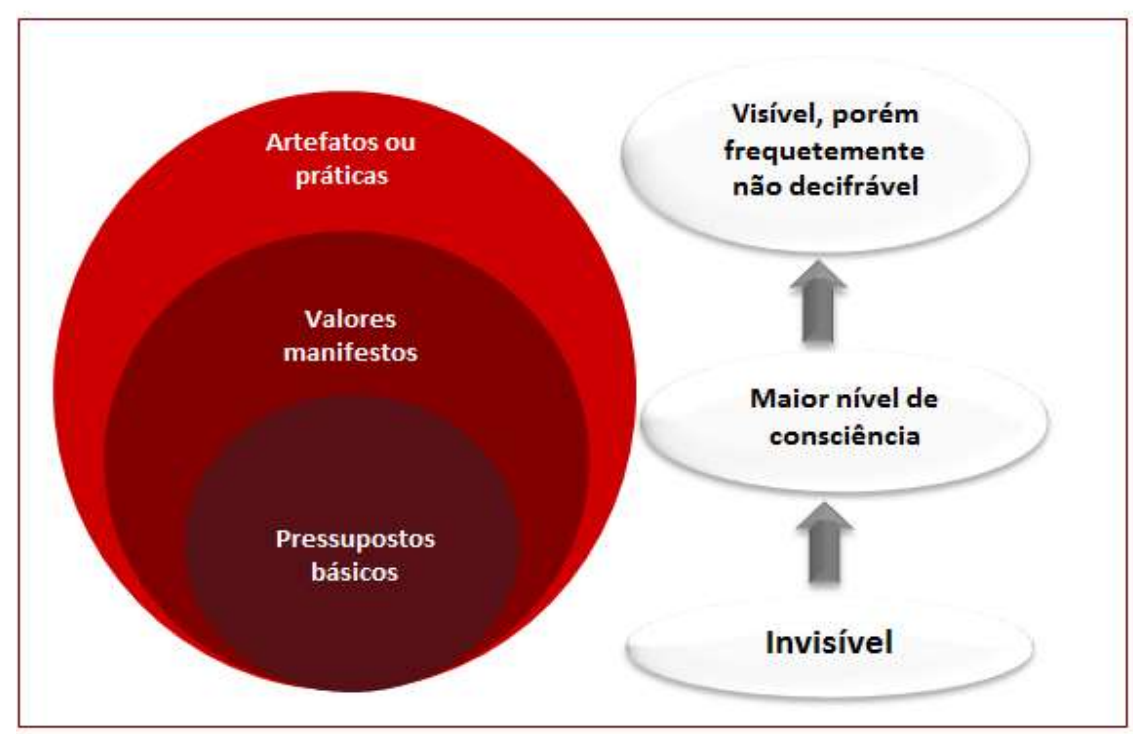

Fonte: Schein (1985), com adaptações

No nível intermediário, encontram-se os valores manifestos por meio da sua hierarquia de valores que têm por objetivo orientar a organização bem como o comportamento dos seus membros. São externalizados nas normas, metas, nos seus códigos de 
conduta, princípios morais, forma de se relacionar com os stakeholders e sistemas de premiações (Schein, 1985, 1999).

No último nível, os pressupostos básicos, estão contidos os valores e crenças compartilhadas, profundamente enraizadas por um longo processo de aprendizagem conjunta, são tão bem assimiladas pela dinâmica organizacional que se tornam difíceis de serem interpretadas até mesmo por seus membros.

Rousseau (1990) acrescenta aos conceitos de Schein (1985) os padrões de comportamento relativos à tomada de decisão, aos mecanismos de coordenação e à comunicação; e as normas comportamentais, que tratam do entendimento da organização de como seus membros devem interagir com seus colegas. Para Hofstede (2003 p. 19), a cultura "sempre é um fenômeno coletivo, uma vez que é, pelo menos em parte, partilhada por pessoas que vivem no mesmo ambiente social onde é adquirida. Podemos defini-la como uma programação coletiva da mente que distingue os membros de um grupo ou categoria de pessoas face a outro".

Os elementos que formam a cultura, segundo o modelo apresentado por Hofstede (2003), são divididos em dois níveis: valores e práticas, sendo que no construto práticas, estão abarcados os símbolos, os heróis e os rituais, como pode ser visto na figura 04.

Figura 04 Níveis de manifestação da cultura

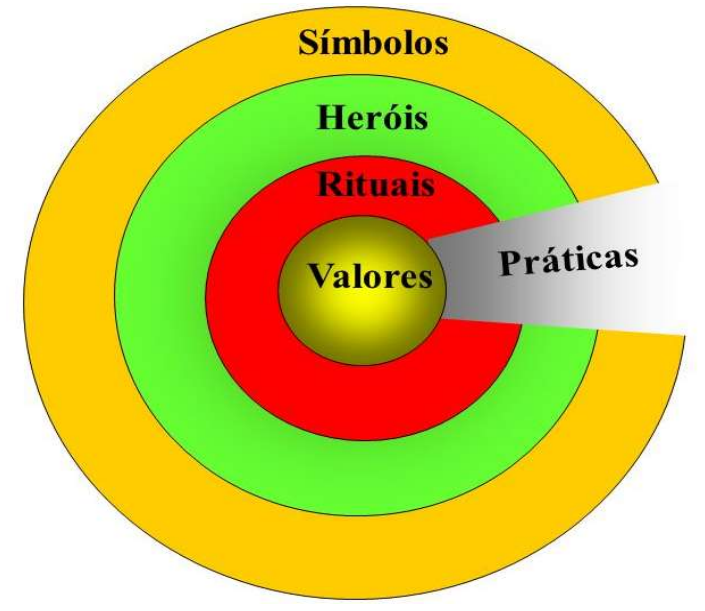

Fonte: Hofstede (2003), com adaptações

Os valores, para Hofstede (2003), referem-se à preferência na escolha de certas coisas a outras, considerando as diferenças entre os valores desejáveis e os valores desejados. E essa distinção está na natureza das normas, isto é, nos padrões de valores vigentes em um grupo ou categoria de pessoas. Durkheim (1983) ressalta que 
as normas morais têm uma finalidade desejável e desejada para aqueles a quem se destinam e que o valor moral dos atos visa a um propósito superior aos indivíduos, sua fonte é mais elevada e seu fim é a sociedade. A norma, no caso do desejado, é estática e contempla a escolha da maioria, vinculando-se mais com os fins pragmáticos. A norma, no caso do desejável, está mais relacionada com o ideológico, como o desejo das pessoas (Hofstede, 2003; Nascimento, 2014).

As práticas, que também podem ser entendidas como convenções, costumes, hábitos, tradições ou usos e que foram desenvolvidas pelo(s) fundador(es) ou por pessoas significativas dentro da organização, incorporam os símbolos (palavras, gestos e ações que têm sentido próprio dentro da organização), os heróis (pessoas com características enaltecidas e capazes que servem de modelo para os demais membros do grupo) e os rituais (atividades coletivas e socialmente imprescindíveis). Hofstede (2003) afirma que, apesar de os valores delinearem a cultura organizacional, a forma como as práticas são manifestadas é o que tipifica a cultura da organização, visto que são repassadas para o grupo por meio da socialização.

A cultura organizacional, para Trompenaars (1993), é o meio do qual as pessoas se utilizam para saberem como agir na resolução de problemas. São modos de agir específicos da organização.

A figura 05 mostra o modelo de Trompenaars (1993), que se assemelha ao modelo de Hofstede quanto à forma de ordenar os elementos culturais em camadas; e quanto ao conteúdo de cada dimensão, assemelha-se ao modelo de Schein.

Figura 05 - Dimensões culturais

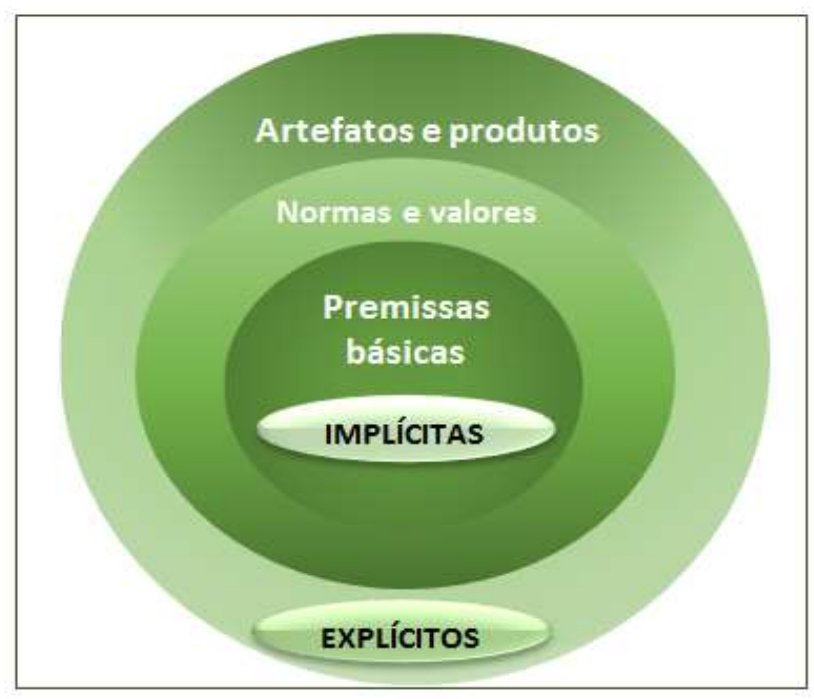

Fonte: Trompenaars (1993), com adaptações 
De acordo com o modelo apresentado na figura $\mathrm{n}^{\circ} 05$, as premissas básicas estão vinculadas às normas e aos valores de comportamento. São elas que delimitam o certo e o errado dentro do grupo. Assim, a estabilidade da cultura organizacional pode ser alcançada quando as normas refletem os valores do grupo. No nível mais baixo (premissas e valores) é onde se define o modo de sentir, pensar e entender 0 ambiente.

Os conceitos de cultura expostos nos modelos teóricos apresentam semelhanças estruturais, entretanto as especificidades conceituais de cada um destes modelos mostram diferentes focos para os estudos relativos à cultura nas organizações. $O$ modelo de Schein (1985) evidencia o comportamento humano e das relações estabelecidas entre os membros da organização, privilegiando estudos interculturais. Os modelos de Hofstede (2003) e Trompenaars (1993), que a princípio foram desenvolvidos para compreenderem culturas nacionais e depois foram analisados para culturas organizacionais, privilegiam a identificação de padrões que podem ser comparados entre diferentes culturas organizacionais e a relação destas com a cultura nacional, privilegiando estudos transculturais (Lacerda, 2011). 


\subsection{Abordagem conceitual de cultura organizacional referenciada neste trabalho}

Para este trabalho, cultura organizacional é um fenômeno coletivo (Hofstede, 2003), em que os pressupostos básicos são compartilhados (SCHEIN, 1985), ou seja, as crenças, os valores e os sistemas de valores são estabelecidos como a forma correta de pensar e de agir e são manifestados por meio das suas práticas organizacionais (Hofstede, 2003). A cultura organizacional pode ser reconhecida por meio de padrões específicos de cada organização e, desta forma, pode ser comparada tanto com outras organizações quanto com culturas nacionais. Os elementos que formam a cultura são divididos em dois níveis: valores e práticas. Hofstede (2003) afirma que, apesar de os valores delinearem a cultura organizacional, a forma como as práticas são manifestadas é que tipifica a cultura da organização, uma vez que são repassadas para o grupo por meio da socialização.

\subsubsection{Cultura nacional e cultura organizacional}

Apesar da semelhança entre os termos cultura de uma nação e cultura de uma

organização, eles apresentam naturezas distintas quanto às suas representatividades, forma de manifestações subjetivas e objetivas.

\subsection{Cultura nacional}

Cultura nacional pode ser entendida como um conjunto de características comuns de comportamentos entre pessoas de uma determinada região ou país (Motta \& Caldas, 2007), como resultado de uma aprendizagem contínua que foi assimilada desde a infância. É vista como um fenômeno coletivo, em que as pessoas que convivem no mesmo ambiente social possuem um conjunto de regras sociais não escritas e parcialmente compartilhadas entre seus membros, ou seja, "cultura é a programação coletiva da mente que distingue os membros de grupo ou categoria, sendo apreendida e derivada do meio ambiente social e não dos genes pessoais" (Hofstede, 1997 p.19). A cultura é adquirida e não herdada, sendo derivada do espaço social do indivíduo e não das características genéticas (Hofstede, 2003).

Assim, cultura nacional trata, segundo Salacuse (1999), de um conjunto de significados compartilhados e duradouros, valores e crenças que caracterizam um grupo nacional, sendo os valores culturais traduzidos em normas, crenças e moral, e, 
consequentemente, refletindo nas leis e nas práticas da sociedade, incluindo na atuação dos indivíduos no seu meio profissional e nas organizações (Venaik \& Brewer, 2010, Nascimento, 2014).

Minkov (2012) fez um estudo detalhado sobre as variáveis que explicam as diferenças entre os grupos de pessoas. As variáveis externas à cultura (também denominadas de exógenas ou estranhas) são clima, localização geográfica e a prevalência de agentes patogênicos. Quanto ao modo de analisar a cultura internamente, Minkov (2012) apresenta diversas perspectivas sobre a forma de se categorizar cultura, primeiramente diferencia cultura subjetiva e cultura objetiva, as quais se relacionam com as percepções invisíveis que residem na mente das pessoas (subjetiva) e fora delas (objetiva).

Para Minkov (2012), a cultura não é um comportamento observável, mas sim os valores e as crenças de que as pessoas se utilizam para interpretar as experiências vividas e estas são refletidas no seu comportamento. Sob essa perspectiva, Minkov (2012) denomina de sharedness a afinidade cultural como aquela que é aceita pela maioria das pessoas em uma sociedade, embora não necessariamente por indivíduos específicos, referindo-se à parte da cultura que é compartilhada pela maioria dos membros da comunidade cultural.

A segunda característica que também está relacionada com o primeiro conceito de sharedness é normalidade, que, segundo o autor, são os fatores que determinam se certas condutas são consideradas comportamentos normais ou desviantes ao longo do tempo, são relativas aos traços culturais e se submetem ao dinamismo das sociedades e variam de acordo com a cultura, já que traços normais ou anormais de comportamento são específicas de cada sociedade.

A terceira característica trata da integração de elementos culturais como funcional. Não há culturas em que traços culturais não sejam combinados de forma aleatória, de sorte que produzam um sistema sem propósitos ou que não sirvam para a sobrevivência da comunidade em circunstâncias específicas. As sobrevivências de algumas sociedades podem ser atribuídas às suas vantagens funcionais. Por exemplo, a maternidade prematura em algumas comunidades africanas ocorre devido à alta taxa de mortalidade infantil e a uma curta vida média dos adultos (média de 40 anos), caso contrário toda a comunidade poderia desaparecer. Isso não significa dizer que todas as características culturais de uma determinada sociedade serão sempre 
funcionais de forma a garantirem a sua sobrevivência, podendo ocorrer, por exemplo, que uma mudança súbita no contexto econômico, político ou no ambiente físico possa pegar uma sociedade despreparada fazendo com que alguns desses traços culturais possam ser mais negativos do que benéficos nessas novas circunstâncias (Minkov, 2012).

A quarta característica, segundo Minkov (2012), é a estabilidade ou mutabilidade das culturas. Apesar de a cultura ser vista como um processo estável, valores, crenças e padrões de comportamento não mudam da noite para o dia, mas haverá variações com o tempo as quais irão se diversificar de forma específica e de acordo com o tipo de sociedade. A quinta característica, abordada pelo autor, refere-se à transmitabilidade, em que a cultura pode ser transmitida de forma sincrônica (entre indivíduos de uma mesma geração) ou diacrônica (de uma geração para outra). Por fim, a última característica trata da complexidade. Segundo Minkov (2012), cultura é uma estrutura complexa que consiste de subculturas cujas especificidades geram algum tipo de diversidade. A cultura nacional pode ser abordada sobre várias linhas: regional, social, profissional, étnica, entre outras. Cientistas políticos e economistas defendem a nação como unidade de análise, visto que, apesar da globalização, a nação continua a ser uma unidade-chave de experiências compartilhadas e suas instituições educacionais e culturais moldam os valores de quase todas as pessoas dessas sociedades (Inglehart \& Barker, 2000).

No entanto, a utilização de nação como unidade de análise é controversa em estudos transculturais (Triandis, 1994; Ros \& Gouveia, 2006; Miller-Loessi \& Parker, 2006; Ryan et al., 1999; Minkov, 2012). Alguns estudiosos expressam pontos de vista mais cuidadosos: as fronteiras nacionais não podem ser uma forma adequada para demarcar fronteiras culturais, porque muitos países têm uma grande variedade de subculturas.

Peterson e Smith (2008), segundo Minkov (2012), identificaram três críticas comuns ao uso da nação como unidade de análise: (1) estudos sobre indivíduos têm uma alta variabilidade dentro da nação; (2) nações têm várias subculturas como as regionais, étnicas, sociais etc.; e (3) teorias estruturais sobre o tema têm sofrido alterações.

Para Minkov (2012), o fato de haver alta variabilidade nas diferenças individuais das pessoas dentro de uma nação é irrelevante, pois nação é, por si só, um sistema 
complexo de pessoas. Se o foco for somente no indivíduo e não no sistema de pessoas, grandes áreas do conhecimento humano como a econômica, política, organizacional, demográfica e histórica seriam simplesmente dizimadas. Comparações do crescimento econômico, níveis de industrialização, desigualdade socioeconômica e muitas outras variáveis de estudo perderiam a equivalência se fossem analisadas somente no nível individual ao invés de serem analisadas no nível de grupo. Mesmo com a existência de subculturas dentro de uma nação, para que esta possa se manter como unidade de análise e reconhecida como nação ela tem que manter uma cultura nacional (Minkov, 2012). Então, apesar da existência de subculturas regionais, o que mantém a nação como um grupo homogêneo, claramente distinta de grupos de nações vizinhas, é a cultura nacional já que a diversidade entre os grupos culturais de uma mesma nação tende a ser menor do que a diversidade entre nações. E o terceiro argumento é puramente teórico, bastando, para tanto, pesquisas empíricas para refutá-lo (Minkov, 2012).

Mais importante é mostrar as razões para a utilização da nação como unidade de análise. Conforme Smith, Bond e Kagitciba (2006), as nações constituem sistemas culturais, de sorte que suas fronteiras e prerrogativas políticas foram sendo definidas historicamente com características ecológicas, históricas, políticas, educacionais, legais, regulatórias, sociais e econômicas distintas de outro sistema cultural em nível nacional.

Outro fator que vale ser analisado, no que se refere a estudos transculturais, é a definição do nível de análise, ou seja, se o foco do estudo será o nível individual (caraterizado pelas prioridades que orientam as pessoas - valores expressados por meio de metas motivacionais das pessoas), o nível cultural (caracterizado pela prioridade que orienta a sociedade como um todo - valores que expressam metas motivacionais desenvolvidas pelos grupos), ou se trata de um estudo multinível, que diferencia níveis individuais e culturais de análise (Knafo, Roccas \& Sagiv, 2011; Carvalho \& Borges, 2012).

Outro aspecto que deve ser levado em consideração na descrição de culturas é a dimensão dos modelos: unidimensionais ou multidimensionais. Os modelos de Triandis e colaboradores (1995) - individualismo versus coletivismo - e o de Inglehart (1990) - valores materialistas e pós-materialistas - são exemplos de modelos unidimensionais. 
Na concepção multidimensional, situam-se as teorias de Kluckhohn e Fred Strodtbeck (1961); Edward T. Hall (1981, 1990); Geert Hofstede (1980, 2001, 2003); Schwartz \&

Bilsky (1987); Schwartz (1990), Fons Trompenaars (1993); Tamayo (1996); Trompenaars \& Hampden-Turner (1998); Denison (2001); Gouveia (2003); Gouveia et al., (2010); House e o projeto GLOBE (2004); Minkov (2012), como os mais destacados.

Nas pesquisas sobre o tema, observa-se uma direção clara quanto à adoção de abordagens multidimensionais, o que é razoável dado que a cultura é um fenômeno complexo. As seguintes tendências, segundo Carvalho e Borges (2012), são observadas nos modelos transculturais: diferenciar aspectos universais de espaços de singularidade; valorizar aspectos multidimensionais e diferenciar níveis individuais e culturais de análise. Além disso, muitas das pesquisas têm se valido dos indicadores propostos nos modelos transculturais para verificar as relações entre as variáveis dimensionais com outras variáveis contextuais (Diener, 1995; Gelade, Dobson \& Auer, 2008; Georgas, Van De Vijver \& Barry, 2004; Páez \& Zubieta, 2006; Welzel, 2010).

\subsection{A atuação da cultura nacional na cultura organizacional}

Um particular interesse para os gestores e consultores internacionais é a interface entre a cultura nacional e organizacional devido ao crescente processo de globalização impulsionando empresas a internacionalizarem-se. Segundo Minkov (2012), as semelhanças, diferenças e as relações entre cultura nacional ou social e cultura organizacional foram tratadas em várias publicações, resultando na identificação de que a cultura social afeta significativamente a cultura organizacional. Segundo sua análise, a cultura nacional não é completamente irrelevante para a cultura organizacional, mas o seu efeito geralmente é subestimado. Essa relação, porém, ainda não está totalmente compreendida.

Smith, Bond e Kaitciba (2006) reforçam que, assim como os países, as organizações também têm diferentes culturas, embora aquelas que se encontrem num mesmo país tendam a refletir internamente a cultura nacional comum. Hofstede et al. (1990) alega que, enquanto as culturas nacionais diferem-se principalmente em termos de conjuntos de valores compartilhados, as culturas organizacionais se diferenciam mais em termos de práticas compartilhadas. Dessa forma, os membros de diferentes 
organizações dentro de um mesmo país poderiam compartilhar valores, mas trabalhar em organizações que adotam maneiras distintas de implementá-los na prática.

Na tentativa de compreender e de enfrentar as diferenças e semelhanças que são manifestadas ao se atuar em contextos culturais distintos, há uma tendência crescente, por parte dos estudiosos, em adotar desenhos transculturais em suas pesquisas (Nardon \& Steers, 2013).

\subsubsection{2 (a) Modelos de Cultura nacional}

Os modelos transculturais têm sido úteis para a comparação de processos de gestão, políticas de gestão de recursos humanos e estratégias de negócio através das fronteiras nacionais, por meio da identificação de diferenças e semelhanças culturais entre países. Alguns modelos têm ido um pouco mais longe e oferecem medidas ou indicadores numéricos para vários países (Hofstede, 2003; Nardon E Steers, 2013). As dimensões culturais que compõem os modelos, segundo Hofstede (2006), permitem distinguir aspectos de uma cultura nacional que pode ser medida em relação a outras culturas nacionais. Maleki \& Jong (2014) fazem uma distinção entre os modelos qualitativos e quantitativos. Nos modelos quantitativos, segundo os autores, há o desenvolvimento de análises sistemáticas utilizando métodos estatísticos, e nos modelos qualitativos há uma análise conceitual das dimensões culturais.

Segundo Maleki \& Jong (2014), os modelos quantitativos que mais têm sido utilizados em pesquisas organizacionais são os propostos por Hofstede, Schwartz, House e seus associados do projeto GLOBE, Minkov e Inglehart e os modelos teóricos culturais conceituais importantes, e bem conhecidos, são os que foram estabelecidos por Triandis, Kluckhohn, Hall, Douglas, Triandis e Trompenaars.

Cada modelo destaca diferentes aspectos de crenças sociais, normas e / ou valores. Tais modelos objetivam identificar dimensões culturais de valores que sejam válidas para comparar culturas. Baseados em diferentes orientações teóricas e procedimentos empíricos, esses modelos foram construídos e testados em um grande número de países (Carvalho \& Borges, 2012).

\section{Modelos Qualitativos}

\section{Kluckhohn e Strodtbeck}


Baseados nas pesquisas iniciais de Clyde Kluckhohn (1951), os autores elaboraram um dos primeiros modelos de cultura nacional que serviram de base para vários modelos posteriores. Fundamentados na forma como os valores orientam as pessoas, argumentam que existe um número limitado de problemas que são comuns as todas as sociedades e, consequentemente, há um número limitado de soluções. Sugeriram, ainda, que os valores em qualquer sociedade são distribuídos de tal forma que seja possível estabelecer um sistema de valores dominante.

Segundo Nardon e Steers (2013), Kluckhohn e Strodtbeck utilizaram-se das teorias antropológicas para identificar seis orientações de valor, quatro dos quais foram depois testados em cinco subculturas do sudoeste americano, duas tribos nativas americanas, uma aldeia hispânica, uma comunidade de Mórmons, e uma comunidade colonial agrícola anglo-americana.

Cada dimensão está representada em um continum de três pontos: (1) relacionamento com a natureza: domínio, harmonia e subjugação; (2) relacionamento com as pessoas: individualista, colateral e linear; (3) atividades humanas: ser, fazer, balanço entre vida e sociedade - individualista, coletivista e hierárquico; (4) relações com o tempo: passado, presente e futuro; (5) natureza humana: boa, adaptável e má; (6) orientação de espaço: privado, público ou a mistura dos dois (Nardon \& Steers, 2013).

Quadro 02 - Dimensões de problemas humanos básicos

\begin{tabular}{|l|l|}
\hline \multicolumn{1}{|c|}{$\begin{array}{c}\text { Dimensões } \\
\text { culturais }\end{array}$} & \multicolumn{1}{|c|}{ Características } \\
\hline $\begin{array}{l}\text { Relações com a } \\
\text { natureza }\end{array}$ & $\begin{array}{l}\text { Crenças sobre a responsabilidade ou a necessidade em } \\
\text { controlar a natureza. }\end{array}$ \\
\hline $\begin{array}{l}\text { Relacionamento } \\
\text { com pessoas }\end{array}$ & Crenças sobre estrutura social \\
\hline Atividades humanas & Crenças sobre metas que sejam adequadas. \\
\hline Natureza humana & $\begin{array}{l}\text { Crenças quanto a natureza do homem ser boa, má ou } \\
\text { adaptável }\end{array}$ \\
\hline $\begin{array}{l}\text { Relações com o } \\
\text { tempo }\end{array}$ & $\begin{array}{l}\text { Medida em que passado, presente e futuro influenciam nas } \\
\text { decisões. }\end{array}$ \\
\hline $\begin{array}{l}\text { Relações com o } \\
\text { espaço }\end{array}$ & Relações entre o privado, o público ou a mistura dos dois. \\
\hline
\end{tabular}

Fonte: Adaptado de Kluckhohn e Strodtbeck (1961); Nardon e Steers (2013). 
Hall

Edward T. Hall (1981, 1990), baseado em suas pesquisas etnográficas de várias sociedades, notadamente Alemanha, França, EUA e Japão, propôs um modelo transcultural cujo foco está na análise de como as culturas variam no processo de comunicação interpessoal (alto e baixo contexto), mas também inclui a forma como as pessoas de diferentes culturas utilizam o tempo e o espaço.

Essas três dimensões da cultura encontram-se resumidos no quadro 03. Muitos dos termos usados hoje no campo da gestão cross-cultural (por exemplo monocrômico policrômico) são derivados deste trabalho (Nardon \& Steers, 2013).

Quadro 03- Dimensões culturais de Hall

\begin{tabular}{|l|l|}
\hline \multicolumn{1}{|c|}{ Dimensões culturais } & \multicolumn{1}{c|}{ Características } \\
\hline Contexto & $\begin{array}{l}\text { Medida em que o contexto de uma mensagem é tão importante } \\
\text { como a própria mensagem. }\end{array}$ \\
\hline Espaço (proximidade) & $\begin{array}{l}\text { Medida em que as pessoas estão confortáveis dividindo o } \\
\text { espaço físico com outros. }\end{array}$ \\
\hline $\begin{array}{l}\text { Tempo monocrômico } \\
\text { Tempo policrômico }\end{array}$ & $\begin{array}{l}\text { Medida em que as pessoas realizam uma tarefa de cada vez } \\
\text { ou várias tarefas ao mesmo tempo. }\end{array}$ \\
\hline
\end{tabular}

Fonte: Adaptado de Hall, 1990.

\section{Trompenaars}

Baseando-se nos trabalhos dos sociólogos Parsons e Shils (1951), o autor apresentou um modelo um pouco diferente da cultura, respaldado em seu estudo na Shell ao longo de um período de dez anos em sete países (Alemanha, Suécia, EUA, Inglaterra, Holanda, França e Japão), centrou-se na identificação de como as diferentes orientações de valores presentes nas culturas nacionais afetam a forma de administrar e de como os relacionamentos pessoais são estabelecidos nas organizações nacionais (Trompenaars, 1996; Santos, 2005).

O modelo consiste de sete dimensões, como mostrado no quadro 04. As primeiras cinco dimensões focalizam as relações entre as pessoas, enquanto as duas últimas, a gestão do tempo e a relação da sociedade com a natureza. 
Quadro 04 - Dimensões culturais de Trompenaars

\begin{tabular}{|c|c|c|}
\hline \multicolumn{2}{|c|}{ Dimensões culturais } & Características \\
\hline \multirow{5}{*}{$\begin{array}{l}\text { Relações com } \\
\text { pessoas }\end{array}$} & $\begin{array}{l}\text { Universalismo } \\
\text { Particularismo }\end{array}$ & $\begin{array}{l}\text { Relaciona as avaliações que as pessoas fazem } \\
\text { no comportamento de outras em situações de } \\
\text { estrita necessidade em respeitar regras, e leis } \\
\text { universais com o contexto ambiental e as } \\
\text { relações de amizade. }\end{array}$ \\
\hline & $\begin{array}{l}\text { Individualismo } \\
\text { Comunitarismo }\end{array}$ & $\begin{array}{l}\text { Relaciona entre as preferências concomitantes } \\
\text { do indivíduo e por seu próprio self ou pela } \\
\text { consideração à comunidade em primeiro lugar. }\end{array}$ \\
\hline & $\begin{array}{l}\text { Neutro } \\
\text { Afetivo }\end{array}$ & $\begin{array}{l}\text { Explora o papel da razão e da emoção nas } \\
\text { relações interpessoais. }\end{array}$ \\
\hline & $\begin{array}{l}\text { Status alcançado } \\
\text { Status atribuído }\end{array}$ & $\begin{array}{l}\text { Refere-se ao critério valorizado para } \\
\text { estabelecer status a uma pessoa. }\end{array}$ \\
\hline & $\begin{array}{l}\text { Específico } \\
\text { Difuso }\end{array}$ & $\begin{array}{l}\text { Relaciona o modo pelo qual as pessoas se } \\
\text { envolvem em áreas específicas da vida das } \\
\text { outras pessoas ou como se envolvem } \\
\text { difusamente em várias áreas de suas vidas } \\
\text { simultaneamente. }\end{array}$ \\
\hline $\begin{array}{l}\text { Relações com } \\
\text { o ambiente }\end{array}$ & $\begin{array}{l}\text { Externamente } \\
\text { orientado } \\
\text { Internamente } \\
\text { orientado }\end{array}$ & $\begin{array}{l}\text { Refere-se ao comportamento do homem em } \\
\text { relação ao ambiente. }\end{array}$ \\
\hline $\begin{array}{l}\text { Relações com } \\
\text { o tempo }\end{array}$ & $\begin{array}{l}\text { Sincrônico } \\
\text { Sequencial }\end{array}$ & $\begin{array}{l}\text { Relaciona-se com o comportamento das } \\
\text { pessoas em relação ao tempo, ou seja, há } \\
\text { pessoas mais orientadas para o futuro } \\
\text { enquanto há outras mais orientadas para o } \\
\text { passado. Analisam como o passado, o presente } \\
\text { e o futuro se relacionam nas diferentes culturas. }\end{array}$ \\
\hline
\end{tabular}

Fonte: Adaptado de Trompenaars, 1996.

\section{Parsons}

Parsons et al. (1965) sugeriram que, em uma dada situação, um indivíduo deve fazer uma série de escolhas antes que a situação tenha um significado determinado para ele. Essas escolhas são dicotômicas, ou seja, escolhas entre duas alternativas. Os autores propuseram que o indivíduo tenha cinco opções para fazer, e eles se referiram a cada escolha como variável padrão. Suas contribuições influenciaram os estudos de personalidade modal, com foco em "até que ponto as condições de vida 
padronizadas em uma sociedade particular dão origem a certos padrões distintivos na personalidade de seus membros? Propôs os termos caráter social, estrutura básica de personalidade e caráter nacional (Gamlath, 2017). Os padrões culturais de Parsons podem ser vistos no quadro 05 .

Quadro 05 - Padrões culturais de Parsons

\begin{tabular}{|l|l|}
\hline \multicolumn{1}{|c|}{ Padrões culturais } & \multicolumn{1}{c|}{ Características } \\
\hline Afetividade vs. Neutralidade afetiva & $\begin{array}{l}\text { Opção entre a necessidade de gratificação ou a } \\
\text { restrição de impulsos }\end{array}$ \\
\hline Auto orientação vs. Coletividade & Opção entre "eu" ou o "nosso" \\
\hline Universalismo vs. Particularismo & $\begin{array}{l}\text { Orientação a regras e aplicação de padrões gerais } \\
\text { ou considerar relações particulares. }\end{array}$ \\
\hline Atribuição vs. realização & $\begin{array}{l}\text { julgando os outros por quem eles são ou julgando- } \\
\text { os pelo que eles fazem. }\end{array}$ \\
\hline Especificidade vs. Difusão & $\begin{array}{l}\text { limitando as relações com os outros com as esferas } \\
\text { específicas ou sem limitações anteriores à natureza } \\
\text { das relações. }\end{array}$ \\
\hline
\end{tabular}

Fonte: Adaptado de Parsons et al., 1965.

\section{Triandis}

A maioria dos pesquisadores concordam que a cultura se reflete nas cognições compartilhadas, nos padrões de procedimentos operacionais e nos pressupostos não examinados. As síndromes culturais consistem em atitudes, crenças, normas, definições de função e auto definição compartilhadas, e valores dos membros de cada cultura organizados em torno de um tema. As síndromes culturais são concebidas como dimensões da variação cultural, que podem ser utilizadas como parâmetros de teorias psicológicas (Triandis, 1996). O quadro 06 apresenta as 10 síndromes culturais de Triandis. 
Quadro 06 - Síndromes culturais de Triandis

\begin{tabular}{|l|l|}
\hline \multicolumn{1}{|c|}{ Síndromes culturais } & \multicolumn{1}{c|}{ Características } \\
\hline Complexidade & $\begin{array}{l}\text { a uniformidade cultural e a conformidade são } \\
\text { maiores em culturas simples e menores em } \\
\text { culturas complexas }\end{array}$ \\
\hline Aperto vs. Frouxidão & $\begin{array}{l}\text { regras apertadas ou soltas, normas e ideias sobre } \\
\text { o que é o comportamento correto em diferentes } \\
\text { situações }\end{array}$ \\
\hline Individualismo vs. Coletivismo & $\begin{array}{l}\text { O "eu" é dependente ou interdependente com } \\
\text { alguns em grupo }\end{array}$ \\
\hline Vertical vs. Horizontal & $\begin{array}{l}\text { Aceitando hierarquia versus igualdade como um } \\
\text { dado }\end{array}$ \\
\hline Ativo vs. Passivo & $\begin{array}{l}\text { Mudando o ambiente versus mudar-se para se } \\
\text { encaixar no ambiente }\end{array}$ \\
\hline Universalismo vs. Particularismo & $\begin{array}{l}\text { tratar outros com base em critérios universais vs. } \\
\text { Relacionamentos }\end{array}$ \\
\hline Difusão vs. Específico & $\begin{array}{l}\text { julgar um indivíduo de maneira holística versus } \\
\text { discernir diferentes papéis }\end{array}$ \\
\hline Atribuição vs. Realização & $\begin{array}{l}\text { Julgar outros com base em atributos atribuídos vs. } \\
\text { atributos alcançados }\end{array}$ \\
\hline Instrumental vs. Expressivo & $\begin{array}{l}\text { Prioridade e importância das relações } \\
\text { instrumentais versus relações sociais }\end{array}$ \\
\hline $\begin{array}{l}\text { Expressão emocional vs. } \\
\text { Supressão }\end{array}$ & $\begin{array}{l}\text { Expressar emoções livremente versus controlar a } \\
\text { expressão de emoção }\end{array}$ \\
\hline
\end{tabular}

Fonte: Adaptado de Triandis, 1996

\section{Douglas}

A teoria cultural de Mary Douglas, muitas vezes referida como teoria do grupo e de grade, refere-se ao contexto sócio cognitivo em que um indivíduo se encontra. Grid descreve o alcance e a coerência de um sistema dominante de classificação, estruturando a visão de mundo do indivíduo. Quanto mais um indivíduo é constrangido a pensar e agir dentro de um único sistema estruturado, maior será o indivíduo na dimensão da grade. Grupo descreve o controle exercido sobre o ego individual pelo resto da comunidade (Hendry, 1999). As duas dimensões são apresentadas no quadro 07. 
Quadro 07 - Dimensões da teoria cultural de Douglas

\begin{tabular}{|l|l|}
\hline \multicolumn{1}{|c|}{ Dimensões } & \multicolumn{1}{c|}{ Características } \\
\hline Grupo & Grau de incorporação em uma unidade social delimitada. \\
\hline Grade & $\begin{array}{l}\text { Grau em que as interações são restringidas por regras específicas da } \\
\text { posição. }\end{array}$ \\
\hline
\end{tabular}

Fonte: adaptado de Hendry, 1999.

\section{Modelos Quantitativos}

\section{Schwartz}

Shalom Schwartz define valores (culturais) como "concepções do desejável que orientam a forma como os atores sociais selecionam ações, avaliam pessoas e eventos e explicam suas ações e avaliações" (Schwartz, 1999 p. 24). Como Hofstede, Schwartz também reconhece que as orientações do valor cultural são relativamente estáveis, embora os valores culturais mudem gradualmente (Schwartz, 2006b). Enquanto Hofstede derivou sua estrutura empiricamente, ou seja, ele tinha alguns dados empíricos e com base neles desenvolveu sua teoria; Schwartz desenvolveu sua estrutura teoricamente, após o que ele empiricamente examinou usando amostras multinacionais em grande escala (Maleki \& Jong, 2014).

Sob uma perspectiva psicológica, Schwartz $(1992,1994)$ e seus colaboradores estabeleceram que a diferença essencial entre os valores de uma sociedade está na forma de expressar as suas metas motivacionais. Identificou dez valores humanos, reconhecidos como universais, que refletem as necessidades motivacionais sociais e as demandas institucionais sociais (Kagitqibasi, 1997). Estes valores são supostamente encontrados em todas as culturas e representam necessidades universais da existência humana. Schwartz (1994) argumentou que os níveis individuais e culturais de análise são conceitualmente independentes. Dimensões no nível individual refletem a dinâmica psicológica que as pessoas experimentam quando seus valores atuam na vida cotidiana, enquanto dimensões de nível cultural refletem as soluções que as sociedades encontram para regular as ações humanas. 
Ao nível cultural de análise, ao contrário de Hofstede e Inglehart que conceitualizaram suas dimensões como fatores independentes e ortogonais, Schwartz (2006) considerou a interação da orientação do valor cultural com base na compatibilidade entre eles em uma estrutura circular. De acordo com Maleki e Jong (2014), essa estrutura reflete orientações (ou dimensões) culturais que são compatíveis (adjacentes no círculo) ou incompatíveis (distantes ao redor do círculo). Considerando questões importantes que enfrentam todas as sociedades, Schwartz derivou sete dimensões da cultura nacional, que por sua vez podem constituir três dimensões culturais bipolares: conservadorismo versus autonomia, hierarquia versus igualitarismo e domínio versus harmonia, resumidos no quadro 08.

Quadro 08 - Dimensões culturais de Schwartz

\begin{tabular}{|l|l|}
\hline Dimensões culturais & \multicolumn{1}{|c|}{ Características } \\
\hline Conservadorismo vs. Autonomia & $\begin{array}{l}\text { Manutenção do status quo e da propriedade; } \\
\text { restrição de ações que possam romper a } \\
\text { solidariedade do grupo ou ordem tradicional. E a } \\
\text { autonomia se refere à extensão em que as } \\
\text { pessoas são livres e independentes para } \\
\text { perseguir seus objetivos, ideias, inclinações } \\
\text { intelectuais e sexuais. }\end{array}$ \\
\hline Hierarquia vs. Igualitarismo & $\begin{array}{l}\text { Extensão em que a distribuição desigual de poder, } \\
\text { papéis na sociedade e recursos é legítima. E o } \\
\text { igualitarismo identifica em que as pessoas são } \\
\text { inclinadas a voluntariamente renunciar aos seus } \\
\text { interesses egoístas em prol do bem-estar dos } \\
\text { outros. }\end{array}$ \\
\hline Domínio vs. Harmonia & $\begin{array}{l}\text { Expressão da importância da superação ao ser } \\
\text { auto assertivo, essa dimensão separa os países } \\
\text { mais decididos ao tratar de tomar determinada } \\
\text { decisão. E a Harmonia vê a adaptação } \\
\text { harmoniosa com o meio ambiente. }\end{array}$ \\
\hline
\end{tabular}

Fonte: Adaptado de Schwartz, 1994. 


\section{Hofstede}

O holandês Geert Hofstede (1980, 2001), pesquisador sobre gestão organizacional, apresentou o modelo de diferenças culturais, este modelo é o que tem sido mais utilizado na literatura sobre organizações transculturais (Minkov, 2012; Nardon \& Steers, 2013). Esse modelo surgiu a partir de um estudo envolvendo funcionários de mais de 50 países de uma grande multinacional e tendo como pressuposto que as diferentes culturas podem ser distintas com base nas diferenças do que elas valorizam, ou seja, algumas culturas valorizam de sobremaneira a igualdade entre os indivíduos, enquanto outras valorizam hierarquias ou distâncias de poder entre as pessoas. Semelhantemente, algumas culturas valorizam o cotidiano e têm dificuldades em lidar com eventos imprevistos, enquanto outras têm uma maior tolerância para a ambiguidade e parecem apreciar a mudança. Hofstede argumenta que, a partir do estudo dessas dimensões de valores, é possível ter uma considerável visão sobre o comportamento entre as culturas.

Inicialmente, Hofstede afirmou que as culturas podiam se diferenciadas por meio de quatro dimensões, porém mais tarde acrescentou uma quinta dimensão com base em sua pesquisa com Michael Bond (1991). As dimensões são ilustradas no quadro 09.

Quadro 09 - Dimensões culturais de Hofstede

\begin{tabular}{|l|l|}
\hline \multicolumn{1}{|c|}{ Dimensões culturais } & \multicolumn{1}{c|}{ Características } \\
\hline Distância do poder & $\begin{array}{l}\text { Crenças sobre a distribuição adequada de poder } \\
\text { na sociedade. }\end{array}$ \\
\hline Aversão à incerteza & $\begin{array}{l}\text { Grau de incerteza que pode ser tolerada e seu } \\
\text { impacto na criação de regras. }\end{array}$ \\
\hline Individualismo vs. Coletivismo & $\begin{array}{l}\text { Importância relativa dos interesses pessoais } \\
\text { versus interesses do grupo. }\end{array}$ \\
\hline Masculinidade vs. Feminilidade & $\begin{array}{l}\text { Assertividade versus passividade; possessões } \\
\text { materiais versus qualidade de vida. }\end{array}$ \\
\hline Longo prazo vs. Curto prazo & $\begin{array}{l}\text { Perspectivas sobre o trabalho, a vida e os } \\
\text { relacionamentos. }\end{array}$ \\
\hline Indulgência vs. Restrição & $\begin{array}{l}\text { Satisfação de impulsos e desejos em busca da } \\
\text { felicidade e do prazer. }\end{array}$ \\
\hline
\end{tabular}

Fonte: Adaptado de Hofstede (2003); Minkov e Hofstede (2012); The Hofstede Centre (2017). 
O autor observou que há diferenças na forma como os indivíduos de diferentes países e culturas dão significados aos seus mundos. Ele delineou quatro dimensões da cultura como particularmente importantes para entender essas diferenças: distância de poder, masculinidade / feminilidade, aversão à incerteza e individualismocoletivismo. A quarta dimensão, individualismo / coletivismo, preocupa-se com a questão básica da prioridade relativa do grupo versus os interesses individuais. É essa quarta dimensão cultural que é de particular importância no contexto organizacional internacional (Triandis, 1995; Randall, 1993). Posteriormente, duas dimensões foram acrescentadas: longo prazo versus curto prazo, que trata das perspectivas sobre o trabalho, a vida e os relacionamentos; e indulgência versus restrição, representando uma sociedade que permite uma gratificação relativamente livre e naturais relacionadas ao aproveitar a vida e a se divertir. A restrição representa uma sociedade que suprime a satisfação das necessidades e as regula por meio de normas sociais rigorosas (Hofstede Centre, 2017).

\section{As dimensões de Hofstede no Brasil}

O gráfico 01 mostra os índices alcançados pelo Brasil em cada uma das dimensões culturais de Hofstede.

Gráfico 01 - Índice das dimensões de Hofstede para o Brasil

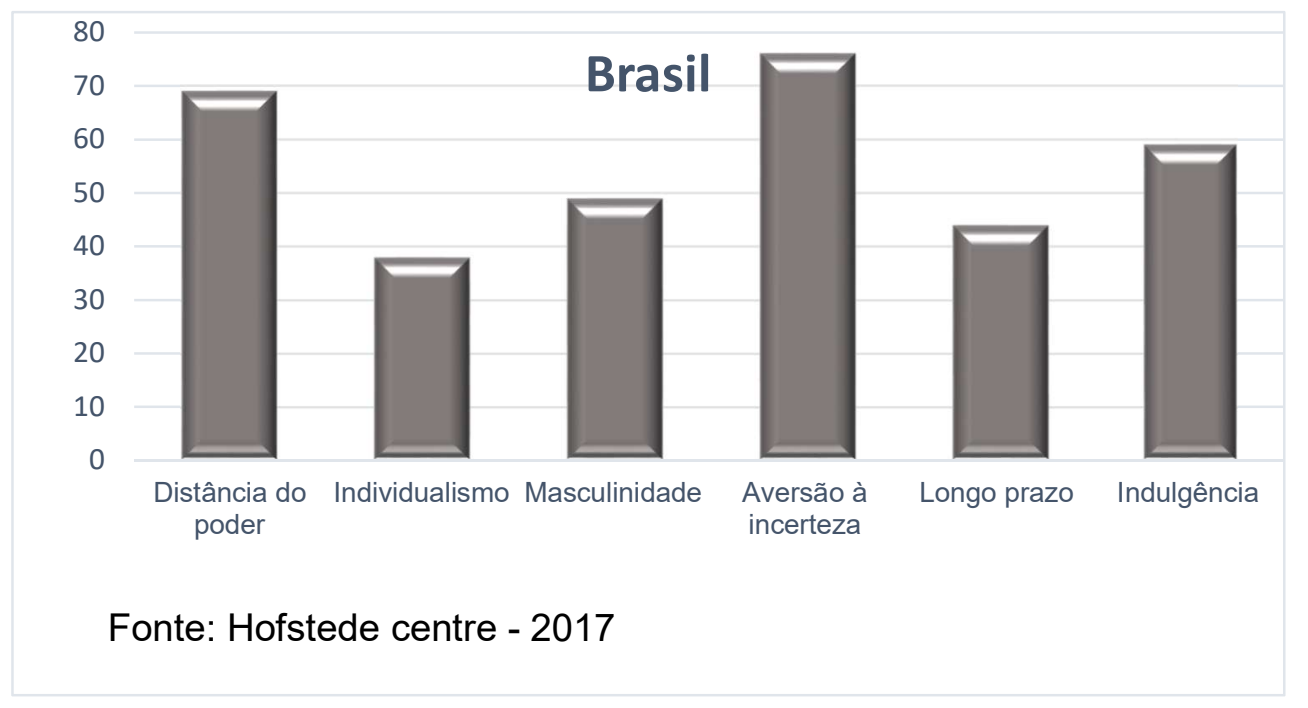

A dimensão distância do poder trata do fato de que todos os indivíduos não são iguais nas sociedades - expressa a atitude da cultura em relação a essas desigualdades entre nós. A distância de poder é definida como a medida em que os membros menos poderosos das instituições e organizações dentro de um país esperam e aceitam esse 
poder distribuído de forma desigual entre as pessoas. O Índice dessa dimensão para o Brasil é 69 , o que reflete uma sociedade que acredita que a hierarquia deve ser respeitada e que as desigualdades entre as pessoas são aceitáveis. A diferente distribuição de poder justifica o fato de que os detentores de poder têm mais benefícios do que os menos poderosos na sociedade. No Brasil, é importante mostrar respeito aos idosos. Nas empresas, existe um chefe que assume total responsabilidade. Os símbolos de status do poder são muito importantes para indicar a posição social e "comunicar" o respeito que pode ser mostrado (The Hofstede Center, 2017).

Na dimensão individualismo o que se aborda é o grau de interdependência que uma sociedade mantém entre seus membros. Tem que ver se a autoimagem das pessoas é definida em termos do "eu" ou do "nós". Nas sociedades individualistas, as pessoas tendem a cuidar de si mesmas e de sua família direta e nas sociedades coletivistas, as pessoas pertencem a "grupos" que cuidam deles em troca de lealdade. $O$ índice brasileiro é 38, o que significa que as pessoas desde o nascimento são integradas em grupos fortes e coesos que continuam protegendo seus membros em troca de lealdade. Este é um aspecto importante no ambiente de trabalho, em que se espera, por exemplo, que um membro mais velho e poderoso de uma família possa "ajudar" um sobrinho mais jovem a ser contratado para um emprego em sua própria empresa. Nos negócios, é importante construir relacionamentos confiáveis e duradouros: uma reunião geralmente começa com conversas gerais para se conhecer antes de fazer negócios. O estilo de comunicação preferido é rico em contexto. As pessoas geralmente falam profusamente e escrevem de forma elaborada (The Hofstede Center, 2017).

Uma pontuação elevada na dimensão masculinidade indica que a sociedade é conduzida pela competição, realização e sucesso, sendo o sucesso definido pelo vencedor - em um sistema de valores que começa na escola e continua ao longo da vida organizacional. E uma pontuação baixa (feminina) nessa dimensão significa que os valores dominantes na sociedade focam no cuidado com os outros e com a qualidade de vida. Uma sociedade feminina é aquela em que a qualidade de vida é sinal de sucesso e se destacar da multidão não é admirável. A questão fundamental aqui é o que motiva as pessoas, querendo ser o melhor (masculino) ou gostando do que você faz (feminino). O Brasil se classifica com pontuação 49, o que indica uma posição intermediária nesta dimensão (The Hofstede Center, 2017). 
A dimensão aversão à incerteza tem a ver com a forma como uma sociedade lida com o fato de que o futuro nunca pode ser conhecido: deve-se tentar controlar o futuro ou simplesmente deixar isso acontecer? Essa ambiguidade traz consigo ansiedade. Culturas diferentes aprenderam a lidar com essa ansiedade de maneiras diferentes. Na medida em que os membros de uma cultura se sentem ameaçados por situações ambíguas ou desconhecidas e passaram a criar crenças e instituições que tentam evitá-las. O índice para o Brasil é 76, o que é considerado alto, como assim é a maioria dos países latino-americanos. São sociedades que mostram uma forte necessidade de regras e sistemas legais elaborados para estruturar a vida. A necessidade do indivíduo de obedecer essas leis, porém, é fraca. Entretanto, se regras não podem ser mantidas, regras adicionais são ditadas. No Brasil, como em todas as sociedades de aversão à incerteza, a burocracia, as leis e as regras são muito importantes para tornar o mundo um lugar mais seguro para se viver. Os brasileiros precisam ter momentos bons e relaxantes na vida cotidiana, conversando com colegas, desfrutando de uma longa refeição ou dança com convidados e amigos. Devido à sua alta pontuação nessa dimensão, os brasileiros são pessoas muito apaixonadas e suas emoções são facilmente demonstradas por meio da linguagem corporal (The Hofstede Center, 2017).

A dimensão orientação de longo prazo descreve como toda sociedade necessita manter relações com seu próprio passado, ao mesmo tempo em que lida com os desafios do presente e do futuro, e as sociedades priorizam esses dois objetivos existenciais de maneira diferente. Sociedades normativas. que pontuam pouco nesta dimensão, por exemplo, preferem manter tradições e normas consagradas, ao mesmo tempo em que observam mudanças societárias com suspeita. Aqueles com uma cultura que apresentam uma pontuação alta nessa dimensão, adotam, por outro lado, uma abordagem mais pragmática: encorajam a economia e os esforços na educação moderna como forma de se preparar para o futuro. O Brasil possui pontuação de 44, que é considerado como intermediário (The Hofstede Center, 2017).

Um desafio que confronta a humanidade, agora e no passado, é o grau em que as crianças pequenas são socializadas. Sem socialização, não nos tornamos "humanos". Esta dimensão é definida como a medida em que as pessoas tentam controlar seus desejos e impulsos com base na forma como foram criados. O controle relativamente fraco é chamado de "Indulgência" e o controle relativamente forte é chamado de 
"Restrição". As culturas podem, portanto, ser descritas como indulgentes ou restritas. A pontuação brasileira é de 59 o que a caracteriza como uma sociedade indulgente. As pessoas em sociedades classificadas por uma pontuação elevada em Indulgência geralmente exibem uma vontade de realizar seus impulsos e desejos e tendem a aproveitar a vida e a se divertirem. Possuem uma atitude positiva e têm tendência ao otimismo. Além disso, colocam um maior grau de importância no tempo de lazer, agem como querem e gastam dinheiro como desejam (The Hofstede Center, 2017).

\section{Projeto - GLOBE (Global Leadership and Organizational Behavior Effectiveness)}

Em um dos esforços mais ambiciosos para estudar dimensões culturais, Robert House liderou uma equipe internacional de pesquisadores com o objetivo de compreender a influência das diferenças culturais sobre os estilos de liderança (House, Hanges, Javidan. Dorfrnan, \& Gupta, 2004). Uma diferença importante entre o Projeto GLOBE e as abordagens anteriores é que cada dimensão cultural é agora investigada em duas manifestações dos valores individuais: as práticas e os valores desejados.

Segundo Nardon e Steers (2013), foram identificadas nove dimensões, conforme resumido no quadro 10. Embora várias dessas dimensões já tivessem sido identificadas anteriormente (por exemplo, individualismo-coletivismo, distância do poder e aversão à incerteza), outros são únicos (por exemplo, igualitarismo de gênero e orientação de desempenho).

Foram coletados dados em sessenta e dois países e seus resultados foram comparados. Diferenças sistemáticas foram encontradas no comportamento do líder através das culturas. Por exemplo, o estilo participativo de liderança que muitas vezes é utilizado no Ocidente, que tem um perfil mais individualista, tem sua eficácia questionável no Leste, cujo perfil tende a ser mais coletivista. Gerentes asiáticos colocam uma ênfase preponderante no estilo paternalista de liderar. Os líderes carismáticos podem ser encontrados na maioria das culturas, embora possam ser altamente agressivos em algumas culturas e extremamente passivos em outras. Um líder que escuta atentamente seus subordinados é mais valorizado nos EUA do que na China. Os líderes da Malásia devem se comportar de uma maneira humilde, digna e modesta, enquanto os líderes norte-americanos raramente se comportam assim. Os indianos preferem líderes mais assertivos, moralmente íntegros e proativos. Famílias e suas normas tribais apoiam líderes altamente autocráticos em muitos países árabes (House et al., 2004). Claramente, uma das principais contribuições do projeto GLOBE 
foi o estudo sistemático não apenas das dimensões culturais, mas de como as variações de tais dimensões afetam o comportamento da liderança e sua efetividade (Nardon \& Steers, 2013).

Quadro 10 - Dimensões do Projeto GLOBE - Global Leadership and Organizational Behavior Effectiveness

\begin{tabular}{|l|l|}
\hline Dimensões culturais & \multicolumn{1}{|c|}{ Características } \\
\hline Distância ao poder & $\begin{array}{l}\text { Nível de aceitação pela sociedade da distribuição desigual do } \\
\text { poder dentro das organizações, por meio das relações } \\
\text { hierárquicas que se criam entre diretores e subordinados. }\end{array}$ \\
\hline Aversão à incerteza & $\begin{array}{l}\text { Nível de tolerância das pessoas para a incerteza ou ambiguidade } \\
\text { em vários aspectos da sua vida quotidiana, inclusive em situação } \\
\text { laboral. }\end{array}$ \\
\hline Orientação humana & $\begin{array}{l}\text { Grau em que a sociedade estimula e recompensa as pessoas por } \\
\text { serem justas, altruístas, generosas, atenciosas e gentis com as } \\
\text { outras. }\end{array}$ \\
\hline $\begin{array}{l}\text { Coletivismo } \\
\text { institucional }\end{array}$ & $\begin{array}{l}\text { Analisa até que ponto as instituições sociais, ou organizações, } \\
\text { estimulam os indivíduos a se integrarem em grupos dentro das } \\
\text { organizações e da sociedade, conduzindo as pessoas a } \\
\text { valorizarem mais a instituição do que o indivíduo }\end{array}$ \\
\hline Coletivismo do grupo & $\begin{array}{l}\text { Grau em que as pessoas se sentem orgulhosas de participar de } \\
\text { seus grupos, como a família, círculo de amigos ou a empresa para } \\
\text { a qual trabalham, conduzindo as pessoas a valorizarem mais o } \\
\text { grupo do que o indivíduo. }\end{array}$ \\
\hline Assertividade & $\begin{array}{l}\text { Grau em que as pessoas são duras, confrontadoras, agressivas e } \\
\text { competitivas, demonstrando predominância na sociedade de } \\
\text { valores tradicionalmente masculinos, como a assertividade, o } \\
\text { materialismo ou a falta de relacionamento com os outros. }\end{array}$ \\
\hline $\begin{array}{l}\text { Igualitarismo entre os } \\
\text { gêneros }\end{array}$ & $\begin{array}{l}\text { Grau em que a sociedade minimiza as desigualdades entre os } \\
\text { gêneros, destacando valores como os relacionamentos } \\
\text { interpessoais e a qualidade de vida. }\end{array}$ \\
\hline $\begin{array}{l}\text { Grau em que os indivíduos têm comportamentos orientados para } \\
\text { o futuro como o planeamento, investimentos e adiamento de } \\
\text { recompensas, traduzindo a propensão de determinada sociedade } \\
\text { para adotar uma visão de longo prazo no seu desenvolvimento. }\end{array}$ \\
\hline
\end{tabular}

Fonte: Adaptado de House et al., 2004. 
A modernização passa por duas fases principais, cada uma das quais traz mudanças distintas nas visões de mundo das pessoas. A Revolução Industrial, que estava ligada a uma mudança dos valores tradicionais para os valores seculares-racionais, trazendo burocratização, centralização, padronização e secularização da autoridade. Na fase pós-industrial da modernização, uma mudança de valores de sobrevivência para valores de auto expressão, traz uma crescente emancipação (Inglehart, 2000, 2006). Embora o desejo de liberdade seja uma aspiração humana universal, não é uma prioridade máxima quando as pessoas crescem com a sensação de que a sobrevivência é incerta. Entretanto, quando a sobrevivência parece segura, a crescente ênfase nos valores de autoexpressão torna a diversificação da democracia cada vez mais provável, onde ela ainda não existe e torna a democracia cada vez mais efetiva onde ela já existe. Esses processos de mudanças econômicas e tecnológicas deram origem a duas dimensões-chave da variação transcultural: (1) uma dimensão tradicional / secular-racional, que reflete o contraste entre os valores relativamente religiosos e tradicionais, que geralmente prevalecem nas sociedades agrárias e a valores relativamente leigos, burocráticos e racionais que geralmente prevalecem nas sociedades urbanas e industrializadas; e (2) uma dimensão de Sobrevivência / Auto expressão que também aproveita uma ampla gama de crenças e valores, refletindo uma mudança Inter geracional de uma ênfase na segurança econômica e física, sobretudo, para uma ênfase na auto expressão, bem-estar subjetivo e preocupações com a qualidade de vida (Inglehart, 2007). O quadro 11 apresenta as duas dimensões de Inglehart. 
Quadro 11 - Dimensões de Inglehart

\begin{tabular}{|c|l|}
\hline \multicolumn{1}{|c|}{ Dimensões } & \multicolumn{1}{|c|}{ Características } \\
\hline $\begin{array}{c}\text { Sradicional vs. } \\
\text { Secular-racional }\end{array}$ & $\begin{array}{l}\text { Reflete o contraste entre os valores religiosos e tradicionais que } \\
\text { geralmente prevalecem nas sociedades agrárias e os valores } \\
\text { seculares, burocráticos e racionais que geralmente prevalecem nas } \\
\text { sociedades urbanas e industrializadas. }\end{array}$ \\
\hline Auto expressão & $\begin{array}{l}\text { Envolve a polarização entre valores materialistas e pós-materialistas } \\
\text { que refletem uma mudança intergeracional de uma ênfase na } \\
\text { segurança econômica e física, para uma ênfase na auto-expressão, } \\
\text { no bem-estar subjetivo e nas preocupações com a qualidade de vida. } \\
\text { As sociedades que se destacam nos valores de sobrevivência tendem } \\
\text { a enfatizar as orientações materialistas e os papéis tradicionais de } \\
\text { gênero; eles são relativamente intolerantes a estrangeiros, gays e } \\
\text { lésbicas e outros grupos não tradicionais, mostram níveis } \\
\text { relativamente baixos de bem-estar subjetivo, possuem uma relativa } \\
\text { baixa confiança interpessoal e enfatiza o trabalho árduo, ao invés da } \\
\text { imaginação, como coisas importantes para ensinar uma criança. } \\
\text { Sociedades que enfatizam valores de auto expressão, exibem as } \\
\text { preferências opostas em todos esses tópicos. }\end{array}$ \\
\hline
\end{tabular}

Fonte: adaptado de Inglehart, 2006.

Usando dados dos World Values Surveys e European Values Surveys, que mediram as crenças e os valores da maioria das pessoas do mundo, Inglehart (2007) apresenta na figura 06 um mapa cultural bidimensional sobre o qual os sistemas de valores de 80 sociedades são retratados. A dimensão vertical representa a dimensão tradicional/secular-racional, e a dimensão horizontal reflete a dimensão valores de sobrevivência/auto expressão. Ambas estão fortemente relacionadas ao desenvolvimento econômico, com os sistemas de valores dos países ricos diferenciando-se sistematicamente dos países pobres. 
Figura 06 - O mapa cultural do mundo em 2000

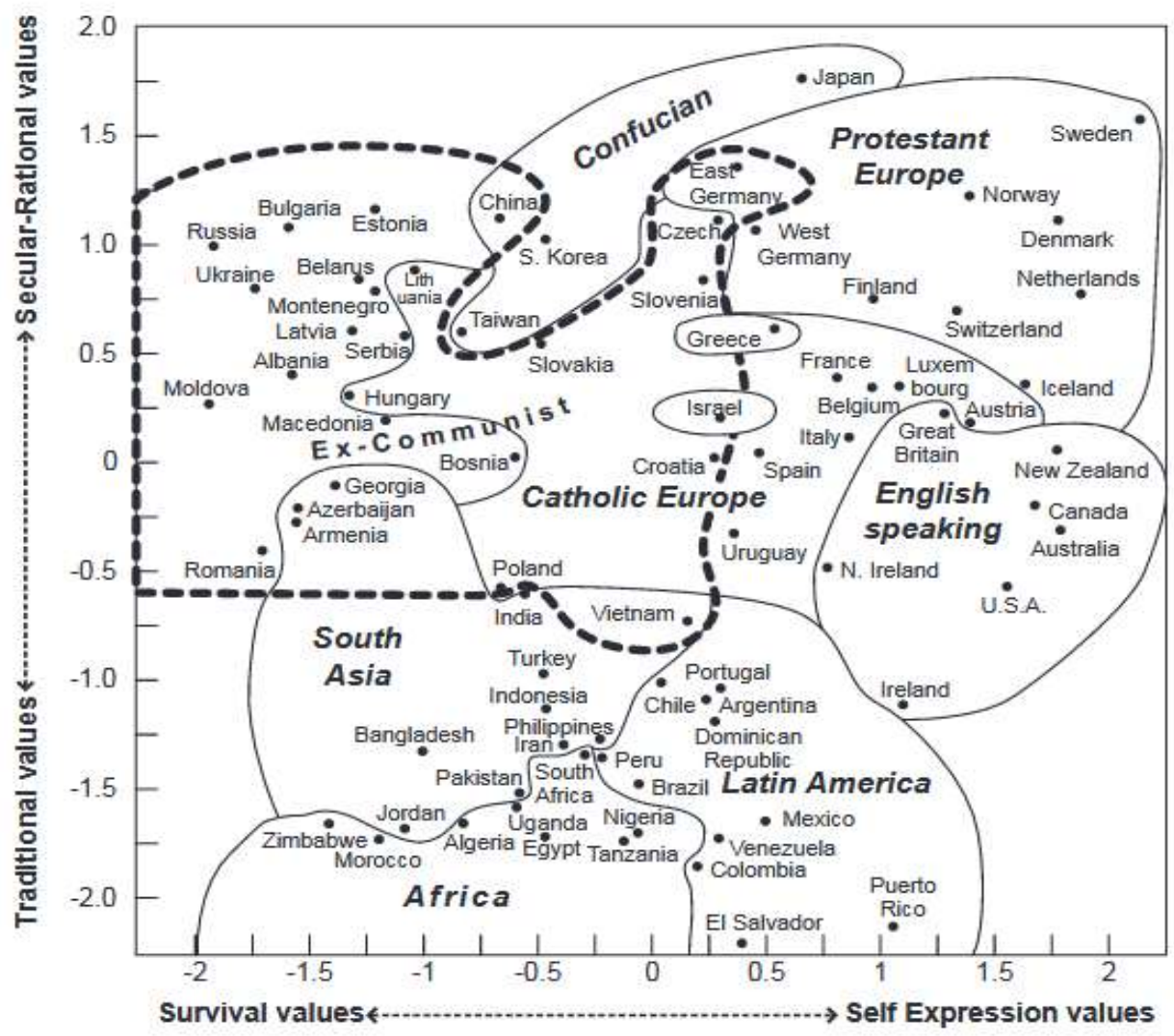

Fonte: World Values Research - WVR, 2017

Uma análise um pouco simplificada da variação da cultura é que, após um aumento nos padrões de vida, há um trânsito do país de desenvolvimento, por meio da industrialização, para a sociedade do conhecimento pós-industrial. Um país tende a se mover diagonalmente na direção do canto inferior esquerdo (pobre) para o superior direito canto (rico), indicando um trânsito em ambas as dimensões. Esse movimento pode ser visto na figura 07 , que, comparativamente à figura anterior (06), vê-se o movimento dos países no tempo. 
Figura 07 - O mapa cultural do mundo em 2015

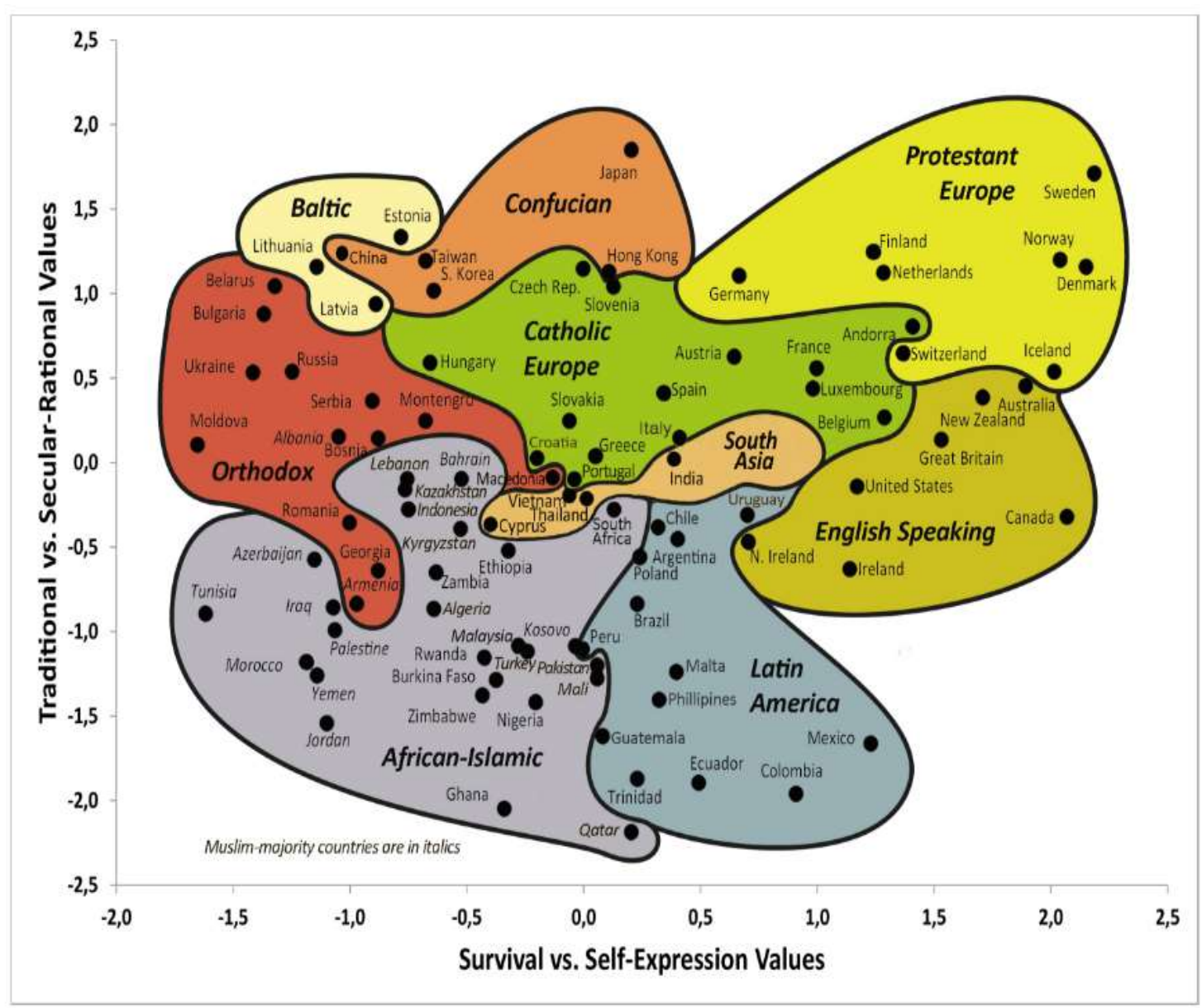

Fonte: World Values Research - WVR, 2017

\section{Minkov}

Minkov (2007) derivou três dimensões culturais dicotômicas da base de dados pública WVS (Inglehart, 2000; World Values Survey do ano de 2006) e analisou os dados no contexto das dimensões do valor cultural definidas por Hofstede, Trompenaars e Global Leadership \& Projeto de Eficácia do Comportamento Organizacional (GLOBE). As dimensões de Minkov foram incorporadas no novo módulo de levantamento de valores de Hofstede (VSM 08). Entretanto, no site Hofstede Centre, a única dimensão apresentada é a de indulgência versus restrição. O quadro 12 apresenta as três dimensões de Minkov. 
Quadro 12 - Dimensões de Minkov

\begin{tabular}{|l|l|}
\hline \multicolumn{1}{|c|}{ Dimensões } & \multicolumn{1}{c|}{ Características } \\
\hline $\begin{array}{l}\text { Monumentalismo } \\
\text { (Autocolapso) }\end{array}$ & $\begin{array}{l}\text { O monumentalismo representa o orgulho e a grande autoconfiança, } \\
\text { demonstração de status e generosidade com dinheiro, favores e } \\
\text { serviços, consistência entre sentimentos e expressão externa e } \\
\text { evitação de sentimentos e pensamentos dialéticos, incluindo maior } \\
\text { religiosidade. Flexumilidade (flexibilidade + humildade) caracteriza-se } \\
\text { pelas situações opostas. }\end{array}$ \\
\hline $\begin{array}{l}\text { Exclusionismo } \\
\text { Universalismo }\end{array}$ & $\begin{array}{l}\text { O exclusionismo é definido como a tendência cultural de tratar as } \\
\text { pessoas com base em sua afiliação grupal e favores pessoais, } \\
\text { serviços e privilégios para os que fazem parte do grupo, ao mesmo } \\
\text { tempo em que excluem grupos que não merecem esse tratamento } \\
\text { privilegiado. O universalismo é a tendência cultural inversa; tratando } \\
\text { as pessoas principalmente com base em quem eles são como } \\
\text { indivíduos e desconsiderando sua afiliação grupal. }\end{array}$ \\
\hline $\begin{array}{l}\text { Indulgência vs. } \\
\text { Restrição }\end{array}$ & \begin{tabular}{l} 
Satisfação de impulsos e desejos em busca da felicidade e do prazer. \\
\hline
\end{tabular}
\end{tabular}

Fonte: adaptado de Minkov, 2007.

\subsection{Buscando a convergência em os modelos de cultura nacional}

Ao analisar esses seis modelos, Nardon e Steers (2013) estabeleceram dois pontos em comum: (1) cada modelo oferece um conjunto bem fundamentado de dimensões ao longo das quais várias culturas podem ser comparadas, permitindo que os investigadores avaliem as diversas culturas nacionais quando a fatores como distância do poder, aversão à incerteza, entre outros e, dessa forma, organizem os seus pensamentos e concentrem a atenção sobre esses fatores, o que de outra forma seria uma tarefa monumental. E (2) quatro dos modelos oferecem pontuações numéricas para avaliar várias culturas, sendo possível dizer que, por exemplo, na escala de Hofstede (que atribui um valor de 0 a 100 para cada uma das categorias), na categoria distância ao poder foi atribuído ao Brasil o valor de 69, à Alemanha 35 e à França 68, sugerindo que a Alemanha é mais igualitária do que a França e que o Brasil e a França têm uma população mais propensa a aceitar a hierarquia.

Independentemente de saber se essas classificações são altamente precisas, ou apenas geralmente indicativas, o certo é que essas medidas podem indicar como esses países variam culturalmente, permitindo aos investigadores estudar as 
influências culturais na gestão e aos gestores compreender as configurações culturais.

Infelizmente, esses seis modelos culturais se concentram em aspectos diferentes de crenças, normas ou valores sociais, limitando, de forma imediata, a convergência entre os modelos. Mas, ao invés de defender um modelo em detrimento a outro. Nardon e Steers (2013) sugerem a abordagem mais produtiva é integrar e adaptar os vários modelos quanto às suas utilidades na gestão do conhecimento de ambientes transculturais. Os autores, então, identificaram temas comuns representativos das principais diferenças entre culturas, de sorte que cinco temas relativamente comuns emergiram dessa comparação, como pode ser visto no veja quadro 13.

Quadro 13 - Temas comuns entre os modelos relativos a cultura nacional

\begin{tabular}{|l|l|l|l|l|l|l|}
\hline \multicolumn{1}{|c|}{ Temas Comuns } & \multicolumn{5}{|c|}{ Modelos de Cultura } \\
\cline { 2 - 7 } & $\begin{array}{l}\text { Kluckhohn/ } \\
\text { Strodtbeck }\end{array}$ & Hofstede & Hall & Trompenaars & Schwatrz & GLOBE \\
\hline $\begin{array}{l}\text { Distribuição } \\
\text { poder e autoridade } \\
\text { Ênfase ou no grupo } \\
\text { ou no indivíduo }\end{array}$ & & & & & & \\
\hline $\begin{array}{l}\text { Relacionamento } \\
\text { com o ambiente }\end{array}$ & & & & & & \\
\hline $\begin{array}{l}\text { Uso do tempo } \\
\text { Controle pessoal e } \\
\text { social }\end{array}$ & & & & & & \\
\hline Outros temas & & & & & & \\
\hline
\end{tabular}

Fonte: Adaptado de Nardon e Steers, 2013. 
E os temas comuns são entendidos da seguinte forma:

1.Distribuição de poder e autoridade na sociedade

2. Centralidade de indivíduos ou grupos como indivíduos ou grupos? Como é que uma sociedade se base das relações sociais organiza para a ação coletiva?

3. Relacionamento das pessoas com o seu ambiente

4. Uso do tempo

Como poder e autoridade são distribuídos em uma sociedade? É esta distribuição baseada em conceitos de hierarquia ou de igualitarismo? Quais são as crenças da sociedade em matéria de igualdade ou de privilégio?

$O$ que é o alicerce fundamental de uma sociedade: Em um nível social, como as pessoas veem o mundo em torno delas e sua relação com o ambiente natural e social? É seu objetivo controlar o ambiente e os eventos em torno deles para viverem em harmonia com estas realidades externas?

Como as pessoas em uma sociedade organizam e gerem o seu tempo para realizar suas atividades de trabalho e não trabalho? As pessoas se aproximam do trabalho de uma forma não linear ou linear?

Como as sociedades tentam assegurar previsibilidade no 5. Mecanismos de controle comportamento dos seus membros? Elas trabalham para pessoal e social controlar as pessoas por meio de regras, políticas, leis e normas sociais uniformemente aplicadas ou confiam mais em laços pessoais ou circunstâncias únicas?

À primeira vista, esses cinco temas parecem replicar cinco dimensões de Hofstede, mas uma análise mais detalhada sugere que os outros modelos sirvam para amplificar, esclarecer e, em alguns casos, reposicionar dimensões para que elas se tornem mais relevantes. A ideia é de que, ao analisar o que é comum entre modelos, reforce-se sua utilidade (e possível validade) como componentes de avaliação críticas para haver uma melhor compreensão melhor da gestão global e do mundo dos negócios internacionais. Como tal, cada modelo acrescenta, assim, algo de valor para este esforço (Nardon \& Steers, 2013).

Maleki \& Jong (2014), com base em análises teóricas e estatísticas, combinaram sistematicamente as dimensões de vários estudos entre si, primeiro conceitualmente e depois estatisticamente, de forma que sintetizaram em nove clusters de dimensões todas as dimensões quantitativas apresentadas por Hofstede, Inglehart, Schwartz, GLOBE, Minkov e autores qualitativos (Douglas, Kluckhohn, Parsons, Hall, Trandis e Trompenaars).Referem-se a clusters de dimensões e não em nove dimensões, porque podem referir-se a dimensões similares e fortemente relacionadas de diferentes estudos, que, no entanto, não são idênticos. A construção dos clusters de dimensões passou por duas análises: uma análise fatorial dos quantitativos e uma análise de conteúdo dos modelos qualitativos. O resultado é apresentado no quadro 14. 
Quadro 14 - conjunto de dimensões culturais

\subsubsection{Valores}

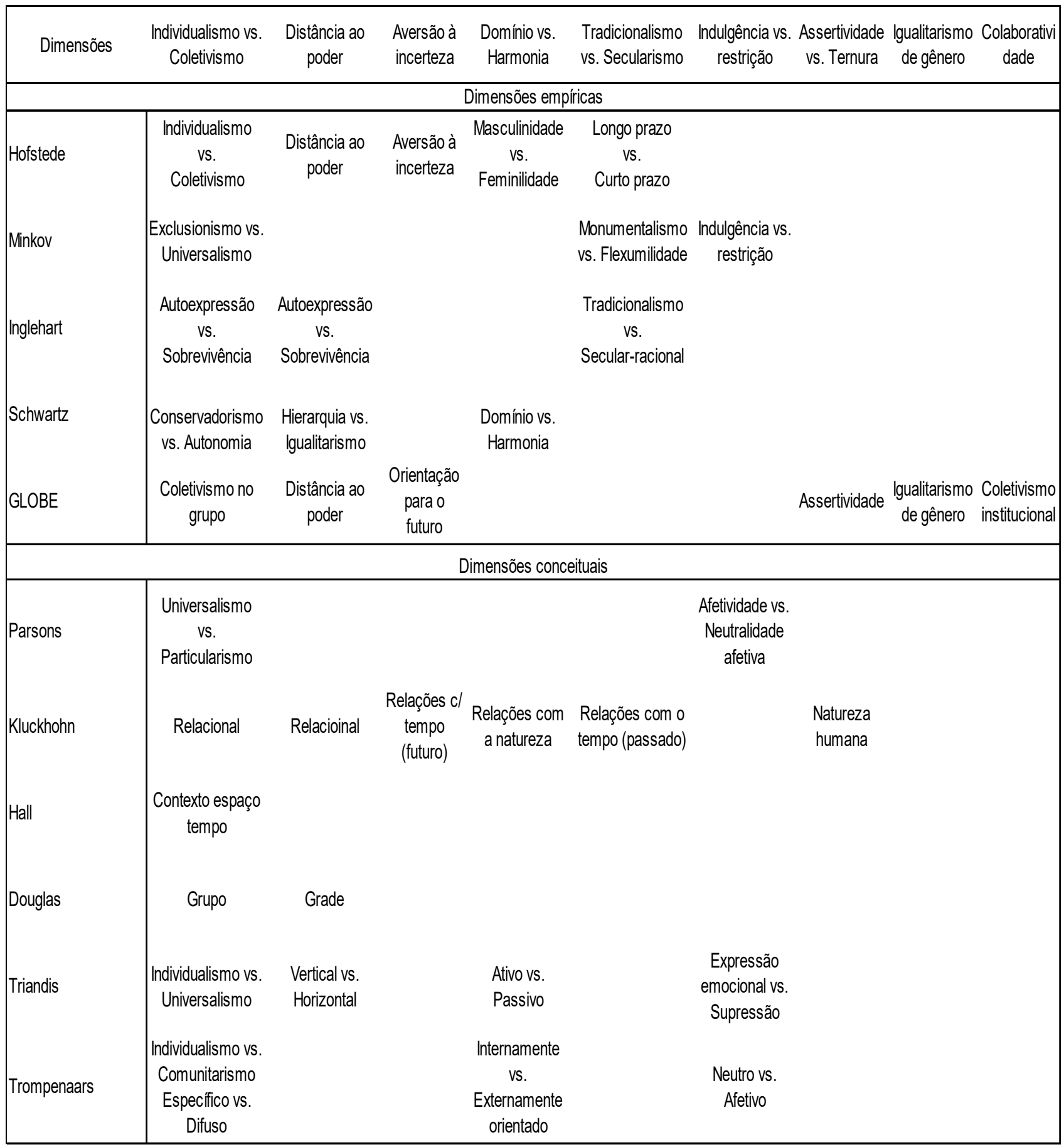

Fonte: Maleki \& Jong - A proposal of clustering the dimensions of national culture - 2014, com adaptações

Neste trabalho os valores organizacionais, variável contextual que será pesquisada nesta tese para verificar alcance de resultados organizacionais, têm como pressuposto o isomorfismo entre a estrutura dos valores humanos e dos valores organizacionais. Inicialmente apresenta-se um breve entendimento histórico dos 
estudos referentes a valores humanos, dando ênfase à teoria de Schwartz e, em seguida, expõe-se a transposição da teoria de valores pessoais de Schwartz para os valores organizacionais, destacando-se os modelos teóricos desenvolvidos por Tamayo, que referencia o instrumento de pesquisa que será usado neste trabalho.

\subsubsection{Valores humanos}

Os valores têm sido estudados por várias áreas do conhecimento humano, tais como filosofia, artes, sociologia e antropologia, mas, apesar disso, ainda se evidencia pouca uniformidade entre os conceitos adotados nessas áreas, sendo comum presenciar os construtos atitudes, traços, normas e necessidades sendo utilizados como sinônimo de valores (Hitlin \& Piliavin, 2004). Assim, de acordo com seu objeto particular de interesse, cada disciplina articularia dialeticamente aqueles aspectos mais objetivos ou mais subjetivos do construto, buscando declarar e entender tanto as funções cognitivas quanto as pragmáticas desempenhadas pelos valores no contexto social.

Quanto a sua aplicabilidade nas ciências sociais, Ros (2001) evidencia que os estudos sobre valores podem assumir duas perspectivas distintas e igualmente significativas:

1. Valores como variável dependente: consideram que os valores resultam da influência de uma série de outras variáveis sociais, políticas, religiosas e econômicas. Os estudos que adotam esta perspectiva buscam determinar em que medida estas variáveis seriam responsáveis pela consolidação de um perfil de valores; e

2. Valores como variável independente: consideram que os valores (pessoais e coletivos) são capazes de explicar o comportamento das pessoas e das sociedades. Neste caso, procura-se demonstrar o papel dos valores como variável preditora de comportamentos, identidades, atitudes e sentimentos.

Seja ela estudada como variável independente ou dependente, o que se entende é que os valores facilitam a adaptação das pessoas ao seu ambiente, constituindo um protótipo do qual derivam atitudes e comportamentos socialmente aceitos. Tornamse, então, elementos deliberativos da rotina das pessoas (Tamayo \& Schwartz, 1993). Clyde Kluckhohn (1951) é um antropologista cultural em cuja época o entendimento comum era de que valores estavam associados a proposições normativas entre o desejável (o que se deve querer) e o desejado (o que se quer). Sua definição de valor 
é "uma concepção, explícita ou implícita, distinta da característica de um indivíduo ou grupo, do desejável que influencia a seleção entre os modos, meios e finalidades de ações disponíveis". E estes valores estão hierarquicamente organizados (Kluckhohn, 1951 p. 395).

Nesse contexto histórico, tem-se a contribuição de Kurt Lewin (1942) teorizando sobre a influência do valor sobre o comportamento, mas não tendo caráter de objeto (de campo de força), por exemplo, a pessoa não tenta atingir o valor honestidade, mas a honestidade guia seu comportamento. Os valores, dessa forma, possivelmente indicam quais tipos de atividades têm valência positiva ou negativa para a pessoa em uma determinada situação específica. Semelhantemente, Allport (1955) corrobora Lewin (1942) no sentido em que valores influenciam no comportamento e dão sentido à vida das pessoas. Utilizando-se da tipologia do psicólogo alemão Eduard Spranger (1928), que qualificou caracteres humanos baseado em valores supra pessoais, propuseram-se seis orientações de valor ou tipo ideal: teórica, estética, econômica, social, política e religiosa. Allport, Vernon e Lindzey (1960) desenvolveram um questionário para medir os valores individuais, formada por seis fatores (um para cada tipo ideal) e consideraram haver níveis diferentes de importância entre esses valores para cada pessoa. Tornaram-se, então, uns dos primeiros teóricos a apresentar um instrumento de medida de valores, sendo uma das escalas mais utilizadas na área de orientação vocacional (Payne, 1988; Ewen, 2003; Porto, 2004; Bedani, 2008).

A teoria das necessidades humanas é apresentada na obra de Maslow (1954) Personality and motivation - em que se mostra a relação das necessidades com os valores humanos (Gouveia, 1998), ao estabelecer que os seres humanos têm vários tipos de necessidades e que estão hierarquicamente organizadas: fisiológicas, segurança, pertencimento, estima, autorrealização. Maslow denomina como prepotência relativa aquilo que uma necessidade nova (nível superior) só poderá ser atendida se a necessidade do nível inferior estiver completamente satisfeita. Esta teoria foi um dos pilares para modelos de valores materialistas e pós-materialistas, mostrando que os valores materialistas só se converteriam para os valores pósmaterialistas se as necessidades de bem-estar econômico fossem totalmente satisfeitas, daí passando para as necessidades de autorrealização (participação política, cuidados com o meio-ambiente, por exemplo). Gouveia (1998) retrata outras 
tipologias de valores que foram influenciadas pela teoria de Maslow (Hofstede, 2003; Rokeach, 1973; Schwartz, 1992).

Milton Rokeach, com a publicação do seu livro The nature of human values (Rokeach, 1973), distinguiu os valores de outros construtos com os quais era de praxe serem relacionados, como as atitudes, os interesses e os traços de personalidade, definindo valores individuais como percepções socialmente compartilhadas do que é desejável em relação a um oposto. Essas percepções são decorrentes do processo de aprendizagem das representações cognitivas e das necessidades internas (força interna) mediadas pelas pressões externas.

Rokeach (1973) descreve dois tipos de valores:

(1) Os terminais -> referem-se às necessidades existenciais, podendo ser pessoais (felicidade, paz interna, por exemplo) e sociais ou interpessoais (segurança familiar, igualdade, entre outros); e

(2) Os instrumentais -> referem-se aos meios para o alcance dos fins, são vistos como morais (honestidade, responsabilidade) que, se não realizados, provocam culpa.

Quanto à natureza dos valores humanos, Rokeach (1973) elencou cinco pressupostos básicos: (1) o número total de valores que um indivíduo possui é relativamente pequeno; (2) todas as pessoas em diferentes lugares possuem os mesmos valores em diferentes graus; (3) valores são organizados dentro de um sistema de valores; (4) os antecedentes dos valores humanos podem ser identificados nas culturas, nas sociedades, nas instituições e na personalidade das pessoas; (5) as consequências dos valores humanos podem ser manifestadas em todos os fenômenos considerados merecedores de investigação e de estudo para as ciências sociais.

Ros (2006) afirma que foi a partir das pesquisas realizadas nos anos de 1970 que a noção de valor ganhou força, iniciando estudos sobre valores individuais de forma mais estruturada e sistemática. E foi assim que o conceito preciso de valor, propriamente, foi desenvolvido entre 1980 e 1990 com os trabalhos de Shalom Schwartz e Bilsky (Ros, 2006).

Schwartz (2005) utilizou-se, principalmente, dos estudos de Rokeach (1973; 1981) e dos diversos conceitos sobre valores na literatura. Schwartz e Bilsky (1987) identificaram cinco características comuns, em que valores são: (a) conceitos ou crenças, (b) sobre comportamentos ou estados finais de existência desejáveis, (c) que 
transcendem situações específicas, (d) que guiam a seleção ou avaliação de comportamentos ou eventos e (e) que são ordenados por sua importância relativa (Schwartz \& Bilsky, 1987 p. 551).

Com vistas a obter uma percepção mais clara do significado do conceito de valores, Schwartz e Bilsky (1987) estabeleceram como pressuposto teórico que a natureza e os princípios dos valores são consubstanciados por três necessidades comuns à humanidade: (1) necessidades biológicas do organismo; (2) necessidade de haver interação social para a regulação das relações interpessoais e (3) necessidade de sobrevivência e bem-estar dos grupos.

Esses pressupostos teóricos foram validados em pesquisas transculturais realizadas por Schwartz (1992, 1994, 1996, 2005b). Ao longo de cada avaliação empírica da teoria, novos conhecimentos foram adquiridos, como a inclusão de mais dois pontos distintos: os valores que estão vinculados aos interesses a que servem (individualistas, coletivistas ou mistos) e a presença de diferentes domínios motivacionais, denominados "tipos motivacionais".

Com esses novos pressupostos de conteúdo dos valores, Schwartz e Bilsky (1987) passaram a definir valores como um conceito individual de uma meta transituacional desejável, remetendo interesses relativos a um tipo motivacional, avaliando-o quanto a sua importância como princípio orientador na vida de uma pessoa ou de outra entidade social.

Os valores como metas transituacionais compreendem a capacidade que os valores podem ter em estenderem-se para vários contextos da vida humana, transcendendo a situações específicas, tendo como pressupostos a relação entre o indivíduo e a estrutura social (Rohan, 2000). Outro fator importante sobre esse conceito é quanto sua diferenciação do apresentado por Rokeach (1973), fundamentalmente ao estabelecer que os valores são considerados como metas ao invés de crenças e ao não diferenciar entre valores terminais e instrumentais.

Atualmente, Schwartz (2005a), os valores possuem cinco principais características: (a) são crenças; (b) são um construto motivacional (motivação para agir, objetivos desejáveis); (c) transcendem circunstâncias e ações específicas (são objetivos abstratos); (d) guiam a seleção e avaliação de ações, políticas, pessoas e eventos; e (e) são classificados pela importância relativa aos demais, ou seja, possuem uma natureza hierárquica (prioridades axiológicas). Todos os valores possuem essas 
características, entretanto será o tipo de motivação latente a cada um dos valores que os tornará diferenciados.

\subsubsection{Modelo teórico dos valores humanos de Schwartz}

Schwartz e Bilsky (1987; 1990), a partir das características dos valores humanos, publicaram um trabalho no ano de 1987, propondo a construção de um modelo estrutural sobre valores humanos organizados de acordo com suas similaridades e diferenciações. $\mathrm{Na}$ estrutura motivacional estariam contidos sete domínios motivacionais de valores: segurança, satisfação, realização, autodireção, pró-social, benevolência e poder social. Para testar o modelo, foi empregada a escala de valores de Rokeach ${ }^{5}$ com 36 valores (18 instrumentais e 18 terminais) em professores israelitas e estudantes da antiga Alemanha Ocidental. Os dados foram analisados por meio do método SSA 6 (Smallest Space Analysis), desenvolvido por Guttman, que possibilita organizar os valores quanto a similaridades e diferenças, pois, se a distância entre os valores for muito pequena, então mostra-se alta prioridade entre os dois valores, demonstrando compatibilidade e, se a distância for grande, evidencia-se baixa prioridade, demonstrando antagonismo.

O resultado confirma os sete domínios motivacionais e classificam-nos em três dimensões, quanto ao tipo de interesse a que servem (coletivos, mistos ou individuais). Assim, as relações sociais com ênfase no coletivo têm como domínios sociais a segurança, a conformidade e pré-social; as individuais têm a realização e poder social como domínios motivacionais; e as que estão embarcadas no domínio coletivo têm a benevolência e a autodireção.

\footnotetext{
${ }^{5} \mathrm{Na}$ escala de valores de Rokeach, os valores são separados em terminais, que representam as grandes metas da humanidade (valores desejáveis) e os instrumentais, que representam modelos ideias de comportamento visando atingir as metas desejadas, estão relacionadas com os modos de conduta, podendo ser morais ou de competência. Os valores terminais são escritos em forma de substantivos (um mundo de paz; prazer) e os valores instrumentais em forma de adjetivos (alegre; amoroso). A escala contém frases explicativas do significado de cada valor e pede-se à pessoa que a partir dos princípios norteadores da sua vida, estabeleça uma hierarquia de valores (Burgess \& Schwartz, 1994; Rohan, 2000).

${ }^{6}$ O método SSA permite "representar os valores como pontos num espaço multidimensional, de forma que as distâncias entre os pontos reflitam as relações empíricas entre os valores como mensurados pelas correlações entre seus índices de importância". Assim, esse método permite avaliar que, quanto maior a similaridade conceitual entre dois valores, maior deve ser sua relação empírica e mais perto devem estar localizados no espaço multidimensional (Schwartz \& Bilsky, 1987, p.553).
} 
Dando continuidade a essa pesquisa, Schwartz e Bilsky (1990) aplicaram o instrumento em mais cinco países (Austrália, Estados Unidos, Hong Kong, Espanha e Finlândia), incluindo mais 20 valores à escala original e a análise dos dados realizada pelo método SSA. A estrutura de similaridades e diferenciações entre os sete domínios motivacionais foi confirmada, senão para Hong Kong, em que somente o domínio poder social foi confirmado.

Os benefícios da teoria desenvolvida por Schwartz e Bilsky $(1987$; 1990) foram: (a) o impacto dos valores como variáveis independentes (explanatórias) nas atitudes e comportamentos, como variáveis preditoras, permitindo identificá-las e interpretá-las; (b) o impacto de variáveis estruturais individuais e sociais (política, religião, família, por exemplo) nos valores como variável dependente; (c) a possibilidade de realizar comparações transculturais quanto às similaridades e diferenças entre os domínios de valores (Rohan, 2000).

Em 1992, Schwartz fez avanços significativos para o aperfeiçoamento da teoria: fez uma revisão teórica sobre os domínios motivacionais, que passaram a ser denominados de "tipos motivacionais de valores" e elaborou a escala Schwartz Values Survey (SVS). Submeteu a escala a testes empíricos, aplicando-a em 20 países, conseguindo identificar dez tipos motivacionais comuns a praticamente todos os pesquisados. Em 1994, obteve resultados muito semelhantes aos resultados obtidos em 96 amostras de 44 países (Schwartz, 1994). Em 2005, o modelo estrutural de valores foi ratificado mediante estudo realizado em 210 amostras correspondendo a 64.271 pesquisados de todos os continentes, perfazendo um total de 67 países. A nova estrutura de valores humanos passou a ser composta por dez tipos motivacionais de valores, cuja base é a de que indivíduos e grupos não se diferenciam em relação aos tipos de valores, e sim pelo grau de relevância atribuída a seus valores, i.e., suas prioridades axiológicas. Os dez tipos motivacionais são: segurança, tradição, benevolência, universalismo, autodeterminação, estimulação, hedonismo, realização e poder (Schwartz, 2006a). Como pode ser visto no quadro 15, a seguir: 


\begin{tabular}{|c|c|c|c|c|c|}
\hline Dimensão & $\begin{array}{c}\text { Tipo } \\
\text { Motivacional }\end{array}$ & $\begin{array}{l}\text { Definição dos tipos } \\
\text { motivacionais em } \\
\text { termos de metas a } \\
\text { serem alcançadas }\end{array}$ & $\begin{array}{l}\text { Exemplos } \\
\text { de } \\
\text { valores }\end{array}$ & $\begin{array}{c}\text { Necessidade } \\
\text { da qual deriva } \\
\text { o valor }\end{array}$ & $\begin{array}{c}\text { Serve } \\
a \\
\text { interesses }\end{array}$ \\
\hline \multirow{3}{*}{ Conservadorismo } & Segurança & $\begin{array}{l}\text { Segurança, } \\
\text { harmonia e } \\
\text { estabilidade da } \\
\text { sociedade, das } \\
\text { relações e do self. }\end{array}$ & $\begin{array}{l}\text { Ordem social, senso de } \\
\text { pertencer, segurança } \\
\text { nacional e da família, } \\
\text { integridade pessoal, } \\
\text { limpeza. }\end{array}$ & $\begin{array}{l}\text { Biológica, } \\
\text { socioinstitucional, } \\
\text { interação social }\end{array}$ & Mistos \\
\hline & Tradição & $\begin{array}{l}\text { Respeito, } \\
\text { compromisso e } \\
\text { aceitação dos } \\
\text { costumes e ideias } \\
\text { de uma cultura ou } \\
\text { religião. }\end{array}$ & $\begin{array}{l}\text { Humildade, moderação, } \\
\text { respeito, aceitação, } \\
\text { devoção }\end{array}$ & Interação social & Coletivos \\
\hline & Conformidade & $\begin{array}{l}\text { Controle de ações e } \\
\text { impulsos que podem } \\
\text { magoar, violar as } \\
\text { normas e } \\
\text { expectativas sociais. }\end{array}$ & $\begin{array}{l}\text { Obediência, } \\
\text { autodisciplina, polidez, } \\
\text { respeito aos pais e } \\
\text { pessoas mais idosas. }\end{array}$ & $\begin{array}{l}\text { socioinstitucional } \\
\text { interação social }\end{array}$ & Coletivos \\
\hline \multirow[t]{2}{*}{ Autotranscedência } & Benevolência & $\begin{array}{l}\text { Preocupação com } \\
\text { a preservação e } \\
\text { bem-estar de } \\
\text { pessoas próximas }\end{array}$ & $\begin{array}{l}\text { Lealdade, } \\
\text { honestidade, amizade, } \\
\text { piedade }\end{array}$ & $\begin{array}{l}\text { Biológica } \\
\text { socioinstitucional, } \\
\text { interação social }\end{array}$ & Coletivos \\
\hline & Universalismo & $\begin{array}{l}\text { Compreensão, } \\
\text { apreço, tolerância } \\
\text { e proteção do } \\
\text { bem-estar de } \\
\text { todas as pessoas } \\
\text { e da natureza }\end{array}$ & $\begin{array}{l}\text { Justiça social, } \\
\text { igualdade, sabedoria, } \\
\text { proteção ao meio } \\
\text { ambiente }\end{array}$ & $\begin{array}{l}\text { Biológica } \\
\text { socioinstitucional }\end{array}$ & Mistos \\
\hline \multirow{2}{*}{$\begin{array}{c}\text { Abertura à } \\
\text { mudança }\end{array}$} & Autodeterminação & $\begin{array}{l}\text { Independência de } \\
\text { pensamento e } \\
\text { ação. }\end{array}$ & $\begin{array}{l}\text { Liberdade, } \\
\text { criatividade, } \\
\text { curiosidade, } \\
\text { independência }\end{array}$ & $\begin{array}{l}\text { Biológica } \\
\text { socioinstitucional } \\
\text { Biológica }\end{array}$ & Individuais \\
\hline & Estimulação & $\begin{array}{l}\text { Excitação, } \\
\text { novidades e } \\
\text { desafios na vida. }\end{array}$ & $\begin{array}{l}\text { Vida variada, } \\
\text { excitante, ousadia. }\end{array}$ & & Individuais \\
\hline $\begin{array}{c}\text { Abertura à } \\
\text { Mudança e } \\
\text { Autopromoção }\end{array}$ & Hedonismos & $\begin{array}{l}\text { Prazer sensual ou } \\
\text { gratificações para } \\
\text { si próprio. }\end{array}$ & $\begin{array}{l}\text { Prazer, } \\
\text { autoindulgência, gozar } \\
\text { a vida }\end{array}$ & Biológica & Individuais \\
\hline \multirow[b]{2}{*}{ Autopromoção } & Realização & $\begin{array}{l}\text { Sucesso pessoal } \\
\text { por meio de } \\
\text { demonstração de } \\
\text { acordo com os } \\
\text { padrões sociais. }\end{array}$ & $\begin{array}{l}\text { Ambição, sucesso, } \\
\text { influência, inteligência }\end{array}$ & $\begin{array}{l}\text { socioinstitucional } \\
\text { Interação social }\end{array}$ & Individuais \\
\hline & Poder & $\begin{array}{l}\text { Status social e } \\
\text { prestígio, controle } \\
\text { ou domínio sobre } \\
\text { pessoas e } \\
\text { recursos }\end{array}$ & $\begin{array}{l}\text { Poder social, } \\
\text { autoridade, saúde, } \\
\text { riqueza. }\end{array}$ & $\begin{array}{l}\text { socioinstitucional } \\
\text { Interação social }\end{array}$ & Individuais \\
\hline
\end{tabular}

Fonte: Schwartz (2005a p. 24-27), com adaptações. 
Schwartz (2005a) define os tipos motivacionais da seguinte forma: (1) autodeterminação - independência de ação e pensamento; (2) Estimulação - busca por excitação, novidade, desafio na vida; (3) Hedonismo - busca o prazer ou a gratificação sensual; (4) Realização - obtenção de sucesso pessoal por meio de demonstração de competência, sempre atendendo aos padrões sociais; (5)Poder obter status social e prestígio, ter controle ou domínio sobre recursos e pessoas; (6) Segurança - harmonia e estabilidade da sociedade e pessoal, objetiva a segurança; (7) Conformidade - evita ações impulsivas que possam prejudicar outras pessoas e violar expectativas ou normas sociais; (8) Tradição - compromisso e aceitação de costumes e ideias de uma determinada cultura; (9) Benevolência - preservação e fortalecimento do bem-estar de pessoas mais íntimas do indivíduo; (10) Universalismo - compreensão e proteção do bem-estar de todas as pessoas e da natureza.

Esses dez tipos motivacionais foram categorizados em quatro tipos motivacionais de segunda ordem (Schwartz, 2005): ( 1) Autopromoção se refere à motivação para a busca dos interesses próprios, ainda que à custa de interesses alheios - insere Poder, Hedonismo e Realização; (2) Autotranscedência, se refere à motivação para superar o egoísmo e promover o bem-estar alheio - contém os tipos motivacionais Universalismo e Benevolência; (3) Abertura à Mudança está relacionada à motivação para seguir os próprios interesses intelectuais e motivacionais em direções incertas agrega Hedonismo, Estimulação e Autodeterminação; (4) Conservação se refere à motivação para a manutenção do status quo e da certeza, inclui Segurança, Conformidade e Tradição. Nesta categorização, o tipo "Hedonismo" participa de duas dimensões de ordem superior (Autopromoção e Abertura à mudança), já que elementos do seu conteúdo são identificados nas duas dimensões.

Os tipos motivacionais de segunda ordem representam as relações de similaridade dentro de cada agrupamento e também as relações de diferenciação entre eles, formando duas dimensões bipolares: Autopromoção versus Autotranscedência e Abertura à Mudança versus Conservação (Schwartz, 2005). A primeira dimensão contrasta a busca de sucesso pessoal e poder sobre os outros com a busca pelo bemestar dos outros. A segunda dimensão opõe a ênfase na independência de ação e pensamento à autorrestrição que promove a preservação da estabilidade. 
Schwartz $(1994,2005 a)$ postula que os valores integram um contínuo de relações e, dessa forma, apresentam uma estrutura circular (disponível na figura 08), quanto mais próximo um tipo motivacional estiver do outro, em qualquer das direções, mais compatíveis são suas motivações subjacentes e quanto mais afastados, mas antagônicas serão suas motivações subjacentes.

A Divisão dos valores em dez tipos diferentes organizados em duas dimensões bipolares pode ser vista na figura 08.

Figura 08: Estrutura Circular dos Valores segundo Schwartz

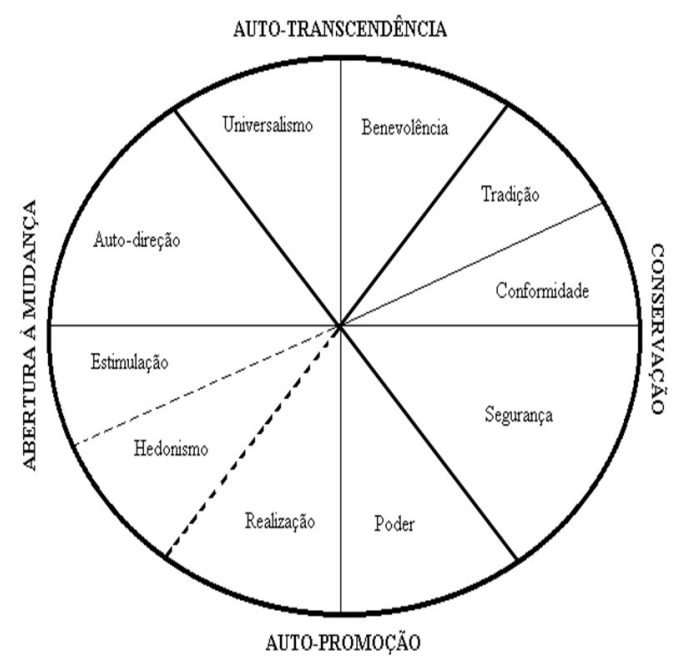

Fonte: Estrutura Circular dos Valores segundo Schwartz (2005a).

Para Schwartz (1994, 2005a), os possíveis tipos motivacionais adjacentes apresentam ênfases similares:

Poder e realização: enfatizam superioridade social e estima;

Realização e hedonismo: focalizam a autossatisfação;

Hedonismo e estimulação: supõem desejo por experiências afetivas prazerosas;

Estimulação e autodeterminação: envolvem o interesse pela novidade e abertura à mudança;

Autodeterminação e universalismo: expressam a confiança no próprio julgamento e bem-estar com relação à diversidade;

Universalismo e benevolência: referem-se à preocupação com as outras pessoas e superação dos interesses individuais 
Tradição e conformidade: manifestam a subordinação do indivíduo em favor de expectativas socialmente impostas;

Conformidade e segurança: relativos à proteção da ordem e da harmonia nas relações;

Segurança e poder: destacam a evitação e superação de ameaças, controlando relacionamentos e recursos.

Mas também haveria a possibilidade de conflito quando os seguintes tipos motivacionais adjacentes fossem priorizados, concomitantemente, pelas pessoas:

Autodeterminação e estimulação versus conformidade, tradição e segurança: o primeiro grupamento enfatiza a liberdade e a independência de pensamentos e ação; o segundo, a submissão, a autorrestrição, a estabilidade e o favorecimento de práticas tradicionais.

Universalismo e benevolência versus realização e poder: a aceitação dos outros como iguais e a preocupação com o bem-estar expressa no primeiro grupo de valores conflitam com a busca por sucesso pessoal e domínio sobre os outros.

Hedonismo versus conformidade e tradição: a satisfação dos próprios desejos confronta com a aceitação dos limites impostos externamente.

Apesar da categorização dos valores em dez tipos motivacionais, Schwartz (2005a) reconhece que no nível mais básico, os valores formam um continuum de motivações relacionadas, haja vista a possibilidade de que algumas ações que são equivalentes com algum valor e seu tipo motivacional gerarem efeitos que podem ser complementares, congruentes ou conflitantes com os objetivos de outros tipos motivacionais que estejam próximos ou opostos (Schwartz, 2005a, Bedani, 2008).

Para Schwartz (2006a), seu modelo não representa apenas uma tipologia para identificação de valores, já que por ele também é possível identificar uma estrutura dinâmica das relações entre os tipos motivacionais. A motivação para o foco pessoal versus o foco social, assim como a motivação para a autoproteção versus expansão, tem integrado a teoria de valores de Schwartz nas duas últimas décadas (Fontaine, Poortinga, Delbeke \& Schwartz, 2008; Schwartz et al., 2012).

Quanto à motivação para o foco pessoal versus o foco social, Schwartz (2006a) relata que o dinamismo da estrutura de valores regula os pressupostos dos interesses 
próprios (ênfase no pessoal - Poder, Estimulação, Hedonismo e Autodeterminação), assim como os pressupostos de como as pessoas interagem com as outras pessoas e como isso afeta os seus interesses (ênfase no social - Benevolência, Universalismo, Tradição, Conformidade e Segurança).

A dinâmica da estrutura de valores também pode ser evidenciada por meio da ansiedade, em que os valores orientam a pessoa para evitar a ansiedade diante da incerteza do mundo social e físico (foco na autoproteção - valores de autopromoção e de conservação). Os valores contidos nas dimensões autotranscedência e abertura à mudança visam à expansão e promovem o desenvolvimento da humanidade (Schwartz, 2006a).

A Teoria de Valores foi reavaliada por Schwartz et al. (2012) com o objetivo de conseguirem um contínuo de valores com melhor confiabilidade entre os itens e menor multicolinearidade entre os valores adjacentes, tornando o modelo mais significativo. O refinamento dos tipos motivacionais de valores foi obtido por meio da elaboração de uma escala composta por 57 itens (PVQ5X) aplicada em 15 amostras em 10 países, cujos resultados revelaram 19 tipos de valores diferentes que são incorporadas aos dez tipos de valores e duas dimensões bipolares, resguardando entre si relações de similaridade e diferenciação, além de ponderarem os demais princípios da dinâmica da estrutura: foco pessoal versus foco social e expansão versus autoproteção (Schwartz et al., 2012; Teixeira, 2014; Nascimento , 2014).

Schwartz et al. (2012) acreditam que a versão ampliada da teoria de valores básicos poderá oferecer maior precisão quanto à capacidade preditiva dos valores em relação a atitudes e comportamentos. Como pode ser visto no quadro 16 , a versão ampliada mostra a importância e resistência da primeira versão da teoria que propunha apenas dez valores organizados em duas dimensões bipolares. 
Quadro 16 - Os 19 Valores da Teoria Refinada, definidos em termos de Metas Motivacionais

\begin{tabular}{|c|c|}
\hline Valor & Definições conceituais em Metas Motivacionais \\
\hline $\begin{array}{l}\text { Autodireção de pensamento } \\
\text { Autodireção de ação }\end{array}$ & $\begin{array}{l}\text { Liberdade para cultivar suas próprias ideias e habilidades. } \\
\text { Liberdade para determinar suas próprias ações. }\end{array}$ \\
\hline Autodireção de estimulação & Excitação, novidade e mudança. \\
\hline Hedonismo & Prazer e gratificação sensual para si mesmo. \\
\hline $\begin{array}{l}\text { Poder de realização } \\
\text { Poder de domínio }\end{array}$ & $\begin{array}{l}\text { Sucesso de acordo com os padrões sociais. } \\
\text { Poder pelo exercício de controle sobre outras pessoas. }\end{array}$ \\
\hline Poder sobre recursos & Poder pelo controle sobre materiais e recursos sociais. \\
\hline Face & Manutenção da sua imagem pública e evitar humilhações. \\
\hline $\begin{array}{l}\text { Segurança pessoal } \\
\text { Segurança social }\end{array}$ & $\begin{array}{l}\text { Segurança em seu ambiente imediato. } \\
\text { Segurança e estabilidade da sociedade (mais ampla). }\end{array}$ \\
\hline Tradição & Manutenção e preservação da cultura, família ou religião. \\
\hline $\begin{array}{l}\text { Conformidade com regras } \\
\text { Conformidade interpessoal }\end{array}$ & $\begin{array}{l}\text { Conformar-se com regras, leis e obrigações formais. } \\
\text { Evitar chatear ou machucar outras pessoas. }\end{array}$ \\
\hline $\begin{array}{l}\text { Benevolência dependência } \\
\text { Benevolência cuidado } \\
\text { Humildade }\end{array}$ & $\begin{array}{l}\text { Ser um membro confiável e fidedigno do endogrupo. } \\
\text { Devoção ao bem-estar dos membros do endogrupo. } \\
\text { Reconhecimento da própria insignificância em um contexto amplo. }\end{array}$ \\
\hline Universalismo compromisso & $\begin{array}{l}\text { Comprometimento com igualdade, justiça e proteção de todas as } \\
\text { pessoas. }\end{array}$ \\
\hline Universalismo natureza & Preservação do ambiente natural. \\
\hline Universalismo tolerância & Aceitação e compreensão daqueles que são diferentes de si mesmo \\
\hline
\end{tabular}

Fonte: Schwartz et al. (2012), com adaptações

Assim como na estrutura circular dos valores que representam os dez tipos motivacionais, os 19 valores da teoria refinada também refletem os conflitos ou compatibilidades. A compatibilidade é constituída quando os comportamentos exteriorizam metas de um par de valores, e o conflito é evidenciado quando os comportamentos expõem consequências opostas para dois valores, quando a meta de um valor irá ser mais preponderante em relação ao outro valor, gerando conflito. Quanto mais dois valores forem compatíveis, mais próximos estarão no ordenamento circular e, quanto maior o conflito entre os valores, mais distantes se configurarão no ordenamento circular. A figura 09 mostra o ordenamento dos 19 valores na estrutura circular da teoria refinada. 
Figura 09 - Círculo motivacional de acordo com a teoria de valores básicos refinada

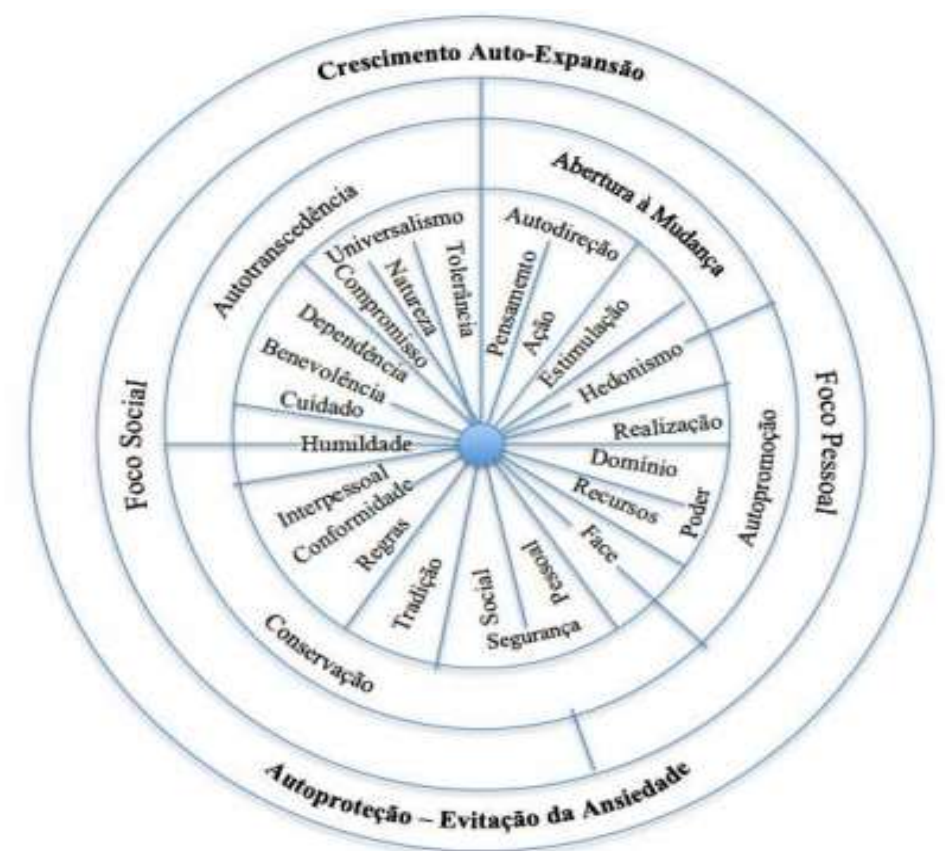

Fonte: Schwartz et al. (2012), com adaptações

Vale observar que a teoria refinada das metas motivacionais, não invalida a estrutura dos dez tipos motivacionais, pois a nova estrutura agrupa os valores de forma semelhante ao da teoria anterior (Schwartz et al., 2012; Sousa, 2013; Nascimento, 2014).

\subsubsection{Valores organizacionais}

Uma organização não é constituída por estrutura físicas e sim por estruturas de eventos, de convívios e diálogos e de atividades realizadas por ela (Allport, 1962). Segundo Katz \& Kahn (1978), três elementos definem e orientam o funcionamento da organização: os papéis, as normas e os valores. Os papéis preconizam formas de comportamento relacionados a determinadas tarefas, as normas são expectativas convertidas em exigências e os valores são parâmetros e pretensões ideológicas mais generalizadas. Os papéis especificam as funções e os cargos executados pelas pessoas na organização, já as normas e os valores são elementos constituintes, pois tendem a ser compartilhados por todos ou quase todos os membros de uma organização (Katz \& Kahn, 1978; Tamayo, 1996). 
Na perspectiva funcionalista de Parsons (1956), os valores estabelecem a forma como as pessoas agem para que a organização execute suas tarefas e atinja os seus objetivos determinados. Teóricos institucionalistas, como Clark (1956), Selznick (1949), Berger e Luckmann (1967), ressaltam que os valores fazem parte das dimensões não racionais que impulsionam e guiam a organização para a execução das suas atividades. Larson e Catton (1961) estudaram as formas com que os valores organizacionais atuam no comportamento das pessoas na organização. Lickert (1961) aborda de forma especulativa o tempo necessário para que novos valores sejam comuns a todos na organização.

Apesar de os estudos sobre valores não serem tão recentes, foi a partir da década de 1980 que houve um maior interesse pelo construto, coadunando-se com o interesse sobre cultura organizacional (Deal \& Kennedy, 1982; Denison, 1997; Agle \& Caldwell,1999; Bedani, 2008). Isso se dá principalmente pela atribuição do sucesso das organizações japonesas em função dos valores que eram compartilhados por seus membros; associando cultura ao desempenho organizacional (Ouchi, 1982; Pascale \& Athos, 1981). A partir daí os valores passaram a ser vistos, entre muitos estudiosos, como importante instrumento para compreender a cultura organizacional (Mendes \& Tamayo, 2001).

Sendo assim, os valores, como o cerne da cultura organizacional, são apresentados por vários teóricos. Deal e Kennedy (1982), por exemplo, alegam que os valores são a base para o desenvolvimento da cultura organizacional. Para Smircich (1983), os valores e as crenças guiam o comportamento e a ação dos seus membros, proporcionando consenso e unidade à organização. Na visão de Schein (1985), os valores são orientadores de como as pessoas se comportam na organização, bem como o próprio comportamento da organização, visto que os valores são a forma de a cultura ser manifestada. Segundo Pascale (1985), os valores são o alicerce que promove a segurança entre a pessoa e a organização, acentuando comportamentos considerados desejáveis. De acordo com Schultz (1994), tanto os valores quanto os pressupostos básicos são os responsáveis pela promoção da adaptação e consequente integração da organização ao seu ambiente.

Para Hofstede (2003), o sistema de valores forma o núcleo da cultura organizacional, sendo responsável pela "programação mental", uma vez que constitui a centralidade da cultura. Nesse sentido, valores poderiam ser entendidos como uma grande 
tendência nas organizações para preferir atingir certos estados e objetivos em detrimento a outros (Macedo, 2005).

Para compreender a dimensão dos valores com a cultura organizacional, os modelos que referenciam cultura organizacional propostos por Kluckhohn e Strodtbeck (1961), Schein (1985), Hofstede (2003), Hall (1990), Trompenaars (1993), Schwartz (1994), Denison (2001) e House (2004) apresentam, nos vários níveis de análise, valores como constituintes da cultura. Entretanto, há outros estudiosos que tratam da relação dos valores com o trabalho (Mendes e Tamayo, 2001).

De acordo com Tamayo (2007), os valores pessoais estruturam-se em duas categorias: (1) a que compreende estrutura de valores genéricos, que integra os valores relacionados com todos os aspectos da vida; e (2) a que compreende estruturas de valores que são de contextos específicos da vida, tais como o sexo, a religião, a família, o trabalho. Avaliar valores no contexto específico busca esclarecer como os valores são expressos em julgamentos e comportamentos peculiares e verificar as diferenças interpessoais e interculturais entre eles (Schwartz, 1992; Tamayo, 2007).

Segundo Deal e Kennedy (1982), valores organizacionais podem ser entendidos como crenças básicas, representando a essência dos pressupostos organizacionais. Essas crenças dizem respeito ao que é ou não desejável para a organização, tornando-se norteadoras do cotidiano organizacional (Tamayo \& Gondim, 1996). Para Collins e Porras (1995), a ideologia é composta por princípios gerais que atendem a vários objetivos, que não se confundem com as práticas, pois não se relacionam com objetivos imediatistas, têm uma natureza transituacional que objetiva orientar diversas ações e comportamentos no ambiente organizacional.

Tamayo e Godim (1996) estabelecem nos valores as seguintes dimensões: cognitiva (as crenças que são valorizadas na organização para responderem aos seus problemas); motivacional (expressa desejos e interesses de indivíduos específicos ou de um grupo); hierárquica (os valores organizacionais são hierarquicamente organizados, indicando a preferência a determinados valores para atingir fins específicos); e funcional (orienta as pessoas na forma de agir e de pensar, influenciando no seu comportamento).

Os valores organizacionais são compartilhados entre os membros da organização e, dessa forma, segundo Canova e Porto (2010), geram modelos mentais semelhantes 
entre as pessoas, propiciando a construção da identidade organizacional (Hofstede, 2003).

Para o estabelecimento de padrões de comportamentos e de valores imbuídos de princípios orientadores das rotinas organizacionais, para Tamayo, Mendes \& Paz (2000), os valores organizacionais devem ser capazes de atender a três problemas fundamentais que as organizações confrontam: (a) a conciliação entre as metas do grupo e as metas e interesses individuais; (b) a elaboração de uma estrutura de valores que garanta o funcionamento da organização; e (c) a harmonização das relações contínuas da organização com a sociedade, com o ambiente e com as outras organizações. Assim, vê-se que os valores organizacionais são recursos importantes para o entendimento da cultura, já que a cultura mantém o processo de socialização por meio do sistema de valores (Mendes \& Tamayo, 2001).

Normalmente, os valores organizacionais são inicializados pelo criador da empresa ou por pessoas que têm influência e que são assim reconhecidas pelos membros da organização (Bansal, 2003). Estabelecem-se, dessa forma, metas organizacionais e princípios motivacionais que são amplamente compartilhados pelos seus membros, impactando, assim, nas políticas e nas práticas organizacionais (Tamayo \& Borges, 2006).

\subsection{Dimensões e tipologias para a identificação dos valores organizacionais}

Ferreira et al. (2009) evidencia a preocupação dos pesquisadores em relação à descrição de dimensões e tipologias que sejam apropriadas para a identificação de valores organizacionais de uma grande variedade de organizações. Quanto às dimensões, normalmente têm a abordagem quantitativa como premissa metodológica. Já as tipologias partem do pressuposto das dimensões para identificar as tipologias estabelecidas pelo modelo.

Tradicionalmente, segundo Tamayo e Borges (2006), os pesquisadores utilizam-se de duas estratégias: (1) análise documental (relatórios, discursos, revistas, entre outros) para reconhecer valores esposados, utilizando-se da análise de conteúdo para 
identificar os valores mais enfatizados, sendo, portanto, qualitativa - uma crítica recorrente a esta abordagem é quanto à validade dos valores identificados, pois o fato de estarem presentes em documentos não significa, necessariamente, que estejam no "modelo mental" das pessoas; (2) parametrização dos valores pessoais dos membros da organização (a média) e estabelecimento de uma estimativa dos valores organizacionais; o problema é que, normalmente, há uma disparidade entre os valores pessoais do empregado e os valores da organização, podendo resultar em uma identificação inadequada ou incompleta dos valores organizacionais.

Com o objetivo de identificar a posição dos valores no sistema axiológico da organização, Tamayo (2007) utilizou-se dos parâmetros da estatística descritiva média e desvio-padrão, para elaborar um modelo que classificasse os valores em função dos aspectos relativos à centralidade do valor no sistema axiológico da organização e do respectivo grau de compartilhamento entre os membros. Conforme apresentado na Figura 10, o autor propôs quatro categorias de valores: centrais, setoriais, desejados e difusos.

Figura 10 - Classificação dos Valores Organizacionais

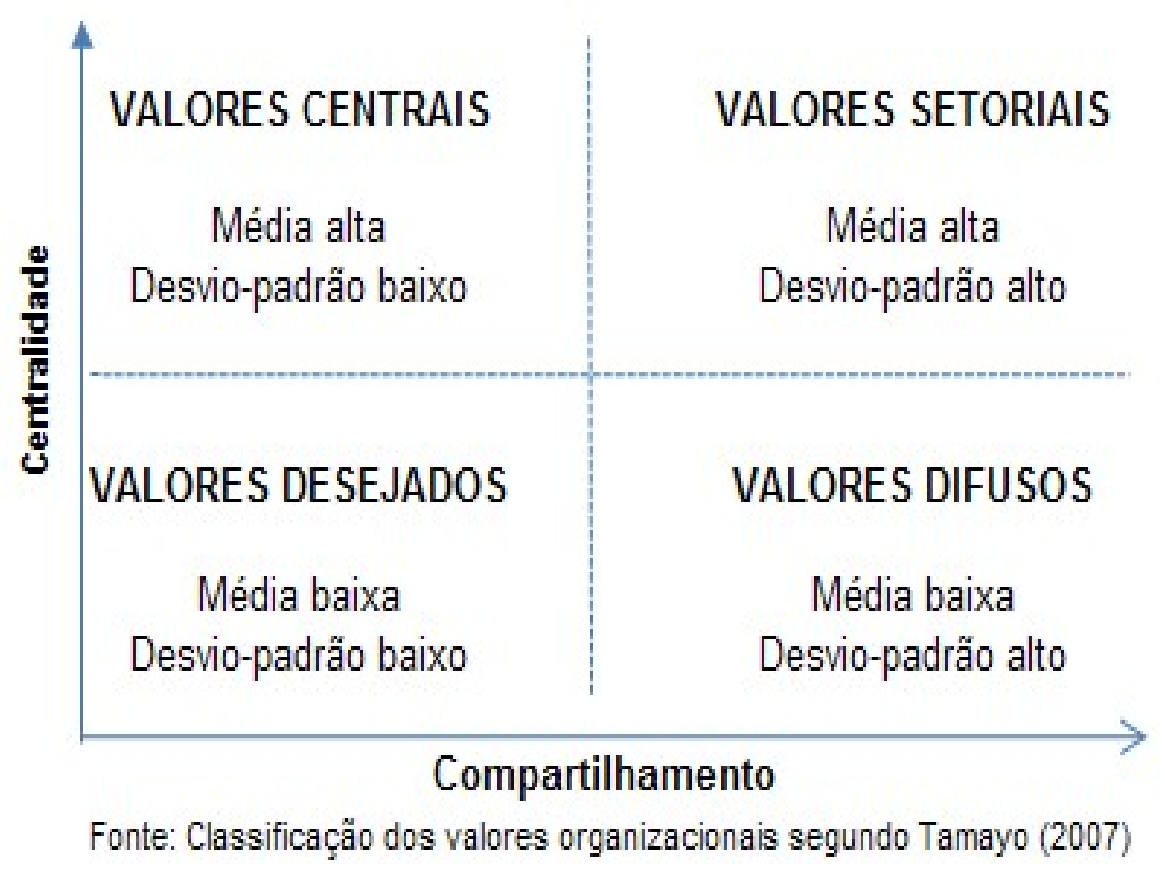


Valores centrais representariam os valores que são proeminentes nas prioridades axiológicas da organização (média alta) e, simultaneamente, apresentariam alto nível de compartilhamento entre os seus membros (desvio padrão baixo). Incorporam a categoria de valores que exercem as funções integradoras e servem como guias de comportamento organizacional.

Valores denominados setoriais, que compõem a segunda categoria, agregam valores que também ocupariam lugar de destaque na hierarquia axiológica da organização (média alta). Contudo, apresentam um grau de compartilhamento menor (desvio-padrão alto). Referem-se principalmente aos valores característicos de determinados grupamentos organizacionais, tais como diretorias, setores, departamentos ou grupos sem fronteiras organizacionais claramente delineadas e constituiriam as subculturas organizacionais.

Valores desejados - abrangem valores que não seriam muito praticados ou enfatizados no contexto organizacional, porém expressam valores que os membros desejariam que ocupassem um lugar mais destacado nas prioridades axiológicas da organização. Assim, os resultados das pesquisas demonstram que estes valores não aparecem como sendo característicos (média baixa), mas apresentam elevado nível de consenso entre seus membros (desvio-padrão baixo).

Valores difusos abarcam valores em torno dos quais se observa pouco consenso entre os membros (desvio-padrão alto) e seriam avaliados como pouco característicos da organização (média baixa). Assim, infere-se que os valores pertencentes a esta categoria teriam pouco impacto sobre a vida da organização, pois de forma consensual seriam julgados pouco relevantes para a empresa.

Para além do que foi visto até agora, Ferreira et al. (2009) apresenta uma relação de autores e seus respectivos modelos ou taxonomias para os valores organizacionais, conforme apresentado no quadro 17. 
Quadro 17 - Resumo das dimensões e tipologias de valores organizacionais

\begin{tabular}{|c|c|c|}
\hline Autores & $\begin{array}{c}\mathbf{N}^{\circ} \text { de } \\
\text { dimensões }\end{array}$ & Tipologias de valores organizacionais \\
\hline Quinn \& Rohrbaugh (1983) & $\begin{array}{c}\text { Duas } \\
\text { ortogonais }\end{array}$ & $\begin{array}{l}\text { Flexibilidade vs. Estabilidade; Orientação } \\
\text { interna vs. Orientação Externa. }\end{array}$ \\
\hline Wiener (1988) & $\begin{array}{c}\text { Duas } \\
\text { dimensões }\end{array}$ & $\begin{array}{l}\text { Elitistas; funcionais; } \\
\text { carismáticos. }\end{array}$ \\
\hline O’Reilly et al. (1991) & $\begin{array}{c}\text { Sete } \\
\text { categorias }\end{array}$ & $\begin{array}{l}\text { Inovação; estabilidade; respeito às } \\
\text { pessoas; orientação para resultados; } \\
\text { orientação aos detalhes; orientação para } \\
\text { as equipes; e agressividade. }\end{array}$ \\
\hline Rousseau (1992) & $\begin{array}{c}\text { Três } \\
\text { categorias }\end{array}$ & Tarefa; interpessoal; e individual. \\
\hline Kababoff (1994) & $\begin{array}{c}\text { Duas } \\
\text { dimensões }\end{array}$ & Elitista; liderança; meritocracia; e colegial. \\
\hline Tamayo (1996) & $\begin{array}{c}\text { Três } \\
\text { dimensões } \\
\text { bipolares }\end{array}$ & $\begin{array}{l}\text { Autonomia vs. Conservadorismo; } \\
\text { Hierarquia vs. Igualitarismo; } \\
\text { Domínio vs. Harmonia. }\end{array}$ \\
\hline Tamayo \& Gondim (1996) & $\begin{array}{c}\text { Cinco } \\
\text { categorias }\end{array}$ & $\begin{array}{l}\text { Eficácia/eficiência; interação no trabalho; } \\
\text { gestão; inovação; e respeito ao } \\
\text { empregado. }\end{array}$ \\
\hline Cameron \& Quinn (1999) & $\begin{array}{l}\text { Duas } \\
\text { bipolares }\end{array}$ & $\begin{array}{l}\text { Flexibilidade vs. Estabilidade; } \\
\text { Foco interno vs. Foco externo. }\end{array}$ \\
\hline Ashkanasy et al. (2000) & $\begin{array}{l}\text { Dez } \\
\text { categorias }\end{array}$ & $\begin{array}{l}\text { Liderança; } \text { estrutura; inovação; } \\
\text { desempenho no trabalho; planejamento; } \\
\text { comunicação; ambiente; local de trabalho } \\
\text { humanizado; desenvolvimento do } \\
\text { indivíduo; e socialização na entrada da } \\
\text { organização. }\end{array}$ \\
\hline Detert et al. (2000) & $\begin{array}{c}\text { Oito } \\
\text { categorias }\end{array}$ & $\begin{array}{l}\text { Bases da confiança e da racionalidade na } \\
\text { organização; natureza do tempo; } \\
\text { motivação; estabilidade vs. inovação; } \\
\text { orientação para o trabalho, tarefa ou } \\
\text { colegas; isolamento vs. colaboração; } \\
\text { controle, coordenação e responsabilidade; } \\
\text { orientação e foco interno e/ou externo. }\end{array}$ \\
\hline Dobni et al. (2000) & $\begin{array}{c}\text { Quatro } \\
\text { categorias }\end{array}$ & $\begin{array}{l}\text { Empreendedorismo; pressão para } 0 \\
\text { desempenho; integração; e temperança. }\end{array}$ \\
\hline Tamayo et al. (2000) & $\begin{array}{l}\text { Três } \\
\text { dimensões } \\
\text { bipolares }\end{array}$ & $\begin{array}{l}\text { Autonomia vs. Conservadorismo; } \\
\text { Hierarquia vs. Igualitarismo; } \\
\text { Domínio vs. Harmonia. }\end{array}$ \\
\hline Oliveira \& Tamayo (2004) & $\begin{array}{c}\text { Oito } \\
\text { categorias }\end{array}$ & $\begin{array}{l}\text { Autonomia; bem-estar; realização; } \\
\text { domínio; prestígio; tradição; conformidade; } \\
\text { e preocupação com a coletividade. }\end{array}$ \\
\hline
\end{tabular}

Fonte: Adaptado de Ferreira et al., 2009.

Na literatura internacional, segundo Ferreira et al. (2009), a estrutura proposta por O'Reilly III, Chatman e Caldwell (1991) é uma das mais referenciadas. No Brasil, Tamayo e parceiros, partindo da premissa da percepção dos colaboradores para avaliar os valores organizacionais, desenvolveram três modelos: (1) a Escala de 
Valores Organizacionais (EVO), elaborada por Tamayo e Gondim (1996); (2) o Inventário de Valores Organizacionais (IVO), desenvolvido por Tamayo, Mendes e Paz (2000); e o Inventário de Perfis de Valores Organizacionais (IPVO), de Oliveira e Tamayo (2004).

\subsection{A Escala de Valores Organizacionais - EVO}

De acordo com Tamayo (2007), o objetivo era averiguar, por meio de um levantamento empírico, se os participantes poderiam identificar valores reconhecidos nas suas organizações que pudessem ser relacionados nas três dimensões bipolares do modelo cultural de Schwartz (Autonomia versus Conservadorismo, Hierarquia versus Igualitarismo e Domínio versus Harmonia). Para a construção dos itens, foi realizado um levantamento de dados por meio de questionário com empregados de cinco organizações de natureza tanto pública quanto privada. Foi solicitado que eles relacionassem cinco valores da sua organização, gerando uma relação com mais de 500 valores. Essa relação foi submetida ao método de análise de conteúdo reduzindo a 48 valores. Poucos itens foram encontrados para os fatores autonomia e igualitarismo e isto foi interpretado como ausência relativa desses valores em organizações brasileiras. Vale ressaltar que nessa escala não foi usado modelo teórico para a elaboração dos itens.

\subsubsection{Inventário de Valores Organizacionais - IVO}

Com o objetivo de tornar mais robusta a escala de valores organizacionais, principalmente quanto a sua deficiência teórica, o modelo passou a integrar, segundo Tamayo (2007), duas abordagens: empírica (os itens da escala anterior foram replicados neste instrumento) e teórica (a partir de pressupostos teóricos, novos itens foram elaborados, em especial a identificação de valores que pudessem exprimir mais adequadamente igualitarismo e autonomia). Após validação da escala por meio de análise multidimensional ALSCAL (Algorithmic Scalling) em que os valores organizacionais se ordenaram sobre as três dimensões bipolares postuladas, confirmaram-se os seis fatores. O questionário ficou com 36 itens. Vale observar que, 
somente na dimensão bipolar Hierarquia versus Igualitarismo, a relação de conflito foi identificada. Enquanto as demais dimensões (Autonomia versus Conservadorismo e Domínio versus Harmonia) apresentaram-se como adjacentes, informando que os valores relacionados a essas dimensões não se apresentaram como conflituosos no contexto organizacional. Isso pode ser em decorrência das características culturais brasileira em que seria possível a convivência de forma harmoniosa entre elementos antagônicos, por exemplo seria possível identificar metas de autonomia convivendo sem conflitos com metas de conservadorismo, ou metas de domínio com metas de harmonia.

\subsection{Inventário de Perfis de Valores Organizacionais - IPVO}

Segundo Tamayo (2007), o instrumento foi elaborado sob o pressuposto de paralelismo entre os valores pessoais e os valores organizacionais, ou seja, mesmo sendo dois sistemas diferentes eles teriam uma interface comum aos dois: compartilham metas universais que exprimem a satisfação de requisitos básicos do ser humano (Oliveira \& Tamayo, 2004). Melhor explicando, é possível considerar que pessoas e organizações busquem valores estruturados semelhantemente.

As justificativas para o paralelismo entre as estruturas dos valores pessoais e organizacionais são: (1) compartilham características gerais dos valores possuindo componentes motivacional, cognitivo, hierárquico e social; (2) as funções dos dois conjuntos de valores são parecidas, na medida em que os pessoais orientam a vida dos indivíduos e os organizacionais a vida da organização; (3) os valores organizacionais estão relacionados com as metas institucionais e os valores pessoais expressam as metas do indivíduo; (4) os valores organizacionais são originários dos valores pessoais dos fundadores, membros influentes na empresa (gestores e trabalhadores); e (5) as pessoas procuram atingir metas fundamentais de sua existência, ao trabalhar nas organizações que, assim, devem ser um espaço para a realização destas metas (Oliveira \& Tamayo, 2004; Tamayo, 2005a).

Para Tamayo (2007 p. 22), “o paralelismo axiológico postulado para a construção do IPVO consiste na correspondência biunívoca dos tipos motivacionais de valores do trabalhador e dos valores organizacionais, isto é, relação entre cada tipo motivacional 
de valores do trabalhador com apenas um fator de valores da organização. Isso implica em correspondência de metas entre o trabalhador e a organização".

Para sustentar empiricamente a dedução de paralelismo axiológico, a construção dos itens teve como pressuposto as metas específicas de cada um dos dez tipos motivacionais de valores pessoais do modelo de Schwartz (1994). O instrumento foi validado e submetido a inferências estatísticas. A análise fatorial mostrou significativa simetria entre valores pessoais e organizacionais, contudo não houve fator que representasse a motivação segurança, como pode ser visto no quadro 18.

Quadro 18 - Correspondência entre os tipos motivacionais de valores pessoais e organizacionais

\begin{tabular}{|c|c|c|c|}
\hline $\begin{array}{l}\text { Valores } \\
\text { Organizacionais }\end{array}$ & $\begin{array}{l}\text { Correspondência } \\
\text { com os valores } \\
\text { pessoais }\end{array}$ & Metas dos valores organizacionais & Polos \\
\hline Autonomia & $\begin{array}{l}\text { Autodeterminação } \\
\text { e estimulação }\end{array}$ & $\begin{array}{l}\text { Oferecer desafios e variedade no } \\
\text { trabalho, estimular a curiosidade, a } \\
\text { criatividade e a inovação. }\end{array}$ & $\begin{array}{l}\text { Abertura à } \\
\text { mudança }\end{array}$ \\
\hline Bem-estar & Hedonismo & $\begin{array}{l}\text { Promover a satisfação, o bem-estar e a } \\
\text { qualidade de vida no trabalho. }\end{array}$ & $\begin{array}{c}\text { Abertura à } \\
\text { mudança ou } \\
\text { autopromoção }\end{array}$ \\
\hline Realização & Realização & $\begin{array}{l}\text { Valorizar a competência e o sucesso } \\
\text { dos trabalhadores. }\end{array}$ & Autopromoção \\
\hline Domínio & Poder & Obter lucros e dominar o mercado. & Autopromoção \\
\hline Prestígio & Poder & $\begin{array}{l}\text { Ter prestígio, ser reconhecida e } \\
\text { admirada por todos e oferecer produtos } \\
\text { e serviços satisfatórios para os clientes }\end{array}$ & Autopromoção \\
\hline Tradição & Tradição & $\begin{array}{l}\text { Manter a tradição e respeitar os } \\
\text { costumes da organização }\end{array}$ & Conservação \\
\hline Conformidade & Conformidade & $\begin{array}{l}\text { Promover a correção, a cortesia e as } \\
\text { boas maneiras no trabalho e o respeito } \\
\text { às normas na organização. }\end{array}$ & Conservação \\
\hline $\begin{array}{l}\text { Preocupação } \\
\text { com a } \\
\text { coletividade }\end{array}$ & $\begin{array}{l}\text { Benevolência e } \\
\text { universalismo }\end{array}$ & $\begin{array}{l}\text { Promover a justiça e a igualdade na } \\
\text { organização, bem como a tolerância, a } \\
\text { sinceridade e a honestidade. }\end{array}$ & Autotranscedência \\
\hline
\end{tabular}

Fonte: Tamayo (2005, p.1703)

Segundo Tamayo (2005a), houve uma correspondência direta entre quatro fatores organizacionais: (1) bem-estar, realização, tradição e conformidade com as motivações pessoais (hedonismo, realização, tradição e conformidade); (2) prestígio e domínio com uma única motivação pessoal: poder; (3) preocupação com a coletividade se relacionou com duas motivações pessoais subjacentes: universalismo e benevolência; e (4) autonomia estaria relacionado com duas motivações pessoais: autodeterminação e estimulação.

O trabalho de Malequi \& Jong (2014) que propôs nove clusters de dimensões da cultura, (quadro 14 da página 82 desta tese) mostra similaridades em dimensões do 
modelo de Schwartz e Hofstede. A partir dessas similaridades e da correspondência dos valores pessoais e organizacionais do modelo de Tamayo para com o modelo de Schwartz, pode-se ter como ponto de partida de análise, os valores organizacionais obtidos pelo Inventário de Perfis de Valores Organizacionais (IPVO) e as dimensões culturais de Hofstede, como proposto no quadro 19.

Quadro 19 - Comparativo entre as dimensões culturais de Schwartz e Hofstede com o IPVO

\begin{tabular}{|l|c|l|}
\hline \multicolumn{1}{|c|}{ Schwartz } & \multicolumn{1}{|c|}{ Hofstede } & \multicolumn{1}{c|}{ Tamayo (IPVO) } \\
\hline Conservação vs. Autonomia & $\begin{array}{l}\text { Individualismo } \\
\text { vs. Coletivismo }\end{array}$ & $\begin{array}{l}\text { Autonomia (Autonomia e Bem-estar) } \\
\text { Conservação (conformidade e tradição) }\end{array}$ \\
\hline Hierarquia vs. Igualitarismo & $\begin{array}{c}\text { Distância } \\
\text { hierárquica }\end{array}$ & \\
\hline Harmonia vs. Domínio & $\begin{array}{c}\text { Masculino } \\
\text { vs. Feminino }\end{array}$ & $\begin{array}{l}\text { Harmonia (Preocupação c/ a Coletividade) } \\
\text { Realização (Realização) } \\
\text { Poder (Domínio e Prestígio) }\end{array}$ \\
\hline
\end{tabular}

Fonte: elaborado pela autora

\subsection{Abordagem conceitual de valores organizacionais referenciadas neste} trabalho

Para esta tese, os valores organizacionais são definidos como representações mentais (Porto \& Pereira, 2012), compartilhados pelos membros da organização, que convivem dentro do mesmo ambiente, em um espaço de tempo consideravelmente duradouro, consistindo em cognições dos princípios que orientam práticas e normas organizacionais (Katz \& Kahn, 1974). Estão hierarquicamente organizados (Tamayo, et al., 2000) e construídos sobre princípios ou crenças relativas a metas e a comportamentos organizacionais desejáveis, que orientam a vida da empresa e estão a serviço de interesses individuais, coletivos ou mistos (Tamayo, 1996), reconhecendo paralelismo entre valores individuais e organizacionais (Oliveira \& Tamayo, 2004).

\subsection{Estudos empíricos sobre a predição dos valores}

Entre os contextos específicos, as pesquisas que tratam sobre trabalho têm sido objeto de muitos estudos (Tamayo, 2007). Como, por exemplo, o estudo de valores como interventores de questões estratégicas relativas às políticas, práticas e estruturas organizacionais (Bansal, 2003, Veiga, 2010), valores relacionados com o comprometimento dos funcionários (Ostroff, Shin \& Kinicki, 2005), valores organizacionais e valores do Trabalho (Paiva \& Dutra, 2017). E a análise dos valores 
organizacionais como preditores de comportamentos manifestos no contexto do trabalho (Chatman, 1989; Hassan, 2007; Weathinghton, 2008; Posner, 2010; Simard, 2010).

No Brasil, pesquisas que abordam o tema de valores organizacionais têm sido publicadas. Estudos bibliométricos (Ferreira et al., 2009; Estivalete et al., 2012, Nascimento et al., 2014) têm mostrado que os valores organizacionais estão sendo estudados não somente como descritor do perfil valorativo das organizações, mas também como variável antecedente ou consequente de múltiplos fenômenos tanto em nível micro quanto macro-organizacional. Assim, nesses estudos de investigação de produção acadêmica, foram identificadas pesquisas que objetivam analisar a influência dos valores organizacionais no desempenho das organizações (Melo \& Domêcio, 2012), nas avaliações relativas à organização (Pereira; Kich, 2009), nos comportamentos de cidadania (Porto; Tamayo, 2005), no comprometimento valorativo (TAMAYO, 2005), no comprometimento organizacional (Estivalete et al., 2010), no burnout (Faller, Santos \& Corso, 2012), no suporte organizacional (Estivalete \& Andrade, 2012), na felicidade no trabalho (Sousa, 2013), na confiança do empregado na organização (Oliveira, A. F.; Souza, M. A. 2014), na criação do conhecimento organizacional inovador (Miguel \& Teixeira, 2009), no desempenho (Melo \& Domenico, 2012), na confiança dos clientes (Guardani; Teixeira; Bido; Mazzon, J. A, 2013), no suporte organizacional (Estivalete \& Andrade, 2012), nas atitudes frente a mudanças organizacionais (Neiva \& Paz, 2007, 2012), no estresse ocupacional (Tamayo, 2007; Canova \& Porto, 2010), na aprendizagem organizacional (Garrido Filho \& Machado-Da-Silva, 2001; Miguel \& Teixeira, 2012), na percepção de estímulos e barreiras à criatividade no ambiente de trabalho (Bedani, 2008), nos processos sucessórios (Lourenço \& Ferreira, 2012), nos processos de transferências tecnológicas (Almeida, 2008; Schreiber \& Pinheiro, 2011), na identidade organizacional (Fernandes; Zanelli, 2006; Teixeira, 2011; Pessoa; Neves, 2008; Nascimento, 2014) e sobre os valores da organização (Tamayo; Mendes; Paz, 2000; Vieira; Cardoso, 2003; Oliveira \& Tamayo, 2004; Tamayo, 2007).

Dada a pluralidade do tema, o que se vê é uma grande fragmentação dos estudos que se referem a valores organizacionais, consequentemente o que se observa é uma deficiência de estudos sobre o tema tanto em nível nacional (Ferreira, 2009; Estivalete, 2013) quanto em nível internacional (Der Wal, Graaf \& Lasthuizen, 2008). 


\subsubsection{Práticas Organizacionais}

Neste trabalho, as práticas organizacionais, variável contextual que será pesquisada nesta tese para verificar alcance de resultados organizacionais, têm como pressuposto o valor atribuído às pessoas quando da adoção de práticas humanistas ou instrumentais. Para tanto, apresenta-se uma retrospectiva sobre práticas organizacionais.

\subsubsection{Práticas Organizacionais: uma retrospectiva}

Assim como ocorreu com o estudo dos valores, o interesse pelas práticas organizacionais se tornou mais preponderante a partir da década de 1980 em decorrência da popularização dos trabalhos sobre cultura organizacional. Principalmente, quando da divulgação de que o sucesso das organizações nipônicas se associava à cultura e, mais especificamente, com os valores compartilhados entre seus membros. A partir daí, estudiosos e pesquisadores ocidentais passaram a investigar as diferentes práticas organizacionais estabelecidas em organizações orientais das quais resultava em maior produtividade.

Semelhantemente, houve um interesse maior em compreender a influência da cultura nacional sobre as práticas organizacionais, mais precisamente as práticas de gerenciamento. Nessa fase, em que as organizações japonesas representavam uma ameaça às corporações americanas, buscaram-se maneiras de contra-atacar o avanço econômico japonês, por meio da adoção de novos modos de gestão inspirados nestas novas práticas, propagando-se entre as organizações ocidentais, principalmente no âmbito de suas linhas de produção, práticas de qualidade, 5S, produção flexível, Just-in-time, Kaisen, Kanban, envolvimento dos funcionários, entre outras (Young, 1992; Erez, 2000; Hofstede, 2003).

Devido às condições do mercado mundial, na década de 1990, o relacionamento interorganizações mudou de conflituoso para cooperativo, na forma de fusões, aquisições, joint ventures e alianças comerciais internacionais. Dessa forma, novos estudos passaram a identificar a influência das culturas nacionais sobre o processo de transferência das práticas entre empresas parceiras e pertencentes a diferentes 
culturas, bem como o sucesso /fracasso na implementação dessas práticas (Erez, 2000; Prochno, 2004).

Numa contextualização mais contemporânea, as organizações, para sobreviverem em um ambiente de negócios turbulento e hipercompetitivo, passaram a adotar novas formas e estruturas organizacionais, exigindo que novas práticas organizacionais fossem capazes de enfatizar a velocidade, a flexibilidade e a inovação, tais como: redes/alianças de colaboradores; terceirização de atividades não estratégicas; desagregação das unidades de negócio; redução das fronteiras organizacionais; grupos de trabalhos flexíveis; empowerment; e contratação temporária de pessoas. Nesse contexto, o foco dos pesquisadores dirige-se para o esclarecimento da relação entre essas novas práticas e as práticas e estruturas tradicionais ainda adotadas pelas organizações, o impacto das práticas sobre a dinâmica do trabalho, o comprometimento, a saúde e o bem-estar dos trabalhadores, entre outras variáveis organizacionais.

\subsubsection{2 conceituando práticas organizacionais}

Kostova (1999) fornece uma definição generalista para as práticas organizacionais, que é muito semelhante à definição de cultura organizacional por Schein (1985).

(...) formas particulares de conduzir as funções organizacionais que evoluem com o passar do tempo, sofrendo a influência da história da organização, das pessoas, interesses e ações que se tornaram institucionalizadas na organização. Refletindo o conhecimento compartilhado e competências da organização, as práticas tendem a ser aceitas e aprovadas pelos membros, pois são percebidas como a maneira correta para a realização de determinadas tarefas (Kostova, 1999, P. 310).

As práticas, segundo Kostova (1999), têm natureza multifacetada, sendo constituídas por dois elementos diferenciados: (1) conjunto de regras escritas ou tácitas sobre como as funções organizacionais devem ser conduzidas, e (2) conjunto formado por elementos cognitivos (valores e crenças) que determinam como compreender e interpretar tais regras.

Nesse sentido, práticas organizacionais podem ser entendidas como o composto de atividades e práticas sociais que fazem com que a estratégia declarada pela organização se realize. Essas práticas se referem às atividades formais e informais 
por meio das quais as ações se realizam, sendo, portanto, ações regulares e recorrentes realizadas por atores sociais, em organizações delimitadas no espaço e no tempo, que continuamente constroem e reconstroem esse sistema social (Whittington 1996; Jarzabkowski 2004).

Verbeke (2000) conceitua práticas organizacionais como teorias em uso que constituem os comportamentos e procedimentos típicos. É durante a realização conjunta das atividades que as práticas organizacionais são repassadas aos membros na organização, sendo por eles compartilhadas. Dessa forma, as práticas significam um conjunto de conhecimentos tácitos, situação que dificulta sua comunicação verbal entre os indivíduos da organização. A aprendizagem das práticas depende do engajamento dos trabalhadores na realização das atividades e na participação do grupo na resolução dos problemas organizacionais, sendo que essa aprendizagem ocorre por processos de socialização, o que garante aos indivíduos como agir e experimentar a vida no ambiente organizacional (Karahanna, Evaristo E Srite, 2005). Diferentemente dos valores e das crenças, as práticas são mais flexíveis, permitindo alterações no ambiente.

É nesse processo de socialização que sucede a legitimação da adoção das práticas, sob um ambiente imerso de valores e crenças dos indivíduos e dos grupos que o compõem, a sua efetivação dependerá da ratificação da cultura organizacional (Zeitz et al., 1999). Então, parece coerente que as práticas sejam capazes de mostrar aspectos mais latentes da cultura de uma organização. Entretanto, a despeito da sua maior superficialidade quando comparada aos valores, as práticas teriam um impacto emocional imediato sobre os membros da organização e, por conseguinte, sobre seu comportamento (Schein, 1985).

As práticas, quando analisadas sob a perspectiva da cultura organizacional, são estudadas em paralelo aos valores e aos pressupostos básicos. Conforme explicam Beyer e Trice (1987), a cultura seria composta por dois componentes fundamentais: (1) a rede de significados formada pelos valores, ideologias e normas; e (2) as práticas organizacionais, que teriam a função de expressar, de afirmar e comunicar o conteúdo desta rede de significados da organização. Hofstede (2003) sugere que a cultura organizacional seja estudada por meio das práticas, já que elas podem ser analisadas por observadores externos. 
A cultura nacional constitui a variável externa de interesse, nos estudos transculturais, que buscam avaliar a influência da cultura nacional sobre a cultura organizacional (Minkov, 2012) e, por conseguinte, esclarecer como esta relação intervém nas práticas organizacionais e no comportamento dos atores. Nos estudos transculturais, são recorrentes as investigações sobre o processo de transferência de práticas entre organizações sediadas em países distintos, destacando-se a perspectiva de convergência global das práticas a várias localidades (Kogut \& Zander, 1993; Kostova, 1999; Szulanski, 1996; Lassere, 2003; Van Der Zee et al., 2004; Minkov, 2012).

Essa transferência de práticas entre organizações de culturas nacionais distintas pode levar ao estabelecimento de estruturas genéricas de gestão de pessoas, ao determinar como princípio que a existência de melhores práticas pode ser aplicada a todas as localidades (Brewster, Wood \& Brookes, 2008).

O que se percebe é a existência de uma dualidade sobre integração global e adaptação local, pois as empresas querem desenvolver suas estratégias de globalização, por meio da utilização das melhores práticas (assim reconhecidas, principalmente no Ocidente) e, ao mesmo tempo, têm de atender obrigações contingenciais específicas nos contextos nacionais e regionais (Brewster, Wood \& Brookes, 2008). A tentativa de respostas a esses problemas tem de ser baseada a partir do reconhecimento de aspectos culturais, técnicos e legais locais (Lassare, 2003) e, no nível organizacional, dos valores e do papel das pessoas (Jackson, 2002). Nesta visão, torna-se um desafio implementar melhores práticas globais de uma maneira que seja aceitável e aderente às situações locais, mas, ao mesmo tempo, seja capaz de estabelecer harmonia em diferentes ambientes culturais e de negócios (Friedman, 2007).

No entanto, ainda é dúbia a definição do que sejam melhores práticas. Tais definições são bastante conhecidas, e criticadas, pela tradicional postura norte-americana no estabelecimento de práticas padrão (Brookes et al., 2011; Legge, 2005; Tomé, 2005). O pressuposto dos modelos calculativos e universalistas, muito comuns entre as práticas ocidentais, é que as pessoas são um recurso valioso para as organizações, pois são elas as responsáveis para que a organização atinja os seus objetivos, demonstrando uma percepção de valor das pessoas mais instrumental. Em contrapartida, o modelo sistêmico, muito comum entre as práticas japonesas, é o de 
que as pessoas são integrantes da organização e que as estratégias organizacionais devem ser adaptadas às pessoas que dela fazem parte, demonstrando uma percepção de valor das pessoas mais humanista (Jackson, 2002; Brookes et al., 2011).

Nessa linha, Jackson (2002) definiu como "locus of human value" (lócus de valor humano) o conceito para descrever como as pessoas são valorizadas de acordo com as características culturais de cada sociedade, e, consequentemente, no estilo das práticas de gestão das diversas culturas nacionais, distinguindo, a partir da percepção dos gestores, entre a visão instrumental ou humanista quanto à forma de gerir as pessoas nas organizações.

A perspectiva instrumental tem sua origem mais fortemente atribuída aos Estados Unidos, resultado de aspectos culturais em que se observa uma maior separação entre a vida profissional (trabalho) e a pessoal (casa e comunidade), percepção individualista e foco no alcance dos resultados. Já a visão humanista está associada a países orientais como Japão, em que se observa maior integração entre a vida profissional (trabalho) e a pessoal (casa e comunidade), já que sua cultura está baseada no dever e no coletivismo (Jackson, 2002). A figura 11 apresenta o modelo conceitual de lócus de valor humano.

Figura 11 - Modelo conceitual de lócus de valor humano

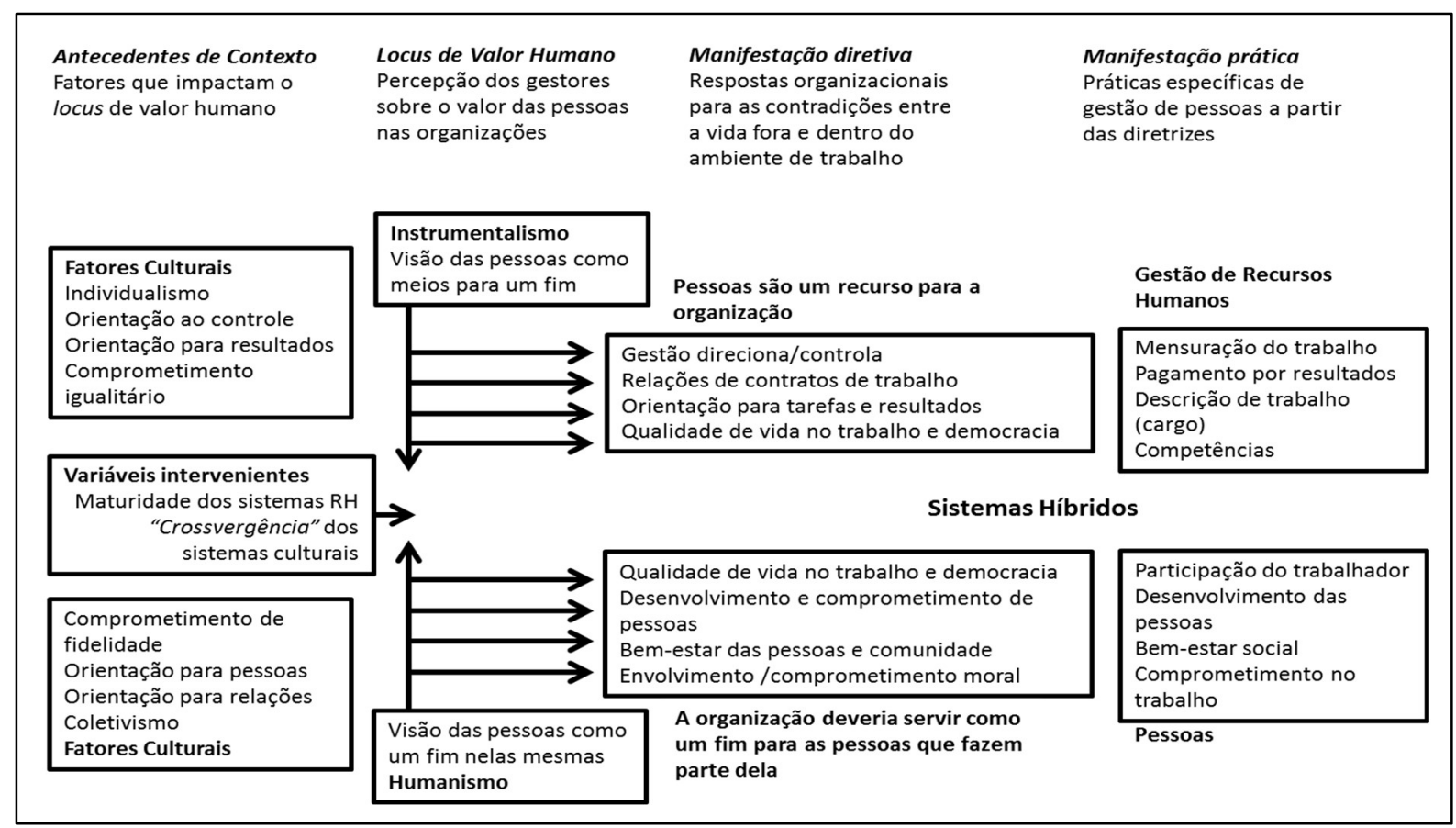

Fonte: Jackson, 2002 - com adaptações 
Os loci de valor humano (humanista e instrumental) não podem ser incompatíveis, tanto que ambos podem estar contidos dentro dos objetivos a serem alcançados pela organização, e funcionários dentro de ambas as abordagens podem ser vistos como cumprindo os objetivos das organizações. Consequentemente, segundo Jackson (2002) é lógico esperar que culturas que têm humanismo elevado também podem ser elevadas na dimensão instrumentalismo. Essa possível correlação também pode ser um aspecto de "crossvergence", (que são mostrados como "variáveis intervenientes" na Figura 11), ou a mistura de sistemas culturais e a maturidade dos sistemas de GRH em qualquer país.

No que se refere aos fatores culturais, segundo Jackson (2002), pode ser tentador assumir que o instrumentalismo e o humanismo sejam semelhantes à dimensão individualismo vs. coletivismo. Parece haver uma divisão simples entre as culturas individualistas ocidentais e as culturas coletivistas não-ocidentais. A proteção das pessoas dentro das sociedades coletivistas (Hofstede, 2001) parece mostrar uma valorização das pessoas como parte de um coletivo. A expectativa de que as pessoas em culturas individualistas cuidam de si mesmas (Hofstede, 2001) parece indicar uma visão mais instrumental das pessoas nas organizações. Mas, como pode ser visto na figura 11, o instrumentalismo e o humanismo podem não se relacionarem de maneira direta ao nível do individualismo e do coletivismo em uma sociedade. Pode haver diferentes influências culturais propulsoras em diferentes sociedades. Estes podem levar a uma diminuição de um lócus humanístico de valor humano dentro da organização e / ou um abrandamento de um lócus instrumental.

Para avaliar o modelo conceitual de lócus de valor humano, Jackson (2002) elaborou e validou a escala de lócus de valor humano. A pesquisa foi aplicada a 520 gestores de empresas de sete países (EUA, Hong Kong, Japão, Coreia do Sul, Polônia, Rússia e Austrália). Essa escala foi adaptada para o contexto desta pesquisa, como será visto no capítulo 3 que trata dos procedimentos metodológicos. 


\subsection{Comprometimento organizacional}

Neste trabalho o comprometimento, variável que será pesquisada nesta tese para verificar alcance de resultados organizacionais, adota o sentido de engajamento, que envolve alguma forma de laço psicológico entre pessoas e aspectos da organização, implicando na aceitação dos valores organizacionais, das suas práticas e dos objetivos da organização (Bastos, 1994), tendo múltiplas bases de comprometimento. Inicialmente apresentam-se os pressupostos conceituais, o estabelecimento de conceitos e dimensões e tipologias do comprometimento organizacional.

\subsubsection{Comprometimento Organizacional: pressupostos conceituais}

Segundo Melo (2001), os estudos referentes a comprometimento organizacional surgiram na segunda metade da década de 1970 nos EUA. O estudo das bases psicológicas que estabelecem o vínculo do trabalhador com a organização à época tentava explicar e prever fenômenos como absenteísmo e rotatividade. A partir dos anos de 1980 assume relevância, dado o cenário mundial que começa a passar por intensas mudanças que refletem nas formas de organização do trabalho e consequentemente nos estilos gerenciais e nas relações das pessoas na organização, fazendo com que pesquisadores buscassem identificar e compreender fatores pessoais e organizacionais determinantes do comprometimento do homem no trabalho.

A psicologia social, as teorias organizacionais e a sociologia têm sido as fontes teóricas para estudos e pesquisas que buscam tanto definir quanto analisar os fenômenos explicativos e preditivos que possam agir de forma específica sobre o comprometimento (Gera, 1998). Essas diferentes fontes têm gerado uma diversidade de definições e de modelos teóricos e, consequentemente, levado à fragmentação e à redundância de conceitos (Siqueira, 2008). Nessa perspectiva, Bastos (1994a), após realizar uma extensiva análise dos conceitos e dos pressupostos relativos a comprometimento, resumiu e agrupo-os em cinco enfoques: afetivo, instrumental calculativo, normativo, sociológico e comportamental. Os modelos com as abordagens conceituais sintetizadas são mostrados na figura 12.

Figura 12 - Síntese dos modelos e suas abordagens conceituais 


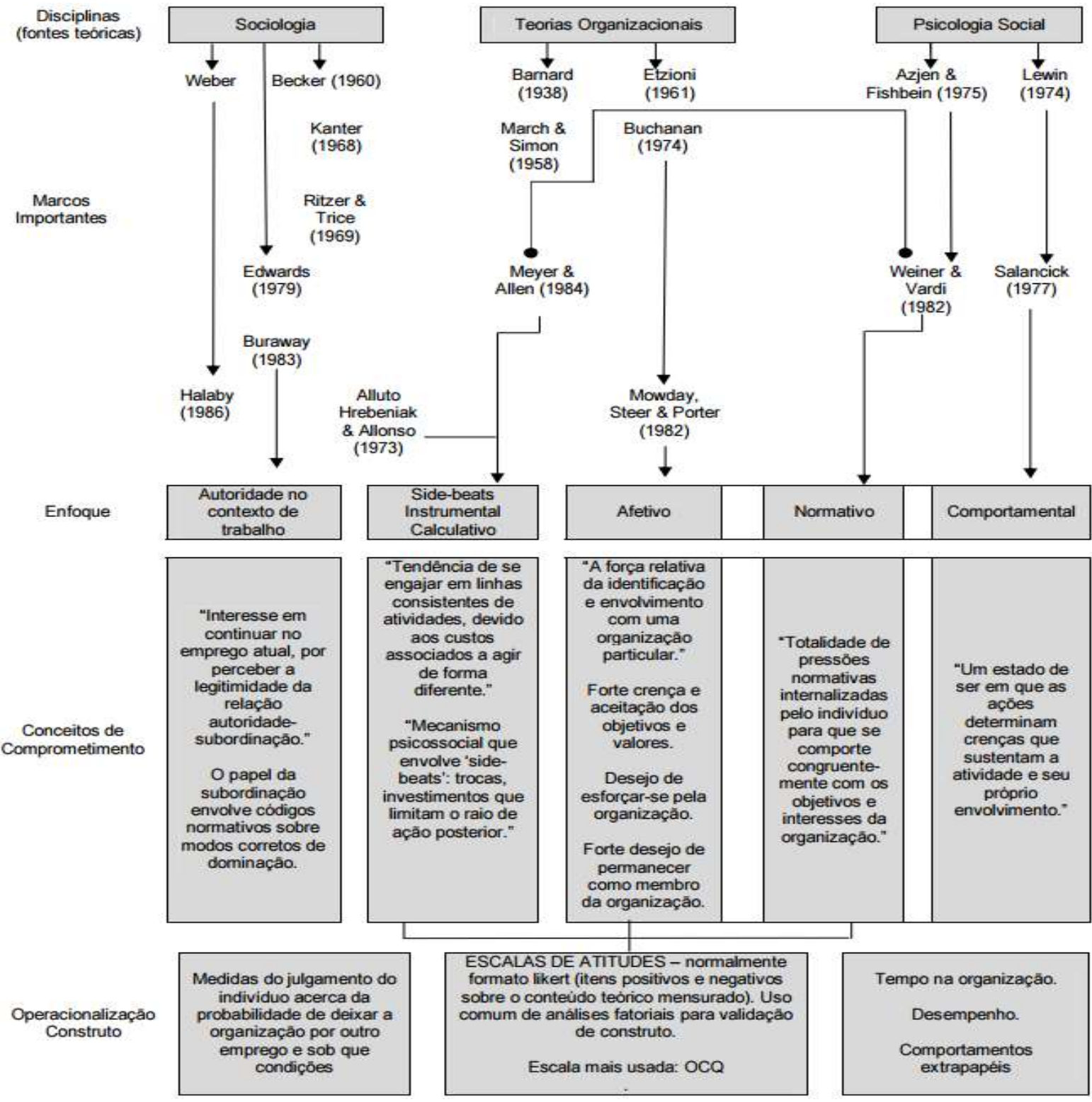

Fonte: adaptado de Bastos, 1994.

A partir do trabalho desenvolvido por Porter e colaboradores (1974) e das teorias organizacionais de Etzioni e de Buchanan, os pesquisadores Mowday, Porter e Steers (1982) estabeleceram o enfoque afetivo do comprometimento, referindo-se aos vínculos empregado - organização, por meio de uma investigação dos fatores comprometimento, absenteísmo e rotatividade, considerando que o primeiro (comprometimento) é condição para a existência dos dois últimos (Bastos, 1993). Seus estudos tiveram início no começo da década de 1970, publicaram no ano de 1982, um livro (Employee-Organization Linkage: The Psychology of Commitment, Absenteeism, and Turnover) e no ano de 1979 validaram instrumento para se medir o comprometimento, o OCQ - Organizational Commitment Questionnaire, que se tornou 
a medida mais bem aceita e difundida em nível mundial. Muitos estudos, inclusive nacionais, aprovam a natureza unidimensional da medida (Morrow, 1983; Blau, 1987; Bastos, 1994; Siqueira, 2008).

Os autores evidenciam a natureza afetiva do processo e definem comprometimento como uma forte relação entre a pessoa e a organização, de tal forma que o indivíduo se envolve com os objetivos e valores da organização, por meio da identificação de três dimensões: (a) forte crença nos valores e nos objetivos da organização; (b) forte desejo de manter o vínculo com a organização; e (c) intenção de se esforçar em prol da organização (Bastos, 1993; Borges-Andrade,1994; Siqueira, 2008).

Dos estudos de Becker (1960), quando publicação do seu artigo (Notes on the Concept of Commitment), deriva-se o enfoque instrumental, que aborda comprometimento a partir da percepção que a pessoa tem ao analisar o resultado da relação custos versus benefícios (side bets) entre o indivíduo e a organização referentes aos benefícios recebidos pela organização e os investimentos realizados pelo indivíduo no trabalho executado desde quando entrou na organização. O indivíduo avalia estas trocas laterais (side bets) e então passa a se empenhar em "linhas consistentes de atividade" (escolha de um curso de ação que melhor atenda às suas finalidades) para se manter no emprego (Kanter, 1968; Meyer \& Allen, 1984). Segundo Meyer e Allen (1997), o funcionário fica na organização devido à necessidade, podendo estar relacionado com a conformidade. Meyer e Allen (1997) denominaram esta modalidade como comprometimento duradouro (continuance commitment).

Vários trabalhos foram realizados tendo como pressuposto o enfoque instrumental em que se buscou a relação entre os investimentos realizados pelos indivíduos no trabalho e permanência no emprego. Allen e Meyer (1990) identificaram alta correlação entre comprometimento instrumental, planos de aposentadoria e investimentos realizados pelos empregados (Medeiros, 2005; Silva, 2014).

No enfoque normativo, apresentado nos trabalhos de Wiener (1982), o pressuposto é que o indivíduo permaneça na organização por se sentir obrigado. Em decorrência da internalização das normas, o indivíduo comprometido mostra certos comportamentos por acreditar que é o certo a ser feito e que é moral permanecer na organização. Para Meyer e Allen (1997), seria um estado psicológico desencadeado por experiências prévias de socialização presentes no convívio familiar e social, bem como no processo 
de socialização organizacional, acontecido depois da entrada do indivíduo na organização. Quanto mais forte for o comprometimento normativo, maior será a predisposição do indivíduo para os padrões internalizados.

Os três enfoques se importam com a natureza da manutenção do indivíduo na organização, mas a pessoa afetivamente engajada permanece nela porque deseja; a normativamente engajada, porque sente que deve; e a engajada no nível instrumental, porque necessita (Meyer \& Herscovitch, 2001).

No enfoque comportamental, para Salancik (1977) o comprometimento ocorre quando o indivíduo se sente responsável por suas ações e pelas consequências dessas ações. Segundo Pereira e Oliveira (1998), "os indivíduos se tornam comprometidos pelos resultados de seus próprios atos. Para Bastos (1993), o comportamento leva o indivíduo a ter determinadas atitudes que se refletem e que são manifestadas em comportamentos futuros, gerando um vínculo vicioso entre o indivíduo e a organização. Neste enfoque, o comprometimento não avalia por meio de escalas, e, sim, da observação do comportamento do indivíduo que esteja para além das expectativas organizacionais.

No enfoque sociológico, o que se analisa é o apego do indivíduo à organização. Segundo Bastos (1994), o indivíduo traz para a organização uma orientação básica para seu papel de subordinado e um conjunto de códigos normativos que especificam maneiras moralmente corretas de dominação. O apego reflete o interesse do indivíduo em permanecer no seu emprego atual ou a expectativa de utilidade atribuída, pelo trabalhador, a dois cursos de ação: permanecer versus buscar novo emprego. Nesse contexto, percebe-se que o apego do trabalhador não está na dependência do amor ou dinheiro, mas na percepção do controle de autoridade do empregador e subordinação do empregado (Bastos, 1994).

Dada a complexidade de se conceituar comprometimento, buscaram-se os pressupostos estabelecidos por Bastos (1994) para compreender seu significado. Dentre esses, Bastos (1994) identifica comprometimento no sentido de engajamento, que envolve alguma forma de laço psicológico entre pessoas e aspectos do seu ambiente. No caso de comprometimento organizacional, esse vínculo seria o resultado do contrato psicológico que se estabelece ao trabalho entrar na 
organização, implicando a aceitação dos valores organizacionais, das suas práticas e dos objetivos da organização.

Comprometimento, segundo Bastos (1994), ainda possui um caráter disposicional, na medida em que descreve não só ações, mas o próprio indivíduo; é assim tomado como um estado, caracterizado por sentimentos ou reações afetivas positivas, tais como lealdade, com intenções de permanecer e trabalhar para a organização.

\subsubsection{Comprometimento Organizacional - conceitos}

O estudo sobre comprometimento apresenta diferentes perspectivas referentes à conceituação do comprometimento: (a) a natureza: atitudinal, comportamental ou atitudinal/comportamental; (b) os focos do conceito: carreira, grupo de trabalho, organização, múltiplos focos; e (c) as bases do comprometimento: normativa, instrumental, afiliativa, entre outras.

\subsubsection{Natureza atitudinal}

No contexto atitudinal a ênfase está na sua dimensionalidade: uni ou multidimensional. Para Monday, Porter e Steers (1982), comprometimento deve ser abordado pela perspectiva unidimensional, pois o envolvimento de um indivíduo com a organização é uma função unívoca, pois, para haver comprometimento, o empregado deve aceitar fortemente as crenças, os valores e os objetivos, bem como deve se esforçar para que a organização atinja seus objetivos e ter um grande desejo de pertença à instituição. O trabalho de Morrow (1983) advertiu sobre a miscelânea conceitual que está contida nos vários modos de entender comprometimento.

Reichers (1985) apontou para que o comprometimento organizacional tivesse uma perspectiva múltipla, que poderia ser decomposta em facetas constituintes. Uma medida global de comprometimento com a organização pode esconder diferentes níveis de compromisso, na medida em que é integrada por vários elementos constituintes (stakeholders) que têm seus próprios objetivos, os quais podem ser tanto convergentes quanto divergentes em relação à organização. De acordo com Medeiros (2005), Kelman, no ano de 1958, foi quem primeiramente concebeu o 
comprometimento em diferentes partes, diferenciando o vínculo psicológico de um indivíduo com a organização em três bases independentes: a) submissão ou envolvimento instrumental, motivado por recompensas extrínsecas; b) identificação ou envolvimento baseado num desejo de afiliação; c) internalização ou envolvimento causado pela congruência entre os valores individuais e organizacionais. O'Reilly e Chatman (1986) desenvolveram um instrumento de mensuração para o modelo de Kelman.

Entre os diversos modelos de conceitualização de mais de um componente do comprometimento, o que foi mais aceito entre os pesquisadores foi o modelo de conceitualização de três componentes, estabelecido por Meyer e Allen (1991), em que há (a) o comprometimento afetivo (o indivíduo se identifica com a organização - fica na organização porque quer); (b) comprometimento instrumental (o indivíduo analisa os custos associados a deixar a organização - fica na organização porque precisa; c) comprometimento normativo (indivíduo sente-se na obrigação de permanecer na organização - fica porque é obrigado).

\subsubsection{Natureza comportamental}

Poucos são os estudos que tratam do comprometimento sob a ótica comportamental (Borges-Andrade \& Pliati, 2001). Na década de 1970, destacam-se as pesquisas de Sanalick (1977) e Pfeffer (1978), que abordam a necessidade de realizar estudos que considerem aspectos relativos ao comportamento observável e não exclusivamente à análise das atitudes, assim como deveria ser analisada a reciprocidade entre atitudes e comportamentos (Menezes, 2009).

No conceito de comprometimento sob a ótica comportamental, o indivíduo autoavalia o seu comprometimento de forma a manter um equilíbrio sobre o seu comportamento, ou seja, o indivíduo se sente responsável por suas ações, assumindo suas consequências Bastos (1993). Segundo Menezes (2009), o trabalhador não só mostra o seu desejo em permanecer no emprego, mas sim estabelece ações proativas em defesa dos interesses da organização.

Benkhoff (1997) estabeleceu uma relação entre comprometimento e desempenho, pois para ele o comprometimento será mais bem visualizado ao considerar o que os indivíduos fazem e não somente ao basear-se em relatos e sentimentos. 


\subsubsection{Articulação da Natureza atitudinal e comportamental}

O objetivo é verificar a consistência (ou não) entre o que se fala e o que se faz. $O$ problema está na dificuldade em associar os dois lados, a priori, antagônicos. Entretanto, para Ajzen e Fishbein (1980), essa dificuldade só permanece se forem desconsideradas variáveis como as intenções comportamentais.

Menezes (2006) ressalta que as pesquisas realizadas com a finalidade de construir e validar instrumentos de avaliação de comprometimento ou focam nas atitudes ou focam nos comportamentos, desconsiderando possíveis relações entre as duas perspectivas. Constata-se, assim, a raridade de instrumentos que façam esse tipo de medição.

Sendo assim, Meneses (2006, 2009) ao considerar necessária a junção entre as duas perspectivas (atitudinal e instrumental) ratificada por pesquisadores da área (Mowday, Porter \& Steers, 1982; Borges-Andrade \& Pilati, 20012; Bastos et al.,2008) tem buscado estruturar o conceito que vislumbre tanto a perspectiva atitudinal quanto a comportamental e, dessa forma, desenvolveu o modelo teórico da Escala de Intenções Comportamentais de Comprometimento Organizacional (EICCO), cuja estrutura é composta por quatro fatores: participação; melhor desempenho e produtividade; empenho extra ou sacrifício adicional; defesa da organização.

\subsubsection{Os focos do conceito}

Entre as diversas possibilidades de recorte sobre o estudo do comprometimento, uma delas está na compreensão de como a pessoa articula seus vínculos com os diferentes focos do trabalho: a organização, a carreira, o sindicato e o grupo com o qual o indivíduo se relaciona na organização em que trabalha, o conjunto de tarefas que executa, os objetivos ou as metas do trabalho, entre outros. Questões externas ao trabalho também podem influenciam este vínculo do trabalhador, como, por exemplo, família, religião, partido político (Mathieu \& Zajac, 1990; Bastos, 2000).

Dada a forma como o trabalho está sendo desenvolvido, quanto ao foco, primordialmente será abordado o comprometimento com a organização e, de forma secundária, carreira e grupos de trabalho. 
De acordo com Blau (2003), o comprometimento com a carreira pode ser entendido como a atitude relativa à profissão ou à vocação que o indivíduo tem conduzindo a desenvolver objetivos de carreira e como, caso sinta idenfiticado com esta, tenta obter progressão (Bastos, 2007). Fenômenos como a flexibilização das relações de trabalho ou a maior expectiva de vida têm impactado o comprometimento para com a carreira (Blau, 2003; Bastos, 2007; Rowe, 2008).

No que tange à identificação de comprometimento em grupos de trabalho, Neiningeret et al. (2010) estabelecem que as pessoas passam o maior tempo no contexto de grupo nas organizações em que trabalham favorecendo a familiaridade e a coesão da equipe. Esse estritamento das relações no grupo tende a influenciar seus membros, beneficiando o comprometimento que reflete em ações comportamentais de cidadania organizacional e de desempenho, por exemplo. Tais comportamentos são mais percebidos quando analisados em relação à equipe do que em relação à organização.

O comprometimento organizacional pode ser representado, segundo Meyer e Allen (1991), pelo estabelecimento do vínculo do indivíduo com a organização. E é esse tipo de comprometimento que tem sido de maior interesse à comunidade científica em face do volume de pesquisa em relação aos demais focos (Demo, 2003; Bastos, 2007; Rowe, 2008).

O vínculo pode ser estabelecido concomitantemente com um ou mais focos e isso pode ocorrer de forma harmoniosa (Bastos, 2000; Leite, 2004). Para Bastos (2000), o comprometimento com a profissão e com a organizaçao ocorre quando há compatibilidade entre a profissão e a vocação do indivíduo de modo a se estabelecer a realização profissional que a pessoa encontra na organização em que trabalha, denominado por Bastos (2000) de duplamente comprometido.

Ao se pensar no vínculo do trabalhador com a organização frente às "profundas reestruturações das arquiteturas organizacionais e das hierarquia das carreiras" reflete-se em medidas mais flexíveis direcionando à redução da força de trabalho e à terceirização de trabalhadores. Essas mudanças, geradoras de incertezas quanto à estabilidade no trabalho, têm impactado no comprometimento organizacional. Ademais, o avanço dos conhecimentos técnicos e científicos tem-se refletido na forma como as atividades são executadas e na criação de novas ocupações. Isso tem 
ocasionado reflexões quanto ao processo de escolha e de comprometimento com uma carreira em particular (Bastos, 2007; Rowe, 2008).

A atenuação do vínculo do trabalhador com a organização, dada a instabilidade no trabalho, e a criação de novas ocupações têm aumentado o comprometimento do indivíduo com a sua carreira, sem que esta seja, necessariamente, ancorada em um único emprego (Motta, 1997; Bastos, 2007).

A relevância de se reconhecer a coexistência de múltiplos focos do comprometimento está na possibilidade da influência que esses focos têm sobre as atitudes e comportamentos dos indíviduos na organização.

\subsubsection{As bases do conceito}

Becker (1992), a partir de estudos sobre comprometimento no trabalho, declara a existência de dois aspectos: os focos (organização, carreira e sindicatos, por exemplo) e as bases de comprometimento (afetiva, instrumental, normativa, entre outras), que se referem à natureza ou aos motivos que levam ao comprometimento. Para Demo (2003), além da característica de múltiplos focos, o conceito de comprometimento também é composto por múltiplas bases, entendendo-se isto como o tipo de vínculo do trabalhador com um determinado foco.

Assim, diante da definição dada por Mowday, Porter \& Steers (1982), os estudiosos de comprometimento entenderam que o empregado poderia se vincular à sua organização, carreira ou sindicato de alguma forma ou em bases diferentes. Bastos (1994) enumera tais bases como: afetiva/atitudinal (processo de identificação do indivíduo com os objetivos e valores da organização); instrumental/calculativa/de continuação (resultados das recompensas e custos percebidos pelo empregado na condição de integrante da organização); sociológica (vínculo que surge das relações de autoridade com o empregador); normativa (conjunto de pressões de normas sociais que definem o vínculo do empregado com a empresa) e comportamental (tal conceito existe em relação a um conjunto de cognições que orientam os comportamentos que fortalecem o vínculo com a organização, como, por exemplo, estar presente em todos os eventos sociais promovidos pela organização). 


\subsubsection{Antecedentes, correlatos e consequentes do comprometimento no trabalho}

Antecedentes, consequentes e correlatos do comprometimento organizacional são, respectivamente: variáveis com potencial de gerar comprometimento; variáveis resultantes do comprometimento; variáveis normalmente associadas ao comprometimento (Steers, 1977).

Numa perspectiva teórica para o comprometimento, Mowday, Steers e Porter (1979) e Mathieu e Zajac (1990) afirmam que seria útil aprender mais sobre os antecedentes e consequentes do comprometimento organizacional.

As variáveis preditoras ou antecedentes do comprometimento são, em sua maioria, relacionadas com as seguintes características: (1) pessoais - sexo, estado civil, idade, escolaridade, tempo no cargo, tempo na organização, percepção de competência, habilidades, salário; e nível do cargo; (2) do trabalho - autonomia na tarefa, variedade de habilidades, desafio, e desenho do cargo; e (3) organizacionais - tamanho e centralidade (Mathieu \& Zajac, 1990; Bastos, 1994; Tamayo et al., 2001; Siqueira, 2008). Maiores níveis de comprometimento tendem a estar associados com: mulheres e pessoas casadas; maiores medidas de idade; tempo na organização; nível ocupacional e remuneração; menores medidas de escolaridade; características de trabalho inovador e não rotineiro; estilo participativo da gerência e liderança com habilidade de comunicação (Monday, Porter \& Steers, 1982; Siqueira \& Gomide, 2004; Siqueira, 2008).

De acordo com Siqueira e Gomide (2004), Medeiros (2003) e Bastos (2007), as pesquisas sobre os antecedentes do comprometimento afetivo têm revelado que empregados comprometidos afetivamente são os que apresentam menores taxas de rotatividade, absenteísmo e intenção de sair da empresa, bem como melhores indicadores de desempenho no trabalho. Já quando o comprometimento afetivo é baixo, são observados atrasos, fraco desempenho e esforço reduzido aplicado ao trabalho. No que diz respeito ao comprometimento instrumental, verifica-se que trabalhadores que percebem altos custos associados ao seu desligamento das organizações - mais comprometidos instrumentalmente - tendem a ser menos 
motivados e a apresentar mais baixos níveis de desempenho no trabalho do que aqueles para quem os custos percebidos seriam em níveis mais baixos.

Mowday, Steers e Porter (1982) identificaram as seguintes variáveis correlatas: envolvimento com o trabalho; comprometimento ocupacional; satisfação com a supervisão; com o próprio trabalho; com os colegas e pessoal; com remuneração e promoção; baixo nível de estresse; e comprometimento com o sindicato.

Estudos que tentam indentificar as consequências do comprometimento têm apontando fatores como absenteísmo, comportamentos de cidadania, desempenho no trabalho, motivação e comportamentos de saída da organização. Um dos primeiros estudos sobre a decorrência do comprometimento foram Mathieu e Zajac (1990) constataram aspectos relacionados ao desempenho e comportamentos de retirada (rotatividade, intenção de procurar alternativas de trabalho, por exemplo). Meyer et al. (2002) na elaboração de uma meta-análise, constataram relações diretamente proporcionais entre os comprometimentos afetivo e normativo em face do desempenho individual e entre relações inversamente proporcionais entre comprometimento instrumental e desempenho individual. Essas relações também foram identificadas no trabalho de Siqueira e Gomide (2004).

Cavalcanti (2009) identificou, como consequentes, maiores desempenhos medidos por meio de indicadores de lucros para o alcance de metas e aumento do número de clientes; e solidez no fortalecimento da imagem organizacional. Os resultados do estudo de Rowe (2008) junto a docentes em Institutos de Ensino Superior (IES) das redes públicas e privadas evidenciaram que o comprometimento influencia mais 0 desepenho docente que os vínculos com a carreira.

Ribeiro (2008) reforça a necessidade de mais estudos sobre os consequentes do comprometimento, pois estes quase não foram explorados pelos estudos nacionais enquanto os estudos sobre os antecedentes são extremamente frequentes.

\subsubsection{Dimensões e tipologias para a identificação do comprometimento}

Como é comum na área de ciências sociais, a pesquisa sobre comprometimento no trabalho é marcada pela diversidade de definições e modelos teóricos e modelos 
teóricos de referência. Inúmeras formas de comprometimento no trabalho têm sido investigadas, considerando-se os diferentes focos (organização, carreira, trabalho, profissão, objetivos, sindicato, entre outros) e as bases do comprometimento (afetivo, normativo, de continuação, afiliativo, alienativo, moral, calculativo, etc.).

Ao se analisar o comprometimento sob a perspectiva de um único foco, a organização, o conceito de comprometimento organizacional ainda apresenta controvérsias, uma vez que há múltiplos conceitos de comprometimento: normativo, de valor, de identificação, afetivo, calculativo, moral, instrumental e de continuação. A partir dessa diversidade, podem-se abordar duas questões conceituais e teóricas que regem os estudos sobre comprometimento organizacional: (1) a natureza atitudinal e/ou comportamental do construto e (2) a natureza do vínculo do comprometimento com a organização, i.e., as bases, que propiciam uma visão multidimensional do construto (Medeiros, 2003; Bastos, 2007; Siqueira, 2008).

As origens de uma perspectiva multidimensional podem ser vistas em trabalhos como a desenvolvida por Etzioni (1975), que relaciona as diferentes formas de como o poder é exercido nas organizações (coerção, remuneração e pressão normativa) a três formas de envolvimento dos trabalhadores (alienativo, calculativo e moral). Outro antecedente de destaque foi a tipologia de comprometimento proposta por Kanter (1968), em que trata três formas de comprometimento que podem ser combinadas pelo indivíduo, embora uma seja dominante: continuação, coesão e controle (Siqueira, 2008).

O’Reilly e Chatman (1986), utilizando das ideias de Etzioni e de Kelman (1958) sobre os processos de influência social, propuseram o comprometimento a partir de três bases independentes (a) compliance (submissão) ou envolvimento instrumental motivado por recompensas extrínsecas; (b) identification (identificação) ou envolvimento baseado em um desejo de afiliação; e (c) internalization (internalização) ou envolvimento causado pela congruência entre os valores organizacionais e individuais.

O quadro 13 mostra uma visão sintética da diversidade que marca a mensuração das diferentes bases de comprometimento organizacional. Para Mowday (1988), há uma sobreposição conceitual entre os modelos propostos que conceitualizam comprometimento: o comprometimento atitudinal/afetivo é similar à dimensão internalização proposta por O'Reilly e Chatman (1986) e à dimensão afetiva proposta 
por Meyer e Allen (1991). Identicamente, percebe-se que a dimensão compliance é similar à dimensão continuance. O que se observa é que esta multiplicidade de medidas mostra a necessidade de mais estudos sobre esse fator no presente.

Quadro 20 - Diferentes bases de comprometimento e autores seminais

\begin{tabular}{|l|l|}
\hline \multicolumn{1}{|c|}{ Bases de comprometimento } & \multicolumn{1}{c|}{ Autores } \\
\hline $\begin{array}{l}\text { Comprometimento afetivo ou atitudinal - } \\
\text { baseado na aceitação dos objetivos da } \\
\text { organização }\end{array}$ & $\begin{array}{l}\text { Etzioni (1961) - Envolvimento moral } \\
\text { Kanter (1968) - Comprometimento de coesão } \\
\text { Porter et al (1974); Mowday et al. (1982); } \\
\text { O'Reilly e Chatman (1986) - internalização }\end{array}$ \\
\hline $\begin{array}{l}\text { Comprometimento de continuação, } \\
\text { calculativo ou instrumental - baseado nas } \\
\text { trocas e na avaliação dos custos } \\
\text { associados à saída da organização }\end{array}$ & $\begin{array}{l}\text { Kecker (1960) - side-bets } \\
\text { continuação } \\
\text { Meyer \& Allen (1968) - comprometimento de } \\
\text { (1986) - compliance. }\end{array}$ \\
\hline $\begin{array}{l}\text { Comprometimento normativo - baseado Chatman } \\
\text { no sentimento de lealdade e obrigação } \\
\text { para com a organização }\end{array}$ & $\begin{array}{l}\text { Kanter (1968) - comprometimento e controle } \\
\text { O'Reilly e Chatman (1986) - identificação } \\
\text { Meyer, Allen e Smith (1993) }\end{array}$ \\
\hline $\begin{array}{l}\text { Comprometimento comportamental } \\
\text { vínculo com ações }\end{array}$ & $\begin{array}{l}\text { Kiesler e Sakamura (1966) } \\
\text { Salancik (1977, 1982). }\end{array}$ \\
\hline
\end{tabular}

Fonte: Adaptado de Siqueira et al., 2008.

No Brasil, o comprometimento organizacional passou a ser mais examinado a partir da década de 1990 com o trabalho realizado por Bastos em 1993, no qual o autor apresenta as principais abordagens conceituais e as respectivas fontes teóricas na investigação do comprometimento organizacional (Medeiros, 2003; Siqueira, 2008; Melo, 2014). 


\subsubsection{A Escala de Bases do Comprometimento Organizacional - EBACO}

A partir das observações de Meyer e Allen (1991) e de O'Reilly e Chatman (1986) sobre a necessidade de ampliar as dimensionalidades do construto comprometimento. Medeiros (2003) desenvolveu e validou a Escala de Bases do Comprometimento Organizacional (EBACO). A concepção do modelo EBACO foi precedida pelo trabalho de Medeiros e Enders (1998) que validou o modelo tridimensional do comprometimento (afetivo, normativo e instrumental) de Meyer e Allen (1991). Nessa validação, os autores chegaram à conclusão semelhante sobre a possibilidade da existência de outras dimensões latentes do comprometimento organizacional, ou ainda, a possibilidade de subdivisões das existentes. Foi neste trabalho que a base afiliativa surgiu ao avaliar o vínculo emocional entre o indivíduo e a organização e que foi posteriormente confirmada por Medeiros et al. (1999).

Para a elaboração da escala EBACO, Medeiros (2003) usou como referência as quatro principais perspectivas do comprometimento: afetiva, normativa, instrumental e afiliativa. Para tanto, aplicou o modelo de O'Reilly e Chatman (1986), associado ao modelo de Meyer e Allen (1991) e propôs uma síntese entre as teorias e os modelos teóricos de comprometimento. A escala EBACO é composta por 28 variáveis observáveis, divididas igualmente em sete dimensões latentes. Uma dimensão representa o enfoque afetivo, uma do afiliativo, duas do normativo e três do instrumental. As dimensões foram validadas por meio de análises fatoriais exploratórias e confirmatórias. As bases obrigação em permanecer e obrigação pelo desempenho correspondem ao enfoque normativo de comprometimento organizacional. $E$ as bases escassez de alternativas, linha consistente de atividade $e$ falta de recompensas e oportunidades correspondem ao enfoque instrumental. $O$ quadro 14 apresenta a fundamentação teórica das bases de comprometimento da escala EBACO. 
Quadro 21 - Bases do comprometimento e fundamentação teórica da EBACO

\begin{tabular}{|c|c|c|}
\hline $\begin{array}{c}\text { Bases do } \\
\text { Comprometimento }\end{array}$ & $\begin{array}{l}\text { Componentes } \\
\text { Definições }\end{array}$ & Fundamentação Teórica da Base \\
\hline $\begin{array}{c}\text { Afetivo } \\
\text { Internalização de } \\
\text { Valores e Objetivos }\end{array}$ & $\begin{array}{l}\text { Crença e identificação com } \\
\text { a filosofia, os valores e os } \\
\text { objetivos organizacionais. }\end{array}$ & $\begin{array}{l}\text { Comprometimento afetivo - Mowday, Porter } \\
\text { e Steers (1982); } \\
\text { Congruência de valores - Kelman (1958); } \\
\text { Introjeção - Gouldner (1960); Envolvimento } \\
\text { moral -Etzioni (apud Mowday, Porter e } \\
\text { Steers, 1982); } \\
\text { Adesão -Thévenet (apud Sá e Lemoine, } \\
\text { 1998) }\end{array}$ \\
\hline $\begin{array}{l}\text { Afiliativo } \\
\text { Sentimento de } \\
\text { Fazer Parte }\end{array}$ & $\begin{array}{l}\text { Crença de que se é } \\
\text { reconhecido pelos colegas } \\
\text { como membro do grupo e } \\
\text { da organização. }\end{array}$ & $\begin{array}{l}\text { Identificação - Kelman (1958); } \\
\text { Integração - Gouldner (1960); } \\
\text { Identificação - Becker (1992); } \\
\text { Coesão - Kanter (apud Mowday, Porter } \\
\text { e Steers, 1982); } \\
\text { Afiliativa - Medeiros e Enders (1999). }\end{array}$ \\
\hline $\begin{array}{l}\text { Normativo } \\
\text { Obrigação em } \\
\text { Permanecer }\end{array}$ & $\begin{array}{l}\text { Crença de que se tem a } \\
\text { obrigação de permanecer; } \\
\text { de que não seria certo } \\
\text { deixar; e de que se tem uma } \\
\text { obrigação moral com as } \\
\text { pessoas da organização. }\end{array}$ & $\begin{array}{l}\text { Pressões normativas - Wiener (1982) e } \\
\text { Jaros et al. (1993); } \\
\text { Controle - Kanter (apud Mowday, Porter e } \\
\text { Steers, 1982). }\end{array}$ \\
\hline $\begin{array}{c}\text { Normativo } \\
\text { Obrigação pelo } \\
\text { Desempenho }\end{array}$ & $\begin{array}{l}\text { Crença de que se deve } \\
\text { realizar esforços em } \\
\text { benefício da organização e } \\
\text { que se deve buscar atingir } \\
\text { os objetivos } \\
\text { organizacionais. }\end{array}$ & $\begin{array}{l}\text { Pressões normativas - Wiener (1982) e } \\
\text { Jaros et al. (1993); } \\
\text { Controle - Kanter (apud Mowday, Porter e } \\
\text { Steers, 1982). }\end{array}$ \\
\hline $\begin{array}{l}\text { Instrumental } \\
\text { Escassez de } \\
\text { Alternativas }\end{array}$ & $\begin{array}{l}\text { Crença de que existem } \\
\text { poucas alternativas de } \\
\text { trabalho fora } \\
\text { organização. }\end{array}$ & Continuação - Meyer e Allen (1991). \\
\hline $\begin{array}{c}\text { Instrumental } \\
\text { Falta de Recompensas } \\
e \\
\text { Oportunidades }\end{array}$ & $\begin{array}{l}\text { Crença de que o esforço } \\
\text { realizado em benefício da } \\
\text { organização deve ser } \\
\text { melhor recompensado e de } \\
\text { que a organização deve lhe } \\
\text { dar mais oportunidade. }\end{array}$ & $\begin{array}{l}\text { Envolvimento calculativo - Etzioni, Porter e } \\
\text { Steers (1982); } \\
\text { Oportunidade - Thévene (apud Sá e } \\
\text { Lemoine, 1998); } \\
\text { Recompensas - Becker (1992). }\end{array}$ \\
\hline $\begin{array}{l}\text { Instrumental } \\
\text { Linha } \\
\text { Consistente de } \\
\text { Atividade }\end{array}$ & $\begin{array}{l}\text { Crença de que se deve } \\
\text { observar certas condutas e } \\
\text { regras da organização } \\
\text { tendo em vista o objetivo de } \\
\text { nela permanecer. }\end{array}$ & $\begin{array}{l}\text { Trocas laterais - Becker (1960); } \\
\text { Hrebiniak e Alutto (1972). }\end{array}$ \\
\hline
\end{tabular}

Fonte: Bastos et al. (2008).

O modelo de Escala de Bases do Comprometimento Organizacional foi aplicado pela primeira vez em um estudo realizado por Medeiros em 2003, cuja finalidade foi examinar as relações existentes entre as características organizacionais, as dimensões latentes do comprometimento organizacional e o desempenho de organizações no contexto brasileiro. O autor realizou um estudo empírico com 305 vendedores de 170 lojas de shopping centers na cidade do Natal e 269 empregados 
de 82 hotéis localizados em três capitais do Nordeste do Brasil: Fortaleza, Natal e Recife.

A Escala de Bases do Comprometimento Organizacional (EBACO) vem sendo utilizada no Brasil, tanto em pesquisas científicas para a realização de dissertações e teses (Pena, 2009; Loth, 2010; Lages, 2010; Cantarelli, 2012) quanto em artigos científicos (Bonavides, Oliveira, Medeiros, 2006; Cavalcante \& Medeiros, 2007; Schirrmeister et al., 2008; Rodrigues et al., 2009; Lopes \& Basso Jr., 2009; Rowe \& Bastos, 2009; Rowe, Bastos e Pinho, 2010; Estivalete et al., 2010; Kuabara \& Sachuk, 2010; Campos, Estivalete, \& Reis, 2011; Nogueira \& Cavazotte, 2011; Sousa \& Honório, 2011; Vale, Lima \& Queiroz, 2011; Aquino \& Honório, 2012; Melo et al., 2014; Paiva \& Dutra, 2015; Fernandes et al., 2016). Apesar de sua larga utilização para a mensuração do comprometimento organizacional, não foram encontrados estudos que avaliem a confiabilidade e a validade das escalas de bases de comprometimento organizacional exclusivamente em instituições públicas com perfil de organização transnacional.

\subsection{Resultados organizacionais}

Avaliar os resultados alcançados frente aos objetivos estabelecidos recai na operacionalização da missão e da estratégica organizacional ao redor de objetivos e medidas não financeiras e financeiras de desempenho (Kaplan \& Norton, 1994). Neste contexto, a medição dos resultados torna-se fundamental para a gestão organizacional porque confere efetividade às metas e aos objetivos estabelecidos, auxiliando o processo decisório quanto aos ajustes e às ações que precisam ser tomadas, caso necessário (Kaplan, 2012).

Neely (1995) define medição de desempenho como o processo de se quantificar uma ação, no qual mensuração é o processo de quantificação e a ação é aquilo que provoca o desempenho. Em organizações públicas, cuja finalidade é o bem-estar social, costuma-se realizar medidas não financeiras como instrumentos de planejamento e de controle estratégico. Com esse objetivo, o DPR estabeleceu medidas que permitissem não só estabelecer um controle mais real das atividades realizadas pelos SECOMs, como também ser um indicador para o planejamento de 
ações junto aos SECOMs identificados como pouco produtivos, assim como o estabelecimento de premiações para os Setores de Promoção Comercial mais produtivos.

Os critérios dispostos no quadro 15 foram estabelecidos mediante as atividades realizadas nos SECOMs e dicotomizadas em "produtividade" e "proatividade". As medidas de produtividade são relativas às atividades obrigatórias e que fazem parte da natureza cotidiana da organização. Já as medidas denominadas "proatividade" se referem a atividades de ação exclusiva que resultam na qualidade das informações disponibilizadas no que concerne às atividades comerciais do País.

A cada trimestre essas atividades são quantificadas e os SECOMs são ranqueados. A par dessas informações, o DPR realiza medidas como justificativas de liberação orçamentária, contratação de novos colaboradores para o SECOM, investimentos em treinamentos para os colaboradores quanto às práticas organizacionais, entre outras ações.

Quadro 22 - Avaliação quantitativa dos resultados conforme os critérios estabelecidos pelo DPR

\begin{tabular}{|l|l|}
\hline \multicolumn{1}{|c|}{ Atividade } & \multicolumn{1}{|c|}{ Critério } \\
\hline Atendimento a consultas telefônicas, por e-mail, por meios oficiais ou presenciais & Produtividade \\
\hline Inserção de feiras locais & Produtividade \\
\hline Organização de missões & Produtividade \\
\hline Organização de seminários, eventos, rodadas de negócios, feiras e mostras & Produtividade \\
\hline Participação em seminários, eventos, rodadas de negócios, feiras e mostras & Produtividade \\
\hline Realização de visitas, encontros e reuniões & Produtividade \\
\hline Resposta a consultas pela Extranet DPR & Produtividade \\
\hline Validação de empresas locais & Produtividade \\
\hline Capacitação e treinamento & Proatividade \\
\hline Elaboração de informação sobre produtos & Proatividade \\
\hline $\begin{array}{l}\text { Elaboração de notícia para o portal Invest\&Export Brasil ou para o Boletim de de } \\
\text { Facilitação de Negócios }\end{array}$ & Proatividade \\
\hline Elaboração de pesquisas de mercado & Proatividade \\
\hline Elaboração de publicações (estudos, boletins, revistas, série "Como Exportar" etc.) & Proatividade \\
\hline Identificação de concorrências públicas locais abertas & Proatividade \\
\hline Identificação de concorrências públicas locais previstas & Proatividade \\
\hline Identificação de Investimento Direto Brasileiro (IDB) & Proatividade \\
\hline Identificação de Investimento Estrangeiro Direto (IED) & Proatividade \\
\hline
\end{tabular}




\subsection{Síntese do capítulo 2}

O capítulo dois apresentou a fundamentação teórica que subsidiará os resultados das pesquisas apresentadas nos próximos capítulos.

Para este trabalho, a instrumentalização da cultura tem como alicerce o paradigma funcionalista, é quantitativamente mensurável e capaz de influenciar outras variáveis organizacionais.

A cultura organizacional é vista como um fenômeno coletivo em que os pressupostos básicos são compartilhados, i.e., as crenças, os valores e os sistemas de valores são estabelecidos como a forma correta de pensar e de agir e são manifestados por meio das suas práticas organizacionais.

Os valores organizacionais são definidos como representações e são compartilhados pelos membros da organização, estão hierarquicamente organizados e construídos sobre princípios ou crenças relativas às metas e à comportamentos organizacionais desejáveis, que orientam a vida da empresa, reconhecendo o paralelismo entre valores individuais e organizacionais. E as práticas organizacionais, têm como pressuposto o valor atribuído às pessoas quando da adoção de práticas humanistas ou instrumentais.

E, por fim, entende-se que comprometimento é uma força que liga um indivíduo a um alvo social ou não social e a um curso de ação relevante para esse alvo e pode ser experimentada de diferentes maneiras e vinculadas de várias formas, podendo ser um vínculo afetivo ou afiliativo com o objetivo, uma consciência dos custos associados à interrupção do envolvimento com o objetivo (comprometimento instrumental) e uma obrigação sentida para o alvo (comprometimento normativo). 


\section{OBJETIVOS DA PESQUISA E PROPOSIÇÃO DO MODELO INTEGRADOR}

\subsection{Introdução ao capítulo 3}

O objetivo central desta pesquisa é examinar as relações preditivas entre valores organizacionais, práticas organizacionais e comprometimento organizacional sobre o resultado final. Para tanto, a revisão da literatura, tanto nacional como estrangeira, serviu de base para a elaboração de um modelo integrador.

A revisão da literatura também possibilitou referenciar a formulação das hipóteses sobre o modelo integrador concebido, de sorte que foram identificadas variáveis que poderiam influenciar as variáveis preditivas que estão relacionadas ao contexto, à tarefa e ao indivíduo (sexo, tempo de serviço e nacionalidade).

Neste capítulo, apresentam-se os objetivos da pesquisa, o modelo integrador e as hipóteses da pesquisa. As hipóteses foram desenvolvidas sobre as relações entre o modelo integrador (efeitos diretos, indiretos e mediadores) e as suposições sobre os efeitos das variáveis individuais (efeitos diretos).

\subsection{Objetivos da pesquisa}

Como já identificado na introdução deste trabalho, o objetivo geral que se pretende atingir com o estudo é:

Identificar e descrever a influência das manifestações da cultura da Instituição, ${ }^{7}$ por meio dos valores e dos tipos de práticas organizacionais, sobre o comprometimento, bem como a influência dessas manifestações e do comprometimento sobre os resultados organizacionais.

Para o alcance do objetivo geral, os seguintes objetivos específicos foram propostos:

OE1: Estudar a influência da cultura organizacional, mensurada por meio dos valores e dos tipos de práticas organizacionais, da instituição nacional (DPR) sobre as organizações locais (SECOMs).

\footnotetext{
${ }^{7}$ Por Instituição se entende a instituição nacional (DPR) e as organizações locais (SECOMs)
} 
OE2: Estudar o comprometimento das organizações locais (SECOMs), identificando a natureza do comprometimento que mais se destaca: normativa, afetiva ou instrumental.

OE3: Analisar a influência da cultura organizacional, mensurada por meio dos valores e dos tipos de práticas organizacionais, das organizações locais (SECOMs) sobre os demais construtos do estudo (comprometimento e resultados).

$\mathrm{O}_{E 4}$ : Estudar as possíveis relações entre as variáveis sociodemográficas das organizações locais (SECOMs) sobre os valores e o comprometimento organizacional.

Oes: Verificar se comprometimento é mediador das relações entre os tipos de práticas e os valores da organização local e seus resultados. E verificar se práticas organizacionais são mediadoras das relações entre valores da organização local e seus resultados bem como o comprometimento.

Os valores têm como função, além da manutenção da identidade organizacional, propiciar condições favoráveis para o desenvolvimento do bem-estar da organização e do trabalhador (Tamayo, 2005), havendo a possibilidade de funcionar como conector entre numerosos aspectos da ciência social, como já foi visto em pesquisas de valores associados com motivação, ética na tomada de decisão, corrupção, comportamento do consumidor, entre outros (Casado, T. et al., 2005).

Práticas são formas particulares de conduzir as funções organizacionais (Kostova, 1999) e, segundo o autor, têm natureza multifacetada e são integradas por dois elementos diferenciados: (1) conjunto de regras escritas ou tácitas sobre como as funções organizacionais devem ser conduzidas, e (2) conjunto formado por elementos cognitivos (valores e crenças) que determinam como compreender e interpretar tais regras. Segundo Jackson (2002), a importância dos valores culturais na condução da vida organizacional está bem estabelecida na literatura. No entanto, o aspecto como as diferenças culturais influenciam a forma como as pessoas são valorizadas nas organizações não foi suficientemente discutida na literatura. Assim, o autor propõe o conceito de "locus of human value" (lócus de valor humano) para descrever como as pessoas são valorizadas de acordo com as características culturais de cada sociedade, e, consequentemente, com o estilo das práticas de gestão das diversas 
culturas nacionais, distinguindo, a partir da percepção dos gestores, entre a visão instrumental ou humanista quanto à forma de gerir as pessoas nas organizações.

Na perspectiva instrumental, observa-se maior separação entre a vida profissional (trabalho) e a pessoal (casa e comunidade), percepção individualista e foco no alcance dos resultados. Na perspectiva humanista, observa-se maior integração entre a vida profissional (trabalho) e a pessoal (casa e comunidade), já que sua cultura está baseada no dever e no coletivismo (Jackson, 2002).

Para este modelo define-se comprometimento como uma força que liga um indivíduo a um alvo social ou não social e a um curso de ação relevante para esse alvo (Meyer, Becker \& Vandenberghe, 2004). Essa força vinculativa pode ser experimentada de diferentes maneiras. Pode ser um vínculo afetivo ou afiliativo com o objetivo, uma consciência dos custos associados à interrupção do envolvimento com o objetivo (comprometimento instrumental) ou uma obrigação sentida para o alvo (comprometimento normativo).

A partir do referencial teórico, foram identificadas lacunas e oportunidades de contribuir para a discussão do tema, levando à definição do objetivo geral do trabalho e dos objetivos específicos. Esses objetivos nortearam o desenvolvimento do modelo integrador e do modelo conceitual apresentados a seguir.

\subsection{Pressupostos do modelo conceitual integrador}

Os resultados organizacionais, tais como apresentados na seção 4.4.3.1.4 do capítulo 4 desta tese, relacionam-se com diversos aspectos da estratégia organizacional, como, por exemplo, a gestão estratégica de marketing, a financeira e a gestão estratégica de pessoas cujo propósito está na melhoria dos desempenhos e no alcance de metas nas quais estão inseridas tanto as necessidades individuais dos colaboradores quanto as necessidades da organização e da sociedade.

A questão de como criar valor às organizações e de como fazer para que a empresa cresça sempre permeou as discussões organizacionais. Nesta perspectiva, a gestão de pessoas tem ganhado um espaço crescente na tentativa de responder a esses desafios, assumindo um papel cada vez mais estratégico e orientado para os 
resultados (Ulrich, 2000). Assim, estudar as relações de construtos da cultura organizacional (valores e gestão de práticas organizacionais) e comprometimento como antecedentes do resultado organizacional pode ser uma boa medida para compreender fatores impeditivos e colaborativos das organizações para que cumpram com os objetivos estabelecidos.

O problema de pesquisa proposto neste trabalho é identificar e descrever a influência das manifestações da cultura da Instituição, ${ }^{8}$ por meio dos valores e dos tipos de práticas organizacionais, sobre o comprometimento, bem como a influência dessas manifestações e do comprometimento sobre os resultados organizacionais.

O problema de pesquisa será investigado em duas partes: a primeira, analisará a influência das manifestações da cultura (valores e tipos de práticas) da instituição nacional (DPR) sobre os valores e os tipos de práticas das organizações locais (SECOMs); a segunda analisará, conjuntamente, se os valores, por meio de suas metas motivacionais, os tipos de práticas (humanista ou instrumental) e o comprometimento organizacional são variáveis antecedentes e/ou explicativas do resultado no nível das organizações locais (SECOMs) e, a partir dos resultados encontrados, propor um modelo conceitual para descrevê-los. Com os resultados das duas análises propõe-se um modelo conceitual integrador, que estabelece o relacionamento antecedente (valores e tipos de práticas da instituição nacional) e explicativas (valores, tipos de práticas e comprometimento da organização local) sobre os resultados organizacionais.

As variáveis foram mensuradas por meio da escala do Inventário de Perfis dos Valores Organizacionais (IPVO), desenvolvida por Oliveira e Tamayo (2004) e construída com base nos valores humanos de Schwartz (1999), pela escala de percepções de práticas de gestão de pessoas (lócus de valor humano) desenvolvida por Jackson (2002) e pela escala de bases de comprometimento (EBACO), desenvolvida por Medeiros (2003). Para o construto dos resultados organizacionais, foi elaborada uma escala a partir dos resultados das organizações locais. Cabe salientar que comprometimento foi analisado não só como antecedente de resultados, mas também como variável mediadora da relação entre os valores e os tipos de práticas organizacionais e os resultados nas organizações locais.

\footnotetext{
${ }^{8}$ Por Instituição se entende a instituição nacional (DPR) e as organizações locais (SECOMs)
} 
O modelo conceitual integrador geral, formulado com base no referencial teórico revisado, possui os componentes dispostos na figura 13.

Figura 13 - Modelo integrador geral

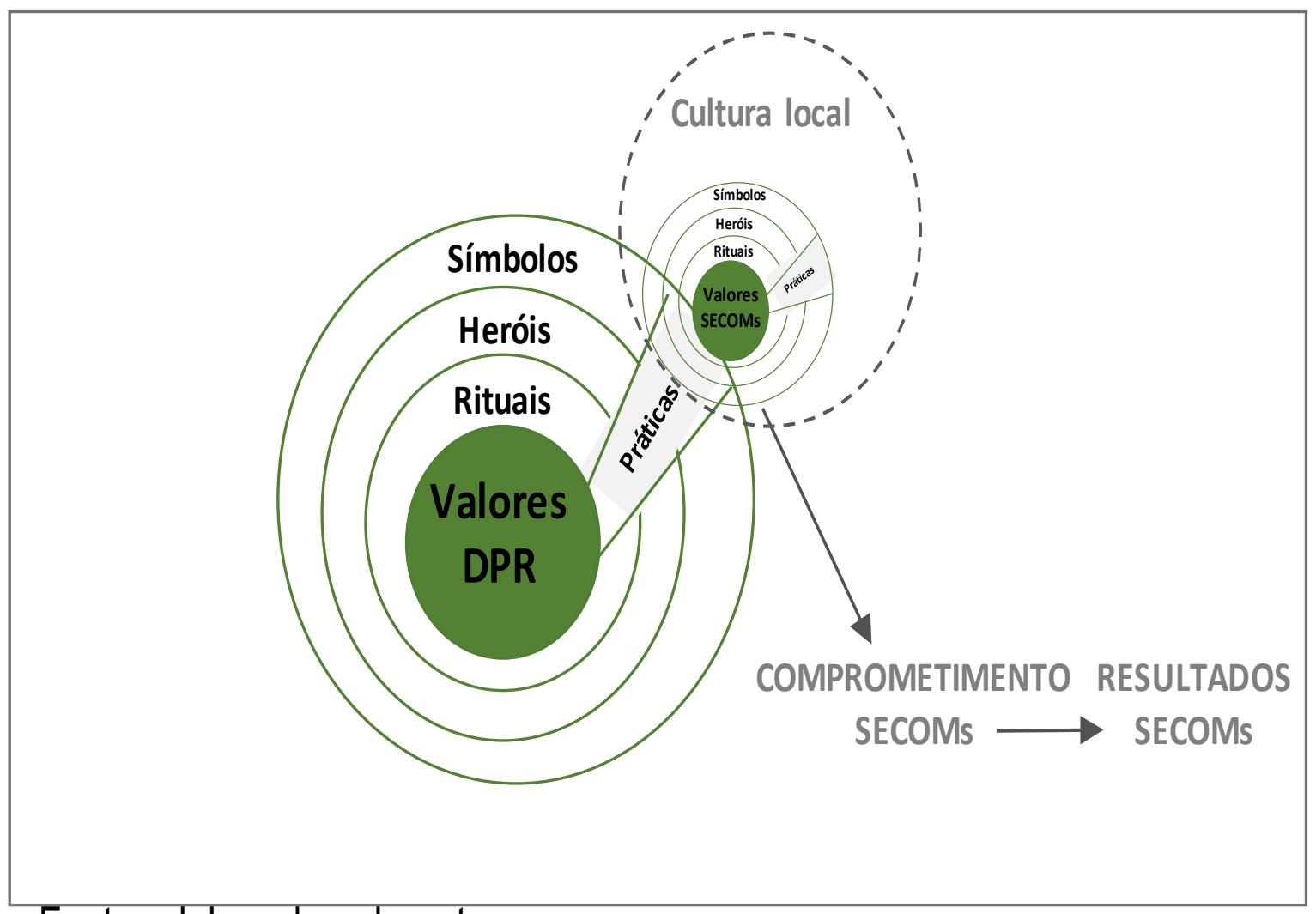

Fonte: elaborado pela autora

A seção a seguir apresentará as hipóteses de pesquisa, especificando as relações entre os diferentes construtos identificados. 


\subsection{Hipóteses da pesquisa}

Nesta seção, serão apresentadas as hipóteses da pesquisa que distinguem as hipóteses relativas às principais variáveis preditoras do modelo integrador e, posteriormente, as variáveis sociodemográficas. Por fim, o modelo integrador é apresentado com as hipóteses referenciadas.

\subsubsection{Hipóteses relativas às principais variáveis}

Neste item são apresentadas as hipóteses relacionadas às variáveis centrais do modelo integrador e suas relações com os resultados da organização local. As hipóteses serão construídas levando-se em conta o efeito da cultura organizacional da instituição nacional (DPR), por meio dos seus valores e dos tipos de práticas organizacionais sobre a cultura da organização local (SECOMs), bem como o efeito da cultura da organização local (SECOMs) sobre seus resultados. Conforme visto, neste trabalho entende-se cultura organizacional como fenômeno coletivo (Hofstede, 2003), em que os pressupostos básicos são compartilhados (Schein, 1985), ou seja, as crenças e os valores e sistemas de valores são estabelecidos como a forma correta de pensar e de agir e são manifestados por meio das suas práticas organizacionais (Hofstede, 2003; D’Lribarne,1983; Dupuls, 2007; Beyer \& Trice, 1987). A cultura organizacional pode ser reconhecida por meio de padrões específicos de cada organização e, desta forma, podem ser comparadas tanto com outras organizações quanto com culturas nacionais. Os elementos que formam a cultura são divididos em dois níveis: valores e práticas. Hofstede (2003) afirma que, apesar de os valores delinearem a cultura organizacional, a forma como as práticas são manifestadas é que tipifica a cultura da organização, visto que são repassadas para o grupo por meio da socialização.

As hipóteses sobre cultura organizacional serão apresentadas com base nos valores organizacionais e nos tipos de práticas organizacionais.

Nesta tese, os valores organizacionais são definidos como representações mentais (Porto \& Pereira, 2012), compartilhados pelos membros da organização, que convivem dentro do mesmo ambiente, em um espaço de tempo consideravelmente duradouro, consistindo em cognições dos princípios que orientam práticas e normas organizacionais (Katz \& Kahn, 1974). Estão hierarquicamente organizados (Tamayo, et al., 2000) e construídos sobre princípios ou crenças relativas a metas e a 
comportamentos organizacionais desejáveis, que orientam a vida da empresa e estão a serviço de interesses individuais, coletivos ou mistos (Tamayo, 1996), reconhecendo paralelismo entre valores individuais e organizacionais (Oliveira \& Tamayo, 2004). Pode-se definir práticas organizacionais como atividades reais que a organização executa, desde as quotidianas até as mais inovadoras (Souza et al.,2011), compartilhadas entre os membros da organização, passíveis de variação no tempo e no espaço e capazes de modificar atitudes e comportamentos das pessoas (Ogaard 2006; Tuomi et al., 2004; Verbeke, 2000). Dessa forma, são representantes das manifestações da cultura organizacional (Dupuls, 2007) ou sua essência (Fischer et al.,2013). Jackson (2002) descreveu como as pessoas são valorizadas de acordo com as características culturais de cada sociedade, e, consequentemente, com o estilo das práticas de gestão das diversas culturas nacionais, distinguindo, a partir da percepção dos gestores, entre a visão instrumental ou humanista quanto à forma de gerir as pessoas nas organizações. Ainda segundo o autor, há um interesse crescente pela relação entre culturas nativas e ocidentais na prática e desenvolvimento de gestão e organização internacional. Este é particularmente o caso das economias de transição do antigo bloco soviético (Koubrek \& Brewster, 1995; Lawrence, 1994; Shekshnia, 1998), na China (Huo \& Von Glinow, 1995; Jackson \& Bak, 1998; Sergeant \& Frenkel, 1998, Wang, 1994), assim como nos países chamados "em desenvolvimento" do sul da Ásia, África e América Latina (Blunt \& Jones, 1992; Jaeger \& Kanungo, 1990).

Vale ressaltar que há discordâncias entre quais componentes (valores ou práticas) concebem o núcleo da cultura organizacional: uns definem os valores organizacionais (Schein, 1999; Paz \& Tamayo, 2004) e outros definem as práticas organizacionais (D’Lribarne, 2003; Hofstede et al., 2003).

Com base nos conceitos estabelecidos e no referencial teórico desenvolvido, as seguintes hipóteses foram formuladas, quando analisadas a instituição nacional (DPR) e organizações locais (SECOMs):

$\mathbf{H}_{1}$ : Não há diferenças nas percepções dos valores organizacionais do DPR (instituição nacional) e dos SECOMs (organização local).

$\mathbf{H}_{2}$ : Não há diferenças nas percepções dos tipos de práticas organizacionais (instrumental ou humanista) do DPR (instituição nacional) e dos SECOMs (organização local). 


\subsubsection{Efeito dos valores da organização local (SECOMs) sobre seus tipos de práticas organizacionais}

Segundo Beyer e Trice (1987), a cultura é formada por dois componentes fundamentais: (1) a rede de significados constituída pelos valores, ideologias e normas, e (2) as práticas organizacionais, que teriam a função de expressar, de afirmar e comunicar o conteúdo desta rede de significados da organização. Hofstede (2003) sugere que a cultura organizacional seja estudada por meio das práticas, já que estas podem ser analisadas por observadores externos.

Os valores organizacionais estão relacionados às crenças e às prioridades partilhadas entre os integrantes de uma organização (Tamayo \& Gondin, 1996). Todos os indivíduos apresentam um sistema pessoal de valores, formado mediante o convívio na sociedade (Rokeach, 1973; Schwartz, 1992). No ambiente de trabalho, os integrantes de uma organização desenvolvem valores compartilhados entre si, os quais, durante a trajetória da organização, levam a práticas específicas de trabalho, por eles julgadas como adequadas e relevantes (Hofstede et al., 1990; TAMAYO \& GONDIN, 1996). Desta forma, a seguinte hipótese foi elaborada:

$\mathrm{H}_{3}$ : Os valores organizacionais influenciam os tipos de práticas organizacionais. 


\subsubsection{Efeito da cultura organizacional local sobre o comprometimento}

O comprometimento organizacional pode ser representado, segundo Meyer e Allen (1991), pelo estabelecimento do vínculo do indivíduo para com a organização. Tendo como base os estudos de vários conceitos de orientação afetiva de autores como Kanter (1968); Sheldon (1971); Hall, Schneider e Nygren (1970); Buchanan (1974); Mowday, Porter e Steers (1982); de orientação baseada em custos de autores como Kanter (1968); Becker (1960); Hrebeniak e Alutto (1972); e de orientação baseada na obrigação e responsabilidade moral conceituada por autores como Wiener e Gechman (1977); Wiener (1982) e Marsh e Mannari (1977), Meyer e Allen (1991) observaram que essas orientações representavam três grandes temas: o comprometimento visto como um reflexo de uma orientação afetiva em relação à organização; como um reconhecimento dos custos associados à saída da organização; e como uma obrigação moral de permanecer na organização.

Em uma perspectiva teórica para o comprometimento, Mowday, Steers \& Porter (1979) e Mathieu \& Zajac (1990) afirmam que seria útil aprender mais sobre os antecedentes e consequentes do comprometimento organizacional. Gutierrez et al. (2012) incluem como antecedentes para o comprometimento afetivo: intercâmbios de membros-líderes, ou seja, relações e relacionamento entre funcionários e supervisores (Wayne et al., 2009; Eisenberger et al., 2010); avaliação positiva da organização pelos funcionários, no que se refere à satisfação destes quanto às suas necessidades de aprovação, estima, afiliação e apoio emocional (Armeli et al., 1998); satisfação no trabalho (Rhoades \& Eisenberger 2002); redução do estresse e maior envolvimento no trabalho; aprimoramento do trabalho-família (Wadsworth \& Owens, 2007) e envolvimento no trabalho (Kinnunen et al., 2008).

Já os antecedentes do comprometimento normativo, segundo Gutierrez et al. (2012), podem envolver a sociedade e as relações sociais do empregado; no entanto, esse comprometimento também pode ser influenciado pelo processo de socialização que ocorre ao entrar na organização, bem como durante o mandato do emprego. Antecedentes do comprometimento de continuidade podem ser descritos, segundo os autores, em duas categorias gerais: investimentos e alternativas. Os investimentos se referem a quanto os funcionários acreditam que investiram no trabalho (por exemplo, tempo, esforço, dinheiro) e, portanto, não querem perder caso tenham de sair. $E$ as 
alternativas podem ser descritas como a percepção dos funcionários sobre o que é (ou não está) disponível para eles em termos de outras oportunidades de emprego (Meyer \& Allen, 1997).

Tamayo (2005) reporta alguns trabalhos sobre antecedentes de comprometimento como o de Arnold e Davey (1999) que, por meio de pesquisa longitudinal, observaram que a natureza do trabalho e o desenvolvimento da carreira são preditores significativos e importantes do comprometimento organizacional. Há também o trabalho de O'Driscoll e Randall (1999), que, utilizando amostras de empregados da Irlanda e da Nova Zelândia, estudaram o impacto do suporte organizacional percebido e da satisfação com as recompensas intrínsecas e extrínsecas e observaram que as duas são preditoras importantes do comprometimento organizacional.

Pesquisas têm sido realizadas tendo como pressuposto os valores como antecedentes de comprometimento organizacional. Como por exemplo: Valores de trabalho e comportamentos de cidadania organizacional orientados a serviços: a mediação de contrato psicológico e comprometimento profissional: um caso de estudantes na faculdade de polícia de Taiwan de Chen, Chun et al. (2012); Valores individuais, comprometimento organizacional e participação em uma mudança: abordagem de professores de Israel para uma reforma educacional de Cohen, Aaron Caspary \& Lilach (2011); Percepções da eficácia da liderança na gestão do conflito intergeracional de trabalho e valores: antecedente do comportamento da cidadania organizacional de enfermeiros de Wright, Patricia (2009); A influência dos valores culturais sobre antecedentes de comprometimento organizacional: análise de nível individual de Arzu Wasti, S. (2003); Um estudo da relação entre comprometimento organizacional e valores humanos em quatro países de Glazer, Sharon et al. (2004); O impacto dos valores culturais na satisfação no trabalho e no comprometimento organizacional nas equipes de trabalho: o papel mediador da resistência dos funcionários de Kirkman, Bradley (2001); Antecedentes do comportamento da cidadania organizacional entre os trabalhadores de colarinho azul e branco na Turquia de Ersoy et al. (2011); Comportamentos de cidadania organizacional em relação ao status do trabalho, insegurança no trabalho, comprometimento e identificação organizacional, satisfação no trabalho e valores de trabalho de Feather \& Rauter (2004); O impacto dos valores das pessoas e da organização no comprometimento organizacional de Finegan, Joan E. (2000); Uma análise da relação entre 
comprometimento organizacional e valores de Garrido et al. (2010); Comprometimento organizacional, intenções de rotatividade e influência de valores culturais de Wasti, S. Arzu (2003).

Com base nessas discussões e no referencial teórico apresentado nesta tese, as seguintes hipóteses foram elaboradas:

$\mathbf{H}_{4}$ : Os valores organizacionais influenciam o comprometimento organizacional $\mathrm{H}_{5}$ : Os tipos de práticas organizacionais influenciam o comprometimento organizacional.

\subsubsection{Efeito da cultura organizacional local sobre os resultados locais}

O resultado organizacional é complexo e, de fato, uma função de muitas variáveis, dado que tratar sobre o resultado como o alcance dos objetivos organizacionais é avaliar a soma de todas as ações realizadas, os esforços de cada membro da organização, das escolhas dos recursos utilizados, enfim, um conjunto de variáveis que devem estar harmoniosamente equilibradas para que os resultados esperados sejam alcançados e assim obtenha-se um bom desempenho na organização. Desta forma, o desempenho organizacional pode ser visto por meio de duas abordagens: (a) a que entende o desempenho como resultados - histórico de resultados produzidos em determinadas atividades - sendo a soma (ou média) dessas atividades medidas quantitativamente; e (b) a que considera como a soma dos comportamentos que controlam os membros da organização em um determinado contexto comportamentos avaliados separadamente que, interligados, geram o desempenho (Bartram, 2000; Campbell, Mccloy, Oppler, \& Sager, 1993; Robertson, Callinan \& Bartram, 2002).

Entre o número de variáveis que podem afetar direta ou indiretamente o desempenho de uma organização, encontram-se os valores organizacionais que, segundo Denison (1997), indicam o modo de resolver problemas e são um dos fundamentos das práticas da organização, e, por conseguinte, dos resultados alcançados (desempenho organizacional).

Holton e Yamkovenko (2008), ao definirem o desenvolvimento estratégico do capital intelectual, afirmam que o comportamento humano em uma organização desempenha 
um papel fundamental no desempenho da empresa, sendo um mediador entre a estratégia e o desempenho organizacional. Desta forma, as práticas organizacionais devem ser projetadas de modo que estimulem comportamentos estrategicamente críticos para o desempenho organizacional.

A influência dos valores no comportamento dos indivíduos em suas escolhas e decisões tem sido apontada como relevante por Kluckhohn (1951), Rokeach (1973), Schwartz (1992) e Rohan (2000). Nas organizações, os valores compartilhados pelos membros de uma organização, ao influenciarem suas opções e decisões, levam ao desenvolvimento de práticas organizacionais (Hofstede et al., 1990; Tamayo \& Gondin, 1996), e as práticas desempenhadas podem influenciar os resultados da organização.

Jackson (2002) definiu como "locus of human value" (lócus de valor humano) o conceito para descrever como as pessoas são valorizadas de acordo com as características culturais de cada sociedade, e, consequentemente, com o estilo das práticas de gestão das diversas culturas nacionais, distinguindo, a partir da percepção dos gestores, entre a visão instrumental ou humanista quanto à forma de gerir as pessoas nas organizações.

A perspectiva instrumental apresenta uma percepção individualista cujo foco está no alcance dos resultados, apresentando uma visão das pessoas como meios para um fim, ou seja, o gestor dirige e controla a execução das tarefas que são direcionais para resultados. Já a perspectiva humanista está baseada no dever e no coletivismo, apresentando uma visão das pessoas como um fim nelas mesmas, ou seja, o gestor busca desenvolver o comprometimento das pessoas no trabalho (Jackson, 2002).

Com base nos conceitos estabelecidos e no referencial teórico desenvolvido, as seguintes hipóteses foram estabelecidas. Estas hipóteses se referem à relação entre a cultura organizacional (mensurada por meio dos valores e dos tipos de práticas organizacionais) dos SECOMS (organização local) e os resultados organizacionais (desempenho organizacional). 
H6: Os valores organizacionais dos SECOMs influenciam os resultados organizacionais.

$\mathrm{H}_{7}$ : Os tipos de práticas organizacionais dos SECOMs influenciam os resultados organizacionais.

\subsubsection{Efeito do comprometimento da organização local sobre seus resultados}

De acordo com Combs, Crook e Shook (2005), o desempenho organizacional é, provavelmente, o construto mais importante para a administração estratégica. Cameron (1981) apresenta o desenvolvimento de quatro abordagens teóricas para o significado de desempenho organizacional: a primeira, da década de 1950, avalia o desempenho como associado à formulação e ao alcance de metas financeiras; duas novas abordagens na década de 1970 foram introduzidas: (1) adaptação ao meio ambiente - representando a obtenção dos recursos do ambiente externo necessários para a sua sobrevivência; e (2) eficiência de estruturas e processos, em que o desempenho é o nível de eficiência do funcionamento da organização. A última abordagem, surgida na década de 1980, concentra-se na satisfação dos stakeholders - em que o desempenho é o grau em que as necessidades e expectativas de diferentes grupos de interesse são satisfeitas pela empresa.

Diversas características organizacionais atuam no comprometimento das pessoas nas organizações em que trabalham. De acordo com Fitz-Enz (1997), valores, estratégia e cultura dominam o comportamento das pessoas na organização e se apresentam como antecedentes aos sistemas organizacionais. Macedo et al. (2016) afirmam que o comprometimento organizacional tem sido um construto estudado com frequência, atraindo estudiosos de várias perspectivas teóricas. Alguns autores examinaram os efeitos do comprometimento organizacional sobre o desempenho e o volume de negócios (Farrell \& Rusbult, 1981, Meyer, Paunonen, Gellatly, Goffin \& Jackson, 1989), ou sobre as múltiplas dimensões do desenvolvimento de recursos humanos e desempenho organizacional (Sung \& Choi, 2014); assim como a relação entre comprometimento do funcionário e o desempenho da organização (Roca-Puig et al., 2007; Muse \& Lori et al., 2005). Além disso, há estudos que tratam sobre empregabilidade e desempenho organizacional (De Cuyper \& De Witte, 2011) e sobre 
a relação entre responsabilidade social corporativa, satisfação no trabalho e comprometimento organizacional (Asrar-Ul-Haq et al., 2017).

Com base nessas discussões e no referencial teórico apresentado nesta tese, a seguinte hipótese foi proposta:

$\mathrm{H}_{8}$ : $\mathrm{O}$ comprometimento organizacional influencia os resultados organizacionais.

\subsubsection{Efeito mediador do comprometimento na relação entre valores organizacionais e tipos de práticas e os resultados organizacionais.}

A mediação ocorre quando uma terceira variável, referida como uma variável mediadora, intervém entre dois outros construtos relacionados. Mais precisamente, uma mudança no construto exógeno resulta em uma mudança da variável do mediador, que, por sua vez, muda o construto endógeno. Assim, uma variável mediadora governa a natureza da relação entre dois construtos e seu objetivo é criar uma relação teórica indireta entre os caminhos e os construtos (Samani, 2016).

Meyer \& Smith (2000) conduziram uma pesquisa para examinar os mecanismos envolvidos nas relações observadas entre as práticas de gerenciamento de recursos humanos $(\mathrm{GRH})$ e o comprometimento dos funcionários. A pesquisa, que incluía medidas de (a) qualidade das práticas de GRH relacionadas à avaliação de desempenho, beneficiamentos, treinamento e desenvolvimento de carreira, (b) justiça processual e suporte organizacional, e (c) comprometimento afetivo, de continuidade e normativo, teve como resultados que as relações entre as avaliações dos funcionários das práticas de GRH e seu comprometimento afetivo e normativo foram amplamente mediadas pelas percepções de apoio organizacional e justiça processual. Kitapci et al. (2014) investigaram o efeito mediador da satisfação no trabalho entre as percepções do pessoal sobre as práticas de GRH no comprometimento organizacional e os resultados revelaram o efeito de mediação total ou parcial da satisfação no trabalho sobre a relação entre as práticas de GRH em dimensões de comprometimento organizacional. 
Para Şendoğdu et al. (2013), os fatores mais importantes que afetam o desempenho operacional das empresas são os recursos humanos. Portanto, o desenvolvimento do comprometimento organizacional precisa de práticas eficazes de gerenciamento de recursos humanos. Partindo desta premissa, as hipóteses de mediação são apresentadas a seguir.

H9a: Tipos de práticas organizacionais são mediadores de valores e resultados.

Hob: Tipos de práticas organizacionais são mediadores de valores e comprometimento.

$H_{10 a}$ : Comprometimento é mediador de valores e resultados.

$\mathrm{H}_{10 \mathrm{~b}}$ : Comprometimento é mediador de práticas e resultados.

\subsubsection{Hipóteses relativas às variáveis sociodemográficas}

Segundo Bastos (1994), pesquisas sobre comprometimento organizacional lidam com uma ampla variedade de variáveis como antecedentes que podem ser agrupadas em: variáveis pessoais, características do trabalho (ocupacionais), experiências no trabalho e características organizacionais. A meta-análise de Mathieu \& Zajac (1990) sobre antecedentes de comprometimento apresenta no grupo das variáveis sociodemográficas a idade e o tempo de serviço na empresa. Com base nisso, a seguinte hipótese foi formulada:

$\mathbf{H}_{11}$ : As variáveis sociodemográficas tempo de serviço, nacionalidade e sexo influenciam na percepção dos valores e do comprometimento na organização local. 
Apresentadas as hipóteses da pesquisa, o modelo nomológico específico com as hipóteses estabelecidas apresenta a seguinte configuração:

Figura 14 - Modelo conceitual integrador específico e hipóteses

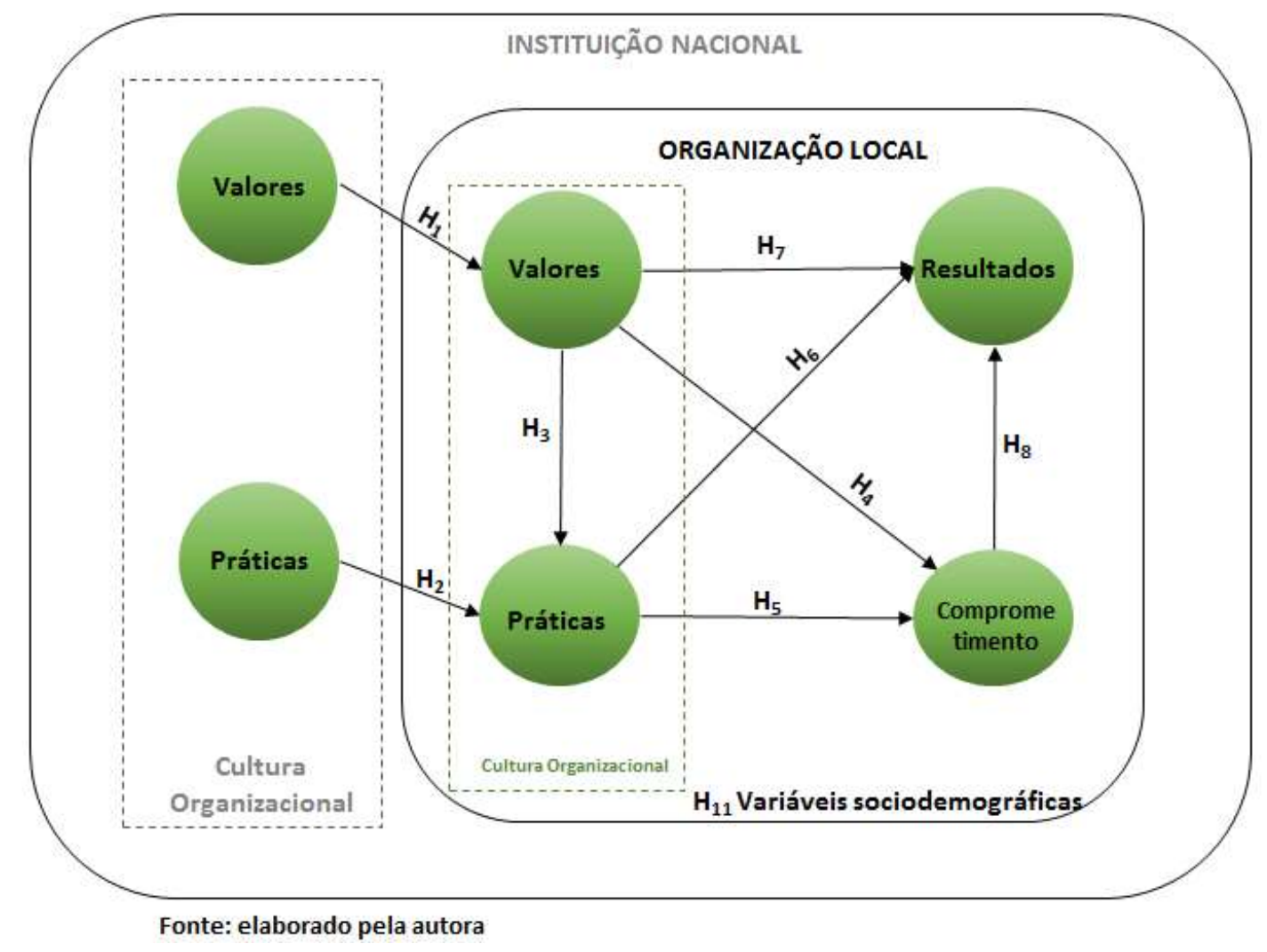

E para as hipóteses de moderação, a seguinte configuração foi estabelecida

Figura 15 - Modelo de moderação para a organização local

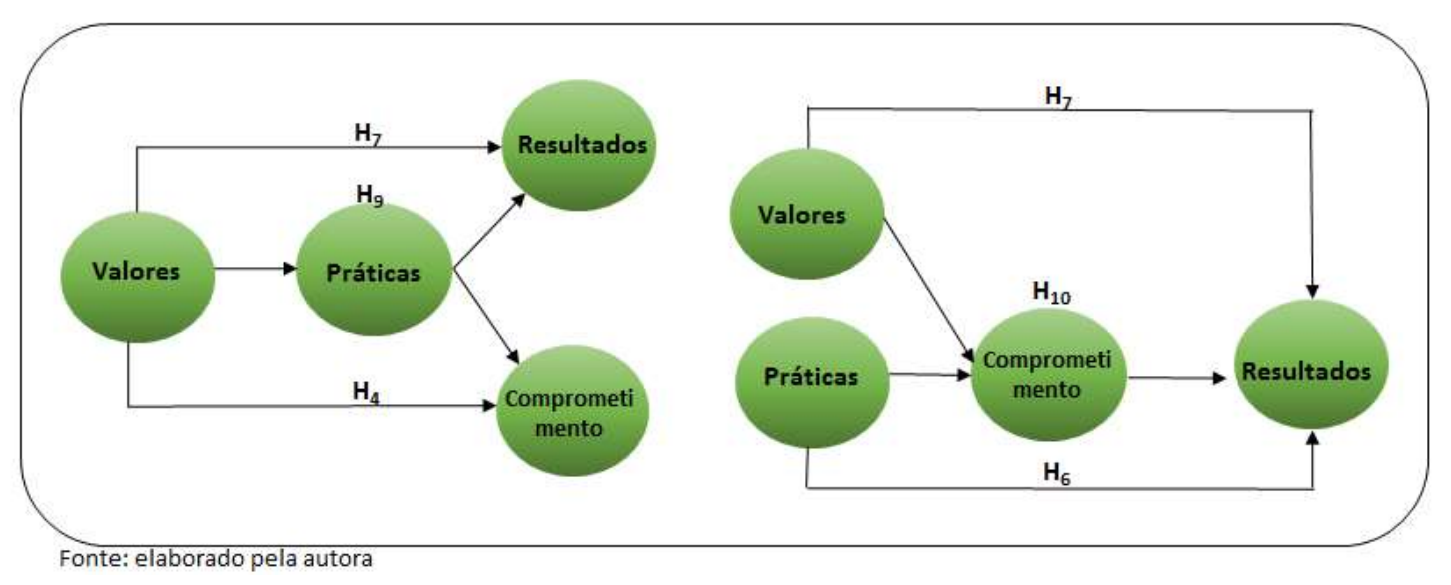


O quadro 19 sintetiza as hipóteses da pesquisa $\left(\mathrm{H}_{1}\right.$ a $\left.\mathrm{H}_{10}\right)$ que refletem o impacto das variáveis principais - antecedentes e mediadoras.

Quadro 23 - Variáveis antecedentes e mediadoras e hipóteses da pesquisa

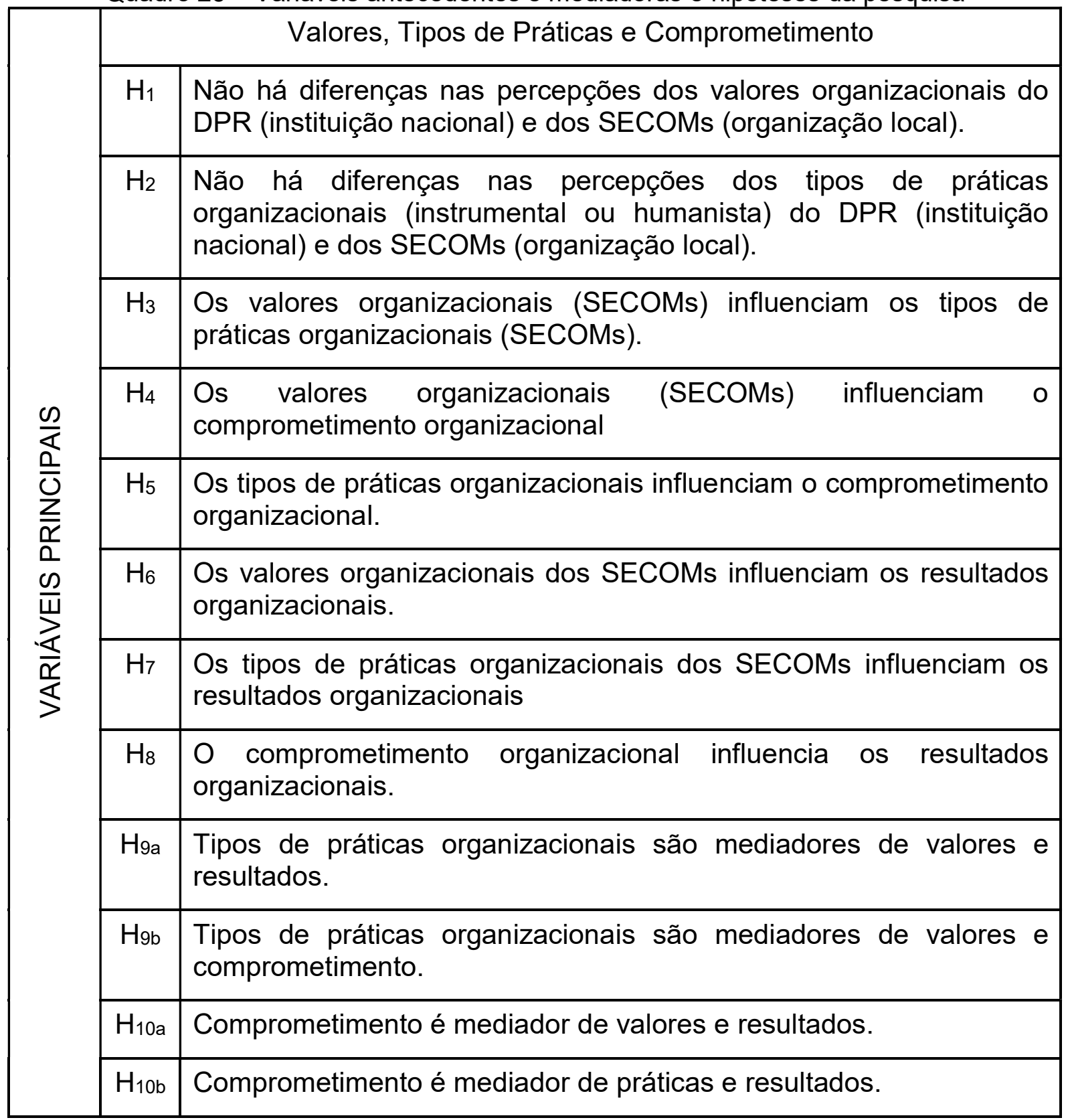

Fonte: elaborado pela autora

O quadro 20 apresenta a hipótese da pesquisa $\left(\mathrm{H}_{11}\right)$ para as relações entre informações sociodemográficas e valores e comprometimento das organizações locais (SECOMs). 
Quadro 24 - Variáveis Sociodemográficas e Hipótese da pesquisa

\begin{tabular}{|c|c|c|}
\hline \multirow{2}{*}{ 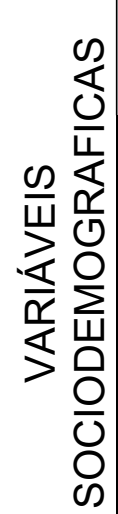 } & \multicolumn{2}{|r|}{$\begin{array}{c}\text { Variáveis sociodemográficas } \\
\text { (tempo de serviço, nacionalidade e sexo) }\end{array}$} \\
\hline & $\mathrm{H}_{11}$ & $\begin{array}{l}\text { As variáveis sociodemográficas tempo de serviço, nacionalidade } \\
\text { e sexo influenciam na percepção dos valores e do } \\
\text { comprometimento na organização local. }\end{array}$ \\
\hline
\end{tabular}

Fonte: elaborado pela autora

\subsection{Síntese do capítulo 3}

O objetivo do capítulo foi apresentar os objetivos da pesquisa, propor o modelo integrador, bem como as hipóteses desenvolvidas a partir do referencial teórico.

As variáveis principais são: valores organizacionais, tipos de práticas organizacionais e comprometimento organizacional. $E$ as variáveis sociodemográficas foram igualmente integradas ao modelo integrador (tempo de serviço, sexo e nacionalidade).

Foram propostas onze hipóteses de pesquisa que correspondem às relações diretas e mediadoras das variáveis estudadas.

O capítulo a seguir apresentará o método de pesquisa. Para tanto, serão apresentados a metodologia, o local da pesquisa, os participantes, os instrumentos de medida, os procedimentos da coleta e da análise dos dados. 


\section{PROCEDIMENTOS METODOLÓGICOS}

\subsection{Introdução ao capítulo 4}

Neste capítulo são especificadas as escolhas metodológicas de investigação (abordagem e tipo de pesquisa), o detalhamento da organização estudada, os instrumentos utilizados e os procedimentos da coleta e análise dos dados. A ideia é que o método escolhido seja capaz de descrever as definições das variáveis, a forma como mensurá-las, a seleção da população-alvo e os procedimentos utilizados para a análise dos dados (Selltiz et al., 1987). A figura 16 demonstra a organização deste capítulo.

Figura 16 - Diagrama do trajeto metodológico

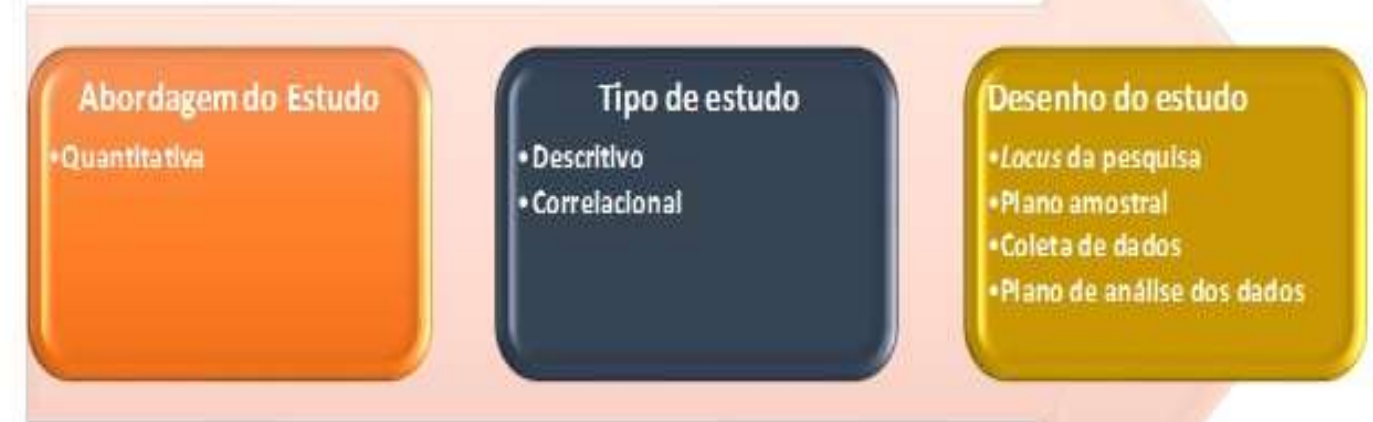


O referencial teórico apresentado nos capítulos anteriores conduziu a elaboração das hipóteses e do modelo integrador de predição dos resultados organizacionais. $O$ fluxograma da figura 17 ilustra as etapas que foram seguidas e que conduzirão às conclusões deste estudo.

Figura 17 - Etapas para o desenvolvimento da pesquisa

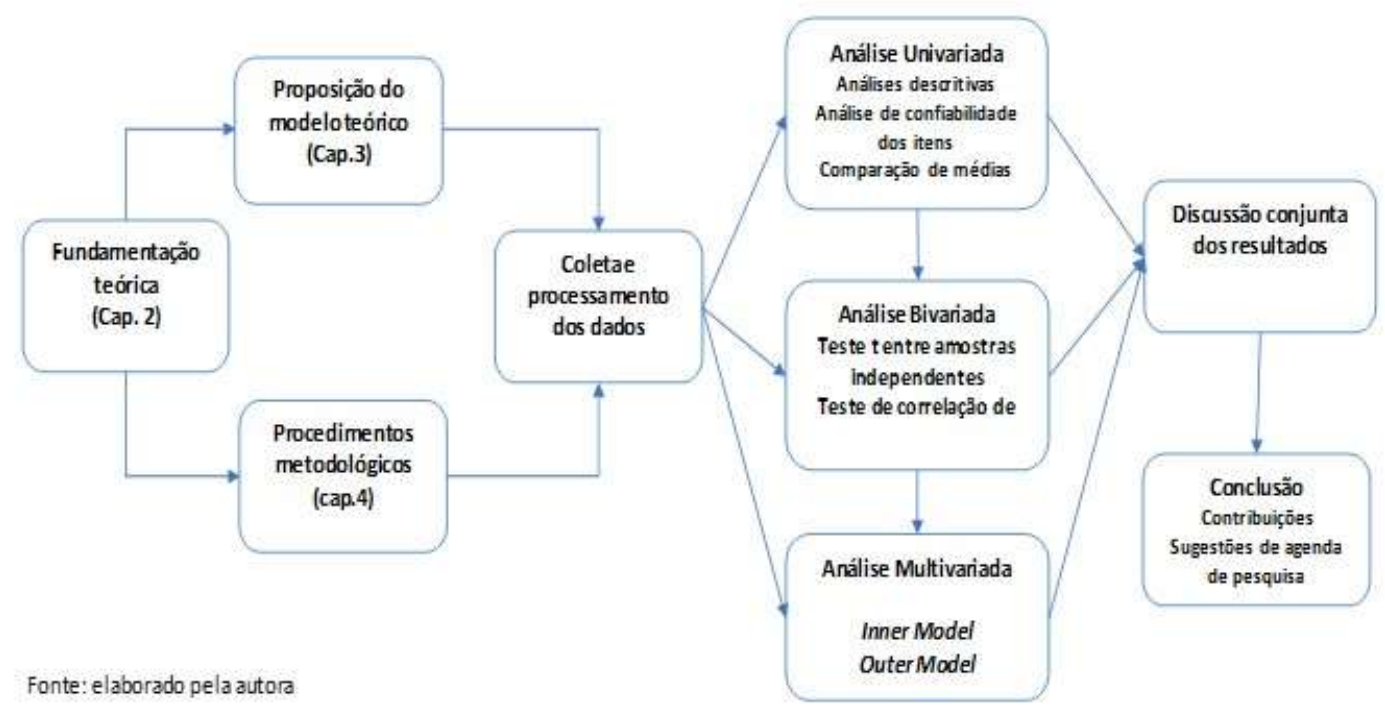

\subsection{Abordagem da pesquisa}

A complexidade que envolve cultura tem sido objeto de acentuadas discussões epistemológicas, principalmente na forma como a cultura deve ser abordada: qualitativa ou quantitativamente (Gherardi \& Turner, 1987; Denison, 1996).

No que se refere à abordagem qualitativa utilizada nas pesquisas sobre cultura, segundo Saffold (1988) sua vantagem está no poder de compreender cultura de forma mais profunda - como gestalt ${ }^{9}$, possibilitando uma visão mais específica e única. Entretanto, o forte elemento subjetivo da abordagem qualitativa dificulta a replicação e a aplicação de procedimentos de validação, prejudicando a objetividade, a comparabilidade e possíveis generalizações, comuns da abordagem quantitativa.

Então, vantagens do uso de técnicas quantitativas, como a survey, seriam a possibilidade de poder aplicar o mesmo instrumento em várias organizações e, assim,

\footnotetext{
${ }^{9}$ Gestalt é uma palavra de origem germânica, com uma tradução aproximada de "forma" ou "figura". Esta doutrina sustenta que a mente configura, através de diversas leis, os elementos que chegam a ela mediante a percepção ou a memória (a inteligência). A psicologia da Gestalt afirma que o todo é mais do que a soma das suas partes.
} 
criar meios para comparações e generalizações. Além disso, pesquisas de cunho quantitativo propiciam o mapeamento e o estudo de populações maiores e mais dispersas.

Schein (1990), ao indagar sobre a validade dos métodos de estudos sobre cultura organizacional, afirma que pesquisas quantitativas do tipo survey apresentariam dificuldades quanto à delimitação dos itens: se seriam demasiadamente amplos para conseguirem absorver as dimensões da cultura. Argumenta ainda que os resultados de surveys seriam incapazes de explicar a variabilidade dos achados e, dessa forma, somente a abordagem qualitativa seria suficiente para se infiltrar nos conceitos mais profundos da cultura da organização.

Segundo Hofstede $(1991 ; 2003)$, tradicionalmente a cultura organizacional tem sido abordada por estudos de caso por meio de observação participante, apesar de serem profundos quanto às suas análises, a subjetividade invalida replicações. Neste sentido, o autor considera a utilização de métodos quantitativos tipo surveys capazes de permitir confirmações com outras pesquisas e, dessa forma, corroborar seus achados.

No que se refere à abordagem, esta pesquisa é quantitativa, sua finalidade é quantificar opiniões, na forma de coleta de dados e transformá-las em informações por meio de técnicas estatísticas para descrever (estatística descritiva) e inferir (estatística inferencial) sobre a população estudada (Vasconcelos, 2007).

\subsection{Tipos de estudo}

Os tipos de estudos a serem realizados nesta pesquisa são, de acordo com Sampieri et al. (2006), descritivo e correlacional ${ }^{10}$. $O$ autor define como estudo descritivo àquele que se ocupa em descrever situações, acontecimentos e feitos, são centrados na coleta de dados que mostrem um evento, um fenômeno no contexto ou na situação em que ocorre e podem oferecer a possibilidade de previsões ou relações, ainda que sejam pouco elaboradas. E os estudos correlacionais tratam de avaliar a relação entre dois ou mais conceitos, categorias ou variáveis, em geral, quantitativas.

\footnotetext{
10 Segundo a classificação de Danhke (1989), os estudos podem ser divididos em: exploratórios, descritivos, correlacionais e explicativos.
} 
Os estudos quantitativos correlacionais quantificam as relações por meio da medição do grau de relação entre duas ou mais variáveis para depois analisar as correlações. Tais correlações são expressas em hipóteses que deverão ser testadas (Sampieri et al., 2006).

\subsection{Desenho do estudo}

A finalidade é explicar a forma como a operacionalização do estudo foi realizada, desde a definição da escolha dos atores, dos procedimentos para a coleta de dados até o seu tratamento, tendo em vista os objetivos a serem alcançados.

\subsubsection{O Lócus da pesquisa}

A escolha pela investigação que utiliza como respondentes os colaboradores do DPR/MRE e dos SECOMs é explicada pela natureza do objeto estudado e pelos objetivos da pesquisa.

No que se refere ao objeto estudado, no ambiente global das organizações que operam em diversos países, o entendimento descritivo da cultura organizacional (isto é, valores e práticas) tem se mostrado particularmente importante (Adler, 1991). Segundo Shafritz e Ott (2001) fatores como a cultura da sociedade em que a organização atua, a tecnologia empregada, mercado, competidores e a personalidade dos seus fundadores e / ou dos seus líderes nos primeiros anos de existência fazem com que a cultura das organizações seja diferente de uma instituição para outra.

A importância da cultura da organização está na premissa de que esta pode promover uma sensação de pertencimento entre os seus membros, aumentando o comprometimento com a organização (Smircich, 1983), além de influenciar a maneira como os empregados interpretam os eventos organizacionais e servir como um mecanismo de controle e determinante no comportamento dos que estão inseridos nesta organização (Schein, 1992).

No entanto, organizações cujas operações atravessam fronteiras geográficas, políticas, nacionais e étnicas aparentemente parecem ser complexas no que concerne às práticas compartilhadas ou à convivência de pontos de vistas culturais diferentes e, então, a sua cultura organizacional pode ser afetada pelos diversos princípios de gestão vinculados às diferentes culturas nacionais. Pesquisas vêm mostrando que a 
adoção de práticas de gestão tem sido influenciada pelos modelos ocidentais norteamericanos que estabelecem um conjunto de práticas ditas como melhores e universais (Legge, 2005) de sorte que muitas vezes são adotadas independentemente das caraterísticas locais, ou seja, não há uma preocupação de adaptação de uma prática "global" às especificidades locais. A discussão sobre o grau de convergência global e adaptação local das práticas de gestão, tanto de estratégia de negócios quanto de Recursos Humanos, está presente na agenda de estudiosos e pesquisadores (Brewster et al., 2007 e 2008; Delery \& Doty, 1996; Legge, 2005; Leung et al., 2005; Mayrhofer \& Reichel, 2006; Mayrhofer, 2011). Após revisão bibliográfica, não foram encontrados estudos referentes à atuação brasileira em nível governamental em outros países e, especificamente, que foquem na efetividade de instituições governamentais brasileiras na captação de recursos a serem investidos no País, assim como na efetividade de instituições governamentais que fomentam a internacionalização de empresas brasileiras, por meio de organizações brasileiras localizadas em outros países e que se utilizam, além de servidores nacionais, a força de trabalho local para cumprir os objetivos estratégicos determinados pelo órgão federal brasileiro.

Com relação aos objetivos desta pesquisa, busca-se compreender a influência das variáveis antecedentes e mediadora (valores organizacionais, práticas organizacionais e comprometimento) sobre os resultados alcançados pelos Setores de Promoção Comercial (SECOMs). Assim, o universo deste estudo passa a ser os colaboradores e a instituição o Departamento de Promoção Comercial e Investimentos do MRE e seus SECOMs.

\subsubsection{Diplomacia comercial}

A diplomacia comercial cumpre a importante tarefa de identificar oportunidades para a exportação de produtos e serviços nacionais, para o aumento da participação do Brasil no comércio internacional e para a atração de investimentos, tendo sempre como norte o objetivo maior do desenvolvimento econômico e social. Sendo uma das mais importantes ferramentas para a inserção competitiva das empresas brasileiras na economia global, e tem a promoção comercial como um dos eixos principais de uma política externa voltada para o desenvolvimento (DPR 50 Anos, 2017). 


\subsubsection{DPR - Departamento de Promoção Comercial e Investimentos}

O Departamento de Promoção Comercial e Investimentos - (DPR), foi criado pela Lei $n^{\circ}$ 4.669, de 8 de junho de 1965. Sob a liderança do então Conselheiro, hoje Embaixador, Paulo Tarso Flecha de Lima, que dirigiu o DPR por uma década, o Departamento se estruturou e se modernizou.

O Departamento de Promoção Comercial e Investimentos (DPR) é a unidade competente do Ministério das Relações Exteriores (MRE) para atuar na definição e na implementação de políticas de promoção das exportações brasileiras e de atração de investimentos estrangeiros, além de apoiar o processo de internacionalização de empresas brasileiras e a divulgação do produto turístico nacional. Em conjunto com outros órgãos da Administração Pública Federal, cabe ao DPR aproximar a oferta de exportações brasileiras à demanda externa e estimular a atração de investimentos estrangeiros, contribuindo para o surgimento de uma cultura exportadora nacional. Além disso, o Departamento participa ativamente da discussão e da elaboração de propostas de políticas governamentais que facilitem a inserção e a presença de empresas brasileiras nos mercados externos, de modo a transformar as oportunidades em benefícios efetivos para o País (Promoção Comercial, 2017). Sua missão está delineada da seguinte forma: Contribuir para a consecução da política externa brasileira, fortalecendo os laços de comércio, de investimentos e de integração com outros países.

O DPR está organizado em quatro divisões: Divisão de Investimentos (DINV), Divisão de Inteligência Comercial (DIC), Divisão de Programas de Promoção Comercial (DPG) e Divisão de Operações de Promoção Comercial (DOC), e no exterior, os Setores de Promoção Comercial (SECOMs) situados nas Embaixadas e Consulados brasileiros como pontos de referência para a promoção comercial e a atração de investimentos.

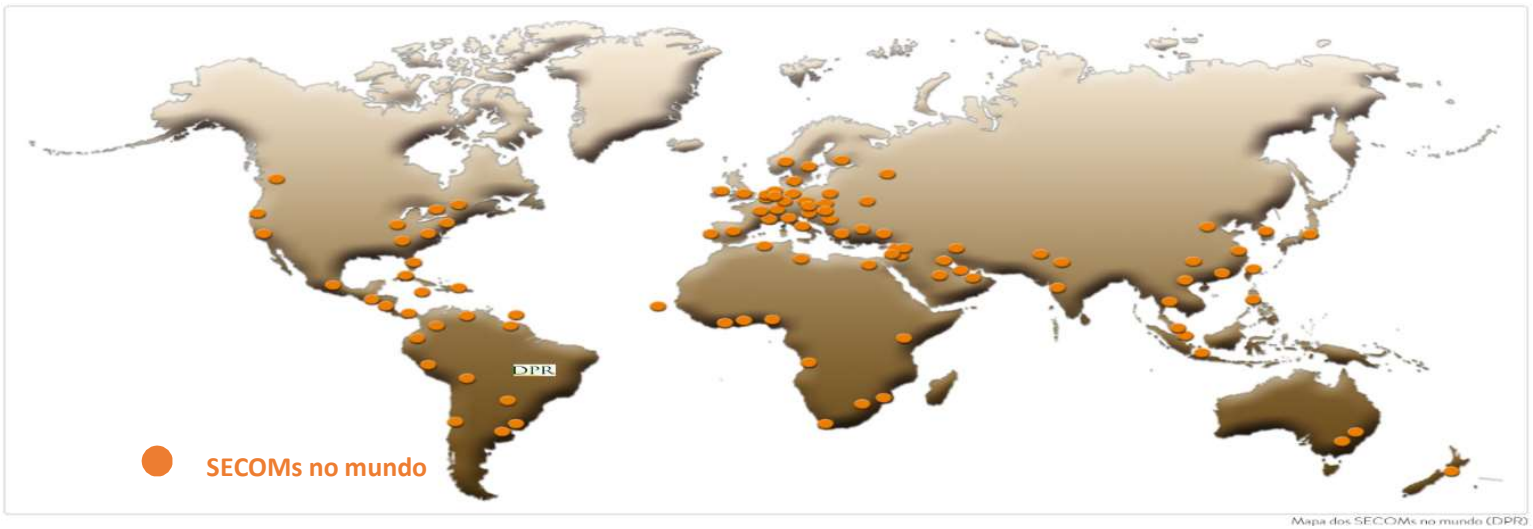


Por meio da Divisão de Investimentos (DINV), o Itamaraty contribui para a internacionalização de empresas brasileiras, divulgando estudos sobre oportunidades em mercados potenciais e realizando gestões oficiais junto a Governos estrangeiros sobre interesses específicos de empresas brasileiras, apoiando diretamente 0 empresariado, a exemplo do atendimento a consultas comerciais e da elaboração de publicações sobre temas de comércio exterior, com o objetivo de identificar e criar oportunidades de negócio em outros países e contribuir para os debates acerca da estratégia de promoção das exportações nacionais que são disponibilizados no portal (Promoção Comercial, 2017).

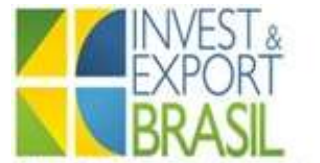

Por meio do portal Invest\&Export Brasil, supervisionado pela Divisão de Programas de Promoção Comercial (DPG), o Itamaraty divulga pesquisas e informações sobre economia e comércio exterior. Por meio da Divisão de Operações de Promoção Comercial (DOC), o Itamaraty organiza missões comerciais - das quais, muitas vezes, participam autoridades governamentais brasileiras, em nível presidencial ou ministerial. Eventos de promoção comercial resultam em ações diretas e imediatas de divulgação dos produtos, das empresas e do turismo brasileiros no exterior (Promoção Comercial, 2017).

Além de contribuir para a execução da política brasileira, sobretudo ao aprofundar os laços de comércio, investimentos e de integração com outros países, o DPR, por meio de atividades de caráter tanto informacional quanto promocional, desenvolve ações de diplomacia comercial com a utilização concomitante de ferramentas de inteligência (estudos e pesquisas) e de marketing (seminários, missões e feiras). Promove também o interesse comercial brasileiro mediante ações de apoio ao empresário nacional no exterior e gestões oficiais (advocacy).

Os SECOMs são responsáveis pela captação e divulgação de informações sobre demandas de importação de produtos brasileiros e de investimento. Apoiam empresas brasileiras em busca de novos mercados e negócios, bem como a participação de empresários em feiras, missões e outros eventos. Produzem pesquisas de mercado e de outros produtos, além de análises de competitividade e concorrência. Atualmente há 104 SECOMs, abrangendo todos os continentes e fixados em 83 países. Apesar da diversidade de locais, todos os SECOMs são orientados pelo DPR e têm a mesma 
finalidade: promoção comercial. Há as especificidades do modo como ocorre essa promoção, de acordo com o país em que o SECOM esteja localizado.

Vale observar que nenhuma outra instituição brasileira, pública ou privada, conta com estrutura de promoção comercial no exterior tão ampla quanto a do Itamaraty, o que demonstra o papel do Ministério na estratégia comercial brasileira - tanto no aspecto político, mediante realização de contatos governamentais e empresariais, quanto no operacional, por meio da produção de informações para subsidiar a promoção do comércio exterior (Diplomacia Comercial, 2017).

\subsubsection{Plano amostral}

O universo da pesquisa, que segundo Vergara (2005) representa o conjunto dos elementos que possuem as características propostas como objeto de estudo, para esta pesquisa, são os colaboradores do Departamento de Promoção Comercial (DPR/MRE) localizado na sede do Ministério das Relações Exteriores em Brasília e dos servidores e funcionários SECOMs localizados nas Embaixadas e Consulados brasileiros dos países em que o Brasil estabelece relações comerciais. Diante do perfil do universo estudado, a amostra é não-probabilística, pois, de acordo com Laville \& Dionne (1999), trata-se de amostragem em que há uma escolha deliberada dos elementos da amostra e atende a critérios como acessibilidade - os elementos são selecionados pela facilidade de acesso a eles, e tipicidade - os elementos são considerados pelo pesquisador como representativos do universo em estudo (Vergara, 2005).

A amostra foi acidental, na medida em que foram considerados os casos que apareceram, ou seja, de acordo com os surveys respondidos pelos colaboradores. (Selltiz et al., 1974). Também foi por quotas, pois ao acompanhar o retorno dos respondentes foram identificados continentes com baixa representatividade e, a partir daí novos comunicados foram enviados aos chefes dos SECOMs, solicitando a colaboração para o desenvolvimento da pesquisa. Por fim, a amostra foi intencional, dado que a análise do retorno das respostas possibilitou estratégias que viabilizassem o retorno dos respondentes, inclusive a escolha dos SECOMs a serem requisitados a partir de suas tipicidades (Selltiz et al., 1974). 


\subsubsection{Coleta de dados}

Para a coleta de dados, foi utilizada uma survey, que se caracteriza por ser quantitativa e que pode ser descrita como a obtenção de dados ou informações sobre características ou percepções de um determinado grupo de pessoas, indicado como representante de uma população-alvo, por meio de um instrumento de pesquisa, frequentemente questionário ou entrevista (Selltiz, 1974; Hair et al., 2009; Babbie \& Mouton, 2001). Quanto à sua finalidade para o tipo de estudo descritivo, visa à descrição das características de determinado fenômeno ou o estabelecimento de relações entre variáveis (Babbie, 1999; Babbie \& Mouton, 2001).

Os questionários foram administrados por meio eletrônico (Hair, 2006) e a coleta de dados ocorreu em dois momentos. No primeiro momento foi realizado no DPR com tempo de duração de dois meses para a coleta dos dados. E, em seguida, nos SECOMs, onde o tempo de duração foi de aproximadamente um ano, dado o reenvio dos instrumentos para aqueles SECOMs cujas respostas aos questionários foram abaixo do esperado.

Para a realização da survey, foram adotadas as escalas de valores (IPVO), percepções de práticas de gestão de pessoas (lócus de valor humano) e de comprometimento (EBACO).

\subsubsection{Considerações sobre os instrumentos de coleta de dados}

A seguir, apresentam-se as escalas de medida que foram utilizadas, explicando o seu processo de operacionalização e/ou de adaptação para a sua utilização.

\subsection{Escala do Inventário de Perfis dos Valores Organizacionais}

Vários são os estudiosos sobre valores organizacionais (Hofstede et al.,1990; O'Reilly et al., 1991; Tamayo et al., 2000; Oliveira \& Tamayo, 2004; Cameron \& Quinn, 2011; Porto et al., 2012). Nesta pesquisa, os valores foram mensurados pela Escala de Inventário de Perfis de Valores Organizacionais (IPVO), desenvolvida por Oliveira e Tamayo (2004), tendo como base a teoria de valores de Schwartz (1999). 
A operacionalização do IPVO sofreu algumas adaptações ao contexto de órgão público federal, cujo objetivo final é a satisfação social, contrapondo-se ao de empresas privadas, cujo objetivo é o lucro. Sendo assim, a palavra "empregado" foi substituída por "colaborador". Alguns itens foram reescritos, sem, contudo, perder a sua dimensionalidade. Caso, por exemplo, da dimensão domínio, que na escala IPVO inclui obtenção de status, lucro, controle sobre as pessoas e recursos, e a busca por uma posição dominante no mercado (Siqueira, 2008). Considerando as especificidades das atividades dos SECOMs, somente um item da dimensão domínio permaneceu, pois os gestores do DPR viram como não necessário para os valores da organização. O quadro 25 apresenta as dimensões e suas definições constitutivas.

Quadro 25 - Dimensões e itens da escala do Inventário de Perfis dos Valores Organizacionais

(Cont.) Dimensões e itens

Dimensão Autonomia: enfatiza a criatividade e o destaque no setor de atuação. Enfatiza o desejo de que os indivíduos busquem suas próprias ideias e interesses intelectuais, se aperfeiçoando constantemente (autonomia intelectual) e o desejo de as pessoas buscarem experiências afetivas positivas (autonomia afetiva) visando valorização dos seus desafios.

$V_{\text {A01 }}$ Estímulo aos colaboradores a enfrentarem desafios.

$\begin{array}{ll}V_{\mathrm{A} 02} & \text { Estímulo ao sucesso profissional dos colaboradores. }\end{array}$

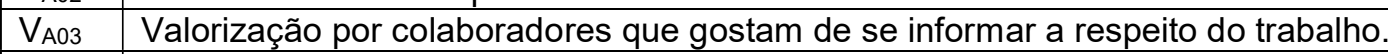

\begin{tabular}{|l|l}
$V_{\text {A04 }}$ & Qualidade, por meio da oferta de melhores serviços. \\
\hline
\end{tabular}

\begin{tabular}{|l|l}
$\mathrm{V}_{\mathrm{A} 05}$ & Valorização por colaboradores que buscam realização no trabalho. \\
\hline
\end{tabular}

\begin{tabular}{|l|l}
$\mathrm{V}_{\mathrm{A} 06}$ & Criatividade \\
\hline
\end{tabular}

$\begin{array}{lll}V_{A 07} & \text { Valorização por colaboradores que tenham experiências profissionais diferentes. }\end{array}$

$V_{\mathrm{A} 08}$ Estímulo à criatividade dos seus colaboradores para desenvolver produtos e serviços originais.

Dimensão Bem-estar: procura propiciar satisfação ao colaborador, atentando para a qualidade de vida no trabalho.

$V_{\text {B01 }}$ Cuidar do bem-estar dos colaboradores.

$\mathrm{V}_{\mathrm{B} 02}$ Oportunizar diversão aos colaboradores.

$\begin{array}{lll}\mathrm{V}_{\mathrm{B} 03} & \text { Atividades prazerosas ao colaborador. }\end{array}$

Dimensão Realização: avalia o sucesso baseado em demonstração de competência, da organização e dos seus colaboradores. O foco é a valorização, por parte da organização, do planejamento e da competência coletiva e individual.

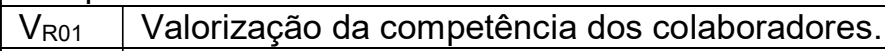

\begin{tabular}{l|l}
$V_{R 02}$ & Valorização da competência da organização.
\end{tabular}

\begin{tabular}{|l|l}
$V_{\mathrm{R} 03}$ & Reconhecimento dos colaboradores competentes.
\end{tabular}

\begin{tabular}{lll}
$V_{\mathrm{R} 04}$ & Desenvolve as competências dos seus colaboradores. \\
\hline
\end{tabular}

$V_{\text {R05 }}$ Realização das metas prova competência da organização.

Dimensão Domínio: Enfatiza o sucesso organizacional. Congrega itens relativos a poder. Domínio do ambiente como forma de demonstrar controle, a partir de um posicionamento assertivo.

\begin{tabular}{l|l}
$V_{\mathrm{D} 01}$ & Segurança dos negócios. \\
\hline
\end{tabular}

Dimensão Prestígio: avalia a busca, por parte da organização, de prestígio, admiração e respeito da sociedade por causa da qualidade dos seus serviços.

\begin{tabular}{l|l}
$V_{\mathrm{P} 01}$ & Influencia outras organizações.
\end{tabular}

\begin{tabular}{|l|l}
\hline$V_{\mathrm{P} 02}$ & Prestígio na sociedade. \\
\hline$V_{\mathrm{P}}$ & Ofeta de \\
\hline
\end{tabular}

\begin{tabular}{|ll}
$\mathrm{V}_{\mathrm{P} 03}$ & Oferta de serviços respeitadas pela sociedade. \\
\hline
\end{tabular}

\begin{tabular}{|l|l}
\hline$V_{\mathrm{P} 04}$ & Influência na sociedade.
\end{tabular} 
Quadro 25 - Dimensões e itens da escala do Inventário de Perfis dos Valores Organizacionais (conc.)

\begin{tabular}{|c|c|}
\hline \multicolumn{2}{|r|}{$\begin{array}{l}\text { Dimensão Conformidade: grau de importância dada pela organização ao respeito à regras e modelos } \\
\text { de comportamento, tanto no ambiente de trabalho quanto no relacionamento com outras } \\
\text { organizações. Valoriza o quanto a organização as boas maneiras, a cortesia, o respeito às regras de } \\
\text { convivência, à correção e à hierarquia. O foco é a definição de limites das ações organizacionais e } \\
\text { comportamento de seus membros. }\end{array}$} \\
\hline $\mathrm{V}_{\mathrm{CO} 1}$ & Comportamento educado dos colaboradores ambiente de trabalho. \\
\hline $\mathrm{V}_{\mathrm{CO} 2}$ & Modelos de comportamentos definidos \\
\hline $\mathrm{V}_{\mathrm{CO} 3}$ & Obediência às regras organizacionais. \\
\hline $\mathrm{V}_{\mathrm{cO} 4}$ & Respeito à hierarquia. \\
\hline $\mathrm{V}_{\mathrm{co5}}$ & Crença na cortesia é importante. \\
\hline $\mathrm{V}_{\mathrm{CO} 6}$ & Importância das regras de convivência. \\
\hline $\mathrm{V}_{\mathrm{CO} 7}$ & Cumprimento das obrigações por parte dos colaboradores. \\
\hline \multicolumn{2}{|r|}{$\begin{array}{l}\text { Dimensão Tradição: ênfase da organização para manter o status quo promovendo a preservação e } \\
\text { o respeito a usos, costumes e práticas organizacionais. }\end{array}$} \\
\hline $\mathrm{V}_{\text {T01 }}$ & Práticas organizacionais que dão continuidade aos seus costumes. \\
\hline $\mathrm{V}_{\text {T02 }}$ & Respeito à tradição. \\
\hline $\mathrm{V}_{\mathrm{T} 03}$ & Evita mudanças na forma de trabalhar. \\
\hline $\mathrm{V}_{\text {T04 }}$ & Manutenção de práticas consagradas. \\
\hline $\mathrm{V}_{\text {T05 }}$ & Preservação da tradição. \\
\hline \multicolumn{2}{|r|}{$\begin{array}{l}\text { Dimensão Preocupação com a coletividade: Valoriza a igualdade, justiça. Lealdade, honestidade e } \\
\text { sinceridade nas práticas organizacionais e no relacionamento com todos: indivíduos, setores } \\
\text { organizacionais, a coletividade organizacional, os clientes e os fornecedores. }\end{array}$} \\
\hline VPC01 & A sinceridade entre os colaboradores. \\
\hline $\mathrm{VPC02}_{\mathrm{P}}$ & Oferta de oportunidades iguais. \\
\hline $\mathrm{VPC03}_{\mathrm{P}}$ & Crença no valor da honestidade. \\
\hline $\mathrm{V}_{\mathrm{PC} 04}$ & Tratamento justo para todos. \\
\hline VPC05 & Princípio da verdade. \\
\hline $\mathrm{VPC06}_{\mathrm{P}}$ & Princípio da lealdade \\
\hline
\end{tabular}

Fonte: Oliveira e Tamayo (2004), com adaptações.

\subsection{Escala de percepções de práticas de gestão de pessoas}

As práticas organizacionais se relacionam tanto com o comportamento dos membros (sugestionando desempenho e atitudes) quanto com o desempenho de toda a organização (Verbeke, 2000). Todavia, ainda são escassos os instrumentos disponibilizados na literatura que sejam capazes de mapeá-las de modo consistente e sistemático (Bedani, 2008; Veiga, 2010). Como exemplo tem-se a Escala de Políticas e Práticas de Recursos Humanos - EPPRH (Demo, Neiva, Nunes \& Rozzett, 2012), Escala de Avaliação de Contexto de Trabalho - EACT (Mendes \& Ferreira, 2008), Escala de Políticas e Práticas de Gestão de Pessoas - EPPGP (Demo, 2008), entre outras. Algumas escalas relativas à cultura contêm, entre seus itens, fatores que avaliam as práticas organizacionais (Hofstede et al., 1990; Calori \& Sarnin, 1991; Ferreira et al., 2002). 
Neste trabalho optou-se pela escala de percepção de práticas de gestão de pessoas, uma adaptação da escala de Locus of Human Value (Jackson, 2012) - aplicada a 520 gestores envolvendo sete países, que objetiva identificar, a partir da percepção dos gestores sobre as práticas de gestão de pessoas, se estas apresentam tendências mais humanistas ou mais instrumentais.

Quanto à operacionalização do instrumento, primeiramente a escala foi apresentada a um comitê gestor do DPR, todos com proficiência e vivência na língua inglesa, para que observassem se a tradução estava adequada e se haveria sugestões. A palavra "empregado" foi substituída pela palavra "colaborador", pelas mesmas razões explicadas quando da operacionalização da escala IPVO. Em seguida, a escala foi aplicada aos gestores do DPR. Nenhum item foi retirado, permanecendo com vinte itens, conforme a escala original. O quadro 26 apresenta as dimensões e suas definições constitutivas.

Quadro 26 - Dimensões e itens da escala de percepção de práticas de gestão de pessoas Dimensão instrumental: Visão das pessoas como meios para um fim. O gestor dirige e controla a execução das tarefas que são direcionais para resultados. Relações de contrato de trabalho claras e específicas quanto à eficácia do trabalhador para o alcance dos objetivos da organização. Busca qualidade de vida no trabalho com o objetivo de propiciar ambiente melhor para produzir mais. A ênfase está nas competências do trabalhador e o pagamento preferencialmente baseado em resultados.

\begin{tabular}{l|l}
$\mathrm{P}_{101}$ & Colaboradores vistos como um recurso.
\end{tabular}

$\mathrm{P}_{102}$ Colaboradores vistos como um instrumento ao alcance dos objetivos organizacionais.

$\mathrm{P}_{103}$ Valoração do colaborador ao atingir os resultados para a organização.

$\mathrm{P}_{104}$ Foco nos resultados.

$\mathrm{P}_{105}$ Foco na geração de resultados planejados.

$\mathrm{P}_{106}$ Foco na produtividade.

$\mathrm{P}_{107}$ Comunicam aos subordinados a respeito das decisões que os afetam.

$\mathrm{P}_{108}$ Inexistência de democracia.

$\mathrm{P}_{109}$ Preocupação com os resultados

$\mathrm{P}_{\mathrm{I} 10}$ Reconhecimento dos colaboradores por meio do alcance dos resultados.

Dimensão humanista: Visão das pessoas como um fim nelas mesmas. O gestor busca desenvolver o comprometimento das pessoas no trabalho, buscando o envolvimento delas bem como propiciando o aprimoramento do comprometimento moral. Visa a qualidade de vida no trabalho objetivando não só o bem-estar das pessoas, mas, também, da comunidade.

$\mathrm{P}_{\mathrm{H} 01}$ Objetivo é a satisfação dos seus colaboradores.

$\mathrm{P}_{\mathrm{H} 02}$ É vista como um meio para os colaboradores alcancem seus objetivos.

$\mathrm{P}_{\mathrm{H} 03}$ Valoração do colaborador pelos seus próprios méritos.

$\mathrm{P}_{\mathrm{H} 04}$ Fator mais importante são os colaboradores.

$\mathrm{P}_{\mathrm{H} 05}$ Foca em beneficiar os seus membros.

$\mathrm{P}_{\mathrm{H} 06}$ Preocupação centrada nos colaboradores.

$\mathrm{P}_{\mathrm{H} 07}$ Esta organização considera melhor consultar os colaboradores a respeito das decisões que os afetam.

$\mathrm{P}_{\text {H08 }}$ Organização democrática.

$\mathrm{P}_{\text {H09 }}$ Organização vista como uma rede de relações humanas.

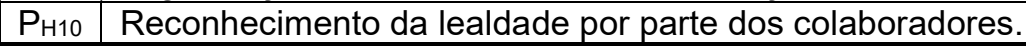

Fonte: Jackson (2002), com adaptações. 


\subsection{Escala de Comprometimento organizacional}

O comprometimento organizacional representa o relacionamento do indivíduo para com a organização em que trabalha. Esta relação pode ocorrer de diversas formas, para Monday et al. (1979), essas formas podem ser estabelecidas por meio de uma forte crença e de aceitação dos valores organizacionais, do esforço da pessoa em benefício da organização, da forte disposição em permanecer na organização; e da análise custo versus benefício em permanecer ou sair da organização. Quanto à forma de medir este comprometimento, modelos de múltiplas bases foram desenvolvidos, por exemplo Meyer e Allen (1993) apresentaram uma escala que tinha por objetivo identificar os comprometimentos afetivo, instrumental e normativo; O'Reilly e Chatman (1986) buscaram diferenciar tipos de comprometimento afetivo, normativo e afiliativo; a escala de Kanter (1968) distingue comprometimento de coesão, de continuação e de controle, por exemplo. Assim como modelos que estabelecem escalas para avaliar comprometimentos unidimensionais, como a Escala de Comprometimento Organizacional Afetivo - ECOA de Siqueira (1995), a de Comprometimento Organizacional Calculativo - ECOC (1995) e de Comprometimento Organizacional Normativo - ECON (Siqueira, 2000). Nesse contexto da dimensionalidade do comprometimento, os modelos de conceitualização de mais de uma base têm sido mais aceitos por teóricos e pesquisadores (Siqueira, 2008), entretanto sem chegar a um consenso, tornando o comprometimento um modelo ainda em construção (Siqueira, 2008).

Neste trabalho optou-se pela Escala de Bases de Comprometimento Organizacional - EBACO, desenvolvida por Medeiros (2003), que mede comprometimento a partir de múltiplas bases: afetiva, obrigação em permanecer, obrigação pelo desempenho, afiliativa, falta de recompensas e oportunidades e linha consistente de atividade e de escassez de alternativas. A escala é composta por 28 itens e foi validada em 819 casos de diversas categorias funcionais, compreendidas em organizações privadas, não-governamentais e públicas.

Quanto à operacionalização do instrumento, a palavra "empregado" foi substituída pela palavra "colaborador", pelas mesmas razões explicadas quando da operacionalização das escalas anteriores. Nenhum dos 28 itens foi retirado, permanecendo conforme a escala original. $O$ quadro 27 apresenta as denominações e suas definições constitutivas. 
Quadro 27 - Bases e definições dos itens da escala de bases de comprometimento organizacional - EBACO

Base afetiva: crença e identificação com a filosofia, valores e os objetivos organizacionais

$\mathrm{C}_{\text {Afe1 }}$ Similaridade entre os valores pessoais e os organizacionais.

CAfe2 Preferência pela organização pelo que ela simboliza.

$\mathrm{C}_{\text {Afe3 }}$ Identificação com a filosofia da organização.

$\mathrm{C}_{\text {Afe4 }}$ Crença nos valores e objetivos da organização.

Base obrigação em permanecer: Crença de que tem uma obrigação em permanecer; de que se sentiria culpado em deixar, de que não seria certo; e que tem uma obrigação moral para com as pessoas da organização.

CPer1 Obrigação moral em permanecer na organização.

CPer2 Não é certo deixar a organização, mesmo se fosse vantajoso.

CPer3 Sentimento de culpa se deixar a organização.

CPer4 Não é certo deixar a organização, porque tem obrigação moral.

Base obrigação pelo desempenho: Crença de que deve se esforçar em benefício da organização e que deve buscar cumprir suas tarefas e atingir os objetivos organizacionais

CDes1 Obrigação em atingir os objetivos da organização.

CDes2 Obrigação em desempenhar com sucesso a função atribuída.

CDes3 Esforço para conseguir os melhores resultados para a organização.

CDes4 Obrigação de cumprir as tarefas.

Base afiliativa: crença de que é reconhecido pelos colegas como membro do grupo e da organização.

$\mathrm{C}_{\text {Afi1 }}$ Sentimento de pertencer ao grupo.

$\mathrm{C}_{\text {Afi2 }}$ Reconhecimento pela organização de ser membro do grupo.

$\mathrm{C}_{\mathrm{Afi} 3}$ Ser considerado membro da equipe pelos demais membros do grupo.

$\mathrm{C}_{\text {Afi4 }}$ Luta pela organização porque faz parte do grupo.

Base falta de recompensas e de oportunidade: crença de que o esforço extra em benefício da organização deve ser recompensado e de que a organização deve lhe dar mais oportunidades.

$\mathrm{C}_{\text {Rec1 }}$ Esforço empregado não compensa sair da organização.

$\mathrm{C}_{\text {Rec2 }}$ Esforço mediante recompensas.

$\mathrm{C}_{\mathrm{Rec} 3}$ Expressar publicamente visão divergente da que expressa na organização.

$\mathrm{C}_{\mathrm{Rec} 4}$ Apesar dos esforços, não vê oportunidades na organização.

Base linha consistente de atividade: crença de que deve manter certas atitudes e regras da organização com o objetivo de se manter na organização

C Con1 Não transgrida regras para manter-se no emprego.

Ccon2 Permanece na organização por necessidade e por desejo.

Ccon3 Recompensas realizadas por meio de atitudes certas.

Ccon4 Faz o possível para manter-se na organização.

Base escassez de alternativas: crença de que possui poucas alternativas de trabalho se deixar a organização

$\mathrm{C}_{\text {Esc1 }}$ Desestruturado se deixar a organização.

$\mathrm{C}_{\mathrm{Esc2}}$ Poucas alternativas se deixar a organização.

CEsc3 Escassas alternativas ao deixar o trabalho de imediatamente.

$\mathrm{C}_{\mathrm{Esc4}}$ Falta de oportunidades de trabalho estabelece a permanência na organização.

Fonte: Siqueira (2008), com adaptações.

\subsection{Resultados organizacionais}


Avaliar os resultados alcançados frente aos objetivos estabelecidos recai na operacionalização da missão e da estratégica organizacional ao redor de objetivos e medidas não financeiras e financeiras de desempenho (Kaplan \& Norton, 1994). Neste contexto, a medição dos resultados torna-se fundamental para a gestão organizacional porque confere efetividade às metas e aos objetivos estabelecidos, auxiliando o processo decisório quanto aos ajustes e ações que precisam ser tomadas, caso necessário (Kaplan, 2012).

Neely (1995) define medição de desempenho como o processo de se quantificar uma ação, no qual mensuração é o processo de quantificação e a ação é aquilo que provoca o desempenho. Em organizações públicas, cuja finalidade é o bem-estar social, costumam-se realizar medidas não financeiras como instrumentos de planejamento e de controle estratégico. E com esse objetivo, o DPR estabeleceu medidas que permitissem não só estabelecer um controle mais real das atividades realizadas pelos SECOMs, como também ser um indicador para o planejamento de ações junto aos SECOMs identificados como pouco produtivos, assim como o estabelecimento de premiações para os Setores de Promoção Comercial mais produtivos.

Os critérios dispostos no quadro 24 foram estabelecidos mediante as atividades realizadas nos SECOMs e dicotomizadas em "produtividade" e "proatividade". As medidas de produtividade são relativas às atividades obrigatórias e que fazem parte da natureza cotidiana da organização. Já as medidas denominadas "proatividade" se referem a atividades de ação exclusiva que resultam na qualidade das informações disponibilizadas no que concerne às atividades comerciais do País.

A cada trimestre, essas atividades são quantificadas e os SECOMs são ranqueados. A par dessas informações, o DPR realiza medidas como justificativas de liberação orçamentária, contratação de novos colaboradores para o SECOM, investimentos em treinamentos para os colaboradores quanto às práticas organizacionais, entre outras ações.

Quadro 28 - Avaliação quantitativa dos resultados conforme os critérios estabelecidos pelo DPR \begin{tabular}{|c|c|}
\hline Atividade & Critério
\end{tabular} 


\begin{tabular}{|l|l|}
\hline $\begin{array}{l}\text { Atendimento a consultas telefônicas, por e-mail, por meios oficiais ou } \\
\text { presenciais }\end{array}$ & Produtividade \\
\hline Inserção de feiras locais & Produtividade \\
\hline Organização de missões & Produtividade \\
\hline $\begin{array}{l}\text { Organização de seminários, eventos, rodadas de negócios, feiras e } \\
\text { mostras }\end{array}$ & Produtividade \\
\hline $\begin{array}{l}\text { Participação em seminários, eventos, rodadas de negócios, feiras e } \\
\text { mostras }\end{array}$ & Produtividade \\
\hline Realização de visitas, encontros e reuniões & Produtividade \\
\hline Resposta a consultas pela Extranet DPR & Produtividade \\
\hline Validação de empresas locais & Produtividade \\
\hline Capacitação e treinamento & Proatividade \\
\hline Elaboração de informação sobre produtos & Proatividade \\
\hline $\begin{array}{l}\text { Elaboração de notícia para o portal Invest\&Export Brasil ou para o o } \\
\text { Boletim de Facilitação de Negócios }\end{array}$ & Proatividade \\
\hline Elaboração de pesquisas de mercado & Proatividade \\
\hline $\begin{array}{l}\text { Elaboração de publicações (estudos, boletins, revistas, série } \\
\text { Exportar" etc.) }\end{array}$ & Proatividade \\
\hline $\begin{array}{l}\text { Identificação de concorrências públicas locais abertas } \\
\text { Identificação de concorrências públicas locais previstas }\end{array}$ & Proatividade \\
\hline Identificação de Investimento Direto Brasileiro (IDB) & Proatividade \\
\hline Identificação de Investimento Estrangeiro Direto (IED) & Proatividade \\
\hline
\end{tabular}

Fonte: DPR/MRE

Para fins de uniformização das atividades realizadas, o total das atividades produtivas e proativas de cada SECOM foi dividido pelo número de colaboradores presentes em cada SECOM. Como a quantitade de atividades proativas e produtivas varia muito entre os SECOMs, foi realizada uma transformação desses quantitativos em uma escala, variando de 1 a 6 . De sorte que, quanto maior a escala, maior a quantidade de atividades realizadas. 
A tabela 01 apresenta as estatísticas descritivas destas atividades. Com os valores mínimos e máximos, mediana e percentis, foi realizada uma secção dos quantitativos proporcional à mediana e aos percentis.

Tabela 01 - Estatísticas descritivas das atividades SECOMs

\begin{tabular}{|c|c|c|c|}
\hline \multicolumn{4}{|c|}{ Resultados das atividades SECOMs } \\
\hline Estatísticas & Produtividade & Proatividade & Total \\
\hline Mínimo & 2 & 0 & 2 \\
\hline Máximo & 4772 & 1563 & 4799 \\
\hline Mediana & 178,5 & 13 & 236,5 \\
\hline Moda & 32 & 0 & 2 \\
\hline 16 & 33,00 & 0,00 & 38,50 \\
\hline 33 & 97,00 & 3,00 & 107,00 \\
\hline 50 & 178,50 & 13,00 & 236,50 \\
\hline 66 & 270,00 & 37,00 & 344,00 \\
\hline 83 & 475,00 & 146,50 & 631,00 \\
\hline
\end{tabular}

Fonte: dados da pesquisa elaborados por meio do SPSS 20.0

A partir das estatísticas resultantes das atividades executadas nos SECOMs, as seguintes escalas foram elaboradas.

PRODUTIVIDADE

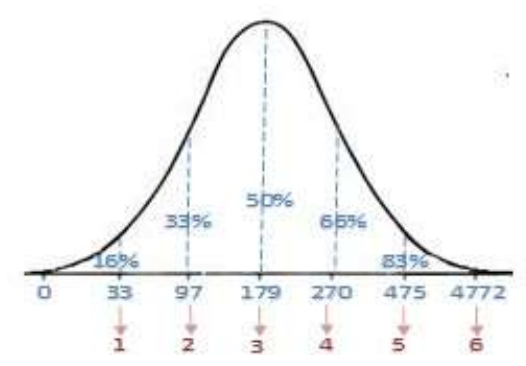

\section{PROATIVIDADE}

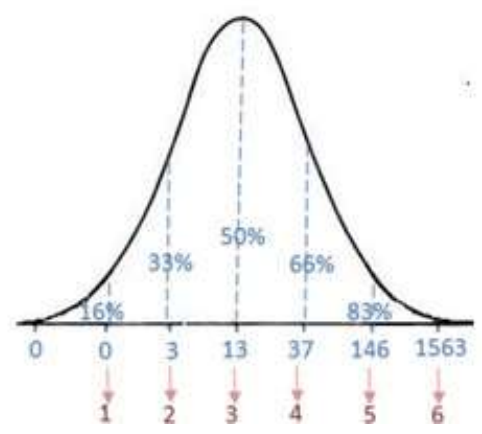

\section{Escala}

Até $33->1$

De 34 até 97 -> 2

De 98 até 179 -> 3

De 178 até 270 -> 4

De 271 até 475 -> 5

De 476 até 4772 -> 6

\section{Escala$$
0->1
$$

De 2 até $3->2$

De 4 até $13->3$

De 14 até $37->4$

De 38 até 146 -> 5

De 157 até 1563 -> 6 
TOTAL (PROATIVIDADE + PRODUTIVIDADE)

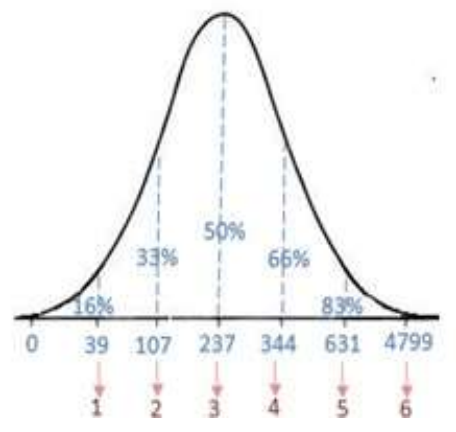

Escala

Até -> 39

De 40 até $107->2$

De 108 até $237->3$

De 238 até $344->4$

De 3445 até $631->5$

De 632 até 4799 -> 6

Com as escalas elaboradas, os resultados das atividades SECOMs foram escalonadas. A tabela 02 apresenta alguns exemplos deste escalonamento.

Tabela 02 - Resultados SECOMs e respectivas escalas

\begin{tabular}{|c|c|c|c|c|c|c|c|}
\hline País & SECOM & $\begin{array}{l}\text { Total } \\
\text { produtivida } \\
\text { de/Num } \\
\text { Func. }\end{array}$ & $\begin{array}{l}\text { ESCALA } \\
\text { PROD/ } \\
\text { FUNC. } \\
\text { (escala } \\
\text { de } 6 \\
\text { pontos) } \\
\end{array}$ & $\begin{array}{c}\text { Total } \\
\text { proatividade/ } \\
\text { Num Func. }\end{array}$ & $\begin{array}{c}\text { ESCALA } \\
\text { PROAT/ } \\
\text { FUNC. } \\
\text { (escala } \\
\text { de } 6 \\
\text { pontos) }\end{array}$ & $\begin{array}{l}\text { Total/ } \\
\text { Num. } \\
\text { Func. }\end{array}$ & $\begin{array}{c}\text { ESCALA } \\
\text { TOTAL/ } \\
\text { FUNC. } \\
\text { (escala de } \\
6 \text { pontos) }\end{array}$ \\
\hline EUA & Atlanta & 4772 & 6 & 27 & 4 & 4799 & 6 \\
\hline Argentina & Buenos Aires & 1294 & 6 & 511 & 6 & 1805 & 6 \\
\hline EUA & Chicago & 529 & 6 & 226 & 6 & 755 & 6 \\
\hline P. Baixos & Haia & 444 & 5 & 0 & 1 & 444 & 5 \\
\hline China & Hong Kong & 180 & 3 & 55 & 5 & 235 & 3 \\
\hline EUA & Houston & 102 & 3 & 70 & 5 & 172 & 3 \\
\hline EUA & Los Angeles & 236 & 4 & 3 & 2 & 239 & 4 \\
\hline EUA & Miami & 832 & 6 & 944 & 6 & 1776 & 6 \\
\hline EUA & N. York & 117 & 3 & 3 & 2 & 120 & 3 \\
\hline China & Pequim & 27 & 1 & 11 & 3 & 38 & 1 \\
\hline Chile & Santiago & 1270 & 6 & 597 & 6 & 1867 & 6 \\
\hline EUA & S. Francisco & 358 & 5 & 26 & 4 & 384 & 5 \\
\hline Japão & Tóquio & 591 & 6 & 1563 & 6 & 2154 & 6 \\
\hline EUA & Washington & 892 & 6 & 127 & 5 & 1019 & 6 \\
\hline China & Xangai & 303 & 5 & 2 & 2 & 305 & 4 \\
\hline
\end{tabular}

Fonte: DPR/MRE com adaptações 
O quadro 29 apresenta uma síntese da operacionalização das variáveis no modelo de pesquisa.

Quadro 29 - Síntese da operacionalização das variáveis

\begin{tabular}{|c|c|c|c|}
\hline \multicolumn{2}{|c|}{ Construtos } & Operacionalização & $\begin{array}{l}\mathrm{N}^{\circ} \mathrm{de} \\
\text { itens }\end{array}$ \\
\hline \multirow{3}{*}{$\begin{array}{l}\text { Variáveis } \\
\text { Independentes } \\
\text { e/ou Mediadora }\end{array}$} & Valores Organizacionais & $\begin{array}{l}\text { IPVO - adaptado de Oliveira e Tamayo } \\
(2004)\end{array}$ & 39 \\
\hline & Práticas Organizacionais & $\begin{array}{l}\text { Escala de percepções de práticas de } \\
\text { gestão de pessoas - adaptado de } \\
\text { Jackson (2002) }\end{array}$ & 20 \\
\hline & Comprometimento & $\begin{array}{l}\text { EBACO - adaptado de Medeiros } \\
(2003)\end{array}$ & 28 \\
\hline $\begin{array}{c}\text { Variável } \\
\text { dependente }\end{array}$ & Resultados organizacionais & $\begin{array}{l}\text { Resumo das atividades } \\
\text { (extranet }- \text { DPR/MRE) }\end{array}$ & 17 \\
\hline Total & & & 104 \\
\hline
\end{tabular}

Fonte: elaborado pela autora

\subsection{Plano de análise dos dados}

Concluída a apresentação do detalhamento do método adotado, é possível construir a Matriz de Amarração Metodológica da pesquisa. Este instrumento, proposto por Mazzon (1981; 1983; Telles, 2001), objetiva ilustrar, de forma sistemática, a qualidade metodológica do estudo, ou seja, a adequação entre o modelo proposto, os objetivos, as hipóteses formuladas e as técnicas de tratamento e análise dos dados adotadas. 


\section{Quadro 30 - Matriz de Amarração Metodológica}

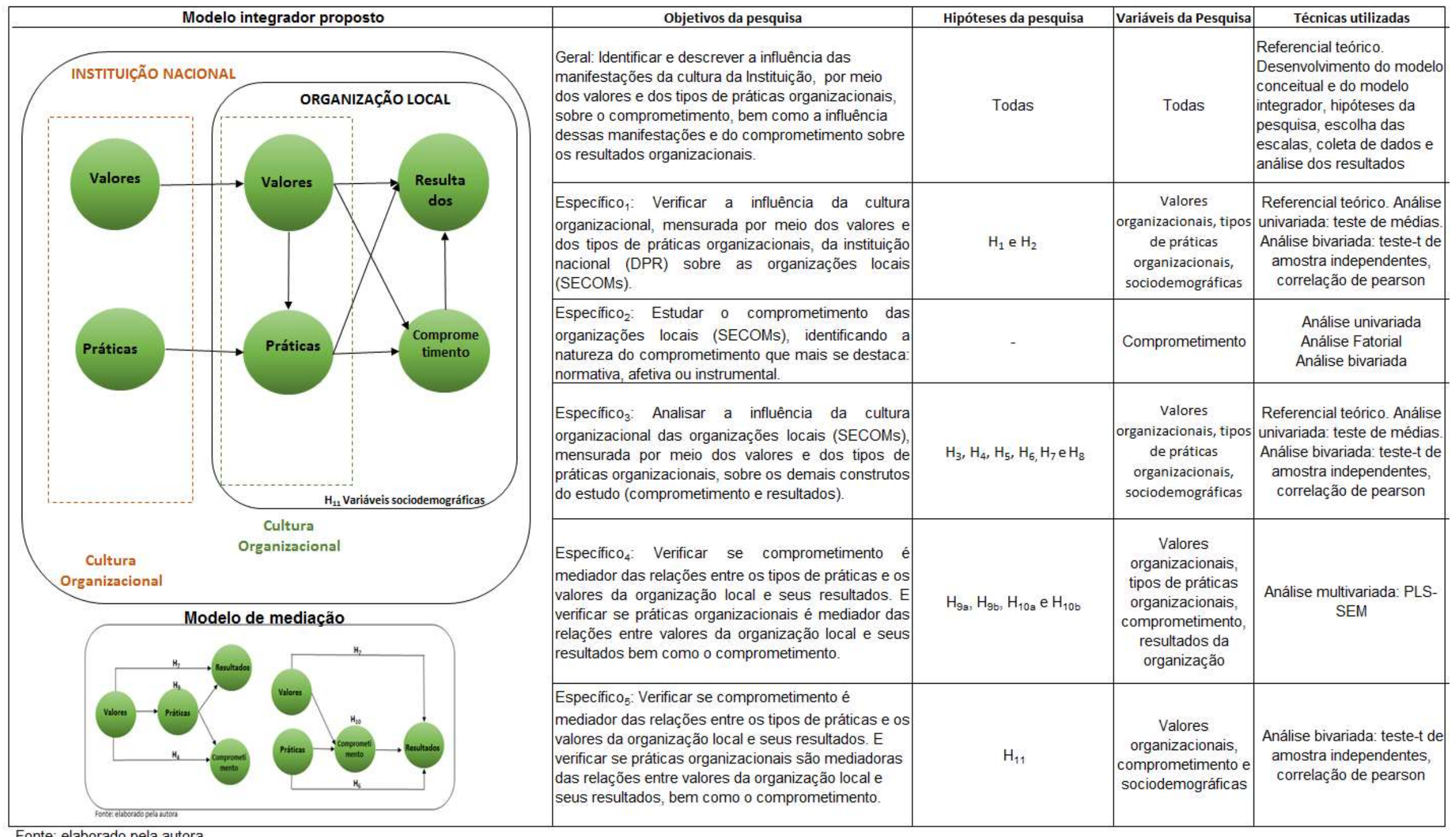

Fonte: elaborado pela autora 


\subsubsection{Análise univariada}

A análise univariada caracteriza-se por descrever os dados coletados examinando uma variável por vez ou característica estudada e de forma descritiva (frequências, medianas, médias, etc.). É a maneira mais simples de restituir a informação e de fazer a estimativa estatística (Hair et al., 2009). Além disso, verificar a acurácia ou a precisão dos dados, com vistas a atender os pressupostos exigidos pelos procedimentos estatísticos utilizados (Tabachnick \& Fidell, 1996) e verifica os seguintes aspectos: distribuição de frequência para identificar as medidas de tendência central (média, moda e mediana), medidas de dispersão (variância e desvio-padrão) e se os valores máximo/mínimo estavam dentro dos limites esperados para cada variável investigada; identificação de dados ausentes (missing values)e de casos extremos (outliers).

Para esta tese, as análises univariadas foram utilizadas para estudar o comportamento dos valores organizacionais e dos tipos de práticas da instituição nacional em relação aos valores e tipos de práticas das organizações locais e o comportamento do comprometimento dos SECOMs e para verificar suas variações quando analisadas por continente.

\subsubsection{Análise descritiva}

A finalidade em realizar a análise descritiva é explorar os dados de forma sistemática a fim de obter parâmetros para realizar uma análise prévia dos resultados encontrados. As medidas de tendência central (neste caso, foi utilizada a média) e as medidas de variabilidade (desvio-padrão e coeficiente de variação) fornecem resumos simples sobre o objeto de análise para explorar os dados demográficos da amostra obtida da população-alvo, bem como a análise descritiva das escalas.

\subsubsection{Homogeneidade, confiabilidade dos itens e comparação de médias}

Para a confiabilidade dos resultados encontrados, deve-se verificar se os instrumentos de pesquisa aplicados são confiáveis com a população-alvo. A análise de confiabilidade objetiva verificar se de fato a escala reflete de forma consistente o que se quer medir. Para este trabalho, a confiabilidade foi estimada por meio da consistência interna, ou seja, da estimativa baseada na correlação entre as variáveis que compõem o conjunto (alfa de Cronbach). De acordo com Pasquali (2005), o alfa 
de Cronbach pode ser interpretado como a porcentagem da variância que a escala observada explicaria na hipotética escala verdadeira composta de todos os itens possíveis da população. Alfa é igual a zero quando o escore verdadeiro não é medido e existe apenas um componente de erro. Alfa é igual a 1.0 quando todos os itens medem apenas o escore verdadeiro e não há nenhum componente de erro. Em outras palavras, quanto maior o coeficiente $\alpha$, mais os itens têm covariância compartilhada e provavelmente medem o mesmo conceito subjacente. Segundo Hair et al. (2009), valores de confiabilidade acima de 0,80 favorecem a consistência da escala; e valores de 0,60 a 0,70 são considerados como o limite inferior de aceitabilidade.

Para a homogeneidade dos dados, foi realizada a ANOVA, que informa a existência de um tratamento discrepante entre os demais itens avaliados e tem como pressuposto a homogeneidade da variância.

O teste de aditividade de Tukey é uma abordagem utilizada na ANOVA para avaliar se as variáveis dos fatores estão aditivamente relacionadas ao valor esperado. A estatística do teste proposto por Tukey tem um grau de liberdade sob a hipótese nula, sendo muitas vezes chamado de "teste de um grau de liberdade de Tukey".

O teste de aditividade de Tukey e Friedman testa a hipótese nula de que não há interação multiplicativa entre os casos e os itens. Se o teste for significativo $(\leq 0,05)$, então há uma interação multiplicativa. Os efeitos de dois ou mais fatores de variação são ditos não-aditivos quando, na associação de um ou mais desses fatores, em vez de se somarem, esses efeitos se multiplicam, de tal forma que o efeito resultante pode ser ampliado (quando o fator multiplicativo é maior que 1), ou reduzido (quando esse fator é menor que 1). É o que comumente ocorre nas chamadas interações entre dois ou mais fatores de variação (Campos, 2001). 


\subsubsection{Análise bivariada}

O interesse está nas relações existentes entre 2 variáveis para fins de explicação e/ou previsão. Esta abordagem necessita a formulação de uma hipótese que a estatística permitirá inferir ou confirmar. Para esta tese, as análises bivariadas serão utilizadas para estudar: (1) a influência da cultura organizacional da instituição nacional sobre as organizações locais (mensuradas por meio dos valores e dos tipos de práticas organizacionais); (2) a influência da cultura organizacional das organizações locais (mensuradas por meio dos valores e dos tipos de práticas organizacionais) sobre demais construtos do estudo (comprometimento e resultados); e (3) as possíveis relações entre variáveis individuais das organizações locais (sociodemográficas) sobre os valores e o comprometimento organizacional das organizações locais SECOMs.

A Estatística Bivariada inclui métodos de análise de duas variáveis, podendo ser ou não estabelecida uma relação de causa/efeito entre elas. São exemplos típicos de métodos de análise bivariada o teste para a independência de duas variáveis (conhecido por teste do t) e o estudo da relação linear entre duas variáveis, quer através dos coeficientes de correlação linear de Pearson ou Spearman, quer do modelo clássico de regressão linear simples (Reis, 1997).

\subsubsection{Teste $t$ entre amostras independentes}

É um teste de hipótese que usa conceitos estatísticos para rejeitar ou não uma hipótese nula quando a estatística de teste $(\mathrm{t})$ segue uma distribuição $\mathrm{t}$ de Student. Neste caso, usa-se o teste para comparar duas amostras independentes, que podem terem sido formados de duas maneiras diferentes: (a) extraídas de uma amostra da população A e outra amostra da população B; (b) Indivíduos da mesma população são alocados aleatoriamente a um dos dois tratamentos em estudo (Ribas \& Viera, 2011; Martinez \& Ferreira, 2010; Hair et al., 2009).

Para realizar o teste há dois procedimentos estatísticos que devem ser analisados: (1) testar se amostras têm variâncias iguais, ou seja, testar a homogeneidade da variância; e (2) testar a igualdade de médias. 
Para a análise da igualdade de variâncias, realizou-se o teste de Levene, cujas hipóteses são:

- Hipótese Nula $\left(\mathrm{H}_{0}\right)$ : as variâncias dos dois grupos são iguais.

- Hipótese Alternativa $\left(\mathrm{H}_{\mathrm{a}}\right)$ : as variâncias dos dois grupos são diferentes.

Para a análise da igualdade de médias, realizou-se o teste "t" entre amostras independentes, cujas hipóteses são:

- Hipótese Nula $\left(\mathrm{H}_{0}\right)$ : as médias dos dois grupos são iguais.

- Hipótese Alternativa $\left(\mathrm{H}_{\mathrm{a}}\right)$ : as médias dos dois grupos são diferentes.

Se o teste de Levene recair sobre a hipótese nula, então pressupõem-se variâncias iguais para os dois grupos em estudo e neste caso, a fórmula para o teste t é assim determinada:

$$
t=\frac{\bar{x}_{1}-\bar{x}_{2}}{s_{p} \sqrt{\frac{1}{n_{1}}+\frac{1}{n_{2}}}} \quad \begin{aligned}
& \mathrm{X}_{1} \text { e } \mathrm{X}_{2} \text { médias das amostras dos grupos } \\
& \mathrm{n}_{1} \text { e } \mathrm{n}_{2} \text { tamanho das amostras dos grupos } \\
& \mathrm{S}_{\mathrm{p}}=\text { desvio padrão-comum }
\end{aligned}
$$

$E S_{p}$ é calculado da seguinte forma:

$$
s_{p}=\sqrt{\frac{\left(n_{1}-1\right) s_{1}^{2}+\left(n_{2}-1\right) s_{2}^{2}}{n_{1}+n_{2}-2}} \quad S_{1} \text { e } S_{2} \text { desvios-padrão dos grupos }
$$

Se o valor calculado for menor que o p-valor de 0,05 para $n 1+n 2-2$ graus de liberdade, então rejeita-se a hipótese nula de igualdade entre as médias dos dois grupos.

$$
t=\frac{\bar{x}_{1}-\bar{x}_{2}}{\sqrt{\frac{s_{1}^{2}}{n_{1}}+\frac{s_{2}^{2}}{n_{2}}}}
$$

Se o teste de Levene indicar que as variâncias não são iguais nos dois grupos (ou seja, p-value menor que 0,05$)$, então não se pressupõem variâncias iguais e o cálculo do teste t usa as variações não agrupadas e uma correção para os graus de liberdade.

$$
d f=\frac{\left(\frac{s_{1}^{2}}{n_{1}}+\frac{s_{2}}{n_{2}}\right)^{2}}{\frac{1}{n_{1}-1}\left(\frac{s_{1}}{n_{1}}\right)^{2}+\frac{1}{n_{2}-1}\left(\frac{z_{2}}{n_{2}}\right)^{2}}
$$


Para complementar o teste-t neste caso, vê-se o Intervalo de Confiança (IC) da Diferença. Se o IC para a diferença média contiver 0 , os resultados não são significativos no nível de significância escolhido. Resumindo, os seguintes resultados podem ser apresentados na tabela 03.

Tabela 03 - Possíveis resultados para o teste-t de amostras independentes

\begin{tabular}{|c|c|c|c|}
\hline No SPSS & Teste Levene & Teste $\mathrm{t}$ & Resultado \\
\hline $\begin{array}{c}\text { Analisar a coluna: } \\
\text { variâncias iguais }\end{array}$ & $p>0,05$ & $p<0,05$ & $\begin{array}{l}\text { Existe diferença entre as } \\
\text { médias dos dois grupos }\end{array}$ \\
\hline assumida & $p>0,05$ & $p>0,05$ & $\begin{array}{l}\text { Não existe dife rença entre } \\
\text { as médias dos dois grupos }\end{array}$ \\
\hline $\begin{array}{l}\text { Analisar a coluna: } \\
\text { variâncias iguais não }\end{array}$ & $p<0,05$ & $\begin{array}{c}\mathrm{p}<0,05 \\
\text { IC não contém zero }\end{array}$ & $\begin{array}{l}\text { Existe diferença entre as } \\
\text { médias dos dois grupos }\end{array}$ \\
\hline assumida & $p<0,05$ & $\begin{array}{c}p>0,05 \\
\text { IC contém zero }\end{array}$ & $\begin{array}{l}\text { Não existe dife rença entre } \\
\text { as médias dos dois grupos }\end{array}$ \\
\hline
\end{tabular}

Fonte: elaborado pela autora

\subsubsection{Teste de correlação de Pearson}

Segundo Garson (2009) correlação é uma medida de associação bivariada (força) do grau de relacionamento entre duas variáveis, ou seja, é possível descobrir com precisão, o quanto uma variável interfere no resultado de outra, pois a correlação mensura a direção e o grau da relação linear entre duas variáveis quantitativas (Moore, 2007).

As técnicas associadas à Análise de Correlação representam uma ferramenta fundamental de aplicação nas Ciências Sociais e do comportamento. Entre essas técnicas, o coeficiente de correlação de Pearson ( $r$ ) é uma medida de associação linear entre variáveis, e tem a seguinte fórmula:

$$
r=\frac{1}{n-1} \Sigma\left(\frac{x i-\bar{X}}{s x}\right)\left(\frac{y i-\bar{Y}}{s y}\right) \quad \begin{aligned}
& \mathrm{X} \text { e } \mathrm{Y} \text { média das variáveis } \\
& \text { Sx e Sy variância das variáveis }
\end{aligned}
$$

Há dois pressupostos para a correlação de linear de Pearson: (1) exige variância compartilhada entre as duas variáveis associadas; e (2) que essa variação seja distribuída linearmente. 
Duas variáveis estão estatisticamente associadas se elas guardarem semelhanças na distribuição dos seus escores, ou seja, elas podem se associar a partir da distribuição das frequências ou pela quantidade de variância compartilhada. A correlação de Pearson ( $r$ ) trata de ser uma medida da variância compartilhada entre duas variáveis. Outra condição é a de linearidade. O modelo linear supõe que o acréscimo ou decréscimo de uma unidade na variável $X$ impactará de forma semelhante na unidade da variável $Y$.

A interpretação do coeficiente de correlação de Pearson está na variação entre -1 e +1 , onde o sinal indica direção positiva (+) ou negativa (-). Diz-se que há correlação perfeita $(-1$ ou +1) quando o escore de uma variável é determinado ao se saber o escore da outra variável, o caso contrário (correlação zero) indica que não há relação linear entre as variáveis. Mas valores extremos são raros de serem encontrados e o que vale é a relevância em como interpretar o resultado desta correlação. Para Cohen (1988), valores entre 0,10 e 0,29 podem ser considerados pequenos; escores entre 0,30 e 0,49 podem ser considerados como médios; e valores entre 0,50 e 1 podem ser interpretados como grandes. Dancey e Reidy (2005) fazem uma classificação um pouco diferente: $r=0,10$ até 0,30 (fraco); $r=0,40$ até 0,6 (moderado); $r=0,70$ até 1 (forte). Seja como for, o que deve ser interpretado é que quanto mais perto de 1 (independentemente do sinal) maior é o grau de dependência estatística linear entre as variáveis. No outro oposto, quanto mais próximo de zero, menor é a força dessa relação (Figueiredo Filho \& Silva Júnior, 2009; Hair et al., 2009; Cohen, 1988).

\subsubsection{Análise multivariada}

A análise multivariada inclui os métodos de análise das relações de múltiplas variáveis dependentes e/ou múltiplas variáveis independentes, quer se estabeleçam ou não relações de causa/efeito entre estes dois grupos. São também incluídos na Estatística Multivariada os métodos de análise das relações entre indivíduos caracterizados por duas ou mais variáveis. Só os métodos de Estatística Multivariada permitem que se explore o desempenho conjunto das variáveis e se determine a influência ou importância de cada uma, estando as restantes presentes (Reis, 1997). Para esta tese, a análise multivariada será utilizada para estudar a influência dos valores, dos tipos de práticas organizacionais e do comprometimento sobre os resultados das organizações locais (SECOMs). 
A modelagem de equações estruturais apresenta os seguintes procedimentos: (1) análise da confiabilidade da escala; (2) teste Outer Model (Modelo de Mensuração); (3) teste do Inner Model (Modelo Estrutural).

\subsubsection{Modelagem de equações estruturais}

\subsection{PLS-SEM}

O modelo de equação estrutural PLS-SEM ${ }^{11}$ é composto por dois submodelos: modelo de medição e modelo estrutural. O modelo de medição representa as relações entre os dados observados e as variáveis latentes ${ }^{12}$. O modelo estrutural representa as relações entre as variáveis latentes (neste caso, valores, práticas, comprometimento e resultados). As medidas empíricas permitem comparar a medida e os modelos estruturais estabelecidos teoricamente com a realidade. Em outras palavras, é possível determinar o quão bem a teoria se encaixa nos resultados.

Os resultados do PLS-SEM são revisados e avaliados usando um processo sistemático, seu objetivo é maximizar a variância explicada (ou seja, o valor $\mathrm{R}^{2}$ ) das variáveis latentes endógenas no modelo de caminho PLS. Por esta razão, a avaliação da qualidade do modelo estrutural e de medidas concentram-se em métricas que indicam os recursos preditivos do modelo. Segundo Hair et al. (2017), da mesma forma como acontece com CB-SEM (modelagem de equações estruturais baseadas na covariância), as métricas mais importantes do modelo de medição para PLS-SEM são confiabilidade, validade convergente e validade discriminante. Para o modelo estrutural, as métricas de avaliação mais importantes são $R^{2}$ (variação explicada), $f^{2}$ (tamanho do efeito), $Q^{2}$ (relevância preditiva) e tamanho e significância estatística dos coeficientes do caminho estrutural. O CB-SEM também depende de várias dessas métricas, mas, além disso, fornece medidas de qualidade de ajuste com base na discrepância entre a matriz de covariância empírica e o modelo implícito (teórico). Uma vez que o PLS-SEM depende de variâncias em vez de covariâncias para determinar uma solução ideal, as medidas de qualidade de ajuste baseadas na covariância não são totalmente transferíveis para o contexto PLS-SEM. As medidas de ajuste em PLS-

\footnotetext{
11 PLS-SEM - Partial Least Squares method to Structural Equation Modeling

12 Hair et al. (2017) define variável latente como as variáveis que não são medidas diretamente. Por exemplo, a variável latente, também conhecida como construto, VALOR não é medida diretamente, e sim a partir dos indicadores (ou variáveis manifestas) autonomia, bem-estar, realização, domínio, conformidade, tradição e preocupação com a coletividade.
} 
SEM geralmente são baseadas em variância e focam a discrepância entre as variáveis observadas (no caso de variáveis manifestas) ou aproximadas (no caso de variáveis latentes) das variáveis dependentes e os valores previstos pelo modelo em questão. A avaliação sistemática dos critérios segue um processo em duas etapas. O processo envolve avaliações separadas de modelos de medição para o reflexivo e para o formativo, como visto no quadro 31.

Quadro 31 - Avaliação dos Modelos de Medição

\begin{tabular}{|c|c|}
\hline Modelos de medição reflexivo & Modelos de medição formativo \\
\hline $\begin{array}{l}\text { Consistência interna } \\
\text { Alfa de Cronbach } \\
\text { Confiabilidade composta } \\
\text { Validade Convergente } \\
\text { Confiabilidade do indicador } \\
\text { Variância média extraída (AVE) } \\
\text { Validade discriminante (HTMT) }\end{array}$ & $\begin{array}{l}\text { Validade convergente } \\
\text { Variância média extraída (AVE) } \\
\text { Colinearidade entre indicadores } \\
\quad \text { Variance Inflation Factor (VIF) } \\
\text { Significância e relevância dos outer } \\
\text { weights } \\
\quad \text { Bootstrapping procedure } \\
\text { t-value e p-value dos outer weights }\end{array}$ \\
\hline \multicolumn{2}{|c|}{ Avaliação do Modelo Estrutural } \\
\hline $\begin{array}{l}\text { Coeficiente de determinação ( } \\
\text { Relevância preditiva - } Q^{2} \\
\text { Tamanho e significância dos co } \\
\text { Tamanho do efeito - } f^{2} \\
\text { Tamanho do efeito }-q^{2}\end{array}$ & ficientes de caminho \\
\hline
\end{tabular}

Fonte: Hair et al. (2017) p. 106 - com adaptações.

A avaliação do modelo PLS_SEM inicialmente se concentra nos modelos de medição. O exame das estimativas permite avaliar a confiabilidade e a validade das medidas do construto. As estimativas do modelo estrutural não são examinadas até a confiabilidade e a validade dos construtos terem sido estabelecidos. Se a avaliação dos modelos de medição reflexiva e formativa evidenciar a qualidade da medida, as estimativas dos modelos estruturais então serão avaliadas, e isto envolve a capacidade de o modelo prever a variação nas variáveis dependentes. 


\subsubsection{Princípios básicos da avaliação do modelo de mensuração - Outer Model}

O modelo de mensuração tem os seguintes procedimentos: análise da confiabilidade interna, validade convergente, variância média extraída e validade discriminante.

\subsection{Confiabilidade - consistência interna}

Segundo Trochim (2003), a consistência interna se refere ao grau com que os itens da escala estão correlacionados entre si e se estão livres de erro e, consequentemente, gerando resultados consistentes. Quando a confiabilidade de uma medida não é levada em consideração, as estimativas de suas correlações com outras variáveis poderão estar enviesadas e as diferenças nas comparações entre as medidas poderão permanecer ocultas, ou seja, não serem reveladas (Bollen, 1989).

De acordo com Hair et al. (2017), o critério tradicional para analisar a consistência interna é o alfa de Cronbach, que fornece uma estimativa da confiabilidade com base nas Inter correlações das variáveis dos indicadores observados. Sua fórmula pode ser assim definida:

$$
\begin{array}{cc}
\alpha=\frac{N \cdot \bar{r}}{1+(N-1) \cdot \bar{r}} \quad & \mathrm{r}=\text { correlação média das variáveis latentes } \\
\mathrm{e}=\text { número de variáveis latentes }
\end{array}
$$

Alfa de Cronbach assume que todos os indicadores são igualmente confiáveis (ou seja, todos os indicadores têm cargas externas - outer loadings - iguais no construto). Mas PLS-SEM prioriza os indicadores de acordo com sua confiabilidade individual. Além disso, o alfa de Cronbach é sensível ao número de itens na escala e geralmente tende a subestimar a confiabilidade da consistência interna. Como tal, pode ser usado como uma medida mais conservadora de confiabilidade (Hair et al., 2017). Devido às limitações, o alfa de Cronbach, é tecnicamente mais apropriado acrescentar à análise uma outra medida, denominada confiabilidade composta:

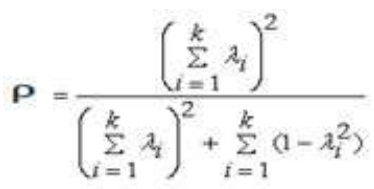

$\Lambda$ é o outer loading padronizado do indicador da variável i de um construto específico e $\varepsilon$ é o erro da variância que é definida por $\left(1-\Lambda_{i}^{2}\right)$ 
A confiabilidade composta varia entre 0 e 1, com valores maiores indicando níveis mais altos de confiabilidade. É geralmente interpretada da mesma forma que o alfa de Cronbach. Especificamente, os valores de confiabilidade composta de 0,60 a 0,70 são aceitáveis na pesquisa exploratória, em estágios mais avançados, os valores entre 0,70 e 0,90 podem ser considerados satisfatórios. Valores abaixo de 0,60 indicam falta de confiabilidade de consistência interna. Os valores acima de 0,90 (e definitivamente acima de 0,95) não são desejáveis porque indicam que todas as variáveis estão medindo o mesmo fenômeno e, portanto, não são prováveis de serem medidas válidas. Isso ocorre, especificamente, quando se usam itens semanticamente redundantes, ou seja, itens diferentes, mas ligeiramente reformulados para a mesma pergunta. Como o uso de itens redundantes tem consequências adversas para a validade do conteúdo das medidas e pode aumentar o erro (Hayduk \& Littvary, 2012), recomenda-se minimizar seu uso.

Segundo Hair et al. (2017), o alfa de Cronbach é uma medida conservadora (o que resulta em valores de confiabilidade relativamente baixos). Em contrapartida, a confiabilidade composta tende a superestimar os resultados e, como consequência, gerar estimativas comparativamente maiores. Portanto, é razoável considerar ambos os critérios, pois, ao analisar e avaliar a confiabilidade da consistência interna, a verdadeira confiabilidade geralmente estará entre o alfa de Cronbach (representando o limite inferior) e a confiabilidade composta (representando o limite superior).

\subsection{Validade convergente}

A validade convergente significa que um conjunto de indicadores representa um único e exclusivo construto subjacente, algo que pode ser demonstrado por sua unidimensionalidade (Henseler et al.,2009), ou seja, um conjunto de indicadores que representa um único e exclusivo construto (unidimensionalidade). Para analisar a validade convergente dos construtos reflexivos, considera-se avaliar as cargas externas dos indicadores e a variância média extraída (AVE).

De acordo com Hair et al. (2017), as altas cargas externas (outer loading) em um construto informam que os indicadores associados a este construto têm muito em comum. O tamanho dos outer loadings também é chamado de confiabilidade do indicador. O ideal é que os outer loadings (cargas externas) sejam de 0,708 ou mais. O raciocínio por trás desta regra é a proporção da variância que é compartilhada com 
os demais indicadores comuns do construto, ou seja, a comunalidade de um item. Uma variável latente deve explicar pelo menos $50 \%$. Isso também implica que a variância compartilhada entre o construto e seu indicador é maior que a variância do erro de medição. Isso significa que o outer loading de um indicador deve estar acima de 0,708 , pois este número ao quadrado $(0,708)^{2}$ é igual a 0,50 , mas 0,70 é considerado aceitável.

É frequente observar na área de ciências sociais a obtenção de outer loadings (cargas externas) mais baixas $(<0,70)$, especialmente quando se usam escalas recentemente desenvolvidas (Hullandd, 1999). Entretanto, ao invés de se eliminarem os indicadores que obtiveram cargas abaixo de 0,70, devem-se examinar os efeitos da remoção de itens na confiabilidade, bem como sobre a validade do construto. Geralmente, os indicadores com cargas (outer loadings) entre 0,40 e 0,70 devem ser removidos da escala somente quando aumentar a confiabilidade composta (ou a variância média extraída - AVE). Outra consideração na decisão de excluir um indicador é a medida em que sua remoção afeta a validade do conteúdo, pois sua retenção pode contribuir para a validade do conteúdo. Os indicadores com carga externa muito baixa (abaixo de 0,40 ) devem, no entanto, ser sempre eliminados do construto (HAIR et al., 2011 e 2017).

\subsection{Variância Média Extraída - AVE}

Este critério é definido como o valor médio do quadrado das cargas quadradas dos indicadores associados ao construto (ou seja, a soma das cargas quadradas divididas pelo número de indicadores). Portanto, o AVE é equivalente à comunalidade de um construto (Hair, et al., 2017). O AVE é calculado usando a seguinte fórmula:

$$
\text { AVE }=\frac{\sum_{i=1}^{n} L_{i}^{2}}{n} \quad \begin{aligned}
& \text { O } L_{i} \text { representa a carga dos fatores } \\
& \text { padronizados e } \\
& \text { i é o número de itens }
\end{aligned}
$$

Semelhantemente à análise dos indicadores individuais, o seu valor é de no mínimo 0,50 e isto significa que o construto explica mais da metade da variância destes indicadores, um AVE menor que 0,50 indica que, em média, mais variância permanece no erro dos itens do que na variância explicada pelo construto (Henseler et al., 2009). 


\subsection{Validade Discriminante}

A validade discriminante é a medida em que um construto é distinto de outros construtos por padrões empíricos. Isto implica que um construto é único e captura fenômenos não representados por outros construtos no modelo, ou seja, segundo Urbach \& Ahlemann (2010), representa o quanto cada medida de um certo construto difere das médias dos outros construtos.

Tradicionalmente, há duas maneiras de medir a validade discriminante: (a) por cargas cruzadas, em que outer loading de um indicador associado ao construto deve ser maior do que qualquer uma das suas cargas cruzadas (ou seja, suas correlações) em outros construtos; (b) pelo critério Fornell-Larcker, que compara a raiz quadrada dos valores AVE com as correlações das variáveis latentes, ou seja, a raiz quadrada do AVE de cada construto deve ser mais alta do que a sua maior correlação com qualquer outro construto (Henseler et al., 2015; Hair et al., 2017).

Segundo Hair et al. (2017), pesquisas recentes examinaram o desempenho do crossloadings (cargas cruzadas) e do critério de Fornell-Larcker e descobriram que nenhuma das duas abordagens detecta de forma confiável problemas de validade discriminante. O critério das cargas cruzadas não indica a falta de validade discriminante quando dois construtos estão perfeitamente correlacionados, tornandoo ineficaz para pesquisas empíricas. Da mesma forma, o critério de Fornell-Larcker funciona muito mal, especialmente quando as cargas dos indicadores dos construtos diferem muito pouco entre si (por exemplo, as cargas de indicadores que variam entre 0,60 e 0,80). Quando as cargas dos indicadores variam mais fortemente, o desempenho do critério do Fornell-Larcker na detecção de problemas de validade discriminante melhora, mas ainda é genérico (Hair et al., 2017).

Henseler et al. (2015) propôs o critério Heterotraço-Monotraço (Heterotrait-Monotrait HTMT), que é a razão entre as correlações intertraço e as correlações dentro dos traços. HTMT é razão da média de todas as correlações dos indicadores dos construtos que medem diferentes construtos (i.e., as correlações HeterotraçoMonotraço) e a média das correlações médias que medem o mesmo construto. Tecnicamente, a abordagem HTMT é uma estimativa de qual seria a verdadeira correlação entre dois construtos se fossem perfeitamente medidas (ou seja, se fossem perfeitamente confiáveis). Esta correlação verdadeira também é referida como 
correlação desatualizada. Uma correlação desatualizada entre dois construtos próxima de 1 indica falta de validade discriminante.

O limite exato do HTMT é discutível; afinal, "quando uma correlação é próxima a 1?" Henseler et al. (2015) sugerem um limite de 0,90 se o modelo de caminhos apresentar construtos conceitualmente muito similares. Quando os construtos no modelo do caminho são conceitualmente mais distintos, um limite inferior e, portanto, mais conservador de 0,85 parece plausível. No entanto, como PLS_SEM não depende de qualquer suposição de distribuição, os testes padrões de significância paramétrica não podem ser aplicados para verificar se a estatística HTMT é significativamente diferente de 1. Neste caso, segundo Hair et al. (2015), deve-se realizar o procedimento bootstrapping para derivar uma distribuição para a estatística HTMT.

No bootstrapping, as subamostras são geradas aleatoriamente (com reposição) do conjunto de dados original. Cada subconjunto é usado para estimar o modelo. Este processo é repetido até que um grande número de subamostras aleatórias tenha sido criado, normalmente cerca de 5.000 subamostras. Os parâmetros estimados das subamostras são usados para derivar erros padrão das estimativas. Com esta informação, é possível derivar um intervalo de confiança do bootstrap. O intervalo de confiança é o intervalo em que o verdadeiro valor da população da estatística HTMT irá cair, assumindo um certo nível de confiança, por exemplo 95\%.

Um intervalo de confiança contendo o valor 1 indica uma falta de validade discriminante. Por outro lado, se os valores 1 estiverem fora do intervalo, isto sugere que os dois construtos são empiricamente distintos. Mesmo com as limitações dos critérios de cross-loadings (cargas cruzadas) de Fornell-Larcker, as duas medidas ainda são significantes para a validade discriminante (Hair et al., 2018).

\subsection{O critério Fornell-Larcker}

Este critério compara a raiz quadrada dos valores AVE com as correlações das variáveis latentes, ou seja, a raiz quadrada do AVE de cada construto deve ser mais alta do que a sua maior correlação com qualquer outro construto.

\subsubsection{Modelos de componentes hierárquicos - HCM}

Com a crescente complexidade de teorias e modelos de causa e consequência nas ciências sociais, a utilização de modelos de componentes hierárquicos tem 
aumentado em estudos de modelagem de equações estruturais de mínimos quadrados (PLS-SEM).

Os modelos de componentes hierárquicos referem-se a um construto medido em mais de um nível de abstração em um modelo de caminho PLS. Mais precisamente, este modelo representa um construto mais geral, medido em um nível de abstração mais elevado, ao mesmo tempo que inclui vários subcomponentes, que cubram mais traços concretos da variável conceitual representada por este construto. Modelos de componentes hierárquicos permitem reduzir o número de relações do modelo estrutural, tornando o modelo de caminho PLS mais parcimonioso, ao mesmo tempo que amplia o limite do conteúdo coberto por determinados construtos (Hair, et al., 2018).

Sob uma perspectiva prática, os HCMs permitem reduzir o número de relacionamentos no modelo estrutural, tornando o modelo de caminho PLS mais parcimonioso e mais fácil de ser compreendido.

Como pode ser visto no modelo complexo (figura 18), existem nove relações de modelos estruturais ligando as variáveis latentes exógenas $\left(\mathrm{Y}_{1}, \mathrm{Y}_{2}, \mathrm{Y}_{3}\right)$ com as variáveis latentes endógenas $\left(\mathrm{Y}_{4}, \mathrm{Y}_{5}, \mathrm{Y}_{6}\right)$. Ao incluir um HOC - Higher-Order Component (figura 18), o número de coeficientes de caminho pode ser reduzido para seis, estabelecendo um modelo mais parcimonioso no modelo estrutural. Neste caso, assume-se que o HOC medeia completamente os efeitos do LOCs (Lower-Order components) nas variáveis latentes endógenas $\left(\mathrm{Y}_{4}, \mathrm{Y}_{5}, \mathrm{Y}_{6}\right)$. Esta redução no modelo complexo vem em detrimento do poder preditivo em relação as variáveis latentes endógenas que a HOC prediz (isto é, $Y_{4}, Y_{5}, Y_{6}$ ). A razão é que é diferente de um modelo de efeitos diretos, em que todas as variáveis latentes exógenas predizem uma variável latente endógena, em um $\mathrm{HCM}$, apenas o HOC prediz as variáveis latentes endógenas (Hair et al., 2018).

Finalmente, os HCMs também são valiosos se os indicadores formativos no modelo de medição de uma variável latente exibirem níveis elevados de colinearidade. Esta é uma questão crucial porque tem um impacto sobre as estimativas dos pesos e sua significância estatística. Mais precisamente, a colinearidade elevada pode resultar em pesos tendenciosos, pois ela também aumenta os erros padrão, reduzindo, portanto, a capacidade de demonstrar que os pesos (weights) estimados são significativamente 
diferentes de zero (Hair et al., 2017). HCM permite lidar com problemas de colinearidade, oferecendo mecanismos para reorganizar os modelos de medição. Desde que a teoria da medição suporte esta etapa, é possível dividir o conjunto de indicadores e estabelecer construtos separados em uma estrutura de ordem superior.

Figura 18 - Modelo complexo e modelo hierárquico

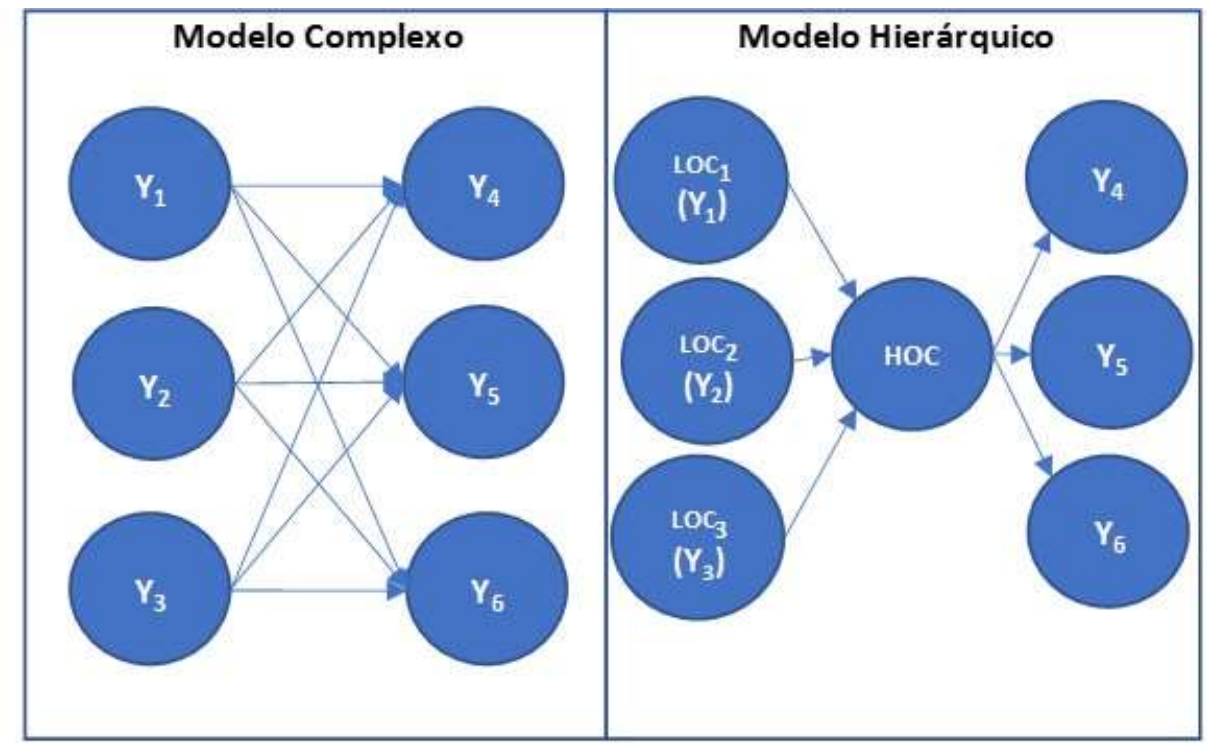

Fonte: Hair et al, 2018 - com adaptações

Conceitualmente, os HCMs podem ser estabelecidos seguindo uma abordagem bottom-up (ou seja, indutiva) ou de up-down (dedutiva) (Johnson et al., 2011). Na abordagem de baixo para cima, várias variáveis latentes são combinadas em um único construto, e na abordagem de cima para baixo, um construto mais abstrato é definido para consistir em vários componentes. Embora, frequentemente, usado em pesquisas empíricas na tentativa de reduzir a complexidade do modelo, não se recomenda simplesmente resumir informações em um construto mais abstrato (Johnson et al., 2011; Hair et al., 2012). O estabelecimento de um HCM no PLS-SEM sempre envolve uma perda de informação como os efeitos indiretos entre os HOCs e o(s) construto(s) através do recém-criado HOC para substituir os efeitos diretos entre os LOCs e o(s) construto(s). PLS-SEM, no entanto, permite estimar todas as relações em uma rede mais ampla de construtos (isto é, sem o HOC) sem perda de informação (HAIR et al.,2018).

Além de usar a teoria para identificar critérios de inclusão a fim de selecionar LOCs adequados, segundo Hair et al. (2018), a natureza das relações entre os LOCs e o 
HOC deve ser esclarecida. Um HOC é um conceito geral que é representado (no modelo reflexivo) ou constituído (no modelo formativo) pelos seus componentes específicos (ou seja, os LOCs). Se o HOC é reflexivo, o conceito geral é manifestado em vários LOCs mais especificos. Este tipo de modelo também é referido como um modelo de propagação (Hair et al., 2017 e 2018). O HOC formativo é uma combinação de vários LOCs específicos que representam componentes mais concretos que formam o conceito geral. Este tipo de modelo também é denominado modelo de coleta. Uma especificação formativa é apropriada quando a definição operacional da variável conceitual sugere que uma alteração em um valor do LOCs devido, por exemplo, a uma avaliação do respondente da característica que está sendo capturada pelo LOC altera o valor do HOC. Analogamente aos indicadores nos modelos de medidas formativas, os LOCs não precisam ser, mas podem ser correlacionados porque não representam manifestações concretas no HOC.

Em vez disso, as especificações do reflexivo são apropriadas quando há um construto abstrato mais geral que explica as correlações entre os LOCs. Portanto, deve haver correlações substanciais entre os LOCs que - análogos aos modelos de medição reflexiva - são assumidos como causados pelo HOC. Ou seja, o HOC é a causa espúria que explica as correlações entre os LOCs (Hair et al.,2018).

Além da relação entre o HOC e os LOCs, os HCMs podem ser caracterizados com base na especificação dos modelos de medição do LOC (ou seja, reflexivos ou formativos). Como resultado, quatro tipos principais de HCMs evoluem conforme discutido na literatura existente e são apresentados na figura 19.

Figura 19 - Tipos de relações entre o HOC e os respectivos LOCs 


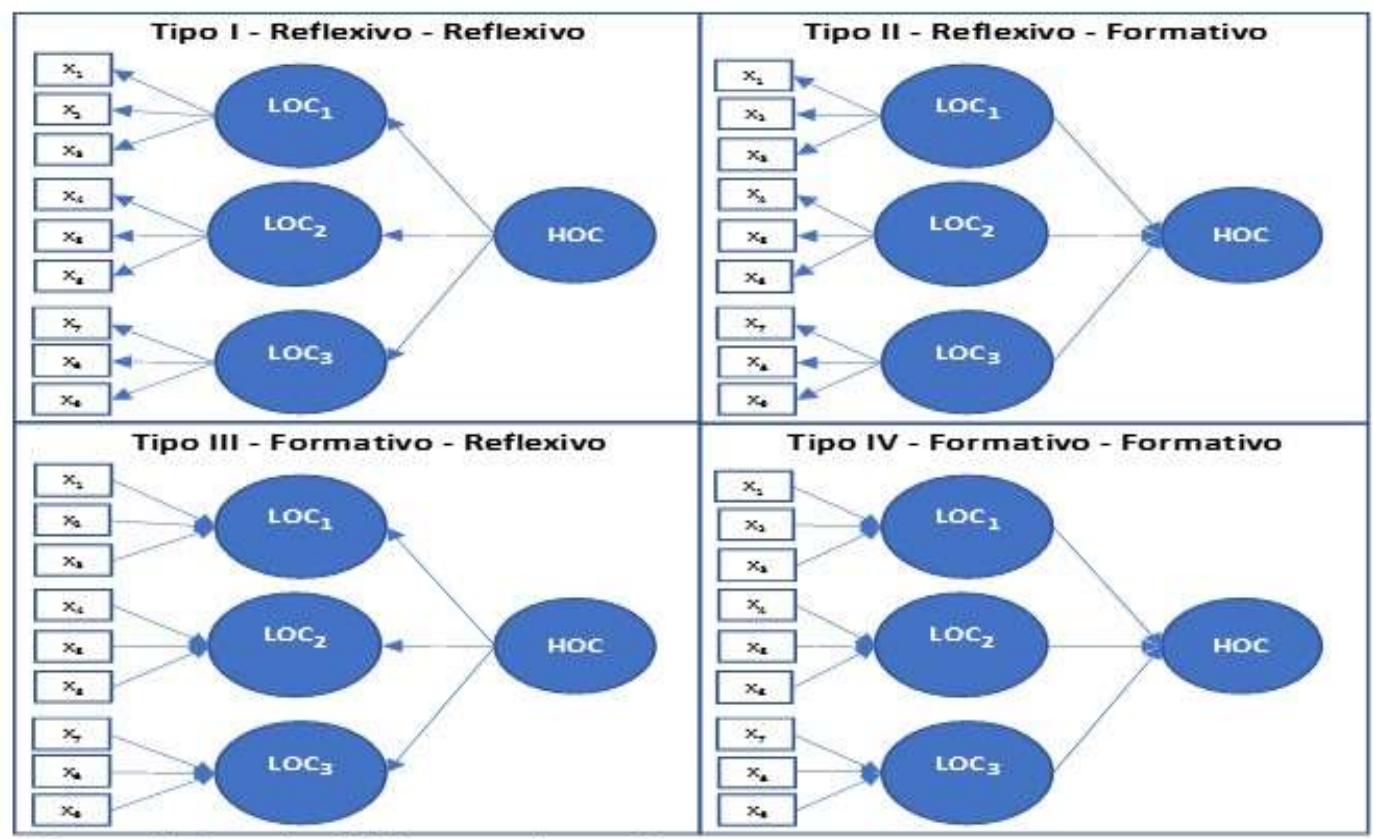

Fonte: Hair et al ., 2018 - com adaptaçōes

Como pode ser visto na figura 19, o HCM reflexivo-reflexivo (Tipo I) indica uma relação reflexiva entre o HOC e os LOCs; neste tipo os LOCs estão altamente correlacionados e o HOC representa a causa espúria que explica essas correlações. Este tipo é chamado de modelo de fator comum hierárquico, onde o HOC geral representa o fator comum de vários fatores específicos (ou seja, LOCs) e é mais apropriado se o objetivo é estabelecer o fator comum de vários LOCs reflexivos relacionados.

Em um HCM reflexivo-formativo (Tipo II), o HOC representa um construto mais geral dos valores refletidos. Os LOCs específicos não compartilham necessariamente uma causa comum, entretanto formam o HOC geral. Por exemplo, no HCM (figura 19), o HOC media completamente a relação entre LOC $_{1}$ e os três construções endógenas $\mathrm{Y}_{4}, \mathrm{Y}_{5}$ e $\mathrm{Y}_{6}$.

O tipo formativo-reflexivo (Tipo III) inclui um HOC mais geral que explica os LOCs. O objetivo é extrair a parte comum de vários LOCs medidos formativamente que foram estabelecidos para representar o mesmo conteúdo teórico. No entanto, cada LOC cria um conjunto de indicadores diferentes. Ao usar vários LOCs formativos, é possível superar o problema de que um só construto medido com indicadores formativos dificilmente conseguiria cobrir o domínio do construto na íntegra.

HCM formativo-formativo (Tipo IV) determina a contribuição relativa dos LOCs medida formativamente para o $\mathrm{HOC}$ mais abstrato. Este tipo de $\mathrm{HCM}$ se revela útil para estruturar um complexo construto formativo com muitos indicadores em vários 
subconstrutos, como é o caso de incluir vários aspectos concretos sob um conceito mais geral. Enquanto HCM do tipo reflexivo-formativo inclui diferentes índices de desempenho de várias empresas como LOCs, o formativo-formativo inclui LOCs representando diferentes aspectos do desempenho, como o desempenho de diferentes atividades organizacionais ou subdivisões que determinam o desempenho geral da empresa (ou seja, o HOC), mas isso não precisa necessariamente estar correlacionado, por exemplo (Hair et al., 2018).

\subsection{Indicadores repetidos}

Neste procedimento, todos os indicadores dos LOCs também são atribuídos aos HOCs. Consequentemente, os indicadores são usados duas vezes: uma vez para os LOCs (cargas/pesos primários) e novamente para o HOC (cargas/pesos secundários). Esta abordagem pode ser facilmente estendida para HCM de terceira ou quarta ordem se teoricamente e conceitualmente forem significativos (Hair et al., 2018).

Figura 20 - Tipos de relações entre o HOC e os respectivos LOCs com repetição

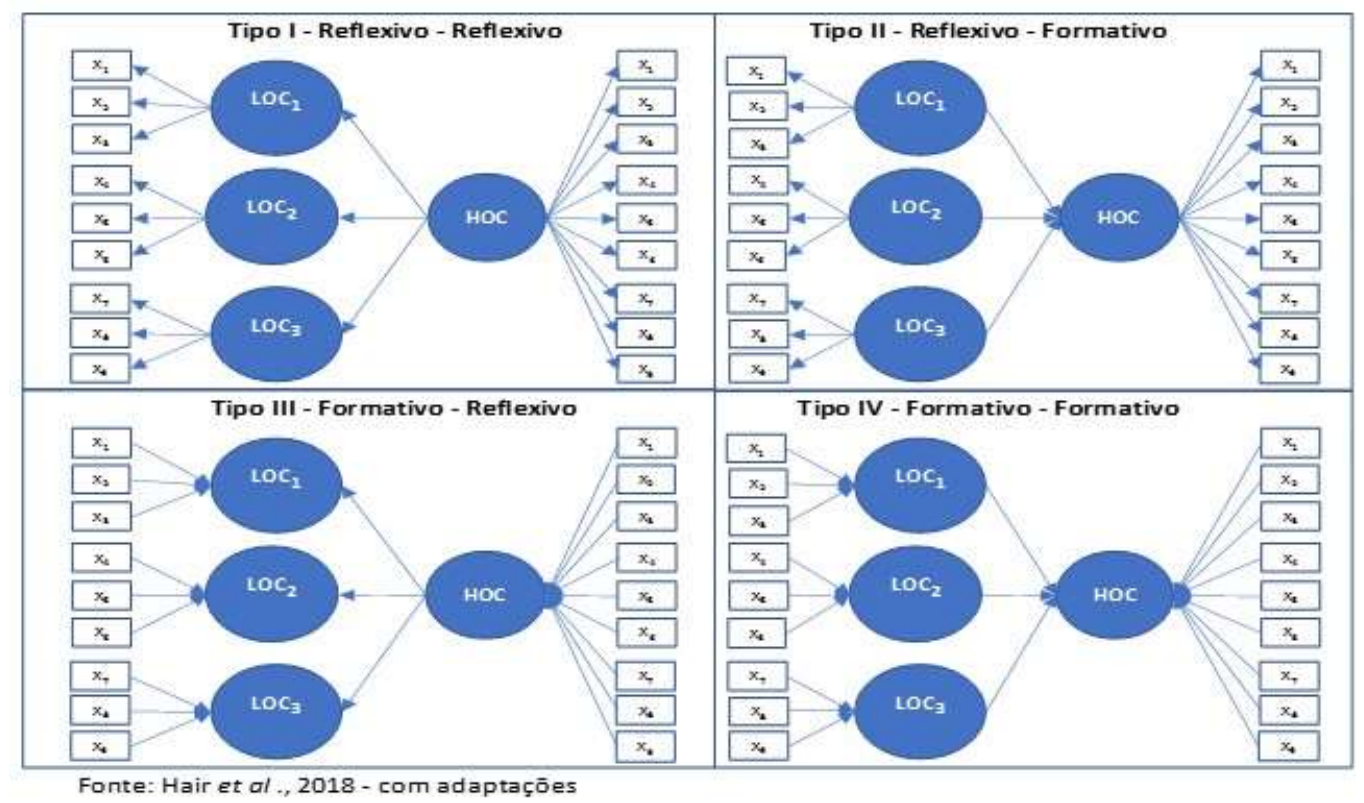

De acordo com Hair et al. (2018), a abordagem de indicadores repetidos deve ter garantias técnicas em três aspectos. Primeiro, as relações entre o HOC e LOCs são significativamente tendenciosas se os modelos de medida do LOC variarem fortemente em termos de número de indicadores. Considere-se, por exemplo, um HCM com dois LOCs, um com oito indicadores ( $\mathrm{LOC}_{1}$ ) e outro com dois indicadores $\left(\mathrm{LOC}_{2}\right)$. Ao usar a abordagem de indicadores repetidos, os dez indicadores são 
simultaneamente atribuídos ao HOC. À medida que compartilham um grande número de indicadores no HCM, espera-se uma relação mais forte entre o HOC e LOC 1 . Além disso, o poder preditivo dos LOCs é em parte uma função da confiabilidade, que depende do número de indicadores. Mais indicadores implicam maior confiabilidade e, portanto, maior poder preditivo, particularmente quando a medição é reflexiva. Para evitar qualquer viés induzido pelo modelo nas estimativas dos parâmetros, deve-se garantir que o número de indicadores seja igual (ou pelo menos comparável) em todos os LOCs. Se isso não for possível, deve-se avaliar sistematicamente o efeito da eliminação de indicadores nas relações entre o HOC e os LOCs. Isto se aplica particularmente quando os LOCs são medidos formativamente, pois os modelos formativos geralmente implicam diferenças na complexidade do modelo de medição, dependendo da amplitude do domínio conceitual. Observe-se que, se os indicadores de cada LOCs forem removidos, o pesquisador deve garantir que os mesmos indicadores também sejam removidos do HOC. Caso contrário, o viés será introduzido nas estimativas do modelo.

Em segundo lugar, deve-se avaliar não apenas os modelos de medição (inner model) dos LOC, mas também o modelo de medição do HOC. No entanto, diferente de outros construtos no modelo de caminho PLS, a avaliação do HOC não está relacionada com as relações entre o $\mathrm{HOC}$ e suas variáveis indicadoras, mas nas relações entre o HOC e seus LOCs. Embora essas relações sejam mapeadas como coeficientes de caminhos em uma análise PLS-SEM, a partir de uma perspectiva de modelagem, elas correspondem às cargas (em caso de reflexivo-reflexivo e formativo-reflexivo) ou pesos (no caso de reflexivo-formativo ou formativo-formativo) e precisam ser interpretadas como tal. Ou seja, nos modelos reflexivo-reflexivo e formativo-reflexivo, as relações entre o $\mathrm{HOC}$ e os LOCs servem como entrada para a estimativa da variância média extraída (AVE), confiabilidade composta e Alfa de Cronbach. A validade discriminante entre o HOC e os LOCs não é preocupante, pois são esperadas redundâncias conceituais e empíricas, tornando a avaliação da validade discriminante entre esses elementos do modelo sem sentido. No entanto, a validade discriminante deve ser estabelecida entre os LOCs em um HCM particular. Para este tipo de avaliação, usa-se o critério HTMT. Se é preciso examinar a validade discriminante entre o HOC e outras construções no modelo, isso ainda é controverso. No caso de querer examinar a validade discriminante do HOC, será necessário calculá-lo 
manualmente (Henseler et al., 2015) usando as correlações dos construtos entre LOCs como correlações monotraço-heterotraço e o indicador de cross-loadings dos construtos fora do HCM com os LOCs como correlações heterotraço-heterotraço. Finalmente, em HCMs reflexivos-formativos ou formativos-formativos, também será necessário avaliar colinearidade, bem como significância e relevância das relações entre os LOCs e HOC (Hair et al., 2018).

\subsubsection{Princípios básicos da avaliação do modelo estrutural - Inner Model}

Uma vez que confirmado que as medidas dos construtos são confiáveis e válidas, o próximo passo aborda a avaliação dos resultados do modelo estrutural. Isto envolve examinar as capacidades preditivas do modelo e as relações entre os construtos. A análise do inner model envolve seis etapas que são apresentadas a seguir.

\subsection{Avaliando o modelo estrutural quanto a problemas de colinearidade - VIF}

Nesta etapa é necessário examinar cada conjunto de preditores no modelo estrutural para colinearidade. O valor de tolerância do construto de cada preditor (TOL) deve ser superior a 0,20 (VIF inferior a 5). Caso contrário, considere eliminar os construtos, mesclar preditores em um único construto ou criar construtos de ordem superior para tratar problemas de colinearidade. Para avaliar a colinearidade, deve-se aplicar a mesma medida do modelo de medição formativo (o VIF). Assim, precisa-se examinar cada conjunto de construtos preditores separadamente para cada subparte do modelo estrutural.

\subsection{Avaliando a importância e a significância do modelo estrutural (path coeficientes e $p$-valor)}

Os coeficientes de caminho (path coefficients) representam as relações das hipóteses estabelecidas entre os construtos. Os coeficientes de caminho têm valores padronizados aproximadamente entre $-1 \mathrm{e}+1$, quanto mais perto de \pm 1 mais fortes serão as relações entre os construtos (positivas ou negativas) e, quanto mais próximo de zero, mais fracos serão os relacionamentos entre os construtos. Valores muito baixos, próximos de 0 , geralmente não são significativamente diferentes de zero. 
Para verificar se o coeficiente de caminho é significativo, depende-se do seu erro padrão obtido por meio do bootstrap. Este procedimento permite calcular os valores $\mathrm{t}$ ( $t$ - student) e p-valores para todos os coeficientes de caminho do modelo estrutural.

Quando o valor $\mathrm{t}$ calculado é maior que um valor crítico estabelecido para os parâmetros do modelo, conclui-se que o coeficiente é estatisticamente significante para um certo nível de erro de probabilidade (i.e., o nível de significância). Para teste bicaudal e nível de significância de 5\%, o t-valor é de 1,96 (Hair et al., 2018).

Um p-valor é igual à probabilidade de obter um valor de t pelo menos tão extremo quanto aquele que realmente é observado. Em outras palavras, o valor de p é a probabilidade de rejeitar erroneamente uma hipótese nula verdadeira (isto é, assumindo um coeficiente de caminho significativo quando de fato não é significativo). Ao assumir um nível de significância de 5\%, o p-valor deve ser menor que 0,05 para concluir que a relação em consideração é significativa a um nível de 5\%.

O intervalo de confiança gerado pelo procedimento bootstrap também permite testar se um coeficiente de caminho é significativamente diferente de zero. O intervalo de confiança fornece informações sobre a estabilidade do coeficiente estimado, oferecendo uma gama de valores populacionais plausíveis para o parâmetro que depende da variância dos dados e do tamanho da amostra. Se o intervalo de confiança para um coeficiente de caminho não incluir o zero, a hipótese de que o caminho é igual a zero é rejeitada e assume um efeito significativo.

Ao interpretar os resultados de um modelo de caminho, é preciso testar o significado para todas as relações do modelo estrutural usando valores de $t$, valores de $p$ e o intervalo de confiança fornecido pelo procedimento Bootstrapping (Hair et al., 2018).

Depois disso, é importante avaliar a relevância das relações de significância. Os coeficientes de caminho no modelo estrutural podem ser significativos, mas seu tamanho pode ser muito pequeno. Tais situações geralmente ocorrem com grandes tamanhos de amostra. Uma análise da importância relativa das relações é crucial para interpretar os resultados e tirar conclusões, uma vez que tais coeficientes pequenos, embora significativos, podem não justificar sua atenção.

De acordo com Hair et al. (2017), se um coeficiente de caminho for maior do que outro, seu efeito sobre a variável latente endógena é maior. Mais especificamente, o coeficiente de caminho individual modelo de caminhos pode ser interpretado 
exatamente como o coeficiente beta padronizado de uma regressão OLS: uma mudança na unidade de um construto exógeno altera o construto endógeno pelo tamanho do coeficiente de caminho enquanto todo o resto (ou seja, todos os outros construtos e seus coeficientes de caminho) permanece constantes. Se o coeficiente do caminho for estatisticamente significativo, indica a proporção em que o construto exógeno está associado ao construto endógeno.

Muitas vezes está-se interessado em avaliar não apenas o efeito direto de um construto em relação a outro, mas também seus efeitos indiretos através de um ou mais construtos mediadores. A soma dos efeitos diretos e indiretos é particularmente útil em estudos voltados para explorar o impacto diferencial de vários construtos de drivers em um construto de critérios através de uma ou mais variáveis de mediação (Hair et al., 2012, 2017).

\subsection{Coeficiente de determinação $\left(R^{2}\right)$}

A medida mais utilizada para avaliar o modelo estrutural é o coeficiente de determinação $\left(R^{2}\right)$. Este coeficiente é uma medida do poder preditivo do modelo calculado como a correlação quadrática entre os valores reais e preditivos do construto endógeno específico. O coeficiente representa os efeitos combinados das variáveis latentes exógenas na variável latente endógena. Ou seja, o coeficiente representa a quantidade de variância nos construtos endógenos explicada por todos os construtos exógenos ligados a ele.

Infelizmente, segundo Hair et al. (2017), não existe um valor fixo de referência para o $\mathrm{R}^{2}$, ou seja, qual é o valor satisfatório e qual não é. Nas ciências exatas, em que há experimentos controlados (como a Física e a Química) realizados em laboratórios, é possível eliminar os efeitos de outras variáveis e assim alcançar medidas precisas, de sorte a se ter $R^{2}$ próximo a 1,0 . Já nas ciências sociais, em que as medidas não são muito precisas e não há controle sobre o objeto pesquisado, como, por exemplo, o comportamento humano, valores aceitáveis de $\mathrm{R}^{2}$ podem estar em um patamar bem inferior. Para Hair et al. (2017), valores próximos a 0,20 são considerados altos em pesquisas que avaliam o comportamento do consumidor.

Os problemas geralmente ocorrem ao usar o valor de $\mathrm{R}^{2}$ para comparar modelos especificados de forma diferente (por exemplo, diferentes construtos exógenos para predizer o mesmo construto endógeno). Por exemplo, a adição de construtos não 
significativos a um modelo estrutural ligeiramente correlacionado com a variável latente endógena aumentará o valor de $\mathrm{R}^{2}$. Esse tipo de impacto é mais insociável se o tamanho da amostra estiver próximo ao número de variáveis latentes exógenas que predizem a variável latente endógena sob consideração. Assim, ao usar o valor $\mathrm{R}^{2}$ como a única base para a compreensão do poder preditivo do modelo, existe um viés inerente na seleção de modelos com muitos construtos exógenos, que podem ser apenas ligeiramente relacionados aos construtos endógenos (Hair et al., 2017).

Selecionar um modelo exclusivamente com base no valor $R^{2}$ não é uma boa abordagem. A adição de construtos adicionais (não significativos) para explicar variáveis latentes endógenas sempre aumenta seu valor $R^{2}$. Quanto mais caminhos apontarem para um construto alvo, o $\mathrm{R}^{2}$ mais alto é seu valor. No entanto, os pesquisadores geralmente preferem modelos que são bons para explicar os dados (assim, com altos valores de $\mathrm{R}^{2}$ ), mas também têm menos construtos exógenos. Tais modelos são chamados de parcimoniosos (Hair et al., 2012, 2017).

\subsection{Tamanho do efeito $\left(\mathrm{f}^{2}\right)$}

Além de avaliar os valores de $\mathrm{R}^{2}$ de todos os construtos endógenos, a mudança no valor de $\mathrm{R}^{2}$ quando um construto exógeno especificado é omitido do modelo pode ser usada se o construto omitido tem um impacto substancial sobre os construtos endógenos (Hair et al., 2017). O cálculo se fundamenta na relação entre o aumento do $\mathrm{R}^{2}$ da variável latente endógena e a proporção de variância não explicada desta variável latente (Urbach \& Ahlemann, 2010). Valores de $f^{2}$ entre 0,02 e 0,15 indicam pequeno efeito da variável exógena sobre a endógena; e valores entre 0,15 a 0,35 efeito médio e acima de 0,35 indicam efeito grande sobre a variável latente endógena.

$$
f^{2}=\frac{R_{\text {included }}^{2}-R_{\text {excluded }}^{2}}{1-R_{\text {included }}^{2}}
$$

$A R^{2}$ included é o $R^{2}$ total do modelo (quando a variável independente é incluída na equação estrutural) e o $\mathrm{R}^{2}$ excluded é o $\mathrm{R}^{2}$ da variável latente dependente quando a variável independente é omitida da equação estrutural (Hair et al., 2017). 


\subsection{Teste da relevância preditiva do Modelo Estrutural $\left(Q^{2}\right)$}

Para avaliar a magnitude dos valores $\mathrm{R}^{2}$ como critério de precisão preditiva, usa-se o valor $Q^{2}$ de Stone-Geisser (Hair et al., 2017). Os valores de $Q^{2}$ maiores que zero para uma variável latente endógena reflexiva específica indicam a relevância preditiva dos modelos do caminho para um construto endógeno (Henseler et al., 2009; Hair et al., 2017).

Para obter o valor de $\mathrm{Q}^{2}$ usa-se o procedimento blindfolding, disponível no software Smart-PLS, que é uma técnica de reutilização de amostras que omite uma parcela dos dados (distância D) de um determinado conjunto de indicadores. Os resultados são utilizados para prever a parcela omitida dos dados, ou seja, a diferença entre os verdadeiros pontos dos dados (isto é, omitidos) e os preditores são usados como entrada para a medida $Q^{2}$. Bilndfolding é um processo iterativo que se repete até que os dados de cada ponto que foram omitidos sejam reestimados, portanto, o número de rodadas blindfolding sempre é igual à distância $\mathrm{D}$ (dados omitidos). Hair et al. (2017) sugere escolher um número de valores de D entre 5 e 10. No software SmartPLS, a técnica bllindfolding foi realizada com uma distância $d=7$. (Hair et al., 2017)

\subsection{Efeito do tamanho - $\mathrm{q}^{2}$}

O tamanho do efeito $q^{2}$ permite avaliar a contribuição de um construto exógeno para um valor $\mathrm{Q}^{2}$ da variável latente endógena. Como medida relativa da relevância preditiva, os valores de $\mathrm{q}^{2}$ de 0,02, 0,15 e 0,35 indicam, respectivamente, que um construto exógeno tem uma relevância prévia pequena, média ou grande para um determinado construto endógeno.

$$
q^{2}=\frac{Q_{\text {included }}^{2}-Q_{\text {exduded }}^{2}}{1-Q_{\text {included }}^{2}}
$$

\subsubsection{Análise Mediadora}

As relações de causa-efeito em modelos de caminho PLS implicam que os construtos exógenos afetam diretamente construtos endógenos sem influências de outras variáveis. Em muitos casos, no entanto, essa suposição não é válida e, inclusive, uma terceira variável na análise pode mudar a compreensão da natureza dos 
relacionamentos do modelo (Hair et al., 2017). Para esta tese, a análise mediadora pretende verificar, em nível de organização local, se comprometimento é mediador das relações entre os tipos de práticas e os valores da organização e seus resultados. E verificar se tipos de práticas organizacionais são mediadores das relações entre valores da organização e seus resultados bem como o comprometimento.

A mediação ocorre quando uma terceira variável, referida como uma variável mediadora, intervém entre dois outros construtos relacionados. Mais precisamente, uma mudança no construto exógeno resulta em uma mudança da variável do mediador, que, por sua vez, muda o construto endógeno. Assim, uma variável mediadora governa a natureza da relação entre dois construtos e seu objetivo é criar uma relação teórica indireta entre os caminhos e os construtos (Samani, 2016).

Os efeitos diretos são os relacionamentos que ligam dois construtos com uma única seta. Os efeitos indiretos são as relações que envolvem uma sequência de relações com pelo menos um construto interveniente envolvido. Assim, um efeito indireto é uma sequência de dois ou mais efeitos diretos e é representado visualmente por várias setas, como pode ser visto na figura 21.

Figura 21 - Modelo geral de mediação

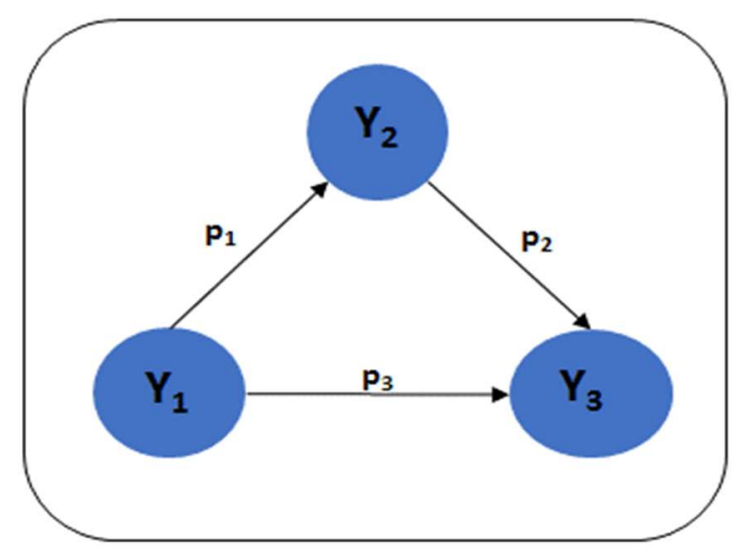

Fonte: Hair, et al., 2017 p. 229

A figura 21 mostra tanto o efeito direto $p_{3}$ entre $Y_{1}$ e $Y_{3}$ quanto $o$ efeito indireto de $Y_{1}$ em $Y_{3}$ na sequência $Y_{1}>Y_{2}>Y_{3}$, em que o efeito indireto $p_{1} \times p_{2}$ representa o efeito mediador do construto $Y_{2}$ na relação entre $Y_{1}$ e $Y_{3}$, ou seja, $Y_{1} \rightarrow Y_{2}$ e $Y_{2} \rightarrow Y_{3}$. Assim, a relação indireta por intermédio do mediador afeta a relação direta de $Y_{1}$ para $Y_{3}$. Isso significa que a variável $Y_{1}$ está relacionada à variável $Y_{2}$ e a variável $Y_{2}$ está relacionada à variável $Y_{3}$ (Little et al., 2012; Samani, 2016) 
Segundo Hair et al. (2017), há os seguintes tipos de efeitos de mediação:

1. Efeito de não mediação: (a) não mediação direta: o efeito direto é significativo, mas não o efeito indireto; e (b) não mediação sem efeito: nem o efeito direto nem indireto são significantes.

2. Efeito de Mediação: (a) mediação complementar: o efeito indireto e o efeito direto são significativos e apontam a mesma direção; (b) mediação competitiva: o efeito indireto e o efeito direto são significativos e apontam em direções opostas; e (c) mediação indireta: os efeitos indiretos são significativos, mas não o efeito direto. Mediação complementar e competitiva também são conhecidas como mediação parcial e mediação indireta como mediação completa.

Para verificar o tipo de mediação, são necessárias várias análises estatísticas que podem ser obtidas por meio do software Smart-PLS. Seguindo o modelo da figura 25 , o primeiro passo é avaliar a significância do efeito indireto $\left(\mathrm{p}_{1} \mathrm{xp}_{2}\right)$ através da variável mediadora $Y_{2}$. Se o efeito indireto não for significativo, então $Y_{2}$ não se comporta como mediadora entre $Y_{1}$ e $Y_{3}$, entretanto, se o $p_{3}$ for significativo, então uma análise mais aprofundada do efeito direto $p_{3}$ pode apontar para mediadores ainda não descobertos.

Se o efeito indireto $p_{1} \times p_{2}$ for significativo, o próximo passo será verificar a significância do efeito direto p3. Se o feito direto p3 for não significativo, é o caso de se ter uma mediação completa que representa o melhor cenário para modelos de mediação. Se o efeito direto $\mathrm{p}_{3}$ for significativo, pode haver a existência de um outro mediador que explique a relação entre $Y_{1}$ e $Y_{3}$. Se tanto o efeito indireto $\left(p_{1} x p_{2}\right)$ quanto direto $\left(p_{3}\right)$ forem significativos, então deve-se distinguir entre mediação complementar ou competitiva. A figura 22 mostra as possíveis relações de mediação.

Figura 22 - Relações de mediação

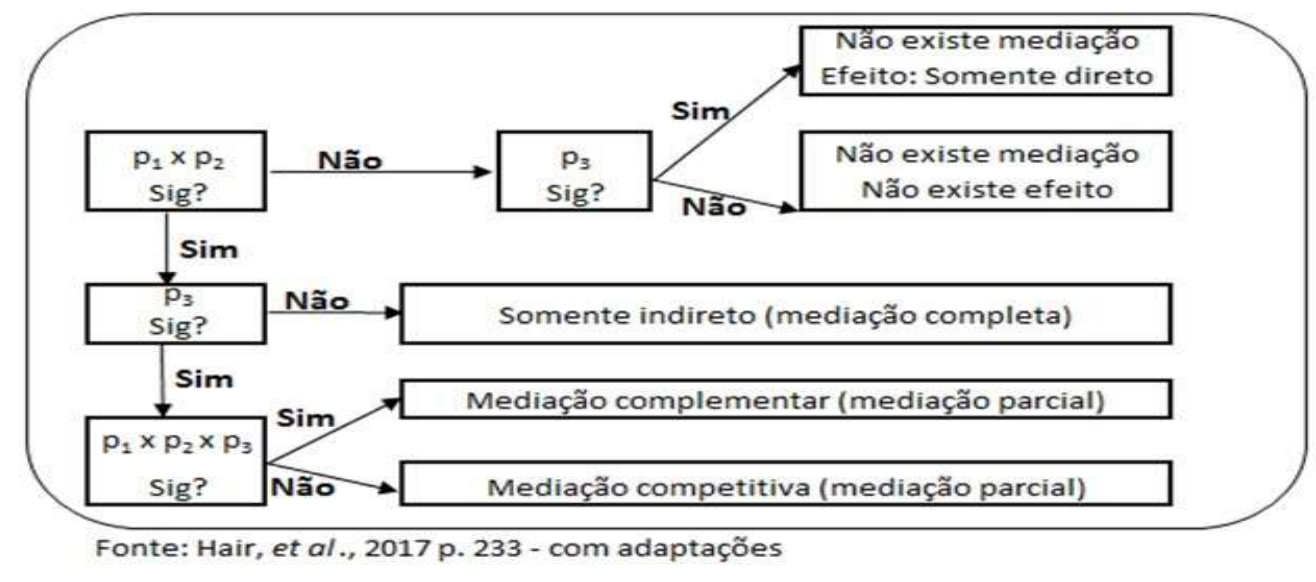




\subsection{Mediação múltipla}

Ocorre quando os construtos exógenos exercem sua influência através de mais de uma variável mediadora. Esta situação exige a execução de múltiplas análises de mediação. No modelo apresentado na figura 23, $p_{3}$ representa o efeito direto entre o construto exógeno $\left(\mathrm{Y}_{1}\right)$ e o construto endógeno $\left(\mathrm{Y}_{3}\right)$. O efeito indireto de $\mathrm{Y}_{1}$ em $\mathrm{Y}_{3}$ por meio do construto mediador $Y_{2}$ é quantificado pelo produto $p_{1} \times p_{2}$, enquanto para 0 segundo construto mediador $\mathrm{Y}_{4} \mathrm{O}$ efeito indireto é dado pelo produto $\mathrm{p}_{4} \mathrm{xp}_{5}$. Segundo Hair et al. (2017), o efeito indireto total será obtido por meio das somas dos específicos efeitos indiretos $\left(p_{1} \times p_{2}+p_{4} \times p_{5}\right)$. $E$ o efeito total de $Y_{1}$ em $Y_{3}$ é obtido somando os efeitos diretos e o total de efeitos indiretos $\left(p_{3}+p_{1} \times p_{2}+p_{4} \times p_{5}\right)$.

Figura 23- Modelo de mediação múltipla

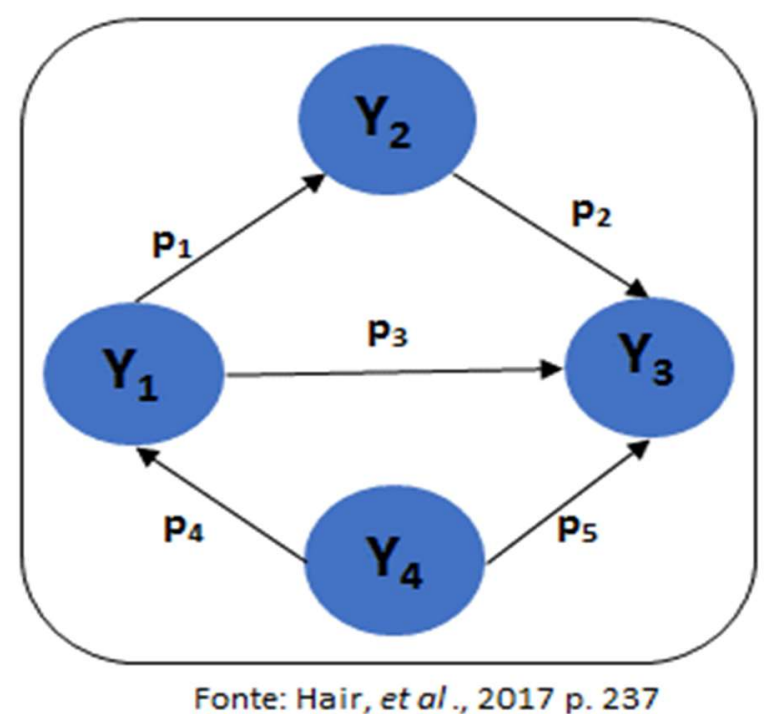

Para testar um modelo como o mostrado na figura 23, ao realizar as análises como se fossem mediações simples, ou seja, uma análise para cada mediador proposto, haverá problemas, pois, segundo Hair et al. (2017), os autores Preacher e Hayes (2008) explicam a inviabilidade de tal procedimento por dois motivos: (a) não se pode simplesmente somar os efeitos indiretos calculados em várias análises simples de mediação para alcançar o efeito indireto total, pois os mediadores em um modelo de mediação múltipla normalmente estão correlacionados, então as estimativas dos efeitos indiretos usando várias análises de mediação simples serão tendenciosas e não somarão o efeito indireto total; e (b) os testes de hipóteses e os intervalos de confiança calculados para efeitos indiretos específicos podem não ser precisos devido à omissão de outros mediadores potencialmente importantes. 
Ao considerar todos os mediadores simultaneamente em um modelo, obtém-se uma imagem mais completa dos mecanismos através dos quais um construto exógeno afeta um construto endógeno (Hair et al., 2017). Em um modelo de mediação múltipla, um específico efeito indireto pode ser interpretado como o efeito indireto de $Y_{1}$ em $Y_{3}$ através de um determinado mediador, controlando todos os outros mediadores que estão incluídos no modelo. Observa-se que esse efeito indireto é diferente do que seria obtido ao examinar vários mediadores separadamente em análises de mediação simples, neste caso o efeito indireto pode ser significativamente inflacionado, exceto na circunstância muito improvável de que todos os outros mediadores não estejam correlacionados com o mediador em questão (Hair et al., 2012, 2017).

Para analisar a mediação múltipla, devem-se seguir os mesmos passos que são realizados para a mediação simples. Ou seja, testar a significância de cada efeito indireto (os efeitos indiretos específicos), bem como testar a significância do efeito direto entre o construto exógeno e o construto endógeno, depois verificar se o efeito indireto total é significativo. Avaliar a importância do efeito indireto total e do efeito direto pode ser feito por meio dos resultados do software Smart-PLS, mas, no modelo de mediação múltipla, o efeito indireto total pode consistir em vários efeitos indiretos específicos. Avaliar a significância dos efeitos indiretos específicos requer calcular manualmente a média e o erro padrão de cada efeito, bem como estabelecer o t-valor e o p-valor deles. 


\subsection{Síntese do capítulo 4}

As escolhas metodológicas apresentadas neste capítulo foram, quanto à abordagem é quantitativa e os tipos de pesquisa escolhidos foram o descritivo e o correlacional. A organização onde a pesquisa foi realizada é o Ministério das Relações Exteriores, em específico o Departamento de Promoção Comercial e Investimentos e seus respectivos Setores de Promoção Comercial - SECOMs. Para o estudo proposto, os seguintes instrumentos foram aplicados: IPVO, para a identificação de valores organizacionais; escala de percepções de práticas de gestão de pessoas, para o reconhecimento dos tipos de práticas organizacionais; e a escala EBACO, para o reconhecimento das bases de comprometimento organizacional.

O universo da pesquisa são os colaboradores do Departamento de Promoção Comercial (DPR/MRE) localizado na sede do Ministério das Relações Exteriores em Brasília e dos servidores e funcionários dos SECOMs localizados nas embaixadas e consulados brasileiros dos países com os quais o Brasil estabelece relações comerciais. Para a coleta de dados, foi utilizada uma survey e os questionários foram administrados por meio eletrônico. Para a análise dos dados, cujos resultados serão apresentados no próximo capítulo, utilizaram-se três níveis de análise: univariada (análise descritiva dos dados, teste de confiabilidade - alfa de Cronbach, teste de homogeneidade - ANOVA e teste de Tukey, e comparação de médias); bivariada (teste $\mathrm{t}$, correlação de Pearson); e multivariada (análise fatorial e modelagem de equações estruturais). 


\section{Resultados do estudo descritivo-quantitativo}

\subsection{Introdução ao capítulo 5}

O capítulo que se inicia tem por objetivo apresentar os resultados da pesquisa. Começa-se pela preparação dos dados em que se verifica a acurácia e a precisão dos dados. Depois, na análise univariada, são apresentadas informações demográficas dos participantes da pesquisa. Em seguida, apresenta-se a análise descritiva das escalas que foram analisadas por meio das médias, desvios-padrão, coeficientes de variabilidade e medidas de assimetria e curtose. Para dar continuidade e aprofundar a análise dos resultados, verificou-se a confiabilidade dos itens e a homogeneidade dos dados. Então, são apresentados resultados obtidos a partir de comparações de médias. Para as dimensões tipos de práticas e comprometimento, além da confiabilidade dos itens e homogeneidade dos dados, também foram realizadas as respectivas análises fatoriais a fim de validar os instrumentos no contexto desta pesquisa. $\mathrm{Na}$ análise bivariada, os testes de Levene e teste-t foram utilizados para verificar diferenças nas percepções entre os construtos; e o teste de correlação de Pearson, para verificar associações entre as dimensões dos construtos. A análise multivariada objetiva verificar os construtos e suas relações com os resultados organizacionais nos SECOMs, para tanto foi utilizado o modelo de equação estrutural PLS-SEM com as seguintes etapas: teste do outer model (modelo de mensuração); teste do inner model (modelo estrutural) e das hipóteses sobre as relações entre as variáveis latentes. Sob este mesmo método, foram realizados estudos sobre relações mediadoras entre os construtos.

\subsection{Preparação dos dados}

Antes de iniciar as análises estatísticas, verificou-se a acurácia ou a precisão dos dados, com vistas a atender os pressupostos exigidos pelos procedimentos estatísticos utilizados (Tabachnick \& Fidell, 1996). Sendo assim, foi realizada uma análise exploratória para verificar os seguintes aspectos: distribuição de frequência para identificar as medidas de tendência central (média, moda e mediana), medidas de dispersão (variância e desvio-padrão) e se os valores máximo/mínimo estavam dentro dos limites esperados para cada variável investigada; identificação de dados 
ausentes (missing values), de casos extremos (outliers). As análises foram realizadas por meio do programa estatístico IBM SPSS (Statistical Package for the Social Sciences) versão 20.0 e com o auxílio da planilha eletrônica Excel, para a parte descritiva. Para as análises inferenciais, foram utilizados os programas SPSS e SmartPLS 3.0.

Dos questionários respondidos, todos estavam preenchidos e apenas com alguns valores ausentes. A análise descritiva dos dados mostrou que as médias aritméticas, desvios-padrão e pontos de máximo e de mínimo apresentaram valores de distribuição de frequência considerados coerentes em relação às características das variáveis pesquisadas.

Os valores ausentes detectados (missing values) não se apresentavam concentrados e sequer excederam a $2,5 \%$ dos casos. $O$ padrão de distribuição dos valores dispersão aleatória - é mais importante que o número de casos ausentes detectados na amostra pesquisada (Tabachnick \& Fidell, 1996). Um dos procedimentos recomendados é a substituição dos valores faltantes pela média do item. A vantagem deste procedimento consiste em não se alterar de forma significativa a média final da variável. Desta forma, optou-se por substituir os dados faltantes pelo valor médio das respectivas variáveis.

A importância da identificação de outliers está na possibilidade de distorções nos resultados que podem levar a conclusões conflitantes. Assim, foram realizados dois testes: (1) outlier univariado, para identificar valores extremos em determinada variável; e (2) outlier multivariado, que trata de investigar valores em diversas variáveis que não são necessariamente atípicas quando a variável é considerada separadamente (Ribas, 2011).

Para o reconhecimento de outliers univariados, procedeu-se à padronização dos escores e a investigação de escores maiores do que 3 ou menores do que -3. Foram observados 20 ouliers $^{13}$ de um total de 28.250 valores das 113 variáveis da pesquisa.

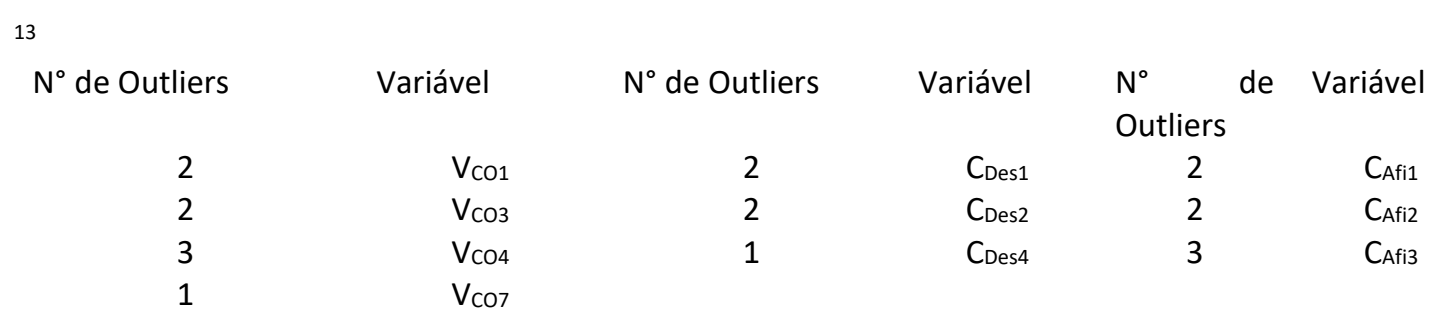


A análise de outliers multivariados trata de observar valores em diversas variáveis que não necessariamente são atípicas quando as variáveis são consideradas separadamente, mas que podem ser atípicas quando das suas combinações. Para a identificação, foi utilizada a distância de Mahalanobis $\left(D^{2}\right)$, que mensura a distância de cada ponto individual no espaço de $n$ dimensões em relação ao centroide dos dados (Hair et al., 2009; Ribas, 2011) e possui propriedades estatísticas que possibilitam teste de significância $\left(d^{2} / d f \sim t\right)$, então é possível utilizar o nível de significância $(0,005$ ou 0,001$)$ como valores de referência para identificar valores atípicos. Dessa forma, valores de $D^{2} / \mathrm{df}>2,5$ em pequenas amostras e 3 ou 4 em grandes amostras podem ser identificadas como possíveis valores atípicos (Hair et al., 2009). Como resultado dessa análise, não foram identificados valores atípicos na vertente multivariada.

Assim, optou-se pela permanência dos valores atípicos identificados na análise de outliers univariados, pois, segundo Hair et al. (2009), não há prova demonstrável de que os valores estão de fato fora do normal. O que se tem, neste caso, são respostas atípicas da maioria, mas isso garante a generalidade das respostas como um todo.

\subsection{Análise univariada}

A estatística descritiva é a etapa inicial da análise utilizada para descrever e resumir os dados. A análise univariada inclui todos os métodos da estatística descritiva que permitem a análise de cada variável separadamente e também métodos de estatística Inferencial para determinada variável, podendo ser medida para uma ou mais amostras independentes. A análise de variância simples - ANOVA e o teste "t", em particular são exemplos de um método de estatística univariada (Reis, 1997).

Neste trabalho, a análise descritiva corresponde à caracterização do perfil demográfico dos respondentes, a unidimensionalidade dos itens das escalas, a confiabilidade dos itens e comparação de médias. 


\subsubsection{Informações sociodemográficas}

Neste estudo, obteve-se a participação de 320 respondentes, 70 colaboradores do DPR locados no MRE e 250 colaboradores dos SECOMs avaliados.

O número de colaboradores do DPR é de 96 , obtendo-se, portanto, $73 \%$ de retorno da população-alvo estudada. Seus colaboradores são compostos por diplomatas, oficiais de chancelaria, auxiliares de chancelaria, consultores, estagiários e terceirizados.

Gráfico 02 - Percentual de colaboradores e percentual de respondentes

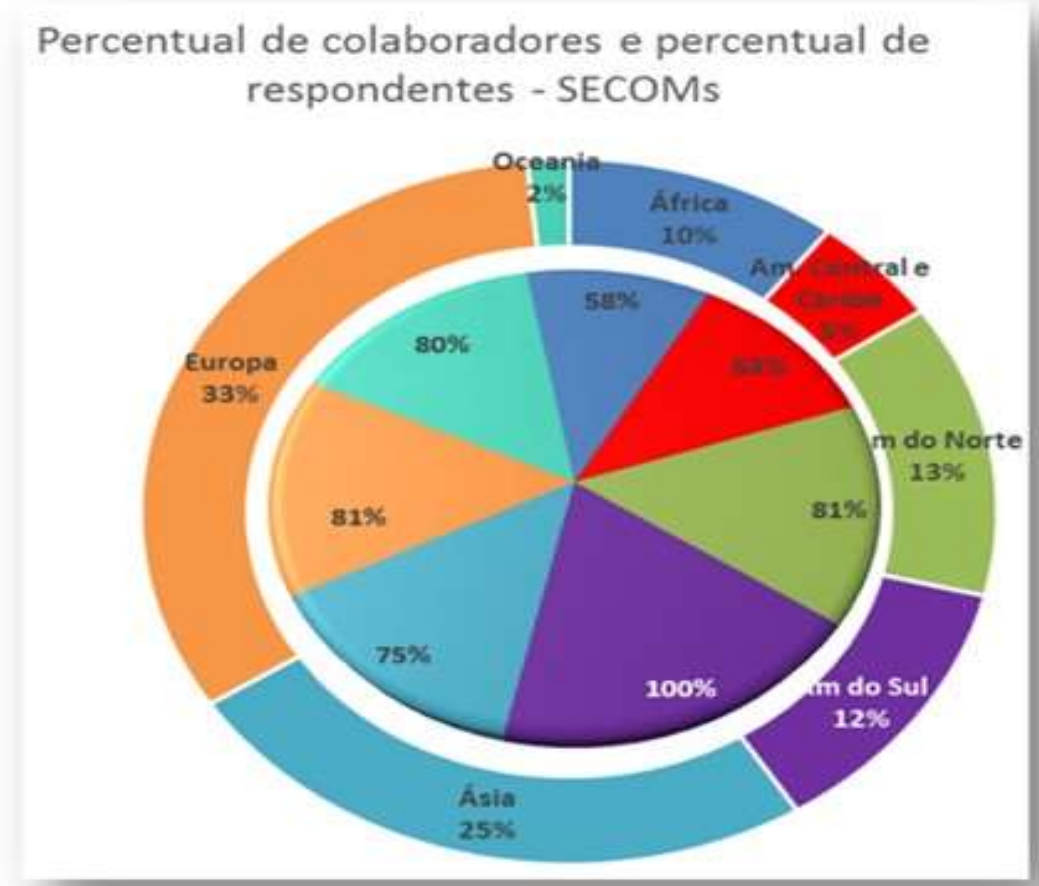

Fonte: dados da pesquisa

O número de colaboradores de todos os SECOMs é de 319, obtendo-se, portanto, aproximadamente $79 \%$ de retorno da população-alvo estudada. Seus colaboradores são compostos por diplomatas, oficiais de chancelaria, auxiliares de chancelaria e terceirizados, sendo que os terceirizados costumam ser brasileiros e nativos do país em que o SECOM atua. Como visto no gráfico 02, o percentual de participação foi alto, também, por continentes, como no caso da América do Sul, em que todos os colaboradores responderam os instrumentos de pesquisa. 


\subsubsection{Características sociodemográficas dos colaboradores do DPR/MRE}

No DPR, aproximadamente $70 \%$ dos respondentes têm de zero a cinco anos de tempo de casa; $82,9 \%$ possuem ensino superior e 43\% têm idade média de 30 a 39 anos de idade. Quanto ao sexo, observou-se uma distribuição quase igualitária: 48,57\% mulheres e 51,43\% homens. Já nos SECOMs, aproximadamente $69 \%$ dos respondentes têm de zero a cinco anos de tempo de casa; 95,6\% possuem ensino superior e $36,4 \%$ já cursaram mestrado, 30,0\% têm idade média de 30 a 39 anos de idade. Quanto ao sexo, observou-se uma distribuição quase igualitária: 48,4\% mulheres e $51,6 \%$ homens.

Tabela 04 - Características socioprofissionais dos colaboradores do DPR e SECOMs

\begin{tabular}{|c|c|c|}
\hline Características & $\begin{array}{c}\text { DPR/MRE } \\
\text { Percentuais }\end{array}$ & $\begin{array}{c}\text { SECOMs/DPR/MRE } \\
\text { Percentuais }\end{array}$ \\
\hline \multicolumn{3}{|l|}{ Diversidade (\%) } \\
\hline $\begin{array}{l}\text { Homens } \\
\text { Mulheres }\end{array}$ & $\begin{array}{l}\mathbf{5 1 , 4 3} \\
48,57 \\
\end{array}$ & $\begin{array}{l}51,6 \\
48,4\end{array}$ \\
\hline \multicolumn{3}{|l|}{ Escolaridade (\%) } \\
\hline $\begin{array}{l}\text { Ensino Médio } \\
\text { Ensino Superior } \\
\text { Especialização } \\
\text { Mestrado } \\
\text { Doutorado }\end{array}$ & $\begin{array}{c}17,1 \\
\mathbf{5 4 , 3} \\
22,9 \\
4,3 \\
1,4\end{array}$ & $\begin{array}{c}4,4 \\
51,6 \\
4,4 \\
36,4 \\
3,2\end{array}$ \\
\hline \multicolumn{3}{|l|}{ Idade (\%) } \\
\hline $\begin{array}{l}\text { De } 20 \text { anos a menos } \\
\text { De } 20 \text { a } 29 \text { anos } \\
\text { De } 30 \text { a } 39 \text { anos } \\
\text { De } 40 \text { a } 49 \text { anos } \\
\text { De } 50 \text { a } 59 \text { anos } \\
\text { De } 60 \text { anos a mais }\end{array}$ & $\begin{array}{c}4,3 \\
24,3 \\
42,9 \\
11,4 \\
11,5 \\
5,7 \\
\end{array}$ & $\begin{array}{c}0,4 \\
13,2 \\
29,6 \\
23,6 \\
19,6 \\
13,6 \\
\end{array}$ \\
\hline \multicolumn{3}{|l|}{ Tempo de casa (\%) } \\
\hline $\begin{array}{l}\text { De } 0 \text { a } 5 \text { anos } \\
\text { De } 6 \text { a } 10 \text { anos } \\
\text { De } 11 \text { a } 15 \text { anos } \\
\text { De } 16 \text { a } 20 \text { anos } \\
\text { De } 21 \text { a } 25 \text { anos } \\
\text { De } 26 \text { a } 30 \text { anos } \\
\text { Acima de } 30 \text { anos }\end{array}$ & $\begin{array}{c}\mathbf{6 8 , 6} \\
15,7 \\
5,7 \\
5,7 \\
2,9 \\
1,4 \\
1,4 \\
\end{array}$ & $\begin{array}{c}\mathbf{5 2 , 8} \\
8,8 \\
13,6 \\
2,0 \\
3,6 \\
8,8 \\
10,4 \\
\end{array}$ \\
\hline
\end{tabular}

Fonte: dados da pesquisa

A seguir, apresenta-se a nacionalidade dos colaboradores que trabalham nos SECOMs. Cabe ressaltar a análise feita a partir da tabela 06 em que $34 \%$ dos SECOMs são compostos totalmente por brasileiros (Grécia, Espanha, Servia, Austrália, Holanda), 46\% são brasileiros e nativos (EUA, África do Sul, Alemanha, Amsterdã, China, Vietnã, Cuba, Bolívia, Peru, Itália, Canadá, Noruega, República do 
Panamá, Cabo Verde, El Salvador, Coreia do Sul e Taiwan); e, na posição oposta, 20\% dos SECOMs compostos somente por nativos (Costa do Marfim, Paraguai, Venezuela, Áustria, Paquistão, Eslovênia, Angola, Nicarágua, Filipinas, Moçambique, México, Suriname, Haiti, Equador, República Dominicana, Polônia e Camarões).

Tabela 05 - Nacionalidade dos respondentes por SECOM

\begin{tabular}{|c|c|c|c|c|c|c|c|c|}
\hline \multirow{2}{*}{$\begin{array}{l}\begin{array}{c}\text { SECOM em } \\
\text { que atua }\end{array} \\
\text { Abidjã }\end{array}$} & \multicolumn{2}{|c|}{ Nacionalidade } & \multirow{2}{*}{$\begin{array}{c}\begin{array}{c}\text { SECOM em } \\
\text { que atua }\end{array} \\
\text { Haia }\end{array}$} & \multicolumn{2}{|c|}{ Nacionalidade } & \multirow{2}{*}{$\begin{array}{c}\begin{array}{c}\text { SECOM em } \\
\text { que atua }\end{array} \\
\text { Nova Delhi }\end{array}$} & \multicolumn{2}{|c|}{ Nacionalidade } \\
\hline & BR 0\% & $\begin{array}{l}\text { Costa Marfim } \\
100 \%\end{array}$ & & BR $100 \%$ & Holanda 0\% & & BR 33\% & Índia 67\% \\
\hline Abuja & BR $50 \%$ & Nigéria 50\% & Hanói & BR $100 \%$ & Vietnã 0\% & Nova York & BR $100 \%$ & EUA 0\% \\
\hline Acra & BR 50\% & Gana 50\% & Havana & BR $100 \%$ & Cuba 0\% & Oslo & BR $100 \%$ & Noruega 0\% \\
\hline Ancara & BR 33\% & Turquia $67 \%$ & H. Kong & BR $50 \%$ & China 50\% & Panamá & BR $100 \%$ & R. Panamá 0\% \\
\hline Argel & BR 33\% & Argélia 67\% & Houston & BR $100 \%$ & EUA 0\% & Paramaribo & BR 0\% & Suriname $100 \%$ \\
\hline Assunção & BR 0\% & Paraguai $100 \%$ & Islamabad & BR 0\% & $\begin{array}{l}\text { Paquistão } \\
100 \%\end{array}$ & Paris & BR $83 \%$ & França 17\% \\
\hline Atenas & BR 100\% & Grécia 0\% & Istambul & BR 75\% & Turquia 25\% & Pequim & BR $20 \%$ & $\begin{array}{l}\text { China 40\% } \\
\text { Austrália 40\% }\end{array}$ \\
\hline Atlanta & BR $100 \%$ & EUA 0\% & Jakarta & BR 16\% & Indone.84\% & Porto Príncipe & BR 0\% & Haiti $100 \%$ \\
\hline Bangkok & BR 33\% & Tailândia 67\% & Kiev & BR 33\% & Ucrânia 67\% & Praga & BR 33\% & R. Tcheca $67 \%$ \\
\hline Barcelona & BR 100\% & Espanha 0\% & $\begin{array}{l}\text { Kuala } \\
\text { Lumpur }\end{array}$ & BR $50 \%$ & Malásia 50\% & Pretoria & BR $67 \%$ & Irlanda 33\% \\
\hline Beirute & BR $50 \%$ & Líbano 50\% & La Paz & BR $100 \%$ & Bolívia 0\% & Quito & BR 0\% & Equador $100 \%$ \\
\hline Belgrado & BR $100 \%$ & Servia 0\% & Lima & BR $100 \%$ & Peru 0\% & Praia & BR100\% & Cabo Verde $0 \%$ \\
\hline Berlim & BR $89 \%$ & Aleman. $11 \%$ & Lisboa & BR $80 \%$ & Portug. 20\% & S. Salvador & BR $100 \%$ & El Salvador 0\% \\
\hline Bogotá & BR 33\% & Colômbia 67\% & Liubliana & BR 0\% & Eslov. 100\% & Santiago & BR $57 \%$ & Chile $43 \%$ \\
\hline Bratislava & BR $50 \%$ & Eslováq. 50\% & Londres & BR 75\% & $\begin{array}{l}\text { Itália } 12,5 \% \\
\text { Portg.12,5\% }\end{array}$ & S. Domingos & BR 0\% & $\begin{array}{l}\text { R. Dominicana } \\
100 \%\end{array}$ \\
\hline Bruxelas & BR 67\% & Bélgica 33\% & L.Angeles & BR $100 \%$ & EUA 0\% & Seul & BR $100 \%$ & Coreia Sul 0\% \\
\hline Budapeste & BR $50 \%$ & Hungria $50 \%$ & Luanda & BR 0\% & $\begin{array}{l}\text { Angola } \\
100 \%\end{array}$ & Sydney & BR $100 \%$ & Austrália 0\% \\
\hline B. Aires & BR $50 \%$ & Argent. 50\% & Madri & BR $80 \%$ & Espanha $20 \%$ & Taipé & BR $100 \%$ & Taiwan 0\% \\
\hline Camberra & BR $100 \%$ & Austrália 0\% & Managua & BR 0\% & $\begin{array}{l}\text { Nicarágua } \\
100 \% \\
\end{array}$ & Tóquio & BR $63 \%$ & Japão 37\% \\
\hline Caracas & BR 0\% & Venez. $100 \%$ & Manila & BR 0\% & $\begin{array}{l}\text { Filipinas } \\
100 \%\end{array}$ & Toronto & BR 100\% & Canadá 0\% \\
\hline Chicago & BR $100 \%$ & EUA 0\% & Maputo & BR 0\% & $\begin{array}{l}\text { Moçambiqu } \\
\text { e } 100 \%\end{array}$ & Vancouver & BR $100 \%$ & Canadá 0\% \\
\hline Cid. Cabo & BR $100 \%$ & África Sul 0\% & México & BR 0\% & $\begin{array}{l}\text { México } \\
100 \%\end{array}$ & Varsóvia & BR 0\% & Polônia 100\% \\
\hline Cingapura & BR $100 \%$ & Cingapura 0\% & Miami & BR $80 \%$ & EUA 20\% & Viena & BR 33\% & $\begin{array}{l}\text { Áustria 33\% } \\
\text { Cabo Verde 33\% }\end{array}$ \\
\hline Dublin & BR 0\% & Irlanda $100 \%$ & Milão & BR $100 \%$ & Itália 0\% & Washington & BR $75 \%$ & EUA $25 \%$ \\
\hline Estocolmo & BR 75\% & Suécia $25 \%$ & Montreal & BR $100 \%$ & Canadá 0\% & Xangai & BR $25 \%$ & China $75 \%$ \\
\hline Frankfurt & BR $100 \%$ & $\begin{array}{l}\text { Alemanha } \\
0 \%\end{array}$ & Moscou & BR 33\% & Rússia 67\% & Yaoundé & BR 0\% & Camarões $100 \%$ \\
\hline Helsinque & BR $50 \%$ & Finlând.50\% & Nairóbi & BR 33\% & Quênia 67\% & & & \\
\hline
\end{tabular}


O que se observa é que, nos países em que o Brasil mantém um volume maior de relações comerciais ${ }^{14}\left(1^{\circ}\right.$ China, $2^{\circ}$ EUA, $3^{\circ}$ Argentina, $4^{\circ}$ Holanda e $5^{\circ}$ Chile), os SECOMs contam, no mínimo, com $50 \%$ de brasileiros entre seus colaboradores, chegando em alguns casos, como exemplo a Holanda, a ter $100 \%$ de brasileiros como colaboradores.

\subsection{Informações sociodemográficas por continente e área continental}

Os itens a seguir apresentam o percentual de respondentes desta pesquisa, bem como as informações sociodemográficas por continente e área continental.

\subsubsection{1(a) SECOMs na África}

Os SECOMs do Departamento de Promoção Comercial e Investimentos do Itamaraty (DPR) estão situados nos seguintes países: Costa do Marfim; Nigéria; Gana; Argélia; Egito; África do Sul; República da Guiné; Camarões; Nigéria; Angola; Moçambique; Quênia; Cabo Verde; Marrocos e Líbia. A tabela 06 mostra o percentual dos respondentes por área continental e cidade.

Tabela 06 - Percentual de respondentes dos SECOMs nos países por área continental - África

\begin{tabular}{|c|c|}
\hline Área continental & $\begin{array}{l}\text { País e cidade em que o SECOM se localiza e percentual de } \\
\text { respondentes }\end{array}$ \\
\hline ÁFRICA MERIDIONAL & $\begin{array}{l}\text { África do Sul - Cidade do Cabo - 100\% } \\
\text { África do Sul - Pretoria - 100\% } \\
\text { Camarões - Yaoundé - } 50 \% \\
\text { Moçambique - Maputo - } 50 \% \\
\text { Angola - Luanda - } 35 \%\end{array}$ \\
\hline ÁFRICA OCIDENTAL & $\begin{array}{l}\text { Gana - Acra - } 100 \% \\
\text { Rep. Cabo Verde - Praia - 50\% } \\
\text { Costa do Marfim - Abdijã - 50\% } \\
\text { Nigéria - Abuja - } 100 \% \\
\text { República da Guiné - 0\% }\end{array}$ \\
\hline ÁFRICA ORIENTAL & Quênia - Nairobi - 100\% \\
\hline NORTE DA ÁFRICA & $\begin{array}{l}\text { Argélia - Argel - } 100 \% \\
\text { Egito - Cairo - } 0 \% \\
\text { Marrocos }-0 \%\end{array}$ \\
\hline $\begin{array}{l}\text { ÁFRICA } \\
\text { SETENTRIONAL }\end{array}$ & Líbia - 0\% \\
\hline
\end{tabular}

Fonte: dados da pesquisa

${ }^{14}$ Veja apêndice $n^{\circ} 01$ - Relações comerciais brasileiras (exportação - importação) período de janeiro a julho de 2017. 
Quanto às características demográficas dos respondentes dos SECOMs na África, mais da metade são mulheres (58\%), todos com no mínimo ensino superior e idade média entre 30 a 39 anos. Quanto à nacionalidade, $42,1 \%$ são brasileiros, incluindo, além dos diplomatas (chefe do SECOM), os terceirizados residentes nos países pesquisados, como pode ser visto na tabela 07.

Tabela 07 - Características socioprofissionais dos colaboradores dos SECOMs por continente e área continental - África

\begin{tabular}{|c|c|c|c|c|c|}
\hline Características & África & $\begin{array}{c}\text { África } \\
\text { Meridional }\end{array}$ & $\begin{array}{c}\text { África } \\
\text { Ocidental }\end{array}$ & $\begin{array}{c}\text { África } \\
\text { Oriental }\end{array}$ & $\begin{array}{c}\text { Norte da } \\
\text { África }\end{array}$ \\
\hline \multicolumn{6}{|l|}{ Diversidade (\%) } \\
\hline $\begin{array}{l}\text { Homens } \\
\text { Mulheres }\end{array}$ & $\begin{array}{l}42,1 \\
57,9\end{array}$ & $\begin{array}{l}14,3 \\
85,7\end{array}$ & $\begin{array}{l}50,0 \\
50,0\end{array}$ & $\begin{array}{l}66,7 \\
33,33\end{array}$ & $\begin{array}{l}66,7 \\
33,33\end{array}$ \\
\hline \multicolumn{6}{|l|}{ Escolaridade (\%) } \\
\hline $\begin{array}{l}\text { Ensino Superior } \\
\text { Especialização } \\
\text { Mestrado }\end{array}$ & $\begin{array}{c}63,2 \\
5,3 \\
31,6\end{array}$ & $\begin{array}{l}71,4 \\
28,6\end{array}$ & $\begin{array}{l}83,3 \\
16,7\end{array}$ & $\begin{array}{r}33,33 \\
66,7\end{array}$ & $\begin{array}{l}33,3 \\
66,7\end{array}$ \\
\hline \multicolumn{6}{|l|}{ Idade (\%) } \\
\hline $\begin{array}{l}\text { De } 20 \text { a } 29 \text { anos } \\
\text { De } 30 \text { a } 39 \text { anos } \\
\text { De } 40 \text { a } 49 \text { anos } \\
\text { De } 50 \text { a } 59 \text { anos } \\
\text { De } 60 \text { anos a mais }\end{array}$ & $\begin{array}{c}21,1 \\
37,7 \\
15,8 \\
20,1 \\
5,3 \\
\end{array}$ & $\begin{array}{l}28,6 \\
28,6 \\
\\
28,6 \\
14,3 \\
\end{array}$ & $\begin{array}{l}16,7 \\
50,0 \\
16,7 \\
16,7\end{array}$ & $\begin{array}{l}33,3 \\
66,7\end{array}$ & $\begin{array}{l}66,7 \\
33,3\end{array}$ \\
\hline \multicolumn{6}{|l|}{ Tempo de casa (\%) } \\
\hline $\begin{array}{l}\text { Menos de } 1 \text { ano } \\
\text { De } 1 \text { a } 5 \text { anos } \\
\text { De } 6 \text { a } 10 \text { anos } \\
\text { De } 11 \text { a } 15 \text { anos } \\
\text { De } 16 \text { a } 20 \text { anos } \\
\text { De } 21 \text { a } 25 \text { anos } \\
\text { De } 26 \text { a } 30 \text { anos }\end{array}$ & $\begin{array}{c}36,8 \\
21,1 \\
5,3 \\
5,3 \\
5,3 \\
15,8 \\
10,5\end{array}$ & $\begin{array}{l}28,6 \\
28,6\end{array}$ & $\begin{array}{l}50,0 \\
16,7 \\
16,7\end{array}$ & $\begin{array}{l}66,7 \\
33,3\end{array}$ & $\begin{array}{l}16,7 \\
16,7 \\
33,3 \\
33,3\end{array}$ \\
\hline
\end{tabular}

Fonte: dados da pesquisa 


\subsubsection{1 (b) SECOMs na América Central e Caribe}

Os SECOMs situam-se nos seguintes países: Cuba, Jamaica, Nicarágua, República do Panamá, Trindade e Tobago, Haiti, República Dominicana e El Salvador. A tabela 08 mostra o percentual dos respondentes por área continental e cidade.

Tabela 08 - Percentual de respondentes dos SECOMs nos países por área continental América Central e Caribe

\begin{tabular}{c|l}
\hline Área continental & $\begin{array}{l}\text { País e cidade em que o SECOM se localiza e percentual de } \\
\text { respondentes }\end{array}$ \\
\hline & Cuba - Havana - 33,33\% \\
Jamaica - Kingston $-0 \%$ \\
Nicarágua - Manágua - $50 \%$ \\
RMÉRICA LATINA & República do Panamá - Panamá - 100\% \\
& El Salvador - San Salvador - 100\% \\
& Trindade e Tobago - Port of Spain - $0 \%$ \\
& Haiti - Porto Príncipe - 100\% \\
& República Dominicana - São Domingos - $100 \%$ \\
\hline
\end{tabular}

Fonte: dados da pesquisa

No que se refere às características demográficas dos respondentes dos SECOMs da América Central e Caribe, todas são mulheres com ensino superior e $50 \%$ já concluíram o mestrado; maior concentração da idade entre 30 a 49 anos e têm até 5 anos de tempo de serviço. Quanto à nacionalidade, 40\% são brasileiras, como pode ser visto na tabela 09.

Tabela 09 - Características socioprofissionais dos colaboradores dos SECOMs por continente e área continental - América Central e Caribe

\begin{tabular}{lc}
\hline Características & América Central e Caribe (América Latina) \\
\hline Mulheres & 100 \\
\hline Escolaridade (\%) & \\
\hline Ensino Superior & 40 \\
Especialização & 10 \\
Mestrado & 50 \\
\hline ldade (\%) & \\
\hline De 20 a 29 anos & 30 \\
De 30 a 39 anos & 40 \\
De 40 a 49 anos & 30 \\
\hline Tempo de casa (\%) & \\
\hline Menos de 1 ano & 40 \\
De 1 a 5 anos & 50 \\
De 11 a 15 anos & 10 \\
\hline
\end{tabular}

Fonte: dados da pesquisa 


\subsubsection{1 (c) SECOMs na América do Norte}

A tabela 10 mostra a distribuição dos SECOMs entre países e cidades do continente, bem como o percentual de respondentes da pesquisa.

Tabela 10 - Percentual de respondentes dos SECOMs nos países por área continental América do Norte

\begin{tabular}{|c|c|}
\hline Área continental & $\begin{array}{l}\text { País e cidade em que o SECOM se localiza e percentual de } \\
\text { respondentes }\end{array}$ \\
\hline $\begin{array}{l}\text { AMÉRICA ANGLO- } \\
\text { SAXÔNICA }\end{array}$ & $\begin{array}{l}\text { Estados Unidos - Atlanta - } 100 \% \\
\text { Estados Unidos - Chicago - } 75 \% \\
\text { Estados Unidos - Houston - } 75 \% \\
\text { Estados Unidos - Los Angeles - 100\% } \\
\text { Estados Unidos - Miami - 100\% } \\
\text { Estados Unidos - Nova York - 100\% } \\
\text { Estados Unidos - São Francisco - 0\% } \\
\text { Estados Unidos - Washington - 100\% } \\
\text { Canadá - Montreal - 100\% } \\
\text { Canadá - Vancouver - 50\% } \\
\text { Canadá - Toronto - 100\% }\end{array}$ \\
\hline AMÉRICA LATINA & México - México - 33,33\% \\
\hline
\end{tabular}

Fonte: dados da pesquisa

Em relação às características demográficas dos respondentes dos SECOMs da América do Norte, quase $70 \%$ são mulheres com ensino superior e $34,3 \%$ já concluíram o mestrado; quanto à idade, observa-se uma amplitude que vai de 20 anos até pessoas com mais de 60 anos e tempo de casa variando entre menos de um ano $(25,7 \%)$ a mais de 30 anos $(11,4 \%)$. Quanto à nacionalidade, $91,4 \%$ são brasileiros. 
Tabela 11 - Características socioprofissionais dos colaboradores dos SECOMs por continente e área continental - América do Norte

\begin{tabular}{|c|c|c|c|}
\hline Características & $\begin{array}{c}\text { América do } \\
\text { Norte }\end{array}$ & $\begin{array}{l}\text { América Anglo- } \\
\text { Saxônica }\end{array}$ & América Latina \\
\hline \multicolumn{4}{|l|}{ Diversidade (\%) } \\
\hline $\begin{array}{l}\text { Homens } \\
\text { Mulheres }\end{array}$ & $\begin{array}{l}34,3 \\
65,7\end{array}$ & $\begin{array}{l}35,3 \\
64,7\end{array}$ & 100 \\
\hline \multicolumn{4}{|l|}{ Escolaridade (\%) } \\
\hline $\begin{array}{l}\text { Ensino Médio } \\
\text { Ensino Superior } \\
\text { Especialização } \\
\text { Mestrado } \\
\text { Doutorado }\end{array}$ & $\begin{array}{c}2,9 \\
\mathbf{5 7 , 1} \\
2,9 \\
34,3 \\
2,9 \\
\end{array}$ & $\begin{array}{c}2,9 \\
\mathbf{5 5 , 9} \\
2,9 \\
35,3 \\
2,9 \\
\end{array}$ & 100 \\
\hline \multicolumn{4}{|l|}{ Idade (\%) } \\
\hline $\begin{array}{l}\text { De } 20 \text { a } 29 \text { anos } \\
\text { De } 30 \text { a } 39 \text { anos } \\
\text { De } 40 \text { a } 49 \text { anos } \\
\text { De } 50 \text { a } 59 \text { anos } \\
\text { De } 60 \text { anos a mais }\end{array}$ & $\begin{array}{l}17,1 \\
31,4 \\
14,3 \\
14,3 \\
22,9 \\
\end{array}$ & $\begin{array}{l}14,7 \\
32,4 \\
14,7 \\
14,7 \\
23,5 \\
\end{array}$ & 100 \\
\hline \multicolumn{4}{|l|}{ Tempo de casa $(\%)$} \\
\hline $\begin{array}{l}\text { Menos de } 1 \text { ano } \\
\text { De } 1 \text { a } 5 \text { anos } \\
\text { De } 6 \text { a } 10 \text { anos } \\
\text { De } 11 \text { a } 15 \text { anos } \\
\text { De } 16 \text { a } 20 \text { anos } \\
\text { De } 21 \text { a } 25 \text { anos } \\
\text { De } 26 \text { a } 30 \text { anos } \\
\text { Acima de } 30 \text { anos }\end{array}$ & $\begin{array}{c}25,7 \\
37,1 \\
5,7 \\
5,7 \\
\\
8,6 \\
5,7 \\
11,4 \\
\end{array}$ & $\begin{array}{c}26,5 \\
38,2 \\
2,9 \\
5,9 \\
\\
8,8 \\
5,7 \\
11,8 \\
\end{array}$ & 100 \\
\hline
\end{tabular}

Fonte: dados da pesquisa

\subsubsection{1 (d) SECOMs na América do Sul}

A tabela 12 mostra a distribuição dos SECOMs entre países e cidades do continente, bem como o percentual de respondentes da pesquisa da América do Sul.

Tabela 12 - Percentual de respondentes dos SECOMs nos países por área continental América do Sul

\begin{tabular}{c|l}
\hline Área continental & País e cidade em que o SECOM se localiza e percentual de respondentes \\
\hline & Paraguai - Assunção - 100\% \\
& Colômbia - Bogotá - 100\% \\
AMÉRICA & Vengentina - Buenos Aires - 100\% \\
LATINA & Bolívia - La Paz - 100\% \\
& Peru - Lima - 100\% \\
& Uruguai - Montevidéu - 100\% \\
& Suriname - Paramaribo - 100\% \\
& Equador - Quito - 100\% \\
& Chile - Santiago - 100\% \\
\hline
\end{tabular}

Fonte: dados da pesquisa 
Dos colaboradores que participaram da pesquisa na América do Sul, $56,4 \%$ são mulheres e quase todos possuem ensino superior $(94,9 \%)$ e desses $23,1 \%$ têm mestrado. A idade média é bem ampla, variando de 25 anos (12,8\%) a acima de 60 anos (12,8\%), mas a concentração está entre 40 a 49 anos $(38,5 \%)$, têm em média um a cinco anos de tempo de serviço $(41,0 \%)$ e somente $33,3 \%$ possuem nacionalidade brasileira.

Tabela 13 - Características socioprofissionais dos colaboradores dos SECOMs por continente e área continental - América do Sul

\begin{tabular}{lc}
\hline Características & América do Sul (América Latina) \\
\hline Diversidade (\%) & \\
\hline Homens & 43,6 \\
Mulheres & 56,4 \\
\hline Escolaridade (\%) & \\
\hline Ensino Médio & 5,1 \\
Ensino Superior & 59,0 \\
Especialização & 12,8 \\
Mestrado & 23,1 \\
\hline Idade (\%) & \\
\hline De 20 a 29 anos & 12,8 \\
De 30 a 39 anos & 23,1 \\
De 40 a 49 anos & 38,5 \\
De 50 a 59 anos & 12,8 \\
De 60 anos a mais & 12,8 \\
\hline Tempo de casa (\%) & \\
\hline Menos de 1 ano & 10,3 \\
De 1 a 5 anos & 41,0 \\
De 6 a 10 anos & 10,3 \\
De 11 a 15 anos & 2,6 \\
De 16 a 20 anos & 12,8 \\
De 21 a 25 anos & 5,1 \\
De 26 a 30 anos & 5,1 \\
Acima de 30 anos & 12,8 \\
\hline
\end{tabular}

Fonte: dados da pesquisa 


\subsubsection{1 (e) SECOMs na Ásia}

A tabela 14 mostra a distribuição dos SECOMs entre países e cidades do continente, bem como o percentual de respondentes da pesquisa na Ásia.

Tabela 14 - Percentual de respondentes dos SECOMs nos países por área continental - Ásia

\begin{tabular}{|c|c|c|}
\hline \multirow{2}{*}{$\begin{array}{l}\text { Área continental } \\
\text { ÁSIA ORIENTAL }\end{array}$} & \multicolumn{2}{|c|}{ País e cidade em que o SECOM se localiza e percentual de respondentes } \\
\hline & Taiwan - Taipé - 100\% & China - Xangai $-100 \%$ \\
\hline & Japão - Tóquio - 100\% & China - Cantão - 0\% \\
\hline & & China - Pequim - $100 \%$ \\
\hline EXTREMO & \multicolumn{2}{|l|}{ Coreia do Sul - Seul - 100\% } \\
\hline ORIENTE & & \\
\hline \multirow[t]{6}{*}{ ORIENTE MÉDIO } & Turquia - Istambul - $100 \%$ & Irã - Teerã - 0\% \\
\hline & Líbano - Beirute - 100\% & Israel - Tel Aviv - 0\% \\
\hline & Turquia - Ancara - 100\% & Emirados Árabes Unidos - Abu Dhabi - \\
\hline & Arábia Saudita - Riade - 0\% & $0 \%$ \\
\hline & Síria - Damasco - 0\% & Jordânia - Amã - 0\% \\
\hline & Kuwait - Kuait - 0\% & Catar - Doha - 0\% \\
\hline \multirow{5}{*}{$\begin{array}{l}\text { SUDESTE } \\
\text { ASIÁTICO }\end{array}$} & Tailândia - Bangkok - 100\% & \multirow{5}{*}{$\begin{array}{l}\text { Indonésia - Jacarta - 100\% } \\
\text { Vietnam - Hanói - 33\% } \\
\text { Filipinas - Manila - 100\% }\end{array}$} \\
\hline & Malásia - Kuala Lumpur - & \\
\hline & $75 \%$ & \\
\hline & Cingapura - Cingapura - & \\
\hline & $100 \%$ & \\
\hline SUL DA ÁSIA & $\begin{array}{l}\text { Índia - Nova Délhi - 100\% } \\
\text { Índia - Mumbai - 0\% }\end{array}$ & Paquistão - Islamabad - 80\% \\
\hline
\end{tabular}

Fonte: dados da pesquisa 
Quanto ao sexo, a Ásia se diferencia dos demais continentes, contendo mais homens $(69,5 \%)$ do que mulheres nos postos de trabalho; todos possuem ensino superior e desses quase metade $(45,8)$ têm mestrado. Há maior concentração da idade entre 30 a 39 anos (33,95\%), o tempo de serviço apresenta grande amplitude, indo desde menos de um ano $(23,7 \%)$ a acima de 30 anos $(6,8 \%)$; quase metade $(49,2 \%)$ possui nacionalidade brasileira, como pode ser visto na tabela 15 .

Tabela 15 - Características socioprofissionais dos colaboradores dos SECOMs por continente e área continental - Ásia

\begin{tabular}{|c|c|c|c|c|c|c|}
\hline Características & ÁSIA & $\begin{array}{c}\text { ÁSIA } \\
\text { ORIENTAL }\end{array}$ & $\begin{array}{l}\text { EXTREMO } \\
\text { ORIENTE }\end{array}$ & $\begin{array}{c}\text { ORIENTE } \\
\text { MÉDIO }\end{array}$ & $\begin{array}{l}\text { SUDESTE } \\
\text { ASIÁTICO }\end{array}$ & $\begin{array}{c}\text { SULL DA } \\
\text { ÁSIA }\end{array}$ \\
\hline \multicolumn{7}{|l|}{ Diversidade (\%) } \\
\hline Homens & 69,5 & 56,5 & 100,0 & 55,6 & 78,9 & 100 \\
\hline Mulheres & 30,5 & 43,5 & & 44,4 & 21,1 & \\
\hline \multicolumn{7}{|l|}{ Escolaridade (\%) } \\
\hline \multicolumn{7}{|l|}{ Ensino Médio } \\
\hline Ensino Superior & 50,8 & 69,6 & 50,0 & 44,4 & 42,1 & 16,7 \\
\hline Especialização & 1,7 & 30,4 & & 11,1 & & \\
\hline Mestrado & 45,8 & & 50,0 & 44,4 & 52,6 & 83,3 \\
\hline Doutorado & 1,7 & & & & 5,3 & \\
\hline \multicolumn{7}{|l|}{ Idade (\%) } \\
\hline $\begin{array}{l}\text { De } 20 \text { anos a } \\
\text { menos }\end{array}$ & 1,7 & 4,3 & & & & \\
\hline De 20 a 29 anos & 13,6 & 17,1 & & 22,2 & 5,3 & 16,7 \\
\hline De 30 a 39 anos & 33,9 & 34,7 & 50,0 & 22,2 & 36,8 & 33,3 \\
\hline De 40 a 49 anos & 25,5 & 21,7 & 50,0 & 22,2 & 31,6 & 16,7 \\
\hline De 50 a 59 anos & 18,7 & 8,7 & & 33,3 & 26,4 & 16,7 \\
\hline De 60 anos a mais & 6,8 & 13,0 & & & & 16,7 \\
\hline \multicolumn{7}{|c|}{ Tempo de casa (\%) } \\
\hline Menos de 1 ano & 23,7 & 13,0 & & 44,4 & 31,6 & 16,7 \\
\hline De 1 a 5 anos & 27,1 & 26,1 & 100,0 & 22,1 & 26,3 & 16,7 \\
\hline De 6 a 10 anos & 13,6 & 17,4 & & 11,1 & 5,3 & 33,3 \\
\hline De 11 a 15 anos & 18,7 & 21,7 & & & 15,8 & \\
\hline De 16 a 20 anos & 1,7 & 4,3 & & & 15,8 & \\
\hline De 21 a 25 anos & 1,7 & 4,3 & & 11,1 & & 16,7 \\
\hline De 26 a 30 anos & 8,5 & & & & 5,3 & 16,7 \\
\hline Acima de 30 anos & 6,8 & 13,0 & & 11,1 & & \\
\hline
\end{tabular}

Fonte: dados da pesquisa 


\subsubsection{1(f) SECOMs na Europa}

A tabela 16 mostra a distribuição dos SECOMs entre países e cidades do continente, bem como o percentual de respondentes da pesquisa nos SECOMs da Europa.

Tabela 16 - Percentual de respondentes dos SECOMs nos países por área continental Europa

\begin{tabular}{c|ll}
\hline Área continental & \multicolumn{2}{l}{ País e cidade em que o SECOM se localiza e percentual de respondentes } \\
\hline EUROPA & Ucrânia - Kiev - 100\% & Sérvia - Belgrado - 100\% \\
CENTRO- & Eslovênia - Liubliana - 100\% & Rep. Checa - Praga - 100\% \\
ORIENTAL & Hungria - Budapeste - 100\% & Rússia - Moscou - 80\% \\
& Eslováquia - Bratislava - 100\% & Polônia - Varsóvia - 33\% \\
& Suíça - Berna - 0\% & \\
\hline EUROPA & Grécia - Atenas - 100\% & Itália - Milão - 100\% \\
MERIDIONAL & Espanha - Madri - 83\% & Itália - Roma - 44\% \\
& Espanha - Barcelona - 20\% & Portugal - Lisboa - 83\% \\
EUROPA & França - Paris - 100\% & Países Baixos - Haia - 33\% \\
OCIDENTAL & Bélgica - Bruxelas - 100\% & Países Baixos - Roterdã - 0\% \\
& Alemanha - Berlim - 100\% & Áustria - Viena - 100\% \\
& Alemanha- Frankfurt - 20\% & Reino Unido - Londres - 100\% \\
\hline EUROPA & Irlanda - Dublin - 50\% & \\
\hline SETENTRIONAL & Nuécia - Estocolmo - 100\% & Finlândia - Helsinki - 50\% \\
\hline
\end{tabular}

Fonte: dados da pesquisa 
O número de homens $(48,8 \%)$ e de mulheres $(51,2 \%)$ é praticamente o mesmo nos SECOMs da Europa, quase todos possuem ensino superior $(90,5 \%)$ e desses $34,5 \%$ têm mestrado e $7,1 \%$, doutorado. Observa-se uma concentração da idade média entre 50 a 59 anos $(28,6 \%)$ e acima de 60 anos (19,0\%); em relação ao tempo de trabalho nos Setores de Promoção Comercial, 42,8\% têm de zero a cinco anos de casa e quase $74 \%$ são brasileiros, como pode ser visto na tabela 17 .

Tabela 17 - Características socioprofissionais dos colaboradores dos SECOMs por continente e área continental - Europa

\begin{tabular}{|c|c|c|c|c|c|}
\hline Características & EUROPA & $\begin{array}{l}\text { EUROPA } \\
\text { C. ORIENT }\end{array}$ & $\begin{array}{c}\text { EUROPA } \\
\text { MERIDIONAL } \\
\end{array}$ & $\begin{array}{c}\text { EUROPA } \\
\text { OCIDENTAL }\end{array}$ & $\begin{array}{c}\text { EUROPA } \\
\text { SETENTRIONAL }\end{array}$ \\
\hline \multicolumn{6}{|l|}{ Diversidade (\%) } \\
\hline Homens & 48,8 & 52,9 & 36,0 & 50,0 & 70,0 \\
\hline Mulheres & 51,2 & 47,1 & 64,0 & 50,0 & 30,0 \\
\hline \multicolumn{6}{|l|}{ Escolaridade (\%) } \\
\hline Ensino Médio & 9,5 & 5,9 & 16,0 & 9,4 & \\
\hline Ensino Superior & 46,4 & 41,2 & 48,0 & 37,5 & 80,0 \\
\hline Especialização & 2,4 & & 4,0 & 3,1 & \\
\hline Mestrado & 34,5 & 41,2 & 24,0 & 43,8 & 20,0 \\
\hline Doutorado & 7,1 & 11,8 & 8,0 & 6,3 & \\
\hline \multicolumn{6}{|l|}{ Idade (\%) } \\
\hline De 20 a 29 anos & 7,1 & 23,5 & & 6,3 & 10,0 \\
\hline De 30 a 39 anos & 23,8 & 35,3 & 20,0 & 18,8 & 30,0 \\
\hline De 40 a 49 anos & 21,4 & 17,7 & 28,0 & 25,1 & \\
\hline De 50 a 59 anos & 28,6 & 11,8 & 36,0 & 28,1 & 40,0 \\
\hline De 60 anos a mais & 19,0 & 11,8 & 16,0 & 21,9 & 30,0 \\
\hline \multicolumn{6}{|c|}{ Tempo de casa (\%) } \\
\hline Menos de 1 ano & 10,7 & 23,5 & 4,0 & 12,5 & \\
\hline De 1 a 5 anos & 32,1 & 58,8 & 20,0 & 28,1 & 30,0 \\
\hline De 6 a 10 anos & 8,3 & & 16,0 & 9,4 & \\
\hline De 11 a 15 anos & 10,7 & & 8,0 & 12,5 & 30,0 \\
\hline De 16 a 20 anos & 8,4 & & 12,0 & 9,4 & 10,0 \\
\hline De 21 a 25 anos & 2,4 & & 8,0 & & \\
\hline De 26 a 30 anos & 8,4 & 11,8 & 4,0 & 9,4 & 30,0 \\
\hline Acima de 30 anos & 21,5 & 5,9 & 28,0 & 18,8 & \\
\hline
\end{tabular}

Fonte: dados da pesquisa 


\subsubsection{1 (g) SECOMs na Oceania}

A tabela 18 mostra a distribuição dos SECOMs entre países e cidades do continente, bem como o percentual de respondentes da pesquisa nos SECOMs da Oceania.

Tabela 18 - Percentual de respondentes dos SECOMs nos países por área continental Oceania

\begin{tabular}{c|ll}
\hline Área continental & \multicolumn{3}{|l}{ País e cidade em que o SECOM se localiza e percentual de respondentes } \\
\hline Australásia & Austrália - Sidney $-100 \%$ & Nova Zelândia - Wellington - $0 \%$ \\
& Austrália - Camberra $-50 \%$ &
\end{tabular}

Fonte: dados da pesquisa

Dos colaboradores que participaram da pesquisa, todos são brasileiros natos com menos de um a cinco anos de tempo de serviço; no que se refere à escolaridade todos possuem ensino superior ( $75 \%$ com mestrado); a distribuição quanto ao sexo mostrouse igualitária (50,0\%); e idade média varia de 25 a 29 anos (25\%) e de 30 a 39 anos $(75 \%)$.

Tabela 19 - Características socioprofissionais dos colaboradores dos SECOMs por continente e área continental - Oceania

\begin{tabular}{lc}
\hline Características & Oceania (Australásia) \\
\hline Diversidade (\%) & \\
\hline Homens & 50,0 \\
Mulheres & 50,0 \\
\hline Escolaridade (\%) & \\
\hline Ensino Superior & 25,0 \\
Mestrado & 75,0 \\
\hline ldade (\%) & \\
\hline De 20 a 29 anos & 25,0 \\
De 30 a 39 anos & 75,0 \\
\hline Tempo de casa (\%) & \\
\hline Menos de 1 ano & 50,0 \\
De 1 a 5 anos & 50,0 \\
\hline
\end{tabular}

Fonte: dados da pesquisa

Com base nas análises univariadas até aqui apresentadas, pode-se descrever que o perfil predominante da amostra como sendo de colaboradores com as seguintes características: homens e mulheres na faixa etária 30 a 49 anos; alto nível educacional (graduação ou pós-graduação) e maioria com tempo de trabalho até 5 anos. 


\subsubsection{Análise descritiva das escalas}

Os construtos que compõem as dimensões dos valores e das práticas organizações, bem como as bases de comprometimento, foram medidos por meio de escalas. Para o mapeamento das variáveis estudadas, foram consideradas as médias e desviospadrão, coeficientes de variabilidade e medidas de assimetria e curtose obtidos nos oito fatores de valores, nos dois fatores de práticas organizacionais e nos sete fatores de comprometimento. Com isso, é possível realizar uma breve descrição dos resultados encontrados, por meio da estatística descritiva.

A finalidade em realizar a análise descritiva é explorar os dados de forma sistemática a fim de obter parâmetros para realizar uma análise prévia dos resultados encontrados. As medidas de tendência central (neste caso, foi utilizada a média) e as medidas de variabilidade (desvio-padrão e coeficiente de variação) fornecem resumos simples sobre o objeto de análise.

Nas tabelas a seguir, além das medidas descritivas, também há os percentuais das respostas em cada nível das escalas de seis pontos dos três instrumentos de pesquisa (valores, práticas e comprometimento) do DPR e dos SECOMs. Observa-se que o instrumento comprometimento foi aplicado somente nos SECOMs.

A normalidade de todas as variáveis foi analisada mediante os testes de KolmogorovSminorf e de Shapiro-Wilk (Hair et al., 2009), porém algumas das dimensões, quando analisadas por área continental, não apresentaram normalidade, mas quando examinadas somente por continentes a maioria foi significante à Análise de Variância (ANOVA) com teste de Tukey para não aditividade e teste $T$ ao quadrado de Hotelling. A falta de normalidade em algumas das dimensões, quando analisadas por área continental, foi o motivo para a escolha do método estatístico PLS-SEM para a fase da análise multidimensional nas organizações locais, conforme mencionado no capítulo que trata da metodologia.

\subsubsection{Análise descritiva das escalas - Valores Organizacionais}

A tabela 20 (páginas 219 a 224) apresenta as variáveis das sete dimensões dos Valores organizacionais. A escala de seis pontos atribuída a cada item teve uma variação de 1 (não se parece em nada) até 6 (é muito parecida) cujo objetivo foi medir a similaridade de valores reconhecidos nas suas organizações. A dimensão de valor 
com maior percepção de similaridade tanto para o DPR $(\mu=5,159)$ como para os SECOMs $(\mu=5,0)$ foi conformidade.

$\mathrm{Na}$ dimensão conformidade, cuja intenção é aferir se valores correspondentes à importância dada pela organização ao respeito às regras e modelos de comportamento fazem parte dela, o item $V_{\mathrm{c} 04}$ (o respeito à hierarquia faz parte desta organização, para ela a hierarquia deve ser respeitada pelos seus colaboradores) apresentou a maior média $(\mu=5,63)$ e coeficiente de variação médio $(C V=0,15)$ nos SECOMs, mostrando concordância deste valor nos Setores de Promoção Comercial. No DPR, este mesmo item ( $\left.\mathrm{V}_{\mathrm{C} 04}\right)$ foi o que obteve a maior média dos sete itens que compõem a dimensão conformidade e coeficiente de variabilidade menor que 0,30 ( $\mu$ $=5,43 ; \mathrm{CV}=0,18)$.

$\mathrm{Na}$ dimensão prestígio, que objetiva verificar se valores relativos a admiração e respeito da sociedade por causa da qualidade dos seus serviços estão presentes na organização, o item VP04 (esta organização tem influência na sociedade local, ela acha importante ser respeitada por todos) foi o que obteve maior média $(\mu=5,01)$ e coeficiente de variabilidade menor que $0,30(C V=0,20)$ no $D P R$, mostrando certo grau de homogeneidade da variância em torno da média. Aliás, esta dimensão também se mostrou importante nos resultados dos SECOMs $(\mu=4,664-$ segunda maior média) e tem como significado a concordância entre ser mais ou menos parecida com a organização em que trabalha.

Além da identificação da dimensão prestígio, outra dimensão que se mostrou relevante foi a dimensão tradição, indicando que a ênfase da organização para manter o status quo, por meio da promoção da preservação e do respeito a usos, costumes e das práticas organizacionais, é percebida pelos colaboradores do DPR $(\mu=4,914)$ como parecida com a organização (aproximadamente 5 na escala de seis pontos). No DPR, o item que mais se destacou desta dimensão foi $\bigvee_{\text {T02 }}$ (esta organização preserva os costumes antigos; ela respeita a tradição) com o coeficiente de variação de 0,19, indicando certo grau de homogeneidade da variância em torno da média, que foi de 4,94. Esta dimensão foi a que teve a terceira maior média quando se avaliam os resultados dos SECOMs $(\mu=4,516)$ e, semelhantemente ao DPR, o item $V_{\text {T02 }}(\mu=$ 5,80; $C V=0,23)$ foi o que obteve maior concordância quanto à percepção de ser parecida com a organização em que trabalha, quando se trata de preservar costumes antigos por respeitar a tradição. 
Algumas dimensões revelaram ordem de importância intermediária com médias oscilando entre 4,4 a 4,0 , como foi o caso das dimensões coletividade $(\mu=4,457)$, realização $(\mu=4,271)$ e autonomia $(\mu=4,079)$ no DPR e das dimensões coletividade $(\mu=4,399)$, domínio $(4,330)$ e realização $(4,114)$ nos SECOMs.

Tanto no DPR quanto nos SECOMs, o item que mais se destacou na dimensão Preocupação com a Coletividade foi $\mathrm{V}_{\mathrm{PC} 03}$ (nesta organização se acredita no valor da honestidade, ela honra seus compromissos com as pessoas e organizações com as quais se relaciona), com média 4,99 e coeficiente de variação igual a 0,20 no DPR, e média 4,71 e coeficiente de variação igual a 0,26 nos SECOMs.

O mesmo item na dimensão Realização $\bigvee_{\mathrm{R} 02}$ (esta organização acha que é importante ser competente, ela quer demonstrar o quanto é capaz) obteve as maiores médias (DPR $\mu=4,90$; CV $=0,24$ e SECOMS $\mu=4,4$; CV $=0,29$ ), observando que os coeficientes de variação foram menores que 0,30 . E, da mesma forma, tanto o DPR como os SECOMs convergiram no item com menor média, a $V_{\mathrm{R} 04}$ (esta organização gosta de colaboradores que mostram as suas habilidades, ela procura desenvolver as competências dos seus colaboradores) com médias iguais a 3,57 e CV de 0,36 para o DPR, e 3,77 e CV de 0,38 para os SECOMs. Os coeficientes de variação mostraramse acima de 0,30 , evidenciando alto grau de dispersão em torno da média, ou seja, falta de homogeneidade da variância no item.

No DPR, a dimensão Autonomia, cuja ênfase está na criatividade, no desejo da organização de que os seus colaboradores tanto busquem suas próprias ideias e interesses intelectuais, se aperfeiçoando constantemente (autonomia intelectual), quanto busquem experiências afetivas positivas (autonomia afetiva), visando valorização dos seus desafios, obteve média igual a 4,049. $O$ item que mais se destacou foi $V_{A 07}$ que avalia, na percepção do respondente, desejo de que o colaborador tenha uma vida profissional variada, valorizando aqueles que têm experiências profissionais diferentes.

As dimensões que apresentaram médias entre 3,3 a 3,7 no DPR foram as dimensões domínio $(3,702)$ e bem-estar $(3,6)$, e nos SECOMs, autonomia $(3,714)$ e bem-estar $(3,395)$.

A dimensão Bem-estar mensura se a organização procura propiciar satisfação ao colaborador, atentando para a qualidade de vida no trabalho. $\mathrm{O}$ item $\mathrm{V}_{\mathbf{B} 01}$ (é muito 
importante para esta organização ajudar seus colaboradores, pois ela deseja cuidar do bem-estar deles) foi o que obteve maior média tanto no DPR $(\mu=4,13 ; \mathrm{CV}=0,31)$ quanto nos SECOMs ( $\mu=3,83 ; \mathrm{CV}=0,41)$, mas se observa que o coeficiente de variação é maior que 0,3 , o que apresenta uma certa falta de homogeneidade da variância em torno da média.

Em resumo, os valores aos quais se atribuem maiores similaridades foram conformidade, prestígio e tradição tanto na percepção dos colaboradores do DPR quanto dos colaboradores dos SECOMs. 
Tabela 20 - Medidas descritivas - VALORES ORGANIZACIONAIS

Dimensão Prestígio: avalia a busca, por parte da organização, de prestígio, admiração e respeito da sociedade por causa da qualidade dos seus serviços.

\begin{tabular}{|c|c|c|c|c|c|c|c|c|c|c|c|c|}
\hline \multirow{2}{*}{\multicolumn{2}{|c|}{ VARIÁVEIS }} & \multicolumn{6}{|c|}{ ESCALA (\%) } & \multirow{2}{*}{ Média } & \multirow{2}{*}{$\begin{array}{l}\text { Desvio- } \\
\text { Padrão }\end{array}$} & \multirow{2}{*}{$\begin{array}{l}\text { Coef. de } \\
\text { Variação }\end{array}$} & \multirow{2}{*}{ Assimetria } & \multirow{2}{*}{ Curtose } \\
\hline & & 1 & 2 & 3 & 4 & 5 & 6 & & & & & \\
\hline \multirow{2}{*}{$\begin{array}{lcc}\text { Esta organização } & \text { influencia } & \text { outras } \\
\text { organizações. Ela tem muito prestígio. } & \end{array}$} & $V_{P 01}-D P R$ & 2,9 & 1,4 & 4,3 & 30,0 & 34,3 & 27,1 & 4,73 & 1,128 & 0,24 & $-1,122$ & 1,981 \\
\hline & VP01 - SECOMS & 3,2 & 7,6 & 11,6 & 26,4 & 31,2 & 20,0 & 4,35 & 1,306 & 0,30 & $-0,678$ & $-0,115$ \\
\hline \multirow{2}{*}{$\begin{array}{l}\text { Esta organização tem prestígio na sociedade } \\
\text { local. }\end{array}$} & $V_{P 02}-D P R$ & - & 2,9 & 5,7 & 12,9 & 45,7 & 32,9 & 5,00 & 0,978 & 0,20 & $-1,148$ & 1,323 \\
\hline & VP02-SECOMs & 1,2 & 2,8 & 8,0 & 16,8 & 37,6 & 33,6 & 4,88 & 1,121 & 0,23 & $-1,097$ & 1,028 \\
\hline \multirow{2}{*}{$\begin{array}{l}\text { Esta organização tem prestígio. Ela oferece } \\
\text { produtos e serviços que são respeitados pela } \\
\text { sociedade local. }\end{array}$} & $V_{P 03}-D P R$ & - & 2,3 & 6,2 & 12,8 & 47,0 & 31,7 & 4,99 & 1,025 & 0,21 & $-0,780$ & 0,867 \\
\hline & $\mathrm{V}_{\mathrm{PO3}-\mathrm{SECOMS}}$ & 1,2 & 3,2 & 7,6 & 26,0 & 40,8 & 21,1 & 4,66 & 1,069 & 0,23 & $-0,890$ & 0,947 \\
\hline \multirow{2}{*}{$\begin{array}{l}\text { Esta organização tem influência na sociedade } \\
\text { local. Ela acha importante ser respeitada por } \\
\text { todos }\end{array}$} & $V_{P 04}-D P R$ & - & 2,9 & 4,3 & 17,1 & 40,0 & 35,7 & 5,01 & 0,985 & 0,20 & $-1,059$ & 1,072 \\
\hline & VP04-SECOMs & 0,8 & 4,0 & 5,2 & 23,2 & 40,4 & 26,4 & 4,78 & 1,071 & 0,22 & $-0,987$ & 1,030 \\
\hline
\end{tabular}

Dimensão Bem-estar: procura propiciar satisfação ao colaborador, atentando para a qualidade de vida no trabalho

\begin{tabular}{|c|c|c|c|c|c|c|c|c|c|c|c|c|}
\hline \multirow{2}{*}{\multicolumn{2}{|c|}{ VARIÁVEIS }} & \multicolumn{6}{|c|}{ ESCALA (\%) } & \multirow{2}{*}{ Média } & \multirow{2}{*}{$\begin{array}{l}\text { Desvio- } \\
\text { Padrão }\end{array}$} & \multirow{2}{*}{$\begin{array}{l}\text { Coef. de } \\
\text { Variação }\end{array}$} & \multirow{2}{*}{ Assimetria } & \multirow{2}{*}{ Curtose } \\
\hline & & 1 & 2 & 3 & 4 & 5 & 6 & & & & & \\
\hline \multirow{2}{*}{$\begin{array}{l}\text { É muito importante para esta Organização } \\
\text { ajudar seus colaboradores. Deseja cuidar do } \\
\text { bem-estar deles }\end{array}$} & $V_{B 01-D P R}$ & 4,3 & 2,9 & 27,1 & 22,9 & 27,1 & 15,7 & 4,13 & 1,296 & 0,31 & $-0,369$ & $-0,301$ \\
\hline & $\mathrm{V}_{\text {B01 }}-\mathrm{SECOMS}$ & 10,8 & 10,8 & 19,2 & 19,6 & 23,2 & 16,4 & 3,83 & 1,570 & 0,41 & $-0,303$ & $-0,955$ \\
\hline \multirow{2}{*}{$\begin{array}{l}\text { Esta organização oferece oportunidade de } \\
\text { diversão aos colaboradores, pois afetam os } \\
\text { colaboradores no sentido de terem mais } \\
\text { prazer no trabalho }\end{array}$} & $V_{B 02}-D P R$ & 27,1 & 12,9 & 20,0 & 18,6 & 8,6 & 12,9 & 3,07 & 1,714 & 0,56 & 0,295 & $-1,089$ \\
\hline & $\mathrm{V}_{\mathrm{B} 02}-\mathrm{SECOMS}$ & 26,0 & 16,4 & 17,6 & 21,6 & 14,0 & 4,4 & 2,94 & 1,544 & 0,53 & $-0,187$ & $-1,143$ \\
\hline \multirow{2}{*}{$\begin{array}{l}\text { Esta organização propõe atividades que dão } \\
\text { prazer ao colaborador. Na visão dela, é } \\
\text { importante o colaborador sentir-se satisfeito } \\
\text { consigo mesmo. }\end{array}$} & $V_{B 03}-D P R$ & 27,1 & 12,9 & 20,0 & 18,6 & 8,6 & 12,9 & 3,07 & 1,714 & 0,56 & 0,295 & $-1,089$ \\
\hline & V & 14,8 & 14,4 & 22,0 & 20,4 & 20,4 & 8,0 & 3,41 & 1,522 & 0,45 & $-0,073$ & $-1,023$ \\
\hline
\end{tabular}

Fonte: dados da pesquisa 
Tabela 20 - Medidas descritivas - VALORES ORGANIZACIONAIS

Dimensão autonomia: enfatiza a criatividade e o destaque no setor de atuação. Enfatiza o desejo de que os indivíduos busquem suas próprias ideias e interesses intelectuais, aperfeiçoando-se constantemente (autonomia intelectual) e o desejo de as pessoas buscarem experiências afetivas positivas (autonomia afetiva) visando valorização dos seus desafios.

\begin{tabular}{|c|c|c|c|c|c|c|c|c|c|c|c|c|}
\hline \multirow{2}{*}{\multicolumn{2}{|c|}{ VARIÁVEIS }} & \multicolumn{6}{|c|}{ ESCALA (\%) } & \multirow{2}{*}{ Média } & \multirow{2}{*}{$\begin{array}{l}\text { Desvio- } \\
\text { Padrão }\end{array}$} & \multirow{2}{*}{$\begin{array}{l}\text { Coef. de } \\
\text { Variação }\end{array}$} & \multirow{2}{*}{ Assimetria } & \multirow{2}{*}{ Curtose } \\
\hline & & 1 & 2 & 3 & 4 & 5 & 6 & & & & & \\
\hline \multirow{2}{*}{$\begin{array}{l}\text { Estímulo aos colaboradores a enfrentarem } \\
\text { desafios }\end{array}$} & $V_{A 01}-D P R$ & 5,7 & 5,7 & 24,3 & 17,1 & 28,6 & 18,6 & 4,13 & 1,424 & \multirow{2}{*}{$\begin{array}{l}0,34 \\
0,39\end{array}$} & -0.450 & -0.580 \\
\hline & $\mathrm{V}_{\mathrm{A} 01}$ - SECOMS & 10,0 & 10,4 & 15,2 & 24,8 & 27,2 & 12,4 & 3,86 & 1,492 & & -0.453 & -0.736 \\
\hline \multirow{2}{*}{$\begin{array}{l}\text { Estímulo ao sucesso profissional dos } \\
\text { colaboradores }\end{array}$} & $V_{A 02}-D P R$ & 2,9 & 2,9 & 22,9 & 20,0 & 35,7 & 15,7 & 4,30 & 1,232 & \multirow{2}{*}{$\begin{array}{l}0,29 \\
0,39\end{array}$} & -0.552 & -0.135 \\
\hline & $\mathrm{V}_{\mathrm{A} 02}-\mathrm{SECOMS}$ & 10,0 & 12,4 & 15,6 & 24,0 & 26,8 & 11,2 & 3,79 & 1,494 & & -0.383 & -0.842 \\
\hline \multirow{2}{*}{$\begin{array}{l}\text { Valorização de colaboradores que gostam de } \\
\text { se informar a respeito do trabalho. }\end{array}$} & $V_{A 03}-D P R$ & 7,1 & 5,7 & 18,6 & 25,7 & 31,4 & 11,4 & 4,03 & 1,362 & \multirow{2}{*}{$\begin{array}{l}0,34 \\
0,35\end{array}$} & -0.620 & -0.177 \\
\hline & VA03-SECOMs & 5,2 & 12,8 & 17,6 & 26,4 & 24,4 & 13,6 & 3,93 & 1,395 & & -0.318 & -0.716 \\
\hline \multirow{2}{*}{$\begin{array}{l}\text { Aperfeiçoamento como forma de melhorar a } \\
\text { qualidade de seus produtos e de seus } \\
\text { serviços. }\end{array}$} & $V_{A 04}-D P R$ & 2,9 & 10,0 & 18,6 & 12,9 & 32,9 & 22,9 & 4,31 & 1,420 & \multirow{2}{*}{$\begin{array}{l}0,33 \\
0,36\end{array}$} & -0.549 & $-0,741$ \\
\hline & $\mathrm{V}_{\mathrm{A} 04}-\mathrm{SECOMS}$ & 6,4 & 13,2 & 18,8 & 28,0 & 23,2 & 10,4 & 3,80 & 1,381 & & -0.284 & -0.686 \\
\hline \multirow{2}{*}{$\begin{array}{l}\text { Valorização de colaboradores que buscam } \\
\text { realização no trabalho, reconhecendo-os } \\
\text { quando têm objetivos profissionais. }\end{array}$} & $V_{A 05}-D P R$ & 4,3 & 5,7 & 21,4 & 24,3 & 22,9 & 21,4 & 4,20 & 1,379 & \multirow{2}{*}{$\begin{array}{l}0,33 \\
0,43\end{array}$} & -0.406 & $-0,496$ \\
\hline & $\mathrm{V}_{\mathrm{A} 05}-\mathrm{SECOMS}$ & 14,4 & 11,2 & 17,2 & 29,6 & 16,4 & 11,2 & 3,56 & 1,531 & & $-0,206$ & $-0,874$ \\
\hline \multirow{2}{*}{$\begin{array}{l}\text { A organização prioriza a criatividade, pois } \\
\text { gosta de ser original. }\end{array}$} & $V_{A 06}-D P R$ & 4,3 & 11,4 & 24,3 & 15,7 & 27,1 & 17,1 & 4,01 & 1,440 & \multirow{2}{*}{$\begin{array}{l}0,36 \\
0,41\end{array}$} & $-0,266$ & $-0,919$ \\
\hline & $\mathrm{V}_{\mathrm{A} 06}-\mathrm{SECOMS}$ & 12,9 & 12,4 & 25,7 & 24,5 & 18,5 & 6,0 & 3,41 & 1,415 & & $-0,124$ & $-0,787$ \\
\hline \multirow{2}{*}{$\begin{array}{l}\text { Desejo que o colaborador tenha uma vida } \\
\text { profissional variada, valorizando aqueles que } \\
\text { têm experiências profissionais diferentes }\end{array}$} & $V_{A 07}-D P R$ & 7,1 & 1,4 & 17,1 & 17,1 & 30,0 & 27,1 & 4,43 & 1,450 & \multirow{2}{*}{$\begin{array}{l}0,33 \\
0,38\end{array}$} & $-0,851$ & 0,060 \\
\hline & $\mathrm{V}_{\mathrm{A} 07}-\mathrm{SECOMS}$ & 8,4 & 15,2 & 15,6 & 30,4 & 22,0 & 8,4 & 3,68 & 1,407 & & $-0,290$ & $-0,760$ \\
\hline \multirow{2}{*}{$\begin{array}{l}\text { Estímulo aos colaboradores a serem criativos } \\
\text { e a desenvolverem produtos e serviços } \\
\text { originais. }\end{array}$} & $V_{A 08}-D P R$ & 7,6 & 6,1 & 19,5 & 24,2 & 31,6 & 11,0 & 4,13 & 1,263 & \multirow{2}{*}{$\begin{array}{l}0,31 \\
0,39\end{array}$} & $-0,635$ & $-0,188$ \\
\hline & $\mathrm{V}_{\mathrm{A} 08}$ - SECOMS & 7,6 & 16,4 & 18,4 & 28,4 & 20,0 & 9,2 & 3,64 & 1,405 & & $-0,171$ & $-0,802$ \\
\hline
\end{tabular}

Fonte: dados da pesquisa 
Tabela 20 - Medidas descritivas - VALORES ORGANIZACIONAIS (cont.)

Dimensão Conformidade: grau de importância dada pela organização ao respeito à regras e modelos de comportamento, tanto no ambiente de trabalho quanto no relacionamento com outras organizações. Valoriza o quanto a organização as boas maneiras, a cortesia, o respeito às regras de convivência, à correção e à hierarquia. O foco é a definição de limites das ações organizacionais e comportamento de seus membros.

\begin{tabular}{|c|c|c|c|c|c|c|c|c|c|c|c|c|}
\hline \multirow{2}{*}{\multicolumn{2}{|c|}{ VARIÁVEIS }} & \multicolumn{6}{|c|}{ ESCALA (\%) } & \multirow{2}{*}{ Média } & \multirow{2}{*}{$\begin{array}{l}\text { Desvio- } \\
\text { Padrão }\end{array}$} & \multirow{2}{*}{$\begin{array}{l}\text { Coef. de } \\
\text { Variação }\end{array}$} & \multirow{2}{*}{ Assimetria } & \multirow{2}{*}{ Curtose } \\
\hline & & 1 & 2 & 3 & 4 & 5 & 6 & & & & & \\
\hline \multirow{2}{*}{$\begin{array}{l}\text { Para esta organização é importante que os } \\
\text { colaboradores se comportem de forma } \\
\text { educada no ambiente de trabalho. Ela } \\
\text { acredita que as boas maneiras devem ser } \\
\text { praticadas. }\end{array}$} & $V_{\mathrm{CO} 1-D P R}$ & \multirow[b]{2}{*}{0,8} & \multirow{2}{*}{$\begin{array}{c}- \\
2,0\end{array}$} & \multirow{2}{*}{$\begin{array}{l}7,1 \\
4,0\end{array}$} & \multirow{2}{*}{$\begin{array}{c}5,7 \\
14,8\end{array}$} & 35,7 & 51,4 & 5,31 & 0,877 & 0,17 & $-1,331$ & 1,234 \\
\hline & VCO1-SECOMs & & & & & 37,6 & 59,2 & 5,09 & 1,010 & 0,20 & $-1,356$ & 2,202 \\
\hline \multirow{2}{*}{$\begin{array}{l}\text { Esta organização acha importante ter } \\
\text { modelos de comportamento definidos. } \\
\text { Colaboradores devem ter um jeito correto de } \\
\text { se comportar no trabalho }\end{array}$} & $\mathrm{V}_{\mathrm{CO} 2}-\mathrm{DPR}$ & \multirow[b]{2}{*}{1,2} & \multirow{2}{*}{$\begin{array}{l}1,4 \\
4,4\end{array}$} & \multirow{2}{*}{$\begin{array}{l}10,0 \\
9,6\end{array}$} & \multirow{2}{*}{$\begin{array}{l}21,4 \\
23,2\end{array}$} & \multirow{2}{*}{$\begin{array}{l}32,9 \\
39,6\end{array}$} & \multirow{2}{*}{$\begin{array}{l}34,3 \\
22,0\end{array}$} & \multirow{2}{*}{$\begin{array}{l}4,89 \\
4,62\end{array}$} & \multirow{2}{*}{$\begin{array}{l}1,043 \\
1,132\end{array}$} & \multirow{2}{*}{$\begin{array}{l}0,21 \\
0,25\end{array}$} & \multirow{2}{*}{$\begin{array}{l}-0,633 \\
-0,843\end{array}$} & \multirow{2}{*}{$\begin{array}{r}-0,410 \\
0,480\end{array}$} \\
\hline & VCO2 - SECOMs & & & & & & & & & & & \\
\hline \multirow{2}{*}{$\begin{array}{l}\text { Esta organização acredita que as regras são } \\
\text { importantes. Para ela, os colaboradores } \\
\text { deveriam obedecê-las. }\end{array}$} & $V_{\mathrm{CO} 3-D P R}$ & \multirow[b]{2}{*}{0,8} & \multirow{2}{*}{$\begin{array}{l}2,9 \\
0,8\end{array}$} & \multirow{2}{*}{$\begin{array}{l}2,9 \\
2,4\end{array}$} & \multirow{2}{*}{$\begin{array}{l}22,9 \\
15,6\end{array}$} & \multirow{2}{*}{$\begin{array}{l}41,4 \\
43,2\end{array}$} & \multirow{2}{*}{$\begin{array}{l}30,0 \\
37,2\end{array}$} & \multirow{2}{*}{$\begin{array}{l}4,93 \\
5,11\end{array}$} & \multirow{2}{*}{$\begin{array}{l}0,953 \\
0,903\end{array}$} & 0,19 & $-0,889$ & 0,977 \\
\hline & VсO3-SECOMs & & & & & & & & & 0,18 & $-1,346$ & 3,138 \\
\hline O respeito à hierarquia faz parte desta & $V_{\mathrm{CO} 4}-\mathrm{DPR}$ & 1,4 & 1,4 & 2,9 & 5,7 & 24,3 & 64,3 & 5,43 & 1,001 & 0,18 & $-2,386$ & 6,539 \\
\hline $\begin{array}{l}\text { organização. Para ela, a hierarquia deve ser } \\
\text { respeitada pelos seus colaboradores. }\end{array}$ & $\mathrm{V}_{\mathrm{CO} 4}-\mathrm{SECOMS}$ & 0,4 & 0,8 & 2,8 & 5,6 & 28,8 & 61,6 & 5,46 & 0,841 & 0,15 & $-2,069$ & 5,374 \\
\hline Esta organização acredita que a cortesia é & $V_{\cos }-\mathrm{DPR}$ & & - & 7,1 & 11,4 & 37,1 & 44,3 & 5,19 & 0,906 & 0,17 & $-0,984$ & 0,240 \\
\hline $\begin{array}{l}\text { Importante. Para ela, as boas manelras } \\
\text { fazem parte do relacionamento entre os } \\
\text { colaboradores e as organizações }\end{array}$ & $V_{C O 5}-S E C O M s$ & 1,6 & 2,4 & 6,0 & 13,6 & 46,8 & - & 5,29 & 1,067 & 0,20 & $-1,385$ & 2,296 \\
\hline Nesta organização as regras de convivência & Vco6-DPR & 0,4 & 0,8 & 2,8 & 3,9 & 37,8 & 54,3 & 4,89 & 1,234 & 0,25 & $-1,456$ & 1,098 \\
\hline $\begin{array}{l}\text { são consideradas importantes. Para ela, os } \\
\text { colaboradores, a sociedade e as demais } \\
\text { instituições deveriam respeitá-las }\end{array}$ & VcO6-SECOMs & 1,2 & 1,6 & 4,0 & 26,4 & 41,6 & - & 4,81 & 0,990 & 0,21 & $-1,016$ & 1,865 \\
\hline Esta organização acredita que os & $V_{\mathrm{CO} 7}-\mathrm{DPR}$ & - & 0,8 & 1,4 & 14,1 & 51,9 & 31,8 & 5,02 & 1,321 & 0,26 & $-0,329$ & 0,444 \\
\hline $\begin{array}{l}\text { colaboradores devem aceitar o trabalho que } \\
\text { têm a fazer. Para ela os colaboradores } \\
\text { devem cumprir suas obrigações. }\end{array}$ & $\mathrm{V}_{\mathrm{CO} 7}-\mathrm{SECOMS}$ & - & 0,4 & 2,0 & 14,0 & 49,2 & 34,4 & 5,15 & 0,761 & 0,15 & $-0,759$ & 0,791 \\
\hline
\end{tabular}

Fonte: dados da pesquisa 
Tabela 20 - Medidas descritivas - VALORES ORGANIZACIONAIS

(cont.)

Dimensão Preocupação com a Coletividade: valoriza a igualdade, justiça. Lealdade, honestidade e sinceridade nas práticas organizacionais e no relacionamento com todos os indivíduos, os setores organizacionais, a coletividade organizacional, os clientes e os fornecedores

\begin{tabular}{|c|c|c|c|c|c|c|c|c|c|c|c|c|}
\hline \multirow{2}{*}{\multicolumn{2}{|c|}{ VARIÁVEIS }} & \multicolumn{6}{|c|}{ ESCALA (\%) } & \multirow{2}{*}{ Média } & \multirow{2}{*}{$\begin{array}{l}\text { Desvio- } \\
\text { Padrão }\end{array}$} & \multirow{2}{*}{$\begin{array}{l}\text { Coef. de } \\
\text { Variação }\end{array}$} & \multirow{2}{*}{ Assimetria } & \multirow{2}{*}{ Curtose } \\
\hline & & 1 & 2 & 3 & 4 & 5 & 6 & & & & & \\
\hline \multirow{2}{*}{$\begin{array}{l}\text { 7Encoraja a sinceridade entre as pessoas, } \\
\text { pois ser verdadeiro com os outros é importante } \\
\text { para a organização. }\end{array}$} & $\mathrm{V}_{\mathrm{PC} 01}-\mathrm{DPR}$ & 4,3 & 7,1 & 28,6 & 15,7 & 25,7 & 18,6 & 4,07 & 1,407 & \multirow{2}{*}{$\begin{array}{l}0,35 \\
0,35\end{array}$} & $-0,259$ & $-0,802$ \\
\hline & VPC01 - SECOMs & 7,6 & 8,0 & 12,8 & 20,8 & 33,2 & 17,6 & 4,17 & 1,466 & & $-0,695$ & $-0,406$ \\
\hline \multirow{2}{*}{$\begin{array}{l}\text { Nesta organização todas as pessoas devem } \\
\text { ser tratadas com igualdade e merecem ter } \\
\text { oportunidades iguais. }\end{array}$} & $\mathrm{V}_{\mathrm{PCO} 2}-\mathrm{DPR}$ & 18,6 & 8,6 & 25,7 & 17,1 & 14,3 & 15,7 & 3,47 & 1,674 & \multirow{2}{*}{$\begin{array}{l}0,48 \\
0,40\end{array}$} & $-0,006$ & $-1,085$ \\
\hline & $\mathrm{V}_{\mathrm{PCO} 2}-\mathrm{SECOMS}$ & 11,2 & 9,6 & 16,0 & 20,8 & 26,8 & 15,6 & 3,89 & 1,563 & & $-0,437$ & $-0,855$ \\
\hline \multirow{2}{*}{$\begin{array}{l}\text { Nesta organização se acredita no valor da } \\
\text { honestidade. Honra seus compromissos com } \\
\text { as pessoas e organizações com as quais se } \\
\text { relaciona. }\end{array}$} & $\mathrm{V}_{\mathrm{PCO}}-\mathrm{DPR}$ & 1,4 & - & 5,7 & 17,1 & 42,9 & 32,9 & 4,99 & 0,985 & \multirow{2}{*}{$\begin{array}{l}0,20 \\
0,26\end{array}$} & $-1,281$ & 2,740 \\
\hline & $\mathrm{VPCO}_{\mathrm{PC}}-\mathrm{SECOMS}$ & 2,8 & 4,0 & 8,8 & 16,0 & 40,4 & 28,0 & 4,71 & 1,234 & & $-1,142$ & 0,976 \\
\hline \multirow{2}{*}{$\begin{array}{l}\text { Esta organização se importa que as pessoas } \\
\text { sejam tratadas de maneira justa e que os } \\
\text { direitos dos outros sejam respeitados. }\end{array}$} & VPCO4-DPR & 2,9 & - & 24,3 & 15,7 & 35,7 & 21,4 & 4,46 & 1,236 & \multirow{2}{*}{$\begin{array}{l}0,28 \\
0,34\end{array}$} & $-0,610$ & $-0,085$ \\
\hline & $\mathrm{V}_{\mathrm{PCO} 4}-\mathrm{SECOMS}$ & 7,2 & 5,6 & 12,0 & 20,4 & 30,8 & 24,0 & 4,34 & 1,467 & & $-0,804$ & $-0,172$ \\
\hline \multirow{2}{*}{$\begin{array}{l}\text { Esta organização acredita que a pessoa deve } \\
\text { ser honesta em qualquer situação. Dizer a } \\
\text { verdade faz parte dos princípios dessa } \\
\text { organização }\end{array}$} & VPC05-DPR & 0,7 & 0,7 & 5,0 & 18,1 & 42,6 & 32,9 & 4,76 & 1,357 & \multirow{2}{*}{$\begin{array}{l}0,29 \\
0,24\end{array}$} & $-0,897$ & -0.651 \\
\hline & VPC05 - SECOMs & 1,6 & 3,6 & 7,6 & 23,6 & 38,4 & 25,2 & 4,69 & 1,132 & &,- 961 & 0,893 \\
\hline \multirow{2}{*}{$\begin{array}{l}\text { Esta organização considera a lealdade } \\
\text { importante. Ela é leal às pessoas e } \\
\text { organizações próximas dela. }\end{array}$} & $\mathrm{VPCO6}_{\mathrm{PC}}-\mathrm{DPR}$ & 1,5 & 2,0 & 12,1 & 25,8 & 36,4 & 22,2 & 4,88 & 1,241 & 0,25 & $-0,968$ & \multirow{2}{*}{$\begin{array}{l}0,876 \\
0,826\end{array}$} \\
\hline & VPc06-SECOMs & 2,0 & 4,4 & 8,8 & 22,8 & 41,6 & 20,4 & 4,59 & 1,156 & 0,25 & $-0,972$ & \\
\hline
\end{tabular}

Fonte: dados da pesquisa 
Tabela 20 - Medidas descritivas - VALORES ORGANIZACIONAIS

(cont.)

Dimensão Realização: avalia o sucesso baseado em demonstração de competência, da organização e dos seus colaboradores. $O$ foco é a valorização, por parte da organização, do planejamento e da competência coletiva e individual.

\begin{tabular}{|c|c|c|c|c|c|c|c|c|c|c|c|c|}
\hline \multirow{2}{*}{\multicolumn{2}{|c|}{ VARIÁVEIS }} & \multicolumn{6}{|c|}{ ESCALA (\%) } & \multirow{3}{*}{$\begin{array}{c}\text { Média } \\
3,96\end{array}$} & \multirow{3}{*}{$\begin{array}{c}\text { Desvio- } \\
\text { Padrão }\end{array}$} & \multirow{3}{*}{$\begin{array}{c}\text { Coef. de } \\
\text { Variação }\end{array}$} & \multirow{3}{*}{$\begin{array}{c}\text { Assimetria } \\
-0,444\end{array}$} & \multirow{3}{*}{$\begin{array}{c}\text { Curtose } \\
-0,614\end{array}$} \\
\hline & & \multirow{2}{*}{$\frac{1}{7,1}$} & \multirow{2}{*}{$\begin{array}{c}2 \\
8,6\end{array}$} & \multirow{2}{*}{\begin{tabular}{c|c}
3 \\
21,4
\end{tabular}} & \multirow{2}{*}{$\frac{4}{20,0}$} & \multirow{2}{*}{$\begin{array}{c}5 \\
30,0\end{array}$} & \multirow{2}{*}{\begin{tabular}{|c|}
6 \\
12,9
\end{tabular}} & & & & & \\
\hline Valoriza a competência, pois é importante que & $V_{R 01}-D P R$ & & & & & & & & & & & \\
\hline $\begin{array}{l}\text { o colaborador demonstre as habilidades e os } \\
\text { conhecimentos que possui. }\end{array}$ & $V_{R 01}-$ SECOMS & 8,4 & 9,2 & 11,6 & 21,2 & 30,4 & 19,2 & 4,14 & 1,517 & 0,37 & $-0,643$ & $-0,569$ \\
\hline Esta organização acha que é importante ser & $V_{R 02}-D P R$ & 2,9 & - & 10,0 & 14,3 & 37,1 & 35,7 & 4,90 & 1,169 & 0,24 & $-1,313$ & 1,919 \\
\hline $\begin{array}{l}\text { competente. Ela quer demonstrar o quanto é } \\
\text { capaz. }\end{array}$ & $\mathrm{V}_{\mathrm{R} 02}-\mathrm{SECOMS}$ & 3,6 & 6,0 & 10,4 & 23,2 & 37,2 & 19,6 & 4,43 & 1,282 & 0,29 & $-0,873$ & 0,298 \\
\hline Nesta organização é importante que os & $V_{R 03}-D P R$ & 7,1 & 4,3 & 10,0 & 25,7 & 31,4 & 21,4 & 4,34 & 1,413 & 0,33 & $-0,891$ & 0,256 \\
\hline $\begin{array}{l}\text { colaboradores conheçam bem o trabalho que } \\
\text { fazem. Ela reconhece os colaboradores } \\
\text { competentes. }\end{array}$ & VR03-SECOMS & 6,8 & 8,8 & 13.2 & 23,6 & 32,0 & 15,6 & 4,12 & 1,426 & 0,35 & $-0,640$ & $-0,408$ \\
\hline Esta organização gosta de colaboradores que & $V_{\mathrm{R} 04}-\mathrm{DPR}$ & 7,0 & 11,2 & 20,2 & 25,4 & 19,8 & 16,4 & 3,57 & 1,287 & 0,36 & $-0,450$ & $-0,556$ \\
\hline $\begin{array}{l}\text { mostram as suas habilidades. Ela procura } \\
\text { desenvolver as competências dos seus } \\
\text { colaboradores. }\end{array}$ & $\mathrm{V}_{\mathrm{R} 04}$-SECOMS & 7,2 & 12,4 & 22,4 & 26,4 & 17,2 & 14,4 & 3,77 & 1,440 & 0,38 & $-0,140$ & $-0,763$ \\
\hline Para esta organização planejar metas é & $V_{R 05}-D P R$ & 2,8 & 7,3 & 11,4 & 37,9 & 26,8 & 13,8 & 4,01 & 1,427 & 0,36 & $-0,240$ & $-0,579$ \\
\hline $\begin{array}{l}\text { essencial. Ela considera a realização das } \\
\text { metas uma prova de sua competência. }\end{array}$ & VR05-SECOMs & 3,2 & 8,4 & 14,0 & 36,4 & 24,8 & 13,2 & 4,11 & 1,239 & 0,30 & $-0,462$ & $-0,108$ \\
\hline
\end{tabular}

Fonte: dados da pesquisa 
Tabela 20 - Medidas descritivas - VALORES ORGANIZACIONAIS

(conc.)

Dimensão Tradição: ênfase da organização para manter o status quo, promovendo a preservação e o respeito a usos, costumes e práticas organizacionais.

\begin{tabular}{|c|c|c|c|c|c|c|c|c|c|c|c|c|}
\hline \multirow{2}{*}{\multicolumn{2}{|c|}{ VARIÁVEIS }} & \multicolumn{6}{|c|}{ ESCALA (\%) } & \multirow{3}{*}{$\begin{array}{c}\text { Média } \\
4,73\end{array}$} & \multirow{3}{*}{$\begin{array}{c}\begin{array}{c}\text { Desvio- } \\
\text { Padrão }\end{array} \\
1,128\end{array}$} & \multirow{3}{*}{$\begin{array}{c}\text { Coef. de } \\
\text { Variação }\end{array}$} & \multirow{3}{*}{$\begin{array}{c}\text { Assimetria } \\
-1,122\end{array}$} & \multirow{3}{*}{$\begin{array}{r}\text { Curtose } \\
1,981\end{array}$} \\
\hline & & \multirow{2}{*}{$\begin{array}{c}1 \\
2,9\end{array}$} & \multirow{2}{*}{$\frac{2}{1,4}$} & \multirow{2}{*}{$\begin{array}{c}3 \\
4,3\end{array}$} & \multirow{2}{*}{\begin{tabular}{c|}
4 \\
30,0
\end{tabular}} & \multirow{2}{*}{$\begin{array}{c}5 \\
34,3\end{array}$} & \multirow{2}{*}{\begin{tabular}{c|}
6 \\
27,1
\end{tabular}} & & & & & \\
\hline A tradição é uma marca desta & $V_{\text {T01 }}-\mathrm{DPR}$ & & & & & & & & & & & \\
\hline $\begin{array}{l}\text { Organização. Ela tem práticas que dão } \\
\text { continuidade aos seus costumes. }\end{array}$ & VT01 - SECOMs & & 9,2 & 8,8 & 22,0 & 33,6 & 24,8 & 4,51 & 1,293 & 0,29 & $-0,762$ & $-0,166$ \\
\hline Esta organização preserva os costumes & $\mathrm{V}_{\mathrm{T} 02}-\mathrm{DPR}$ & - & 1,4 & 5,7 & 22,9 & 37,1 & 32,9 & 4,94 & 0,961 & 0,19 & $-0,689$ & 0,074 \\
\hline & $\mathrm{V}_{\mathrm{TO2}}$ - SECOMS & 0,8 & 3,6 & 7,2 & 22,4 & 34,8 & 31,2 & 4,8 & 1,115 & 0,23 & $-0,904$ & 0,558 \\
\hline Esta organização evita mudanças. Ela & $\mathrm{V}_{\mathrm{T} 03}-\mathrm{DPR}$ & 10,0 & 10,0 & 15,7 & 28,6 & 21,4 & 14,3 & 3,84 & 1,500 & 0,39 & $-0,387$ & $-0,678$ \\
\hline $\begin{array}{l}\text { prefere manter a mesma forma de } \\
\text { trabalhar. }\end{array}$ & $\mathrm{V}_{\mathrm{T} 03-\mathrm{SECOMS}}$ & 2,0 & 7,6 & 18,8 & 30,0 & 21,6 & 20,8 & 4,24 & 1,289 & 0,30 & $-0,309$ & $-0,572$ \\
\hline Esta organização procura manter práticas & $\mathrm{V}_{\mathrm{T} 04}-\mathrm{DPR}$ & 5,7 & 4,3 & 17,1 & 28,6 & 31,4 & 12,9 & 4,14 & 1,300 & 0,31 & $-0,681$ & 0,149 \\
\hline $\begin{array}{l}\text { consagradas. Ela acredita que é importante } \\
\text { trabalhar sempre do mesmo modo. }\end{array}$ & VT04-SECOMs & 2,4 & 4,0 & 12,0 & 36,0 & 30,0 & 15,6 & 4,34 & 1,144 & 0,26 & $-0,614$ & 0,453 \\
\hline O comportamento do colaborador, nesta & $\mathrm{V}_{\mathrm{T} 05}-\mathrm{DPR}$ & - & 1,4 & 10,0 & 21,4 & 32,9 & 34,3 & 4,89 & 1,043 & 0,21 & $-0,633$ & $-0,410$ \\
\hline $\begin{array}{l}\text { organização, deve mostrar respeito aos } \\
\text { costumes. Para ela a tradição deve ser } \\
\text { preservada. }\end{array}$ & $\mathrm{V}_{\mathrm{T} 05}$ - SECOMs & 1,2 & 2,4 & 8,0 & 24,8 & 42,4 & 21,2 & 4,68 & 1,045 & 0,22 & $-0,912$ & 1,094 \\
\hline
\end{tabular}

preservada.

Dimensão Domínio: Enfatiza o sucesso organizacional. Congrega itens relativos a poder. Domínio do ambiente como forma de demonstrar controle, a partir de um posicionamento assertivo.

\begin{tabular}{|c|c|c|c|c|c|c|c|c|c|c|c|c|}
\hline \multirow{2}{*}{\multicolumn{2}{|c|}{ VARIÁVEIS }} & \multicolumn{6}{|c|}{ ESCALA (\%) } & \multirow{2}{*}{ Média } & \multirow{2}{*}{$\begin{array}{l}\text { Desvio- } \\
\text { Padrão }\end{array}$} & \multirow{2}{*}{$\begin{array}{l}\text { Coef. de } \\
\text { Variação }\end{array}$} & \multirow{2}{*}{ Assimetria } & \multirow{2}{*}{ Curtose } \\
\hline & & 1 & 2 & 3 & 4 & 5 & 6 & & & & & \\
\hline \multirow{2}{*}{$\begin{array}{l}\text { Esta organização considera a segurança } \\
\text { dos negócios muito importante. Ela está } \\
\text { atenta às ameaças do mercado }\end{array}$} & $V_{D 01}-D P R$ & 7,8 & 10,2 & 18,8 & 31,4 & 15,4 & 16,4 & 3,71 & 1,582 & 0,43 & $-0,562$ & 0,345 \\
\hline & VD01 - SECOMs & 3,2 & 5,2 & 9,2 & 36,4 & 29,6 & 16,4 & 4,33 & 1,198 & 0,28 & $-0,721$ & 0,509 \\
\hline
\end{tabular}

Fonte: dados da pesquisa 


\subsubsection{Análise descritiva das escalas - Tipos de Práticas Organizacionais}

A tabela 21 (páginas 228 e 229) apresenta as variáveis das duas dimensões das Práticas Organizacionais. A escala de seis pontos atribuída a cada item teve uma variação de 1 (não se parece em nada) até 6 (é muito parecida) e seu objetivo foi medir a similaridade humanista ou instrumental das práticas organizacionais sob a perspectiva dos gestores do DPR e dos respectivos gestores dos SECOMs. Aqui é importante ratificar que somente gestores (chefes das divisões do Departamento de Promoção Comercial do Ministério das Relações Exteriores e chefes dos Setores de Promoção Comercial dos Consulados brasileiros) foram os respondentes, isto significa que todos são brasileiros natos.

Na dimensão humanista, o propósito foi averiguar se o ambiente em que os modelos de práticas organizacionais vivenciadas na organização são focados nas pessoas como um fim nelas mesmas, visando qualidade de vida no trabalho por meio do bemestar delas e da comunidade. O item $\mathrm{P}_{\mathrm{H} 03}$ (nesta organização o colaborador é valorizado pelos seus próprios méritos) foi o que obteve maior concordância entre os respondentes das duas populações-alvo (DPR $\mu=4,50$; CV $=0,29$ e SECOMs $(\mu=$ $4,44 ; \mathrm{CV}=0,30)$. A meritocracia é um pressuposto das organizações públicas, especificamente, no caso das organizações brasileiras, desde a Constituição Federal de 1934 no seu artigo 170, quando pela primeira vez foi definido que o critério para o ingresso em cargos públicos seria por meio de concursos de provas e títulos. Esse princípio passou por profundas reformas no governo do Presidente Fernando Henrique Cardoso, com a criação do Ministério da Administração e Reforma (MARE), conduzido por Bresser Pereira, em que a melhora dos serviços públicos passaria por seleções mais aprimoradas dos seus servidores, de constante avaliação do desempenho e de que a promoção em cargos gerenciais ocorreria por meio da capacitação (Abrucio, 2007). O item $\mathrm{P}_{\mathrm{H} 10}$ (nesta organização as pessoas são reconhecidas principalmente por sua lealdade) reforça esta percepção dos gestores (que são servidores públicos), pois as médias, além de convergirem, têm variabilidade abaixo de 0,30 (DPR $\mu=4,250$ CV = 0,12 e SECOMs $\mu=4,37$; CV = 0,29). Outro item que pode estar associado a esta percepção é $\mathrm{P}_{\mathrm{H} 07}$ (nesta organização os colaboradores sempre são consultados a respeito das decisões importantes que os afetam), com média maior e variância menor no DPR do que nos SECOMs (DPR $\mu=$ $4,5 \mathrm{CV}=021$ e SECOMs $\mu=4,11$; CV =0,36). Uma análise prévia da alta variabilidade 
nas respostas deste item nos SECOMs talvez seja pela subordinação que estes têm ao DPR, a gestora.

Todos os demais itens desta dimensão ficaram entre 2 e 3 na escala de respostas. Também foram observadas divergências entre as duas populações-alvo no item $\mathrm{P}_{\mathrm{H} 02}$ (esta organização é vista como um meio para as pessoas alcançarem seus objetivos); os servidores do DPR têm uma percepção mais pessimista $(\mu=2,75 \mathrm{CV}=0,55)$ do que os servidores localizados nos SECOMs $(\mu=3,27 \mathrm{CV}=0,43)$.

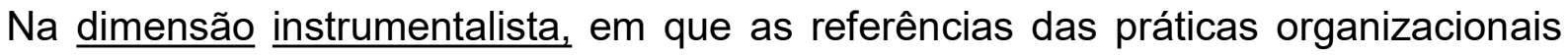
vivenciadas na organização são focadas nos resultados, onde as pessoas são vistas como meios para um fim com relações de contrato de trabalho claras e específicas, buscou-se avaliar qual é a percepção dos dirigentes quanto a essas práticas. Nos itens $\mathrm{P}_{103}, \mathrm{P}_{104}$ e $\mathrm{P}_{105}$ as médias das duas populações-alvo foram acima de 4,00 e quase todas com variabilidades (CV) abaixo de 30\%. Nestes itens, o foco está na visão de que são os resultados a principal razão da existência da organização e que os resultados planejados devem ser alcançados. Esta visão converge com princípios da Nova Gestão Pública (NGP), cujo pressuposto é a gestão por resultados, por meio da eficiência (resultados planejados, recursos e processos flexíveis) e accountability transparência dos indicadores de resultados e das metas permitindo controle e sanções mais inequívocas (Abrucio, 2007; Gomes, 2015).

O item $\mathrm{P}_{102}$ (o colaborador desta organização é visto primordialmente como um instrumento de alcance dos objetivos organizacionais) foi o que teve maior distanciamento nas respostas das duas populações, pois para o DPR $(\mu=3,25$; CV = $0,46)$ esta percepção é menos similar à realidade que vivem no ambiente de trabalho do que para os SECOMs ( $\mu=4,28 ; C V=0,33)$. Entre as possibilidades para esta divergência, talvez esteja a forma como os SECOMs são comunicados das suas tarefas, muitas vezes por meio de "despachos telegráficos - DESPTEL", ou a própria distância física destes com a organização nacional.

Em resumo, tanto o DPR quanto os SECOMs apresentam médias maiores na dimensão instrumental do que na humanista. Por se tratar da mesma organização (MRE), mas localizada em países diferentes e pelo fato dos respondentes deste instrumento em específico serem servidores (brasileiros natos), esses fatores podem ter influenciado na leve tendência mais instrumental de suas práticas organizacionais. 


\section{TIPOS DE PRÁTICAS ORGANIZACIONAIS}

(cont.)

ssoas como meios para um fim. O gestor dirige e controla a execução das tarefas que são direcionais para resultados. as e específicas quanto à eficácia do trabalhador para o alcance dos objetivos da organização. Busca qualidade de propiciar ambiente melhor para produzir mais. A ênfase está nas competências do trabalhador e o pagamento dos.

\begin{tabular}{|c|c|c|c|c|c|c|c|c|c|c|c|c|}
\hline & \multicolumn{6}{|c|}{ ESCALA (\%) } & \multirow{2}{*}{ Média } & \multirow{2}{*}{$\begin{array}{l}\text { Desvio- } \\
\text { Padrão }\end{array}$} & \multirow{2}{*}{$\begin{array}{l}\text { Coef. de } \\
\text { Variação }\end{array}$} & \multirow{2}{*}{ Assimetria } & \multirow{2}{*}{ Curtose } \\
\hline & & 1 & 2 & 3 & 4 & 5 & 6 & & & & & \\
\hline \multirow{2}{*}{$\begin{array}{l}\text { ente um } \\
\text { recursos }\end{array}$} & $P_{101}-D P R$ & 25,0 & 25,0 & - & 25,0 & - & - & 2,75 & 1,500 & 0,55 & $-0,370$ & $-3,901$ \\
\hline & PIO1 - SECOMS & 14,4 & 15,9 & 27,4 & 16,4 & 15,4 & 10,4 & 3,34 & 1,535 & 0,46 & 0,137 & $-0,939$ \\
\hline \multirow{2}{*}{$\begin{array}{l}\text { é visto } \\
\text { alcance }\end{array}$} & $P_{102}-D P R$ & - & 50,0 & - & 25,0 & 25,0 & - & 3,25 & 1,500 & 0,46 & 0,371 & $-3,887$ \\
\hline & PIO2 - SECOMs & 8,0 & 3,0 & 12,4 & 24,4 & 33,8 & 18,4 & 4,28 & 1,401 & 0,33 & $-0,880$ & 0,200 \\
\hline \multirow[t]{2}{*}{ ado por } & $\mathrm{P}_{103}-\mathrm{DPR}$ & - & - & 50,0 & 25,0 & - & 25,0 & 4,00 & 1,414 & 0,35 & 1,404 & 1,500 \\
\hline & PI03-SECOMs & 7,0 & 1,5 & 15,4 & 34,8 & 27,9 & 13,4 & 4,15 & 1,281 & 0,31 & $-0,753$ & 0,489 \\
\hline \multirow[t]{2}{*}{ ante são } & $P_{104}-D P R$ & - & - & 25,0 & 50,0 & 25,0 & - & 4,0 & 0,826 & 0,21 & 0,000 & 1,500 \\
\hline & $\mathrm{PIO4}_{\mathrm{O}} \mathrm{SECOMS}$ & 7,0 & 5,5 & 6,5 & 28,4 & 42,3 & 10,4 & 4,25 & 1,303 & 0,31 & $-1,101$ & 0,703 \\
\hline \multirow[t]{2}{*}{ yerar os } & $P_{105}-D P R$ & - & - & 25,0 & 50,0 & - & 25,0 & 4,25 & 1,258 & 0,30 & 1,129 & 2,227 \\
\hline & $P_{105}$ - SECOMs & 8,0 & - & 9,0 & 40,3 & 31,8 & 10,9 & 4,21 & 1,235 & 0,29 & $-1,080$ & 1,349 \\
\hline \multirow[t]{2}{*}{ ção é a } & $P_{106}-D P R$ & - & - & 25,0 & 75,0 & - & - & 3,75 & 0,500 & 0,13 & $-2,00$ & 4,00 \\
\hline & PI06 - SECOMs & 4,0 & 5,5 & 16,4 & 40,8 & 27,9 & 5,5 & 4,00 & 1,116 & 0,28 & $-0,688$ & 0,562 \\
\hline \multirow{2}{*}{$\begin{array}{l}\text { nicar os } \\
\text { afetam. }\end{array}$} & $P_{107}-D P R$ & - & - & 25,0 & 75,0 & - & - & 3,75 & 0,500 & 0,13 & $-2,000$ & 4,000 \\
\hline & PI07 - SECOMs & 31,8 & 15,9 & 22,4 & 16,4 & 8,5 & 5,0 & 2,69 & 1,515 & 0,56 & 0,483 & $-0,783$ \\
\hline \multirow[t]{2}{*}{ ocupada } & $P_{108}-D P R$ & - & - & 25,0 & 75,0 & - & - & 3,75 & 0,500 & 0,13 & $-2,000$ & 4,000 \\
\hline & PI08 - SECOMs & 4,0 & 9,5 & 14,9 & 27,4 & 34,8 & 9,5 & 4,08 & 1,270 & 0,31 & $-0,624$ & $-0,227$ \\
\hline \multirow[t]{2}{*}{ hecidas } & $P_{109}-D P R$ & - & - & 33,3 & 66,7 & - & - & 3,67 & 0,577 & 0,16 & $-1,732$ & 0,502 \\
\hline & PIO9 - SECOMS & 11,9 & 6,5 & 18,4 & 28,4 & 26,9 & 8,0 & 3,76 & 1,434 & 0,38 & $-0,520$ & $-0,538$ \\
\hline nesta & $P_{110}-D P R$ & 25,0 & - & 75,0 & - & - & - & 2,50 & 1,00 & 0,40 & $-2,000$ & 4,000 \\
\hline
\end{tabular}


Tabela 21 - Medidas descritivas - TIPOS DE PRÁTICAS ORGANIZACIONAIS

(conc.)

Dimensão humanista: Visão das pessoas como um fim nelas mesmas. O gestor busca desenvolver o comprometimento das pessoas no trabalho, buscando o envolvimento delas bem como propiciando o aprimoramento do comprometimento moral. Visa a qualidade de vida no trabalho objetivando não só o bemestar das pessoas, mas, também, da comunidade.

\begin{tabular}{|c|c|c|c|c|c|c|c|c|c|c|c|c|}
\hline \multirow{2}{*}{\multicolumn{2}{|c|}{ VARIÁVEIS }} & \multicolumn{6}{|c|}{ ESCALA (\%) } & \multirow{3}{*}{$\begin{array}{c}\text { Média } \\
3,00\end{array}$} & \multirow{3}{*}{$\begin{array}{c}\text { Desvio- } \\
\text { Padrão } \\
0,816\end{array}$} & \multirow{3}{*}{$\begin{array}{c}\text { Coef. de } \\
\text { Variação }\end{array}$} & \multirow{3}{*}{$\begin{array}{c}\text { Assimetria } \\
0,000\end{array}$} & \multirow{3}{*}{$\begin{array}{r}\text { Curtose } \\
1,500\end{array}$} \\
\hline & & \multirow{3}{*}{$\begin{array}{c}1 \\
- \\
10,0\end{array}$} & \multirow{3}{*}{$\begin{array}{c}2 \\
25,0 \\
18,9\end{array}$} & \multirow{2}{*}{$\begin{array}{c}3 \\
50,0\end{array}$} & \multirow{2}{*}{$\begin{array}{c}4 \\
25,0\end{array}$} & \multirow{2}{*}{$\begin{array}{l}5 \\
-\end{array}$} & \multirow{2}{*}{$\frac{6}{-}$} & & & & & \\
\hline O principal objetivo desta organização & $P_{\mathrm{H} 01}-\mathrm{DPR}$ & & & & & & & & & & & \\
\hline é a satisfação dos seus colaboradores. & PH01 - SECOMS & & & 17,4 & 37,3 & 14,9 & 1,5 & 3,33 & 1,2262 & 0,37 & $-0,309$ & $-0,790$ \\
\hline Esta organização é vista como um & $\mathrm{P}_{\mathrm{H} 02}$ - DPR & & 25,0 & - & 50,0 & - & - & 2,75 & 1,500 & 0,55 & $-0,370$ & $-3,901$ \\
\hline $\begin{array}{l}\text { meio para as pessoas alcançarem } \\
\text { seus objetivos. }\end{array}$ & PHO2 - SECOMs & 17,4 & 10,9 & 21,9 & 30,8 & 14,9 & 4,0 & 3,27 & 1,417 & 0,43 & $-0,198$ & $-0,850$ \\
\hline Nesta organização o colaborador é & PH03 - DPR & - & - & 25,0 & 25,0 & 25,0 & 25,0 & 4,50 & 1,291 & 0,29 & 0,000 & $-1,200$ \\
\hline valorizado pelos seus próprios méritos. & $\mathrm{P}_{\mathrm{H} 03}-\mathrm{SECOMS}$ & 5,5 & 3,5 & 14,9 & 12,4 & 45,3 & 18,4 & 4,44 & 1,337 & 0,30 & $-1,019$ & 0,409 \\
\hline Para esta organização o fator mais & PH04-DPR & - & - & 25,0 & 75,0 & - & - & 3,75 & 0,500 & 0,13 & $-2,000$ & 4,000 \\
\hline importante são as pessoas. & $\mathrm{P}_{\mathrm{H} 04}$-SECOMS & 5,0 & 12,4 & 18,4 & 42,8 & 15,4 & 6,9 & 3,69 & 1,198 & 0,32 & $-0,319$ & $-0,115$ \\
\hline O ponto central desta organização é & $\mathrm{PH}_{\mathrm{H} 05}-\mathrm{DPR}$ & 25,0 & 50,0 & - & 25,0 & - & - & 2,25 & 1,258 & 0,56 & 1,129 & 2,227 \\
\hline beneficiar os seus membros. & PHO5 - SECOMS & 24,9 & 26,9 & 26,4 & 15,4 & 4,5 & 2,0 & 2,54 & 1,253 & 0,49 & 0,546 & $-0,256$ \\
\hline A principal preocupação desta & $P_{\text {H06 }}-\mathrm{DPR}$ & - & 33,3 & - & 66,7 & - & - & 3,33 & 1,155 & 0,35 & $-1,732$ & 1,225 \\
\hline organização é relativa às pessoas. & PHOG - SECOMS & 7,0 & 21,9 & 24,9 & 35,8 & 9,0 & 1,5 & 3,22 & 1,142 & 0,35 & $-0,124$ & $-0,549$ \\
\hline Nesta organização os colaboradores & $P_{H 07}-D P R$ & - & - & - & 75,0 & 25,0 & - & 4,50 & 1,000 & 0,22 & 2,000 & 4,000 \\
\hline $\begin{array}{l}\text { sempre são consultados a respeito das } \\
\text { decisões importantes que os afetam. }\end{array}$ & PH07 - SECOMs & 7,5 & 10,0 & 11,9 & 22,4 & 31,1 & 16,9 & 4,11 & 1,476 & 0,36 & $-0,624$ & $-0,538$ \\
\hline Esta organização é completamente & Рн08 - DPR & - & 25,0 & 50,0 & 25,0 & - & - & 3,00 & 0,816 & 0,27 & 0,000 & 1,500 \\
\hline & PH08 - SECOMS & 12,4 & 16,9 & 26,4 & 21,9 & 18,4 & 4,0 & 3,29 & 1,381 & 0,42 & $-0,025$ & $-0,861$ \\
\hline Esta organização é vista & PH09-DPR & - & 25,0 & 25,0 & - & 50,0 & - & 3,75 & 1,500 & 0,40 & $-0,370$ & $-3,901$ \\
\hline $\begin{array}{l}\text { principalmente como uma rede de } \\
\text { relações humanas. }\end{array}$ & PHO9 - SECOMS & 8,0 & 6,5 & 30,8 & 28,4 & 14,9 & 11,4 & 3,70 & 1,346 & 0,36 & $-0,113$ & $-0,367$ \\
\hline Nesta organização as pessoas são & $P_{\mathrm{H} 10}-\mathrm{DPR}$ & - & - & - & 75,0 & 25,0 & - & 4,25 & 0,500 & 0,12 & 2,000 & 4,000 \\
\hline $\begin{array}{l}\text { reconhecidas principalmente por sua } \\
\text { lealdade. }\end{array}$ & $P_{H 10}-$ SECOMS & 2,0 & 8,0 & 10,0 & 33,3 & 24,4 & 22,4 & 4,37 & 1,267 & 0,29 & $-0,538$ & $-0,205$ \\
\hline
\end{tabular}

Fonte: dados da pesquisa 


\subsubsection{Análise descritiva das escalas -Comprometimento Organizacional}

A tabela 22 (páginas 232 e 233) apresenta as variáveis das sete bases de Comprometimento. A escala de seis pontos destinada a cada item teve uma variação de 1 (discordo totalmente) até 6 (concordo totalmente) e seu objetivo foi medir a concordância atribuída a cada uma das bases de comprometimento (afetiva, obrigação em permanecer, obrigação pelo desempenho, afiliativa, falta de recompensas e oportunidades, linha consistente de atividade, e escassez de alternativas).

A base de comprometimento com maior percepção de concordância, com todas as médias acima de 5, foi obrigação pelo desempenho, ou seja, a maioria dos respondentes dos SECOMs concorda e muito com a crença de que devem se esforçar em benefício da organização e que devem buscar cumprir suas tarefas e atingir os objetivos organizacionais. Dentro dos itens desta base, o CDes2 (eu tenho obrigação em desempenhar bem minha função nesta organização) obteve praticamente total concordância, com média 5,74 e coeficiente de variabilidade muito baixo, 0,09.

A base afiliativa, que teve a intenção de aferir qual o nível de concordância quanto à crença de que é reconhecido pelos colegas como membro do grupo e da organização, foi a segunda com as maiores médias, entre 4,0 e 5,0 e variabilidades baixas (CVs < 0,20 ), com destaque para a $\mathrm{C}_{\mathrm{Afi} 3}$ (sinto que meus colegas me consideram como membro da equipe de trabalho), cujo nível de concordância foi alto, com média 5,22 e variância em torno da média homogênea, pois o coeficiente de variação apresentou abaixo de $30 \%(0,17)$.

A base afetiva, que pretendeu averiguar se os colaboradores se identificam com a filosofia, valores e os objetivos organizacionais, obteve como resposta a concordância, com médias entre os itens deste construto, variando de 4,09 a 4,65 e coeficientes de variabilidade menores que 30\%. O item com maior concordância com média 4,65, ou seja, próximo à interpretação da escala de que concorda muito, foi a crença nos valores e nos objetivos desta organização ( $\left.\mathrm{C}_{\mathrm{Afe}} 4\right)$, denotando o envolvimento causado pela congruência entre os valores individuais e organizacionais. 
Houve uniformidade na presunção de que devem manter certas atitudes e regras da organização com o objetivo de se manterem nela - base linha consistente de atividade, com médias entre 4,36 e 4,64 e coeficientes de variação abaixo de $30 \%$. O item com maior média foi $\mathrm{C}_{\text {con4 }}$ cuja pergunta se referia a possibilidade em fazer sempre o possível no trabalho para manter-se no emprego.

Ao avaliar as bases escassez de alternativas, que pretendia averiguar se os colaboradores acreditam que possuem poucas alternativas se deixarem a organização, e obrigação em permanecer (ter o dever em permanecer por causa das pessoas da organização), suas respostas ficaram no meio da escala, entre discorda pouco e concorda pouco. Na base escassez de alternativas, a maior média $(\mu=3,83)$ foi o item $\mathrm{C}_{\mathrm{Esc1}}$ (se eu decidisse deixar minha organização agora, minha vida ficaria bastante desestruturada) e na base obrigação em permanecer, foi o item CPer1 ( $\mu=3,85$ - eu não deixaria minha organização agora porque eu tenho uma obrigação moral com as pessoas daqui), significando que eles concordam pouco com as situações hipotéticas.

Nos itens referentes à base falta de recompensas e de oportunidades, todos discordaram de que o esforço dedicado à Instituição deve ser recompensado e que precisam receber mais oportunidades. A menor média $(2,31)$ foi no item $\mathrm{C}_{\text {Rec3 }}$ - minha visão pessoal sobre esta organização é diferente daquela que eu expresso publicamente - indicando que os colaboradores discordam e muito deste tipo de comportamento.

Em resumo, os respondentes que trabalham nos SECOMs dos consulados e embaixadas brasileiros têm médias mais altas na base de comprometimento afiliativa do que na afetiva. Em média, concordam totalmente no esforço em prol da instituição e no cumprimento das tarefas para que os objetivos da organização sejam alcançados (base obrigação pelo desempenho). Sentem que fazem parte da organização (base afetiva), que pertencem ao grupo e à organização (base afiliativa) e que, para se manterem onde trabalham, devem concordar com certas atitudes e regras da organização (linha consistente de atividade). Leve discordância que têm poucas alternativas se deixarem a organização (escassez de alternativas) e que têm que permanecer onde trabalham por causa das pessoas que ali estão (obrigação em permanecer). 


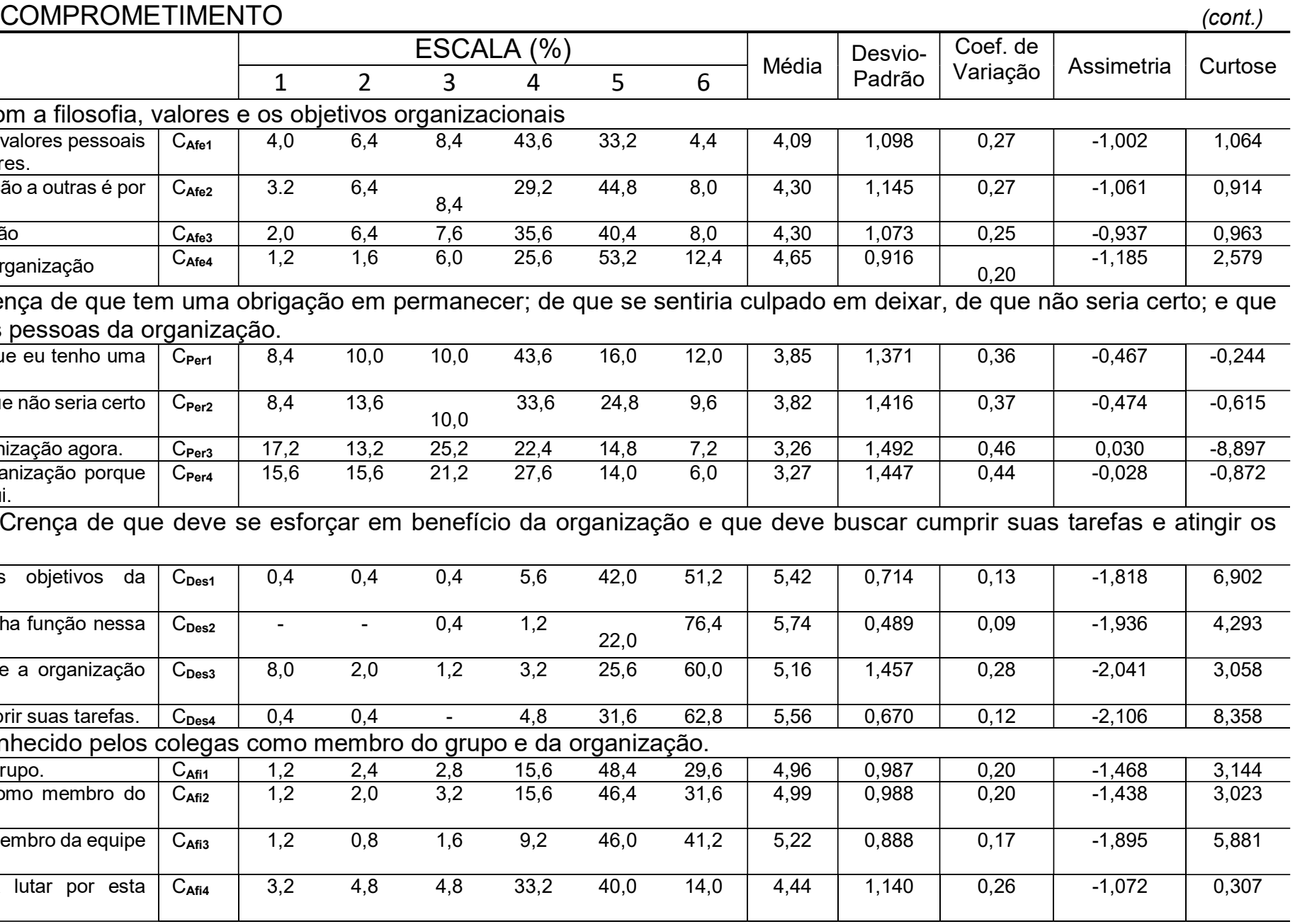


Tabela 22 - Medidas descritivas - COMPROMETIMENTO

\section{VARIÁVEIS}

\begin{tabular}{|llll|l|l|l|l|l|}
\hline \multicolumn{3}{|c|}{ ESCALA (\%) } & \multirow{2}{*}{ Média } & $\begin{array}{c}\text { Desvio- } \\
\text { Padrão }\end{array}$ & $\begin{array}{c}\text { Coef. de } \\
\text { Variação }\end{array}$ & Assimetria & Curtose \\
\hline 1 & 2 & 3 & 4 & 5 & 6 & & & \\
\hline
\end{tabular}

Base falta de recompensas e de oportunidades: Crença de que o esforço extra em benefício da organização deve ser recompensado e de que a organização deve lhe dar mais oportunidades

\begin{tabular}{|c|c|c|c|c|c|c|c|c|c|c|c|c|}
\hline $\begin{array}{l}\text { Se eu já não tivesse dado tanto de mim nesta organização, eu } \\
\text { poderia considerar trabalhar em outro lugar. }\end{array}$ & $C_{\text {Rec1 }}$ & 12,4 & 18,8 & 25,6 & 28,0 & 12,0 & 3,2 & 3,18 & 1,306 & 0,41 & 0,000 & $-0,694$ \\
\hline $\begin{array}{l}\text { A menos que eu seja recompensado de alguma maneira, eu não vejo } \\
\text { razões para despender esforços extras em benefício desta } \\
\text { organização. }\end{array}$ & CRec2 & 22,8 & 39,2 & 18,8 & 11,2 & 6,0 & 2,0 & 2,44 & 1,238 & 0,51 & 0,872 & 0,307 \\
\hline $\begin{array}{l}\text { Minha visão pessoal sobre esta organização é diferente daquela que } \\
\text { eu expresso publicamente. }\end{array}$ & $\mathrm{CRec}_{\mathrm{Re}}$ & 35,6 & 29,2 & 14,8 & 11,6 & 6,8 & 2,0 & 2,31 & 1,346 & 0,58 & 0,887 & $-0,119$ \\
\hline $\begin{array}{l}\text { Apesar dos esforços que eu já realizei, não vejo oportunidades para } \\
\text { mim nesta organização. }\end{array}$ & $\mathrm{CRec}_{\mathrm{Re}}$ & 19,2 & 20,0 & 23,2 & 20,4 & 9,2 & 8,0 & 3,04 & 1,506 & 0,50 & 0,316 & $-0,793$ \\
\hline \multicolumn{13}{|c|}{ Base linha consistente de atividade: Crença de que deve manter certas atitudes e regras da organização com o objetivo de se manter na organização } \\
\hline $\begin{array}{l}\text { Procuro não transgredir as regras aqui, pois assim sempre manterei } \\
\text { meu emprego }\end{array}$ & CCon1 & 3,2 & 7,2 & 7,6 & 32,0 & 32,4 & 17,6 & 4,36 & 1,248 & 0,29 & $-0,784$ & 0,319 \\
\hline $\begin{array}{l}\text { Na situação atual, ficar com minha organização é na realidade uma } \\
\text { necessidade tanto quanto um desejo }\end{array}$ & CCon2 & 4,4 & 4,4 & 7,6 & 38,0 & 30,4 & 15,2 & 4,31 & 1,212 & 0,28 & $-0,850$ & 0,818 \\
\hline $\begin{array}{l}\text { Para conseguir ser recompensado aqui é necessário expressar a } \\
\text { atitude certa }\end{array}$ & Ccon3 & 4,0 & 8,8 & 8,4 & 41,2 & 24,2 & - & 4,13 & 1,248 & 0,30 & $-0,607$ & 0,154 \\
\hline $\begin{array}{l}\text { Farei sempre o possível no meu trabalho para me manter neste } \\
\text { emprego }\end{array}$ & CCon4 & 0,4 & 4,0 & 6,0 & 26,8 & 46,0 & 16,8 & 4,64 & 0,989 & 0,21 & $-0,871$ & 0,970 \\
\hline \multicolumn{13}{|c|}{ Base escassez de alternativas: crença de que possui poucas alternativas de trabalho se deixar a organização } \\
\hline $\begin{array}{l}\text { Se eu decidisse deixar minha organização agora, minha vida ficaria } \\
\text { bastante desestruturada }\end{array}$ & CEsc1 & 9,2 & 12,8 & 10,4 & 32,8 & 23,2 & 11,6 & 3,83 & 1,456 & 0,38 & $-0,446$ & $-0,658$ \\
\hline Eu acho que teria poucas alternativas se deixasse essa organização. & CEsc2 & 12,4 & 23,6 & 29,2 & 20,4 & 9,2 & 5,2 & 3,06 & 1,332 & $\begin{array}{l}0,44 \\
\end{array}$ & 0,341 & $-0,466$ \\
\hline $\begin{array}{l}\text { Uma das consequências negativas de deixar esta organização seria } \\
\text { a escassez de alternativas imediatas de trabalho. }\end{array}$ & CEsc3 & 12,8 & 19,2 & 31,2 & 21,2 & 9,2 & 6,4 & 3,14 & 1,359 & 0,33 & 0,276 & $-0,474$ \\
\hline $\begin{array}{l}\text { Não deixaria este emprego agora devido à falta de oportunidades de } \\
\text { trabalho. }\end{array}$ & CEsc4 & 10,4 & 13,2 & 26,8 & 29,2 & 13,2 & 7,2 & 3,43 & 1,355 & 0,40 & $-0,050$ & $-0,548$ \\
\hline
\end{tabular}

trabalho.

Fonte: dados da pesquisa 


\subsubsection{A confiabilidade dos itens e comparação de médias}

Para a confiabilidade dos resultados encontrados, deve-se verificar se os instrumentos de pesquisa aplicados são confiáveis em relação à população-alvo. A análise de confiabilidade se refere ao fato de que uma escala deve refletir a construção do que se está medindo. É alcançada pela obtenção da proporção da variância sistemática em uma escala, o que pode ser feito determinando a associação entre os escores obtidos de diferentes regiões da escala. Assim, se a associação na análise de confiabilidade for alta, a escala produz resultados consistentes e, portanto, confiáveis (SPSS Statistcs 22.0, IBM 2017).

Para este trabalho, a confiabilidade foi estimada por meio da consistência interna, ou seja, da estimativa baseada na correlação entre as variáveis que compõem o conjunto (alfa de Cronbach). De acordo com Pasquali (2005), o alfa de Cronbach pode ser interpretado como a porcentagem da variância que a escala observada explicaria na hipotética escala verdadeira composta de todos os itens possíveis da população. Alfa é igual a zero quando o escore verdadeiro não é medido e existe apenas um componente de erro. Alfa é igual a 1.0 quando todos os itens medem apenas o escore verdadeiro e não há nenhum componente de erro. Segundo Hair et al. (2009), valores de confiabilidade acima de 0,80 favorecem a consistência da escala; e valores de 0,60 a 0,70 são considerados como o limite inferior de aceitabilidade.

Para verificar a homogeneidade dos dados, foi feito o teste ANOVA e a identificação de aditividade das médias nas escalas aplicadas ao DPR, SECOMs e seus respectivos estratos de continente e área continental. $O$ que se espera é que as variâncias dos dados sejam homogêneas. Isto não significa que devam ser idênticas, o que se deseja é que elas não sejam discrepantes a ponto de ultrapassarem determinados limites de tolerância, sendo então compatíveis e podendo ser comparadas entre si.

O teste de aditividade de Tukey ${ }^{15}$ é uma abordagem utilizada na ANOVA para avaliar se as variáveis dos fatores estão aditivamente relacionadas ao valor esperado. A

\footnotetext{
${ }^{15} \mathrm{O}$ teste de aditividade de Tukey e Firedman no SPSS testa a hipótese nula de que não há interação multiplicativa entre os casos e os itens. Se o teste for significativo $(\leq 0,05)$ então há uma interação multiplicativa. Os efeitos de dois ou mais fatores de variação são ditos não-aditivos quando, na associação de um ou mais desses fatores, em vez de se somarem, esses efeitos se multiplicam, de tal forma que o efeito resultante pode ser ampliado (quando o fator multiplicativo é maior que 1), ou reduzido (quando
} 
estatística do teste proposta por Tukey tem um grau de liberdade sob a hipótese nula, sendo muitas vezes chamado de "teste de um grau de liberdade de Tukey".

Em geral não foram constatadas diferenças significativas das médias entre continente e as variáveis de estudo. Casos específicos serão apresentados quando da análise de cada uma das escalas, a seguir.

\subsubsection{A confiabilidade dos itens e comparação de médias - Valores}

Todas as dimensões da escala IPVO (Valores Organizacionais) apresentaram consistência interna, acima de 0,60, com exceção para o fator domínio por se tratar de um item simples (single-item) com apenas uma pergunta. Quase todos apresentaram variância homogênea, com exceções das dimensões autonomia e prestígio na população-alvo DPR, cujas significâncias ficaram acima de 0,05. Quanto ao teste de médias, as dimensões coletividade e conformidade nos SECOMs e coletividade e bem-estar no DPR apresentaram significância para interações multiplicativas.

Os itens destes fatores deverão receber atenção quando da fase da análise multivariada, mas, por enquanto, para fins exploratórios, admite-se trabalhar com alguns desses itens significativos quanto à possibilidade de interações multiplicativas.

esse fator é menor que 1). É o que comumente ocorre nas chamadas interações entre dois ou mais fatores de variação (Campos, 2001). 
Tabela 23 - ANOVA com teste de Tukey e de Friedman para não aditividade - Valores

\begin{tabular}{|c|c|c|c|c|c|c|c|c|c|c|c|c|c|}
\hline & Média & DP & $\begin{array}{l}\text { Soma dos } \\
\text { quadrados }\end{array}$ & df & $\begin{array}{l}\text { Quadrado } \\
\text { médio }\end{array}$ & F. Stat & Sig & $\begin{array}{l}\text { Soma dos } \\
\text { quadrados }\end{array}$ & $\mathrm{df}$ & $\begin{array}{l}\text { Quadrado } \\
\text { Médio }\end{array}$ & $\begin{array}{c}\mathrm{F} \\
\mathrm{X}^{2} \\
\text { Fridman }\end{array}$ & Sig & $\begin{array}{c}\text { Alfa de } \\
\text { Cronbach }\end{array}$ \\
\hline $\begin{array}{l}\text { SECOM } \\
\text { Autonomia }\end{array}$ & 3,714 & 1,44 & 50,697 & 7 & 7,242 & 11,657 & ,000 & 1,388 & 1 & 1,388 & 2,236 & , 135 & .949 \\
\hline $\begin{array}{l}\text { DPR } \\
\text { Autonomia }\end{array}$ & 4,164 & 1,37 & 5,907 & 5 & 1,181 & 1,209 & ,105 & ,191 & 1 & ,191 & , 195 & ,659 & .850 \\
\hline $\begin{array}{l}\text { SECOM } \\
\text { Coletividade }\end{array}$ & 4,399 & 1,34 & 133,357 & 5 & 26,671 & 42,230 & ,000 & 31,194 & 1 & 31,194 & 51,391 & ,000 & .918 \\
\hline $\begin{array}{l}\text { DPR } \\
\text { Coletividade }\end{array}$ & 4,246 & 1,32 & 85,554 & 3 & 28,518 & 38,037 & ,000 & 14,592 & 1 & 14,592 & 21,379 & ,000 & .851 \\
\hline $\begin{array}{l}\text { SECOM } \\
\text { Realização }\end{array}$ & 4,114 & 1,38 & 54,661 & 4 & 13,665 & 20,213 & ,000 & 6,653 & 1 & 6,653 & 9,929 &, 052 & .902 \\
\hline $\begin{array}{l}\text { DPR } \\
\text { Realização }\end{array}$ & 4,407 & 1,36 & 31,500 & 3 & 10,500 & 14,490 & ,000 岂 & 1,510 & 1 & 1,510 & 2,095 & ,149 & .864 \\
\hline $\begin{array}{l}\text { SECOM } \\
\text { Bem-estar }\end{array}$ & 3,395 & 1,54 & 97,795 & 2 & 48,897 & 63,935 & ,000 & ,048 & 1 & ,048 & ,063 & ,802 & .864 \\
\hline $\begin{array}{l}\text { DPR } \\
\text { Bem-estar }\end{array}$ & 3,60 & $1,50 \lesssim$ & 39,114 & 1 & 39,114 & 42,246 & , 000 岂 & 7,398 & 1 & 7,398 & 8,906 & ,004 & .749 \\
\hline $\begin{array}{l}\text { SECOM } \\
\text { Tradição }\end{array}$ & 4,516 & $1,17 \underset{2}{z}$ & 54,584 & 4 & 13,646 & 19,191 & ,000을 & 826 & 1 & ,826 & 1,162 & 2081 & .828 \\
\hline $\begin{array}{l}\text { DPR } \\
\text { Tradição }\end{array}$ & 4,454 & 1,237 & 62,696 & 3 & 20,899 & 20,401 & ,000 言 & 9,947 & 1 & 9,947 & 10,139 & ,062 & .680 \\
\hline $\begin{array}{l}\text { SECOM } \\
\text { Prestígio }\end{array}$ & 4,664 & 1,14 & 39,352 & 3 & 13,117 & 24,704 & ,000 운 & 2,176 & 1 & 2,176 & 4,116 &, 043 & .855 \\
\hline $\begin{array}{l}\text { DPR } \\
\text { Prestígio }\end{array}$ & 4,932 & 1,01 & 3,896 & 3 & 1,299 & 2,734 & ,045 & ,093 & 1 & ,093 & ,196 & ,659 & .821 \\
\hline $\begin{array}{l}\text { SECOM } \\
\text { Conformidade }\end{array}$ & 5,001 & 0,95 & 111,894 & 6 & 18,649 & 32,985 & ,000 & 37,027 & 1 & 37,027 & 68,447 & ,000 & .819 \\
\hline $\begin{array}{l}\text { DPR } \\
\text { Conformidade }\end{array}$ & 5,159 & 0,95 & 15,731 & 4 & 3,933 & 7,185 & ,000 & 1,177 & 1 & 1,177 & 2,159 & ,143 & .772 \\
\hline $\begin{array}{l}\text { SECOM } \\
\text { Domínio }\end{array}$ & 4,330 & 1,19 & & & & & & & & & & & \\
\hline $\begin{array}{l}\text { DPR } \\
\text { Domínio }\end{array}$ & 3,702 & 1,36 & & & & & & & & & & & \\
\hline
\end{tabular}

Fonte: dados da pesquisa 


\subsection{Classificação dos Valores Organizacionais}

Baseado no modelo proposto por Tamayo (2007) apresentado no referencial teórico desta tese, foi realizada a classificação dos valores organizacionais a partir de suas médias e desvios-padrão.

Esta classificação pode ser vista na figura 24 a partir das médias e desvios-padrão dos valores organizacionais identificados no DPR e nos SECOMs.

Figura 24 - Classificação dos Valores Organizacionais DPR e SECOMs

\begin{tabular}{|c|c|}
\hline \multirow[t]{2}{*}{ Centrais } & Setoriais \\
\hline & Domínio SECOMs \\
\hline Conformidade DPR e SECOMs & Preocupação com a coletividade DPR e SECOMs \\
\hline Prestígio DPR e SECOMs & Realização - DPR e SECOMs \\
\hline Tradição DPR e SECOMs & Autonomia - DPR \\
\hline Desejados & Difusos \\
\hline Domínio - DPR & Bem-estar DPR e SECOMs \\
\hline Autonomia - SECOMs & \\
\hline
\end{tabular}

Os valores que ocupam o lugar de maior destaque na hierarquia axiológica tanto do DPR quanto dos SECOMs são conformidade, prestígio e tradição, estabelecendo que estes são valores altamente compartilhados entre os seus membros e que guiam o comportamento da organização.

Os valores tradição e conformidade representam o aspecto conservador da organização tanto no ambiente de trabalho quanto no relacionamento com outras organizações, já o valor prestígio empenha-se com o respeito e a admiração devidos à qualidade de seus produtos e serviços.

Outro ponto que deve ser observado é que, ao encontrar os mesmos valores centrais para as duas populações-alvo, é de pressupor que haja convergência entre os valores 
do DPR (nacional) e dos SECOMs (local), demonstrando que os valores mais importantes da organização nacional são percebidos pelas organizações locais.

Realização, cuja meta central é o sucesso demonstrado por meio do desempenho como forma de sobreviência da organização e da permanência das pessoas nela e preocupação com a coletividade, que orienta e equilibra o relacionamento cotidiano com outras pessoas e com a comunidade em geral, mostrou-se como valor setorial para as duas populações-alvo, ocupando lugar de destaque no perfil axiológico da organização, sendo, entretanto, valores menos compartilhados entre seus membros, ou seja, mesmo sendo importantes no contexto organizacional, são percebidos diferentemente entre os grupos dentro da organização.

Já o valor autonomia, que incita aos desafios correntes por meio do constante aperfeiçoamento das pessoas e da organização, foi percebido somente pelo DPR como valor setorial. Em contrapartida, somente nos SECOMs o valor domínio, que prioriza a atenção da organização às ameaças do mercado, foi inferido com destaque no perfil axiológico, mas pouco compartilhado entre os seus grupos.

Essa situação se inverte quando se analisam na matriz de hierarquia axiológica os valores desejados, ou seja, aqueles que os membros da organização gostariam que fossem mais enfatizados no contexto do trabalho. Neste caso, o valor domínio para o DPR e o valor autonomia para os SECOMs são os que as pessoas desejariam que ocupassem um lugar mais destacado nas prioridades axiológicas da organização.

E por último, há bem-estar, valor difuso para as duas populações-alvo, em que as pessoas não percebem preocupação institucional em proporcionar satisfação aos seus colaboradores e qualidade de vida no ambiente de trabalho como relevante ou que seja enfatizada pela cultura da organização. 


\subsection{Comparação de médias entre continentes e DPR- Valores}

As figuras a seguir apresentam as dispersões das médias do DPR, dos SECOMs como um todo e dos seus estratos continentais. A ideia é analisar proximidades e distâncias das dimensões entre os continentes e o DPR. Para tanto, foram realizados dois testes: (1) de Levene, que trata de verificar a homogeneidade da variância; e (2) HSD de Tukey ${ }^{16}$ (Tukey's Honestly Significant Difference).

\subsubsection{2 (a) Tradição e Conformidade}

A figura 25 foi elaborada a partir das médias gerais das dimensões conformidade e tradição do DPR, SECOMs e suas divisões continentais.

Figura 25 Comparação de médias - Tradição e Conformidade DPR e SECOMs por continente

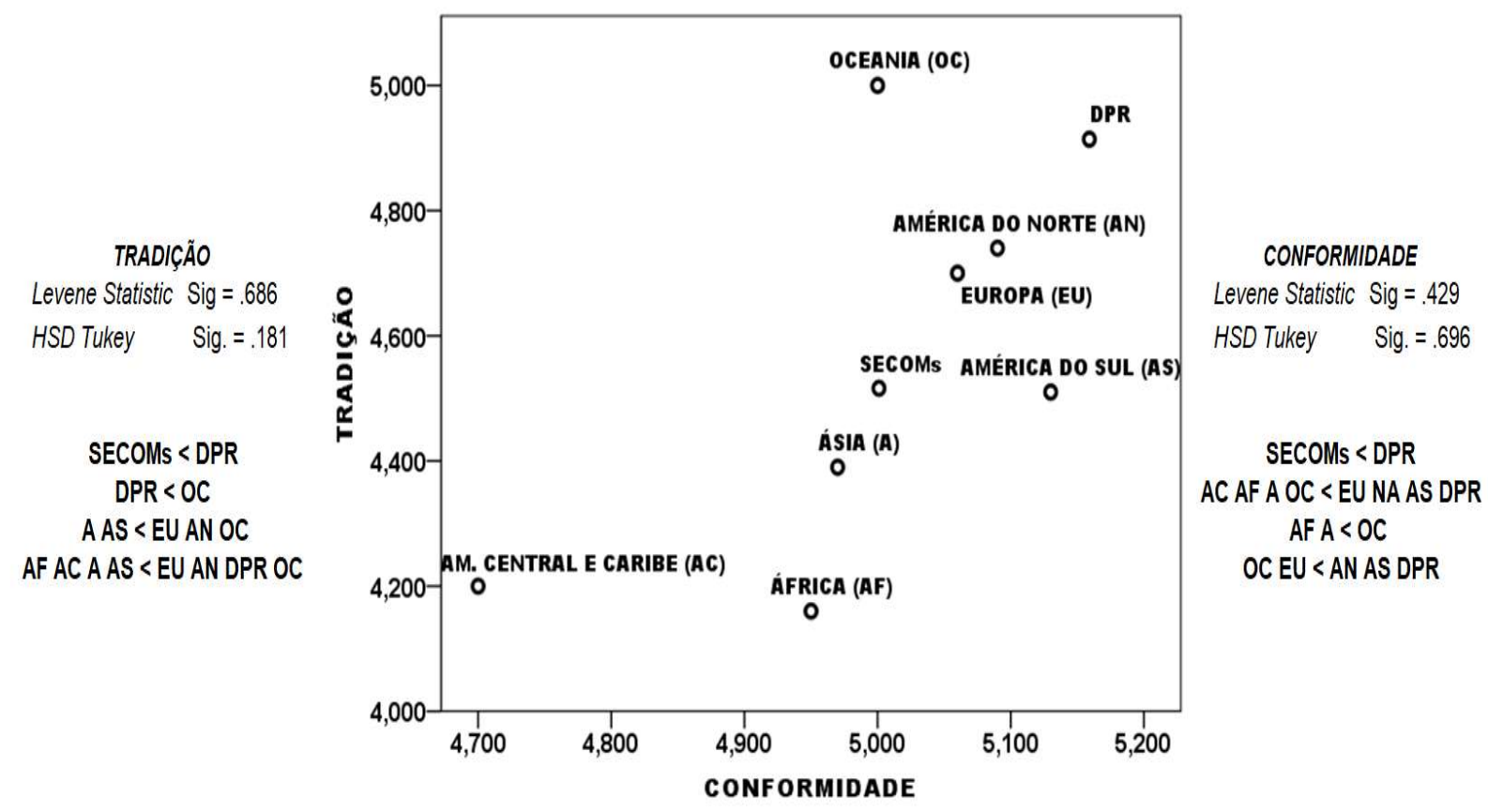

Fonte: dados da pesquisa

\footnotetext{
${ }^{16}$ O teste HSD de Tukey (diferença realmente significativa), também chamado de HSD de Tukey, WSD ou teste de Tukey, controla a taxa de falso positivo relativo ao conjunto de dados. Isso significa que, se o teste for significativo $(\leq 0,05)$ para todas as comparações por pares, a probabilidade de obter um ou mais falsos positivos é de 0,05 .
} 
A dimensão conformidade, cujo objetivo foi verificar qual o grau de importância dado pela organização quanto às regras e modelos de comportamento. Na percepção dos respondentes, todos afirmaram que é parecida com o local em que trabalham. O DPR foi o que obteve a maior média de concordância $(5,159)$, seguido pela América do Sul $(5,13)$. Os continentes que concordam, mas com as menores médias, foram América Central e Caribe $(4,7)$ e África $(4,95)$, informando ser esta dimensão mais ou menos parecida com a organização em que trabalham

A dimensão cultural individualismo versus coletivismo de Hofstede (2003) pondera o grau de interdependência que uma sociedade mantém entre seus membros, analisando se a autoimagem das pessoas é definida em termos de "eu" ou "nós". Nas sociedades individualistas, as pessoas devem cuidar de si mesmas e apenas de sua família direta, já nas sociedades coletivistas, as pessoas pertencem a grupos que se cuidam em troca de lealdade (Hofstede Centre, 2017).

O Brasil tem uma pontuação de 38 , isto significa que as pessoas desde o nascimento são integradas em grupos fortes e coesos (especialmente representados pela família, incluindo tios, tias, avós e primos) que continuam protegendo seus membros em troca de lealdade. Este é um aspecto importante no ambiente de trabalho, onde se espera, por exemplo, de um membro mais velho e poderoso de uma família "ajudar" um sobrinho mais jovem a ser contratado para um emprego em sua própria empresa. No ambiente de negócios, busca-se construir relacionamentos confiáveis e duradouros: uma reunião geralmente começa com conversas gerais para se conhecer os membros antes de fazer negócios (Hofstede, 2003; Hofstede Centre, 2017).

Dos países da África que participaram do trabalho de Hofstede e desta pesquisa, no seu Índice Individualismo (IDV), o único país com escore acima do brasileiro é a África do Sul, ${ }^{17}$ onde há dois SECOMs (Cidade do Cabo e Pretória). Os demais países têm escores abaixo do Brasil, indicando que se trata de países mais coletivistas do que o Brasil, entretanto apresentam um nível de concordância um pouco menor que a do DPR quanto à dimensão conformidade. No continente africano, o percentual de respondentes brasileiros foi de $42,1 \%$.

\footnotetext{
${ }^{17}$ IDV África > BR: África do Sul $=65$ (+ individualista)

IDV África < BR: Nigéria=30; Quênia=25; Cabo Verde=20; Angola=15; Moçambique=15; Gana = 15 (+ coletivistas)
} 
Na América Central, com a menor média nesta dimensão $(4,7)$, todos os países que participaram desta pesquisa e dos estudos de Hofstede (excetuando Cuba, Nicarágua e Haiti, que não estão presentes nos estudos do autor) apresentam IDV ${ }^{18}$ abaixo do índice de individualismo do Brasil, ou seja, são vistos como países mais coletivistas do que individualistas. Neste continente, o percentual de colaboradores brasileiros que participaram da pesquisa foi de $40 \%$.

A América do Sul ${ }^{19}$ apresenta baixo nível de individualismo e obteve na dimensão conformidade o mesmo nível de similaridade do DPR, apesar de ter menor percentual de respondentes brasileiros, 33,3\%, com exceção da Argentina e do Suriname, que apresentam pontuações intermediárias, sendo, portanto, ligeiramente coletivistas,

Nos países que compõem o continente asiático ${ }^{20}$, verifica-se que $22 \%$ deles (Japão, Líbano e Índia - com dois SECOMs: Nova Délhi e Mimbai) têm índices maiores de IDV do que o Brasil(38). Aqui vale um comentário sobre o porquê de Japão e Índia terem escores menores de coletivismo.

Segundo Hofstede, o Japão, apesar de apresentar características de uma sociedade coletivista (como priorizar a harmonia do grupo em relação às opiniões individuais e as pessoas apresentarem um forte sentimento de vergonha em situações de exposição de falhas), não é tão coletivista como a maioria de seus vizinhos asiáticos, porque a sociedade japonesa não dispõe de um sistema familiar alargado que se baseia em sociedades mais coletivistas (como a China e a Coreia) e porque, apesar da fama pela sua lealdade a suas empresas, a fidelidade à empresa é algo que as pessoas escolheram para si, o que é uma ação individualista, enquanto os chineses parecem trabalhar com mais facilidade em qualquer organização (Hofstede Centre, 2017).

18 IDV Am. Central < BR: Rep. Dominicana=30; El Salvador=19; Trind. Tobago=16; Panamá=11 (+ coletiv.)

19 IDV América do Sul > BR: Argentina=46; Suriname=47 (- coletivistas)

IDV América do Sul < BR: Uruguai=36; Chile=23; Peru=16; Colômbia=13; Venezuela=12; Equador=8 (+ coletivistas)

20 IDV da Ásia > BR: Líbano = 40; Japão = 46; Índia = 48 (- coletivistas)

IDV da Ásia < BR: Turquia=37; Filipinas=32; Malásia=26; Cingapura=20; Tailândia=20; Vietnã=20; China=20; Coreia do Sul=18; Taiwan=17; Paquistão=14; Indonésia=14 (+ coletivistas). 
A índia, segundo a visão do Geert Hofstede, é uma sociedade com características coletivistas e individualistas. O lado coletivista significa que existe uma grande preferência por pertencer a um quadro social maior no qual se espera que os indivíduos atuem de acordo com o bem maior de um grupo definido. Isso é visto na relação empregador/empregado em que há lealdade pelo empregado e proteção quase familiar pelo empregador. $O$ aspecto individualista resulta de sua religião/filosofia dominante - o hinduísmo. Os hindus acreditam em um ciclo de morte e renascimento, com a maneira de cada renascimento ser dependente de como o indivíduo viveu a vida precedente. As pessoas são, portanto, individualmente responsáveis pela maneira de liderar suas vidas e pelo impacto que terão sobre o seu renascimento. Este foco no individualismo interage com as tendências, de outra forma, coletivistas da sociedade indiana, que conduzem à sua pontuação intermediária nesta dimensão (Hofstede Centre, 2017).

Ao verificar o índice de individualismo de Hofstede (2003) nos países da Ásia em que os SECOMs estão localizados, cuja média na dimensão conformidade foi de 4,97, portanto um pouco inferior à média do $\operatorname{DPR}(5,159)$, percebe-se que o nível de concordância desta dimensão é característico de países coletivistas. E no que se refere à nacionalidade dos respondentes, praticamente metade são brasileiros $(49,2 \%)$.

Ainda sobre a dimensão individualismo de Hofstede (2003), nos países europeus ${ }^{21}$ que também foram estudados nesta pesquisa, 22\% têm IDV abaixo do índice brasileiro (IDV= 38) e, mesmo asssim, o continente europeu apresentou média de 5,06 , indicando que, na dimensão conformidade, a concordância é alta no que se refere à importância dada à correção, cortesia e boas maneiras no trabalho, bem como no respeito às normas da organização. Vale observar que o percentual de brasileiros nestes SECOMs é de $74 \%$, ou seja, 3 em cada 4 colaboradores que responderam à pesquisa não são nativos. Este, talvez, seja o motivo da média geral dos respondentes estar próxima à média geral do DPR.

21 IDV da Europa > BR: Rússia=39; Espanha=51; Eslováquia=52; Áustria=55; Rep. Checa=58; Polônia $=60$; Finlândia $=63$; Alemanha $=67$; Noruega $=69$; Irlanda $=70 ; \quad$ Suécia $=71 ; \quad$ França $=71$; Dinamarca $=74$; Bélgica $=75$; Itália $=76$; Países Baixos $=80$; Hungria $=80$; Reino Unido=89; (+ individualistas)

IDV da Europa < BR: Grécia=35; Portugal=27; Eslovênia=27; Ucrânia=25; Sérvia=25 (+ coletivistas) 
Semelhantemente, a América do Norte ${ }^{22}$, em que somente um país possui perfil mais coletivista (México), sendo os demais individualistas (EUA e Canadá), mas com 91,4\% de brasileiros respondentes, obteve média 5,09 no que se refere à dimensão conformidade, que é próxima à média mais alta, que foi a do DPR. E a Oceania, em que todos os colaboradores que participaram da pesquisa são brasileiros, teve como média 5,0 na dimensão conformidade, apesar de ter o IDV ${ }^{23}$ situado entre os mais altos do total de países que fizeram parte da investigação de Hofstede (1991, 2003, 2017).

Ao verificar os resultados encontrados na dimensão tradição, que se refere à manutenção do status quo a fim de promover a preservação e o respeito aos usos, costumes e práticas organizacionais, praticamente todos responderam que a organização em que trabalham tem contextos mais ou menos parecidos com as situações apresentadas nas frases elaboradas na escala IPVO. A Oceania foi a que obteve maior média de concordância $(5,0)$, inclusive sendo a única com grau de similaridade "parecida" ao invés de "mais ou menos parecida", como os demais respondentes. Os continentes da África $(4,16)$ e da América Central e Caribe $(4,2)$ foram os que tiveram as menores médias.

A dimensão individualismo versus coletivismo de Hofstede (2003), como já mencionado, reflete o grau em que a identidade individual é definida com base nos objetivos e realizações pessoais ou com base nos interesses coletivos do grupo em que o indivíduo se sente relacionado.

As posições dos países da Oceania são maiores do que a posição brasileira (IDV=38) no que se refere ao individualismo, mas tiveram média superior à do DPR na dimensão tradição. O que deve ser observado é que todos os respondentes são brasileiros.

Quanto ao continente africano que obteve a menor média na dimensão tradição $(4,16)$, quando se verifica o IDV dos países que participaram tanto desta pesquisa quanto das pesquisas de Hofstede, observa-se que, com exceção da África do Sul, todos os

\footnotetext{
22 IDV da América do Norte < BR: México $=30$ (+ coletivista)

IDV da América do Norte > BR: Canadá = 80; e EUA = 91 (+ individualista)

${ }^{23}$ IDV Oceania > BR: Nova Zelândia $=79$ e Austrália $=90$ (+ individualista)
} 
demais países têm índice abaixo do índice brasileiro (38), com percentual de respondentes brasileiros de $42,1 \%$.

A América Central e Caribe obtiveram a segunda menor média $(4,20)$ nesta dimensão que averigua a valorização de costumes e praticas consagradas. Observa-se que dos três países que fizeram parte das duas pesquisas todos são mais coletivistas do que o Brasil, e o percentual de brasileiros respondentes foi de $40 \%$.

A Ásia, que atingiu média 4,39 nesta dimensão, possui $78 \%$ dos países com IDV inferior ao IDV do Brasil (nota de rodapé $\mathrm{n}^{\circ} 08$ ), com isso esperava-se que o nível de similaridade da dimensão tradição fosse maior do que a do DPR. O que se viu foi uma leve diferença entre as médias do DPR $(4,914)$ e da Ásia $(4,39)$, mas os dois estão no mesmo nível da escala. Não se pode deixar de ressaltar que o número de respondentes brasileiros nos SECOMs da Ásia foi de $49,2 \%$.

Segundo Hofstede (2003), a América do Sul apresenta de médio a alto índice de coletivismo. Dos países que participaram do trabalho de Hofstede e desta pesquisa, $75 \%$ (nota de rodapé $\mathrm{n}^{\circ} 07$ ) têm IDV abaixo do brasileiro, ou seja, mais coletivistas. A média do continente sul americano $(4,51)$ foi superior à da Ásia e à da América Central na dimensão tradição. Houve $33,3 \%$ de respondentes brasileiros.

Em relação à Europa, 23 países estão presentes nas respostas desta dimensão, cuja média 4,70 pode ser interpretada entre "mais ou menos parecida" e "parecida" com a organização em que trabalha. Ao examinar o IDV destes países, percebe-se que praticamente todos têm perfil mais individualistas do que coletivistas, e, ao verificar o percentual de respondentes quanto à nacionalidade, $74 \%$ são brasileiros.

A América do Norte $(4,74)$, com a média imediatamente menor à do $\operatorname{DPR}(4,914)$, assim como a Europa, também pode ser interpretada entre "mais ou menos parecida" e "parecida" com a organização em que trabalha, possui $91,4 \%$ dos respondentes de nacionalidade brasileira e, mesmo com IDV de dois países acima do IDV brasileiro, a média na dimensão tradição foi muito próxima à do DPR. 
Para fins de comparações, as médias obtidas nas duas dimensões (conformidade e tradição) foram transformadas em percentuais. Então, por exemplo, na dimensão tradição, cuja maior média foi 5,0 (Oceania), passou a ser $100 \%$ e a menor média $(4,16)$ passou para $88 \%$ (África). Assim, foi possível estabelecer um comparativo entre percentual de nativos, brasileiros e respostas nestas duas dimensões.

Gráfico 03 - Comparação do percentual de brasileiros e de respostas das dimensões tradição e conformidade

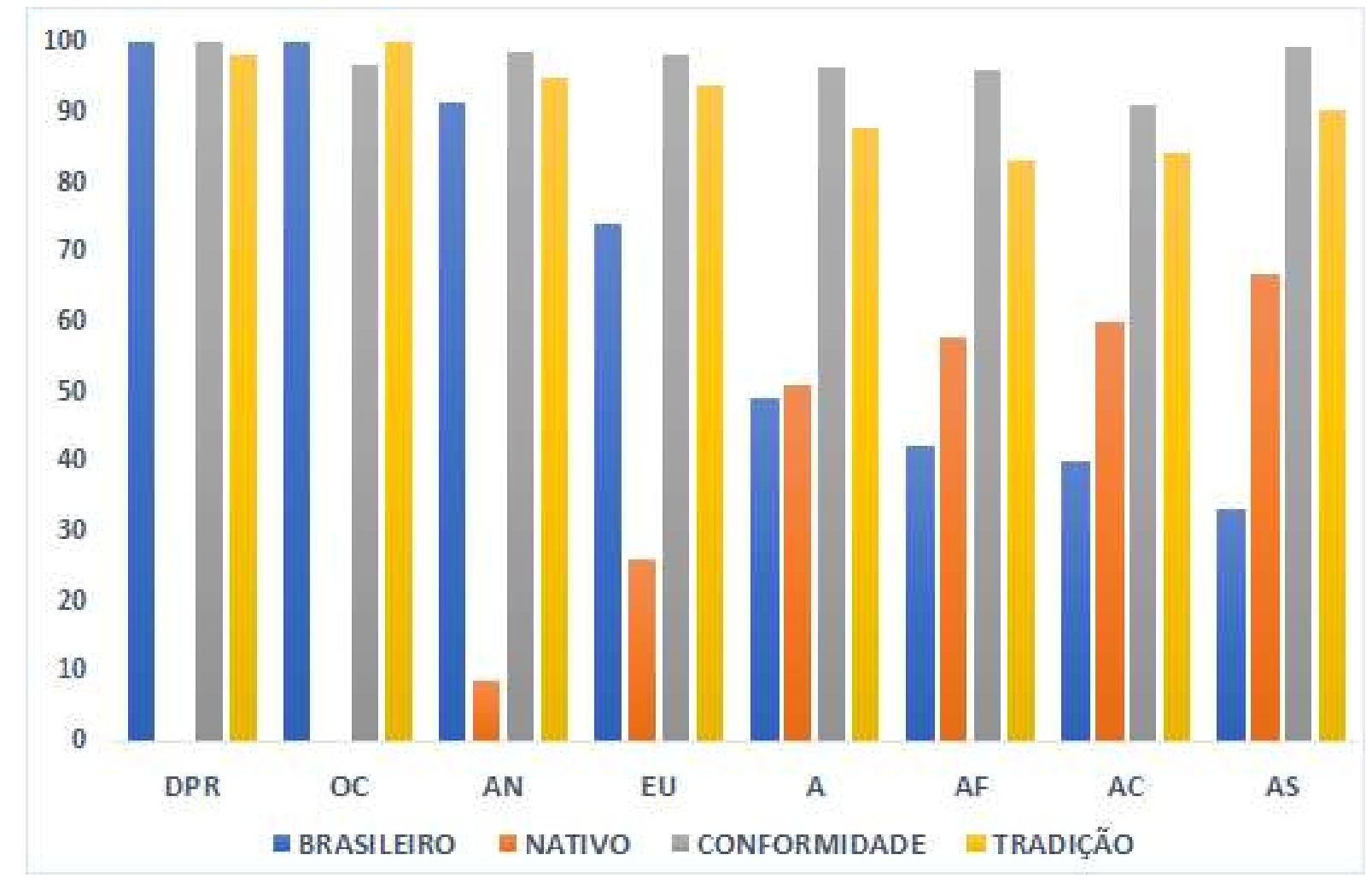

Fonte: dados da pesquisa

O que pode ser interpretado a partir do gráfico 03 é que, quando o percentual de respondentes brasileiros é muito maior em relação ao percentual de nativos, as médias se aproximam das médias do DPR, como Europa, América do Norte e Oceania nas dimensões tradição e conformidade. 


\subsubsection{2 (b) Bem-estar e Autonomia}

A figura 26 foi elaborada a partir das médias gerais das dimensões autonomia e bemestar do DPR, SECOMs e suas divisões continentais.

Figura 26 - Comparação de médias - Bem-estar e Autonomia DPR e SECOMs por continente

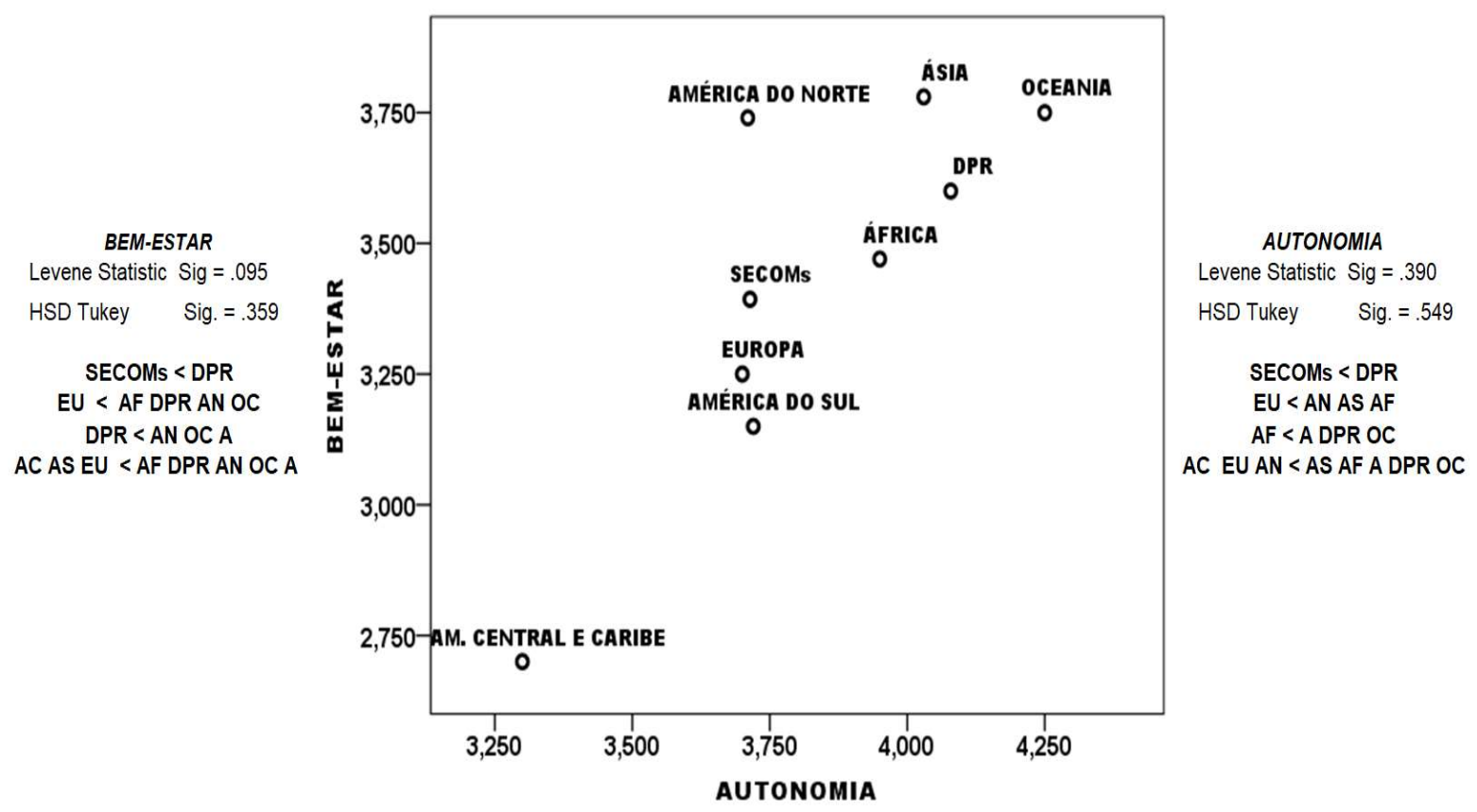

Fonte: dados da pesquisa

Ao analisar a dimensão autonomia, que enfatiza a criatividade, o desejo da organização de que as pessoas busquem suas próprias ideias, satisfação e aperfeiçoamento contínuo. Oceania $(4,25)$, DPR $(4,079)$ e Ásia $(4,03)$ responderam que a organização em que trabalham apresenta cenários mais ou menos parecidos com as circunstâncias retratadas nas frases da escala IPVO. Já África (3,95), América do Sul $(3,72)$, América do Norte $(3,71)$, Europa $(3,7)$ e América Central e Caribe $(3,3)$ entenderam que estas situações são pouco parecidas com o ambiente em que trabalham.

Sob a ótica da dimensão individualismo versus coletivismo de Hofstede (2003), o que se espera é que países mais individualistas sejam mais similares nas dimensões autonomia e bem-estar, visto que estas estão contidas na dimensão abertura à mudança da Estrutura Bidimensional dos Tipos Motivacionais de Valores (Tamayo, 2007) cujo foco está em valores que enfatizam pensamentos e ações independentes. 
Os países da Oceania $(\mu=4,25)$ têm alto índice de individualismo (Nova Zelândia $=79$ e Austrália =90), mas seus respondentes são todos brasileiros, que têm suas origens em país cujo perfil é mais coletivista, segundo a escala de Hofstede (2003). É de se supor que os valores da cultura institucional (DPR-BR) sejam mais preponderantes que os valores locais (países em que estão localizados os SECOMs na Oceania).

A Ásia $(\mu=4,03)$ em que há preponderância de países coletivistas, teve sua média próxima à média do DPR, que se situa em país também coletivista, e ainda tendo quase metade dos respondentes brasileiros, era de se esperar certa convergência tanto do ponto de vista coletivista quanto do peso destes brasileiros na percepção dos colaboradores deste continente.

Com exceção da África do Sul que é individualista, todos os demais países do continente africano são mais coletivistas do que o Brasil, e apresentou, no seu conjunto de respostas, pouca identificação com as circunstâncias apresentadas nas frases que tratam da dimensão autonomia, com 3,95 de média. O que é de se esperar quanto ao coletivismo que se manifesta quando prevalecem os interesses do grupo (Hofstede, 1991, 2003, 2013). Resultados semelhantes ao da África foram encontrados na América do Sul e na América Central e Caribe, em que todos os países que fizeram parte dos estudos de Hofstede e desta pesquisa são coletivistas e têm os menores percentuais de respondentes brasileiros: 33,3\% América do Sul e 40\% América Central e Caribe. É de considerar uma possível predominância dos valores locais (países em que estão localizados os SECOMs) sobre a cultura institucional (DPR).

Já América do Norte $(\mu=3,71)$ e Europa $(\mu=3,7)$, em que os países são predominantemente individualistas, obtiveram respostas semelhantes aos dos continentes de soberania coletivista: os itens que tratam de identificar metas motivacionais referentes à busca de aperfeiçoamento constante do colaborador e da organização que se expressa por meio de competência, curiosidade, criatividade, variedade de experiência e definição de objetivos profissionais de seus colaboradores, foram identificadas com pouca similaridade ao ambiente em que trabalham. Mas há de se observar o percentual de respondentes brasileiros nestes dois continentes, que foi de $91,4 \%$ na América do Norte e de $74 \%$ na Europa. 
Para a dimensão bem-estar que tem como objetivo identificar metas motivacionais relativas ao hedonismo - expressas no interesse da organização pela satisfação das necessidades dos colaboradores, assim como pela sua qualidade de vida no trabalho, evidenciando uma postura de abertura e inovação por parte da organização, praticamente todos os respondentes disseram, para as situações apresentadas nas frases da escala IPVO, que são pouco parecidas com o ambiente em que trabalham. Excetuando a América Central e Caribe onde seus respondentes informaram que não se parecem com a organização em que trabalham.

Ao fazer uma investigação dos resultados da dimensão bem-estar sob a perspectiva individualista de Hofstede, os países da Oceania, América do Norte e da Europa que têm supremacia individualista, e, dessa forma, quanto a dimensão bem-estar deveriam apresentar médias superiores às médias encontradas $(O C=3,78 ; A N=3,74$ e EU $=3,25$ ), que pelos resultados apresentam-se com perfis mais coletivistas. Isso pode ser compreendido pelo alto percentual de respondentes brasileiros nestes três continentes.

As médias do DPR $(3,6)$ da América Central e Caribe $(2,7)$ e da América do Sul $(3,15)$, que são coletivistas, foram de acordo com o esperado quanto a percepção hedonista da organização para com seus colaboradores. Os continentes africano e asiático, que têm perfil mais coletivista, tiveram médias um pouco superior aos continentes latinos $(A F=3,47 ; A=3,78)$, mas ainda com pouca similaridade quanto a dimensão bem-estar. Para fins de comparações, as médias obtidas nas duas dimensões (autonomia e bemestar) foram transformadas em percentuais. Então, por exemplo, na dimensão autonomia cuja maior média foi 4,25 (Oceania) passou a ser $100 \%$ e a menor média $(3,3)$ passou para 78\% (América Central e Caribe). Assim, foi possível estabelecer um comparativo entre percentual de nativos, brasileiros e respostas nestas duas dimensões. 
Gráfico 04 - Comparação do percentual de brasileiros e de respostas nas dimensões autonomia e bem-estar

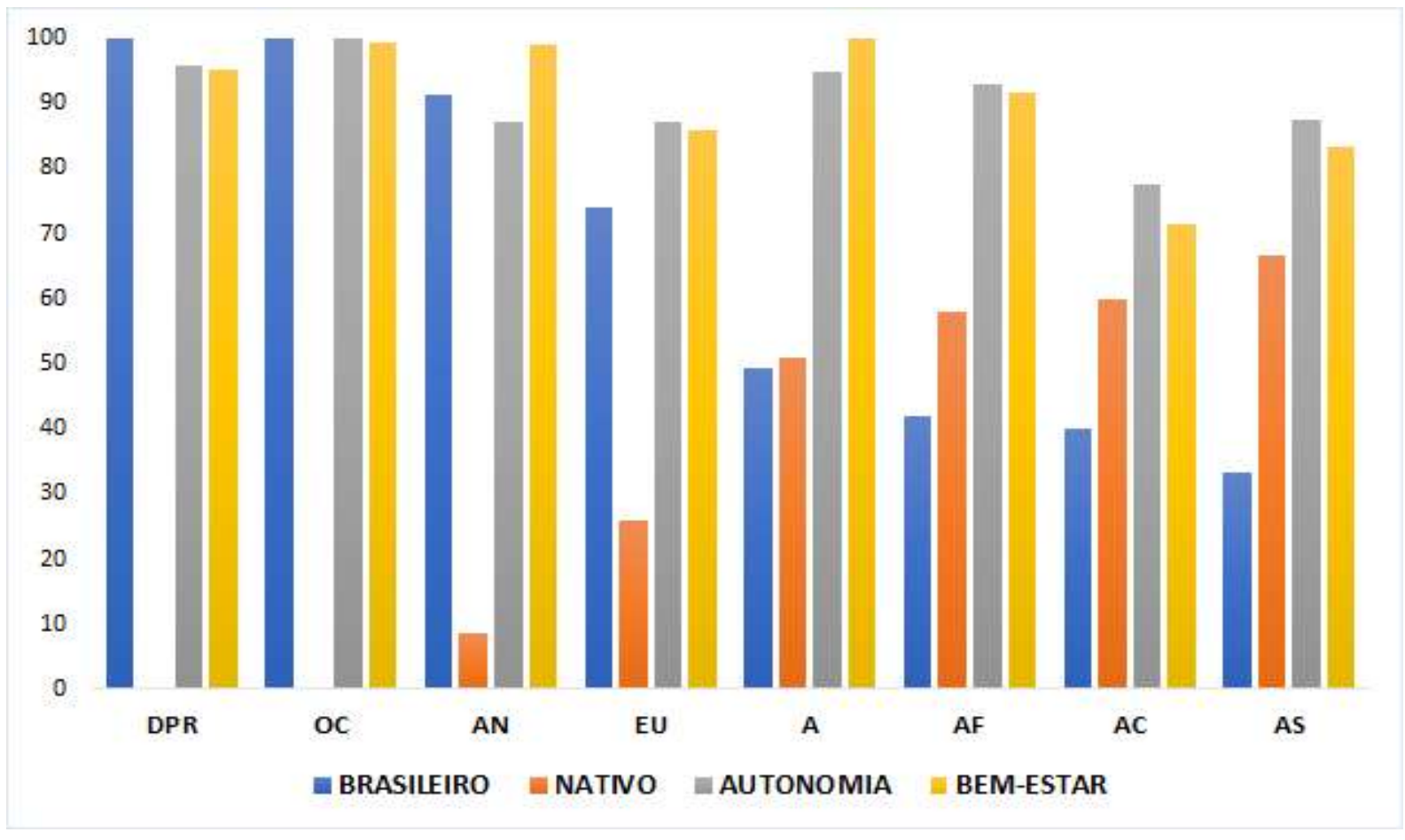

Fonte: dados da pesquisa

O que pode ser interpretado a partir do gráfico 04 é que continentes mais coletivistas têm percepções de pouca similaridade no que se refere a autonomia e bem-estar (África e América do Sul). Continentes onde o percentual de respondentes brasileiros é maior que $50 \%$, as médias são menores para as dimensões autonomia e bem-estar, mesmo tendo países mais individualistas no seu contexto (América do Norte e Europa). Quanto menor o número de respondentes brasileiros nos continentes com perfis coletivistas, menor é a média nas dimensões autonomia e bem-estar (África, América Central e América do Sul).

Segundo Tamayo e Oliveira (2003), as dimensões domínio, prestígio e realização representam fatores distintos. Os dois primeiros configuram o tipo motivacional poder, e o último o tipo realização. Ambos compartilham metas motivacionais e estão localizados no polo da Autopromoção da estrutura bidimensional dos tipos motivacionais de valores. Observando a teoria dos valores humanos de Schwartz (1999), a relação de compatibilidade entre realização e poder é prevista, pois os dois salientam estima e superioridade social. Para os valores organizacionais, o destaque é dado à superioridade, à competência e ao sucesso da organização. 


\subsubsection{2 (c) Realização e Prestígio}

A figura 27 foi elaborada a partir das médias gerais das dimensões prestígio e realização do DPR, SECOMs e suas divisões continentais.

Figura 27 - Comparação de médias - Prestígio e Realização DPR e SECOMs por continente

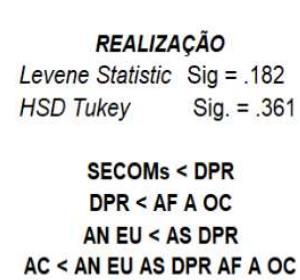

$A C<$ AN EU AS DPR AF A OC

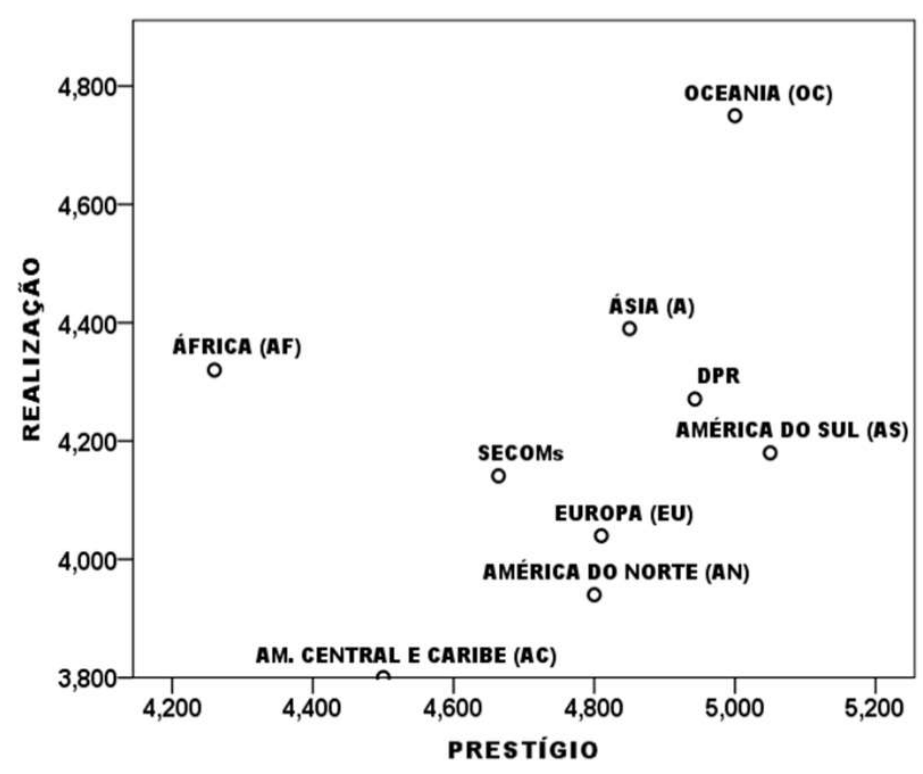

Fonte: dados da pesquisa

$$
\begin{gathered}
\text { PRESTIGIO } \\
\text { Levene Statistic Sig }=.839 \\
\text { HSD Tukey Sig. }=.324 \\
\text { SECOMs }<\text { DPR } \\
\text { AS DPR }<\text { OC AS } \\
\text { AF AC }<\text { AN EU } \\
\text { AF AC }<\text { AN EU A DPR OC AS }
\end{gathered}
$$

Ao verificar os resultados encontrados na dimensão prestígio, que se refere à busca pela organização de admiração e respeito da sociedade por causa da qualidade dos seus produtos e serviços, praticamente todos responderam que a organização em que trabalham têm contextos mais ou menos parecidos com as situações apresentadas nas frases elaboradas na escala IPVO. América do Sul $(5,05)$ e Oceania $(5,0)$ obtiveram as maiores médias de concordância, inclusive sendo as únicas com grau de similaridade "parecida" ao invés de "mais ou menos parecida", como os demais respondentes. Os continentes da África $(4,26)$ e da América Central e Caribe $(4,5)$ foram os que tiveram as menores médias.

Se for averiguar os resultados da dimensão masculinidade de Hofstede (2003), em que sociedades mais masculinas entendem que motivação está relacionada com concessão de oportunidades de reconhecimento e de promoção e com a perspectiva de enfrentar novos desafios (Hofstede, 1991, 2003). O autor situa o Brasil no Índice de Masculinidade (IMAS) na posição 49, interpretada por Hofstede com intermediária, 
nem tão masculina e nem tão feminina (Hofstede Centre, 2017). O que se espera é que sociedades com perfis masculinos deem ênfase a metas motivacionais de prestígio e domínio; e que a realização seja importante, mas não preponderante.

A América do Sul teve a maior média $(5,05)$ na dimensão prestígio, o que mostra que há uma busca por admiração e reconhecimento da sociedade local. Dos países sul americanis, que participaram das investigações de Hofstede e desta pesquisa, metade tem IMAS acima ${ }^{24}$ do índice brasileiro (49) e 66,7\% dos respondentes são nativos.

Todos os países da Oceania ${ }^{25}$ são classificados como masculinos e obtiveram a segunda maior média $(5,00)$, mesmo com todos os respondentes sendo brasileiros.

O DPR com média 4,943 é condizente com um país cuja posição encontra-se como intermediária na escala IMAS de Hofstede.

A Ásia, que atingiu média 4,85 nesta dimensão, possui metade dos países ${ }^{26} \mathrm{com}$ IMAS superior ao IMAS do Brasil, e 49,2\% dos respondentes são brasileiros. Apresenta nível de similaridade próximo ao do DPR.

A América do Norte ${ }^{27}(4,8)$, cujos países são potencialmente masculinos, apresentou média próxima à média do $\operatorname{DPR}(4,943)$. Ora, o perfil masculino, indica que seus países tendem a ser sociedades conduzidas pela competição, realização e sucesso, sendo este definido pelo vencedor em um sistema de valores que começa na escola e continua ao longo da vida organizacional (Hofstede Centre, 2017). Por isso, era de se esperar que a média da dimensão prestígio tivesse nível de similaridade superior ao do DPR, entretanto, com praticamente todos os respondentes brasileiros, é razoável pensar que haja influência dos valores da nacionalidade da maioria dos respondentes (Brasil por meio dos seus colaboradores brasileiros) sobre os valores da região local (países da América do Norte, por meio dos seus colaboradores nativos).

\footnotetext{
24 IMAS América do Sul > BR: Argentina=56; Equador=63; Colômbia=64; Venezuela=73 (+ Masc.) IMAS América do Sul < BR: Peru=42; Uruguai=38; Suriname=37; Chile=28.

25 IMAS Oceania > BR: Austrália $=61 ;$ Nova Zelândia $=58$

${ }^{26}$ IMAS Ásia > BR: Malásia=50; Paquistão= 50; Índia= 56; Filipinas=64; Líbano= 65; China = 66; Japão= 95 IMAS Ásia < BR: Cingapura=48; Indonésia=46; Taiwan=45; Turquia=45; Coreia Sul=39; Vietnã = 40; Tailândia=34.

27 IMAS América do Norte > BR: EUA = 62; Canadá = 52; México = 69 .
} 
A Europa ${ }^{28}$ com média 4,81, ou seja, próxima à média do DPR na dimensão prestígio, tem países potencialmente masculinos (Eslováquia, Hungria, Áustria, por exemplo) e países potencialmente femininos (Suécia, Dinamarca, Noruega) e com três quartos de respondentes brasileiros, o valor encontrado "mais ou menos parecida com a organização em que trabalha" parece previsível.

A América Central e Caribe obtiveram a segunda menor média $(4,5)$ nesta dimensão que averigua a similaridade da organização ao sucesso profisional e ao poder de influenciar outras organizações. Observa-se que dos três países que fizeram parte das duas pesquisas, dois têm IMAS inferior ao do Brasil' ${ }^{29}$. E, como o percentual de respondentes brasileiros foi de $40 \%$, pode-se indagar provável atuação da cultura local sobre a institucional (DPR - BR).

O continente africano que obteve a menor média na dimensão prestígio $(4,26)$, quando se verifica o IMAS dos países que participaram tanto desta pesquisa quanto das pesquisas de Hofstede, observa-se que três países ${ }^{30}$ possuem índices superiores ao do Brasil, e os demais países ${ }^{31}$ índices inferiores. Faz-se notar que o percentual de respondentes brasileiros foi de $42,1 \%$ no continente africano. Verificando uma possível atuação da cultura local sobre a cultura institucional (DPR-BR).

A dimensão realização avalia o sucesso baseado em demonstração de competência, da organização e dos seus colaboradores, em que o foco é a valorização, por parte da organização, do planejamento e da competência coletiva e individual. Oceania, Ásia, África, DPR, América do Sul e Europa afirmaram que a organização em que trabalham têm contextos mais ou menos parecidos com as situações apresentadas nas frases estruturadas na escala IPVO. Já América do Norte e América Central e Caribe responderam que é pouco parecida com o ambiente em que exercem suas atividades laborais.

\footnotetext{
28 IMAS Europa > BR: Bélgica=54; Rep. Checa = 57; Grécia=57; Polônia=64; Alemanha=66; Reino Unido=66; Irlanda=68; Itália=70; Áustria=79; Hungria = 88; Eslováquia = 100. (+ masc.)

IMAS Europa < BR: Sérvia=43; França=43; Espanha=42; Rússia=36; Portugal=31; Ucrânia=27; Finlândia=26; Eslovênia=19; Países Baixos=14; Noruega=8; Dinamarca=16; Suécia=5 (+ Fem.)

29 IMAS América Central e Caribe < BR: Panamá = 44; El Salvador = 40 (- masc.) IMAS América Central e Caribe > BR: Trindade Tobago = 58 (+ masc.)

30 IMAS África > BR: Quênia = 60; Nigéria = 60; África do Sul = 63 (+ masc.)

31 IMAS África < BR: Gana = 40; Moçambique = 38; Angola = 20; Cabo Verde = 15. (+ Feminino)
} 
A maior média foi da Oceania $(4,75)$, em que todos os países têm IMAS classificados como masculino, conforme os estudos de Hofstede (1991, 2003, 2017).

A média do continente asiático foi de 4,39 (segunda maior) e 49,2\% de respondentes brasileiros. Ao analisar o IMAS dos países, verifica-se que a posição da Malásia e do Paquistão (IMAS = 50) é mediana, ou seja, não se pode dizer se há preferência masculina ou feminina. Segundo a intepretação de Hofstede (Hofstede Centre, 2017). Cingapura, (IMAS=48) está no meio da escala, mas tendendo para o lado feminino. Segundo o autor, Indonésia (IMAS=46) tende a ser masculina, mas fraca, embora não seja inteiramente fraca, como a maioria dos países da Europa do Norte que são muito baixos em masculinidade e, portanto, considerados femininos, a Indonésia é menos masculina do que alguns outros países asiáticos, como Japão, China e Índia. Taiwan e Turquia (IMAS=45) já são consideradas sociedades ligeiramente femininas. Coreia do Sul (IMAS=39, Vietnã (IMAS=40) e Tailândia (IMAS=34) já são classificadas como sociedades femininas.

Nos países femininos, o foco é "trabalhar para viver", os gerentes se esforçam para o consenso, as pessoas valorizam a igualdade, a solidariedade e a qualidade em suas vidas trabalhadoras (Hofstede Centre, 2017), e isso não se distancia da meta motivacional realização, cujo foco da organização deve ser a valorização do planejamento e da competência coletiva e individual.

Os demais países asiáticos que participaram da pesquisa (Índia= 56; Filipinas=64; Líbano=65; China = 66 e Japão=95) têm perfil masculino, e nestes o enriquecimento do trabalho consiste em oferecer mais oportunidades de reconhecimento, promoção e possibilidades de enfrentar novos desafios (Hofstede, 2003 p. 116), e isso também está contido na meta motivacional realização quando avalia o sucesso fundamentado na demonstração de competência tanto da organização quanto dos seus colaboradores. Daí o resultado da Ásia nesta dimensão como a segunda maior média pode ser explicado tanto pela visão masculina quanto feminina.

A África obteve média 4,32, que foi superior à do $\operatorname{DPR}(4,271)$ e percentual de respondentes brasileiros de $42,1 \%$. Ao mergulhar na dimensão masculino versus feminino de Hofstede, vê-se que há mais países femininos (Gana, Moçambique, Angola e Cabo Verde) do que masculinos (Quênia, Nigéria e África do Sul) nesta 
pesquisa. E a dimensão realização não se opõe a nenhum dos lados desta dimensão de Hofstede, como analisado anteriormente para o continente asiático.

A América do Sul $(4,18)$ com média inferior à do DPR $(4,271)$ e com o menor percentual de brasileiros participantes da pesquisa (33,3\%), possui metade dos países com perfil masculino (Argentina=56; Equador=63; Colômbia=64; Venezuela=73) e metade com perfil feminino (Peru=42; Uruguai=38; Suriname=37; Chile=28). Daí a percepção dos seus colaboradores de que a organização seja mais ou menos parecida com a organização em que trabalha não difere do esperado.

Semelhantemente, a Europa $(4,04)$ não difere do esperado (organização mais ou menos parecida com o ambiente em que trabalham), dado que possui países tanto masculinos quanto femininos.

Já na América do Norte $(3,94)$, onde todos os países são classificados como masculinos na escala de Hofstede e quase todos os respondentes são brasileiros, esperava-se uma média igual ou maior à do $\operatorname{DPR}(4,271)$. Outros fatores podem ter influenciado nas respostas destes colaboradores. E a América Central e Caribe $(3,8)$, que obtiveram a menor média na dimensão realização, esse resultado não pode ser explicado pela dimensão masculinidade versus feminilidade de Hofstede, pois dos três países que estão presentes nos dois trabalhos, somente um possui perfil masculino (Trindade e Tobago) e dois femininos (Panamá e El Salvador). Talvez os outros países que não participaram da pesquisa de Hofstede (Cuba, Nicarágua e Haiti) possam ter influenciado no resultado.

Para fins de comparações, as médias obtidas nas duas dimensões (realização e prestígio) foram transformadas em percentuais. Então, por exemplo, a dimensão prestígio, em que a maior média foi 5,05 (América do Sul), passou a ser $100 \%$ e a menor média $(4,26)$ passou para $84 \%$ (África). Assim, foi possível estabelecer um comparativo entre percentual de nativos, brasileiros e respostas nestas duas dimensões. 
Gráfico 05 - Comparação do percentual de brasileiros e de respostas nas dimensões realização e prestígio

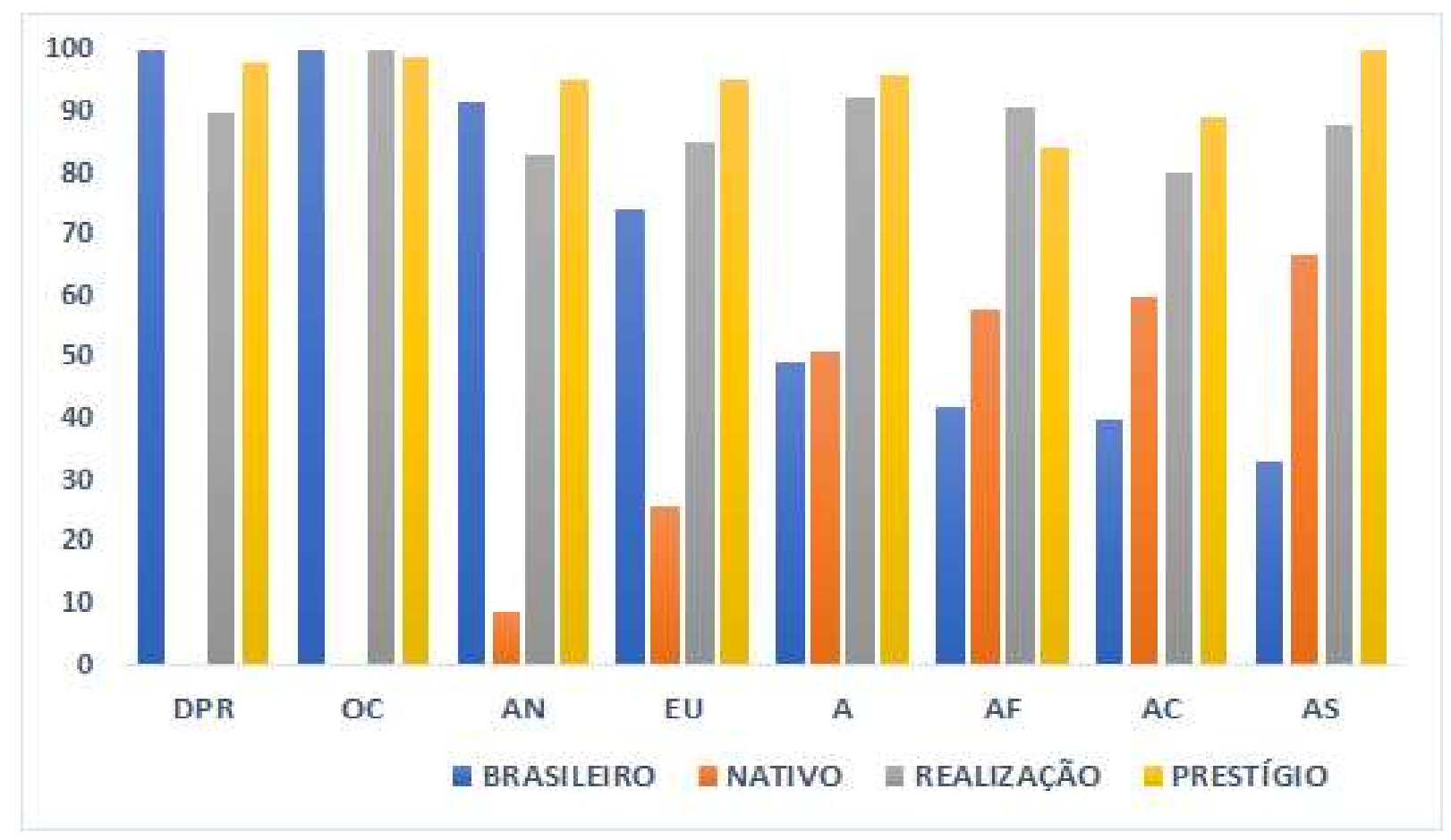

Fonte: dados da pesquisa

A partir do gráfico 05 se observa, quanto à dimensão prestígio, que continentes com menor percentual de respondentes brasileiros têm percepções de pouca similaridade (África, América Central e Caribe). Quando o percentual de respondentes brasileiros é muito maior em relação ao percentual de nativos, as médias se aproximam da média do DPR (Europa. América do Norte e Oceania). Quanto à dimensão realização, África e Ásia, com menores percentuais de respondentes brasileiros, mas com perfil menos masculino, tendem a ser mais similares. 


\subsubsection{2 (d) Domínio e Coletividade}

A figura 28 foi elaborada a partir das médias gerais das dimensões coletividade e domínio do DPR, SECOMs e suas divisões continentais.

Figura 28 - Comparação de médias - Domínio e Coletividade DPR e SECOMs por continente
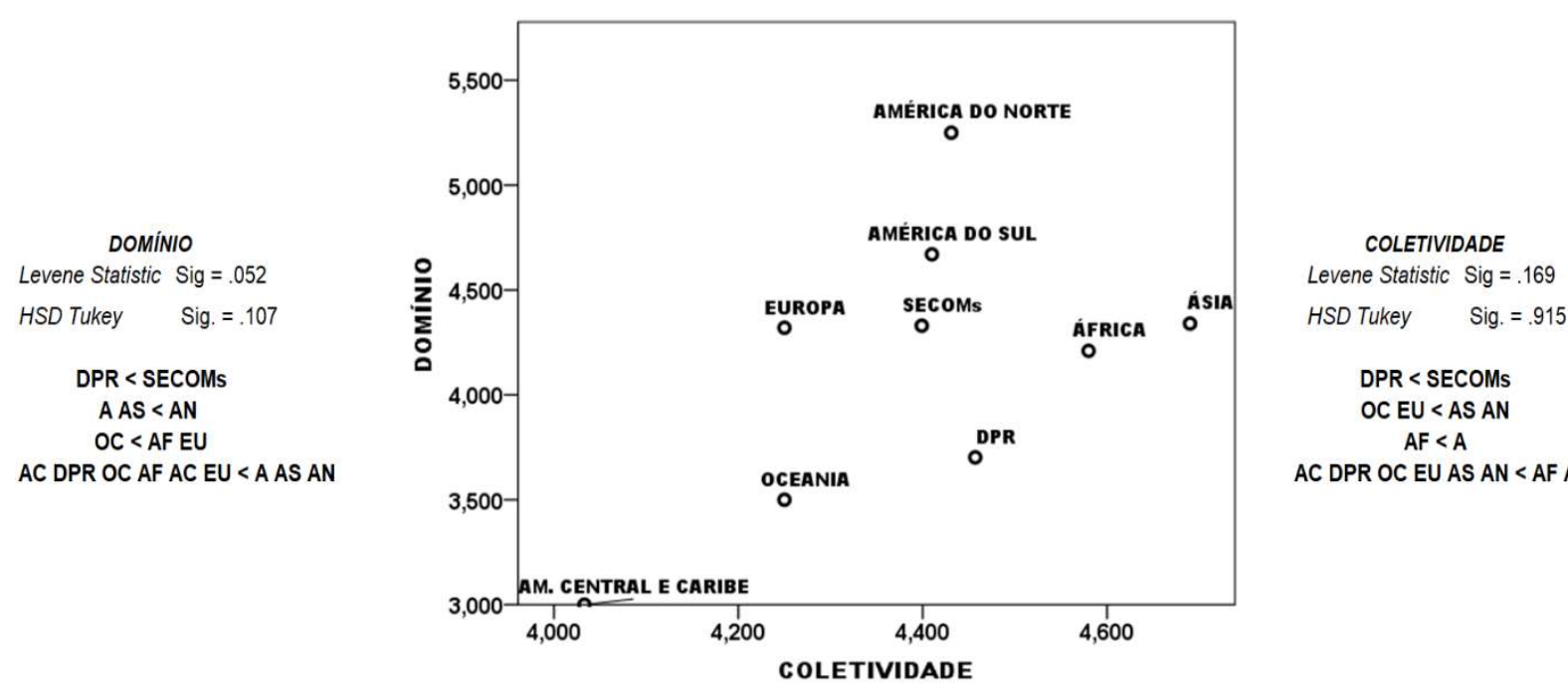

Fonte: dados da pesquisa

A dimensão domínio prioriza o sucesso organizacional, congregando itens relativos a poder e ao domínio do ambiente como forma de demonstrar controle, a partir de um posicionamento assertivo. Sobre essa dimensão, houve somente um item, pois os gestores do DPR identificaram os itens como díspares à finalidade de uma organização pública: o bem-estar social. Daí somente o item "Esta organização considera a segurança dos negócios muito importante. Ela está atenta às ameaças do mercado" fez parte da pesquisa.

Quanto aos resultados, somente a América do Norte afirmou que é parecida com a organização em que trabalha com média 5,25. América do Sul $(4,67)$, Ásia $(4,34)$, Europa $(4,35)$ e África $(4,21)$ afirmaram que é mais ou menos parecida com a organização em que trabalham. E Oceania $(3,5)$, DPR $(3,07)$ e América Central e Caribe $(3,0)$ afirmaram que é pouco parecida.

A média da América do Norte $(5,25)$, quando sondada sob a visão da dimensão masculina de Hofstede, fica fácil de ser compreendida por ser tratar de países com visões mais masculinas do que femininas, mesmo tendo $91,4 \%$ de respondentes brasileiros. 
Nos continentes América do Sul, Ásia, Europa e África compreendem que a dimensão domínio é mais ou menos parecida, o que era de se esperar dada a distribuição de países masculinos e femininos ser praticamente igualitária entre os pesquisados.

A Oceania $(3,5)$ e a América Central $(3,0)$ têm médias próximas a do DPR $(3,07)$. Entretanto, os países da Oceania são masculinos e, para tanto, esperava-se um resultado mais concordante com a dimensão domínio, entretanto não se pode esquecer que todos os questionados nestes países são brasileiros. E a América Central, cujos países respondentes são mais femininos, teve uma média próxima à média do DPR, que se situa em país nem tão masculino e nem tão feminino.

Acerca da dimensão preocupação com a coletividade, que valoriza a igualdade, justiça, lealdade e honestidade nas práticas organizacionais e no relacionamento da organização para com seus stakeholders. Todos concordaram que a organização em que trabalham é mais ou menos parecida com a organização onde executam suas atividades laborais.

No que se refere à dimensão masculino versus feminino de Hofstede, o que se espera é que sociedades mais femininas deem mais ênfase à preocupação com a coletividade, dado que tem como um de seus valores dominantes o cuidado pelos outros.

A Ásia foi o continente que obteve maior média $(4,69)$ seguido da África $(4,58)$ e, no que concerne ao índice de masculinidade, ambos têm países femininos e masculinos representados nos resultados encontrados, mas sob a ótica coletivista versus individualista de Hofstede, os dois contêm países mais coletivistas, reforçando o resultado encontrado.

Os países da América do Norte $(4,431)$ e da Oceania $(4,25)$ são todos classificados como masculinos, e, portanto, não se esperavam médias superiores à do DPR $(4,208)$, mas vale lembrar que há o alto índice de respondentes brasileiros nestes continentes.

Na Europa $(4,25)$, com a disposição de países masculinos e femininos praticamente igualitária, respostas que levam à interpretação mais ou menos parecida com a organização em que trabalha seriam o esperado. E ainda deve-se levar em consideração o percentual de brasileiros $(74 \%)$ que responderam à pesquisa neste continente. 
A América do Sul $(4,41)$, com média superior à do DPR $(4,208)$ e com menor percentual de respondentes brasileiros, é representada nesta pesquisa por países tanto masculinos quanto femininos, mas, sob a perspectiva coletivista de Hofstede, vê-se que há mais países coletivistas do que individualistas, o que pode corroborar a média encontrada.

A América Central e o Caribe $(4,033)$ obtiveram a menor média entre os continentes e o DPR, possuem países menos masculinos e todos são coletivistas, o que pode explicar a média encontrada.

Para fins de comparações, as médias obtidas nas duas dimensões (domínio e coletividade) foram transformadas em percentuais. Então, por exemplo, na dimensão domínio em que a maior média foi 5,25 (América do Nortel), o percentual passou a ser 100 e a menor média $(3,0)$ passou para 57 (América Central e Caribe). Dessa forma, foi possível estabelecer um comparativo entre percentual de nativos, brasileiros e respostas nestas duas dimensões.

Gráfico 06 - Comparação do percentual de brasileiros e de respostas nas dimensões Domínio e Coletividade

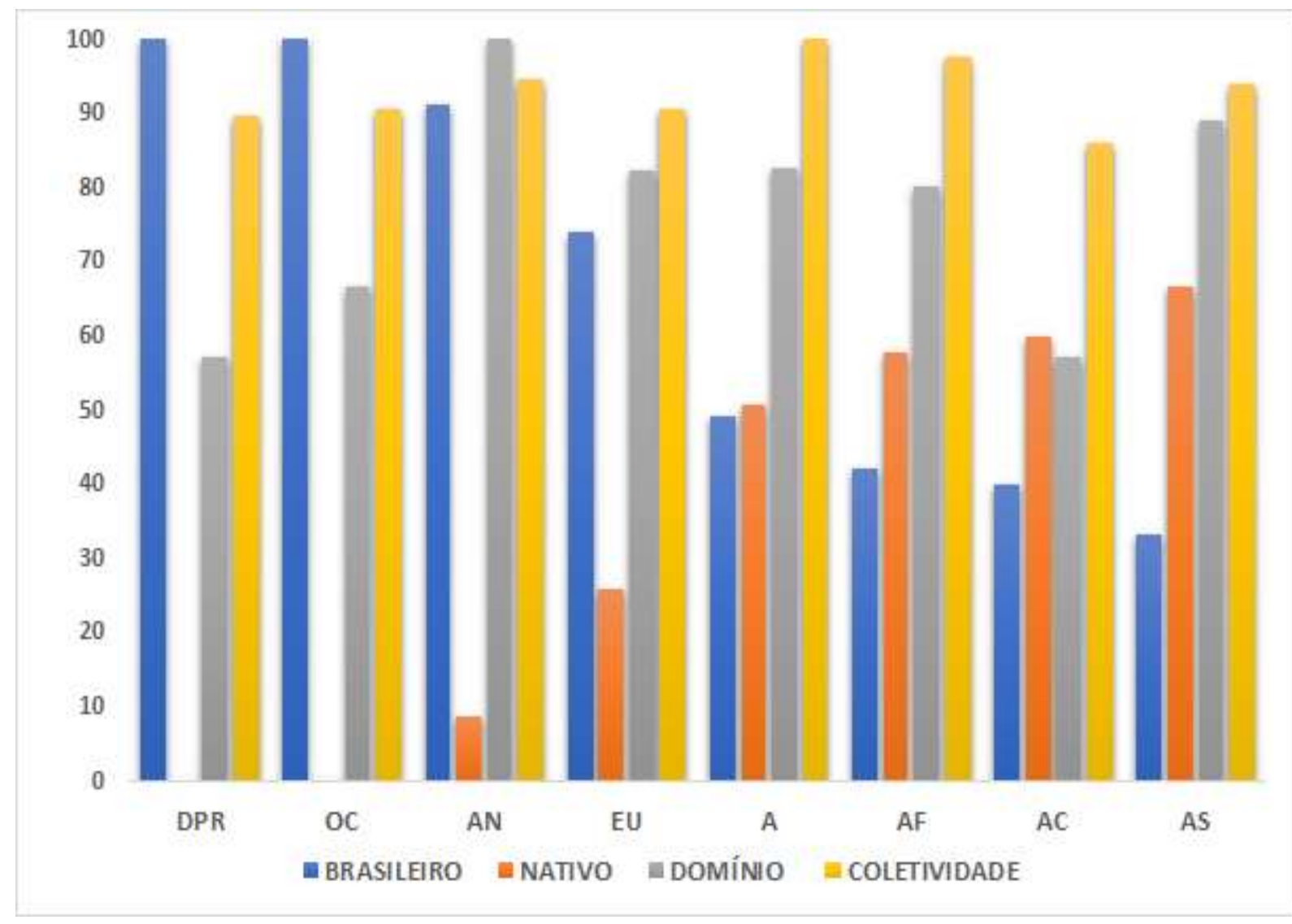

Fonte: dados da pesquisa 
O que pode ser interpretado a partir do gráfico 06 é que continentes com percentual elevado de respondentes brasileiros tendem a ser similares à dimensão coletividade (América do Norte, Europa e Oceania). Continentes com distribuição quase igualitária de países masculinos e femininos, porém mais coletivistas, tendem a ser similares à dimensão coletividade (Ásia, África, América Central e Caribe e América do Sul).

Em resumo, os valores que ocupam o lugar de destaque na hierarquia axiológica do DPR e SECOMs são conformidade, prestígio e tradição, sendo, portanto, valores altamente compartilhados entre os membros da organização.

No comparativo de médias, o DPR foi o que obteve maior média de concordância quanto à dimensão conformidade, seguido pelos SECOMs da América do Sul. Já para a dimensão tradição foram os SECOMs da Oceania que obtiveram a maior média de concordância. Outro fator importante que foi identificado nestas duas dimensões foi que, quando o percentual de respondentes brasileiros é muito maior do que o de nativos, as médias se aproximam das médias do DPR, como o caso dos SECOMs da Europa, América do Norte e Oceania.

Para a dimensão autonomia, a maior concordância foi encontrada nos SECOMs da Oceania, seguidos pelo DPR e SECOMs da Ásia. E para a dimensão bem-estar, os SECOMs da Ásia e da Oceania foram os que obtiveram as maiores médias, entretanto estas médias tendem no sentido de que as situações apresentadas nos itens relativos a esta dimensão são pouco parecidas com o ambiente em que trabalham. O que deve ser ressaltado é que, quanto o menor o número de respondentes brasileiros nos continentes com perfis mais coletivistas, menor é a média nas dimensões autonomia e bem-estar, como o caso da África, América Central e América do Sul.

Os SECOMs da América do Sul e da Oceania foram os que mais concordaram com a dimensão prestígio. E para a dimensão realização, os SECOMs da Oceania foram os que mais apresentaram similaridade. Para a dimensão domínio a maior concordância foi entre os SECOMs localizados da América do Norte. Já para a dimensão preocupação com a coletividade, os SECOMs da Ásia foram os que apresentaram as maiores médias. O que deve ser observado é que continentes que possuem um quantitativo alto de respondentes brasileiros tendem a ser similares à dimensão coletividade, como o caso da América do Norte, da Europa e da Oceania. 


\subsubsection{A confiabilidade dos itens e comparação de médias - Tipos de Práticas Organizacionais}

A seguir serão desenvolvidos a análise fatorial para a escala de tipos de práticas (lócus de valor humano) no contexto da população-alvo deste trabalho, em seguida apresentam-se a ANOVA com teste de Tukey para não aditividade para as os resultados do DPR e dos SECOMs e a comparação das médias obtidas nos SECOMs por continente e o DPR.

\subsection{Análise Fatorial - Escala de percepções de práticas de gestão de pessoas}

A Escala de percepções de práticas de gestão de pessoas foi adaptado da escala lócus de valor humano desenvolvido por Jackson (2002). A análise da escala foi feita com todos os respondentes (DPR e SECOMs), pois a finalidade foi verificar a confiabilidade e a validade do instrumento de pesquisa.

$\mathrm{Na}$ análise fatorial, deve-se verificar a consistência dos fatores. O fator, que é uma escala, deve apresentar os parâmetros básicos de qualquer medida, i.e., validade e precisão. A validade do fator é garantida pela própria análise fatorial, sendo expressa pelo tamanho das cargas fatoriais: quanto maior a carga mais a variável será representativa do fator. Entretanto, validade não garante consistência. A consistência está relacionada ao tamanho das cargas fatoriais e ao número de itens que compõem o fator. Então, fatores com reduzido número de itens e com cargas moderadas (abaixo de 0,45$)$ tendem a ser não confiáveis e variantes. O coeficiente Alfa de Cronbach é um teste de confiabilidade que realiza a análise da consistência dos fatores para as variáveis unidirecionais (todas têm que ter cargas com mesmo sinal) do fator. Um alfa acima de 0.80 favorece a consistência do fator. $E$ os valores de 0,6 a 0,7 considerados como o limite inferior de aceitabilidade.

A escala de percepções de práticas de gestão de pessoas foi adaptada da escala lócus de valor humano desenvolvido por Jackson (2002). A análise de consistência interna foi confirmada por meio do alpha de Cronbach, 0,886 que é considerada alta, pois o valor mínimo aceitável é maior ou igual 0,70. E, para as duas dimensões (instrumental e humanista) foram calculados os respectivos alfas de Cronbach, como pode ser visto na tabela 24 , os valores para cada uma das dimensões também ultrapassaram os limites exigidos. Para a realização da análise fatorial, após a extração de componentes principais, procedeu-se à rotação varimax e a oblimin, 
comparando-se os resultados em função da distribuição das cargas fatoriais face às dimensões teóricas existentes (Hair et al., 2009). Também observou, como critério de análise, que a medida de adequação da amostra $(\mathrm{KMO})$ foi superior a 0,50 ; a variância explicada pelos fatores correspondeu ao mínimo de $50 \%$; cada fator extraído apresentou eigenvalue superior a 1,0 ; e as cargas fatoriais superiores a $\pm 0,30$ estão apresentadas na tabela 24; a análise fatorial produziu três componentes, explicando a variação total em 70,01\%. Foi observado uma predominância no fator 1 de itens instrumentalistas e no fator 2 de itens humanistas.

Os itens "Esta organização considera melhor comunicar os colaboradores a respeito das decisões que os afetam" e "Nesta organização o funcionário é valorizado pelos seus próprios méritos" de natureza humanista carregam tanto em no fator instrumental quanto no fator humanista. Como explicado no item 5.3.2.2 desta tese, a meritocracia é um pressuposto das organizações públicas brasileiras e a comunicação prévia das ações de gestão faz parte dos procedimentos da administração das organizações públicas. Esses fatores podem esclarecer porque esses dois itens são interpretados como semelhantes entre as duas dimensões.

O item "Não há espaço para democracia nesta organização" de natureza instrumental, apresentou carga fatorial negativa, indicando uma influência do item na escala, mas com impacto inverso, podendo ser interpretado como o contrário do item: há espaço para a democracia na organização. 
Tabela 24 - Resultado da Análise Fatorial - Tipos de práticas

\begin{tabular}{|c|c|c|c|c|}
\hline Fator & Componente 1 - Tendência mais Instrumentalista (alfa de Cronbach = 0,883) & 1 & 2 & 3 \\
\hline 6 & Para esta organização o fator mais importante são os resultados.(I) &, 867 & & \\
\hline 18 & Esta organização está primordialmente preocupada com seus resultados.(l) & ,763 & & \\
\hline 16 & Nesta organização as pessoas são reconhecidas principalmente por atingirem resultados.(I) & ,761 & & \\
\hline 8 & O ponto central desta organização é gerar os resultados planejados.(l) & ,756 & &,- 413 \\
\hline 2 & $\begin{array}{l}\text { O colaborador desta organização é visto primordialmente como um instrumento de alcance dos objetivos } \\
\text { oroanizacionais.(ll) }\end{array}$ &, 574 & & ,353 \\
\hline 10 & A principal preocupação desta organização é a produtividade.(I) &, 560 &, 436 &,- 428 \\
\hline 13 & $\begin{array}{l}\text { Esta organização considera melhor comunicar os colaboradores a respeito das decisões que os } \\
\text { afetam. }(\mathrm{H})\end{array}$ &, 544 &, 414 &,- 536 \\
\hline 12 & $\begin{array}{l}\text { Nesta organização os colaboradores sempre são consultados a respeito das decisões importantes que } \\
\text { os afetam.(H) }\end{array}$ &, 496 &, 465 &,- 465 \\
\hline 4 & O funcionário é principalmente valorizado por atingir os resultados para a organização.(l) & ,438 & & \\
\hline 1 & $\begin{array}{l}\text { As pessoas são consideradas primordialmente um recurso, como qualquer outro, tais como recursos } \\
\text { financeiros, maquinários e infraestruturas. (l) }\end{array}$ &, 396 & & ,322 \\
\hline 5 & Nesta organização o funcionário é valorizado pelos seus próprios méritos. $(H)$ &, 313 & ,402 & \\
\hline 20 & Nẫo há espaço para democracia nesta organização.(l) &,- 522 & & , 446 \\
\hline Fator & Componente 2- Tendência mais humanista (alfa de Cronbach $=0,806$ ) & 1 & 2 & 3 \\
\hline 1 & O principal objetivo desta organização é a satisfação dos seus colaboradores.(H) & & ,881 & \\
\hline 11 & A principal preocupação desta organização é relativa às pessoas. $(\mathrm{H})$ & & ,868 & \\
\hline 3 & Esta organização é vista principalmente como um meio para as pessoas alcançarem seus objetivos. (H) & & ,867 & \\
\hline 9 & 0 ponto central desta organização é beneficiar os seus membros. $(\mathrm{H})$ & & ,801 & \\
\hline 15 & Esta organização é vista principalmente como uma rede de relações humanas. $(H)$ & &, 777 & \\
\hline 7 & Para esta organização o fator mais importante são as pessoas. $(\mathrm{H})$ & & ,657 &,- 309 \\
\hline 14 & Esta organização é completamente democrática. $(H)$ & &, 509 &,- 347 \\
\hline 12 & $\begin{array}{l}\text { Nesta organização os colaboradores sempre são consultados a respeito das decisões importantes que } \\
\text { os afetam. }(\mathrm{H})\end{array}$ &, 496 & ,465 & -465 \\
\hline 10 & A principal preocupação desta organização é a produtividade.(I) &, 560 &, 436 &,- 428 \\
\hline 13 & $\begin{array}{l}\text { Este organização considera melhor comunicar os colaboradores a respeito das decisões que os } \\
\text { afetam. }(\mathrm{H})\end{array}$ &, 544 &, 414 &,- 536 \\
\hline 5 & Nesta organização o funcionário é valorizado pelos seus próprios méritos. $(H)$ &, 313 & ,402 & \\
\hline 17 & Nesta organização as pessoas são reconhecidas principalmente por sua lealdade.(H) & & ,324 & \\
\hline
\end{tabular}

Extraction Method: Principal Component Analysis. Rotation Method: Oblimin with Kaiser Normalization.

Fonte: Dados da pesquisa 


\subsection{ANOVA com teste de Tukey para não aditividade - Tipos de Práticas}

Praticamente todas as dimensões da escala práticas organizacionais apresentaram consistência interna acima de 0,80, com exceção para a dimensão instrumental do DPR.

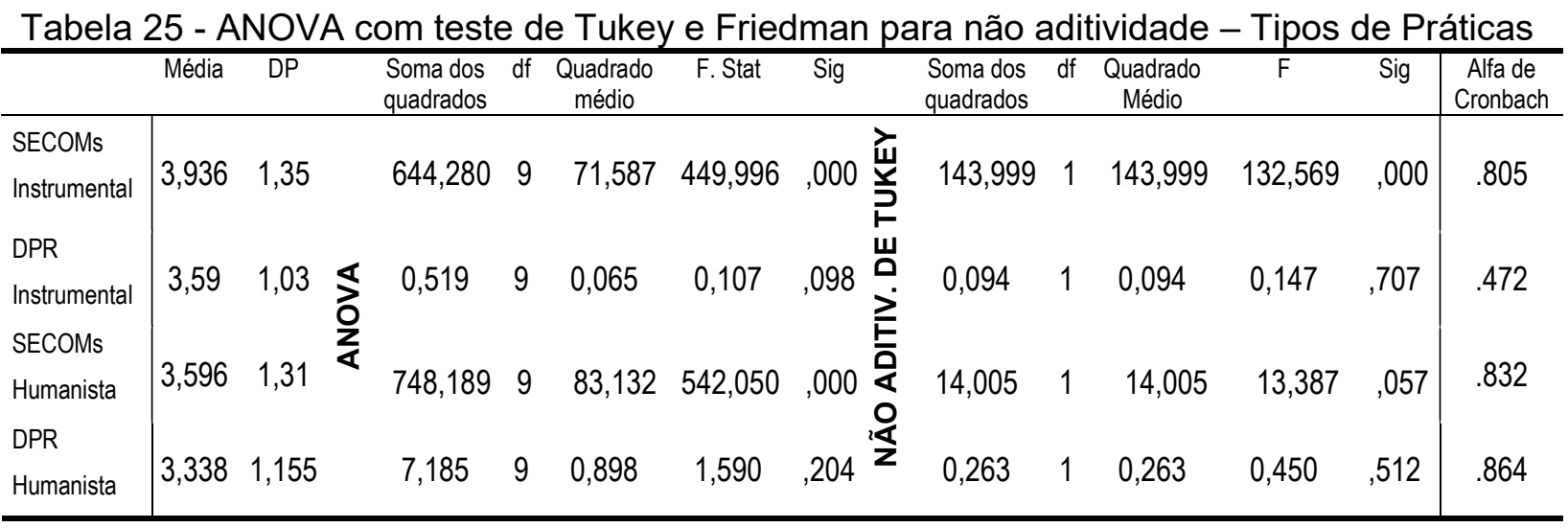

Fonte: Resultados da pesquisa elaborados a partir do Software SPSS 20.0

Quase todos apresentaram variância homogênea com significância menor de 0,05, com exceções das dimensões instrumental e humanista no DPR. Quanto ao teste de médias, a dimensão instrumental nos SECOMs apresentou significância para interações multiplicativas.

Os itens destes fatores deverão receber atenção na fase da análise multivariada, mas, por enquanto, para fins exploratórios, admite-se trabalhar com alguns destes itens significativos quanto â possibilidade de interações multiplicativas.

\subsection{Comparação de médias entre continentes e DPR - Tipos de Práticas Organizacionais}

A figura 29 foi elaborada a partir das médias gerais das dimensões instrumental e humanista do DPR, SECOMs e suas divisões continentais. 
Figura 29 - Comparação de médias DPR e SECOMs por continente - Instrumental e Humanista

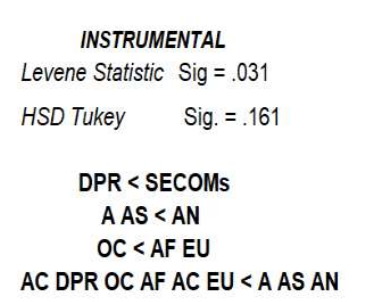

AC DPR OC AF AC EU < A AS AN

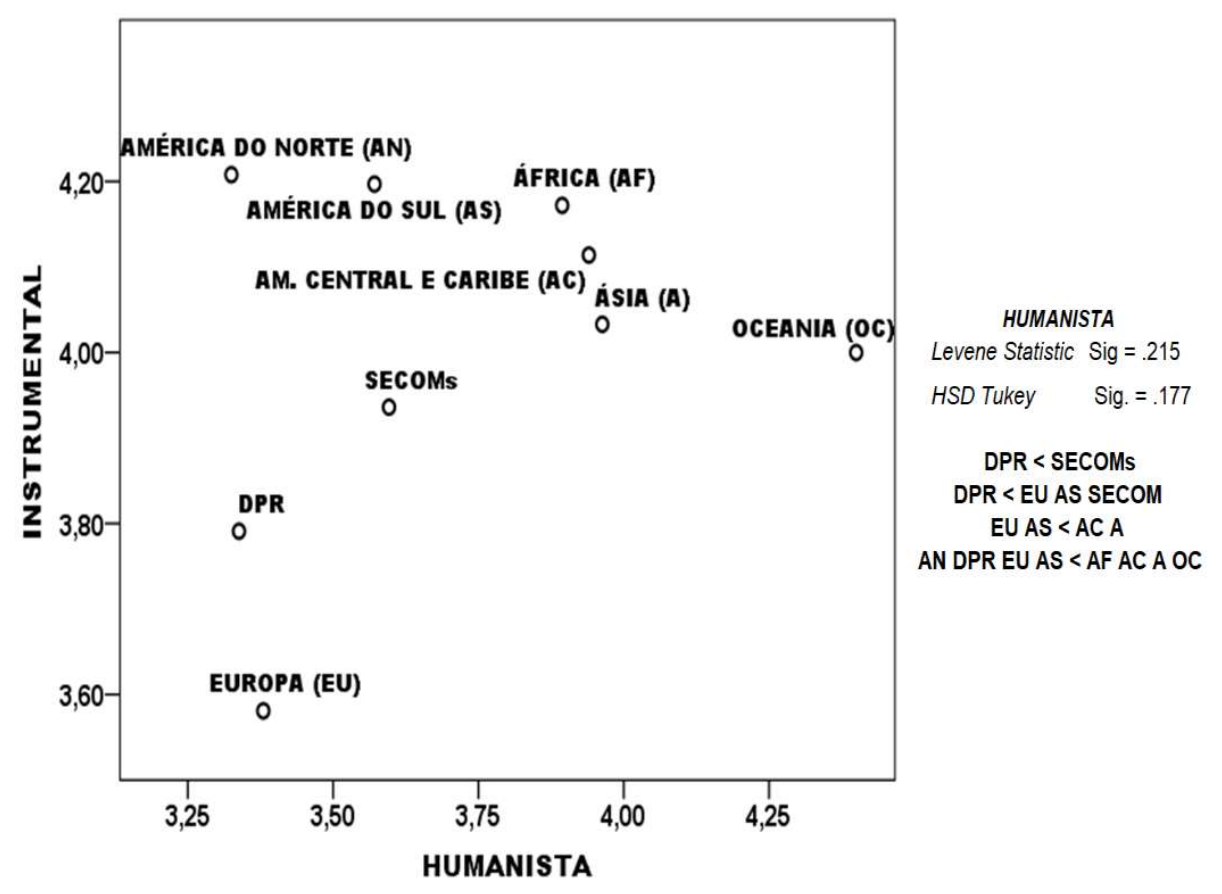

Fonte: dados da pesquisa

O que se pretendeu medir neste instrumento foi a forma como as diferenças culturais influenciam o modo como as pessoas são valorizadas nas organizações: mais instrumentalistas ou mais humanistas. Aparentemente, estas duas visões opostas também podem conter semelhanças, pois ambas são vistas como o cumprimento das atividades para o alcance dos objetivos da organização; a diferença, segundo Jackson (2002) é que o instrumental é mais representativo de uma abordagem sistêmica e a humanista, de uma abordagem fenomenológica.

Na visão sistêmica ou funcionalista, a estratégia é vista como uma entidade concreta (Silverman, 1970) em que todos na organização propõem-se a alcançar os objetivos estabelecidos pelos gestores, caso contrário serão considerados disfuncionais, por isso os funcionários são utilizados para alcançarem os objetivos dos executivos. $\mathrm{Na}$ visão fenomenológica de organização, as pessoas constroem a realidade (incluindo os seus objetivos) por meio de um processo de negociação, ainda que dentro de uma série de relações de poder (Silverman, 1970; Jackson, 2002).

Então, os loci de valor humano não podem ser incompatíveis, tanto que ambos podem estar contidos dentro dos objetivos a serem alcançados pela organização, e funcionários dentro de ambas as abordagens podem ser vistos como cumprindo os objetivos das organizações. Consequentemente, segundo Jackson (2002), é lógico 
esperar que culturas que têm humanismo elevado também poderiam ser elevadas na dimensão instrumentalismo. Isso não significa que seja possível prever o nível de instrumentalismo com base no nível de humanismo. Este pressuposto metodológico apenas indica que instrumentalismo e humanismo não estão correlacionados negativamente (embora possam ser correlacionados positivamente) e que um não é preditor do outro nem uma explicação sobre o outro. Então, uma possível correlação entre práticas humanistas e instrumentalistas pode ser um aspecto de crossvergence ou a miscigenação de sistemas culturais e da maturidade dos sistemas de recursos humanos dentro de um mesmo país ou de uma instituição que possui organizações localizadas em outros países.

Quanto aos resultados da dimensão instrumental, cujo foco das práticas está para os resultados, ou seja, as pessoas são mais valorizadas quanto à eficácia das suas atividades laborais para o alcance dos objetivos da organização, a América do Norte $(4,208)$ apresentou a maior média, seguida da América do Sul $(4,197)$, África $(4,172)$, América Central e Caribe $(4,114)$, Ásia $(4,033)$ e Oceania $(4,00)$, em que seus respondentes informaram que a organização em que trabalham é mais ou menos parecida com as situações apresentas no contexto de práticas instrumentais. Já o DPR $(3,791)$ e a Europa $(3,581)$ veem como pouco parecida com o contexto de trabalho que vivenciam.

Segundo Jackson (2002), práticas instrumentais podem ser vistas dentro de culturas mais individualistas (foco no sucesso) e as práticas humanistas em culturais mais coletivistas nas quais a base do dever é o compromisso.

A América do Norte $(4,208)$ e a Oceania $(4,00)$ são, segundo Hofstede $(2003)$, predominantemente individualistas e, apesar de terem médias mais altas comparativamente ao DPR, como todos os respondentes são brasileiros, isto pode ter provocado um abrandamento no lócus instrumental destes dois continentes, pois, de acordo com Jackson (2002), tanto nas organizações australianas como nas americanas, no que se refere à forma de controle e comando, utilizam-se modelos que apresentam uma gestão topdown, podendo ser um fator promotor de práticas calculativas $^{32}$ (Gooderham et al.,2006; Brookes, 2011).

\footnotetext{
32 Posiciona-se no estabelecimento do desempenho dos empregados às metas organizacionais que beneficiará a organização como um todo. As práticas são destinadas a alcançar a eficiência em nível
} 
América do Sul $(4,197)$, África $(4,172)$ e América Central e Caribe $(4,114)$ e Ásia $(\mu=4,003)$ são preeminentemente coletivistas e apresentaram médias semelhantes à dos continentes mais individualistas (América do Norte e Oceania), mas é importante ressaltar que os respondentes são todos brasileiros natos (diplomatas concursados que chefiam os SECOMs) e isto pode ter promovido uma intensificação na dimensão instrumental, pois estes servidores fazem parte da Nova Gestão Pública brasileira, na qual a gestão é por resultados.

A Europa (3,581), que obteve a menor média na dimensão instrumental, congrega países com tendências a práticas mais humanistas (Brookes et al., 2011; Legge, 2005; Tomé, 2005), ou seja, práticas mais colaborativas ${ }^{33}$ convergindo para um perfil cultural mais coletivista.

Na dimensão humanista, em que o gestor busca desenvolver o comprometimento das pessoas no trabalho por meio do bem-estar e da qualidade de vida no trabalho e do aprimoramento do comprometimento moral, a Oceania obteve a maior média $(4,4)$ esse valor não é de se estranhar dado que esta orientação humanista já foi identificada em outras pesquisas (England, 1975, 1978). Segundo Jackson (2002), autores como Westwood e Posner (1997) afirmam que esta visão mais humanista em países com a Austrália e Nova Zelândia, está associada à preocupação do bem-estar da força de trabalho e à qualidade da vida profissional, e também ao alto nível de comprometimento igualitário identificado por Schwartz (1994) e Smith et al. (1996).

A Ásia $(3,963)$, com a segunda maior média, apresenta como resultado que os itens apresentados na dimensão humanista são pouco parecidos com a organização em que trabalham. Segundo Jackson (2002), países recém industrializados da Ásia Oriental (nesta pesquisa, Taiwan e China) são suscetíveis a serem influenciadas pelos países industrializados mais velhos a adotarem medidas de curto prazo que foram bem-sucedidas em outros lugares para competirem na economia global.

individual e envolvem: avaliações e sistemas de recompensas individuais; participação financeira dos empregados, inclusive nos lucros; práticas individuais de desenvolvimento; e avaliação formal dos treinamentos realizados (Poutsma et al., 2013; Croucher, Brookes, Wood \& Brewster, 2010)

33 São práticas baseadas em contratos psicológicos estabelecidos entre empregados e empregador, que procura desenvolver atitudes e comportamentos organizacionais favoráveis. Caracteriza-se por uma cultura de parceria, que enfatiza a comunicação e a cooperação de forma que os funcionários são vistos como participantes ativos na empresa (Gooderham et al., 2006; Uysal, 2014; Poutsma et al., 2006). 
China, Taiwan e Coreia do Sul, a partir da metade do século $X X$, abraçaram plenamente o capitalismo e, com o apoio do governo e sob a influência dos EUA, recuperaram-se rapidamente da devastação da Guerra Pacífico-Asiática (Brewster \& Mayrhofer, 2012; Debroux et al., 2011).

No Japão, embora o país tenha aplicado por completo as técnicas ocidentais, as atuais organizações tendem a aprender com suas histórias antigas e aplicarem seu patrimônio cultural às recentes questões de gestão e de organização. $O$ confucionismo e o budismo influenciam fortemente a vida das pessoas e muitos líderes empresariais adotam estes valores, como, por exemplo, na incorporação dos princípios espirituais nas atividades dos " $5 S^{34}$ ". Esses líderes têm uma forte visão de que o gerenciamento depende das pessoas mais do que os recursos materiais e financeiros. Muitas empresas enfatizam a disciplina moral e, com isso, a gestão de Recursos Humanos torna-se uma parte fundamental na continuação dessa tradição e, aparentemente, permite que o Departamento de GRH tenha mais poder do que é encontrado nas organizações ocidentais (Brewster \& Mayrhofer, 2012).

A América Central e o Caribe $(\mu=3,94)$, a América do Sul $(\mu=3,571)$, apesar de conterem países mais coletivistas, também veem a forma mais humanista de valorizar as pessoas nas organizações como pouco parecida com a que trabalham. Fato semelhante ocorre no DPR $(\mu=3,338)$, que se situa em país caracterizado como coletivista.

Na Europa $(\mu=3,38)$, o contraste é maior entre o que existe nos países europeus como práticas organizacionais e o que se vivencia nos SECOMs, pois as práticas realizadas nestas organizações tendem a ser semelhantes entre si, já que todos os SECOMs têm um conjunto de atividades que devem ser realizadas (atividades produtivas e atividades proativas) e estas práticas (operacionalização) das atividades são comuns em todos os SECOMs. Independentemente de onde estão localizados, todas devem ser focadas nos resultados.

De acordo com Brewster (1999; 2007), diferentes modelos de Gestão de Recursos Humanos $(\mathrm{GRH})$ foram discutidos por pesquisadores europeus e chegaram às seguintes características comuns quanto as práticas de $\mathrm{RH}$ : a $\mathrm{GRH}$ é localizada em

\footnotetext{
${ }^{34}$ Seiri (armazenagem), Seiton (alisamento), Seiso (limpeza), Seiktsu (cuidados sanitários) e Shitsuke (sustentação).
} 
um ambiente de cultura nacional, legislação nacional, envolvimento estadual e representação sindical. Segundo o autor, esses fatores são vistos como parte da GRH e não apenas como antecedentes, o que leva a um sentimento generalizado de que as empresas precisam ser controladas e que devem tratar seus funcionários de forma socialmente responsável.

Com a menor média na dimensão humanista, está a América do Norte $(\mu=3,325)$, onde somente o México tem perfil mais coletivista e os demais países são mais individualistas. A cultura dos EUA é mais orientada para a realização do que a maioria dos outros países (Hofstede, 2001; House, 2004). Na verdade, argumenta-se (GUEST, 1990) que a suposição de liberdade de negócios e autonomia é peculiarmente americana (EUA) e está relacionada à visão americana de seu país como uma terra de oportunidades que recompensa o sucesso. $\mathrm{Na} \mathrm{GRH}$, isso se traduz em uma visão de que os empresários devem ser tão livres quanto possível para administrarem seus negócios da maneira que eles querem e que os indivíduos devem assumir a responsabilidade individual pela sua situação. Esta cultura do individualismo é claramente discernível no pensamento que sustenta as noções norte-americanas de sistemas de recompensa, com sua ênfase em recompensas individuais baseadas em desempenho (Brookes, 2011; Jackson, 2002).

Em resumo, para a dimensão instrumental, a maior média foi apresentada pelos SECOMs localizados na América do Norte, seguidos pelos que estão situados na América do Sul. E na dimensão humanista, a maior média está entre os SECOMs da Oceania, seguidos pelos SECOMs situados na Ásia.

\subsubsection{Comprometimento organizacional - análise das dimensões}

Nos próximos itens serão desenvolvidos a análise fatorial para a escala de comprometimento (EBACO) no contexto da população-alvo deste trabalho, em seguida apresentam-se a ANOVA com teste de Tukey para não aditividade para as os resultados dos SECOMs e a comparação das médias obtidas nos SECOMs por continente. 


\subsection{Análise Fatorial - Escala EBACO}

Apesar de a Escala EBACO de ter sido validada estatisticamente e testada em vários estudos, optou-se por realizar a análise fatorial para as 28 questões a fim de validá-la no contexto desta pesquisa. Segundo Medeiros (2005), a pesquisa sobre comprometimento organizacional ainda não apresenta conformidade no que se refere às dimensões ou fatores, o que faz do conceito comprometimento um processo em evolução, apesar de o tema ter apresentado significativos avanços nas últimas décadas (Wasti et al., 2016).

Similar ao ocorrido na pesquisa exploratória de Medeiros (2003), a análise fatorial produziu sete componentes, explicando a variação total em $69,75 \%$. Por sua vez, a análise de consistência interna foi confirmada por meio do alpha de Cronbach, 0,825, que é considerada alto, pois o valor mínimo aceitável é maior ou igual 0,70 . Além disso, o alfa de Cronbach foi calculado para cada uma das setes dimensões isoladamente, como pode ser visto na tabela 26 , com os resultados dos alfas variando de 0,756 a 0,910. Portanto, em termos de confiabilidade, o instrumento EBACO possui precisão para medir através de seus itens (indicadores) as dimensões (bases) do comprometimento, já que apresenta boa qualidade psicométrica.

Com relação à adequação da amostra, foi utilizada a medida de Kaiser-Meyer-Olkin, obtendo-se um KMO de 0,838, considerado bom, já que o patamar mínimo de adequabilidade é de 0,50 (HAIR et al, 2009). Também foi realizado o teste de esfericidade de Bartlett (sig=.001), rejeitando-se a hipótese nula de que a matriz de correlação das variáveis é uma matriz identidade (HAIR et al., 2007). A comunalidade apresenta a proporção da variância explicada pelo fator; ao realizar sua análise para a amostra neste instrumento, todos apresentaram-se maiores que 0,5, que é considerado satisfatório (Hair et al., 2009; Pestana \& Gageiro, 2003).

Em seguida, foi realizada a validade da escala, cuja finalidade é verificar se os indicadores de cada uma das dimensões estavam medindo as dimensões preestabelecidas. Constatou-se que os sete fatores extraídos pela análise possuem quatro indicadores cada, corroborando o modelo EBACO proposto por Medeiros (2003). O critério adotado para seleção do número de fatores foi o do autovalor (eigenvalue) $\geq 1$. 
A extração dos fatores foi realizada por meio do método de componentes principais com normalização Kaiser (eigenvalue $\geq 1$ ) e rotação oblimin (permite que os fatores sejam correlacionados). As cargas fatoriais estão acima de 0,3 , sendo que quanto maior a carga melhor o item (Pasquali, 2005). Ao considerar as cargas fatoriais mais fortes, nenhum dos indicadores mede outra dimensão ao invés da previamente determinada. Portanto, a escala EBACO representa adequadamente as bases do comprometimento nos SECOMs estudados.

Tabela 26 - Resultado da Análise Fatorial - Comprometimento

\begin{tabular}{l}
\hline \multicolumn{1}{c}{ Base afetiva (Fator 1) } \\
\hline Desde que me juntei a essa organização, meus valores pessoais e os da organização têm se tornado mais \\
similares. \\
A razão de eu preferir esta organização em relação a outras é por causa do que ela simboliza, de seus valores. \\
Eu me identifico com a filosofia desta organização \\
Eu acredito nos valores e nos objetivos dessa organização
\end{tabular}

\begin{tabular}{lcc}
\hline Base Escassez de alternativas (Fator2) & Carga Fatorial \\
\hline Se eu decidisse deixar minha organização agora, minha vida ficaria bastante desestruturada & .663 \\
Eu acho que teria poucas alternativas se deixasse essa organização. & .881 \\
Uma das consequências negativas de deixar esta organização seria a escassez de alternativas imediatas de & .907 &
\end{tabular}

Uma das consequências negativas de deixar esta organização seria a escassez de alternativas imediatas de

.907

Não deixaria este emprego agora devido à falta de oportunidades de trabalho

.778

\begin{tabular}{lll}
\hline \multicolumn{1}{c}{ Base Obrigação pelo desempenho (Fator3) } & Carga Fatorial \\
\hline Todo colaborador deve buscar atingir os objetivos da organização & .685 \\
Eu tenho obrigação em desempenhar bem minha função nessa organização & .854 & .470 \\
O bom colaborador deve se esforçar para que a organização tenha os melhores resultados possíveis. & .800
\end{tabular}

O colaborador tem a obrigação de sempre cumprir suas tarefas.

\begin{tabular}{cc} 
Base Obrigação em permanecer (Fator4) Carga Fat \\
\hline Eu não deixaria minha organização agora porque eu tenho uma obrigação moral com as pessoas daqui
\end{tabular}

Mesmo se fosse vantagem para mim, eu sinto que não seria certo deixar minha organização agora

Eu me sentiria culpado se deixasse minha organização agora.

.777

Acredito que não seria certo deixar minha organização porque tenho uma obrigação moral em permanecer aqui.

.945

\begin{tabular}{|c|c|}
\hline Base Falta de recompensas e oportunidades (Fator5) & Carga Fatorial \\
\hline Se eu já não tivesse dado tanto de mim nesta organização, eu poderia considerar trabalhar em outro lugar. & .712 \\
\hline $\begin{array}{l}\text { A menos que eu seja recompensado de alguma maneira, eu não vejo razões para despender esforços extras em } \\
\text { benefício desta organização. }\end{array}$ & .759 \\
\hline Minha visão pessoal sobre esta organização é diferente daquela que eu expresso publicamente. & .641 \\
\hline Apesar dos esforços que eu já realizei, não vejo oportunidades para mim nesta organização. & 622 \\
\hline Base Afiliativa (Fator6) & Carga Fatorial \\
\hline Nesta organização, eu sinto que faço parte do grupo. & .585 \\
\hline Sou reconhecido por todos na organização como membro do grupo & .785 \\
\hline Sinto que meus colegas me consideram como membro da equipe de trabalho. & .777 \\
\hline Fazer parte do grupo é o que me leva a lutar por esta organização. & .945 \\
\hline Base Linha consistente de atividade (Fator7) & Carga Fatorial \\
\hline Procuro não transgredir as regras aqui, pois assim sempre manterei meu emprego. & .710 \\
\hline Na situação atual, ficar com minha organização é na realidade uma necessidade tanto quanto um desejo. & .754 \\
\hline Para conseguir ser recompensado aqui é necessário expressar a atitude certa. & .417 \\
\hline Farei sempre o possível no meu trabalho para me manter neste emprego. & 636 \\
\hline
\end{tabular}




\subsection{A confiabilidade dos itens e comparação de médias - Comprometimento}

Todas as bases da escala comprometimento apresentaram consistência interna acima de 0,60. Assim como todos apresentaram variância homogênea com significância menor de 0,05 e somente a dimensão desempenho apresentou significância para interações multiplicativas no teste de médias para não aditividade de Tukey, como pode ser visto na tabela 27.

Os itens dessa escala serão observados mais atentamente no momento da análise multivariada, mas, por enquanto, para fins descritivos, admite-se trabalhar da forma como os resultados foram encontrados.

Tabela 27 - ANOVA com teste de Tukey e de Friedman para não aditividade - Comprometimento

\begin{tabular}{|c|c|c|c|c|c|c|c|c|c|c|c|c|c|}
\hline & Média & $\mathrm{DP}$ & $\begin{array}{l}\text { Soma dos } \\
\text { quadrados }\end{array}$ & df & $\begin{array}{l}\text { Quadrado } \\
\text { médio }\end{array}$ & F. Stat & Sig & $\begin{array}{l}\text { Soma dos } \\
\text { quadrados }\end{array}$ & $\mathrm{df}$ & $\begin{array}{l}\text { Quadrado } \\
\text { Médio }\end{array}$ & $\begin{array}{c}\mathrm{F} \\
\mathrm{X}^{2} \\
\text { Fridman }\end{array}$ & Sig & $\begin{array}{c}\text { Alfa de } \\
\text { Cronbach }\end{array}$ \\
\hline Afetiva & 4,335 & 1,05 & 40,499 & 3 & 13,500 & 65,426 & ,000 & 1,907 & 1 & 1,907 & 3,373 & ,067 & .910 \\
\hline $\begin{array}{l}\text { Obrigação em } \\
\text { permanecer }\end{array}$ & 3,548 & 1,43 & 80,792 & 3 & 26,931 & 112,943 & 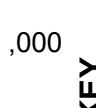 & 1,585 & 1 & 1,585 & 2,603 & 107 & .904 \\
\hline Desempenho & 5,471 & 0,93 & 44,651 & 3 & 14,884 & 64,246 & ,000 & 81,167 & 1 & 81,167 & 153,125 & ,000 & .795 \\
\hline Afiliativa & 4,902 & ${ }^{1,00} \varangle$ & 80,820 & 3 & 26,940 & 169,552 & ,000 岂 & 1,034 & 1 & 1,034 & 2,798 & ,095 & .873 \\
\hline $\begin{array}{l}\text { Falta de } \\
\text { recompensas }\end{array}$ & 2,744 & 1,33 $\frac{\text { Oे }}{\mathbf{z}}$ & 140,048 & 3 & 46,683 & 109,985 &, $000 \stackrel{4}{\sum}$ & 2,251 & 1 & 2,251 & 2,066 & 151 & .733 \\
\hline Linha & & & & & & & & & & & & & \\
\hline $\begin{array}{l}\text { consistente de } \\
\text { atividade }\end{array}$ & 4,361 & 1,17 & 34,195 & 3 & 11,398 & 34,344 & ,000 & 2,326 & 1 & 2,326 & 2,443 & ,118 & .756 \\
\hline $\begin{array}{l}\text { Escassez de } \\
\text { alternativas }\end{array}$ & 3,365 & 1,37 & 90,627 & 3 & 30,209 & 85,149 & ,000 & 5,065 & 1 & 5,065 & 5,378 & ,051 & .800 \\
\hline
\end{tabular}

Fonte: Resultados da pesquisa elaborados a partir do Software SPSS 20.0 


\subsection{Comparação de médias entre continentes e DPR- Comprometimento} A seguir será analisado as médias dos SECOMs por continente para cada uma das bases de comprometimento.

\subsubsection{3 (a) Obrigação pelo desempenho}

A figura 30 foi elaborada a partir das médias gerais dos SECOMs de acordo com as divisões continentais.

Figura 30 - Comparação de médias SECOMs por continente - Obrigação pelo desempenho

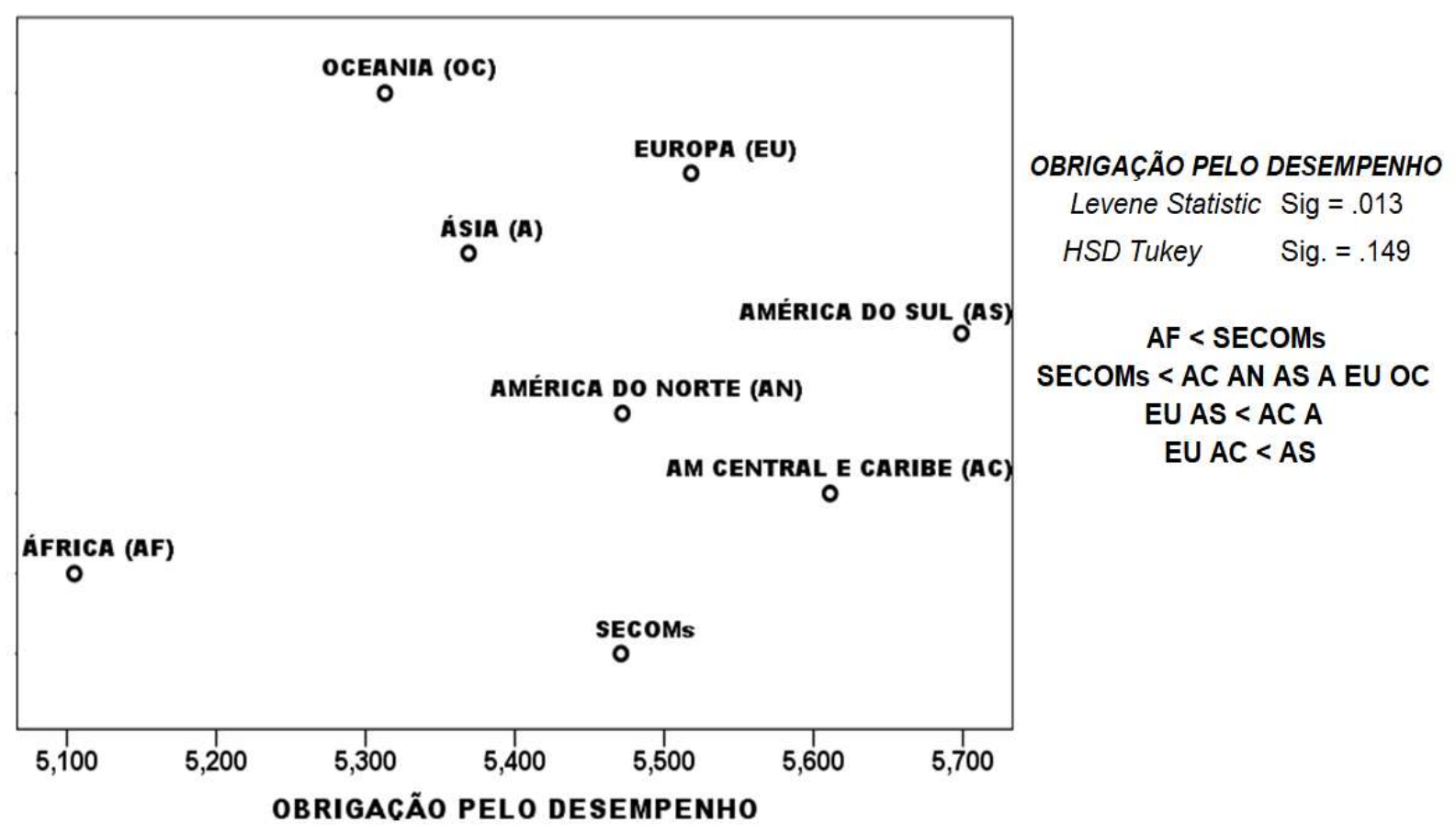

Fonte: dados da pesquisa

Os colaboradores dos SECOMs da América do Sul $(5,79)$, em média, são os que possuem maior nível de concordância dos esforços que devem fazer e do cumprimento de suas tarefas para que a organização atinja seus objetivos. Seguidos pelos SECOMs da América Central $(5,61)$, Europa $(5,60)$, Oceania $(5,50)$ e América do Norte $(5,49)$.

Os continentes que, apesar de concordarem com este esforço pessoal para alcançar os objetivos organizacionais, apresentaram menor média foram a África $(5,21)$ e a Ásia $(5,46)$. 


\subsubsection{3 (b) Afiliativa e Afetiva}

A figura 31 foi elaborada a partir a partir das médias gerais dos SECOMs de acordo com as divisões continentais.

Figura 31 - Comparação de médias SECOMs por continente - Bases Afiliativa e Afetiva

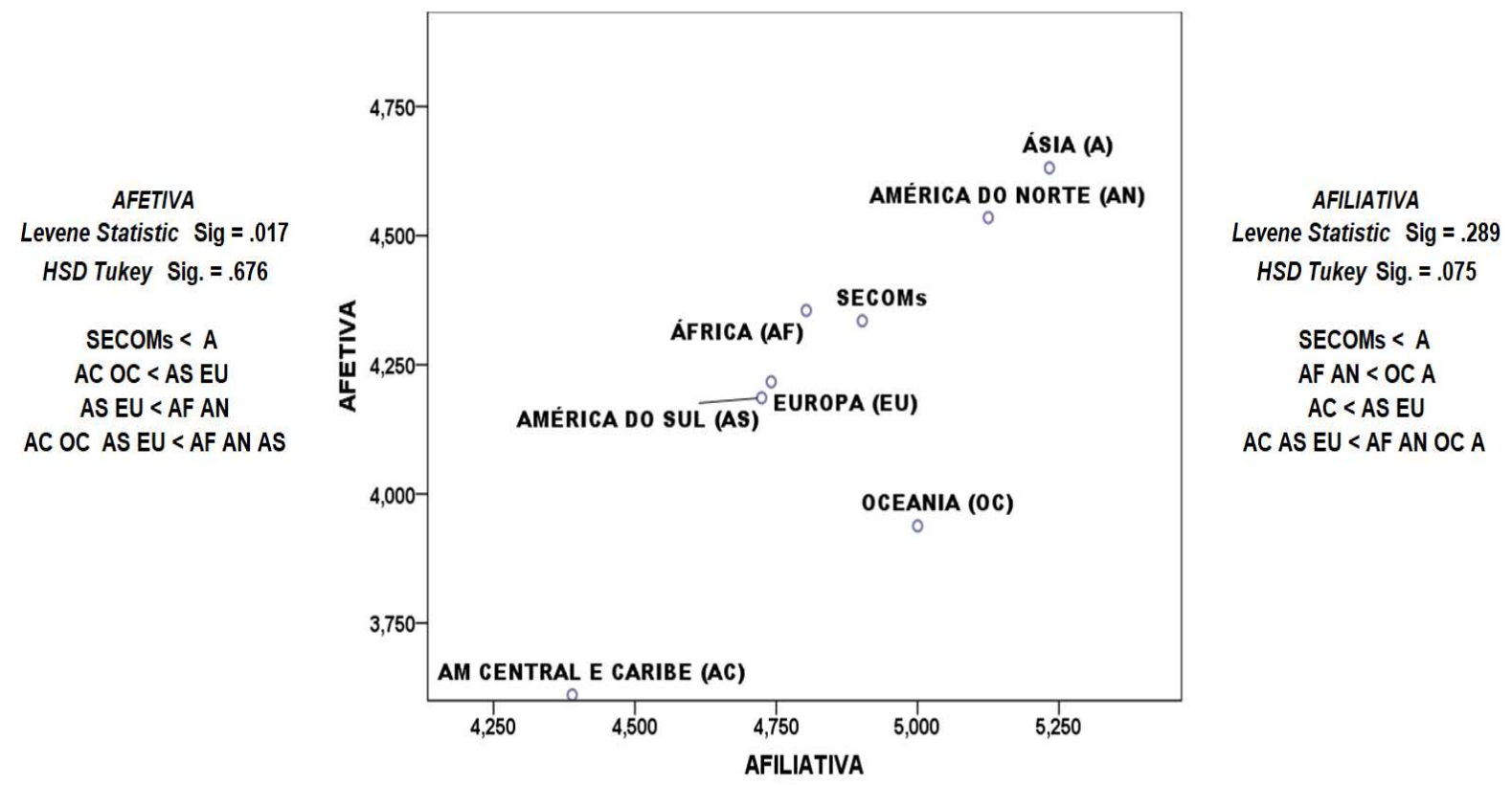

Fonte: dados da pesquisa

Todos os respondentes dos SECOMs acreditam que são reconhecidos como membros do grupo e da organização pelos colegas (base afiliativa), mas esta percepção é maior na Ásia $(5,233)$ e na América do Norte $(5,125)$, seguido pela Oceania $(5,00)$ e menor na América Central $(4,389)$ e América do Sul $(4,724)$. Aliás, a América Central e Caribe apresentam as menores médias tanto para a base afiliativa quanto afetiva.

Ásia $(4,631)$, América do Norte $(4,535)$ e África $(4,355)$ são os que mais se identificam com a filosofia, os valores e os objetivos organizacionais (base afetiva), já América Central e Caribe $(3,611)$ e Oceania $(3,938)$ discordam pouco, mas discordam, de que haja equivalência de valores e objetivos organizacionais. Os SECOMs situados nos países da Europa $(4,217)$ e da América do Sul $(4,186)$ são os que concordam pouco com esta similaridade. 


\subsubsection{3 (c) Falta de Recompensas e Linha Consistente de Atividade}

A figura 32 foi elaborada a partir das médias gerais dos SECOMs de acordo com as divisões continentais.

Figura 32 SECOMs por continente - Bases Falta de Recompensas e L. Const. de Atividade

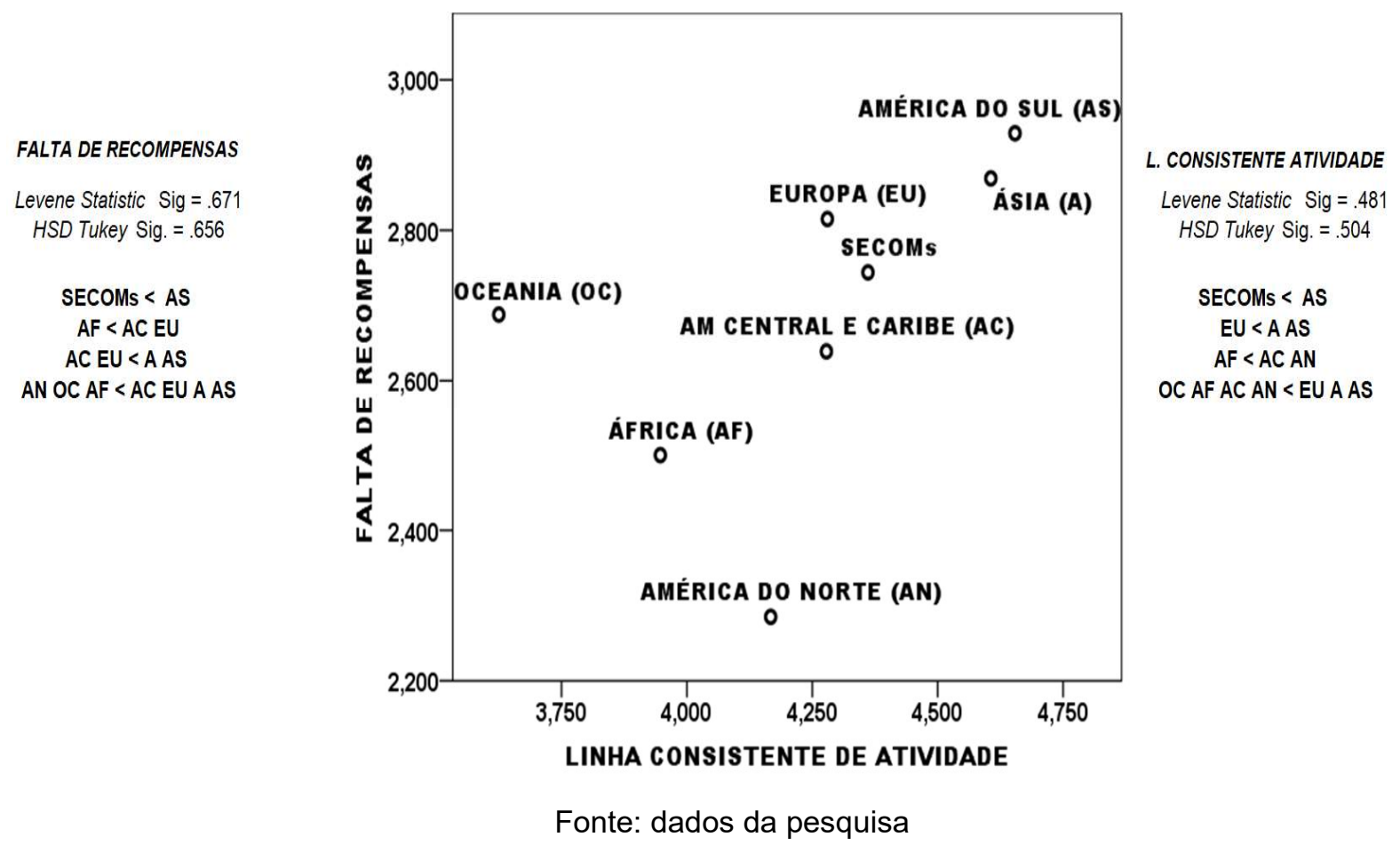

No que se refere à base que questiona se os colaboradores concordam que, para permanecerem na organização devem manter certas atitudes e regras por ela declaradas (linha consistente de atividade), América do Sul $(4,654)$ e Ásia $(4,608)$ estão entre os que mais concordam com essa afirmativa, de forma mediana, concordando pouco, tem-se a Europa $(4,28)$, América Central e Caribe $(4,278)$ e América do Norte $(4,167)$. Os que discordam pouco sobre a permanência na instituição mediante a anuência de certas atitudes e regras da organização são os SECOMs da Oceania $(3,625)$ e da África $(3,947)$.

Já em relação à base falta de recompensas e de oportunidades, todos discordaram de que o esforço extra em benefício da organização deve ser recompensado e de que a organização deve lhes dar mais oportunidades. Essa discordância é maior entre os colaboradores dos SECOMs situados na América do Norte $(2,285)$, África $(2,5)$, América Central e Caribe $(2,639)$ e Oceania $(2,688)$ e menor entre os respondentes da América do Sul $(2,929)$ e Ásia $(2,869)$. 


\subsubsection{3 (d) Escassez de Alternativas e Obrigação em Permanecer}

A figura 33 foi elaborada a partir das médias gerais dos SECOMs de acordo com as divisões continentais.

Figura 33 SECOMs por continente - Bases Escassez de alternativas e Ob.em Permancer

ESC. ALTERNATIVAS Levene Statistic Sig $=.357$ HSD Tukey Sig. $=.110$

SECOMs $<$ A

AS $<$ EU A

AN $<$ AS EU A OC AC AF AN < AS EU A

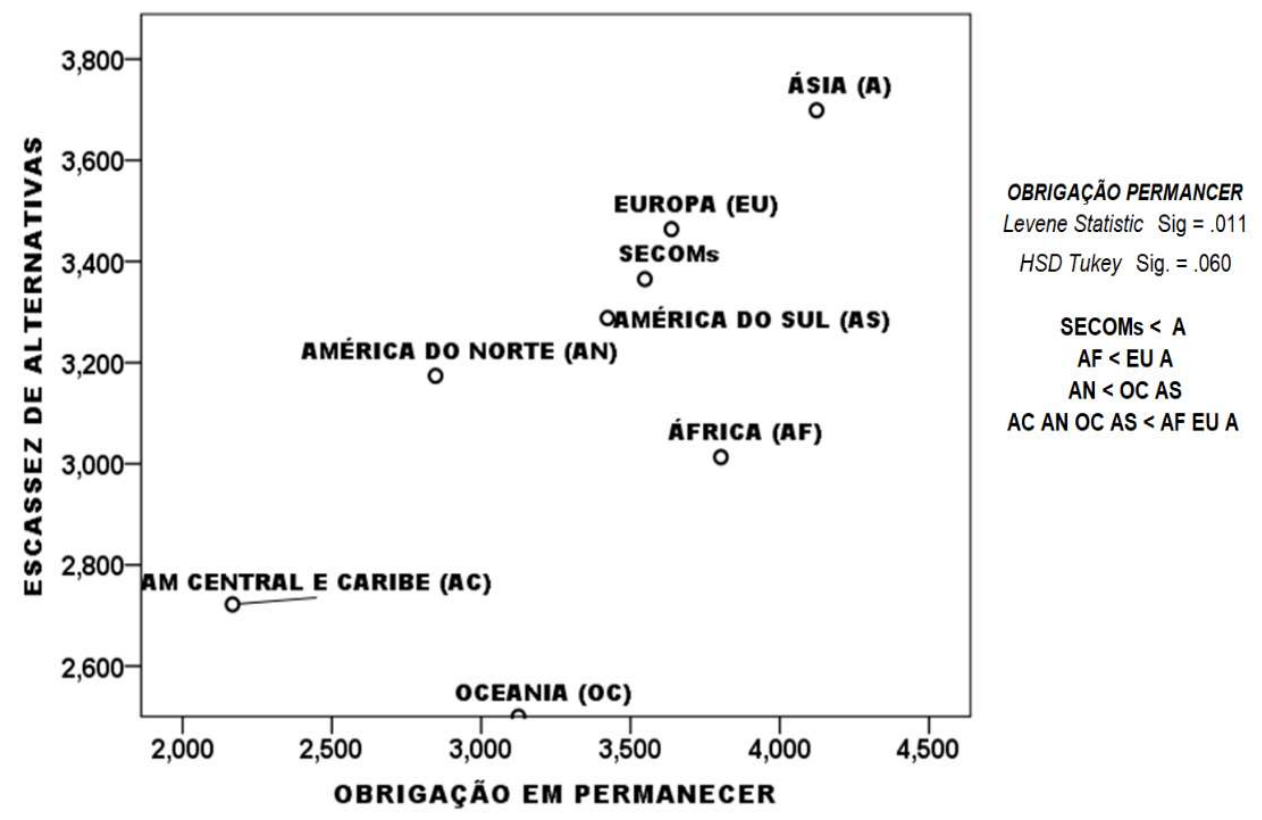

Fonte: dados da pesquisa

Somente a Ásia $(4,123)$ concorda pouco com a alegação de que eles têm obrigação em permanecer, de que se sentiriam culpados em deixar a organização e de que têm obrigação moral para com as pessoas da organização (obrigação em permanecer). Os demais discordam. Entre os que discordam muito estão os colaboradores da América Central e Caribe $(2,167)$ e da América do Norte $(2,847)$. Os demais respondentes (Oceania, América do Sul, Europa e África) discordam pouco dessa alegação.

No que se refere à base escassez de alternativas, Oceania $(2,5)$ e América Central e Caribe $(2,722)$ discordam muito de que possuem poucas alternativas de trabalho se deixarem a organização. Já os demais discordam pouco dessa possibilidade. 


\subsection{Interpretação das bases de comprometimento segundo a escala EBACO}

Para interpretar os dados obtidos da escala EBACO, utilizou-se a mensuração dos fatores por meio dos pesos das variáveis, conforme demonstrado no estudo original do Medeiros (2003) e Siqueira (2008) e Bastos et al. (2008). Para tanto, calculou-se a média para cada item da escala e então multiplicou-se a média de cada variável pelo peso estipulado para cada item e depois somou-se o produto de todos os itens de cada base. Para interpretar os resultados obtidos, conforme enfatizado por Bastos et al. (2008), deve-se considerar que algumas bases do comprometimento possuem relação diretamente proporcional ao desempenho das organizações, outras, inversamente proporcionais. Assim, para as bases afetiva, obrigação em permanecer, obrigação pelo desempenho e afiliativa, é importante um ALTO comprometimento. Nas bases instrumentais - falta de recompensas e oportunidades, linha consistente de atividade e escassez de alternativas - é importante que o comprometimento seja BAIXO.

Para a interpretação dos resultados, utilizaram-se os intervalos propostos por Medeiros et al. (2005) e Bastos (2008), conforme consta na Tabela 28.

Tabela 28 - Interpretação dos resultados - escala EBACO

\begin{tabular}{|c|c|c|c|c|}
\hline \multirow{2}{*}{$\begin{array}{l}\text { Bases/ fatores do } \\
\text { comprometimento }\end{array}$} & \multicolumn{4}{|c|}{ Interpretação do resultado } \\
\hline & Baixo & Abaixo da média & Acima da média & Alto \\
\hline Afetiva & $<5,87$ & $5,87 \leq$ Afe $<11,21$ & $11,21 \leq$ Afe $\leq 16,55$ & $>16,55$ \\
\hline Obrigação em permanecer & $<10,62$ & $10,62 \leq$ Per $<14,69$ & $14,69 \leq$ Per $\leq 18,75$ & $>18,75$ \\
\hline Obrigação pelo desempenho & $<3,60$ & $3,60 \leq$ Des $<8,38$ & $8,38 \leq$ Des $\leq 13,34$ & $>13,34$ \\
\hline Afiliativa & $<14,77$ & $14,77 \leq$ Afi $<16,82$ & $16,82 \leq$ Afi $\leq 17,88$ & $>17,88$ \\
\hline Falta de recompensas & $<4,36$ & $4,36 \leq \operatorname{Rec}<8,78$ & $8,78 \leq \operatorname{Rec} \leq 13,20$ & $>13,20$ \\
\hline Linha consistente de atividade & $<8,52$ & $8,52 \leq$ Con $<12,13$ & $12,13 \leq$ Con $\leq 15,63$ & $>15,63$ \\
\hline Escassez de alternativas & $<11,46$ & $11,46 \leq \mathrm{Esc}<14,78$ & $14,78 \leq \mathrm{Esc} \leq 17,85$ & $>17,85$ \\
\hline
\end{tabular}

Fonte: adaptado de Bastos (2008) 
Todos os cálculos estão disponibilizados no apêndice $n^{\circ} 02$. O quadro 22 apresenta uma síntese dos resultados encontrados.

Quadro 32 - Intepretação dos resultados da escala EBACO para os SECOMs

\begin{tabular}{|c|c|c|c|c|c|c|c|c|c|}
\hline $\begin{array}{l}\text { Interpretaçäo dos } \\
\text { resultados }\end{array}$ & AFETIVA & AFLLATVA & & $\begin{array}{l}\text { OвRIGACÃO EM } \\
\text { PERMANECER }\end{array}$ & $\begin{array}{l}\text { OERIGACB̈O PELO } \\
\text { DESEMPENHO }\end{array}$ & & $\begin{array}{c}\text { IALTADE } \\
\text { RECOMPENSASE } \\
\text { OPOETUNIDADES }\end{array}$ & $\begin{array}{l}\text { UTAA CONSISTEMTE } \\
\text { DE ATMDAOE }\end{array}$ & $\begin{array}{l}\text { ESCASSEZ DE } \\
\text { ALTERNATVAS }\end{array}$ \\
\hline $\begin{array}{c}\text { Baixo } \\
\text { comprometimento }\end{array}$ & & $\begin{array}{c}\text { SEcouss } \\
\text { Europa } \\
\text { Árica } \\
\text { America do Sul } \\
\text { America Ce Caribe }\end{array}$ & & $\begin{array}{l}\text { América c e Coribe } \\
\text { Oceania } \\
\text { Amtrica do None }\end{array}$ & & 1 & & & \\
\hline $\begin{array}{l}\text { Comp. abaixo da } \\
\text { média }\end{array}$ & America C e caribe & $\begin{array}{l}\text { America do Nonte } \\
\text { Asia ceania }\end{array}$ & $\begin{array}{l}\mathrm{N} \\
\mathrm{O} \\
\mathrm{R} \\
\mathrm{M} \\
\mathrm{A}\end{array}$ & $\begin{array}{l}\text { SECOMLs } \\
\text { América do Sul } \\
\text { Ásia Europa } \\
\text { Átricas }\end{array}$ & & $\begin{array}{l}\mathrm{N} \\
\mathrm{S} \\
\mathrm{T} \\
\mathrm{R} \\
\mathrm{U} \\
\mathrm{M}\end{array}$ & $\begin{array}{c}\text { SEcous } \\
\text { África } \\
\text { Amentrica do Norte } \\
\text { America do Sul } \\
\text { America C C Caribe } \\
\text { Oceania } \\
\text { Europa Ásia }\end{array}$ & $\begin{array}{c}\text { SEcoms } \\
\text { Aftica } \\
\text { América do Nonte } \\
\text { Oceania } \\
\text { Europa Asia } \\
\text { América C e Caribe }\end{array}$ & $\begin{array}{c}\text { Secoms } \\
\text { Érica } \\
\text { América do Sul } \\
\text { America do Norte } \\
\text { Oceania } \\
\text { Europa Ásia } \\
\text { America C e Can be }\end{array}$ \\
\hline $\begin{array}{l}\text { Comp. acima da } \\
\text { média }\end{array}$ & $\begin{array}{c}\text { SEcoMs } \\
\text { Atrica } \\
\text { Ameirica do Norte } \\
\text { America do Sul } \\
\text { Ásia Europa } \\
\text { Ocesnis }\end{array}$ & & $\begin{array}{l}T \\
1 \\
\text { V } \\
\text { A }\end{array}$ & & & $\begin{array}{l}\text { E } \\
\text { N } \\
\text { T } \\
\text { A } \\
\text { L }\end{array}$ & & America do Sut & \\
\hline $\begin{array}{c}\text { Alto } \\
\text { comprometimento }\end{array}$ & & & & & $\begin{array}{l}\text { SECONS } \\
\text { America do Nonte } \\
\text { America do Sul } \\
\text { America Ce Caribe } \\
\text { Lsia Europa } \\
\text { Oceania Áftica }\end{array}$ & & & & \\
\hline
\end{tabular}

Fonte: Dados da pesquisa

No que se refere à base afetiva, os SECOMs demonstram um comprometimento acima da média. Isto significa que a maioria dos respondentes possui uma forte crença e identificação com a filosofia, os valores e os objetivos da instituição. Este tipo de comprometimento representa uma associação positiva entre a organização e os funcionários, pois compartilham valores semelhantes. Quando o comprometimento afetivo é alto, os funcionários não ficam em uma organização simplesmente porque precisam do trabalho, mas porque querem ficar (Meyer, Allen e Smith, 1993).

O resultado para a base obrigação pelo desempenho indica um alto comprometimento, mostrando identificação dos respondentes com a crença de que o colaborador deve se esforçar em benefício da instituição, cumprindo suas tarefas e visando atingir os objetivos e metas da instituição. Este resultado vem ao encontro do que foi proposto por Wiener (1982) que sugere um foco centrado nos controles normativos por parte da organização, como, por exemplo, regulamentos, normas e missão organizacional fortemente disseminada entre os colaboradores. Para 
Medeiros (2003), este é um comprometimento de controle, em que as relações do indivíduo às normas moldam seu comportamento na direção desejada, ou seja, aos objetivos da organização.

Por outro lado, a base afiliativa resultou como baixo comprometimento, isto mostra a possibilidade de os respondentes não acreditarem que são reconhecidos pelos colegas como integrantes do grupo e da instituição. E a base obrigação em permanecer com comprometimento abaixo da média, indica uma certa despreocupação em deixar a organização, nem mesmo havendo uma obrigação moral com os colegas de trabalho, caso deixem a instituição.

Mowday, Porter e Steers (1982 p. 27) afirmam que o comprometimento pode ser caracterizado por no mínimo três fatores: "(a) uma forte crença e a aceitação dos objetivos e valores da organização; (b) estar disposto em exercer um esforço considerável em benefício da organização; e (c) um forte desejo de se manter membro da organização". Bastos et al. (2008) destacam a importância de os colaboradores perceberem alto comprometimento para as bases afiliativa, afetiva, obrigação em permanecer e obrigação pelo desempenho.

As bases falta de recompensas e oportunidades, escassez de alternativas e linha consistente de atividade tiveram como resultado comprometimento abaixo da média, e isso é um bom sinal para o desempenho da organização, pois são bases em que se espera um baixo comprometimento, já que, para Ellen e Mayer (1991), os colaboradores com comprometimento instrumental (escassez de alternativas) permanecem na instituição porque precisam ou, como afirma Becker (1960), a pessoa permanece na organização devido aos custos e benefícios associados a sua saída e então passa a se envolver em linhas consistentes de atividades para se manter empregada, ou devido à percepção do empregado de que há poucas alternativas de emprego e do sacrifício pessoal que deverá realizar se deixar a organização em que trabalha (Bastos, 1994). 


\subsection{Interpretação dos resultados da escala EBACO por continente e áreas continentais}

A análise por continentes e unidades continentais apresentou algumas poucas diferenças com o resultado dos SECOMs como todo, mas que valem a pena serem detalhadas.

\subsubsection{5(a) SECOMs da Europa}

Figura 34 - Resultados da Escala EBACO para os SECOMs da Europa

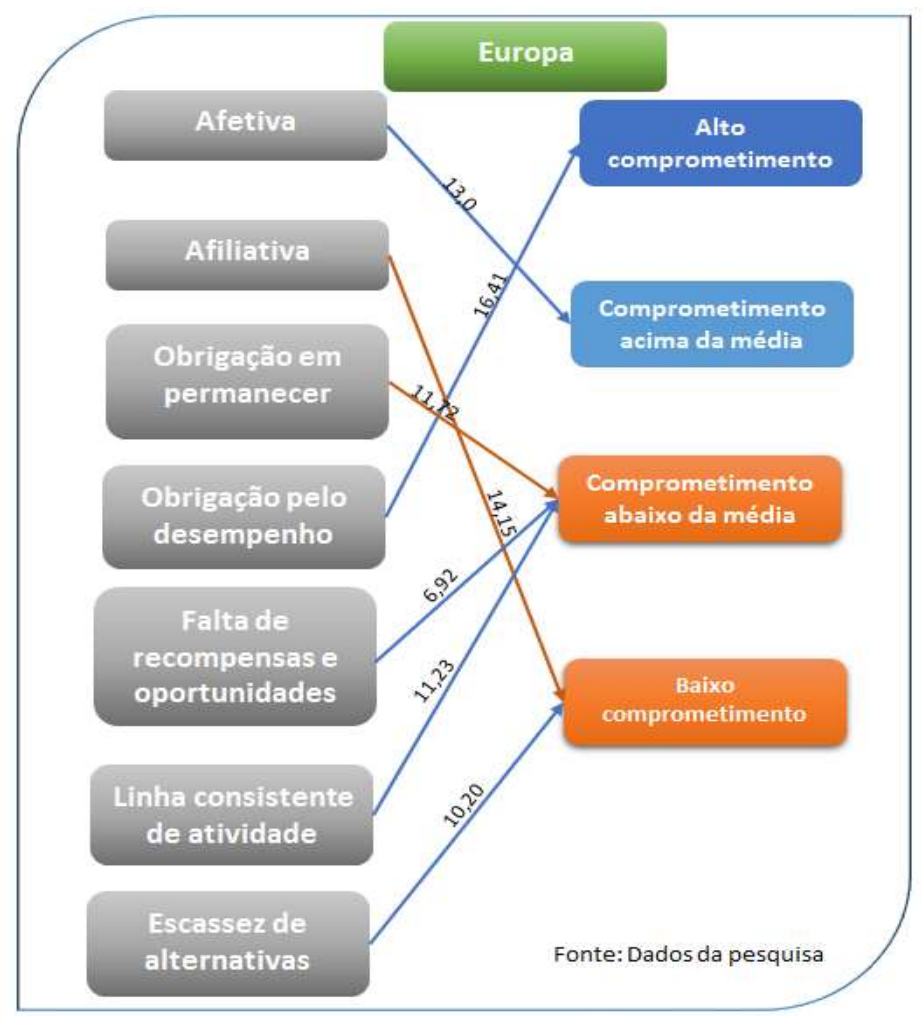

A figura 34 mostra as bases de comprometimento e os resultados dos SECOMs na Europa. A base afetiva teve o mesmo resultado em todos os SECOMs, ou seja, acima da média. E este resultado se manteve para todas as áreas continentais: Europa Centro Oriental; Europa Meridional; Europa Ocidental e Europa Setentrional. A base afiliativa apresentou resultado de baixo comprometimento nos SECOMs situados na Europa Meridional ${ }^{35}$; Europa Ocidental ${ }^{36}$ e Europa

Setentrional ${ }^{37}$. Nestas áreas continentais, países da Europa Meridional, como Espanha e Portugal, da Europa Setentrional, como Suécia, Finlândia, Noruega, e, da Europa Ocidental, como França e Holanda são classificados como mais femininos na dimensão masculinidade de Hofstede (2003), em que a qualidade de vida e o equilíbrio entre vida pessoal e trabalho são evidentes.

Além disso, Brewster (2007) informa que na Europa há um sentimento generalizado de que as empresas precisam ser controladas e que devem tratar seus funcionários

\footnotetext{
35 SECOMs da Grécia, Espanha, Itália e Portugal.

${ }^{36}$ França, Bélgica, Alemanha, Irlanda, Países Baixos, Áustria e Reino Unido.

37 Suécia, Noruega, Finlândia e Dinamarca.
} 
de forma socialmente responsável. O emprego europeu é fortemente regulamentado pela legislação. A União Europeia é a única no mundo a ter seus países comprometidos em nível supranacional sobre uma gama considerável de aspectos legais da relação empregador-empregado, em que incluem restrições nas horas que os indivíduos podem trabalhar e um requisito para as empresas maiores criarem conselhos empresariais nos quais os representantes dos funcionários se reúnem regularmente com gerentes seniores para debaterem uma série de assuntos estabelecidos na legislação.

Entretanto, o envolvimento do Estado na GRH na Europa não se restringe à legislação. As evidências sugerem que as administrações, particularmente nos países nórdicos, podem ver os sindicatos como parceiros sociais que desempenham papel positivo na gestão de recursos humanos. A integração bem-sucedida da GRH com os sindicatos, a cooperação dos empregadores com os sindicatos - com estes adotando uma abordagem menos adversa - podem fazer com que os empregados se considerem com o direito ao apoio organizacional e institucional, de sorte que não percebam por que eles devem se sentir comprometidos com uma determinada organização em específico. Além do mais, os funcionários que são demitidos podem confiar em um forte sistema de segurança social que geralmente inclui novas oportunidades de educação ou treinamento (Wasti et al., 2016; Brewster, 2007; Brewster \& Mayrhofer, 2012).

As demais bases de comprometimento - obrigação em permanecer, obrigação pelo desempenho e as três bases instrumentais (falta de recompensas e oportunidades, linha consistente de atividade e escassez de alternativas) - foram classificadas no mesmo nível de comprometimento que os demais SECOMs. 


\subsubsection{5(b) SECOMS da Ásia}

Figura 35 - Resultados da Escala EBACO para os SECOMs da Ásia

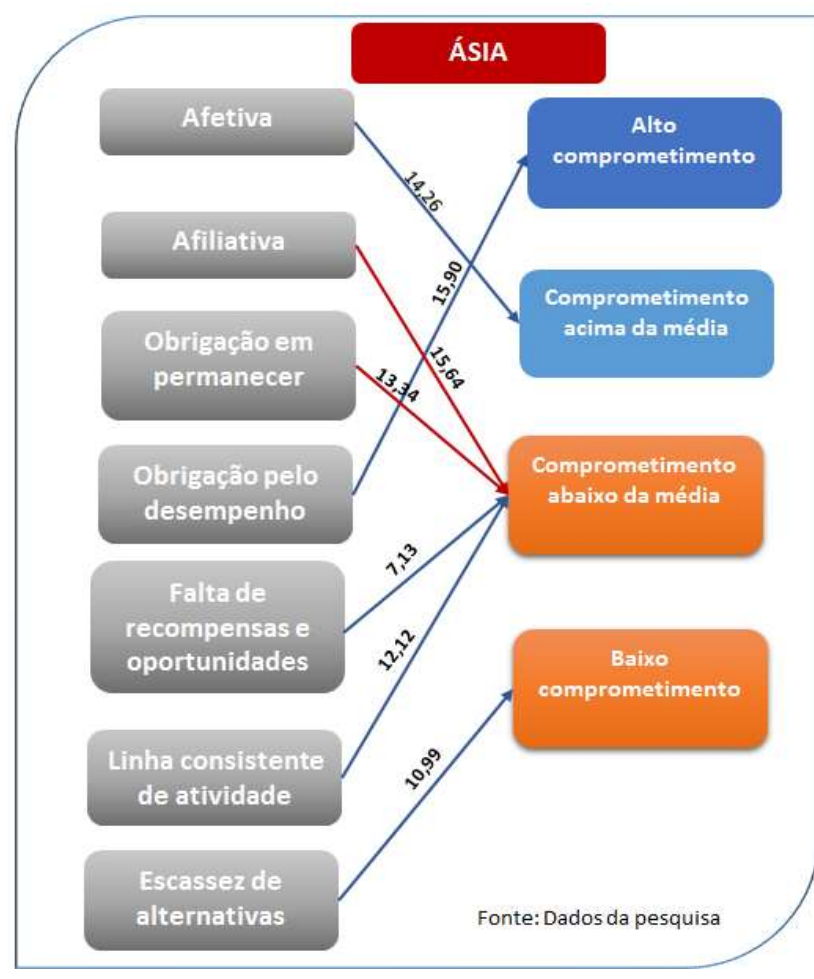

A base afetiva teve o mesmo resultado em todos os SECOMs das unidades continentais da Ásia: comprometimento acima da média.

Os resultados de comprometimento acima da média na base afetiva, no Sul da Ásia ${ }^{38}$, corroboram estudos recentes de Neelam (2015), em que o comprometimento afetivo foi significativamente alto entre os trabalhadores indianos de Tecnologia da Informação (TI); e a relação positiva entre apoio organizacional e comprometimento afetivo em

enfermeiras na Índia (Gupta V. et al., 2016), assim como a identificação de correlação positiva entre satisfação no trabalho e comprometimento afetivo entre funcionários indianos (Kwantes, 2009).

Os tradicionais valores da Índia enfatizam os relacionamentos personalizados (Dhar, 1994; Gupta, 1995; Singh, 1990) e o paternalismo (Aycan et al., 2000), sugerindo que o comprometimento com a organização seja valorizado no contexto indiano. O desenvolvimento real de tal comprometimento, no entanto, é impactado por muitos fatores além dos valores tradicionais, incluindo o mercado de trabalho (Kwantes, 2009).

A Índia, que, desde o início do século passado, já havia institucionalizado sindicato dos trabalhadores (lei sindical de 1926) e que, em 1948, com a Lei das Fábricas, estabeleceu deveres e qualificações objetivando o bem-estar do trabalhador (Brewster \& Mayrhofer, 2012), tem passado por recentes mudanças no ambiente de trabalho, o que tem exigido uma nova compreensão da dinâmica do comprometimento dos

${ }^{38}$ SECOMs da Índia e do Paquistão 
funcionários. Para se ter uma ideia, o número total de profissionais de serviços de TI e de serviços informáticos passou de 56 mil em 1990 para mais de 2,97 milhões em 2013 (Neelam, 2015). À medida que corporações estrangeiras e multinacionais movem suas operações para a Índia, crescem as oportunidades de emprego, e esta mudança de atitude é corroborada pelo aumento da taxa de rotatividade nas organizações. Segundo Neelam (2015), desde 2000, essa taxa aumentou, com algumas empresas registrando taxas de rotatividade altas de até $8 \%$ ao mês para o pessoal técnico. E isso talvez possa explicar o comprometimento abaixo da média para a base afiliativa. Outro país que faz parte do Sul da Ásia em que a promoção comercial brasileira atua é o Paquistão, mas este teve sua independência no ano de 1971 e herdou os modelos de gestão ingleses. De acordo com Brewster e Mayrhofer (2012), tanto no Paquistão quanto em Bangladesh há uma escassa literatura de Gestão de Recursos Humanos. Os autores apresentam os estudos de Khilji (Khilji, 2002; 2003; 2004a; 2004b; Khilji \& Wang, 2006), em que é feita uma análise abrangente do impacto dos principais fatores nacionais em vários aspectos da GRH no Paquistão. Sob o fator da cultura nacional, esta destaca como a configuração social e hierárquica da sociedade paquistanesa, marcada por alta distância de poder, possuindo uma forte herança de sistemas de classes britânicas e como a influência dos sistemas de gestão americano afeta a maioria das esferas da GRH desde o recrutamento, treinamento, formas de recompensas, avaliações de desempenho e o processo de tomada de decisão (mais central). Da mesma forma, a análise destaca como o ambiente empresarial competitivo está impactando no treinamento e como instabilidade nacional e incerteza política estão contribuindo para a falta de confiança entre os principais atores do sistema de emprego. Os sindicatos (como na Índia) parecem ter sido uma influência significativa na GRH no Paquistão (em questões como rescisão, demissões e segurança e saúde). O impacto do islamismo no local de trabalho também é evidente no Paquistão (aproximadamente $95 \%$ da população é mulçumana). Por exemplo, salas de oração, estadas de almoço prolongadas às sextas-feiras e menos tempo de trabalho durante os meses de jejum são fornecidos na maioria das organizações. Devido à existência de uma estrutura empresarial e institucional única (caracterizada pelo impacto crescente dos princípios islâmicos nos sistemas de trabalho, estruturas sociais sólidas de castas, corrupção e descontentamento na sociedade em geral devido ao baixo crescimento econômico, à instabilidade econômica e nacional relacionada à segurança e à escassez de recursos 
para compartilhar com a população em rápida expansão) e ao forte impacto disso nas organizações no Paquistão, as empresas multinacionais são obrigadas a modificar suas práticas de GRH para atender a tais contextos. Ressalta-se que o percentual de brasileiros natos nos SECOMs do Sul da Ásia é baixo, apenas 16\%.

A base de comprometimento obrigação em permanecer que mede a crença de que o colaborador tem uma obrigação em permanecer; de que se sentiria culpado em deixar ou de que não seria certo sair da organização; e que tem uma obrigação moral para com as pessoas que trabalham juntamente com ele, apresentou resultados diferentes no Sul da Ásia (Índia e Paquistão) e Extremo Oriente (Coreia do Sul) com o comprometimento acima da média, enquanto as demais unidades continentais da Ásia (Ásia Oriental, Oriente Médio e Sudeste Asiático) tiveram como resultado abaixo da média nesta base de comprometimento. Na pesquisa de Neelam (2015) com trabalhos de TI da Índia, o coletivismo (Hofstede, 2003) foi um preditor significativo do comprometimento normativo, assim como na pesquisa de Jong-Wook Ko (1997), que identifica o comprometimento normativo a partir do reconhecimento das recompensas sociais e organizacionais dentro da organização.

A base falta de recompensas e de oportunidades em que se mede a crença do colaborador de que o esforço extra em benefício da organização deve ser recompensado e que a organização deve lhe dar mais oportunidades teve como resultado comprometimento abaixo da média, mas o Extremo Oriente (Coreia do Sul) apresentou baixo comprometimento como resultado. Isto talvez possa ser explicado por dois fatores: (a) todos os respondentes do SECOM da Coreia do Sul são brasileiros e talvez já tenham estabilidade no serviço público; e/ou (b) por fortes fatores sociais como a alta mobilidade laboral entre as empresas que sempre foi uma norma na Coreia do Sul, e que as pessoas coreanas sempre foram empreendedoras individuais em contraste com a maioria dos povos asiáticos. Esta tendência cresceu ainda mais a partir da década de 1990. E isto faz com que os funcionários se tornem mais individualistas e mais dispostos a assumirem o controle de suas próprias carreiras, ou seja, eles não ficam tão emocionados com slogans, músicas, bandeiras e outras manifestações de cultura corporativa (Brewster \& Mayrhofer, 2012; Pucik \& Lim, 2001; Hwang, 2006). 
O Sudeste Asiático ${ }^{39}$ e o Sul da Ásia ${ }^{40}$ tiveram como resultado comprometimento acima da média para a base, de cunho instrumental, linha consistente de atividade que busca medir o dever que os colaboradores devem ter em manter certas atitudes e regras da organização com o objetivo de se manterem nela. Este resultado, que foi diferente dos demais países asiáticos (comprometimento abaixo da média), pode estar relacionado à idade dos respondentes. Kwantes (2009) abordou que um maior comprometimento de continuidade (instrumental) é frequentemente visto em funcionários que são mais velhos $\mathrm{e}$, portanto, menos propensos a combinarem benefícios de aposentadoria se eles se mudarem para outra organização no final da carreira; a percepção de que outras opções razoáveis não existem também pode resultar do acúmulo de auto investimento de um funcionário em uma organização. Os funcionários que têm mais tempo de serviço ou que alcançaram níveis mais altos na hierarquia institucional podem sentir que investiram demais em sua organização atual para considerar sair dela. Os respondentes dos SECOMs nestas duas unidades continentais têm esse perfil, pois $58 \%$ dos colaboradores do Sudeste Asiático têm idade entre 40 a 59 anos e $36,9 \%$ de 11 a 30 anos de trabalho; e no Sul da Ásia 50,1\% têm idade variando entre 40 a 59 anos e $33,4 \%$ com mais de 21 anos de casa.

Idade e tempo de serviço talvez possam explicar por que os colaboradores do Sul da Ásia divergiram dos demais respondentes asiáticos na base escassez de alternativas, pois enquanto estes tiveram como resultado baixo comprometimento aqueles tiveram comprometimento abaixo da média.

Todas as unidades continentais da Ásia tiveram alto comprometimento na base obrigação pelo desempenho, que é de natureza normativa. Wasti et al. (2016) apresentam várias pesquisas sobre como os valores coletivistas (Hofstede, 2003) promovem comprometimento normativo nos funcionários chineses (Chan \& Qiu, 2011; Miao, Newman, \& Lamb, 2012; Sun, 2010). Yamaguhi (2012) descreve que os trabalhadores japoneses têm traços culturais de forte comprometimento organizacional. E, assim como a Índia, Hong Kong, Malásia e Cingapura foram colônias britânicas e têm seus sistemas legais, educacionais e políticos sustentados pelas tradições inglesas. Além disso, têm uma herança cultural comum dos chineses (Chen 1995; Seagrave, 1997). Hong Kong, no entanto, é etnicamente uma

\footnotetext{
39 Tailândia, Malásia, Cingapura, Indonésia, Vietnam e Filipinas.

40 Índia e Paquistão
} 
monocultura (aproximadamente $98 \%$ da população é de etnia chinesa) com fortes influências das multinacionais e de expatriados. Cingapura é mais multicultural, e as políticas governamentais não só apoiam a integração dos três principais grupos (chineses, malaios e indianos), como também o governo incentivou o Investimento Direto Estrangeiro (IDE) e a industrialização, bem como o desenvolvimento estratégico com a utilização da força de trabalho de Cingapura (Sharma \& Chew 1992; Wan, 1996). No entanto, os valores confucionistas, que subscrevem a estabilidade social baseada em relações desiguais entre pessoas, a necessidade de um respeito pela família e a importância da educação e o valor no trabalho árduo e diligente podem ser compreendidos como fatores que levam ao alto comprometimento normativo das pessoas nas organizações (Chen 1995; Hofstede 1991; Shaw et al., 1993; Pearson \& Entrekin, 2001).

\subsubsection{5(c) SECOMS da África}

Figura 36 - Resultados da Escala EBACO para os SECOMs da África

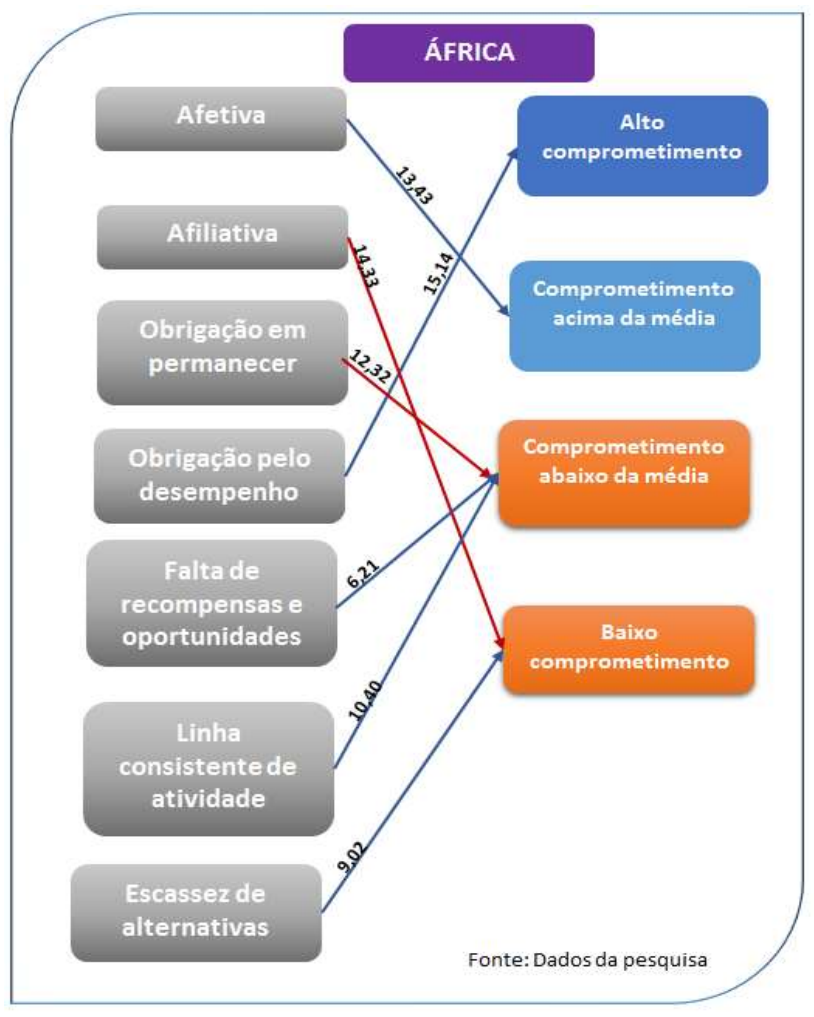

Segundo Gbadamosi (2003), muito pouco trabalho empírico tem sido desenvolvido na África sobre comprometimento nas organizações. $\mathrm{O}$ problema dos estudos de gestão na África é agravado em função da vastidão e da diversidade cultural inerente ao próprio continente. Do norte árabe (que não é monolítico) para o oeste culturalmente diverso (com uma dicotomia francófona-anglófona e fortes divisões étnicas), e o leste com um domínio aparente da língua suaíli ${ }^{41}$, nas diferenças culturais; da sempre volátil bacia do Congo (com guerras e etnias profundamente arraigadas) para o sul relativamente mais estável, tem mantido a

\footnotetext{
${ }^{41}$ O suaíli e línguas correlatas são faladas em Congo, Quênia, Burundi, Ruanda, Moçambique, Somália, Zâmbia e Camarões.
} 
história da heterogeneidade cultural deste continente. Nesse contexto, a base afetiva teve o mesmo resultado em todos os SECOMs das unidades continentais da África: comprometimento acima da média. Já o baixo comprometimento na base afiliativa pode ser compreendido no contexto africano como provável dissociação entre o indivíduo e a organização quanto a sentimentos de pertencimento, pois a sociedade africana tem uma natureza altamente comunalista (Gbadamosi, 2003), ou seja, uma sociedade que se preocupa com a comunidade em que se vive e isto não significa, necessariamente, com a organização em que se trabalha. Essa mesma análise pode explicar o porquê do comprometimento abaixo da média na base obrigação em permanecer, visto que esta base foca na obrigação moral que os colaboradores devem ter para com as pessoas da organização.

As bases obrigação em permanecer e obrigação pelo desempenho têm enfoque normativo (Medeiros, 2003), que se referem ao sentimento de obrigação de um funcionário em manter-se com a organização. Entretanto, a base obrigação em permanecer nos SECOMs da África resultou em comprometimento abaixo da média e a base obrigação pelo desempenho com alto comprometimento. Porém, se ambas são de natureza normativa, por que os resultados foram diferentes? Obrigação em permanecer trata de uma obrigação moral para com as pessoas da organização e a obrigação pelo desempenho avalia a percepção dos respondentes quanto a sua relação pessoal para com os objetivos da organização, razão pela qual foram contratados.

As bases de cunho instrumental (Medeiros, 2003), cujo foco está no comprometimento em função dos benefícios em ficar na organização versus os custos associados em sair dela, tiveram como resultados o comprometimento abaixo da média (base falta de recompensas e oportunidades e a base linha consistente de atividade) e baixo comprometimento para a base escassez de alternativas. De acordo com Hrebiniak e Alutto (1972), o comprometimento como fenômeno estrutural ocorre como um resultado das transações indivíduo-organização e das alterações nos benefícios adquiridos e investimentos realizados pelo indivíduo em seu trabalho (side bets Becker, 1960) ao longo do tempo. Entretanto, apesar de a idade média estar concentrada entre 30 a 39 anos (37,7\%), o tempo de serviço entre menos de um ano até 5 anos é de $57,9 \%$, talvez o tempo de serviço na instituição não dê a eles esta percepção de side bets como apresentado por Becker (1960). 


\subsubsection{5(d) SECOMS da América do Norte}

Figura 37 - Resultados da Escala EBACO para os SECOMs da América do Norte

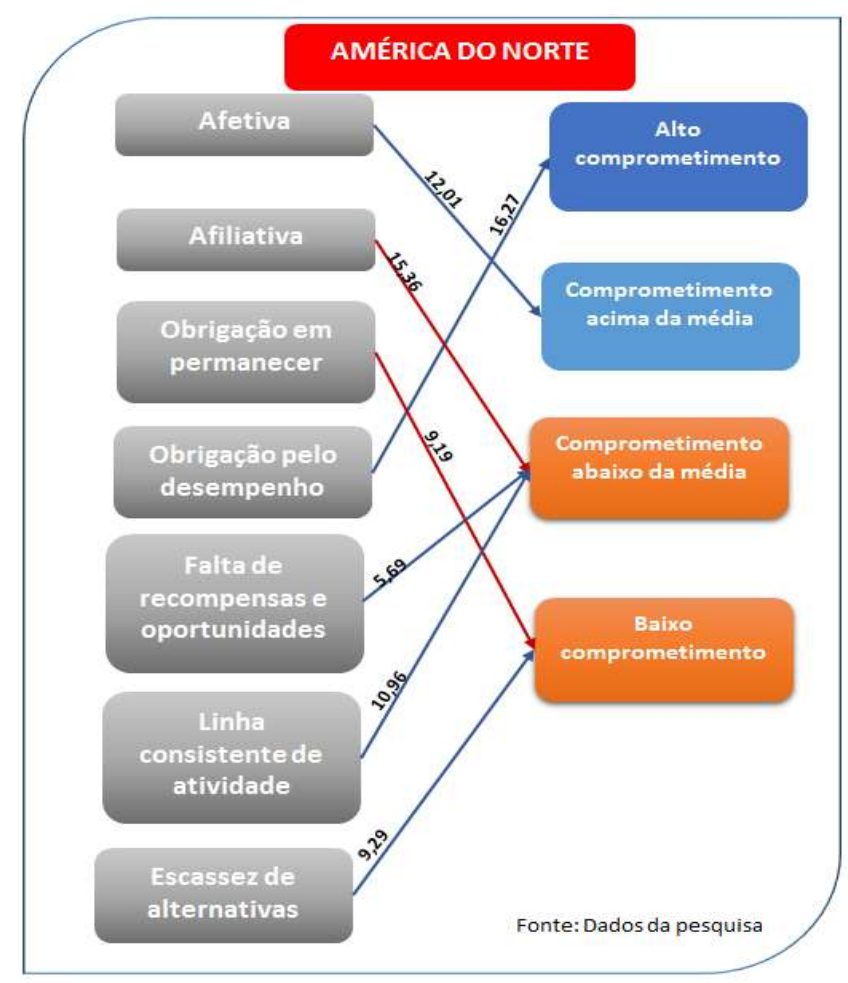

A América do Norte possui duas unidades continentais: América AngloSaxônica ${ }^{42}$ e América Latina ${ }^{43}$. Semelhantemente aos outros continentes, a base afetiva apresentou comprometimento acima da média. A diferença está na base afiliativa para a unidade continental América Latina, pois, enquanto a América AngloSaxônica teve resultado semelhante aos demais continentes comprometimento abaixo da média. A América Latina apresentou comprometimento acima da média para esta base. Ressalta-se que todos os respondentes do SECOM nesta unidade são mulheres, com ensino superior, idade entre 20 a 29 anos e tempo de casa variando entre 6 a 10 anos.

A base obrigação em permanecer teve como resultado baixo comprometimento para a unidade continental da América Anglo-Saxônica e comprometimento abaixo da média para a unidade continental da América Latina. Essa divergência coincide com os índices de coletivismo e individualismo de Hofstede (2003), pois EUA (IDV = 91) e Canadá (IDV=80) caracterizam-se como sociedades mais individualistas, em que as pessoas são individualmente responsáveis pela forma de conduzirem suas vidas, e México (IDV=30) com perfil mais coletivista. Já a base obrigação pelo desempenho apresentou os mesmos resultados que os demais continentes, ou seja, alto comprometimento. As bases de cunho instrumental - falta de recompensas e oportunidades e linha consistente de atividade - apresentaram resultados

\footnotetext{
${ }^{42}$ Canadá (3 SECOMs) e Estados Unidos (8 SECOMs).

${ }^{43}$ México (1 SECOM).
} 
semelhantes com comprometimentos abaixo da média. Já a base escassez de alternativas teve como resultado o baixo comprometimento.

\subsubsection{5(e) SECOMs na Oceania}

Segundo Brewster e Mayrhofer (2012), Austrália e Nova Zelândia têm muito em comum e estão cada vez mais integrados no que se refere às suas atividades econômicas. Colonizados pelos britânicos durante a expansão marítima nos séculos XVIII e XIX, são sociedades anglófonas com pequenas proporções de pessoas para o espaço que possuem. A Nova Zelândia tem uma população de 4,23 milhões de pessoas em 2008, enquanto a Austrália tem 20,61 milhões. São economias desenvolvidas com infraestrutura de primeiro mundo. Nova Zelândia é dominada por indústrias de processamento de alimentos (lácteos, carne, horticultura, vinho e peixe) e pelo turismo, e a Austrália por importantes setores rurais, industriais e de turismo e indústrias de mineração com alto investimento de capital. O acordo de livre comércio (Closer Economic Relations - CER) promove um nível elevado de integração econômica e de regulação, fazendo com que empresas australianas tratem os trabalhadores da Nova Zelândia como parte de seu grupo de recrutamento e viceversa. O horário de trabalho em ambos os países é ligeiramente superior ao de outros países da OCDE, com média em torno de 44 horas semanais. Leis sobre reconhecimento sindical, negociação coletiva, saúde e segurança no emprego, mínimas condições de emprego e a igualdade de oportunidades de emprego são importantes, mas há uma regulação significativamente menor do mercado de trabalho do que nas economias de mercado coordenadas da Europa (Brewster \& Mayrhofer, 2012; Boxall \& Frenkel, 2012).

Quanto ao Índice de Individualismo (IDV), Austrália (IDV=90) e Oceania (IDV=79) são compreendidos como países individualistas. 
Figura 38 - Resultados da Escala EBACO para os SECOMs da Oceania

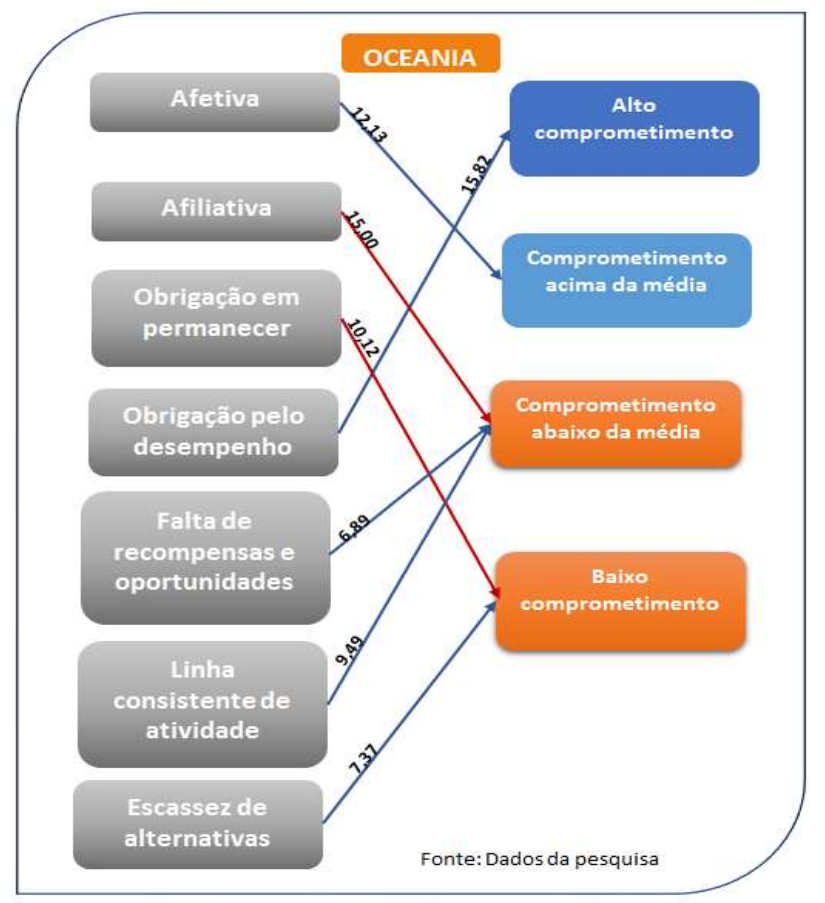

$\mathrm{Na}$ base afetiva, 0 resultado foi semelhante aos SECOMs dos outros continentes cuja interpretação foi avaliada como comprometimento acima da média. Estudos sobre comprometimento organizacional na Austrália têm mostrado a relação do comprometimento afetivo com variáveis antecedentes e consequentes, como a mediação de Confiança Organizacional na relação entre justiça e comprometimento afetivo na Austrália (Jiang, 2014), em que o comprometimento afetivo mostrou-se altamente relacionado com a percepção de justiça nas organizações; ou o trabalho de Joiner e Bakalis (2006) com acadêmicos na Austrália, onde identificaram que as características relacionadas ao trabalho desempenham um papel particularmente importante no comprometimento afetivo. $O$ trabalho de Zatzick et al. (2015) com 3.057 funcionários em 563 agências bancárias australianas demonstrou que o comprometimento organizacional afetivo diminui a probabilidade de um empregado ser demitido. Na base afiliativa, o comprometimento foi abaixo da média, semelhante aos continentes asiático e norte-americano. O baixo comprometimento na base obrigação em permanecer coincide com os SECOMs dos continentes da América Central e Caribe e da América do Norte.

A base obrigação pelo desempenho de natureza normativa resultou em alto comprometimento em todos os SECOMs da Oceania. Pesquisa realizada com 196 administradores do Australian Institute of Management mostrou que os níveis de comprometimento afetivo e normativo são influenciados pelo valor que os funcionários percebem nas ofertas de desenvolvimento de carreira em suas organizações (Bambacas, 2010). Iverson e Buttigieg (1999) identificaram que o comprometimento organizacional é mais bem representado pelas bases afiliativa e normativa e alto sacrifício pessoal. O que se observa é que o comprometimento normativo nestas 
pesquisas tem se mostrado relacionado com o comprometimento afetivo, da mesma forma que as bases obrigação pelo desempenho e afetiva nos SECOMs.

É comum que o coletivismo, caracterizado pela interdependência entre as pessoas, adoção de normas que favorecem a incorporação em grupo, o dever e a harmonia no grupo, esteja relacionado com comprometimento normativo. Autores têm relatado que o coletivismo se correlaciona mais positivamente com comprometimento normativo do que o comprometimento afetivo e o comprometimento de continuidade (Clugston, Howell \& Dorfman; 2000; Gelade et al., 2008; Chen et al., 2016). Apesar de os países da Oceania terem perfis mais individualistas, todos os respondentes são brasileiros, e segundo Allen \& Meyer (1996), o comprometimento normativo se baseia mais em experiências iniciais de socialização (na família e na comunidade) do que em experiências na organização empregadora.

As bases falta de recompensas e oportunidades e linha consistente de atividade apresentaram resultados semelhantes com comprometimentos abaixo da média. Já a base escassez de alternativas teve como resultado o baixo comprometimento. Esses resultados não diferem dos resultados dos demais SECOMs em outros continentes.

\subsubsection{5(f) SECOMs da América do Sul}

Uma característica marcante e comum de todos os países da América Latina é a sua formação histórica. A partir do século XVI, todos os países foram colonizados pelas potências europeias da época (Espanha e Portugal) e tinham como objetivo atender aos interesses econômicos das metrópoles, sendo caracterizadas como colônias de exploração, diferentemente do Canadá e Estados Unidos em que prevaleceu as colônias de povoamento (Feldmann, 2010).

O tipo de colonização realizado na América Latina deixou marcas profundas que permanecem até hoje. Exemplos dessas marcas podem ser observados em quase todas as empresas latino-americanas quanto ao tipo de controle acionário, que é concentrado nas mãos de um indivíduo ou, quando muito, nas mãos de uma ou duas famílias, conduzindo, de acordo com Feldmann (2010), a um afrouxamento dos controles sobre os resultados e à ausência de profissionalização da gestão. Outra característica, segundo Fairbanks \& Lindsay (2000), é uma espécie de paternalismo que os governos dos países têm para com os empresários, pois estes só agem se o 
governo agir antes. É comum que haja lobbies e pressões de associações de empresários sobre os governantes para obtenção de proteções (Feldmann, 2010).

Segundo Feldmann (2010), um traço preponderante dos latino-americanos é a necessidade de que haja uma liderança superior para tomar decisões importantes. A busca de uma resposta para tudo por intermédio de um líder é algo frequente e, talvez por isso, é comum observar nas organizações que as decisões gerenciais sejam realizadas por uma única pessoa de uma maneira central e decisiva - "o chefe mandou".

Figura 39 - Resultados da Escala EBACO para os SECOMs da América do Sul

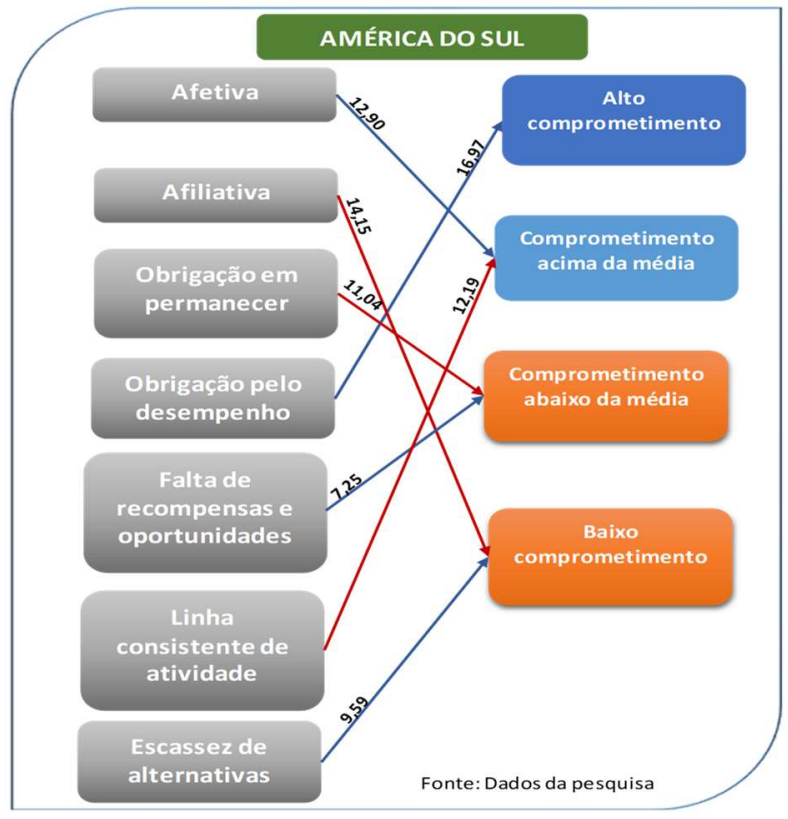

A base afetiva teve o mesmo resultado em todos os SECOMs da América do Sul: comprometimento acima da média. $\mathrm{Na}$ base afiliativa, $\mathrm{O}$ resultado baixo comprometimento foi semelhante aos continentes europeu, africano e da América Central e Caribe. Segundo Rajagopal (2006), os latino-americanos são pessoas hospitaleiras e calorosas. A família e o parentesco constituem a principal forma de associação, diferentemente das associações

voluntárias comuns entre os norte-americanos (Lester, 1993). Os valores coletivistas são vistos no sentido da família e de amigos muito próximos, mas não necessariamente no ambiente de trabalho, aliás tais questões culturais da sociedade podem não apoiar a cultura do local de trabalho. O comprometimento abaixo da média na base obrigação em permanecer coincide com os SECOMs dos continentes da Europa, Ásia e África.

A base obrigação pelo desempenho, de natureza normativa, resultou em alto comprometimento em todos os SECOMs da América do Sul. Estudos sobre comprometimento organizacional no Chile têm mostrado a relação do comprometimento organizacional com variáveis organizacionais. Figueroa et al. (2009) analisaram a relação entre as variáveis constitutivas da dimensão cultura 
trabalho-família numa empresa de serviços financeiros e o comprometimento organizacional, estando a cultura fortemente associada a este e ainda observou que, quanto mais se percebe $o$ apoio diretivo da empresa, maiores são os comprometimentos afetivo e normativo. Liberman (2014), ao comparar o estilo paternalista de gestão e práticas de delegação em dois contextos organizacionais, o Chile e os EUA, assim como os efeitos dessas práticas de gestão na satisfação no trabalho e no comprometimento organizacional, registram que os resultados encontrados sugerem que a delegação de autoridade era mais comum nos EUA do que no Chile, enquanto o paternalismo era maior no Chile do que nos EUA. Semelhantemente aos demais SECOMs, a base de comprometimento obrigação pelo desempenho apresentou alto comprometimento.

Já o resultado da base linha consistente de atividade mostrou-se totalmente diferente dos SECOMs dos demais continentes, com comprometimento acima da média. Essa base de cunho instrumental identifica que o trabalhador permanece na organização devido aos custos e benefícios associados à sua saída e que passa a se engajar em linhas consistentes de atividades para se manter no emprego (agir de forma que não transgrida regras para manter-se no emprego, permanecer na organização por necessidade e por desejo, realiza recompensas por meio de atitudes certas, fazer o possível para manter-se na organização foram os itens apresentados para os colaboradores na escala de comprometimento). Uma possível explicação para este resultado pode estar no baixo percentual de tempo de serviço acima de 21 anos (23\%) e no alto percentual de colaboradores acima de 40 anos $(64,1 \%)$.

As demais bases de cunho instrumental, falta de recompensas e oportunidades e escassez de alternativas apresentaram resultados semelhantes aos outros SECOMs, abaixo da média e baixo comprometimento, respectivamente. 


\subsubsection{5(g) SECOMS na América Central e Caribe}

Figura 40 - Resultados da Escala EBACO para os SECOMs da América Central e Caribe

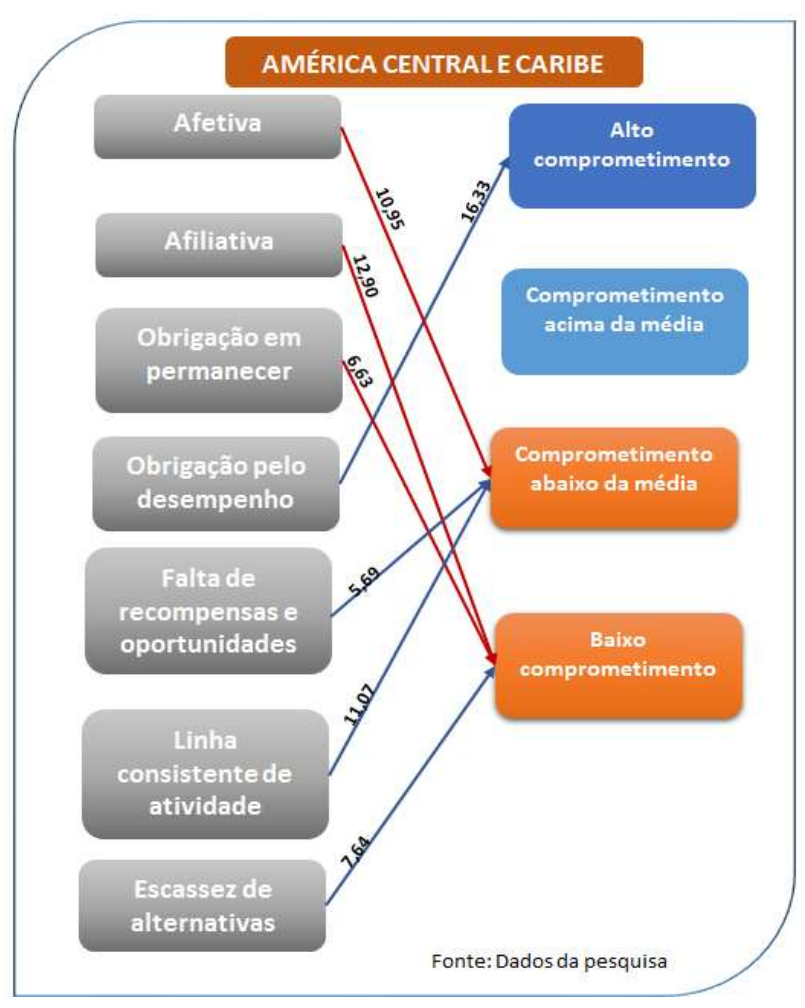

Somente nos SECOMs da América Central a base afetiva teve como resultado comprometimento abaixo da média. Em essência o comprometimento afetivo avalia a identificação e o envolvimento do empregado com a sua organização (similaridade entre os valores pessoais e os organizacionais, preferência pela organização pelo que ela simboliza, identificação com a filosofia da organização e crença nos valores e objetivos da organização foram os itens apresentados aos colaboradores ao avaliarem a associação desse tipo de comprometimento e a organização em que trabalham). Na base afiliativa, o resultado baixo comprometimento foi semelhante aos continentes da América do Sul, África e Europa. Semelhantemente aos SECOMs da África, a base obrigação em permanecer resultou em comprometimento abaixo da média e a base obrigação pelo desempenho em alto comprometimento. Como ambas são de natureza normativa, a diferença entre elas está no fato de que a base obrigação em permanecer trata de uma obrigação moral para com as pessoas da organização e a obrigação pelo desempenho avalia a percepção dos respondentes quanto a sua relação pessoal para com os objetivos da organização. As bases de comprometimento de natureza instrumental apresentaram resultados esperados, ou seja, comprometimento abaixo da média (bases falta de recompensas e oportunidades e base linha consistente de atividade) e baixo comprometimento para a base escassez de alternativas. 
Em resumo, somente nos SECOMs da América Central e Caribe é que a base afetiva teve como resultado comprometimento abaixo da média. Todos os demais SECOMs apresentaram comprometimento acima da média nesta base.

Na base afiliativa os SECOMs da Europa, África, América do Sul e América Central teve como resultado baixo comprometimento. E na Ásia, América do Norte e Oceania os respondentes avaliaram como comprometimento abaixo da média.

Nas bases de comprometimento de cunho normativo, comprometimento abaixo da média na base obrigação em permanecer foram identificados nos SECOMs da Europa, Ásia, África e América do Sul; e baixo comprometimento nos SECOMs da América do Norte, Oceania e América Central e Caribe. Na base obrigação pelo desempenho, todos os SECOMs têm alto comprometimento. E nas bases de natureza instrumental, todos os SECOMs têm baixo comprometimento na base escassez de alternativas e comprometimento abaixo da média para a base falta de recompensas e oportunidades; somente os SECOMs da América do Sul veem a base linha consistente de atividade como comprometimento acima da média, os demais veem como comprometimento abaixo da média.

Unidades continentais onde a concentração de países é mais coletivista apresentaram resultados na dimensão obrigação em permanecer comprometimento abaixo da média. E nas unidades continentais com perfis mais individualistas, o resultado desta dimensão foi de baixo comprometimento.

É possível que haja uma provável relação entre as bases afetiva e as bases obrigação pelo desempenho e obrigação em permanecer, aliás estudos têm mostrado que comprometimento normativo está substancialmente inter-relacionado com o comprometimento afetivo (Van Breugel et al., 2005; Meyer et al., 2002; Bambacas, 2010; Iverson \& Buttigieg, 1999; Veitch \& Cooper-Thomas, 2009).

Muitas pesquisas se concentraram no componente afetivo do comprometimento organizacional (Field \& Buitendach, 2011). O componente afetivo tem a relação mais forte e consistente com resultados desejáveis no local de trabalho (Arzu Wasti, 2003). Kwantes (2009) aborda que o comprometimento normativo é derivado das normas culturais que foram obtidas por meio de experiências de socialização da primeira infância, mas também pode resultar da influência das normas organizacionais (Meyer et al., 1998). A socialização dos recém-chegados na instituição pode complementar a 
aprendizagem da infância ao transmitir o que é esperado em um ambiente de trabalho (Wiener, 1982). Quando o comprometimento é ensinado como uma norma cultural, é ensinado em um sentido muito geral, mas, quando transmitido por intermédio da socialização dos recém-chegados, as expectativas da organização e de outros colaboradores desta lealdade tornam-se específicas para esta organização. 


\subsection{Análises Bivariadas}

Nesta sessão serão utilizados o teste de independência de duas variáveis (conhecido como teste t) e o coeficiente de correlação linear de Pearson para estudo da relação linear entre duas variáveis.

\subsubsection{Análises bivariadas entre o DPR e os SECOMs}

Para verificar o efeito da cultura organizacional da instituição nacional sobre a cultura organizacional da organização local, foi realizada a análise bivariada teste de médias para amostras independentes para as dimensões valores organizacionais do DPR e dos SECOMs e os tipos de práticas do DPR e dos SECOMs. O que se pretende verificar é se há diferenças entre os resultados das dimensões encontrados no DPR e nos SECOMs, conforme pode ser visto no modelo a seguir.

Figura 41 - Valores e práticas da instituição nacional e valores e práticas da organização local

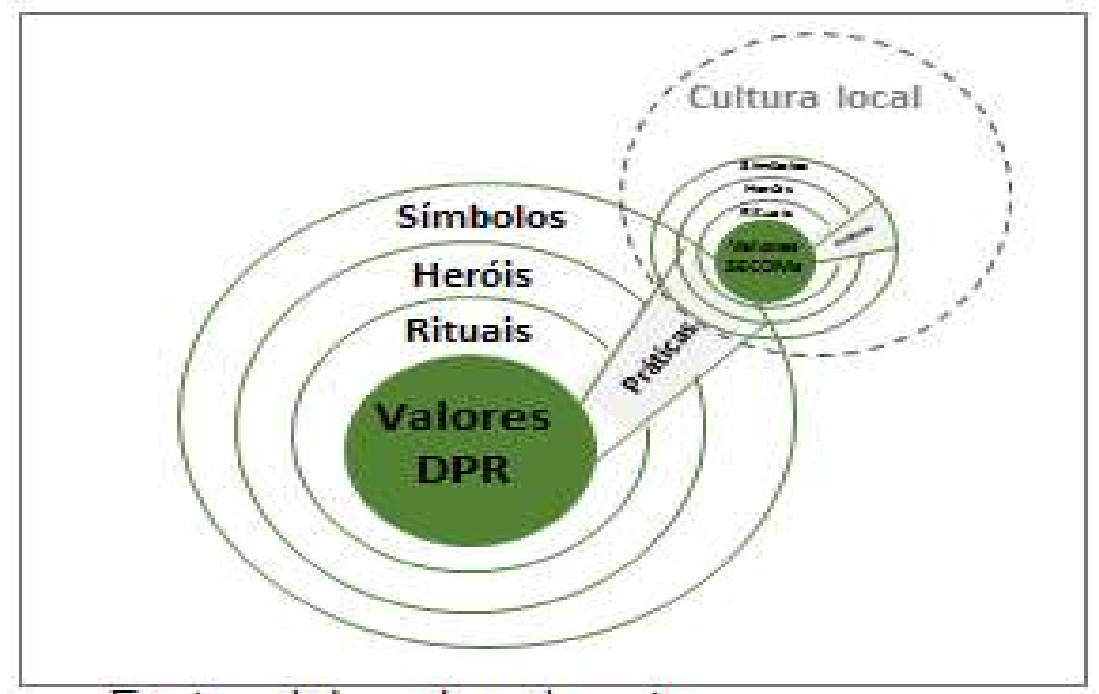

Fonte: elaborado pela autora 


\subsubsection{Diferenças entre os valores organizacionais identificados no DPR e nos SECOMs}

Neste estudo, pretende-se verificar se há diferenças na percepção dos valores organizacionais do DPR e dos SECOMs. Para tanto, foram realizados os testes de Levene e o teste $t$, os resultados foram interpretados a partir das interpretações desses testes, como apresentados na tabela 29.

Tabela 29 - Possíveis resultados para o teste-t de amostras independentes

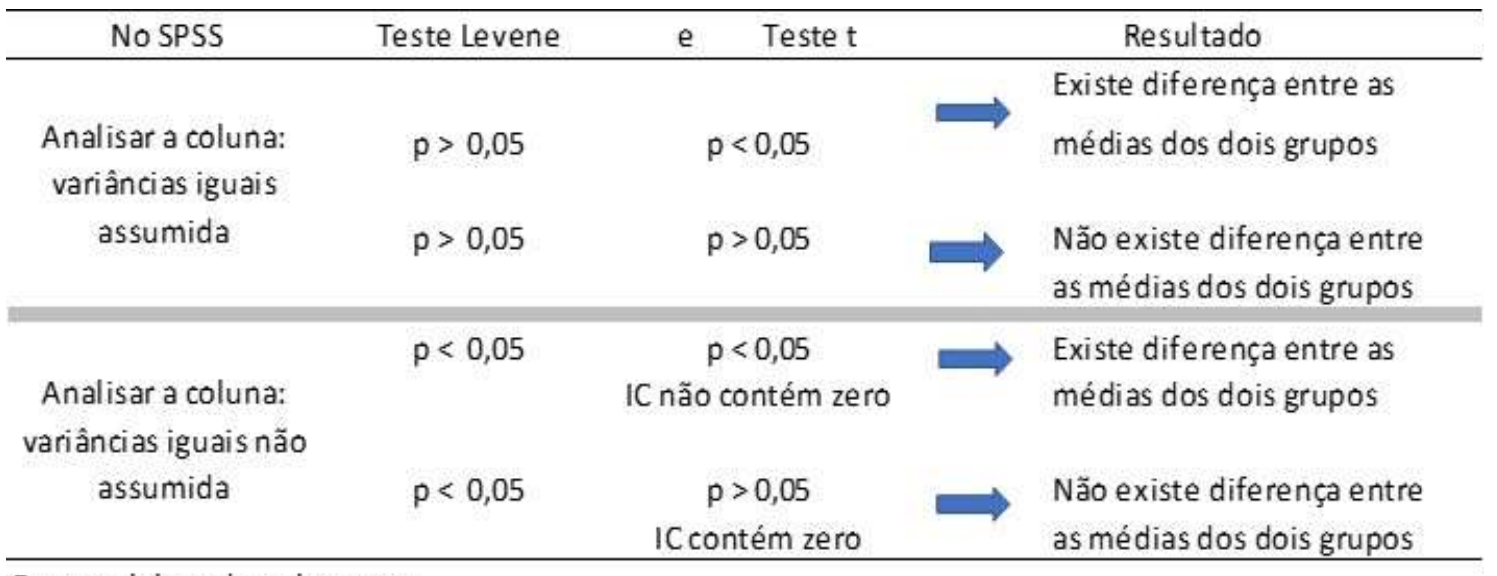

Fonte: elaborado pela autora

Na tabela 30, verifica-se no que se refere à dimensão autonomia, que a média do DPR foi de 4,24 e dos SECOMs de 3,80. O teste de Levene foi maior que 0,05 ( $p=0,062$ ) e o teste-t=2,642 teve como resultado significância menor que 0,05 ( $p=0,009)$. Então a dimensão autonomia é mais reconhecida no DPR do que nos SECOMs, dado que existe diferença entre as médias dos dois grupos.

Tabela 30 - Teste de amostras independentes para a dimensão autonomia no DPR e SECOMs

\begin{tabular}{|c|c|c|c|c|c|c|c|c|c|c|}
\hline & & \multicolumn{2}{|c|}{$\begin{array}{l}\text { Teste de Levene para } \\
\text { igualdade de } \\
\text { variâncias }\end{array}$} & \multicolumn{7}{|c|}{ teste-t para Igualdade de Médias } \\
\hline & & \multirow[t]{2}{*}{$\mathrm{F}$} & \multirow[t]{2}{*}{ Sig. } & \multirow[t]{2}{*}{$\mathrm{t}$} & \multirow[t]{2}{*}{ df } & \multirow[t]{2}{*}{$\begin{array}{l}\text { Sig. (2 } \\
\text { extremida } \\
\text { des) }\end{array}$} & \multirow[t]{2}{*}{$\begin{array}{l}\text { Diferença } \\
\text { média }\end{array}$} & \multirow[t]{2}{*}{$\begin{array}{c}\text { Erro } \\
\text { padrão de } \\
\text { diferença }\end{array}$} & \multicolumn{2}{|c|}{$\begin{array}{c}95 \% \text { Intervalo de } \\
\text { confiança da } \\
\text { diferença }\end{array}$} \\
\hline & & & & & & & & & Inferior & Superior \\
\hline \multirow{2}{*}{ AUT_SEC_DPR } & Variâncias iguais assumidas & 3,510 & ,062 & 2,642 & 318 &, 009 & ,447 & 169 & 114 & ,780 \\
\hline & Variâncias iguais não assumidas & & & 2,873 & 125,907 & ,005 & 447 & 156 & 139 & 755 \\
\hline
\end{tabular}

Fonte: dados da pesquisa obtidos por meio do Software SPSS 
A tabela 31 apresenta as médias da dimensão coletividade, que foram 4,39 para o DPR e 4,46 para os SECOMs. O teste de Levene 0,878 ( $p$-value $>0,05$ ) e $t=-0,497$ e p-valor = 0,619 ( $p$-value >0,05), neste caso pode-se afirmar que não existe diferença entre as médias dos dois grupos. Então, quanto à dimensão coletividade, tanto o DPR quanto os SECOMs têm a mesma percepção.

Tabela 31 - Teste de amostras independentes para a dimensão coletividade no DPR e SECOMs

\begin{tabular}{|c|c|c|c|c|c|c|c|c|c|c|}
\hline & & \multicolumn{2}{|c|}{$\begin{array}{c}\text { Teste de Levene para } \\
\text { igualdade de } \\
\text { variâncias }\end{array}$} & \multirow{3}{*}{$\mathrm{t}$} & \multirow{3}{*}{ df } & \multicolumn{3}{|c|}{ teste-t para Igualdade de Médias } & \multirow{2}{*}{\multicolumn{2}{|c|}{$\begin{array}{c}95 \% \text { Intervalo de } \\
\text { confiança da } \\
\text { diferença }\end{array}$}} \\
\hline & & \multirow[t]{2}{*}{$F$} & \multirow[t]{2}{*}{ Sig. } & & & \multirow[t]{2}{*}{$\begin{array}{l}\text { Sig. (2 } \\
\text { extremida } \\
\text { des) }\end{array}$} & \multirow[t]{2}{*}{$\begin{array}{c}\text { Diferença } \\
\text { média }\end{array}$} & \multirow{2}{*}{$\begin{array}{c}\text { Erro } \\
\text { padrão de } \\
\text { diferença }\end{array}$} & & \\
\hline & & & & & & & & & Inferior & Superior \\
\hline \multirow{2}{*}{ COLET_SEC_DEP } & Variâncias iguais assumidas & 024 & 878 &,- 497 & 318 & 619 &,- 078 & 157 &,- 388 & ,231 \\
\hline & Variâncias iguais não assumidas & & &,- 503 & 112,423 & ,616 &,- 078 & 156 &,- 387 & ,230 \\
\hline
\end{tabular}

A tabela 32 apresenta os resultados para a dimensão realização, em que o DPR obteve média 4,54 e os SECOMs 4,15. O teste de Levene 0,953 (p-value > 0,05) e t $=2,374$ e $p$-valor $=0,018$ ( $p$-value $<0,05)$. Então a dimensão realização é mais reconhecida no DPR do que nos SECOMs, dado que existe diferença entre as médias das organizações.

Tabela 32 - Teste de amostras independentes para a dimensão realização no DPR e SECOMs

\begin{tabular}{|c|c|c|c|c|c|c|c|c|c|c|}
\hline & & \multicolumn{2}{|c|}{$\begin{array}{c}\text { Teste de Levene } \\
\text { para igualdade de } \\
\text { variâncias }\end{array}$} & \multicolumn{7}{|c|}{ teste-t para Igualdade de Médias } \\
\hline & & \multirow[t]{2}{*}{$\mathrm{F}$} & \multirow[t]{2}{*}{ Sig. } & \multirow[t]{2}{*}{$t$} & \multirow[t]{2}{*}{ df } & \multirow[t]{2}{*}{$\begin{array}{c}\text { Sig. (2 } \\
\text { extremid } \\
\text { ades) }\end{array}$} & \multirow[t]{2}{*}{$\begin{array}{l}\text { Diferenç } \\
\text { a média }\end{array}$} & \multirow{2}{*}{$\begin{array}{c}\text { Erro } \\
\text { padrão } \\
\text { de } \\
\text { diferença }\end{array}$} & \multicolumn{2}{|c|}{$\begin{array}{c}95 \% \text { Intervalo de } \\
\text { confiança da } \\
\text { diferença }\end{array}$} \\
\hline & & & & & & & & & Inferior & Superior \\
\hline \multirow{2}{*}{ REAL_SEC_DPR } & Variâncias iguais assumidas &, 003 & 953 & 2,374 & 318 & ,018 & ,391 & 165 &, 067 &, 715 \\
\hline & Variâncias iguais não assumidas & & & 2,382 & 111,172 & ,019 & ,391 & 164 & ,066 & ,716 \\
\hline
\end{tabular}

Fonte: dados da pesquisa obtidos por meio do Software SPSS 
Quanto à dimensão bem-estar, a média do DPR foi 3,73 e dos SECOMs 3,43. O teste de Levene 0,738 (p-value > 0,05) e t = 1,569 e p-valor $=0,118$ ( $p$-value $>0,05)$, neste caso pode-se afirmar que não existe diferença entre as médias dos dois grupos. Então, no que se refere à dimensão bem-estar, o DPR e os SECOMs têm as mesmas percepções, como pode ser visto na tabela 33.

Tabela 33 - Teste de amostras independentes para a dimensão bem-estar no DPR e SECOMs

\begin{tabular}{|c|c|c|c|c|c|c|c|c|c|c|}
\hline & & \multicolumn{2}{|c|}{$\begin{array}{c}\text { Teste de Levene } \\
\text { para igualdade de } \\
\text { variâncias }\end{array}$} & \multicolumn{7}{|c|}{ teste-t para Igualdade de Médias } \\
\hline & & \multirow[t]{2}{*}{$\mathrm{F}$} & \multirow[t]{2}{*}{ Sig. } & \multirow[t]{2}{*}{$\mathrm{t}$} & \multirow[t]{2}{*}{ df } & \multirow[t]{2}{*}{$\begin{array}{l}\text { Sig. (2 } \\
\text { extremid } \\
\text { ades) }\end{array}$} & \multirow[t]{2}{*}{$\begin{array}{l}\text { Diferenç } \\
\text { a média }\end{array}$} & \multirow{2}{*}{$\begin{array}{c}\text { Erro } \\
\text { padrão } \\
\text { de } \\
\text { diferença }\end{array}$} & \multicolumn{2}{|c|}{$\begin{array}{l}\text { 95\% Intervalo de } \\
\text { confiança da } \\
\text { diferença }\end{array}$} \\
\hline & & & & & & & & & Inferior & Superior \\
\hline & Variâncias iguais assumidas & 112 & ,738 & 1,569 & 318 & 118 & ,297 & 189 &,- 075 & ,668 \\
\hline \multirow[t]{2}{*}{ BEM_SEC_DPR } & & & & & & & & & & \\
\hline & Variâncias iguais não assumidas & & & 1,573 & 111,039 & 119 & 297 & 189 & -077 & 670 \\
\hline
\end{tabular}

Fonte: dados da pesquisa obtidos por meio do Software SPSS

No que se refere à dimensão tradição, a média do DPR foi de 4,64 e dos SECOMs 4,55. O teste de Levene 0,774 ( $p$-value >0,05) e t $=0,750$ e p-valor $=0,454$ ( $p$-value $>0,05)$, isto significa que não há diferença entre as médias dos dois grupos e, portanto, DPR e SECOMs têm a mesma percepção na dimensão tradição, como pode ser visto na tabela 34 .

Tabela 34 - Teste de amostras independentes para a dimensão tradição no DPR e SECOMs

\begin{tabular}{|c|c|c|c|c|c|c|c|c|c|c|}
\hline & & \multicolumn{2}{|c|}{$\begin{array}{l}\text { Teste de Levene } \\
\text { para igualdade de } \\
\text { variâncias }\end{array}$} & \multicolumn{7}{|c|}{ teste-t para Igualdade de Médias } \\
\hline & & \multirow[t]{2}{*}{$\mathrm{F}$} & \multirow[t]{2}{*}{ Sig. } & \multirow[t]{2}{*}{$\mathrm{t}$} & \multirow[t]{2}{*}{ df } & \multirow[t]{2}{*}{$\begin{array}{l}\text { Sig. (2 } \\
\text { extremid } \\
\text { ades) }\end{array}$} & \multirow[t]{2}{*}{$\begin{array}{l}\text { Diferenç } \\
\text { a média }\end{array}$} & \multirow{2}{*}{$\begin{array}{c}\text { Erro } \\
\text { padrão } \\
\text { de } \\
\text { diferença }\end{array}$} & \multicolumn{2}{|c|}{$\begin{array}{c}95 \% \text { Intervalo de } \\
\text { confiança da } \\
\text { diferença }\end{array}$} \\
\hline & & & & & & & & & Inferior & Superior \\
\hline & Variâncias iguais assumidas & ,082 & ,774 &, 750 & 318 & ,454 & ,095 & 126 &,- 154 &, 344 \\
\hline \multicolumn{11}{|l|}{ TRAD_SEC_DPR } \\
\hline & Variâncias iguais não assumidas & & & ,743 & 109,072 & 459 & 095 & 128 &,- 158 & 348 \\
\hline
\end{tabular}

Fonte: dados da pesquisa obtidos por meio do Software SPSS 
Para a dimensão prestígio, o DPR obteve média 5,06 e os SECOMs 4,80. O teste de Levene 0,007 ( $p$-value $<0,05)$ e $t=2,155$ e $p$-valor $=0,033(p$-value $<0,05)$, e o intervalo de confiança não contém o zero (IC $[0,021 ; 0,486])$, o que significa que há diferença entre as médias e que a dimensão prestígio é mais reconhecida no DPR do que nos SECOMs, como pode ser visto na tabela 35.

Tabela 35 - Teste de amostras independentes para a dimensão prestígio no DPR e SECOMs

\begin{tabular}{|c|c|c|c|c|c|c|c|c|c|c|}
\hline & & \multirow{3}{*}{\multicolumn{2}{|c|}{$\begin{array}{l}\text { Teste de Levene } \\
\text { para igualdade de } \\
\text { variâncias }\end{array}$}} & \multirow{2}{*}{\multicolumn{7}{|c|}{ teste-t para Igualdade de Médias }} \\
\hline & & & & & & & & & & \\
\hline & & & & \multirow{3}{*}{$\mathrm{t}$} & \multirow{3}{*}{$\mathrm{df}$} & \multirow{3}{*}{$\begin{array}{l}\text { Sig. }(2 \\
\text { extremid } \\
\text { ades) }\end{array}$} & \multirow{3}{*}{$\begin{array}{l}\text { Diferenç } \\
\text { a média }\end{array}$} & \multirow{3}{*}{$\begin{array}{c}\text { Erro } \\
\text { padrão } \\
\text { de } \\
\text { diferença }\end{array}$} & \multirow{2}{*}{\multicolumn{2}{|c|}{$\begin{array}{c}95 \% \text { Intervalo de } \\
\text { confiança da } \\
\text { diferença }\end{array}$}} \\
\hline & & \multirow[t]{2}{*}{$\mathrm{F}$} & \multirow[t]{2}{*}{ Sig. } & & & & & & & \\
\hline & & & & & & & & & Inferior & Superior \\
\hline \multirow{2}{*}{ PREST_SEC_DPR } & Variâncias iguais assumidas & 7,304 & ,007 & 1,956 & 318 & 051 & 253 & 129 &,- 001 & ,508 \\
\hline & Variâncias iguais não assumidas & & & 2,155 & 128,762 & ,033 & 253 & 117 & 021 & 486 \\
\hline
\end{tabular}

Quanto à dimensão conformidade, o DPR obteve média de 5,14 e os SECOMs 5,03.

O teste de Levene 0,116 ( $p$-value $>0,05)$ e $t=1,157$ e $p$-valor $=0,248$ ( $p$-value $>0,05)$, fato que significa que não há diferença entre as médias dos dois grupos e, portanto, DPR e SECOMs têm a mesma percepção no que se refere à dimensão conformidade, como pode ser visto na tabela 36.

Tabela 36 - Teste de amostras independentes para a dimensão conformidade no DPR e SECOMs

\begin{tabular}{|c|c|c|c|c|c|c|c|c|c|c|}
\hline & & \multicolumn{2}{|c|}{$\begin{array}{l}\text { Teste de Levene } \\
\text { para igualdade de } \\
\text { variâncias }\end{array}$} & \multicolumn{7}{|c|}{ teste-t para Igualdade de Médias } \\
\hline & & \multirow[t]{2}{*}{$\mathrm{F}$} & \multirow[t]{2}{*}{ Sig. } & \multirow[t]{2}{*}{$\mathrm{t}$} & \multirow[t]{2}{*}{ df } & \multirow[t]{2}{*}{$\begin{array}{l}\text { Sig. (2 } \\
\text { extremid } \\
\text { ades) }\end{array}$} & \multirow[t]{2}{*}{$\begin{array}{l}\text { Diferenç } \\
\text { a média }\end{array}$} & \multirow{2}{*}{$\begin{array}{c}\text { Erro } \\
\text { padrão } \\
\text { de } \\
\text { diferença }\end{array}$} & \multicolumn{2}{|c|}{$\begin{array}{l}\text { 95\% Intervalo de } \\
\text { confiança da } \\
\text { diferença }\end{array}$} \\
\hline & & & & & & & & & Inferior & Superior \\
\hline & Variâncias iguais assumidas & 2,460 & 118 & 1,157 & 318 & 248 & 115 & 099 &,- 080 & 310 \\
\hline \multicolumn{11}{|l|}{ CONF_SEC_DPR } \\
\hline & Variâncias iguais não assumidas & & & 1,121 & 106,001 & ,265 & 115 & 102 &,- 088 & ,318 \\
\hline
\end{tabular}


No que se refere à dimensão domínio, o DPR obteve média de 3,71 e os SECOMs 4,33. O teste de Levene 0,001 ( $p$-value $<0,05)$ e $\mathrm{t}=-3,035$ e $\mathrm{p}$-valor $=0,003$ ( $p$-value $<0,05)$, e o intervalo de confiança não contém o zero (IC [-1,022; $-0,214]$ ), isto significa que há diferença entre as médias e que a dimensão domínio é mais reconhecida nos SECOMs do que no DPR, como pode ser visto na tabela 37.

Tabela 37 - Teste de amostras independentes para a dimensão domínio no DPR e SECOMs

\begin{tabular}{|c|c|c|c|c|c|c|c|c|c|c|}
\hline & & \multicolumn{2}{|c|}{$\begin{array}{c}\text { Teste de Levene } \\
\text { para igualdade de } \\
\text { variâncias }\end{array}$} & \multicolumn{7}{|c|}{ teste-t para Igualdade de Médias } \\
\hline & & \multirow[t]{2}{*}{$\mathrm{F}$} & \multirow[t]{2}{*}{ Sig. } & \multirow[t]{2}{*}{$\mathrm{t}$} & \multirow[t]{2}{*}{ df } & \multirow[t]{2}{*}{$\begin{array}{l}\text { Sig. ( } 2 \\
\text { extremid } \\
\text { ades) }\end{array}$} & \multirow[t]{2}{*}{$\begin{array}{l}\text { Diferenç } \\
\text { a média }\end{array}$} & \multirow{2}{*}{$\begin{array}{c}\text { Erro } \\
\text { padrão } \\
\text { de } \\
\text { diferença }\end{array}$} & \multicolumn{2}{|c|}{$\begin{array}{l}95 \% \text { Intervalo de } \\
\text { confiança da } \\
\text { diferença }\end{array}$} \\
\hline & & & & & & & & & Inferior & Superior \\
\hline \multirow{2}{*}{ DOM_SEC_DPR } & Variâncias iguais assumidas & 12,213 & 001 & $-3,539$ & 318 &, 000 &,- 618 & 175 &,- 961 &,- 274 \\
\hline & Variâncias iguais não assumidas & & & $-3,035$ & 92,340 &, 003 &,- 618 & ,203 & $-1,022$ &,- 214 \\
\hline
\end{tabular}

Para fins de sumarização, os seguintes resultados foram encontrados:

Quadro 33 - Resultado dos testes de amostras independentes para as dimensões do DPR e dos SECOMs

\begin{tabular}{|l|c|c|l|}
\hline \multicolumn{1}{|c|}{ Dimensões dos valores } & Teste Levene & Teste t & Percepções do DPR e dos SECOMs \\
\hline Autonomia & $p>0,05$ & $p<0,05$ & Diferentes \\
\hline Realização & $p>0,05$ & $p<0,05$ & Diferentes \\
\hline Prestígio & $p<0,05$ & $p<0,05$ & Diferentes \\
\hline Domínio & $p<0,05$ & $p<0,05$ & Diferentes \\
\hline Bem-estar & $p>0,05$ & $p>0,05$ & Iguais \\
\hline Tradição & $p>0,05$ & $p>0,05$ & Iguais \\
\hline Coletividade & $p>0,05$ & $p>0,05$ & Iguais \\
\hline Conformidade & $p>0,05$ & $p>0,05$ & Iguais \\
\hline
\end{tabular}

Fonte: elaborado pela autora 


\subsection{Diferenças entre a percepção dos valores organizacionais do DPR e dos valores organizacionais dos colaboradores brasileiros nos SECOMs}

Em decorrência das diferenças encontradas entre as dimensões de valores organizacionais identificadas no DPR e nos SECOMs, foi verificado se o número de colaboradores de nacionalidade brasileira nas organizações locais (SECOMs) poderia influenciar a semelhança dos valores da organização local e dos valores da instituição nacional (DPR), independentemente do continente que estejam situados, pois, pela a análise descritiva, foi verificado que $34 \%$ dos SECOMs são compostos totalmente por brasileiros e $46 \%$ por brasileiros e nativos. O teste-t de amostras independentes foi realizado e os resultados encontrados estão disponibilizados na tabela 38 .

Tabela 38 - Teste de amostras independentes para os valores do DPR e colaboradores brasileiros nos SECOMs

\begin{tabular}{|c|c|c|c|c|c|c|c|c|c|c|}
\hline \multirow{3}{*}{ VALORE } & & \multicolumn{2}{|c|}{$\begin{array}{c}\text { Teste de Levene } \\
\text { para igualdade de } \\
\text { variâncias }\end{array}$} & \multicolumn{7}{|c|}{ teste-t para Igualdade de Médias } \\
\hline & & \multirow[t]{2}{*}{$\mathrm{F}$} & \multirow[t]{2}{*}{ Sig. } & \multirow[t]{2}{*}{$\mathrm{t}$} & \multirow[t]{2}{*}{ df } & \multirow[t]{2}{*}{$\begin{array}{l}\text { Sig. (2 } \\
\text { extremidades) }\end{array}$} & \multirow[t]{2}{*}{$\begin{array}{l}\text { Diferença } \\
\text { média }\end{array}$} & \multirow[t]{2}{*}{$\begin{array}{l}\text { Erro padrão } \\
\text { de diferença }\end{array}$} & \multicolumn{2}{|c|}{$\begin{array}{c}95 \% \text { Intervalo de } \\
\text { confiança da } \\
\text { diferença }\end{array}$} \\
\hline & & & & & & & & & Inferior & Superior \\
\hline AUTONOMIA & Variâncias iguais assumidas & 4,938 & 027 & 2,338 & 220 &, 020 &, 427 & , 183 & 067 & ,787 \\
\hline$\mu \mathrm{DPR}=4,24 \mu \mathrm{BR}-\mathrm{SECOMs}=3,82$ & Variâncias iguais não assumidas & & & 2,499 & 158,755 &, 013 &, 427 &, 171 &, 090 & ,765 \\
\hline COLETIVIDADE & Variâncias iguais assumidas &, 120 &, 729 &,- 670 & 220 &, 503 &,- 114 &, 171 &,- 450 & ,222 \\
\hline$\mu \mathrm{DPR}=4,39 \mu \mathrm{BR}-\mathrm{SECOMs}=4,50$ & Variâncias iguais não assumidas & & &,- 681 & 139,563 & ,497 &,- 114 & ,168 &,- 446 & ,218 \\
\hline REALIZAÇÄO & Variâncias iguais assumidas & ,224 & ,636 & 1,914 & 220 & 052 &, 345 & , 180 &,- 010 &, 701 \\
\hline$\mu \mathrm{DPR}=4,54 \mu \mathrm{BR}-\mathrm{SECOMs}=4,20$ & Variâncias iguais não assumidas & & & 1,946 & 139,659 &, 054 & ,345 & , 178 &,- 006 & 697 \\
\hline BEM-ESTAR & Variâncias iguais assumidas &, 089 &, 766 & 1,203 & 220 &, 230 &, 242 & ,201 &,- 154 & ,638 \\
\hline$\mu \mathrm{DPR}=3,73 \mu \mathrm{BR}-\mathrm{SECOMs}=3,49$ & Variâncias iguais não assumidas & & & 1,202 & 133,989 &, 231 & ,242 &, 201 &,- 156 & 639 \\
\hline TRADIÇÄO & Variâncias iguais assumidas & 3,271 &, 072 &,- 954 & 220 &, 341 &,- 120 & ,126 &,- 369 & ,128 \\
\hline$\mu \mathrm{DPR}=4,64 \mu \mathrm{BR}-\mathrm{SECOMs}=4,76$ & Variâncias iguais não assumidas & & &,- 911 & 120,149 &, 364 &,- 120 & ,132 &,- 382 &, 141 \\
\hline PRESTIGIO & Variâncias iguais assumidas & 1,616 & 205 &, 905 & 220 &, 366 &, 116 &, 129 &,- 137 &, 370 \\
\hline$\mu \mathrm{DPR}=5,06 \mu \mathrm{BR}-\mathrm{SECOMs}=4,94$ & Variâncias iguais não assumidas & & &, 938 & 146,516 &, 350 & ,116 &, 124 &,- 129 &, 362 \\
\hline CONFORMIDADE & Variâncias iguais assumidas & 2,995 &, 085 &, 179 & 220 &, 858 &, 018 &, 100 &,- 179 & ,215 \\
\hline$\mu \mathrm{DPR}=5,14 \mu \mathrm{BR}-\mathrm{SECOMs}=5,13$ & Variâncias iguais não assumidas & & &, 169 & 117,003 & 866 & 018 &, 106 &,- 192 &, 228 \\
\hline DOMINIO & Variâncias iguais assumidas & 11,167 &, 001 & $-3,794$ & 220 &, 000 &,- 720 &, 190 & $-1,094$ &,- 346 \\
\hline$\mu \mathrm{DPR}=3,71 \quad \mu \mathrm{BR}-\mathrm{SECOMs}=4,43$ & Variâncias iguais não assumidas & & & $-3,405$ & 105,289 & 001 &,- 720 & ,211 & $-1,139$ &,- 301 \\
\hline
\end{tabular}

A tabela 38, que trata do teste de médias independentes entre os colaboradores do DPR e os colaboradores brasileiros dos SECOMs, viu que as dimensões coletividade, realização, bem-estar, tradição, prestígio e conformidade não diferem quanto à percepção desses valores entre as duas organizações. Há divergência na dimensão autonomia, teste de Levene 0,027 ( $p$-value $<0,05)$ e $\mathrm{t}=2,499$ e $p$-valor $=0,013(p$ value $<0,05)$, e o intervalo de confiança não contém o zero (IC $[0,090 ; 0,765]$ ), 
evidenciando a diferença entre as médias e que a dimensão autonomia é mais reconhecido entre os colaboradores do DPR do que entre os colaboradores brasileiros dos SECOMs. E na dimensão domínio também há divergência, teste de Levene 0,001 $(p$-value < 0,05) e $\mathrm{t}=-3,405$ e $p$-valor $=0,001$ ( $p$-value < 0,05), e o intervalo de confiança não contém o zero (IC [-1,139; -0,301]), e esta dimensão é mais reconhecida entre os brasileiros dos SECOMs do que entre os colaboradores do DPR.

\subsection{Diferenças entre os valores organizacionais identificadas no DPR e nos colaboradores não brasileiros nos SECOMs}

A partir da tabela 39, observa-se que, ao comparar as percepções dos valores organizacionais dos colaboradores do DPR e dos colaboradores não brasileiros dos SECOMs, o resultado é bem diferente da análise anterior. As dimensões coletividade e bem-estar não diferem quanto à percepção desses valores entre as duas organizações. E em todas as demais há divergências, sendo que as dimensões autonomia, realização, tradição, prestígio e conformidade são mais percebidas entre os colaboradores do DPR e a dimensão domínio é mais percebida entre os colaboradores não brasileiros dos SECOMs.

Tabela 39 - Teste de amostras independentes para os valores do DPR e colaboradores não brasileiros nos SECOMs

\begin{tabular}{|c|c|c|c|c|c|c|c|c|c|c|}
\hline \multirow{3}{*}{ VALORE } & & \multicolumn{2}{|c|}{$\begin{array}{c}\text { Teste de Levene } \\
\text { para igualdade de } \\
\text { variâncias } \\
\end{array}$} & \multicolumn{7}{|c|}{ teste-t para Igualdade de Médias } \\
\hline & & \multirow[t]{2}{*}{$\mathrm{F}$} & \multirow[t]{2}{*}{ Sig. } & \multirow[t]{2}{*}{$\mathrm{t}$} & \multirow[t]{2}{*}{ df } & \multirow[t]{2}{*}{$\begin{array}{c}\text { Sig. (2 } \\
\text { extremidades) }\end{array}$} & \multirow[t]{2}{*}{$\begin{array}{c}\text { Diferença } \\
\text { média }\end{array}$} & \multirow[t]{2}{*}{$\begin{array}{l}\text { Erro padrão } \\
\text { de diferença }\end{array}$} & \multicolumn{2}{|c|}{$\begin{array}{c}95 \% \text { Intervalo de } \\
\text { confiança da } \\
\text { diferença }\end{array}$} \\
\hline & & & & & & & & & Inferior & Superior \\
\hline AUTONOMIA & Variâncias iguais assumidas & 1,049 &, 307 & 2,590 & 166 &, 010 &, 478 & ,184 &, 113 &, 842 \\
\hline$\mu_{\text {DPR }}=4,24 \quad \mu_{\text {NBR-SECOMs }}=3,77$ & Variâncias iguais não assumidas & & & 2,633 & 156,910 &, 009 & , 478 & ,181 &, 119 &, 836 \\
\hline COLETIVIDADE & Variâncias iguais assumidas & 024 & 878 &,- 126 & 166 & 900 &,- 022 &, 178 &,- 373 &, 329 \\
\hline$\mu_{\mathrm{DPR}}=4,39 \mu \mathrm{NBR}-\mathrm{SECOMs}=4,41$ & Variâncias iguais não assumidas & & &,- 126 & 147,458 &, 900 &,- 022 &, 178 &,- 375 &, 330 \\
\hline REALIZAÇÄO & Variâncias iguais assumidas &, 845 &, 359 & 2,511 & 166 &, 013 & ,461 & ,184 &, 099 & 824 \\
\hline$\mu_{\text {DPR }}=4,54 \quad \mu_{\text {NBR-SECOMs }}=4,08$ & Variâncias iguais não assumidas & & & 2,487 & 143,584 &, 014 &, 461 &, 185 & 095 &, 828 \\
\hline BEM-ESTAR & Variâncias iguais assumidas &, 043 &, 837 & 1,735 & 166 & 085 & ,382 &, 220 &,- 053 &, 816 \\
\hline$\mu_{\mathrm{DPR}}=3,73 \quad \mu_{\text {NBR-SECOMs }}=3,35$ & Variâncias iguais não assumidas & & & 1,739 & 150,179 & 084 & ,382 &, 219 &,- 052 &, 815 \\
\hline TRADIÇÄO & Variâncias iguais assumidas &, 026 &, 873 & 2,838 & 166 &, 005 &, 429 &, 151 & ,130 &, 727 \\
\hline$\mu_{\mathrm{DPR}}=4,64 \quad \mu_{\text {NBR-SECOMs }}=4,21$ & Variâncias iguais não assumidas & & & 2,852 & 151,333 &, 005 &, 429 &, 150 &, 132 &, 725 \\
\hline PRESTIGIO & Variâncias iguais assumidas & 11,150 &, 001 & 3,053 & 166 &, 003 &, 465 & 152 & ,164 & ,766 \\
\hline$\mu_{\mathrm{DPR}}=5,06 \quad \mu_{\mathrm{NBR}-\mathrm{SECOM}}=4,59$ & Variâncias iguais não assumidas & & & 3,179 & 164,572 &, 002 &, 465 &, 146 & 176 & ,754 \\
\hline CONFORMIDADE & Variâncias iguais assumidas &, 003 & 955 & 2,151 & 166 &, 033 & 265 &, 123 &, 022 &, 509 \\
\hline$\mu_{\mathrm{DPR}}=5,14 \mu_{\mathrm{NBR}-\mathrm{SECOMs}}=4,88$ & Variâncias iguais não assumidas & & & 2,168 & 152,749 &, 032 & ,265 & , 122 &, 024 &, 507 \\
\hline DOMiNIO & Variâncias iguais assumidas & 9,150 &, 003 & $-2,119$ & 166 &, 036 &,- 459 & 217 &,- 887 &,- 031 \\
\hline$\mu_{\text {DPR }}=3,71 \quad \mu_{\text {NBR-SECOMs }}=4,17$ & Variâncias iguais não assumidas & & & $-2,033$ & 124,775 & 044 &,- 459 & ,226 &,- 906 &,- 012 \\
\hline
\end{tabular}




\subsection{Diferenças entre a percepção dos valores organizacionais do DPR e dos valores organizacionais dos colaboradores nos SECOMs por continente}

Em função das diferenças encontradas entre os valores do DPR e dos SECOMs, decidiu-se verificar em quais SECOMs essas diferenças se mantêm quando analisadas por continente.

No item 5.4.1.1 a dimensão autonomia foi percebida como diferente entre os colaboradores do DPR e dos SECOMs, mas, de acordo com a tabela 40, essas diferenças são específicas nos SECOMs da América Central (teste de Levene 0,968 $(p$-value $>0,05)$ e $t=2,58$ e $p$-valor $=0,017(p$-value $<0,05))$, América do Norte (teste de Levene 0,070 ( $p$-value $>0,05)$ e $t=2,088$ e $p$-valor $=0,039$ ( $p$-value $<0,05)$ ), América do Sul (teste de Levene 0,192 ( $p$-value $>0,05)$ e $t=2,243$ e $p$-valor $=0,027$ $(p$-value $<0,05)$ e Europa (teste de Levene $0,020(p$-value $<0,05)$ e $t=2,726$ e $p$-valor $=0,017(p$-value $<0,05)$ e intervalo de confiança não contém o zero $[0,149 ; 0,932])$. A percepção da dimensão autonomia é maior no DPR do que nesses continentes. E os SECOMs localizados na África, Ásia e Oceania têm a mesma percepção no que se refere à dimensão autonomia do construto valores do DPR.

Tabela 40 - Teste de amostras independentes para os valores do DPR e dos SECOMs por continente - Autonomia

\begin{tabular}{|c|c|c|c|c|c|c|c|c|c|c|}
\hline \multirow{3}{*}{ AUTONC } & & \multicolumn{2}{|c|}{$\begin{array}{l}\text { Teste de Levene } \\
\text { para igualdade de } \\
\text { variâncias }\end{array}$} & \multirow{3}{*}{$\mathrm{t}$} & \multirow{3}{*}{ df } & \multicolumn{3}{|c|}{ teste-t para Igualdade de Médias } & \multirow{2}{*}{\multicolumn{2}{|c|}{$\begin{array}{c}95 \% \text { Intervalo de } \\
\text { confiança da } \\
\text { diferença }\end{array}$}} \\
\hline & & \multirow[t]{2}{*}{$\mathrm{F}$} & \multirow[t]{2}{*}{ Sig. } & & & \multirow[t]{2}{*}{$\begin{array}{l}\text { Sig. (2 } \\
\text { extremidades) }\end{array}$} & \multirow[t]{2}{*}{$\begin{array}{l}\text { Diferença } \\
\text { média }\end{array}$} & \multirow[t]{2}{*}{$\begin{array}{l}\text { Erro padrão } \\
\text { de diferença }\end{array}$} & & \\
\hline & & & & & & & & & Inferior & Superior \\
\hline ÁFRICA & Variâncias iguais assumidas &, 554 & 459 & ,999 & 87 & 321 & ,295 & ,296 &,- 293 & 884 \\
\hline$\mu_{\text {DPR }}=4,24 \quad \mu_{\text {AFRICA }}=3,95$ & Variâncias iguais não assumidas & & & ,924 & 25,958 &, 364 & 295 & ,320 &,- 362 & 953 \\
\hline AMÉRICA CENTRAL & Variâncias iguais assumidas &, 002 & 968 & 2,528 & 78 & 014 & 943 & ,373 & ,200 & 1,686 \\
\hline$\mu_{\text {DPR }}=4,24 \quad \mu_{\text {AMERICACENTRAL }}=3,30$ & Variâncias iguais não assumidas & & & 2,617 & 12,001 &, 023 &, 943 &, 360 & 158 & 1,728 \\
\hline AMÉRICA DO NORTE & Variâncias iguais assumidas & 3,355 &, 070 & 2,088 & 103 & 039 &, 529 & ,253 & 027 & 1,031 \\
\hline$\mu_{\mathrm{DPR}}=4,24 \quad \mu_{\text {AMNORTE }}=3,71$ & Variâncias iguais não assumidas & & & 1,921 & 55,187 &, 060 &, 529 & ,275 &,- 023 & 1,080 \\
\hline AMÉRICA DO SUL & Variâncias iguais assumidas & 1,723 & 192 & 2,243 & 107 &, 027 &, 525 & ,234 &, 061 & 989 \\
\hline$\mu_{\text {DPR }}=4,24 \quad \mu_{\text {AMSUL }}=3,72$ & Variâncias iguais não assumidas & & & 2,155 & 69,888 &, 035 &, 525 & 244 & ,039 & 1,011 \\
\hline ÁSIA & Variâncias iguais assumidas &, 000 & ,990 & 1,051 & 127 & 295 & 209 & 199 &,- 185 & 602 \\
\hline$\mu_{\mathrm{DPR}}=4,24 \mu_{\dot{\mathrm{A} S I A}}=4,03$ & Variâncias iguais não assumidas & & & 1,048 & 121,949 & 297 & ,209 & 199 &,- 186 & 604 \\
\hline EUROPA & Variâncias iguais assumidas & 5,546 &, 020 & 2,678 & 152 & 008 &, 540 & 202 & ,142 & ,939 \\
\hline$\mu_{\mathrm{DPR}}=4,24 \quad \mu_{\text {EUROPA }}=3,70$ & Variâncias iguais não assumidas & & & 2,726 & 151,970 &, 007 &, 540 & 198 & 149 & ,932 \\
\hline OCEANIA & Variâncias iguais assumidas & 1,178 & 281 &,- 012 & 72 & 990 &,- 007 &, 580 & $-1,163$ & 1,149 \\
\hline$\mu_{\text {DPR }}=4,24 \quad \mu_{\text {OCEANIA }}=4,25$ & Variâncias iguais não assumidas & & &,- 009 & 3,190 & ,993 &,- 007 &, 762 & $-2,351$ & 2,337 \\
\hline
\end{tabular}

Fonte: dados da pesquisa obtidos por meio do Software SPSS 
A dimensão coletividade foi percebida como igual entre o DPR e os SECOMs (item 5.4.1.1). Este resultado permaneceu inalterado quando se fez o mesmo teste nos SECOMs por continentes, ou seja, a dimensão coletividade é percebida da mesma forma tanto para os colaboradores do DPR quanto para os dos SECOMs, mesmo quando analisada por continente, conforme pode ser visto na tabela 41.

Tabela 41 - Teste de amostras independentes para os valores do DPR e dos SECOMs por continente - Coletividade

\begin{tabular}{|c|c|c|c|c|c|c|c|c|c|c|}
\hline \multirow{3}{*}{\multicolumn{2}{|c|}{ COLETIVIDADE }} & \multicolumn{3}{|c|}{$\begin{array}{c}\text { Teste de Levene } \\
\text { para igualdade de } \\
\text { variâncias }\end{array}$} & \multicolumn{4}{|c|}{ teste-t para lgualdade de Médias } & \multirow{2}{*}{\multicolumn{2}{|c|}{$\begin{array}{c}95 \% \text { Intervalo de } \\
\text { confiança da } \\
\text { diferença }\end{array}$}} \\
\hline & & \multirow[t]{2}{*}{$\mathrm{F}$} & \multirow[t]{2}{*}{ Sig. } & \multirow[t]{2}{*}{$t$} & \multirow[t]{2}{*}{ df } & \multirow[t]{2}{*}{$\begin{array}{c}\text { Sig. (2 } \\
\text { extremidades) }\end{array}$} & \multirow[t]{2}{*}{$\begin{array}{c}\text { Diferença } \\
\text { média }\end{array}$} & \multirow[t]{2}{*}{$\begin{array}{l}\text { Erro padrão } \\
\text { de diferença }\end{array}$} & & \\
\hline & & & & & & & & & Inferior & Superior \\
\hline ÁFRICA & Variâncias iguais assumidas &, 040 & 842 &,- 649 & 87 &, 518 &,- 193 & ,298 &,- 785 &, 398 \\
\hline$\mu_{\text {DPR }}=4,39 \quad \mu_{\text {AFRICA }}=4,58$ & Variâncias iguais não assumidas & & &,- 641 & 28,098 &, 526 &,- 193 & ,301 &,- 810 &, 424 \\
\hline AMÉRICA CENTRAL & Variâncias iguais assumidas & 002 & 968 & 480 & 78 & 633 & ,186 & 387 &,- 585 & 956 \\
\hline$\mu_{D P R}=4,39 \mu_{\text {AMERICACENTRAL }}=4,20$ & Variâncias iguais não assumidas & & &, 483 & 11,777 &, 638 & , 186 &, 384 &,- 653 & 1,025 \\
\hline AMÉRICA DO NORTE & Variâncias iguais assumidas &, 576 & 449 & $-1,279$ & 103 &, 204 &,- 300 &, 234 &,- 765 &, 165 \\
\hline$\mu_{\mathrm{DPR}}=4,39 \quad \mu_{\mathrm{AMNORTE}}=4,69$ & Variâncias iguais não assumidas & & & $-1,295$ & 70,341 &, 200 &,- 300 & ,232 &,- 762 &, 162 \\
\hline AMÉRICA DO SUL & Variâncias iguais assumidas & ,749 & ,389 &,- 103 & 107 & 918 &,- 025 & ,238 &,- 497 & 448 \\
\hline$\mu_{\mathrm{DPR}}=4,39 \quad \mu_{\mathrm{AMSUL}}=4,41$ & Variâncias iguais não assumidas & & &,- 100 & 72,041 &, 921 &,- 025 &, 245 &,- 514 &, 465 \\
\hline ÁSIA & Variâncias iguais assumidas & 3,488 &, 064 & $-1,648$ & 127 & ,102 &,- 309 & ,188 &,- 680 &, 062 \\
\hline$\mu_{\mathrm{DPR}}=4,39 \mu_{\dot{A} S A_{A}}=4,69$ & Variâncias iguais não assumidas & & & $-1,674$ & 126,977 &, 097 &,- 309 & ,185 &,- 675 &, 056 \\
\hline EUROPA & Variâncias iguais assumidas &, 568 & 452 & 693 & 152 & 489 & , 136 & , 196 &,- 251 &, 522 \\
\hline$\mu_{D P R}=4,39 \quad \mu_{E U R O P A}=4,25$ & Variâncias iguais não assumidas & & & 699 & 150,813 & ,485 & , 136 & ,194 &,- 248 &, 519 \\
\hline OCEANIA & Variâncias iguais assumidas & 850 & 360 & 227 & 72 & 821 & , 136 &, 598 & $-1,056$ & 1,327 \\
\hline$\mu_{\text {DPR }}=4,39 \mu_{\text {OCEANIA }}=4,25$ & Variâncias iguais não assumidas & & & ,178 & 3,203 & 869 & ,136 &, 762 & $-2,206$ & 2,477 \\
\hline
\end{tabular}

Ao fazer o teste de diferença de médias da dimensão realização, o resultado apresentou como diferente entre o DPR e os SECOMs. Esta diferença é percebida nos SECOMs da América do Norte (teste de Levene 0,783 ( $p$-value $>0,05$ ) e $t=2,34$ e p-valor $=0,021(p$-value $<0,05))$ e na Europa (teste de Levene 0,272 ( $p$-value $>$ $0,05)$ e $\mathrm{t}=2,43$ e $p$-valor $=0,016(p$-value $<0,05))$. A percepção é maior entre os colaboradores do DPR do que entre os colaboradores dos SECOMs da América do Norte e Europa. Os colaboradores dos SECOMs localizados nos continentes africano, da América Central, da América do Sul, da Ásia e Oceania têm a mesma percepção que os colaboradores do DPR, como pode ser visto na tabela 42 . 
Tabela 42 - Teste de amostras independentes para os valores do DPR e dos SECOMs por continente - Realização

\begin{tabular}{|c|c|c|c|c|c|c|c|c|c|c|}
\hline \multirow{3}{*}{\multicolumn{2}{|c|}{ REALIZAÇÄO }} & \multicolumn{3}{|c|}{$\begin{array}{c}\text { Teste de Levene } \\
\text { para igualdade de } \\
\text { variâncias }\end{array}$} & \multicolumn{4}{|c|}{ teste-t para Igualdade de Médias } & & \\
\hline & & \multirow[t]{2}{*}{$\mathrm{F}$} & \multirow[t]{2}{*}{ Sig. } & \multirow[t]{2}{*}{$t$} & \multirow[t]{2}{*}{ df } & \multirow{2}{*}{$\begin{array}{c}\text { Sig. (2 } \\
\text { extremidades) }\end{array}$} & \multirow{2}{*}{$\begin{array}{l}\text { Diferença } \\
\text { média }\end{array}$} & \multirow{2}{*}{$\begin{array}{l}\text { Erro padrão } \\
\text { de diferença }\end{array}$} & \multicolumn{2}{|c|}{$\begin{array}{c}95 \% \text { Intervalo de } \\
\text { confiança da } \\
\text { diferença }\end{array}$} \\
\hline & & & & & & & & & Inferior & Superior \\
\hline ÁFRICA & Variâncias iguais assumidas & 014 & ,907 &, 725 & 87 & 470 & 227 & ,313 &,- 395 & 849 \\
\hline$\mu_{\mathrm{DPR}}=4,54 \quad \mu_{\mathrm{AFRICA}}=4,32$ & Variâncias iguais não assumidas & & &, 728 & 28,693 &, 473 & ,227 &, 312 &,- 411 & 865 \\
\hline AMÉRICA CENTRAL & Variâncias iguais assumidas & ,188 & 665 & 1,826 & 78 & ,072 & ,743 & ,407 &,- 067 & 1,553 \\
\hline$\mu_{\text {DPR }}=4,54 \quad \mu_{\text {AMERICACENTRAL }}=3,80$ & Variâncias iguais não assumidas & & & 1,919 & 12,128 &, 079 &, 743 & ,387 &,- 100 & 1,585 \\
\hline AMÉRICA DO NORTE & Variâncias iguais assumidas & 076 &, 783 & 2,346 & 103 & 021 & 600 & 256 & 093 & 1,107 \\
\hline$\mu_{\mathrm{DPR}}=4,54 \quad \mu_{\mathrm{AMNORTE}}=3,94$ & Variâncias iguais não assumidas & & & 2,302 & 64,803 &, 025 & 600 &, 261 &, 079 & 1,121 \\
\hline AMÉRICA DO SUL & Variâncias iguais assumidas &, 125 &, 725 & 1,473 & 107 & , 144 &, 363 & 247 &,- 126 & 852 \\
\hline$\mu_{\mathrm{DPR}}=4,54 \quad \mu_{\mathrm{AMSUL}}=4,18$ & Variâncias iguais não assumidas & & & 1,452 & 75,392 & ,151 & ,363 &, 250 &,- 135 & 862 \\
\hline ÁSIA & Variâncias iguais assumidas & 3,452 &, 065 & ,788 & 127 & 432 &, 153 & ,194 &,- 231 &, 537 \\
\hline$\mu_{\mathrm{DPR}}=4,54 \mu_{\dot{A} S \mathrm{~A}}=4,39$ & Variâncias iguais não assumidas & & &, 804 & 126,319 &, 423 & ,153 & , 190 &,- 223 &, 530 \\
\hline EUROPA & Variâncias iguais assumidas & 1,217 & 272 & 2,432 & 152 &, 016 & ,507 & ,208 &, 095 & 919 \\
\hline$\mu_{\mathrm{DPR}}=4,54 \quad \mu_{\mathrm{EUROPA}}=4,04$ & Variâncias iguais não assumidas & & & 2,456 & 151,102 &, 015 &, 507 &, 206 &, 099 & ,915 \\
\hline OCEANIA & Variâncias iguais assumidas & 427 &, 516 &,- 335 & 72 & 739 &,- 207 & 618 & $-1,440$ & 1,025 \\
\hline$\mu_{\text {DPR }}=4,54 \quad \mu_{\text {OCEANAA }}=4,75$ & Variâncias iguais não assumidas & & &,- 414 & 3,573 &, 702 &,- 207 &, 500 & $-1,664$ & 1,249 \\
\hline
\end{tabular}

No item 5.4.1.1 a dimensão bem-estar apresentou como resultado a não diferenciação de percepções entre o DPR e os SECOMs. Entretanto, há diferenças quando analisada por continentes. América Central (teste de Levene 0,593 ( $p$-value $>0,05) \mathrm{e}$ $\mathrm{t}=2,16$ e p-valor $=0,033(p$-value $<0,05))$, América do Sul (teste de Levene 0,828 ( $p$ value $>0,05)$ e $t=2,05$ e $p$-valor $=0,042(p$-value $<0,05)$ ) e Europa (teste de Levene $0,294$ ( $p$-value $>0,05)$ e $t=2,02$ e $p$-valor $=0,045(p$-value $<0,05)$ ) têm percepções divergentes e essa percepção é maior no DPR. Já os colaboradores dos SECOMs localizados na África, na América do Norte, na Ásia e na Oceania têm a mesma percepção dos colaboradores do DPR, como pode ser visto na tabela 43.

Tabela 43 - Teste de amostras independentes para os valores do DPR e dos SECOMs por continente - Bem-estar

\begin{tabular}{|c|c|c|c|c|c|c|c|c|c|c|}
\hline \multirow{3}{*}{\multicolumn{2}{|c|}{ BEM-ESTAR }} & \multicolumn{4}{|c|}{$\begin{array}{l}\text { Teste de Levene para } \\
\text { igualdade de } \\
\text { variâncias }\end{array}$} & \multicolumn{3}{|c|}{ teste-t para Igualdade de Médias } & \multirow{2}{*}{\multicolumn{2}{|c|}{$\begin{array}{c}95 \% \text { Intervalo de } \\
\text { confiança da } \\
\text { diferença }\end{array}$}} \\
\hline & & \multirow[t]{2}{*}{$\mathrm{F}$} & \multirow[t]{2}{*}{ Sig. } & \multirow[t]{2}{*}{$t$} & \multirow[t]{2}{*}{ df } & \multirow[t]{2}{*}{$\begin{array}{c}\text { Sig. (2 } \\
\text { extremidades) }\end{array}$} & \multirow[t]{2}{*}{$\begin{array}{c}\text { Diferença } \\
\text { média }\end{array}$} & \multirow[t]{2}{*}{$\begin{array}{l}\text { Erro padrão } \\
\text { de diferenç̧a }\end{array}$} & & \\
\hline & & & & & & & & & Inferior & Superior \\
\hline ÁFRICA & Variâncias iguais assumidas & 209 & 648 & ,716 & 87 & 476 & 255 &, 356 &,- 452 & 962 \\
\hline$\mu_{D P R}=3,73 \quad \mu_{A F R I C A}=3,47$ & Variâncias iguais não assumidas & & &, 743 & 30,065 &, 463 & ,255 &, 343 & -445 & ,955 \\
\hline AMÉRICA CENTRAL & Variâncias iguais assumidas & 288 &, 593 & 2,166 & 78 & 033 & 1,029 & 475 &, 083 & 1,974 \\
\hline$\mu_{\text {DPR }}=3,73 \mu_{\text {AMERICACENTRAL }}=2,70$ & Varâncias iguais não assumidas & & & 2,053 & 11,349 &, 064 & 1,029 &, 501 &,- 070 & 2,127 \\
\hline AMÉRICA DO NORTE & Variâncias iguais assumidas & 1,349 & 248 &,- 053 & 103 & 958 &,- 014 & 271 &,- 552 &, 523 \\
\hline$\mu_{\text {DPR }}=3,73 \quad \mu_{\text {AINORTE }}=3,74$ & Variâncias iguais não assumidas & & &,- 057 & 82,548 & 955 &,- 014 & ,252 &,- 516 & ,487 \\
\hline AMÉRICA DO SUL & Variâncias iguais assumidas & 047 & ,828 & 2,058 & 107 &, 042 &, 575 & 279 &, 021 & 1,128 \\
\hline$\mu_{D P R}=3,73 \quad \mu_{A M S U L}=3,15$ & Variâncias iguais não assumidas & & & 2,053 & 78,077 & 043 &, 575 & 280 &, 017 & 1,132 \\
\hline ÁSIA & Variâncias iguais assumidas & 1,357 & 246 & -217 & 127 & 829 &,- 051 & 236 &,- 518 &, 415 \\
\hline$\mu_{\mathrm{DPR}}=3,73 \mu_{\dot{A S I A}}=3,78$ & Variâncias iguais não assumidas & & & -219 & 126,336 & 827 &,- 051 & 234 &,- 514 &, 411 \\
\hline EUROPA & Variâncias iguais assumidas & 1,110 & ,294 & 2,021 & 152 &, 045 &, 479 & 237 & 011 & 947 \\
\hline$\mu_{D P R}=3,73 \quad \mu_{\text {EUROPA }}=3,25$ & Variâncias iguais não assumidas & & & 2,037 & 150,604 &, 043 &, 479 & 235 &, 014 &, 943 \\
\hline OCEANIA & Variâncias iguais assumidas & 2,374 & ,128 &,- 029 & 72 & ,977 &,- 021 & ,734 & $-1,484$ & 1,441 \\
\hline$\mu_{\text {DPR }}=3,73 \quad \mu_{\text {OCEANA }}=3,75$ & Variâncias iguais não assumidas & & &,- 021 & 3,158 & ,985 &,- 021 & 1,044 & $-3,252$ & 3,209 \\
\hline
\end{tabular}


$\mathrm{Na}$ dimensão prestígio, o teste de médias para verificar diferenças nas percepções dos colaboradores do DPR e dos SECOMs obteve como resultado a diferença entre as duas amostras. Ao se fazer o mesmo teste seccionado por continente, observouse que os colaboradores dos SECOMs do continente africano têm uma percepção diferente desta dimensão em relação aos colaboradores do DPR (teste de Levene $0,084$ ( $p$-value $>0,05)$ e $t=3,34$ e $p$-valor $=0,001(p$-value $<0,05))$. Já os respondentes dos SECOMs localizados nos demais continentes (América Central, América do Norte, América do Sul, Ásia, Europa e Oceania) têm a mesma percepção que os respondentes do DPR.

Tabela 44 - Teste de amostras independentes para os valores do DPR e dos SECOMs por continente - Prestígio

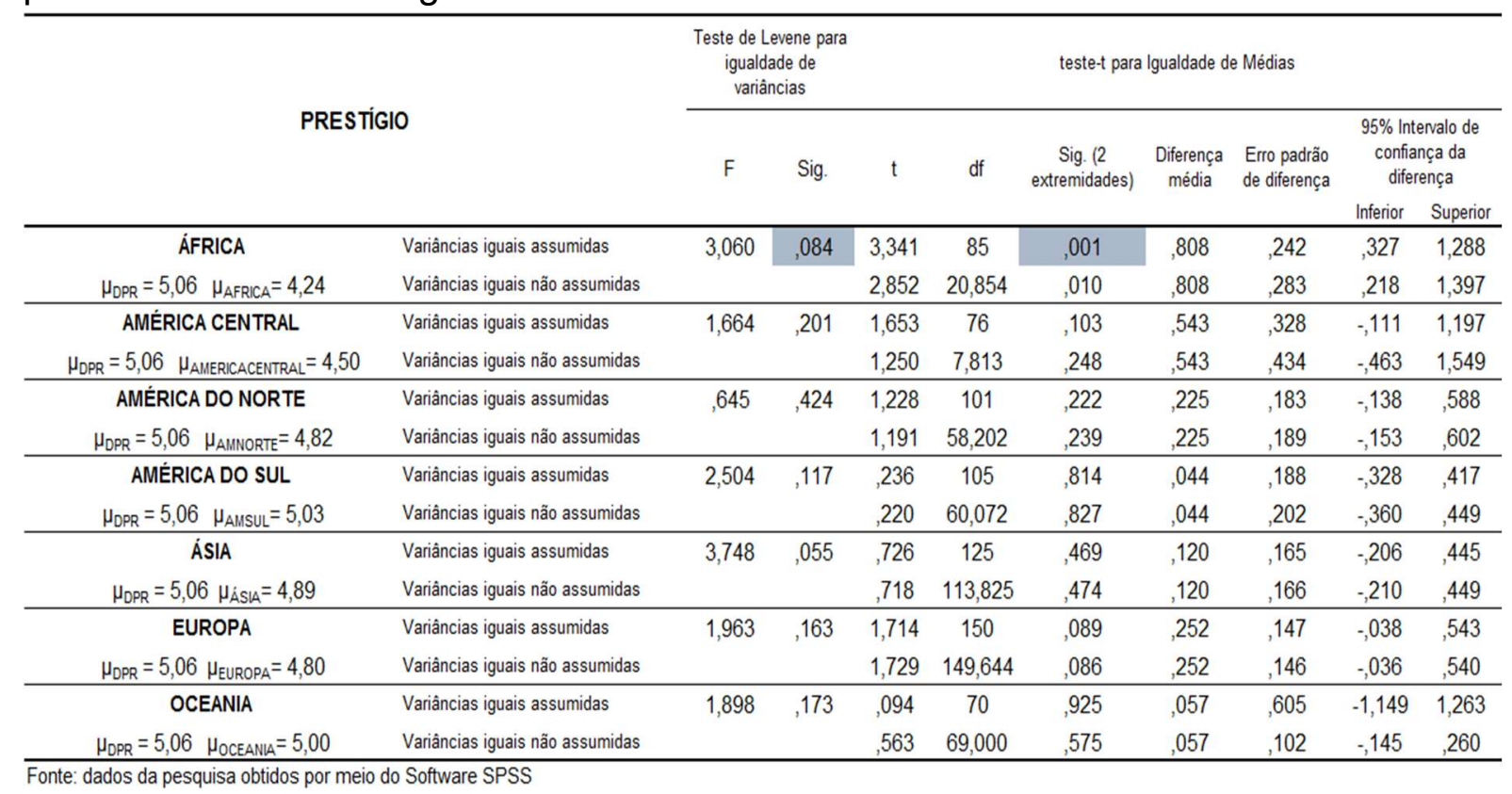

Ao analisar se há diferenças nas percepções dos valores organizacionais do DPR e dos SECOMs, a dimensão conformidade foi identificada como igual, ou seja, não há divergência na percepção dos colaboradores do DPR e dos SECOMs. E este mesmo resultado foi encontrado ao realizar o teste-t entre o DPR e os SECOMs por continente, conforme apresentado na tabela 45. 
Tabela 45 - Teste de amostras independentes para os valores do DPR e dos SECOMs por continente - Conformidade

\begin{tabular}{|c|c|c|c|c|c|c|c|c|c|c|}
\hline \multirow{3}{*}{\multicolumn{2}{|c|}{ CONFORMIDADE }} & \multicolumn{3}{|c|}{$\begin{array}{c}\text { Teste de Levene } \\
\text { para igualdade de } \\
\text { variâncias }\end{array}$} & \multicolumn{6}{|c|}{ teste-t para Igualdade de Médias } \\
\hline & & \multirow[t]{2}{*}{$\mathrm{F}$} & \multirow[t]{2}{*}{ Sig. } & \multirow[t]{2}{*}{$\mathrm{t}$} & \multirow[t]{2}{*}{ df } & \multirow[t]{2}{*}{$\begin{array}{c}\text { Sig. (2 } \\
\text { extremidades) }\end{array}$} & \multirow[t]{2}{*}{$\begin{array}{l}\text { Diferençaa } \\
\text { média }\end{array}$} & \multirow[t]{2}{*}{$\begin{array}{l}\text { Erro padrão } \\
\text { de diferença }\end{array}$} & \multicolumn{2}{|c|}{$\begin{array}{l}95 \% \text { Intervalo de } \\
\text { confiança da } \\
\text { diferença }\end{array}$} \\
\hline & & & & & & & & & Inferior & Superior \\
\hline ÁFRICA & Variâncias iguais assumidas & 2,283 & 134 & 1,023 & 87 & ,309 & , 195 & ,191 &,- 185 &, 575 \\
\hline$\mu_{\mathrm{DPR}}=5,14 \quad \mu_{\mathrm{AFRICA}}=4,95$ & Variâncias iguais não assumidas & & & 1,154 & 34,428 &, 257 &, 195 &, 169 &,- 149 &, 540 \\
\hline AMÉRICA CENTRAL & Variâncias iguais assumidas & 1,691 &, 197 & 1,594 & 78 &, 115 & 443 & 278 &,- 110 &, 996 \\
\hline$\mu_{\text {DPR }}=5,14 \quad \mu_{\text {AMERICACENTRAL }}=4,70$ & Variâncias iguais não assumidas & & & 1,172 & 10,155 &, 268 &, 443 & ,378 &,- 398 & 1,283 \\
\hline AMÉRICA DO NORTE & Variâncias iguais assumidas & 3,010 &, 086 &, 384 & 103 &, 702 &, 057 & ,149 &,- 238 &, 353 \\
\hline$\mu_{\text {DPR }}=5,14 \quad \mu_{\text {AMNORTE }}=5,09$ & Variâncias iguais não assumidas & & &, 413 & 83,074 & 680 &, 057 &, 138 &,- 218 &, 332 \\
\hline AMÉRICA DO SUL & Variâncias iguais assumidas & ,299 &, 585 &, 099 & 107 &, 921 &, 015 & ,148 &,- 279 &, 309 \\
\hline$\mu_{\text {DPR }}=5,146 \quad \mu_{\text {AMSUL }}=5,13$ & Variâncias iguais não assumidas & & &, 102 & 85,384 & ,919 &, 015 &, 144 &,- 272 & 301 \\
\hline ÁsIA & Variâncias iguais assumidas &, 427 &, 515 & 1,289 & 127 &, 200 &, 177 &, 137 &,- 095 &, 448 \\
\hline$\mu_{\mathrm{DPR}}=5,14 \quad \mu_{\dot{A} S \mathrm{~A}}=4,97$ & Variâncias iguais não assumidas & & & 1,286 & 122,186 & 201 &, 177 &, 137 &,- 095 &, 449 \\
\hline EUROPA & Variâncias iguais assumidas & 2,081 & ,151 &, 704 & 152 &, 482 &, 083 & ,118 &,- 150 &, 317 \\
\hline$\mu_{\mathrm{DPR}}=5,14 \quad \mu_{\mathrm{EUROPA}}=5,06$ & Variâncias iguais não assumidas & & &, 698 & 141,443 &, 486 &, 083 & ,119 &,- 153 &, 319 \\
\hline OCEANIA & Variâncias iguais assumidas &, 121 &, 729 &, 361 & 72 &, 719 &, 143 &, 395 &,- 645 &, 931 \\
\hline$\mu_{\mathrm{DPR}}=5,14 \quad \mu_{\text {OCEANAA }}=5,00$ & Variâncias iguais não assumidas & & &, 341 & 3,310 &, 753 &, 143 &, 418 & $-1,121$ & 1,407 \\
\hline
\end{tabular}

A dimensão tradição foi percebida como igual entre o DPR e os SECOMs. Este resultado permaneceu inalterado após a realização do teste dos SECOMs por continentes, ou seja, a dimensão tradição é percebida da mesma forma tanto para os colaboradores do DPR quanto para os dos SECOMs, mesmo quando analisada por continente, conforme pode ser visto na tabela 46 .

Tabela 46 - Teste de amostras independentes para os valores do DPR e dos SECOMs por continente - Tradição

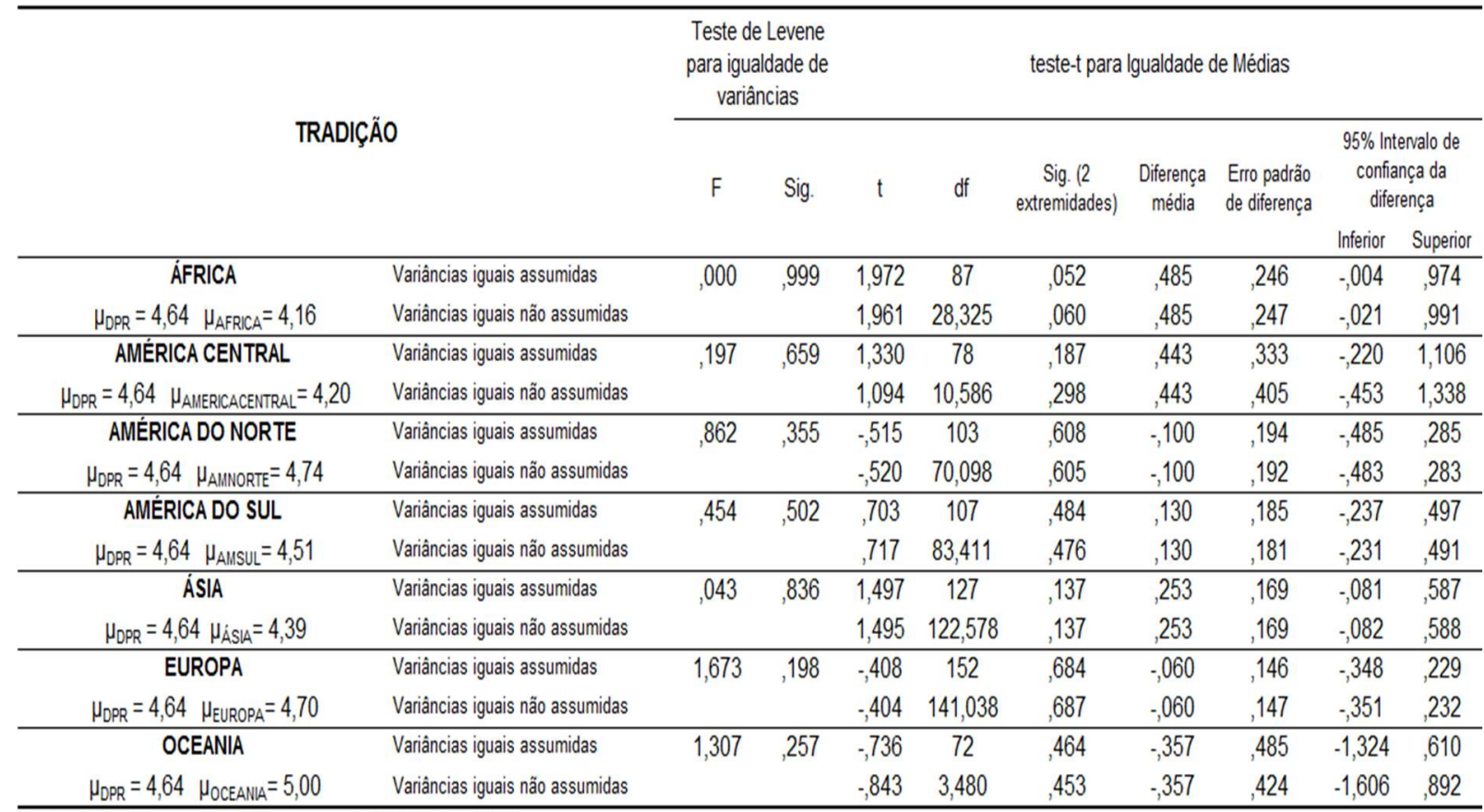

Fonte: dados da pesquisa obtidos por meio do Software SPSS 
No item 5.4.4.1.1, a dimensão domínio apresentou como resultado a diferenciação nas percepções entre o DPR e os SECOMs. Os colaboradores dos SECOMs localizados nos continentes da América do Norte (teste de Levene 0,043 ( $p$-value < $0,05)$ e $\mathrm{t}=-3,890$ e $\mathrm{p}$-valor $=0,005(p$-value $<0,05)$ e intervalo de confiança não contém o zero [-1,350; -0,250]), da América do Sul (teste de Levene 0,001 ( $p$-value < $0,05)$ e $\mathrm{t}=-3,964$ e $\mathrm{p}$-valor $=0,000(p$-value $<0,05)$ e intervalo de confiança não contém o zero [-1,3429; -0,476]), da Ásia (teste de Levene 0,001 ( $p$-value < 0,05) e t $=-2,656$ e $p$-valor $=0,009(p$-value $<0,05)$ e intervalo de confiança não contém o zero $[-1,090 ;-0,159])$ e da Europa (teste de Levene 0,012 ( $p$-value < 0,05) e t = -2,618 e pvalor $=0,010(p$-value < 0,05) e intervalo de confiança não contém o zero [-1,066; $0,148]$ ) diferem quanto à percepção dessa dimensão em relação aos colaboradores do DPR. Os SECOMs dos continentes da África, da América Central e da Oceania têm percepções iguais à do DPR.

Tabela 47 - Teste de amostras independentes para os valores do DPR e dos SECOMs por continente - Domínio

\begin{tabular}{|c|c|c|c|c|c|c|c|c|c|c|}
\hline \multirow{3}{*}{ DOMiNI } & & \multicolumn{2}{|c|}{$\begin{array}{c}\text { Teste de Levene } \\
\text { para igualdade de } \\
\text { variâncias }\end{array}$} & \multicolumn{7}{|c|}{ teste-t para Igualdade de Médias } \\
\hline & & \multirow[t]{2}{*}{$\mathrm{F}$} & \multirow[t]{2}{*}{ Sig. } & \multirow[t]{2}{*}{$\mathrm{t}$} & \multirow[t]{2}{*}{ df } & \multirow[t]{2}{*}{$\begin{array}{c}\text { Sig. (2 } \\
\text { extremidades) }\end{array}$} & \multirow[t]{2}{*}{$\begin{array}{l}\text { Diferençaa } \\
\text { média }\end{array}$} & \multirow[t]{2}{*}{$\begin{array}{l}\text { Erro padrão } \\
\text { de diferença }\end{array}$} & \multicolumn{2}{|c|}{$\begin{array}{c}95 \% \text { Intervalo de } \\
\text { confiança da } \\
\text { diferença }\end{array}$} \\
\hline & & & & & & & & & Inferior & Superior \\
\hline ÁFRICA & Variâncias iguais assumidas & 3,801 & .054 & $-1,273$ & 87 & 206 &,- 496 & 390 & $-1,271$ & 278 \\
\hline$\mu_{\text {DPR }}=3,71 \quad \mu_{\text {AFRICA }}=4,21$ & Variâncias iguais näo assumidas & & & $-1,501$ & 37,395 & ,142 &,- 496 & ,331 & $-1,166$ &, 173 \\
\hline AMÉRICA CENTRAL & Variâncias iguais assumidas & 1,125 & ,292 & 1,367 & 78 & ,175 &, 714 &, 522 &,- 326 & 1,754 \\
\hline$\mu_{\text {DPR }}=3,71 \quad \mu_{\text {AMERICACENTRAL }}=3,00$ & Variâncias iguais não assumidas & & & 1,633 & 13,508 & ,125 & ,714 &, 437 &,- 227 & 1,655 \\
\hline AMÉRICA DO NORTE & Variâncias iguais assumidas & 4,217 &, 043 & $-2,638$ & 103 & 010 &,- 800 & ,303 & $-1,401$ &,- 199 \\
\hline$\mu_{\mathrm{DPR}}=3,71 \quad \mu_{\text {AMNORTE }}=4,51$ & Variâncias iguais não assumidas & & & $-2,890$ & 86,629 &, 005 &,- 800 & 277 & $-1,350$ &,- 250 \\
\hline AMÉRICA DO SUL & Variâncias iguais assumidas & 12,368 &, 001 & $-3,444$ & 107 &, 001 &,- 952 &, 277 & $-1,501$ &,- 404 \\
\hline$\mu_{\mathrm{DPR}}=3,71 \quad \mu_{\text {AMSUL }}=4,67$ & Variâncias iguais não assumidas & & & $-3,964$ & 106,666 &, 000 &,- 952 & ,240 & $-1,429$ &,- 476 \\
\hline ÁSIA & Variâncias iguais assumidas & 11,182 & 001 & $-2,574$ & 127 & 011 &,- 625 & ,243 & $-1,105$ &,- 144 \\
\hline$\mu_{\mathrm{DPR}}=3,71 \mu_{\text {ASSAA }}=4,34$ & Variâncias iguais não assumidas & & & $-2,656$ & 121,931 &, 009 &,- 625 & ,235 & $-1,090$ &,- 159 \\
\hline EUROPA & Variâncias iguais assumidas & 6,516 & 012 & $-2,677$ & 152 & 008 &,- 607 & ,227 & $-1,055$ &,- 159 \\
\hline$\mu_{\mathrm{DPR}}=3,71 \mu_{\mathrm{EUROPA}}=4,32$ & Variâncias iguais não assumidas & & & $-2,618$ & 129,189 &, 010 &,- 607 & ,232 & $-1,066$ &,- 148 \\
\hline OCEANIA & Variâncias iguais assumidas & 2,435 & 123 & 257 & 72 & ,798 & 214 & 834 & $-1,447$ & 1,876 \\
\hline$\mu_{\text {DPR }}=3,71 \quad \mu_{\text {OCEANIA }}=3,50$ & Variâncias iguais não assumidas & & &, 178 & 3,153 & 870 & ,214 & 1,205 & $-3,518$ & 3,946 \\
\hline
\end{tabular}

\subsubsection{Diferenças entre os tipos de práticas organizacionais identificadas no DPR e nos SECOMs}

Quanto ao tipo de práticas instrumentais, a média do DPR foi de 3,50 e dos SECOMS de 4,00. O teste de Levene 0,598 ( $p$-value > 0,05) e $t=-4,694$ e $p$-valor $=0,000(p$ value $<0,05)$, isto significa que há diferença entre as médias e que a prática de cunho 
instrumental é mais reconhecida nos SECOMs do que no DPR, como pode ser visto na tabela 48.

Tabela 48 - Teste de amostras independentes para os tipos de práticas instrumentais no DPR e SECOMs

\begin{tabular}{|c|c|c|c|c|c|c|c|c|c|c|}
\hline \multirow{3}{*}{\multicolumn{2}{|c|}{ Tipo de prática Instrumental }} & \multicolumn{3}{|c|}{$\begin{array}{c}\text { Teste de Levene } \\
\text { para igualdade de } \\
\text { variâncias } \\
\end{array}$} & \multicolumn{4}{|c|}{ teste-t para Igualdade de Médias } & \multirow{2}{*}{\multicolumn{2}{|c|}{$\begin{array}{c}95 \% \text { Intervalo de } \\
\text { confiança da } \\
\text { diferença }\end{array}$}} \\
\hline & & \multirow[t]{2}{*}{$\mathrm{F}$} & \multirow[t]{2}{*}{ Sig. } & \multirow[t]{2}{*}{$\mathrm{t}$} & \multirow[t]{2}{*}{ df } & \multirow[t]{2}{*}{$\begin{array}{c}\text { Sig. } \\
\text { (2 extremidades) }\end{array}$} & \multirow[t]{2}{*}{$\begin{array}{l}\text { Diferença } \\
\text { média }\end{array}$} & \multirow[t]{2}{*}{$\begin{array}{c}\text { Erro } \\
\text { padrão de } \\
\text { diferença }\end{array}$} & & \\
\hline & & & & & & & & & Inferior & Superior \\
\hline \multirow{2}{*}{ INST_SEC_DPR } & Variâncias iguais assumidas & 278 &, 598 & $-4,694$ & 318 &, 000 &,- 504 &, 107 &,- 715 &,- 293 \\
\hline & Variâncias iguais não assumidas & & & $-6,221$ & 191,463 &, 000 &,- 504 &, 081 &,- 664 &,- 344 \\
\hline
\end{tabular}

Fonte: dados da pesquisa obtidos por meio do Software SPSS

No que se refere às práticas caracterizadas como humanistas, a média do DPR foi de 3,51 e dos SECOMs de 3,46. O teste de Levene 0,000 ( $p$-value < 0,05) e $\mathrm{t}=0,648$ e p-valor $=0,518$ ( $p$-value $>0,05)$, e o intervalo de confiança contém o zero (IC $[-, 111$; $0,220]$ ), isto significa que não existe diferença entre as médias dos dois grupos e, no que se refere às práticas de cunho humanista, o DPR e os SECOMs têm a mesma percepção, como pode ser visto na tabela 49.

Tabela 49 - Teste de amostras independentes para os tipos de práticas humanistas no DPR e SECOMs

\begin{tabular}{|c|c|c|c|c|c|c|c|c|c|c|}
\hline \multirow{3}{*}{\multicolumn{2}{|c|}{ Tipo de prática Humanista }} & \multicolumn{3}{|c|}{$\begin{array}{c}\text { Teste de Levene } \\
\text { para igualdade de } \\
\text { variâncias }\end{array}$} & \multicolumn{4}{|c|}{ teste-t para Igualdade de Médias } & \multirow{2}{*}{\multicolumn{2}{|c|}{$\begin{array}{c}95 \% \text { Intervalo de } \\
\text { confiança da } \\
\text { diferença }\end{array}$}} \\
\hline & & \multirow[t]{2}{*}{$\mathrm{F}$} & \multirow[t]{2}{*}{ Sig. } & \multirow[t]{2}{*}{$\mathrm{t}$} & \multirow[t]{2}{*}{ df } & \multirow[t]{2}{*}{$\begin{array}{c}\text { Sig. } \\
\text { (2 extremidades) }\end{array}$} & \multirow[t]{2}{*}{$\begin{array}{l}\text { Diferença } \\
\text { média }\end{array}$} & \multirow[t]{2}{*}{$\begin{array}{l}\text { Erro } \\
\text { padrão de } \\
\text { diferença }\end{array}$} & & \\
\hline & & & & & & & & & Inferior & Superior \\
\hline \multirow{2}{*}{ HUMAN_SEC_DPR } & Variâncias iguais assumidas & 17,490 &, 000 & 472 & 318 &, 637 &, 054 & 115 &,- 172 &, 280 \\
\hline & Variâncias iguais não assumidas & & & 648 & 208,758 &, 518 &, 054 & 084 &,- 111 & 220 \\
\hline
\end{tabular}

Para fins de sumarização, os seguintes resultados foram encontrados:

Quadro 34 - Resultado dos testes de amostras independentes para as dimensões do DPR e dos SECOMs

\begin{tabular}{|c|c|c|c|}
\hline $\begin{array}{c}\text { Dimensões } \\
\text { Práticas }\end{array}$ & Teste Levene & Teste t & Percepções do DPR e dos SECOMs \\
\hline Instrumental & $p>0,05$ & $p<0,05$ & Diferentes \\
\hline Humanista & $p<0,05$ & $p>0,05$ & Iguais \\
\hline
\end{tabular}

Fonte: elaborado pela autora 


\subsection{Diferenças entre os tipos de práticas organizacionais identificadas no DPR e nos continentes onde os SECOMs estão localizados}

Em decorrência da análise das diferenças entre os tipos de práticas entre o DPR e os SECOMs, foi verificado se há diferenças na percepção dos tipos de práticas organizacionais entre o DPR e os SECOMs localizados nos continentes.

\subsubsection{1(a) Práticas Instrumentais}

Como pode ser visto na tabela 50, o DPR obteve média de 3,50 e os SECOMs localizados no continente africano 4,25. O teste de Levene 0,001 (p-value < 0,05) e t $=-3,301$ e $p$-valor $=0,034(p$-value $<0,05)$, e o intervalo de confiança não contém o zero (IC [-1,059; -0,0406]) isto significa que há diferença entre as médias e que o tipo de prática instrumental é mais reconhecido nos SECOMs da África do que no DPR.

Tabela 50 - Teste de amostras independentes para os tipos de práticas instrumentais no DPR e SECOMs localizados nos continentes

\begin{tabular}{|c|c|c|c|c|c|c|c|c|c|c|}
\hline \multirow{3}{*}{ INSTRUME } & \multirow{3}{*}{ ITAL } & \multicolumn{4}{|c|}{$\begin{array}{l}\text { Teste de Levene para } \\
\text { igualdade de } \\
\text { variâncias }\end{array}$} & \multicolumn{3}{|c|}{ teste-t para Igualdade de Médias } & \multirow{2}{*}{\multicolumn{2}{|c|}{$\begin{array}{c}95 \% \text { Intervalo de } \\
\text { confiança da } \\
\text { diferença }\end{array}$}} \\
\hline & & \multirow[t]{2}{*}{$\mathrm{F}$} & \multirow[t]{2}{*}{ Sig. } & \multirow[t]{2}{*}{$\mathrm{t}$} & \multirow[t]{2}{*}{ df } & \multirow[t]{2}{*}{$\begin{array}{c}\text { Sig. (2 } \\
\text { extremidades) }\end{array}$} & \multirow[t]{2}{*}{$\begin{array}{l}\text { Diferença } \\
\text { média }\end{array}$} & \multirow[t]{2}{*}{$\begin{array}{l}\text { Erro padrão } \\
\text { de diferençça }\end{array}$} & & \\
\hline & & & & & & & & & Inferior & Superior \\
\hline ÁFRICA & Variâncias iguais assumidas & 5,264 & 024 & $-3,301$ & 87 & 001 &,- 553 & , 167 &,- 885 &,- 220 \\
\hline$\mu_{\mathrm{DPR}}=3,50 \quad \mu_{\mathrm{AFRICA}}=4,25$ & Variâncias iguais não assumidas & & & $-2,275$ & 20,409 &, 034 &,- 553 & ,243 & $-1,059$ &,- 046 \\
\hline AMÉRICA CENTRAL & Variâncias iguais assumidas & 13,000 & 001 & $-4,721$ & 78 &, 000 &,- 800 &, 169 & $-1,137$ &,- 463 \\
\hline$\mu_{\mathrm{DPR}}=3,50 \mu_{\text {AMÉRICACENTRAL }}=4,30$ & Variâncias iguais não assumidas & & & $-4,873$ & 11,974 &, 000 &,- 800 & 164 & $-1,158$ &,- 442 \\
\hline AMÉRICA DO NORTE & Variâncias iguais assumidas & ,164 & 686 & $-4,643$ & 103 & 000 &,- 586 &, 126 &,- 836 &,- 336 \\
\hline$\mu_{\mathrm{DPR}}=3,50 \quad \mu_{\text {AMÉRICANORTE }}=4,19$ & Variâncias iguais não assumidas & & & $-4,037$ & 48,569 &, 000 &,- 586 &, 145 &,- 877 &,- 294 \\
\hline AMÉRICA DO SUL & Variâncias iguais assumidas & 1,148 & 286 & $-9,309$ & 107 &, 000 &,- 936 &, 101 & $-1,135$ &,- 737 \\
\hline$\mu_{\mathrm{DPR}}=3,50 \quad \mu_{\text {AMÉRICASUL }}=4,44$ & Variâncias iguais não assumidas & & & $-9,315$ & 78,853 &, 000 &,- 936 &, 100 & $-1,136$ &,- 736 \\
\hline ÁSIA & Variâncias iguais assumidas & 6,376 &, 013 & $-6,208$ & 127 & 000 &,- 585 &, 094 &,- 771 &,- 398 \\
\hline$\mu_{\mathrm{DPR}}=3,50 \quad \mu_{\hat{A} \mathrm{SA}}=4,18$ & Variâncias iguais não assumidas & & & $-6,146$ & 117,327 &, 000 &,- 585 &, 095 &,- 773 &,- 396 \\
\hline EUROPA & Variâncias iguais assumidas & 22,465 &, 000 & $-1,199$ & 152 & 232 &,- 167 & ,139 &,- 441 &, 108 \\
\hline$\mu_{\mathrm{DPR}}=3,50 \quad \mu_{\mathrm{EUROPA}}=3,67$ & Variâncias iguais não assumidas & & & $-1,271$ & 122,696 & ,206 &,- 167 &, 131 &,- 426 & 093 \\
\hline OCEANIA & Variâncias iguais assumidas & 0,000 & 1,000 & $-1,869$ & 72 &, 066 &,- 500 & ,268 & $-1,033$ & ,033 \\
\hline$\mu_{\text {DPR }}=3,50 \quad \mu_{\text {OCEANAA }}=3,98$ & Variâncias iguais não assumidas & & & $-1,212$ & 3,132 &, 309 &,- 500 &, 413 & $-1,783$ & ,783 \\
\hline
\end{tabular}

Os SECOMs da América Central obtiveram média 4,30. O teste de Levene 0,001 ( $p$ value $<0,05)$ e $t=-4,721$ e $p$-valor $=0,000$ ( $p$-value $<0,05)$, e o intervalo de confiança não contém o zero (IC [-1,158; -0,442]). Isto significa que há diferença entre as médias e que o tipo de prática instrumental é mais reconhecido nos SECOMs da América Central do que no DPR.

Os SECOMs da América do Norte obtiveram média 4,19. O teste de Levene 0,686 ( $p$ value $>0,05)$ e $t=-4,642$ e $p$-valor $=0,000(p$-value $<0,05)$, com isso verifica-se que 
há diferença entre as médias e que o tipo de prática instrumental é mais reconhecido nos SECOMs da América do Norte do que no DPR. Semelhantemente, os SECOMs localizados na América do Sul com média 4,44 apresentaram pelo teste de médias, diferenças em relação ao DPR, pois o resultado do teste de Levene 0,286 ( $p$-value > $0,05)$ e $\mathrm{t}=-9,309$ e $\mathrm{p}$-valor $=0,000(p$-value $<0,05)$.

Os SECOMs da Ásia, com média 4,18 tiveram como resultado no teste de médias, teste de Levene 0,013 ( $p$-value $<0,05), t=-6,208$ e $p$-valor $=0,000$ ( $p$-value $<0,05)$, e o intervalo de confiança não contém o zero (IC [-,773; -0,396]). Com esse resultado, verifica-se que há diferença entre as médias e que o tipo de prática instrumental é mais reconhecido nos SECOMs da Ásia do que no DPR.

Já os SECOMs localizados na Europa e na Oceania apresentaram resultados semelhantes ao do DPR, visto que o teste de médias no que se refere às práticas de cunho instrumental têm a mesma percepção do DPR.

\subsubsection{1(b) Práticas Humanistas}

Tabela 51 - Teste de amostras independentes para os tipos de práticas humanistas no DPR e SECOMs localizados nos continentes

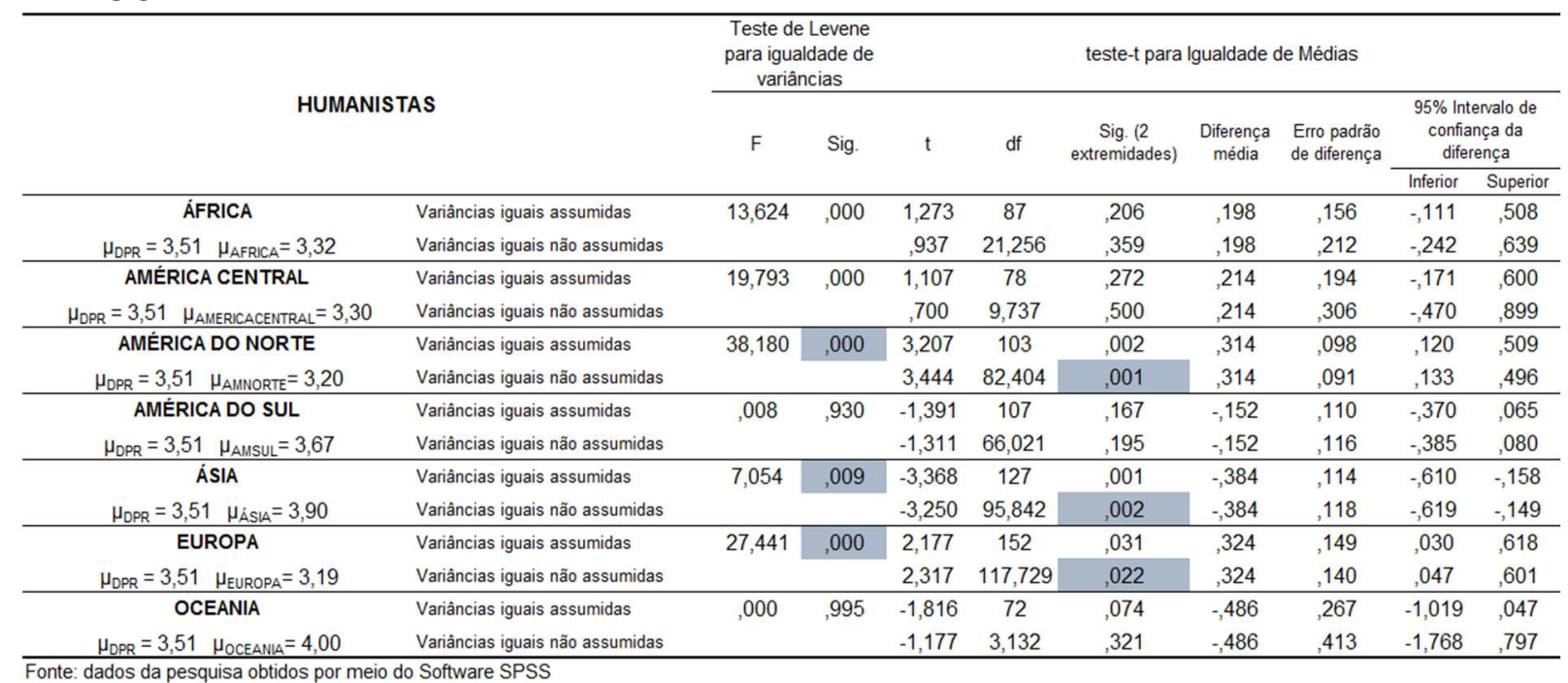

Os SECOMs localizados nos continentes da América do Norte, América do Sul, Ásia e Europa têm percepções diferentes quanto às práticas humanistas, como pode ser visto na tabela 50. Nos SECOMs da América do Norte $(\mu=3,20)$ e Europa $(\mu=3,19)$, o tipo de prática humanista é menos reconhecido do que no DPR e nos SECOMs da Ásia $(\mu=3,90)$ é mais reconhecido do que no DPR $(\mu=3,51)$. África, América Central, América do Sul e Oceania não diferem quanto às práticas de cunho humanista com o DPR, tendo, assim, a mesma percepção. 


\subsubsection{Análises bivariadas entre variáveis sociodemográficas dos SECOMs e Valores - Teste $\mathbf{t}$}

Em decorrência da identificação de algumas divergências quanto às percepções dos valores organizacionais entre o DPR e SECOMs, passou-se a verificar se os valores nos SECOMs divergem ou não quanto às variáveis sociodemográficas.

\subsubsection{Diferenças na percepção dos valores na organização local (SECOMs) em função do tempo de serviço}

Foi realizado o teste-t de amostras independentes para verificar diferenças nos SECOMs entre a percepção dos valores organizacionais e o tempo de serviço e verificar se colaboradores com menos tempo de casa têm percepções diferentes de valores organizacionais dos colaboradores mais antigos.

Ao testar esta hipótese, primeiramente foi feito corte entre colaboradores com até 1 ano de serviço e colaboradores até 5 anos de tempo de casa - Tabela 51 . Os resultados apresentaram não haver diferença entre as médias, de sorte que não se pode rejeitar a hipótese nula. Ou seja, até 5 anos de tempo de casa, todos têm a mesma percepção quanto aos valores organizacionais; e o comparativo com os valores do DPR ficou como o apresentado na tabela 52.

Tabela 52 - Teste de amostras independentes - Valores e tempo de serviço até 1 ano e até 5 anos de casa

\begin{tabular}{|c|c|c|c|c|c|c|c|c|c|c|}
\hline \multirow{3}{*}{ VALOR } & & \multicolumn{2}{|c|}{$\begin{array}{c}\text { Teste de Levene } \\
\text { para igualdade de } \\
\text { variâncias }\end{array}$} & \multicolumn{7}{|c|}{ teste-t para Igualdade de Médias } \\
\hline & & \multirow[t]{2}{*}{$\mathrm{F}$} & \multirow[t]{2}{*}{ Sig. } & \multirow[t]{2}{*}{$\mathrm{t}$} & \multirow[t]{2}{*}{ df } & \multirow[t]{2}{*}{$\begin{array}{l}\text { Sig. (2 } \\
\text { extremidades) }\end{array}$} & \multirow[t]{2}{*}{$\begin{array}{l}\text { Diferença } \\
\text { média }\end{array}$} & \multirow[t]{2}{*}{$\begin{array}{l}\text { Erro padrão } \\
\text { de diferença }\end{array}$} & \multicolumn{2}{|c|}{$\begin{array}{l}95 \% \text { Intervalo de } \\
\text { confiança da } \\
\text { diferença }\end{array}$} \\
\hline & & & & & & & & & Inferior & Superior \\
\hline AUTONOMIA & Variâncias iguais assumidas & ,376 &, 541 & 544 & 130 & ,588 & 120 & ,222 &,- 318 &, 559 \\
\hline$\mu_{\text {Menos1ANO }}=4,00 \quad \mu_{\text {ATÉSANOS }}=3,88$ & Variâncias iguais não assumidas & & &, 548 & 103,224 &, 585 &, 120 & ,220 &,- 316 &, 557 \\
\hline COLETIVIDADE & Variâncias iguais assumidas & 019 & ,891 & 736 & 130 & ,463 & ,163 & ,221 &,- 275 & 600 \\
\hline$\mu_{\text {MenOS1ANO }}=4,63 \quad \mu_{\text {ATÉSANOS }}=4,47$ & Variâncias iguais não assumidas & & &, 722 & 94,821 &, 472 & , 163 & ,226 &,- 285 & 611 \\
\hline REALIZAÇÃO & Variâncias iguais assumidas & 005 & ,941 & 1,456 & 130 & ,148 & ,309 & ,212 &,- 111 & ,729 \\
\hline$\mu_{\text {Menos } 1 \text { ANO }}=4,49 \mu_{\text {ATÉSANOS }}=4,18$ & Variâncias iguais não assumidas & & & 1,449 & 99,310 &, 151 &, 309 &, 213 &,- 114 &, 732 \\
\hline BEM-ESTAR & Variâncias iguais assumidas & 149 & ,700 & 1,425 & 130 & 157 & ,339 & ,238 &,- 132 & 810 \\
\hline$\mu_{\text {Menos1ANO }}=3,86 \mu_{\text {ATÉSANOS }}=3,52$ & Variâncias iguais não assumidas & & & 1,410 & 97,589 & ,162 & ,339 &, 240 &,- 138 & ,816 \\
\hline TRADIÇĀO & Variâncias iguais assumidas & ,740 & ,391 & 133 & 130 & ,894 & , 023 & ,171 &,- 316 & 362 \\
\hline$\mu_{\text {Menos1ANO }}=4,67 \quad \mu_{\text {ATÉSANOS }}=4,65$ & Variâncias iguais não assumidas & & &, 135 & 104,861 & 893 &, 023 & 169 &,- 313 &, 358 \\
\hline PRESTÍGIO & Variâncias iguais assumidas & ,249 & 619 & 1,263 & 130 & ,209 & ,235 & ,186 & -133 & 604 \\
\hline$\mu_{\text {Menos1ANO }}=4,90 \quad \mu_{\text {ATÉEANOS }}=4,66$ & Variâncias iguais não assumidas & & & 1,247 & 96,961 & ,215 & ,235 &, 189 &,- 139 & 610 \\
\hline CONFORMIDADE & Variâncias iguais assumidas & 1,233 & ,269 & 738 & 130 & ,462 & ,098 & ,133 &,- 165 & 362 \\
\hline$\mu_{\text {Menos1ANo }}=5,12 \mu_{\text {AtÉSANOS }}=5,02$ & Variâncias iguais não assumidas & & &, 710 & 89,533 &, 479 & 098 & ,138 &,- 177 &, 373 \\
\hline DOMiNIO & Variâncias iguais assumidas & 1,692 & , 196 &,- 797 & 130 &, 427 &,- 174 & ,219 &,- 606 & ,258 \\
\hline$\mu_{\text {Menos1ANO }}=4,16 \mu_{\text {ATÉSANOS }}=4,34$ & Variâncias iguais não assumidas & & &,- 746 & 81,839 &, 458 &,- 174 & ,233 &,- 638 &, 290 \\
\hline
\end{tabular}


Em seguida, outro corte foi realizado: entre colaboradores com até 5 anos de serviço no SECOM e acima de 5 anos de serviço. Algumas divergências foram encontradas nas dimensões destes dois grupos, como pode ser visto na tabela 53.

Realização, bem-estar e tradição são dimensões mais reconhecidas entre os que têm até 5 anos de tempo de serviço na organização do que entre os que têm acima de 5 anos de casa. A média da dimensão tradição no DPR foi de 4,64 e dos colaboradores dos SECOMs com até 5 anos de tempo de serviço foi de 4,66. E a média da dimensão bem-estar no DPR foi de 3,73 e no grupo de até 5 anos de serviço foi de 3,64, ou seja, média mais próxima à média do DPR do que a média daqueles que têm acima de cinco anos de casa que foi de 3,20. A dimensão realização obteve média de 4,54 no DPR e 4,30 no grupo dos colaboradores com até cinco anos de casa, que é mais próxima à média do DPR do que a média daqueles que têm acima de 5 anos de casa: 3,98 .

Tabela 53- Teste de amostras independentes - Valores e tempo de serviço até 5 anos e acima de 5 anos de casa

\begin{tabular}{|c|c|c|c|c|c|c|c|c|c|c|}
\hline \multirow{3}{*}{ VALORES } & & \multicolumn{3}{|c|}{$\begin{array}{l}\text { Teste de Levene para } \\
\text { igualdade de } \\
\text { variâncias }\end{array}$} & \multicolumn{6}{|c|}{ teste-t para Igualdade de Médias } \\
\hline & & \multirow[t]{2}{*}{$\mathrm{F}$} & \multirow[t]{2}{*}{ Sig. } & \multirow[t]{2}{*}{$\mathrm{t}$} & \multirow[t]{2}{*}{$\mathrm{df}$} & \multirow[t]{2}{*}{$\begin{array}{c}\text { Sig. (2 } \\
\text { extremidades) }\end{array}$} & \multirow[t]{2}{*}{$\begin{array}{l}\text { Diferença } \\
\text { média }\end{array}$} & \multirow[t]{2}{*}{$\begin{array}{l}\text { Erro padrão } \\
\text { de diferença }\end{array}$} & \multicolumn{2}{|c|}{$\begin{array}{c}95 \% \text { Intervalo de } \\
\text { confiança da } \\
\text { diferença }\end{array}$} \\
\hline & & & & & & & & & Inferior & Superior \\
\hline AUTONOMIA & Variâncias iguais assumidas & 2,775 &, 097 & 1,739 & 247 &, 083 & ,283 & ,163 &,- 037 &, 604 \\
\hline$\mu_{\text {ATÉSANOS }}=3,92 \mu_{\text {ACIMASANOS }}=3,64$ & Variâncias iguais não assumidas & & & 1,730 & 236,578 &, 085 &, 283 &, 164 &,- 039 &, 606 \\
\hline COLETIVIDADE & Variâncias iguais assumidas & 1,403 &, 237 &, 980 & 247 &, 328 & 146 & 149 &,- 147 &, 438 \\
\hline$\mu_{\text {ATÉSANOS }}=4,53 \quad \mu_{\text {ACIMASANOS }}=4,38$ & Variâncias iguais não assumidas & & &, 986 & 246,925 & ,325 & ,146 & ,148 &,- 145 &, 437 \\
\hline REALIZAÇÄO & Variâncias iguais assumidas &, 069 &, 793 & 2,029 & 247 &, 044 & ,313 & 154 &, 009 & 616 \\
\hline$\mu_{\text {ATÉSANOS }}=4,30 \quad \mu_{\text {ACMIASANOS }}=3,98$ & Variâncias iguais não assumidas & & & 2,023 & 239,899 &, 044 &, 313 &, 155 &, 008 &, 617 \\
\hline BEM-ESTAR & Variâncias iguais assumidas & 1,269 &, 261 & 2,541 & 247 &, 012 &, 447 & 176 & ,101 &, 794 \\
\hline$\mu_{\text {ATESANOS }}=3,64 \mu_{\text {ACIMASANOS }}=3,20$ & Variâncias iguais não assumidas & & & 2,527 & 236,468 &, 012 &, 447 & 177 &, 099 &, 796 \\
\hline TRADIÇÄO & Variâncias iguais assumidas &, 000 & ,984 & 1,969 & 247 &, 050 & ,232 & 118 &, 000 &, 464 \\
\hline$\mu_{\text {ATÉSANOS }}=4,66 \quad \mu_{\text {ACIMASANOS }}=4,43$ & Variâncias iguais não assumidas & & & 1,974 & 245,688 &, 049 & ,232 &, 117 &, 001 &, 463 \\
\hline PRESTIGIO & Variâncias iguais assumidas &, 668 & 415 &,- 900 & 247 &, 369 &,- 113 &, 126 &,- 361 &, 135 \\
\hline$\mu_{\text {ATÉSANOS }}=4,75 \quad \mu_{\text {ACIMASANOS }}=4,86$ & Variâncias iguais não assumidas & & &,- 906 & 246,901 &, 366 &,- 113 &, 125 &,- 360 & ,133 \\
\hline CONFORMIDADE & Variâncias iguais assumidas &, 067 &, 796 &, 845 & 247 & ,399 &, 078 &, 092 &,- 103 & 259 \\
\hline$\mu_{\text {ATÉSANOS }}=5,06 \quad \mu_{\text {ACIMASANOS }}=4,98$ & Variâncias iguais não assumidas & & &, 847 & 245,546 & ,398 & 078 &, 092 &,- 103 &, 258 \\
\hline DOMINIO & Variâncias iguais assumidas & 189 &, 664 &,- 790 & 247 & 430 &,- 120 & 152 &,- 421 &, 180 \\
\hline$\mu_{\text {ATÉSANOS }}=4,27 \quad \mu_{\text {ACIMASANOS }}=4,39$ & Variâncias iguais não assumidas & & &,- 791 & 244,434 &, 430 &,- 120 & ,152 &,- 420 & 180 \\
\hline
\end{tabular}




\subsubsection{Diferenças na percepção dos valores na organização local (SECOMs) em função da nacionalidade}

Neste estudo, pretende-se verificar se há diferenças na percepção dos valores organizacionais dos SECOMs quanto à nacionalidade, para tanto realizou-se o teste de médias independente entre dois grupos: brasileiros (BR) e não brasileiros (NBR) que trabalham nas organizações locais. A partir dos resultados apresentados na tabela 54, autonomia, coletividade, realização, bem-estar e domínio não apresentam diferenças entre as médias, ou seja, tanto brasileiros como não brasileiros têm a mesma percepção. A dimensão tradição, com média de 4,76 para brasileiros e 4,21 para não brasileiros, teve como resultado no teste de Levene $0,090(p$-value $>0,05) \mathrm{e}$ $t=4,742$ e $p$-valor $=0,000(p$-value $<0,05)$, evidenciando que essa dimensão é mais reconhecida entre os brasileiros do que entre os não brasileiros.

Tabela 54 - Teste de amostras independentes - Valores e nacionalidade dos colaboradores nos SECOMs

\begin{tabular}{|c|c|c|c|c|c|c|c|c|c|c|}
\hline & & \multicolumn{3}{|c|}{$\begin{array}{c}\text { Teste de Levene } \\
\text { para igualdade de } \\
\text { variâncias }\end{array}$} & \multicolumn{6}{|c|}{ teste-t para lgualdade de Médias } \\
\hline & & \multirow[t]{2}{*}{$\mathrm{F}$} & \multirow[t]{2}{*}{ Sig. } & \multirow[t]{2}{*}{$\mathrm{t}$} & \multirow[t]{2}{*}{ df } & \multirow[t]{2}{*}{$\begin{array}{c}\text { Sig. (2 } \\
\text { extremidades) }\end{array}$} & \multirow[t]{2}{*}{$\begin{array}{l}\text { Diferença } \\
\text { média }\end{array}$} & \multirow[t]{2}{*}{$\begin{array}{l}\text { Erro padrão } \\
\text { de diferença }\end{array}$} & \multicolumn{2}{|c|}{$\begin{array}{l}95 \% \text { Intervalo de } \\
\text { confiança da } \\
\text { diferença }\end{array}$} \\
\hline & & & & & & & & & Inferior & Superior \\
\hline AUTONOMIA & Variâncias iguais assumidas & 1,557 & ,213 & ,302 & 248 & ,763 &, 050 &, 167 &,- 279 &, 380 \\
\hline$\mu_{B R}=3,82 \quad \mu_{N B R}=3,77$ & Variâncias iguais não assumidas & & &, 308 & 219,063 &, 759 &, 050 &, 164 &,- 273 &, 374 \\
\hline COLETIVIDADE & Variâncias iguais assumidas & ,321 & 572 & 606 & 248 &, 545 & ,092 & 152 &,- 207 & 390 \\
\hline$\mu_{B R}=4,50 \quad \mu_{N B R}=4,41$ & Variâncias iguais não assumidas & & &, 613 & 215,613 &, 540 &, 092 & , 150 & -203 &, 387 \\
\hline REALIZAÇÄO & Variâncias iguais assumidas & 2,603 & ,108 &, 732 & 248 & 465 &, 116 &, 158 &,- 196 &, 427 \\
\hline$\mu_{B R}=4,20 \quad \mu_{N B R}=4,08$ & Variâncias iguais não assumidas & & &, 748 & 221,619 & ,455 &, 116 & ,155 &,- 189 &, 421 \\
\hline BEM-ESTAR & Variâncias iguais assumidas &, 005 & ,945 &, 771 & 248 &, 441 &, 140 &, 181 &,- 217 &, 497 \\
\hline$\mu_{B R}=3,49 \quad \mu_{N B R}=3,35$ & Variâncias iguais não assumidas & & &, 768 & 204,479 & 443 &, 140 &, 182 &,- 219 &, 499 \\
\hline TRADIÇÄO & Variâncias iguais assumidas & 2,904 &, 090 & 4,742 & 248 &, 000 &, 549 &, 116 & 321 &, 777 \\
\hline$\mu_{B R}=4,76 \quad \mu_{N B R}=4,21$ & Variâncias iguais não assumidas & & & 4,586 & 183,904 &, 000 &, 549 &, 120 &, 313 & ,785 \\
\hline PRESTIGIO & Variâncias iguais assumidas & 6,555 &, 011 & 2,760 & 248 &, 006 &, 349 &, 126 & ,100 &, 598 \\
\hline$\mu_{B R}=4,94 \quad \mu_{N B R}=4,59$ & Variâncias iguais não assumidas & & & 2,673 & 184,712 &, 008 & ,349 &, 131 &, 091 & 607 \\
\hline CONFORMIDADE & Variâncias iguais assumidas & 3,039 & 083 & 2,668 & 248 &, 008 &, 247 &, 093 &, 065 &, 430 \\
\hline$\mu_{B R}=5,13 \quad \mu_{N B R}=4,88$ & Variâncias iguais não assumidas & & & 2,553 & 176,982 &, 012 &, 247 &, 097 &, 056 &, 439 \\
\hline DOMINIO & Variâncias iguais assumidas & 134 & ,715 & 1,686 & 248 &, 093 &, 261 & ,155 &,- 044 &, 565 \\
\hline$\mu_{B R}=4,43 \quad \mu_{N B R}=4,17$ & Variâncias iguais não assumidas & & & 1,669 & 200,152 &, 097 & ,261 &, 156 &,- 047 &, 569 \\
\hline
\end{tabular}

A dimensão prestígio com média de 4,94 para brasileiros e 4,59 para não brasileiros teve como resultado no teste de Levene 0,011 ( $p$-value $<0,05)$ e $t=2,760$ e $p$-valor $=$ $0,008$ ( $p$-value < 0,05), e o intervalo de confiança não contém o zero (IC $[0,091 ; 0,607])$ e com isso tem-se que essa dimensão é mais reconhecida entre os brasileiros do que os não brasileiros. E a dimensão conformidade obteve no teste de Levene 0,083 ( $p$ value $>0,05)$ e $t=2,668$ e $p$-valor $=0,008$ ( $p$-value $<0,05)$, de sorte que os brasileiros reconhecem mais esta dimensão do que os não brasileiros. 


\subsubsection{Diferenças na percepção dos valores na organização local (SECOMs) em função do sexo}

O teste-t de amostras independentes foi realizado para verificar diferenças entre os colaboradores dos SECOMs do sexo feminino e masculino quanto a percepção dos valores organizacionais.

Partindo do pressuposto que os valores organizacionais são percebidos de forma diferente entre os sexos, o que pode ser visto na tabela 55, é que houve diferenças entre as médias em algumas dimensões para os dois grupos em estudo. Autonomia, coletividade, realização, bem-estar e conformidade são dimensões mais reconhecidas entre os colaboradores do sexo masculino do que os do sexo feminino.

A média da dimensão autonomia no DPR foi de 4,24 e a dos colaboradores dos SECOMs do sexo masculino foi 4,11 ambos veem fatores na dimensão autonomia como mais ou menos parecida com a organização em que trabalham, já as colaboradoras dos SECOMs veem como pouco parecida. Na dimensão coletividade, a média dos colaboradores do sexo masculino $(4,67)$ está mais próxima à média do $\operatorname{DPR}(4,39)$ do que a média das colaboradoras $(4,27)$.

Tabela 55 - Teste de amostras independentes - valores dos colaboradores nos SECOMs analisados quanto ao sexo

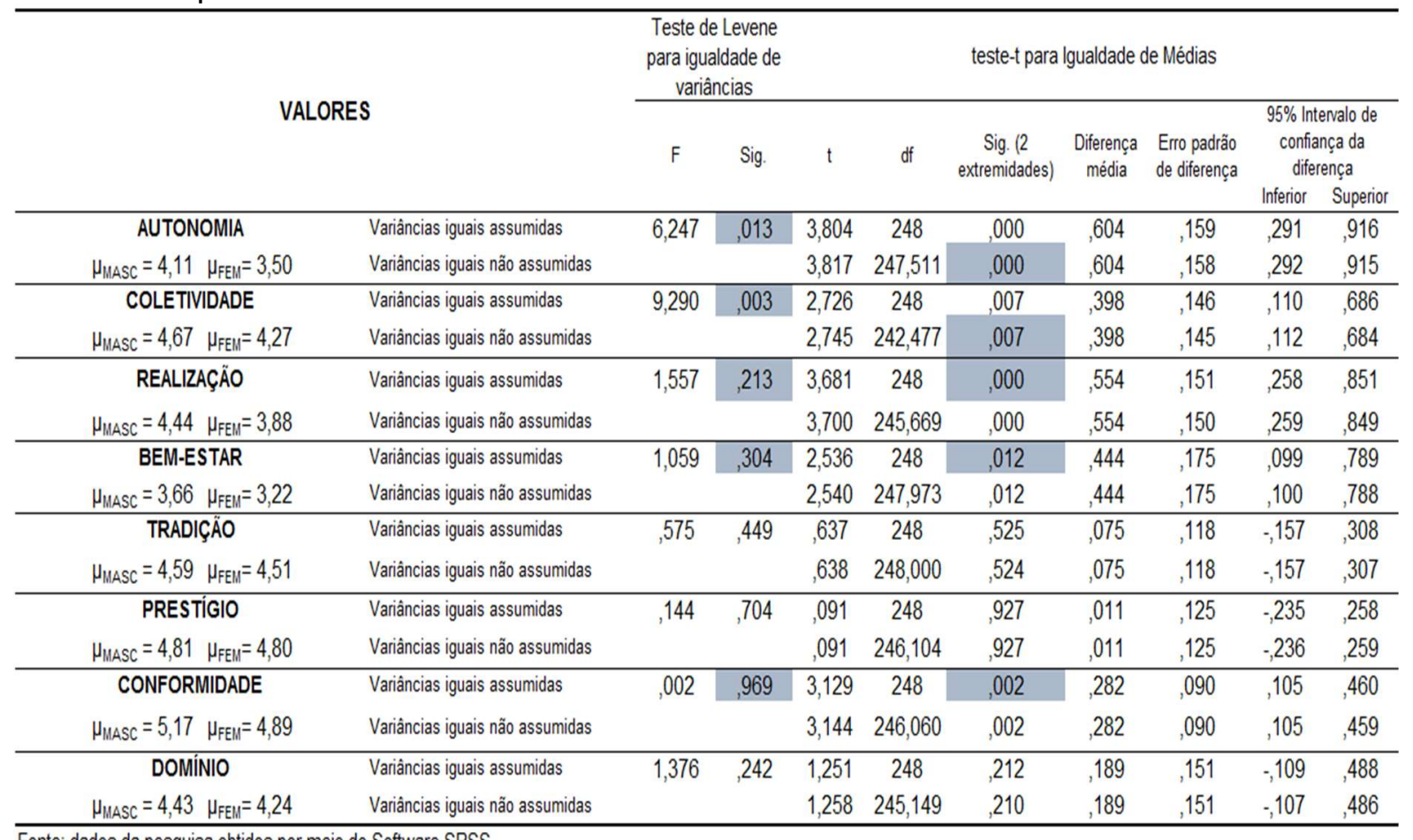


A média da dimensão realização no DPR foi de 4,54 e a dos colaboradores dos SECOMs do sexo masculino foi 4,44 , ou seja, os dois veem fatores na dimensão realização como mais ou menos parecida com a organização em que trabalham, já as colaboradoras dos SECOMs veem como pouco parecida, pois sua média foi 3,88. A percepção dos colaboradores masculinos quanto a dimensão bem-estar é mais próxima do DPR, dado que a média desta foi de 3,73 e daquela 3,66. E a dimensão conformidade, cuja média entre os colaboradores do sexo masculino foi de 5,17 e no DPR foi de 5,14 , de sorte que ambos veem os fatores na dimensão autonomia como parecida com a organização em que trabalham, já as colaboradoras dos SECOMs veem como mais ou menos parecida, pois a média resultante deste grupo foi de 4,89.

\subsubsection{Análises bivariadas entre variáveis sociodemográficas dos SECOMs e Comprometimento - Teste $\mathbf{t}$}

Segundo Bastos (1994), pesquisas sobre comprometimento organizacional lidam com uma ampla variedade de variáveis como antecedentes que podem ser agrupadas em: variáveis pessoais, características do trabalho (ocupacionais), experiências no trabalho e características organizacionais. A meta-análise de Mathieu e Zajac (1990) sobre antecedentes de comprometimento apresenta no grupo das variáveis demográficas a idade e o tempo de serviço na empresa. Com base em estudos sobre o impacto de variáveis demográficas anteriores, testes de amostras independentes foram realizados com as variáveis sociodemográficas: tempo de serviço, nacionalidade e sexo.

\subsubsection{Diferenças na percepção do comprometimento em função do tempo de serviço}

Ao analisar a percepção do comprometimento quanto ao tempo de serviço, o que se observou foi que as bases de comprometimento afetiva, afiliativa, obrigação em permanecer, obrigação pelo desempenho e falta de recompensas não houve diferenças entre os colaboradores que têm até 5 anos de casa e entre os que têm mais de 5 anos de serviço nos SECOMs. A divergência ocorre entre os tipos de comprometimento compreendidos como instrumentais - linha consistente de atividade 
e escassez de alternativas - e esta percepção é maior entre os colaboradores que têm mais têm de serviço, como pode ser visto na tabela 56 .

Tabela 56 - Teste de amostras independentes - Comprometimento e tempo de serviço

\begin{tabular}{|c|c|c|c|c|c|c|c|c|c|c|}
\hline \multirow{3}{*}{\multicolumn{2}{|c|}{ COMPROMETIMENTO }} & \multicolumn{3}{|c|}{$\begin{array}{l}\text { Teste de Levene } \\
\text { para igualdade de } \\
\text { variâncias }\end{array}$} & \multicolumn{6}{|c|}{ teste-t para lgualdade de Médias } \\
\hline & & \multirow[t]{2}{*}{$\mathrm{F}$} & \multirow[t]{2}{*}{ Sig. } & \multirow[t]{2}{*}{$t$} & \multirow[t]{2}{*}{ df } & \multirow[t]{2}{*}{$\begin{array}{c}\text { Sig. (2 } \\
\text { extremidades) }\end{array}$} & \multirow[t]{2}{*}{$\begin{array}{l}\text { Diferença } \\
\text { média }\end{array}$} & \multirow[t]{2}{*}{$\begin{array}{l}\text { Erro padrão } \\
\text { de diferença }\end{array}$} & \multicolumn{2}{|c|}{$\begin{array}{l}95 \% \text { Intervalo de } \\
\text { confiança da } \\
\text { differença }\end{array}$} \\
\hline & & & & & & & & & Inferior & Superior \\
\hline AFETIVA & Variâncias iguais assumidas &, 032 & 859 &,- 895 & 247 &, 371 & -109 & ,122 & -350 & ,131 \\
\hline$\mu_{\text {ATESANOS }}=4,39 \mu_{\text {ACIMASANOS }}=4,50$ & Variâncias iguais não assumidas & & &,- 894 & 242,387 &, 372 &,- 109 & , 122 &,- 350 & ,131 \\
\hline OBRIGAÇÄO EM PERMANECER & Variâncias iguais assumidas & 1,153 & 284 &,- 913 & 247 & ,362 &,- 151 & , 165 &,- 476 & ,174 \\
\hline$\mu_{\text {ATESANOS }}=3,58 \quad \mu_{\text {ACMASANOS }}=3,73$ & Variâncias iguais não assumidas & & &,- 917 & 246,398 &, 360 & -151 & , 164 &,- 474 &, 173 \\
\hline OBRIGAÇÄO PELO DESEMPENHO & Variâncias iguais assumidas & 2,205 & 139 & $-1,439$ & 247 & 152 &,- 114 & 080 &,- 271 & 042 \\
\hline$\mu_{\text {ATESANOS }}=5,49 \mu_{\text {ACMASANOS }}=5,61$ & Variâncias iguais não assumidas & & & $-1,452$ & 246,626 &, 148 & -114 &, 079 &,- 270 &, 041 \\
\hline AFILIATIVA & Variâncias iguais assumidas &, 432 &, 512 & 341 & 247 & ,733 & 038 & ,111 &,- 181 & 257 \\
\hline$\mu_{\text {ATESANOS }}=5,04 \quad \mu_{\text {ACIMASANOS }}=5,0$ & Variâncias iguais não assumidas & & &, 340 & 241,105 &, 734 & ,038 &, 111 &,- 181 &, 257 \\
\hline FALTA DE RECOMPENSAS & Variâncias iguais assumidas & 098 & ,755 & $-1,836$ & 247 & 068 & -240 & , 130 &,- 496 & 017 \\
\hline$\mu_{\text {ATESANOS }}=2,73 \mu_{\text {ACMASANOS }}=2,97$ & Variâncias iguais não assumidas & & & $-1,832$ & 241,149 &, 068 &,- 240 &, 131 &,- 497 &, 018 \\
\hline L. CONSISTENTE DE ATIVIDADE & Variâncias iguais assumidas & 3,247 &, 073 & $-2,021$ & 247 &, 044 & -219 & , 108 &,- 432 &,- 006 \\
\hline$\mu_{\text {ATESANOS }}=4,37 \quad \mu_{\text {ACMASANOS }}=4,59$ & Variâncias iguais não assumidas & & & $-2,040$ & 246,675 &, 042 &,- 219 &, 107 &,- 430 &,- 008 \\
\hline ESCASSEZ DE ALTERNATIVAS & Variâncias iguais assumidas & 6,061 & 015 & $-3,209$ & 247 & ,002 & -450 & , 140 &,- 726 & -174 \\
\hline$\mu_{\text {ATESANOS }}=3,24 \quad \mu_{\text {ACIMASANOS }}=3,69$ & Variâncias iguais não assumidas & & & $-3,179$ & 229,687 &, 002 & -450 & ,142 & -729 & -171 \\
\hline
\end{tabular}

\subsubsection{Diferenças na percepção do comprometimento na organização local em função da nacionalidade}

O teste de médias independentes objetiva verificar se há diferenças na percepção do comprometimento organizacional em função da nacionalidade dos colaboradores dos SECOMs. O que pode ser visto na tabela 57 é que as bases de comprometimento afetiva, afiliativa, Linha consistente de atividade e escassez de alternativas não divergem entre nacionais e nativos. Já a base de comprometimento obrigação em permanecer os resultados (teste de Levene 0,027 ( $p$-value $<0,05)$ e $t=1,903$ e $p$ valor $=0,051$ ( $p$-value $<0,05)$ e o intervalo de confiança não contém o zero $($ IC $[0,632$; $0,011])$ mostram que a percepção é diferente entre os grupos e que os colaboradores não brasileiros têm uma percepção maior do que os colaboradores brasileiros. Os resultados base de comprometimento obrigação pelo desempenho (teste de Levene $0,002(p$-value $<0,05)$ e $t=2,689$ e $p$-valor $=0,008(p$-value $<0,05)$ e intervalo de confiança (IC $[0,061 ; 0,339]$ mostram que a percepção é diferente entre os grupos e que os colaboradores brasileiros têm uma percepção maior $(\mu=5,64)$ do que os 
colaboradores não brasileiros ( $\mu=5,41)$; e a dimensão falta de recompensas (teste de Levene 0,599 ( $p$-value $>0,05)$ e $\mathrm{t}=-2,660$ e $p$-valor $=0,008(p$-value $<0,05))$

Tabela 57 - Teste de amostras independentes - comprometimento e nacionalidade

\begin{tabular}{|c|c|c|c|c|c|c|c|c|c|c|}
\hline \multirow{3}{*}{\multicolumn{2}{|c|}{ COMPROMETIMENTO }} & \multicolumn{3}{|c|}{$\begin{array}{c}\text { Teste de Levene } \\
\text { para igualdade de } \\
\text { variâncias }\end{array}$} & \multicolumn{6}{|c|}{ teste-t para Igualdade de Médias } \\
\hline & & \multirow[t]{2}{*}{$\mathrm{F}$} & \multirow[t]{2}{*}{ Sig. } & \multirow[t]{2}{*}{$\mathrm{t}$} & \multirow[t]{2}{*}{ df } & \multirow[t]{2}{*}{$\begin{array}{c}\text { Sig. (2 } \\
\text { extremidades) }\end{array}$} & \multirow[t]{2}{*}{$\begin{array}{c}\text { Diferença } \\
\text { média }\end{array}$} & \multirow[t]{2}{*}{$\begin{array}{l}\text { Erro padrão } \\
\text { de diferença }\end{array}$} & \multicolumn{2}{|c|}{$\begin{array}{c}95 \% \text { Intervalo de } \\
\text { confiança da } \\
\text { diferença }\end{array}$} \\
\hline & & & & & & & & & Inferior & Superior \\
\hline AFETIVA & Variâncias iguais assumidas &, 026 & 871 & ,825 & 248 & ,410 &, 103 &, 124 &,- 142 &, 348 \\
\hline$\mu_{B R}=4,48 \quad \mu_{N B R}=4,38$ & Variâncias iguais não assumidas & & & 819 & 202,332 & ,413 &, 103 & ,125 &,- 144 &, 350 \\
\hline OBRIG. EM PERMANECER & Variâncias iguais assumidas & 4,981 & 027 & 1,856 & 248 & 065 &,- 310 &, 167 &, 640 & 019 \\
\hline$\mu_{\mathrm{BR}}=3,53 \quad \mu_{\mathrm{NBR}}=3,84$ & Variâncias iguais não assumidas & & & 1,903 & 223,877 & 051 &,- 310 &, 163 & 632 & 011 \\
\hline OBRIG. PELO DESEMPENHO & Variâncias iguais assumidas & 9,368 &, 002 & 2,872 & 248 &, 004 & 230 &, 080 &, 072 & ,388 \\
\hline$\mu_{\mathrm{BR}}=5,64 \quad \mu_{\mathrm{NBR}}=5,41$ & Variâncias iguais não assumidas & & & 2,689 & 163,089 &, 008 &, 230 &, 086 &, 061 & ,399 \\
\hline AFILIATIVA & Variâncias iguais assumidas & 627 &, 429 & ,645 & 248 &, 520 &, 073 & ,113 &,- 150 & ,296 \\
\hline$\mu_{\mathrm{BR}}=5,05 \quad \mu_{\mathrm{NBR}}=4,98$ & Variâncias iguais não assumidas & & & 622 & 181,784 &, 535 &, 073 &, 117 &,- 159 &, 305 \\
\hline FALTA DE RECOMPENSAS & Variâncias iguais assumidas & ,278 & 599 & $-2,660$ & 248 &, 008 &,- 351 & 132 &,- 610 &,- 091 \\
\hline$\mu_{B R}=2,71 \quad \mu_{N B R}=3,06$ & Variâncias iguais não assumidas & & & $-2,565$ & 182,113 & 011 &,- 351 &, 137 &,- 620 &,- 081 \\
\hline L. CONSISTÊNCIA DE ATIVIDADE & Variâncias iguais assumidas & 010 & 922 & $-1,725$ & 248 & 086 &,- 191 & 110 &,- 408 &, 027 \\
\hline$\mu_{B R}=4,40 \quad \mu_{N B R}=4,59$ & Variâncias iguais não assumidas & & & $-1,720$ & 205,011 &, 087 &,- 191 &, 111 &,- 409 & 028 \\
\hline ESCASSEZ DE ALTERNATIVAS & Variâncias iguais assumidas & ,401 &, 527 & $-1,540$ & 248 &, 125 &,- 223 &, 145 &,- 509 &, 062 \\
\hline$\mu_{B R}=3,37 \quad \mu_{N B R}=3,59$ & Variâncias iguais não assumidas & & & $-1,577$ & 223,132 & ,116 &,- 223 & 142 &,- 503 & 056 \\
\hline
\end{tabular}

\subsubsection{Diferenças na percepção comprometimento na organização local em função do sexo}

O teste de médias independentes objetiva verificar se há diferenças na percepção do comprometimento organizacional em função do sexo dos colaboradores dos SECOMs. O que pode ser visto na tabela 58 é que as bases de comprometimento obrigação em permanecer, obrigação pelo desempenho, falta de recompensas, linha consistente de atividade, e escassez de alternativas não divergem entre os sexos. Já a base de comprometimento afetiva os resultados (teste de Levene 0,035 (p-value < $0,05)$ e $t=3,497$ e p-valor $=0,001(p$-value $<0,05)$ e o intervalo de confiança não contém o zero (IC $[0,180 ; 0,645])$ mostram que a percepção é diferente entre os grupos e que os colaboradores do sexo masculino têm uma percepção maior do que os colaboradores do sexo feminino. E os resultados da base de comprometimento afiliativa (teste de Levene 0,009 ( $p$-value <0,05) e t =3,465 e p-valor $=0,001(p$-value $<0,05)$ e intervalo de confiança (IC $[0,159 ; 0,580]$ mostram que a percepção é diferente entre os grupos e que os colaboradores do sexo masculino têm uma percepção maior $(\mu=5,21)$ do que os colaboradores do sexo feminino $(\mu=4,84)$. 
Tabela 58 - Teste de amostras independentes - Comprometimento e sexo

\begin{tabular}{|c|c|c|c|c|c|c|c|c|c|c|}
\hline \multirow{3}{*}{\multicolumn{2}{|c|}{ COMPROMETIMENTO }} & \multicolumn{3}{|c|}{$\begin{array}{l}\text { Teste de Levene } \\
\text { para igualdade de } \\
\text { variâncias }\end{array}$} & \multicolumn{6}{|c|}{ teste-t para Igualdade de Médias } \\
\hline & & \multirow[t]{2}{*}{$\mathrm{F}$} & \multirow[t]{2}{*}{ Sig. } & \multirow[t]{2}{*}{$t$} & \multirow[t]{2}{*}{ df } & \multirow[t]{2}{*}{$\begin{array}{c}\text { Sig. (2 } \\
\text { extremidades) }\end{array}$} & \multirow[t]{2}{*}{$\begin{array}{l}\text { Diferença } \\
\text { média }\end{array}$} & \multirow[t]{2}{*}{$\begin{array}{l}\text { Erro padrão } \\
\text { de diferença }\end{array}$} & \multicolumn{2}{|c|}{$\begin{array}{c}95 \% \text { Intervalo de } \\
\text { confiança da } \\
\text { diferença }\end{array}$} \\
\hline & & & & & & & & & Inferior & Superior \\
\hline AFETIVA & Variâncias iguais assumidas & 4,485 & 035 & 3,469 & 248 & 001 & ,413 & ,119 & 178 & 647 \\
\hline$\mu_{\text {MASC }}=4,65 \mu_{\mathrm{FEM}}=4,24$ & Variâncias iguais não assumidas & & & 3,497 & 240,047 &, 001 & , 413 &, 118 &, 180 & 645 \\
\hline OBRIGAÇÃO EM PERMANECER & Variâncias iguais assumidas & 3,571 & ,060 & 1,922 & 248 &, 056 & ,314 & 163 &,- 008 & 635 \\
\hline$\mu_{\text {MASC }}=3,81 \mu_{\text {FEM }}=3,50$ & Variâncias iguais não assumidas & & & 1,927 & 247,790 &, 055 &, 314 &, 163 &,- 007 & 634 \\
\hline OBRIGAÇÄO PELO DESEMPENHO & Variâncias iguais assumidas &, 562 & 454 & 139 & 248 & ,889 & ,011 & 080 &,- 146 & 168 \\
\hline$\mu_{\text {MASC }}=5,55 \mu_{\text {FEM }}=5,54$ & Variâncias iguais não assumidas & & & 140 & 247,419 & ,889 &, 011 & 079 &,- 145 & 167 \\
\hline AFILIATIVA & Variâncias iguais assumidas & 6,862 &, 009 & 3,418 & 248 & ,001 & ,370 & ,108 & 157 & ,583 \\
\hline$\mu_{\text {MASC }}=5,21 \quad \mu_{\text {FEM }}=4,84$ & Variâncias iguais não assumidas & & & 3,465 & 219,717 &, 001 &, 370 &, 107 &, 159 &, 580 \\
\hline FALTA DE RECOMPENSAS & Variâncias iguais assumidas & ,467 & ,495 &, 048 & 248 & 962 & ,006 & 131 &,- 251 & 264 \\
\hline$\mu_{\text {MASC }}=2,85 \mu_{\text {FEM }}=2,84$ & Variâncias iguais não assumidas & & &, 048 & 245,263 & ,962 &, 006 & 131 &,- 251 & ,264 \\
\hline L. CONSISTENTE DE ATIVIDADE & Variâncias iguais assumidas & 670 & 414 & 1,843 & 248 &, 066 & ,199 & ,108 &,- 014 & 411 \\
\hline$\mu_{\text {MASC }}=4,58 \mu_{\text {FEM }}=4,38$ & Variâncias iguais não assumidas & & & 1,848 & 247,900 &, 066 & 199 & 107 &,- 013 &, 410 \\
\hline ESCASSEZ DE ALTERNATIVAS & Variâncias iguais assumidas & 171 & 680 & 1,906 & 248 & ,058 & ,269 & ,141 &,- 009 & ,548 \\
\hline$\mu_{M A S C}=3,60 \quad \mu_{\mathrm{FEM}}=3,33$ & Variâncias iguais não assumidas & & & 1,908 & 247,704 &, 058 & ,269 &, 141 &,- 009 &, 548 \\
\hline
\end{tabular}

Em resumo, no que concerne às diferenças entre os valores organizacionais identificadas no DPR e nos SECOMs viu-se que as dimensões autonomia, realização, prestígio e domínio são percebidas de forma diferente entre as duas organizações, já os valores bem-estar, tradição, coletividade e conformidade são percebidos de forma semelhante entre o DPR e os SECOMs.

Ao verificar em quais SECOMs essas diferenças se mantêm quando analisadas por continente, nos SECOMs do continente europeu as dimensões autonomia, realização, bem-estar e domínio são percebidos de forma diferente do que o DPR e as dimensões coletividade, tradição, prestígio e conformidade foram identificadas como iguais, ou seja, não havendo divergência na percepção dos colaboradores do DPR e dos SECOMs da Europa nestas dimensões.

Para os respondentes dos SECOMs localizados na América Central, a divergência foi para as dimensões autonomia, bem-estar; para as dimensões coletividade, realização, prestígio, conformidade, tradição e domínio, a percepção foi a mesma dos colaboradores do DPR.

Na América do Norte a divergência apresentada foi para as dimensões autonomia, realização e domínio e convergência para as dimensões coletividade, bem-estar, prestígio e conformidade. E na América do Sul as diferenças encontradas foram para as dimensões autonomia, bem-estar, tradição e domínio e não há diferenças para as dimensões coletividade, realização, prestígio e conformidade. 
Já os SECOMs localizados na África têm percepções diferentes somente para a dimensão prestígio e iguais ao do DPR para as demais dimensões. E na Ásia, os colaboradores divergem dos colaboradores do DPR somente na dimensão Domínio. E os SECOMs localizados na Oceania não divergem em nenhuma das dimensões de valores em relação ao DPR. Vale ressaltar que não houve diferença para as dimensões coletividade e conformidade entre o DPR e os SECOMs por continente.

Em decorrência das diferenças encontradas entre as dimensões de valores organizacionais identificadas no DPR e nos SECOMs, foi verificado que há divergência na dimensão autonomia (que é mais reconhecida entre os colaboradores do DPR) e domínio (que é mais reconhecida entre os brasileiros dos SECOMs). E, ao comparar as percepções dos valores organizacionais dos colaboradores do DPR e os colaboradores não brasileiros dos SECOMs, as dimensões autonomia, realização, tradição, prestígio e conformidade são mais percebidos entre os colaboradores do DPR, e a dimensão domínio é mais percebida entre os colaboradores não brasileiros dos SECOMs.

Já a percepção dos valores nos SECOMs diverge em função do tempo de serviço entre os colaboradores. Realização, bem-estar e tradição são mais reconhecidas entre os que têm até 5 anos de tempo de serviço na organização do que entre os que têm acima de 5 anos de casa. No que se refere à nacionalidade, tradição, prestígio e conformidade são dimensões mais percebidas entre os brasileiros do que entre os não brasileiros. E quanto ao sexo, as dimensões autonomia, coletividade, realização, bem-estar e conformidade são mais reconhecidas entre os homens do que as mulheres que trabalham nos SECOMs.

A respeito das diferenças entre os tipos de práticas organizacionais identificadas no DPR e nos SECOMs, as práticas instrumentais são percebidas diferentemente, sendo mais reconhecida nos SECOMs do que no DPR especificamente entre os gestores dos SECOMs localizados nos continentes da África, da América Central, do Norte e do Sul e da Ásia. Não se veem, porém, diferenças entre os gestores SECOMs da Europa e da Oceania em relação aos do DPR quanto às práticas instrumentais.

No que se refere às práticas caracterizadas como humanistas, em geral, não foram verificadas diferenças entre os dois grupos. Mas, ao analisar a percepção dos gestores SECOMs por continente, verificou-se que a semelhança permanece entre os 
gestores SECOMs localizados na África, América Central, América do Sul e Oceania, mas os gestores da América do Norte e da Europa têm uma percepção menor do que os dos DPR e os gestores da Ásia têm uma percepção mais humanista do que os gestores do DPR.

Acerca da percepção das bases de comprometimento em função do tempo de serviço, as bases linha consistente de atividade e escassez de alternativas são mais percebidas entre colaboradores que têm acima de 5 anos de trabalho nos SECOMs dos que têm até 5 anos. Quanto a nacionalidade, os brasileiros têm maior percepção da base de comprometimento obrigação pelo desempenho do que os não brasileiros, e as bases obrigação em permanecer e falta de recompensas e oportunidades são mais percebidas entre não brasileiros do que entre brasileiros. Por fim, em relação ao sexo, as bases afetiva e afiliativa são mais percebidas entre os homens que trabalham nos SECOMs. 


\subsubsection{Análises bivariadas entre Valores, Práticas e Comprometimento e os resultados nos SECOMs - Teste de Correlação de Pearson}

Para estas análises, foi utilizado o teste de correlação de Pearson que trata em ser uma medida de associação bivariada que mede a (força) do grau de relacionamento entre duas variáveis, ou seja, o que se pretende é descobrir com precisão, o quanto uma variável interfere no resultado de outra. O coeficiente de correlação de Pearson (r) mede o grau da correlação linear entre duas variáveis quantitativas. É um índice adimensional com valores situados ente -1,0 e 1.0 que identifica a intensidade de uma relação linear entre dois conjuntos de dados.

O que se pretende é analisar as possíveis relações entre valores, práticas, comprometimento e resultados nos SECOMs, conforme o modelo proposto na figura 42.

Figura 42 - Modelo conceitual para a organização local - relações entre os construtos

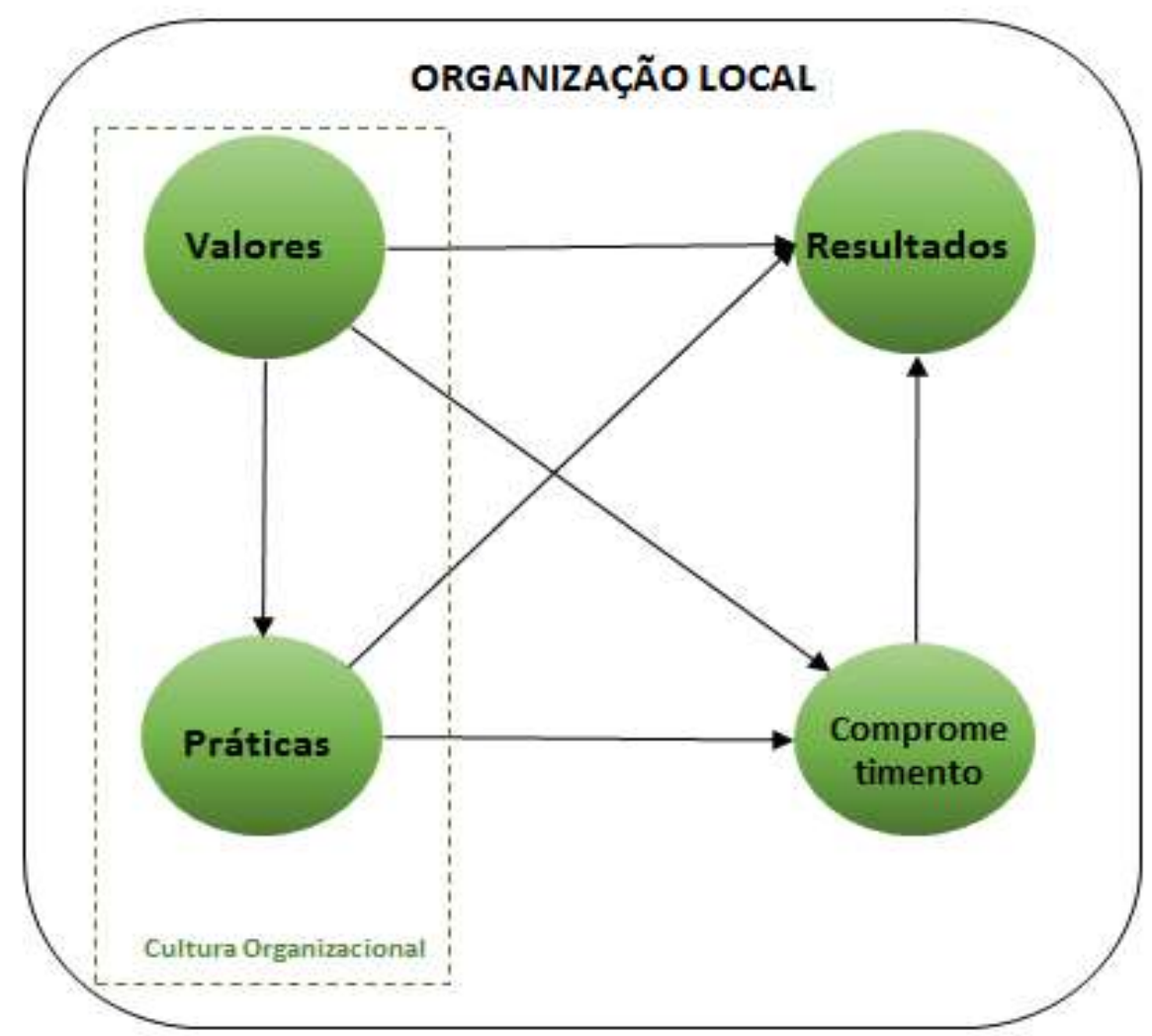

Fonte: elaborado pela autora 


\subsubsection{Relações entre valores organizacionais e resultados organizacionais nos SECOMs}

Como pode ser visto na tabela 59, não houve correlação entre os valores organizacionais percebidos pelos colaboradores dos SECOMs e os resultados organizacionais classificados como produtivos e proativos.

Tabela 59 - Correlações - valores organizacionais e resultados proativos e produtivos

\begin{tabular}{|c|c|c|c|c|c|c|c|c|c|}
\hline Correlação de Pearson & & AUTONOMIA & COLETIVIDADE & REALIZAÇÄO & BEM-ESTAR & TRADIÇÄO & CONFORMIDADE & PRESTIGIO & DOMINIO \\
\hline \multirow{2}{*}{ PRODUTIVIDADE } & \multirow[b]{2}{*}{$\mathrm{p}$-value } &, 035 & 071 & 021 &, 019 &,- 068 &,- 044 &, 016 &, 012 \\
\hline & &, 579 & ,285 &, 736 & ,766 &, 285 &, 486 &, 803 &, 844 \\
\hline \multirow{2}{*}{ PROATIVIDADE } & \multirow[b]{2}{*}{$\mathrm{p}$-value } &, 024 & 0,095 &, 013 &, 061 &,- 002 & 0,037 &,- 046 &, 085 \\
\hline & & ,706 & 134, & 842 & ,337 &, 970 &, 557 &, 473 & , 180 \\
\hline
\end{tabular}

Fonte: Dados da pesquisa elaborados a partir do Software SPSS

\subsubsection{Relações entre tipos práticas organizacionais e resultados organizacionais}

Ao analisar se há relação entre os tipos de práticas (instrumental ou humana) e os resultados mensurados nos SECOMs e classificados como proativos e produtivos, verificou-se que o tipo de prática humanista tem uma relação positiva $(r=0,128$ e $p$ valor $=0,044$ ) com os resultados classificados como proativos (capacitação e treinamento, elaboração de notícia para o site Invest \& Export Brasil ou para o Boletim de Facilitação de Negócios, elaboração de pesquisas de mercado, elaboração de publicações (estudos, boletins, revistas, série "Como Exportar" etc.), identificação de concorrências públicas locais abertas, identificação de concorrências públicas locais previstas, identificação de Investimento Direto Brasileiro (IDB), identificação de Investimento Estrangeiro Direto - IED). Já os tipos de práticas instrumentais não se apresentaram correlacionadas com os resultados organizacionais, como pode ser visto na tabela 60 .

Tabela 60 - Correlações - tipos de práticas organizacionais e resultados proativos e produtivos

\begin{tabular}{l|lcc}
\hline \multicolumn{1}{c}{ Correlação de Pearson } & PRODUTIVIDADE & PROATIVIDADE \\
\hline INSTRUMENTAL & &, 024 &,- 051 \\
& p-value &, 708 &, 419 \\
\hline HUMANISTA & &,- 085 &, $128^{\circ}$ \\
& p-value &, 179 &, 044 \\
\hline
\end{tabular}

${ }^{*} A$ correlação é significativa no nivel 0,05 (2 ext.). ${ }^{* *} A$ correlação é significativa no nível 0,01 (2 Fonte: Dados da pesquisa elaborados a partir do Software SPSS 


\subsubsection{Relações entre comprometimento da organização local e resultados organizacionais}

Como pode ser visto na tabela 61 , as medidas de produtividade que se referem às atividades obrigatórias e que fazem parte da natureza cotidiana da organização estão correlacionadas com a base de comprometimento obrigação pelo desempenho ( $\rho=$ $0,141$ e p-valor $=0,026)$, mas o sentido da correção negativo mostra que, quanto maior a importância das atividades produtivas, menor será a importância dessa base de comprometimento.

Já as medidas classificadas como proativas se referem a atividades de ações exclusivas de cada SECOM, que contribuem para a qualidade das informações disponibilizadas no que concerne às atividades comerciais do País. Essas medidas estão correlacionadas com as bases afiliativa ( $\rho=0,150$ e p-valor $=0,018)$ e linha consistente de atividade ( $\rho=0,167$ e p-valor=0,008), então, quanto maior for a ênfase as atividades proativas, maior será a importância dessas bases de comprometimento.

Tabela 61 - Correlações - Comprometimento e Resultados Organizacionais

\begin{tabular}{|c|c|c|c|c|c|c|c|c|c|}
\hline Correlaçäo de Pearson & & AUTONOMIA & COLETIVIDADE & REALIZAÇÄO & BEM-ESTAR & TRADIÇÃO & CONFORMIDADE & PRESTIGIO & DOMINIO \\
\hline \multirow{2}{*}{ PRODUTIVIDADE } & &, 035 & 071 & 021 &, 019 &,- 068 &,- 044 &, 016 & 012 \\
\hline & $p$-value &, 579 & 285 &, 736 &, 766 & 285 & ,486 & 803 & 844 \\
\hline \multirow{2}{*}{ PROATIVIDADE } & & 024 & 0,095 & 013 & 061 &,- 002 & 0,037 &,- 046 &, 085 \\
\hline & p-value & 706 &, 134 & 842 & 337 & 970 &, 557 & 473 & 180 \\
\hline
\end{tabular}

**. A correlação é significativa no nivel 0,01 (2 extremidades). * . A correlação é significativa no nivel 0,05 (2 extremidades).

Fonte: Dados da pesquisa elaborados a partir do Software SPSS

\subsubsection{Relações entre valores e tipos de práticas organizacionais}

Como apresentado na tabela 62, a correlação entre o tipo de prática instrumental e valores percebidos pelos colaboradores dos SECOMs mostrou uma correlação positiva entre autonomia $(r=0,132$ e p-valor=0,037), coletividade $(r=0,146$ e p-valor= $0,021)$ e bem-estar ( $~(=0,132$ e p-valor=0,036). Quanto ao tipo de prática humanista, houve correlação positiva entre autonomia ( $\Sigma=0,140$ e p-valor=0,027), coletividade $(\ulcorner=0,162$ e p-valor=0,010), realização $(r=0,152$ e p-valor $=0,016)$ e bem-estar $(\ulcorner=$ 0,185 e p-valor=0,003). 
Tabela 62 - Correlações entre Valores e tipos de Práticas Organizacionais- SECOMs

\begin{tabular}{|c|c|c|c|c|c|c|c|c|c|}
\hline \multicolumn{2}{|c|}{ Correlaçäo de Pearson } & \multirow{2}{*}{$\begin{array}{c}\text { AUTONOMIA } \\
132^{*}\end{array}$} & COLETIVIDADE & \multirow{2}{*}{$\begin{array}{c}\text { REALIZAC̣ÃO } \\
107\end{array}$} & \multirow{2}{*}{$\begin{array}{c}\text { BEM-ESTAR } \\
132^{*}\end{array}$} & \multirow{2}{*}{$\begin{array}{c}\text { TRADIÇÃO } \\
-, 058\end{array}$} & \multirow{2}{*}{$\begin{array}{c}\text { PRESTIGIO } \\
, 063\end{array}$} & \multirow{2}{*}{$\begin{array}{c}\text { CONFORMIDADE } \\
-013\end{array}$} & \multirow{2}{*}{$\begin{array}{c}\text { DOMINIO } \\
, 057\end{array}$} \\
\hline INSTRUMENTA| & & & $146^{2}$ & & & & & & \\
\hline 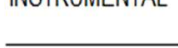 & $p$-value &, 037 &, 021 &, 091 &, 036 &, 360 &, 325 & 837 &, 367 \\
\hline \multirow{2}{*}{ HUMANISTA } & & $140^{2}$ & $162^{*}$ & $152^{\circ}$ & $185^{\prime \prime}$ &,- 070 &, 002 & 011 &, 018 \\
\hline & $p$-value & 027 &, 010 &, 016 &, 003 & 269 & ,970 & ,866 & ,783 \\
\hline
\end{tabular}

**. A correlação é significativa no nivel 0,01 (2 extremidades). *. A correlação é significativa no nivel 0,05 (2 extremidades).

Fonte: Dados da pesquisa elaborados a partir do Software SPSS

\subsubsection{Relações entre tipos de práticas organizacionais e comprometimento}

Não houve correlações quanto ao tipo de prática (instrumental ou humanista) e percepção de comprometimento entre os colaboradores dos SECOMs.

Tabela 63 - Correlações entre Comprometimento e tipos de Práticas Organizacionais

\begin{tabular}{|c|c|c|c|c|c|c|c|c|}
\hline \multicolumn{2}{|l|}{ Correlaçäo de Pearson } & \multirow{2}{*}{$\begin{array}{c}\text { AFETIVA } \\
, 061\end{array}$} & \multirow{2}{*}{$\begin{array}{c}\text { AFILIATIVA } \\
, 016\end{array}$} & \multirow{2}{*}{$\begin{array}{c}\text { OBRIGAÇÃO EM } \\
\text { PERMANECER } \\
-, 024\end{array}$} & \multirow{2}{*}{$\begin{array}{c}\text { OBRIGAÇÄO } \\
\text { P/ } \\
\text { DESEMPENHO } \\
-, 027\end{array}$} & \multirow{2}{*}{$\begin{array}{c}\text { FALTADE } \\
\text { RECOMPENSA } \\
\mathrm{S} \\
-, 013\end{array}$} & \multirow{2}{*}{$\begin{array}{l}\text { L. CONSISTENTE } \\
\text { DE ATIVIDADE } \\
, 074\end{array}$} & \multirow{2}{*}{$\begin{array}{c}\text { ESCASSEZ DE } \\
\text { ALTERNATIVAS } \\
-, 090\end{array}$} \\
\hline & & & & & & & & \\
\hline INSTRUMENIAL & $p$-value & ,335 & 802 & ,706 & 677 & 839 & ,243 & 158 \\
\hline \multirow{2}{*}{ HUMANISTA } & &, 092 & ,106 & 096 & 028 & 002 & 067 &,- 029 \\
\hline & $p$-value & 145 & 095 & ,132 & 664 &, 975 & ,288 &, 650 \\
\hline
\end{tabular}

ॠ*. A correlação é significativa no nivel 0,01 (2 extremidades). *. A correlação é significativa no nivel 0,05 (2 extremidades).

Fonte: Dados da pesquisa elaborados a partir do Software SPSS

\subsubsection{Relações entre os valores organizacionais e comprometimento organizacional}

Os resultados das correlações de Pearson mostraram que praticamente todas as dimensões de valores organizacionais estão relacionadas com os comprometimentos afetivo, afiliativo e obrigação em permanecer, com exceção da dimensão tradição cujo foco está na manutenção da tradição e do respeito aos costumes da organização.

As dimensões autonomia e bem-estar não foram significativas em relação ao comprometimento obrigação pelo desempenho. Assim como tradição e prestígio não foram significativas para o comprometimento falta de recompensas. Esta base de comprometimento teve, em todas as demais dimensões, correlações significativas, mas negativas. Isto revela que, quanto maior a importância destas dimensões, menor será o comprometimento falta de recompensas entre seus membros. 
Tabela 64 - Correlações entre Valores Organizacionais e Comprometimento - SECOMs

\begin{tabular}{|c|c|c|c|c|c|c|c|c|c|}
\hline \multicolumn{2}{|l|}{ Correlaçäo de Pearson } & \multicolumn{8}{|c|}{ VALORES } \\
\hline BASES DE COMPROMETIMENTO & & AUTONOMIA & COLETIVIDADE & REALIZAÇÄO & BEM-ESTAR & TRADIC̣ÄO & PRESTIGIO & CONFORMIDADE & DOMINIO \\
\hline AFETIVA & $p$-value & $\begin{array}{l}, 502 " \\
, 000\end{array}$ & $\begin{array}{l}580^{\circ} \\
, 000\end{array}$ & $\begin{array}{l}550^{\circ} \\
, 000\end{array}$ & $\begin{array}{l}4,471^{-1} \\
, 000\end{array}$ & $\begin{array}{l}017 \\
, 793\end{array}$ & $\begin{array}{l}294^{\prime \prime} \\
, 000\end{array}$ & $\begin{array}{l}.357^{*} \\
, 000\end{array}$ & $\begin{array}{l}480^{\circ} \\
, 000\end{array}$ \\
\hline AFILIATIVA & p-value & $\begin{array}{l}, 415^{*} \\
, 000\end{array}$ & $\begin{array}{l}.528 \\
, 000\end{array}$ & $\begin{array}{l}4,464 \\
, 000\end{array}$ & $\begin{array}{l}, 412 " \\
, 000\end{array}$ & $\begin{array}{l}068 \\
, 286\end{array}$ & $\begin{array}{l}206 " \\
, 001\end{array}$ & $\begin{array}{l}, 367 " \\
, 000\end{array}$ & $\begin{array}{l}, 338^{*} \\
, 000\end{array}$ \\
\hline OBRIGAÇÄO EM PERMANECER & p-value & $\begin{array}{l}, 363 " \\
, 000\end{array}$ & $\begin{array}{l}344^{\prime \prime} \\
000\end{array}$ & $\begin{array}{l}326 " \\
, 000\end{array}$ & $\begin{array}{l}310^{\prime \prime} \\
, 000\end{array}$ & $\begin{array}{l}, 082 \\
, 194\end{array}$ & $\begin{array}{l}212^{*} \\
, 001\end{array}$ & $\begin{array}{l}164 \\
, 009\end{array}$ & $\begin{array}{l}267^{-1} \\
, 000\end{array}$ \\
\hline $\begin{array}{l}\text { OBRIGACCÃO PELO } \\
\text { DESEMPENHO }\end{array}$ & $p$-value & $\begin{array}{l}099 \\
, 118 \\
\end{array}$ & $\begin{array}{l}167^{*} \\
, 008 \\
\end{array}$ & $\begin{array}{l}148^{\circ} \\
, 019 \\
\end{array}$ & $\begin{array}{l}095 \\
, 133\end{array}$ & $\begin{array}{l}254^{\prime \prime} \\
, 000 \\
\end{array}$ & $\begin{array}{l}297^{*} \\
, 000 \\
\end{array}$ & $\begin{array}{l}302 " \\
, 000\end{array}$ & $\begin{array}{l}233^{*} \\
, 000 \\
\end{array}$ \\
\hline FALTARECOMPENSAS & $\mathrm{p}$-value & $\begin{array}{r}-220^{*} \\
, 000\end{array}$ & $\begin{array}{r}-305^{\prime \prime} \\
, 000\end{array}$ & $\begin{aligned}-234 " \\
, 000\end{aligned}$ & $\begin{array}{l}-356 " \\
, 000\end{array}$ & $\begin{array}{l}-, 093 \\
, 143\end{array}$ & $\begin{array}{l}-100 \\
, 113\end{array}$ & $\begin{array}{l}-, 134^{\circ} \\
, 034\end{array}$ & $\begin{array}{l}-, 170^{*} \\
, 007\end{array}$ \\
\hline $\begin{array}{l}\text { LINHA CONSISTENTE DE } \\
\text { ATIVIDADE }\end{array}$ & p-value & $\begin{array}{l}110 \\
.082\end{array}$ & $\begin{array}{l}156^{\circ} \\
014\end{array}$ & $\begin{array}{l}.61^{\circ} \\
, 011^{\circ}\end{array}$ & $\begin{array}{l}126^{\circ} \\
, 046\end{array}$ & $\begin{array}{l}.049 \\
.437\end{array}$ & $\begin{array}{l}239^{\prime \prime} \\
, 000\end{array}$ & $\begin{array}{l}205 " \\
, 001\end{array}$ & $\begin{array}{l}186^{*} \\
, 003\end{array}$ \\
\hline ESCASSEZ DE ALTERNATIVAS & $p$-value & $\begin{array}{l}084 \\
, 185\end{array}$ & $\begin{array}{l}.031 \\
627\end{array}$ & $\begin{array}{l}090 \\
156\end{array}$ & $\begin{array}{l}.079 \\
, 215\end{array}$ & $\begin{array}{l}-102 \\
, 109\end{array}$ & $\begin{array}{l}.052 \\
, 414\end{array}$ & $\begin{array}{r}-, 035 \\
, 577\end{array}$ & $\begin{array}{l}-, 026 \\
678\end{array}$ \\
\hline
\end{tabular}

*夫. A correlaçäo é significativa no nivel 0,01 (2 extremidades). *. A correlação é significativa no nivel 0,05 (2 extremidades).

Fonte: Dados da pesquisa elaborados a partir do Software SPSS

No que se refere à base de comprometimento linha consistente de atividade, as dimensões autonomia e tradição não foram significativas, e na base escassez de alternativas, nenhuma das dimensões obteve significância em suas correlações. 


\subsection{Relações entre valores e comprometimento em função do tempo de serviço}

A tabela 65 apresenta as correlações de Pearson entre valores organizacionais e bases de comprometimento separadas entre colaboradores que têm até 5 anos de serviço e colaboradores acima de 5 anos de tempo de serviço.

A base de comprometimento afetiva apresentou correlação com praticamente todas as dimensões de valores, exceto a dimensão tradição. Semelhantemente, a base de comprometimento afiliativa foi positivamente correlacionada com quase todas as dimensões dos valores, com exceção para os colaboradores acima de 5 anos de tempo de casa para as dimensões tradição e prestígio. Isso significa que para colaboradores com até 5 anos de tempo de casa, quanto maior for a ênfase dada às dimensões tradição e prestígio maior será o comprometimento afiliativo entre os colaboradores que estão entrando na organização.

Obrigação em permanecer não se correlacionou com a dimensão tradição e com as dimensões prestígio e conformidade a correlação positiva ocorreu somente com os colaboradores acima de 5 anos de tempo de serviço, isto quer dizer que quanto mais ênfase for dada as duas dimensões maior será o comprometimento obrigação em permanecer entre os colaboradores que têm mais de 5 anos de tempo de serviço. As demais dimensões (autonomia, coletividade, realização, bem-estar e domínio) foram positivamente relacionadas com o comprometimento obrigação em permanecer.

A base de comprometimento obrigação pelo desempenho foi positivamente correlacionada com as dimensões tradição, prestígio e conformidade, para as dimensões coletividade e domínio houve correlação somente com os colaboradores com até 5 anos de serviço e para a dimensão realização houve correlação positiva somente para os colaboradores que estão na organização há mais de 5 anos. Já a base falta de recompensas foi relacionada negativamente com as dimensões autonomia, coletividade, realização, bem-estar e domínio (somente para os colaboradores com até 5 anos de serviço nos SECOMs), e com isto pode-se perceber que se for dado maior ênfase a estas dimensões menor será a percepção do comprometimento falta de recompensas.

A base de comprometimento linha consistente de atividade foi positivamente relacionada com as dimensões coletividade, realização e prestígio entre os 
colaboradores acima de 5 anos de serviço, ou seja, colaboradores com mais tempo de casa dão maior ênfase a estas dimensões, já os colaboradores com até 5 anos de casa dão mais ênfase às dimensões conformidade, domínio e prestígio. $E$ a base escassez de alternativas foi positivamente relacionada com as dimensões autonomia e realização, mas somente entre os colaboradores acima de 5 anos de serviço.

Tabela 65 - Correlações entre valores organizacionais dos SECOMs e comprometimento em função do tempo de serviço

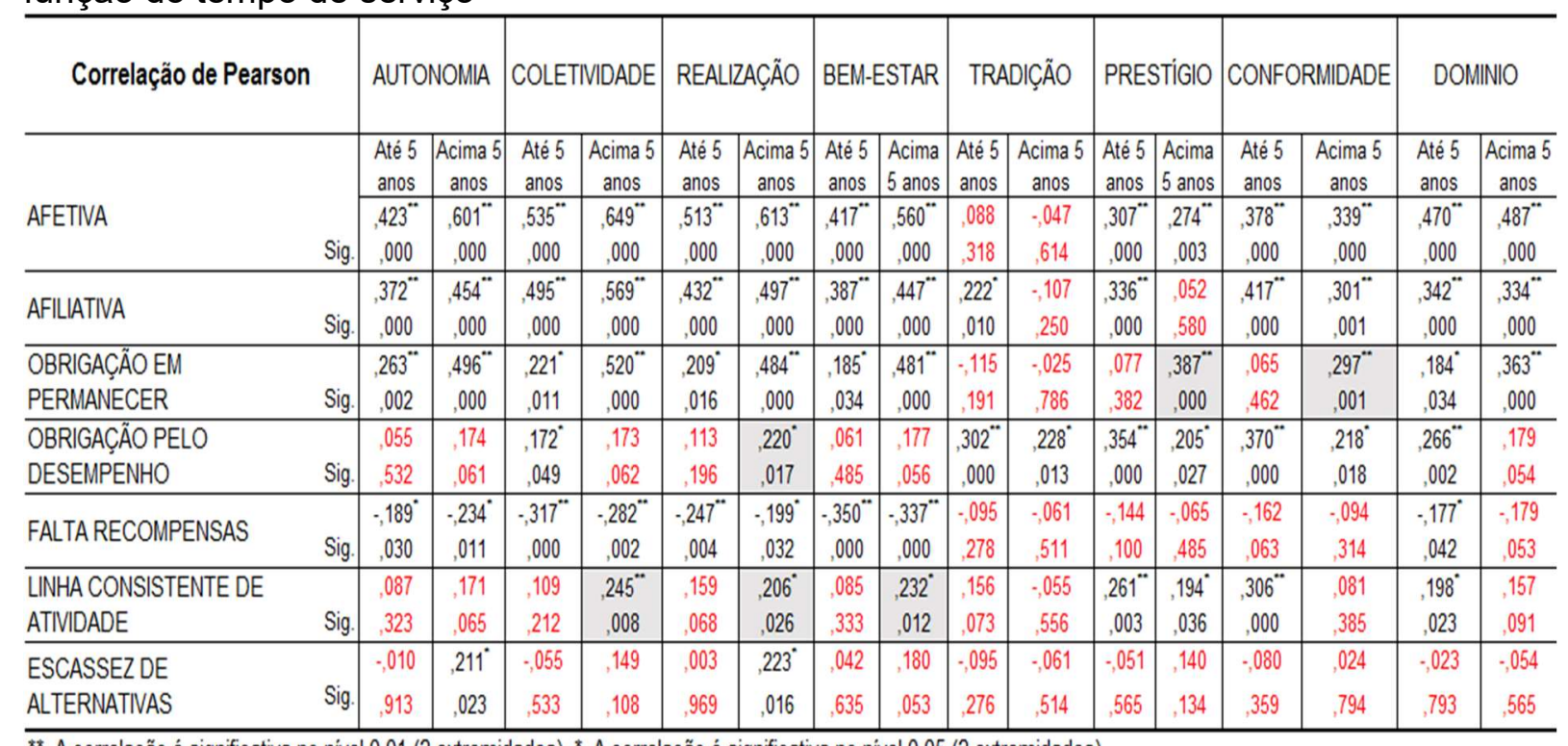

**. A correlação é significativa no nivel 0,01 (2 extremidades). *. A correlação é significativa no nivel 0,05 (2 extremidades).

Fonte: resultados da pesquisa elaborados a partir do Software SPSS

\subsection{Relações entre valores e comprometimento em função da nacionalidade}

A tabela 66 apresenta as correlações de Pearson entre valores organizacionais e bases de comprometimento separadas entre colaboradores brasileiros e não brasileiros que trabalham nos SECOMs.

As bases de comprometimento afetiva e afiliativa se correlacionaram com praticamente todas as dimensões de valores, exceto a dimensão tradição. $\mathrm{E}$ a base de comprometimento obrigação em permanecer não se correlacionou com as dimensões tradição e conformidade entre os não brasileiros.

Houve relação entre a base obrigação pelo desempenho e os colaboradores não brasileiros para as dimensões coletividade, prestígio e domínio e se correlacionou 
tanto com brasileiros e não brasileiros com as dimensões tradição e conformidade. $E$ a base de comprometimento falta de recompensas foi negativamente relacionada com as dimensões coletividade, realização, bem-estar e autonomia (somente para os colaboradores não brasileiros).

A base de comprometimento linha consistente de atividade foi positivamente relacionada com as dimensões coletividade, realização e domínio entre os colaboradores não brasileiros e houve correlação com as dimensões prestígio e conformidade tanto para brasileiros como não brasileiros. E a base escassez de alternativas foi positivamente relacionada com a dimensão realização, mas somente entre os colaboradores não brasileiros que trabalham nos SECOMs.

Tabela 66- Correlações entre valores organizacionais dos SECOMs e comprometimento em função da nacionalidade

\begin{tabular}{|c|c|c|c|c|c|c|c|c|c|c|c|c|c|c|c|c|c|}
\hline \multicolumn{2}{|l|}{ Correlaçāo de Pearson } & \multicolumn{2}{|c|}{ AUTONOMIA } & \multicolumn{2}{|c|}{ COLETIVIDADE } & \multicolumn{2}{|c|}{ REALIZAÇÄO } & \multicolumn{2}{|c|}{ BEM-ESTAR } & \multicolumn{2}{|c|}{ TRADIC̣ÄO } & \multicolumn{2}{|c|}{ PRESTIGIO } & \multicolumn{2}{|c|}{ CONFORMIDADE } & \multicolumn{2}{|c|}{ DOMNNO } \\
\hline \multirow{3}{*}{ AFETVA } & & $B R$ & NBR & $B R$ & NBR & $B R$ & NBR & $B R$ & NBR & $B R$ & $\mathrm{NE}$ & $B R$ & NBR & $B R$ & NBR & $B R$ & NBR \\
\hline & &, $485^{\circ}$ &, $530^{\circ}$ &, $563^{*}$ &, 000 &, $510^{\circ}$ &, $615^{\circ}$ &, $484^{\prime \prime}$ & $448^{\prime \prime}$ & ;064 &, 087 &, $231^{\prime \prime}$ & $367^{\circ}$ & $s^{3}$ &, $387^{\prime \prime}$ &, $532^{\circ}$ &, $400^{\circ}$ \\
\hline & Sig. &, 000 &, 000 &, 000 &, 000 &, 000 &, 000 &, 000 &, 000 & .431 &, 394 &, 004 &, 000 &, 000 &, 000 &, 000 &, 000 \\
\hline \multirow{2}{*}{ AFLLIATIVA } & &, $457^{\circ}$ & $363^{*}$ &, $525^{*}$ & $539^{\circ}$ & $.492^{\circ}$ &, $431^{\circ}$ &, $476^{\circ}$ &, $331^{\prime \prime}$ & 018 &, 103 &, $174^{\circ}$ & $233^{\circ}$ & $349^{\circ}$ & $383^{\circ}$ & $317^{\prime \prime}$ &, $361^{\prime \prime}$ \\
\hline & Sig. &, 000 &, 000 &, 000 &, 000 &, 000 &, 000 &, 000 &, 001 & 821 &, 311 & 33 &, 021 &, 000 &, 000 &, 000 &, 000 \\
\hline \multirow{2}{*}{$\begin{array}{l}\text { OBRIGAC̣ÄO EM } \\
\text { PERMANECER }\end{array}$} & & $399^{\circ}$ &, $311^{*}$ & $345^{*}$ & $362^{\circ}$ &, $361^{\prime \prime}$ & $280^{\circ}$ & $9^{*}$ &, $301^{\prime \prime}$ & -112 & 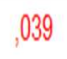 & $30^{\circ}$ & $65^{\circ}$ & $225^{*}$ &, 140 & $312^{"}$ &, $237^{\circ}$ \\
\hline & $\mathrm{Sin}$ &, 000 &, 002 &, 000 &, 000 &, 000 &, 005 & 00 &, 003 & 169 &, 703 & 04 & 011 &, 005 &, 170 &, 000 &, 019 \\
\hline \multirow{2}{*}{$\begin{array}{l}\text { OBRIGAÇAO PELO } \\
\text { DESEMPENHO }\end{array}$} & & 083 & 120 & 109 & $234^{\circ}$ & 136 &, 157 & 069 &, 111 &, $178^{\circ}$ & $252^{\circ}$ & ,132 &, $416^{\circ}$ & $263^{\prime \prime}$ & $297^{*}$ & 105, &, $346^{\prime \prime}$ \\
\hline & J &, 311 & 240 & 182 &, 021 & 096 &, 123 & , 396 & 276 &, 029 & 012 & 105 & , 000 &, 001 &, 003 & 200 &, 000 \\
\hline \multirow{2}{*}{ FALTA RECOMPENSAS } & & -148 & $-328^{\prime \prime}$ & $-246^{*}$ & $387^{\prime \prime}$ & $-162^{\circ}$ & $-333^{\prime \prime}$ & $-305^{\prime \prime}$ & "4, & 087 & 003 & 0,066 & $-0,03$ & -102 & , 118 & 149 &., 165 \\
\hline & Sig &, 069 &, 001 &, 002 &, 000 &, 046 &, 001 &, 000 &, 000 & 285 &, 979 & 421 & 4418 & 213 & 248 & 068 &, 104 \\
\hline \multirow{2}{*}{$\begin{array}{l}\text { LINHA CONSISTENTE DE } \\
\text { ATIVIDADE }\end{array}$} & &, 095 &, 143 &, 108 & $248^{\circ}$ &, 111 & $264^{\prime \prime}$ & , 153 &, 101 & 098 &, 068 & $253^{\circ}$ &, $278^{\circ}$ & $196^{\circ}$ & $270^{\circ}$ &, 157 &, $263^{*}$ \\
\hline & vily. & 242 &, 160 & , 186 & 014 &, 174 &, 009 & 0,059 & 324 & 231 &, 503 &, 002 &, 006 & 016 &, 007 & 054 &, 009 \\
\hline \multirow{2}{*}{$\begin{array}{l}\text { ESCASSEZ DE } \\
\text { ALTERNATINAS }\end{array}$} & &, 044 & 166 &, 038 &, 029 &, 031 & $218^{\circ}$ &, 113 &, 034 & -134 &, 006 &, 058 &, 090 & $; 061$ &, 038 &, 008 &,- 057 \\
\hline & oly. &, 590 &, 102 & 642 &, 776 & .703 & 031 &, 165 &, 739 & .100 &, 955 & 479 & 379 & 457 & 709 &, 921 &, 578 \\
\hline
\end{tabular}

\footnotetext{
"* A correlação é significativa no nivel 0,01 (2 extremidades). *. A correlaçăo é significativa no nivel 0,05 (2 extremidades).

Fonte: resultados da pesquisa elaborados a partir do Sottware SPSS
} 


\subsection{Relações entre valores e comprometimento em função do sexo}

A tabela 66 apresenta as correlações de Pearson entre valores organizacionais e bases de comprometimento seccionadas entre sexo masculino e feminino.

A dimensão tradição apresentou poucas correlações: com o comprometimento obrigação pelo desempenho para ambos os sexos (ГFEM $=0,309$ e ГMAS $=0,183$ ) e somente para o sexo masculino com o comprometimento escassez de alternativas (ГMAS $=-0,204)$ mas, por se tratar de correlação negativa, então pode ser interpretada como quanto maior a importância para a dimensão tradição entre os homens dos SECOMs, menor será o comprometimento escassez de alternativas.

A dimensão autonomia apresentou correlação com praticamente todas as bases de comprometimento, com exceção para as bases obrigação pelo desempenho e linha consistente de atividade, para ambos os sexos e para o sexo masculino para a base de comprometimento escassez de alternativas, ou seja, quanto maior for a importância para a dimensão autonomia entre as mulheres dos SECOMs maior será o comprometimento escassez de alternativas.

Nas dimensões coletividade e realização, as bases obrigação pelo desempenho e linha consistente de atividade não se correlacionaram com os colaboradores do sexo masculino, isto significa que para as mulheres que trabalham nos SECOMs quanto maior for a importância dada às dimensões coletividade e realização maiores serão esses dois tipos de comprometimento. Não houve correlação dessas dimensões com o comprometimento escassez de alternativas.

$\mathrm{Na}$ dimensão bem-estar, as correlações entre os sexos mostraram-se divergentes para as bases obrigação em permanecer e escassez de alternativas, enquanto nos respondentes não houve correlação, nas colaboradoras a correlação mostrou-se positiva, indicando que quanto mais de dê relevância para esta dimensão, maior será a importância dada pelas mulheres para os comprometimentos obrigação em permanecer e escassez de alternativas. As bases de comprometimento obrigação pelo desempenho e linha consistente de atividade não apresentaram correlacionadas com nenhum dos dois grupos.

A dimensão prestígio apresentou-se correlacionada com quase todas as bases de comprometimento, com exceções às bases afiliativa, falta de recompensas e 
escassez de alternativas. Na base de comprometimento afiliativa, somente as colaboradoras apresentaram correlação positiva ( ГFEM $=0,244)$ com esta dimensão, isto significa que quanto mais ênfase for dada à dimensão prestígio, maior será o comprometimento afiliativo das mulheres que trabalham nos SECOMs.

$\mathrm{Na}$ dimensão conformidade, as bases de comprometimento obrigação em permanecer, falta de recompensas e escassez de alternativas não apresentaram correlações, e a base linha consistente de atividade mostrou-se correlacionada somente com os colaboradores do sexo feminino ( ГFEM $=0,281)$.

As bases de comprometimento afiliativa, obrigação em permanecer e falta de recompensas apresentaram-se correlacionadas somente com os colaboradores do sexo feminino para a dimensão domínio. E a base escassez de alternativas não obteve correlação com nenhum dos dois grupos nesta dimensão.

Tabela 66 - Correlações - Valores Organizacionais dos SECOMs e Comprometimento em função do sexo

\begin{tabular}{|c|c|c|c|c|c|c|c|c|c|c|c|c|c|c|c|c|c|}
\hline Correlação de Pearson & & AUTON & IOMIA & COLETIV & IDADE & REALIZ & ÇÃo & BEM- & ESTAR & TRAD & IÇÃO & PREST & GlO & CONFOP & DADE & DOM & INIO \\
\hline \multirow[b]{2}{*}{ AFETIVA } & \multirow[b]{2}{*}{ Sig. } & Masc & Fem & Masc & Fem & Masc & Fem & Masc & Fem & Masc & Fem & Masc & Fem & Masc & Fem & Masc & Fem \\
\hline & & $\begin{array}{l}, 386^{* 2} \\
, 000\end{array}$ & $\begin{array}{l}, 536^{* *} \\
, 000\end{array}$ & $\begin{array}{l}, 383^{* *} \\
, 000\end{array}$ & $\begin{array}{l}, 671^{* *} \\
000\end{array}$ & $\begin{array}{l}, 381^{* *} \\
, 000\end{array}$ & $\begin{array}{l}, 618^{* *} \\
, 000\end{array}$ & $\begin{array}{l}, 341^{* *} \\
, 000\end{array}$ & $\begin{array}{l}, 534^{* z} \\
, 000\end{array}$ & $\begin{array}{l}-, 095 \\
, 300\end{array}$ & $\begin{array}{l}\text {,079 } \\
, 374\end{array}$ & $\begin{array}{l}, 245^{* *} \\
, 007\end{array}$ & $\begin{array}{l}, 346^{* *} \\
, 000\end{array}$ & $\begin{array}{l}, 224^{*} \\
, 014\end{array}$ & $\begin{array}{l}396^{* *} \\
, 000\end{array}$ & $\begin{array}{l}, 274^{* *} \\
, 002\end{array}$ & $\begin{array}{l}, 600^{* *} \\
, 000\end{array}$ \\
\hline AFILIATIVA & Sig. & $\begin{array}{l}, 220^{*} \\
, 015\end{array}$ & $\begin{array}{l}, 481{ }^{*} \\
, 000\end{array}$ & $\begin{array}{l}, 297^{* *} \\
, 001\end{array}$ & $\begin{array}{l}618^{* *} \\
, 000\end{array}$ & $\begin{array}{l}, 350^{* *} \\
, 000\end{array}$ & $\begin{array}{l}, 487^{* *} \\
, 000\end{array}$ & $\begin{array}{l}, 180^{\circ} \\
, 048\end{array}$ & $\begin{array}{l}, 524 \\
, 000\end{array}$ & $\begin{array}{l}-, 032 \\
, 726\end{array}$ & $\begin{array}{l}114 \\
, 197\end{array}$ & $\begin{array}{l}, 166 \\
, 069\end{array}$ & $\begin{array}{l}, 244^{* *} \\
, 005\end{array}$ & $\begin{array}{l}, 206^{*} \\
, 023\end{array}$ & $\begin{array}{l}, 414^{* *} \\
, 000\end{array}$ & $\begin{array}{l}, 081 \\
, 378\end{array}$ & $\begin{array}{l}, 459^{* *} \\
, 000\end{array}$ \\
\hline OBRIGAÇÃO EM PERMANECER & Sig. & $\begin{array}{l}, 244^{* *} \\
, 007\end{array}$ & $\begin{array}{l}426 * * \\
, 000\end{array}$ & $\begin{array}{l}, 229^{*} \\
, 011\end{array}$ & $\begin{array}{l}, 401^{* *} \\
000\end{array}$ & $\begin{array}{l}, 225^{*} \\
, 013\end{array}$ & $\begin{array}{l}, 369^{* *} \\
, 000\end{array}$ & $\begin{array}{l}, 173 \\
058\end{array}$ & $\begin{array}{l}397^{* *} \\
, 000\end{array}$ & $\begin{array}{l}-, 087 \\
, 344\end{array}$ & $\begin{array}{l}-, 089 \\
, 316\end{array}$ & $\begin{array}{l}, 235^{* *} \\
, 010\end{array}$ & $\begin{array}{l}, 195^{*} \\
, 027\end{array}$ & $\begin{array}{l}, 114 \\
, 213\end{array}$ & $\begin{array}{l}, 167 \\
, 059\end{array}$ & $\begin{array}{l}162 \\
, 076\end{array}$ & $\begin{array}{l}, 331^{* *} \\
, 000\end{array}$ \\
\hline OBRIGAÇÃO PELO DESEMPENHO & Sig. & $\begin{array}{l}, 045 \\
, 621\end{array}$ & $\begin{array}{l}\text {,141 } \\
\text {,111 }\end{array}$ & $\begin{array}{l}, 127 \\
, 167\end{array}$ & $\begin{array}{l}, 196^{*} \\
026\end{array}$ & $\begin{array}{l}, 112 \\
, 220\end{array}$ & $\begin{array}{l}177^{*} \\
045\end{array}$ & $\begin{array}{l}, 018 \\
, 846\end{array}$ & $\begin{array}{l}\text {,156 } \\
\text {,077 }\end{array}$ & $\begin{array}{l}183^{\circ} \\
, 045\end{array}$ & $\begin{array}{l}309^{* *} \\
, 000\end{array}$ & $\begin{array}{l}, 320^{* *} \\
, 000\end{array}$ & $\begin{array}{l}, 279^{* *} \\
, 001\end{array}$ & $\begin{array}{l}, 245^{* *} \\
, 007\end{array}$ & $\begin{array}{l}350^{* *} \\
, 000\end{array}$ & $\begin{array}{l}, 301^{* *} \\
, 001\end{array}$ & $\begin{array}{l}, 184^{*} \\
, 036\end{array}$ \\
\hline FALTA RECOMPENSAS & Sig. & $\begin{array}{r}-, 215^{*} \\
, 018\end{array}$ & $\begin{array}{l}-, 240 * \\
006\end{array}$ & $\begin{array}{c}-, 317^{* *} \\
, 000\end{array}$ & $\begin{array}{l}-, 308 * \\
000\end{array}$ & $\begin{array}{l}-, 197^{*} \\
, 030\end{array}$ & $\begin{array}{l}-, 280 * \\
001 \\
, 001\end{array}$ & $\begin{array}{l}-, 336^{* *} \\
, 000\end{array}$ & $\begin{array}{l}-, 385 * \\
, 000\end{array}$ & $\begin{array}{l}-, 030 \\
, 742\end{array}$ & $\begin{array}{l}-, 151 \\
088\end{array}$ & $\begin{array}{c}-, 122 \\
, 184\end{array}$ & $\begin{array}{l}-, 079 \\
, 373\end{array}$ & $\begin{array}{l}-, 131 \\
, 151\end{array}$ & $\begin{array}{l}-, 144 \\
, 105\end{array}$ & $\begin{array}{l}-, 133 \\
, 146\end{array}$ & $\begin{array}{l}-, 205^{*} \\
, 020\end{array}$ \\
\hline $\begin{array}{l}\text { LINHA CONSISTENTE DE } \\
\text { ATIVIDADE }\end{array}$ & Sig. & $\begin{array}{l}-, 005 \\
, 961\end{array}$ & $\begin{array}{l}, 156 \\
, 077\end{array}$ & $\begin{array}{l}072 \\
, 435\end{array}$ & $\begin{array}{l}, 186^{*} \\
035\end{array}$ & $\begin{array}{l}, 022 \\
, 810\end{array}$ & $\begin{array}{l}, 226^{*} \\
, 010\end{array}$ & $\begin{array}{l}, 082 \\
, 374\end{array}$ & $\begin{array}{l}, 133 \\
134\end{array}$ & $\begin{array}{l}-, 080 \\
, 381\end{array}$ & $\begin{array}{l}, 146 \\
, 098\end{array}$ & $\begin{array}{l}, 228^{*} \\
, 012\end{array}$ & $\begin{array}{l}, 251^{* *} \\
, 004\end{array}$ & $\begin{array}{l}, 060 \\
, 511\end{array}$ & $\begin{array}{l}, 281^{* *} \\
, 001\end{array}$ & $\begin{array}{l}\text {,178 } \\
, 050\end{array}$ & $\begin{array}{l}, 179^{*} \\
, 042\end{array}$ \\
\hline ESCASSEZ DE ALTERNATIVAS & Sig. & $\begin{array}{r}-, 082 \\
, 373\end{array}$ & $\begin{array}{l}\text {,172 } \\
\text {,050 }\end{array}$ & $\begin{array}{r}-, 158 \\
, 084\end{array}$ & $\begin{array}{l}\text { 134 } \\
\text { 130 }\end{array}$ & $\begin{array}{l}-, 025 \\
, 788\end{array}$ & $\begin{array}{l}134 \\
, 129\end{array}$ & $\begin{array}{r}-, 099 \\
, 279\end{array}$ & $\begin{array}{l}199^{\circ} \\
024\end{array}$ & $\begin{array}{l}-, 204^{*} \\
025\end{array}$ & $\begin{array}{l}-, 025 \\
, 778\end{array}$ & $\begin{array}{l}-, 010 \\
, 914\end{array}$ & $\begin{array}{l}\text {, } 109 \\
219\end{array}$ & $\begin{array}{l}-, 145 \\
, 113\end{array}$ & $\begin{array}{l}, 005 \\
, 955\end{array}$ & $\begin{array}{l}-, 090 \\
, 325\end{array}$ & $\begin{array}{l}, 005 \\
957\end{array}$ \\
\hline
\end{tabular}

**. A correlação é significativa no nível 0,01 (2 extremidades). * . A correlação é significativa no nível 0,05 (2 extremidades).

Fonte: resultados da pesquisa elaborados a partir do Software SPSS 
Em resumo, no que se refere aos testes de correlações de Pearson realizados entre os construtos, viu-se que entre os valores organizacionais e os resultados da organização não houve correlação. Houve correlação positiva somente para os resultados classificados como proativos e os tipos de práticas humanistas. E para o comprometimento e resultados, a base de comprometimento obrigação pelo desempenho foi negativamente relacionada com resultados classificados como produtivos, e as bases afiliativa e escassez de alternativas com os resultados identificados como produtivos.

Para as relações entre valores e práticas organizacionais, o tipo de prática instrumental se relacionou positivamente com as dimensões autonomia, coletividade e bem-estar e para o tipo de prática humanista com as dimensões autonomia, coletividade, realização e bem-estar.

Os construtos práticas e comprometimento não se apresentaram correlacionados. Já entre valores e comprometimento quase todas as dimensões se apresentaram relacionadas com exceção da dimensão tradição que só se mostrou relacionada com a base obrigação pelo desempenho. A dimensão autonomia não se relacionou com as bases obrigação pelo desempenho, linha consistente de atividade e escassez de alternativas. A dimensão bem-estar não se relacionou com as bases obrigação pelo desempenho e escassez de alternativas. Nenhuma das dimensões se relacionou com a base de comprometimento escassez de alternativas.

Quando analisados as relações entre valor e comprometimento em função do tempo de serviço, observou-se que as dimensões tradição e prestígio passam a se relacionar positivamente com a base afiliativa somente para os colaboradores com até 5 anos de serviço. E a base obrigação em permanecer passa a se correlacionar somente com os colaboradores que têm acima de 5 anos de serviço para as dimensões prestígio e conformidade. Já a base obrigação pelo desempenho, as dimensões coletividade e domínio se relacionam positivamente com os colaboradores com até 5 anos de serviço e realização com os que têm acima de 5 anos de trabalho nos SECOMs. E o comprometimento falta de recompensas passa a se correlacionar negativamente com a dimensão domínio para os colaboradores com até 5 anos de tempo de casa. A base linha consistente de atividade passa a se correlacionar com as dimensões coletividade, realização e bem-estar somente para os colaboradores acima de 5 anos de tempo de serviço e para com as dimensões conformidade e domínio àqueles que 
têm acima de 5 anos de trabalho. Há correlação entre a base escassez de alternativas e as dimensões autonomia e realização somente com os colaboradores que têm mais tempo de serviço na organização.

Ao analisar as relações entre valor e comprometimento em função da nacionalidade, as diferenças observadas foi que a base obrigação em permanecer passa a se correlacionar somente com os brasileiros que atuam nos SECOMs, e para a base de comprometimento obrigação pelo desempenho somente de relaciona com os colaboradores não brasileiros no que se refere às dimensões coletividade, prestígio e domínio. A dimensão autonomia passa a se relacionar negativamente com a base falta de recompensas para os não brasileiros. Linha consistente de atividade apresentou correlações somente com não brasileiros para as dimensões coletividade, realização e domínio. E escassez de alternativas com a dimensão realização entre os não brasileiros.

Ao fazer a investigação de valor e comprometimento em função do sexo, as seguintes diferenças foram observadas: passam a se relacionar somente com o sexo feminino a dimensão autonomia com a base escassez de alternativas, a dimensão coletividade com as bases obrigação pelo desempenho e linha consistente de atividade, a dimensão realização com obrigação pelo desempenho e linha consistente de atividade, bem-estar com as bases obrigação em permanecer e escassez de alternativas, a dimensão prestígio com a base afiliativa, conformidade com linha consistente de atividade e a dimensão domínio com as bases de comprometimento afiliativa, obrigação em permanecer e falta de recompensas; e passam a se relacionar somente com o sexo masculino a dimensão tradição e a base escassez de alternativas, mas esta correlação é negativa. 


\subsection{Análises Multivariadas}

As análises multivariadas a seguir apresentam os seguintes procedimentos: (1) teste Outer Model (Modelo de Mensuração) e (2) teste do Inner Model (Modelo Estrutural).

\subsubsection{Avaliação do Modelo - SECOMs}

O modelo apresentado na figura 43 tem como proposta verificar os valores, as práticas e o comprometimento e como suas relações podem ser estabelecidas com os resultados organizacionais nos SECOMs. O modelo será analisado por meio da análise de equações estruturais pelo método de mínimos quadrados.

Figura 43 - Análise multivariada conjunta para a organização local

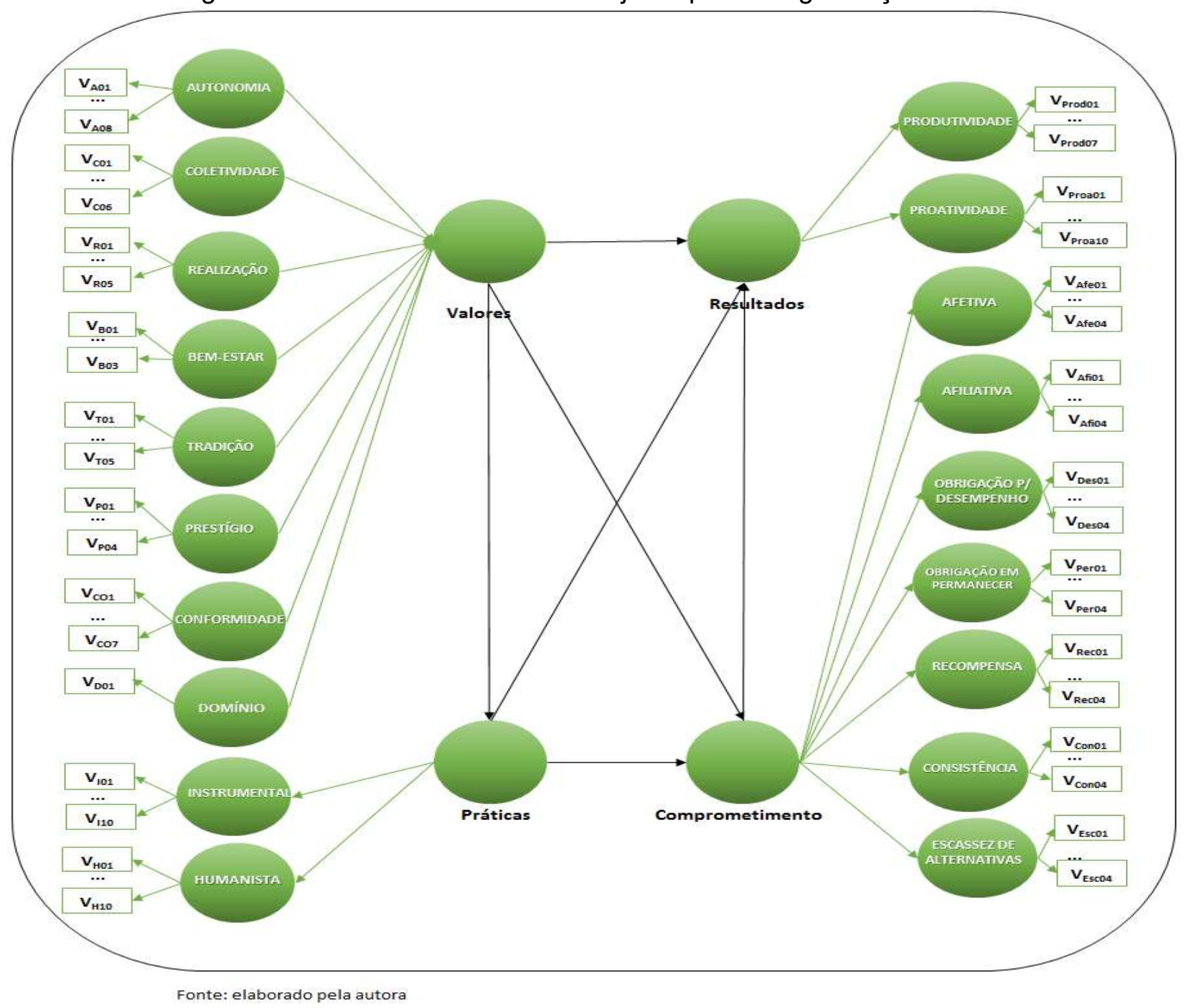




\subsubsection{Avaliação do Outer Model - Modelo de Medição}

A avaliação sistemática dos critérios segue um processo em duas etapas. O processo envolve avaliações separadas de modelos de mensuração para o reflexivo e para o formativo, como visto no quadro 25 :

Quadro 35 - Avaliação dos Modelos de Medição - Outer Model

\begin{tabular}{|c|c|}
\hline Modelos de medição reflexivo & Modelos de medição formativo \\
\hline Consistência interna & Validade convergente \\
\hline Alfa de Cronbach & Variância média extraída (AVE) \\
\hline Confiabilidade composta & Colinearidade entre indicadores \\
\hline Validade Convergente & Variance Inflation Factor (VIF) \\
\hline Confiabilidade do indicador & Significância e relevância dos outer weights \\
\hline Variância média extraída (AVE) & Bootstrapping procedure \\
\hline Validade discriminante (HTMT) & t-value e p-value dos outer weights \\
\hline \multicolumn{2}{|c|}{ Avaliação do Modelo Estrutural - Inner Model } \\
\hline \multicolumn{2}{|c|}{ Coeficiente de determinação $\left(R^{2}\right)$ ou variação explicada } \\
\hline \multicolumn{2}{|l|}{ Relevância preditiva - $Q^{2}$} \\
\hline \multicolumn{2}{|c|}{ Tamanho e significância dos coeficientes de caminho } \\
\hline \multicolumn{2}{|l|}{ Tamanho do efeito - $f^{2}$} \\
\hline \multicolumn{2}{|l|}{ Tamanho do efeito $-q^{2}$} \\
\hline
\end{tabular}

Fonte: Hair et al. (2017) p. 106 - com adaptações

A seguir são apresentados os resultados das avaliações dos construtos valores, práticas e comprometimento. O construto valores possui as seguintes variáveis latentes: autonomia, coletividade, realização, bem-estar, tradição, prestígio, conformidade e domínio. Todas as variáveis latentes desse construto são reflexivas.

O construto tipos de práticas possui as variáveis latentes instrumental e humanistas e também são reflexivas, assim como as variáveis latentes do construto comprometimento, que são: afetiva, afiliativa, obrigação pelo desempenho, obrigação em permanecer, recompensas, linha consistente de atividade e escassez de alternativas. E da mesma forma, as variáveis latentes (proatividade e produtividade) do construto resultados organizacionais. 


\subsection{Resultados do modelo de medição reflexivo (Outer Model) para as variáveis latentes - Valores}

$\mathrm{Na}$ tabela 68 apesentam-se os resultados dos testes de confiabilidade Alfa de Cronbach e Confiabilidade Composta para as medidas de consistência interna. Já para as medidas de validade, calculou-se a validade convergente (análise dos outer loadings e o quadrado do outer loading - indicador de confiabilidade) e a Variância Média Extraída (AVE), bem como a validade discriminante, que é o complemento metodológico da validade convergente. Nesta tabela a Validade Discriminante foi verificada por meio da estatística HTMT (Heterotrait-Monotrait).

\subsubsection{1(a) Analise da Confiabilidade e de Validade Convergente das variáveis latentes que compõem o construto valores}

A variável latente autonomia apresentou confiabilidade composta acima do valor máximo estabelecido de 0,95. De acordo com Hayduk \& Littvary (2012), o resultado acima de 0,95 pode indicar que há variáveis que estejam medindo o mesmo fenômeno, ou seja, quando se usam itens semanticamente redundantes. Dessa forma, retirou-se $\mathrm{V}_{\mathrm{A} 03}$ (Esta organização valoriza colaboradores curiosos. Ela gosta de colaboradores que gostam de se informar a respeito do trabalho), que apresenta semelhança ao item $V_{\text {A07 }}$ (Esta organização deseja que o colaborador tenha uma vida profissional variada, valorizando aqueles que têm experiências profissionais diferentes). Da mesma forma o item $\mathrm{V}_{\mathrm{A} 06}$ (Esta organização prioriza a criatividade, pois gosta de ser original) foi retirado da análise multivariada por apresentar semelhança semântica ao item $V_{\text {A08 }}$ (Esta organização estimula o colaborador a ser criativo. Ela estimula o desenvolvimento de produtos e serviços originais). Repetiu-se o algoritmo e o resultado foi confiabilidade composta de 0,945 e alfa de Cronbach no valor de 0,929 .

A variável latente conformidade apresentou $A V E=0,451(<0,5)$, ao analisar os itens verificou-se que $V_{\text {co04 }}$ possui outer loading $=0,366$ que é menor que 0,70, este item foi retirado e o algoritmo PLS-SEM foi rodado novamente, de sorte que o AVE aumentou ( $\mathrm{AVE}=0,540$ ) e, consequentemente, alfa de Cronbach que passou de 0,816 para 0,833 e a confiabilidade composta de 0,860 para 0,874 . 
A análise discriminante que examina a unicidade do construto foi avaliada por três critérios: HTMT, Fornell-Larcker e Cross-loadings. Pelo critério HTMT, em que o intervalo de confiança não pode conter o 1 e o valor limite da média entre as variáveis latentes é de 0,90. A relação entre realização -> autonomia apresentou média 0,973 e intervalos contendo o $1[0,93-1,00]$. No critério de cross-loading, o item $V_{R 04}$ apresentou valor maior que as cargas entre os indicadores e seus respectivos construtos da variável latente autonomia. 
Tabela 68-Análise de confiabilidade e de validade convergente - Valores Organizacionais - SECOMs

\begin{tabular}{|c|c|c|c|c|c|c|c|c|c|}
\hline \multirow{4}{*}{$\begin{array}{l}\text { Variável Latente } \\
\text { (Construto) }\end{array}$} & \multirow{2}{*}{\multicolumn{2}{|c|}{$\begin{array}{c}\text { Confiabilidade } \\
\text { Medida de consistência interna }\end{array}$}} & \multirow{4}{*}{ Indicadores } & \multicolumn{6}{|c|}{ Validade } \\
\hline & & & & \multicolumn{3}{|c|}{ Validade convergente } & \multirow{2}{*}{\multicolumn{3}{|c|}{$\begin{array}{c}\text { Validade Discriminante } \\
\begin{array}{l}\text { Intervalo de confiança não inclui } 1 \\
\text { (bootstrapping procedure) }\end{array}\end{array}$}} \\
\hline & \multirow{2}{*}{$\begin{array}{c}\text { Confiabilidade } \\
\text { composta } \\
0,60 \leq \rho \leq 0,95\end{array}$} & \multirow{2}{*}{$\begin{array}{c}\text { Alfa de } \\
\text { Cronbach } \\
0,60 \leq \alpha \leq \\
0,95\end{array}$} & & \multirow{2}{*}{$\begin{array}{c}\text { Outer } \\
\text { Loadings } \\
\geq 0,708\end{array}$} & \multirow{2}{*}{$\begin{array}{l}\text { Indicador de } \\
\text { confiabilidade } \\
>0,50\end{array}$} & \multirow[t]{2}{*}{$\begin{array}{l}\text { AVE } \\
>0,50\end{array}$} & & & \\
\hline & & & & & & & Variáveis & $2,5 \%$ & $97,5 \%$ \\
\hline \multirow{8}{*}{ Autonomia } & \multirow{8}{*}{$\begin{array}{c}0,958 \\
\text { Retirou-se } \\
\mathrm{V}_{\mathrm{A} 03} \text { e } \mathrm{V}_{\mathrm{A} 06}\end{array}$} & \multirow{8}{*}{$\begin{array}{l}0,950 \\
0,929\end{array}$} & $\mathrm{~V}_{\mathrm{A} 01}$ & 0,800 & 0,640 & \multirow{8}{*}{0,740} & \multirow{2}{*}{$\begin{array}{c}\text { Bem-estar -> } \\
\text { Autonomia } \\
(\mu=0,898)\end{array}$} & \multirow{2}{*}{0,85} & \multirow{2}{*}{0,94} \\
\hline & & & $\mathrm{V}_{\mathrm{A} 02}$ & 0,867 & 0,751 & & & & \\
\hline & & & $\mathrm{V}_{\mathrm{A} 03}$ & 0,865 & 0,749 & & \multirow{2}{*}{$\begin{array}{l}\text { Coletividade - } \\
\text { Autonomia } \\
\quad(\mu=0,848)\end{array}$} & \multirow{2}{*}{0,79} & \multirow{2}{*}{0,89} \\
\hline & & & $\mathrm{V}_{\mathrm{A} 04}$ & 0,824 & 0,678 & & & & \\
\hline & & & $\mathrm{V}_{\mathrm{A} 05}$ & 0,911 & 0,830 & & Conformidade & & \\
\hline & & & $V_{A 06}$ & 0,853 & 0,728 & & $\begin{array}{c}\rightarrow>\text { Autonomia } \\
\quad(\mu=0,587)\end{array}$ & 0,49 & 0,68 \\
\hline & & & $\mathrm{V}_{\mathrm{A} 07}$ & 0,857 & 0,735 & & Prestígio-> & 041 & 060 \\
\hline & & & $V_{\mathrm{A} 08}$ & 0,899 & 0,809 & & $(\mu=0,514)$ & 0,41 & 0,00 \\
\hline \multirow{6}{*}{ Coletividade } & \multirow{6}{*}{0,933} & & $\mathrm{~V}_{\mathrm{C01}}$ & 0,866 & 0,750 & & Realização-> & 093 & 100 \\
\hline & & & $\mathrm{V}_{\mathrm{C02}}$ & 0,817 & 0,668 & & $\begin{array}{l}\text { Autonoma } \\
\qquad(\mu=0,973)\end{array}$ & 0,93 & 1,00 \\
\hline & & & $\mathrm{V}_{\mathrm{CO3}}$ & 0,834 & 0,696 & & Tradição -> & & \\
\hline & & $0,9<2$ & $\mathrm{~V}_{\mathrm{CO4}}$ & 0,897 & 0,805 & 0,119 & $\begin{array}{l}\text { Autonoma } \\
(\mu=0,250)\end{array}$ & $0,1 /$ & 0,35 \\
\hline & & & $\mathrm{V}_{\mathrm{CO5}}$ & 0,839 & 0,704 & & Conformidd- & & \\
\hline & & & $\mathrm{V}_{\mathrm{CO6}}$ & 0,832 & 0,693 & & $\begin{array}{r}\text { Coletividade } \\
(\mu=0,738)\end{array}$ & 0,65 & 0,80 \\
\hline & & & $\mathrm{V}_{\mathrm{R} 01}$ & 0,880 & 0,775 & & $\begin{array}{l}\text { Coletividade- } \\
\text { Bem-estar } \\
\quad(\mu=0,808)\end{array}$ & 0,75 & 0,86 \\
\hline & & & $\mathrm{V}_{\mathrm{R} 02}$ & 0,783 & 0,613 & & $\begin{array}{l}\text { Prestígio -> } \\
\text { Bem-estar } \\
\quad(\mu=0,484)\end{array}$ & 0,36 & 0,59 \\
\hline Realızaçao & $0,9<8$ & 0,902 & $\mathrm{~V}_{\mathrm{R} 03}$ & 0,858 & 0,736 & $0, / 20$ & $\begin{array}{c}\text { Conformidade } \\
\rightarrow>\text { Bem-estar } \\
(\mu=0,538)\end{array}$ & 0,43 & 0,65 \\
\hline & & & $\mathrm{V}_{\mathrm{R} 04}$ & 0,872 & 0,760 & & Prestígio & & \\
\hline & & & $\mathrm{V}_{\mathrm{R} 05}$ & 0,846 & 0,715 & & $\begin{array}{c}\rightarrow>\text { coletividade } \\
\quad(\mu=0,512)\end{array}$ & 0,40 & 0,62 \\
\hline & & & $V_{B 01}$ & 0,868 & 0,754 & & $\begin{array}{l}\text { Prestígio } \\
\text {-Conformidd } \\
(\mu=0,593)\end{array}$ & 0,47 & 0,71 \\
\hline Bem-estar & 0,917 & 0,865 & $\mathrm{~V}_{\mathrm{B} 02}$ & 0,870 & 0,756 & 0,787 & $\begin{array}{l}\text { Realização } \\
\rightarrow \text { Bem-estar } \\
(\mu=0,793)\end{array}$ & 0,74 & 0,88 \\
\hline & & & $\mathrm{V}_{\mathrm{B} 03}$ & 0,922 & 0,850 & & $\begin{array}{c}\text { Realização } \\
\rightarrow>\text { coletividade } \\
(\mu=0,902)\end{array}$ & 0,85 & 0,96 \\
\hline Prestígio & 0,905 & 0,860 & $\mathrm{~V}_{\mathrm{P} 01}$ & 0,818 & 0,669 & 0,707 & Realização- & 0,61 & 0,78 \\
\hline & & & $\mathrm{V}_{\mathrm{P} 02}$ & 0,841 & 0,707 & & $\begin{array}{c}\text { Contormidade } \\
\quad(\mu=0,730)\end{array}$ & & \\
\hline & & & $\mathrm{V}_{\mathrm{P} 03}$ & 0,820 & 0,672 & & Realiz-> Prest & 0,43 & 0,66 \\
\hline & & & $\mathrm{V}_{\mathrm{P} 04}$ & 0,875 & 0,766 & & & & \\
\hline Conformidade & 0,860 & 0,816 & $\mathrm{~V}_{\mathrm{CO01}}$ & 0,834 & 0,696 & 0,481 & Tradição & 0,17 & 0,35 \\
\hline & & & $\mathrm{V}_{\mathrm{COO2}}$ & 0,776 & 0,602 & & $\begin{array}{c}>\text { Autonomia } \\
\quad(\mu=0,250)\end{array}$ & & \\
\hline & & & $V_{\text {CO03 }}$ & 0,612 & 0,375 & Saiu & Trad->Bem- & 0,17 & 0,36 \\
\hline & 0,874 & 0,833 & $V_{\text {CO04 }}$ & 0,366 & 0,134 & $\mathrm{~V}_{\mathrm{CO} 4}$ & $\operatorname{estar}(\mu=0,258)$ & & \\
\hline & & & $V_{C 005}$ & 0,783 & 0,614 & & Tradição- & 0,15 & 0,32 \\
\hline & & & $V_{c 006}$ & 0,791 & 0,626 & 0,540 & $\begin{array}{c}\text { Coletividade } \\
(\mu=0,211)\end{array}$ & & \\
\hline & & & $V_{\text {C007 }}$ & 0,567 & 0,321 & & & 0,40 & 0,65 \\
\hline Tradição & 0,808 & 0,833 & $\mathrm{~V}_{\text {T01 }}$ & 0,881 & 0,776 & 0,485 & $\begin{array}{c}\text { Conformidade } \\
\quad(\mu=0,513)\end{array}$ & & \\
\hline & & & $\mathrm{V}_{\text {T02 }}$ & 0,860 & 0,740 & & Tradição & 0,26 & 0,56 \\
\hline & 0865 & 0,822 & $\mathrm{~V}_{\text {T03 }}$ & 0,294 & 0,086 & $V_{T R 2}$ & $\begin{array}{c}->\text { PrestigIO } \\
(\mu=0,419)\end{array}$ & & \\
\hline & & & $\mathrm{V}_{\text {T04 }}$ & 0,492 & 0,242 & $\begin{array}{l}\text { VT03 } \\
\mathbf{0 . 6 2 2}\end{array}$ & Trad-Realiz & 0,18 & 0,37 \\
\hline & & & $\mathrm{V}_{\text {T05 }}$ & 0,762 & 0,580 & $0,6<2$ & $(\mu=0,249)$ & & \\
\hline
\end{tabular}

Fonte: Dados da pesquisa por meio do software Smart-PLS 3.0 


\subsubsection{1(b) Análise da Validade Discriminante das variáveis latentes - Valores}

\section{Critério cross-loadings}

Neste critério, o outer loading de um indicador associado ao construto deve ser maior do que qualquer uma das suas cargas cruzadas (ou seja, suas correlações) em outros construtos.

Tabela 69 - Critério Cross-loadings para avaliar a Validade Discriminante - Valores

\begin{tabular}{|c|c|c|c|c|c|c|c|c|}
\hline Itens & Autonomia & Bem-Estar & Coletividade & Conformidade & Domínio & Prestígio & Realização & Tradição \\
\hline$V_{A 01}$ & 0,8223 & 0,6458 & 0,6773 & 0,4695 & 0,3339 & 0,3493 & 0,7887 & 0,2022 \\
\hline $\mathrm{V}_{\mathrm{A} 02}$ & 0,8834 & 0,7563 & 0,7404 & 0,5372 & 0,3917 & 0,4469 & 0,8152 & 0,3145 \\
\hline$V_{\text {A04 }}$ & 0,8388 & 0,6415 & 0,6584 & 0,4898 & 0,4514 & 0,4784 & 0,7530 & 0,2310 \\
\hline $\mathrm{V}_{\mathrm{A} 05}$ & 0,9109 & 0,7476 & 0,7136 & 0,4943 & 0,4193 & 0,3741 & 0,8160 & 0,2083 \\
\hline$V_{\text {A07 }}$ & 0,8598 & 0,7151 & 0,6249 & 0,4518 & 0,4596 & 0,3982 & 0,7625 & 0,2515 \\
\hline$V_{\text {A08 }}$ & 0,8516 & 0,7240 & 0,6898 & 0,4791 & 0,4738 & 0,4041 & 0,7968 & 0,1719 \\
\hline$V_{\text {B01 }}$ & 0,7794 & 0,8684 & 0,7297 & 0,5050 & 0,3465 & 0,3327 & 0,7317 & 0,2337 \\
\hline$V_{\text {B02 }}$ & 0,6310 & 0,8698 & 0,5005 & 0,3364 & 0,3966 & 0,3809 & 0,5230 & 0,2013 \\
\hline$V_{\text {B03 }}$ & 0,7396 & 0,9216 & 0,6930 & 0,5309 & 0,5106 & 0,4244 & 0,6766 & 0,2637 \\
\hline$V_{c 01}$ & 0,7550 & 0,6587 & 0,8662 & 0,6011 & 0,5010 & 0,3951 & 0,7939 & 0,2208 \\
\hline $\mathrm{V}_{\mathrm{C02}}$ & 0,7028 & 0,6672 & 0,8177 & 0,5223 & 0,3924 & 0,2558 & 0,7291 & 0,0355 \\
\hline $\mathrm{V}_{\mathrm{c03}}$ & 0,5740 & 0,5420 & 0,8337 & 0,6224 & 0,4289 & 0,4827 & 0,6110 & 0,2671 \\
\hline vCO4 & 0,6927 & 0,6646 & 0,8971 & 0,6499 & 0,4153 & 0,3780 & 0,7310 & 0,1696 \\
\hline vc05 & 0,6451 & 0,5856 & 0,8393 & 0,5832 & 0,4812 & 0,4056 & 0,6611 & 0,1591 \\
\hline vc06 & 0,6384 & 0,6058 & 0,8318 & 0,6324 & 0,4559 & 0,4479 & 0,6687 & 0,1952 \\
\hline vco01 & 0,4209 & 0,3655 & 0,6005 & 0,8504 & 0,3972 & 0,3562 & 0,5353 & 0,3033 \\
\hline vco02 & 0,4215 & 0,4125 & 0,5042 & 0,7715 & 0,3875 & 0,3822 & 0,5117 & 0,3964 \\
\hline vco05 & 0,5325 & 0,4899 & 0,6886 & 0,8172 & 0,4144 & 0,4230 & 0,5438 & 0,2592 \\
\hline vco06 & 0,5065 & 0,5027 & 0,5590 & 0,8011 & 0,5809 & 0,4721 & 0,5490 & 0,4237 \\
\hline vco07 & 0,1757 & 0,0998 & 0,2392 & 0,5383 & 0,2615 & 0,2507 & 0,2254 & 0,3106 \\
\hline VD01 & 0,4882 & 0,4723 & 0,5261 & 0,5477 & 1,0000 & 0,3794 & 0,4851 & 0,2891 \\
\hline VP01 & 0,4970 & 0,4537 & 0,4553 & 0,4034 & 0,2954 & 0,8186 & 0,4928 & 0,3645 \\
\hline VP02 & 0,2959 & 0,2654 & 0,2880 & 0,3705 & 0,3177 & 0,8405 & 0,3276 & 0,3052 \\
\hline VP03 & 0,3678 & 0,3457 & 0,3884 & 0,4614 & 0,3561 & 0,8191 & 0,3797 & 0,3526 \\
\hline VP04 & 0,3605 & 0,3369 & 0,3963 & 0,4468 & 0,3055 & 0,8751 & 0,3885 & 0,3047 \\
\hline VR01 & 0,7847 & 0,6298 & 0,7495 & 0,5489 & 0,3462 & 0,3821 & 0,8808 & 0,2020 \\
\hline VR02 & 0,6864 & 0,5187 & 0,6310 & 0,5760 & 0,4187 & 0,4233 & 0,7825 & 0,2835 \\
\hline VR03 & 0,7533 & 0,6160 & 0,7300 & 0,5770 & 0,4208 & 0,3735 & 0,8578 & 0,2061 \\
\hline VR04 & 0,8943 & 0,7245 & 0,7048 & 0,5095 & 0,4026 & 0,4253 & 0,8715 & 0,2328 \\
\hline VR05 & 0,7554 & 0,6172 & 0,6877 & 0,5284 & 0,4736 & 0,4427 & 0,8458 & 0,1978 \\
\hline VT01 & 0,2872 & 0,2843 & 0,2137 & 0,3617 & 0,2294 & 0,4036 & 0,2923 & 0,8841 \\
\hline VT02 & 0,1973 & 0,1894 & 0,1609 & 0,3473 & 0,2474 & 0,3118 & 0,2072 & 0,8746 \\
\hline VT04 & $-0,0644$ & $-0,0547$ & $-0,0726$ & 0,0976 & 0,0081 & 0,1489 & $-0,0543$ & 0,5583 \\
\hline VT05 & 0,1448 & 0,1809 & 0,1353 & 0,4130 & 0,2701 & 0,2801 & 0,1431 & 0,7844 \\
\hline
\end{tabular}


A tabela 69 indica que somente a carga cruzada (cross-loading) do item $\mathrm{V}_{\mathrm{R} 04}$ apresentou valor maior que as cargas entre os indicadores e seus respectivos construtos.

\section{Critério Fornell-Larcker}

O critério de Fornell-Larcker se utiliza da AVE para verificar se a variância dos indicadores de uma mesma variável latente é maior na variável latente em questão do que nas demais variáveis latentes. Por este critério, a variância da variável latente mostra-se maior que as demais variáveis.

Tabela 70 - Critério Fornell-Larcker para avaliar a validade discriminante - Valores

\begin{tabular}{lllllllll}
\hline Variável Latente & Autonomia & Bem-Estar & Coletividade & Conformidade & Domínio & Prestigio & Realização & Tradição \\
Autonomia & $\mathbf{0 , 9 6 0 1}$ & & & & & & & \\
Bem-Estar & 0,8141 & $\mathbf{0 , 8 8 6 9}$ & & & & & & \\
Coletividade & 0,7898 & 0,7333 & $\mathbf{0 , 8 4 8 0}$ & & & & & \\
Conformidade & 0,5664 & 0,5248 & 0,7099 & $\mathbf{0 , 7 6 3 9}$ & & & & \\
Domínio & 0,4882 & 0,4723 & 0,5261 & 0,5477 & $\mathbf{1 , 0 0 0 0}$ & & & \\
Prestígio & 0,4634 & 0,4271 & 0,4639 & 0,5036 & 0,3794 & $\mathbf{0 , 8 3 8 7}$ & & \\
Realização & 0,8657 & 0,7347 & 0,8267 & 0,6445 & 0,4851 & 0,4819 & $\mathbf{0 , 8 4 8 4}$ & \\
Tradição & 0,2577 & 0,2648 & 0,2060 & 0,4353 & 0,2891 & 0,3988 & 0,2633 & $\mathbf{0 , 7 8 6 3}$ \\
\hline
\end{tabular}

Fonte: Resultados da pesquisa elaborados por meio do software Smart-PLS 3.0

\subsection{Resultados do modelo de medição reflexivo (Outer Model) para as variáveis latentes do construto Práticas Organizacionais}

$\mathrm{Na}$ tabela 71 apresentam-se os resultados dos testes de confiabilidade Alfa de Cronbach e Confiabilidade composta para as medidas de consistência interna. Já para as medidas de validade, calculou-se a validade convergente (análise dos outer loadings e o quadrado do outer loading - indicador de confiabilidade) e a Variância Média Extraída (AVE), bem como a validade discriminante, que é o complemento metodológico da validade convergente. Nesta tabela a Validade Discriminante foi verificada por meio da estatística HTMT (Heterotrait-Monotrait). 


\subsubsection{2(a) Análise de confiabilidade e análise convergente das variáveis latentes - Tipos de Práticas Organizacionais}

A variável latente instrumental apresentou $A V E=0,455(<0,5)$, ao se analisarem os itens, verificou-se que $\mathrm{V}_{101}, \mathrm{~V}_{102}, \mathrm{~V}_{107}$ possuíam outer loadings inferiores a 0,708. Após a retirada dos itens e algoritmo PLS-SEM rodado novamente, o resultado da Variância Média Extraída aumentou, passando para 0,615 e, consequentemente, alfa de Cronbach, que passou de 0,816 para 0,896 e a confiabilidade composta de 0,864 para 0,918. Semelhantemente, o item $V_{\mathrm{H} 02}$ da variável latente humanista apresentou carga de 0,036. Após sua retirada a Variância Média Extraída - AVE, passou de 0,415 para 0,461 que ainda é inferior ao limite estabelecido de 0,50. Então, foram retirados os itens com as menores cargas: $\mathrm{V}_{\mathrm{H} 05}(0,497)$ e $\mathrm{V}_{\mathrm{H} 10}(0,585)$, o que resultou no aumento da AVE para 0,514 e, com isso as medidas de consistência interna alteram de 0,849 para 0,881 para a confiabilidade composta e de 0,825 para 0,844 para o alfa de Cronbach.

Tabela 71 - Análise de confiabilidade e de validade convergente - Práticas Organizacionais - SECOMs

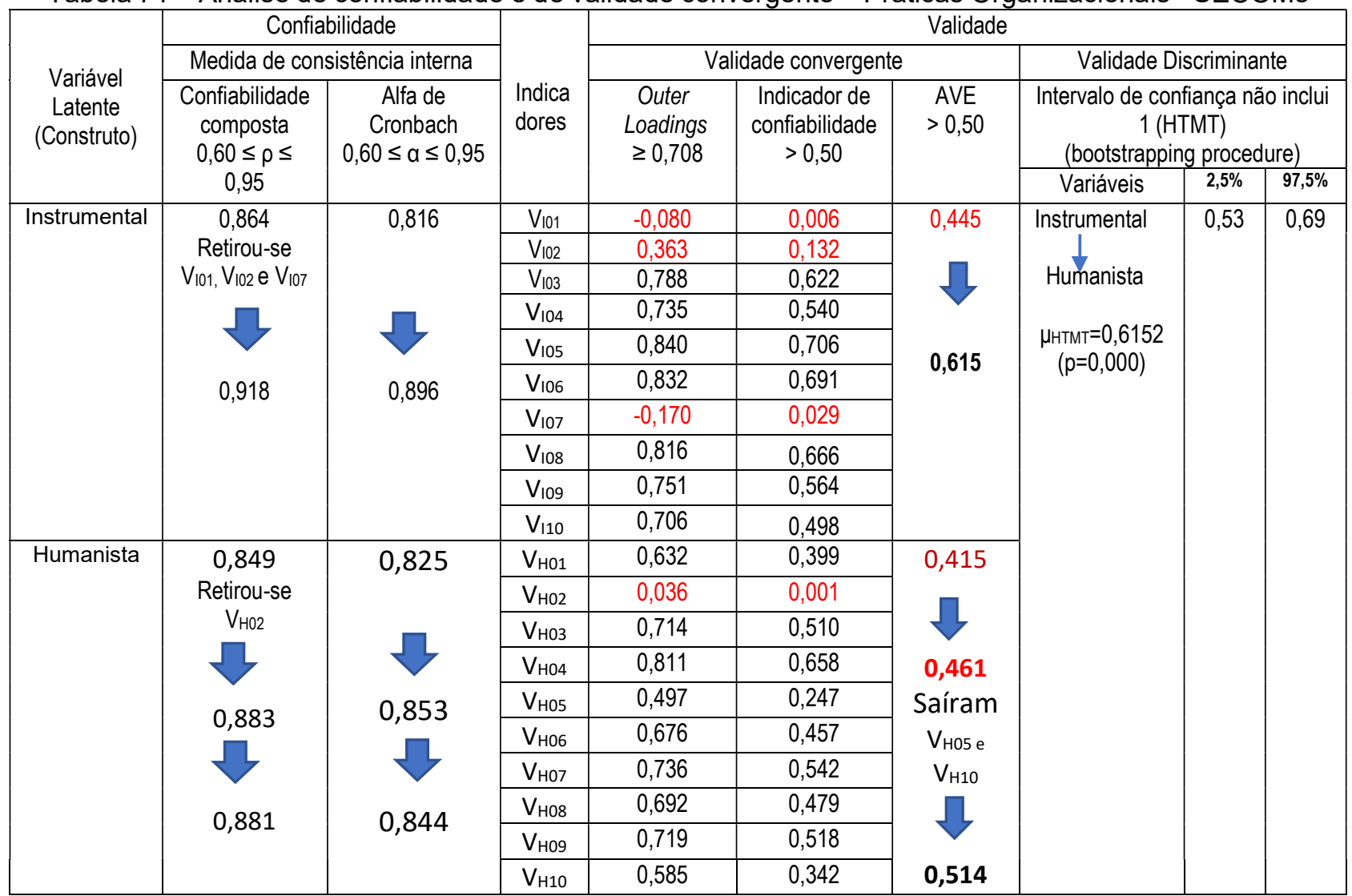

Fonte: Resultados da pesquisa elaborados por meio do software Smart-PLS 3.0 


\subsubsection{2(b) Análise da Validade Discriminante das variáveis latentes - Práticas Organizacionais}

\section{Critério cross-loadings}

A análise discriminante avaliada pelo critério HTMT apresentou-se dentro dos limites estabelecidos com média de 0,6152 para a relação entre as variáveis latentes instrumental -> humanista e intervalo sem conter o 1, [0,53-0,69]. Nos critérios de Fornell-Larcker e de Cross-loadings, os resultados também se apresentaram nos limites determinados pelos modelos de avaliação, conforme podem ser vistos nas tabelas 72 e 73 .

Tabela 72 - Critério Cross-loadings para avaliar a validade discriminante - Práticas

\begin{tabular}{lcc}
\hline & Humanista & Instrumental \\
$\mathbf{V}_{\text {H01 }}$ & $\mathbf{0 , 6 3 1 7}$ & 0,1583 \\
$\mathbf{V}_{\text {H03 }}$ & $\mathbf{0 , 7 1 4 1}$ & 0,6497 \\
$\mathbf{V}_{\text {H04 }}$ & $\mathbf{0 , 8 1 1 4}$ & 0,3489 \\
$\mathbf{V}_{\text {H06 }}$ & $\mathbf{0 , 6 7 5 9}$ & 0,2492 \\
$\mathbf{V}_{\text {H07 }}$ & $\mathbf{0 , 7 3 6 4}$ & 0,5675 \\
$\mathbf{V}_{\text {H08 }}$ & $\mathbf{0 , 6 9 1 9}$ & 0,3602 \\
$\mathbf{V}_{\text {H09 }}$ & $\mathbf{0 , 7 1 9 4}$ & 0,4502 \\
$\mathbf{V}_{\mathbf{1 0 3}}$ & 0,5458 & $\mathbf{0 , 7 8 8 4}$ \\
$\mathbf{V}_{\mathbf{1 0 4}}$ & 0,1189 & $\mathbf{0 , 7 3 4 9}$ \\
$\mathbf{V}_{\mathbf{1 0 5}}$ & 0,4527 & $\mathbf{0 , 8 4 0 1}$ \\
$\mathbf{V}_{\mathbf{1 0 6}}$ & 0,4907 & $\mathbf{0 , 8 3 1 6}$ \\
$\mathbf{V}_{\mathbf{1 0 8}}$ & 0,2357 & $\mathbf{0 , 8 1 6 0}$ \\
$\mathbf{V}_{\mathbf{1 0 9}}$ & 0,2807 & $\mathbf{0 , 7 5 0 7}$ \\
$\mathbf{V}_{\mathbf{1 0 0}}$ & 0,6916 & $\mathbf{0 , 7 0 5 9}$ \\
\hline
\end{tabular}

Fonte: Resultados da pesquisa elaborados por meio do software Smart-PLS 3.0

\section{Critério Fornell-Larcker}

O critério de Fornell-Larcker se utiliza da AVE para verificar se a variância dos indicadores de uma mesma variável latente é maior na variável latente em questão do que nas demais variáveis latentes. Por este critério, a variância da variável latente mostra-se maior que as demais variáveis.

Tabela73 - Critério Fornell-Larcker para avaliar a validade discriminante - Práticas

\begin{tabular}{lcc}
\hline & Humanista & Instrumental \\
Humanista & 0,6445 & \\
Instrumental & 0,5537 & 0,6673 \\
\hline
\end{tabular}

Fonte: Resultados da pesquisa elaborados por meio do software Smart-PLS 3.0 


\subsection{Resultados do modelo de medição reflexivo (Outer Model) para as variáveis latentes do construto Comprometimento}

$\mathrm{Na}$ tabela 74, apesentam-se os resultados dos testes de confiabilidade Alfa de Cronbach e Confiabilidade composta para as medidas de consistência interna. Já para as medidas de validade, calculou-se a validade convergente (análise dos outer loadings e o quadrado do outer loading - indicador de confiabilidade) e a Variância Média Extraída ( $\mathrm{AVE}$ ), bem como a validade discriminante, que é o complemento metodológico da validade convergente. Nesta tabela a Validade Discriminante foi verificada por meio da estatística HTMT (Heterotrait-Monotrait).

\subsubsection{3(a) Análise de confiabilidade e análise convergente das variáveis latentes - Comprometimento}

O outer loading do item $V_{\text {Des3 }}$ da variável latente obrigação pelo desempenho apresentou carga inferior a 0,708 , assim como o item $\vee_{\text {Rec1 }}$ da variável latente falta de recompensas. Os itens foram retirados e, como consequência, as medidas de consistência interna das duas variáveis foram alteradas. $O$ alfa de Cronbach passou de 0,695 para 0,760 e a confiabilidade composta de 0,799 para 0,862 na variável latente obrigação pelo desempenho e na variável falta de recompensas o alfa de Cronbach passou de 0,733 para 0,775 e a confiabilidade composta de 0,768 para 0,864 . A variável latente linha consistente de atividade apresentou $A V E=0,4908$ (<

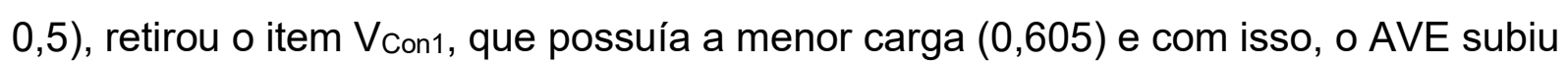
para 0,559 . 
Tabela 74 - Análise de confiabilidade e de validade convergente - Comprometimento - SECOMs

\begin{tabular}{|c|c|c|c|c|c|c|c|c|c|}
\hline \multirow{4}{*}{ Variável Latente } & \multirow{2}{*}{\multicolumn{2}{|c|}{$\begin{array}{c}\text { Confiabilidade } \\
\text { Medida de consistência interna }\end{array}$}} & \multirow{4}{*}{$\begin{array}{l}\text { Indica } \\
\text { dores }\end{array}$} & \multicolumn{6}{|c|}{ Validade } \\
\hline & & & & \multicolumn{3}{|c|}{ Validade convergente } & \multirow{2}{*}{\multicolumn{3}{|c|}{$\begin{array}{c}\text { Validade Discriminante (HTMT) } \\
\text { Intervalo de confiança não inclui } 1 \\
\text { (bootstrapping procedure) }\end{array}$}} \\
\hline & \multirow{2}{*}{$\begin{array}{c}\text { Confiabilidade } \\
\text { composta } \\
0,60 \leq \rho \leq 0,95\end{array}$} & \multirow{2}{*}{$\begin{array}{c}\text { Alfa de } \\
\text { Cronbach } \\
0,60 \leq \alpha \leq \\
0,95\end{array}$} & & \multirow{2}{*}{$\begin{array}{c}\text { Outer } \\
\text { Loadings } \\
\geq 0,708\end{array}$} & \multirow{2}{*}{$\begin{array}{l}\text { Indicador de } \\
\text { confiabilidade } \\
>0,50\end{array}$} & \multirow[t]{2}{*}{$\begin{array}{l}\text { AVE } \\
>0,50\end{array}$} & & & \\
\hline & & & & & & & Variáveis & $2,5 \%$ & $97,5 \%$ \\
\hline \multirow{4}{*}{ Afetiva } & \multirow{4}{*}{0,9382} & \multirow{4}{*}{0,9121} & $V_{\text {Afe1 }}$ & 0,869 & 0,754 & \multirow{4}{*}{0,7915} & $\begin{array}{l}\text { Afi -> Afe } \\
(\mu=0,733)\end{array}$ & 0,637 & 0,823 \\
\hline & & & $V_{\text {Afe2 }}$ & 0,906 & 0,822 & & $\begin{array}{c}\text { Con -> Afe } \\
(\mu=0,464)\end{array}$ & 0,360 & 0,729 \\
\hline & & & $V_{\text {Afe3 }}$ & 0,891 & 0,794 & & $\begin{array}{c}\text { Des -> Afe } \\
(\mu=0,399)\end{array}$ & 0,261 & 0,543 \\
\hline & & & $V_{\text {Afe4 }}$ & 0,892 & 0,796 & & $\begin{array}{l}\text { Esc } \rightarrow \text { Afe } \\
(\mu=0,222)\end{array}$ & 0,086 & 0,377 \\
\hline \multirow{4}{*}{ Afiliativa } & \multirow{4}{*}{0,9194} & \multirow{4}{*}{0,8813} & $V_{\text {Afi1 }}$ & 0,919 & 0,845 & \multirow{4}{*}{0,7414} & Per-> Afe & O 393 & 0613 \\
\hline & & & $V_{\text {Afi2 }}$ & 0,888 & 0,789 & & $(\mu=0,544)$ & 0,000 & , \\
\hline & & & $V_{\text {Afi3 }}$ & 0,875 & 0,766 & & $\begin{array}{l}\text { Rec }>\text { Afe } \\
(\mu=0,601)\end{array}$ & 0,435 & 0,750 \\
\hline & & & $\mathrm{V}_{\mathrm{Afi} i}$ & 0,752 & 0,566 & & $\begin{array}{l}\text { Con -> Afi } \\
(\mu=0,548)\end{array}$ & 0,271 & 0,663 \\
\hline \multirow{4}{*}{$\begin{array}{l}\text { Obrigação pelo } \\
\text { desempenho }\end{array}$} & \multirow{4}{*}{$\begin{array}{c}0,7992 \\
\text { Retirou-se } \\
\Downarrow V_{\text {Des3 }} \\
0,862\end{array}$} & \multirow{4}{*}{$\begin{array}{c}0,6954 \\
\Downarrow \\
0,760\end{array}$} & VDes1 & 0,823 & 0,677 & \multirow{4}{*}{$\begin{array}{c}0,5262 \\
\Downarrow \\
0,676\end{array}$} & $\begin{array}{l}\text { Des -> Afi } \\
(\mu=0,516)\end{array}$ & 0,336 & 0,679 \\
\hline & & & $V_{\text {Des2 }}$ & 0,817 & 0,668 & & $\begin{array}{l}\text { Esc -> Afi } \\
(\mu=0,257)\end{array}$ & 0,102 & 0,406 \\
\hline & & & $V_{\text {Des3 }}$ & 0,281 & 0,079 & & Per $->$ Afi & 0260 & 0.536 \\
\hline & & & $V_{\text {Des4 }}$ & 0,825 & 0,681 & & $(\mu=0,424)$ & $0, \angle 00$ & , \\
\hline \multirow{4}{*}{$\begin{array}{c}\text { Obrigação em } \\
\text { permanecer }\end{array}$} & \multirow{4}{*}{0,9336} & \multirow{4}{*}{0,9050} & $V_{\text {Per1 }}$ & 0,899 & 0,808 & \multirow{4}{*}{0,7787} & Des $->$ Con & 0382 & 0733 \\
\hline & & & $\mathrm{V}_{\text {Per2 }}$ & 0,858 & 0,737 & & $(\mu=0,435)$ & 0,002 & 0,100 \\
\hline & & & $V_{\text {Per3 }}$ & 0,858 & 0,736 & & Esc $->$ Con & 0387 & 0790 \\
\hline & & & $V_{\text {Per4 }}$ & 0,914 & 0,835 & & $(\mu=0,163)$ & 0,001 & 0,100 \\
\hline \multirow[t]{4}{*}{$\begin{array}{l}\text { Escassez de } \\
\text { alternativas }\end{array}$} & 0,8740 & 0,8042 & $\mathrm{~V}_{\mathrm{Esc} 1}$ & 0,652 & 0,424 & 0,6371 & $\begin{array}{l}\text { Rec ->Afi } \\
(\mu=0,540)\end{array}$ & 0,385 & 0,705 \\
\hline & & & $V_{\text {Esc2 }}$ & 0,861 & 0,741 & & $\begin{array}{l}\text { Per-> Con } \\
(\mu=0,382)\end{array}$ & 0,199 & 0,576 \\
\hline & & & $\mathrm{V}_{\mathrm{Esc} 3}$ & 0,870 & 0,756 & & Rec -> Des & 0241 & 0613 \\
\hline & & & $\mathrm{V}_{\mathrm{EsC} 4}$ & 0,792 & 0,627 & & $(\mu=0,434)$ & ו ו & , , \\
\hline Falta de & 0,7687 & 0,7330 & $V_{\text {Rec1 }}$ & 0,163 & 0,027 & 0,5016 & Per-> Esc & 0146 & 0469 \\
\hline recompensas & & 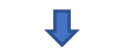 & $\mathrm{V}_{\text {Rec2 }}$ & 0,638 & 0,407 & I & $(\mu=0,305)$ & 0,140 & 0,409 \\
\hline & $\begin{array}{l}V_{\operatorname{Rec} 1} \\
0864\end{array}$ & 0,775 & $V_{\text {Rec3 }}$ & 0,902 & 0,813 & 0,682 & Per $->$ Des & 0.085 & 0338 \\
\hline & & & $V_{\operatorname{Rec} 4}$ & 0,871 & 0,759 & & $(\mu=0,220)$ & & \\
\hline Linha & 0,7926 & 0,6559 & $V_{\text {con1 }}$ & 0,605 & 0,366 & 0,4908 & Rec -> Esc & 0,087 & 0,201 \\
\hline consistente de & 0791 & & $V_{\text {con2 }}$ & 0,753 & 0,567 & Saim & $\operatorname{Rec}->$ Con & 0.140 & 0.413 \\
\hline & & & $V_{\text {Con3 }}$ & 0,665 & 0,442 & $V_{\text {Con1 }}$ & $(\mu=0,284)$ & & \\
\hline & & & $V_{\text {con4 }}$ & 0,766 & 0,587 & 0,559 & $\begin{array}{c}\text { Rec -> Per } \\
(\mu=0,302)\end{array}$ & 0,134 & 0,379 \\
\hline
\end{tabular}

Fonte: Resultados da pesquisa elaborados por meio do software Smart-PLS 3.0 


\subsubsection{3(b) Análise da Validade Discriminante das variáveis latentes - Comprometimento}

\section{Critério cross-loadings}

A análise discriminante avaliada pelo critério HTMT apresentou-se dentro dos limites estabelecidos, em que a maior média $(0,733)$ da relação entre as variáveis latentes afiliativa e afetiva é inferior ao limite (conservador) de 0,85 deste critério. Todos os intervalos das variáveis latentes deste construto não apresentaram o valor 1 entre seus limites. Nos critérios de Fornell-Larcker e de Cross-loadings, os resultados também se apresentaram nos limites determinados pelos modelos de avaliação, conforme podem ser vistos nas tabelas 75 e 76 .

Por meio do critério de Cross-loadings, os resultados apresentaram-se nos limites determinados pelos modelos de avaliação.

Tabela 75 - Critério Cross-loadings para avaliar a validade discriminante - Comprometimento

\begin{tabular}{|c|c|c|c|c|c|c|c|}
\hline Itens & Afetiva & Afiliativa & Consistência & Ob. Desempenho & Escassez & Ob. Permanecer & Recompensa \\
\hline Afe1 & 0,869 & 0,576 & 0,295 & 0,203 & 0,123 & 0,449 & $-0,507$ \\
\hline Afe2 & 0,906 & 0,560 & 0,319 & 0,324 & 0,222 & 0,473 & $-0,522$ \\
\hline Afe3 & 0,891 & 0,621 & 0,296 & 0,330 & 0,174 & 0,397 & $-0,518$ \\
\hline Afe4 & 0,892 & 0,589 & 0,297 & 0,325 & 0,128 & 0,441 & $-0,479$ \\
\hline Afi1 & 0,628 & 0,919 & 0,315 & 0,388 & 0,148 & 0,364 & $-0,459$ \\
\hline Afi2 & 0,512 & 0,888 & 0,390 & 0,341 & 0,200 & 0,248 & $-0,398$ \\
\hline Afi3 & 0,514 & 0,875 & 0,390 & 0,430 & 0,127 & 0,222 & $-0,369$ \\
\hline Afi4 & 0,605 & 0,752 & 0,247 & 0,273 & 0,248 & 0,458 & $-0,415$ \\
\hline Con2 & 0,234 & 0,248 & 0,753 & 0,213 & 0,374 & 0,220 & $-0,076$ \\
\hline Con3 & 0,274 & 0,357 & 0,665 & 0,266 & 0,268 & 0,181 & $-0,186$ \\
\hline Con4 & 0,269 & 0,293 & 0,766 & 0,384 & 0,298 & 0,227 & $-0,132$ \\
\hline Des1 & 0,320 & 0,349 & 0,358 & 0,823 & 0,123 & 0,140 & $-0,309$ \\
\hline Des2 & 0,227 & 0,325 & 0,263 & 0,817 & 0,079 & 0,145 & $-0,285$ \\
\hline Des4 & 0,277 & 0,362 & 0,363 & 0,825 & 0,086 & 0,142 & $-0,231$ \\
\hline Esc1 & 0,170 & 0,170 & 0,377 & 0,172 & 0,652 & 0,132 & $-0,121$ \\
\hline Esc2 & 0,162 & 0,167 & 0,249 & 0,037 & 0,861 & 0,256 & 0,003 \\
\hline Esc3 & 0,150 & 0,209 & 0,243 & 0,057 & 0,870 & 0,249 & 0,049 \\
\hline Esc4 & 0,092 & 0,111 & 0,354 & 0,102 & 0,792 & 0,173 & 0,024 \\
\hline Per1 & 0,448 & 0,315 & 0,209 & 0,186 & 0,172 & 0,899 & $-0,315$ \\
\hline Per2 & 0,451 & 0,291 & 0,249 & 0,151 & 0,230 & 0,858 & $-0,269$ \\
\hline Per3 & 0,456 & 0,416 & 0,259 & 0,082 & 0,290 & 0,858 & $-0,255$ \\
\hline Per4 & 0,387 & 0,307 & 0,235 & 0,184 & 0,212 & 0,914 & $-0,254$ \\
\hline Rec2 & $-0,249$ & $-0,243$ & 0,123 & $-0,263$ & 0,179 & $-0,036$ & 0,638 \\
\hline Rec3 & $-0,517$ & $-0,435$ & $-0,158$ & $-0,335$ & $-0,033$ & $-0,219$ & 0,902 \\
\hline $\operatorname{Rec} 4$ & $-0,499$ & $-0,438$ & $-0,123$ & $-0,208$ & $-0,033$ & $-0,329$ & 0,871 \\
\hline
\end{tabular}

Fonte: Resultados da pesquisa elaborados por meio do software Smart-PLS 3.0 


\section{Critério Fornell-Larcker}

O critério de Fornell-Larcker se utiliza da AVE para verificar se a variância dos indicadores de uma mesma variável latente é maior na variável latente em questão do que nas demais variáveis latentes. Por este critério, a variância da variável latente mostra-se maior que as demais variáveis.

Tabela 76 - Critério Fornell-Larcker para avaliar a validade discriminante - Comprometimento

\begin{tabular}{llcccccc}
\hline & Afetiva & Afiliativa & Consistência & Ob. Desempenho & Escassez & Ob.Permanecer & Recompensa \\
Afetiva & $\mathbf{0 , 8 8 9 7}$ & & & & & & \\
Afiliativa & 0,6590 & $\mathbf{0 , 8 6 1 0}$ & & & & & \\
Consistência & 0,3394 & 0,3890 & $\mathbf{0 , 7 0 0 6}$ & & & & \\
Desempenho & 0,3336 & 0,4165 & 0,4037 & $\mathbf{0 , 7 2 5 4}$ & & \\
Escassez & 0,1828 & 0,2096 & 0,3811 & 0,1143 & $\mathbf{0 , 7 9 8 2}$ & & \\
Obrigação & 0,4946 & 0,3783 & 0,2701 & 0,1697 & 0,2570 & $\mathbf{0 , 8 8 2 5}$ & $\mathbf{0 , 7 0 8 2}$ \\
Recompensa & $-0,5693$ & $-0,4791$ & $-0,1426$ & $-0,3306$ & $-0,0144$ & $-0,3098$ & \\
\hline
\end{tabular}

Fonte: Resultados da pesquisa elaborados por meio do software Smart-PLS 3.0

\subsection{Resultados do modelo de medição reflexivo (Outer Model) para as variáveis latentes do construto Resultados Organizacionais}

As variáveis proatividade e produtividade foram bem avaliadas e dentro dos critérios estabelecidos.

Tabela 77 - Análise de confiabilidade e de validade convergente - Resultados - SECOMs

\begin{tabular}{|c|c|c|c|c|c|c|}
\hline \multirow[b]{3}{*}{ Variável Latente } & Confiab & ade & \multirow{3}{*}{$\begin{array}{l}\text { Indica } \\
\text { dores }\end{array}$} & \multirow{2}{*}{\multicolumn{3}{|c|}{$\begin{array}{c}\text { Validade } \\
\text { Validade convergente }\end{array}$}} \\
\hline & \multicolumn{2}{|c|}{$\begin{array}{l}\text { Medida de consistência } \\
\text { interna }\end{array}$} & & & & \\
\hline & $\begin{array}{c}\text { Confiabilidade } \\
\text { composta } \\
0,60 \leq \rho \leq 0,95\end{array}$ & $\begin{array}{c}\text { Alfa de } \\
\text { Cronbach } \\
0,60 \leq \alpha \leq \\
0,95\end{array}$ & & $\begin{array}{c}\text { Outer } \\
\text { Loadings } \\
\geq 0,708\end{array}$ & $\begin{array}{l}\text { Indicador de } \\
\text { confiabilidade } \\
>0,50\end{array}$ & $\begin{array}{c}\text { AVE } \\
>0,50\end{array}$ \\
\hline \multirow{2}{*}{ Resultados } & \multirow{2}{*}{0,872} & \multirow{2}{*}{0,707} & Proat & 0,890 & 0,793 & \multirow{2}{*}{0,773} \\
\hline & & & Prodt & 0,868 & 0,754 & \\
\hline
\end{tabular}

Fonte: Resultados da pesquisa elaborados por meio do software Smart-PLS 3.0 


\subsubsection{4(a) Análise de confiabilidade e análise convergente das variáveis latentes - Resultados}

Nos critérios de Fornell-Larcker e de Cross-loadings, os resultados se apresentaram nos limites determinados pelos modelos de avaliação, conforme podem ser vistos nas tabelas 78 e 79.

\section{Critério cross-loadings}

Tabela 78 - Critério Cross-loadings para avaliar a validade discriminante - Resultado

$\begin{array}{cc}\text { EscalaProat } & 0,8885 \\ \text { EscalaProdut } & 0,8704\end{array}$

Fonte: Resultados da pesquisa elaborados por meio do software Smart-PLS 3.0

\section{Critério Fornell-Larcker}

Por este critério, a variância da variável latente mostra-se nos limites permitidos.

Tabela 79 - Critério Cross-loadings para avaliar a validade discriminante - Resultado

\begin{tabular}{lc}
\hline & Resultados \\
Resultados & 0,8795
\end{tabular}

Fonte: Resultados da pesquisa elaborados por meio do software Smart-PLS 3.0 


\subsection{Modelo de medição reflexivo-formativo para o HOC Valores (Outer Model)}

No modelo proposto, o construto valores corresponde a um HOC (Higher Order Construct) composto a partir de oito variáveis latentes: autonomia, coletividade, realização, bem-estar, tradição, prestígio, conformidade e domínio - que são os LOCs (Lower Order Constructs) que contêm seus respectivos itens, como pode ser visto na figura 44.

Figura 44 - Modelo de medição reflexivo-formativo para o HOC Valores

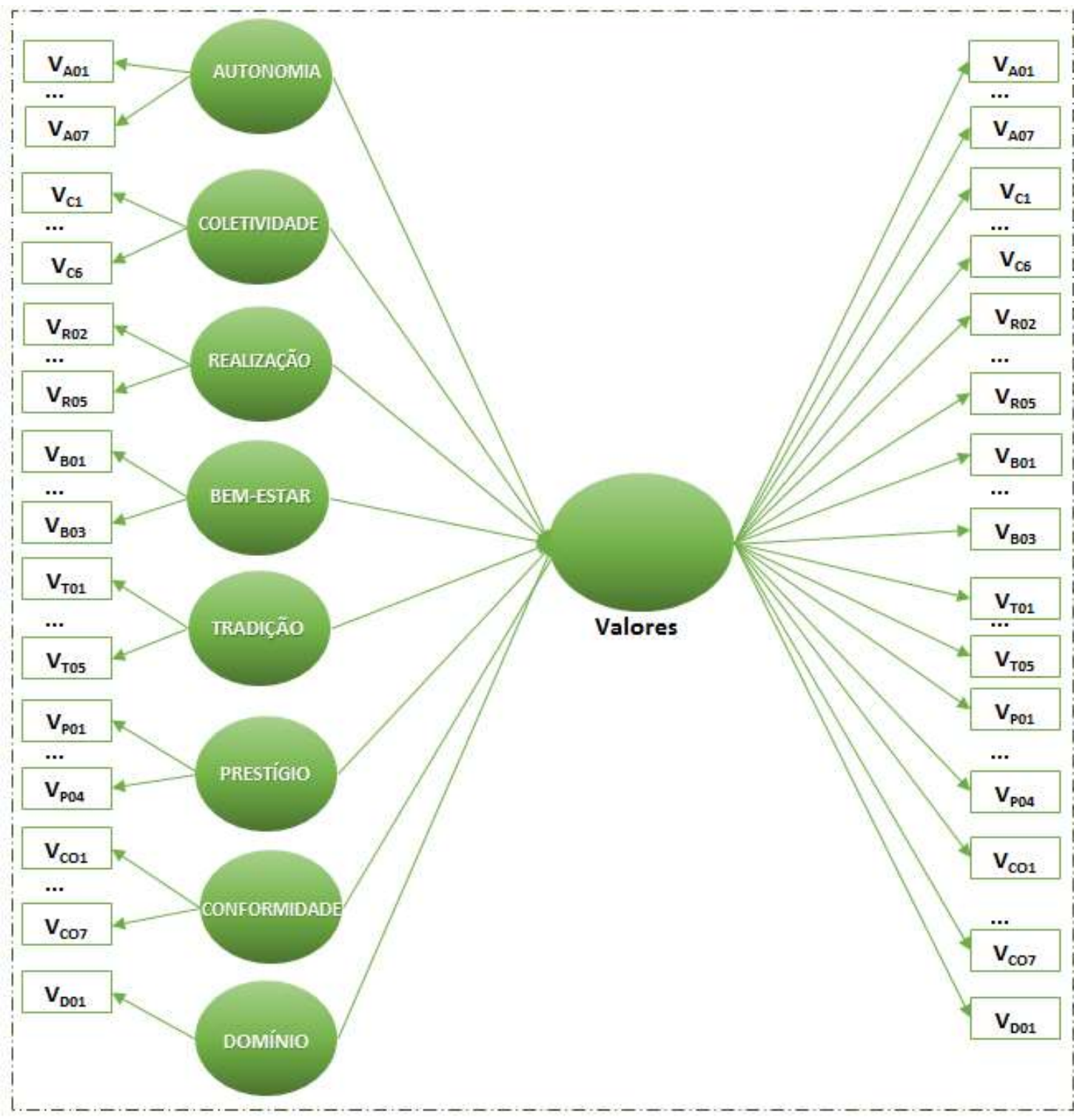

Fonte: elaborado pela autora 
Neste modelo, uma potencial colinearidade entre os LOCs do HCM reflexivo-formativo deve ser avaliada com muita atenção, pois um indicador pode ser uma combinação linear do outro indicador. Foi realizada a estatística VIF (Variance Inflation Factor). VIF igual ou superior a 5 indica um potencial problema de colinearidade (HAIR et al., 2012, 2017). Mais especificamente, isso indica que $80 \%$ de sua variância é explicada pelos demais indicadores formativos que estão associados ao mesmo construto. Os resultados dos VIFs para os LOCs do construto valores estão apresentados na tabela 80 , em que foi possível identificar que as variáveis latentes autonomia $(\mathrm{VIF}=6,964)$ e realização (VIF=6,045) estão acima do limite estabelecido de 5,0, após a retirada dos itens $V_{A 2}, V_{A 5}$ e $V_{A 8}$ do LOC autonomia e $V_{R 1}$ e $V_{R 4}$ do LOC realização. Os quesitos deste critério foram atendidos.

Tabela 80 - VIF - LOCs do HOC Valores

\begin{tabular}{l|c|l|c}
\hline Variáveis latentes & VIF & Itens retirados & VIF \\
\hline Autonomia & $\mathbf{6 , 9 6 4 5}$ & $\mathrm{V}_{\mathrm{A} 2}, \mathrm{~V}_{\mathrm{A} 5} \mathrm{e} \mathrm{V}_{\mathrm{A} 8}$ & 4,6836 \\
Bem-Estar & 3,3514 & & 2,8826 \\
Coletividade & 4,4394 & & 4,1304 \\
Conformidade & 2,7474 & & 2,7278 \\
Domínio & 1,5752 & & 1,5803 \\
Prestígio & 1,5404 & & 1,5463 \\
Realização & 6,0453 & $\mathrm{~V}_{\mathrm{R} 1}$ e $\mathrm{V}_{\mathrm{R} 4}$ & 4,9499 \\
Tradição & 1,4285 & & 1,4227 \\
\hline \multicolumn{2}{c}{ Fonte: dados da pesquisa elaborados por meio do Software Smart PLS }
\end{tabular}

O passo seguinte é analisar o efeito total que cada LOC (variáveis latentes) causa no HOC valores. Além de avaliar os efeitos, também foi utilizado o processo Bootstrapping para verificar se estes valores eram significantes, como pode ser visto na figura 45. 
Figura 45 - Efeito total que cada LOC sobre o HOC - valores

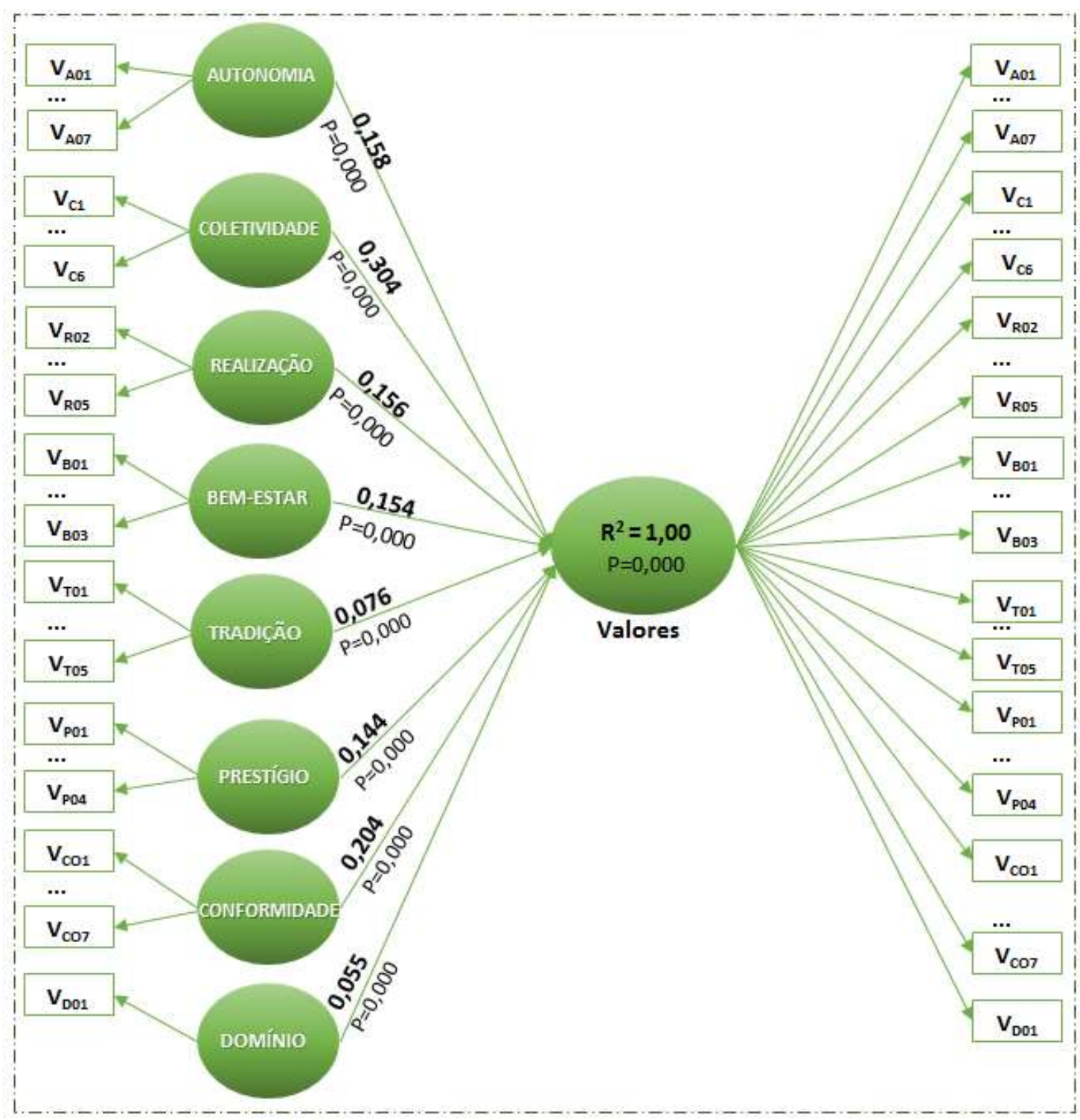

Fonte: Resultados obtidos por meio do Software Smart-PLS 3.0 


\subsection{Modelo de medição reflexivo-reflexivo para o HOC Práticas (Outer Model)}

No modelo proposto, o construto tipos de práticas corresponde a um HOC (Higher Order Construct) composto a partir de duas variáveis latentes: instrumental e humanista (LOCs - Lower Order Constructs) contendo seus respectivos itens, como pode ser visto na figura 46.

Figura 46 - Medição reflexivo-reflexivo para o HOC Práticas

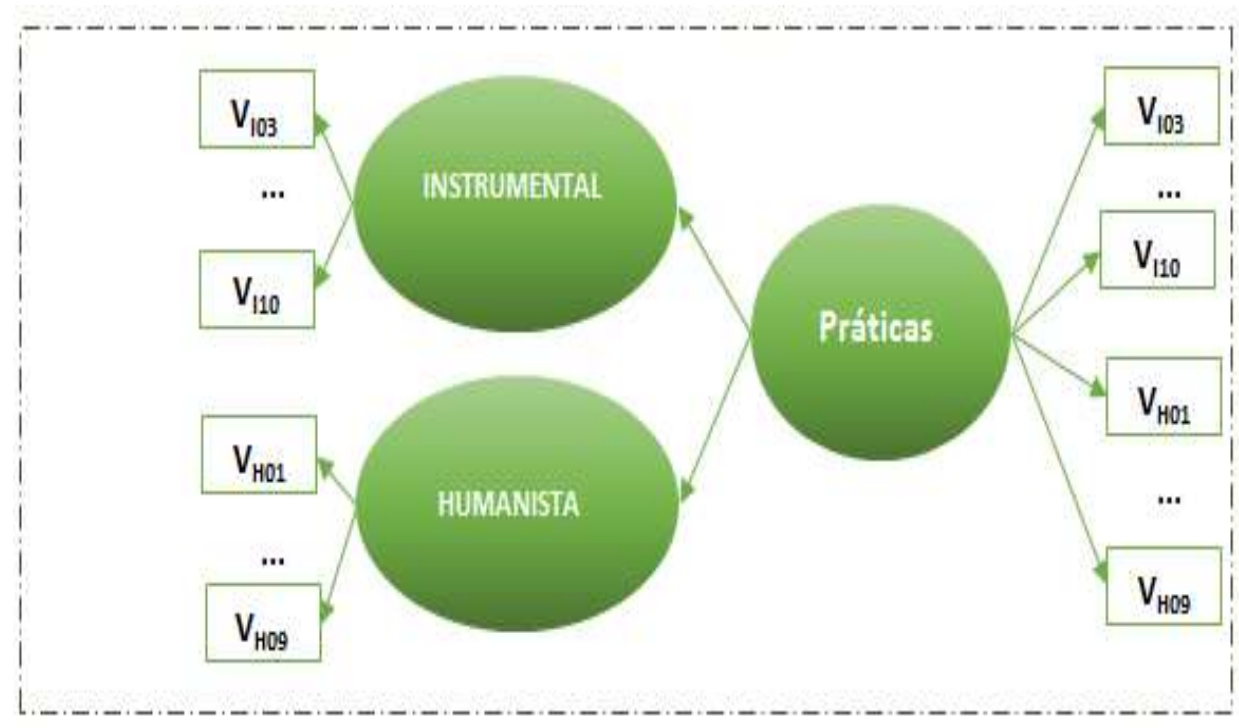

Fonte: elaborado pela autora

Os resultados da avaliação dos modelos de medição reflexiva diferem um pouco do modelo de medição para variáveis latentes que foi apresentado até agora. Os construtos "instrumental" e humanista" agem como LOCs. As medidas do construto INSTRUMENTAL produzem níveis satisfatórios de validade convergente (AVE = 0,615 ) e confiabilidade de consistência interna (confiabilidade composta $=0,918$; alfa de Cronbach $=0,896$ ). As medidas do construto humanista também mostram níveis satisfatório de validade convergente $(A V E=0,514)$ e confiabilidade de consistência interna (confiabilidade composta $=0,881$; Alfa de Cronbach $=0,844$ ). E O HOC práticas, cujo modelo de medição é descrito pelas relações de caminho de PRÁTICAS com os dois LOCs instrumental e humanista, como pode ver na figura 47. As cargas do HCM são 0,909 para instrumental e 0,867 para humanista. Como essas cargas correspondem tecnicamente aos coeficientes do caminho no modelo de caminho PLS, o software (Smart PLS) não apresenta estatísticas do modelo de medição para HCM. No entanto, pode-se calcular as estatísticas relevantes manualmente. 
O AVE é a média do quadrado das cargas do HCM, isto é, $\left(0,909^{2}+0,867^{2}\right) / 2=0,78$, indicando validade convergente.

Para o cálculo da confiabilidade composta $(\rho)$, usa-se a seguinte fórmula:

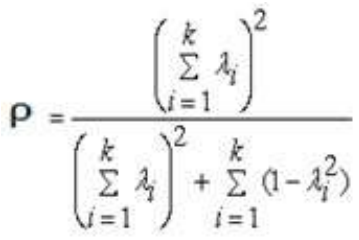

Onde

$\Lambda_{i}$ são as cargas dos LOCs de um HOC específico medido por M LOCs e $\left(1-\Lambda^{2}\right)$ é o erro da variância da medida.

Neste caso, tem-se:

$\rho=(0,909+0,867)^{2} /(0,909+0,867)^{2}+\left(1-0,909^{2}\right)+\left(1-0,867^{2}\right)=3,154176 / 3,576206$ $=0,8819$

Para o cálculo do alfa de Cronbach, usa-se a fórmula abaixo:

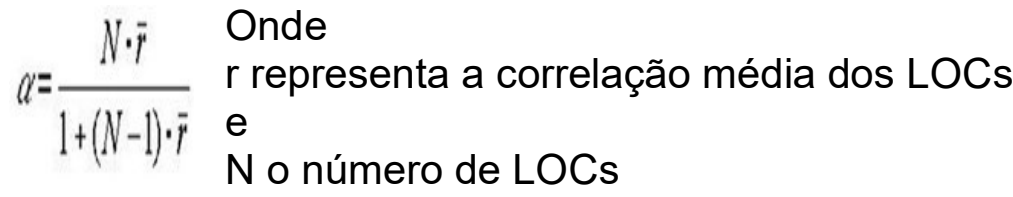

Neste caso, a correlação entre os LOCs humanista e instrumental obtido por meio do software Smart PLS é de 0,5806, então

$\alpha=(2 \times 0,5806) /(1+(2-1) \times 0,5806)=0,7346$

Os resultados da consistência interna estão acima do limite recomendado de 0,70 (HAIR et al., 2012, 2017, 2018). O próximo passo é avaliar a validade discriminante entre os LOCs instrumental e humanista usando o critério HTMT (HENSELER et al., 2015). Os valores do HTMT, juntamente com seus intervalos de confiança de bootstrap de $95 \%$ indicam validade discriminante entre instrumental e humanista, uma vez que o valor HTMT de 0,615 (Tabela 71 da página 342) está abaixo do limite (conservador) de 0,85. Além disso, o intervalo de confiança bootstrap correspondente não inclui o valor $1([0,5317 ; 0,6985])$. Observa-se que não se pode estabelecer validade discriminante entre os LOCs instrumental e humanista e seu HOC práticas, dado que o modelo de medição do HOC repete os indicadores dos seus LOCs. 
Figura 47 - Efeito total que cada LOC sobre o HOC - práticas

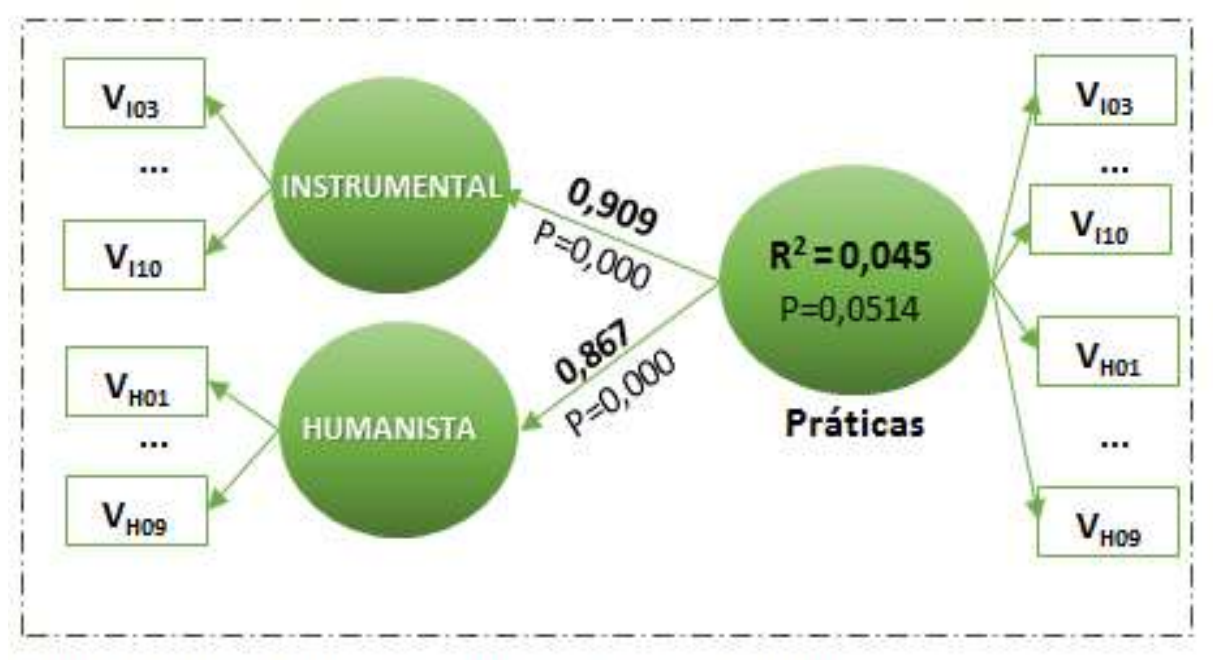

Fonte: Resultados obtidos por meio do Software Smart-PLS 3.0 


\subsection{Modelo de medição reflexivo-reflexivo para o HOC Comprometimento (Outer Model)}

No modelo proposto, o construto comprometimento corresponde a um HOC (Higher Order Construct) composto a partir de sete variáveis latentes: afetiva, afiliativa, obrigação pelo desempenho, obrigação em permanecer, escassez de alternativas, falta de recompensas e linha consistente de atividade (LOCs - Lower Order Constructs), contendo seus respectivos itens, como pode ser visto na figura 48 .

Figura 48 - Medição reflexivo-reflexivo para o HOC Comprometimento

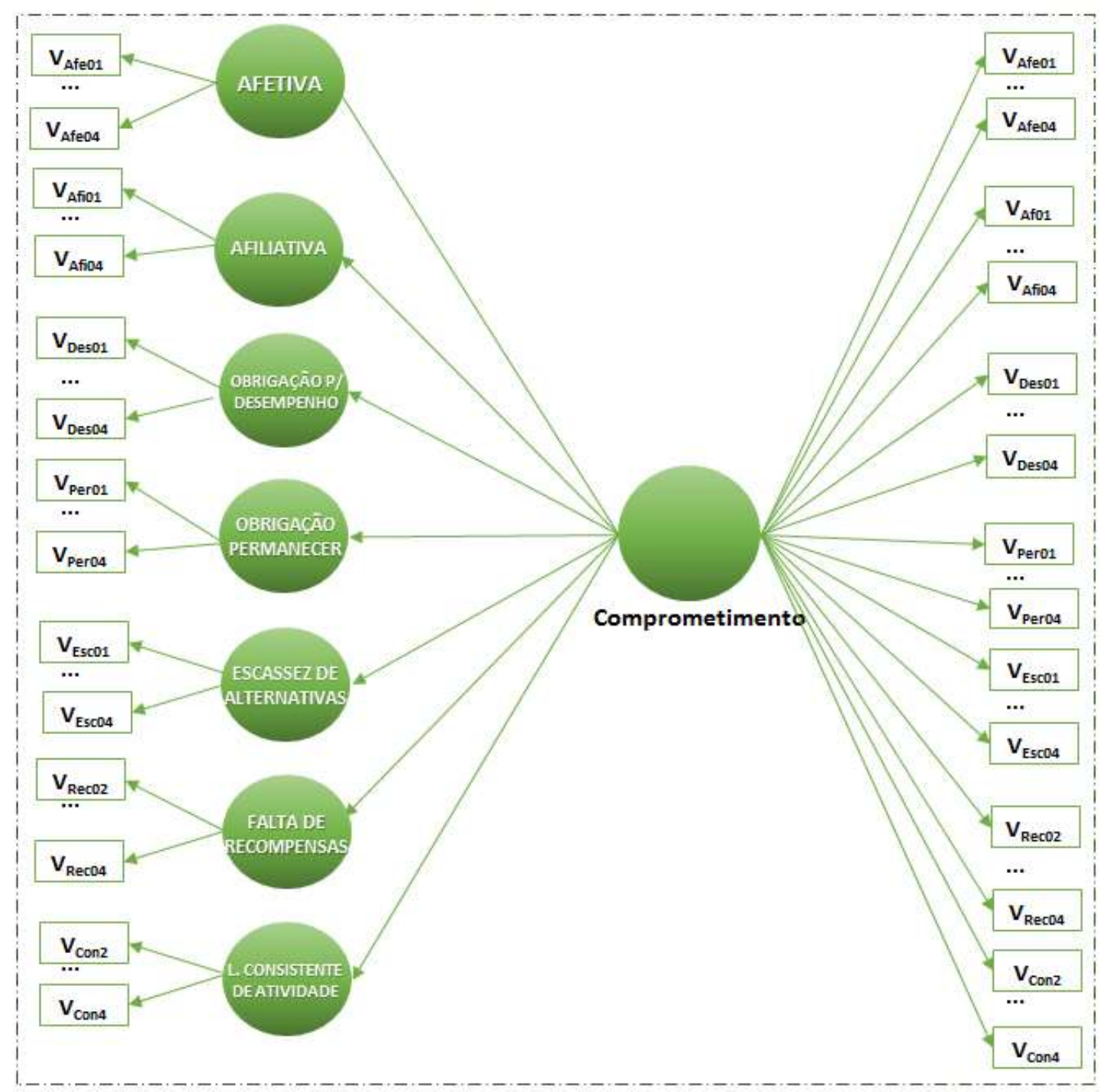

Fonte: elaborado pela autora 
Os construtos que agem como LOCs produziram níveis satisfatórios de validade convergente e confiabilidade de consistência interna: afetiva (AVE $=0,791$; confiabilidade composta $=0,938$; alfa de Cronbach $=0,912$ ) afiliativa (AVE=0,741; confiabilidade composta $=0,919$; alfa de Cronbach $=0,881$ ), obrigação pelo desempenho ( $\mathrm{AVE}=0,675$; confiabilidade composta $=0,862$; alfa de Cronbach $=$ 0,760 ), obrigação em permanecer ( $\mathrm{VVE}=0,778$; confiabilidade composta $=0,933$; alfa de Cronbach $=0,905$ ), escassez de alternativas ( $A \bigvee E=0,636$; confiabilidade composta $=0,873$; alfa de Cronbach $=0,804$ ), falta de recompensas ( $\mathrm{VVE}=0,682$; confiabilidade composta $=0,864$; alfa de Cronbach $=0,775)$ e linha consistente de atividade $(A \bigvee E=0,559$; confiabilidade composta $=0,791$; alfa de Cronbach $=0,605)$. $\mathrm{E} \circ \mathrm{HOC}$ comprometimento, cujo modelo de medição é descrito pelas relações de caminho de comprometimento com os sete LOCs, como pode ver na fig. 49. As cargas do HCM são: 0,863 para afetiva; 0,834 para afiliativa; 0,543 para obrigação pelo desempenho; 0,661 para obrigação em permanecer; 0,368 para escassez de alternativas; $-0,617$ para falta de recompensas e 0,561 para linha consistente de atividade. Como essas cargas correspondem tecnicamente aos coeficientes do caminho no modelo de caminho PLS, e o software (Smart PLS) não apresenta estatísticas do modelo de medição para HCM. No entanto, elas podem ser calculadas manualmente. O AVE é a média do quadrado das cargas do HCM, isto é $\left(0,863^{2}+0,834^{2}+0,543^{2}+0,661^{2}+\right.$ $\left.0,368^{2}+(-0,617)^{2}+0,561^{2}\right) / 7=0,4889 \sim 5,0$ indicando validade convergente.

o cálculo da confiabilidade composta $(\rho)$ :

$\rho=(0,863+0,834+0,543+0,661+0,368+(-0,617)+0,561)^{2} /(0,863+0,834+0,543$

$+0,661+0,368+(-0,617)+0,561)^{2}+\left(1-0,863^{2}\right)+\left(1-0,834^{2}\right)+\left(1-0,543^{2}\right)+(1-$ $\left.0,661^{2}\right)+\left(1-0,368^{2}\right)+\left(1-\left(-0,617^{2}\right)+\left(1-0,561^{2}\right)=10,323 / 14,321=0,721=\rho\right.$

O cálculo do alfa de Cronbach $(\alpha)$ :

Lembrando que r é a média das correlações dos LOCs $=0,3405$; então:

$\alpha=(7 \times 0,3405) /(1+(7-1) \times 0,3405)=0,783=\alpha$

Os resultados da consistência interna estão acima do Limite recomendado de 0,70 (HAIR, et al., 2012, 2017, 2018). Para avaliar a validade discriminante entre os LOCs, usou-se o critério HTMT recomendado por Henseler et al. (2015). Os valores do HTMT, juntamente com seus intervalos de confiança de bootstrap de $95 \%$ indicam validade discriminante entre todos os LOCs do HOC comprometimento, uma vez que 
o maior valor HTMT foi de 0,733 e que está abaixo do limite (conservador) de 0,85. Além disso, o intervalo de confiança bootstrap correspondente não inclui o valor 1 (veja tabela 74 da página 345). Observa-se que não se pode estabelecer validade discriminante entre os LOCs e seu HOC comprometimento, pois o modelo de medição do HOC repete os indicadores dos seus LOCs.

Figura 49 - Efeito total que cada LOC sobre o HOC - Comprometimento

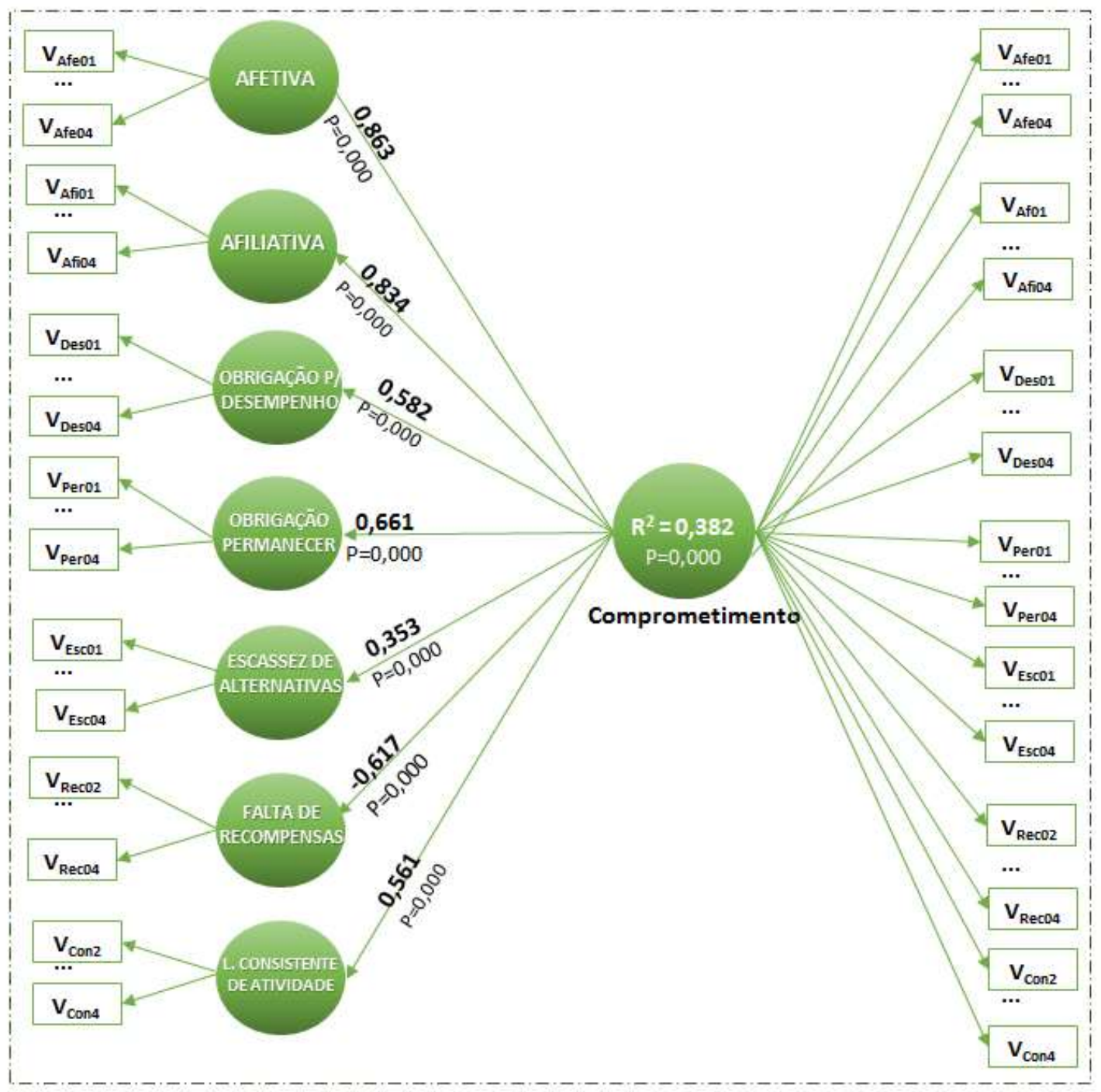

Fonte: Resultados obtidos por meio do Software Smart-PLS 3.0 
Ao finalizar esta etapa, os seguintes itens foram retirados:

Tabela 81 - Análise das variáveis latentes

\begin{tabular}{l|lll}
\hline Variável Latente & Carga $<0,708$ & AVE $>0,50$ & VIF $>5$ (colinearidade) \\
\hline Valores & $\mathrm{V}_{\mathrm{A} 03}, \mathrm{~V}_{\mathrm{A} 06}$ & $\mathrm{~V}_{\mathrm{C} 04}, \mathrm{~V}_{\mathrm{T} 03}$ & $\mathrm{~V}_{\mathrm{A} 02}, \mathrm{~V}_{\mathrm{A} 05}, \mathrm{~V}_{\mathrm{A} 08,}, \mathrm{~V}_{\mathrm{R} 01}, \mathrm{~V}_{\mathrm{R} 04}$ \\
Práticas & $\mathrm{V}_{101}, \mathrm{~V}_{102}, \mathrm{~V}_{107}, \mathrm{~V}_{\mathrm{H} 02}$ & $\mathrm{~V}_{\mathrm{I05}}, \mathrm{V}_{\mathrm{H} 10}$ & \\
Comprometimento & $\mathrm{V}_{\text {Des3 }}, \mathrm{V}_{\mathrm{Rec} 1}$ & $\mathrm{C}_{\mathrm{Con} 1}$ & \\
\hline
\end{tabular}

Fonte: elaborado pela autora

Após a retirada dos itens acima relacionados, a análise de confiabilidade e de validade dos itens das variáveis indicadoras apresentaram níveis satisfatórios de qualidade, bem como as análises do modelo de medição formativo-reflexivo para o HOC valores e dos modelos de medição reflexivo-reflexivo para os HOCs práticas e comprometimento, podendo, então, prosseguir para a próxima etapa, a avaliação do modelo estrutural.

\subsubsection{Análise do Inner Model (Modelo Estrutural)}

Uma vez confirmado que as medidas dos construtos são confiáveis e válidas, o próximo passo será a avaliação dos resultados do modelo estrutural. Isto envolve examinar as capacidades preditivas do modelo e as relações entre os construtos.

A figura 50 mostra os procedimentos que serão realizados para analisar o modelo estrutural

Figura 50 - Etapas para a análise do modelo estrutural

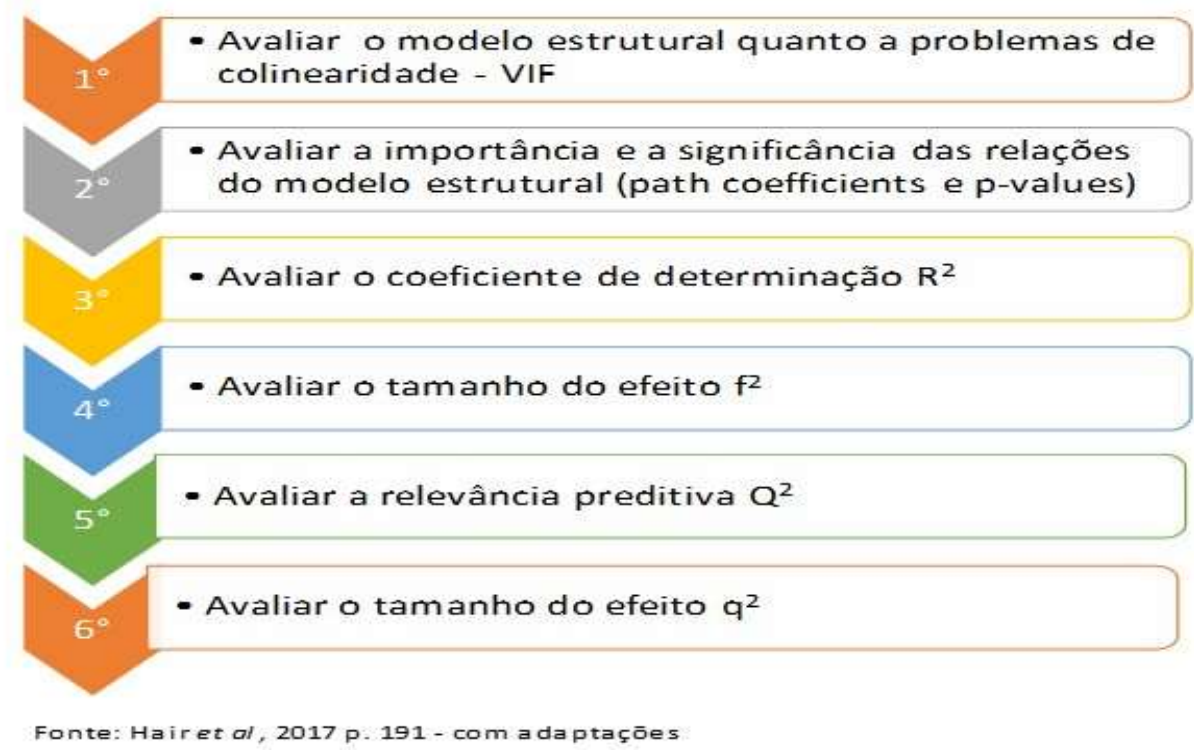




\subsection{Avaliando o modelo estrutural quanto a problemas de colinearidade - VIF}

Nesta etapa é necessário examinar cada conjunto de preditores no modelo estrutural para colinearidade. $O$ valor de tolerância do construto de cada preditor (TOL) deve ser superior a 0,20 (VIF inferior a 5). Caso contrário, considere-se eliminar os construtos, mesclar preditores em um único construto ou criar construtos de ordem superior para tratar problemas de colinearidade (Hair et al., 2017).

A tabela 80 mostra as relações entre cada uma das preditoras (valores, práticas e comprometimento) e de como cada uma delas se relacionam entre si e elas com o construto resultados. Pode-se ver que em todas as relações o VIF se apresenta abaixo de 5,0 e, portanto, a colinearidade entre os construtos não é uma questão crítica no modelo estrutural, e assim pode-se continuar examinando os resultados.

Tabela 82 - Valores VIF no modelo estrutural Outer VIF Values

Práticas Comprometimento Resultados

\begin{tabular}{|c|c|c|c|}
\hline Valores & 1,00 & 1,04 & 1,67 \\
\hline Práticas & & 1,04 & ,05 \\
\hline
\end{tabular}

Comprometimento

1,6

Fonte: Resultados obtidos por meio do Software Smart-PLS 3.0

\subsection{Avaliando a importância e a significância do modelo estrutural (path coeficientes e p-valor)}

Os coeficientes de caminho (path coefficients) representam as relações das hipóteses estabelecidas entre os construtos. Os coeficientes de caminho têm valores padronizados aproximadamente entre \pm 1 . A verificação se o coeficiente de caminho é significativo dependerá do seu erro padrão obtido por meio do bootstrap. Este procedimento permite calcular os valores $\mathrm{t}$ ( $t$ - student) e p-valores para todos os coeficientes de caminho do modelo estrutural. Para teste bicaudal e nível de significância de $5 \%$, o t-valor é de 1,96. 
O intervalo de confiança gerado pelo procedimento bootstrap permite testar se um coeficiente de caminho é significativamente diferente de zero. Se o intervalo de confiança para um coeficiente de caminho não incluir o zero, a hipótese de que o caminho é igual a zero é rejeitada e então se assume que há um efeito significativo.

Ao interpretar os resultados de um modelo de caminho, é preciso testar o significado para todas as relações do modelo estrutural usando valores de $t$, valores de $p$ e o intervalo de confiança fornecido pelo procedimento Bootstrapping. Muitas vezes, estáse interessado em avaliar não apenas o efeito direto de um construto em relação a outro, mas também seus efeitos indiretos por meio de um ou mais construtos mediadores. A soma dos efeitos diretos e indiretos é particularmente útil em estudos voltados para explorar o impacto diferencial de vários construtos de drivers em um construto de critérios por meio de uma ou mais variáveis de mediação.

Os resultados apresentados na tabela 83 mostram que para as relações entre práticas -> comprometimento e valores -> resultados, os intervalos contêm o valor 1 , o valor $t$ é abaixo de 1,96 e p-valor acima de 0,05, mostrando que não há relação entre esses construtos. Mostram ainda que as relações entre valores -> comprometimento são o mais importante, seguidas pelas relações valores -> práticas e práticas -> resultados.

Tabela 83 - Relações entre as variáveis latentes

\begin{tabular}{l|ccccc}
\hline \multicolumn{1}{c|}{ Variáveis latentes } & $\begin{array}{c}\text { Path } \\
\text { coefficients (o) }\end{array}$ & DP & $95 \%$ & $\begin{array}{c}\text { T Statistics } \\
(|\mathrm{O} / \mathrm{DP}|)\end{array}$ & P Values \\
\hline Valores -> Práticas & 0,2126 & 0,058 & {$[0,109 ; 0,336]$} & 3,6226 & 0,0003 \\
Valores -> Comprometimento & $\mathbf{0 , 6 2 7 9}$ & $\mathbf{0 , 0 4 8}$ & {$[\mathbf{0 , 5 3 9 ; 0 , 7 1 8 ]}$} & $\mathbf{1 3 , 0 2 9 3}$ & $\mathbf{0 , 0 0 0 0}$ \\
Práticas -> Comprometimento & $-0,0605$ & 0,054 & {$[-0,168 ; 0,056]$} & 1,1039 & 0,2702 \\
Valores -> Resultados & $-0,0978$ & 0,072 & {$[-0,245 ; 0,038]$} & 1,3429 & 0,1799 \\
Práticas -> Resultados & 0,2023 & 0,068 & {$[0,077 ; 0,337]$} & 2,9495 & 0,0033 \\
Comprometimento -> Resultados & 0,1851 & 0,072 & {$[0,041 ; 0,325]$} & 2,5687 & 0,0105 \\
\hline
\end{tabular}

Fonte: Resultados da pesquisa elaborados a partir do Software Smart-PLS 3.0 


\subsection{Coeficiente de determinação $\left(R^{2}\right)$}

A medida mais utilizada para avaliar o modelo estrutural é o coeficiente de determinação $\left(R^{2}\right)$, que representa a quantidade de variância nos construtos endógenos explicada por todos os construtos exógenos ligados a ele. Não existe um valor fixo de referência para o $\mathrm{R}^{2}$, ou seja, qual é o valor satisfatório e qual não é. Em ciências do comportamento humano, valores aceitáveis de $\mathrm{R}^{2}$ podem estar em um patamar bem inferior. Hair et al. (2017) afirmam que valores próximos a 0,20 são considerados altos em pesquisas que avaliam o comportamento do consumidor. A tabela 84 apresenta os coeficientes de determinação a partir do modelo proposto.

\begin{tabular}{cccccc}
\multicolumn{6}{c}{ Tabela 84 - Coeficiente de determinação $\mathbf{R}^{2}$ do modelo proposto } \\
\hline $\begin{array}{c}\text { Path } \\
\text { coefficients (o) } \\
\mathbf{R}^{2}\end{array}$ & DP & $95 \%$ & $\begin{array}{c}\text { T Statistics } \\
(\text { (OO/DP|) }\end{array}$ & P Values \\
Valores & 1,000 & 0,000 & {$[1,000 ; 1,000]$} & $14.573,77$ & 0,000 \\
Práticas & 0,045 & 0,026 & {$[0,012 ; 0,113]$} & 1,724 & 0,085 \\
Comprometimento & 0,382 & 0,057 & {$[0,287 ; 0,503]$} & 6,701 & 0,000 \\
Resultados & 0,060 & 0,031 & {$[0,025 ; 0,147]$} & 1,907 & 0,057 \\
\hline
\end{tabular}

Fonte: Resultados da pesquisa elaborados a partir do Software Smart-PLS 3.0

\subsection{Tamanho do efeito $\left(\mathrm{f}^{2}\right)$}

Além de avaliar os valores do $\mathrm{R}^{2}$ de todos os construtos endógenos, a mudança no valor de $\mathrm{R}^{2}$ quando um construto exógeno especificado é omitido do modelo pode ser usada se o construto omitido tem um impacto substancial sobre os construtos endógenos (Hair et al., 2017). O cálculo se fundamenta na relação entre o aumento do $R^{2}$ da variável latente endógena e a proporção de variância não explicada desta variável latente (Urbach \& Ahlemann, 2010). Valores de $f^{2}$ entre 0,02 e 0,15 indicam pequeno efeito da variável exógena sobre a endógena; e valores entre 0,15 a 0,35 efeito médio e acima de 0,35 efeito grande sobre a variável latente endógena.

Pelos resultados desse teste (Tabela 85 ) em relação às variáveis preditoras, verificase que o maior efeito é de valores em relação a comprometimento, indicando que as dimensões de valores impactam nas bases de comprometimento organizacional dos SECOMs. Já as relações entre as variáveis preditoras (valores, comprometimento e tipos de práticas) o impacto ou é pequeno (práticas e comprometimento) ou muito fraco (valores). 
Tabela 85 - Relações entre as variáveis e seus efeitos

\begin{tabular}{l|r|c}
\hline Relações entre as variáveis & \multicolumn{1}{|c}{$\mathbf{f}^{\mathbf{2}}$} & Efeito \\
\hline Valores -> Práticas & 0,0473 & Fraco \\
Valores -> Comprometimento & $\mathbf{0 , 6 0 8 8}$ & Grande \\
Práticas -> Comprometimento & 0,0056 & S/Efeito \\
Valores -> Resultados & 0,0060 & S/Efeito \\
Práticas -> Resultados & 0,0413 & Pequeno \\
Comprometimento -> Resultados & 0,0225 & Pequeno \\
\hline
\end{tabular}

Fonte: Resultados da pesquisa elaborados a partir do Software Smart-PLS 3.0

\subsection{Teste da relevância preditiva do Modelo Estrutural $\left(Q^{2}\right)$}

Para avaliar a magnitude dos valores $\mathrm{R}^{2}$ como critério de precisão preditiva, usa-se o valor $\mathrm{Q}^{2}$ de Stone-Geisser (Hair et al., 2017). Os valores de $Q^{2}$ maiores que zero para uma variável latente endógena reflexiva específica indicam a relevância preditiva dos modelos do caminho para um construto endógeno (Henseler et al., 2009; Hair et al., 2017).

Esse valor é geralmente aplicado a construtos endógenos que possuem medidas reflexivas, bem como a construtos endógenos de um único item. Como pode ser visto na tabela 86.

Tabela 86 - Relevância Preditiva das variáveis

\begin{tabular}{l|c}
\hline \multicolumn{1}{c|}{ Variáveis } & $\mathrm{Q}^{2}$ \\
\hline Valores & 0,3020 \\
Práticas & 0,0342 \\
Comprometimento & 0,1746 \\
Resultados & 0,0595 \\
\hline
\end{tabular}

Fonte: Resultados da pesquisa elaborados a partir do Software Smart-PLS 3.0

O valor final $Q^{2}$ é o que se interpreta para julgar a relevância preditiva do modelo em relação a cada construto endógeno. Como pode ser visto, os valores de $\mathrm{Q}^{2}$ dos quatro construtos endógenos estão acima de zero. Esses resultados fornecem suporte claro para a relevância preditiva do modelo em relação às variáveis latentes endógenas. 


\subsubsection{5 (a) Efeito do tamanho - $q^{2}$}

O tamanho do efeito $q^{2}$ permite avaliar a contribuição de um construto exógeno para um valor $\mathrm{Q}^{2}$ da variável latente endógena. Como medida relativa da relevância preditiva, os valores de $\mathrm{q}^{2}$ de 0,02, 0,15 e 0,35 indicam, respectivamente, que um construto exógeno tem uma relevância prévia pequena, média ou grande para um determinado construto endógeno.

$$
q^{2}=\frac{Q_{\text {included }}^{2}-Q_{\text {exduded }}^{2}}{1-Q_{\text {included }}^{2}}
$$

Os cálculos são realizados manualmente, pois o Smart-PLS 3.0 não faz este procedimento.

$$
\begin{aligned}
& Q^{2} \text { VALOR-> RESULTADO }=(0,3020-0,0595) / 1-0,3020=0,347 \\
& q^{2} \text { VALOR-> PRÁTICAS }=(0,3020-0,0342) / 1-0,3020=0,383 \\
& q^{2} \text { VALOR-> COMPROMETIMENTO }=(0,302-0,1746) / 1-0,3020=0,182 \\
& q^{2} \text { COMPROMETIMENTO-> RESULTADOS }=(0,1746-0,0595) / 1-0,1746=0,1394 \\
& q^{2} \text { PRÁTICAS-> COMPROMETIMENTO }=(0,0342-0,1746) / 1-0,0342=-0,145 \\
& q^{2} \text { PRÁTICAS-> RESULTADOS }=(0,0342-0,0595) / 1-0,0342=-0,026
\end{aligned}
$$


Figura 51 - Modelo conceitual teórico para a organização local testado

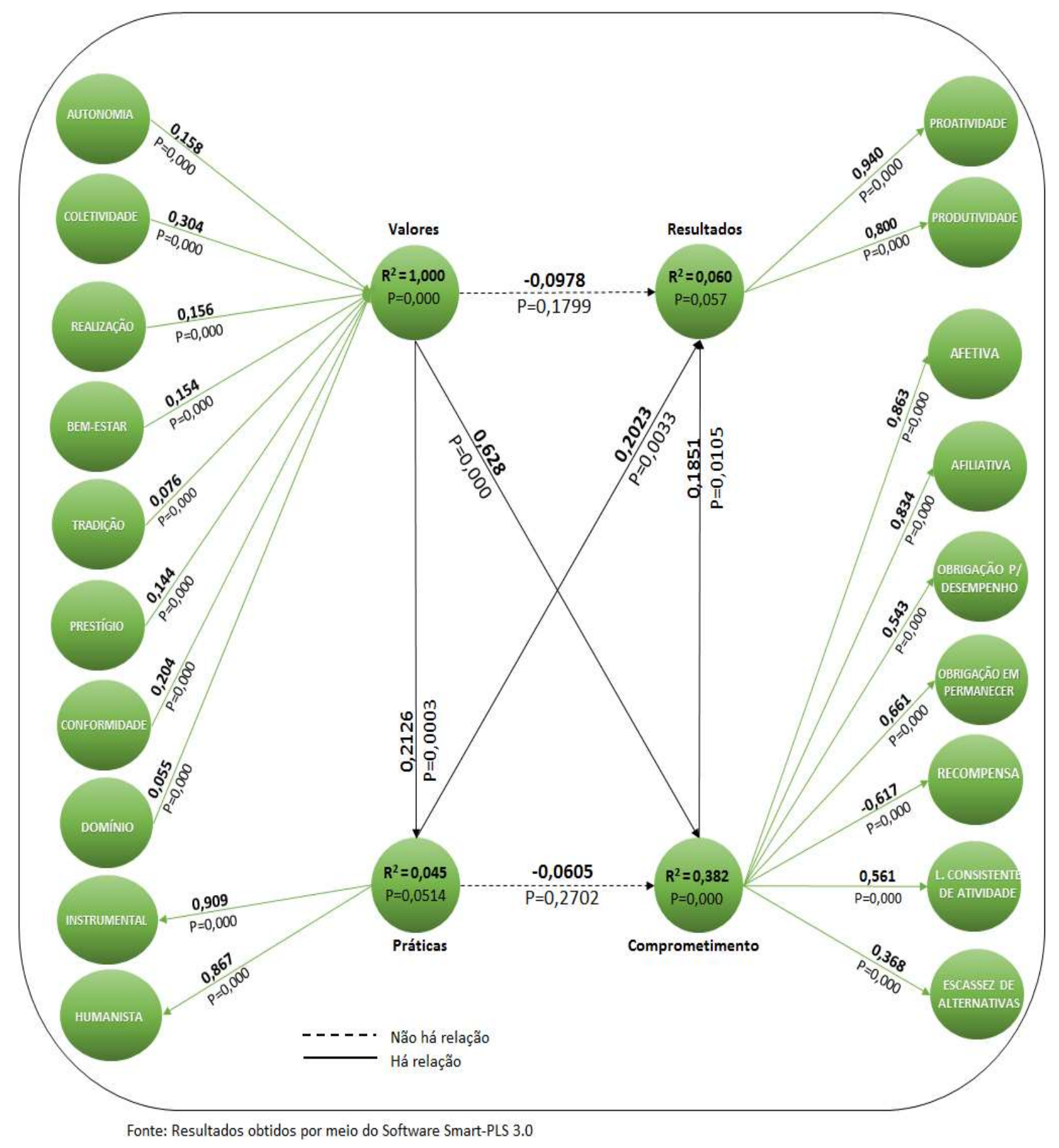

A partir do modelo teórico testado, vê-se que as relações entre os construtos e resultados, somente valores não se apresentou relacionado. Nas relações entre os construtos, tipos de práticas e comprometimento não se apresentaram relacionados. 


\subsubsection{Análise Mediadora}

A mediação ocorre quando uma terceira variável, referida como uma variável mediadora, intervém entre dois outros construtos relacionados. Mais precisamente, uma mudança no construto exógeno resulta em uma mudança da variável do mediador, que, por sua vez, muda o construto endógeno. Assim, uma variável mediadora governa a natureza da relação entre dois construtos e seu objetivo é criar uma relação teórica indireta entre os caminhos e os construtos (Samani, 2016).

\subsubsection{Análise da mediação simples no modelo proposto}

Figura 52 - Mediação entre os construtos para a organização local

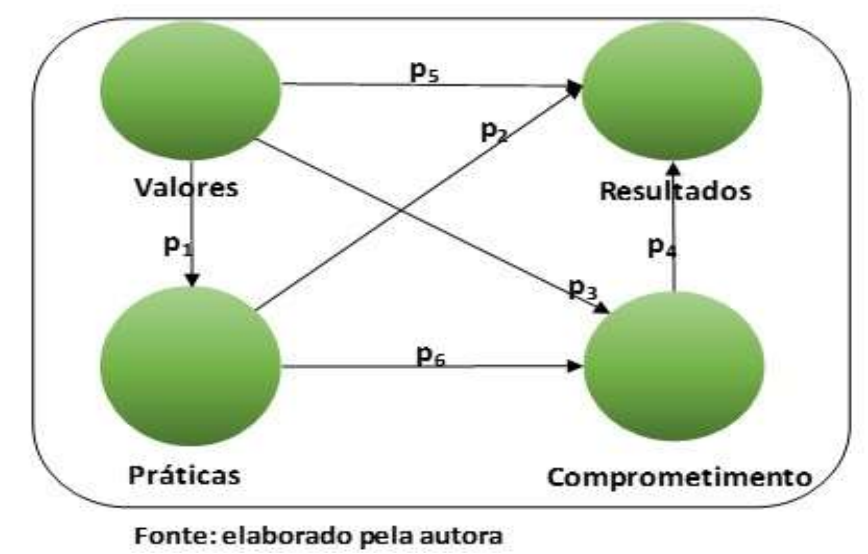

No modelo acima, as seguintes hipóteses foram estabelecidas:

H9a: O construto tipos de práticas organizacionais é mediador dos construtos valores e resultados.

H9b: O construto tipos de práticas organizacionais é mediador dos construtos valores e comprometimento.

H10a: O construto comprometimento é mediador dos construtos valores e resultados.

$\mathrm{H}_{10 \mathrm{~b}}$ : O construto comprometimento é mediador dos construtos práticas e resultados.

De acordo com as hipóteses estabelecidas, as seguintes análises devem ser realizadas: 
1. Na relação entre valor e resultado, o efeito indireto de práticas e resultados representa o efeito mediador do construto práticas? Ou seja, no modelo mediador, as práticas representam um mecanismo para explicar o relacionamento entre valores e resultados?

2. Na relação entre valor e comprometimento, o efeito indireto de práticas e comprometimento representa o efeito mediador do construto práticas? Ou seja, no modelo mediador, as práticas representam um mecanismo para explicar o relacionamento entre valores e comprometimento?

3. Na relação entre valor e resultado, o efeito indireto de comprometimento e resultados representa o efeito mediador do construto comprometimento? Ou seja, no modelo mediador, o comprometimento representa um mecanismo para explicar o relacionamento entre valores e resultados?

4. Na relação entre prática e resultado, o efeito indireto de comprometimento e resultados representa o efeito mediador do construto comprometimento? Ou seja, no modelo mediador, o comprometimento representa um mecanismo para explicar o relacionamento entre práticas e resultados?

Para testar o tipo de mediação múltipla no modelo em estudo, o primeiro passo é verificar a significância dos efeitos indiretos $\left(p_{1} \times p_{2}\right)$ e ( $\left.p_{1} \times p_{6}\right)$ por meio da variável mediadora práticas. Se o efeito indireto não for significante, então práticas não age como um mediador capaz de explicar o relacionamento entre valores e resultados ou entre valores e comprometimento.

Semelhantemente, deve-se verificar a significância dos efeitos indiretos $\left(\mathrm{p}_{3} \times \mathrm{p}_{4}\right)$ e (p6xp4) por meio da variável mediadora comprometimento. Se o efeito indireto não for significante, então comprometimento não age como um mediador capaz de explicar o relacionamento entre valores e resultados ou entre práticas e resultados. Para melhor compreensão, o quadro 36 demonstra as relações estabelecidas e os construtos propostos como mediadores.

Quadro 36 - Mediação e efeitos indiretos

\begin{tabular}{|c|c|c|c|}
\hline $\begin{array}{l}p_{1} \times p_{2} \\
P_{1} \times p_{6}\end{array}$ & Mediadora é prática & Efeito indireto & $\begin{array}{l}\text { VAL -> RESULT } \\
\text { VAL -> COMP }\end{array}$ \\
\hline $\begin{array}{l}\mathrm{p}_{3} \times \mathrm{p}_{4} \\
\mathrm{p}_{6} \times \mathrm{p}_{4}\end{array}$ & $\begin{array}{c}\text { Mediadora é } \\
\text { comprometimento }\end{array}$ & Efeito indireto & $\begin{array}{l}\text { VAL -> RESULT } \\
\text { PRÁT -> RESULT }\end{array}$ \\
\hline
\end{tabular}

Fonte: elaborado pela autora 
Os efeitos diretos, obtidos por meio do software Smart-PLS, são apresentados na tabela 87 e os efeitos indiretos, que são produtos das relações diretas, são apresentados na tabela 88 .

Tabela 87 - Efeitos diretos práticas, valores e comprometimento

\begin{tabular}{l|cccccc}
\hline \multicolumn{1}{c|}{ Direct Effects } & $\begin{array}{c}\text { Original } \\
\text { Sample }(\mathrm{O})\end{array}$ & $\begin{array}{c}\text { Sample } \\
\text { Mean }(\mathrm{M})\end{array}$ & $\mathrm{DP}$ & $\begin{array}{c}\text { Intervalo Confiança } \\
95 \%\end{array}$ & $\begin{array}{c}\text { T Statistics (|O/DP|) } \\
\mathrm{T}>1,96\end{array}$ & $\begin{array}{c}\mathrm{P} \text { Values } \\
\mathrm{P}<0,05\end{array}$ \\
\hline Práticas $->$ resultados & 0,202 & 0,211 & 0,069 & {$[0,077 ; 0,337]$} & 2,949 & 0,003 \\
Valores $->$ práticas & 0,628 & 0,634 & 0,048 & {$[0,539 ; 0,718]$} & 13,029 & 0,000 \\
Práticas $>$ > comprometimento & $-0,061$ & $-0,059$ & 0,054 & {$[-0,167 ; 0,056]$} & 1,104 & 0,270 \\
Valor $>$ c comprometimento & 0,628 & 0,634 & 0,0482 & {$[0,538 ; 0,718]$} & 13,029 & 0,000 \\
Comprometimento -> resultados & 0,184 & 0,195 & 0,0721 & {$[0,041 ; 0,325]$} & 2,568 & 0,010 \\
\hline
\end{tabular}

Fonte: Resultados elaborados a partir dos dados da pesquisa e calculados por meio do Software Smart-PLS

Tabela 88 - Efeitos indiretos valores, práticas, comprometimento e resultados

\begin{tabular}{|c|c|c|}
\hline Efeitos diretos & Produto entre & Original Sample (O) \\
\hline Valores -> Práticas -> Resultados & \begin{tabular}{l}
\multicolumn{1}{c}{$\mathrm{p}_{1} \times \mathrm{p}_{2}$} \\
$\mathrm{p}_{1}=$ VAL $>>$ PRAT \\
$\mathrm{p}_{2}=$ PRAT $->$ RESUL
\end{tabular} & 0,0430 \\
\hline Valores -> Práticas -> Comprometimento & $\begin{array}{c}p_{1} \times p_{6} \\
p_{1}=\text { VAL }>\text { PRAT } \\
p_{6}=\text { PRAT }>>C O M P\end{array}$ & $-0,0129$ \\
\hline Valores -> Comprometimento -> Resultado & $\begin{array}{c}\mathrm{p}_{3} \times \mathrm{p}_{4} \\
\mathrm{p}_{3}=\text { VAL } \rightarrow \text { COMP } \\
\mathrm{p}_{4}=\text { COMP } \rightarrow \text { RESUL }\end{array}$ & 0,1162 \\
\hline Práticas -> Comprometimento -> Resultado & $\begin{array}{c}\mathrm{p}_{6} \times \mathrm{p}_{4} \\
\mathrm{p}_{6}=\text { PRAT }>\text { COMP } \\
\mathrm{p}_{4}=\text { COMP }->\text { RESUL }\end{array}$ & $-0,0112$ \\
\hline
\end{tabular}

Fonte: Resultados elaborados a partir dos dados da pesquisa e calculados por meio do Software Excel

3. Efeitos indiretos total

A média (sample mean) e o desvio-padrão (DP) foram obtidos a partir de todas as amostras bootstrapping geradas, ou seja, 499 amostras das relações entre os construtos mediadores. As médias, desvio-padrão e testes estatísticos t e o p-valor foram calculados por meio da planilha Excel.

Tabela 89 - Resultado da Análise de significância para efeitos indiretos total - Mediação múltipla

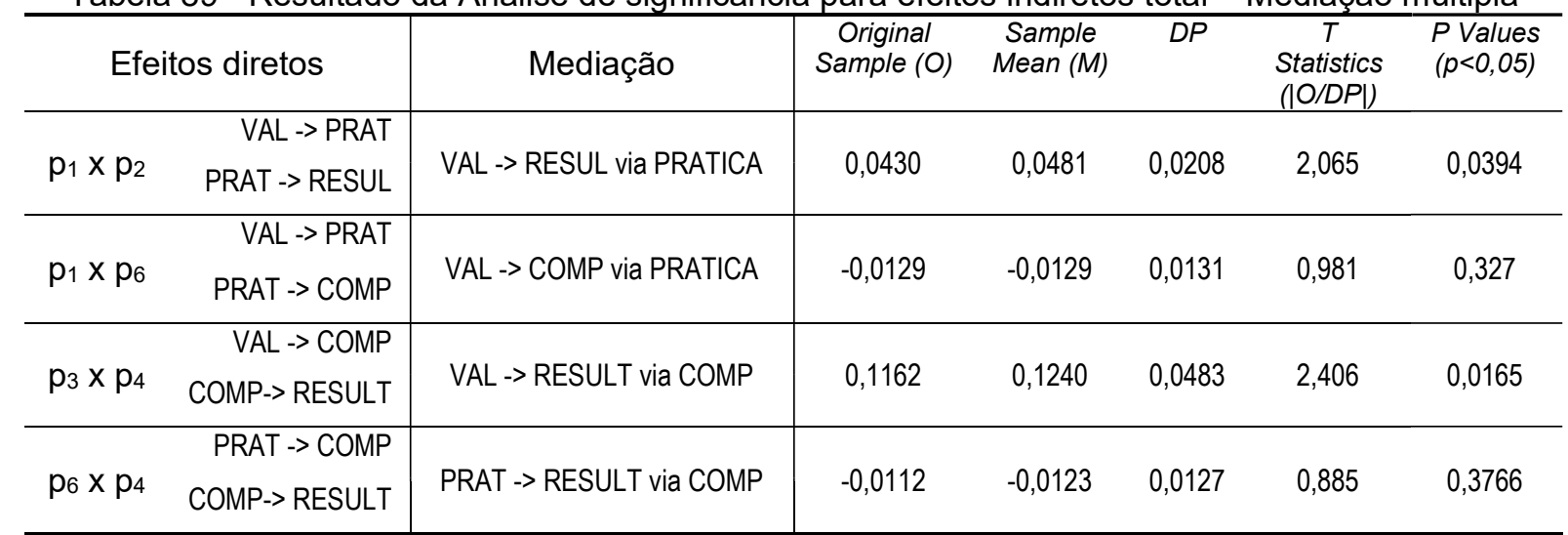

Fonte: Resultados elaborados a partir dos dados da pesquisa e calculados por meio dos Softwares Smart-PLS e Excel 
A partir das tabelas 87,88 e 89 foi possível chegar às seguintes conclusões

Quadro 37- Resultados das análises mediadoras para comprometimento e práticas

\begin{tabular}{|c|c|c|c|c|}
\hline \multirow{2}{*}{ Mediadora } & \multirow{2}{*}{ Relação } & \multicolumn{2}{|c|}{ Significância } & \multirow{2}{*}{ Interpretação } \\
\hline & & Indireto & Direto & \\
\hline \multirow[b]{2}{*}{ Comprometimento } & Valores-> Resultados & Sim & Não & Mediação completa \\
\hline & Prática -> Resultados & Não & Sim & $\begin{array}{l}\text { Não há mediação } \\
\text { Efeito somente direto }\end{array}$ \\
\hline \multirow[b]{2}{*}{ Práticas } & Valores-> Resultados & Sim & Não & Mediação completa \\
\hline & Valores -> Comprometimento & Não & Sim & $\begin{array}{l}\text { Não há mediação } \\
\text { Efeito somente direto }\end{array}$ \\
\hline
\end{tabular}

Fonte: elaborado pela autora

Das perguntas elaboradas no início deste item, após a análise dos dados, têm-se as seguintes respostas:

1. No modelo mediador, as práticas representam um mecanismo para explicar o relacionamento entre valores e resultados? Sim, e a mediação é caracterizada como mediação completa.

2. As práticas organizacionais representam um mecanismo para explicar o relacionamento entre valores e comprometimento? Não, o efeito entre valores e comprometimento se dá de forma direta.

3. No modelo mediador, o comprometimento representa um mecanismo para explicar o relacionamento entre valores e resultados? Sim, e a mediação é caracterizada como mediação completa.

4. O comprometimento representa um mecanismo para explicar o relacionamento entre práticas e resultados? Não, mas existe o efeito direto entre práticas organizacionais e resultados.

Seguindo as análises de mediação, a seção 5.5.3.2 tratará das possíveis mediações múltiplas referentes às metas motivacionais e aos construtos. 


\subsubsection{Análise da mediação múltipla no modelo proposto}

Dado que práticas medeiam valores para o alcance dos resultados organizacionais, então todas as metas motivacionais também serão mediadas pelas práticas organizacionais para o alcance dos resultados. Então, a seguinte hipótese foi estabelecida:

H9c: Todas as metas motivacionais são mediadas pelos valores e pelas práticas organizacionais para o alcance dos resultados.

Figura 53 - Mediação múltipla metas motivacionais para resultados

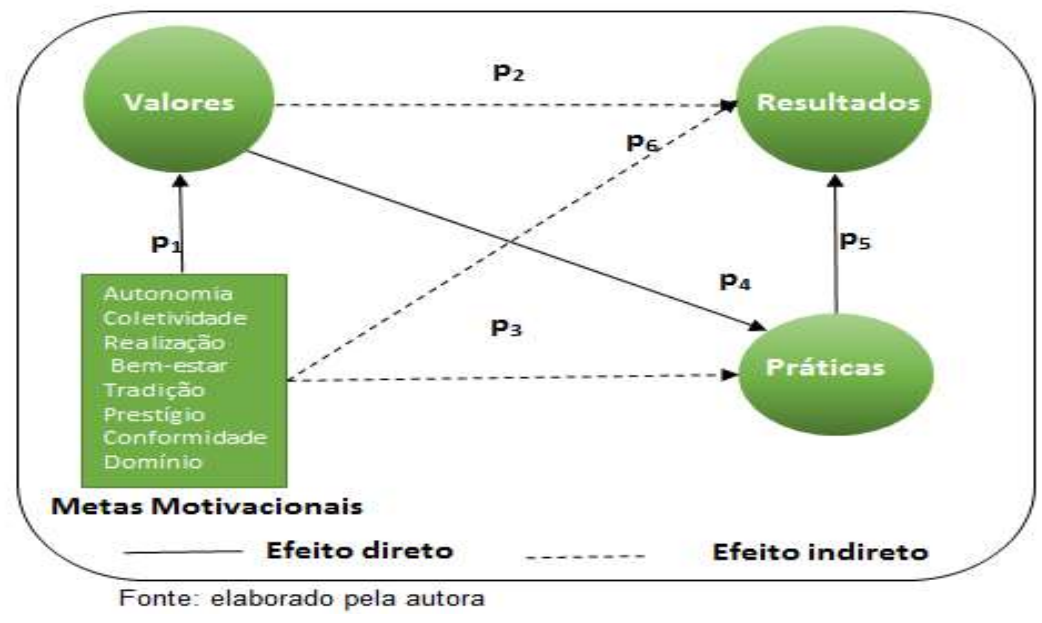

Para a verificação desta hipótese, foram obtidos dos softwares Smart-PLS e planilha eletrônica Excel e os resultados das tabelas intermediárias (efeitos específicos indiretos e diretos e efeitos indiretos total) estão disponíveis no apêndice $\mathrm{n}^{\circ} 03$.

Os resultados da análise mediadora múltipla das metas motivacionais para os resultados estão no quadro 38.

Quadro 38 - Resultados da análise mediadora múltipla das metas motivacionais e resultados

\begin{tabular}{|c|c|c|c|c|}
\hline \multirow{2}{*}{ Mediadoras } & \multirow[b]{2}{*}{ Relação } & \multicolumn{2}{|c|}{ Significância } & \multirow[b]{2}{*}{ Interpretação } \\
\hline & & Indireto & Direto & \\
\hline \multirow{8}{*}{ Valores e Práticas } & Autonomia -> Resultados & Sim & Sim & Mediação parcial \\
\hline & Bem-estar -> Resultados & Sim & $\operatorname{Sim}$ & Mediação parcial \\
\hline & Coletividade -> Resultados & Sim & $\operatorname{Sim}$ & Mediação parcial \\
\hline & Conformidade -> Resultados & Sim & Sim & Mediação parcial \\
\hline & Domínio -> Resultados & Sim & Sim & Mediação parcial \\
\hline & Prestígio -> Resultados & Sim & $\operatorname{Sim}$ & Mediação parcial \\
\hline & Realização -> Resultados & Sim & Sim & Mediação parcial \\
\hline & Tradição -> Resultados & Sim & Sim & Mediação parcial \\
\hline
\end{tabular}

Fonte: elaborado pela autora 
Então, existe uma mediação parcial dos construtos valores e práticas sobre as metas motivacionais para o alcance dos resultados.

Dado que valores têm relação direta com práticas, então as metas motivacionais serão mediadas pelos construtos valores e práticas para o alcance das práticas organizacionais humanistas e instrumentais. Então, as seguintes hipóteses foram estabelecidas:

H9d: Todas as metas motivacionais são mediadas pelos valores e pelas práticas para o alcance das práticas organizacionais humanistas.

E

Hye: Todas as metas motivacionais são mediadas pelos valores e pelas práticas para o alcance das práticas organizacionais instrumentais.

Figura 54 - Mediação múltipla metas motivacionais para tipos de práticas

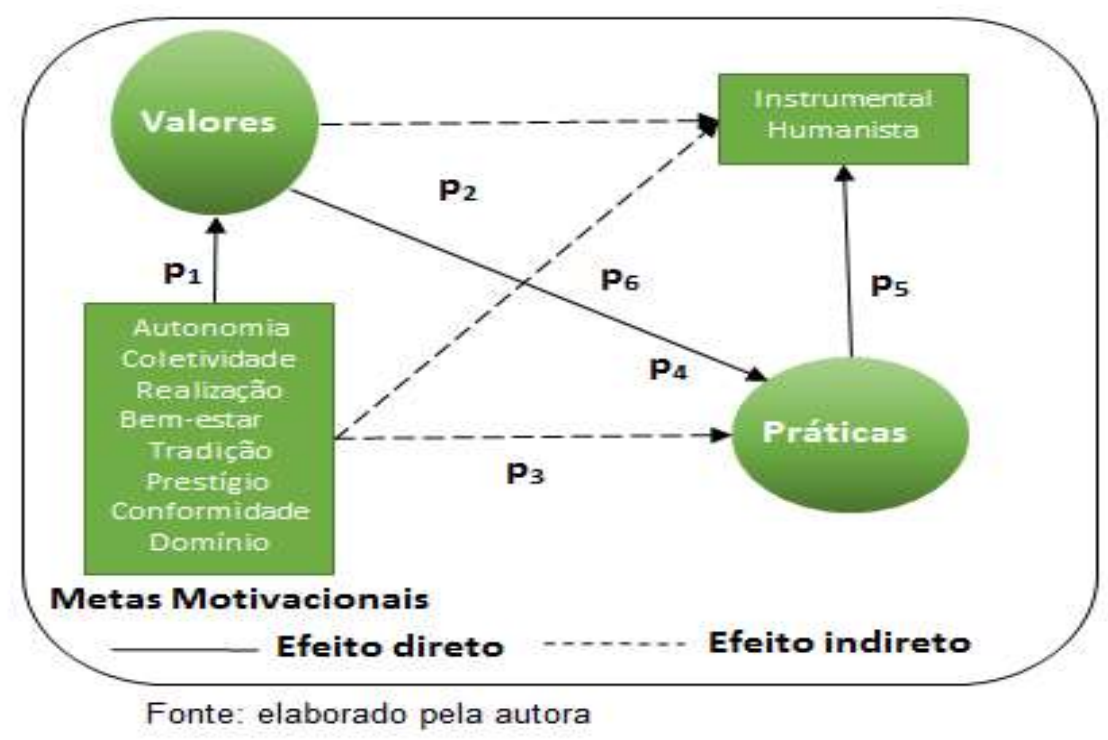

Para a verificação desta hipótese, foram obtidos dos softwares Smart-PLS e planilha eletrônica Excel e os resultados das tabelas intermediárias (efeitos específicos indiretos e diretos e efeitos indiretos total) estão disponíveis no apêndice $n^{\circ} 03$.

Os resultados da análise mediadora múltipla das metas motivacionais para os tipos de práticas estão no quadro 39.

Quadro 39 - Resultados da análise mediadora múltipla de valores e práticas 


\begin{tabular}{|c|c|c|c|c|}
\hline \multirow{2}{*}{ Mediadoras } & \multirow{2}{*}{ Relação } & \multicolumn{2}{|c|}{ Significância } & \multirow{2}{*}{ Interpretação } \\
\hline & & Indireto & Direto & \\
\hline \multirow{8}{*}{ Valores e Tipos de Práticas } & $\begin{array}{l}\text { Autonomia -> Humanista } \\
\text { Autonomia -> Instrumental }\end{array}$ & Sim & Sim & Mediação parcial \\
\hline & $\begin{array}{l}\text { Bem-estar -> Humanista } \\
\text { Bem-estar -> Instrumental }\end{array}$ & Sim & Sim & Mediação parcial \\
\hline & $\begin{array}{l}\text { Coletividade -> Humanista } \\
\text { Coletividade -> Instrumental }\end{array}$ & Sim & Sim & Mediação parcial \\
\hline & $\begin{array}{l}\text { Conformidade -> Humanista } \\
\text { Conformidade }->\text { Instrumental }\end{array}$ & Sim & Sim & Mediação parcial \\
\hline & $\begin{array}{l}\text { Domínio -> Humanista } \\
\text { Domínio -> Instrumental }\end{array}$ & Sim & Sim & Mediação parcial \\
\hline & $\begin{array}{l}\text { Prestígio -> Humanista } \\
\text { Prestígio -> Instrumental }\end{array}$ & Sim & Sim & Mediação parcial \\
\hline & $\begin{array}{l}\text { Realização -> Humanista } \\
\text { Realização -> Instrumental }\end{array}$ & Sim & Sim & Mediação parcial \\
\hline & $\begin{array}{l}\text { Tradição -> Humanista } \\
\text { Tradição -> Instrumental }\end{array}$ & Sim & Sim & Mediação parcial \\
\hline
\end{tabular}

Fonte: Resultados elaborados a partir dos dados da pesquisa e calculados por meio do Software Smart-PLS

Então, existe uma mediação parcial dos construtos valores e tipos de práticas sobre as relações das metas motivacionais e tipos de práticas humanistas e instrumentais

Dado que comprometimento medeia valores para 0 alcance dos resultados organizacionais, então as metas motivacionais também serão mediadas pelo comprometimento organizacional para o alcance dos resultados. Então, a seguinte hipótese foi estabelecida:

$\mathrm{H}_{10 \mathrm{c}}$ : Todas as metas motivacionais são mediadas pelo comprometimento organizacional para o alcance dos resultados.

Figura 55 - Mediação múltipla metas motivacionais para resultados via valores e comprometimento 


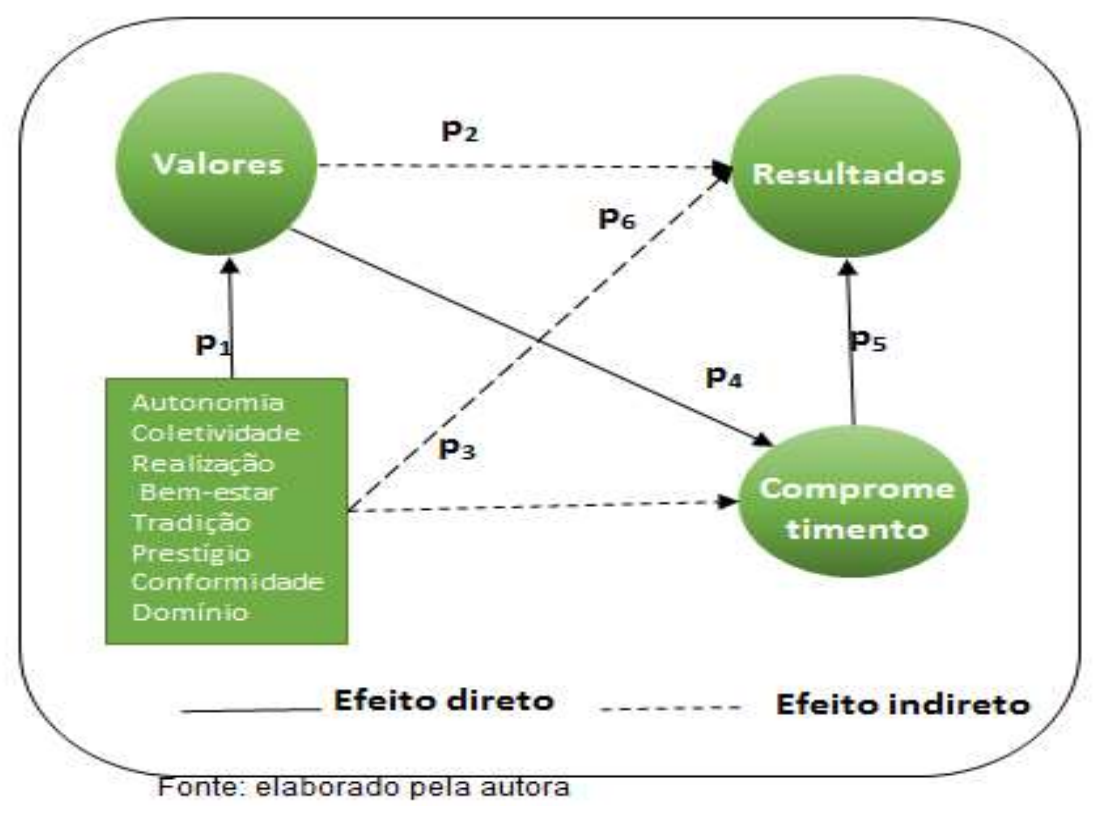

Para a verificação desta hipótese, foram obtidos dos softwares Smart-PLS e planilha eletrônica Excel e os resultados das tabelas intermediárias (efeitos específicos indiretos e diretos e efeitos indiretos total) estão disponíveis no apêndice $n^{\circ} 03$.

Os resultados da análise mediadora múltipla dos valores e comprometimento estão no quadro 40.

Quadro 40 - Resultados da análise mediadora múltipla entre valores e comprometimento

\begin{tabular}{|c|c|c|c|c|}
\hline \multirow{2}{*}{ Mediadoras } & \multirow{2}{*}{ Relação } & \multicolumn{2}{|c|}{ Significância } & \multirow{2}{*}{ Interpretação } \\
\hline & & Indireto & Direto & \\
\hline \multirow{8}{*}{ Valores e Comprometimento } & Autonomia -> Resultados & Sim & Sim & Mediação parcial \\
\hline & Bem-estar -> Resultados & Sim & Sim & Mediação parcial \\
\hline & Coletividade -> Resultados & Sim & Sim & Mediação parcial \\
\hline & Conformidade -> Resultados & Sim & Sim & Mediação parcial \\
\hline & Domínio -> Resultados & Sim & Sim & Mediação parcial \\
\hline & Prestígio -> Resultados & Sim & Sim & Mediação parcial \\
\hline & Realização -> Resultados & Sim & Sim & Mediação parcial \\
\hline & Tradição -> Resultados & Sim & Sim & Mediação parcial \\
\hline
\end{tabular}

Fonte: Resultados elaborados a partir dos dados da pesquisa e calculados por meio do Software Smart-PLS

Então, existe uma mediação parcial dos construtos valores e comprometimentos sobre as relações das metas motivacionais e resultados. 
Dado que comprometimento e práticas organizacionais medeiam valores para o alcance dos resultados organizacionais, então as metas motivacionais também serão mediadas concomitantemente pelas práticas e pelo comprometimento para o alcance dos resultados. E a seguinte hipótese foi estabelecida:

$\mathrm{H}_{10 \mathrm{~d}}$ : Todas as metas motivacionais são mediadas concomitantemente pelas práticas e pelo comprometimento para o alcance dos resultados.

A figura 56 representa a proposta de mediação da hipótese $10 \mathrm{~d}$.

Figura 56 - Mediação múltipla metas motivacionais para resultados via valores, práticas e comprometimento

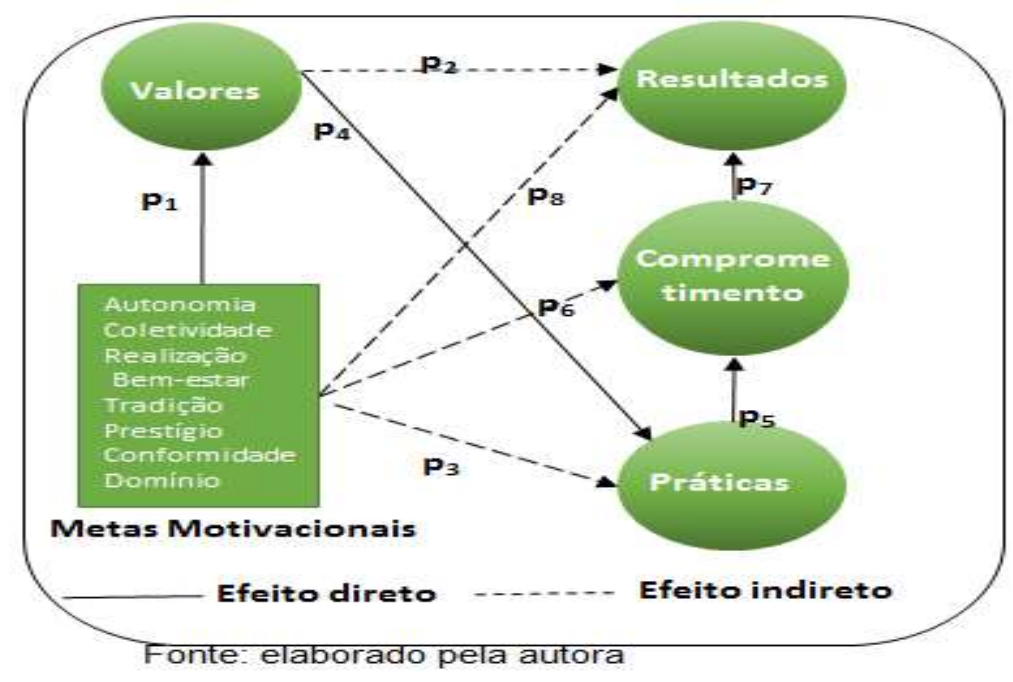

Esta relação não foi estabelecida, pois a primeira condição para que haja mediação é que as relações indiretas sejam significantes. $E$, como pode ser visto na tabela $A_{3} 10$ no apêndice $n^{\circ} 03$, em nenhum dos casos houve significância, pois todas as relações apresentaram $t<1,96$ e, consequentemente, $p>0,05$. 
Dado que valores têm relação direta com comprometimento, então as metas motivacionais serão mediadas pelos construtos valores e comprometimento para o alcance das bases de comprometimento. E a seguinte hipótese foi estabelecida:

$\mathrm{H}_{10 \mathrm{e}}$ : Todas as metas motivacionais são mediadas pelos construtos valores e comprometimento para o alcance das bases de comprometimento.

A figura 57 representa a proposta de mediação da hipótese 10e.

Figura 57 - Mediação múltipla metas motivacionais para bases de comprometimento via valores e comprometimento

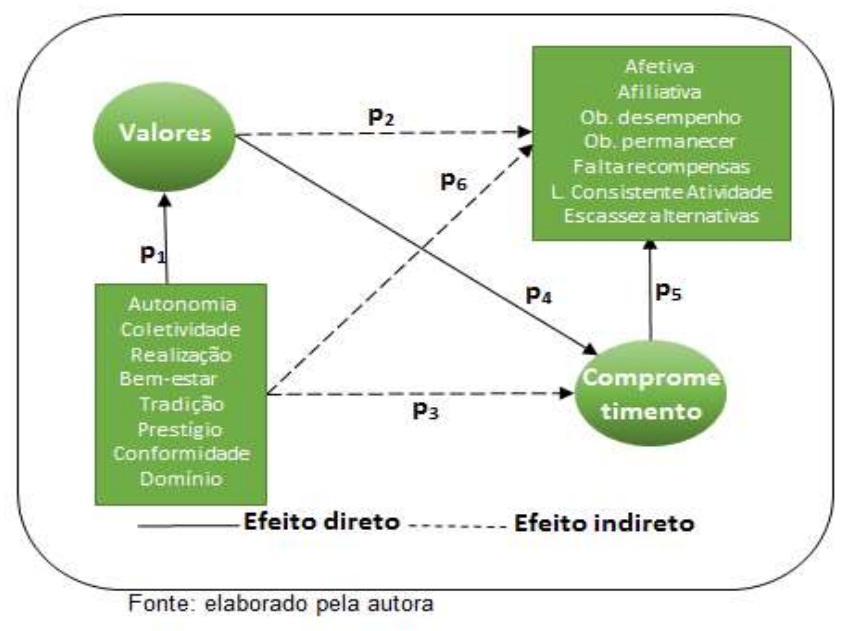

Para a verificação desta hipótese, foram obtidos dos softwares Smart-PLS e planilha eletrônica Excel e os resultados das tabelas intermediárias (efeitos específicos indiretos e diretos e efeitos indiretos total) estão disponíveis no apêndice $n^{\circ} 03$.

\section{Metas Motivacionais e Base de Comprometimento Afetiva}

Os resultados da análise mediadora múltipla das metas motivacionais e a base de comprometimento afetiva estão no quadro 41.

Quadro 41 - Resultados da análise mediadora múltipla valores e base afetiva

\begin{tabular}{|c|c|c|c|c|}
\hline \multirow{2}{*}{ Mediadoras } & \multirow{2}{*}{ Relação } & \multicolumn{2}{|c|}{ Significância } & \multirow{2}{*}{ Interpretação } \\
\hline & & Indireto & Direto & \\
\hline \multirow{8}{*}{$\begin{array}{c}\text { Valores e Comprometimento } \\
\text { base afetiva }\end{array}$} & Autonomia -> Afetiva & Sim & Sim & Mediação parcial \\
\hline & Bem-estar -> Afetiva & Sim & Sim & Mediação parcial \\
\hline & Coletividade $->$ Afetiva & Sim & Sim & Mediação parcial \\
\hline & Conformidade $->$ Afetiva & Sim & Sim & Mediação parcial \\
\hline & Domínio -> Afetiva & Sim & Sim & Mediação parcial \\
\hline & Prestígio -> Afetiva & Sim & Sim & Mediação parcial \\
\hline & Realização -> Afetiva & Sim & Sim & Mediação parcial \\
\hline & Tradição -> Afetiva & Não & Sim & Não há mediação \\
\hline
\end{tabular}


Então, existe uma mediação parcial dos construtos valores e comprometimento sobre as relações das metas motivacionais e base de comprometimento afetiva, com exceção da meta motivacional tradição e a base de comprometimento afetiva.

\section{Metas Motivacionais e Base de Comprometimento Afiliativa}

Quadro 42 - Resultados da análise mediadora múltipla entre valores e base afiliativa

\begin{tabular}{|c|c|c|c|c|}
\hline \multirow{2}{*}{ Mediadoras } & \multirow{2}{*}{ Relação } & \multicolumn{2}{|c|}{ Significância } & \multirow{2}{*}{ Interpretação } \\
\hline & & Indireto & Direto & \\
\hline \multirow{8}{*}{$\begin{array}{l}\text { Valores e Comprometimento } \\
\text { Base afiliativa }\end{array}$} & Autonomia -> Afiliativa & Sim & Sim & Mediação parcial \\
\hline & Bem-estar -> Afiliativa & Sim & Sim & Mediação parcial \\
\hline & Coletividade -> Afiliativa & Sim & Sim & Mediação parcial \\
\hline & Conformidade -> Afiliativa & Sim & Sim & Mediação parcial \\
\hline & Domínio -> Afiliativa & Sim & Sim & Mediação parcial \\
\hline & Prestígio -> Afiliativa & Sim & Sim & Mediação parcial \\
\hline & Realização -> Afiliativa & Sim & Sim & Mediação parcial \\
\hline & Tradição -> Afiliativa & Não & Sim & Não há mediação \\
\hline
\end{tabular}

Fonte: Resultados elaborados a partir dos dados da pesquisa e calculados por meio do Software Smart-PLS

O que se verifica é a existência de mediação parcial dos construtos valores e comprometimento sobre as relações das metas motivacionais e base de comprometimento afiliativa, com exceção da meta motivacional tradição. 


\section{Metas Motivacionais e Base de Comprometimento Obrigação pelo desempenho}

Quadro 43 - Resultados da análise mediadora múltipla valores e base obrigação p/ desempenho

\begin{tabular}{|c|c|c|c|c|}
\hline \multirow{2}{*}{ Mediadoras } & \multirow{2}{*}{ Relação } & \multicolumn{2}{|c|}{ Significância } & \multirow{2}{*}{ Interpretação } \\
\hline & & Indireto & Direto & \\
\hline \multirow{8}{*}{$\begin{array}{c}\text { Valores e } \\
\text { Comprometimento }\end{array}$} & Autonomia -> Obrigação p/ desempenho & Sim & Sim & Mediação parcial \\
\hline & Bem-estar -> Obrigação p/ desempenho & Sim & Sim & Mediação parcial \\
\hline & Coletividade -> Obrigação $\mathrm{p} /$ desempenho & Sim & Sim & Mediação parcial \\
\hline & Conformidade -> Obrigação $\mathrm{p} /$ desempenho & Sim & Sim & Mediação parcial \\
\hline & Domínio -> Obrigação p/ desempenho & Sim & Sim & Mediação parcial \\
\hline & Prestígio -> Obrigação p/ desempenho & Sim & Sim & Mediação parcial \\
\hline & Realização -> Obrigação p/ desempenho & Sim & Sim & Mediação parcial \\
\hline & Tradição -> Obrigação p/ desempenho & Não & Sim & Não há mediação \\
\hline
\end{tabular}

Fonte: Resultados elaborados a partir dos dados da pesquisa e calculados por meio do Software Smart-PLS

O que se verifica é a existência de mediação parcial dos construtos valores e comprometimento sobre as relações das metas motivacionais e base de comprometimento obrigação pelo desempenho, com exceção da meta motivacional tradição.

\section{Metas Motivacionais e Base de Comprometimento Obrigação em permanecer}

Quadro 44 - Resultados da análise mediadora múltipla entre valores e obrigação em permanecer

\begin{tabular}{|c|c|c|c|c|}
\hline \multirow{2}{*}{ Mediadoras } & \multirow{2}{*}{ Relação } & \multicolumn{2}{|c|}{ Significância } & \multirow{2}{*}{ Interpretação } \\
\hline & & Indireto & Direto & \\
\hline \multirow{8}{*}{$\begin{array}{c}\text { Valores e } \\
\text { Comprometimento } \\
\text { base obrigação em } \\
\text { permanecer }\end{array}$} & Autonomia -> Obrigação em permanecer & Sim & Sim & Mediação parcial \\
\hline & Bem-estar -> Obrigação em permanecer & Sim & Sim & Mediação parcial \\
\hline & Coletividade -> Obrigação em permanecer & Sim & Sim & Mediação parcial \\
\hline & Conformidade -> Obrigação em permanecer & Sim & Sim & Mediação parcial \\
\hline & Domínio -> Obrigação em permanecer & Sim & Sim & Mediação parcial \\
\hline & Prestígio -> Obrigação em permanecer & Sim & Sim & Mediação parcial \\
\hline & Realização -> Obrigação em permanecer & Sim & Sim & Mediação parcial \\
\hline & Tradição -> Obrigação em permanecer & Não & Sim & Não há mediação \\
\hline
\end{tabular}

Fonte: Resultados elaborados a partir dos dados da pesquisa e calculados por meio do Software Smart-PLS

Há a existência de mediação parcial dos construtos valores e comprometimento sobre as relações das metas motivacionais e base de comprometimento obrigação em permanecer, com exceção da meta motivacional tradição. 


\section{Metas Motivacionais e Base de Comprometimento L. Consistente de Atividade}

Quadro 45 - Resultados da análise mediadora múltipla valores e linha consistente de atividade

\begin{tabular}{|c|c|c|c|c|}
\hline \multirow{2}{*}{ Mediadoras } & \multirow[b]{2}{*}{ Relação } & \multicolumn{2}{|c|}{ Significância } & \multirow{2}{*}{ Interpretação } \\
\hline & & Indireto & Direto & \\
\hline \multirow{8}{*}{$\begin{array}{c}\text { Valores e } \\
\text { Comprometimento } \\
\text { Base linha } \\
\text { consistente de } \\
\text { atividade }\end{array}$} & Autonomia -> Linha consistente de atividade & Sim & Sim & Mediação parcial \\
\hline & Bem-estar -> Linha consistente de atividade & Sim & Sim & Mediação parcial \\
\hline & Coletividade $->$ Linha consistente de atividade & Sim & Sim & Mediação parcial \\
\hline & Conformidade $->$ L. consistente de atividade & Sim & Sim & Mediação parcial \\
\hline & Domínio -> Linha consistente de atividade & Não & Sim & Não há mediação \\
\hline & Prestígio -> Linha consistente de atividade & Sim & Sim & Mediação parcial \\
\hline & Realização -> Linha consistente de atividade & Sim & Sim & Mediaçao parcial \\
\hline & Tradição -> Linha consistente de atividade & Não & Sim & Não há mediação \\
\hline
\end{tabular}

Fonte: Resultados elaborados a partir dos dados da pesquisa e calculados por meio do Software Smart-PLS

O que se verifica é a existência de mediação parcial dos construtos valores e comprometimento sobre as relações das metas motivacionais e base de comprometimento linha consistente de atividade, com exceção das metas motivacionais tradição e domínio.

\section{Metas Motivacionais e Base de Comprometimento Escassez de Alternativas}

Quadro 46 - Resultados da análise mediadora múltipla entre valores e escassez de alternativas

\begin{tabular}{|c|c|c|c|c|}
\hline \multirow{2}{*}{ Mediadoras } & \multirow{2}{*}{ Relação } & \multicolumn{2}{|c|}{ Significância } & \multirow{2}{*}{ Interpretação } \\
\hline & & Indireto & Direto & \\
\hline \multirow{8}{*}{$\begin{array}{c}\text { Valores e } \\
\text { Comprometimento }\end{array}$} & Autonomia -> Escassez de alternativas & Não & Sim & Não há mediação \\
\hline & Bem-estar -> Escassez de alternativas & Não & Sim & Não há mediação \\
\hline & Coletividade -> Escassez de alternativas & Não & Sim & Não há mediação \\
\hline & Conformidade -> Escassez de alternativas & Não & Sim & Não há mediação \\
\hline & Domínio -> Escassez de alternativas & Não & Sim & Não há mediação \\
\hline & Prestígio -> Escassez de alternativas & Não & Sim & Não há mediação \\
\hline & Realização -> Escassez de alternativas & Não & Sim & Não há mediação \\
\hline & Tradição -> Escassez de alternativas & Não & Sim & Não há mediação \\
\hline
\end{tabular}

Fonte: Resultados elaborados a partir dos dados da pesquisa e calculados por meio do Software Smart-PLS

Não há mediação dos construtos valores e comprometimento nas relações das metas motivacionais e base de comprometimento escassez de alternativas. 


\section{Metas Motivacionais e Base de Comprometimento Falta de Recompensas e Oportunidades}

Quadro 47 - Resultados da análise mediadora múltipla entre valores e falta de recompensas e oportunidades

\begin{tabular}{|c|c|c|c|c|}
\hline \multirow{2}{*}{ Mediadoras } & \multirow{2}{*}{ Relação } & \multicolumn{2}{|c|}{ Significância } & \multirow{2}{*}{ Interpretação } \\
\hline & & Indireto & Direto & \\
\hline \multirow{8}{*}{$\begin{array}{c}\text { Valores e } \\
\text { Comprometimento } \\
\text { base falta de } \\
\text { recompensas e } \\
\text { oportunidades }\end{array}$} & Autonomia -> Falta de recompensas & Sim & Sim & Mediação parcial \\
\hline & Bem-estar -> Falta de recompensas & Sim & Sim & Mediação parcial \\
\hline & Coletividade -> Falta de recompensas & Sim & Sim & Mediação parcial \\
\hline & Conformidade -> Falta de recompensas & Sim & Sim & Mediação parcial \\
\hline & Domínio -> Falta de recompensas & Sim & Sim & Mediação parcial \\
\hline & Prestígio -> Falta de recompensas & Sim & Sim & Mediação parcial \\
\hline & Realização -> Falta de recompensas & Sim & Sim & Mediação parcial \\
\hline & Tradição -> Falta de recompensas & Não & Sim & Não há mediação \\
\hline
\end{tabular}

Fonte: Resultados elaborados a partir dos dados da pesquisa e calculados por meio do Software Smart-PLS

Há a existência de mediação parcial dos construtos valores e comprometimento sobre as relações das metas motivacionais e base de comprometimento falta de recompensa e oportunidades, com exceção da meta motivacional tradição. 


\subsection{Testes das Hipóteses de Pesquisa}

Esta seção destina-se à apresentação das hipóteses da pesquisa e os seus resultados após a realização das análises bivariadas e multivariada. Primeiramente serão apresentados os resultados de todas as análises realizadas para verificar similaridade da cultura organizacional da instituição nacional e das organizações locais. Em seguida, os resultados de todos os testes realizados para a análise das relações estruturais diretas nos SECOMs, ou seja, valores, práticas, comprometimento e resultados. No terceiro instante, apresentam-se as implicações das hipóteses das relações indiretas (mediadoras). E, por fim, a hipótese que contempla as variáveis individuais (tempo de serviço, nacionalidade e sexo) em relação aos construtos valores e comprometimento.

\subsection{1 - Teste das hipóteses de similaridade cultural do DPR e dos SECOMs}

Para testar a hipótese sobre a similaridade das culturas no que se refere à relação direta entre os construtos que compõem a cultura, que nesta pesquisa foi mensurada pelos valores e tipos de práticas organizacionais do DPR e dos SECOMs, as relações diretas foram avaliadas pelo teste $t$ para amostras independentes. As seguintes hipóteses foram testadas:

$\mathrm{H}_{1}$ : Não há diferenças nas percepções dos valores organizacionais do DPR (instituição nacional) e dos SECOMs (organização local).

$\mathrm{H}_{2}$ : Não há diferenças nas percepções dos tipos de práticas organizacionais (instrumental ou humanista) do DPR (instituição nacional) e dos SECOMs (organização local).

Os resultados demonstraram que:

- Relativos aos valores organizacionais, o DPR e os SECOMs têm em comum os valores que tratam da coletividade, do bem-estar, da tradição e da conformidade. Mas diferem dos valores que visam a autonomia, realização, prestígio e domínio, e estes valores são mais reconhecidos no DPR do que nos SECOMs, com exceção do valor domínio, para o qual os SECOMs dão mais ênfase do que o DPR. Porém, ao analisar os valores do DPR somente com os brasileiros que trabalham nos SECOMs, apenas os valores autonomia e domínio são percebidos diferentemente. Ao realizar o teste-t entre o DPR e os SECOMs por continente, os SECOMs da Oceania foram os únicos 
que não se diferenciaram dos valores do DPR, seguidos pela África, que se diferencia somente para valores relativos a prestígio, e a Ásia, que se distingue no que se refere aos valores relacionados ao domínio. O continente mais díspar é o da Europa, seguidos pelos SECOMs da América do Norte, América Central e América do Sul. Estes resultados permitem corroborar parcialmente com a hipótese $\mathrm{H}_{1}$. O quadro 48 na página 381 apresenta os resultados sistematizados das relações diretas entre os tipos motivacionais entre o DPR e os SECOMs

. No que se refere aos tipos de práticas organizacionais, o DPR e os SECOMs se diferenciam quanto ao tipo de prática instrumental e esta diferença permanece nos SECOMs localizados na África, América Central, América do Norte, América do Sul e Ásia, e os SECOMs da Europa e da Oceania têm a mesma percepção dos gestores do DPR. E as práticas humanistas são percebidas da mesma forma entre o DPR e os SECOMs, em geral; e quando comparados por continentes os SECOMs da América do Norte, Ásia e Europa passam a se diferenciarem em relação ao DPR. Por isso, é que a hipótese 2 apresenta-se como parcialmente confirmada. $O$ quadro 49 apresenta os resultados para esta hipótese.

Quadro 49 - Resultados das análises bivariadas para $\mathrm{H}_{2}$

\begin{tabular}{|c|c|c|c|}
\hline \begin{tabular}{c|l}
5.4 .1 .2 & H2: Não há \\
5.4 .1 .2 .1 & organizacionais \\
& nacional) e dos
\end{tabular} & $\begin{array}{l}\text { diferenças nas } \\
\text { (instrumental } \\
\text { ECOMs (organiz }\end{array}$ & $\begin{array}{l}\text { percepções dos } \\
\text { u humanista) d } \\
\text { ação local). }\end{array}$ & $\begin{array}{l}\text { tipos de práticas } \\
\text { DPR (instituição }\end{array}$ \\
\hline Tema & \multirow{2}{*}{$\begin{array}{l}\text { Teste } \\
\text { Teste-t de } \\
\text { amostras } \\
\text { independentes }\end{array}$} & \multicolumn{2}{|c|}{ Resultados } \\
\hline $\begin{array}{l}\text { Diferenças entre os tipos } \\
\text { de } \\
\text { organizacionais } \\
\text { identificadas no DPR e nos } \\
\text { SECOMs }\end{array}$ & & $\begin{array}{c}\text { Igual } \\
\text { Humanista }\end{array}$ & $\begin{array}{c}\text { Diferente } \\
\text { Instrumental }\end{array}$ \\
\hline \multirow{4}{*}{$\begin{array}{l}\text { Diferenças entre os tipos } \\
\text { de práticas } \\
\text { organizacionais } \\
\text { identificadas no DPR e nos } \\
\text { continentes onde os } \\
\text { SECOMs } \\
\text { localizados }\end{array}$} & \multirow{4}{*}{$\begin{array}{l}\text { Teste-t de } \\
\text { amostras } \\
\text { independentes }\end{array}$} & \multicolumn{2}{|c|}{ Iguais } \\
\hline & & \multicolumn{2}{|c|}{\begin{tabular}{l|l}
\multicolumn{1}{c|}{ Instrumental } & \multicolumn{1}{c}{ Humanista } \\
Europa & África \\
Oceania & América Central \\
& América do Sul \\
& Oceania \\
\end{tabular}} \\
\hline & & \multicolumn{2}{|c|}{ Diferentes } \\
\hline & & $\begin{array}{l}\text { Instrumental } \\
\text { África } \\
\text { América Central } \\
\text { América do } \\
\text { Norte } \\
\text { América do Sul } \\
\text { Ásia } \\
\end{array}$ & \begin{tabular}{l}
\multicolumn{1}{c}{ Humanista } \\
América do Norte \\
Ásia \\
Europa
\end{tabular} \\
\hline
\end{tabular}

Fonte: dados da pesquisa 
Quadro 48 - Resultados das análises bivariadas para $\mathrm{H}_{1}$

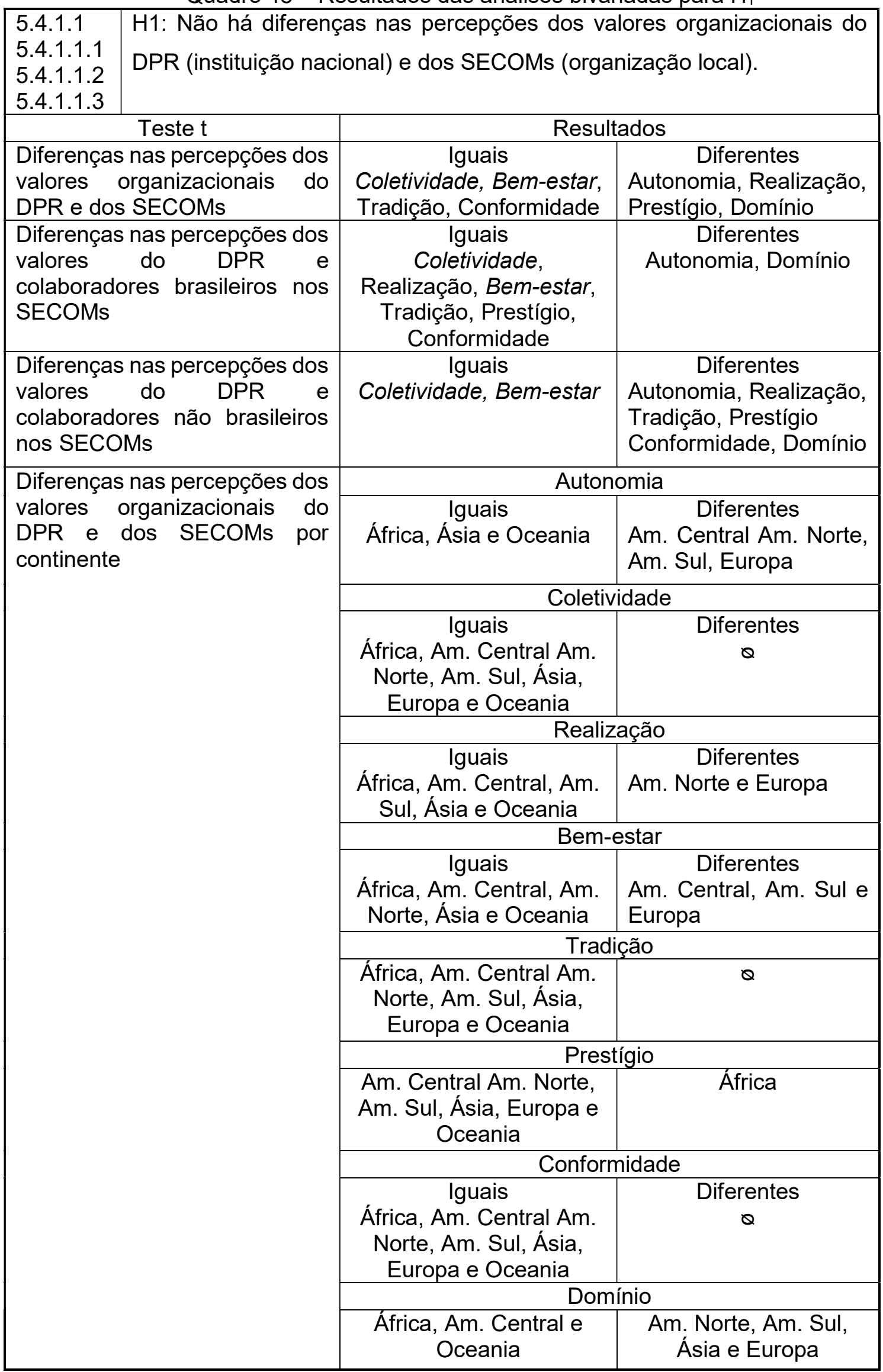




\subsection{2 - Teste das hipóteses das relações do modelo proposto para os SECOMs}

Para testar as hipóteses das relações do modelo proposto para os SECOMs, foi realizado o teste de correlação de Pearson entre eles, ou seja, de valores -> tipos de práticas, de valores -> comprometimento, e de práticas -> comprometimento, e depois foi realizado o mesmo teste das três variáveis sobre os resultados: valores e resultados; tipos de práticas e resultados; e comprometimento e resultados. Para analisar o efeito conjunto dos construtos valores, tipos de práticas e comprometimento sobre os resultados, foi realizada a análise multivariada, cujo objetivo foi explorar o desempenho conjunto das variáveis e determinar a importância de cada uma, estando as demais presentes. O método escolhido foi o da modelagem de equações estruturais. As seguintes hipóteses foram testadas:

$\mathrm{H}_{3}$ : Os valores organizacionais (SECOMs) influenciam os tipos de práticas organizacionais (SECOMs).

$\mathrm{H}_{4}$ : Os valores organizacionais (SECOMs) influenciam o comprometimento organizacional.

$\mathrm{H}_{5}$ : Os tipos de práticas organizacionais influenciam o comprometimento organizacional.

$\mathrm{H}_{6}$ : Os valores organizacionais dos SECOMs influenciam os resultados organizacionais.

$\mathrm{H}_{7}$ : Os tipos de práticas organizacionais dos SECOMs influenciam os resultados organizacionais

$\mathrm{H}_{8}$ : O comprometimento organizacional influencia os resultados organizacionais

Os resultados demonstraram que:

- Os valores organizacionais influenciam os tipos de práticas organizacionais realizadas nos SECOMs, e os valores que visam a autonomia, o bem-estar e a coletividade têm relação direta com os tipos de práticas instrumentais e para as práticas humanistas os valores que objetivam a autonomia, a coletividade, a realização e o bem-estar são os que se relacionam a este tipo de prática. O quadro 50 apresenta os resultados para esta hipótese. 
Quadro 50 - Resultados das análises bivariadas e multivariadas para $\mathrm{H}_{3}$

\begin{tabular}{|l|l|l|l|}
\hline $\begin{array}{l}5.4 .4 .4 \\
5.5\end{array}$ & $\mathrm{H}_{3}$ : Os valores organizacionais (SECOMs) influenciam os tipos de \\
práticas organizacionais (SECOMs).
\end{tabular}

Fonte: dados da pesquisa

- Os valores organizacionais influenciam o comprometimento organizacional nos SECOMs, a dimensão tradição foi a que menos se apresentou relacionada com as bases de comprometimento, estando presente somente com a base de comprometimento obrigação pelo desempenho. As dimensões dos valores organizacionais que se relacionam com a base de comprometimento falta de recompensas apresentaram relações negativas, ou seja, quanto mais ênfase for dada a autonomia, a coletividade, a realização, ao bem-estar, a conformidade e ao domínio menor será o tipo de comprometimento falta de recompensas parte do pressuposto que o esforço extra em benefício da organização deve ser recompensado e de que a organização deve lhe dar mais oportunidades. O quadro 51 apresenta os resultados para esta hipótese. 
Quadro 51 - Resultados das análises bivariadas e multivariadas para $\mathrm{H}_{4}$

\begin{tabular}{|c|c|c|c|}
\hline $\begin{array}{ll}5.4 .4 .6 \\
5.5\end{array}$ & \multicolumn{3}{|c|}{$\begin{array}{l}\text { H4: Os valores organizacionais } \\
\text { comprometimento organizacional }\end{array}$} \\
\hline Cor. de Pearson & \multicolumn{3}{|c|}{ Resultados } \\
\hline \multirow[t]{3}{*}{$\begin{array}{l}\text { Os valores } \\
\text { organizacionais } \\
\text { da organização } \\
\text { local influenciam o } \\
\text { comprometimento } \\
\text { da organização } \\
\text { local }\end{array}$} & \begin{tabular}{l}
\multicolumn{1}{c}{ Afetiva } \\
(+) Autonomia \\
(+) Coletividade \\
(+) Realização \\
(+) Bem-estar \\
(+) Prestígio \\
(+) Conformidade \\
(+) Domínio
\end{tabular} & $\begin{array}{l}\quad \text { Afiliativa } \\
(+) \text { Autonomia } \\
(+) \text { Coletividade } \\
(+) \text { Realização } \\
(+) \text { Bem-estar } \\
(+) \text { Prestígio } \\
(+) \text { Conformidade } \\
(+) \text { Domínio }\end{array}$ & $\begin{array}{l}\text { Ob. em permanecer } \\
(+) \text { Autonomia } \\
(+) \text { Coletividade } \\
\text { (+) Realização } \\
\text { (+) Bem-estar } \\
\text { (+) Prestígio } \\
\text { (+) Conformidade } \\
\text { (+) Domínio }\end{array}$ \\
\hline & $\begin{array}{l}\text { Ob. desempenho } \\
\text { (+) Coletividade } \\
\text { (+) Realização } \\
\text { (+) Tradição } \\
\text { (+) Prestígio } \\
\text { (+) Conformidade } \\
\text { (+) Domínio }\end{array}$ & $\begin{array}{l}\text { Falta recompensas } \\
\text { (-) Autonomia } \\
\text { (-) Coletividade } \\
\text { (-) Realização } \\
\text { (-) Bem-estar } \\
\text { (-) Conformidade } \\
\text { (-) Domínio }\end{array}$ & $\begin{array}{l}\text { Linha C. Atividade } \\
(+) \text { Coletividade } \\
(+) \text { Realização } \\
\text { (+) Bem-estar } \\
\text { (+) Prestígio } \\
\text { (+) Conformidade } \\
(+) \text { Domínio }\end{array}$ \\
\hline & \multicolumn{3}{|c|}{ Escassez de Alternativas $Q$} \\
\hline $\begin{array}{c}\text { Análise } \\
\text { Multivariada }\end{array}$ & \multicolumn{3}{|c|}{$\begin{array}{l}\text { Valores -> comprometimento } \\
\text { Relação significativa positiva e direta } \\
\text { path coefficients }=0,628 \text { ( } p \text {-value } 0,0000)\end{array}$} \\
\hline
\end{tabular}

Fonte: dados da pesquisa

- Os tipos de práticas organizacionais não influenciam o comprometimento organizacional e nem mesmo quando analisadas as correlações dos tipos de práticas organizacionais (instrumentais ou humanistas) e as bases de comprometimento apresentaram-se correlacionadas, como pode ser visto no quadro 52.

Quadro 52 - Resultados das análises bivariadas e multivariadas para $\mathrm{H}_{5}$

\begin{tabular}{|l|l|c|c|}
\hline $\begin{array}{l}5.4 .4 .5 \\
5.5\end{array}$ & $\begin{array}{l}\mathrm{H}_{5}: \text { Os tipos de práticas organizacionais influenciam } 0 \\
\text { comprometimento organizacional. }\end{array}$ \\
\hline \multicolumn{2}{|c|}{$\begin{array}{l}\text { Correlação de Pearson } \\
\text { comprometimento }\end{array}$} & \multicolumn{2}{c|}{ Resultados } \\
\hline \multicolumn{2}{|c|}{ Anstrumentais } & Humanistas \\
\hline \multicolumn{2}{|c|}{ Práticas -> comprometimento } & \multicolumn{2}{c|}{$\begin{array}{c}\text { Relação não significativa } \\
\text { path coefficients }=-0,0605 \text { (p-value } 0,2702)\end{array}$} \\
\hline
\end{tabular}

Fonte: dados da pesquisa

. Os valores organizacionais não impactam nos resultados organizacionais produzidos pelos SECOMs, nem mesmo as dimensões dos valores organizacionais influenciam diretamente os resultados classificados como proativos e produtivos. O quadro 53 apresenta os resultados para esta hipótese. 
Quadro 53 - Resultados das análises bivariadas e multivariadas para $\mathrm{H}_{6}$

\begin{tabular}{|l|l|c|c|}
\hline $\begin{array}{l}5.4 .4 .1 \\
5.5\end{array}$ & $\begin{array}{l}\mathrm{H}_{6}: \text { Os valores organizacionais dos SECOMs influenciam os } \\
\text { resultados organizacionais. }\end{array}$ \\
\hline \multicolumn{2}{|c|}{$\begin{array}{l}\text { Correlação de Pearson } \\
\text { organizacional }\end{array}$} & $\begin{array}{c}\text { Proatividade } \\
\text { Pesultados }\end{array}$ \\
\hline \multicolumn{2}{|c|}{ Análise multivariada } & \multicolumn{2}{c|}{ Resultados } \\
\hline \multicolumn{2}{|c|}{$\begin{array}{c}\text { Relação não significativa } \\
\text { Valores -> resultados }\end{array}$} & path coefficients $=-0,0978$ (p-value 0,1799 \\
\hline
\end{tabular}

Fonte: dados da pesquisa

- Os tipos de práticas organizacionais influenciam os resultados organizacionais, entretanto pela análise de correlação de Pearson esta relação não foi verificada. Mas a análise multivariada avalia o impacto conjunto das variáveis determinando a importância de cada uma, estando as demais presentes. Neste caso, práticas organizacionais se mostraram relevantes juntamente com comprometimento nos resultados organizacionais dos SECOMs. O quadro 54 apresenta os resultados para esta hipótese.

Quadro 54 - Resultados das análises bivariadas e multivariadas para $\mathrm{H}_{7}$

\begin{tabular}{|c|c|c|c|}
\hline $\begin{array}{l}5.4 .4 .2 \\
5.5\end{array}$ & \multicolumn{3}{|c|}{$\begin{array}{l}\mathrm{H}_{7}: \text { Os tipos de práticas organizacionais dos SECOMs influenciam os } \\
\text { resultados organizacionais }\end{array}$} \\
\hline \multicolumn{2}{|r|}{ Correlação de Pearson } & \multicolumn{2}{|c|}{ Resultados } \\
\hline $\begin{array}{l}\text { Relaçõe } \\
\text { resultad }\end{array}$ & $\begin{array}{l}\text { entre tipos de práticas e } \\
\text { o organizacional }\end{array}$ & $\begin{array}{l}\text { Proatividade } \\
Q\end{array}$ & $\begin{array}{l}\text { Produtividade } \\
\qquad\end{array}$ \\
\hline & Análise multivariada & \multicolumn{2}{|c|}{ Resultados } \\
\hline & Práticas -> Resultados & \multicolumn{2}{|c|}{$\begin{array}{c}\text { Relação significativa positiva e direta } \\
\text { path coefficients }=0,2023 \text { ( } p \text {-value } 0,0033 \text { ) }\end{array}$} \\
\hline
\end{tabular}

Fonte: dados da pesquisa

. O comprometimento organizacional influencia os resultados organizacionais, e os resultados classificados como proativos estão relacionados positivamente com as bases de comprometimento afiliativa e linha consistente de atividade; e os resultados produtivos estão negativamente relacionados com base de comprometimento obrigação pelo desempenho, como pode ser visto no quadro 55 . 
Quadro 55 - Resultados das análises para bivariadas e multuvariadas $\mathrm{H}_{8}$

\begin{tabular}{|c|c|c|}
\hline \multicolumn{3}{|c|}{$\begin{array}{l}\text { H8: O comprometimento organizacional influencia os resultados } \\
\text { organizacionais }\end{array}$} \\
\hline Correlação de Pearson & \multicolumn{2}{|c|}{ Resultados } \\
\hline $\begin{array}{l}\text { Relações entre comprometimento e } \\
\text { resultado organizacional }\end{array}$ & \begin{tabular}{l}
\multicolumn{1}{c}{ Proatividade } \\
$(+)$ Afiliativa \\
$(+)$ L. consistente \\
de atividade
\end{tabular} & $\begin{array}{l}\text { Produtividade } \\
\text { (-) Ob. pelo } \\
\text { desempenho }\end{array}$ \\
\hline Análise multivariada & \multicolumn{2}{|c|}{ Resultados } \\
\hline Comprometimento -> Resultados & \multicolumn{2}{|c|}{$\begin{array}{c}\text { Relação significativa positiva e direta } \\
\text { path coefficents }=0,1851 \text { ( } p \text {-value } 0,0105\end{array}$} \\
\hline
\end{tabular}

Fonte: dados da pesquisa

\subsubsection{Teste das hipóteses das relações indiretas (efeitos mediadores)}

Para testar as hipóteses sobre os relacionamentos indiretos, foram realizados estudos de mediação simples e de mediação múltipla.

\subsubsection{Teste das hipóteses de mediação simples de práticas organizacionais entre os valores, comprometimento e resultados}

Para testar a hipótese de mediação simples que o construto tipos de práticas organizacionais pode estabelecer entre os construtos, foram avaliadas as relações indiretas por meio do modelo de equação estrutural PLS-SEM $^{44}$ e as seguintes hipóteses foram testadas:

H9a: O construto tipos de práticas organizacionais é mediador dos construtos valores e resultados.

H9b: O construto tipos de práticas organizacionais é mediador dos construtos valores e comprometimento.

Os resultados demonstraram que:

${ }^{44}$ PLS-SEM - Partial Least Squares method to Structural Equation Modeling 
- No modelo mediador, as práticas representam um mecanismo para explicar o relacionamento entre valores e resultados e a mediação foi caracterizada como completa. Ao analisar se as práticas organizacionais representavam um mecanismo para explicar o relacionamento entre valores e comprometimento, verificou-se que não, e que o efeito entre valores e comprometimento se dá de forma direta.

\subsubsection{Teste das hipóteses de mediação simples de comprometimento organizacional entre os valores, práticas e resultados}

Para testar a hipótese de mediação simples que o construto comprometimento pode estabelecer entre os outros construtos, foram avaliadas as relações indiretas por meio da modelagem de equações estruturais, com aplicação do método de estimação dos mínimos quadrados parciais -PLS-SEM ${ }^{45}$ e as seguintes hipóteses foram testadas:

$\mathrm{H}_{10 \mathrm{a}} \mathrm{O}$ construto comprometimento é mediador dos construtos valores e resultados. $\mathrm{H}_{10 \mathrm{~b}} \mathrm{O}$ construto comprometimento é mediador dos construtos práticas e resultados. Os resultados demonstraram que:

- No modelo mediador, comprometimento representa um mecanismo para explicar o relacionamento entre valores e resultados, e esta mediação é caracterizada como mediação completa. E na análise de mediação de comprometimento como um mecanismo para explicar o relacionamento entre práticas e resultados, a mediação não foi estabelecida, entretanto existe o efeito direto entre práticas organizacionais e resultados.

\footnotetext{
${ }^{45}$ PLS-SEM - Partial Least Squares method to Structural Equation Modeling
} 


\subsubsection{Teste das hipóteses de mediação múltipla de práticas organizacionais entre as metas motivacionais, comprometimento e resultados}

Em decorrência do resultado do construto práticas organizacionais como mediadoras de valores para o alcance dos resultados organizacionais, então outras hipóteses foram estabelecidas entre as metas motivacionais e os demais construtos. $E$ as seguintes hipóteses foram estabelecidas:

H9c: Todas as metas motivacionais são mediadas pelos valores e pelas práticas organizacionais para o alcance dos resultados.

H9d: Todas as metas motivacionais são mediadas pelos valores e pelas práticas para o alcance das práticas organizacionais humanistas.

H9e: Todas as metas motivacionais são mediadas pelos valores e pelas práticas para o alcance das práticas organizacionais instrumentais.

Os resultados demonstraram que:

- Existe mediação parcial dos construtos valores e práticas sobre as metas motivacionais para o alcance dos resultados, pois todas as metas motivacionais apresentaram mediação parcial.

. Existe uma mediação parcial dos construtos valores e práticas sobre as relações das metas motivacionais tanto com os tipos de práticas humanistas quanto os tipos de práticas instrumentais.

Visto que o construto comprometimento medeia valores para o alcance dos resultados organizacionais, então passou-se a verificar se as metas motivacionais também seriam mediadas pelo comprometimento organizacional para o alcance dos resultados. Foram estabelecidas as seguintes hipóteses:

$\mathrm{H}_{10 c}$ : Todas as metas motivacionais são mediadas pelo comprometimento organizacional para o alcance dos resultados.

$\mathrm{H}_{10 \mathrm{~d}}$ : Todas as metas motivacionais são mediadas concomitantemente pelas práticas e pelo comprometimento para o alcance dos resultados.

$\mathrm{H}_{10 \mathrm{e}}$ : Todas as metas motivacionais são mediadas pelos construtos valores e comprometimento para o alcance das bases de comprometimento.

Os resultados demonstraram que: 
- Existe mediação parcial dos construtos valores e comprometimento sobre as relações das metas motivacionais e resultados.

- Não existe mediação dos construtos práticas organizacionais e comprometimento sobre as relações das metas motivacionais para o alcance dos resultados.

- Em relação às bases de comprometimento afetiva, afiliativa, obrigação pelo desempenho e falta de recompensas e oportunidades, verificou-se a existência de mediação parcial dos construtos valores e comprometimento sobre as relações das metas motivacionais e estas bases, com exceção para a meta motivacional tradição. A base de comprometimento obrigação em permanecer além da meta motivacional tradição, domínio também não resultou mediada pelos construtos valores e comprometimento. E não houve mediação dos construtos valores e comprometimento nas relações das metas motivacionais e base de comprometimento escassez de alternativas.

\subsubsection{Teste das hipóteses das relações entre as variáveis individuais e os construtos valores e comprometimento}

Para testar a hipótese das relações das variáveis individuais (tempo de serviço, nacionalidade e sexo) e os construtos valores e comprometimento, foram realizados o teste t para amostras independentes e o teste de correlação de Pearson. A seguinte hipótese foi testada:

$\mathrm{H}_{11}$ : As variáveis sociodemográficas tempo de serviço, nacionalidade e sexo influenciam na percepção dos valores e do comprometimento na organização local.

Os resultados demonstraram que:

. No que se refere aos valores organizacionais e tempo de serviço, os colaboradores dos SECOMs se diferenciam: os que têm menos tempo na casa (até 5 anos) priorizam valores que se referem à tradição, ao prestígio e à conformidade; os não brasileiros dão menos ênfase aos valores relativos à tradição, prestígio e conformidade do que os brasileiros que trabalham nos SECOMs; e os homens priorizam mais os valores atinentes à autonomia, coletividade, realização, bem-estar e conformidade.

- No que tange ao comprometimento organizacional, a percepção dos colaboradores dos SECOMs se diferencia, os que têm mais tempo de casa (acima de 5 anos) 
reconhecem mais as bases de comprometimento linha consistente de atividade e escassez de alternativas; os não brasileiros dão mais importância as bases de comprometimento obrigação em permanecer e falta de recompensas e oportunidades, enquanto os brasileiros que trabalham nos SECOMs priorizam a base de comprometimento obrigação pelo desempenho; os homens evidenciam mais as bases de comprometimento afiliativa e afetiva do que as mulheres.

- Ao verificar as relações conjuntas entre valores e comprometimento diante das variáveis demográficas, verificou-se que colaboradores com menos tempo de serviço em relação à base afiliativa se relacionam com os valores que focam a tradição e o prestígio, em referência à base obrigação pelo desempenho os mais novos se relacionam com os valores que priorizam a coletividade e o domínio e para estes colaboradores, a base de comprometimento falta de recompensas e oportunidades somente com a dimensão domínio. Já os colaboradores mais velhos de casa em relação à base de comprometimento obrigação em permanecer enfatizam valores que se referem ao prestígio e à conformidade; e com a base de comprometimento linha consistente de atividade, estes colaboradores ressaltam valores relativos à coletividade, realização, bem-estar e prestígio; e com a base escassez de alternativas, os valores que focam a autonomia e a realização.

. No tocante aos brasileiros nos SECOMs, a base de comprometimento obrigação em permanecer se relaciona com os valores que focam a conformidade. Já os não brasileiros percebem que o comprometimento obrigação pelo desempenho está relacionado com valores que evidenciam a coletividade e o domínio; e estes colaboradores distinguem a base de comprometimento falta de recompensas por meio de valores que priorizam a autonomia; a base de comprometimento linha consistente de atividade por meio de valores relativos à coletividade, realização e domínio; e comprometimento escassez de alternativas com valores que enfatizam a realização. Essas análises estão disponíveis no quadro 56 das páginas 391 a 393. 
Quadro 56 - Resultados das análises para $\mathrm{H}_{11}$ - valores e comprometimento (cont.)

\begin{tabular}{|c|c|c|c|c|}
\hline $\begin{array}{l}5.4 .2 .1 \\
5.4 .2 .2 \\
5.4 .2 .3\end{array}$ & $\begin{array}{l}5.4 .3 .1 \\
5.4 .3 .2 \\
5.4 .3 .3\end{array}$ & \multicolumn{3}{|c|}{$\begin{array}{l}\mathrm{H}_{11} \text { : As variáveis sociodemográficas tempo de serviço, nacionalidade e } \\
\text { sexo influenciam na percepção dos valores e do comprometimento na } \\
\text { organização local. }\end{array}$} \\
\hline \multicolumn{3}{|c|}{ Teste-t } & \multicolumn{2}{|c|}{ Resultados } \\
\hline $\begin{array}{l}\text { Diferen } \\
\text { valores } \\
\text { (SECO } \\
\text { de serv } \\
5 \text { anos }\end{array}$ & $\begin{array}{l}\text { ças na } \\
\text { na or } \\
\text { Us) em } f \\
\text { ço até } 5\end{array}$ & $\begin{array}{l}\text { percepção dos } \\
\text { yanização local } \\
\text { unção do tempo } \\
\text { anos e acima de }\end{array}$ & \begin{tabular}{l}
\multicolumn{1}{c}{ Iguais } \\
Autonomia, \\
Coletividade, Prestígio, \\
Conformidade e \\
Domínio
\end{tabular} & \begin{tabular}{l}
\multicolumn{2}{c}{ Diferentes } \\
Realização, Bem-estar e \\
Tradição \\
\end{tabular} \\
\hline $\begin{array}{l}\text { Diferen } \\
\text { valores } \\
\text { (SECO } \\
\text { naciona } \\
\text { brasilei }\end{array}$ & $\begin{array}{l}\text { as na } \\
\text { na or } \\
\text { Us) en } \\
\text { lidade b } \\
\text { os }\end{array}$ & \begin{tabular}{|rr} 
percepção & dos \\
ganização & local \\
função & da \\
rasileiros e & não
\end{tabular} & \begin{tabular}{l}
\multicolumn{1}{c}{ Iguais } \\
Autonomia, \\
Coletividade, \\
Realização, \\
Bem-estar, e Domínio
\end{tabular} & $\begin{array}{l}\text { Diferentes } \\
\text { Tradição, Prestígio } \\
\text { Conformidade } \\
\text { para os brasileiros }\end{array}$ \\
\hline $\begin{array}{l}\text { Diferen } \\
\text { valores } \\
\text { (SECO }\end{array}$ & $\begin{array}{l}\text { cas na } \\
\text { na or } \\
\text { us) em fu }\end{array}$ & $\begin{array}{l}\text { percepção dos } \\
\text { ganização local } \\
\text { inção do sexo }\end{array}$ & $\begin{array}{l}\text { Iguais } \\
\text { Tradição, Prestígio e } \\
\text { Domínio }\end{array}$ & \begin{tabular}{l}
\multicolumn{2}{c}{ Diferentes } \\
Autonomia, Coletividade, \\
Realização, Bem-estar e \\
Conformidade \\
para os homens
\end{tabular} \\
\hline $\begin{array}{l}\text { Diferen } \\
\text { compro } \\
\text { organiz } \\
\text { função } \\
\text { anos e }\end{array}$ & $\begin{array}{l}\text { jas na } \\
\text { metiment } \\
\text { ação locé } \\
\text { do tempo } \\
\text { acima de }\end{array}$ & $\begin{array}{l}\text { percepção do } \\
\text { o } \\
\text { na } \\
\text { (SECOMs) em } \\
\text { de serviço até } 5 \\
5 \text { anos }\end{array}$ & $\begin{array}{l}\text { Iguais } \\
\text { Afetiva, Obrigação em } \\
\text { permanecer, Obrigação } \\
\text { pelo desempenho, } \\
\text { afiliativa e falta de } \\
\text { recompensas }\end{array}$ & $\begin{array}{l}\text { Diferentes } \\
\text { Linha consistente de } \\
\text { atividade e Escassez de } \\
\text { alternativas }\end{array}$ \\
\hline $\begin{array}{l}\text { Diferen } \\
\text { compro } \\
\text { organiz } \\
\text { função } \\
\text { brasilei }\end{array}$ & $\begin{array}{l}\text { sas na } \\
\text { metiment } \\
\text { ação locá } \\
\text { da } \\
\text { os e não }\end{array}$ & $\begin{array}{l}\text { percepção } \\
\text { o do } \\
\text { (SECOMs) } \\
\text { na } \\
\text { nacionalidade } \\
\text { brasileiros }\end{array}$ & $\begin{array}{l}\text { Iguais } \\
\text { Afetiva, Afiliativa, Linha } \\
\text { consistente de atividade } \\
\text { e Escassez de } \\
\text { alternativas }\end{array}$ & \begin{tabular}{l}
\multicolumn{1}{c}{ Diferentes } \\
Obrigação em permanecer \\
e falta de recompensas \\
(para os NBR) e Obrigação \\
pelo desempenho (para os \\
BR)
\end{tabular} \\
\hline $\begin{array}{l}\text { Diferen } \\
\text { compro } \\
\text { Organiz } \\
\text { função }\end{array}$ & $\begin{array}{l}\text { ças na } \\
\text { metiment } \\
\text { ação locé } \\
\text { do sexo }\end{array}$ & $\begin{array}{ll}\text { percepção } & \text { do } \\
\text { o } & \text { na } \\
\text { (SECOMs) em }\end{array}$ & $\begin{array}{l}\text { Iguais } \\
\text { Obrigação em } \\
\text { permanecer, Obrigação } \\
\text { pelo desempenho, falta } \\
\text { de recompensas, Linha } \\
\text { consistente de atividade } \\
\text { e Escassez de } \\
\text { alternativas } \\
\end{array}$ & $\begin{array}{l}\text { Afetiva e Afiliativa } \\
\text { para os homens }\end{array}$ \\
\hline
\end{tabular}


Quadro 56 - Resultados das análises para $\mathrm{H}_{11}$ - valores e comprometimento (cont.)

\begin{tabular}{|c|c|c|c|c|}
\hline $\begin{array}{l}5.4 .4 .6 .1 \\
5.4 .4 .6 .2 \\
5.4 .4 .6 .3\end{array}$ & \multicolumn{4}{|c|}{$\begin{array}{l}\mathrm{H}_{11} \text { : As variáveis sociodemográficas tempo de serviço, } \\
\text { nacionalidade e sexo influenciam na percepção dos valores e do } \\
\text { comprometimento na organização local. }\end{array}$} \\
\hline Cor. de Pearson & \multicolumn{4}{|c|}{ Resultados } \\
\hline \multirow{11}{*}{$\begin{array}{lr}\text { Relações entre } \\
\text { valores } \\
\text { comprometimento } \\
\text { em função do } \\
\text { sexo }\end{array}$} & \multicolumn{2}{|c|}{ Afetiva } & \multicolumn{2}{|c|}{ Afiliativa } \\
\hline & Masc & Fem & Masc & Fem \\
\hline & $\begin{array}{l}\text { (+) Autonomia } \\
(+) \text { Coletividade } \\
(+) \text { Realização } \\
(+) \text { Bem-estar } \\
\text { (+) Prestígio } \\
\text { (+) Conformidade } \\
(+) \text { Domínio }\end{array}$ & $\begin{array}{l}\text { (+) Autonomia } \\
(+) \text { Coletividade } \\
(+) \text { Realização } \\
\text { (+) Bem-estar } \\
\text { (+) Prestígio } \\
(+) \text { Conformidade } \\
(+) \text { Domínio }\end{array}$ & $\begin{array}{l}\text { (+) Autonomia } \\
(+) \text { Coletividade } \\
(+) \text { Realização } \\
(+) \text { Bem-estar } \\
(+) \text { Conformidade }\end{array}$ & $\begin{array}{l}\text { (+) Autonomia } \\
(+) \text { Coletividade } \\
(+) \text { Realização } \\
(+) \text { Bem-estar } \\
(+) \text { Prestígio } \\
(+) \text { Conformidade } \\
(+) \text { Domínio }\end{array}$ \\
\hline & \multicolumn{2}{|c|}{ Ob. em permanecer } & \multicolumn{2}{|c|}{ Ob. desempenho } \\
\hline & Masc & Fem & Masc & Fem \\
\hline & $\begin{array}{l}(+) \text { Autonomia } \\
(+) \text { Coletividade } \\
(+) \text { Realização } \\
(+) \text { Prestígio } \\
(+) \text { Domínio }\end{array}$ & $\begin{array}{l}\text { (+) Autonomia } \\
(+) \text { Coletividade } \\
(+) \text { Realização } \\
(+) \text { Bem-estar } \\
\text { (+) Prestígio } \\
\text { (+) Domínio }\end{array}$ & $\begin{array}{l}\text { (+) Tradição } \\
(+) \text { Prestígio } \\
(+) \text { Conformidade } \\
(+) \text { Domínio }\end{array}$ & $\begin{array}{l}\text { (+) Coletividade } \\
(+) \text { Realização } \\
(+) \text { Tradição } \\
\text { (+) Prestígio } \\
\text { (+) Conformidade } \\
\text { (+) Domínio }\end{array}$ \\
\hline & \multicolumn{2}{|c|}{ Falta recompensas } & \multicolumn{2}{|c|}{ Linha C. Atividade } \\
\hline & Masc & Fem & Masc & Fem \\
\hline & $\begin{array}{l}\text { (-) Autonomia } \\
\text { (-) Coletividade } \\
\text { (-) Realização } \\
\text { (-) Bem-estar }\end{array}$ & $\begin{array}{l}\text { (-) Autonomia } \\
\text { (-) Coletividade } \\
\text { (-) Realização } \\
\text { (-) Bem-estar } \\
\text { (-) Domínio }\end{array}$ & $\begin{array}{l}\text { (+) Prestígio } \\
(+) \text { Domínio }\end{array}$ & $\begin{array}{l}(+) \text { Coletividade } \\
(+) \text { Realização } \\
(+) \text { Prestígio } \\
(+) \text { Conformidade } \\
(+) \text { Domínio }\end{array}$ \\
\hline & \multirow{2}{*}{\multicolumn{2}{|c|}{ Escassez de Alternativas }} & Masc & Fem \\
\hline & & & (-) Tradição & $\begin{array}{l}(+) \text { Autonomia } \\
(+) \text { Bem-estar }\end{array}$ \\
\hline \multirow{6}{*}{$\begin{array}{l}\text { Relações entre } \\
\text { valores } \\
\text { comprometimento } \\
\text { em função da } \\
\text { nacionalidade }\end{array}$} & \multicolumn{2}{|c|}{ Afetiva } & \multicolumn{2}{|c|}{ Afiliativa } \\
\hline & BR & NBR & $\mathrm{BR}$ & NBR \\
\hline & $\begin{array}{l}\text { (+) Autonomia } \\
(+) \text { Coletividade } \\
(+) \text { Realização } \\
\text { (+) Bem-estar } \\
\text { (+) Prestígio } \\
\text { (+) Conformidade } \\
\text { (+) Domínio }\end{array}$ & $\begin{array}{l}(+) \text { Autonomia } \\
(+) \text { Coletividade } \\
(+) \text { Realização } \\
(+) \text { Bem-estar } \\
\text { (+) Prestígio } \\
(+) \text { Conformidade } \\
(+) \text { Domínio }\end{array}$ & $\begin{array}{l}\text { (+) Autonomia } \\
(+) \text { Coletividade } \\
(+) \text { Realização } \\
\text { (+) Bem-estar } \\
\text { (+) Prestígio } \\
\text { (+) Conformidade } \\
(+) \text { Domínio }\end{array}$ & $\begin{array}{l}(+) \text { Autonomia } \\
(+) \text { Coletividade } \\
(+) \text { Realização } \\
\text { (+) Bem-estar } \\
\text { (+) Prestígio } \\
\text { (+) Conformidade } \\
(+) \text { Domínio } \\
\end{array}$ \\
\hline & \multicolumn{2}{|c|}{ Ob. em permanecer } & \multicolumn{2}{|c|}{ Ob. desempenho } \\
\hline & BR & NBR & BR & NBR \\
\hline & $\begin{array}{l}\text { (+) Autonomia } \\
(+) \text { Coletividade } \\
(+) \text { Realização } \\
(+) \text { Bem-estar } \\
\text { (+) Prestígio } \\
(+) \text { Conformidade } \\
(+) \text { Domínio }\end{array}$ & $\begin{array}{l}\text { (+) Autonomia } \\
(+) \text { Coletividade } \\
(+) \text { Realização } \\
(+) \text { Bem-estar } \\
\text { (+) Prestígio } \\
\text { (+) Domínio }\end{array}$ & $\begin{array}{l}(+) \text { Tradição } \\
(+) \text { Conformidade }\end{array}$ & $\begin{array}{l}(+) \text { Coletividade } \\
(+) \text { Tradição } \\
(+) \text { Prestígio } \\
\text { (+) Conformidade } \\
(+) \text { Domínio }\end{array}$ \\
\hline
\end{tabular}


Quadro 56 - Resultados das análises para $\mathrm{H}_{11}$ - valores e comprometimento (conc.)

\begin{tabular}{|l|l|l|l|l|l|}
\hline $\begin{array}{l}5.4 .4 .6 .1 \\
5.4 .4 .6 .2\end{array}$ & H 11 : As variáveis sociodemográficas tempo de serviço, nacionalidade e \\
5.4.4.6.3 & sexo influenciam na percepção dos valores e do comprometimento na \\
organização local.
\end{tabular}

Fonte: dados da pesquisa 
O quadro 57 apresenta uma síntese do teste das hipóteses da pesquisa.

Quadro 57 - Sumário dos testes das hipóteses da pesquisa

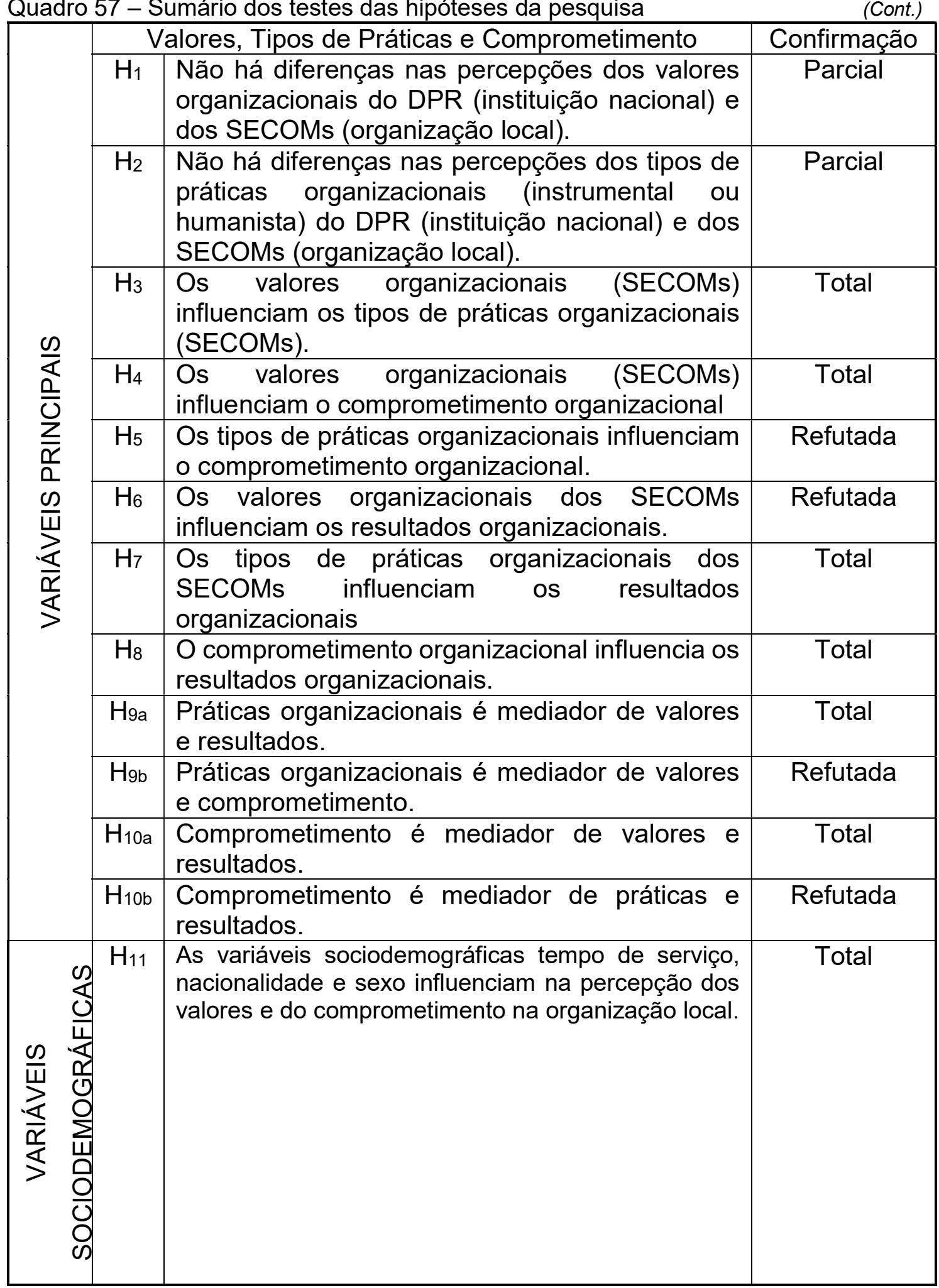

Fonte: elaborado pela autora 
Quadro 57 - Sumário dos testes das hipóteses da pesquisa

\begin{tabular}{|c|c|c|c|}
\hline \multicolumn{3}{|r|}{ Mediação múltipla } & Confirmação \\
\hline \multirow{7}{*}{ 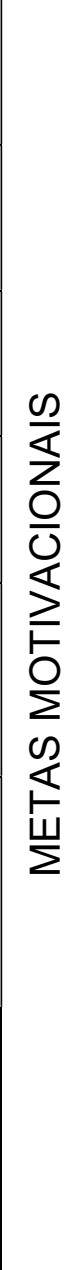 } & H9c & $\begin{array}{l}\text { Todas as metas motivacionais são mediadas } \\
\text { pelos valores e pelas práticas organizacionais } \\
\text { para o alcance dos resultados. }\end{array}$ & Parcial \\
\hline & $\mathrm{H}_{9 \mathrm{~d}}$ & $\begin{array}{l}\text { Todas as metas motivacionais são mediadas } \\
\text { pelos valores e pelas práticas para o alcance das } \\
\text { práticas organizacionais humanistas }\end{array}$ & Parcial \\
\hline & $\mathrm{H}_{9 e}$ & $\begin{array}{l}\text { Todas as metas motivacionais são mediadas } \\
\text { pelos valores e pelas práticas para o alcance das } \\
\text { práticas organizacionais instrumentais. }\end{array}$ & Parcial \\
\hline & $\mathrm{H}_{10 \mathrm{c}}$ & $\begin{array}{l}\text { Todas as metas motivacionais são mediadas } \\
\text { pelo comprometimento organizacional para o } \\
\text { alcance dos resultados. }\end{array}$ & Parcial \\
\hline & $\mathrm{H}_{10 \mathrm{~d}}$ & $\begin{array}{l}\text { Todas as metas motivacionais são mediadas } \\
\text { concomitantemente pelas práticas e pelo } \\
\text { comprometimento para o alcance dos } \\
\text { resultados. }\end{array}$ & Refutada \\
\hline & $\mathrm{H}_{10 \mathrm{e}}$ & $\begin{array}{l}\text { Todas as metas motivacionais são mediadas } \\
\text { pelos construtos valores e comprometimento } \\
\text { para o alcance das bases de comprometimento. }\end{array}$ & $\begin{array}{l}\text { Refutada } p / \text { as } \\
\text { metas tradição } \\
\text { e domínio } \\
\text { Parcial para as } \\
\text { demais metas }\end{array}$ \\
\hline & & & $\begin{array}{c}\text { Refutada para } \\
\text { a base } \\
\text { escassez de } \\
\text { alternativas } \\
\text { Parcial para as } \\
\text { demais bases }\end{array}$ \\
\hline
\end{tabular}

Fonte: elaborado pela autora

\subsection{Síntese do capítulo 5}

Este capítulo apresentou os resultados propiciados pela realização dos testes das hipóteses estabelecidas para esta pesquisa. No primeiro momento, foram realizadas as análises univariadas nas quais ocorreram as análises descritivas, a verificação da homogeneidade e confiabilidade dos itens das escalas aplicadas ao público-alvo, bem como uma análise preliminar dos resultados por meio da comparação de médias. Em seguida foram realizadas as análises bivariadas, em que foi feito o teste-t para amostras independentes para verificar similaridade entre os valores e as práticas do DPR e dos SECOMs e verificar similaridades entre as variáveis sociodemográficas e os construtos valores e comprometimento nos SECOMs; o teste de correlação de Pearson foi realizado para estudar as relações dos construtos do modelo proposto para os SECOMs. E, por último, a análise multivariada, que verificou as relações dos construtos e o impacto destes com os resultados organizacionais. 


\section{DISCUSSÃO}

\subsection{Introdução ao capítulo 6}

Este capítulo discute os resultados concernentes aos objetivos específicos propostos para este trabalho. Os cinco objetivos específicos serão discutidos na próxima seção e, depois das discussões realizadas, apresenta-se o modelo integrador final.

\subsection{Discussão dos objetivos específicos}

A seguir são apresentadas discussões de cada um dos objetivos específicos.

\subsubsection{Discussão do objetivo específico 1}

OE1: Estudar a influência da cultura organizacional, mensurada por meio dos valores e dos tipos de práticas organizacionais, da instituição nacional sobre as organizações locais.

O referencial teórico apresentado nesta tese mostrou que cultura organizacional pode ser reconhecida por meio de padrões específicos de cada organização e, desta forma, pode ser comparada tanto com outras organizações quanto com culturas nacionais. Mostrou também que os elementos que formam a cultura são divididos em dois níveis: valores e práticas. Hofstede (2003) afirma que, apesar de os valores delinearem a cultura organizacional, a forma como as práticas são manifestadas é que tipificam a cultura da organização, uma vez que são repassadas para o grupo por meio da socialização. E, de acordo com Tryce \& Beyer (1996), é possível acessar as principais características da cultura organizacional analisando-se dois dos seus componentes fundamentais: valores e práticas.

As análises univariadas mostraram que valores que correspondem à importância que a organização dá ao respeito às regras e a modelos de comportamento são os que mais se destacam nas organizações estudadas nesta pesquisa (DPR e SECOMs), pois os colaboradores entendem que a hierarquia deve ser respeitada (valor conformidade). Outros valores muito importantes para os colaboradores são os que se referem à admiração e ao respeito da sociedade dada a qualidade dos serviços prestados pelos SECOMs e pelo DPR, de sorte que os colaboradores reconhecem que a Instituição não só influencia a sociedade, mas também que é respeitada por ela (valor prestígio). E os colaboradores concordam na ênfase que a Instituição dá para 
manter seu status quo por meio da promoção, da preservação e do respeito a usos, costumes e das práticas organizacionais (valor tradição).

Ressalta-se que esses valores são altamente compartilhados entre os seus membros e que guiam o comportamento da Instituição (DPR e SECOMs). Os valores tradição e conformidade representam o aspecto conservador da organização tanto no ambiente de trabalho quanto no relacionamento com outras organizações, e o valor prestígio representa os valores que se ocupam com o respeito e a admiração da sociedade devidos à qualidade de seus produtos e serviços. O que não causa estranheza haja vista a natureza da organização, cuja imagem é importante pressuposto de relações comerciais entre países.

Valores considerados como importantes, entretanto, menos compartilhados entre seus membros e percebidos diferentemente entre os grupos dentro na Instituição (DPR e SECOMs), são os que valorizam a competência para o alcance do sucesso da organização e dos seus colaboradores (realização), os que orientam e equilibram o relacionamento cotidiano com outras pessoas e com a comunidade em geral (coletividade). Tanto o DPR como os SECOMs não percebem relevância ou preocupação institucional em proporcionar satisfação aos seus colaboradores e qualidade de vida no ambiente de trabalho (bem-estar).

Os valores que foram percebidos de forma diferente entre as duas populações-alvo são os que priorizam a atenção da organização às ameaças do mercado (domínio) sendo enfatizado entre os colaboradores dos SECOMs e os valores que incitam aos desafios diários por meio do aperfeiçoamento das pessoas e da organização (autonomia) sendo priorizado entre os colaboradores do DPR. E essa diferença foi ratificada no teste $t$ de amostras independentes (análise bivariada).

Fatores que podem ter levado à similaridade entre os valores do DPR e dos SECOMs são o número de brasileiros que trabalham nos SECOMs e/ou a similaridade cultural dos países em que os SECOMs estão localizados em relação ao Brasil. Este estudo foi realizado ao verificar os resultados das médias dos SECOMs por continente e compará-los com a média do DPR e aferir, junto às dimensões culturais de Hofstede, possíveis razões das similaridades ou dissimilaridades.

A dimensão individualismo versus coletivismo de Hofstede (2003) reflete o grau em que a identidade individual é definida com base nos objetivos e realizações pessoais 
ou com base nos interesses coletivos do grupo em que o indivíduo se sente relacionado.

Tanto na análise univariada quanto na bivariada, há concordância entre os colaboradores dos SECOMs e do DPR dos valores que priorizam o respeito às regras e modelos de comportamento no ambiente de trabalho e o relacionamento com outras organizações (valor conformidade). Os SECOMs localizados na América do Sul foram os que mais se assimilaram ao DPR (seguidos da América do Norte e Oceania). E, dos países sul-americanos que participaram desta pesquisa, semelhantemente ao Brasil, a maioria apresenta baixo nível de individualismo, com exceção da Argentina e do Suriname que mostram pontuações que as categorizam como ligeiramente coletivistas. Na América do Norte, com média muito próxima à do DPR, há somente um país com perfil mais coletivista (México), sendo os demais individualistas (EUA e Canadá), mas com $91,4 \%$ de respondentes brasileiros. E na Oceania, apesar de ter o índice de individualismo situado entre os mais altos de todos os países que fizeram parte da investigação de Hofstede, todos os seus colaboradores são brasileiros; este continente, também apresentou média muito próxima à do DPR. A menor média foi apresentada pelos SECOMs da América Central, é interessante observar que todos os países da América Central que participaram desta pesquisa e dos estudos de Hofstede (excetuando Cuba, Nicarágua e Haiti, que não estão presentes nos estudos do autor) apresentam índice de individualismo abaixo do Brasil, ou seja, são vistos como países mais coletivistas do que individualistas, mas o percentual de colaboradores brasileiros destes SECOMs é de 40\%.

$\mathrm{Na}$ análise univariada de médias e na análise bivariada para amostras independentes, os valores que se referem à manutenção do status quo a fim de promover a preservação e o respeito aos usos, costumes e práticas organizacionais (valor tradição) são comuns à Instituição (DPR e SECOMs). Os SECOMs localizados nos continentes da Oceania, Europa e América do Sul foram os que obtiveram as médias mais próximas à média do DPR. Apesar de os países da Oceania serem mais individualistas e terem obtido média muito próxima à do DPR, há que se observar que todos os respondentes são brasileiros. Segundo Hofstede (2003), a América do Sul apresenta de médio a alto índice de coletivismo, e dos países que participaram do trabalho de Hofstede e deste trabalho, 75\% têm Índice de individualismo abaixo do brasileiro, ou seja, são mais coletivistas e possuem $33,3 \%$ de respondentes 
brasileiros. Ao examinar o índice de individualismo dos países europeus que participaram desta pesquisa, praticamente todos têm perfil mais individualistas do que coletivistas, mas, ao verificar o percentual de respondentes quanto à nacionalidade, $74 \%$ são brasileiros. As menores médias foram apresentadas pelos SECOMs localizados na África e na América Central, e nestes SECOMs o percentual de respondentes brasileiros é de $42,1 \%$ e $40 \%$, respectivamente.

A dimensão masculinidade de Hofstede (2003), em que sociedades mais masculinas entendem que motivação está relacionado com concessão de oportunidades de reconhecimento e de promoção e à perspectiva de enfrentar novos desafios (Hofstede, 1991, 2003). O Brasil se situa em posição intermediária, i.e., nem tão masculina e nem tão feminina (Hofstede Centre, 2017). Ao analisar esta dimensão com os resultados de valores organizacionais, o que se espera é que sociedades com perfis masculinos deem ênfase a valores relacionados ao prestígio e ao domínio; e que valores que tratam de realização sejam importantes, mas não preponderantes.

O terceiro valor considerado como central para os dois grupos de estudo, na análise univariada, é o que se se refere à busca pela organização de admiração e respeito da sociedade por causa da qualidade dos seus produtos e serviços (prestígio). A América do Sul e a Oceania obtiveram as maiores médias de concordância e um pouco acima da média do DPR, e os SECOMs da Ásia, América do Norte e Europa apresentaram médias muito semelhantes à média da instituição nacional. No teste da análise bivariada para diferenças nas percepções dos valores organizacionais do DPR e dos SECOMs por continente, somente a África resultou como diferente do DPR.

Na América do Sul, dos países que participaram das investigações de Hofstede e desta pesquisa, metade possui índice de masculinidade acima do brasileiro e 33\% dos respondentes são brasileiros. Todos os países da Oceania apresentam alto índice de masculinidade, e todos os respondentes são brasileiros. Como se espera que países com perfil mais masculinos deem ênfase a valores como prestígio, pode-se perceber influência da cultura nacional local sobre a cultura institucional (DPR-BR).

A Ásia possui metade dos países com índice de masculinidade superior ao do Brasil, e aproximadamente metade dos respondentes brasileiros. Na América do Norte, os países são preponderantemente masculinos, entretanto praticamente todos os respondentes são brasileiros. A Europa possui tanto países potencialmente 
masculinos (Eslováquia, Hungria, Áustria, por exemplo) como países potencialmente femininos (Suécia, Dinamarca, Noruega) e com três quartos de respondentes brasileiros. Nestes casos, talvez seja razoável pensar que haja influência da cultura institucional (DPR-BR) sobre os valores culturais nacionais locais.

Os continentes com as menores médias, mas não tão distantes da média do DPR, são a América Central e a África. Na América Central, dos três países que fizeram parte das pesquisas de Hofstede e desta, dois têm índice de masculinidade inferior ao do Brasil, e percentual de respondentes brasileiros é de $40 \%$. Na África, dos países que participaram tanto desta pesquisa quanto das pesquisas de Hofstede, três possuem índices superiores ao do Brasil, e os outros quatro países têm índices inferiores, e com percentual de respondentes brasileiros de $42,1 \%$ pode-se indagar provável atuação da cultura local sobre a institucional (DPR - BR). Na análise bivariada para identificar diferenças nas percepções dos valores organizacionais do DPR e dos SECOMs por continente, a África foi a única que se apresentou como diferente para valores que tratam de prestígio.

Para os valores relativos ao interesse da organização pela satisfação das necessidades dos colaboradores, assim como pela sua qualidade de vida no trabalho (bem-estar), somente os SECOMs da América Central diferenciaram-se do DPR, todos os demais apresentaram respostas similares no sentido de perceberem pouco esses valores na organização. $\mathrm{Na}$ análise bivariada que identificou as diferenças nas percepções dos valores organizacionais do DPR e dos SECOMs, este valor apresentou-se como igual entre as duas organizações estudadas.

Valores que avaliam o sucesso baseado em demonstrações de competências, da organização e dos seus colaboradores (realização), na análise univariada, foram reconhecidos de forma similar ao DPR os SECOMs localizados na Oceania, África, América do Sul e Europa. América do Norte e América Central apresentaram dissimilaridades em relação ao DPR. $\mathrm{Na}$ análise bivariada, os SECOMs que permancem como diferentes do DPR são os da América do Norte.

Houve homogeneidade nas respostas de todos os SECOMs e do DPR acerca dos valores que prezam a igualdade, a justiça, a lealdade e a honestidade nas práticas organizacionais e no relacionamento da organização para com seus stakeholders (coletividade). E este resultado permaneceu em todas as análises bivariadas 
realizadas, inclusive na identificação de diferenças nas percepções dos valores do DPR e colaboradores não brasileiros nos SECOMs

$\mathrm{Na}$ análise univariada, os SECOMs da Oceania e da Ásia apresentaram resultados equivalentes ao DPR no que se refere aos valores que enfatizam a criatividade e o desejo da organização de que as pessoas busquem suas próprias ideias, satisfação e aperfeiçoamento contínuo (autonomia). Sob a óptica da dimensão individualismo versus coletivismo de Hofstede (2003), o que se espera é que países mais individualistas sejam mais similares quanto aos valores que priorizam a autonomia, visto que esta está contida na dimensão abertura à mudança da Estrutura Bidimensional dos Tipos Motivacionais de Valores (Tamayo, 2007), cujo foco está em valores que enfatizam pensamentos e ações independentes. Os países da Oceania têm alto índice de individualismo, mas seus respondentes são todos brasileiros, que têm suas origens em país cujo perfil é mais coletivista, segundo a escala de Hofstede (2003). E na Ásia, em que há preponderância de países coletivistas e em que quase metade dos respondentes são brasileiros, era de se esperar esta convergência. $\mathrm{Na}$ análise bivariada, além dos continentes da Ásia e da Oceania, os SECOMs do continente africano apresentaram-se com resultados semelhantes ao do DPR.

Os valores que priorizam o sucesso organizacional congregam itens relativos ao poder e ao domínio do ambiente como forma de demonstrar controle, a partir de um posicionamento assertivo (domínio). A priorização desses valores foi evidenciada para os SECOMs da América do Norte. Os SECOMs da Oceania e da América Central foram os que apresentaram similaridade com o DPR. Na análise bivariada, além dos continentes da Ásia e da América Central, a África também se apresentou como similar ao DPR.

No que se refere aos tipos de práticas organizacionais, a análise bivariada buscou identificar as diferenças entre os tipos de práticas organizacionais identificadas no DPR e nos SECOMs. Dessa análise, resultou que para as práticas humanistas a percepção é a mesma entre as duas organizações, mas diferem quando se trata das práticas instrumentais, e esta diferença é preponderante entre os gestores dos SECOMs da África, América Central, América do Norte, América do Sul e Ásia Na análise univariada, o item que obteve maior concordância nas práticas humanistas, para o DPR e SECOMs, foi o que questiona se na organização o colaborador é 
valorizado pelos seus próprios méritos. A meritocracia é um pressuposto das organizações públicas brasileiras desde a promulgação da Constituição Federal de 1934, mas este princípio passou por profundas reformas no governo do Presidente Fernando Henrique Cardoso, com a criação do Ministério da Administração e Reforma (MARE), em que a melhora dos serviços públicos passaria por seleções mais aprimoradas dos seus servidores, de constante avalição do desempenho e de que a promoção em cargos gerenciais ocorreria por meio da capacitação (Abrucio, 2007). E para o tipo de prática instrumental os itens com maior concordância entre as duas organizações são as que estabeleceram que os resultados são a principal razão da existência da organização e mais, que os resultados planejados devem ser alcançados. E isto é exatamente um dos princípios da Nova Gestão Pública (NGP), cujo pressuposto é a gestão por resultados, por meio da eficiência (resultados planejados, recursos e processos flexíveis) e accountability - transparência dos indicadores de resultados e das metas permitindo controle e sanções mais inequívocas (Abrucio, 2007; Gomes, 2015).

No teste de médias da análise univariada, verificou-se que, para os tipos de prática instrumental, a maior média foi apresentada pelos SECOMs localizados na América do Norte, seguidos pelos que estão situados na América do Sul. E para os tipos de prática humanista, a maior média está entre os SECOMs da Oceania, seguidos pelos SECOMs situados na Ásia.

Para finalizar este item, vê-se que o objetivo 1 foi alcançado, pois, no que se refere à influência da cultura organizacional da instituição nacional sobre as organizações locais, verificou-se, por meio dos valores organizacionais, a similaridade de alguns valores. Os relativos à coletividade são percebidos da mesma forma em toda a Instituição, e os que tratam da conformidade e da tradição são comuns entre o DPR e todos os SECOMs, com exceção para os não brasileiros que trabalham nas organizações locais. Somente os colaboradores dos SECOMs da África percebem de forma diferente do DPR os valores relativos ao prestígio. Todos os brasileiros que trabalham nos SECOMs percebem os valores referentes à realização de forma semelhante à instituição nacional. Tanto o DPR como os SECOMs não percebem de forma enfática os valores relativos ao bem-estar, mas os colaboradores da América Central percebem bem menos que os demais. Houve dois valores que foram percebidos de forma diferente entre as duas populações-alvo: domínio, que é mais 
enfatizado entre os colaboradores dos SECOMs; e autonomia, que é mais priorizado entre os colaboradores do DPR. E a hipótese para esta relação previa que:

$\mathrm{H}_{1}$ : Não há diferenças nas percepções dos valores organizacionais do DPR (instituição nacional) e dos SECOMs (organização local).

Então, os resultados da presente pesquisa indicam que $\mathrm{H}_{1}$ foi confirmada parcialmente.

Quanto à influência da cultura organizacional da instituição nacional por meio dos tipos de práticas organizacionais na organização local, viu-se que há similaridade entre o DPR e os SECOMs nas práticas compreendidas como humanistas, mais especificamente nos SECOMs da África, da América Central, da América do Sul e da Oceania. E nas práticas instrumentais há similaridade do DPR e dos SECOMs da Europa e da Oceania. E a hipótese para esta relação previa que:

$\mathrm{H}_{2}$ : Não há diferenças nas percepções dos tipos de práticas organizacionais (instrumental ou humanista) do DPR (instituição nacional) e dos SECOMs (organização local).

Sendo assim, resultados para esta relação mostra que $\mathrm{H}_{2}$ foi parcilamente confirmada.

\subsubsection{Discussão do objetivo específico 2}

OE2: Estudar o comprometimento das organizações locais, identificando a natureza do comprometimento que mais se destaca: normativa, afetiva ou instrumental.

As bases de comprometimento de natureza normativa são obrigação pelo desempenho e obrigação em permanecer.

A análise univarida identificou que a base de maior percepção de concordância foi obrigação pelo desempenho, ou seja, a maioria dos respondentes dos SECOMs concorda e muito com a crença de que deve se esforçar em benefício da organização e que deve buscar cumprir suas tarefas e atingir os objetivos organizacionais. O que coincide com a interpretação desta base pela escala EBACO que foi de alto comprometimento. Ao analisar as médias dos SECOMs por continente, constata-se que os colaboradores dos SECOMs da América do Sul são os que possuem maior 
nível de concordância, seguidos pelos SECOMs da América Central, Europa, Oceania e América do Norte. Os continentes que, apesar de concordarem com este esforço pessoal para alcançar os objetivos organizacionais, apresentaram menores médias foram África e Ásia.

A análise univariada da segunda base de natureza normativa, obrigação em permanecer, indicou que os colaboradores concordam pouco com ter o dever em pernanecer por causa das pessoas da organização, coincidindo com a interpretação da escala EBACO, que foi de comprometimento abaixo da média, indicando uma certa despreocupação em deixar a organização. $A$ análise das médias dos SECOMs por continente mostrou que somente a Ásia concorda um pouco com esta alegação. Os demais discordam, e entre os que discordam muito estão os colaboradores da América Central e Caribe e da América do Norte, e os colaboradores dos SECOMs da Oceania, América do Sul, Europa e África discordam pouco dessa alegação.

A interpretação da escala EBACO para as unidades continentais da Ásia mostrou diferenças na percepção do comprometimento obrigação em permanecer: para os respondentes dos SECOMs localizados no Sul da Ásia (Índia e Paquistão) e no Extremo Oriente (Coreia do Sul), comprometimento resultou em acima da média, enquanto nas demais unidades continentais da Ásia (Oriente Médio e Sudeste Asiático) a percepção dos colaboradores apresentou abaixo da média nesta base de comprometimento. Pesquisas nesta região têm mostrado o coletivismo como preditor do comprometimento normativo, assim como a identificação do comprometimento normativo a partir do reconhecimento das recompensas sociais e organizacionais dentro da organização (Jong-Wook Ko, 1997; Neelam, 2015).

Na América do Norte, a base obrigação em permanecer teve como resultado baixo comprometimento para a unidade continental da América Anglo-Saxônica e comprometimento abaixo da média para a unidade continental da América Latina. Essa divergência coincide com os índices de coletivismo e individualismo de Hofstede (2003), pois EUA e Canadá (América Anglo-Saxônica) caracterizando-se como sociedades mais individualistas onde as pessoas são individualmente responsáveis pela forma de conduzirem suas vidas, e México (América Latina) com perfil mais coletivista. 
As bases obrigação em permanecer e obrigação pelo desempenho têm enfoque normativo (Medeiros, 2003) e se referem ao sentimento de obrigação de um funcionário em manter-se com a organização. Entretanto, a base obrigação em permanecer resultou para quase todos os SECOMs em comprometimento abaixo da média e a base obrigação pelo desempenho com alto comprometimento. Entretanto, se ambas são de natureza normativa por que os resultados foram diferentes? Obrigação em permanecer trata de uma obrigação moral para com as pessoas da organização e a obrigação pelo desempenho avalia a percepção dos respondentes quanto a sua relação pessoal para com os objetivos da organização, razão pela qual foram contratados.

As bases de comprometimento de natureza instrumental são linha consistente de atividade, escassez de alternativas e falta de recompensas e de oportunidades.

A análise univariada mostrou uniformidade nas respostas na base de comprometimento linha consistente de atividade já que os colaboradores acreditam que, para se manterem onde trabalham, devem concordar com certas atitudes e regras da organização. Ao analisar as médias desta base de comprometimento por continente, a América do Sul e a Ásia foram os que mais concordaram com essa afirmativa, de forma mediana, concordando pouco, tem-se a Europa, América Central e América do Norte, e os que discordam pouco sobre a permanência na instituição mediante a anuência de certas atitudes e regras da organização são os SECOMs da Oceania e da África.

A interpretação da Escala EBACO para as unidades continentais da Ásia identificou que, diferentemente dos demais países asiáticos, para os colaboradores dos SECOMs do Sudeste Asiático (Tailândia, Malásia, Cingapura, Indonésia, Vietnam e Filipinas) e do Sul da Ásia (Índia e Paquistão) o resultado para a base linha consistente de atividade foi acima da média. Esta percepção pode estar relacionada à idade dos respondentes, pois um maior comprometimento de continuidade é comum entre funcionários que são mais velhos e, portanto, menos propensos a combinarem benefícios de aposentadoria se eles se mudarem para outra organização no final da carreira (Kwantes, 2009). Os respondentes dos SECOMs nestas duas unidades continentais têm esse perfil, pois $58 \%$ dos colaboradores do Sudeste Asiático têm 
idade entre 40 a 59 anos e 36,9\% de 11 a 30 anos de trabalho; e no Sul da Ásia 50,1\% com idade variando entre 40 a 59 anos e $33,4 \%$ com mais de 21 anos de casa.

Os resultados da escala EBACO para os SECOMs da América do Sul no que se refere ao comprometimento linha consistente de atividade foi totalmente diferente dos demais SECOMs, com comprometimento acima da média. Uma possível explicação para este resultado pode estar no baixo percentual de tempo de serviço acima de 21 anos $(23 \%)$ e no alto percentual de colaboradores acima de 40 anos $(64,1 \%)$.

A análise univariada para a base de comprometimento escassez de alternativas o item que teve a maior média foi o que questionava se o colaborador decidisse deixar a organização, a sua vida ficaria bastante desestruturada, significando que eles concordam pouco com esta situação hipotética. A análise das médias desta base por continente mostrou que Oceania e América Central discordam muito de que possuem poucas alternativas de trabalho se deixarem a organização, já os demais continentes discordam pouco desta possibilidade. E a intepretação da Escala EBACO para os SECOMs por continente foi comprometimento abaixo da média para todos eles.

A análise univariada para a base falta de recompensas e de oportunidades mostrou que todos os colaboradores discordam de que o esforço dedicado à instituição deve ser recompensado e que precisam receber mais oportunidades. Esta discordância é maior entre os colaboradores dos SECOMs situados na América do Norte, África, América Central e Oceania e menor entre os respondentes da América do Sul e Ásia.

As três bases instrumentais tiveram como resultado comprometimento abaixo da média e isso é um bom sinal para o desempenho da organização, pois são bases em que se esperam um baixo comprometimento já que, para Ellen e Mayer (1991), os colaboradores com comprometimento instrumental (escassez de alternativas) permanecem na instituição porque precisam ou, como afirma Becker (1960), a pessoa permanece na organização devido aos custos e benefícios associados a sua saída e então passa a se envolver em linhas consistentes de atividades para se manter empregada; ou da percepção do empregado de que há poucas alternativas de emprego e o sacrifício pessoal que deverá realizar se deixar a organização em que trabalha (Bastos, 1994).

A análise univariada da base de comprometimento afiliativa obteve médias que são interpretadas como concordam pouco, e o item que mais se destacou foi o que trata 
da percepção de que os colaboradores sentem que seus colegas de trabalho os consideram como membros da equipe de trabalho. Esta percepção é maior entre os colaboradores dos SECOMS situados na Ásia, América do Norte e Oceania, e com uma percepção menor estão os colaboradores dos SECOMs da América Central e América do Sul.

A interpretação da escala EBACO apresentou baixo comprometimento nos SECOMs localizados na Europa, África, América do Sul e América Central e comprometimento abaixo da média para os SECOMs da América do Norte, Ásia e Oceania para a base afiliativa.

Ao fazer a intepretação da Escala EBACO para as unidades continentais, países da Europa Meridional como Espanha e Portugal e da Europa Setentrional como Suécia, Finlândia, Noruega e França e a Holanda da Europa Ocidental que apresentaram baixo comprometimento na base afiliativa, são países classificados como mais femininos na dimensão masculinidade de Hofstede (2003), em que a qualidade de vida e o equilíbrio entre vida pessoal e trabalho são evidentes. O emprego europeu é fortemente regulamentado pela legislação, e a integração bem-sucedida da GRH com os sindicatos (Wasti et al., 2016; Brewster, 2007; Brewster \& Mayrhofer, 2012) pode fazer com que os empregados se considerem com o direito ao apoio organizacional e institucional, de sorte que não percebem por que eles devem se sentir comprometidos com uma determinada organização em específico.

Países do Sul da Ásia, como a Índia, que apresentou na base afetiva comprometimento abaixo da média, tem passado por recentes mudanças no ambiente de trabalho. Para se ter uma ideia, o número total de profissionais de serviços de Tecnologia da Informação (TI) e de serviços informáticos passou de 56 mil em 1990 para mais de 2,97 milhões em 2013 (Neelam, 2015). À medida que corporações estrangeiras e multinacionais movem suas operações para a Índia, crescem as oportunidades de emprego, e esta mudança de atitude é corroborada pelo aumento da taxa de rotatividade nas organizações. Segundo Neelam (2015) desde 2000, essa taxa aumentou, registrando taxas de rotatividade altas de até $8 \%$ ao mês para o pessoal técnico. E isso talvez possa explicar o comprometimento abaixo da média.

O baixo comprometimento na base afiliativa na África pode ser compreendido como provável dissociação entre o indivíduo e a organização quanto a sentimentos de 
pertencimento, pois a sociedade africana tem uma natureza altamente comunalista (Gbadamosi, 2003), ou seja, uma sociedade que se preocupa com a comunidade em que se vive e isto não significa, necessariamente, com a organização em que se trabalha.

$\mathrm{Na}$ América do Sul, o baixo comprometimento na base afiliativa pode ser entendido pelo perfil mais coletivista dos seus países, pois, segundo Rajagopal (2006), os latinoamericanos são pessoas hospitaleiras e calorosas, sendo a família e o parentesco a principal forma de associação, diferentemente das associações voluntárias comuns entre os norte-americanos (Lester, 1993). Os valores coletivistas são vistos no sentido da família e de amigos muito próximos, mas não necessariamente no ambiente de trabalho.

Já na América do Norte, os resultados apresentaram diferenças na base afiliativa para a unidade continental da América Latina, pois enquanto a América Anglo-Saxônica (EUA e Canadá) teve resultado semelhante aos demais continentes comprometimento abaixo da média, a América Latina (México) apresentou comprometimento acima da média para esta base. Ressalta-se que todos os respondentes do SECOM nesta unidade são mulheres, com ensino superior, idade entre 20 a 29 anos e tempo de casa variando entre 6 a 10 anos.

A análise univariada da base de comprometimento afetiva apresentou no item que examina a crença nos valores e nos objetivos dessa organização a maior concordância entre os colaboradores, com resultado médio próximo à interpretação da escala de que concorda muito. E na análise das médias por continente, Ásia, América do Norte e África foram os que mais se identificaram com a filosofia, os valores e os objetivos organizacionais, já América Central e Oceania discordaram pouco de que haja equivalência de valores e objetivos organizacionais. E os SECOMs situados nos países da Europa e da América do Sul $(4,186)$ são os que concordaram pouco com esta similaridade. Pela interpretação da escala EBACO, praticamente todos os SECOMs apresentam comprometimento acima da média para a base afetiva. A exceção está nos SECOMs da América Central, que apresentaram comprometimento abaixo da média, então estes colaboradores não se sentem totalmente envolvidos com a organização ou não estão totalmente identificados com a filosofia da instituição. Uma explicação plausível para isso pode ser o tempo de 
serviço desses colaboradores, pois $40 \%$ têm menos de um ano de trabalho e $50 \%$ têm de um a cinco anos de tempo de serviço.

Ao finalizar este item, o objetivo dois foi contemplado e as bases de comprometimento que mais se destacaram foram o de natureza afetiva e de natureza normativa obrigação pelo desempenho.

\subsubsection{Discussão do objetivo específico 3}

OE3: Estudar a influência da cultura organizacional, mensurada por meio dos valores e dos tipos de práticas organizacionais, das organizações locais sobre os demais construtos do estudo (comprometimento e resultados).

Para este objetivo foram realizadas as análises bivariadas e multivariada entre os construtos.

Segundo Hofstede et al. (1990) e Tamayo (1996), no ambiente de trabalho, os integrantes de uma organização desenvolvem valores compartilhados entre si, os quais, durante a trajetória da organização, levam a práticas específicas de trabalho, por eles julgadas como adequadas e relevantes. Para o estudo dos relacionamentos entre valores, tipos de práticas e comprometimento, os resultados apresentaram que, nas relações entre os valores e os tipos de práticas nos SECOMs, os valores influenciam os tipos de práticas organizacionais realizadas nos SECOMs, ou seja, os valores que visam à criatividade e variedade no trabalho, que promovam o bem-estar e a qualidade de vida no trabalho e que tratam da promoção da justiça e da igualdade estão relacionados com as práticas organizacionais; e os valores que enaltecem a competência e o sucesso nos trabalhadores se apresentaram unicamente relacionados à percepção de práticas humanistas que buscam o envolvimento e o aprimoramento do comprometimento moral dos colaboradores. No entanto, os tipos de práticas organizacionais não influenciam o comprometimento organizacional.

Como visto no referencial teórico, estudos realizados fornecem algumas evidências que sugerem que as organizações podem influenciar o comprometimento dos funcionários por meio de suas práticas organizacionais e que a natureza e a força da influência podem ser determinadas pela forma como os funcionários percebem essas práticas (Meyer \& Smith, 2000), mas para este trabalho esta relação não foi identificada. 
Confirmou-se que os valores influenciam o comprometimento organizacional nos SECOMs, e, praticamente, todos os valores estão positivamente relacionados com comprometimento, confirmando que os valores, diferentemente de características ou formas de realizar o trabalho dentro das organizações, constitui um preditor menos fragmentado da realidade organizacional, uma vez que, juntamente com as normas, políticas e práticas, especificam como o trabalho deve ser executado, i.e., os valores estabelecem as formas culturais de executar o trabalho em cada organização (Tamayo, 2005).

Contudo, valores que ressaltam a manutenção da tradição e do respeito aos costumes e às normas apresentaram-se unicamente relacionados com a crença de que os colaboradores devem se esforçar e cumprir suas tarefas a fim de que os objetivos da organização sejam atingidos. Os valores que se relacionam com a base de comprometimento falta de recompensas apresentaram relações negativas, ou seja, quanto mais ênfase for dada aos valores relativos à autonomia, coletividade, realização, bem-estar, conformidade e domínio menor será a crença de que o esforço extra em benefício da organização deve ser recompensado e de que a organização deve dar mais oportunidades aos colaboradores.

As seguintes hipóteses contemplam este objetivo específico:

$\mathrm{H}_{3}$ : Os valores organizacionais (SECOMs) influenciam os tipos de práticas organizacionais (SECOMs).

$\mathrm{H}_{4}$ : Os valores organizacionais (SECOMs) influenciam o comprometimento organizacional.

$\mathrm{H}_{5}$ : Os tipos de práticas organizacionais (SECOMs) influenciam o comprometimento organizacional.

Os resultados mostram que $\mathrm{H}_{3}$ e $\mathrm{H}_{4}$ foram confirmadas, pois os valores se relacionam com as práticas e com o comprometimento organizacional, o que ratifica pesquisas realizadas mostrando os valores como antecedentes de comprometimento organizacional, porque, à medida que os valores são internalizados eles passam a ser compartilhados e então influenciam os padrões de comportamento dos indivíduos (Meyer \& Allen, 1991; Tamayo et al., 2001). H6 foi refutada, pois nesta pesquisa não foi possível estabelecer relacionamentos das práticas organizacionais e comprometimento. 
Como referenciado, o desempenho organizacional pode ser visto por meio de duas abordagens: (a) a que entende o desempenho como resultados; e (b) a que considera como a soma dos comportamentos que controlam os membros da organização em um determinado contexto - comportamentos avaliados separadamente que interligados geram o desempenho. Entre o número de variáveis que podem afetar direta ou indiretamente o desempenho de uma organização, encontram-se os valores organizacionais que, segundo Denison (1997), indicam o modo de resolver problemas e são um dos fundamentos das práticas da organização, e, por conseguinte, dos resultados alcançados (desempenho organizacional).

No estudo das relações dos construtos valores, práticas e comprometimento e seus impactos nos resultados organizacionais, verificou-se que os valores não impactam diretamente nos resultados organizacionais produzidos pelos SECOMs, entretanto os tipos de práticas influenciam os resultados organizacionais, pois este construto, na análise multivariada, mostrou-se relevante juntamente com 0 construto comprometimento. O comprometimento organizacional influencia os resultados organizacionais, e os resultados classificados como proativos estão relacionados positivamente com as bases de comprometimento afiliativa e linha consistente de atividade; e os resultados classificados como produtivos estão negativamente relacionados com base de comprometimento obrigação pelo desempenho. Vale observar que a base de comprometimento afetiva não se correlacionou com os resultados organizacionais e segundo Meyer \& Smith (2000) as vantagens para as organizações de ter uma força de trabalho comprometida tendem a ser maiores no caso de comprometimento afetivo; as consequências de altos níveis de comprometimento de continuidade podem ser negativas

As hipóteses estabelecidas e que contemplam este objetivo específico foram:

$\mathrm{H}_{6}$ : Os valores organizacionais dos SECOMs influenciam os resultados organizacionais.

$\mathrm{H}_{7}$ : Os tipos de práticas organizacionais dos SECOMs influenciam os resultados organizacionais

$\mathrm{H}_{8}: \quad \mathrm{O}$ comprometimento organizacional influencia os resultados organizacionais 
Os resultados indicam que $\mathrm{H}_{6}$ foi refutada, ou seja, os valores não apresentaram uma relação direta com os resultados organizacionais, mas $\mathrm{H}_{7}$ e $\mathrm{H}_{8}$ foram totalmente aceitas, pois há relação direta entre práticas e resultados e entre comprometimento e resultados. Esse resultado ratifica pesquisas como as realizadas por Farrell \& Rusbult (1981); Meyer et al. (1989) e Sung \& Choi (2014), por exemplo.

Ao finalizar este item, o objetivo três foi contemplado. Valores se relacionam com os tipos de práticas e com o comprometimento organizacional, entretanto os tipos de práticas organizacionais não se relacionam com o comprometimento. A análise conjunta dos construtos, mostrou que tipos de práticas e comprometimento influenciam diretamente nos resultados organizacionais, e o impacto dos valores organizacionais sobre os resultados não ocorre de forma direta.

\subsubsection{Discussão do objetivo específico 4}

OE4: Estudar as possíveis relações entre as variáveis sociodemográficas das organizações locais sobre os valores e o comprometimento as organizações locais.

As variáveis sociodemográficas apresentaram-se correlacionadas com os construtos valores e comprometimento. No que se refere aos valores organizacionais e tempo de serviço, os colaboradores dos SECOMs se diferenciam: os que têm menos tempo na casa priorizam o bem-estar e a qualidade de vida no trabalho, desejam o reconhecimento pelas suas competências e sucessos pessoais, e também são os que dão mais ênfase à tradição e ao respeito aos costumes da organização. Na relação entre tempo de serviço e comprometimento, os colaboradores que têm mais tempo de casa são os que creem que possuem poucas alternativas de trabalho se deixarem a organização e que devem manter atitudes e aceitar regras com o objetivo de se manterem no trabalho. No estudo das relações entre comprometimento e valores em função do tempo de serviço, observou-se que entre os que acreditam que têm poucas alternativas de trabalho se deixarem o atual emprego (acima de 5 anos de serviço) são os que gostariam que a organização oferecesse mais desafios e variedades no trabalho, bem como que suas competências e sucessos fossem mais reconhecidas pela organização. 
Houve diferença na percepção dos valores organizacionais entre brasileiros e não brasileiros, pois os brasileiros dão mais ênfase à manutenção da tradição e do respeito às normas, bem como esperam o reconhecimento da sociedade pelos serviços ofertados pela organização, demonstrando respeito dos brasileiros à organização. No que se refere ao comprometimento, os brasileiros reconhecem mais do que os não brasileiros que devem se esforçarem em benefício da organização e que devem buscar cumprir suas tarefas e atingir os objetivos organizacionais, enquanto os não brasileiros ocupam-se mais na obrigação em permanecer no sentido de acharem que têm uma obrigação moral para com as pessoas da organização. No estudo das relações entre comprometimento e valores, os que acreditam que têm poucas alternativas de trabalho se deixarem a organização (não brasileiros) são os que gostariam que a organização reconhecessem mais as suas competências e seus sucessos; e para os brasileiros, quanto maior for o reconhecimento da sociedade pelos serviços oferecidos e quanto maior a percepção de cortesia e do respeito às normas da organização, maior será a anuência às regras para se manterem na organização.

Em relação aos valores em função do sexo, a percepção foi maior entre os homens no que se refere a valores que privilegiam a liberdade e a independência de pensamentos e ação, que favoreçam a busca pelo sucesso pessoal e reconhecimento desse sucesso pela organização, bem como a promoção da justiça e da igualdade, a tolerância e a sinceridade no ambiente em que trabalham. Quanto ao comprometimento, os homens se identificam mais com a filosofia da organização e percebem que são mais reconhecidos pelos colegas como membros do grupo do que as mulheres. No estudo das relações entre comprometimento e valores, as mulheres acreditam que têm poucas alternativas de trabalho se deixarem a organização e gostariam que a organização oferecesse mais desafios e variedades no trabalho e mais qualidade de vida no trabalho.

Os resultados indicam que $\mathrm{H}_{11}$ foi aceita por completo e que as variáveis tempo de serviço, nacionalidade e sexo influenciam a percepção dos valores e do comprometimento na organização local, e desta forma, contemplando o objetivo específico quatro. 


\subsubsection{Discussão do objetivo específico 5}

OEs: Verificar se comprometimento é mediador das relações entre os tipos de práticas e os valores da organização local e seus resultados. E verificar se práticas organizacionais são mediadoras das relações entre valores da organização local e seus resultados, bem como o comprometimento

A mediação ocorre quando uma terceira variável, referida como uma variável mediadora, intervém entre dois outros construtos relacionados. O resultado, para o modelo mediador, mostrou que as práticas e o comprometimento medeiam completamente o relacionamento entre valores e resultados. Assim, pode-se dizer que práticas e comprometimento criam uma relação teórica indireta entre valores e resultados.

Os demais testes de mediação mostraram que práticas não são mediadoras do relacionamento entre valores e comprometimento e nem comprometimento um mecanismo para explicar o relacionamento entre práticas e resultados. No entanto, comprometimento e práticas são relacionadas diretamente com os resultados organizacionais.

Dado que práticas e comprometimento criam uma relação indireta entre valores e resultados, a análise de mediação passou a verificar quais as metas motivacionais que compõem os valores influenciariam a relação entre valores, práticas e comprometimento para o alcance dos resultados. Este estudo pode ser realizado em função da técnica de mediação múltipla por meio de equações estruturais (modelo PSL-SEM). Esta análise não estava proposta neste estudo, mas em decorrência da conclusão que valores não impactam diretamente nos resultados organizacionais e que práticas e comprometimento criam uma relação teórica indireta entre valores e resultados, resolveu-se aprofundar a análise mediadora.

O que se verificou na análise de mediação múltipla foi a existência de mediação parcial dos construtos valores e práticas sobre as metas motivacionais para o alcance dos resultados. Semelhantemente, existe mediação parcial dos construtos valores e comprometimento sobre as metas motivacionais para o alcance dos resultados. Assim 
como mediação parcial dos construtos valores e práticas sobre as relações das metas motivacionais para os tipos de práticas humanistas e instrumentais.

Existe mediação parcial dos construtos valores e comprometimento sobre as relações das metas motivacionais para o alcance das bases de comprometimento, com exceção da meta motivacional tradição e da base de comprometimento escassez de alternativas.

As hipóteses que contemplaram este objetivo foram:

H9a: O construto práticas organizacionais é mediador dos construtos valores e resultados.

H9b: O construto práticas organizacionais é mediador dos construtos valores e comprometimento.

$\mathrm{H}_{10 a}$ : Comprometimento é mediador de valores e resultados

$\mathrm{H}_{10 \mathrm{~b}}$ Comprometimento é mediador de práticas e resultados.

Os resultados mostraram que $\mathrm{H}_{9 a}$ e $\mathrm{H} 1_{0 a}$ foram totalmente aceitas e $\mathrm{H}_{9 b}$ e $\mathrm{H} 1_{0 b}$ foram refutadas.

\subsection{Modelo conceitual teórico e modelo conceitual integrador}

O problema de pesquisa proposto neste trabalho foi investigado em duas partes: a primeira, analisou a influência das manifestações da cultura (valores e tipos de práticas) da instituição nacional (DPR) sobre os valores e os tipos de práticas das organizações locais (SECOMs); e a segunda realizou uma análise conjunta dos valores, por meio de suas metas motivacionais, dos tipos de práticas (humanista ou instrumental) e das bases de comprometimento para verificar se essas variáveis são antecedentes e/ou explicativas do resultado no nível das organizações locais (SECOMs), e, a partir dos resultados encontrados, propor um modelo conceitual teórico para descrevê-los. Com os resultados das duas análises propõe-se um modelo integrador que estabelece o relacionamento antecedente (valores e tipos de práticas da instituição nacional) e explicativas (valores, tipos de práticas e comprometimento da organização local) sobre os resultados organizacionais. 
Para a segunda parte da investigação do problema de pesquisa, foi realizada a análise multivariada PLS-SEM que mediu as relações conjuntas entre os construtos e o impacto que valores, tipos de práticas e comprometimento têm sobre os resultados organizacionais dos SECOMs.

Os resultados, para a organização local, mostraram que valores não impactam em resultados e o construto tipos de práticas não se relaciona com o construto comprometimento. As demais relações foram confirmadas.

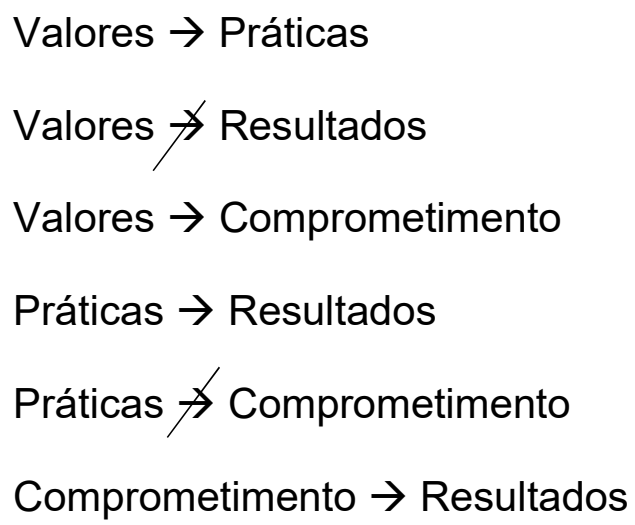

As análises estatísticas mostraram que há influência da cultura organizacional (valores e tipos de práticas) e do comprometimento sobre os resultados. Entretanto, a relação entre os valores da organização local e os resultados ocorre de forma indireta, por meio das mediações dos construtos práticas e comprometimento na relação entre valores e resultados.

Então, após essas análises, o modelo nomológico conceitual teórico para as organizações locais foi ajustado e apresentado na figura 58.

Figura 58 - Modelo conceitual teórico

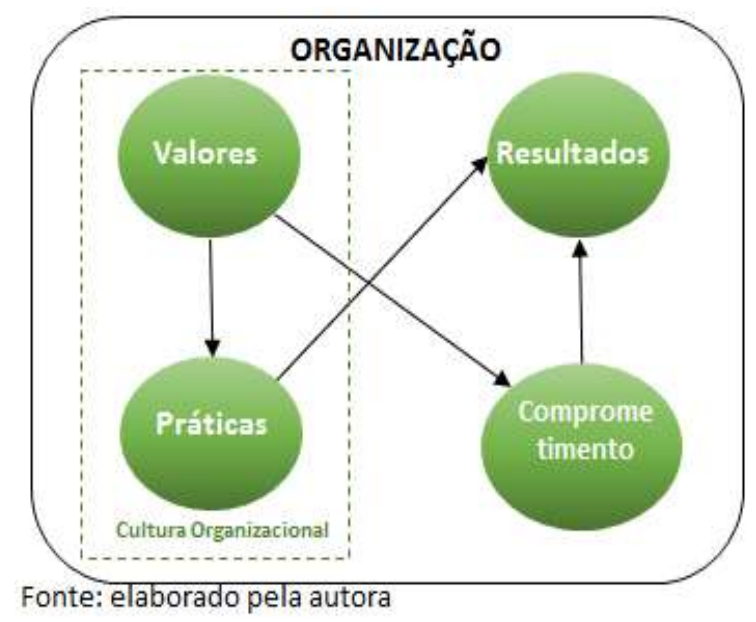


Para a primeira parte da investigação do problema proposto, as análises estatísticas mostraram que há similaridades entre valores e tipos de práticas da instituição nacional (DPR) e das organizações locais (SECOMs).

Então, com os resultados encontrados (primeira e segunda partes), o modelo nomológico conceitual integrador final é apresentado na figura 59.

Figura 59 - Modelo conceitual integrador

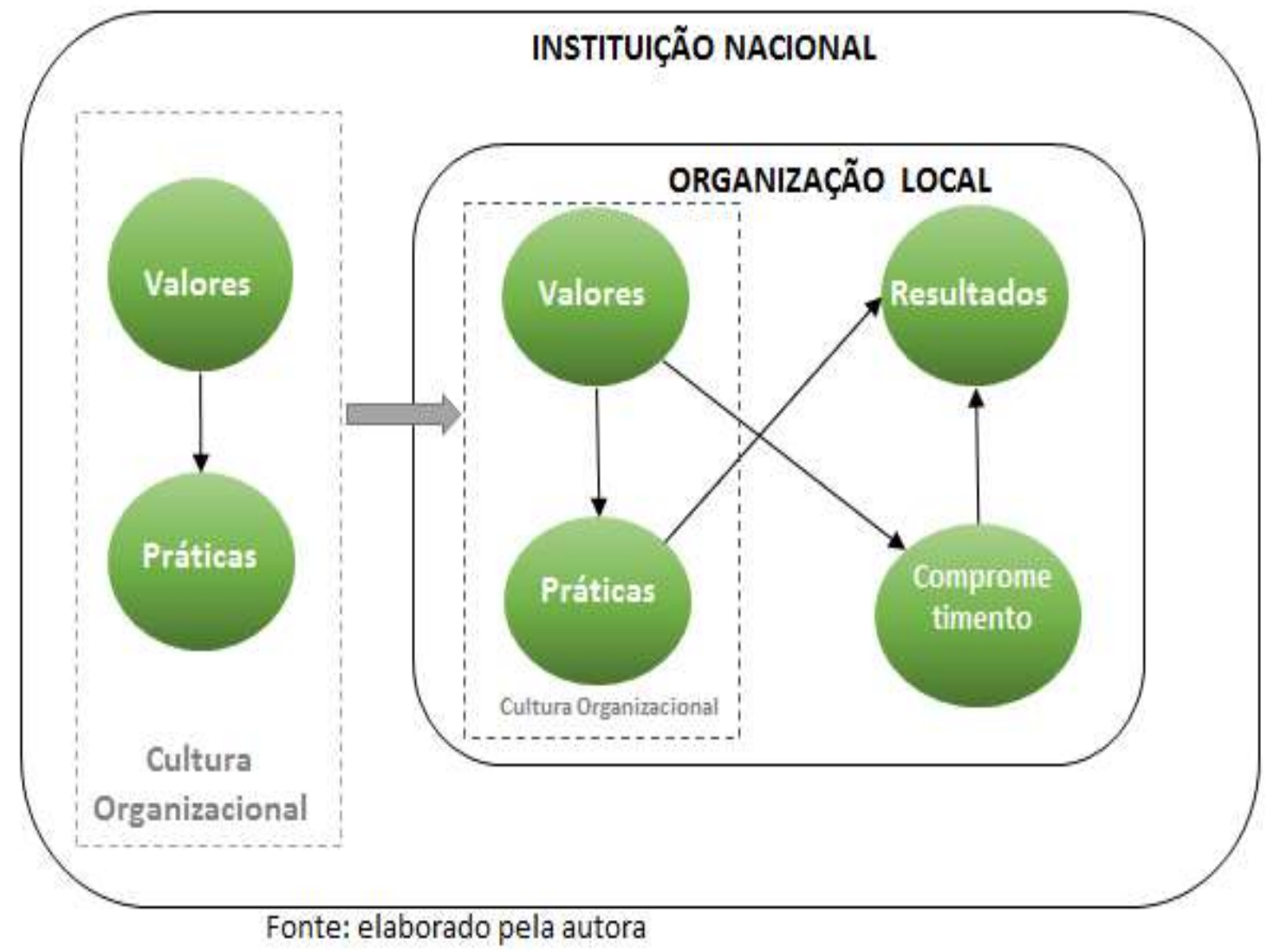




\subsection{Síntese do capítulo 6}

O capítulo seis apresentou as discussões dos objetivos específicos por meio da interpretação dos resultados e das hipóteses da pesquisa.

Mostrou-se que os itens das escalas para medir valores, comprometimento e tipos de práticas apresentaram-se com índice de confiabilidade suficiente para que permitissem as análises dos resultados.

Verificou-se, por meio dos valores organizacionais, a similaridade de valores entre o DPR e os SECOMs: conformidade, tradição, realização e prestígio (exceto para os SECOMs da África), bem como dos tipos de práticas compreendidas como humanistas e para os tipos de práticas instrumentais somente entre os SECOMs da Europa e da Oceania. E, quanto ao comprometimento nas organizações locais, as bases que mais se destacaram são as de natureza afetiva e de natureza normativa (obrigação pelo desempenho).

Foi averiguado que, no ambiente das organizações locais, os valores se relacionam com as práticas e com o comprometimento organizacional, mas valores não impactam diretamente nos resultados, enquanto tipos de práticas e comprometimento impactam diretamente nos resultados organizacionais. E o modelo mediador mostrou que práticas e comprometimento criam uma relação teórica indireta entre valores e resultados.

Os resultados confirmaram que as variáveis tempo de serviço, nacionalidade e sexo influenciam a percepção dos valores e do comprometimento na organização local. 


\section{CONCLUSÃO}

O objetivo geral desta tese foi identificar e descrever a influência das manifestações da cultura da Instituição, ${ }^{46}$ por meio dos valores e dos tipos de práticas organizacionais, sobre o comprometimento, bem como a influência dessas manifestações e do comprometimento sobre os resultados organizacionais. Para atingir este objetivo, foram elaborados cinco objetivos específicos e proposto um modelo conceitual integrador, que permitiu responder às seguintes questões de pesquisa que deram origem ao objetivo geral:

Para a instituição nacional (DPR) e a organização local (SECOMs)

Questão da pesquisa 1: Os valores e os tipos de práticas identificados na instituição nacional são próximos aos valores e as práticas identificados na organização local?

Para a organização local (SECOMs)

Questão da pesquisa 2: Os valores organizacionais influenciam os tipos de práticas organizacionais e o comprometimento? Os tipos de práticas organizacionais influenciam o comprometimento?

Questão da pesquisa 3: Os valores, os tipos de práticas (humanista ou instrumental) e o comprometimento organizacional são variáveis antecedentes e explicativas do resultado organizacional?

Questão da pesquisa 4: Caso os valores, os tipos de práticas e o comprometimento sejam antecedentes do resultado organizacional, que dimensões emergem dos valores, dos tipos de práticas e do comprometimento para explicar o resultado organizacional?

Questão da pesquisa 5: Há diferenças na percepção dos valores e do comprometimento para os brasileiros e os não brasileiros que trabalham nos SECOMs? E estas diferenças seriam percebidas entre os que têm mais tempo de serviço em relação aos mais novos? Há diferenças entre homens e mulheres?

Questão da pesquisa 6: Os tipos de práticas organizacionais atuam como mediadoras da relação entre valores e os resultados? E da relação entre valores e comprometimento

\footnotetext{
${ }^{46}$ Por Instituição se entende a instituição nacional (DPR) e as organizações locais (SECOMs)
} 
Questão da pesquisa 7: O comprometimento atua como mediador da relação entre os tipos de práticas e os resultados? E da relação entre valores e resultados?

Para responder às questões da pesquisa, foi elaborada uma revisão da literatura referente às diferentes variáveis antecedentes e explicativas do resultado organizacional (cultura, valores, práticas, e resultados organizacionais). Esta revisão foi baseada em uma abordagem histórica, conceitual e interdisciplinar, de sorte a permitir evidenciar as relações entre as variáveis.

\subsection{Respostas às questões da pesquisa}

A seguir seguem as respostas para cada uma das questões da pesquisa.

\section{Resposta à primeira questão da pesquisa}

A primeira questão da pesquisa se refere ao primeiro objetivo específico e às hipóteses 1 e 2, que propuseram estudar a influência da cultura organizacional da instituição nacional sobre as organizações locais, mensuradas por meio dos valores e dos tipos de práticas organizacionais. As considerações realizadas com base nos resultados obtidos com as análises do teste t para amostras independentes mostraram que:

$\checkmark$ Há similaridades de valores entre o DPR e os SECOMs.

$\checkmark$ Há similaridades de tipos de práticas entre o DPR e os SECOMs

A identificação de similaridades entre os valores e os tipos de práticas entre o DPR e os SECOMs coincide com o que Smith, Bond e Kagitçibasi (2006) abordam, pois para eles, assim como os países, as organizações também têm diferentes culturas, embora aquelas que se encontrem num mesmo país tendam a refletir internamente a cultura nacional comum. E, mesmo com alguns SECOMs situados em países com divergências culturais em relação ao Brasil, o que se percebeu foi a percepção de valores e práticas semelhantes ao do DPR, principalmente se o número de trabalhadores brasileiros for maior do que a de não brasileiros, como o caso dos SECOMs da Oceania e da Ásia, no que se refere ao conjunto de valores, e os SECOMs da Oceania relativo aos tipos de práticas. Hofstede et al. (1990), com base nos resultados de um estudo referente à cultura organizacional, desenvolvido em vinte unidades de dez diferentes organizações na Holanda e Dinamarca, já defendiam a ideia de que, na medida em que as culturas nacionais divergem principalmente em termos de conjuntos de valores compartilhados, as culturas organizacionais se 
diferenciam mais em termos de práticas compartilhadas. Sendo assim, os membros de diferentes organizações dentro de um mesmo país poderiam compartilhar valores, mas trabalhar em organizações que adotam maneiras distintas de implementá-los na prática. E este é o perfil dos SECOMs que atuam na América do Norte, Ásia e Europa, pois, mesmo com alto percentual de brasileiros, os tipos de práticas são percebidos diferentemente em relação ao DPR.

\section{Resposta à segunda questão da pesquisa}

A segunda questão da pesquisa se refere ao terceiro objetivo específico e contempla as hipóteses 3 e 4, que trataram de analisar se os valores organizacionais influenciam os tipos de práticas organizacionais e o comprometimento e se as práticas influenciam o comprometimento. As análises dos resultados do modelo conceitual para a organização local e dos testes de correlação de Pearson mostraram que:

$\checkmark$ Há relações entre os valores e os tipos de práticas.

$\checkmark$ Há relações entre os valores e o comprometimento organizacional

$\checkmark$ Não há relações entre os tipos de práticas e o comprometimento

E os resultados encontrados vão ao encontro do que estabelece a literatura revisada, pois, conforme Hofstede et al. (1990), os valores permeiam a cultura organizacional e estão associados às práticas organizacionais e que as práticas organizacionais se respaldam em manifestações dos valores organizacionais (Calori; Sarnin, 1991; Levin, 2000). A relação entre valores e comprometimento foi estabelecida na aplicação do IPVO e do comprometimento afetivo entre servidores públicos por Tamayo (2005) e foi muito próxima ao resultado encontrado nesta pesquisa em relação à base de comprometimento afetivo e os valores identificados nas organizações locais. Entretanto, para esta pesquisa, a escala que avaliou os tipos de práticas não foi associada ao comprometimento, e isso diverge de estudos anteriores, por exemplo, Meyer \& Smith (2000); Gaertner \& Nollen (1989); Koys (1991); e Ogilvie (1986) na demonstração de vínculos entre as práticas organizacionais e o comprometimento afetivo dos funcionários

\section{Resposta à terceira questão da pesquisa}

A terceira questão da pesquisa se refere ao terceiro objetivo específico e às hipóteses de 6 a 8 , no que se refere a investigar se os valores, os tipos de práticas (humanista ou instrumental) e o comprometimento organizacional são variáveis antecedentes e 
explicativas do resultado organizacional. As análises dos resultados do modelo conceitual para a organização local e dos testes de correlação de Pearson mostraram que:

$\checkmark$ Os tipos de práticas impactam de forma direta no resultado organizacional

$\checkmark$ O comprometimento exerce forte impacto no resultado organizacional

$\checkmark$ Valores não impactam diretamente no resultado das organizações

No geral, os resultados confirmaram os aspectos teóricos e empíricos no que se refere às relações de predição que as variáveis antecedentes (práticas e comprometimento diretamente e valores indiretamente) exercem sobre os resultados.

\section{Resposta à quarta questão da pesquisa}

A quarta questão da pesquisa é continuidade da terceira e se refere ao terceiro objetivo específico e às hipóteses de 6 a 8 , sobre a identificação de quais valores, tipos de práticas e bases de comprometimento estão relacionadas com o resultado. Os testes de correlação de Pearson foram significantes somente para as correlações entre as seguintes bases de comprometimento e resultados.

$\checkmark$ Resultados proativos relacionados com a crença dos colaboradores de que são reconhecidos pelos colegas e como membros do grupo e da organização e de que devem manter certas atitudes e regras da organização com o objetivo de manter-se na organização

$\checkmark$ Resultados produtivos relacionados com a crença de que devem se esforçar em benefício da organização, buscando cumprir as tarefas para atingir os objetivos organizacionais.

Esses resultados mostram que a proatividade está relacionada com aqueles que sentem que fazem parte da organização e com os que, para se manterem no SECOM, aceitam as regras estabelecidas. Também revelam que a produtividade está relacionada com os que cumprem as regras e querem ver os objetivos alcançados no sentido mais de lealdade à organização.

\section{Resposta à quinta questão da pesquisa}

A quinta questão da pesquisa se refere ao quinto objetivo específico e à hipótese 11, que propõe estudar as possíveis relações entre variáveis individuais das organizações locais (sociodemográficas) sobre os valores e o comprometimento organizacional. As 
análises dos resultados do teste t para amostras independentes e correlação de Pearson mostraram que:

Colaboradores com menos tempo de serviço priorizam

$\checkmark$ o bem-estar e a qualidade de vida no trabalho

$\checkmark$ o reconhecimento pelas suas competências e sucessos pessoais

$\checkmark$ a tradição e o respeito aos costumes da organização

Colaboradores com mais tempo de serviço acreditam que

$\checkmark$ possuem poucas alternativas de trabalho se deixarem a organização

$\checkmark$ devem manter atitudes e aceitar regras para se manterem no trabalho

Mas são os mesmos que gostariam que a organização

$\checkmark$ oferecesse mais desafios e variedades no trabalho

$\checkmark$ reconhecessem mais as suas competências e sucessos

Os brasileiros priorizam

$\checkmark$ a manutenção da tradição e do respeito às normas

$\checkmark$ o reconhecimento da sociedade pelos serviços ofertados pela organização

$\checkmark$ a importância que a organização dá ao respeito às regras e modelos de comportamento, tanto no ambiente de trabalho quanto no relacionamento com outras organizações

Os brasileiros acreditam que

$\checkmark$ devem se esforçar em benefício da organização, buscando cumprir suas tarefas para atingir os objetivos organizacionais. E este esforço será maior, quanto maior for o reconhecimento da sociedade pelos serviços oferecidos e maior percepção de cortesia e do respeito às normas da organização.

Os não brasileiros acreditam que

$\checkmark$ o esforço extra que é feito para a organização deve ser recompensado e que a organização deve dar mais oportunidades a eles

$\checkmark$ devem permanecer na organização, pois têm uma obrigação moral para com as pessoas que trabalham com eles

$\checkmark$ têm poucas alternativas de trabalho se deixarem a organização

E são os mesmos que 
$\checkmark$ acreditam que têm poucas alternativas de trabalho se deixarem a organização, mas gostariam de serem mais reconhecidos institucionalmente

Os homens priorizam

$\checkmark$ a liberdade e a independência de pensamentos e ação

$\checkmark$ a busca pelo sucesso pessoal e reconhecimento desse sucesso pela organização

$\checkmark$ a promoção da justiça e da igualdade, a tolerância e a sinceridade no ambiente laboral, assim como a cortesia, o respeito às regras de convivência e à hierarquia.

$\checkmark$ a qualidade de vida no trabalho

Os homens acreditam que

$\checkmark$ se identificam mais com a filosofia da organização

$\checkmark$ são mais reconhecidos pelos colegas como membros do grupo

$E$ as mulheres que acreditam que têm poucas alternativas de trabalho se deixarem a organização são as mesmas que

$\checkmark$ gostariam que a organização oferecesse mais desafios e variedades no trabalho

$\checkmark$ houvesse mais qualidade de vida no trabalho

Para fins de compreensão, uma visão geral dos colaboradores mostra que o perfil predominante dos que responderam a esta pesquisa foi quase igualitário entre homens e mulheres que estão na faixa etária de 30 a 49 anos; alto nível educacional (graduação ou pós-graduação) e maioria com tempo de trabalho até 5 anos. $O$ maior percentual de respondentes das organizações locais foi dos SECOMs estabelecidos na América do Sul, seguidos pelos da América do Norte e da Europa. O percentual de brasileiros nos SECOMs é de 60,8\%.

Segundo Meyer e Allen (1997), o comprometimento normativo está relacionado a um alto nível de comprometimento por parte do indivíduo em relação à organização. $O$ que se viu é que tanto brasileiros quanto os não brasileiros priorizam esse tipo de comprometimento, estes porque sentem uma obrigação moral para com as pessoas da organização e aqueles porque acreditam que devem se esforçar em benefício da organização. 
Colaboradores mais velhos dão mais ênfase ao comprometimento instrumental, que segundo Meyer e Allen (1997), é percebido como custos associados a deixar a organização; esses colaboradores acreditam que, para permanecerem nela, precisam das recompensas oferecidas. $E$ este resultado foi ao encontro da pesquisa realizada por Meyer \& Smith, 2000.

O comprometimento afetivo se apresentou maior entre os homens do que entre as mulheres, e este resultado se assemelha às pesquisas de Meyer e Allen (1997) e de Simon \& Coltre (2012). Não só o comprometimento afetivo, mas também o afiliativo se mostrou mais forte entre os homens.

Os brasileiros se assemelham mais aos valores centrais do DPR (tradição, prestígio e conformidade) e os que têm menos tempo de serviço se assemelham ao DPR no que se refere a valores que priorizam a realização, a tradição e o bem-estar. Os não brasileiros se identificam mais com o DPR no que se refere a valores que tratam da coletividade e do bem-estar.

Todos os colaboradores dos SECOMs desejam ser mais reconhecidos pela organização, mas esta percepção é maior entre as mulheres e os estrangeiros.

\section{Resposta à sexta questão da pesquisa}

A sexta questão da pesquisa se refere à mediação entre os tipos de práticas na relação entre valores e resultados e entre valores e comprometimento e esta questão foi abordada no quinto objetivo específico e nas hipóteses 9a e 9b. As análises de mediação fizeram parte dos estudos do modelo integral onde foi realizado análises multivariadas por meio da modelagem de equações estruturais com aplicação do método de estimação dos mínimos quadrados parciais (PLS-SEM), e os resultados mostraram que:

$\checkmark$ tipos de práticas medeiam a relação entre valores e resultados

$\checkmark$ tipos de práticas não medeiam a relação entre valores e comprometimento

Diferentemente do que foi visto em pesquisas anteriores sobre o tema, os tipos de práticas não apresentaram relação direta e nem indireta com o comprometimento organizacional, talvez a escala utilizada (escala de percepções de práticas de gestão de pessoas) não tenha conseguido medir este tipo de relacionamento. Isso deixa em 
aberto uma nova tentativa de medição, mas com outra escala para práticas organizacionais.

\section{Resposta à sétima questão da pesquisa}

A sétima questão da pesquisa se refere ao sexto objetivo específico e às hipóteses 10a e 10b para analisar se o comprometimento atua como mediador da relação entre os tipos de práticas e os resultados e da relação entre valores e resultados. As análises multivariadas, por meio da modelagem de equações estruturais com aplicação do método de estimação dos mínimos quadrados, mostraram que:

$\checkmark$ comprometimento medeia as relações entre valores e resultados

$\checkmark$ comprometimento não medeia as relações entre práticas e resultados

As análises de mediação mostraram que nem tipos de práticas têm relação indireta ou direta com o comprometimento e nem comprometimento tem relação indireta com os tipos de práticas.

Entretanto, como há mediação do comprometimento nas relações entre valores e resultados, foi realizado o teste de mediação múltipla para identificar quais são as bases de comprometimento que seriam responsáveis por esta intermediação. O que se viu foi que valores que visam a tradição não foram mediados por nenhuma das bases de comprometimento, aliás, no teste de correlação de Pearson entre valores e comprometimento, tradição só se apresentou correlacionada com a base obrigação pelo desempenho e este valor é mais percebido entre os brasileiros que trabalham nos SECOMs. E quanto aos comprometimentos de natureza instrumental, o que mediu a crença da existência de poucas alternativas de trabalho se deixar a organização não foi mediadora de nenhuma das metas motivacionais. 


\subsection{Aportes da pesquisa}

Neste item apresentam-se os aportes teóricos, as contribuições metodológicas e as implicações gerenciais.

\section{Aportes teóricos}

Esta pesquisa está inserida entre as que buscam uma melhor compreensão dos fatores que explicam os resultados organizacionais.

A primeira contribuição está na busca de evidências empíricas para os pressupostos abordados pelas teorias da Administração, demostrando como algumas variáveis antecedentes dos resultados, o comprometimento, os tipos de práticas (de forma direta) e os valores (de forma indireta) e de como estas variáveis também se relacionam entre si. O modelo conceitual integrador, proposto para o estudo, colocou em evidência a influência simultânea da cultura organizacional (medida por meio dos valores e das práticas) e do comprometimento sobre os resultados organizacionais. Essa contribuição é entendida como inovadora no estudo e aplicação a uma organização pública transnacional que trata da promoção comercial brasileira no exterior.

A segunda contribuição foi identificar o comprometimento como variável mediadora dos valores sobre os resultados alcançados pela organização. Tradicionalmente, a literatura nacional e estrangeira apresenta resultados de pesquisas com ênfase nas relações entre os valores pessoais e organizacionais e o comprometimento, mas não foram encontradas até então investigações que tratem o comprometimento como mediador dos valores organizacionais sobre os resultados alcançados pela organização com o perfil apresentado neste trabalho, organização pública que atua em outros países por meio do incentivo às relações comerciais transnacionais.

\section{Contribuições metodológicas}

Esta pesquisa apresentou duas contribuições metodológicas no nível dos instrumentos dos construtos: revalidação da escala EBACO e tradução, aplicação e validação da escala de lócus de valor humano.

A primeira contribuição foi avaliar a confiabilidade e a validade da Escala EBACO desenvolvida por Medeiros (2003), para a qual, apesar de sua larga utilização para a mensuração do comprometimento organizacional, não se apresentava como validade 
para aplicação em instituição pública com perfil de organização transnacional. E, similar ao ocorrido na pesquisa exploratória de Medeiros (2003), a análise fatorial produziu sete componentes, apresentando confiabilidade de acordo com os níveis estabelecidos pela literatura da área. A validade da escala verificou que os indicadores de cada uma das dimensões mediram as dimensões preestabelecidas, pois dos sete fatores extraídos pela análise cada um possuía quatro indicadores, semelhante aos resultados apresentados por Medeiros (2003).

A segunda contribuição foi a aplicação e validação da escala percepções de práticas de gestão de pessoas, adaptada da escala lócus de valor humano, que foi desenvolvida por Jackson (2002). A escala é inédita no País e espera-se que este instrumento possa ser replicado em outras realidades e organizações, ampliando o conhecimento sobre o tema, e que eventuais comparações possam ser feitas dos cenários nacional e internacionais, de sorte a complementar a compreensão sobre a aplicabilidade e a relevância da escala de lócus de valor humano para as práticas organizacionais.

\section{Implicações gerenciais}

Esta tese apresenta implicações gerencias, por meio da demonstração do impacto de construtos da cultura nos resultados organizacionais, e, de maneira particular, para 0 DPR que gerencia os SECOMs.

No survey havia uma questão aberta destinada a sugestões. E muitas das sugestões propostas coincidiram com os resultados quantitativos retratados. Todos os entrevistados nos SECOMs apresentaram alto comprometimento normativo, mas eles percebem a falta de um plano de cargos, salários e carreiras para os secomnianos (forma como se denominam) causando uma certa frustração e, talvez seja por isso, que o comprometimento afetivo não tenha se destacado, como é comum nas pesquisas desta área.

Os chefes dos SECOMs, que são diplomatas de carreiras, percebem que deveriam ser pauta do curso de formação do Instituto Rio Branco, disciplinas e palestras que tratem de assuntos sobre Administração, e, em específico, de Gestão de Pessoas, pois assim sentir-se-iam mais preparados para ocuparem cargos de chefia. $E$ isto poderá refletir no ambiente organizacional, como observado por parte dos colaboradores dos SECOMs que apresentam fatores como melhorar o diálogo com a 
chefia imediata, e promover atividades sociais para melhorar o ambiente, como sugestões de aprimoramento. Entre os que disseram que o ambiente organizacional é bom e agradável, associaram isto à boa gestão da chefia imediata.

A baixa identificação de valores relativos à percepção de que a organização se preocupa em proporcionar satisfação e qualidade de vida no trabalho, pode ser identificada em discursos que evidenciam a falta de reconhecimento da organização àqueles que demonstram interesse pelo trabalho, e que deveria promover, por exemplo, o mérito por produtividade e pelos resultados obtidos.

Se o DPR promover ações que favoreçam o reconhecimento das competências dos contratados locais, que propicie mais treinamentos que visem o aprendizado sobre a promoção comercial brasileira e a realização de workshops com outros SECOMs para a efetivação de trocas de experiências e compartilhamentos de boas práticas, que são atividades relacionadas a aumentar à assimilação de pertencimento à organização, talvez seja possível identificar maior percepção do comprometimento afiliativo nos SECOMs.

Dado que os secomnianos brasileiros apresentam valores mais similares aos do DPR, uma sugestão é que, nos países em que o Brasil apresenta uma relação comercial preponderante, como EUA, China, Argentina, Holanda, Chile e Alemanha, por exemplo, houvesse a manutenção do maior número possível de brasileiros nos SECOMs, pois colaboradores estrangeiros apresentaram como dificuldade a falta de conhecimento do que "falam e do que recomendam", pois nunca foram ao Brasil, desconhecendo certos procedimentos e práticas usuais da cultura brasileira. Ou, como sugeriram, que promovam workshops no Brasil, para melhor compreensão dos processos de importação e exportação pelas organizações que tratam do comércio internacional brasileiro, como a Receita Federal, a APEX e o MDIC, além do MRE.

\subsection{Limites da pesquisa}

Como todo trabalho científico, as escolhas metodológicas levam a algumas limitações. A primeira, refere-se à aglomeração dos resultados por continente, o que não permitiu a análise mais acurada das diferenças nacionais dos resultados obtidos, e que poderia 
trazer facetas e especificidades relevantes.

\subsection{Agenda da pesquisa}

Apesar das contribuições e das limitações deste trabalho, torna-se imprescindível a realização de novas pesquisas sobre o tema. Recomenda-se aplicar este mesmo estudo em empresas públicas e privadas que realizem operações internacionais de origem brasileira, para que haja uma melhor compreensão sobre o impacto dos valores e das práticas e do comprometimento sobre os resultados organizacionais.

Outro ponto que merece aprofundamento seria aplicar, em outros contextos, a escala de percepções de práticas de gestão de pessoas, de forma a verificar sua adequação em circunstâncias diversificadas à deste trabalho.

Por fim, recomenda-se que este estudo seja feito nos consulados brasileiros para verificar a similaridade entre estas organizações inseridas no contexto internacional e o MRE. 


\section{REFERÊNCIAS BIBLIOGRÁFICAS}

A

Abrucio, Fernando Luiz. (2007). Trajetória recente da gestão pública brasileira: um balanço crítico e a renovação da agenda de reformas. Rev. Adm. Pública, Rio de Janeiro, v. 41, n. spe http://www.scielo.br/scielo.php?script=sci arttext\&pid=S0034$\underline{6122007000700005}$.

Abubakar, Tabiu; Abubakar, Nura Allumi. (2013) Assessing the effects of human resource management (HRM) practices on employee job performance: a study Of Usmanu Danfodiyo University Sokoto. Journal of Business Studies Quarterly, Vol.5 (2), p.247-260.

Adler, N. (2000) International dimensions of organizational behavior. Cincinnati: SouthWestern/ Thomson Learning.

Akoto, E.O, \& Akoto, E.V. (2014). The configural approach to organisational commitment: An application in Ghana. Journal of Industrial Psychology/SA Tydskrif vir Bedryfsielkunde, v40i2.120740(2), Art. \#1207, 11 pages. http:// dx.doi.org/10.4102/sajip.

Al Ariss, A., Cascio, W. F., \& Paauwe, J. (2014). Talent management: Current theories and future research directions. Journal of World Business, 49: 173-179.

Allen, N. and Meyer, J. (1990). The measurement and antecedents of affirmative, continuance and normative commitment to the organization. Journal of Occupational Psychology, Vol. 63, pp. 1-18.

Adams, J. S. (1963). Towards an understanding of inequity. The Journal of Abnormal and Social Psychology, 67(5), 422-436.

Adams, J. S. (1965). Inequity in social exchange. In L. Berkowitz (Ed.), Advances in experimental social psychology (Vol. 2, pp. 267-299). New York, NY: Academic Press.

Adler, N. J. (1997). International dimensions of organizational behavior. (3rd ed.). Cincinnati, $\mathrm{OH}$ : Southern-Western.

Allen, N. J., \& Meyer, J. P. (1990). The measurement and antecedents of affective, continuance and normative commitment to the organization. Journal of Occupational Psychology, 63, 1-18.

Allen, N. J., \& Meyer, J. P. (1996). Affective, continuance, and normative commitment to the organization: An examination of construct validity. Journal of Vocational Behavior, 49(3), 252-276.

Allport, G.W., \& Vernon, P.E.A. (1931). A Study of Values: Manual of Directions. (Rev. ed.) New York: Houghton Mifflin.

Allport, F.H. (1962). The structuring of events: outline of a general theory with applications to psychology. Psychological Review, n. 61, p. 281-393, 1962. 
Alencar, E. M. L. S. (2005) A gerência da criatividade: abrindo as janelas para a criatividade pessoal nas organizações. São Paulo: Makron Books.

Alvesson, Mats. (1987). Organization Theory and Technocratic ConsciousnessRationality, Ideology and Quality Work. New York, Walter de Gruyter.

Alvesson, Mats. (2002). Understanding organizational culture. London: SAGE. ISBN 0-7619-7005-30-7619-7006-1 (pb).

Amabile, T. M. (1996). Creativity in Context: Update to the social psychology of creativity. Boulder, CO: Westview Press.

Ansoff, H. Igor; McDonnel, E. J. (1993). Implantando a administração estratégica. 2. ed. São Paulo: Atlas.

Aquino, C. V.; Honório, L. C. (2012). Comprometimento organizacional pós-aquisição: estudo de caso em uma empresa do setor alimentício. In: Anais do VII Encontro de Estudos Organizacionais (ENEO) da Associação Nacional de Pós-Graduação e Pesquisa em Administração.

Aragão, Cecília Vescovi de. (1997) Burocracia, eficiência e modelos de gestão pública: um ensaio. Revista do Serviço Público, RJ, ano 48, n. 3, p. 105-132, set-dez.

Argyris, Cris. (1957) Personalidade e organização: o conflito entre o sistema e o indivíduo: RJ: Renes.

Asrar-ul-haq, Muhammad; KuchinkE, K. Peter; IqbaL, Anam. The relationship between corporate social responsibility, job satisfaction, and organizational commitment: Case of Pakistani higher education. Journal of Cleaner Production, 20 January 2017, Vol.142, pp.2352-2363. doi: 10.1016/j.jclepro.2016.11.040

\section{B}

Babbie, Earl. (2001). Métodos de pesquisas de survey. Belo Horizonte: UFMG.

Babbie, E. \& Mouton, J. (2001). The practice of social research. Cape Town: Oxford University Press.

Balança Comercial Brasileira - MDIC. (2018). http://www.mdic.gov.br/index.php/comercioexterior/estatisticas-de-comercio-exterior/balanca-comercial-brasileira-acumulado-do-ano

Baldwin, R. (2016). The Great Convergence. Harvard U. Press, Cambridge.

Bambacas, Mary. (2010). Organizational handling of careers influences managers 'organizational commitment. Journal of Management Development, Vol. 29 Issue: 9, pp.807-827, https://doi.org/10.1108/02621711011072513

Baron R.M.; KennY, D.A. (1986). The Moderator-Mediator Variable Distinction in Social Psychological Research: Conceptual, Strategic, and Statistical Considerations. Journal of Personality and Social Psychology, v.51, n.6, p.11731182. 
Bastos, A.V.B. (1994) O conceito de comprometimento: sua natureza e papel nas explicações do comportamento humano no trabalho. Organização e sociedade. V. 01 n. 02. Salvador pp. 77-106.

Bastos, A.V.B. (1994a). Comprometimento no Trabalho: a estrutura dos vínculos do trabalhador com a organização, a carreira e o sindicato. Tese de Doutorado. Universidade de Brasília.

Bastos, A.V.B. (1993). Comprometimento Organizacional: um balanço dos resultados e desafios que cercam essa tradição de pesquisa. Revista de Administração de Empresas, 33(3):52-64.

Bastos, A.V.B. (1995). Comprometimento no Trabalho: o estado da arte e uma possível agenda de pesquisa. Cadernos de Psicologia, 1 (1), 44-63.

Bastos, A. V. B. e Borges-Andrade, J. (1995a). Comprometimento no Trabalho: Identificando padrões de comprometimento do trabalhador com a organização, a carreira e o sindicato. Revista Brasileira de Administração Contemporânea, vol.1 (9), 219-240.

Bastos, A.V. B. (1996). Comprometimento no Trabalho: os caminhos da pesquisa e os seus desafios metodológicos. Em Tamayo, A., Borges-Andrade, J. E. e Codo, W., Trabalho, Organizações e Cultura. São Paulo: Cooperativa de Autores Associados, p. 105-127.

Barros, B. T. \& Prates, M. A. S. (1996). O estilo brasileiro de administrar. São Paulo: Atlas.

Barros, B. T. (1996). Comprometimento no trabalho: o estado da arte e uma possível agenda de pesquisa. In: Cadernos de Psicologia. V. 01 pp. 46 - 63.

Barros, B. T. (1998). Comprometimento no trabalho: contextos em mudança e os rumos da pesquisa deste domínio. Anais da ENANPAD. (cd-rom).

Bastos, A.V.B. \& Costa, F.M. (2000). Múltiplos comprometimentos no trabalho: articulando diferentes estratégias de pesquisa. Anais da ENANPAD. Florianópolis SC (cd-rom).

Barney, J. B. (1986) Organizational culture: can it be a source of sustained competitive advantage? Academy of management review, Vol 16, n. 2 pp. 656-665.

Becker, H. S. (1960). Notes on the concept of commitment. American Journal of Sociology, 32-40.

Becker, J.M., Rai, A., Ringle, C. M., and Völckner, F. (2013). Discovering Unobserved Heterogeneity in Structural Equation Models to Avert Validity Threats., MIS Quarterly, 37(3): 665-694.

Becker, B.; Heselid, Mark A.; Ulrich, Dave. (2001). Gestão Estratégica de pessoas com "scorecard": interligando pessoas, estratégia e performance. RJ:Elsevier. 
Bedani, M. (2007). Efetividade das equipes de trabalho: clima organizacional como variável preditora do desempenho. Trabalho apresentado no $31^{\circ}$ Encontro Nacional de Programas de Pós-Graduação em Administração, Belo Horizonte.

Bedani, M. (2009). Valores, práticas e criatividade organizacionais: estudo do perfil cultural de uma instituição bancária. Tese de doutorado. Programa de Pósgraduação em Psicologia Social, do Trabalho e das Organizações. Universidade de Brasília, Brasília.

Beechler, S. \& Javidan, M. (2007) Leading with a Global Mindset. In: Advances in International Management: the global mindset, 131-169. Elsevier.

Becker, T. (1992). Foci and Bases of commitment: are they distinctions e worth making? Academy of Management Journal, 35(1):232-244.

Becker, J.M.; Klein, K., \& Wetzels, M. (2012). Hierarchical latent variable models in PLS-SEM: guidelines for using reflective-formative type models. Long range planning, 45 (5-6), 359-394.

Beierlein, C., Davidov, E., Schmidt, P., Schwartz, S. H., \& Rammstedt, B. (2012). Testing the discriminant validity of Schwartz' Portrait Value Questionnaire items - A replication end extension of Knoppen and Saris (2009a). Survey Research Methods, 6(1), 25-36.

Berlo, D. K. (1999) O Processo da comunicação: introdução à teoria e à prática. São Paulo: Martins Fontes.

Bern, Huber Campos \& Porto, J. B. (2010). Escala de Valores Pessoais: validação da versão reduzida em amostra de trabalhadores brasileiros. Psico, 41(2), 208-213.

Bisso, Ely Moraes. (1990) O que é segurança do trabalho. São Paulo: Brasiliense.

Bilsky, W., Janik, M.; Schachwartz, S. H. (2011). The structural organization of human values - Evidence from three rounds of the European Social Survey (ESS). Journal of Cross-Cultural Psychology, 42(5), 759-776.

Bilsky, W., Gollan, T., \& Döring, A. (2008) Análise Confirmatória de Escalonamento Multidimensional (EMD) de Valores Baseada em uma Matriz de Desenho: uma nota de pesquisa. Em M. L. M. Teixeira (Org). Valores Humanos e Gestão: novas perspectivas (213-224). São Paulo: Senac.

Bollen. K.A. (1989). Structural Equations with Latent Variables. Wiley. ISBN: 0-47101171-1

Bonavides, R. O. P.; Oliveira, J. A.; Medeiros, C. A. F. (2006). Comprometimento organizacional: um estudo de consequentes do comprometimento para os trabalhadores. In: Anais do XXX Encontro da Associação Nacional de Pesquisa e Pós-Graduação em Administração. 
Borg, I; Groenen, P.J.F. (2005). Modern Multidimensional Scaling. 2nd edition. New York: Springer.

Borg, I; Groenen, P.J.F.; Bilsky, W., \& Schwartz, S.H. (2011) Embedding the Organizational Culture Profile into Schwartz's Theory of Universals in Values. Journal of Personnel Psychology, 10(1), 1-12.

Borg, I., \& Shye, S. (1995). Facet theory: Form and content. California: Sage.

Borg, I., \& Staufenbiel, T. (2007). Theorien und Methoden der Sklierung. California: Sage.

Borges, L. de O. et al. (2004) Organizações e comprometimento no trabalho e sua sustentação na cultura e no contexto organizacional. RAE eletrônica, v. 3, n. 1, jan./jun.

Borges, L. O; Vikan, A.; Pilati, R. (2011) Valores humanos: uma perspectiva comparativa e transcultural entre amostras estudantis brasileiras e norueguesas. Simpósio Internacional de Valores Humanos e Gestão, 3. Anais. São Paulo: Universidade Presbiteriana Mackenzie.

Botelho, R. D. (2009). Comprometimento organizacional: um estudo no Tribunal de Justiça do Estado de Minas Gerais. Dissertação de mestrado defendida na Faculdade Novos Horizontes. MG.

Boxall, P. \& Macky, K. (2007) High-performance work systems and organisational performance: Bridging theory and practice. Asia Pacific Journal of Human Resources 45(3):261-270.

Brasil. Ministério das Relações Exteriores. Divisão de Programas de Promoção Comercial. Exportação Passo a Passo / Ministério das Relações Exteriores. Brasília: MRE, 2011. ISBN 85-98712-12.

Brewster, Chris. (2008). Similarity, Isomorphism or Duality? Recent Survey Evidence on the Human Resource Management Policies of Multinational Corporations. British Journal of Management. London.

Brewster, Chris \& Mayrhofer, Wolfang (2012) Handbook of Research on Comparative Human Resource Management - ISBN: 9781781002940).

Brown, S. P.; Leigh, T. W. (1996). A new look at psychological climate and its relationship to job involvement, effort, and performance. Journal of Applied Psychology, 81, 358-368.

Buchanan, B. Building organizational commitment. The socialization of managers in work organizations. New York: Administrative Science Quarterly, n.19, p. 533-546, 1974.

Bueno, Wilson da Costa. (1998). Uma cultura de comunicação para a Universidade brasileira. Comunicação. Seminário sobre Comunicação e Universidade, USP. 
Bruno-Faria M. F. (2003) Criatividade, inovação e mudança organizacional. In: Lima, S. M. V. (Org.). Mudança organizacional: teoria e gestão. Rio de Janeiro: FGV, 2003. pp. $111-142$.

Burrell, G. \& Morgan, G. (1979). Part I: In search of a framework. In: G. Burrell \& G. Morgan (Eds.), Sociological paradigms and organizational analysis: Elements of sociology of corporate life. London: Heinemann.

Burgess, S.; Schwartz, S. (1994). Do values share universal content and structure? A south African test. In: South African Journal of Psychology, 24(1).

C

Calori, R.; Sarnin, P. (1991) Corporate culture and economic performance: a french study. Organization Studies, v. 12, n. 1, p. 49-74. http://dx.doi. org/10.1177/017084069101200104.

Cameron, K. (1981). Domains of organizational effectiveness in colleges and universities. Academy of Management Journal, v. 24, n. 1, p. 25-47.

Campos, Geraldo Maia. (2001). Estatística prática para docentes e pós-graduandos. http://www.forp.usp.br/restauradora/gmc/gmc_livro/gmc_livro.html

Campos, S. A. P., Estivalete, V. F. B., \& Reis, E. (2011). Percepções de Suporte e Comprometimento: investigando a relação entre os construtos. GESTÃO.ORG Revista Eletrônica de Gestão Organizacional, 9(3), 534-564.

Cantarelli, N. M. (2012). Carreira e Comprometimento Organizacional: Ampliando a sua Compreensão. (Dissertação de Mestrado). UFSM, Santa Maria, RS, Brasil.

Cao, Jie \& Hamori, Monika. (2016). The Impact of Management Development Practices on Organizational Commitment. Human Resource Management, MayJune, Vol. 55, No. 3. Pp. 499-517.

Caligiuri, P. (2006). Developing Global Leaders. Human Resource Management Review, 16, 219-228.

Carbone, P. P. (2000). Cultura organizacional no setor público brasileiro: desenvolvendo uma metodologia de gerenciamento da cultura. Revista de Administração Pública, RJ, v. 34, n. 2, p. 133-144, mar./abr. 2000.

Carrieri, T. (2001). O fim do mundo TELEMIG: a transformação das significações culturais em uma empresa de telecomunicações. SP: Elsevier.

Carvalho, V. et al. (2011) Resiliência e socialização organizacional entre servidores públicos brasileiros e noruegueses. Revista de Administração Contemporânea, v. 15 , n. 5 , p. 815-833.

Carvalho \& Borges. (2012) Desenhos transculturais na pesquisa organizacional: considerações teóricas e metodológicas. Revista de Administração Mackenzie, vol.13 no. 3 São Paulo May/June. 
Casado, T.; Gouvêa, M.; Ralston, D.; Egri, C.; Castro, F.; Tong, J.T.; Lenartowics, T.; DArder, F.L.; Barber, J.P.; Carranza, M. (2005) Valores Ancestrais, Práticas Profissionais e Carreiras: um estudo sobre aspectos convergentes entre Valores na Carreira e a Colonização Ibérica. In: Anais do Annual Conference of the Iberoamerican Academy of Management - IAM.

Casado, Tânia. As pessoas na organização. 10. ed. São Paulo: Gente, 2002

Casali, A. M. (2004). Comunicação organizacional: considerações epistemológicas. Anais do XXVIII Encontro Nacional dos Programas de Pós-Graduação em Administração - ENANPAD.

Casanova, K. R., \& Porto, J. B. (2010). O impacto dos valores organizacionais no estresse ocupacional: um estudo com professores de ensino médio. Revista de Administração Mackenzie, 11(5), pp. 04-31. doi: 10.1590/S167869712010000500002.

Cavalcante, C. E.; Medeiros, A. C. F. (2007). Desenho do trabalho voluntário e comprometimento organizacional: um estudo nas organizações não governamentais. In: Anais Encontro de Gestão de Pessoas e Relações de Trabalho - ENGPR.

Cesar, Ana M. R.; Bido, Diógenes S.; Saad, Sheila M. (2007). Evolução da área de Recursos Humanos, em termos de importância estratégica e capacidade instalada: cinco anos de levantamento em empresas que atuam no Brasil. Anais do XXXI Encontro da Associação Nacional de Pós-Graduação e Pesquisa em Administração.

Chanda, N. (1998). In the bunker. Far Eastern Economic Review 161(32): 24-8.

Chen, M. (1995). Asian management systems. London: Routlege.

Chen, J.; Wang, L.; Tang, Ny. (2016). Half the Sky: The Moderating Role of Cultural Collectivism in Job Turnover Among Chinese Female Workers. Journal of Business Ethics, Feb, Vol.133(3), pp.487-498

Chew, I.K.H. and J. Putti. (1995). Relationships on work-related values of Singapore and Japanese managers in Singapore. Human Relations, 48(10):1149-70.

Child, J.; Faulkner, D. (1998). Strategies of cooperation: managing alliances, networks and joint ventures. Oxford: Oxford University.

Chin, W. W., Marcolin, B. L., and Newsted, P. R. (2003). A Partial Least Squares Latent Variable Modeling Approach for Measuring Interaction Effects: Results from a Monte Carlo Simulation Study and an Electronic-Mail Emotion/Adoption Study. Information Systems Research, 14(2): 189-217.

Clegg, Brian. (2001). Administración del tiempo al instante. México: Granica, ISBN, 9685015198, 9789685015196.

Clugston, Michael; Howell, Jon; Dorfman, Peter. (2000). Dispositional Influences on Pay Preferences. Journal of Business and Psychology, Vol.15(2). 
Cohen, Jacob. (1988), Statistical power analysis for the behavioral sciences. Hillsdale, NJ, Erlbaum.

Combs, J. G; Crook, T. R; Shook, C. L. (2005). The dimension of organizational performance and its implications for strategic management research. In: D. J. KETCHEN, D. J; BERGH, D. D. (Orgs). Research methodology in strategy and management. San Diego: Elsevier p. 259-286.

Costa, F. L. \& Castanhar, J. C. (2003) Avaliação de programas públicos: desafios conceituais e metodológicos. RAP - Revista de Administração Pública, Rio de Janeiro, v. 37, n. 5, pp. 969-992, set./out.

Creswell, J. W. (2014). Research Design: qualitative, quantitative, and mixed methods approach (4th ed.). Thousand Oaks, California: SAGE.

Cronbach, L J. (2004). My current thoughts on coefficient alpha and successors procedures. Educational and Psychological Measurement, vol. 64, n.o 3, 391-418.

Croucher, R.; Gooderham, P.; Parry, E. (2006). The influences on direct communication in British and Danish firms: country. European Journal of Industrial Relations, 12(3), 267-286. doi: 10.1177/0959680106068913

Cultura. Disponível em http://www.dicionarioetimologico.com.br/cultura/.

\section{D}

Da Matta, R. (1984). O que faz o Brasil, Brasis? Rio de Janeiro: Rocco.

Dancey, Christine \& Reidy, John. (2006). Estatística sem matemática para psicologia: usando SPSS para windows. Porto Alegre: Artmed.

Danhke, G.L. (1989). Investigación y Comunicación. En C. Fernandez-Collado y G.L. Danhkw (Eds.) La comunicación Humana: ciencia social (pp.385-454) Mexico: Mcgraw Hill.

Das, T. K. (1989) Organizational Control: an evolutionary perspective. Journal of Management Studies, New York, v.26, n.5, pp. 459-475.

De Cuyper, Nele; De Witte, Hans. (2011). The management paradox: Self-rated employability and organizational commitment and performance. Personnel Review, 08 February Vol.40(2), pp.152-172

Deal, T. \& Kennedy, A. (1982). Corporate Culture: the rites and rituals of the corporate life. Massachusets: Addison-Wesley.

Dejours, C.; Abdouchelli, E. JayeT, C. (1994) Psicodinâmica do trabalho: contribuições da escola dejouriana à análise de prazer, sofrimento e trabalho. São Paulo: Atlas.

Denison, D. R. (1990) Corporative culture and organizational effectiveness. New York: John Wiley and sons. 
Diamantopoulos, A., \& Siguaw, J. A. (2006). Formative versus reflective indicators in organizational measure development: a comparison and empirical ilustration. British Journal of Management, 17(4), 263-282.

DiMaggio, P. J. (1988) Interest and agency in institutional theory. In L.G. Zucker (Org.), institutional patterns and organizations: culture and environments. pp.3-21.

Diplomacia Comercial.http://www.itamaraty.gov.br/pt-BR/politica-externa/diplomaciaeconomica-comercial-e-financeira/156-diplomacia-comercial.

Demo, Pedro. A grande convergência. https://docs.google.com/document/d/14jecsu2ZBI6TBngOwKpNGWmmngDaLhfzfAGeK5h5pAQ/pub

Demorgon \& Lipiansky (Orgs). (1999) Guide de línterculturel em formation. Paris: Retz.

Denison, D. R. (1990). Corporate Culture and Organizational Effectiveness. New York: Wiley.

Denison, D. R. (1997). Corporate culture and organizational effectiveness. New York: John Wiley \& Sons.

Denison, D. R. (1984), Bringing corporate culture to the bottom line - Organizational Dynamics - 13 (20) - pp.4-22.

Denison, D. R. (1996), What is the difference between organizational culture and organizational climate? A native's point of view on a decade of paradigm wars. Academy of Management Review - 21 - (3).

D'iribarne, P. (2003). Práticas modernas de gestão inseridas nas culturas do terceiro mundo. Civitas - Revista de Ciências Sociais. 3(2), 327- 337.

Durkheim, Émile. (1983). As regras do método sociológico. In: Durkheim. 2. ed. Trad. de Margarida Garrido Esteves. São Paulo: Abril Cultural. (Coleção Os Pensadores)

Dias, H.B. P. D. (2010). Liderança, confiança e desempenho percebido. 175 p. Dissertação (Mestrado em Gestão). Faculdade de Economia, Universidade de Coimbra. Coimbra.

DPR 50 anos.http://www.itamaraty.gov.br/pt-BR/component/tags/tag/promocaocomercial. Acesso em 20/10/2017.

Drucker, Peter F. (1993). Sociedade pós-capitalista. São Paulo: Pioneira.

Dupuis, J. P. (1996). Antropologia, cultura e organização: proposta de um modelo construtivista. In: Chalant, J. F. (Org.). O indivíduo na organização: dimensões esquecidas. São Paulo: Atlas.

Dupuis, J. P. (2007). Entre as culturas latinas, anglo-saxã e nórdica: os quebequenses em economia, negócios e administração. In: J. F., Chanlat; Fachin, R \& Fischer, T. (Org.). Análise das organizações perspectivas latinas. Porto Alegre: UFRGS. 
Eisenberger, R., Stinglhamber, F., Becker T.E., Karagonglar G., Neves P. \& GonzalesMorales M.G. (2010) Leader-member exchange and affective commitment and affective organizational commitment: the contribution of supervisors' organizational embodiment. Journal of Applied Psychology 95, 1085-1103.

Efron, B. (1979). Bootstrap methods: another look at the jackknife. Ann. Stat., Washington, v.7, p.1-26, 1979.

Efron, B. Tibshirani, R. (1993). An introduction to the bootstrap. Nova York: Chapman \&Hall, 1993. 436p.

England, G. (1967). Personal Value Systems of American Managers. Academy of Management Journal, 10(1), 53-68.

England, G.W. (1975). The manager and his values. Cambridge, MA: Ballinger Publishing Co.

England, G.W. (1978). Managers and their value systems: A five country comparative study. Columbia Journal of World Business, 13(2), 33-44.

Estivalete, V. F. B., Löbler, M. L., Visentini, M. S., \& Andrade, T. (2010). Valores Relativos ao Trabalho e a Relação com o Comprometimento Organizacional: a percepção dos 14 colaboradores de uma empresa internacionalizada. BASE Revista de Administração e Contabilidade da Unisinos. 7(2), 135-148.

Estrutura de valores dos brasileiros. (2012). Rev. Psicol., Organ. Trab., abril-junho 2014, vol. 14 num. 2151 ESS, European Social Survey. http://www.europeansocialsurvey.orgl. Acesso em 20/8/2017.

Estivalete, V. B. et al. (2012). Valores organizacionais no Brasil: uma análise da produção científica na área da administração nos últimos 10 anos. Gestão Contemporânea, Porto Alegre, ano 9, n. 12, p. 43-68, jul./dez. 2012 Disponível em: http://seer2.fapa.com.br/index.php/arquivo

Estivalete, V. F. B.; Andrade, T. (2012). A influência dos valores organizacionais na percepção de suporte organizacional com base na concepção dos colaboradores do setor bancário. RAM - Revista de Administração Mackenzie, São Paulo, v. 13, n. 13, p. 214-244.

$\mathbf{F}$

Fairbanks, M.; Lindsay, S. (2000). Arando o mar: fortalecendo as fontes ocultas de crescimento em países em desenvolvimento. Rio de Janeiro: Qualitymark.

Faria A. N. \& Suassuna, N. (1982) A comunicação na administração. RJ: Livros Técnicos e Científicos.

Farndale, E., Scullion, H., \& Sparrow, P. (2010). The role of the corporate HR function in global talent management. Journal of World Business, 45:161-168. 
Fernandes, L. T.; Lins Filho; Danjour, M.E. (2016). (Re)validação da escala de bases do comprometimento organizacional. Seminários em Administração - SEMEAD, ISSN 2177-3866

Ferreira, M. C., Assmar, E. M. L., Estol, K. M. F., Helena, M. C. C., \& Cisne, M. C. (2002). Desenvolvimento de um instrumento brasileiro para avaliação da cultura organizacional. Estudos de Psicologia (UFRN), 7(2), 271-280. doi. 10.1590/S1413294 X2002000200008.

Ferreira, M. C. et al. (2006) Individualismo, coletivismo, percepções de justiça e comprometimento em organizações latino-americanas. Revista Interamericana de Psicologia, v. 40, n. 1, p. 13-24.

Ferreira, M. C. \& Mendes, A. M. (2008). Contexto de trabalho. In M. M. M. Siqueira (Ed.). Medidas do comportamento organizacional: ferramentas de diagnóstico e de gestão. (pp. 111-123). Porto alegre: Artmed.

Ferreira, M. C., Fernandes, H. A., \& Corrêa e Silva, A. P. (2009). Valores organizacionais: um balanço da produção nacional do período de 2000 a 2008 nas áreas de administração e psicologia. RAM. Revista de Administração Mackenzie, 10(3), 84-100. doi. 10.1590/S1678-69712009000300006.

Fidell, L. S., \& Tabachnick, B. G. (2012). Preparatory Data Analysis. In I. B. Weiner, J. A. Schinka \& W. F. Velicer (Eds.), Handbook of Psychology, Research Methods in Psychology (2nd ed., Vol. 2): John Wiley \& Sons, Inc.

Figueiredo Filho, Dalson Britto; Silva Júnior, José A. (2009) Desvendando os Mistérios do Coeficiente de Correlação de Pearson (r). Revista Política Hoje, Vol. 18, n. 1.

Finegan, J. E. (2000) The impact of person and organizational values on organizational commitment. Journal of Occupational and Organizational Psychology, v. 73, n. 2, p. 149-169.

Finegan, J., \& Theriault, C. (1997). The relationship between personal values and the perception of the corporation's code of ethics. Journal of Applied Social Psychology, 27, 708-724. doi. 0.1111/j.1559-1816.tb00655. x.

Fiol, C. M., \& O'Connor, E. J. (2005). Identification in face-to-face, hybrid, and pure virtual teams: Untangling the contradictions. Organization Science, V. 16, 19-32. doi:10.1287/orsc.1040.0101.

Fiol, M., Hatch, M. J., \& Golden-Biddle, K. (1998). Organizational culture and identity: What's the difference anyway? In D. Whetten \& P. Godfrey (Eds.), Identity in organizations: 56-59. CA: Thousand Oaks: Sage.

Fischer, R. (2006). Congruence and Functions of Personal and Cultural Values: Do My Values Reflect My Culture's Values? Personality and Social Psychology Bulletin, 32, 1419-1431. 
Fischer, R. et al. (2007) How do organizations allocate rewards? The predictive validity of national values, economic and organizational factors across six nations. Journal of Cross-Cultural Psychology, v. 38, n. 1, p. 3-18.

Fischer, R., Ferreira, M. C., Leal, Assmar, E. M., Baris, G., Berberoglu, G., Dalyan, F., Wong, C. C., Hassan, A., Hanke, K., \& Boer, D. (2013). Organizational practices across cultures: An exploration in six cultural contexts. International Journal of Cross Cultural Management, 14, 105-125. doi. 10.1177/1470595813510644. 515

Fitzgerald, A., \& Teal, G. (2003) Health reform, professional identity and occupational sub- cultures: The changing interprofessional relations between doctors and nurses. Contemporary Nurse 16(1-2), 9-19.

Fleury, M. T. L. (1992). O desvendar da cultura de uma organização: uma discussão metodológica. In: M. T. L. Fleury \& R. M. Fischer (Orgs.) Cultura e poder nas organizações (pp.15-27). São Paulo: Atlas.

Fiúza, M. S. \& Kilimnilk, Z. M. (2004) Indicadores de mensuração da qualidade de comunicação. Revista Administração - FECAP, v. 5 № 2, pp. 1-20 abril/maio/junho.

Fitz-Enz, J. Tlle. (1997). Practices of exceptional companies: how great organizations make the most of their human assets. New York: Amacon.

Flauzino, D. P. \& Borges-Andrade, J. E. (2008). Revista RAP - Rio de Janeiro 42(2): 253-73, mar./abr.

Feldmann, Paulo Roberto. (2010). A influência da cultura na gestão das empresas latino-americanas. Estud. av. vol.24 no.68 SP. http://dx.doi.org/10.1590/S010340142010000100022

Figueroa, Andrés Eduardo J.; Olea, Daniela A.; CONCHA, Ana Luisa S.; Díaz, Emilio M. (2009). Cultura trabajo, familia y compromiso organizacional en empresa de servicios. Psicologia em Estudo, 4(4):729-738 doi 10.1590/S141373722009000400013

Finegan, J. E. (2000). The impact of person and organizational values on organizational commitment. Journal of Occupational and Organizational Psychology, V. 73, n. 2, p. 149-169.

Fleury, M. T. et al. (2007). Cultura e poder nas organizações. 2. ed. São Paulo: Atlas.

Fleury, M. T.; Fischer, R. M. (1989). Cultura e poder nas organizações. São Paulo: Atlas, 1989.

Fleury, M. T. (1995). Aprendizagem e inovações organizacionais: as experiências de Japão, Coreia e Brasil. São Paulo: Atlas.

Fleury, M. T. (1996). Conceitualizando cultura e poder. Cultura e poder nas organizações. São Paulo: Atlas. 
Fornell, C., \& Larcker, D. F. (1981). Evaluating Structural Equation Models with Unobservable Variables and Measurement Error. Journal of Marketing Research, v.18(1), 39-50.

Fraenkel, J. R., Wallen, N. E., \& Hyun, H. H. (2011). How to Design and Evaluate Research in Education. 8th ed. New York: McGraw-Hill.

Freitas, A. B. (1991). Traços brasileiros para uma análise organizacional. In: Motta, F. C. P.; Freitas, M. E. de. Cultura organizacional: formação, tipologias e impactos. São Paulo: Makron Books.

Freitas, A. B. (1997). Traços brasileiros para uma análise organizacional. In: Motta, F. C. P. (Org.). Cultura organizacional e cultura brasileira. São Paulo: Atlas.

Freitas, A. B. (1997a). Cultura organizacional: o doce controle no clube dos raros. In: MOTTA, F.C.P.; CALDAS, M.P. (Org). Cultura organizacional e cultura brasileira. São Paulo: Atlas.

França, V. R. V. (1994) Teoria (s) da comunicação: busca de identidade e de caminhos. Belo Horizonte: Depto. de Comunicação da UFMG.

França, L. H. F. P. (2009) Influências sociais nas atitudes dos "tops" executivos em face da aposentadoria: um estudo transcultural. Revista de Administração Contemporânea, v. 13, n. 1, p. 17-35.

Friedman, Barry A. (2007). Globalization Implications for Human Resources Management Roles. Employ Respons Rights. V.19, p. 157-171

Friedman, Thomas L. (2005). O Mundo é Plano: uma breve história do século XXI. Rio de Janeiro: Objetiva, 2005.

G

Gaertner, K.N., \& Nollen, S.D. (1989). Career experiences, perceptions of employment practices, and psychological commitment to the organization. Human Relations, 42.

Gao, S.; Mokhtarian, P. \& Johnston, R. (2008). Nonnormality of Data in Structural Equation Models. Paper presented at the Transportation Research Board's 87th Annual Meeting

Gamlath, Sharmila. (2017). Human Development and National Culture: A Multivariate Exploration. Social Indicators Research, v. 133: 3pp 907-930

Garrido, A; Rodriguez, M; Alvaro, Jl. (2010). An analysis of the relationship between organizational commitment and values. Revista de Psicologia Social, Oct, Vol.25(3), pp.351-363

Garson, G. David. (2009), Statnotes: Topics in Multivariate Analysis. http://faculty.chass.ncsu.edu/garson/PA765/statnote.htm. Acesso em 22/10/2017. 
Gelade, Garry A; Dobson, Paul; Auer, Katharina. (2008). Individualism, Masculinity, and the Sources of Organizational Commitment. Journal of Cross-Cultural Psychology, Vol.39(5), pp.599-617

Gellatly, lan R.; Hunter, Karen H.; Currie, Luanne G.; Irving, P. Gregory. (2009). HRM practices and organizational commitment profiles. International Journal of Human Resource Management, Vol.20(4), p.869(16)

Gera, Maria Z. Figueiredo (1998). O comprometimento organizacional: teoria e pesquisa. FACEF - Pesquisa, Franca V. I n. 111-24.

Gherardi, S. e Turner, B. (1987), Real men do not collect soft data - Trento, Italy: Universitá di Trento - Dipartamento di Politica Sociale.

Ghemawat, Pankaj. (2008). Redefinindo estratégia global: cruzando fronteiras em um mundo de diferenças que ainda importam. Porto Alegre: Bookman.

Gooderham, P. N., Nordhaug, O., \& RIngdal, K. (2006). National embeddedness and HRM in US Subsidiaries in Europe and Australia. Human Relations, 59(1), 1491-1513.

Gbadamosi, Gbolahan. (2003). HRM and the commitment rhetoric: challenges for Africa. Management Decision, Vol. 41 Issue: 3, pp.274-280, https://doi.org/10.1108/00251740310475218

Giacomoni, James. (2007). Orçamento público. 14. ed. São Paulo: Atlas.

Giauque, David; Anderfuhren-Biget, Simon. (2013). HRM Practices, Intrinsic Motivators, and Organizational Performance in the Public Sector. Public Personnel Management, Vol.42 (2), p.123-151

Gibson, J.L., Ivancevich, J.M., Donnelly JR., J.H. (1981) Organizações: comportamento, estrutura, processos. São Paulo: Atlas.

Ghosn, C. \& Reis, P. (2003). O cidadão e o mundo. SP: A Girafa.

Gomes, Eduardo G. Magalhães. (2015). Gestão por Resultados e eficiência na Administração Pública: uma análise à luz da experiência de Minas Gerais. São Paulo: EAESP/FGV, 187 p. (Tese de Doutorado apresentada ao Curso de Doutorado de Administração Pública e Governo da EAESP/FGV, Área de Concentração: Transformações do Estado e Políticas Públicas).

Gomes, José Pereira (2013). Os determinantes do desempenho de um mediador de seguros e o efeito moderador da cultura: o caso AXA. Dissertação de Mestrado em Marketing Relacional apresentada à ESTG - Escola Superior de Tecnologia e Gestão do Instituto Politécnico de Leiria.

Görden, W. (1984) Organizational Imperatives and Cultural Modifiers. Business Horizons, V. 27, mai/ jun. 
Gouveia, V.V. et al. (2001). A estrutura e o conteúdo universais dos valores humanos: análise fatorial confirmatória da tipologia de Schwartz. Estudos de Psicologia, V. 6 (2), 133-142.

Gouveia, V. V. (2003) A natureza motivacional dos valores humanos: evidências acerca de uma nova tipologia. Estudos de Psicologia, v. 8, n. 3, p. 431-443.

Guardani, F.; Teixeira, M. L. M.; Bido, D. S.; Mazzon, J. A. (2013). A relação entre valores, práticas organizacionais e confiança de clientes no setor de serviços. Produção, v. 23, n. 4, p. 806-817.

Guarido Filho, E. R.; Machado-Da-Silva, C. L. (2001). A influência de valores ambientais e organizacionais sobre a aprendizagem organizacional na indústria alimentícia paranaense. RAC - Revista de Administração Contemporânea, v. 5, n. 2, p. 33-63.

Gutierrez, A.P., Candela L.L. \& Carver L. (2012) The structural relationships between organizational commitment, global job satisfaction, developmental experiences, work values, organizational support, and person-organization fit among nursing faculty. Journal of Advanced Nursing, V. 68(7), 1601-1614.

Guttman, L. (1968). A general nonmetric technique for finding the smallest coordinate space for a configuration of points. Psychometrica, V. 33, 469-506.

\section{H}

Hahn, C., Johnson, M. D., Herrmann, A., and Huber, F. (2002). Capturing Customer Heterogeneity Using a Finite Mixture PLS Approach, Schmalenbach Business Review, 54(3): 243-269.

Hair, J. F., Hult, G. T. M., Ringle, C. M., and Sarstedt, M. (2017). A Primer on Partial Least Squares Structural Equation Modeling (PLS-SEM), 2nd ed., Thousand Oaks: Sage.

Hair, J. F.; Sarstedt, M., Ringle, C. M., \& Gudergan, S. P. (2018). Advanced Issues in Partial Least Squares Structural Equation Modeling (PLS-SEM), Thousand Oaks, CA: Sage.

Hair, J. F.; Sarstedt, M., Ringle, C. M., and Mena, J. A. (2012). An Assessment of the Use of Partial Least Squares Structural Equation Modeling in Marketing Research, Journal of the Academy of Marketing Science, 40(3): 414-433.

Hair, J. F.; Sarstedt, M., Matthews, L., and Ringle, C. M. (2016). Identifying and Treating Unobserved Heterogeneity with FIMIX-PLS: Part I - Method, European Business Review, 28(1): 63-76.

Hall, R. H. (1978). Organizações: estruturas e processos. Rio de Janeiro: Prentice Hall do Brasil.

Hall, E. T. (1981). The Silent Language. New York: Doubleday.

Hall, D.T.; Schneider, B.; Nygren, H.T. (1970). Personal factors in organizational identification. Administrative Science Quarterly, n.15, p. 176-190. 
Hardy, C.; Nord, W.R. (2007). Handbook de estudos organizacionais: modelos de análise e novas questões em estudos organizacionais. São Paulo: Atlas.

Hayes, B. E. (1995). Medindo a satisfação do cliente. Rio de Janeiro: Qualitymark, 1995.

Hendry, John. (1999). Cultural theory and contemporary management organization. Human Relations, 52.5.

Henseler, J., Ringle, C. M., \& Sinkovics, R. R. (2009). The use of partial least squares path modeling in international marketing. Advances in International Marketing (AIM), v. $20,277-320$.

Henseler, J.; Ringle, C.M. \& Sarsted, M. (2015). A new criterion for assessing discriminant validity in variance-based structural equation modeling. Journal of the Academy of Marketing Science, v.43, 115-135.

Henseler, J \& Chin, W. W. (2010). A Comparison of Approaches for the Analysis of Interaction Effects Between Latent Variables Using Partial Least Squares Path Modeling. Structural Equation Modeling. A Multidisciplinary Journal, v.17(1): 82-109.

Henseler, J.; Fassott, G., Dijkstra, T., and Wilson, B. (2012). Analyzing Quadratic Effects of Formative Constructs by Means of Variance-Based Structural Equation Modelling. European Journal of Information Systems, v.21(1): 99-112.

Hofstede, G. (2001). Culture's Consequences: comparing values, behaviors, institutions, culture organizations across cultures. Thousand Oaks. CA: Sage.

Hofstede, G. (1997) Culture Organizations: software of the Mind. G. Hofstede. Nova York: McGraw-Hill.

Hofstede, G. (2001). Culture's Consequences: Comparing Values, Behaviors, Institutions, culture organizations across cultures. Thousand Oaks. CA: Sage.

Hofstede, G. (2003) Culturas e organizações: compreender a nossa programação mental. Lisboa: Sílabo.

Hofstede, G. et al. (1990). Measuring organizational cultures: a qualitative and quantitative study across twenty cases. Administrative Science Quarterly, v. 35, n. 2, p. 286-316, http://dx.doi.org/10.2307/293392

Rokeach, M. (1973). The nature of human values. New York: Free Press.

House, R. J., Hanges, P. J., JAVIDAN, M., DORFMAN, P. W., and GUPTA, V. (2004). Culture, Leadership and Organizations: The GLOBE Study of 62 Societies. Thousand Oaks, CA: Sage.

Hrebiniak, L. G.; Alutto, J. A. (1972). Personal and role-related factors in the development of organizational commitment. Administrative Science Quarterly, n.17, p.555-573. 
Hulland, J. (1999). Use of partial least square (PLS) in strategic management research: A review of four recent studies. Strategic Management Journal, v. 20, 195-204.

I

Inglehart, R. (2006). Mapping global values. Comparative Sociology, 5(2/3), 115-136.

Inglehart, R. (2007). Nation-level mean scores on traditional/secular-rational and survival/self-expression values dimensions, 1981-2007.

Inglehart, R., \& Baker, W. (2000). Modernization, cultural Change and the persistence of traditional values. American Sociological Review, 65(1), 19-51.

Iverson, Roderick D.; Buttigieg, Donna M. (1999). Affective, normative and continuance commitment: can the 'right kind' of commitment be managed? Journal of Management Studies, v.36(3), p.307(2).

Irving, J. A. (2008). Educating Global Leaders: Exploring intercultural competence in leadership education. Journal of International Business and Cultural Studies, v.1-14.

$J$

Jackson, Terence. (2002). The Management of People Across Cultures: Valuing People Differently. Human Resources Management. V.41, no. 4, P. 455-475.

Jarzabkowski, Paula. (2004) Strategy as practice: recursiveness, adaptation, and practices-in-use. Organization Studies. v. 25, n. 4, p. 529-560.

Jiang, Zhou (2014). A cross-cultural study of the relationship between organizational justice and organizational commitment: China, South Korea, and Australia. International Journal of Human Resource Management.

Joiner, Therese A., Bakalis, Steve. (2006). The antecedents of organizational commitment: the case of Australian casual academics, International Journal of Educational Management, v. 20 Issue: 6, pp.439-452, https://doi.org/10.1108/09513540610683694

Johnson, B. (2001). Toward a new classification of nonexperimental quantitative research. Educational Researcher, v. 30(2), 3-13.

Jong-Wook Ko; James L. Price and Charles W. Mueller. (1997). Assessment of Meyer and Allen's Three-Component Model of Organizational Commitment in South Korea. Journal of Applied Psychology. V.1. 82, No. 6, 961-973.

Jung, G.M. (2007). Structural equation modeling between leisure involvement, consumer satisfaction, and behavioral loyalty in fitness centers in Taiwan: ProQuest.

K

Kagitqibasi, C. (1991). Individualism and collectivism, in J. B. Segal and C. KagitEibasi (eds.), Handbook of Cross Cultural Psychology. Boston: Allyn \& Bacon, Vol. 3, pp. I49.

Kanter, R. (1983). The Change Masters. New York: Simon \& Schuster. 
Kanter, R. M. (1968). Commitment and social organization: a study of commitment mechanism in utopian communities, American Sociological Review, v. 33, n. 4, p. 499-517.

Kinnunen, U., Feldt, T. \& Makikangas, A. (2008) Testing the effort reward imbalance model among Finnish managers: the role of perceived organizational support. Journal of Occupational Health Psychology 13, 114-127.

Kitapcl, Hakan; Kaygisiz, Ozgur K., Hakan. (2014). Analyzing the mediating effects of the job satisfaction on relations between personnel perceptions about the HRM practices and organizational commitment. Journal of Social Sciences Institute, v.17(31), pp.157-192

Kock, N. (2012). WarpPLS 3.0 user manual. Laredo, Texas: ScriptWarp Systems.

Kostova, T. (1996). Success of transnational transfer of organizational practices within multinational companies. Tese de Doutorado, Universidade de Minnesota. http://proquest.umi.com/pqdweb?index=0\&did=739308861.

Kostova, T. (1999). Transnational transfer of strategic organizational pratices: A contextual perspective, The Academy of Management Review, v. 24(2), 308-324. doi. 10.5465/AMR.1999.1893938.

Kousha, Jalil; NAYERI, Mahmoud Dehghan; MALEKI, Mojtaba. (2017). Analysis of the relationship between human resource management practices and organizational commitment from a strategic perspective (the case of Iran oil industry pension fund), Journal of Interdisciplinary Research, Vol.7 (1), p.83-92

Koys, D.J. (1991). Fairness, legal compliance, and organizational commitment. Employee Responsibility and Rights Journal, 4, 283-291.

Kluckhohn, C. (1951). Values and value-orientations in the theory of action: An exploration in definition and classification. In T. Parsons \& E. Shils (Orgs.), Toward a general theory of action (pp. 469-506). Cambridge: Harvard University.

Kluckhohn, C. (1954). Culture and behavior. Handbook of Social Psychology, ed. G. Lindzey, vol. 2, pp. 931-76. Cambridge, MA: Addison-Wesley.

Kluckhohn, C. (1962). Universal categories of culture. In S. Tax (Ed.), Anthropology today. Chicago: University of Chicago.

Kras, E. (1995), Management in Two Cultures. Cambridge, MA: Harvard University, p. 34-66.

Kuabara, P. S. S., \& Sachuk, M. I. (2010). Estudo do Comprometimento Organizacional na PEM - Penitenciária Estadual de Maringá. Qualit@s Revista Eletrônica, 9(3), 1-16.

Kumar, R. (2005). Research Methodology: a step-by-step guide for beginners. London: SAGE. 
Kumar, R. (2010). Research Methodology: a step-by-step guide for beginners. London: SAGE.

Kwantes, Catherine T. (2009) Culture, job satisfaction and organizational commitment in India and the United States, Journal of Indian Business Research, v.1 Issue: 4, pp.196-212, https://doi.org/10.1108/17554190911013265.

$\mathbf{L}$

Lages, I. P. (2010). Comprometimento e Cultura Organizacionais: estudo de caso em uma prestadora de serviços na área de análises de materiais e fluidos isolantes. (Dissertação de Mestrado). Faculdades Integradas Pedro Leopoldo, Pedro Leopoldo, MG, Brasil.

Laserre, Philippe. (2003). Global Strategic Management. New York: Palgrave Macmillan.

Laville, Christian; Dionne, Jean. (1999). A construção do saber. BH: UFMG.

Lester, T. (1993). Head to Head: The Coming Economic Battle among Japan, Europe and America. New York: Warner Books pp. 28-46.

Levin, I. M. (2000). Five windows into orgnization culture: an assessment framework and approach. Organization Development Journal, v. 18, n. 1, p. 83-94.

Liberman, L. (2014). The impact of a Paternalistic Style of Management and Delegation of Authority on Job Satisfaction and Organizational Commitment in Chile and the US. Innovar, v. 24(53), 187-196.

Little, T. D.; Card, N. A.; Bovaird, J. A.; Preacher, K. J., \& Crandall, C. S. (2012). Structural equation modeling of mediation and moderation with contextual factors. In T. D. Little, J. A. Bovaird \& N. A. Card (Eds.), Modeling contextual effects in longitudinal studies (Vol. 1, pp. 392): Lawrence Erlbaum Associates.

Little, R. J. A., \& Rubin, D. B. (2002). Statistical Analysis with missing data (2nd ed.): Wiley Series in Probability and Statistics.

Lopes, F. C., \& Basso Jr., E. (2009). Comprometimento organizacional: um experimento de campo com os colaboradores na planta de Esteio de uma empresa do ramo alimentício. OPINIO - Revista de Ciências Empresariais, Políticas e Sociais, 23(2), 42-61.

Loth, A. F. (2010). Avaliação do Comprometimento dos Trabalhadores da Companhia Águas de Joinville com a Política de Saneamento Básico. (Dissertação de Mestrado). UNIVALI, Itajaí, SC, Brasil.

\section{M}

Macedo, K. B.; Pereira, C.; Rossil, E. (2005). Valores individuais e organizacionais: estudo com dirigentes de organizações pública, privada e cooperativa em Goiás. Cad. Psicol. soc. trab. v.8 SP. ISSN 1516-3717. 
Macedo, Isabel Maria; Pinho, Jose Carlos; Silva, Anabela Martins. (2016). Revisiting the link between mission statements and organizational performance in the non-profit sector: The mediating effect of organizational commitment. European Management Journal, v. $3436 \mathrm{e} 46$.

Maleki, Ammar; Jong, Martin. (2014). A Proposal for Clustering the Dimensions of National Culture. Cross-Cultural Research, v. 48(2) $107-143$. doi: 10.1177/1069397113510268 ccr.sagepub.com

Marconi, M. A. (2010). Antropologia: uma introdução. 7. ed. São Paulo: Atlas.

Marsh, R. M.; Mannari, H. (1977). Organizational commitment and turnover: A predictive study. Administrative Science Quartely, n. 22, p. 57-75.

Mattar, F. N. (1996). Pesquisa de Marketing. São Paulo: Atlas.

Martin-Alcazar, Fernando; Fernadez, Pedro M. R.; Sanchez-Gardey, Gonzalo (2005). Strategic human resource management: integrating the universalistic, contingent, configurational and contextual perspectives. The International Journal of Human Resource Management 16:5 633-659.

Mathieu, J.E. \& Zajac, D.M. (1990). A review and meta-analysis of the antecedents, correlates, and consequences of organizational commitment. Psychological Bulletin, v.108, 171-194.

Matthews, L., Sarstedt, M., Hair, J. F., and Ringle, C. M. (2016). Identifying and Treating Unobserved Heterogeneity with FIMIX-PLS: Part II - A Case Study, European Business Review, v. 28(2): 208-224.

Mazzon, J.A. (1981). Análise do programa de alimentação do trabalhador sob o conceito de marketing social. Tese (Doutorado em). Faculdade de Economia, Administração e Contabilidade. Universidade de São Paulo (USP), São Paulo.

Mazzon, J.A. (1983). Avaliação do Programa de Alimentação do Trabalhador: subsídios à formulação de um plano de marketing social. Revista de Administração, v. 18, n. 4, p. 33-58. http://www.spell.org.br/documentos/ver/19247/avaliacao-doprograma-de-alimentacao-do-trabalhador--subsidios-a-formulacao-de-um-plano-demarketing-social/i/pt-br.

MDIC - Comex Vis: Países Parceiros - Exportações, Importações e Balança Comercial. http://www.mdic.gov.br/comercio-exterior/estatisticas-de-comercio-exterior/comex-vis/framepais?pais=civ

Melo, Luiz N.; Tigreiro, Leandro; Araujo, Afrânio. (2014). Validação da escala de bases de comprometimento organizacional na gestão pública: um estudo de caso no Tribunal de Contas do Estado do Rio Grande Do Norte. ENANPAD. http://www.anpad.org.br/admin/pdf/2014 EnANPAD GPR1863.pdf

Melo, W. F.; Domenico, S. M. R. (2012). A influência de valores organizacionais no desempenho de agências bancárias. RAC - Revista de Administração Contemporânea, Rio de Janeiro, v. 16, n. 1, p. 137-156. 
Mendes, A. M. (2007) Psicodinâmica do trabalho: teoria, método e pesquisas. SP: casa do psicólogo.

Mendes, A. M. \& Ferreira, M. C. (2008) Contexto de Trabalho. In: Mirlene Maria Matias Siqueira. (Org.). Medidas do comportamento organizacional: ferramentas de diagnóstico e gestão. Porto Alegre RS: Artmed, pp. 111-123.

Mendonça, E. Furtado. (2007). A tutela ambiental nos tribunais de contas estaduais e municipais. http://200.198.41.151:8081/tribunal_contas/2007/03/02/2007_08_22_0003.2xt/.

Meyer, John P.; SMITH, Catherine A. (2000). HRM Practices and Organizational Commitment: Test of a Mediation Model. Canadian Journal of Administrative Sciences, v.17(4), 319-331.

Meyer, J. P., Stanley, David J., Herscovitch, Lynne and Topolnytsky, Laryssa. (2002). Affective, Continuance, and Normative Commitment to the Organization: A Metaanalysis of Antecedents, Correlates, and Consequences. Journal of Vocational Behavior, v. 61, 20-52 doi:10.1006/jvbe.2001.1842.

Meyer, J. P. \& Allen, N.J. (1991). A three-component conceptualization of organizational commitment, Human Resource Management Review, v.1 No. 1, pp. 61-89.

Meyer, J. P. \& Allen, N.J. (1997). Commitment in the Workplace: Theory, Research and Application. Thousand Oaks, CA: Sage.

Meyer, J. P., Irving, P.G. \& Allen, N.J. (1998), "Examination of the combined effects of work values and early work experiences on organizational commitment", Journal of Organizational Behavior, v. 19 No. 1, pp. 29-52.

Meyers, M. C., \& van Woerkom, M. (2014). The influence of underlying philosophies on talent management: Theory, implications for practice, and research agenda. Journal of World Business, 49: 192-203.

Miguel, L. A. P.; Teixeira, M. L. M. (2009). Valores organizacionais e criação do conhecimento organizacional inovador. RAC - Revista de Administração Contemporânea, v. 13, n. 1, p. 36- 56.

Minkov, M. (2007). What makes us different and similar: a new interpretation of the World Values Survey and other cross-cultural data. Sofia, Bulgaria: Klasika y Stil Publishing House. ISBN: 978-954-327-023-1, 240 pp.

Mintzberg, H. (1983). Power in and around organizations. New York: Prentice Hall.

Miranda, A. B. (1996) O Sistema de Comunicação numa média empresa têxtil do estado do Ceará. Fortaleza: UECE. 
Miranda, Rejane C.C. (2013). Identificação de valores organizacionais do Departamento de Promoção Comercial do Ministério das Relações Exteriores. Brasília. BRA/07/017 - "Projeto - Promoção Comercial e Atração de Investimentos: Coordenação Institucional em Contexto de Aceleração do Crescimento" Projeto de cooperação técnica entre o MRE e o PNUD.

Monday, R.T.; Porter, L.W.; Steers, R.M. (1982). The measurement of Organizational, Commitment Journal of Vocational Behavior, v. 14 p. 225.

Mowday, R.T.; Porter, L. W.; Steers, R. (1982). Organizational linkages: the psychology of commitment, absenteeism and turnover. New York: Academic Press.

Moore, David S. \& McCabe, George. (2004). Introduction to the practice of statistics. New York: Freeman.

Moore, David S. (2007). The basic practice of statistics. New York: Freeman.

Morgan, G. (2007). Paradigmas, metáforas e resolução de quebra-cabeças na teoria das organizações. In: Caldas, M.P.; Bertero, C.O. (Orgs) Teoria das organizações: série RAE-clássicos. São Paulo: Atlas p.12-33.

Morini, Cristiano; Simões, Regina Célia; Dainez, Valdir lusif. (2010). Administração de Mercado Exterior. Curitiba: IESDE Brasil.

Mozzato, A. R.; Grybovski, D. (2013). Abordagem Crítica nos Estudos Organizacionais: Concepção de indivíduo sob a perspectiva emancipatória Cad. EBAPE.BR, v. 11, n. 4, artigo 1, Rio de Janeiro.

Motta, Fernando C. \& Caldas, Miguel P. (2007). Cultura Organizacional e Cultura Brasileira. RJ: Atlas.

Munck, L.; Souza, Borim. (2010) Estudos organizacionais. PRETEXTO v. 11 n. 2 p. 95 - 112 abr. /jun. ISSN 1517-672 x ISSN 1984-6983.

Muse, Lori A.; Matthew, W. Rutherford; Sharon L.; Oswald, Jennie E. (2005). Commitment to Employees: Does It Help or Hinder Small Business Performance? Small Business Economics, v. 24: 97-111.

\section{$\mathbf{N}$}

Nardon, Luciara; Steers, Richard M. (2013). The culture theory jungle: divergence and convergence in models of national culture. Cambridge Handbook of Culture, Organizations, and Work. Cambridge University Press 9780521877428.

Nascimento, T.G.; Adaid-Castro, B.; Carvalho, Gabriel; Demo, G.; Menelau, S. (2014). Valores Organizacionais: Uma análise bibliométrica da produção nacional do Período de 2000 a 2013 na área de Administração. ENANPAD.

Neelam; Netra; Bhattacharya, Sonali; Tanksale, Deepa. (2016). Organizational Culture as a Determinant of Organizational Commitment: What Drives IT Employees in India? Global Business and Organizational Excellence v.34 iss:2 pg:62.

Negroponte, Nicholas. (1995). A vida digital. São Paulo: Companhia das Letras. 
Neves, José Gonçalves. (2000). Clima Organizacional, Cultura Organizacional e Gestão de Recursos Humanos. Lisboa: RH.

Nogueira, A. S.; Lemos A. H. C.; Cavazotte, F. S. C. N. (2011). Impacto das diferenças geracionais no comprometimento dos oficiais intendentes com a organização comando da aeronáutica. Anais do XXXV Encontro da Associação Nacional de Pesquisa e Pós-Graduação em Administração.

O

Ogaard, T. (2006). Do organizational practices matter for hotel industry employees' jobs? A study of organizational practice archetypical configurations and job outcomes. Hospitality Management, v.25, 647-661. doi. 10.1016/j.ijhm.2005.06.003.

Ogilvie, J.R. (1986). The role of human resource management practices in predicting organizational commitment. Group and Organization Studies, 11,335-359.

Oliveira, A. F., \& Tamayo, A. (2004). Inventário de perfis de valores organizacionais. Revista de Administração da USP, v. 39(2), pp. 129-140.

Oliveira, A. F.; Souza, M. A. (2014). Confiança do empregado na organização: o impacto dos valores pessoas e organizacionais. Revista Psicologia: Organizações e Trabalho, v. 14, n. 2, p. 204-217.

Oliveira, D. R. (2002) Sistemas, organização \& métodos: uma abordagem gerencial. 13. ed. SP: Atlas.

Omar, A. et al. (2007) Colectivismo, justicia y ciudadania organizacional en empresas argentinas, mexicanas y brasileiras. Revista Mexicana de Psicología, v. 24, n. 1, pp. 101-116.

O’Reilly, C. (1989) Corporation, culture and commitment. California Management Review, v. 31, p. 9-25.

O'Reilly, C., \& CHATMAN, J. (1986). Organizational commitment and psychological attachment: The effects of compliance, identification, and internalization on prosocial behavior. Journal of Applied Psychology, 71(3), 492-499.

Osland, A. \& Osland, J. 2005. Contextualization and strategic international human resource management approaches: the case of Central America and Panama. International Journal of Human Resource Management, 16(2): 2218-2236.

$\mathbf{P}$

Paiva, Kely Martins; Dutra, Michelle Santana. (2017). Valores organizacionais e valores do trabalho: um estudo com operadores de call center. Cad. EBAPE.BR, v. 15, $\mathrm{n}^{\circ}$ 1, Artigo 3, Rio de Janeiro.

Parsons, Talcott \& Shils, Edward. (1965). Toward a general theory of action: Theoretical foundations for the social sciences. Piscataway: Transaction Publishers.

Pasquali, Luiz. (2005). Análise fatorial para pesquisadores. Porto Alegre: Artmed. 
Pena, L. M. L. M. (2009). Comprometimento de Enfermeiros: estudo de caso de um hospital privado em Belo Horizonte. (Dissertação de Mestrado). Faculdade Novos Horizontes, Belo Horizonte, MG, Brasil.

Perovano, Dalton Gean. (2014). Manual de metodologia científica. SP: Juruá.

Pestana, Maria Helena; Gageiro, João Nunes. (2003). Análise de dados para as Ciências Sociais: a complementaridade do SPSS. 3. ed. Lisboa: Sílabo.

Peter, J. P. (1999). Reliability: a review of psychometric basics and recent marketing practices, Journal of Marketing Research, v. 16, 6-17.

Porter, L.; Steers, R.; Mowday, R., \& Boulian, P. (1974). Organizational commitment, job satisfaction and turnover among psychiatric technics. Journal of Applied Psychology, v. 59, 603e609.

Poutsma, E., Ligthart, P. E. M., \& Veersma, U. (2006). The diffusion of calculative and collaborative HRM practices in European firms. Industrial Relations, v. 45(4), 513546. doi: 10.1111/j.1468-232X.2006. 00442.x

Poutsma, E., Ligthart, P. E. M., \& Dietz, B. (2013). HRM policies and firm performance: the role of synergy of policies. In E. Parry, E. Stavrou, \& M. Lazarova (Eds.), Global Trends in Human Resource Management (1st ed., pp. 78-102). London: Palgrave Macmillan.

Prabhakar, Gantasala V.; Ram, Padmakumar. (2011). Antecedent HRM practices for organizational commitment. International Journal of Business and Social Science, v.2(2), p.55(8).

Promoção Comercial. https://profwalfredoferreira.files.wordpress.com/2014/02/min-rel-exterioresdepartamento-de-promoc3a7c3a3o-comercial-e28094.pdf.

Putnam, L. (1982). Paradigms for organizational communication research: An overview and synthesis. The western journal of speech communication, v.46(2), 192206.

Putnam, L. (1983). The interpretive perspective: An alternative to functionalism Chapter 2. In L. L.

Putnam, L. \& Pacanowsky, M. E. (Eds.), Communication and organizations: An interpretive approach. Beverly Hills: Sage Publications.

Putnam, L., Phillips, N., \& Chapman, P. (1996). Metaphors of communication and organization. In S. Clegg, C. Hardy e W. R. Nord (Eds.), Handbook of organization studies. London; Thousand Oaks: Sage. 
Rajagopal, Ananya. (2006). Trust and cross-cultural dissimilarities in corporate environment. Team Performance Management, v. 12 No. 7/8, pp. 237-252

Reed, M. (2007). Teorização organizacional: um campo historicamente contestado. In: Clegg, S.R; Rigdon, E. E., Ringle, C. M., And Sarstedt, M. 2010. Structural Modeling of Heterogeneous Data with Partial Least Squares, in Review of Marketing Research, N. K. Malhotra (ed.), Sharpe: Armonk, 255-296.

Reed, M.; Ringle, C. M., Sarstedt, M., and Gudergan, S. P. (2011). Assessing Heterogeneity in Customer Satisfaction Studies: Across Industry Similarities and Within Industry Differences, Advances in International Marketing, (22): 169-194.

Reis, Elizabeth. Estatística multivariada aplicada. 2. ed. SP: Silabo, 1997.

Revista Exame (2017). https://exame.abril.com.br/negocios/as-20-empresascampeas-de-exportacao-no-brasil-em-julho/

Ribeiro, Fernando J. A evolução da balança comercial brasileira no período 1985 2008. In: Revista Brasileira de Comércio Exterior, Rio de Janeiro, ano XXIII, n. 100, jul./set. 2009, p. 12-25.

Richards, Malika et al. (2012). How Can We Better Understand Current and Future Workforce Values in the Global Business Environment? Thunderbird International Business Review, [s.I.], v. 54, n. 5, p.609-623, 29 ago. 2012. Wiley-Blackwell. http://dx.doi.org/10.1002/tie.21488.

Ringle, C. M., Sarstedt, M., and Mooi, E. A. (2010). Response-Based Segmentation Using Finite Mixture Partial Least Squares: Theoretical Foundations and an Application to American Customer Satisfaction Index Data, Annals of Information Systems, v. (8): 19-49.

Ringle, C. M., Sarstedt, M., and Straub, D. W. (2012). A Critical Look at the Use of PLS-SEM in MIS Quarterly. MIS Quarterly, 36(1), iii-xiv.

Rodrigues, C. M. C.; Arruda, G. S.; Ribas, F. T. T.; Catarina, G. M. F. S. (2009). Relações entre valores pessoais e comprometimento organizacional: o caso das empresas juniores de Santa Maria. In: Anais do XXXIII Encontro da Associação Nacional de Pesquisa e Pós-Graduação em Administração.

Rhoades, L. \& EisenbergeR, R. (2002) Perceived organizational support: a review of the literature. Journal of Applied Psychology 87(4), 698-714.

Rhoades, L; eisenberger, R; \& Armeli, S. (2001) Affective commitment to the organization: the contribution of perceived organizational support. Journal of Applied Psychology v. 86, 825- 836.

Rokeach, M. (1972). Beliefs, attitudes, and values: a theory of organization and change. Londres: Jossey-Bass. 
Rokeach, M. (1973). The nature of human values. Nova York: Free Press.

Rokeach, M. (1979). Understanding human values. Nova York: Free Press.

Rokeach, M. (1979a). From individual to institutional values: with special reference to the values of science. In: ROKEACH, M. Understanding human values. Nova York: Free Press.

Rousseau, D. M. (1990). Assessing organizational culture: The case for multiple methods. In: B. Schneider (Org.), Organizational climate and culture (pp.153-192). San Francisco: Jossey-Bass.

Rousseau, D. M. (1992). Assessing organizational culture: the case for multiple methods. In: Schein, E. H. Organizational culture and leadership. 2. ed. San Francisco: Jossey-Bass.

Rousseau, D. M. (1997). Organizational behavior in the new organizational area. Annual Review of Psychology, v. 48, 515-546.

Rousseau, D. M. (1998). Why workers still identify with organizations. Journal of Organizational Behavior, v. 19, 217-233. doi:10.1002/(SICl)10991379(199805)19:3<217: AID-JOB931>3.0.CO;2-N.

Rousseau, P., Durrieu, F., Campoy, E. \& Akremi, A. E. (2002), Méthodes d'équations structurelles: recherche et applications en gestion. Economica: Paris.

Rowe, D. E. O.; Bastos, A. V. B. (2009). Comprometimento organizacional e desempenho acadêmico: um estudo com docentes do ensino superior brasileiro. In: Anais do XXXIII Encontro da Associação Nacional de Pesquisa e Pós-Graduação em Administração.

Rowe, D. E. O.; Bastos, A. V. B.; Pinho, A. P. M. (2010). O comprometimento organizacional e o esforço instrucional de docente do ensino superior: explorando o impacto das diferentes bases do comprometimento. In: Anais do VI Encontro de Estudos Organizacionais da ANPAD.

\section{S}

Santos, N; Farias, M. S. Modelos meta-teóricos para estudos epistemológicos do processo de pesquisa acadêmica. doi: 10.13140/RG.2.1.2247.6006. Conference: 10 Congresso Usp de Controladoria e Contabilidade.

Saffold, G., (1988), Culture traits, strength and organizational performance: moving beyond strong culture, Academy of Management Review, v.13 - pp. 546-558.

Samani, Sanaz Ahmadpoor. (2016). Steps in Research Process (Partial Least Square of Structural Equation Modeling (PLS-SEM)) International Journal of Social Science and Business, v. 1 No. 2.

Sampierl, R. H., Collado, C. F., \& Lucio, P. B. (2006). Metodologia de pesquisa. 3. ed. São Paulo: MacGraw-Hill. 
Sarstedt, M., Henseler, J., and Ringle, C. M. (2011). Multi-Group Analysis in Partial Least Squares (PLS) Path Modeling: Alternative Methods and Empirical Results, Advances in International Marketing, 22: 195-218.

Sarstedt, M., Becker, J.-M., Ringle, C. M., and Schwaiger, M. (2011). Uncovering and Treating Unobserved Heterogeneity with FIMIX-PLS: Which Model Selection Criterion Provides an Appropriate Number of Segments?, Schmalenbach Business Review, 63(1): 34-62.

Sarstedt, M., and Ringle, C. M. (2010). Treating Unobserved Heterogeneity in PLS Path Modelling: A Comparison of FIMIX-PLS with Different Data Analysis Strategies, Journal of Applied Statistics, 37(8): 1299-1318.

Sarstedt, M., Ringle, C. M., and Gudergan, S. P. (2016). Guidelines for Treating Unobserved Heterogeneity in Tourism Research: A Comment on Marques and Reis (2015), Annals of Tourism Research, 57(March): 279-284.

Sarstedt, M., Schwaiger, M., and Ringle, C. M. (2009). Do We Fully Understand the Critical Success Factors of Customer Satisfaction with Industrial Goods? - Extending Festge and Schwaiger's Model to Account for Unobserved Heterogeneity, Journal of Business Market Management, 3(3): 185-206.

Şendoğdu, A. Aslan; Kocabacak, Ayşe; Güven, Şükrü. (2013). The Relationship between Human Resource Management Practices and Organizational Commitment: A Field Study. Procedia - Social and Behavioral Sciences, Vol.99, pp.818-827

Sergiovanni, T. (2004). Novos caminhos para a liderança escolar. Porto: ASA.

Seagrave, S. (1997). Lords of the rim. Reading, Berkshire: Corgi Books.

Schaffer, B.S. \& Riordan, C.M. (2003) A review of cross-cultural methodologies for organizational research: a best-practices approach. Organizational Research Methods, v. 6, n. 2, pp. 169-215.

Schein, E.H. (1984) Corporative culture. Sloan Management Review. Winter.

Schein, E.H. (1985). Organizational Culture and Leadership. San Francisco: JosseyBass.

Schein, E.H. (1992). Organizational Culture and Leadership. San Francisco: JosseyBass. 2nd ed.

Schein, E.H. (1996). The corporate culture survival guide: sense and nonsense about culture change. São Francisco, CA: Josey-Bass.

Schein, E. H. (2004). Organizational culture and leadership. San Francisco: JosseyBass. 3rd ed.

Schein, E.H. (1999). Culture: the missing concept in organizational studies. Administrative Science Quarterly, 44, 229-241. doi. 10.2307/2393715. 
Schein, E. H. (1999) Organizational culture and leadership. San Francisco: JosseyBass. 4rd ed.

Schneider, B. (1985). Organizational Behavior. Annual Review of Psychology. Vol. 36: 573-611 (Volume publication date Feb.1985). doi: 10.1146/annurev.ps.36.02085.003041

Schirrmeister, R.; Nunes, L. A. P.; Limongi-França, A. C; Gonçalves, A. F. (2008). As Relações De Trabalho No Porto De Santos: Um Estudo Sobre A Qualidade de Vida no Trabalho e o comprometimento organizacional no contexto da modernização dos portos. In: Anais de Encontro da Associação Nacional de Pesquisa e Pós-Graduação em Administração, XXXII.

Schwandt, T.A. (2006). Três posturas epistemológicas para a investigação qualitativa. Interpretativismo, hermenêutica e construcionismo social. In: Denzin, N.K.; Lincoln, Y.S. (Orgs.) O planejamento da pesquisa qualitativa: teorias e abordagens. Porto Alegre: Artmed, p.193-218.

Schwartz, Howard and Stanley Davis (1981). Matching Corporate Culture and Business Strategy. Organizational Dynamics, 1. (Summer), 318- 328.

Schwartz, S. H., \& Bilsky, W. (1987). Toward a universal psychological structure of human values. Journal of Personality and Social Psychology, 53(3), 550-562.

Schwartz, S. H. (1990). Toward a theory of the universal content and structure of values: Extensions and cross-cultural replications. Journal of personality and social psychology, 58(5), 878-891.

Schwartz, S.H. (1992). Universals in the content and structure of values: theoretical advances and empirical tests in 20 countries. Advances in Experimental Social Psychology, v.25, p.1-65.

Schwartz, S.H. (1994). Are there universal aspects in the structure and contents of human values? Journal of Social Issues, 50(4), 19-45.

Schwartz, S.H.; Melech, G., Lehmann, A., Burgess, S., \& Harris, M. (2001). Extending the cross-cultural validity of the theory of basic human values with a different method of measurement. Journal of Cross Cultural Psychology, 32(5), 519-542.

Schwartz, S.H. (2001) Existen aspectos universales em la estructura y contenido de los valores humanos? In: ROS, M.; GOUVEIA, V. V. Psicología social de los valores humanos. Madrid: Biblioteca Nueva Universidad, p.53-77.

schwartz, S.H. (2005). Valores Humanos básicos: Seu contexto e estrutura intercultural. In A. Tamayo \& J. B. Porto (Orgs.), Valores e comportamento nas organizações. Petrópolis: Vozes.

Schwartz, S.H. (2006a). Les valeurs de base de la personne: théorie, mesures et applications [Basic personal values: Theory, measurement and application]. Revue Française de Sociologie, 42, 249-288. 
Schwartz, S.H. (2006b). Há aspectos universais na estrutura e no conteúdo dos valores humanos? Em R. Maria, e V. Gouveia. Psicologia Social dos Valores Humanos. São Paulo: Senac.

Schwartz, H.S., Cieciuch, J., Vecchione, M., Davidov, E., Fisher, R., Beierlein, C., Ramos, A., Lonnqvist, J.E., Dirilen-Gumus, O. \& Konty, M. (2012). Refining the Theory of Basic Individual Values. Journal of Personality and Social Psychology, 103(4), 663-688.

Sharma, B. and I. Chew. (1992). The role of compensation policies in Singapore's competitiveness. Asia Pacific Journal of Human Resources 30(2): 16-24.

Shaw, J.B., P.S. Kirkbride, C.D. Fisher and S.F.Y. Tang. (1995). Human resource practices in Hong Kong and Singapore: The impact of political forces and imitation processes. Asia Pacific Journal of Human Resources 33(1): 22-39.

Sheldon, M. E. (1971). Investments and involvements as mechanisms producing commitment to the organization. Administrative Science Quarterly, 16, 143-150.

Simon, J. \& Coltre. (2012). Comprometimento Organizacional Afetivo, Instrumental e Normativo: estudo de caso de uma empresa familiar. Qualit@s Revista Eletrônica, v.13. No 1. ISSN 16774280.

Siqueira, Mirlene Maria Matias (org). (2008). Medidas do comportamento organizacional: ferramentas de diagnóstico e de gestão. Porto Alegre: Artmed.

Silva, J. C. R.; Vieira, E. T.; Rodrigues, J. L. K. (2014). Comprometimento Organizacional: Estudo de Caso em Uma Instituição Financeira em Processo de Integração no Vale do Paraíba Paulista Revista Gestão.Org, v. 12, n. 2, 2014. p 173184 ISSN 1679-1827 http://www.revista.ufpe.br/gestaoorg

Silva, M. A. O. M.; Gomes, L. F. A. M.; Correia, M. F. (2009) Cultura e orientação empreendedora: uma pesquisa comparativa entre empreendedores em incubadoras no Brasil e em Portugal. Revista de Administração Contemporânea, v. 13, n. 1, pp. 57-71.

Silva, Wellington Diolice Felix da. (2003) Introdução à gestão da informação. Campinas, SP: Alínea.

Spranger, E. (1976). Formas de vida. São Paulo: Zahar Editores.

Smeenk, S. G. A.; Eisinga, R. N.; Teelken, J. C.; Doorewaard, J. A. C. M. (2006). The effects of HRM practices and antecedents on organizational commitment among university employees. International Journal of Human Resource Management, Vol.17(12), p.2035(20).

Smeenk, Sanne; Eelken, Christine; Eisinga, Rob. An International Comparison of the Effects of HRM Practices and Organizational Commitment on Quality of Job Performances among European University Employees. Higher Education Policy, 2008, Vol.21 (3), p.323-345. 
Smith, P. B.; Bond, M. H.; kaitçibaii, C. Understanding social psychology across cultures: living and working in a changing world. London: Sage, 2006.

Smith, P.B., Dugan, S., \& Trompenaars, F. (1996). National culture and values of organizational employees: A dimensional analysis across 43 nations. Journal of Cross-Cultural Psychology, 27(2), 231-264.

Smith, P. B. et al. (2011) Individualism-collectivism and business context as predictors of behaviors in cross-national work settings: Incidence and outcomes. International Journal of Intercultural Relations, v. 35, n. 3, pp. 440-451.

Smith, P. B., Torres, C. V.; Leong, C., Budhwar. P., Achoui, M., \& Lebedeva, N. (2012), Are Indigenous Approaches to Achieving influence in Business Organizations distinctive? A Comparative Study of Guanxi, Wasta, Jeitinho, Svyazi and Pulling Stings. The Interantional Journal of Resource Management, 23(2), 333-348.

Smircich, Linda. (1983). Concepts of culture and organizational analysis. In.: Administrative Science Quarterly. Vol. 28, n. 3, Organizational Culture, Sep. 1983, p. 339-358.

Smircich, L., e CALAS, M. B. (1987) Organizational culture: A critical assessment. In F. M. Jablin, L. Putnam, K. H. Roberts \& L. W. Porter (Eds.), Handbook of organizational communication: An interdisciplinary perspective. Newbury Park, Calif.: Sage Publications.

Sørensen, J. B. (2002). The strength of corporate culture and the reliability of firm performance. Administrative Science Quarterly, v. 47(1), 70-91. doi. 10.2307/3094891.

Souza, E. C. L.; Castro-Lucas, C. \& Torres, C. V. (2011). Práticas sociais, cultura e inovação: três conceitos associados. Faces. v. 2, n. 2. p. 210-230.

Souza, E. C. L., CASTRO-LUCAS, C., FENILI, R. R., \& CHAVES FARIAS, R. M. C. (2013). Internacionalização de organizações: propostas de análise à luz da cultura. Faces Journal: Revista de Administração, v.12(1), 139-151.

Sousa, J. M. (2013). Felicidade no trabalho: impacto de valores laborais e organizacionais. Dissertação de Mestrado. Instituto de Psicologia, Universidade de Brasília, Brasília.

Sousa, J. S., \& Honório, L. C. Comprometimento Organizacional: Avaliando Professores Universitários em Regimes Diferenciados de Carga Horária de Trabalho. In: XXXV ENANPAD, Rio de Janeiro, 2011. Anais do XXXV ENANPAD Encontro Nacional dos Programas de Pós-graduação em Administração. Rio de Janeiro: 2011. CD-ROM.

Spencer, Stuart. (2006). Governance lexicon: a diretor's guide to corporate governance around the world. 2. ed. Chicago, EUA: Spencer Stuart.

Steinberg, H. (2003). A dimensão humana da governança corporativa: pessoas criam as melhores e as piores práticas. São Paulo: Gente. 
Steinberg, H. et al. (2008). Governança corporativa: conselhos que perpetuam empresas. São Paulo: Gente, 2008.

Sun Young Sung; Jin Nam Choi. (2014). Multiple dimensions of human resource development and organizational performance. Journal of Organizational Behavior, v. 35 iss:6 pg:851-870.

\section{T}

Tabachnick, B.G. \& Fidel, L. S. (1989). Using multivariate statistics. New York: Harper \& Row.

Takeuchl, Norihiko; Takeuchi, Tomokazu. (2013). Committed to the organization or the job? Effects of perceived HRM practices on employees' behavioral outcomes in the Japanese healthcare industry. International Journal of Human Resource Management, Vol.24(11), p.2089(18).

Tavares, M. C. (2000). Gestão Estratégica. São Paulo: Atlas.

Tamayo, A. (1988). Influência do sexo e da idade sobre o sistema de valores. Arquivos Brasileiros de Psicologia, v. 38 (3), 91-104.

Tamayo, A. \& Schwartz, S.H. (1993). Estrutura motivacional dos valores humanos. Psicologia: teoria e pesquisa, v. 9, 329-348.

Tamayo, A. (1994). Hierarquia de valores transculturais e brasileiros. Psicologia: teoria e pesquisa, v. 10 (2), 269-285.

Tamayo, A. (1996). Valores organizacionais. In Tamayo, A., Borges-Andrade, J. \& Codo, W. (Eds.) Trabalho, organizações e cultura, 175-193. São Paulo: Cooperativa de Autores Associados.

Tamayo, A. (1997). Valores e clima organizacional. In Paz, M.G. \& Tamayo, A. Escola, saúde e trabalho. Brasília: UnB.

Tamayo, A. et al. (1998). Diferenças nas prioridades axiológicas de músicos e advogados. In: Psicologia: reflexão e crítica, 11(2), 281-293.

Tamayo, A. et al. (2000). Inventário de valores organizacionais. Estudos de Psicologia, v. 5 (2), 289-315.

Tamayo, A.; Borges, L. (2001). Valores del trabajo y valores de las organizaciones. In Ros \& Gouveia. Psicologia Social de los Valores Humanos. Madrid: Biblioteca Nueva.

Tamayo, A.; Mendonça, H. (2001). Prioridades axiológicas e escolhas acadêmicoprofissionais: dados empíricos e perspectivas teóricas. In: Estudos,28(4), 625-638.

Tamayo, A. et al. (2001). Prioridades axiológicas e uso de preservativo. Psicologia: reflexão e crítica, v. 14, 151-159.

Tamayo, A. et al. (2001). Prioridades axiológicas e comprometimento organizacional. Psicologia - teoria e pesquisa. v. 17 n. 01 pp. 027-035. 
Tamayo, A. et al. (2005). Valores organizacionais e comprometimento afetivo. Revista de Administração Mackenzie, vol. 6, núm. 3, pp. 192-213.

Tamayo, A. (2007) Valores Organizacionais. In: M. M. M. Siqueira (Org.). Medidas de comportamento organizacional (pp.309-340). Porto Alegre: Artmed.

Tamayo, A., \& Gondim, M. G. C. (1996). Escala de valores organizacionais. Revista de Administração, 31(2), 62-72.

Tamayo, A. (2008). Valores Organizacionais. In: Siqueira, M. M. M. (Org.). Medida do comportamento organizacional: Ferramentas de diagnóstico e de gestão. Porto Alegre: Artmed, p. 309-340.

Telles, R. (2001). A efetividade da matriz de amarração metodológica de Mazzon nas pesquisas em Administração. Revista de Administração, V. 36, n. 4, p. 64-72.

Torres, M. G. \& Neiva, E. R. (2008) Construção e validação da escala de configurações de poder organizacional. In: III Congresso Brasileiro de Psicologia Organizacional e do Trabalho, 2008, Florianópolis. Anais do III Congresso Brasileiro de Psicologia Organizacional e do Trabalho, v. 1.

Torres, C. V.; Allen, M. W. (2009) Valores humanos e escolha do consumidor na Austrália e Brasil. Psicologia: teoria e pesquisa, v. 25, n. 4, p. 489-497.

Torres, C. V.; Pérez-Nebra, A. R. (2007) The influence of human values on holiday destination choice in Australia and Brazil. Brazilian Administration Review, v. 4, n. 3, pp. 63-76.

Torres, Leonor Lima (2009) - Cultura Organizacional no Contexto Escolar: o regresso à escola como desafio na reconstrução de um modelo teórico». In: Ensaio: aval. pol. públ. Educ., Rio de Janeiro, v.13, n.49, p. 435-451. Em http://www.scielo.br/pdf/ensaio/v13n49/29240.pdf

Teixeira, M. L. M.; Domenico, S. M. R. (2008) Gestores brasileiros e portugueses: estrutura única de valores de sentido de vida? Comportamento Organizacional e Gestão, v. 14, n. 1, p. 45-64.

Tremblay, M.; Cloutier, J.; Simard, G.; Chenevert, D. (2010). The role of HRM practices, procedural justice, organizational support and trust in organizational commitment and in-role and extra-role performance, International Journal of Human Resource Management, v.21(3), p.405(29).

Triandis, H. C. (1993). Collectivism and individualism as cultural syndromes. CrossCultural Research, v.27(3-4), 155-180.

Triandis, H. C. (1994). Culture and social behavior. New York, NY: McGraw-Hill.

Triandis, H. C. (1995). Individualism and collectivism. Boulder, CO: Westview.

Triandis, H. C. (1996). The psychological measurement of cultural syndromes. American Psychologist, 51(4), 407-415. doi:10.1037/0003-066X.51.4.407 
Triandis, H. C. (2001). Individualism-collectivism and personality, Journal of Personality, V. 69(6), 907-924.

Triandis, H. C., \& Gelfand, M. J. (1998). Converging measurement of horizontal and vertical individualism and collectivism. Journal of Personality and Social Psychology, 74(1), 118-128.

Trice, Harrison M. \& Beyer, Janice M. Beyer. (1994). The Cultures of Work Organizations. The Academy of Management, v. 19, No., pp. 836-839. http://www.jstor.org/stable/258750

Trice, Harrison M. \& Beyer, Janice M. Beyer. (1994). The Cultures of Work Organizations. The Academy of Management, v. 19, No., pp. 836-839. http://www.jstor.org/stable/258750

Trochim, W. M. The Research Methods Knowledge Base. (2003). 2nd Edition. Internet WWW page, at URL: <http://trochim.human.cornell.edu/kb/index.htm>

Trompenaars, Fons. (1996). Resolving international conflict: culture and business strategy. London Business School, v. 7, n. 3, p. 51-88.

Trompenaars, Fons. (1994). Nas ondas da cultura: como entender a diversidade cultural nos negócios. São Paulo: Educator.

Trompenaars, F.; Woolliams, P. (2003). A new framework for managing change across cultures, Journal of Change Management, v. 3, n. 4, p. 361-375.

Tuomi, K., Vanhala, S., Nykyri, E., \& Janhonen, M. (2004). Organizational practices, work demands and the well-being of employees: A follow-up study in the metal industry and retail trade, Occupational Medicine, v. 54, 115-121.

Turner B. (1996). The rise of organizational symbolism. In: The theory and philosophy of organizations - J.Hassard and D. Pym (Eds) - pp. 83-96 -London: Routledge.

Tuţu, A., \& Constantin, T. (2012). Understanding job performance through persistence and job competency, Procedia - Social and Behavioral Sciences, 33, 612-616.doi. 10.1016/j.sbspro.2012.01.194.

$\mathbf{U}$

Urbach, N. \& Ahlemann, F. (2010). Structural Equation Modeling in information systems research using partial least square. Journal of Information Technology Theory and Application: Vol. 11, Issue 2; pp. 5-40.

Uysal, G. (2014). Convergence or divergence between European HRM. Journal of Business and Economics, v. 5(10), 1923-1928. doi: 10.17265/23287144/2016.02.004 


\section{V}

Vale, J. C. F; Lima T. C. B.; Queiroz, G. C. (2011). O comprometimento organizacional entre grupos geracionais em uma Instituição Federal de Ensino Superior. In: Anais do XXXV Encontro da Associação Nacional de Pesquisa e Pós-Graduação em Administração,

Van Breugel, G; Van Olffen, W \& Olie R. (2005). Temporary liasons: The commitment of 'temps' towards their agencies. Journal of Management Studies 42(3): 539-566.

Vasconcelos, E. \& Hemsley, James R. (1986). Estrutura das organizações. SP: Pioneira.

Vasconcelos, E \& Guedes, L. (2007) E-surveys: vantagens e limitações dos questionários eletrônicos via Internet no contexto da pesquisa científica. In: X SemeAd - Seminários em Administração FEA-USP.

Veitch, Rwd; Cooper-Thomas, HD. (2009). Tit for tat? Predictors of temporary agency workers' commitments Asia Pacific Journal of Human Resources, Dec, Vol.47(3), pp.318-337.

Ventura, Magda Maria. (2007). O Estudo de Caso como Modalidade de Pesquisa. Rev SOCERJ, V. 20(5):383-386.

Verbeke, W. (1990). A revision of Hofstede organizational practices scale. Journal of Organizational Behavior, v. 21, n. 5, p. 587-602, 2000 . http://dx.doi. org/10.1002/1099-1379(200008)21:53.0.CO;2-5

Verbeke, W. (2000). A revision of Hofstede et al. (1990) organizational practices scale. Journal of Organizational Behavior, 21(5), 587-602. doi. 10.1002/10991379(200008)21:5<587: AID-JOB22>3.0.CO;2-5.

Vergara, S. C. (2005). Métodos de pesquisa em administração. São Paulo: Atlas.

Vergara, S.C.; Caldas, M. (2005). Paradigma interpretacionista: a busca da superação do objetivismo funcionalista nos anos 1980 e 1990, RAE, v.45, n.4, p.66-72.

Verdu, Fabiane Cortez e Bulgacov, Sergio. (2012). REBRAE. Revista Brasileira de Estratégia, Curitiba, v. 5, n. 2, pp. 179-190, maio. /ago.

Vesentini, J. W. (2005). Sociedade e Espaço: Geografia Geral e do Brasil. 44. ed. São Paulo: Ática.

W

Wadsworth, L.L.; OWENS, B.P. (2007) The effects of social support on work-family enhancement and work-family conflict in the public sector. Public Administration Review 67, 75-86.

Wan, D.T.W. (1996). Developing human resources and labor flexibility. In Singapore International Employment Relations Review, V2(1): 77-90. 
Washington, D. C. GEFEN, D., STRAUB, D., \& BOUDREAU, M.C. (2000). Structural Equation Modeling and Regression: Guidelines for Research Practice. Communications of the Association for Information Systems, v. 4(1), 7.

Wasti, S. Arzu et al. (2016). Location, location, location: contextualizing workplace commitment. Journal of Organizational Behavior, v. 37, 613-632.

Wayne, S.; SHORE L.M. \& LIDEN, R.C. (1997). Perceived organizational support and leader-member exchange: a social exchange perspective. Academy of Management Journal, v. 40, 82-111.

Wayne, S.J.; Coyle-Shapiro J.A.; Eisenberger R.; Liden R.C., Rousseau D.M. \& Shore L.M. (2009) Social influences. In Commitment in Organizations: Accumulated Wisdom and New Directions (Klein H.J., Becker T.E. \& Meyer J.P. eds.), Taylor \& Francis, New York, pp. 253-284.

Wee, C.H., K.S. Lee and Bambang. (1996). Sun Tzu: War and management. Singapore: Addison-Wesley Publishing Company.

Weihui, Fu; Satish, P. (2014). Deshpande. The Impact of Caring Climate, Job Satisfaction, and Organizational Commitment on Job Performance of Employees in a China's Insurance Company. Journal of Business Ethics, v. 124 iss:2 pg:339 -349

Wetzels, M.; Odekerken-Schroder, G.; and Oppen, Van C. (2009). Using PLS path Modeling for Assessing Hierarchical Construct Models: Guidelines and Empirical Illustration. MIS Quarterly, 33(1), 177-195.

Westwood, R.J., \& Posner, B.Z. (1997). Managerial values across cultures: Australia, Hong Kong, and the United States. Asia Pacific Journal of Management, 14, 31-66.

Whittington, R. (1996) Strategy as practice. Long Range Planning, v. 29, n. 5, pp. 731735.

Wiener, Y.; Gechman, A. S. (1977). Commitment: A behavioral approach to job involvement. Journal of Vocational Behavior. n. 10, p. 47-52.

Wiener, Y. Commitment in organizations: a normative view. Academy of Management Review, n.7, p. 418-428, 1982.

Winter, R. (2009) Academic manager or managed academic? Academic identity schisms in higher education. Journal of Higher Education, Policy and Management, v.31(2), 121-131.

$\begin{array}{lllll}\text { World } & \text { Values } & \text { Research } & - & \text { WVR, }\end{array}$

http://www.worldvaluessurvey.org/images/Culture_Map_2017_conclusive.png

$\mathbf{Y}$

Yamaguchi, Ikushi. (2012). A Japan-US cross-cultural study of relationships among team autonomy, organizational social capital, job satisfaction, and organizational commitment. International Journal of Intercultural Relations, v. 37 (2013) 58-71 
Zaccarelli, S. B. (2000). Estratégias e Sucesso nas Empresas. São Paulo: Saraiva, 2000.

Zatzick, CD; Deery, SJ; Iverson, RD. (2015). Understanding the determinants of who gets laid off: does affective organizational commitment matter? Human Resource Management, v.54(6), pp.877-891. 


\section{Relações comerciais: Exportações, Importações}

Relações comerciais brasileiras nos países dos SECOMs pesquisados

JAN-JUL 2017

cont.

\begin{tabular}{|c|c|c|c|c|c|c|}
\hline \multirow[b]{2}{*}{ País } & \multicolumn{3}{|c|}{ Exportação } & \multicolumn{3}{|c|}{ Importação } \\
\hline & Ranking & $\begin{array}{l}\text { Volume } \\
\text { (US\$MI) e } \\
\text { Part. nas } \\
\text { export. }\end{array}$ & Principais produtos & Ranking & $\begin{array}{l}\text { Volume } \\
\text { (US\$MI) e } \\
\text { Part. nas } \\
\text { Import. }\end{array}$ & Principais produtos \\
\hline China & $1^{\circ}$ & $\begin{array}{c}30,787,82 \\
24,3 \%\end{array}$ & $\begin{array}{l}\text { Soja; Minérios de Ferro } \\
\text { Óleos Brutos de } \\
\text { Petróleo, Celulose } \\
\text { Aviões, couros e peles } \\
\text { depilados }\end{array}$ & $2^{\circ}$ & $\begin{array}{c}15.505,84 \\
17,3 \%\end{array}$ & $\begin{array}{l}\text { Circuitos impressos } \\
\text { p/apars. de telefonia } \\
\text { Partes de aparelhos } \\
\text { Transmissores ou } \\
\text { Receptores; Hulhas, } \\
\text { peixes congelados, } \\
\text { tripas de animais, alho }\end{array}$ \\
\hline EUA & $2^{\circ}$ & $\begin{array}{c}15.245,22 \\
12,1 \%\end{array}$ & $\begin{array}{l}\text { Aviões, óleos brutos } \\
\text { de petróleo } \\
\text { Café cru em grãos }\end{array}$ & $1^{\circ}$ & $\begin{array}{c}14.593,83 \\
17,4 \%\end{array}$ & $\begin{array}{c}\text { Óleos Combustíveis } \\
\text { (Diesel, Fuel-Oil, etc.); } \\
\text { etanol; Medicamentos } \\
\text { medicina humana e } \\
\text { veterinária }\end{array}$ \\
\hline Argentina & $3^{\circ}$ & $\begin{array}{c}9.814,22 \\
7,76 \%\end{array}$ & $\begin{array}{l}\text { Automóveis de } \\
\text { Passageiros } \\
\text { Minérios de Ferro } \\
\text { Partes e peças para } \\
\text { Veículos e Tratores } \\
\text { Carne de Suíno; Soja }\end{array}$ & $3^{\circ}$ & $\begin{array}{c}5.312,07 \\
6,33 \%\end{array}$ & $\begin{array}{l}\text { Veículos de Carga } \\
\text { Automóveis de } \\
\text { Passageiros } \\
\text { Trigo, alho; cevada }\end{array}$ \\
\hline $\begin{array}{l}\text { Países Baixos } \\
\text { (Holanda) }\end{array}$ & $4^{\circ}$ & $\begin{array}{c}5.465,43 \\
4,32 \%\end{array}$ & $\begin{array}{l}\text { Minérios de Ferro } \\
\text { Tubos Flexíveis, de } \\
\text { Ferro ou Aço } \\
\text { Óleo de soja } \\
\text { Suco de laranja } \\
\text { Soja, aviões }\end{array}$ & $15^{\circ}$ & $\begin{array}{c}1.290,99 \\
1,54 \%\end{array}$ & $\begin{array}{c}\text { Gasolina } \\
\text { Óleos Combustíveis } \\
\text { (Diesel, fuel-oil, etc.) } \\
\text { Medicamentos } \\
\text { medicina humana e } \\
\text { veterinária } \\
\text { Cebola }\end{array}$ \\
\hline Chile & $5^{\circ}$ & $\begin{array}{c}2.952,62 \\
2,33 \%\end{array}$ & $\begin{array}{l}\text { Automóveis; Veículos } \\
\text { de Carga; chassis com } \\
\text { motor e carroçarias p/ } \\
\text { automóveis; Óleos } \\
\text { Brutos de Petróleo } \\
\text { Carne de bovino; } \\
\text { Óleo de Soja }\end{array}$ & $9^{\circ}$ & $\begin{array}{c}1.983,77 \\
2,36 \%\end{array}$ & $\begin{array}{l}\text { Minérios de Cobre; } \\
\text { Salmões-do-pacífico; } \\
\text { Cloreto de Potássio } \\
\text { Azeite de Oliva }\end{array}$ \\
\hline Alemanha & $6^{\circ}$ & $\begin{array}{c}2.708,19 \\
2,14 \%\end{array}$ & $\begin{array}{l}\text { Café Cru } \\
\text { Óleo de Soja }\end{array}$ & $4^{\circ}$ & $\begin{array}{c}5.107,1 \\
6,08 \%\end{array}$ & $\begin{array}{c}\text { Medicamentos } \\
\text { medicina humana e } \\
\text { veterinária; partes e } \\
\text { peças para veículos } \\
\text { automóveis e Tratores }\end{array}$ \\
\hline Índia & $7^{\circ}$ & $\begin{array}{c}2.700,64 \\
2,14 \%\end{array}$ & $\begin{array}{l}\text { Óleos Brutos de } \\
\text { Petróleo; minérios de } \\
\text { cobre e de Ferro; } \\
\text { açúcar de cana, em } \\
\text { bruto; Óleo de Soja }\end{array}$ & $12^{\circ}$ & $\begin{array}{c}1.516,57 \\
1,81 \%\end{array}$ & $\begin{array}{l}\text { Fios de Fibras Têxteis, } \\
\text { Compostos } \\
\text { Heterocíclicos, } \\
\text { Medicamentos para } \\
\text { Medicina Humana e } \\
\text { Veterinária }\end{array}$ \\
\hline
\end{tabular}




\begin{tabular}{|c|c|c|c|c|c|c|}
\hline Japão & $8^{\circ}$ & $\begin{array}{c}2.663,99 \\
2,11 \%\end{array}$ & $\begin{array}{l}\text { Minérios de Ferro } \\
\text { Carne de Frango } \\
\text { Café Cru em Grão } \\
\text { Aviões; suco de } \\
\text { Laranja Congelado; } \\
\text { Alumínio, celulose }\end{array}$ & $8^{\circ}$ & $\begin{array}{c}2.109,89 \\
2,41 \%\end{array}$ & $\begin{array}{l}\text { Partes e peças } \mathrm{p} / \\
\text { automóveis e Tratores } \\
\text { Demais Produtos } \\
\text { Manufaturados } \\
\text { Automóveis de } \\
\text { Passageiro }\end{array}$ \\
\hline México & $9^{\circ}$ & $\begin{array}{c}2.590,52 \\
2,05 \%\end{array}$ & $\begin{array}{l}\text { Automóveis de } \\
\text { Passageiros } \\
\text { Motores p/ Veículos e } \\
\text { de Carga; Carne de } \\
\text { Frango; soja; minérios } \\
\text { de Ferro }\end{array}$ & $6^{\circ}$ & $\begin{array}{c}2.207,04 \\
2,63 \%\end{array}$ & $\begin{array}{l}\text { Partes e peças p/ } \\
\text { veículos Automóveis e } \\
\text { Tratores automóveis; } \\
\text { Ácidos carboxílicos }\end{array}$ \\
\hline Espanha & $10^{\circ}$ & $\begin{array}{c}2.257,59 \\
1,79 \%\end{array}$ & $\begin{array}{c}\text { Soja } \\
\text { Óleos brutos de } \\
\text { petróleo }\end{array}$ & $14^{\circ}$ & $\begin{array}{c}1.475,56 \\
1,76 \%\end{array}$ & $\begin{array}{c}\text { Naftas } \\
\text { Medicamentos } \\
\text { medicina humana e } \\
\text { veterinária }\end{array}$ \\
\hline Cingapura & $11^{\circ}$ & $\begin{array}{c}1.983,63 \\
1,57 \%\end{array}$ & 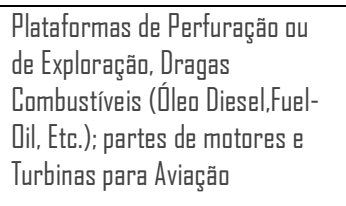 & $42^{\circ}$ & $\begin{array}{l}290,36 \\
0,35 \%\end{array}$ & $\begin{array}{l}\text { Inseticidas, Formicidas, } \\
\text { Herbicidas; Circuitas Integrados } \\
\text { e Micracanjuntas Eletrânicas } \\
\text { Medicamentas para Medicina } \\
\text { Humana e Veterinária }\end{array}$ \\
\hline Itália & $12^{\circ}$ & $\begin{array}{c}1.951,96 \\
1,54 \%\end{array}$ & $\begin{array}{l}\text { Café Cru em Grão } \\
\text { Minérios de Ferro } \\
\text { Soja; Celulose; Couros } \\
\text { e peles }\end{array}$ & $7^{\circ}$ & $\begin{array}{c}2.136,17 \\
2,54 \%\end{array}$ & $\begin{array}{l}\text { Medicamentos para } \\
\text { Medicina Humana e } \\
\text { Veterinária; Produtos } \\
\text { manufaturados; partes } \\
\text { e peças p/ Automóveis } \\
\text { e Tratores }\end{array}$ \\
\hline Bélgica & $13^{\circ}$ & $\begin{array}{c}1.701,61 \\
1,35 \%\end{array}$ & $\begin{array}{c}\text { Suco de Laranja } \\
\text { Café cru }\end{array}$ & $22^{\circ}$ & $\begin{array}{l}901,05 \\
1,07 \%\end{array}$ & $\begin{array}{c}\text { Medicamentos } \\
\text { medicina humana e } \\
\text { veterinária; Óleos } \\
\text { Combustíveis (Diesel, } \\
\text { Fuel-Oil, etc.); Gasolina }\end{array}$ \\
\hline Rússia & $14^{\circ}$ & $\begin{array}{c}1.646,14 \\
1,3 \%\end{array}$ & $\begin{array}{l}\text { Carne de Suíno; de } \\
\text { Bovino; soja Tratores } \\
\text { Café Solúvel } \\
\text { Aviões }\end{array}$ & $11^{\circ}$ & $\begin{array}{c}1.656,27 \\
1,98 \%\end{array}$ & $\begin{array}{l}\text { Adubos ou fertilizantes. } \\
\text { Naftas; Nitrato de } \\
\text { Amônio, Cloreto de } \\
\text { Potássio; Alumínio; } \\
\text { borracha Sintética e } \\
\text { Borracha Artificial } \\
\end{array}$ \\
\hline Irã & $15^{\circ}$ & $\begin{array}{c}1.611,68 \\
1,27 \%\end{array}$ & $\begin{array}{l}\text { Milha em Gräos } \\
\text { Soja Mesma Triturada } \\
\text { Carne de Bovino } \\
\text { Açúcar de cana em bruto } \\
\end{array}$ & $71^{\circ}$ & $\begin{array}{c}38,19 \\
0,045 \%\end{array}$ & $\begin{array}{l}\text { Ureia Mesmo em Soluçãa Aquosa } \\
\text { Produtos Semimanufaturados de } \\
\text { Ferro du Aços; uvas frescas ou } \\
\text { secas. }\end{array}$ \\
\hline Coreia do Sul & $16^{\circ}$ & $\begin{array}{c}1.594,39 \\
1,26 \%\end{array}$ & $\begin{array}{l}\text { Óleo de Soja } \\
\text { Minérios de Ferro; } \\
\text { Soja; Celulose; Couros } \\
\text { e peles; etanol }\end{array}$ & $5^{\circ}$ & $\begin{array}{c}3.054,48 \\
3,64 \%\end{array}$ & $\begin{array}{l}\text { Circuitos Integrados e } \\
\text { eletrônicos; partes e } \\
\text { peças p/ automóveis e } \\
\text { tratores; circuitos } \\
\text { Impressos e Outras } \\
\text { partes p/ Apars.de } \\
\text { Telefonia; enxofre }\end{array}$ \\
\hline $\begin{array}{l}\text { Arábia } \\
\text { Saudita }\end{array}$ & $17^{\circ}$ & $\begin{array}{c}1.543,68 \\
1,22 \%\end{array}$ & $\begin{array}{l}\text { Carne de Frango } \\
\text { Carne de Bavina; Saja; Açúcar } \\
\text { refinado e bruto }\end{array}$ & $19^{\circ}$ & $\begin{array}{c}1.108,71 \\
1,32 \%\end{array}$ & $\begin{array}{l}\text { Óleos brutos de } \\
\text { petróleo }\end{array}$ \\
\hline Canadá & $18^{\circ}$ & $\begin{array}{c}1.526,18 \\
1,21 \%\end{array}$ & $\begin{array}{l}\text { Óxidos e Hidróxidos de } \\
\text { Alumínio; maquinas e } \\
\text { aparelhos p/ } \\
\text { terraplanagem, } \\
\text { Antibióticos; açúcar de } \\
\text { Cana, em Bruto } \\
\text { Ouro de uso não } \\
\text { monetário } \\
\end{array}$ & $21^{\circ}$ & $\begin{array}{l}946,41 \\
1,13 \%\end{array}$ & $\begin{array}{c}\text { Medicamentos } \\
\text { medicina humana e } \\
\text { veterinária; Óleos } \\
\text { Combustíveis } \\
\text { (Diesel,Fuel-Oil,etc.) } \\
\text { Cloreto de Potássio } \\
\text { Alumínio em Bruto }\end{array}$ \\
\hline
\end{tabular}




\begin{tabular}{|c|c|c|c|c|c|c|}
\hline Reino Unido & $19^{\circ}$ & $\begin{array}{c}1.501,08 \\
1,19 \%\end{array}$ & $\begin{array}{l}\text { Carne de frango; carne } \\
\text { bovina; Ouru Nãa Monetárí } \\
\text { Celulase; Estanho em Bruta; café } \\
\text { cru em grãus }\end{array}$ & $17^{\circ}$ & $\begin{array}{c}1.155,21 \\
1,38\end{array}$ & $\begin{array}{l}\text { Medicamentos para Medicina } \\
\text { Humana e Veterinária } \\
\text { Demais Pradutos Manufaturados } \\
\text { Gasolina; uísques }\end{array}$ \\
\hline Paraguai & $20^{\circ}$ & $\begin{array}{c}1.216,67 \\
1,13 \%\end{array}$ & $\begin{array}{l}\text { Adubos } \\
\text { Máq. agrícolas }\end{array}$ & $29^{\circ}$ & $\begin{array}{l}597,24 \\
0,84 \%\end{array}$ & Arroz, Trigo e soja \\
\hline Malásia & $23^{\circ}$ & $\begin{array}{c}1.399,54 \\
1,11 \%\end{array}$ & $\begin{array}{l}\text { Minérios de Ferro } \\
\text { Milho em Grãos } \\
\text { Óleos Brutos de } \\
\text { Petróleo, Açúcar de } \\
\text { cana bruto }\end{array}$ & $26^{\circ}$ & $\begin{array}{c}811,68 \\
0,97 \%\end{array}$ & $\begin{array}{l}\text { Circuitos Integrados e } \\
\text { Microconjuntos } \\
\text { Eletrônicos } \\
\text { Luvas e Outs.Acess.de } \\
\text { Borracha Vulcan. } \\
\text { Partes e Acessórios de } \\
\text { Máqs.Automát.P/Proce } \\
\text { ss.de Dados } \\
\end{array}$ \\
\hline Colômbia & $24^{\circ}$ & $\begin{array}{c}1.351,14 \\
1,07 \%\end{array}$ & $\begin{array}{c}\text { Automóveis de } \\
\text { Passageiros } \\
\text { Sementes Forrageiras }\end{array}$ & $25^{\circ}$ & $\begin{array}{l}812,7 \% \\
0,97 \%\end{array}$ & $\begin{array}{c}\text { Hulhas } \\
\text { Policloreto de Vinila } \\
\text { (Pvc) }\end{array}$ \\
\hline França & $26^{\circ}$ & $\begin{array}{c}1.300,94 \\
1,03 \%\end{array}$ & $\begin{array}{l}\text { Óleo de Soja } \\
\text { Minérios de ferro; } \\
\text { soja; calçados; partes } \\
\text { e peças de Aviões, } \\
\text { helicópt. e outros veíc. } \\
\text { Aéreos e para } \\
\text { automóveis e Tratores; } \\
\text { café em grãos }\end{array}$ & $10^{\circ}$ & $\begin{array}{c}1.971,27 \\
2,35 \%\end{array}$ & $\begin{array}{l}\text { Medicamentos para } \\
\text { Medicina Humana e } \\
\text { Veterinária; produtos } \\
\text { Manufaturados; } \\
\text { Compostos } \\
\text { Heterocíclicos; } \\
\text { borracha sintética, } \\
\text { maças frescas; vinhos } \\
\text { de uva }\end{array}$ \\
\hline $\begin{array}{l}\text { Emirados } \\
\text { Árabes } \\
\text { Unidos }\end{array}$ & $27^{\circ}$ & $\begin{array}{c}1.205,55 \\
0,95 \%\end{array}$ & $\begin{array}{l}\text { Saja Mesma Triturada } \\
\text { Farela e Resíduas da Extraçãa de } \\
\text { Ólea de Saja } \\
\text { Algadãa em Bruta }\end{array}$ & $23^{\circ}$ & $\begin{array}{c}860,01 \\
1,02 \%\end{array}$ & $\begin{array}{l}\text { Partes e peças para } \\
\text { automóveis e Tratores } \\
\text { Máquinas Automáticas } \\
\text { P/Process.de Dadas e Suas } \\
\text { Unidades }\end{array}$ \\
\hline Peru & $28^{\circ}$ & $\begin{array}{c}1.258,11 \\
0,99 \%\end{array}$ & $\begin{array}{l}\text { Polímeros de Etileno, } \\
\text { Propileno e Estireno; } \\
\text { Carne de Frango; } \\
\text { Automóveis, veículos de } \\
\text { carga; óleos brutos de } \\
\text { Petróleo; Arroz em } \\
\text { Grãos }\end{array}$ & $27^{\circ}$ & $\begin{array}{c}787,98 \\
0,94 \%\end{array}$ & $\begin{array}{l}\text { Minérios de Cobre, de } \\
\text { Zinco, Fosfatos de } \\
\text { Cálcio; Naftas }\end{array}$ \\
\hline Tailândia & $29^{\circ}$ & $\begin{array}{c}1.063,37 \\
0,99 \%\end{array}$ & $\begin{array}{l}\text { Soja; Farelos e } \\
\text { resíduos da soja }\end{array}$ & $23^{\circ}$ & $\begin{array}{l}729,97 \\
1,02 \%\end{array}$ & $\begin{array}{c}\text { Partes e peças para } \\
\text { automóveis e Tratores } \\
\text { Fios de fibras Têxteis }\end{array}$ \\
\hline Turquia & $30^{\circ}$ & $\begin{array}{l}878,89 \\
0,82 \%\end{array}$ & Minérios de ferro & $45^{\circ}$ & $\begin{array}{l}229,73 \\
0,32 \%\end{array}$ & $\begin{array}{l}\text { Óleos combustíveis } \\
\text { Fios de fibras Têxteis }\end{array}$ \\
\hline África do Sul & $31^{\circ}$ & $\begin{array}{l}769,1 \\
0,71 \%\end{array}$ & $\begin{array}{l}\text { Açúcar Refinado } \\
\text { Carne de frango } \\
\text { Tratores, Veículos de } \\
\text { carga; Zinco }\end{array}$ & $48^{\circ}$ & $\begin{array}{l}219,36 \\
0,31 \%\end{array}$ & $\begin{array}{c}\text { Hulhas } \\
\text { Inseticidas, Formicidas, } \\
\text { Herbicidas }\end{array}$ \\
\hline $\begin{array}{c}\text { Taiwan } \\
\text { (Formosa) }\end{array}$ & $32^{\circ}$ & $\begin{array}{l}925,32 \\
0,73 \%\end{array}$ & $\begin{array}{l}\text { Soja; óleos brutos de } \\
\text { petróleo; Minérios de } \\
\text { Ferro; celulose, milho } \\
\text { em grãos; café cru }\end{array}$ & $18^{\circ}$ & $\begin{array}{c}1.113,81 \\
1,33 \%\end{array}$ & $\begin{array}{l}\text { Circuitos Integrados e } \\
\text { eletrônicos; partes de } \\
\text { Aparelhos } \\
\text { transmissores ou } \\
\text { receptores }\end{array}$ \\
\hline
\end{tabular}




\begin{tabular}{|c|c|c|c|c|c|c|}
\hline Bolívia & $34^{\circ}$ & $\begin{array}{r}836,17 \\
0,66 \%\end{array}$ & $\begin{array}{l}\text { Produtos } \\
\text { Manufaturados } \\
\text { Fio-Máquina e Barras } \\
\text { de Ferro ou Aços; } \\
\text { Calçados } \\
\text { Arroz em Grãos, } \\
\text { Carne de Frango } \\
\end{array}$ & $31^{\circ}$ & $\begin{array}{l}633,98 \\
0,76 \%\end{array}$ & $\begin{array}{l}\text { Gás natural } \\
\text { Boratos naturais e seus } \\
\text { concentrados }\end{array}$ \\
\hline Argélia & $35^{\circ}$ & $\begin{array}{l}684,7 \\
0,64 \%\end{array}$ & $\begin{array}{l}\text { Açúcar de cana } \\
\text { bruto, Milho } \\
\text { Açúcar refinado }\end{array}$ & $12^{\circ}$ & $\begin{array}{c}1.307,71 \\
1,83 \%\end{array}$ & $\begin{array}{l}\text { Naftas } \\
\text { Óleos brutos de } \\
\text { petróleo }\end{array}$ \\
\hline Indonésia & $36^{\circ}$ & $\begin{array}{r}824,33 \\
0,65 \%\end{array}$ & $\begin{array}{l}\text { Óleo de Soja } \\
\text { Algodão em Bruto } \\
\text { Fumo em Folhas } \\
\text { Café solúvel } \\
\text { Semimanufaturados de } \\
\text { Ferro ou Aços Açúcar } \\
\text { de Cana }\end{array}$ & $28^{\circ}$ & $\begin{array}{l}766,44 \\
0,91 \%\end{array}$ & $\begin{array}{l}\text { Óleo de Palmiste, Fios } \\
\text { de Fibras Têxteis } \\
\text { sintéticas; Borracha } \\
\text { natural; Hulhas }\end{array}$ \\
\hline Vietnã & $37^{\circ}$ & $\begin{array}{r}749,73 \\
0,59 \%\end{array}$ & $\begin{array}{l}\text { Soja, milho, óleo de } \\
\text { soja, Couros e Peles } \\
\text { depilados, celulose }\end{array}$ & $16^{\circ}$ & $\begin{array}{c}1.185,23 \\
1,41 \%\end{array}$ & $\begin{array}{l}\text { Circuitos impressos } \\
\text { p/apars.de telefonia } \\
\text { Circuitos Integrados e } \\
\text { Microconjuntos } \\
\text { Eletrônicos } \\
\text { Calçados, Filés de } \\
\text { Peixes Congelados }\end{array}$ \\
\hline Portugal & $39^{\circ}$ & $\begin{array}{l}735,72 \\
0,58 \%\end{array}$ & $\begin{array}{l}\text { Óleos Brutos de } \\
\text { Petróleo; Soja } \\
\text { Minérios de Ferro } \\
\text { Produtos Laminados } \\
\text { Planos de Ferro ou } \\
\text { Aços; Aviões }\end{array}$ & $37^{\circ}$ & $\begin{array}{l}408,08 \\
0,49 \%\end{array}$ & $\begin{array}{l}\text { Óleos Combustíveis } \\
\text { (Diesel, Fuel-Oil, etc.) } \\
\text { Produtos } \\
\text { Manufaturados } \\
\text { Vinho de Uvas; Azeite }\end{array}$ \\
\hline Suíça & $40^{\circ}$ & $\begin{array}{r}524,98 \\
0,42 \%\end{array}$ & $\begin{array}{l}\text { Demais Produtas } \\
\text { Semimanufaturados } \\
\text { Dura Não Manetário } \\
\text { Açúcar de Cana, em Bruta } \\
\end{array}$ & $20^{\circ}$ & $\begin{array}{c}1,078,46 \\
1,28 \%\end{array}$ & $\begin{array}{l}\text { Medicamentas para Medicina } \\
\text { Humana e Veterinária } \\
\text { Compostas de Funçōes } \\
\text { Nitragenadas } \\
\end{array}$ \\
\hline Nigéria & $41^{\circ}$ & $\begin{array}{r}473,78 \\
0,41 \%\end{array}$ & Açúcar cana bruto & $38^{\circ}$ & $\begin{array}{l}294,32 \\
0,41 \%\end{array}$ & Gás natural \\
\hline Noruega & $42^{\circ}$ & $\begin{array}{r}449,27 \\
0,36 \%\end{array}$ & $\begin{array}{l}\text { Óxidos e Hidróxidos de } \\
\text { Alumínio } \\
\text { Maquinas e aparelhos } \\
\text { p/ terraplanagem, } \\
\text { perfuração; Leveduras } \\
\text { e Outros } \\
\text { Microorganismos } \\
\text { Monocelulares mortos }\end{array}$ & $43^{\circ}$ & $\begin{array}{l}288,17 \\
0,34 \%\end{array}$ & $\begin{array}{l}\text { Adubos ou fertiliz; } \\
\text { produtos } \\
\text { Manufaturados; } \\
\text { chapas, folhas, tiras, e } \\
\text { lâminas de plástico; } \\
\text { Bacalhaus e outros } \\
\text { peixes secos }\end{array}$ \\
\hline Equador & $43^{\circ}$ & $\begin{array}{r}441,38 \\
0,35 \%\end{array}$ & $\begin{array}{l}\text { Polímeros de Etileno, } \\
\text { Propileno e Estireno } \\
\text { Produtos laminados } \\
\text { planos de ferro ou } \\
\text { aços; calçados; café } \\
\text { solúvel; automóveis }\end{array}$ & $64^{\circ}$ & $\begin{array}{c}80,35 \\
0,096 \%\end{array}$ & $\begin{array}{l}\text { Preparações e } \\
\text { conservas, de peixes; } \\
\text { Aparelhos de } \\
\text { Radionavegação } \\
\text { (Radar); produtos de } \\
\text { confeitaria S/ cacau }\end{array}$ \\
\hline Paquistão & $46^{\circ}$ & $\begin{array}{r}392,58 \\
0,31 \%\end{array}$ & $\begin{array}{c}\text { Soja; Óleo de soja } \\
\text { Celulose; Borracha } \\
\text { sintética }\end{array}$ & $76^{\circ}$ & $\begin{array}{c}32,92 \\
0,039 \%\end{array}$ & $\begin{array}{c}\text { Produtos } \\
\text { Manufaturados } \\
\text { Instrumentos e } \\
\text { Aparelhos Médicos } \\
\text { Tecidos de Algodão } \\
\end{array}$ \\
\hline
\end{tabular}




\begin{tabular}{|c|c|c|c|c|c|c|}
\hline Angola & $47^{\circ}$ & $\begin{array}{l}389,59 \\
0,31 \%\end{array}$ & $\begin{array}{l}\text { Açúcar Refinado } \\
\text { Demais Produtos } \\
\text { Manufaturados } \\
\text { Enchidos de Carne } \\
\text { Carne de Frango; } \\
\text { Carnes Salgadas, } \\
\text { Carne de Suíno } \\
\end{array}$ & $54^{\circ}$ & $\begin{array}{l}142,96 \\
0,17 \%\end{array}$ & $\begin{array}{l}\text { Naftas; Gás Natural } \\
\text { Liquefeito; aparelhos de } \\
\text { Fotocópia e de } \\
\text { Termocópia }\end{array}$ \\
\hline Polônia & $50^{\circ}$ & $\begin{array}{l}296,48 \\
0,23 \%\end{array}$ & $\begin{array}{l}\text { Minérios de Cobre e de } \\
\text { Ferro; Fumo em } \\
\text { Folhas; café cru; } \\
\text { calçados; amendoim }\end{array}$ & $39^{\circ}$ & $\begin{array}{l}303,5 \\
0,36 \%\end{array}$ & $\begin{array}{l}\text { Partes e peças } \mathrm{p} / \\
\text { automóveis e Tratores } \\
\text { Demais Produtos } \\
\text { Manufaturados; moveis } \\
\text { e suas partes; borracha } \\
\text { sintética }\end{array}$ \\
\hline $\begin{array}{c}\text { Rep. } \\
\text { Dominicana }\end{array}$ & $51^{\circ}$ & $\begin{array}{l}295,17 \\
0,23 \%\end{array}$ & $\begin{array}{l}\text { Polímeros de Etileno, } \\
\text { Propileno e Estireno; } \\
\text { pisos e revestimentos } \\
\text { cerâmicos; milho em } \\
\text { grãos; café Cru em } \\
\text { Grão; fumo em folhas }\end{array}$ & $96^{\circ}$ & $\begin{array}{c}9,62 \\
0,011 \%\end{array}$ & $\begin{array}{l}\text { Obras de plástico; } \\
\text { Instrumentos e } \\
\text { aparelhos médicos; } \\
\text { aparelhos para } \\
\text { interrupção e proteção } \\
\text { de energia }\end{array}$ \\
\hline Venezuela & $52^{\circ}$ & $\begin{array}{c}282,38 \\
0,22 \%\end{array}$ & $\begin{array}{l}\text { Óleo de soja; Leite e } \\
\text { creme de leite, Carne } \\
\text { de Frango, Açúcar de } \\
\text { cana bruto }\end{array}$ & $49^{\circ}$ & $\begin{array}{l}246,05 \\
0,29 \%\end{array}$ & $\begin{array}{l}\text { Naftas, Álcoois } \\
\text { acíclicos } \\
\text { Energia elétrica } \\
\text { Ureia } \\
\text { Hulhas }\end{array}$ \\
\hline Filipinas & $53^{\circ}$ & $\begin{array}{l}280,87 \\
0,22 \%\end{array}$ & $\begin{array}{l}\text { Minérios de Ferro e de } \\
\text { Cobre; Carne de } \\
\text { Bovino; calçados }\end{array}$ & $55^{\circ}$ & $\begin{array}{l}129,94 \\
0,15 \%\end{array}$ & $\begin{array}{l}\text { Circuitos Integrados e } \\
\text { Microconjuntos } \\
\text { eletrônicos } \\
\text { Máquinas Automáticas } \\
\text { p/process.de dados. }\end{array}$ \\
\hline Israel & $54^{\circ}$ & $\begin{array}{c}259,20 \\
0,2 \%\end{array}$ & $\begin{array}{l}\text { Carne de Baviñ; Milho em Grãas } \\
\text { Saja; açúcar em bruta; café сгu } \\
\text { em grãos }\end{array}$ & $36^{\circ}$ & $\begin{array}{c}464,41 \\
0,55 \%\end{array}$ & $\begin{array}{l}\text { lnseticidas, Formicidas, } \\
\text { Herbicidas; Superfasfatas } \\
\text { (Adubas au Fertilizantes) } \\
\text { Polímeras de Etilena, Propilena e } \\
\text { Estirena; cloreta de patássia }\end{array}$ \\
\hline Catar & $55^{\circ}$ & $\begin{array}{l}253,82 \\
0,2 \%\end{array}$ & $\begin{array}{l}\text { Autamóveis de Passageiras } \\
\text { Ćxidas e Hidróxidas de Alumínia } \\
\text { Chassis cam Motar e } \\
\text { Carraçarias P/ Veículas } \\
\text { Automóveis } \\
\text { Carne de frango } \\
\end{array}$ & $47^{\circ}$ & $\begin{array}{c}254,08 \\
0,3 \%\end{array}$ & $\begin{array}{l}\text { Ureia mesmo em soluçãa aquosa; } \\
\text { gás natural liqufeito }\end{array}$ \\
\hline Suécia & $56^{\circ}$ & $\begin{array}{c}247,89 \\
0,2 \%\end{array}$ & $\begin{array}{l}\text { Minérios de Cobre } \\
\text { Café Cru } \\
\text { Carne de Bovino }\end{array}$ & $32^{\circ}$ & $\begin{array}{l}560,84 \\
0,67 \%\end{array}$ & $\begin{array}{l}\text { Partes e peças para } \\
\text { Veículos Automóveis e } \\
\text { Tratores; } \\
\text { Medicamentos para } \\
\text { Medicina Humana e } \\
\text { Veterinária } \\
\end{array}$ \\
\hline Austrália & $57^{\circ}$ & $\begin{array}{l}237,47 \\
0,19 \%\end{array}$ & $\begin{array}{l}\text { Maquinas e aparelhos } \\
\text { p/terraplanagem, } \\
\text { perfuração } \\
\text { Sapatos, Suco laranja, } \\
\text { Café Cru }\end{array}$ & $24^{\circ}$ & $\begin{array}{c}844,94 \\
1,01 \%\end{array}$ & $\begin{array}{l}\text { Hulhas } \\
\text { Óleos Brutos de } \\
\text { Petróleo }\end{array}$ \\
\hline Eslovênia & $58^{\circ}$ & $\begin{array}{c}233,41 \\
0,18 \%\end{array}$ & $\begin{array}{l}\text { Óleo de Soja } \\
\text { Café Cru em Grão } \\
\text { Minérios de Ferro }\end{array}$ & $72^{\circ}$ & $\begin{array}{c}38,07 \\
0,045 \%\end{array}$ & $\begin{array}{l}\text { Medicamentos para } \\
\text { Medicina Humana e } \\
\text { Veterinária; Papel e } \\
\text { Cartão, para Escrita; } \\
\text { demais Produtos } \\
\text { Manufaturados }\end{array}$ \\
\hline Rep. Panamá & $59^{\circ}$ & $\begin{array}{c}229,54 \\
0,18 \%\end{array}$ & $\begin{array}{l}\text { Medicamentos para } \\
\text { Medicina Humana e } \\
\text { Veterinária } \\
\text { Maquinas e aparelhos } \\
\text { p /terraplanagem, } \\
\text { perfuração; arroz em } \\
\text { Grãos } \\
\end{array}$ & $103^{\circ}$ & $\begin{array}{c}5,23 \\
0,006 \%\end{array}$ & $\begin{array}{l}\text { Alumínio; produtos } \\
\text { manufaturados; } \\
\text { borracha natural }\end{array}$ \\
\hline
\end{tabular}




\begin{tabular}{|c|c|c|c|c|c|c|}
\hline Cuba & $62^{\circ}$ & $\begin{array}{l}194,79 \\
0,15 \%\end{array}$ & $\begin{array}{l}\text { Óleo de Soja } \\
\text { Enchidos de Carne } \\
\text { Calçados; Carne de } \\
\text { Frango; Óleo de Soja } \\
\text { Arroz em Grãos }\end{array}$ & $85^{\circ}$ & $\begin{array}{l}17,02 \\
0,02 \%\end{array}$ & $\begin{array}{l}\text { Medicamentos para } \\
\text { Medicina Humana e } \\
\text { Veterinária } \\
\text { Reagentes de } \\
\text { diagnósticos de } \\
\text { laboratório } \\
\text { Semimanufaturados de } \\
\text { ferro ou aços }\end{array}$ \\
\hline Dinamarca & $65^{\circ}$ & $\begin{array}{l}168,41 \\
0,43 \%\end{array}$ & $\begin{array}{l}\text { Medicamentos para Medicina } \\
\text { Humana e Veterinária } \\
\text { Demais Produtos Manufaturados } \\
\text { Ćleo de saja }\end{array}$ & $38^{\circ}$ & $\begin{array}{c}340,26 \\
0,41 \%\end{array}$ & $\begin{array}{l}\text { Medicamentas para Medicina } \\
\text { Humana a Veterinária } \\
\text { Hormônios Naturais, Reprod.por } \\
\text { Síntese e Seus Derivados } \\
\text { Demais Produtas Manufaturados }\end{array}$ \\
\hline Finlândia & $68^{\circ}$ & $\begin{array}{l}160,7 \\
0,13 \%\end{array}$ & $\begin{array}{l}\text { Minérios de Cobre } \\
\text { Café Cru, Ferro-Ligas, } \\
\text { Açúcar de Cana Bruto }\end{array}$ & $50^{\circ}$ & $\begin{array}{c}238,38 \\
0,28 \%\end{array}$ & $\begin{array}{l}\text { Artigos farmacêuticos } \\
\text { p/cirurgia, Papel e } \\
\text { Cartão para Escrita } \\
\text { Tratores } \\
\text { Medicamentos para } \\
\text { Medicina Humana e } \\
\text { Veterinária }\end{array}$ \\
\hline Irlanda & $69^{\circ}$ & $\begin{array}{l}153,3 \\
0,12 \%\end{array}$ & $\begin{array}{l}\text { Reexportação; Pedras } \\
\text { em bruto; Minérios de } \\
\text { Alumínio; Óleo de soja } \\
\text { Maçãs Frescas }\end{array}$ & $48^{\circ}$ & $\begin{array}{c}248,51 \\
0,3 \%\end{array}$ & $\begin{array}{l}\text { Medicamentos para } \\
\text { medicina humana e } \\
\text { veterinária; artigos e } \\
\text { Apars.de Prótese, de } \\
\text { ortopedia; preparações } \\
\text { e artigos farmacêuticos } \\
\text { p/cirurgia }\end{array}$ \\
\hline Líbano & $71^{\circ}$ & $\begin{array}{l}140,8 \\
0,11 \%\end{array}$ & $\begin{array}{l}\text { Carne bovina } \\
\text { Café cru }\end{array}$ & $83^{\circ}$ & $\begin{array}{l}122,31 \\
0,022 \%\end{array}$ & $\begin{array}{l}\text { Superfosfatos (Adubos } \\
\text { ou Fertilizantes) }\end{array}$ \\
\hline Kuwait & $72^{\circ}$ & $\begin{array}{c}135,29 \\
0,11 \%\end{array}$ & $\begin{array}{l}\text { Carne de Frango } \\
\text { Ćleo de Saja } \\
\text { Castanha de Caju }\end{array}$ & $57^{\circ}$ & $\begin{array}{l}121,36 \\
0,14 \%\end{array}$ & $\begin{array}{c}\text { Querosene de } \\
\text { aviação; Ureia } \\
\text { mesmo em solução } \\
\text { aquosac }\end{array}$ \\
\hline Gana & $73^{\circ}$ & $\begin{array}{l}120,58 \\
0,11 \%\end{array}$ & Açúcar refinado & $52^{\circ}$ & $\begin{array}{l}146,61 \\
0,21 \%\end{array}$ & Cacau \\
\hline Jordânia & $79^{\circ}$ & $\begin{array}{l}112,32 \\
0,089 \%\end{array}$ & $\begin{array}{l}\text { Carne de Franga; Carne de } \\
\text { Bovino; Bavinos Vivos; café cru } \\
\text { em gräos }\end{array}$ & $112^{\circ}$ & $\begin{array}{c}3,19 \\
0,004 \%\end{array}$ & $\begin{array}{l}\text { Adubas Cant. Nitragênia, Fósfora } \\
\text { e Potássia; demais Produtas } \\
\text { Manufaturados }\end{array}$ \\
\hline Hungria & $80^{\circ}$ & $\begin{array}{l}103,27 \\
0,082 \%\end{array}$ & $\begin{array}{c}\text { Couros e peles, } \\
\text { depilados } \\
\text { Motores para Veículos } \\
\text { Café solúvel }\end{array}$ & $51^{\circ}$ & $\begin{array}{l}182,36 \\
0,22 \%\end{array}$ & $\begin{array}{c}\text { Automóveis de } \\
\text { Passageiros } \\
\text { Instrumentos e } \\
\text { Aparelhos de Medida, } \\
\text { de Verificação } \\
\text { Hortícolas Secos }\end{array}$ \\
\hline Áustria & $86^{\circ}$ & $\begin{array}{c}69,59 \\
0,055 \%\end{array}$ & $\begin{array}{l}\text { Motores p/ automóveis } \\
\text { e suas Partes } \\
\text { Cabos e fibras } \\
\text { sintéticas } \\
\text { Semimanufaturados de } \\
\text { Ferro ou Aços }\end{array}$ & $34^{\circ}$ & $\begin{array}{l}521,12 \\
0,62 \%\end{array}$ & $\begin{array}{c}\text { Medicamentos } \\
\text { medicina humana e } \\
\text { veterinária; Minérios de } \\
\text { Cobre }\end{array}$ \\
\hline
\end{tabular}




\begin{tabular}{|c|c|c|c|c|c|c|}
\hline Ucrânia & $87^{\circ}$ & $\begin{array}{c}67,61 \\
0,053 \%\end{array}$ & $\begin{array}{l}\text { Fumo em Folhas } \\
\text { Tripas e Buchos de } \\
\text { Animais, Minérios de } \\
\text { Alumínio, Café solúvel }\end{array}$ & $88^{\circ}$ & $\begin{array}{c}13,92 \\
0,017 \%\end{array}$ & $\begin{array}{l}\text { Aparelhos } \\
\text { Eletromecânicos ou } \\
\text { Térmicos, Produtos } \\
\text { Laminados Planos de } \\
\text { Ferro ou Aços } \\
\text { Medicamentos para } \\
\text { Medicina Humana e } \\
\text { Veterinária }\end{array}$ \\
\hline Quênia & $90^{\circ}$ & $\begin{array}{c}62,42 \\
0,049 \%\end{array}$ & $\begin{array}{l}\text { Açúcar de Cana, em } \\
\text { Bruto } \\
\text { Ceras Vegetais } \\
\text { Celulose }\end{array}$ & $124^{\circ}$ & $\begin{array}{c}1 \\
0,001 \%\end{array}$ & $\begin{array}{l}\text { Produtos } \\
\text { Manufaturados } \\
\text { Bombas, } \\
\text { Compressores, } \\
\text { Ventiladores, etc. } \\
\text { Partes e peças para } \\
\text { veículos automóveis e } \\
\text { tratores }\end{array}$ \\
\hline El Salvador & $91^{\circ}$ & $\begin{array}{c}59,07 \\
0,047 \%\end{array}$ & $\begin{array}{l}\text { Chassis com Motor e } \\
\text { Carroçarias P/ } \\
\text { automóveis } \\
\text { Polímeros de Etileno, } \\
\text { Propileno e Estireno } \\
\text { Café solúvel; calçados }\end{array}$ & $113^{\circ}$ & $\begin{array}{c}2,98 \\
0,004 \%\end{array}$ & $\begin{array}{l}\text { Preparações e } \\
\text { Conservas, de Peixes } \\
\text { Condensadores } \\
\text { Elétricos; alumínio; } \\
\text { tecidos de malha }\end{array}$ \\
\hline Grécia & $93^{\circ}$ & $\begin{array}{c}48,05 \\
0,045 \%\end{array}$ & Café cru & $84^{\circ}$ & $\begin{array}{c}14,2 \\
0,02 \%\end{array}$ & $\begin{array}{c}\text { Facas, navalhas e } \\
\text { aparelhos de barbear }\end{array}$ \\
\hline Camarões & $94^{\circ}$ & $\begin{array}{c}56,21 \\
0,044 \%\end{array}$ & $\begin{array}{l}\text { Óxidos e Hidróxidos de } \\
\text { Alumínio; açúcar } \\
\text { Refinado; ônibus e } \\
\text { outros veículos; cana } \\
\text { de açúcar em bruto }\end{array}$ & $129^{\circ}$ & $\begin{array}{c}0,7 \\
0,0008 \%\end{array}$ & $\begin{array}{l}\text { Demais produtos } \\
\text { manufaturados; } \\
\text { Instrumentos e } \\
\text { aparelhos de medida, } \\
\text { de verificação; } \\
\text { rolamentos e } \\
\text { Engrenagens; borracha } \\
\text { natural }\end{array}$ \\
\hline Nicarágua & $98^{\circ}$ & $\begin{array}{l}44,14 \% \\
0,035 \%\end{array}$ & $\begin{array}{l}\text { Maquinas e aparelhos } \\
\text { p/terraplanagem, } \\
\text { perfuração, e p/Uso } \\
\text { agrícola; Arroz em } \\
\text { Grãos, sementes } \\
\text { forrageiras; fumo em } \\
\text { folhas. }\end{array}$ & $123^{\circ}$ & $\begin{array}{c}42,9 \\
0,001 \%\end{array}$ & $\begin{array}{l}\text { Produtos Manufaturad; } \\
\text { calças, jardineiras, } \\
\text { Bermudas e shorts, de } \\
\text { uso masc; fios, cabos e } \\
\text { Condutores; alumínio }\end{array}$ \\
\hline Síria & $99^{\circ}$ & $\begin{array}{c}43,76 \\
0,035 \%\end{array}$ & $\begin{array}{l}\text { Açúcar de Cana; Café em grãos, } \\
\text { Celulase }\end{array}$ & $125^{\circ}$ & $\begin{array}{c}0,9 \\
0,0001\end{array}$ & $\begin{array}{l}\text { Demais produtos } \\
\text { básicos }\end{array}$ \\
\hline $\begin{array}{c}\text { Nova } \\
\text { Zelândia }\end{array}$ & $107^{\circ}$ & $\begin{array}{c}37,17 \\
0,029 \%\end{array}$ & $\begin{array}{l}\text { Coque, Betume e Dutras } \\
\text { Resíduos de Ćlea de Petróleo } \\
\text { Suca de Laranja Congelada } \\
\text { Café cru em grãos }\end{array}$ & $74^{\circ}$ & $\begin{array}{c}33,7 \\
0,04 \%\end{array}$ & $\begin{array}{l}\text { Produtas Constituídas da Leite, } \\
\text { Demais Produtas Manufaturadas } \\
\text { Medicamentas para Medicina } \\
\text { Humana e Veterinária }\end{array}$ \\
\hline Rep. Tcheca & $110^{\circ}$ & $\begin{array}{c}33,76 \\
0,027 \%\end{array}$ & $\begin{array}{l}\text { Produtos de ferro ou } \\
\text { aços; produtos } \\
\text { Semimanufaturados } \\
\text { sucos e extratos } \\
\text { Vegetais; fumo em } \\
\text { Folhas; Café Cru em } \\
\text { Grão }\end{array}$ & $45^{\circ}$ & $\begin{array}{c}270,11 \\
0,32 \%\end{array}$ & $\begin{array}{l}\text { Partes e peças p/ } \\
\text { veículos Automóveis e } \\
\text { Tratores; demais } \\
\text { Produtos; ferragens p/ } \\
\text { portas; manufaturados } \\
\text { Aceleradores de } \\
\text { Reação e Preparações } \\
\text { Catalíticas }\end{array}$ \\
\hline $\begin{array}{l}\text { Costa do } \\
\text { Marfim }\end{array}$ & $111^{\circ}$ & $\begin{array}{c}25,66 \\
0,024 \%\end{array}$ & Açúcar refinado & $72^{\circ}$ & 32,25 & Borracha \\
\hline
\end{tabular}




\begin{tabular}{|c|c|c|c|c|c|c|}
\hline Haiti & $115^{\circ}$ & $\begin{array}{c}27,54 \\
0,022 \%\end{array}$ & $\begin{array}{l}\text { Pisos e revestimentos } \\
\text { Cerâmicos; produtos } \\
\text { Manufaturados } \\
\text { Enchidos de Carne } \\
\text { Açúcar de Cana em } \\
\text { Bruto }\end{array}$ & $135^{\circ}$ & $\begin{array}{c}0,5 \\
0,0006 \%\end{array}$ & $\begin{array}{l}\text { Óleos Essenciais } \\
\text { Calças, jardineiras, } \\
\text { bermudas e shorts de } \\
\text { uso masculino }\end{array}$ \\
\hline Sérvia & $117^{\circ}$ & $\begin{array}{l}25,74 \\
0,02 \% \\
\end{array}$ & $\begin{array}{l}\text { Fumo em Folhas } \\
\text { Carne de frango }\end{array}$ & $89^{\circ}$ & $\begin{array}{c}13,47 \\
0,016 \%\end{array}$ & $\begin{array}{c}\text { Pneumáticos } \\
\text { Tubos e Acessórios de } \\
\text { Plásticos }\end{array}$ \\
\hline Suriname & $122^{\circ}$ & $\begin{array}{c}15,87 \\
0,013 \%\end{array}$ & $\begin{array}{l}\text { Maquinas e aparelhos } \\
\text { p/terraplanagem, } \\
\text { perfuração; pisos e } \\
\text { Revestimentos } \\
\text { Cerâmicos; Carne de } \\
\text { Frango; amendoim em } \\
\text { grãos }\end{array}$ & $111^{\circ}$ & $\begin{array}{c}3,28 \\
0,004 \%\end{array}$ & Arroz em Grãos \\
\hline Eslováquia & $124^{\circ}$ & $\begin{array}{c}14,96 \\
0,012 \%\end{array}$ & $\begin{array}{l}\text { Bombas, } \\
\text { Compressores, } \\
\text { Ventiladores }\end{array}$ & $67^{\circ}$ & $\begin{array}{c}60,84 \\
0,072 \%\end{array}$ & $\begin{array}{c}\text { Partes e peças para } \\
\text { veículos automóveis e } \\
\text { Tratores } \\
\text { Enxofre }\end{array}$ \\
\hline Cabo Verde & $127^{\circ}$ & $\begin{array}{c}13,56 \\
0,011 \%\end{array}$ & $\begin{array}{l}\text { Açúcar Refinado; } \\
\text { demais produtos } \\
\text { Manufaturados; café } \\
\text { cru, carne de frango, } \\
\text { de boi; arroz em grãos }\end{array}$ & $170^{\circ}$ & $\begin{array}{c}0,04 \\
0,00005 \%\end{array}$ & $\begin{array}{l}\text { Demais produtos } \\
\text { manufaturados; } \\
\text { semicondutores }\end{array}$ \\
\hline Moçambique & $131^{\circ}$ & $\begin{array}{c}11,29 \\
0,009 \%\end{array}$ & $\begin{array}{l}\text { Correia p/ transmissão } \\
\text { de Borracha; } \\
\text { Máquinas e aparelhos } \\
\text { p/terraplanagem, } \\
\text { Carne de Frango, de } \\
\text { Suíno e de Peru }\end{array}$ & $63^{\circ}$ & $\begin{array}{l}84,15 \\
0,1 \%\end{array}$ & Hulha; fumo em folhas \\
\hline
\end{tabular}

Fonte: MDIC - Comex Vis: Países Parceiros - Exportações, Importações e Balança Comercial 


\section{APENSO Nº2 - Intepretação dos resultados da escala EBACO para os SECOMs}

Tabela 01 - EBACO - COMPROMETIMENTO

Base afetiva: crença e identificação com a filosofia, valores e os objetivos organizacionais

\begin{tabular}{|c|c|c|c|c|c|c|c|c|c|c|c|c|c|c|c|c|c|c|}
\hline VARIÁVEIS & & PESO & $\begin{array}{l}\text { Média } \\
\text { secOMs }\end{array}$ & $\begin{array}{c}\begin{array}{c}\text { Média } \\
\text { Peso }\end{array} \\
\end{array}$ & $\begin{array}{c}\text { Média } \\
\text { África }\end{array}$ & $\begin{array}{c}\text { Média" } \\
\text { Peso }\end{array}$ & $\begin{array}{c}\text { Média Am. } \\
\text { Central }\end{array}$ & $\begin{array}{c}\text { Média* } \\
\text { Peso }\end{array}$ & \begin{tabular}{|c|} 
Média Am. \\
do Norte
\end{tabular} & $\begin{array}{c}\text { Média }^{*} \\
\text { Pesoo }\end{array}$ & \begin{tabular}{|c|} 
Média \\
Am. do Sul
\end{tabular} & $\begin{array}{c}\begin{array}{c}\text { Média } \\
\text { Peso }\end{array} \\
\end{array}$ & $\begin{array}{c}\text { Média } \\
\text { Ásia }\end{array}$ & $\begin{array}{c}\text { Média- } \\
\text { Peso }\end{array}$ & \begin{tabular}{|l|} 
Média \\
Europa
\end{tabular} & $\begin{array}{c}\text { Média* } \\
\text { Peso }\end{array}$ & $\begin{array}{c}\text { Média } \\
\text { Oceania }\end{array}$ & $\begin{array}{c}\text { Média" } \\
\text { Peso }\end{array}$ \\
\hline 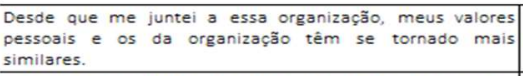 & $\mathrm{C}_{\text {Afe 1 }}$ & 0,74 & 4,09 & 3,027 & 4,21 & 3,115 & 3,3 & 2,442 & 4,26 & 3,152 & 3,95 & 2,923 & 4,47 & 3,308 & 3,89 & 2,879 & 3,75 & 2,775 \\
\hline $\begin{array}{l}\text { razão de eu preferir esta organizacão em relação a outras } \\
\text { por causa do que ela simboliza, de seus valores. }\end{array}$ & $\mathrm{C}_{\text {Afe2 }}$ & 0.76 & 4,3 & 3,268 & 4,05 & 3,078 & 3,3 & 2,508 & 4,46 & 3,390 & 4,1 & 3,116 & 4,75 & 3,610 & 4,21 & 3,200 & 3,75 & 2,850 \\
\hline u me identifico com a filosofia desta organização & $\mathrm{C}_{\text {Afe3 }}$ & 0.8 & 4,3 & 3,440 & 4,42 & 3,536 & 3,6 & 2,880 & 4,57 & 3,656 & 4,18 & 3,344 & 4,47 & 3,576 & 4,21 & 3,368 & 3,5 & 2,800 \\
\hline acredito nos valores e nos objetivos dessa organização & $C_{\text {Afe4 }}$ & 0,78 & 4,65 & 3,627 & 4,74 & 3,6972 & 4 & 3,120 & 4,89 & 3,814 & 4,51 & 3,518 & 4,83 & 3,767 & 4,55 & 3,549 & 4,75 & 3,705 \\
\hline $\begin{array}{l}\text { ixo de } 5,87 \text { Baixo comprometimento } \\
\text { re } 5,87 \text { e } 11,21 \text { Comprometimento abaixo da média } \\
\text { re } 11,21 \text { e } 16,55 \text { comprometimento acima da média } \\
\text { or que } 16,55 \text { Alto comprometimento }\end{array}$ & & SECOMS & esultado & $\begin{array}{c}13,36 \\
\text { comp. } \\
\text { acima da } \\
\text { média }\end{array}$ & AF & $\begin{array}{c}13,43 \\
\text { comp. } \\
\text { acima da } \\
\text { média }\end{array}$ & $\mathrm{AC}$ & $\begin{array}{l}\text { abaixo da } \\
\text { média }\end{array}$ & AN & $\begin{array}{l}\text { acima da } \\
\text { média }\end{array}$ & AS & $\begin{array}{c}12,90 \\
\text { comp. } \\
\text { acima da } \\
\text { média }\end{array}$ & A & $\begin{array}{c}14,26 \\
\text { comp. } \\
\text { acima da } \\
\text { média }\end{array}$ & EU & $\begin{array}{c}13,00 \\
\text { comp. } \\
\text { acima da } \\
\text { média }\end{array}$ & oc & $\begin{array}{c}12,13 \\
\text { comp. } \\
\text { acima da } \\
\text { média }\end{array}$ \\
\hline
\end{tabular}

Base obrigação em permanecer: Crença de que tem uma obrigação em permanecer; de que se sentiria culpado em deixar, de que não seria certo; e que tem uma obrigação moral para com as pessoas da organização.

\begin{tabular}{|c|c|c|c|c|c|c|c|c|c|c|c|c|c|c|c|c|c|c|}
\hline VARIÁVEIS & & PESO & $\begin{array}{l}\text { Média } \\
\text { SECOMS }\end{array}$ & \begin{tabular}{c|} 
Média * \\
Peso
\end{tabular} & $\begin{array}{l}\text { Média } \\
\text { África }\end{array}$ & $\begin{array}{c}\text { Média } \\
\text { Peso }\end{array}$ & $\begin{array}{l}\text { Média Am. } \\
\text { Central }\end{array}$ & $\begin{array}{c}\text { Média } \\
\text { Peso }\end{array}$ & \begin{tabular}{|c|} 
Média Am. \\
do Norte
\end{tabular} & $\begin{array}{c}\text { Média } \\
\text { Peso }\end{array}$ & \begin{tabular}{|c|} 
Média \\
Am. do sul
\end{tabular} & $\begin{array}{c}\text { Média } \\
\text { Peso }\end{array}$ & $\begin{array}{l}\text { Média } \\
\text { Ásia }\end{array}$ & $\begin{array}{c}\text { Média } \\
\text { peso }\end{array}$ & \begin{tabular}{|c|} 
Média \\
Europa
\end{tabular} & $\begin{array}{c}\text { Média- } \\
\text { Peso }\end{array}$ & $\begin{array}{l}\text { Média } \\
\text { Oceania }\end{array}$ & $\begin{array}{c}\text { Média:- } \\
\text { Peso }\end{array}$ \\
\hline $\begin{array}{l}\text { Eu não deixaria minha organizaç̃o agora porque eu tenho } \\
\text { uma obrigaçăo moral com as pessoss daqui }\end{array}$ & $C_{\text {Per } 1}$ & 0,78 & 3,85 & 3,003 & 3,79 & 2,956 & 2,2 & 1,716 & 3,2 & 2,496 & 3,95 & 3,081 & 4,41 & 3,440 & 3,95 & 3,081 & 2,5 & 1,950 \\
\hline $\begin{array}{l}\text { Mesmo se fosse vantagem para mim, eu sinto que não } \\
\text { seria certo deixar minha organizaşao agora }\end{array}$ & $C_{\text {Per2 }}$ & 0,79 & 3,82 & 3,018 & 3,63 & 2,868 & 2,2 & 1,738 & 2,91 & 2,299 & 4,08 & 3,223 & 4,36 & 3,444 & 3,93 & 3,105 & 3,75 & 2,963 \\
\hline $\begin{array}{l}\text { Eu me sentiria culpado se deixasse minha organização } \\
\text { agora. }\end{array}$ & CPer3 & 0,82 & 3,26 & 2,673 & 4,16 & 3,411 & 1,9 & 1,558 & 2,66 & 2,181 & 2,67 & 2,189 & 3,88 & 3,182 & 3,3 & 2,706 & 3,5 & 2,870 \\
\hline $\begin{array}{l}\text { Acredito que não seria certo deixar minha organizą̧̃o } \\
\text { porque tenho uma obrigaç̃o moral lem permanecer aqui. }\end{array}$ & Per4 & 0,85 & 3,27 & 2,780 & 3,63 & 3,086 & 1,9 & 1,615 & 2,6 & 2,210 & 3 & 2,550 & 3,85 & 3,273 & 3,37 & 2,865 & 2,75 & 2,338 \\
\hline $\begin{array}{l}\text { Abaixo de } 10,62 \text { Baixo comprometimento } \\
\text { Entre } 10,62 \text { e } 14,69 \text { Comprometimento abaixo da média } \\
\text { Entre } 14,69 \text { e } 18,75 \text { comprometimento acima da média }\end{array}$ & & & 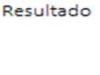 & $\begin{array}{l}11,47 \\
\text { comp. }\end{array}$ & & comp. & & & & & & & & $\begin{array}{l}\text { comp. } \\
\text { cabaixo }\end{array}$ & & =omp. & & \\
\hline
\end{tabular}

Entre 14,69 e 14,69 Comprometimento abaixo da média

SECOMs

$\begin{gathered}\text { comp. } \\ \text { abaixodada } \\ \text { média }\end{gathered}$
AF
$\begin{gathered}\text { compl. } \\ \text { abaixoda da } \\ \text { média }\end{gathered}$ AC $\quad \begin{gathered}\text { Baixo } \\ \text { comp. }\end{gathered}$

Baixo
comp.

As comp. $\begin{gathered}\text { comaixoda A } \\ \text { abédia } \\ \text { mécaixo } \\ \text { da } \\ \text { média }\end{gathered}$

EU comp. $\begin{gathered}\text { comaixo da oc } \\ \text { média }\end{gathered}$

Base obrigação pelo desempenho: Crença de que deve se esforçar em beneficio da organização e que deve buscar cumprir suas tarefas e atingir os objetivos organizacionais.

\begin{tabular}{|c|c|c|c|c|c|c|c|c|c|c|c|c|c|c|c|c|c|c|}
\hline VARIÁVEIS & & PESO & $\begin{array}{l}\text { Média } \\
\text { SECOMs }\end{array}$ & \begin{tabular}{|c|}
$\begin{array}{c}\text { Média * } \\
\text { Peso }\end{array}$ \\
\end{tabular} & \begin{tabular}{l|l} 
Média \\
África
\end{tabular} & $\begin{array}{c}\text { Média* } \\
\text { Pesoo }\end{array}$ & $\begin{array}{l}\text { Média Am. } \\
\text { Central }\end{array}$ & $\begin{array}{c}\text { Média- } \\
\text { Peso }\end{array}$ & $\begin{array}{l}\text { Média Am. } \\
\text { do Norte }\end{array}$ & $\begin{array}{l}\text { Média*- } \\
\text { Peso }\end{array}$ & \begin{tabular}{|l|} 
Média \\
Am. do sul
\end{tabular} & $\begin{array}{c}\text { Média: } \\
\text { Peso }\end{array}$ & \begin{tabular}{l|l} 
Média \\
Ásia
\end{tabular} & $\begin{array}{c}\text { Média- } \\
\text { Peso }\end{array}$ & \begin{tabular}{|c|} 
Média \\
Europa
\end{tabular} & $\begin{array}{c}\text { Média- } \\
\text { Peso }\end{array}$ & $\begin{array}{l}\text { Média } \\
\text { Oceania }\end{array}$ & $\begin{array}{l}\text { Média: } \\
\text { Peso }\end{array}$ \\
\hline Todo colaborador deve buscar ating gir os objetivos da organizaş̄o o & $c_{\text {Des1 }} \mid$ & 0,65 & 5,42 & 3,523 & 5,26 & 3,419 & 5,6 & 3,640 & 5,51 & 3,582 & 5,38 & 3,497 & 5,53 & 3,595 & 5,37 & 3,491 & 4,75 & 3,088 \\
\hline $\begin{array}{l}\text { Eu tenho obrigaşão am desempenhar bem minha função nessa } \\
\text { organizaģă }\end{array}$ & $c_{\text {Des2 }}$ & 0,81 & 5,74 & 4,649 & 5,79 & 4,690 & 5,7 & 4,617 & 5,69 & 4,609 & 5,82 & 4,714 & 5,69 & 4,609 & 5,76 & 4,666 & 5,75 & 4,658 \\
\hline $\begin{array}{l}\text { Obom colaborador deve sa esforçar para que a organ izagąo ten na } \\
\text { os melhores resultad os possives. }\end{array}$ & C Des & 0,81 & 5,16 & 4,180 & 4,26 & 3,451 & 5,3 & 4,293 & 5,06 & 4,099 & 5,87 & 4,755 & 4,71 & 3,815 & 5,39 & 4,366 & 5 & 4,050 \\
\hline O colä borador tem a obrigaşă de sempre cumprir suas tarefáas. & $c_{\text {Des4 }}$ & 0.7 & 5,56 & 3,892 & 5,11 & 3,577 & 5,4 & 3,780 & 5,69 & 3,983 & 5,72 & 4,004 & 5,54 & 3,878 & 5,55 & 3,885 & 5,75 & 4,025 \\
\hline
\end{tabular}

Abaixo de 3,60 Baixo comprometimento

ento acima da méd

SECOMS

Alto AF Alto
comp. AC Alto
comp.

AN Alto

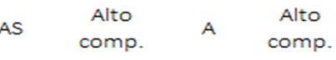

EU Alto

oc Alto 
Base Afiliativa: Crença de que é reconhecido pelos colegas como membro do grupo e da organização.

\begin{tabular}{|c|c|c|c|c|c|c|c|c|c|c|c|c|c|c|c|c|c|c|}
\hline \multicolumn{2}{|l|}{ VARIÁVEIS } & \multirow{2}{*}{$\begin{array}{l}\text { PESO } \\
0,72 \\
\end{array}$} & \multirow{2}{*}{$\begin{array}{c}\text { Média } \\
\text { SECOMS }\end{array}$} & \multirow{2}{*}{\begin{tabular}{|c|}
$\begin{array}{c}\text { Média } \\
\text { Peso }\end{array}$ \\
3,571 \\
\end{tabular}} & \multirow{2}{*}{\begin{tabular}{c|c|c|} 
Média \\
Africa \\
4,89 \\
\end{tabular}} & \multirow{2}{*}{$\begin{array}{c}\begin{array}{c}\text { Média } \\
\text { Peso }\end{array} \\
3,521 \\
\end{array}$} & \multirow{2}{*}{$\begin{array}{c}\begin{array}{c}\text { Média Am. } \\
\text { Central }\end{array} \\
4,1 \\
\end{array}$} & \multirow{2}{*}{\begin{tabular}{c|}
$\begin{array}{c}\text { Média - } \\
\text { Peso }\end{array}$ \\
2,952 \\
\end{tabular}} & \multirow{2}{*}{\begin{tabular}{|c|}
$\begin{array}{c}\text { Média Am. } \\
\text { do Norte }\end{array}$ \\
5,14 \\
\end{tabular}} & \multirow{2}{*}{$\begin{array}{c}\begin{array}{c}\text { Média - } \\
\text { Peso }\end{array} \\
3,701 \\
\end{array}$} & \multirow{2}{*}{\begin{tabular}{c|}
$\begin{array}{c}\text { Média } \\
\text { Am. do Sul }\end{array}$ \\
4,72 \\
\end{tabular}} & \multirow{2}{*}{\begin{tabular}{c|}
$\begin{array}{c}\text { Média. } \\
\text { Peso }\end{array}$ \\
3,398 \\
\end{tabular}} & \multirow{2}{*}{$\begin{array}{c}\text { Média } \\
\text { Ásia }\end{array}$} & \multirow{2}{*}{$\begin{array}{c}\text { Média - } \\
\text { Peso } \\
3,938 \\
\end{array}$} & \multirow{2}{*}{ 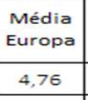 } & \multirow{2}{*}{$\begin{array}{c}\begin{array}{c}\text { Média } \\
\text { Peso }\end{array} \\
3,427 \\
\end{array}$} & \multirow{2}{*}{$\begin{array}{c}\text { Média } \\
\text { Oceania }\end{array}$} & \multirow{2}{*}{$\begin{array}{c}\begin{array}{c}\text { Média - } \\
\text { Peso }\end{array} \\
3,600\end{array}$} \\
\hline Nesta organizaçăo, eu sinto que faço parte do grupo. & $C_{\text {Afi1 }}$ & & & & & & & & & & & & & & & & & \\
\hline $\begin{array}{l}\text { Sou reconhecido por todos na organizą̧ăo como men } \\
\text { grupo }\end{array}$ & $C_{\text {Afi2 }}$ & 0,82 & 4,99 & 4,092 & 4,74 & 3,887 & 4,3 & 3,526 & 5,26 & 4,313 & 4,92 & 4,034 & 5,39 & 4,420 & 4,75 & 3,895 & 5,25 & 4,305 \\
\hline Sinto que meus colegas me consideram como men & $C_{\text {Afi3 }}$ & 0,76 & 5,22 & 3,967 & 5,11 & 3,884 & 4,6 & 3,496 & 5,49 & 4,172 & 5,21 & 3,960 & 5,46 & 4,150 & 5,01 & 3,808 & 5,75 & 4,370 \\
\hline $\begin{array}{l}\text { Fazer parte do grupo é o que me leva a lutar por esta } \\
\text { organizaç̃o. }\end{array}$ & $\mathrm{C}_{\mathrm{Afi} 4}$ & 0,68 & 4,44 & 3,019 & 4,47 & 3,040 & 4,3 & 2,924 & 4,66 & 3,169 & 4,05 & 2,754 & 4,61 & 3,135 & 4,44 & 3,019 & 4 & 2,720 \\
\hline $\begin{array}{l}\text { Abaixo de } 14,77 \text { saixo comprometimento } \\
\text { Entre } 14,77 \text { en, } 1,82 \text { Comprometimento abaixo da média } \\
\text { Entre } 16,82 \text { e17.8B Comprometimento acima da média } \\
\text { Maior que } 17,88 \text { Alto comprometimento }\end{array}$ & & con & . & 14,65 & AF & 14,33 & $\mathrm{AC}$ & $\begin{array}{l}\text { Baixo } \\
\text { comp. }\end{array}$ & AN & abaixo & AS & $\begin{array}{l}\text { Baixo } \\
\text { camp. }\end{array}$ & $\mathbf{A}$ & $\begin{array}{l}\text { comp. } \\
\text { abaixo }\end{array}$ & EU & $\begin{array}{l}\text { Baixo } \\
\text { como. }\end{array}$ & $o c$ & baixo da \\
\hline
\end{tabular}

Entre 14,77 e 16,82 Comprometimento abaixo da média
Entre 16,82 e 17,88 comprometimento acima da média
Maior que 17,88 Alto comprometimento

SECOMS

Baixo
comp. AF
comp

da média

abaixo
da
média

Base falta de recompensas e de oportunidades: Crença de que o esforço extra em beneficio da organização deve ser recompensado e de que a organização deve Ihe dar mais oportunidades

\begin{tabular}{|c|c|c|c|c|c|c|c|c|c|c|c|c|c|c|c|c|c|c|}
\hline VARIÁVEIS & & PESO & $\begin{array}{c}\text { Média } \\
\text { SECOMS }\end{array}$ & $\begin{array}{c}\text { Média* } \\
\text { Peso }\end{array}$ & $\begin{array}{l}\text { Média } \\
\text { África }\end{array}$ & $\begin{array}{c}\text { Média: } \\
\text { Peso }\end{array}$ & $\begin{array}{l}\text { Média Am. } \\
\text { Central }\end{array}$ & \begin{tabular}{|c|} 
Média:- \\
Peso
\end{tabular} & \begin{tabular}{|c|}
$\begin{array}{c}\text { Média Am. } \\
\text { do Norte }\end{array}$ \\
\end{tabular} & $\begin{array}{c}\text { Média - } \\
\text { Peso }\end{array}$ & \begin{tabular}{|c|} 
Média \\
Am. do sul
\end{tabular} & \begin{tabular}{|c|}
$\begin{array}{c}\text { Média: } \\
\text { Peso }\end{array}$ \\
\end{tabular} & $\begin{array}{c}\text { Média } \\
\text { Ásia }\end{array}$ & $\begin{array}{c}\text { Média- } \\
\text { Peso }\end{array}$ & $\begin{array}{c}\text { Média } \\
\text { Europa }\end{array}$ & $\begin{array}{c}\text { Média: } \\
\text { Peso }\end{array}$ & $\begin{array}{l}\text { Média } \\
\text { Oceania }\end{array}$ & $\begin{array}{c}\text { Média- } \\
\text { Peso }\end{array}$ \\
\hline $\begin{array}{l}\text { Se eu já não tivesse dado tanto de mim nesta organização, } \\
\text { eu poderia considerar trabalnar em outro lugar. }\end{array}$ & $\mathrm{C}_{\text {Rec1 }}$ & 0,45 & 3,18 & 1,431 & 2,84 & 1,278 & 1,9 & 0.855 & 2,43 & 1,094 & 3,36 & 1,512 & 3,32 & 1,494 & 3,6 & 1,620 & 2 & 0,900 \\
\hline 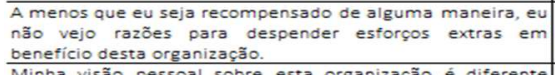 & $c_{\text {Recz }}$ & 0,77 & 2,44 & 1,879 & 2,32 & 1,786 & 2,1 & 1,617 & 2,03 & 1,563 & 2,56 & 1,971 & 2,64 & 2,033 & 2,5 & 1,925 & 2,25 & 1,733 \\
\hline $\begin{array}{l}\text { Minha višo pessoal sobre esta organizaç̧̃o é diferente } \\
\text { daquela que ev expresso publicamente. }\end{array}$ & $C_{\text {Rec3 }}$ & 0,72 & 2,31 & 1,663 & 2,05 & 1,476 & 2,8 & 2,016 & 1,89 & 1,361 & 2,41 & 1,735 & 2,44 & 1,757 & 2,31 & 1,663 & 3 & 2,160 \\
\hline 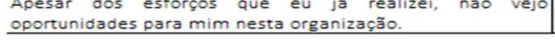 & $c_{\text {Reca }}$ & 0,6 & 3,04 & 1,824 & 2,79 & 1,674 & 4,3 & 2,580 & 2,8 & 1,680 & 3,38 & 2,028 & 3,07 & 1,842 & 2,86 & 1,716 & 3,5 & 2,100 \\
\hline $\begin{array}{l}\text { Abaixo de } 4,36 \text { Baixo comprometimento } \\
\text { Entre } 4,36 \text { e } 8,78 \text { Comprometimento abaixo da média } \\
\text { Entre } 8,78 \text { e } 13,20 \text { Comprometimento acima da média } \\
\text { Maior que } 13,20 \text { Alto comprometimento }\end{array}$ & & & Resultado & $\begin{array}{c}6,80 \\
\text { comp. } \\
\text { abaixo da } \\
\text { média }\end{array}$ & AF & $\begin{array}{c}6,21 \\
\text { comp. } \\
\text { abaixo da } \\
\text { média }\end{array}$ & $A C$ & $\begin{array}{c}7,07 \\
\text { comp. } \\
\text { abaixo da } \\
\text { média }\end{array}$ & $A N$ & $\begin{array}{c}5,70 \\
\text { comp. } \\
\text { abaixo da } \\
\text { média }\end{array}$ & AS & $\begin{array}{c}7,25 \\
\text { comp. } \\
\text { abaixo da } \\
\text { média }\end{array}$ & A & $\begin{array}{c}7,13 \\
\text { comp. } \\
\text { abaixo } \\
\text { da } \\
\text { média }\end{array}$ & EU & $\begin{array}{c}6,92 \\
\text { comp. } \\
\text { abaixo da } \\
\text { média }\end{array}$ & $O C$ & $\begin{array}{c}6,89 \\
\text { comp. } \\
\text { abaixo da } \\
\text { média }\end{array}$ \\
\hline
\end{tabular}

Base linha consistente de atividade: Crença de que deve manter certas atitudes e regras da organização com o objetivo de se manter na organizą̧̧̃o

\begin{tabular}{|c|c|c|c|c|c|c|c|c|c|c|c|c|c|c|c|c|c|c|}
\hline VARIÁVEIS & & PESO & $\begin{array}{c}\text { Média } \\
\text { SECOMS }\end{array}$ & $\begin{array}{c}\text { Média }= \\
\text { Peso }\end{array}$ & $\begin{array}{l}\text { Média } \\
\text { Affrica }\end{array}$ & $\begin{array}{c}\text { Média : } \\
\text { Peso }\end{array}$ & $\begin{array}{l}\text { Média Am. } \\
\text { Central }\end{array}$ & $\begin{array}{c}\text { Média - } \\
\text { Peso }\end{array}$ & $\begin{array}{c}\text { Média Am. } \\
\text { do Norte }\end{array}$ & $\begin{array}{c}\text { Média- } \\
\text { Peso }\end{array}$ & \begin{tabular}{|c|} 
Média \\
Am. do sul
\end{tabular} & $\begin{array}{c}\text { Média. } \\
\text { Peso }\end{array}$ & $\underset{\substack{\text { Média } \\
\text { Asia }}}{ }$ & $\begin{array}{c}\text { Média - } \\
\text { Peso }\end{array}$ & $\begin{array}{l}\text { Média } \\
\text { Europa }\end{array}$ & $\begin{array}{c}\text { Média } \\
\text { Peso }\end{array}$ & $\begin{array}{c}\text { Média } \\
\text { Oceania }\end{array}$ & $\begin{array}{c}\text { Média : } \\
\text { Peso }\end{array}$ \\
\hline $\begin{array}{l}\text { Procuro näo tranngredir as regras aqui, pois assim sempre } \\
\text { manterei meu empreg }\end{array}$ & $c_{\text {con } 1}$ & 0,69 & 4,36 & 3,008 & 4,05 & 2,795 & 4,2 & 2,898 & 4,03 & 2,781 & 4,82 & 3,326 & 4,56 & 3,146 & 4,25 & 2,933 & 4 & 2,760 \\
\hline $\begin{array}{l}\text { Na situação atual, ficar com minha organizaçäo é na } \\
\text { realidade uma necessidade tanto quanto um desejo }\end{array}$ & $C_{\text {con2 }}$ & 0,58 & 4,31 & 2,500 & 3,74 & 2,169 & 4,1 & 2,378 & 4,2 & 2,436 & 4,82 & 2,796 & 4,47 & 2,593 & 4,2 & 2,436 & 3,5 & 2,030 \\
\hline $\begin{array}{l}\text { Para conseguir ser recompensado aqui è necessário } \\
\text { expressar a atitude certa }\end{array}$ & $\mathrm{C}_{\text {cons }}$ & 0,71 & 4,13 & 2,932 & 4 & 2,840 & 4,4 & 3,124 & 4,14 & 2,939 & 3,92 & 2,783 & 4,61 & 3,273 & 3,95 & 2,805 & 2,5 & 1,775 \\
\hline $\begin{array}{l}\text { Farei sempre o possivel no meu trabalino para me manter } \\
\text { neste emprego }\end{array}$ & $c_{\text {con } 4}$ & 0,65 & 4,64 & 3,016 & 4 & 2,600 & 4,1 & 2,665 & 4,31 & 2,802 & 5,05 & 3.283 & 4,78 & 3,107 & 4,71 & 3,062 & 4,5 & 2,925 \\
\hline 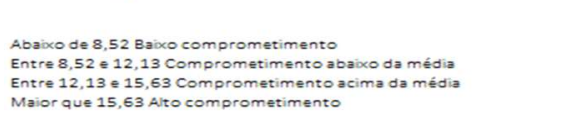 & & SECOMS & esultado & $\begin{array}{l}11,46 \\
\text { comp. } \\
\text { abaiio da } \\
\text { média }\end{array}$ & AF & $\begin{array}{l}10,40 \\
\text { comp. } \\
\text { abaixo da } \\
\text { média }\end{array}$ & AC & $\begin{array}{c}11,07 \\
\text { comp. } \\
\text { abaixo da } \\
\text { média }\end{array}$ & AN & $\begin{array}{l}10,96 \\
\text { comp. } \\
\text { abaixo da } \\
\text { média }\end{array}$ & AS & $\begin{array}{c}12,19 \\
\text { comp. } \\
\text { acima } \\
\text { da } \\
\text { média }\end{array}$ & A & $\begin{array}{l}12,12 \\
\text { comp. } \\
\text { abaixo } \\
\text { da } \\
\text { média }\end{array}$ & EU & $\begin{array}{c}11,23 \\
\text { comp. } \\
\text { abaixo do } \\
\text { média }\end{array}$ & oc & $\begin{array}{c}9,49 \\
\text { comp. } \\
\text { abaixo da } \\
\text { média }\end{array}$ \\
\hline
\end{tabular}

Base escassez de alternativas: crença de que possui poucas alternativas de trabalho se deixar a organização

\begin{tabular}{|c|c|c|c|c|c|c|c|c|c|c|c|c|c|c|c|c|c|c|}
\hline VARIÁVEIS & & PEsO & $\begin{array}{l}\text { Média } \\
\text { SECOMSS }\end{array}$ & \begin{tabular}{|c|} 
Média* \\
Peso
\end{tabular} & $\begin{array}{c}\text { Média } \\
\text { África }\end{array}$ & $\begin{array}{l}\text { Média - } \\
\text { Peso }\end{array}$ & $\begin{array}{l}\text { Média Am. } \\
\text { Central }\end{array}$ & $\begin{array}{l}\text { Média:- } \\
\text { Peso- }\end{array}$ & \begin{tabular}{|c|}
$\begin{array}{c}\text { Média Am. } \\
\text { do Norte }\end{array}$ \\
\end{tabular} & \begin{tabular}{|l|} 
Média - \\
Peso
\end{tabular} & \begin{tabular}{|c|} 
Média \\
Am. do sul
\end{tabular} & $\begin{array}{l}\text { Média- } \\
\text { Peso- }\end{array}$ & $\begin{array}{c}\text { Média } \\
\text { Ásia }\end{array}$ & \begin{tabular}{|c|}
$\begin{array}{c}\text { Média- } \\
\text { Peso }\end{array}$ \\
\end{tabular} & \begin{tabular}{|c|} 
Média \\
Europa
\end{tabular} & $\begin{array}{c}\text { Média:- } \\
\text { Peso- }\end{array}$ & $\begin{array}{c}\text { Média } \\
\text { Oceania }\end{array}$ & $\begin{array}{c}\text { Média - } \\
\text { Peso }\end{array}$ \\
\hline $\begin{array}{l}\text { Se eu decidisse deicar minha o } \\
\text { bastante desestruturada }\end{array}$ & $C_{\text {Esc1 }}$ & 0,59 & 3,83 & 2,260 & 2,84 & 1,676 & 2,4 & 1,416 & 3,97 & 2,342 & 4,15 & 2,449 & 3,81 & 2,248 & 4,06 & 2,395 & 3 & 1,770 \\
\hline 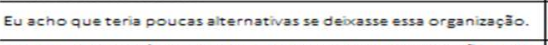 & $\mathrm{C}_{\mathrm{Esc2}}$ & 0,77 & 3,06 & 2,356 & 2,95 & 2,272 & 2,1 & 1,617 & 2,83 & 2,179 & 2,69 & 2,071 & 3,66 & 2,818 & 3,08 & 2,372 & 2,25 & 1,733 \\
\hline 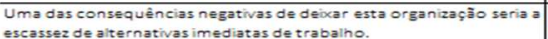 & $C_{\text {Esc3 }}$ & 0,84 & 3,14 & 2,638 & 3,11 & 2,612 & 2,7 & 2,268 & 2,97 & 2,495 & 2,44 & 2,050 & 3,63 & 3,049 & 3,27 & 2,747 & 2,75 & 2,310 \\
\hline 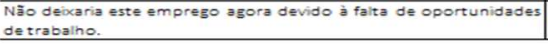 & $\mathrm{C}_{\mathrm{Esc4}}$ & 0,78 & 3,43 & 2,675 & 3,16 & 2,465 & 3 & 2,34 & 2,91 & 2,270 & 3,87 & 3,019 & 3,69 & 2,878 & 3,44 & 2,683 & 2 & 1,560 \\
\hline $\begin{array}{l}\text { Abaixo de } 11,46 \text { Baixo comprometimento } \\
\text { Entre } 11,46 \text { e } 14,78 \text { Comprometimento abaixo da média } \\
\text { Entre } 14,78 \text { e } 17,85 \text { Comprometimento acima da média } \\
\text { Maior que } 17,85 \text { Alto comprometimento }\end{array}$ & & SECOMS & sultado & $\begin{array}{l}\text { Balxo } \\
\text { comp. }\end{array}$ & AF & 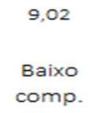 & $\mathrm{AC}$ & comp. & AN & comp. & AS & $\begin{array}{l}\text { Balxo } \\
\text { comp. }\end{array}$ & $\mathrm{A}$ & $\begin{array}{l}\text { Baixo } \\
\text { comp. }\end{array}$ & EU & $\begin{array}{l}\text { Baixo } \\
\text { comp. }\end{array}$ & oc & $\begin{array}{l}\text { Baixo } \\
\text { comp. }\end{array}$ \\
\hline
\end{tabular}


Tabela 02 - EBACO - COMPROMETIMENTO - ÁFRICA

Base afetiva: crença e identificação com a filosofia, valores e os objetivos organizacionais

\begin{tabular}{|c|c|c|c|c|c|c|c|c|c|c|c|c|}
\hline VARIÁVEIS & & PESO & $\begin{array}{l}\text { Média } \\
\text { África }\end{array}$ & $\begin{array}{l}\text { Média * } \\
\text { Peso }\end{array}$ & $\begin{array}{l}\text { África } \\
\text { Meridional }\end{array}$ & $\begin{array}{l}\text { Média - } \\
\text { Peso }\end{array}$ & $\begin{array}{l}\text { África } \\
\text { Ocidental }\end{array}$ & $\begin{array}{l}\text { Média - } \\
\text { Peso }\end{array}$ & $\begin{array}{c}\text { África } \\
\text { Oriental }\end{array}$ & $\begin{array}{l}\text { Média - } \\
\text { Peso }\end{array}$ & $\begin{array}{l}\text { Norte da } \\
\text { África }\end{array}$ & $\begin{array}{l}\text { Média } \\
\text { Peso }\end{array}$ \\
\hline $\begin{array}{l}\text { Desde que me juntei a essa organização, meus valores } \\
\text { pessoais e os da organização têm se tornado mais } \\
\text { similares. }\end{array}$ & $\mathrm{C}_{\text {Afe1 }}$ & 0,74 & 4,21 & 3,115 & 3,71 & 2,745 & 4,17 & 3,086 & 5 & 3,700 & 4,67 & 3,456 \\
\hline $\begin{array}{l}\text { A razão de eu preferir esta organização em relação a outras } \\
\text { é por causa do que ela simboliza, de seus valores. }\end{array}$ & $\mathrm{C}_{\text {Afez }}$ & 0,76 & 4,05 & 3,078 & 3,86 & 2,934 & 4 & 3,040 & 4,33 & 3,291 & 4,33 & 3,291 \\
\hline Eu me identifico com a filosofia desta organização & $\mathrm{C}_{\text {Afe3 }}$ & 0,8 & 4,42 & 3,536 & 4,43 & 3,544 & 4,33 & 3,464 & 5 & 4,000 & 4 & 3,200 \\
\hline Eu acredito nos valores e nos objetivos dessa organização & $\mathrm{C}_{\text {Afe4 }}$ & 0,78 & 4,74 & 3,697 & 4,33 & 3,377 & 4,83 & 3,767 & 5 & 3,900 & 5 & 3,900 \\
\hline $\begin{array}{l}\text { Abaixo de } 5,87 \text { Baixo comprometimento } \\
\text { Entre } 5,87 \text { e } 11,21 \text { comprometimento abaixo da média } \\
\text { Entre } 11,21 \text { e } 16,55 \text { Comprometimento acima da média } \\
\text { Maior que } 16,55 \text { Alto comprometimento }\end{array}$ & & & Resultado & $\begin{array}{l}13,43 \\
\text { comp. } \\
\text { acima da } \\
\text { média }\end{array}$ & & $\begin{array}{l}12,60 \\
\text { comp. } \\
\text { acima da } \\
\text { média }\end{array}$ & & $\begin{array}{l}13,36 \\
\text { comp. } \\
\text { acima da } \\
\text { média }\end{array}$ & & $\begin{array}{l}14,89 \\
\text { comp. } \\
\text { acima da } \\
\text { média }\end{array}$ & & $\begin{array}{l}13,85 \\
\text { comp. } \\
\text { acima da } \\
\text { média }\end{array}$ \\
\hline
\end{tabular}

Base obrigação em permanecer: Crença de que tem uma obrigạăo em permanecer; de que se sentiria culpado em deicar, de que não seria certo; eque tem u ma obrigação moral para com as pessoas da organização.

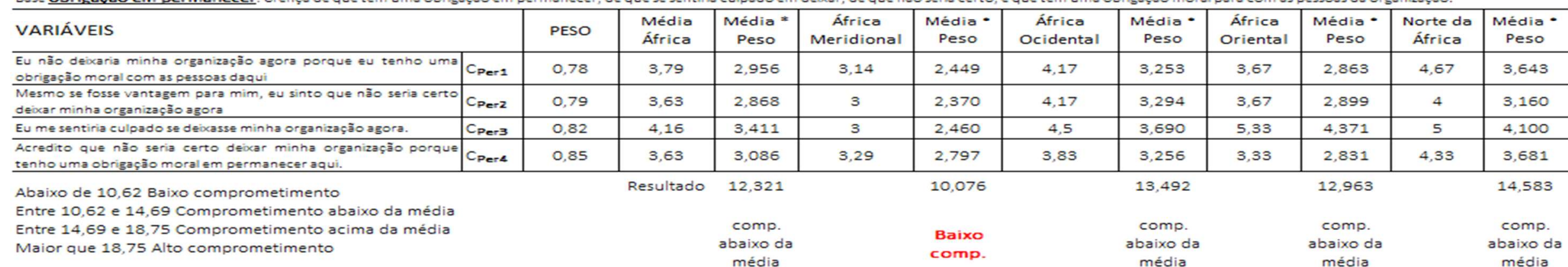

Mtre 14,69 e 18,75 Comprometimento acima da média

Base obrigação pelo desempenho: Crença de que deve se esforçar em benefício da organização e que deve buscar cumprir suas tarefas e atingir os objetivos VARIÁVEIS

Todo colaborador deve buscar atingir os objetivos da organização Eu tenho obrigạão em desempenhar bem minha função ness Organizą̧ăo

os melhores resultados possiveis.

Abaixo de 3,60 Baixo comprometimento

\begin{tabular}{|c|c|c|c|c|c|c|}
\hline & PESO & $\begin{array}{l}\text { Média } \\
\text { África }\end{array}$ & $\begin{array}{c}\text { Média * } \\
\text { Peso }\end{array}$ & $\begin{array}{c}\text { África } \\
\text { Meridional }\end{array}$ & $\begin{array}{c}\text { Média. } \\
\text { Peso }\end{array}$ & $\begin{array}{c}\text { África } \\
\text { Ocidental }\end{array}$ \\
\hline$C_{\text {Des } 1}$ & 0,65 & 5,26 & 3,419 & 5,29 & 3,439 & 5 \\
\hline$C_{\text {Desz }}$ & 0,81 & 5,79 & $4, \in 90$ & 5,71 & 4,625 & 5,67 \\
\hline$C_{\text {Des } 3}$ & 0,81 & 4,26 & 3,451 & 4,14 & 3,353 & 4,67 \\
\hline$C_{\text {Dese }}$ & 0,7 & 5,11 & 3,577 & 5,29 & 3,703 & 5,33 \\
\hline
\end{tabular}

Entre 3,60 e 8,38 Comprometimento abaixo da média

Maior que 13,34 Alto comprometimento

\author{
Alto
}

15,120

édia*

\begin{tabular}{|c|c|c|c}
\hline $\begin{array}{c}\text { África } \\
\text { Oriental }\end{array}$ & $\begin{array}{c}\text { Média - } \\
\text { Peso }\end{array}$ & $\begin{array}{c}\text { Norte da } \\
\text { África }\end{array}$ & $\begin{array}{c}\text { Média * } \\
\text { Peso }\end{array}$ \\
\hline 5,33 & 3,465 & 5,67 & 3,686 \\
\hline 6 & 4,860 & 6 & 4,860 \\
\hline 2,67 & 2,163 & 5,33 & 4,317 \\
\hline 3,67 & 2,569 & 5,67 & 3,969 \\
\hline \multicolumn{5}{|c}{13,056} & 16,832
\end{tabular}


Base Afiliativa: Crença de que é reconhecido pelos colegas como membro do grupo e da organizaça.

\begin{tabular}{|c|c|c|c|c|c|c|c|c|c|c|c|c|}
\hline \multicolumn{2}{|l|}{ VARIÁVEIS } & \multirow{2}{*}{$\begin{array}{c}\text { PESO } \\
0,72 \\
\end{array}$} & \multirow{2}{*}{$\begin{array}{l}\text { Média } \\
\text { África } \\
4,89\end{array}$} & \multirow{2}{*}{$\begin{array}{c}\begin{array}{c}\text { Média * } \\
\text { Peso }\end{array} \\
3,521 \\
\end{array}$} & \multirow{2}{*}{\begin{tabular}{c|}
$\begin{array}{c}\text { Africa } \\
\text { Meridional }\end{array}$ \\
4,71 \\
\end{tabular}} & \multirow{2}{*}{$\begin{array}{c}\begin{array}{c}\text { Media- } \\
\text { Peso }\end{array} \\
3,391 \\
\end{array}$} & \multirow{2}{*}{$\begin{array}{c}\text { África } \\
\text { Ocidental } \\
5\end{array}$} & \multirow{2}{*}{$\begin{array}{c}\begin{array}{c}\text { Média - } \\
\text { Peso }\end{array} \\
3,600\end{array}$} & \multirow{2}{*}{$\begin{array}{c}\text { África } \\
\text { Oriental } \\
5,33\end{array}$} & \multirow{2}{*}{$\begin{array}{c}\begin{array}{c}\text { Média - } \\
\text { Peso }\end{array} \\
3,838\end{array}$} & \multirow{2}{*}{$\begin{array}{c}\text { Norte da } \\
\text { África } \\
4,67\end{array}$} & \multirow{2}{*}{$\begin{array}{c}\begin{array}{c}\text { Média - } \\
\text { Peso }\end{array} \\
3,362 \\
\end{array}$} \\
\hline Nesta organização, eu sinto que faço parte do grupo. & $C_{\text {Afi1 }}$ & & & & & & & & & & & \\
\hline $\begin{array}{l}\text { Sou reconhecido por todos na organização como membro do } \\
\text { grupo }\end{array}$ & $c_{\text {afiz }}$ & 0,82 & 4,74 & 3,887 & 4,71 & 3,862 & 4,5 & 3,690 & 5,33 & 4,371 & 4,67 & 3,829 \\
\hline $\begin{array}{l}\text { Sinto que meus colegas me consideram como membro da equipe } \\
\text { detrabalho. }\end{array}$ & $C_{\text {Afi3 }}$ & 0,76 & 5,11 & 3,884 & 5,14 & 3,906 & 5 & 3,800 & 5,33 & 4,051 & 5 & 3,800 \\
\hline Fazer parte do grupoé o que me leva a lutar por esta organização. & Cafie & 0,68 & 4,47 & 3,040 & 4,29 & 2,917 & 4,17 & 2,836 & 5 & 3,400 & 5 & 3,400 \\
\hline $\begin{array}{l}\text { Abaixo de } 14,77 \text { Baixo comprometimento } \\
\text { Entre } 14,77 \text { e } 16,82 \text { Comprometimento abaixo da média } \\
\text { Entre } 16,82 \text { e } 17,88 \text { Comprometimento acima da média } \\
\text { Maior que } 17,88 \text { Alto comprometimento }\end{array}$ & & & Resultado & $\begin{array}{l}\text { Baixo } \\
\text { comp. }\end{array}$ & & $\begin{array}{l}\text { Baixo } \\
\text { comp. }\end{array}$ & & $\begin{array}{l}\text { Baixo } \\
\text { comp. }\end{array}$ & & $\begin{array}{c}15,659 \\
\text { comp. } \\
\text { abaixo } \\
\text { da } \\
\text { média }\end{array}$ & & $\begin{array}{l}\text { Baixo } \\
\text { comp. }\end{array}$ \\
\hline
\end{tabular}

Base falta de recompensas e de oportunidades: Crença de que o esforço extra em benefício da organização deve ser recompensado e de que a organizacão deve lhe dar mais oportunidades

VARIÁVEIS Se eu já não tivesse dado tanto de mim nesta A menos que eu seja recompensado de alguma maneira, ey hà vejo razbes para despender esforços extras em benefício desta organização.

daquela que eu expresso publicamente. Apesar dos estorcsos que eu já realla Abaixo de 4,36 Baixo comprometimento

\begin{tabular}{|c|c|c|}
\multicolumn{2}{l|}{} & PESO \\
\hline$C_{\text {Rec1 }}$ & 0,45 \\
\hline$C_{\text {Rec2 }}$ & 0,77 \\
\hline$C_{\text {Rec3 }}$ & 0,72 \\
\hline$C_{\text {Rec4 }}$ & 0,6 \\
\hline
\end{tabular}

\begin{tabular}{|c|c|}
\hline $\begin{array}{c}\text { Média } \\
\text { África }\end{array}$ & \\
\hline 2,84 & \\
\hline 2,32 & \\
\hline 2,05 & \\
2,79 & \\
\hline
\end{tabular}

\begin{tabular}{|c|}
\hline $\begin{array}{c}\text { Média * } \\
\text { Peso }\end{array}$ \\
\hline 1,278 \\
\hline 1,786 \\
\hline 1,476 \\
\hline 1,674 \\
\hline 6,214
\end{tabular}

\begin{tabular}{|c|c|c|}
\hline $\begin{array}{c}\text { África } \\
\text { Meridional }\end{array}$ & \\
\hline 2,86 & \\
\hline 2,14 & \\
\hline 2,29 & \\
3,14 & \\
\hline
\end{tabular}

intre 4,36 e 8,78 comprometimento abaixo da média Maior que 13,20 Alto comprometimento comp.
abaixo da 3,14

\begin{tabular}{|c|}
$\begin{array}{c}\text { Média- } \\
\text { Peso }\end{array}$ \\
\hline 1,287 \\
\hline 1,648 \\
\hline 1,649 \\
\hline 1,884 \\
\hline
\end{tabular}

\begin{tabular}{|c|c|}
\hline $\begin{array}{c}\text { África } \\
\text { Ocidental }\end{array}$ & $\begin{array}{c}\text { Média } \\
\text { Peso }\end{array}$ \\
\hline 2,17 & 0,977 \\
\hline 2 & 1,540 \\
\hline 2,33 & 1,678 \\
\hline 2,5 & 1,500 \\
\hline
\end{tabular}

\begin{tabular}{|c|c|c|c}
\hline $\begin{array}{c}\text { África } \\
\text { Oriental }\end{array}$ & $\begin{array}{c}\text { Média- } \\
\text { Peso }\end{array}$ & $\begin{array}{c}\text { Norte da } \\
\text { Africa }\end{array}$ & $\begin{array}{c}\text { Média- } \\
\text { Peso }\end{array}$ \\
\hline 2,67 & 1,202 & 4,33 & 1,949 \\
\hline 2 & 1,540 & 3,67 & 2,826 \\
\hline 1,33 & 0,958 & 2,35 & 1,692 \\
\hline 1,67 & 1,002 & 3,67 & 2,202 \\
\hline
\end{tabular}

abaixo da

5,694

1,002

8,668

Base linha consistente de atividade: Crença de que deve VARIÁVEIS Procuro não transgredir as regras aqui, pois assim sempre mantere meu emprago nesessidade tanto quanto um desejo atitudecerta Farsi sempro
emprego Abaixo de 8,52 Baixo comprometimento Entre 8,52 e 12,13 comprometimento abaixo da média Entre 8,52 e 12,13 Comprometimento abaixo da média
Entre 12,13 e 15,63 Comprometimento acima da média
Maior que 15,63 Alto comprometimento

\begin{tabular}{|c|c|}
\hline & PESO \\
\hline$c_{\text {con } 1}$ & 0,69 \\
\hline$c_{\text {conn }}$ & 0,58 \\
\hline$c_{\text {cons }}$ & 0,71 \\
\hline$c_{\text {Cona }}$ & 0,65 \\
\hline
\end{tabular}

\begin{tabular}{|c|}
\hline $\begin{array}{c}\text { Média } \\
\text { África }\end{array}$ \\
\hline 4,05 \\
\hline 3,74 \\
\hline 4 \\
\hline 4 \\
\hline
\end{tabular}

ertas a tit média

abaixo da

comp.

comp.
abaixo da média abaixo da
media

Base escassez de alternativas: crença de que possui poucas alternativas de trabalho se deixar a organização VARIÁVEIS

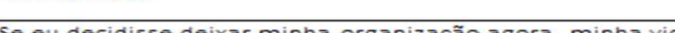
ficaria bastante desestruturada
Eu acho que teria poucas alternativas se deixasse essa organização. trabalho. Não deixaria este empre
oportunidades de trabalho. Abaixo de 11,46 Baixo comprometimento

baixo da média Entre 14,78 e 17,85 comprometimento acima da média

\begin{tabular}{|l|c|c|c|}
\multicolumn{2}{|l|}{} & PESO & $\begin{array}{c}\text { Média } \\
\text { África }\end{array}$ \\
\hline$C_{\text {ESc1 }}$ & 0,59 & 2,84 \\
\hline$C_{E S C 2}$ & 0,77 & 2,95 \\
\hline$C_{E S C 3}$ & 0,84 & 3,11 \\
\hline$C_{\text {Esc4 }}$ & 0,78 & 3,16 \\
\hline
\end{tabular}

Média * África

Me

manter na organização

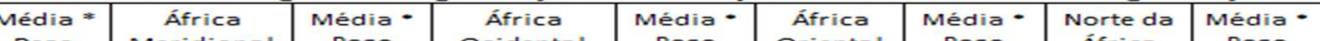
\begin{tabular}{c|c|c|}
\hline 2,795 & 4 & Meridional \\
\hline
\end{tabular} \begin{tabular}{l}
$\begin{array}{c}\text { Média } \\
\text { Peso }\end{array}$ \\
\hline 2,760 \\
\hline 2,071 \\
\hline 3,046 \\
\hline 2,600
\end{tabular} 2,840

\begin{tabular}{|l|}
\hline 3,57 \\
\hline 4,29 \\
\hline
\end{tabular}

\begin{tabular}{|c|c|}
\hline $\begin{array}{c}\text { África } \\
\text { Ocidental } \\
3,5\end{array}$ \\
\hline 3,33 \\
\hline 4 \\
\hline 4 \\
\hline
\end{tabular}

\begin{tabular}{|c|c|}
\hline $\begin{array}{c}\text { Média } \\
\text { Peso }\end{array}$ \\
\hline 2,415 \\
\hline 1,931 \\
\hline 2,840 \\
\hline 2,600 \\
\hline 9,780
\end{tabular}

\begin{tabular}{|c|c|}
\hline $\begin{array}{c}\text { África } \\
\text { Oriental }\end{array}$ \\
\hline 5 & \\
\hline 4,33 & \\
\hline 3,33 & \\
\hline 2,67 & \\
\hline
\end{tabular}

9,786

abaixo da
média

comp. $\begin{array}{ccc}\begin{array}{c}\text { abaixo da } \\ \text { média }\end{array} & \begin{array}{c}\text { abaixo da } \\ \text { média }\end{array} & \text { maixo da } \\ & & \text { média }\end{array}$

\begin{tabular}{c|c|c}
$\begin{array}{c}\text { Média- } \\
\text { Peso }\end{array}$ & $\begin{array}{c}\text { Norte da } \\
\text { Africa }\end{array}$ & $\begin{array}{c}\text { Média- } \\
\text { Peso }\end{array}$ \\
\hline 3,450 & 4,33 & 2,988 \\
\hline 2,511 & 4,33 & 2,511 \\
\hline 2,364 & 4 & 2,840 \\
\hline 1,736 & 5,33 & 3,465 \\
\hline
\end{tabular}

10,061

comp. $\begin{array}{ccc}\begin{array}{c}\text { abaixo da } \\ \text { média }\end{array} & \begin{array}{c}\text { abaixo da } \\ \text { média }\end{array} & \text { maixo da } \\ & & \text { média }\end{array}$

11.804

\begin{tabular}{|c|c|}
\hline $\begin{array}{c}\text { África } \\
\text { Meridional }\end{array}$ \\
\hline 3 \\
2,71 \\
2,71 \\
\hline 2,86 \\
\hline
\end{tabular}

(1)

$\mid$

\begin{tabular}{|c|c|c|c}
\hline $\begin{array}{c}\text { África } \\
\text { Oriental }\end{array}$ & $\begin{array}{c}\text { Média- } \\
\text { Peso }\end{array}$ & $\begin{array}{c}\text { Norte da } \\
\text { Africa }\end{array}$ & $\begin{array}{c}\text { Média- } \\
\text { Peso }\end{array}$ \\
\hline 3,67 & 2,165 & 2,33 & 1,375 \\
\hline 3,33 & 2,564 & 2 & 1,540 \\
\hline 3,33 & 2,797 & 2,67 & 2,243 \\
\hline 3 & 2,340 & 2,67 & 2,083 \\
\hline
\end{tabular}

8,364

2,987

9.867

7.240

Baixo

Baixo

Baixo
comp.

Baixo
comp. 
Tabela 03 - EBACO - COMPROMETIMENTO - AMÉRICA DO NORTE

Base afetiva: crença e identificação com a filosofia, valores e os objetivos organizacionais

\begin{tabular}{|c|c|c|c|c|c|c|c|c|}
\hline \multicolumn{2}{|l|}{ VARIÁVEIS } & \multirow{2}{*}{$\frac{\text { PESO }}{0,74}$} & \multirow{2}{*}{\begin{tabular}{|c|}
$\begin{array}{c}\text { Média Am. } \\
\text { do Norte }\end{array}$ \\
4,26
\end{tabular}} & \multirow{2}{*}{$\begin{array}{c}\begin{array}{c}\text { Média } \\
\text { Peso }\end{array} \\
3,152\end{array}$} & \multirow{2}{*}{$\begin{array}{c}\text { América Anglo- } \\
\text { Saxônica } \\
4,26\end{array}$} & \multirow{2}{*}{$\begin{array}{c}\begin{array}{c}\text { Média - } \\
\text { Peso }\end{array} \\
3,152\end{array}$} & \multirow{2}{*}{$\begin{array}{c}\text { América } \\
\text { Latina (AN) } \\
4\end{array}$} & \multirow{2}{*}{$\begin{array}{c}\begin{array}{c}\text { Média - } \\
\text { Peso }\end{array} \\
2,960\end{array}$} \\
\hline $\begin{array}{l}\text { Desde que me juntei a essa organização, meus valores } \\
\text { pessoais e os da organização têm se tornado mais } \\
\text { similares. }\end{array}$ & $C_{\text {Afe } 1}$ & & & & & & & \\
\hline $\begin{array}{l}\text { A razão de eu preferir esta organização em relação a outras } \\
\text { é por causa do que ela simboliza, de seus valores. }\end{array}$ & $C_{\text {Afe } 2}$ & 0,76 & 4,46 & 3,390 & 4,47 & 3,397 & 4 & 3,040 \\
\hline Eu me identifico com a filosofia desta organização & $C_{\text {Afe3 }}$ & 0,8 & 4,57 & 3,656 & 4,53 & 3,624 & 6 & 4,800 \\
\hline Eu acredito nos valores e nos objetivos dessa organização & $C_{\text {Afe4 }}$ & 0,78 & 4,89 & 3,814 & 4,88 & 3,806 & 5 & 3,900 \\
\hline
\end{tabular}

comp. acima da média

comp. acima da média

comp. acima da média

Base obrigação em permanecer: Crença de que tem uma obrigação em permanecer; de que se sentiria culpado em deixar, de que não seria certo; e que tem uma obrigação moral para com as pessoas da organização.

\begin{tabular}{|c|c|c|c|c|c|c|c|c|}
\hline VARIÁVEIS & & PESO & \begin{tabular}{|c|}
$\begin{array}{c}\text { Média Am. } \\
\text { do Norte }\end{array}$ \\
\end{tabular} & $\begin{array}{l}\text { Média * } \\
\text { Peso }\end{array}$ & $\begin{array}{c}\text { América Anglo- } \\
\text { Saxônica }\end{array}$ & $\begin{array}{l}\text { Média - } \\
\text { Peso }\end{array}$ & $\begin{array}{c}\text { América } \\
\text { Latina (AN) }\end{array}$ & $\begin{array}{c}\text { Média - } \\
\text { Peso }\end{array}$ \\
\hline $\begin{array}{l}\text { Eu não deicaria minha organização agora porque eu tenho uma } \\
\text { obrigaçăo moral com as pessoas daqui }\end{array}$ & $C_{\text {Per } 1}$ & 0,78 & 3,2 & 2,496 & 3,18 & 2,480 & 4 & 3,120 \\
\hline $\begin{array}{l}\text { Mesmo se fosse vantagem para mim, eu sinto que não seria certo } \\
\text { deixar minha organização agora }\end{array}$ & Cer2 & 0,79 & 2,91 & 2,299 & 2,91 & 2,299 & 3 & 2,370 \\
\hline Eu me sentiria culpado se deixasse minha organização agora. & $C_{\text {Per3 }}$ & 0,82 & 2,66 & 2,181 & 2,59 & 2,124 & 5 & 4,100 \\
\hline $\begin{array}{l}\text { Acredito que não seria certo deicar minha organização porque } \\
\text { tenho uma obrigação moral em permanecer aqui. }\end{array}$ & $C_{\text {Per } 4}$ & 0,85 & 2,6 & 2,210 & 2,56 & 2,176 & 4 & 3,400 \\
\hline
\end{tabular}

Baixo comp.

Baixo comp.

comp. abaixo da média

Base obrigação pelo desempenho: Crença de que deve se esforçar em benefício da organização e que deve buscar

\begin{tabular}{|c|c|c|c|c|c|c|c|c|}
\hline \multicolumn{2}{|l|}{ VARIÁVEIS } & \multirow{2}{*}{ PESO } & \multirow{2}{*}{\begin{tabular}{|c|}
$\begin{array}{c}\text { Média Am. } \\
\text { do Norte }\end{array}$ \\
5,51 \\
\end{tabular}} & \multirow{2}{*}{$\begin{array}{c}\begin{array}{c}\text { Média * } \\
\text { Peso }\end{array} \\
3,582\end{array}$} & \multirow{2}{*}{$\begin{array}{c}\text { América Anglo- } \\
\text { Saxônica } \\
5,5\end{array}$} & \multirow{2}{*}{$\begin{array}{c}\begin{array}{c}\text { Média - } \\
\text { Peso }\end{array} \\
6,150\end{array}$} & \multirow{2}{*}{$\begin{array}{c}\text { América } \\
\text { Latina (AN) } \\
6\end{array}$} & \multirow{2}{*}{$\begin{array}{c}\text { Média - } \\
\text { Peso } \\
3,900\end{array}$} \\
\hline Todo colaborador deve buscar atingir os objetivos da organização & $C_{\text {Des1 }}$ & & & & & & & \\
\hline $\begin{array}{l}\text { Eu tenho obrigação em desempenhar bem minha função nessa } \\
\text { organização }\end{array}$ & $C_{\text {Des2 }}$ & 0,81 & 5,69 & 4,609 & 5,71 & 6,520 & 5 & 4,050 \\
\hline $\begin{array}{l}\text { O bom colaborador devese esforçar para que a organização tenha } \\
\text { os melhores resultados possiveis. }\end{array}$ & $C_{\text {Des3 }}$ & 0,81 & 5,06 & 4,099 & 5,09 & 5,900 & 4 & 3,240 \\
\hline O colaborador tem a obrigação de sempre cumprir suas tarefas. & $C_{\text {Des4 }}$ & 0,7 & 5,69 & 3,983 & 5,68 & 6,380 & 6 & 4,200 \\
\hline & & & Resultado & 16,272 & & 24,950 & & 15,390 \\
\hline
\end{tabular}

Alto comp.

Alto comp.

Alto comp. 
Base Afiliativa: Crença de que é reconhecido pelos colegas como membro do grupo e da organização VARIÁVEIS

Nesta organizaçăo, eu sinto que faco partedo grupo.

Sou reconhecido por todos na organizaça como membro

grupo

detrabalho.

Fazer partedo grupób oue meleva a lutar por esta organizạăo.

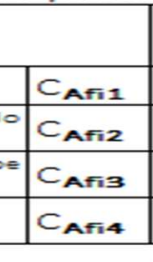

\begin{tabular}{|c|c|}
\hline PESO & $\begin{array}{c}\text { Média Am. } \\
\text { do Norte }\end{array}$ \\
\hline 0,72 & 5,14 \\
\hline 0,82 & 5,26 \\
\hline 0,76 & 5,49 \\
\hline 0,68 & 4,66 \\
\hline
\end{tabular}

Resultado

\begin{tabular}{c|c}
$\begin{array}{c}\text { Média } \\
\text { Peso }\end{array}$ & $\begin{array}{c}\text { América Anglo- } \\
\text { Saxônica }\end{array}$ \\
\hline 3,701 & 5,12 \\
\hline 4,313 & 5,24 \\
\hline 4,172 & 5,47 \\
\hline 3,169 & 4,62 \\
\hline
\end{tabular}

\begin{tabular}{|c|}
$\begin{array}{c}\text { Média } \\
\text { Peso }\end{array}$ \\
\hline 3,686 \\
\hline 4,297 \\
\hline 4,157 \\
\hline 3,142 \\
\hline
\end{tabular}

15,282

comp. Abaixo da média

\begin{tabular}{|c|c}
\hline $\begin{array}{c}\text { América } \\
\text { Latina (AN) }\end{array}$ & $\begin{array}{c}\text { Média - } \\
\text { Peso }\end{array}$ \\
\hline 6 & 4,320 \\
\hline 6 & 4,920 \\
\hline 6 & 4,560 \\
\hline 6 & 4,080 \\
\hline \multicolumn{2}{|c}{17,880}
\end{tabular}

comp. Acima da média

Base falta de recompensas e de oportunidades: Crença de que o esforço extra em benefício da organização deve ser recompensado e de que a organização deve lhe dar mais oportunidades

\section{VARIÁVEIS}

Se eu já não tivesse dado tanto de mim nesta organizaçăo, eu $\pm 0 \mid C_{\text {Rec1 }}$ A menos que eu seja recompensado de alguma maneira, eu não

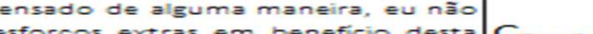
Minha visão pessoal sobre esta organização édiferente daquela que Au expresso publicamente. mim nesta organizaçầ.

\begin{tabular}{|l|}
\hline Rec1 \\
\hline$C_{\text {Rec2 }}$ \\
\hline$C_{\text {Rec3 }}$ \\
\hline Rec4 \\
\hline
\end{tabular}

\begin{tabular}{|c|c|}
\hline PESO & $\begin{array}{c}\text { Média Am. } \\
\text { do Norte }\end{array}$ \\
\hline 0,45 & 2,43 \\
\hline 0,77 & 2,03 \\
\hline 0,72 & 1,89 \\
\hline 0,6 & 2,8 \\
\hline
\end{tabular}

Resultado

\begin{tabular}{l|l}
2,8 & 1,680 \\
\hline
\end{tabular}

5,697

comp abaixo da média

\begin{tabular}{c|c|c|c|c}
$\begin{array}{c}\text { Média } \\
\text { Peso }\end{array}$ & $\begin{array}{c}\text { América Anglo- } \\
\text { Saxônica }\end{array}$ & $\begin{array}{c}\text { Média } \\
\text { Peso }\end{array}$ & $\begin{array}{c}\text { América } \\
\text { Latina (AN) }\end{array}$ & $\begin{array}{c}\text { Média - } \\
\text { Peso }\end{array}$ \\
\hline 1,094 & 2,44 & 1,098 & 2 & 0,900 \\
\hline 1,563 & 2,03 & 1,563 & 2 & 1,540 \\
\hline 1,361 & 1,91 & 1,375 & 1 & 0,720 \\
\hline 1,680 & 2,82 & 1,692 & 2 & 1,200 \\
\hline 5,697 & \multicolumn{4}{c|}{5,728} \\
\hline
\end{tabular}

comp abaixo da media

Baixo comp

Base linha consistente de atividade: Crença de que deve manter certas atitudes e regras da organizaçăo com o objetivo de se manter VARIÁVEIS

Procuro nãotransgredir as regras aqui, pois assim sempremantere meu emprego necessidadetanto tauanto um desejo
Para conseguir ser recompensado aqui é necessário expressar

\begin{tabular}{l|l} 
atitudecerta & $C_{\text {Con3 }}$ \\
\hline Farei sempre o possivel no meu trabalho para me manter neste & C Cons
\end{tabular} empreso

\begin{tabular}{|l|}
$c_{\operatorname{con} 1}$ \\
$c_{\operatorname{con} 2}$ \\
\hline$c_{\text {con } 3}$ \\
\hline
\end{tabular}

\begin{tabular}{c|c|c} 
PESO & $\begin{array}{c}\text { Média Am } \\
\text { do Norte }\end{array}$ & $\begin{array}{c}\text { Média * } \\
\text { Peso }\end{array}$ \\
\hline 0,69 & 4,03 & 2,781 \\
\hline 0,58 & 4,2 & 2,436 \\
\hline 0,71 & 4,14 & 2,939 \\
\hline 0,65 & 4,31 & 2,802 \\
\hline
\end{tabular}

Resultado 10,958

comp. abaixo da médi

\begin{tabular}{c|c|c|c}
$\begin{array}{c}\text { América Anglo- } \\
\text { Saxónica }\end{array}$ & $\begin{array}{c}\text { Média } \\
\text { Peso }\end{array}$ & $\begin{array}{c}\text { América } \\
\text { Latina (AN) }\end{array}$ & $\begin{array}{c}\text { Médiá- } \\
\text { Peso }\end{array}$ \\
\hline 4,09 & 2,822 & 2 & 1,380 \\
\hline 4,21 & 2,442 & 4 & 2,320 \\
\hline 4,12 & 2,925 & 5 & 3,550 \\
\hline 4,32 & 2,808 & 4 & 2,600 \\
\hline \multicolumn{4}{c}{10,997}
\end{tabular}

comp. abaixo da média

Base escassez de alternativas: crença de que possui poucas alternativas de trabalho se deixar a organização

\section{VARIÁVEIS}

Se eu decidisse deixar minha organização agora, minha vida ficaria $C_{\text {Esc1 }}$ bastantedesestruturada

Eu acho que teria poucas alternativas se deixasse essa organização. Uma das consequências nęativas de deicar esta organizacão seria escassez de alternativas imediatas detrabalho. detrabalno.

\begin{tabular}{|l|}
\hline \\
$C_{\text {Esc1 }}$ \\
\hline$C_{\text {Esc2 } 3}$ \\
\hline$C_{\text {Esc4 }}$ \\
\hline
\end{tabular}

\begin{tabular}{|c|c|}
\hline PESO & M \\
\hline 0,59 & \\
\hline 0,77 & \\
\hline 0,84 & \\
\hline 0,78 & \\
\hline
\end{tabular}

\begin{tabular}{|c|c|c|}
$\begin{array}{c}\text { Média Am. } \\
\text { do Norte }\end{array}$ & $\begin{array}{c}\text { Média } \\
\text { Peso }\end{array}$ & $\begin{array}{c}\text { América Anglo- } \\
\text { Saxônica }\end{array}$ \\
\hline 3,97 & 2,342 & 3,91 \\
\hline 2,83 & 2,179 & 2,79 \\
\hline 2,97 & 2,495 & 2,88 \\
\hline 2,91 & 2,270 & 2,88 \\
\hline
\end{tabular}

\begin{tabular}{l|r} 
& 2,270 \\
\hline & 9,286
\end{tabular}

2,88

\begin{tabular}{|c|c|c}
$\begin{array}{c}\text { Média - } \\
\text { Peso }\end{array}$ & $\begin{array}{c}\text { América } \\
\text { Latina (AN) }\end{array}$ & $\begin{array}{c}\text { Média- } \\
\text { Peso }\end{array}$ \\
\hline 2,307 & 6 & 3,540 \\
\hline 2,148 & 4 & 3,080 \\
\hline 2,419 & 6 & 5,040 \\
\hline 2,246 & 4 & 3,120 \\
\hline 9,121 & \multicolumn{3}{|c}{14,780}
\end{tabular}

Baixo comp. 14,780
comp. abaixo da média 
Tabela 04 - EBACO - COMPROMETIMENTO - ÁSIA

Base afetiva: crença e identificação com a filosofia, valores e os objetivos organizacionais

\begin{tabular}{|c|c|c|c|c|c|c|c|c|c|c|c|c|c|c|}
\hline VARIÁVEIS & & PESO & $\begin{array}{c}\text { Média } \\
\text { Ásia }\end{array}$ & \begin{tabular}{|c|c|c|} 
Média * \\
Peso
\end{tabular} & $\begin{array}{l}\text { Ásia } \\
\text { Oriental }\end{array}$ & $\begin{array}{c}\text { Média* } \\
\text { Peso }\end{array}$ & $\begin{array}{l}\text { Extremo } \\
\text { Oriente }\end{array}$ & $\begin{array}{c}\text { Média } * \\
\text { Peso }\end{array}$ & $\begin{array}{l}\text { Oriente } \\
\text { Médio }\end{array}$ & $\begin{array}{l}\text { Média }{ }^{*} \\
\text { Peso }\end{array}$ & $\begin{array}{l}\text { Sudeste } \\
\text { Asiático }\end{array}$ & \begin{tabular}{|c|} 
Média * \\
Peso
\end{tabular} & $\begin{array}{c}\text { Sul da } \\
\text { Ásia }\end{array}$ & $\begin{array}{c}\text { Média * } \\
\text { Peso }\end{array}$ \\
\hline $\begin{array}{l}\text { Desde que me juntei a essa organização, meus valores } \\
\text { pessoais e os da organização têm se tornado mais } \\
\text { similares. }\end{array}$ & $C_{\text {Afe1 }}$ & 0,74 & 4,47 & 3,308 & 4,35 & 3,219 & 4 & 2,960 & 4,44 & 3,286 & 4,37 & 3,234 & 5,5 & 4,070 \\
\hline $\begin{array}{l}\text { A razão de eu preferir esta organização em relação a } \\
\text { outras é por causa do que ela simboliza, de seus valores. }\end{array}$ & $\mathrm{C}_{\text {Afe2 }}$ & 0,76 & 4,75 & 3,610 & 4,52 & 3,435 & 4,5 & 3,420 & 5 & 3,800 & 4,79 & 3,640 & 5,17 & 3,929 \\
\hline Eu me identifico com a filosofia desta organização & $C_{\text {Afe3 }}$ & 0,8 & 4,47 & 3,576 & 4,3 & 3,440 & 4,5 & 3,600 & 4,44 & 3,552 & 4,42 & 3,536 & 5,33 & 4,264 \\
\hline $\begin{array}{l}\text { Eu acredito nos valores e nos objetivos dessa } \\
\text { organização }\end{array}$ & $\mathrm{C}_{\text {Afe4 }}$ & 0,78 & 4,83 & 3,767 & 4,57 & 3,565 & 5 & 3,900 & 5 & 3,900 & 4,84 & 3,775 & 5,5 & 4,290 \\
\hline
\end{tabular}

Base obrigação em permanecer: Crença de que tem uma obrigação em permanecer; de que se sentiria culpado em deixar, de que não seria certo; e que tem uma obrigação moral para com as pessoas da organizacão.

\begin{tabular}{|c|c|c|c|c|c|c|c|c|c|c|c|c|c|c|}
\hline VARIÁVEIS & & PESO & $\begin{array}{c}\text { Média } \\
\text { Ásia }\end{array}$ & $\begin{array}{c}\begin{array}{c}\text { Média * } \\
\text { Peso }\end{array} \\
\end{array}$ & \begin{tabular}{|c|} 
Ásia \\
Oriental \\
\end{tabular} & \begin{tabular}{|c|} 
Média* \\
Peso
\end{tabular} & $\begin{array}{l}\text { Extremo } \\
\text { Oriente }\end{array}$ & $\begin{array}{c}\text { Média* } \\
\text { Peso }\end{array}$ & $\begin{array}{l}\text { Oriente } \\
\text { Médio }\end{array}$ & $\begin{array}{c}\text { Média* } \\
\text { Peso }\end{array}$ & $\begin{array}{r}\text { Sudeste } \\
\text { Asiático }\end{array}$ & $\begin{array}{c}\text { Média* } \\
\text { Peso }\end{array}$ & $\begin{array}{c}\text { Sul da } \\
\text { Ásia }\end{array}$ & $\begin{array}{c}\text { Média * } \\
\text { Peso }\end{array}$ \\
\hline $\begin{array}{l}\text { Eu não deixaria minha organização agora porque eu } \\
\text { tenho uma obrigação moral com as pessoas daqui }\end{array}$ & $C_{\text {Per } 1}$ & 0,78 & 4,41 & 3,440 & 4,43 & 3,455 & 5,5 & 4,290 & 4,33 & 3,377 & 4 & 3,120 & 5,33 & 4,157 \\
\hline $\begin{array}{l}\text { Mesmo se fosse vantagem para mim, eu sinto que não } \\
\text { seria certo deixar minha organização agora }\end{array}$ & $C_{\text {Per2 }}$ & 0,79 & 4,36 & 3,444 & 4,48 & 3,539 & 4,5 & 3,555 & 4,33 & 3,421 & 4 & 3,160 & 5 & 3,950 \\
\hline $\begin{array}{l}\text { Eu me sentiria culpado se deixasse minha organização } \\
\text { agora. }\end{array}$ & Cer3 & 0,82 & 3,88 & 3,182 & 3,7 & 3,034 & 5 & 4,100 & 3,67 & 3,009 & 4 & 3,280 & 4,17 & 3,419 \\
\hline $\begin{array}{l}\text { Acredito que não seria certo deixar minha organização } \\
\text { porque tenho uma obrigação moral em permanecer } \\
\text { aqui. }\end{array}$ & $C_{\text {Per4 }}$ & 0,85 & 3,85 & 3,273 & 3,91 & 3,324 & 5 & 4,250 & 3,67 & 3,120 & 3,68 & 3,128 & 4 & 3,400 \\
\hline & & & Resultado & $\begin{array}{l}13,338 \\
\text { comp. } \\
\text { abaixo da } \\
\text { média }\end{array}$ & & $\begin{array}{l}13,352 \\
\text { comp. } \\
\text { abaixo da } \\
\text { média }\end{array}$ & & $\begin{array}{l}16,195 \\
\text { comp. } \\
\text { acima da } \\
\text { média }\end{array}$ & & $\begin{array}{l}12,927 \\
\text { comp. } \\
\text { abaixo da } \\
\text { média }\end{array}$ & & $\begin{array}{l}12,688 \\
\text { comp. } \\
\text { abaixo da } \\
\text { média }\end{array}$ & A. & $\begin{array}{l}14,927 \\
\text { comp. } \\
\text { acima da } \\
\text { média }\end{array}$ \\
\hline
\end{tabular}

Base obrigação pelo desempenho: Crença de que deve se esforçar em beneficio da organização e que deve buscar cumprir suas tarefas e atingir os objetivos organizacionais.

\begin{tabular}{|c|c|c|c|c|c|c|c|c|c|c|c|c|c|c|}
\hline \multicolumn{2}{|l|}{ VARIÁVEIS } & \multirow{2}{*}{$\begin{array}{c}\text { PESO } \\
0,65\end{array}$} & \multirow{2}{*}{$\begin{array}{c}\begin{array}{c}\text { Média } \\
\text { Ásia }\end{array} \\
5,53\end{array}$} & \multirow{2}{*}{\begin{tabular}{|c|}
$\begin{array}{c}\text { Média * } \\
\text { Peso }\end{array}$ \\
3,595
\end{tabular}} & \multirow{2}{*}{\begin{tabular}{|c|}
$\begin{array}{c}\text { Ásia } \\
\text { Oriental }\end{array}$ \\
5,39 \\
\end{tabular}} & \multirow{2}{*}{\begin{tabular}{|c}
$\begin{array}{c}\text { Média * } \\
\text { Peso }\end{array}$ \\
3,504 \\
\end{tabular}} & \multirow{2}{*}{$\begin{array}{c}\begin{array}{c}\text { Extremo } \\
\text { Oriente }\end{array} \\
5,5\end{array}$} & \multirow{2}{*}{$\begin{array}{c}\begin{array}{c}\text { Média * } \\
\text { Peso }\end{array} \\
3,575\end{array}$} & \multirow{2}{*}{$\begin{array}{c}\begin{array}{c}\text { Oriente } \\
\text { Médio }\end{array} \\
5,33\end{array}$} & \multirow{2}{*}{$\begin{array}{c}\begin{array}{c}\text { Média * } \\
\text { Peso }\end{array} \\
3,465\end{array}$} & \multirow{2}{*}{$\begin{array}{c}\begin{array}{r}\text { Sudeste } \\
\text { Asiático }\end{array} \\
5,63\end{array}$} & \multirow{2}{*}{\begin{tabular}{|c|}
$\begin{array}{c}\text { Média * } \\
\text { Peso }\end{array}$ \\
3,660 \\
\end{tabular}} & \multirow{2}{*}{$\begin{array}{c}\begin{array}{c}\text { Sul da } \\
\text { Ásia }\end{array} \\
6\end{array}$} & \multirow{2}{*}{\begin{tabular}{|c|}
$\begin{array}{c}\text { Média * } \\
\text { Peso }\end{array}$ \\
3,900
\end{tabular}} \\
\hline $\begin{array}{l}\text { Todo colaborador deve buscar atingir os objetivos da } \\
\text { organização }\end{array}$ & $\mathrm{C}_{\text {Des1 }}$ & & & & & & & & & & & & & \\
\hline $\begin{array}{l}\text { Eu tenho obrigação em desempenhar bem minha } \\
\text { função nessa organização }\end{array}$ & $C_{\text {Des2 }}$ & 0,81 & 5,69 & 4,609 & 5,65 & 4,577 & 6 & 4,860 & 5,56 & 4,504 & 5,68 & 4,601 & 6 & 4,860 \\
\hline $\begin{array}{l}\text { O bom colaborador deve se esforçar para que a } \\
\text { organização tenha os melhores resultados possiveis. }\end{array}$ & $C_{\text {Des3 }}$ & 0,81 & 4,71 & 3,815 & 5,57 & 4,512 & 3 & 2,430 & 4,78 & 3,872 & 4,11 & 3,329 & 3,83 & 3,102 \\
\hline $\begin{array}{l}\text { O colaborador tem a obrigação de sempre cumprir suas } \\
\text { tarefas. }\end{array}$ & $C_{\text {Des4 }}$ & 0,7 & 5,54 & 3,878 & 5,57 & 3,899 & 5,5 & 3,850 & 5,33 & 3,731 & 5,53 & 3,871 & 5,83 & 4,081 \\
\hline & & & esultado & $\begin{array}{l}15,897 \\
\text { Alto } \\
\text { comp. }\end{array}$ & & $\begin{array}{l}16,491 \\
\text { Alto } \\
\text { comp. }\end{array}$ & & $\begin{array}{l}14,715 \\
\text { Alto } \\
\text { comp. }\end{array}$ & & $\begin{array}{l}15,571 \\
\text { Alto } \\
\text { comp. }\end{array}$ & & $\begin{array}{l}15,460 \\
\text { Alto } \\
\text { comp. }\end{array}$ & & $\begin{array}{l}15,943 \\
\text { Alto } \\
\text { comp. }\end{array}$ \\
\hline
\end{tabular}


Base Afiliativa: Crença de que é reconhecido pelos colegas como membro do grupo e da organização.

\begin{tabular}{|c|c|c|c|c|c|c|c|c|c|c|c|c|c|c|}
\hline VARIÁVEIS & & PESO & $\begin{array}{l}\text { Média } \\
\text { Ásia }\end{array}$ & $\begin{array}{c}\text { Média * } \\
\text { Peso }\end{array}$ & $\begin{array}{c}\text { Asia } \\
\text { Oriental }\end{array}$ & $\begin{array}{l}\text { Média* } \\
\text { Peso }\end{array}$ & $\begin{array}{l}\text { Extremo } \\
\text { Oriente }\end{array}$ & $\begin{array}{l}\text { Média* } \\
\text { Peso }\end{array}$ & $\begin{array}{l}\text { Oriente } \\
\text { Médio }\end{array}$ & $\begin{array}{c}\text { Média }{ }^{*} \\
\text { Pesoo }\end{array}$ & $\begin{array}{l}\text { Sudeste } \\
\text { Asiático }\end{array}$ & $\begin{array}{c}\text { Média } * \mid \\
\text { Peso }\end{array}$ & $\begin{array}{l}\text { Sul da } \\
\text { Ásia }\end{array}$ & $\begin{array}{c}\text { Média * } \\
\text { Peso }\end{array}$ \\
\hline Nesta organização, eu sinto que faço parte do grupo. & $C_{\text {Afi1 }}$ & 0,72 & 5,47 & 3,938 & 5,39 & 3,881 & 5,5 & 3,960 & 5,33 & 3,838 & 5,63 & 4,054 & 5,5 & 3,960 \\
\hline $\begin{array}{l}\text { Sou reconhecido por todos na organização como } \\
\text { membro do grupo }\end{array}$ & $C_{\text {Afi2 }}$ & 0,82 & 5,39 & 4,420 & 5,17 & 4,239 & 5,5 & 4,510 & 5,33 & 4,371 & 5,63 & 4,617 & 5,5 & 4,510 \\
\hline $\begin{array}{l}\text { Sinto que meus colegas me consideram como membro } \\
\text { da equipe de trabalho. }\end{array}$ & $C_{\text {Afi3 }}$ & 0.76 & 5,46 & 4,150 & 5,35 & 4,066 & 5,5 & 4,180 & 5,33 & 4,051 & 5,58 & 4,241 & 5,67 & 4,309 \\
\hline $\begin{array}{l}\text { Fazer parte do grupo é o que me leva a lutar por esta } \\
\text { organização. }\end{array}$ & $\mathrm{C}_{\mathrm{Afi} i}$ & 0,68 & 4,61 & 3,135 & 4,57 & 3,108 & 4,5 & 3,060 & 4,56 & 3,101 & 4,58 & 3,114 & 5 & 3,400 \\
\hline & & & Resultado & $\begin{array}{l}15,643 \\
\text { comp. } \\
\text { abaixo da } \\
\text { média }\end{array}$ & & $\begin{array}{l}15,294 \\
\text { comp. } \\
\text { abaixo da } \\
\text { média }\end{array}$ & & $\begin{array}{l}15,710 \\
\text { comp. } \\
\text { abaixo da } \\
\text { média }\end{array}$ & & $\begin{array}{l}15,360 \\
\text { comp. } \\
\text { abaixo da } \\
\text { média }\end{array}$ & & $\begin{array}{l}16,025 \\
\text { comp. } \\
\text { abaixo da } \\
\text { média }\end{array}$ & & $\begin{array}{l}16,179 \\
\text { comp. } \\
\text { abaixo } \\
\text { da } \\
\text { média }\end{array}$ \\
\hline
\end{tabular}

Base falta de recompensas e de oportunidades: Crença de que o esforço extra em benefício da organização deve ser recompensado e de que a organização deve lhe dar mais méd

\begin{tabular}{|c|c|c|c|c|c|c|c|c|c|c|c|c|c|c|}
\hline VARIÁVEIS & & PESO & $\begin{array}{l}\text { Média } \\
\text { Ásia }\end{array}$ & \begin{tabular}{|c|} 
Média * \\
Peso
\end{tabular} & $\begin{array}{c}\text { Ásia } \\
\text { Oriental }\end{array}$ & $\begin{array}{c}\text { Média * } \\
\text { Peso }\end{array}$ & $\begin{array}{l}\text { Extremo } \\
\text { Oriente }\end{array}$ & $\begin{array}{c}\text { Média } \\
\text { Peso }\end{array}$ & $\begin{array}{l}\text { Oriente } \\
\text { Médio }\end{array}$ & $\begin{array}{c}\text { Média * } \\
\text { Peso }\end{array}$ & $\begin{array}{l}\text { Sudeste } \\
\text { Asiático }\end{array}$ & \begin{tabular}{|c|}
$\begin{array}{c}\text { Média } \\
\text { Peso }\end{array}$ \\
\end{tabular} & $\begin{array}{l}\text { Sul da } \\
\text { Ásia }\end{array}$ & $\begin{array}{l}\text { Média * } \\
\text { Peso }\end{array}$ \\
\hline $\begin{array}{l}\text { Se eu já não tivesse dado tanto de mim nesta } \\
\text { organizaçao, eu poderia considerar trabalhar em outro } \\
\text { lugar. }\end{array}$ & $C_{\text {Rec1 }}$ & 0,45 & 3,32 & 1,494 & 3,65 & 1,643 & 1,5 & 0,675 & 3,11 & 1,400 & 3,37 & 1,517 & 2,83 & 1,274 \\
\hline $\begin{array}{l}\text { A menos que eu seja recompensado de alguma maneira, } \\
\text { eu não vejo razóes para despender esforços extras em } \\
\text { benefício desta organizaçao. }\end{array}$ & $C_{\text {Rec2 }}$ & 0,77 & 2,64 & 2,033 & 2,7 & 2,079 & 1,5 & 1,155 & 2,56 & 1,971 & 2,79 & 2,148 & 2,5 & 1,925 \\
\hline $\begin{array}{l}\text { Minha visão pessoal sobre esta organização é diferente } \\
\text { daquela que euv expresso publicamente. }\end{array}$ & $C_{\text {Rec3 }}$ & 0,72 & 2,44 & 1,757 & 2,83 & 2,038 & 2 & 1,440 & 2,11 & 1,519 & 2,42 & 1,742 & 1,67 & 1,202 \\
\hline $\begin{array}{l}\text { Apesar dos esforços que eu já realizei, não vejo } \\
\text { oportunidades para mim nesta organizacão. }\end{array}$ & $C_{\text {Rec4 }}$ & 0,6 & 3,07 & 1,842 & 3,57 & 2,142 & 1,5 & 0,900 & 3 & 1,800 & 2,84 & 1,704 & 2,5 & 1,500 \\
\hline & & & tsultado & $\begin{array}{c}7,126 \\
\text { comp. } \\
\text { abaixo da } \\
\text { média }\end{array}$ & & $\begin{array}{l}7,901 \\
\text { comp. } \\
\text { abaixo da } \\
\text { média }\end{array}$ & & $\begin{array}{l}4,170 \\
\text { Baixo } \\
\text { comp. }\end{array}$ & & $\begin{array}{c}6,690 \\
\text { comp. } \\
\text { abaixo da } \\
\text { média }\end{array}$ & & $\begin{array}{l}7,111 \\
\text { comp. } \\
\text { abaixo da } \\
\text { média }\end{array}$ & & $\begin{array}{l}5,901 \\
\text { comp. } \\
\text { abaixo } \\
\text { da } \\
\text { média }\end{array}$ \\
\hline
\end{tabular}

Base linha consistente de atividade: Crença de que deve manter certas atitudes e regras da organização com o objetivo de se manter na organização

\begin{tabular}{|c|c|c|c|c|c|c|c|c|c|c|c|c|c|c|}
\hline VARIÁVEIS & & PESO & $\begin{array}{c}\text { Média } \\
\text { Ásia }\end{array}$ & \begin{tabular}{|c|} 
Média* \\
Peso
\end{tabular} & $\begin{array}{c}\text { Ásia } \\
\text { Oriental }\end{array}$ & $\begin{array}{c}\text { Média * } \\
\text { Peso }\end{array}$ & $\begin{array}{l}\text { Extremo } \\
\text { Oriente }\end{array}$ & $\begin{array}{c}\text { Média * } \\
\text { Peso }\end{array}$ & $\begin{array}{l}\text { Oriente } \\
\text { Médio }\end{array}$ & $\begin{array}{c}\text { Média* } \\
\text { Peso }\end{array}$ & $\begin{array}{l}\text { Sudeste } \\
\text { Asiático }\end{array}$ & $\begin{array}{c}\text { Média * } \\
\text { Peso }\end{array}$ & $\begin{array}{c}\text { Sulda } \\
\text { Ásia }\end{array}$ & $\begin{array}{c}\text { Média * } \\
\text { Peso }\end{array}$ \\
\hline $\begin{array}{l}\text { Procuro não transgredir as regras aqui, pois assim } \\
\text { sempre manterei meu emprego }\end{array}$ & $c_{\text {con1 }}$ & 0,69 & 4,56 & 3,146 & 4,52 & 3,119 & 2 & 1,380 & 4,44 & 3,064 & 4,53 & 3,126 & 5,83 & 4,023 \\
\hline $\begin{array}{l}\text { Na situaça atual, ficar com minha organização é na } \\
\text { realidade uma necessidade tanto quanto um desejo }\end{array}$ & $c_{\text {con2 }}$ & 0,58 & 4,47 & 2,593 & 4,43 & 2,569 & 4,5 & 2,610 & 4,44 & 2,575 & 4,37 & 2,535 & 5 & 2,900 \\
\hline $\begin{array}{l}\text { Para conseguir ser recompensado aqui é nece. } \\
\text { expressar a atitude certa }\end{array}$ & $c_{\text {con3 }}$ & 0,71 & 4,61 & 3,273 & 4,26 & 3,025 & 4,5 & 3,195 & 4,44 & 3,152 & 5,11 & 3,628 & 4,67 & 3,316 \\
\hline $\begin{array}{l}\text { Farei sempre o possivel no meu trabalho para me manter } \\
\text { neste emprego }\end{array}$ & cons & 0,65 & 4,78 & 3,107 & 4,78 & 3,107 & 4 & 2,600 & 4,89 & 3,179 & 4,68 & 3,042 & 5,17 & 3,361 \\
\hline & & & Resultado & $\begin{array}{l}12,119 \\
\text { comp. } \\
\text { abaixo da } \\
\text { média }\end{array}$ & & $\begin{array}{l}11,820 \\
\text { comp. } \\
\text { abaixo da } \\
\text { média }\end{array}$ & & $\begin{array}{c}9,785 \\
\text { comp. } \\
\text { abaixo da } \\
\text { média }\end{array}$ & & $\begin{array}{l}11,970 \\
\text { comp } \\
\text { abaixo da } \\
\text { média }\end{array}$ & & $\begin{array}{l}12,330 \\
\text { comp. } \\
\text { acima } \\
\text { da } \\
\text { média }\end{array}$ & & $\begin{array}{c}13,599 \\
\text { comp. } \\
\text { acima } \\
\text { da } \\
\text { média }\end{array}$ \\
\hline
\end{tabular}

Base escassez de alternativas: crença de que possui poucas alternativas de trabalho se deixar a organização

\begin{tabular}{|c|c|c|c|c|c|c|c|c|c|c|c|c|c|c|}
\hline VARIÁVEIS & & PESO & $\begin{array}{c}\text { Média } \\
\text { Ásia }\end{array}$ & $\begin{array}{c}\text { Média } \\
\text { Peso }\end{array}$ & $\begin{array}{c}\text { Ásia } \\
\text { Oriental }\end{array}$ & $\begin{array}{c}\text { Média * } \\
\text { Peso }\end{array}$ & $\begin{array}{l}\text { Extremo } \\
\text { Oriente }\end{array}$ & $\begin{array}{c}\text { Média } \\
\text { Peso }\end{array}$ & $\begin{array}{l}\text { Oriente } \\
\text { Médio }\end{array}$ & $\begin{array}{c}\text { Média * } \\
\text { Peso }\end{array}$ & $\begin{array}{l}\text { Sudeste } \\
\text { Astático }\end{array}$ & $\begin{array}{c}\text { Média } \\
\text { Peso }\end{array}$ & $\begin{array}{c}\text { Sul da } \\
\text { Ásia }\end{array}$ & $\begin{array}{c}\text { Média * } \\
\text { Peso }\end{array}$ \\
\hline $\begin{array}{l}\text { Se eu decidisse deixar minha organização agora, minha } \\
\text { vida ficaria bastante desestruturada }\end{array}$ & $c_{\text {Esc1 }}$ & 0,59 & 3,81 & 2,248 & 3,74 & 2,207 & 3 & 1,770 & 3,89 & 2,295 & 3,68 & 2,171 & 4,67 & 2,755 \\
\hline $\begin{array}{l}\text { Eu acho que teria poucas alternativas se deixasse essa } \\
\text { organizaça. }\end{array}$ & $C_{\text {Esc2 }}$ & 0,77 & 3,66 & 2,818 & 3,61 & 2,780 & 2,87 & 2,210 & 3,33 & 2,564 & 4 & 3,080 & 3,33 & 2,564 \\
\hline $\begin{array}{l}\text { Uma das consequências negativas de deixar esta } \\
\text { organizaç̃o seria a escassez de alternativas imediatas de } \\
\text { trabalho. }\end{array}$ & $C_{\text {Esc3 }}$ & 0,84 & 3,63 & 3,049 & 3,43 & 2,881 & 3.5 & 2,940 & 3,44 & 2,890 & 3,79 & 3,184 & 4,17 & 3,503 \\
\hline $\begin{array}{l}\text { Não deixaria este emprego agora devido à falta de } \\
\text { oportunidades de trabalho. }\end{array}$ & $C_{\text {Esc4 }}$ & 0.78 & 3,69 & 2,878 & 3,43 & 2,675 & 4 & 3,120 & 3,56 & 2,777 & 3,79 & 2,956 & 4,5 & s,510 \\
\hline & & & Resultado & $\begin{array}{c}10,994 \\
\text { Baixo } \\
\text { comp. }\end{array}$ & & $\begin{array}{c}10,543 \\
\text { Baixo } \\
\text { comp. }\end{array}$ & & $\begin{array}{c}10,040 \\
\text { Baixo } \\
\text { comp. }\end{array}$ & & $\begin{array}{c}10,526 \\
\text { Baixo } \\
\text { comp. }\end{array}$ & & $\begin{array}{c}11,391 \\
\text { Baixo } \\
\text { comp. }\end{array}$ & & $\begin{array}{c}12,332 \\
\text { comp. } \\
\text { abaixo } \\
\text { da } \\
\text { média }\end{array}$ \\
\hline
\end{tabular}


Tabela 05 - EBACO - COMPROMETIMENTO - EUROPA

Base afetiva: crença e identificação com a filosofia, valores e os objetivos organizacionais

\begin{tabular}{l|l|l|}
\hline VARIÁVEIS \\
$\begin{array}{l}\text { Desde que me juntei a essa organização, meus valores } \\
\text { pessoais e os da organização têm se tornado mais } \\
\text { similares. }\end{array}$ & C Afe1 \\
\hline $\begin{array}{l}\text { A razão de eu preferir esta organização em relação a } \\
\text { outras é por causa do que ela simboliza, de seus valores. }\end{array}$ & $C_{\text {Afe2 }}$ \\
\hline $\begin{array}{l}\text { Eu me identifico com a filosofia desta organização } \\
\text { Eu acredito nos valores e nos objetivos dessa }\end{array}$ & $C_{\text {Afe3 }}$ \\
\hline \begin{tabular}{l} 
organização \\
\hline
\end{tabular}
\end{tabular}

\begin{tabular}{|c|c|c|c|c|c|}
\hline $\begin{array}{c}\text { Média } \\
\text { Europa }\end{array}$ & PESO & $\begin{array}{c}\text { Média } \\
\text { Peso }\end{array}$ & $\begin{array}{c}\text { Europa Centro } \\
\text { Oriental }\end{array}$ & $\begin{array}{c}\text { Média - } \\
\text { Peso }\end{array}$ \\
\hline 3,89 & 0,74 & 2,879 & 4,12 & 3,049 & \\
\hline 4,21 & 0,76 & 3,200 & 4 & 3,040 & 3,392 \\
\hline 4,21 & 0,8 & 3,368 & 4,24 & 4,71 & 3,674 \\
\hline
\end{tabular}

\begin{tabular}{|c|c|c|c|c|c}
\hline $\begin{array}{c}\text { Europa } \\
\text { Meridional }\end{array}$ & $\begin{array}{c}\text { Média* } \\
\text { Peso }\end{array}$ & $\begin{array}{c}\text { Europa } \\
\text { Ocidental }\end{array}$ & $\begin{array}{c}\text { Média* } \\
\text { Peso }\end{array}$ & $\begin{array}{c}\text { Europa } \\
\text { Setentrional }\end{array}$ & $\begin{array}{c}\text { Média* } \\
\text { Peso }\end{array}$ \\
\hline 3,84 & 2,842 & 3,84 & 2,842 & 3,8 & 2,812 \\
\hline 4,36 & 3,314 & 4,22 & 3,207 & 4,2 & 3,192 \\
\hline 4,24 & 3,392 & 4,19 & 3,352 & 4,2 & 3,360 \\
\hline 4,64 & 3,619 & 4,44 & 3,463 & 4,4 & 3,432 \\
\hline \multicolumn{7}{c|}{13,166} \\
\hline
\end{tabular}

comp. acima da comp. acima da média

comp.

comp.

comp. acima da média média média média

Base obrigação em permanecer: Crença de que tem uma obrigação em permanecer; de que se sentiria culpado em deixar, de que não seria certo; e que tem uma obrigação VARIÁVEIS VARIÁVEIS tenho uma obrigaçáo moral com as pessoas daqui Mesmo se fosse vantagem para mim, eu sinto que nã

Eu me sentiria culpado se deixasse minha organizaçã agora.

ño seria certo deixar minha organizaçã porque tenho uma obrigação moral em permanecer

\begin{tabular}{|c|c|c|c|c|c|}
\hline & $\begin{array}{l}\text { Média } \\
\text { Europa }\end{array}$ & PESO & $\begin{array}{l}\text { Média * } \\
\text { Peso }\end{array}$ & $\begin{array}{c}\text { Europa Centro } \\
\text { Oriental }\end{array}$ & $\begin{array}{l}\text { Média } \\
\text { Peso }\end{array}$ \\
\hline$C_{\text {Per } 1}$ & 3,95 & 0,78 & 3,081 & 4,41 & 3,440 \\
\hline$C_{\text {Per } 2}$ & 3,93 & 0,79 & 3,105 & 4 & 3,160 \\
\hline$C_{\text {Per3 }}$ & 3,3 & 0,82 & 2,706 & 3,53 & 2,895 \\
\hline$C_{\text {Per4 }}$ & 3,37 & 0,85 & 2,865 & 3,47 & 2,950 \\
\hline
\end{tabular}

\begin{tabular}{|c|c|c|c|c|c}
$\begin{array}{c}\text { Europa } \\
\text { Meridional }\end{array}$ & $\begin{array}{c}\text { Média*- } \\
\text { Peso }\end{array}$ & $\begin{array}{c}\text { Europa } \\
\text { Ocidental }\end{array}$ & $\begin{array}{c}\text { Média* } \\
\text { Peso }\end{array}$ & $\begin{array}{c}\text { Europa } \\
\text { Setentrional }\end{array}$ & $\begin{array}{c}\text { Média* } \\
\text { Peso }\end{array}$ \\
\hline 3,68 & 2,870 & 4,03 & 3,143 & 3,6 & 2,808 \\
\hline 3,96 & 3,128 & 3,91 & 3,089 & 3,8 & 3,002 \\
\hline 3,52 & 2,886 & 3,13 & 2,567 & 2,9 & 2,378 \\
\hline 3,4 & 2,890 & 3,41 & 2,899 & 3 & 2,550 \\
\hline
\end{tabular}

comp. abaixo da

comp. abaixo da média comp. abaixo da média

comp. abaixo da

comp. abaixo da média

Base obrigação pelo desempenho: Crença de que deve se esforçar em benefício da organização e que deve buscar cumprir suas tarefas e atingir os objetivos organizacionais.

\begin{tabular}{|c|c|c|c|c|c|c|c|c|c|c|c|c|}
\hline \multicolumn{2}{|l|}{ VARIÁVEIS } & \multirow{2}{*}{$\begin{array}{c}\text { Média } \\
\text { Europa } \\
5,37\end{array}$} & \multirow{2}{*}{$\begin{array}{l}\text { PESO } \\
0,65\end{array}$} & \multirow{2}{*}{\begin{tabular}{|c|}
$\begin{array}{c}\text { Média * } \\
\text { Peso }\end{array}$ \\
3,491
\end{tabular}} & \multirow{2}{*}{\begin{tabular}{|c|}
$\begin{array}{c}\text { Europa Centro } \\
\text { Oriental }\end{array}$ \\
5 \\
\end{tabular}} & \multirow{2}{*}{$\begin{array}{c}\begin{array}{c}\text { Média - } \\
\text { Peso }\end{array} \\
3,250\end{array}$} & \multirow{2}{*}{$\begin{array}{c}\text { Europa } \\
\text { Meridional }\end{array}$} & \multirow{2}{*}{$\begin{array}{c}\begin{array}{c}\text { Média * } \\
\text { Peso }\end{array} \\
3,562\end{array}$} & \multirow{2}{*}{\begin{tabular}{|c|}
$\begin{array}{c}\text { Europa } \\
\text { Ocidental }\end{array}$ \\
5,47
\end{tabular}} & \multirow{2}{*}{$\begin{array}{c}\begin{array}{c}\text { Média*- } \\
\text { Peso }\end{array} \\
3,556\end{array}$} & \multirow{2}{*}{$\begin{array}{c}\begin{array}{c}\text { Europa } \\
\text { Setentrional }\end{array} \\
5,4\end{array}$} & \multirow{2}{*}{$\begin{array}{c}\begin{array}{c}\text { Média - } \\
\text { Peso }\end{array} \\
3,510\end{array}$} \\
\hline $\begin{array}{l}\text { Todo colaborador deve buscar atingir os objetivos da } \\
\text { organização }\end{array}$ & $C_{\text {Des1 } 1}$ & & & & & & & & & & & \\
\hline $\begin{array}{l}\text { Eu tenho obrigação em desempenhar bem minha } \\
\text { função nessa organização }\end{array}$ & $C_{\text {Des2 }}$ & 5,76 & 0,81 & 4,666 & 5,35 & 4,334 & 5,84 & 4,730 & 5,94 & 4,811 & 5,7 & 4,617 \\
\hline $\begin{array}{l}\text { O bom colaborador deve se esforçar para que a } \\
\text { organização tenha os melhores resultados possiveis. }\end{array}$ & $C_{\text {Des3 }}$ & 5,39 & 0,81 & 4,366 & 4,59 & 3,718 & 5,56 & 4,504 & 5,63 & 4,560 & 5,6 & 4,536 \\
\hline $\begin{array}{l}\text { O colaborador tem a obrigação de sempre cumprir suas } \\
\text { tarefas. }\end{array}$ & $C_{\text {Des } 4}$ & 5,55 & 0,7 & 3,885 & 5,29 & 3,703 & 5,6 & 3,920 & 5,63 & 3,941 & 5,6 & 3,920 \\
\hline & & Resultado & & $\begin{array}{c}16,407 \\
\text { Alto } \\
\text { comp. }\end{array}$ & & $\begin{array}{c}15,004 \\
\text { Alto } \\
\text { comp. }\end{array}$ & & $\begin{array}{c}16,716 \\
\text { Alto } \\
\text { comp. }\end{array}$ & & $\begin{array}{c}16,868 \\
\text { Alto } \\
\text { comp. }\end{array}$ & & $\begin{array}{c}16,583 \\
\text { Alto } \\
\text { comp. }\end{array}$ \\
\hline
\end{tabular}


Base Afiliativa: Crença de que é reconhecido pelos colegas como membro do grupo e da organização.

VARIÁVEIS Sou reconhecido por todos na organizaça como

membro do grupo fa equipe de trabalho. organização.

\begin{tabular}{|c|c|c|}
\hline & $\begin{array}{l}\text { Média } \\
\text { Europa }\end{array}$ & PESO \\
\hline$C_{\text {Afi1 } 1}$ & 4,76 & 0,72 \\
\hline$C_{\text {Afi2 }}$ & 4,75 & 0,82 \\
\hline$C_{\text {Afi3 }}$ & 5,01 & 0,76 \\
\hline$C_{\text {Afi4 }}$ & 4,44 & 0,68 \\
\hline
\end{tabular}

\begin{tabular}{|c|c|c|}
$\begin{array}{c}\text { Média * } \\
\text { Peso }\end{array}$ & $\begin{array}{c}\text { Europa Centro } \\
\text { Oriental }\end{array}$ \\
\hline 3,427 & 5,06 & \\
\hline 3,895 & 4,94 & 4 \\
\hline 3,808 & 5,18 & \\
\hline 3,019 & 4,65 & \\
\hline
\end{tabular}

Comp. Abaixo da
média

\begin{tabular}{|c|c|}
\hline $\begin{array}{c}\text { Média- } \\
\text { Peso }\end{array}$ & $\begin{array}{c}\text { Europa } \\
\text { Meridional }\end{array}$ \\
\hline 3,643 & 4,68 \\
\hline 4,051 & 4,8 \\
\hline 3,937 & 4,88 \\
\hline 3,162 & 4,4 \\
\hline
\end{tabular}

comp

media

162

\begin{tabular}{r|r}
2,992 \\
14,006
\end{tabular}

, 006

comp.

\begin{tabular}{|c|c|c|c}
$\begin{array}{c}\text { Europa } \\
\text { Ocidental }\end{array}$ & $\begin{array}{c}\text { Média- } \\
\text { Peso }\end{array}$ & $\begin{array}{c}\text { Europa } \\
\text { Setentrional }\end{array}$ & $\begin{array}{c}\text { Média- } \\
\text { Peso }\end{array}$ \\
\hline 4,81 & 3,463 & 4,3 & 3,096 \\
\hline 4,75 & 3,895 & 4,3 & 3,526 \\
\hline 5,06 & 3,846 & 4,9 & 3,724 \\
\hline 4,41 & 2,999 & 4,3 & 2,924 \\
\hline \multicolumn{4}{|c|}{14,203} \\
\hline
\end{tabular}

Base fatta derecompensas

VARIÁVEIS

Se eu já não tivesse dado tanto de mim nesta organização, eu poderia considerar trabalhar em outro A menos que eu seja recompensado de alguma maneira beneficio desta oreanizacie. Minha visão pessoal sobre esta organização é diferent daquela que eu expresso publicamente. oportunidades para mim nesta organização.

\begin{tabular}{|l|l|c|c|}
\hline \multicolumn{2}{|l|}{} & $\begin{array}{c}\text { Média } \\
\text { Europa }\end{array}$ & PESO \\
\hline$C_{\text {Rec1 }}$ & 3,6 & 0,45 \\
\hline$C_{\text {Rec2 }}$ & 2,5 & 0,77 \\
\hline$C_{\text {Rec3 }}$ & 2,31 & 0,72 \\
\hline$C_{\text {Rec4 }}$ & 2,86 & 0,6 \\
\hline \multicolumn{3}{|c|}{ Resultado } \\
\hline
\end{tabular}

\begin{tabular}{|c|c|}
\hline $\begin{array}{l}\text { Média }= \\
\text { Peso }\end{array}$ & $\begin{array}{c}\text { Europa Centro } \\
\text { Oriental }\end{array}$ \\
\hline 1,620 & 3,65 \\
\hline 1,925 & 2,71 \\
\hline 1,663 & 2,47 \\
\hline 1,716 & 2,94 \\
\hline
\end{tabular}

\begin{tabular}{c|c|c|} 
Média - \\
Peso
\end{tabular}

\begin{tabular}{|c|c|c|c|c|c|}
\hline $\begin{array}{c}\text { Europa } \\
\text { Meridional }\end{array}$ & $\begin{array}{c}\text { Média - } \\
\text { Peso }\end{array}$ & $\begin{array}{c}\text { Europa } \\
\text { Ocidental }\end{array}$ & $\begin{array}{c}\text { Média - } \\
\text { Peso }\end{array}$ & $\begin{array}{c}\text { Europa } \\
\text { Setentrional }\end{array}$ & \begin{tabular}{|c} 
Média- \\
Peso
\end{tabular} \\
\hline 3,6 & 1,620 & 3,56 & 1,602 & 3,6 & 1,620 \\
\hline 2,36 & 1,817 & 2,44 & 1,879 & 2,7 & 2,079 \\
\hline 2,04 & 1,469 & 2,41 & 1,735 & 2,4 & 1,728 \\
\hline 2,84 & 1,704 & 2,75 & 1,650 & 3,1 & 1,860 \\
\hline & $\begin{array}{c}6,610 \\
\text { comp. } \\
\text { abaixo da } \\
\text { média }\end{array}$ & & $\begin{array}{c}6,866 \\
\text { comp. } \\
\text { abaixo da } \\
\text { média }\end{array}$ & & $\begin{array}{l}7,287 \\
\text { comp. } \\
\text { abaixo da } \\
\text { média }\end{array}$ \\
\hline
\end{tabular}
média média média

VARIÁVEIS

des e regras da organização

mo objetivo de se manter na Procuro não transgredir as regras aqui, pois as Na situação atual, ficar com minha organização é realidade uma necessidade tanto quanto um desejo Para conseguir ser recompensado aqui é necessári
expressar a atitude certa neste emprego

\begin{tabular}{|c|c|c|}
\hline & $\begin{array}{l}\text { Média } \\
\text { Europa }\end{array}$ & PESO \\
\hline$c_{\text {con } 1}$ & 4,25 & 0.69 \\
\hline$c_{\text {con } 2}$ & 4,2 & 0,58 \\
\hline$c_{\text {cons }}$ & 3,95 & 0,71 \\
\hline$C_{\text {cons }}$ & 4,71 & 0,65 \\
\hline
\end{tabular}

Média * Europa Centro Média -

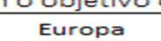

Média. Europa

Média -

\begin{tabular}{|c|c|c|c|c|c}
$\begin{array}{c}\text { Europa } \\
\text { Meridional }\end{array}$ & $\begin{array}{c}\text { Média- } \\
\text { Peso }\end{array}$ & $\begin{array}{c}\text { Europa } \\
\text { Ocidental }\end{array}$ & $\begin{array}{c}\text { Média- } \\
\text { Peso }\end{array}$ & $\begin{array}{c}\text { Europa } \\
\text { Setentrional }\end{array}$ & $\begin{array}{c}\text { Média-- } \\
\text { Peso }\end{array}$ \\
\hline 4,4 & 3,036 & 4,28 & 2,953 & 4,2 & 2,898 \\
\hline 4,48 & 2,598 & 4,09 & 2,372 & 4 & 2,320 \\
\hline 3,72 & 2,641 & 4 & 2,840 & 4,2 & 2,982 \\
\hline 5,12 & 3,328 & 4,59 & 2,984 & 4,5 & 2,925 \\
\hline \multicolumn{5}{|c|}{11,604} \\
\hline \multicolumn{5}{|c|}{11,149} & \multicolumn{3}{c}{11,125}
\end{tabular}

$$
\begin{aligned}
& \text { comp. abaixo } \\
& \text { média }
\end{aligned}
$$

\begin{tabular}{l|r|}
10,938 \\
\hline 1,235
\end{tabular}

comp. abaixo da média

Base escassez de alternativas: crença de que possui poucas alternativas de trabalho se deixar a organização

\section{VARIÁVEIS}

\begin{tabular}{l|c|c|c|} 
& $\begin{array}{c}\text { Média } \\
\text { Europa }\end{array}$ & PESO \\
\hline$C_{\text {Esc1 }}$ & 4,06 & 0,59 & \\
$C_{\text {Esc2 }}$ & 3,08 & 0,77 & \\
$C_{\text {Esc3 }}$ & 3,27 & 0,84 \\
C Esc4 $^{\mid}$ & 3,44 & 0,78 \\
\hline \multicolumn{4}{|c|}{ Resultado } \\
\hline
\end{tabular}

\begin{tabular}{|c|c|c|}
\hline $\begin{array}{l}\text { Média * } \\
\text { Peso }\end{array}$ & $\begin{array}{c}\text { Europa Centro } \\
\text { Oriental }\end{array}$ & $\begin{array}{l}\text { Média } \\
\text { Peso }\end{array}$ \\
\hline 2,395 & 3,88 & 2,289 \\
\hline 2,372 & 2,88 & 2,218 \\
\hline 2,747 & s & 2,520 \\
\hline 2,683 & 3,18 & 2,480 \\
\hline $\begin{array}{c}10,197 \\
\text { Baixo }\end{array}$ & & $\begin{array}{r}9,507 \\
\text { Baixo }\end{array}$ \\
\hline
\end{tabular}

comp. abaixo da média

comp. abaixo da

comp. abaixo da média

Se eu decidisse deixar minha organização agora, minh vida ficaria bastante desestruturada Urganizaçaso. organização seria a escassez de alternativas imediatas de trabalho. oportunidades de trabalho.

\begin{tabular}{|c|c|}
\hline $\begin{array}{c}\text { Europa } \\
\text { Meridional }\end{array}$ \\
\hline 4,32 \\
\hline 3,24 \\
\hline 3,36 \\
\hline 3,56 \\
\hline
\end{tabular}

\begin{tabular}{|c|c|c|c|c|}
\hline $\begin{array}{c}\text { Média - } \\
\text { Peso }\end{array}$ & $\begin{array}{l}\text { Europa } \\
\text { Ocidental }\end{array}$ & $\begin{array}{c}\text { Média - } \\
\text { Peso }\end{array}$ & $\begin{array}{c}\text { Europa } \\
\text { Setentrional }\end{array}$ & $\begin{array}{c}\text { Média - } \\
\text { Peso }\end{array}$ \\
\hline 2,549 & 3,94 & 2,325 & 4,1 & 2,419 \\
\hline 2,495 & 2,94 & 2,264 & 3,5 & 2,695 \\
\hline 2,822 & 3,25 & 2,730 & 3,6 & 3,024 \\
\hline 2,777 & 3,41 & 2,660 & 3,7 & 2,886 \\
\hline $\begin{array}{c}10,643 \\
\text { Baixo } \\
\text { comp. }\end{array}$ & & $\begin{array}{l}9,978 \\
\text { Baixo } \\
\text { comp. }\end{array}$ & & $\begin{array}{c}11,024 \\
\text { Baixo } \\
\text { comp. }\end{array}$ \\
\hline
\end{tabular}




\section{APÊNDICE $\mathbf{N}^{\circ} 03$}

\section{Análise da mediação múltipla no modelo proposto}

Dado que práticas medeiam valores para o alcance dos resultados organizacionais, então todas as metas motivacionais também serão mediadas pelas práticas organizacionais para o alcance dos resultados. Então, a seguinte hipótese foi estabelecida:

H9c: Todas as metas motivacionais são mediadas pelos valores e pelas práticas organizacionais para o alcance dos resultados.

Figura $\mathrm{A}_{3} 01$ - Mediação múltipla metas motivacionais para resultados

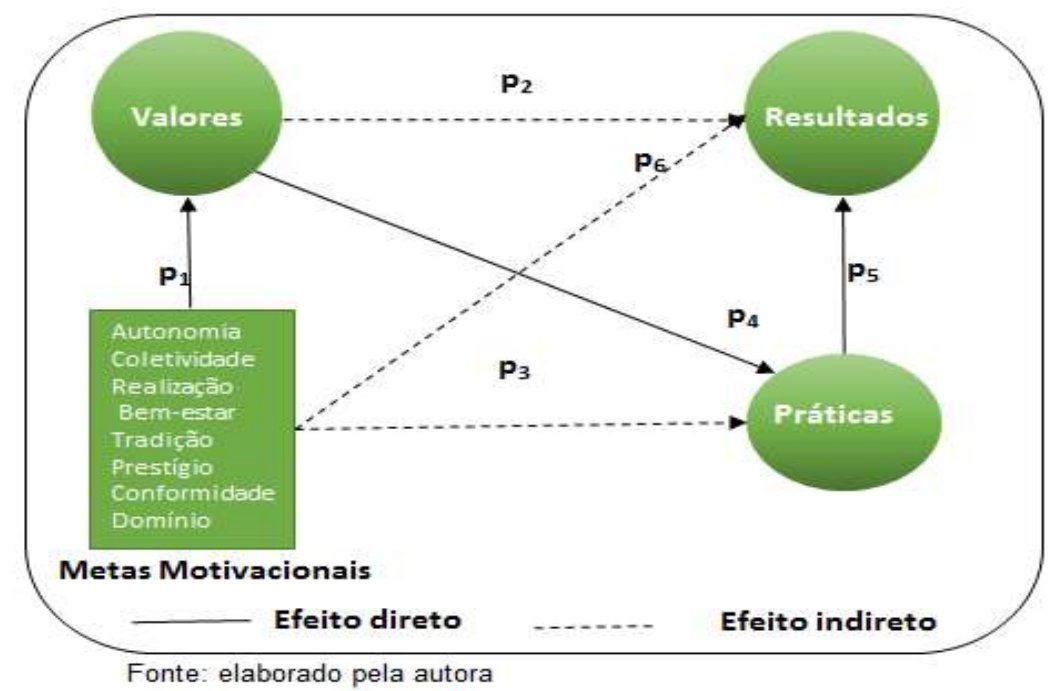

Os efeitos indiretos, obtidos por meio do software Smart-PLS são apresentados na tabela $\mathrm{A}_{3} 01$ e os efeitos diretos na tabela $\mathrm{A}_{3} 02$.

Tabela $A_{3} 01$ - Efeitos específicos indiretos das metas motivacionais $>>$ resultados

\begin{tabular}{|c|c|c|c|c|c|c|}
\hline Specific Indirect Effects & $\begin{array}{c}\text { Original } \\
\text { Sample (O) }\end{array}$ & $\begin{array}{l}\text { Sample } \\
\text { Mean } \\
\text { (M) }\end{array}$ & DP & $\begin{array}{l}\text { Intervalo Confiança } \\
95 \%\end{array}$ & $\begin{array}{l}\text { T Statistics } \\
(|\mathrm{O} / \mathrm{DP}|) \\
\mathrm{T}>1,96\end{array}$ & $\begin{array}{l}P \text { Values } \\
P<0,05\end{array}$ \\
\hline Autonomia -> valores & 0,007 & 0,007 & 0,003 & {$[0,0019 ; 0,0142]$} & 2,032 & 0,043 \\
\hline Bem-estar -> valores -> práticas -> resultados & 0,007 & 0,007 & 0,003 & {$[0,0018 ; 0,0143]$} & 1,962 & 0,050 \\
\hline Coletividade -> valores -> práticas -> resultados & 0,014 & 0,016 & 0,007 & {$[0,0038 ; 0,0307]$} & 1,998 & 0,046 \\
\hline Conformidade -> valores -> práticas -> resultados & 0,009 & 0,010 & 0,004 & {$[0,0025 ; 0,0180]$} & 2,123 & 0,034 \\
\hline Domínio -> valores -> práticas -> resultados & 0,002 & 0,003 & 0,001 & {$[0,0006 ; 0,0049]$} & 2,033 & 0,043 \\
\hline Prestígio -> valores -> práticas -> resultados & 0,006 & 0,007 & 0,003 & {$[0,0016 ; 0,0123]$} & 2,085 & 0,038 \\
\hline Realização -> valores -> práticas -> resultados & 0,007 & 0,008 & 0,003 & {$[0,0020 ; 0,0151]$} & 2,019 & 0,044 \\
\hline Tradição -> valores -> práticas -> resultados & 0,002 & 0,002 & 0,001 & {$[0,0005 ; 0,0038]$} & 2,152 & 0,032 \\
\hline
\end{tabular}

Fonte: Resultados elaborados a partir dos dados da pesquisa e calculados por meio do Software Smart-PLS 
Tabela $\mathrm{A}_{3} \mathrm{O} 2$ - Efeitos diretos das metas motivacionais -> valores

\begin{tabular}{l|cccccc}
\hline \multicolumn{1}{c|}{ Direct Effects } & $\begin{array}{c}\text { Original } \\
\text { Sample }(0)\end{array}$ & $\begin{array}{c}\text { Sample } \\
\text { Mean }(\mathrm{M})\end{array}$ & $\begin{array}{c}\text { DP } \\
\text { Intervalo Confiança } \\
95 \%\end{array}$ & $\begin{array}{c}\text { T Statistics (|O/DPI) } \\
\mathrm{T}>1,96\end{array}$ & $\begin{array}{c}\mathrm{P} \text { Values } \\
\mathrm{P}<0,05\end{array}$ \\
\hline Práticas -> resultados & 0,202 & 0,211 & 0,069 & {$[0,077 ; 0,337]$} & 2,949 & 0,003 \\
Valores -> práticas & 0,628 & 0,634 & 0,048 & {$[0,539 ; 0,718]$} & 13,029 & 0,000 \\
Autonomia -> valores & 0,155 & 0,154 & 0,008 & {$[0,139 ; 0,169]$} & 19,338 & 0,000 \\
Bem-estar -> valores & 0,152 & 0,152 & 0,010 & {$[0,134 ; 0,171]$} & 15,604 & 0,000 \\
Coletividade -> valores & 0,321 & 0,321 & 0,014 & {$[0,295 ; 0,347]$} & 22,737 & 0,000 \\
Conformidade -> valores & 0,206 & 0,205 & 0,016 & {$[0,176 ; 0,238]$} & 12,921 & 0,000 \\
Domínio -> valores & 0,053 & 0,052 & 0,004 & {$[0,045 ; 0,059]$} & 14,742 & 0,000 \\
Prestígio -> valores & 0,139 & 0,138 & 0,014 & {$[0,112 ; 0,165]$} & 10,291 & 0,000 \\
Realização -> valores & 0,161 & 0,161 & 0,007 & {$[0,146 ; 0,176]$} & 21,960 & 0,000 \\
Tradição -> valores & 0,043 & 0,041 & 0,010 & {$[0,020 ; 0,060]$} & 4,257 & 0,000
\end{tabular}

Fonte: Resultados elaborados a partir dos dados da pesquisa e calculados por meio do Software Smart-PLS

\section{Efeitos indiretos total}

A média (sample mean) e o desvio-padrão (DP) foram obtidos a partir de todas as amostras bootstrapping geradas, ou seja, 499 amostras das relações entre os construtos mediadores. As médias, desvio-padrão e testes estatísticos t e o p-valor foram calculados por meio da planilha Excel.

Tabela $\mathrm{A}_{3} 03$ - Resultado da Análise de significância para efeitos indiretos total - Mediação múltipla

\begin{tabular}{|c|c|c|c|c|c|c|c|}
\hline $\begin{array}{c}\text { Relações } \\
\text { Diretas }\end{array}$ & $\begin{array}{l}\text { Relações } \\
\text { Indiretas }\end{array}$ & Mediação & $\begin{array}{c}\text { Original } \\
\text { Sample (O) }\end{array}$ & $\begin{array}{c}\text { Sample } \\
\text { Mean (M) }\end{array}$ & DP & $\begin{array}{c}\text { T Statistics } \\
(|\mathrm{O} / \mathrm{DP}|) \\
\mathrm{t}>1,96\end{array}$ & $\begin{array}{c}P \text { Values } \\
p<0,05\end{array}$ \\
\hline TRAD->VAL & TRAD -> PRAT & \multirow{3}{*}{ TRADIÇÃO -> RESUL via VALORES e PRATICA } & \multirow{3}{*}{0,0019} & \multirow{3}{*}{0,0019} & \multirow{3}{*}{0,0009} & \multirow{3}{*}{2,150} & \multirow{3}{*}{0,0320} \\
\hline VAL->PRAT & VAL -> RESUL & & & & & & \\
\hline PRAT->RESUL & TRAD -> RESUL & & & & & & \\
\hline AUT->VAL & AUT ->PRAT & \multirow{3}{*}{ AUTONOMIA -> RESULT via VALORES E PRÁTICAS } & \multirow{3}{*}{0,0067} & \multirow{3}{*}{0,0074} & \multirow{3}{*}{0,0033} & \multirow{3}{*}{2,030} & \multirow{3}{*}{0,043} \\
\hline VAL->PRAT & VAL $\rightarrow>$ RESUL & & & & & & \\
\hline PRAT->RESUL & AUT -> RESUL & & & & & & \\
\hline$B E M->V A L$ & BEM -> PRAT & \multirow{3}{*}{ BEM-ESTAR -> RESULT via VALORES E PRÁTICAS } & \multirow{3}{*}{0,0065} & \multirow{3}{*}{0,0073} & \multirow{3}{*}{0,0033} & \multirow{3}{*}{1,961} & \multirow{3}{*}{0,0505} \\
\hline VAL-> PRAT & VAL -> RESUL & & & & & & \\
\hline PRAT-RESULT & AUT -> RESUL & & & & & & \\
\hline COLT->VAL & BEM $->$ PRAT & \multirow{3}{*}{ COLETIVIDADE -> RESULT via VALORES E PRÁTICAS } & \multirow{3}{*}{0,0138} & \multirow{3}{*}{0,0155} & \multirow{3}{*}{0,0069} & \multirow{3}{*}{1,996} & \multirow{3}{*}{0,0464} \\
\hline VAL-> PRAT & VAL -> RESUL & & & & & & \\
\hline PRAT-RESULT & AUT -> RESUL & & & & & & \\
\hline CONF->VAL & CONF -> PRAT & \multirow{3}{*}{ CONFORMIDADE -> RESULT via VALORES E PRÁTICAS } & \multirow{3}{*}{0,0088} & \multirow{3}{*}{0,0098} & \multirow{3}{*}{0,0042} & \multirow{3}{*}{2,121} & \multirow{3}{*}{0,0344} \\
\hline VAL-> PRAT & VAL ->RESUL & & & & & & \\
\hline PRAT-RESULT & AUT -> RESUL & & & & & & \\
\hline DOM->VAL & DOM -> PRAT & \multirow{3}{*}{ DOMÍNIO -> RESULT via VALORES E PRÁTICAS } & \multirow{3}{*}{0,0023} & \multirow{3}{*}{0,0025} & & & \\
\hline VAL-> PRAT & VAL -> RESUL & & & & 0,0011 & 2,031 & 0,0428 \\
\hline PRAT-RESULT & AUT -> RESUL & & & & & & \\
\hline PREST->VAL & PREST -> PRAT & & & & & & \\
\hline VAL-> PRAT & VAL ->RESUL & PRESTÍGIO -> RESULT via VALORES E PRÁTICAS & 0,0060 & 0,0066 & 0,0029 & 2,083 & 0,0378 \\
\hline PRAT-RESULT & AUT -> RESUL & & & & & & \\
\hline REAL->VAL & REAL -> PRAT & & & & & & \\
\hline VAL-> PRAT & VAL -> RESUL & REALIZAÇÃO -> RESULT via VALORES E PRÁTICAS & 0,0069 & 0,0078 & 0,0034 & 2,017 & 0,0442 \\
\hline PRAT-RESULT & AUT -> RESUL & & & & & & \\
\hline
\end{tabular}


A partir das tabelas $\mathrm{A}_{3} 01, \mathrm{~A}_{3} \mathrm{O} 2$ e $\mathrm{A}_{3} 03$, foi possível chegar às seguintes conclusões

Quadro $\mathrm{A}_{3} 01$ - Resultados da análise mediadora múltipla das metas motivacionais e resultados

\begin{tabular}{|c|c|c|c|c|}
\hline \multirow{2}{*}{ Mediadoras } & \multirow{2}{*}{ Relação } & \multicolumn{2}{|c|}{ Significância } & \multirow{2}{*}{ Interpretação } \\
\hline & & Indireto & Direto & \\
\hline \multirow{8}{*}{ Valores e Práticas } & Autonomia -> Resultados & Sim & Sim & Mediação parcial \\
\hline & Bem-estar -> Resultados & Sim & Sim & Mediação parcial \\
\hline & Coletividade -> Resultados & Sim & Sim & Mediação parcial \\
\hline & Conformidade -> Resultados & Sim & Sim & Mediação parcial \\
\hline & Domínio -> Resultados & Sim & Sim & Mediação parcial \\
\hline & Prestígio -> Resultados & Sim & Sim & Mediação parcial \\
\hline & Realização -> Resultados & Sim & Sim & Mediação parcial \\
\hline & Tradição -> Resultados & Sim & Sim & Mediação parcial \\
\hline
\end{tabular}

Fonte: elaborado pela autora

Então, existe uma mediação parcial dos construtos valores e práticas sobre as metas motivacionais para o alcance dos resultados.

Dado que valores têm relação direta com práticas, então as metas motivacionais serão mediadas pelos construtos valores e práticas para o alcance das práticas organizacionais humanistas e instrumentais. Então, as seguintes hipóteses foram estabelecidas:

H9d: Todas as metas motivacionais são mediadas pelos valores e pelas práticas para o alcance das práticas organizacionais humanistas.

E

Hye: Todas as metas motivacionais são mediadas pelos valores e pelas práticas para o alcance das práticas organizacionais instrumentais. 
Figura $\mathrm{A}_{3} \mathrm{O2}$ - Mediação múltipla metas motivacionais para tipos de práticas

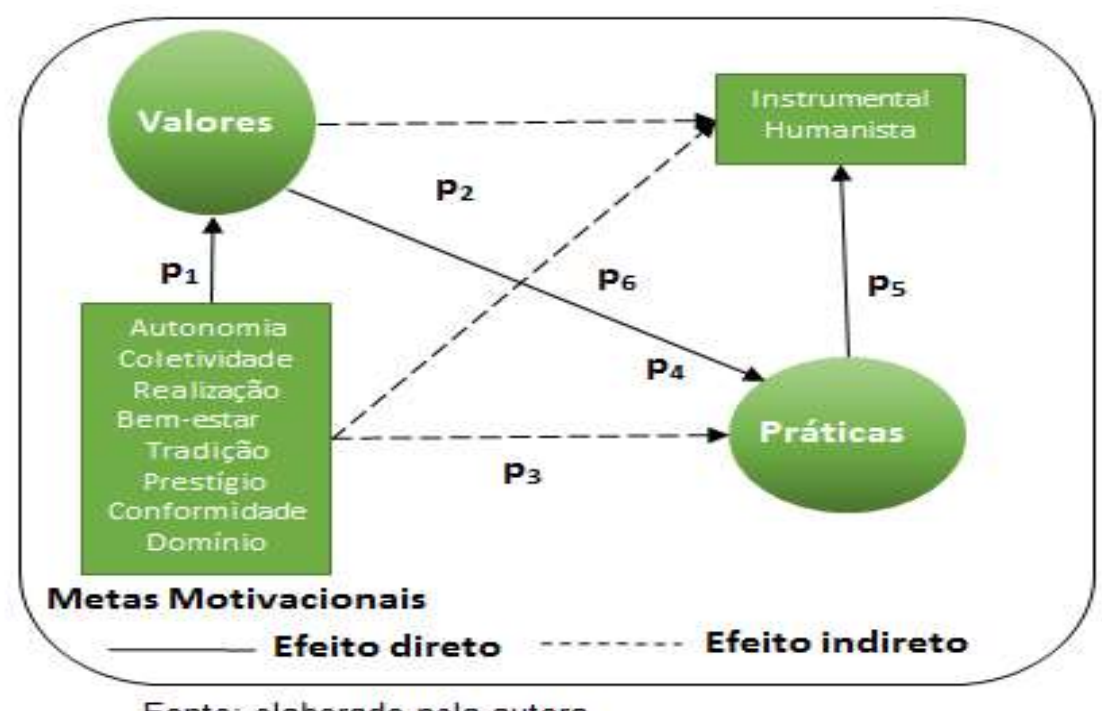

Fonte: elaborado pela autora

Os efeitos indiretos, obtidos por meio do software Smart-PLS são apresentados na tabela $\mathrm{A}_{3} 04$ e os efeitos diretos na tabela $\mathrm{A}_{3} 05$.

Tabela $\mathrm{A}_{3} \mathrm{O} 4$ - Efeitos específicos indiretos das metas motivacionais -> práticas humanistas e instrumental

\begin{tabular}{|c|c|c|c|c|c|c|}
\hline Efeitos indiretos & $\begin{array}{c}\text { Original } \\
\text { Sample (0) }\end{array}$ & $\begin{array}{l}\text { Sample } \\
\text { Mean } \\
\text { (M) }\end{array}$ & DP & $\begin{array}{l}\text { Intervalo Confiança } \\
\quad 95 \%\end{array}$ & $\begin{array}{c}\text { TStatistics } \\
(|\mathrm{O} / \mathrm{DP}|) \\
\mathrm{t}>1,96\end{array}$ & $\begin{array}{l}\begin{array}{l}P \text { Values } \\
p<0,05\end{array}\end{array}$ \\
\hline Autonomia -> valores -> práticas -> humanista & 0,029 & 0,031 & 0,008 & {$[0,014 ; 0,048]$} & 3,352 & 0,0009 \\
\hline Autonomia -> valores -> práticas -> instrumental & 0,029 & 0,031 & 0,008 & {$[0,014 ; 0,048]$} & 3,403 & 0,0007 \\
\hline Bem-estar -> valores -> práticas -> humanista & 0,028 & 0,030 & 0,008 & {$[0,014 ; 0,047]$} & 3,336 & 0,0009 \\
\hline Bem-estar $->$ valores $>>$ práticas $->$ instrumental & 0,028 & 0,030 & 0,008 & {$[0,014 ; 0,047]$} & 3,381 & 0,0008 \\
\hline Coletividade -> valores -> práticas -> humanista & 0,060 & 0,065 & 0,018 & {$[0,030 ; 0,100]$} & 3,385 & 0,0008 \\
\hline Coletividade -> valores -> práticas -> instrumental & 0,060 & 0,064 & 0,017 & {$[0,030 ; 0,099]$} & 3,434 & 0,0006 \\
\hline Conformidade -> valores $->$ práticas -> humanista & 0,038 & 0,041 & 0,010 & {$[0,019 ; 0,061]$} & 3,570 & 0,0004 \\
\hline Conformidade -> valores -> práticas -> instrumental & 0,038 & 0,041 & 0,010 & {$[0,019 ; 0,060]$} & 3,630 & 0,0003 \\
\hline Domínio -> valores -> práticas -> humanista & 0,009 & 0,010 & 0,002 & {$[0,005 ; 0,016]$} & 3,406 & 0,0007 \\
\hline Domínio -> valores -> práticas -> instrumental & 0,009 & 0,010 & 0,002 & {$[0,005 ; 0,016]$} & 3,460 & 0,0006 \\
\hline Prestígio -> valores $->$ práticas -> humanista & 0,026 & 0,027 & 0,007 & {$[0,013 ; 0,042]$} & 3,478 & 0,0005 \\
\hline Prestígio -> valores -> práticas -> instrumental & 0,026 & 0,027 & 0,007 & {$[0,013 ; 0,041]$} & 3,539 & 0,0004 \\
\hline Realização -> valores -> práticas -> humanista & 0,030 & 0,032 & 0,009 & {$[0,015 ; 0,050]$} & 3,381 & 0,0008 \\
\hline Realização -> valores -> práticas -> instrumental & 0,030 & 0,032 & 0,008 & {$[0,015 ; 0,049]$} & 3,429 & 0,0007 \\
\hline Tradição -> valores -> práticas -> humanista & 0,008 & 0,008 & 0,002 & {$[0,003 ; 0,013]$} & 3,314 & 0,0010 \\
\hline Tradição -> valores -> práticas -> instrumental & 0,008 & 0,008 & 0,002 & {$[0,003 ; 0,013]$} & 3,356 & 0,0008 \\
\hline
\end{tabular}

Fonte: Resultados elaborados a partir dos dados da pesquisa e calculados por meio do Software Smart-PLS 
Tabela $\mathrm{A}_{3} 05$ - Efeitos diretos práticas e valores

\begin{tabular}{|c|c|c|c|c|c|c|}
\hline Direct Effects & $\begin{array}{l}\text { Original } \\
\text { Sample (0) }\end{array}$ & $\begin{array}{c}\text { Sample } \\
\text { Mean (M) }\end{array}$ & DP & $\begin{array}{l}\text { Intervalo Confiança } \\
95 \%\end{array}$ & $\begin{array}{c}\text { T Statistics }(|\mathrm{O} / \mathrm{DP}|) \\
\mathrm{T}>1,96\end{array}$ & $\begin{array}{l}P \text { V Values } \\
P<0,05\end{array}$ \\
\hline Práticas -> Humanista & 0,891 & 0,892 & 0,013 & {$[0,863 ; 0,917]$} & 68,549 & 0,000 \\
\hline Práticas -> Instrumental & 0,885 & 0,885 & 0,015 & {$[0,856 ; 0,914]$} & 59,672 & 0,000 \\
\hline Valores -> práticas & 0,628 & 0,634 & 0,048 & {$[0,539 ; 0,718]$} & 13,029 & 0,000 \\
\hline Autonomia -> valores & 0,155 & 0,154 & 0,008 & {$[0,139 ; 0,169]$} & 19,338 & 0,000 \\
\hline Bem-estar -> valores & 0,152 & 0,152 & 0,010 & {$[0,134 ; 0,171]$} & 15,604 & 0,000 \\
\hline Coletividade -> valores & 0,321 & 0,321 & 0,014 & {$[0,295 ; 0,347]$} & 22,737 & 0,000 \\
\hline Conformidade $->$ valores & 0,206 & 0,205 & 0,016 & {$[0,176 ; 0,238]$} & 12,921 & 0,000 \\
\hline Domínio -> valores & 0,053 & 0,052 & 0,004 & {$[0,045 ; 0,059]$} & 14,742 & 0,000 \\
\hline Prestígio -> valores & 0,139 & 0,138 & 0,014 & {$[0,112 ; 0,165]$} & 10,291 & 0,000 \\
\hline Realização -> valores & 0,161 & 0,161 & 0,007 & {$[0,146 ; 0,176]$} & 21,960 & 0,000 \\
\hline Tradição -> valores & 0,043 & 0,041 & 0,010 & {$[0,020 ; 0,060]$} & 4,257 & 0,000 \\
\hline
\end{tabular}

Fonte: Resultados elaborados a partir dos dados da pesquisa e calculados por meio do Software Smart-PLS

Tabela A406 - Resultado da Análise de significância para efeitos indiretos total - Mediação múltipla

\begin{tabular}{|c|c|c|c|c|c|c|c|}
\hline Relações Diretas & Relações Indiretas & Mediação & $\begin{array}{c}\text { Original } \\
\text { Sample (O) }\end{array}$ & $\begin{array}{c}\text { Sample } \\
\text { Mean (M) }\end{array}$ & DP & $\begin{array}{l}\text { T Statistics } \\
\text { (|O/DP|) } \\
t>1,96\end{array}$ & $\begin{array}{c}P \text { Values } \\
p<0,05\end{array}$ \\
\hline $\begin{array}{l}\text { TRAD->VAL } \\
\text { VAL->PRAT } \\
\text { PRAT->HUM }\end{array}$ & $\begin{array}{l}\text { TRAD -> PRAT } \\
\text { VAL >> HUM } \\
\text { TRAD -> HUM }\end{array}$ & TRADIÇÃO -> HUMANISTA via VALORES e PRÁTICAS & 0,0082 & 0,0082 & 0,0025 & 3,312 & 0,0010 \\
\hline $\begin{array}{l}\text { TRAD->VAL } \\
\text { VAL->PRAT } \\
\text { PRAT ->INST }\end{array}$ & $\begin{array}{l}\text { TRAD }>\text { PRAT } \\
\text { VAL }>\text { INST } \\
\text { TRAD }>>\text { INST }\end{array}$ & TRADIÇÃO -> INSTRUMENTAL via VALORES e PRÁTICAS & 0,0082 & 0,0081 & 0,0024 & 3,354 & 0,0009 \\
\hline $\begin{array}{l}\text { AUT }>>V A L \quad \text { VAL- } \\
>\text { PRAT PRAT- } \\
>\text { PHUM }\end{array}$ & $\begin{array}{l}\text { AUT }>>\text { PRAT } \\
\text { VAL }>>\text { HUM } \\
\text { AUT }>\text { HUM }\end{array}$ & AUTONOMIA -> HUMANISTA via VALORES E PRÁTICAS & 0,0293 & 0,0314 & 0,0087 & 3,349 & 0,001 \\
\hline $\begin{array}{l}\text { AUT->VAL VAL. } \\
>\text { PRAT PRAT - } \\
>\text { INST }\end{array}$ & $\begin{array}{l}\text { AUT }>\text { PRAT } \\
\text { VAL }>>\text { INST } \\
\text { AUT }>\text { INST }\end{array}$ & AUTONOMIA $>$ INSTRUMENTAL via VALORES E PRÁTICAS & 0,0291 & 0,0311 & 0,0086 & 3,400 & 0,001 \\
\hline $\begin{array}{l}\text { BEM-> VAL } \\
\text { VAL-> PRAT } \\
\text { PRAT-HUM }\end{array}$ & $\begin{array}{l}\text { BEM }>>\text { PRAT } \\
\text { VAL }>\text { HUM } \\
\text { BEM }>\text { HUM }\end{array}$ & BEM-ESTAR ->HUMANISTA via VALORES E PRÁTICAS & 0,0287 & 0,0308 & 0,0086 & 3,333 & 0,0009 \\
\hline $\begin{array}{l}\text { BEM-> VAL } \\
\text { VAL-> PRAT } \\
\text { PRAT-INST }\end{array}$ & $\begin{array}{l}\text { BEM }>\text { PRAT } \\
\text { VAL }>>\text { INST } \\
\text { BEM }>>\text { INST }\end{array}$ & BEM-ESTAR ->INSTRUMENTAL via VALORES e PRÁTICAS & 0,0285 & 0,0305 & 0,0084 & 3,378 & 0,0008 \\
\hline $\begin{array}{l}\text { COLET }>\text { VAL } \\
\text { VAL-> PRAT } \\
\text { PRAT }>\text { HUM }\end{array}$ & $\begin{array}{l}\text { COLET }>>\text { PRAT } \\
\text { VAL >>HUM } \\
\text { COLET }>\text { HUM }\end{array}$ & COLETIVIDADE -> HUMANISTA via VALORES e PRÁTICAS & 0,0608 & 0,0653 & 0,0180 & 3,382 & 0,0008 \\
\hline $\begin{array}{l}\text { COLET -> VAL } \\
\text { VAL-> PRAT } \\
\text { PRAT -> INST }\end{array}$ & $\begin{array}{l}\text { COLET }>\text { PRAT } \\
\text { VAL }->\text { INST } \\
\text { COLET }>\text { INST }\end{array}$ & COLETIVIDADE -> INSTRUMENTAL Via VALORES e PRÁTICAS & 0,0605 & 0,0647 & 0,0176 & 3,431 & 0,0007 \\
\hline $\begin{array}{l}\text { CONF-> VAL } \\
\text { VAL-> PRAT } \\
\text { PRAT-> HUM }\end{array}$ & $\begin{array}{l}\text { CONF -> PRAT } \\
\text { VAL -> HUM } \\
\text { CONF -> HUM }\end{array}$ & CONFORMIDADE -> HUMANISTA via VALORES e PRÁTICAS & 0,0389 & 0,0415 & 0,0109 & 3,567 & 0,0004 \\
\hline $\begin{array}{l}\text { CONF-> VAL } \\
\text { VAL-> PRAT } \\
\text { PRAT -> INST }\end{array}$ & $\begin{array}{l}\text { CONF -> PRAT } \\
\text { VAL ->INST } \\
\text { CONF -> INST }\end{array}$ & CONFORMIDADE -> INSTRUMENTAL via VALORES e PRÁTICAS & 0,0387 & 0,0411 & 0,0107 & 3,627 & 0,0003 \\
\hline $\begin{array}{l}\text { DOM-> VAL } \\
\text { VAL-> PRAT } \\
\text { PRAT }>\text { HUM }\end{array}$ & $\begin{array}{l}\text { DOM }>\text { PRAT } \\
\text { VAL }>\text { HUM } \\
\text { DOM }>\text { HUM }\end{array}$ & DOMINIO -> HUMANISTA via VALORES e PRÁTICAS & 0,0099 & 0,0107 & 0,0029 & 3,403 & 0,0007 \\
\hline $\begin{array}{l}\text { DOM-> VAL } \\
\text { VAL-> PRAT } \\
\text { PRAT -> INST }\end{array}$ & \begin{tabular}{|l} 
DOM $>>$ PRAT \\
VAL -> INST \\
DOM $>$ INST
\end{tabular} & DOMINIO -> INSTRUMENTAL via VALORES e PRÁTICAS & 0,0099 & 0,0106 & 0,0029 & 3,457 & 0,0006 \\
\hline $\begin{array}{l}\text { PREST }->\text { VAL } \\
\text { VAL-> PRAT } \\
\text { PRAT -> HUM }\end{array}$ & $\begin{array}{l}\text { PREST -> PRAT } \\
\text { VAL -> HUM } \\
\text { PREST -> HUM }\end{array}$ & PRESTIGIO >> HUMANISTA via VALORES e PRÁTICAS & 0,0263 & 0,0278 & 0,0076 & 3,475 & 0,0006 \\
\hline $\begin{array}{l}\text { PREST -> VAL } \\
\text { VAL-> PRAT } \\
\text { PRAT -> INST }\end{array}$ & \begin{tabular}{|l} 
PREST -> PRAT \\
VAL -> INST \\
PREST -> INST
\end{tabular} & PRESTIGIO -> INSTRUMENTAL via VALORES E PRÁTICAS & 0,0262 & 0,0276 & 0,0074 & 3,536 & 0,0004 \\
\hline $\begin{array}{l}\text { REAL-> VAL } \\
\text { VAL-> PRAT } \\
\text { PRAT -> HUM }\end{array}$ & $\begin{array}{l}\text { REAL >> PRAT } \\
\text { VAL -> HUM } \\
\text { REAL >> HUM }\end{array}$ & REALIZAÇÃOO -> HUMANISTA via VALORES e PRÁTICAS & 0,0304 & 0,0327 & 0,0090 & 3,378 & 0,0008 \\
\hline $\begin{array}{l}\text { REAL-> VAL } \\
\text { VAL-> PRAT } \\
\text { PRAT -> INST }\end{array}$ & $\begin{array}{l}\text { REAL >> PRAT } \\
\text { VAL -> INST } \\
\text { REAL -> INST }\end{array}$ & REALIZAÇÃO -> INSTRUMENTAL via VALORES e PRÁTICAS & 0,0302 & 0,0324 & 0,0088 & 3,426 & 0,0007 \\
\hline
\end{tabular}


A partir das tabelas $A_{3} 04, A_{3} 05$ e $A_{3} 06$, foi possível chegar às seguintes conclusões:

Quadro $\mathrm{A}_{3} \mathrm{O} 2$ - Resultados da análise mediadora múltipla valores e práticas

\begin{tabular}{|c|c|c|c|c|}
\hline \multirow{2}{*}{ Mediadoras } & \multirow{2}{*}{ Relação } & \multicolumn{2}{|c|}{ Significância } & \multirow{2}{*}{ Interpretação } \\
\hline & & Indireto & Direto & \\
\hline \multirow{8}{*}{ Valores e Práticas } & $\begin{array}{l}\text { Autonomia -> Humanista } \\
\text { Autonomia -> Instrumental }\end{array}$ & Sim & Sim & Mediação parcial \\
\hline & $\begin{array}{l}\text { Bem-estar -> Humanista } \\
\text { Bem-estar -> Instrumental }\end{array}$ & Sim & Sim & Mediação parcial \\
\hline & $\begin{array}{l}\text { Coletividade -> Humanista } \\
\text { Coletividade -> Instrumental }\end{array}$ & Sim & Sim & Mediação parcial \\
\hline & $\begin{array}{l}\text { Conformidade -> Humanista } \\
\text { Conformidade -> Instrumental }\end{array}$ & Sim & Sim & Mediação parcial \\
\hline & $\begin{array}{l}\text { Domínio -> Humanista } \\
\text { Domínio -> Instrumental }\end{array}$ & Sim & Sim & Mediação parcial \\
\hline & $\begin{array}{l}\text { Prestígio -> Humanista } \\
\text { Prestígio -> Instrumental }\end{array}$ & Sim & Sim & Mediação parcial \\
\hline & $\begin{array}{l}\text { Realização -> Humanista } \\
\text { Realização -> Instrumental }\end{array}$ & Sim & Sim & Mediação parcial \\
\hline & $\begin{array}{l}\text { Tradição -> Humanista } \\
\text { Tradição -> Instrumental }\end{array}$ & Sim & Sim & Mediação parcial \\
\hline
\end{tabular}

Fonte: Resultados elaborados a partir dos dados da pesquisa e calculados por meio do Software Smart-PLS

Então, existe uma mediação parcial dos construtos valores e práticas sobre as relações das metas motivacionais e práticas humanistas e instrumentais

Dado que comprometimento medeia valores para o alcance dos resultados organizacionais, então as metas motivacionais também serão mediadas pelo comprometimento organizacional para o alcance dos resultados. Então, a seguinte hipótese foi estabelecida:

$\mathrm{H}_{10 c}$ : Todas as metas motivacionais são mediadas pelo comprometimento organizacional para o alcance dos resultados.

A figura $\mathrm{A}_{3} \mathrm{O} 3$ representa a proposta de mediação da hipótese 10c 
Figura $\mathrm{A}_{3} \mathrm{O} 3$ - Mediação múltipla metas motivacionais para resultados via valores e comprometimento

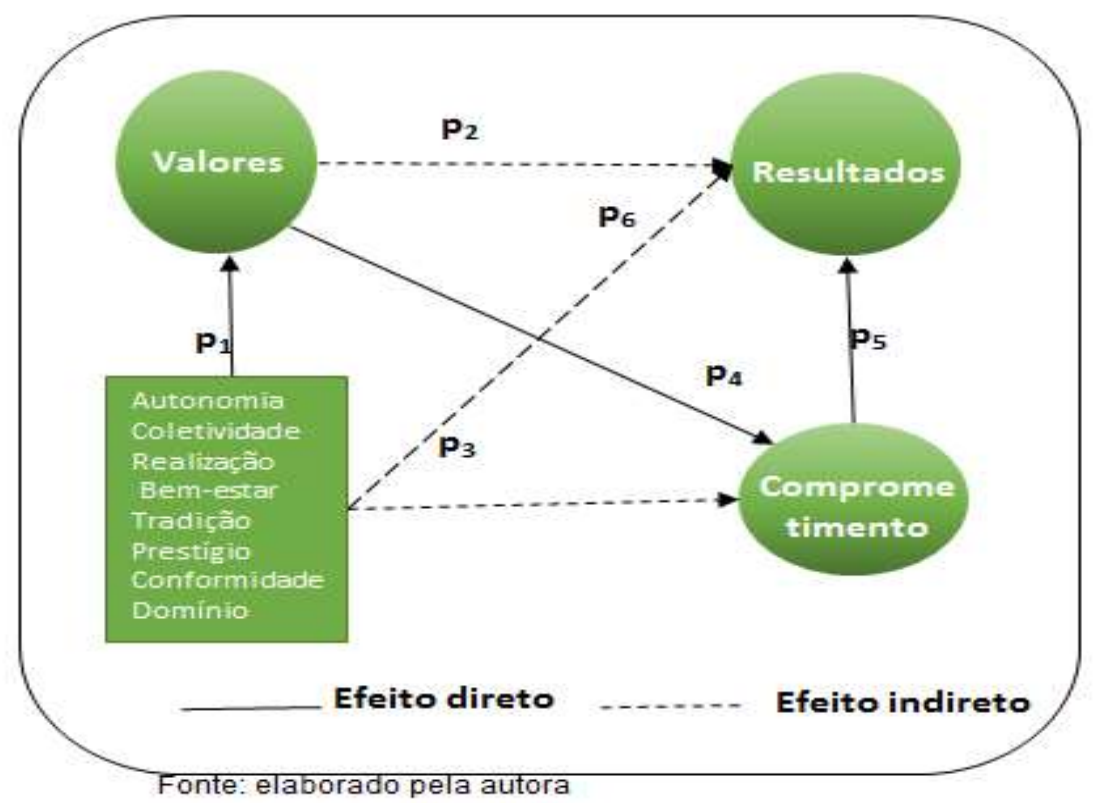

Para a verificação desta hipótese, foram obtidos dos softwares Smart-PLS e planilha eletrônica Excel os seguintes resultados:

Os efeitos indiretos, obtidos por meio do software Smart-PLS, são apresentados na tabela $\mathrm{A}_{3} 07$ e os efeitos diretos na tabela $\mathrm{A}_{3} 08$.

Tabela $\mathrm{A}_{3} 07$ - Efeitos específicos indiretos das metas motivacionais -> resultados

\begin{tabular}{|c|c|c|c|c|c|c|}
\hline Specific Indirect Effects & $\begin{array}{c}\text { Original } \\
\text { Sample } \\
\text { (0) }\end{array}$ & $\begin{array}{l}\text { Sample } \\
\text { Mean } \\
\text { (M) }\end{array}$ & DP & $\begin{array}{c}\text { Intervalo } \\
\text { Confiança 95\% }\end{array}$ & $\begin{array}{c}\text { T Statistics } \\
(|\mathrm{O} / \mathrm{DP}|) \\
\mathrm{T}>1,96\end{array}$ & $\begin{array}{l}P \text { Values } \\
P<0,05\end{array}$ \\
\hline Autonomia -> valores -> comprometimento -> resultados & 0,018 & 0,019 & 0,007 & {$[0,0040 ; 0,0354]$} & 2,467 & 0,014 \\
\hline Bem-estar -> valores -> comprometimento -> resultados & 0,018 & 0,019 & 0,007 & {$[0,0042 ; 0,0354]$} & 2,458 & 0,014 \\
\hline Coletividade -> valores -> comprometimento -> resultados & 0,037 & 0,040 & 0,016 & {$[0,0084 ; 0,0654]$} & 2,393 & 0,017 \\
\hline Conformidade $->$ valores $->$ comprometimento $->$ resultados & 0,024 & 0,026 & 0,010 & {$[0,0053 ; 0,0454]$} & 2,320 & 0,021 \\
\hline Domínio -> valores -> comprometimento -> resultados & 0,006 & 0,007 & 0,003 & {$[0,0013 ; 0,0154]$} & 2,327 & 0,020 \\
\hline Prestígio -> valores -> comprometimento -> resultados & 0,016 & 0,017 & 0,007 & {$[0,0039 ; 0,0354]$} & 2,312 & 0,021 \\
\hline Realização -> valores -> comprometimento -> resultados & 0,019 & 0,020 & 0,008 & {$[0,0041 ; 0,0354]$} & 2,432 & 0,015 \\
\hline Tradição -> valores -> comprometimento -> resultados & 0,005 & 0,005 & 0,002 & {$[0,0007 ; 0,0154]$} & 2,067 & 0,039 \\
\hline
\end{tabular}

Fonte: Resultados elaborados a partir dos dados da pesquisa e calculados por meio do Software Smart-PLS 
Tabela $\mathrm{A}_{3} 08$ - Efeitos diretos dos construtos

\begin{tabular}{l|cccccc}
\hline \multicolumn{1}{c|}{ Direct Effects } & $\begin{array}{c}\text { Original } \\
\text { Sample }(0)\end{array}$ & $\begin{array}{c}\text { Sample } \\
\text { Mean }(\mathrm{M})\end{array}$ & DP & $\begin{array}{c}\text { Intervalo Confiança } \\
95 \%\end{array}$ & $\begin{array}{c}\text { T Statistics }(|\mathrm{O} / \mathrm{DP}|) \\
\mathrm{T}>1,96\end{array}$ & $\begin{array}{c}\text { P Values } \\
\mathrm{P}<0,05\end{array}$ \\
\hline Comprometimento -> resultados & 0,185 & 0,195 & 0,072 & {$[0,041 ; 0,325]$} & 2,569 & 0,010 \\
Valores -> Comprometimento & 0,628 & 0,634 & 0,048 & {$[0,539 ; 0,718]$} & 13,029 & 0,000 \\
Autonomia -> valores & 0,155 & 0,154 & 0,008 & {$[0,139 ; 0,169]$} & 19,338 & 0,000 \\
Bem-estar -> valores & 0,152 & 0,152 & 0,010 & {$[0,134 ; 0,171]$} & 15,604 & 0,000 \\
Coletividade -> valores & 0,321 & 0,321 & 0,014 & {$[0,295 ; 0,347]$} & 22,737 & 0,000 \\
Conformidade -> valores & 0,206 & 0,205 & 0,016 & {$[0,176 ; 0,238]$} & 12,921 & 0,000 \\
Domínio -> valores & 0,053 & 0,052 & 0,004 & {$[0,045 ; 0,059]$} & 14,742 & 0,000 \\
Prestígio -> valores & 0,139 & 0,138 & 0,014 & {$[0,112 ; 0,165]$} & 10,291 & 0,000 \\
Realização -> valores & 0,161 & 0,161 & 0,007 & {$[0,146 ; 0,176]$} & 21,960 & 0,000 \\
Tradição -> valores & 0,043 & 0,041 & 0,010 & {$[0,020 ; 0,060]$} & 4,257 & 0,000 \\
\hline
\end{tabular}

Fonte: Resultados elaborados a partir dos dados da pesquisa e calculados por meio do Software Smart-PLS

Tabela $A_{3} 09$ - Resultado da Análise de significância para efeitos indiretos total - Mediação múltipla

\begin{tabular}{|c|c|c|c|c|c|c|c|}
\hline $\begin{array}{c}\text { Relações } \\
\text { Diretas }\end{array}$ & $\begin{array}{l}\text { Relações } \\
\text { Indiretas }\end{array}$ & Mediação & $\begin{array}{c}\text { Original } \\
\text { Sample (0) }\end{array}$ & $\begin{array}{c}\text { Sample } \\
\text { Mean (M) }\end{array}$ & DP & $\begin{array}{c}\text { S Statistics } \\
(|0 / D P|) \\
t>1,96\end{array}$ & $\begin{array}{c}\text { PValues } \\
p<0,05\end{array}$ \\
\hline $\begin{array}{l}\text { TRAD->VAL } \\
\text { VAL->COMP } \\
\text { COMP->RESUL }\end{array}$ & $\begin{array}{l}\text { TRAD ->PRAT } \\
\text { VAL -> RESUL } \\
\text { TRAD }->\text { RESUL }\end{array}$ & TRADIÇÃO $>$ > RESUL via VALORES e COMPROMETIMENTO & 0,0050 & 0,0052 & 0,0024 & 2,064 & 0,0395 \\
\hline $\begin{array}{l}\text { AUT->VAL } \\
\text { VAL->COMP } \\
\text { COMP->RESUL }\end{array}$ & $\begin{array}{l}\text { AUT }->\text { PRAT } \\
\text { VAL ->RESUL } \\
\text { AUT }->\text { RESUL }\end{array}$ & AUTONOMIA $>>$ RESULT via VALORES e COMPROMETIMENTO & 0,0180 & 0,0191 & 0,0073 & 2,464 & 0,014 \\
\hline $\begin{array}{l}\text { BEM->VAL } \\
\text { VAL->COMP } \\
\text { COMP-RESULT }\end{array}$ & $\begin{array}{l}\text { BEM }->\text { PRAT } \\
\text { VAL }->\text { RESUL } \\
\text { AUT }->\text { RESUL }\end{array}$ & BEM-ESTAR $>>$ RESULT via VALORES e COMPROMETIMENTO & 0,0176 & 0,0187 & 0,0072 & 2,455 & 0,0144 \\
\hline $\begin{array}{l}\text { COLET->VAL } \\
\text { VAL->COMP } \\
\text { COMP-RESULT }\end{array}$ & $\begin{array}{l}\text { COLET }->\text { PRAT } \\
\text { VAL }>\text { RESUL } \\
\text { COLET }>\text { RESUL }\end{array}$ & COLETIVIDADE $>$ RESULT via VALORES e COMPROMETIMENTO & 0,0374 & 0,0398 & 0,0156 & 2,391 & 0,0172 \\
\hline $\begin{array}{l}\text { CONF->VAL } \\
\text { VAL->COMP } \\
\text { COMP-RESULT }\end{array}$ & $\begin{array}{l}\text { CONF }>>\text { PRAT } \\
\text { VAL }->\text { RESUL } \\
\text { CONF }>\text { RESUL }\end{array}$ & CONFORMIDADE $>$ RESULT via VALORES e COMPROMETIMENTO & 0,0239 & 0,0255 & 0,0103 & 2,318 & 0,0209 \\
\hline $\begin{array}{l}\text { DOM->VAL } \\
\text { VAL->COMP } \\
\text { COMP-RESULT }\end{array}$ & $\begin{array}{l}\text { DOM }->\text { PRAT } \\
\text { VAL ->RESUL } \\
\text { DOM }>\text { RESUL }\end{array}$ & DOMÍNIO -> RESULT via VALORES e COMPROMETIMENTO & 0,0061 & 0,0065 & 0,0026 & 2,325 & 0,0205 \\
\hline $\begin{array}{l}\text { PREST->VAL } \\
\text { VAL->COMP } \\
\text { COMP-RESULT }\end{array}$ & $\begin{array}{l}\text { PREST ->PRAT } \\
\text { VAL -> RESUL } \\
\text { PREST -> RESUL }\end{array}$ & PRESTÍGIO -> RESULT via VALORESe COMPROMETIMENTO & 0,0162 & 0,0171 & 0,0070 & 2,310 & 0,0213 \\
\hline $\begin{array}{l}\text { REAL->VAL } \\
\text { VAL->COMP } \\
\text { COMP-RESULT }\end{array}$ & $\begin{array}{l}\text { REAL }>>\text { PRAT } \\
\text { VAL ->RESUL } \\
\text { REAL }>\text { RESUL }\end{array}$ & REALIZAÇÃO $>$ RESULT via VALORES e COMPROMETIMENTO & 0,0187 & 0,0199 & 0,0077 & 2,429 & 0,0155 \\
\hline
\end{tabular}

Fonte: Resultados elaborados a partir dos dados da pesquisa e calculados por meio dos Softwares Smart-PIS excel 
A partir das tabelas $A_{3} 07, A_{3} 08$ e $A_{3} 09$ foi possível chegar às seguintes conclusões.

Quadro $\mathrm{A}_{3} \mathrm{O} 3$ - Resultados da análise mediadora múltipla

\begin{tabular}{|c|c|c|c|c|}
\hline \multirow{2}{*}{ Mediadoras } & \multirow{2}{*}{ Relação } & \multicolumn{2}{|c|}{ Siqnificância } & \multirow{2}{*}{ Interpretação } \\
\hline & & Indireto & Direto & \\
\hline \multirow{8}{*}{ Valores e Comprometimento } & Autonomia -> Resultados & Sim & Sim & Mediação parcial \\
\hline & Bem-estar -> Resultados & Sim & Sim & Mediação parcial \\
\hline & Coletividade -> Resultados & Sim & Sim & Mediação parcial \\
\hline & Conformidade -> Resultados & Sim & Sim & Mediação parcial \\
\hline & Domínio -> Resultados & Sim & Sim & Mediação parcial \\
\hline & Prestígio -> Resultados & Sim & Sim & Mediação parcial \\
\hline & Realização -> Resultados & Sim & Sim & Mediação parcial \\
\hline & Tradição -> Resultados & Sim & Sim & Mediação parcial \\
\hline
\end{tabular}

Fonte: Resultados elaborados a partir dos dados da pesquisa e calculados por meio do Software Smart-PLS

Então, existe uma mediação parcial dos construtos valores e comprometimentos sobre as relações das metas motivacionais e resultados.

Dado que comprometimento e práticas organizacionais medeiam valores para o alcance dos resultados organizacionais, então as metas motivacionais também serão mediadas concomitantemente pelas práticas e pelo comprometimento para o alcance dos resultados. E a seguinte hipótese foi estabelecida: 
$\mathrm{H}_{10 d}$ : Todas as metas motivacionais são mediadas concomitantemente pelas práticas e pelo comprometimento para o alcance dos resultados.

A figura $\mathrm{A}_{3} 04$ representa a proposta de mediação da hipótese $10 \mathrm{~d}$.

Figura $\mathrm{A}_{3} \mathrm{O} 4$ - Mediação múltipla metas motivacionais para resultados via valores, práticas e comprometimento

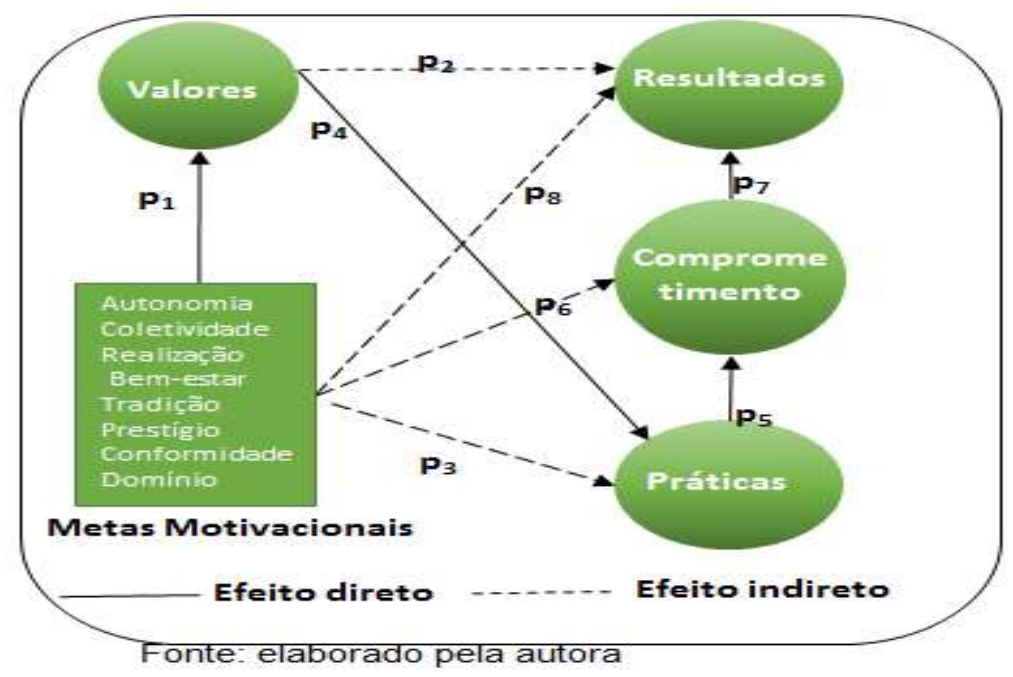

Para a verificação destas hipóteses, foram obtidos dos softwares Smart-PLS e planilha eletrônica Excel os seguintes resultados:

Tabela $A_{3} 10$ - Efeitos específicos indiretos das metas motivacionais -> resultados

\begin{tabular}{|c|c|c|c|c|c|c|}
\hline & $\begin{array}{l}\text { Original } \\
\text { Sample (0) }\end{array}$ & $\begin{array}{c}\text { Sample } \\
\text { Mean (M) }\end{array}$ & DP & $\begin{array}{c}\text { Intervalo } \\
\text { Confiança 95\% }\end{array}$ & $\begin{array}{c}\text { T Statistics } \\
(|\mathrm{O} / \mathrm{DP}|) \\
\mathrm{t}>1,96 \\
\end{array}$ & $\begin{array}{r}P \text { Values } \\
p<0,05 \\
\end{array}$ \\
\hline $\begin{array}{l}\text { Autonomia }->\text { valores }->\text { práticas }-> \\
->\text { comprometimento }->\text { resultados }\end{array}$ & $-0,0004$ & $-0,0004$ & 0,0005 & {$[-0,001 ; 0,000]$} & 0,806 & 0,421 \\
\hline $\begin{array}{l}\text { Bem-estar }->\text { valores }->\text { práticas-> } \\
->\text { comprometimento }->\text { resultados }\end{array}$ & $-0,0004$ & $-0,0004$ & 0,0004 & {$[-0,001 ; 0,000]$} & 0,803 & 0,423 \\
\hline $\begin{array}{l}\text { Coletividade }->\text { valores }->\text { práticas-> } \\
\rightarrow>\text { comprometimento }->\text { resultados }\end{array}$ & $-0,0008$ & $-0,0009$ & 0,0010 & {$[-0,003 ;-0,001]$} & 0,795 & 0,427 \\
\hline $\begin{array}{l}\text { Conformidade -> valores }->\text { práticas-> } \\
\rightarrow>\text { comprometimento } \rightarrow>\text { resultados }\end{array}$ & $-0,0005$ & $-0,0006$ & 0,0006 & {$[-0,002 ; 0,000]$} & 0,804 & 0,422 \\
\hline $\begin{array}{l}\text { Domínio }->\text { valores }->\text { práticas }-> \\
\text {-> comprometimento }->\text { resultados }\end{array}$ & $-0,0001$ & $-0,0001$ & 0,0002 & {$[0,000 ; 0,000]$} & 0,797 & 0,426 \\
\hline $\begin{array}{l}\text { Prestígio }->\text { valores }->\text { práticas }-> \\
\rightarrow>\text { comprometimento }->\text { resultados }\end{array}$ & $-0,0003$ & $-0,0004$ & 0,0004 & {$[-0,001 ; 0,000]$} & 0,810 & 0,418 \\
\hline $\begin{array}{l}\text { Realização }->\text { valores }->\text { práticas }-> \\
\text {-> comprometimento } \rightarrow>\text { resultados }\end{array}$ & $-0,0004$ & $-0,0004$ & 0,0005 & {$[-0,001 ; 0,000]$} & 0,803 & 0,422 \\
\hline Tradição -> valores -> práticas -> & $-0,0001$ & $-0,0001$ & 0,0001 & {$[0,000 ; 0,000]$} & 0,820 & 0,413 \\
\hline
\end{tabular}

$\rightarrow$ comprometimento $\rightarrow$ resultados

Fonte: Resultados elaborados a partir dos dados da pesquisa e calculados por meio do Software Smart-PLS

Esta relação não é estabelecida, pois a primeira condição para que haja mediação é que as relações indiretas sejam significantes. E, como visto na tabela A10, em nenhum dos casos há significância, pois todos apresentam $t<1,96 \mathrm{e}$, consequentemente, $\mathrm{p}\rangle$ 0,05 . 
Dado que valores têm relação direta com comprometimento, então as metas motivacionais serão mediadas pelos construtos valores e comprometimento para o alcance das bases de comprometimento. E a seguinte hipótese foi estabelecida:

$\mathrm{H}_{10 \mathrm{e}}$ : Todas as metas motivacionais são mediadas pelos construtos valores e comprometimento para o alcance das bases de comprometimento.

A figura $\mathrm{A}_{3} 05$ representa a proposta de mediação da hipótese $10 \mathrm{e}$.

Figura $\mathrm{A}_{3} \mathrm{O} 5$ - Mediação múltipla metas motivacionais bases de comprometimento via valores e comprometimento

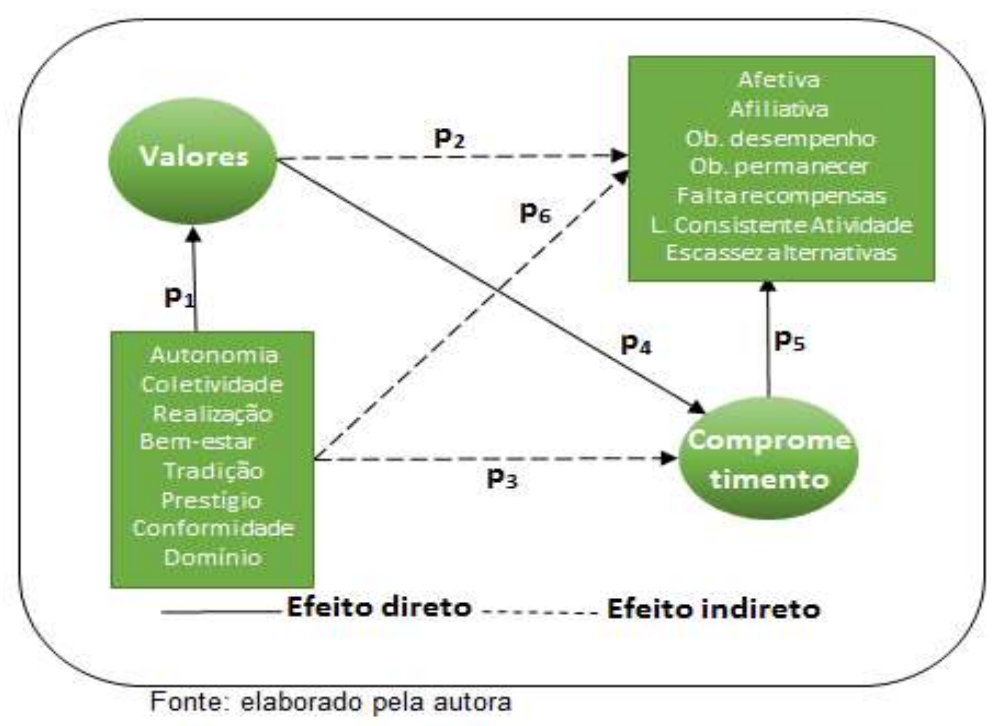

\section{Metas Motivacionais e Base de Comprometimento Afetiva}

Tabela $A_{3} 11$ - Efeitos específicos indiretos das metas motivacionais -> bases de comprometimento

\begin{tabular}{|c|c|c|c|c|c|c|}
\hline $\begin{array}{c}\text { Efeitos indiretos } \\
\text { Metas motivacionais e Base } \\
\text { de Comprometimento Afetiva }\end{array}$ & $\begin{array}{l}\text { Original } \\
\text { Sample } \\
\text { (0) }\end{array}$ & $\begin{array}{l}\text { Sample } \\
\text { Mean } \\
(\mathrm{M})\end{array}$ & DP & $\begin{array}{l}\text { Intervalo } \\
\text { Confiança } \\
95 \%\end{array}$ & $\begin{array}{l}\text { T Statistics } \\
(|\mathrm{O} / \mathrm{DP}|) \\
t>1,96\end{array}$ & $\begin{array}{c}p \text {-values } \\
p<0,05\end{array}$ \\
\hline Autonomia -> valores -> comprometimento -> afetiva & 0,083 & 0,084 & 0,008 & {$[0,068 ; 0,099]$} & 10,440 & 0,0000 \\
\hline Bem-estar -> valores -> comprometimento -> afetiva & 0,081 & 0,082 & 0,008 & {$[0,066 ; 0,096]$} & 10,466 & 0,0000 \\
\hline Coletividade $->$ valores $->$ comprometimento $->$ afetiva & 0,172 & 0,174 & 0,016 & {$[0,144 ; 0,204]$} & 10,832 & 0,0000 \\
\hline Conformidade $->$ valores $->$ comprometimento $->$ afetiva & 0,110 & 0,111 & 0,014 & {$[0,086 ; 0,137]$} & 7,974 & 0,0000 \\
\hline Domínio -> valores -> comprometimento -> afetiva & 0,028 & 0,028 & 0,003 & {$[0,022 ; 0,035]$} & 8,529 & 0,0000 \\
\hline Prestígio -> valores -> comprometimento -> afetiva & 0,075 & 0,075 & 0,009 & {$[0,056 ; 0,092]$} & 7,896 & 0,0000 \\
\hline Realização -> valores -> comprometimento -> afetiva & 0,086 & 0,087 & 0,008 & {$[0,071 ; 0,100]$} & 11,076 & 0,0000 \\
\hline Tradição -> valores -> comprometimento -> afetiva & 0,023 & 0,022 & 0,006 & {$[0,009 ; 0,034]$} & 3,895 & 0,0001 \\
\hline
\end{tabular}

Fonte: Resultados elaborados a partir dos dados da pesquisa e calculados por meio do Software Smart-PLS 
Tabela $A_{3} 12$ - Efeitos diretos dos construtos -> base de comprometimento afetiva

\begin{tabular}{l|cccccc}
\hline $\begin{array}{c}\text { Metas motivacionais e Base } \\
\text { de Comprometimento Afetiva }\end{array}$ & $\begin{array}{c}\text { Original } \\
\text { Sample (O) }\end{array}$ & $\begin{array}{c}\text { Sample } \\
\text { Mean (M) }\end{array}$ & DP & $\begin{array}{c}\text { Intervalo } \\
\text { Confiança 95\% }\end{array}$ & $\begin{array}{c}\text { T Statistics } \\
(|\mathrm{O} / \mathrm{DP}|) \\
\mathrm{t}>1,96\end{array}$ & $\begin{array}{c}\mathrm{p} \text {-values } \\
\mathrm{p}<0,05\end{array}$ \\
\hline Valores -> comprometimento & 0,628 & 0,634 & 0,048 & {$[0,539 ; 0,718]$} & 13,029 & 0,000 \\
Comprometimento -> afetiva & 0,854 & 0,854 & 0,020 & {$[0,813 ; 0,888]$} & 42,467 & 0,000 \\
Autonomia -> valores & 0,155 & 0,154 & 0,008 & {$[0,139 ; 0,169]$} & 19,338 & 0,000 \\
Bem-estar -> valores & 0,152 & 0,152 & 0,010 & {$[0,134 ; 0,171]$} & 15,604 & 0,000 \\
Coletividade -> valores & 0,321 & 0,321 & 0,014 & {$[0,295 ; 0,347]$} & 22,737 & 0,000 \\
Conformidade -> valores & 0,206 & 0,205 & 0,016 & {$[0,176 ; 0,238]$} & 12,921 & 0,000 \\
Domínio -> valores & 0,053 & 0,052 & 0,004 & {$[0,045 ; 0,059]$} & 14,742 & 0,000 \\
Prestígio -> valores & 0,139 & 0,138 & 0,014 & {$[0,112 ; 0,165]$} & 10,291 & 0,000 \\
Realização -> valores & 0,161 & 0,161 & 0,007 & {$[0,146 ; 0,176]$} & 21,960 & 0,000 \\
Tradição -> valores & 0,043 & 0,041 & 0,010 & {$[0,020 ; 0,060]$} & 4,257 & 0,000 \\
\hline
\end{tabular}

Fonte: Resultados elaborados a partir dos dados da pesquisa e calculados por meio do Software Smart-PLS

Tabela A313 - Resultado da Análise de significância para efeitos indiretos total - Mediação múltipla

\begin{tabular}{|c|c|c|c|c|c|c|c|}
\hline $\begin{array}{c}\text { Relações } \\
\text { Diretas }\end{array}$ & $\begin{array}{l}\text { Relações } \\
\text { Indiretas }\end{array}$ & Mediação & $\begin{array}{c}\text { Original } \\
\text { Sample (0) }\end{array}$ & $\begin{array}{c}\text { Sample } \\
\text { Mean (M) }\end{array}$ & DP & $\begin{array}{c}\text { TStatistics } \\
(|\mathrm{O} / \mathrm{DP}|) \\
t>1,96\end{array}$ & $\begin{array}{c}P \text { Values } \\
p<0,05\end{array}$ \\
\hline $\begin{array}{l}\text { TRAD->VAL } \\
\text { VAL->COMP } \\
\text { COMP->AFET }\end{array}$ & $\begin{array}{l}\text { TRAD ->AFET } \\
\text { VAL ->AFET } \\
\text { TRAD -> COMP }\end{array}$ & TRADIÇÃO -> AFETIVA via VALORES e COMPROMETIMENTO & 0,0079 & 0,0225 & 0,0060 & 1,318 & 0,1882 \\
\hline $\begin{array}{l}\text { AUT->VAL } \\
\text { VAL->COMP } \\
\text { COMP->AFET }\end{array}$ & $\begin{array}{l}\text { AUT ->AFET } \\
\text { VAL ->AFET } \\
\text { AUT ->COMP }\end{array}$ & AUTONOMIA $>>$ AFETIVA via VALORES e COMPROMETIMENTO & 0,0281 & 0,0835 & 0,0080 & 3,531 & 0,000 \\
\hline $\begin{array}{l}\text { BEM->VAL } \\
\text { VAL->COMP } \\
\text { COMP->AFET }\end{array}$ & $\begin{array}{l}\text { BEM }->\text { AFET } \\
V A L ~->A F E T \\
\text { BEM }->C O M P\end{array}$ & BEM-ESTAR $>>$ AFETIVA via VALORES e COMPROMETIMENTO & 0,0275 & 0,0820 & 0,0078 & 3,540 & 0,0004 \\
\hline $\begin{array}{l}\text { COLET->VAL } \\
\text { VAL->COMP } \\
\text { COMP->AFET }\end{array}$ & $\begin{array}{l}\text { COLET ->AFET } \\
\text { VAL ->AFET } \\
\text { COLET -> COMP }\end{array}$ & COLETIVIDADE ->AFETIVA via VALORES e COMPROMETIMENTO & 0,0584 & 0,1738 & 0,0159 & 3,664 & 0,0003 \\
\hline $\begin{array}{l}\text { CONF->VAL } \\
\text { VAL->COMP } \\
\text { COMP->AFET }\end{array}$ & $\begin{array}{l}\text { CONF }->A F E T \\
V A L->A F E T \\
\text { CONF }>>C O M P\end{array}$ & CONFORMIDADE -> AFETIVA via VALORES e COMPROMETIMENTO & 0,0373 & 0,1112 & 0,0138 & 2,697 & 0,0072 \\
\hline $\begin{array}{l}\text { DOM->VAL } \\
\text { VAL->COMP } \\
\text { COMP->AFET }\end{array}$ & $\begin{array}{l}\text { DOM ->AFET } \\
\text { VAL ->AFET } \\
\text { DOM ->COMP }\end{array}$ & DOMÍNIO -> AFETIVA via VALORES e COMPROMETIMENTO & 0,0095 & 0,0284 & 0,0033 & 2,885 & 0,0041 \\
\hline $\begin{array}{l}\text { PREST->VAL } \\
\text { VAL->COMP } \\
\text { COMP->AFET }\end{array}$ & \begin{tabular}{|l} 
PREST ->AFET \\
VAL ->AFET \\
PREST -> COMP
\end{tabular} & PRESTÍGIO -> AFETIVA via VALORESe COMPROMETIMENTO & 0,0252 & 0,0746 & 0,0095 & 2,671 & 0,0078 \\
\hline $\begin{array}{l}\text { REAL->VAL } \\
\text { VAL->COMP } \\
\text { COMP ->AFET }\end{array}$ & $\begin{array}{l}\text { REAL }>>\text { AFET } \\
\text { VAL }>>\text { AFET } \\
\text { REAL }>>\text { COMP }\end{array}$ & REALIZAÇÃO ->AFETIVA via VALORES e COMPROMETIMENTO & 0,0292 & 0,0869 & 0,0078 & 3,747 & 0,0002 \\
\hline
\end{tabular}

Fonte: Resultados elaborados a partir dos dados da pesquisa e calculados por meio dos Softwares Smart-PLS e Excel 
A partir das tabelas $A_{3} 11, A_{3} 12$ e $A_{3} 13$ foi possível chegar às seguintes conclusões.

Quadro A305 - Resultados da análise mediadora múltipla

\begin{tabular}{|c|c|c|c|c|}
\hline \multirow{2}{*}{ Mediadoras } & \multirow{2}{*}{ Relação } & \multicolumn{2}{|c|}{ Significância } & \multirow{2}{*}{ Interpretação } \\
\hline & & Indireto & Direto & \\
\hline \multirow{8}{*}{ Valores e Comprometimento } & Autonomia -> Afetiva & Sim & Sim & Mediação parcial \\
\hline & Bem-estar -> Afetiva & Sim & Sim & Mediação parcial \\
\hline & Coletividade -> Afetiva & Sim & Sim & Mediação parcial \\
\hline & Conformidade -> Afetiva & Sim & Sim & Mediação parcial \\
\hline & Domínio -> Afetiva & Sim & Sim & Mediação parcial \\
\hline & Prestígio -> Afetiva & Sim & Sim & Mediação parcial \\
\hline & Realização -> Afetiva & Sim & Sim & Mediação parcial \\
\hline & Tradição -> Afetiva & Não & Sim & Não há mediaçã \\
\hline
\end{tabular}

Então, existe uma mediação parcial dos construtos valores e comprometimento sobre as relações das metas motivacionais e base de comprometimento afetiva, com exceção da meta motivacional tradição e a base afetiva.

\section{Metas Motivacionais e Base de Comprometimento Afiliativa}

Tabela $A_{3} 14$ - Efeitos específicos indiretos das metas motivacionais $\rightarrow$ base de comprometimento afiliativa

\begin{tabular}{|c|c|c|c|c|c|c|}
\hline $\begin{array}{c}\text { Efeitos indiretos } \\
\text { Metas motivacionais e Base de } \\
\text { Comprometimento Afiliativa }\end{array}$ & $\begin{array}{c}\text { Original } \\
\text { Sample } \\
\text { (0) }\end{array}$ & $\begin{array}{l}\text { Sample } \\
\text { Mean } \\
\text { (M) }\end{array}$ & DP & $\begin{array}{c}\text { Intervalo } \\
\text { Confiança 95\% }\end{array}$ & $\begin{array}{c}\text { T Statistics } \\
(|\mathrm{O} / \mathrm{DP}|) \\
\mathrm{t}>1,96\end{array}$ & $\begin{array}{c}P \text { Values } \\
p<0,05\end{array}$ \\
\hline Autonomia -> valores -> comprometimento -> afiliativa & 0,080 & 0,081 & 0,008 & {$[0,066 ; 0,096]$} & 10,568 & 0,0000 \\
\hline Bem-estar -> valores -> comprometimento -> afiliativa & 0,079 & 0,079 & 0,007 & {$[0,065 ; 0,092]$} & 10,899 & 0,0000 \\
\hline Coletividade -> valores $->$ comprometimento -> afiliativa & 0,167 & 0,169 & 0,015 & {$[0,139 ; 0,197]$} & 11,111 & 0,0000 \\
\hline Conformidade -> valores -> comprometimento -> afiliativa & 0,107 & 0,108 & 0,014 & {$[0,083 ; 0,134]$} & 7,578 & 0,0000 \\
\hline Domínio -> valores -> comprometimento -> afiliativa & 0,027 & 0,028 & 0,003 & {$[0,021 ; 0,034]$} & 8,500 & 0,0000 \\
\hline Prestígio -> valores -> comprometimento -> afiliativa & 0,072 & 0,072 & 0,009 & {$[0,053 ; 0,089]$} & 7,773 & 0,0000 \\
\hline Realização -> valores -> comprometimento -> afiliativa & 0,084 & 0,084 & 0,008 & {$[0,069 ; 0,098]$} & 10,824 & 0,0000 \\
\hline Tradição -> valores -> comprometimento -> afiliativa & 0,023 & 0,022 & 0,006 & {$[0,009 ; 0,033]$} & 3,820 & 0,0002 \\
\hline
\end{tabular}

Fonte: Resultados elaborados a partir dos dados da pesquisa e calculados por meio do Software Smart-PLS 
Tabela $\mathrm{A}_{3} 15$ - Efeitos diretos das metas motivacionais -> base de comprometimento afiliativa

\begin{tabular}{l|cccccc}
\hline $\begin{array}{c}\text { Efeitos diretos } \\
\begin{array}{c}\text { Metas motivacionais e Base } \\
\text { de Comprometimento Afiliativa }\end{array}\end{array}$ & $\begin{array}{c}\text { Original } \\
\text { Sample }(0)\end{array}$ & $\begin{array}{c}\text { Sample } \\
\text { Mean (M) }\end{array}$ & DP & $\begin{array}{c}\text { Intervalo } \\
\text { Confiança 95\% }\end{array}$ & $\begin{array}{c}\text { T Statistics } \\
(|\mathrm{O} / \mathrm{DP}|) \\
t>1,96\end{array}$ & $\begin{array}{c}\text { P Values } \\
p<0,05\end{array}$ \\
\hline Valores -> comprometimento & 0,628 & 0,634 & 0,048 & {$[0,539 ; 0,718]$} & 13,029 & 0,000 \\
Comprometimento -> afiliativa & 0,828 & 0,828 & 0,024 & {$[0,774 ; 0,871]$} & 33,371 & 0,0000 \\
Autonomia -> valores & 0,155 & 0,154 & 0,008 & {$[0,139 ; 0,169]$} & 19,338 & 0,000 \\
Bem-estar -> valores & 0,152 & 0,152 & 0,010 & {$[0,134 ; 0,171]$} & 15,604 & 0,000 \\
Coletividade -> valores & 0,321 & 0,321 & 0,014 & {$[0,295 ; 0,347]$} & 22,737 & 0,000 \\
Conformidade -> valores & 0,206 & 0,205 & 0,016 & {$[0,176 ; 0,238]$} & 12,921 & 0,000 \\
Domínio -> valores & 0,053 & 0,052 & 0,004 & {$[0,045 ; 0,059]$} & 14,742 & 0,000 \\
Prestígio -> valores & 0,139 & 0,138 & 0,014 & {$[0,112 ; 0,165]$} & 10,291 & 0,000 \\
Realização -> valores & 0,161 & 0,161 & 0,007 & {$[0,146 ; 0,176]$} & 21,960 & 0,000 \\
Tradição -> valores & 0,043 & 0,041 & 0,010 & {$[0,020 ; 0,060]$} & 4,257 & 0,000 \\
\hline
\end{tabular}

Fonte: Resultados elaborados a partir dos dados da pesquisa e calculados por meio do Software Smart-PLS

Tabela $A_{3} 16$ - Resultado da Análise de significância para efeitos indiretos total - Mediação múltipla

\begin{tabular}{|c|c|c|c|c|c|c|c|}
\hline $\begin{array}{l}\text { Relações } \\
\text { Diretas }\end{array}$ & $\begin{array}{l}\text { Relações } \\
\text { Indiretas }\end{array}$ & Mediação & $\begin{array}{c}\text { Original } \\
\text { Sample (0) }\end{array}$ & $\begin{array}{c}\text { Sample } \\
\text { Mean (M) }\end{array}$ & DP & $\begin{array}{c}\text { T Statistics } \\
(|\mathrm{O} / \mathrm{DP}|) \\
t>1,96\end{array}$ & $\begin{array}{l}\text { PValues } \\
p<0,05\end{array}$ \\
\hline $\begin{array}{l}\text { TRAD->VAL } \\
\text { VAL->COMP } \\
\text { COMP->AFIL }\end{array}$ & $\begin{array}{l}\text { TRAD -> AFIL } \\
\text { VAL ->AFIL } \\
\text { TRAD -> COMP }\end{array}$ & TRADIÇÃO -> AFILIATIVA via VALORES e COMPROMETIMENTO & 0,0076 & 0,0219 & 0,0059 & 1,292 & 0,1969 \\
\hline $\begin{array}{l}\text { AUT->VAL } \\
\text { VAL->COMP } \\
\text { COMP->AFIL }\end{array}$ & $\begin{array}{l}\text { AUT }->\text { AFIL } \\
\text { VAL }>>\text { AFIL } \\
\text { AUT }>>\text { COMP }\end{array}$ & AUTONOMIA ->AFILIATIVA via VALORES e COMPROMETIMENTO & 0,0273 & 0,0810 & 0,0076 & 3,575 & 0,000 \\
\hline $\begin{array}{l}\text { BEM->VAL } \\
\text { VAL->COMP } \\
\text { COMP->AFIL }\end{array}$ & $\begin{array}{l}\text { BEM }->A F I L \\
V A L->A F I L \\
B E M->C O M P\end{array}$ & BEM-ESTAR -> AFILIATIVA via VALORES e COMPROMETIMENTO & 0,0267 & 0,0795 & 0,0072 & 3,687 & 0,0003 \\
\hline $\begin{array}{l}\text { COLET->VAL } \\
\text { VAL->COMP } \\
\text { COMP->AFIL }\end{array}$ & $\begin{array}{l}\text { COLET ->AFIL } \\
\text { VAL ->AFIL } \\
\text { COLET -> COMP }\end{array}$ & COLETIVIDADE ->AFILIATIVA via VALORES e COMPROMETIMENTO & 0,0566 & 0,1686 & 0,0151 & 3,759 & 0,0002 \\
\hline $\begin{array}{l}\text { CONF->VAL } \\
\text { VAL->COMP } \\
\text { COMP->AFIL }\end{array}$ & $\begin{array}{l}\text { CONF ->AFIL } \\
\text { VAL ->AFIL } \\
\text { CONF }->\text { COMP }\end{array}$ & CONFORMIDADE -> AFILIATIVA via VALORES e COMPROMETIMENTO & 0,0362 & 0,1080 & 0,0141 & 2,564 & 0,0107 \\
\hline $\begin{array}{l}\text { DOM->VAL } \\
\text { VAL->COMP } \\
\text { COMP->AFIL }\end{array}$ & $\begin{array}{l}\text { DOM ->AFIL } \\
\text { VAL ->AFIL } \\
\text { DOM ->COMP }\end{array}$ & DOMÍNIO -> AFILIATIVA via VALORES e COMPROMETIMENTO & 0,0092 & 0,0276 & 0,0032 & 2,875 & 0,0042 \\
\hline $\begin{array}{l}\text { PREST->VAL } \\
\text { VAL->COMP } \\
\text { COMP->AFIL }\end{array}$ & \begin{tabular}{|l} 
PREST $->A F I L$ \\
VAL ->AFIL \\
PREST $->$ COMP
\end{tabular} & PRESTÍGIO -> AFILIATIVA via VALORESe COMPROMETIMENTO & 0,0245 & 0,0724 & 0,0093 & 2,630 & 0,0088 \\
\hline $\begin{array}{l}\text { REAL->VAL } \\
\text { VAL-> COMP } \\
\text { COMP ->AFIL }\end{array}$ & $\begin{array}{l}\text { REAL ->AFIL } \\
\text { VAL ->AFIL } \\
\text { REAL ->COMP }\end{array}$ & REALIZAÇÃO ->AFILIATIVA via VALORES e COMPROMETIMENTO & 0,0283 & 0,0843 & 0,0077 & 3,662 & 0,0003 \\
\hline
\end{tabular}

Fonte: Resultados elaborados a partir dos dados da pesquisa e calculados por meio dos Softwares Smart-PLS e Excel 
A partir das tabelas $A_{3} 14, A_{3} 15$ e $A_{3} 16$, as seguintes conclusões foram obtidas

Quadro $\mathrm{A}_{3} \mathrm{O6}$ - Resultados da análise mediadora múltipla

\begin{tabular}{|c|c|c|c|c|}
\hline \multirow{2}{*}{ Mediadoras } & \multirow{2}{*}{ Relação } & \multicolumn{2}{|c|}{ Significância } & \multirow{2}{*}{ Interpretação } \\
\hline & & Indireto & Direto & \\
\hline \multirow{8}{*}{ Valores e Comprometimento } & Autonomia -> Afiliativa & Sim & Sim & Mediação parcial \\
\hline & Bem-estar -> Afiliativa & Sim & Sim & Mediação parcial \\
\hline & Coletividade $->$ Afiliativa & Sim & Sim & Mediação parcial \\
\hline & Conformidade -> Afiliativa & Sim & Sim & Mediação parcial \\
\hline & Domínio -> Afiliativa & Sim & Sim & Mediação parcial \\
\hline & Prestígio -> Afiliativa & Sim & Sim & Mediação parcial \\
\hline & Realização -> Afiliativa & Sim & Sim & Mediação parcial \\
\hline & Tradição -> Afiliativa & Não & Sim & Não há mediação \\
\hline
\end{tabular}

Fonte: Resultados elaborados a partir dos dados da pesquisa e calculados por meio do Software Smart-PLS

O que se verifica é a existência de mediação parcial dos construtos valores e comprometimento sobre as relações das metas motivacionais e base de comprometimento afiliativa, com exceção da meta motivacional tradição.

\section{Metas Motivacionais e Base de Comprometimento Obrigação pelo desempenho}

Tabela $A_{3} 17$ - Efeitos específicos indiretos das metas motivacionais $\rightarrow$ base de comprometimento obrigação pelo desempenho

\begin{tabular}{|c|c|c|c|c|c|c|}
\hline $\begin{array}{c}\text { Efeitos indiretos } \\
\text { Metas motivacionais e Base de } \\
\text { Comprometimento obrigação pelo desempenho }\end{array}$ & $\begin{array}{l}\text { Original } \\
\text { Sample } \\
(0)\end{array}$ & $\begin{array}{l}\text { Sample } \\
\text { Mean } \\
\text { (M) }\end{array}$ & DP & $\begin{array}{c}\text { Intervalo } \\
\text { Confiança 95\% }\end{array}$ & $\begin{array}{c}\text { T Statistics } \\
\text { (|O/DP|) } \\
\text { t>1,96 }\end{array}$ & $\begin{array}{l}P \text { Values } \\
p<0,05\end{array}$ \\
\hline Autonomia -> valores -> comprometimento -> desempenho & 0,057 & 0,057 & 0,006 & {$[0,044 ; 0,068]$} & 8,842 & 0,0000 \\
\hline Bem-estar -> valores -> comprometimento -> desempenho & 0,055 & 0,056 & 0,006 & {$[0,043 ; 0,066]$} & 9,004 & 0,0000 \\
\hline Coletividade -> valores -> comprometimento -> desempenho & 0,117 & 0,118 & 0,014 & {$[0,089 ; 0,144]$} & 8,489 & 0,0000 \\
\hline Conformidade -> valores $->$ comprometimento $->$ desempenho & 0,075 & 0,076 & 0,013 & {$[0,051 ; 0,101]$} & 5,878 & 0,0000 \\
\hline Domínio -> valores -> comprometimento -> desempenho & 0,019 & 0,019 & 0,003 & {$[0,014 ; 0,025]$} & 6,815 & 0,0000 \\
\hline Prestígio -> valores -> comprometimento -> desempenho & 0,051 & 0,051 & 0,008 & {$[0,034 ; 0,067]$} & 6,033 & 0,0000 \\
\hline Realização -> valores -> comprometimento -> desempenho & 0,059 & 0,059 & 0,007 & {$[0,044 ; 0,073]$} & 8,143 & 0,0000 \\
\hline Tradição -> valores -> comprometimento -> desempenho & 0,016 & 0,015 & 0,004 & {$[0,006 ; 0,023]$} & 3,550 & 0,0004 \\
\hline
\end{tabular}

Fonte: Resultados elaborados a partir dos dados da pesquisa e calculados por meio do Software Smart-PLS 
Tabela $\mathrm{A}_{3} 18$ - Efeitos diretos das metas motivacionais -> base de comprometimento obrigação pelo desempenho

\begin{tabular}{l|cccccc}
\hline $\begin{array}{c}\text { Efeitos diretos } \\
\text { Metas motivacionais e Base de } \\
\begin{array}{c}\text { Comprometimento obrigação pelo } \\
\text { desempenho }\end{array}\end{array}$ & $\begin{array}{c}\text { Original } \\
\text { Sample } \\
(0)\end{array}$ & $\begin{array}{c}\text { Sample } \\
\text { Mean (M) }\end{array}$ & DP & $\begin{array}{c}\text { Intervalo } \\
\text { Confiança 95\% }\end{array}$ & $\begin{array}{c}\text { T Statistics } \\
(\mid \mathrm{O} / \mathrm{DP}) \\
\mathrm{t}>1,96\end{array}$ & $\begin{array}{c}\text { P Values } \\
p<0,05\end{array}$ \\
\hline $\begin{array}{l}\text { Valores -> comprometimento } \\
\text { Comprometimento -> desempenho }\end{array}$ & 0,628 & 0,634 & 0,048 & {$[0,539 ; 0,718]$} & 13,029 & 0,000 \\
Autonomia -> valores & 0,581 & 0,581 & 0,061 & {$[0,447 ; 0,683]$} & 9,604 & 0,000 \\
Bem-estar -> valores & 0,155 & 0,154 & 0,008 & {$[0,139 ; 0,169]$} & 19,338 & 0,000 \\
Coletividade -> valores & 0,152 & 0,152 & 0,010 & {$[0,134 ; 0,171]$} & 15,604 & 0,000 \\
Conformidade -> valores & 0,321 & 0,321 & 0,014 & {$[0,295 ; 0,347]$} & 22,737 & 0,000 \\
Domínio -> valores & 0,206 & 0,205 & 0,016 & {$[0,176 ; 0,238]$} & 12,921 & 0,000 \\
Prestígio -> valores & 0,053 & 0,052 & 0,004 & {$[0,045 ; 0,059]$} & 14,742 & 0,000 \\
Realização -> valores & 0,139 & 0,138 & 0,014 & {$[0,112 ; 0,165]$} & 10,291 & 0,000 \\
Tradição -> valores & 0,161 & 0,161 & 0,007 & {$[0,146 ; 0,176]$} & 21,960 & 0,000 \\
\hline
\end{tabular}

Fonte: Resultados elaborados a partir dos dados da pesquisa e calculados por meio do Software Smart-PLS

Tabela $A_{3} 19$ - Resultado da Análise de significância para efeitos indiretos total - Mediação múltipla

\begin{tabular}{|c|c|c|c|c|c|c|c|}
\hline $\begin{array}{l}\text { Relações } \\
\text { Diretas }\end{array}$ & Relações Indiretas & Mediação & Original Sample (0) & $\begin{array}{l}\text { Sample Mean } \\
\text { (M) }\end{array}$ & $\mathrm{DP}$ & $\begin{array}{c}\text { TStafistics } \\
(\mid 0 / D P \|) \\
t>1,96\end{array}$ & $\begin{array}{l}p \text {-values } \\
p<0,05\end{array}$ \\
\hline $\begin{array}{l}\text { TRAD->VAL } \\
\text { VAL->COMP } \\
\text { COMP->DES }\end{array}$ & $\begin{array}{l}\text { TRAD }->\text { DES } \\
\text { VAL }>>\text { DES } \\
\text { TRAD }>>\text { COMP }\end{array}$ & TRADIÇÃO >> OBRIGAÇÃO P/ DESEMPENHO via VALORES e COMPROMETIMENTO & 0,0054 & 0,0153 & 0,0045 & 1,201 & 0,2304 \\
\hline $\begin{array}{l}\text { AUT->VAL } \\
\text { VAL->COMP } \\
\text { COMP->DES }\end{array}$ & $\begin{array}{l}\text { AUT }>>D E S \\
V A L->D E S \\
D E S ~>>C O M P\end{array}$ & AUTONOMIA $>O B R I G A C ̧ A ̃ O P / D E S E M P E N H O$ via VALORES \& COMPROMETIMENTO & 0,0191 & 0,0566 & 0,0064 & 2,991 & 0,003 \\
\hline $\begin{array}{l}B E M->V A L \\
V A L->C O M P \\
\text { COMP->DES }\end{array}$ & $\begin{array}{l}\text { BEM }>>D E S \\
V A L->D E S \\
B E M ~>>C O M P\end{array}$ & BEM-ESTAR -> OBRIGAÇÃO P/ DESEMPENHO via VALORES e COMPROMETIMENTO & 0,0187 & 0,0556 & 0,0062 & 3,046 & 0,0024 \\
\hline $\begin{array}{l}\text { COLET->VAL } \\
\text { VAL->COMP } \\
\text { COMP->DES }\end{array}$ & $\begin{array}{l}\text { COLET }>>\text { DES } \\
\text { VAL }>>\text { DES } \\
\text { COLET }>>\text { COMP }\end{array}$ & COLETIVIDADE ->OBRIGAÇÃO P/ DESEMPENHO via VALORES e COMPROMETIMENTO & 0,0398 & 0,1179 & 0,0138 & 2,871 & 0,0043 \\
\hline $\begin{array}{l}\text { CONF->VAL } \\
V A L->C O M P \\
\text { COMP->DES }\end{array}$ & $\begin{array}{l}\text { CONF }>>\text { DES } \\
\text { VAL }>D \text { DES } \\
\text { CONF }>\text { COMP }\end{array}$ & CONFORMIDADE -> OBRIGAÇÃO PI DESEMPENHO via VALORES e COMPROMETIMENTO & 0,0254 & 0,0757 & 0,0128 & 1,988 & 0,0473 \\
\hline $\begin{array}{l}\text { DOM-> VAL } \\
\text { VAL->COMP } \\
\text { COMP-> DES }\end{array}$ & $\begin{array}{l}\text { DOM }>>D E S \\
V A L \text {-> DES } \\
\text { DOM }>>\text { COMP }\end{array}$ & DOMÍNIO -> OBRIGAÇÃO PI DESEMPENHO via VALORES e COMPROMETIMENTO & 0,0065 & 0,0193 & 0,0028 & 2,305 & 0,0216 \\
\hline $\begin{array}{l}\text { PREST->VAL } \\
\text { VAL-> COMP } \\
\text { COMP->DES }\end{array}$ & $\begin{array}{l}\text { PREST -> DES } \\
\text { VAL -> DES } \\
\text { PREST }>>\text { COMP }\end{array}$ & PRESTIGIO $>>$ OBRIGAÇÃO P/ DESEMPENHO via VALORESe COMPROMETIMENTO & 0,0172 & 0,0508 & 0,0084 & 2,041 & 0,0418 \\
\hline $\begin{array}{l}\text { REAL->VAL } \\
\text { VAL-> COMP } \\
\text { COMP ->DES }\end{array}$ & $\begin{array}{l}\text { REAL }>>\text { DES } \\
\text { VAL ->DES } \\
\text { REAL }>>\text { COMP }\end{array}$ & REALIZAÇÃO ->OBRIGAÇÃO P/ DESEMPENHO via VALORES e COMPROMETIMENTO & 0,0199 & 0,0590 & 0,0072 & 2,754 & 0,0061 \\
\hline
\end{tabular}

Fonte: Resultados elaborados a partir dos dados da pesquisa e calculados por meio dos Softwares Smart-PLS e Excel 
A partir das tabelas $A_{3} 17, A_{3} 18$ e $A_{3} 19$, as seguintes conclusões foram obtidas.

Quadro $\mathrm{A}_{3} 07$ - Resultados da análise mediadora múltipla

\begin{tabular}{|c|c|c|c|c|}
\hline \multirow{2}{*}{ Mediadoras } & \multirow{2}{*}{ Relação } & \multicolumn{2}{|c|}{ Significância } & \multirow{2}{*}{ Interpretação } \\
\hline & & Indireto & Direto & \\
\hline \multirow{8}{*}{$\begin{array}{c}\text { Valores e } \\
\text { Comprometimento }\end{array}$} & Autonomia -> Obrigação p/ desempenho & Sim & Sim & Mediação parcial \\
\hline & Bem-estar -> Obrigação $p /$ desempenho & Sim & Sim & Mediação parcial \\
\hline & Coletividade -> Obrigação $p /$ desempenho & Sim & Sim & Mediação parcial \\
\hline & Conformidade -> Obrigação $p /$ desempenho & Sim & Sim & Mediação parcial \\
\hline & Domínio -> Obrigação $\mathrm{p} /$ desempenho & Sim & Sim & Mediação parcial \\
\hline & Prestígio -> Obrigação $\mathrm{p} /$ desempenho & Sim & Sim & Mediação parcial \\
\hline & Realização -> Obrigação $p /$ desempenho & Sim & Sim & Mediação parcial \\
\hline & Tradição -> Obrigação $p /$ desempenho & Não & Sim & ão há mediação \\
\hline
\end{tabular}

Fonte: Resultados elaborados a partir dos dados da pesquisa e calculados por meio do Software Smart-PLS

O que se verifica é a existência de mediação parcial dos construtos valores e comprometimento sobre as relações das metas motivacionais e base de comprometimento obrigação pelo desempenho, com exceção da meta motivacional tradição.

\section{Metas Motivacionais e Base de Comprometimento Obrigação em permanecer}

Tabela $\mathrm{A}_{3} 20$ - Efeitos específicos das metas motivacionais -> base de comprometimento obrigação em permanecer

\begin{tabular}{l|cccccc}
\multicolumn{1}{c|}{$\begin{array}{c}\text { Eetas motivacionais e Base de } \\
\text { Comprometimento obrigação em permanecer }\end{array}$} & $\begin{array}{c}\text { Original } \\
\text { Sample } \\
(\mathrm{O})\end{array}$ & $\begin{array}{c}\text { Sample } \\
\text { Mean } \\
(\mathrm{M})\end{array}$ & $\begin{array}{c}\text { DP } \\
\text { Autonomia -> valores ->COMP-> obrigação em permanecer }\end{array}$ & $\begin{array}{c}\text { Intervalo } \\
\text { Confiança } \\
95 \%\end{array}$ & $\begin{array}{c}\text { T Statistics } \\
(|\mathrm{O} / \mathrm{DP}|) \\
\mathrm{t}>1,96\end{array}$ & $\begin{array}{c}\mathrm{p} \text {-values } \\
\mathrm{p}<0,05\end{array}$ \\
Bem-estar -> valores -> COMP -> obrigação em permanecer & 0,060 & 0,008 & {$[0,044 ; 0,075]$} & 7,751 & 0,000 \\
Coletividade -> valores -> COMP -> obrigação em permanecer & 0,058 & 0,059 & 0,008 & {$[0,042 ; 0,075]$} & 7,114 & 0,000 \\
Conformidade -> valores -> COMP -> obrigação em permanecer & 0,079 & $0,0,126$ & 0,016 & {$[0,094 ; 0,154]$} & 7,879 & 0,000 \\
Domínio -> valores -> COMP -> obrigação em permanecer & 0,020 & 0,021 & 0,003 & {$[0,015 ; 0,026]$} & 7,084 & 0,000 \\
Prestígio -> valores -> COMP.-> obrigação em permanecer & 0,053 & 0,054 & 0,008 & {$[0,038 ; 0,069]$} & 6,623 & 0,000 \\
Realização -> valores -> COMP.-> obrigação em permanecer & 0,062 & 0,063 & 0,008 & {$[0,048 ; 0,077]$} & 8,162 & 0,000 \\
Tradição -> valores -> COMP-> obrigação em permanecer & 0,017 & 0,016 & 0,004 & {$[0,007 ; 0,024]$} & 3,953 & 0,000 \\
\hline
\end{tabular}

Fonte: Resultados elaborados a partir dos dados da pesquisa e calculados por meio do Software Smart-PLS 
Tabela $\mathrm{A}_{3} 21$ - Efeitos diretos das metas motivacionais -> base de comprometimento obrigação em permanecer

\begin{tabular}{l|cccccc}
\hline $\begin{array}{c}\text { Eetas motivacionais e Base de } \\
\text { Comprometimento obrigação em } \\
\text { permanecer }\end{array}$ & $\begin{array}{c}\text { Original } \\
\text { Sample } \\
(0)\end{array}$ & $\begin{array}{c}\text { Sample } \\
\text { Mean (M) }\end{array}$ & DP & $\begin{array}{c}\text { Intervalo } \\
\text { Confiança 95\% }\end{array}$ & $\begin{array}{c}\text { T Statistics } \\
(|\mathrm{O} / \mathrm{DP}|) \\
\mathrm{t}>1,96\end{array}$ & $\begin{array}{c}\mathrm{p} \text {-values } \\
p<0,05\end{array}$ \\
\hline $\begin{array}{l}\text { Valores -> comprometimento } \\
\text { Comprometimento -> permanecer }\end{array}$ & 0,628 & 0,634 & 0,048 & {$[0,539 ; 0,718]$} & 13,029 & 0,000 \\
Autonomia -> valores & 0,612 & 0,614 & 0,058 & {$[0,496 ; 0,710]$} & 10,549 & 0,000 \\
Bem-estar -> valores & 0,155 & 0,154 & 0,008 & {$[0,139 ; 0,169]$} & 19,338 & 0,000 \\
Coletividade -> valores & 0,152 & 0,152 & 0,010 & {$[0,134 ; 0,171]$} & 15,604 & 0,000 \\
Conformidade -> valores & 0,321 & 0,321 & 0,014 & {$[0,295 ; 0,347]$} & 22,737 & 0,000 \\
Domínio -> valores & 0,206 & 0,205 & 0,016 & {$[0,176 ; 0,238]$} & 12,921 & 0,000 \\
Prestígio -> valores & 0,053 & 0,052 & 0,004 & {$[0,045 ; 0,059]$} & 14,742 & 0,000 \\
Realização -> valores & 0,139 & 0,138 & 0,014 & {$[0,112 ; 0,165]$} & 10,291 & 0,000 \\
Tradição -> valores & 0,161 & 0,161 & 0,007 & {$[0,146 ; 0,176]$} & 21,960 & 0,000 \\
\hline
\end{tabular}

Fonte: Resultados elaborados a partir dos dados da pesquisa e calculados por meio do Software Smart-PLS

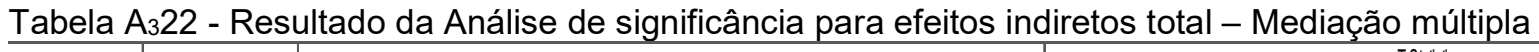

\begin{tabular}{|c|c|c|c|c|c|c|c|}
\hline $\begin{array}{l}\text { Relações } \\
\text { Diretas }\end{array}$ & Relações Indiretas & Mediação & Original Sample (0) & $\begin{array}{c}\text { Sample Mean } \\
\text { (M) }\end{array}$ & DP & $\begin{array}{l}\text { TStaisics } \\
(\text { (OIDP) } \\
t>1,96 \\
\end{array}$ & $\begin{array}{l}\text { p-values } \\
\text { p<0,05 }\end{array}$ \\
\hline $\begin{array}{l}\text { TRAD->VAL } \\
\text { VAL->COMP } \\
\text { COMP->PER }\end{array}$ & $\begin{array}{l}\text { TRAD }>>\text { PER } \\
\text { VAL }>\text { PER } \\
\text { TRAD }>\text { COMP }\end{array}$ & TRADIÇÃO -> OBRIGAÇÃOO EM PERMANECER via VALORES E COMPROMETIMENTO & 0,0056 & 0,0162 & 0,0042 & 1,337 & 0,1817 \\
\hline $\begin{array}{l}\text { AUT->VAL } \\
\text { VAL->COMP } \\
\text { COMP->PER }\end{array}$ & $\begin{array}{l}\text { AUT }>\text { PER } \\
V A L ~>>P E R \\
\text { DES }>>\text { COMP }\end{array}$ & AUTONOMIA $>O B R I G A C ̧ A ̃ O$ EM PERMANECER via VALORES e COMPROMETIMENTO & 0,0201 & 0,0604 & 0,0077 & 2,622 & 0,009 \\
\hline $\begin{array}{l}\text { BEM->VAL } \\
\text { VAL->COMP } \\
\text { COMP-> PER }\end{array}$ & $\begin{array}{l}\text { BEM }>>\text { PER } \\
\text { VAL }>>\text { PER } \\
\text { BEM }>\text { >COMP }\end{array}$ & BEM-ESTAR $>$ OBRIGAÇÃO EM PERMANECER via VALORES e COMPROMETIMENTO & 0,0197 & 0,0594 & 0,0082 & 2,406 & 0,0165 \\
\hline $\begin{array}{l}\text { COLET->VAL } \\
\text { VAL->COMP } \\
\text { COMP.>PER }\end{array}$ & $\begin{array}{l}\text { COLET }>>\text { PER } \\
\text { VAL }>>\text { PER } \\
\text { COLET }>\text { COMP }\end{array}$ & COLETIVIDADE ->OBRIGAÇÃO EM PERMANECER via VALORES e COMPROMETIMENTO & 0,0418 & 0,1257 & 0,0157 & 2,665 & 0,0079 \\
\hline $\begin{array}{l}\text { CONF->VAL } \\
\text { VAL->COMP } \\
\text { COMP.>PER }\end{array}$ & $\begin{array}{l}\text { CONF }>>\text { PER } \\
\text { VAL }>\text { PER } \\
\text { CONF }>\text { COMP }\end{array}$ & CONFORMIDADE -> OBRIGAÇÃO EM PERMANECER via VALORES E COMPROMETMENTO & 0,0267 & 0,0802 & 0,0102 & 2,631 & 0,0088 \\
\hline $\begin{array}{l}\text { DOM->VAL } \\
\text { VAL }>\text { COMP } \\
\text { COMP }>>\text { PER }\end{array}$ & $\begin{array}{l}\text { DOM }>\text { PPER } \\
\text { VAL }>>\text { PER } \\
\text { DOM }>\text { >COMP }\end{array}$ & DOMINIO -> OBRIGAÇÃO EM PERMANECER via VALORES E COMPROMETIMENTO & 0,0068 & 0,0206 & 0,0028 & 2,396 & 0,0169 \\
\hline $\begin{array}{l}\text { PREST }>\text { VAL } \\
\text { VAL->COMP } \\
\text { COMP.>PER }\end{array}$ & $\begin{array}{l}\text { PREST -> PER } \\
\text { VAL }>>\text { PER } \\
\text { PREST }>\text { COMP }\end{array}$ & PRESTIGIO -> OBRIGAÇÃO EM PERMANECER via VALORESe COMPROMETIMENTO & 0,0181 & 0,0539 & 0,0081 & 2,240 & 0,0255 \\
\hline $\begin{array}{l}\text { REAL->VAL } \\
\text { VAL->COMP } \\
\text { COMP }>\text { PER }\end{array}$ & $\begin{array}{l}\text { REAL ->PER } \\
\text { VAL ->PER } \\
\text { REAL •>COMP }\end{array}$ & REALLZAÇÃO >OBRIGAÇ̧ÃO EM PERMANECER via VALORES e COMPROMETIMENTO & 0,0209 & 0,0629 & 0,0076 & 2,761 & 0,0060 \\
\hline
\end{tabular}

Fonte: Resultados elaborados a partir dos dados da pesquisa e calculados por meio dos Softwares Smart-PLS e Excel 
A partir das tabelas $A_{3} 20, A_{3} 21$ e $A_{3} 22$, as seguintes conclusões foram obtidas.

Quadro $\mathrm{A}_{3} 08$ - Resultados da análise mediadora múltipla

\begin{tabular}{|c|c|c|c|c|}
\hline \multirow{2}{*}{ Mediadoras } & \multirow{2}{*}{ Relação } & \multicolumn{2}{|c|}{ Significância } & \multirow{2}{*}{ Interpretação } \\
\hline & & Indireto & Direto & \\
\hline \multirow{8}{*}{$\begin{array}{c}\text { Valores e } \\
\text { Comprometimento }\end{array}$} & Autonomia -> Obrigação em permanecer & Sim & Sim & Mediação parcial \\
\hline & Bem-estar -> Obrigação em permanecer & Sim & Sim & Mediação parcial \\
\hline & Coletividade -> Obrigação em permanecer & Sim & Sim & Mediação parcial \\
\hline & Conformidade -> Obrigação em permanecer & Sim & Sim & Mediação parcial \\
\hline & Domínio -> Obrigação em permanecer & Sim & Sim & Mediação parcial \\
\hline & Prestígio -> Obrigação em permanecer & Sim & Sim & Mediação parcial \\
\hline & Realização -> Obrigação em permanecer & Sim & Sim & Mediação parcial \\
\hline & Tradição -> Obrigação em permanecer & Não & Sim & Não há mediação \\
\hline
\end{tabular}

Fonte: Resultados elaborados a partir dos dados da pesquisa e calculados por meio do Software Smart-PLS

Há a existência de mediação parcial dos construtos valores e comprometimento sobre as relações das metas motivacionais e base de comprometimento obrigação em permanecer, com exceção da meta motivacional tradição.

Metas Motivacionais e Base de Comprometimento L. Consistente de Atividade Verificar a significância das relações indiretas

Tabela $\mathrm{A}_{3} 23$ - Efeitos específicos das metas motivacionais -> base de comprometimento linha consistente de atividade

\begin{tabular}{l|cccccc}
\hline \multicolumn{1}{c|}{$\begin{array}{c}\text { Eetas motivacionais e Base de } \\
\text { Comprometimento Linha Consistente de Atividade }\end{array}$} & $\begin{array}{c}\text { Original } \\
\text { Sample } \\
(\mathrm{O})\end{array}$ & $\begin{array}{c}\text { Sample } \\
\text { Mean } \\
(\mathrm{M})\end{array}$ & $\begin{array}{c}\text { DP } \\
\text { Intervalo } \\
\text { Confiança } \\
95 \%\end{array}$ & $\begin{array}{c}\text { TStatistics } \\
(\mid \mathrm{O} / \mathrm{DP}) \\
\mathrm{t}>1,96\end{array}$ & $\begin{array}{c}\mathrm{p} \text {-values } \\
\mathrm{p}<0,05\end{array}$ \\
\hline Autonomia -> VAL -> COMP -> L.Consistente atividade & 0,058 & 0,059 & 0,009 & {$[0,041 ; 0,075]$} & 6,502 & 0,000 \\
Bem-estar-> VAL -> COMP -> L.Consistente atividade & 0,057 & 0,058 & $0,008[0,041 ; 0,073]$ & 7,168 & 0,000 \\
Coletividade -> VAL-> COMP-> L.Consistente atividade & 0,121 & 0,122 & 0,017 & {$[0,088 ; 0,156]$} & 6,931 & 0,000 \\
Conformidade > VAL-> COMP-> L.Consistente atividde & 0,077 & 0,079 & $0,015[0,050 ; 0,107]$ & 5,148 & 0,000 \\
Domínio -> VAL -> COMP -> L.Consistente atividade & 0,020 & 0,020 & 0,003 & {$[0,013 ; 0,027]$} & 5,642 & 0,000 \\
Prestígio -> VAL -> COMP -> L.Consistente atividade & 0,052 & 0,053 & 0,010 & {$[0,032 ; 0,071]$} & 5,072 & 0,000 \\
Realização -> VAL -> COMP -> L.Consistente atividade & 0,060 & 0,061 & 0,009 & {$[0,044 ; 0,078]$} & 6,540 & 0,000 \\
Tradição -> VAL -> COMP -> L.Consistente atividade & 0,016 & 0,016 & 0,005 & {$[0,006 ; 0,025]$} & 3,435 & 0,001 \\
\hline
\end{tabular}

Verificar a significância das relações diretas 
Tabela $\mathrm{A}_{3} 24$ - Efeitos diretos das metas motivacionais -> base de comprometimento linha consistente de atividade

\begin{tabular}{l|cccccc}
\hline \multicolumn{1}{c|}{$\begin{array}{c}\text { Efeitos diretos } \\
\quad \begin{array}{c}\text { Comprometimento Linha } \\
\text { Consistente de Atividade }\end{array}\end{array}$} & $\begin{array}{c}\text { Original } \\
\text { Sample } \\
(\mathrm{O})\end{array}$ & $\begin{array}{c}\text { Sample } \\
\text { Mean (M) }\end{array}$ & DP & $\begin{array}{c}\text { Intervalo } \\
\text { Confiança 95\% }\end{array}$ & $\begin{array}{c}\text { T Statistics } \\
(|\mathrm{O} / \mathrm{DP}|) \\
\mathrm{t}>1,96\end{array}$ & $\begin{array}{c}\mathrm{p} \text {-values } \\
\mathrm{p}<0,05\end{array}$ \\
\hline Valores -> comprometimento & 0,628 & 0,634 & 0,048 & {$[0,539 ; 0,718]$} & 13,029 & 0,000 \\
Comprometimento -> consistente & 0,598 & 0,601 & 0,070 & {$[0,448 ; 0,719]$} & 8,507 & 0,000 \\
Autonomia -> valores & 0,155 & 0,154 & 0,008 & {$[0,139 ; 0,169]$} & 19,338 & 0,000 \\
Bem-estar -> valores & 0,152 & 0,152 & 0,010 & {$[0,134 ; 0,171]$} & 15,604 & 0,000 \\
Coletividade -> valores & 0,321 & 0,321 & 0,014 & {$[0,295 ; 0,347]$} & 22,737 & 0,000 \\
Conformidade -> valores & 0,206 & 0,205 & 0,016 & {$[0,176 ; 0,238]$} & 12,921 & 0,000 \\
Domínio -> valores & 0,053 & 0,052 & 0,004 & {$[0,045 ; 0,059]$} & 14,742 & 0,000 \\
Prestígio -> valores & 0,139 & 0,138 & 0,014 & {$[0,112 ; 0,165]$} & 10,291 & 0,000 \\
Realização -> valores & 0,161 & 0,161 & 0,007 & {$[0,146 ; 0,176]$} & 21,960 & 0,000 \\
Tradição -> valores & 0,043 & 0,041 & 0,010 & {$[0,020 ; 0,060]$} & 4,257 & 0,000 \\
\hline
\end{tabular}

Fonte: Resultados elaborados a partir dos dados da pesquisa e calculados por meio do Software Smart-PLS

Tabela A $_{3} 25-$ Resultado da Análise de significância para efeitos indiretos total - Mediação múltipla

\begin{tabular}{|c|c|c|c|c|c|c|c|}
\hline $\begin{array}{c}\text { Relações } \\
\text { Diretas }\end{array}$ & Relações Indiretas & Mediação & Original Sample (0) & $\begin{array}{l}\text { Sample Mean } \\
\text { (M) }\end{array}$ & DP & $\begin{array}{l}\text { TStaisitics } \\
(|0 / D P|) \\
t>1,96\end{array}$ & $\begin{array}{c}\text { p-values } \\
p<0,05\end{array}$ \\
\hline $\begin{array}{l}\text { TRAD->VAL } \\
\text { VAL->COMP } \\
\text { COMP->CONS }\end{array}$ & $\begin{array}{l}\text { TRAD }>\text { CONS } \\
\text { VAL }>\text { CONS } \\
\text { TRAD }>>\text { COMP }\end{array}$ & TRADIÇÃO ->L. CONSISTENTE DE ATIVIDADE Via VALORES E COMPROMETIMENTO & 0,0055 & 0,0159 & 0,0047 & 1,162 & 0,2458 \\
\hline $\begin{array}{l}\text { AUT->VAL } \\
\text { VAL->COMP } \\
\text { COMP-> CONS }\end{array}$ & $\begin{array}{l}\text { AUT }>\text { CONS } \\
\text { VAL }>\text { CONS } \\
\text { DES }>\text { COMP }\end{array}$ & AUTONOMIA ->L. CONSISTENTE DE ATIVIDADE via VALORES e COMPROMETIMENTO & 0,0197 & 0,0588 & 0,0090 & 2,199 & 0,028 \\
\hline $\begin{array}{l}\text { BEM->VAL } \\
\text { VAL }>>\text { COMP } \\
\text { COMP }->\text { CONS }\end{array}$ & $\begin{array}{l}\text { BEM }>\text { CONS } \\
\text { VAL }>\text { CONS } \\
\text { BEM }>\text { COMP }\end{array}$ & BEM-ESTAR $>>$ L. CONSISTENTE DE ATIVIDADE via VALORES e COMPROMETIMENTO & 0,0193 & 0,0576 & 0,0080 & 2,425 & 0,0157 \\
\hline $\begin{array}{l}\text { COLET->VAL } \\
\text { VAL->COMP } \\
\text { COMP->CONS }\end{array}$ & $\begin{array}{l}\text { COLET }>\text { CONS } \\
\text { VAL }>\text { CONS } \\
\text { COLET }>\text { COMP }\end{array}$ & COLETIVIDADE $>>$ L. CONSISTENTE DE ATIVIDADE via VALORES e COMPROMETIMENTO & 0,0409 & 0,1223 & 0,0175 & 2,345 & 0,0194 \\
\hline $\begin{array}{l}\text { CONF->VAL } \\
\text { VAL }->\text { COMP } \\
\text { COMP }>>\text { CONS }\end{array}$ & $\begin{array}{l}\text { CONF }>\text { CONS } \\
\text { VAL }>\text { CONS } \\
\text { CONF }>\text { COMP }\end{array}$ & CONFORMIDADE $>>$ L. CONSISTENTE DE ATIVIDADE Via VALORES e COMPROMETIMENTO & 0,0262 & 0,0786 & 0,0150 & 1,741 & 0,0822 \\
\hline $\begin{array}{l}\text { DOM->VAL } \\
\text { VAL }>>\text { COMP } \\
\text { COMP }>>\text { CONS }\end{array}$ & $\begin{array}{l}\text { DOM }>\text { CONS } \\
\text { VAL }>\text { CONS } \\
\text { DOM }>\text { COMP }\end{array}$ & DOMINIO -> L. CONSISTENTE DE ATIVIDADE via VALORES E COMPROMETIMENTO & 0,0067 & 0,0201 & 0,0035 & 1,908 & 0,0569 \\
\hline $\begin{array}{l}\text { PREST }->\text { VAL } \\
\text { VAL }->\text { COMP } \\
\text { COMP }>>\text { CONS }\end{array}$ & \begin{tabular}{|l} 
PREST $>$ CONS \\
VAL $>$ CONS \\
PREST $>>$ COMP
\end{tabular} & PRESTÍGIO -> L. CONSISTENTE DE ATIVIDADE via VALORESe COMPROMETIMENTO & 0,0177 & 0,0528 & 0,0103 & 1,716 & 0,0869 \\
\hline $\begin{array}{l}\text { REAL }>\text { VAL } \\
\text { VAL }>\text { COMP } \\
\text { COMP }>\text { CONS }\end{array}$ & $\begin{array}{l}\text { REAL }>>\text { CONS } \\
\text { VAL }>>\text { CONS } \\
\text { REAL }>>\text { COMP }\end{array}$ & REALIZAÇÃO ->L. CONSISTENTE DE ATIVIDADE via VALORES e COMPROMETIMENTO & 0,0205 & 0,0612 & 0,0092 & 2,212 & 0,0274 \\
\hline
\end{tabular}

Fonte: Resultados elaborados a partir dos dados da pesquisa e calculados por meio dos Softwares Smart-PLS e Excel

A partir das tabelas $A_{3} 23, A_{3} 24$ e $A_{3} 25$, as seguintes conclusões foram obtidas. 
Quadro $A_{3} 09$ - Resultados da análise mediadora múltipla

\begin{tabular}{|c|c|c|c|c|}
\hline \multirow[b]{2}{*}{ Mediadoras } & \multirow[b]{2}{*}{ Relação } & \multicolumn{2}{|c|}{ Significância } & \multirow[b]{2}{*}{ Interpretação } \\
\hline & & Indireto & Direto & \\
\hline \multirow{8}{*}{$\begin{array}{c}\text { Valores e } \\
\text { Comprometimento }\end{array}$} & Autonomia -> Linha consistente de atividade & Sim & Sim & Mediação parcial \\
\hline & Bem-estar -> Linha consistente de atividade & Sim & Sim & Mediação parcial \\
\hline & Coletividade $->$ Linha consistente de atividade & Sim & Sim & Mediação parcial \\
\hline & Conformidade $->$ L. consistente de atividade & Sim & Sim & Mediação parcial \\
\hline & Domínio -> Linha consistente de atividade & Não & Sim & Não há mediação \\
\hline & Prestígio -> Linha consistente de atividade & Sim & Sim & Mediação parciaí \\
\hline & Realização -> Linha consistente de atividade & Sim & Sim & Mediaçäo parcial \\
\hline & Tradição -> Linha consistente de atividade & Não & Sim & Não há mediação \\
\hline
\end{tabular}

Fonte: Resultados elaborados a partir dos dados da pesquisa e calculados por meio do Software Smart-PLS

O que se verifica é a existência de mediação parcial dos construtos valores e comprometimento sobre as relações das metas motivacionais e base de comprometimento linha consistente de atividade, com exceção das metas motivacionais tradição e domínio.

\section{Metas Motivacionais e Base de Comprometimento Escassez de Alternativas}

Verificar a significância das relações indiretas

Tabela $A_{3} 26$ - Efeitos específicos das metas motivacionais -> base de comprometimento escassez de alternativas

\begin{tabular}{|c|c|c|c|c|c|c|}
\hline $\begin{array}{c}\text { Efeitos indiretos } \\
\text { Metas motivacionais e Base de } \\
\text { Comprometimento Escassez de Alternativas }\end{array}$ & $\begin{array}{l}\text { Original } \\
\text { Sample } \\
\qquad(\mathrm{O})\end{array}$ & $\begin{array}{l}\text { Sample } \\
\text { Mean } \\
\text { (M) }\end{array}$ & DP & $\begin{array}{l}\text { Intervalo } \\
\text { Confiança } \\
95 \%\end{array}$ & $\begin{array}{c}\text { T Statistics } \\
(|\mathrm{O} / \mathrm{DP}|) \\
\mathrm{t}>1,96\end{array}$ & $\begin{array}{c}p \text {-values } \\
p<0,05\end{array}$ \\
\hline Autonomia -> valores -> comprometimento -> escassez & 0,034 & 0,035 & 0,009 & {$[0,016 ; 0,053]$} & 3,672 & 0,000 \\
\hline Bem-estar -> valores -> comprometimento -> escassez & 0,034 & 0,034 & 0,009 & {$[0,016 ; 0,051]$} & 3,815 & 0,000 \\
\hline Coletividade -> valores -> comprometimento -> escassez & 0,071 & 0,072 & 0,018 & {$[0,034 ; 0,106]$} & 3,854 & 0,000 \\
\hline Conformidade -> valores -> comprometimento -> escassez & 0,046 & 0,047 & 0,014 & {$[0,021 ; 0,072]$} & 3,358 & 0,001 \\
\hline Domínio -> valores -> comprometimento -> escassez & 0,012 & 0,012 & 0,003 & {$[0,005 ; 0,018]$} & 3,463 & 0,001 \\
\hline Prestígio -> valores -> comprometimento -> escassez & 0,031 & 0,031 & 0,010 & {$[0,014 ; 0,051]$} & 3,202 & 0,001 \\
\hline Realização -> valores -> comprometimento -> escassez & 0,036 & 0,036 & 0,009 & {$[0,017 ; 0,053]$} & 3,758 & 0,000 \\
\hline Tradição -> valores -> comprometimento -> escassez & 0,010 & 0,010 & 0,004 & {$[0,003 ; 0,017]$} & 2,519 & 0,012 \\
\hline
\end{tabular}

Fonte: Resultados elaborados a partir dos dados da pesquisa e calculados por meio do Software Smart-PLS

Verificar a significância das relações diretas 
Tabela $\mathrm{A}_{3} 27$ - Efeitos diretos das metas motivacionais -> base de comprometimento escassez de alternativas

\begin{tabular}{l|cccccc}
\hline \multicolumn{1}{c|}{$\begin{array}{c}\text { Efeitos diretos } \\
\text { Comprometimento Escassez de } \\
\quad \text { Alternativas }\end{array}$} & $\begin{array}{c}\text { Original } \\
\text { Sample } \\
(0)\end{array}$ & $\begin{array}{c}\text { Sample } \\
\text { Mean (M) }\end{array}$ & DP & $\begin{array}{c}\text { Intervalo } \\
\text { Confiança 95\% }\end{array}$ & $\begin{array}{c}\text { T Statistics } \\
(|\mathrm{O} / \mathrm{DP}|) \\
\mathrm{t}>1,96\end{array}$ & $\begin{array}{c}\mathrm{p} \text {-values } \\
p<0,05\end{array}$ \\
\hline Valores -> comprometimento & 0,628 & 0,634 & 0,048 & {$[0,539 ; 0,718]$} & 13,029 & 0,000 \\
Comprometimento -> escassez & 0,353 & 0,357 & 0,091 & {$[0,171 ; 0,530]$} & 3,907 & 0,0001 \\
Autonomia -> valores & 0,155 & 0,154 & 0,008 & {$[0,139 ; 0,169]$} & 19,338 & 0,000 \\
Bem-estar -> valores & 0,152 & 0,152 & 0,010 & {$[0,134 ; 0,171]$} & 15,604 & 0,000 \\
Coletividade -> valores & 0,321 & 0,321 & 0,014 & {$[0,295 ; 0,347]$} & 22,737 & 0,000 \\
Conformidade -> valores & 0,206 & 0,205 & 0,016 & {$[0,176 ; 0,238]$} & 12,921 & 0,000 \\
Domínio -> valores & 0,053 & 0,052 & 0,004 & {$[0,045 ; 0,059]$} & 14,742 & 0,000 \\
Prestígio -> valores & 0,139 & 0,138 & 0,014 & {$[0,112 ; 0,165]$} & 10,291 & 0,000 \\
Realização -> valores & 0,161 & 0,161 & 0,007 & {$[0,146 ; 0,176]$} & 21,960 & 0,000 \\
Tradição -> valores & 0,043 & 0,041 & 0,010 & {$[0,020 ; 0,060]$} & 4,257 & 0,000 \\
\hline
\end{tabular}

Fonte: Resultados elaborados a partir dos dados da pesquisa e calculados por meio do Software Smart-PLS

Tabela $A_{3} 28$ - Resultado da Análise de significância para efeitos indiretos total - Mediação múltipla

\begin{tabular}{|c|c|c|c|c|c|c|c|}
\hline $\begin{array}{c}\text { Relaçōes } \\
\text { Diretas }\end{array}$ & Relações Indiretas & Mediação & Original Sample (0) & $\begin{array}{l}\text { Sample Mean } \\
\text { (M) }\end{array}$ & DP & $\begin{array}{l}\text { TStaisics } \\
(\mid / / D P) \\
t>1,96\end{array}$ & $\begin{array}{c}p \text {-values } \\
p<0,05\end{array}$ \\
\hline $\begin{array}{l}\text { TRAD->VAL } \\
\text { VAL->COMP } \\
\text { COMP.>ESC }\end{array}$ & $\begin{array}{l}\text { TRAD }>>\text { ESC } \\
\text { VAL }>\text { ESC } \\
\text { TRAD }>\text { COMP }\end{array}$ & TRADIÇÃO -> ESCASSEZ DE ALTERNATIVAS Via VALORES E COMPROMETIMENTO & 0,0032 & 0,0095 & 0,0038 & 0,852 & 0,3947 \\
\hline $\begin{array}{l}\text { AUT->VAL } \\
\text { VAL->COMP } \\
\text { COMP-> ESC }\end{array}$ & $\begin{array}{l}\text { AUT }>\text { ESC } \\
\text { VAL }>>E S C \\
\text { DES }>>C O M P\end{array}$ & AUTONOMIA-_ESCASSEZ DE ALTERNATIVAS via VALORES e COMPROMETIMENTO & 0,0116 & 0,0349 & 0,0093 & 1,242 & 0,215 \\
\hline $\begin{array}{l}\text { BEM->VAL } \\
\text { VAL-> COMP } \\
\text { COMP-> ESC }\end{array}$ & $\begin{array}{l}\text { BEM }>\text { ESC } \\
\text { VAL }>>\text { ESC } \\
\text { BEM }>>\text { COMP }\end{array}$ & BEM-ESTAR - $>$ ESCASSEZ DE ALTERNATIVAS via VALORES e COMPROMETIMENTO & 0,0114 & 0,0341 & 0,0088 & 1,290 & 0,1975 \\
\hline $\begin{array}{l}\text { COLET->VAL } \\
\text { VAL->COMP } \\
\text { COMP->ESC }\end{array}$ & \begin{tabular}{|l} 
COLET $>>$ ESC \\
VAL -> ESC \\
COLET -> COMP
\end{tabular} & COLETIVIDADE $>$ ESCASSEZ DE ALTERNATIVAS via VALORES E COMPROMETIMENTO & 0,0241 & 0,0724 & 0,0185 & 1,304 & 0,1930 \\
\hline $\begin{array}{l}\text { CONF->VAL } \\
\text { VAL-> COMP } \\
\text { COMP->ESC }\end{array}$ & $\begin{array}{l}\text { CONF }>\text { ESC } \\
\text { VAL -> ESC } \\
\text { CONF }>\text { COMP }\end{array}$ & CONFORMIDADE -> ESCASSEZ DE ALTERNATIVAS via VALORES E COMPROMETIMENTO & 0,0154 & 0,0466 & 0,0136 & 1,136 & 0,2566 \\
\hline $\begin{array}{l}\text { DOM->VAL } \\
\text { VAL-> COMP } \\
\text { COMP-> ESC }\end{array}$ & $\begin{array}{l}\text { DOM }>\text { ESC } \\
\text { VAL }>>\text { ESC } \\
\text { DOM }>>\text { COMP }\end{array}$ & DOMINIIO -> ESCASSEZ DE ALTERNATIVAS via VALORES C COMPROMETIMENTO & 0,0039 & 0,0119 & 0,0034 & 1,171 & 0,2420 \\
\hline $\begin{array}{l}\text { PREST->VAL } \\
\text { VAL-> COMP } \\
\text { COMP-> ESC }\end{array}$ & \begin{tabular}{|l} 
PREST -> ESC \\
VAL -> ESC \\
PREST -> COMP
\end{tabular} & PRESTIGIO -> ESCASSEZ DE ALTERNATIVAS via VALORESe COMPROMETIMENTO & 0,0104 & 0,0314 & 0,0096 & 1,083 & 0,2793 \\
\hline $\begin{array}{l}\text { REAL->VAL } \\
\text { VAL-> COMP } \\
\text { COMP }>\text { ESC }\end{array}$ & $\begin{array}{l}\text { REAL -> ESC } \\
\text { VAL -> ESC } \\
\text { REAL -> COMP }\end{array}$ & REALIZAÇÃO ->ESCASSEZ DE ALTERNATIVAS via VALORES e COMPROMETIMENTO & 0,0121 & 0,0362 & 0,0095 & 1,271 & 0,2043 \\
\hline
\end{tabular}

Fonte: Resultados elaborados a partir dos dados da pesquisa e calculados por meio dos Softwares Smart-PLS e Excel 
A partir das tabelas $A_{3} 26, A_{3} 27$ e $A_{3} 28$, as seguintes conclusões foram obtidas.

Quadro $\mathrm{A}_{3} 10$ - Resultados da análise mediadora múltipla

\begin{tabular}{|c|c|c|c|c|}
\hline \multirow{2}{*}{ Mediadoras } & \multirow{2}{*}{ Relação } & \multicolumn{2}{|c|}{ Significância } & \multirow{2}{*}{ Interpretação } \\
\hline & & Indireto & Direto & \\
\hline \multirow{8}{*}{$\begin{array}{c}\text { Valores e } \\
\text { Comprometimento }\end{array}$} & Autonomia -> Escassez de alternativas & Não & Sim & Não há mediação \\
\hline & Bem-estar -> Escassez de alternativas & Não & Sim & Não há mediação \\
\hline & Coletividade -> Escassez de alternativas & Não & Sim & Não há mediação \\
\hline & Conformidade -> Escassez de alternativas & Não & Sim & Não há mediação \\
\hline & Domínio -> Escassez de alternativas & Não & Sim & Não há mediação \\
\hline & Prestígio -> Escassez de alternativas & Não & Sim & Não há mediação \\
\hline & Realização -> Escassez de alternativas & Não & Sim & Não há mediação \\
\hline & Tradição -> Escassez de alternativas & Não & Sim & Não há mediação \\
\hline
\end{tabular}

Fonte: Resultados elaborados a partir dos dados da pesquisa e calculados por meio do Software Smart-PLS

Não há mediação dos construtos valores e comprometimento nas relações das metas motivacionais e base de comprometimento escassez de alternativas.

\section{Metas Motivacionais e Base de Comprometimento Falta de Recompensas e Oportunidades}

\section{Verificar a significância das relações indiretas}

Tabela $\mathrm{A}_{3} 29$ - Efeitos específicos das metas motivacionais -> base de comprometimento falta de recompensas

\begin{tabular}{|c|c|c|c|c|c|c|}
\hline $\begin{array}{c}\text { Efeitos indiretos } \\
\text { Metas motivacionais e Base de } \\
\text { Comprometimento Falta de Recompensas e de Oportunidades }\end{array}$ & $\begin{array}{c}\text { Original } \\
\text { Sample (0) }\end{array}$ & $\begin{array}{c}\text { Sample } \\
\text { Mean (M) }\end{array}$ & DP & $\begin{array}{c}\text { Intervalo } \\
\text { Confiança 95\% }\end{array}$ & $\begin{array}{l}\text { T Statistics } \\
(|\mathrm{O} / \mathrm{DP}|) \\
t>1,96\end{array}$ & $\begin{array}{l}p \text {-values } \\
p<0,05\end{array}$ \\
\hline Autonomia -> VAL -> comprometimento -> F. recompensas & $-0,062$ & $-0,062$ & 0,008 & {$[-0,078 ;-0,047]$} & 8,063 & 0,000 \\
\hline Bem-estar $->$ VAL $>>$ comprometimento $->$ F. recompensas & $-0,061$ & $-0,061$ & 0,009 & {$[-0,078 ;-0,044]$} & 7,039 & 0,000 \\
\hline Coletividade $->$ VAL $->$ comprometimento $->$ F. recompensas & $-0,129$ & $-0,130$ & 0,017 & {$[-0,162 ;-0,095]$} & 7,662 & 0,000 \\
\hline Conformidade -> VAL -> comprometimento -> F. recompensas & $-0,083$ & $-0,083$ & 0,012 & {$[-0,104 ;-0,060]$} & 7,079 & 0,000 \\
\hline Domínio -> VAL -> comprometimento -> F. recompensas & $-0,021$ & $-0,021$ & 0,003 & {$[-0,026 ;-0,015]$} & 7,762 & 0,000 \\
\hline Prestígio -> VAL -> comprometimento -> F. recompensas & $-0,056$ & $-0,056$ & 0,009 & {$[-0,072 ;-0,038]$} & 6,299 & 0,000 \\
\hline Realização -> VAL -> comprometimento -> F. recompensas & $-0,065$ & $-0,065$ & 0,008 & {$[-0,078 ;-0,049]$} & 8,505 & 0,000 \\
\hline Tradição -> VAL -> comprometimento -> F. recompensas & $-0,017$ & $-0,017$ & 0,005 & {$[-0,026 ;-0,007]$} & 3,459 & 0,001 \\
\hline
\end{tabular}

Fonte: Resultados elaborados a partir dos dados da pesquisa e calculados por meio do Software Smart-PLS 
Tabela $\mathrm{A}_{3} 30$ - Efeitos diretos das metas motivacionais -> base de comprometimento falta de recompensas e oportunidades

\begin{tabular}{l|cccccc}
\hline $\begin{array}{c}\text { Metas motivacionais e Base de } \\
\text { Comprometimento Falta de } \\
\text { Recompensas e de Oportunidades }\end{array}$ & $\begin{array}{c}\text { Original } \\
\text { Sample } \\
(0)\end{array}$ & $\begin{array}{c}\text { Sample } \\
\text { Mean (M) }\end{array}$ & DP & $\begin{array}{c}\text { Intervalo } \\
\text { Confiança 95\% }\end{array}$ & $\begin{array}{c}\text { T Statistics } \\
(|\mathrm{D} / \mathrm{DP}|) \\
\mathrm{t}>1,96\end{array}$ & $\begin{array}{c}\mathrm{p} \text {-values } \\
\mathrm{p}<0,05\end{array}$ \\
\hline Valores -> comprometimento & 0,628 & 0,634 & 0,048 & {$[0,539 ; 0,718]$} & 13,029 & 0,000 \\
Comprometimento -> recompensas & $-0,641$ & $-0,639$ & 0,064 & {$[-0,753 ;-0,513]$} & 9,984 & 0,000 \\
Autonomia -> valores & 0,155 & 0,154 & 0,008 & {$[0,139 ; 0,169]$} & 19,338 & 0,000 \\
Bem-estar -> valores & 0,152 & 0,152 & 0,010 & {$[0,134 ; 0,171]$} & 15,604 & 0,000 \\
Coletividade -> valores & 0,321 & 0,321 & 0,014 & {$[0,295 ; 0,347]$} & 22,737 & 0,000 \\
Conformidade -> valores & 0,206 & 0,205 & 0,016 & {$[0,176 ; 0,238]$} & 12,921 & 0,000 \\
Domínio -> valores & 0,053 & 0,052 & 0,004 & {$[0,045 ; 0,059]$} & 14,742 & 0,000 \\
Prestígio -> valores & 0,139 & 0,138 & 0,014 & {$[0,112 ; 0,165]$} & 10,291 & 0,000 \\
Realização -> valores & 0,161 & 0,161 & 0,007 & {$[0,146 ; 0,176]$} & 21,960 & 0,000 \\
Tradição -> valores & 0,043 & 0,041 & 0,010 & {$[0,020 ; 0,060]$} & 4,257 & 0,000 \\
\hline
\end{tabular}

Fonte: Resultados elaborados a partir dos dados da pesquisa e calculados por meio do Software Smart-PLS

Tabela $A_{3} 31$ - Resultado da Análise de significância para efeitos indiretos total - Mediação múltipla

\begin{tabular}{|c|c|c|c|c|c|c|c|}
\hline $\begin{array}{c}\text { Relações } \\
\text { Diretas }\end{array}$ & Relações Indiretas & Mediação & Original Sample (0) & $\begin{array}{c}\text { Sample Mean } \\
\text { (M) }\end{array}$ & DP & $\begin{array}{l}\text { TStasisics } \\
(|0| D P \|) \\
t>1,96\end{array}$ & $\begin{array}{l}\text { p-values } \\
\text { p<0,05 }\end{array}$ \\
\hline $\begin{array}{l}\text { TRAD->VAL } \\
\text { VAL->COMP } \\
\text { COMP->REC }\end{array}$ & $\begin{array}{l}\text { TRAD }>>\text { REC } \\
\text { VAL -> REC } \\
\text { TRAD }>>\text { COMP }\end{array}$ & TRADIÇÄO $\rightarrow$ FALTA DE RECOMPENSAS via VALORES E COMPROMETIMENTO & $-0,0059$ & $-0,0169$ & 0,0050 & 1,170 & 0,2426 \\
\hline $\begin{array}{l}\text { AUT.>VAL } \\
\text { VAL->COMP } \\
\text { COMP->REC }\end{array}$ & $\begin{array}{l}\text { AUT }>\text { REC } \\
\text { VAL }>\text { REC } \\
D E S \text {.> COMP }\end{array}$ & AUTONOMIA $\rightarrow$ FALTA DE RECOMPENSAS via VALORES E COMPROMETIMENTO & $-0,0211$ & $-0,0624$ & 0,0077 & 2,728 & 0,007 \\
\hline $\begin{array}{l}\text { BEM->VAL } \\
\text { VAL->COMP } \\
\text { COMP-> REC }\end{array}$ & $\begin{array}{l}B E M \text {.> REC } \\
V A L ~>>R E C \\
B E M ~>C O M P\end{array}$ & BEM-ESTAR $\rightarrow$ FALTA DE RECOMPENSAS via VALORES C COMPROMETIMENTO & $-0,0207$ & $-0,0614$ & 0,0087 & 2,381 & 0,0176 \\
\hline $\begin{array}{l}\text { COLET->VAL } \\
\text { VAL->COMP } \\
\text { COMP->REC }\end{array}$ & $\begin{array}{l}\text { COLET }>>\text { REC } \\
\text { VAL }>\text { REC } \\
\text { COLET }>\text { COMP }\end{array}$ & COLETIVIDADE $>$ FALTA DE RECOMPENSAS via VALORES C COMPROMETIMENTO & $-0,0438$ & $-0,1301$ & 0,0169 & 2,592 & 0,0098 \\
\hline $\begin{array}{l}\text { CONF.> VAL } \\
\text { VAL->COMP } \\
\text { COMP }>\text { REC }\end{array}$ & $\begin{array}{l}\text { CONF }>>\text { REC } \\
\text { VAL }>\text { REC } \\
\text { CONF }>\text { COMP }\end{array}$ & CONFORMDADE $>>$ FALTA DE RECOMPENSAS via VALORES C COMPROMETMENTO & $-0,0280$ & $-0,0830$ & 0,0117 & 2,395 & 0,0170 \\
\hline $\begin{array}{l}\text { DOM->VAL } \\
\text { VAL->COMP } \\
\text { COMP->REC }\end{array}$ & $\begin{array}{l}\text { DOM }>\text { PEC } \\
\text { VAL }>>\text { REC } \\
\text { DOM }>\text { COMP }\end{array}$ & DOMINIIO -> FALTA DE RECOMPENSAS via VALORES e COMPROMETIMENTO & $-0,0072$ & $-0,0212$ & 0,0027 & 2,626 & 0,0089 \\
\hline $\begin{array}{l}\text { PREST->VAL } \\
\text { VAL->COMP } \\
\text { COMP->REC }\end{array}$ & \begin{tabular}{|l} 
PREST $>>$ REC \\
VAL $>$ REC \\
PREST $>$ COMP
\end{tabular} & PRESTIGIO-> FALTA DE RECOMPENSAS via VALORES COMPROMETIMENTO & $-0,0190$ & $-0,0558$ & 0,0089 & 2,131 & 0,0336 \\
\hline $\begin{array}{l}\text { REAL->VAL } \\
\text { VAL->COMP } \\
\text { COMP }>>\text { REC }\end{array}$ & $\begin{array}{l}\text { REAL -> REC } \\
\text { VAL -> REC } \\
\text { REAL ->COMP }\end{array}$ & REALIZAÇÃO ->FALTA DE RECOMPENSAS via VALORES e COMPROMETIMENTO & $-0,0219$ & $-0,0649$ & 0,0076 & 2,877 & 0,0042 \\
\hline
\end{tabular}

Fonte: Resultados elaborados a partir dos dados da pesquisa e calculados por meio dos Softwares Smart-PLS e Excel 
A partir das tabelas $A_{3} 28, A_{3} 29$ e $A_{3} 31$, as seguintes conclusões foram obtidas.

Quadro $A_{3} 11$ - Resultados da análise mediadora múltipla

\begin{tabular}{|c|c|c|c|c|}
\hline \multirow{2}{*}{ Mediadoras } & \multirow{2}{*}{ Relação } & \multicolumn{2}{|c|}{ Significância } & \multirow{2}{*}{ Interpretação } \\
\hline & & Indireto & Direto & \\
\hline \multirow{8}{*}{$\begin{array}{c}\text { Valores e } \\
\text { Comprometimento }\end{array}$} & Autonomia -> Falta de recompensas & Sim & Sim & Mediação parcial \\
\hline & Bem-estar -> Falta de recompensas & Sim & Sim & Mediação parcial \\
\hline & Coletividade -> Falta de recompensas & Sim & Sim & Mediação parcial \\
\hline & Conformidade -> Falta de recompensas & Sim & Sim & Mediação parcial \\
\hline & Domínio -> Falta de recompensas & Sim & Sim & Mediação parcial \\
\hline & Prestígio -> Falta de recompensas & Sim & Sim & Mediação parcial \\
\hline & Realização -> Falta de recompensas & Sim & Sim & Mediação parcial \\
\hline & Tradição -> Falta de recompensas & Não & Sim & Não há mediação \\
\hline
\end{tabular}

Fonte: Resultados elaborados a partir dos dados da pesquisa e calculados por meio do Software Smart-PLS

Há a existência de mediação parcial dos construtos valores e comprometimento sobre as relações das metas motivacionais e base de comprometimento falta de recompensa e oportunidades, com exceção da meta motivacional tradição. 
ANEXO $\mathbf{N}^{\circ} 01$

\title{
Quadro com as principais características dos quatro paradigmas Burrel e Morgan.
}

\author{
QUATRO PARADIGMAS DE BURREL E MORGAN
}

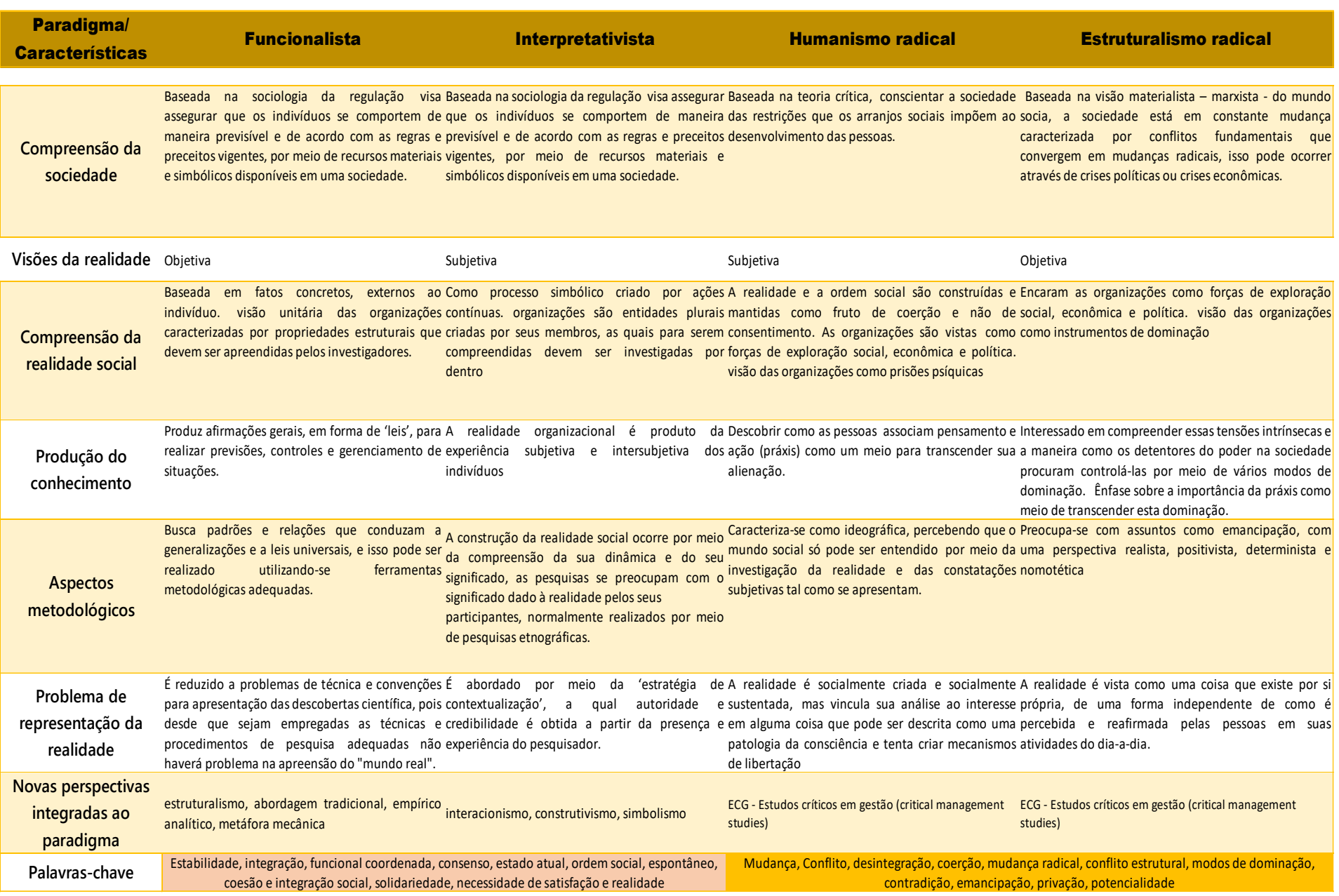

Fonte: Mozzato e Grzybovski (2013); Santos e Farias (2010); Munck e Souza (2010). 